\author{
UNIVERSIDADE DE SÃO PAULO \\ ESCOLA DE ENGENHARIA DE SÃO CARLOS \\ DEPARTAMENTO DE HIDRÁULICA E SANEAMENTO
}

DANIEL MOUREIRA FONTES LIMA

\title{
PRODUÇÃO DE BIOHIDROGÊNIO A PARTIR DE SORO DE LEITE EM AnSBBR COM RECIRCULAÇÃO DA FASE LÍQUIDA
}

VERSÃO CORRIGIDA

São Carlos, SP

2015 
DANIEL MOUREIRA FONTES LIMA

\title{
PRODUÇÃO DE BIOHIDROGÊNIO A PARTIR DE SORO DE LEITE EM AnSBBR COM RECIRCULAÇÃO DA FASE LÍQUIDA
}

\begin{abstract}
Tese apresentada à Escola de Engenharia de São Carlos, da Universidade de São Paulo, como parte dos requisitos para obtenção do título de Doutor em Ciências: Engenharia Hidráulica e Saneamento
\end{abstract}

Orientador: Professor Dr. José Alberto Domingues Rodrigues

São Carlos, SP 
AUTORIZO A REPRODUÇÃO TOTAL OU PARCIAL DESTE TRABALHO, POR QUALQUER MEIO CONVENCIONAL OU ELETRÔNICO, PARA FINS DE ESTUDO E PESQUISA, DESDE QUE CITADA A FONTE.

Moureira Fontes Lima, Daniel

M732p Produção de biohidrogênio a partir de soro de leite em AnSBBR com recirculação da fase líquida / Daniel Moureira Fontes Lima; orientador José Alberto Domingues Rodrigues. São Carlos, 2015.

Tese (Doutorado) - Programa de Pós-Graduação e Área de Concentração em Hidráulica e Saneamento -- Escola de Engenharia de São Carlos da Universidade de são Paulo, 2015.

1. concentração afluente. 2. tempo de enchimento. 3. temperatura. 4. lactose. 5. clostridium. 6. estabilidade. I. Título. 
FOLHA DE JULGAMENTO

Candidatc: Engenheiro DANIEL MOUREIRA FONTES LIMA.

Título da tese: "Produção de biohidrogênio a partir de soro de leite em ANSBBB cam recirculação da fase líquida".

Data da defesa: 02/06/2015

Comissão Julgadora:

Resultado:

Prof. Dr. José Alberto Domingues Rodrigues (Orientador) (Instituto de Medicina Tropical de São Paulo/IMT-USP)

Prof. Dr. Edson Luiz Silva

(Universidade Federal de São Carlos/UFSCar)

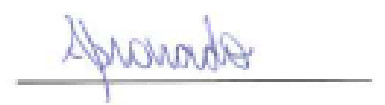

Prof. Dr. Rogers Ribeiro Aprovado (Faculdade de Zootecnia e Engenharia de Alimentos/FZEA-USP)

Profa. Associada Giovana Tommaso (Faculdade de Zootecnia e Engenharia de Alimentos/FZEA-USP)

Prof. Dr. Eduardo Lucena Cavalcante de Amorim (Universidade Federal de Alagoas/UFAL)

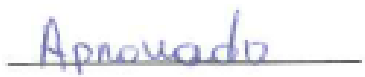

Coordenadora do Programa de Pós-Graduação em Engenharia Hidráulica e Saneamento:

Profa. Associada Maria Bernadete A. Varesche Silva

Presidente da Comissāo de Pós-Graduação:

Prof. Associado Paulo César Lima Segantine 
Novamente (pois não poderia ser diferente) À minha mãe Rosângela Aos meus irmãos Arthur e Deborah Ao meu pai Oscar (in memorian) À minha avó Ruth (in memorian) 
"So make your way to the ocean"

Beulah

(sim, de novo, pois continuo traçando meu caminho para o oceano) 


\section{Agradecimentos}

Foram quatro anos intensos. Intensos de verdade. Trabalhei de verdade, muito. Até tenho na cabeça uma resposta praticamente pronta quando me perguntam "mas você só estuda?" (a resposta, pois sei que existem curiosos no mundo, é algo como "se você acha que ir todos os dias para um laboratório, até em sábados e feriados, e realizar diversas atividades que exigem extrema atenção e cuidado (manuseio ácidos e produtos tóxicos com frequência!), depois ter que ler diversos artigos e livros sobre temas extremamente específicos e complexos em diversas línguas, para então escrever relatórios e artigos também complexos em diversas línguas, tudo isto com prazos muitas vezes apertados e que te fazem trabalhar também à noite ao chegar em casa quando na verdade você deveria estar descansando, for apenas estudar, então eu só estudo"). Também sofri bastante durante o tempo em que o reator teimava em não produzir hidrogênio. Mas aprendi que devemos perserverar. Foi triste ficar longe de pessoas importantes para mim durante todo este tempo, mas outras pessoas igualmente importantes se juntaram à minha vida e tornaram todo este "processo biológico" mais feliz. Me tornei um pesquisador, sim, mas me tornei principalmente uma pessoa conciente. Pude rodar um pouco pelo mundo e perceber que eu não sou nem pior nem melhor do que ninguém. E pude sentir que eu posso chegar em qualquer lugar e mostrar que sou capaz de trabalhar com excelência. E agora eu sinto que obter este título de doutor foi algo natural. Sinto que seria estranho se eu não o obtesse. Porque foram exatamente estes quatro anos que me deram esta confiança para me sentir um doutor muito antes do dia da defesa da minha tese.

Me desculpem, não citerei nenhum nome aqui. Sinto que seria injusto se eu esquecesse alguém e quem for citado aqui já recebeu agradecimentos pessoalmente, o que para mim é o mais importante. E tem o fato de que foram quatro anos longos, sem exagero. Se eu for citar o nome de todos precisarei de muitas páginas e esta tese que você tem em mãos já tem um número considerável de páginas.

Vou sentir falta de tudo que me aconteceu durante este doutorado. Mas minha vida já mudou e graças ao pai celestial isto não tem volta. Muito obrigado, do fundo do coração.

E gostaria de agradecer com sinceridade à Fapesp (Processos nº 2009/15.984-0, 2013/22659-4 e 2010/19.315-3) pelo apoio financeiro.

O dinheiro gira o mundo e não podemos fugir disto (ou não). 


\section{Resumo}

Lima, D. M. F. Produção de biohidrogênio a partir de soro de leite em AnSBBR com recirculação da fase líquida. 506p. Tese (Doutorado) - Escola de Engenharia de São Carlos, Universidade de São Paulo, São Carlos, 2015.

O presente estudo investigou a aplicação de dois tipos de AnSBBR (reatores anaeróbio com biofilme e operados em batelada e batelada alimentada sequenciais: com recirculação da fase líquida e com agitação) para produção de biohidrogênio tratando água residuária sintética (a base de soro de leite e lactose, respectivamente). O AnSBBR com recirculação da fase líquida, que foi o estudo principal do presente trabalho, apresentou problemas na produção de hidrogênio utilizando soro de leite como substrato. Algumas alternativas, como adaptação da biomassa com substratos puros de degradação mais fácil, controle do pH em valores muito baixos e diferentes formas de inoculação foram testadas, entretanto, sem obtenção de sucesso. A solução do problema foi obtida ao refrigerar o meio de alimentação a $4^{\circ} \mathrm{C}$ para evitar a fermentação no frasco de armazenamento, retirar a uréia e a suplementação de nutrientes, e realizar lavagens periódicas do material suporte para retirada de parte da biomassa. Dessa forma eliminaram-se indícios de produção de $\mathrm{H}_{2} \mathrm{~S}$ por possível ação de bactérias redutoras de sulfato (BRS) e atingiu-se uma produção estável de hidrogênio sem, entretanto, eliminar completamento o metano, que foi produzido em baixas concentrações. Depois de atingida a estabilidade, investigou-se a influência da concentração afluente de substrato, do tempo de enchimento e da temperatura na produção de biohidrogênio no AnSBBR com recirculação da fase líquida tratando soro de leite. O estudo da concentração afluente apresentou um ponto ótimo para a concentração de 5400 $\operatorname{mgDQO} \cdot \mathrm{L}^{-1}$, atingindo valores de $0,80 \mathrm{molH}_{2} \cdot \mathrm{mol}^{-1}$ lactose e de $660 \mathrm{mLH}_{2} \cdot \mathrm{L}^{-1} \cdot \mathrm{d}^{-1}$. O estudo do tempo de enchimento apresentou resultados similares para as condições analisadas. Com relação à temperatura, os melhores resultados foram obtidos com a temperatura mais baixa 
testada de $15^{\circ} \mathrm{C}\left(1,12 \mathrm{molH}_{2} \cdot\right.$ mollactose $^{-1}$ e $\left.1080 \mathrm{mLH}_{2} \cdot \mathrm{L}^{-1} \cdot \mathrm{d}^{-1}\right)$, sendo que na temperatura mais alta testada $\left(45^{\circ} \mathrm{C}\right)$ não ocorreu produção de hidrogênio. Para o AnSBBR com agitação mecânica, que foi um estudado complementar realizado pelo fato da lactose ser o principal complemento do soro de leite, o desempenho do biorreator foi avaliado de acordo com influência conjunta do tempo de ciclo $\left(t_{C}-2,3\right.$ e 4 h), da concentração afluente $\left(\mathrm{C}_{\mathrm{STA}}-\right.$ 3600-5400 mgDQO.L ${ }^{-1}$ ) e da carga orgânica volumétrica aplicada (COAV - 9,3, 12,3, 13,9, 18,5 e 27,8 mgDQO. $\left.\mathrm{L}^{-1} \cdot \mathrm{d}^{-1}\right)$. Foram obtidos excelentes resultados: consumos de carboidratos (lactose), com valores médios sempre acima de $90 \%$ e uma produção estável de biohidrogênio em todas as condições estudadas, com metano em baixas concentrações apenas na condição de maior COAV. A diminuição do $t_{C}$ apresentou tendência clara de melhora sobre o $\mathrm{RMCR}_{\mathrm{C}, \mathrm{n}}$ (rendimento molar entre hidrogênio produzido e carboidrato removido) apenas para as condições com menor concentração $\mathrm{C}_{\mathrm{STA}}$, havendo uma relação direta entre $\mathrm{C}_{\mathrm{STA}}$ e $\mathrm{RMCR}_{\mathrm{C}, \mathrm{n}}$ em todos os valores de $\mathrm{t}_{\mathrm{C}}$, exceto para o tempo de ciclo de $3 \mathrm{~h}$, exatamente onde ocorreu produção de metano. $\mathrm{O}$ melhor valor de $\mathrm{RMCR}_{\mathrm{C}, \mathrm{n}}$ obtido na operação com lactose $\left(1,65 \mathrm{molH}_{2} \cdot\right.$ molCarboidrato $\left.^{-1}\right)$ foi superior aos obtidos em outros trabalhos utilizando a mesma configuração de reator e sacarose como substrato. As análises filogenéticas mostraram que a maioria dos clones analisados foi semelhante à Clostridium. Além destes, clones filogeneticamente semelhantes com a Família Lactobacilaceae, especificamente Lactobacillus rhamnosus foram observados em menor porcentagem no reator, assim como clones com sequências semelhantes a Acetobacter indonesiensis.

Palavras chave: Concentração afluente, tempo de enchimento, temperatura, lactose, clostridium, estabilidade. 


\section{Abstract}

Lima, D. M. F. Biohydrogen production from chhese whey in an AnSBBR with recirculation of the liquid phase. 506p. Thesis (Doctorate) - Escola de Engenharia de São Carlos, Universidade de São Paulo, São Carlos, 2015.

The present study investigated the application of two types of AnSBBR (anaerobic reactors with biofilm and operated in batch and fed-batch sequences: with recirculation of the liquid phase and with agitation) for biohydrogen production treating synthetic wastewater (cheese whey and lactose-based, respectively). The AnSBBR with recirculation of the liquid phase, which was the main study of this work, presented problems in the hydrogen production using cheese whey as substrate. Some alternatives, such as adaptation of the biomass with pure substrates of easier degradation, $\mathrm{pH}$ control at very low values and different forms of inoculation were tested but without achieving success. The solution of the problem was obtained by cooling the feed medium at $4{ }^{\circ} \mathrm{C}$ to prevent fermentation in the storage flasks, removing the urea and the nutrient supplementation, and performing periodic washing of the support material for the removal of part of the biomass. Thus, $\mathrm{H}_{2} \mathrm{~S}$ production evidences by possible action of sulphate-reducing bacteria (SRB) were eliminated, reaching a stable production of hydrogen without eliminate the presence of methane completely, which was produced in low concentrations. After reaching the stability, it was investigated the influence of the influent concentration of the substrate, the influence of the filling time and the influence of the temperature on the production of biohydrogen in an AnSBBR with recirculation of the liquid phase treating cheese whey. The study of the influent concentration showed an optimum point for the concentration of $5400 \mathrm{mgDQO} . \mathrm{L}^{-1}$, reaching values of $0.80 \mathrm{molH}_{2} \cdot \mathrm{mol}^{-1}$ lactose and $660 \mathrm{mLH}_{2} \cdot \mathrm{L}^{-1} \cdot \mathrm{d}^{-1}$. The study of the filling time showed similar results for the analyzed conditions. With respect to the temperature, the 
best results were obtained with the lowest temperature tested of $15^{\circ} \mathrm{C}\left(1.12 \mathrm{molH}_{2} \cdot \mathrm{mol}^{-}\right.$ ${ }^{1}$ lactose and $\left.1080 \mathrm{mLH}_{2} \cdot \mathrm{L}^{-1} \cdot \mathrm{d}^{-1}\right)$, while the highest temperature tested $\left(45^{\circ} \mathrm{C}\right)$ didn't produce hydrogen. For the AnSBBR with mechanical stirring (which was an additional study that was performed by the fact that the lactose is the main component of the cheese whey) the performance of the bioreactor was evaluated in accordance with the joint influence og the cycle time $\left(\mathrm{t}_{\mathrm{C}}-2,3\right.$ and $\left.4 \mathrm{~h}\right)$, the influent concentration $\left(\mathrm{C}_{\mathrm{STA}}-3600-5400 \mathrm{mgDQO} . \mathrm{L}^{-1}\right)$ and the applied volumetric organic load (COAV - 9.3, 12.3, 13.9, 18.5 and 27.8 mgDQO.L ${ }^{-}$ $\left.{ }^{1} \cdot \mathrm{d}^{-1}\right)$. Excellent results were obtained: consumption of carbohydrates (lactose) always above $90 \%$ and a stable production of biohydrogen in all conditions studied, with low methane concentrations just in the condition with the biggest COAV. The decrease in the $t_{C}$ showed a clear trend of improvement of the $\mathrm{RMCR}_{\mathrm{C}, \mathrm{n}}$ (molar yield between the hydrogen produced and removed carbohydrate) only for the conditions with the low influent concentration $\left(\mathrm{C}_{\mathrm{STA}}\right)$. There was a direct relationship between $\mathrm{C}_{\mathrm{STA}}$ and $\mathrm{RMCR}_{\mathrm{C}, \mathrm{n}}$ in all values of $t_{C}$, except for the cycle time of 3 hours, exactly in which there was methane production. The best value of $\mathrm{RMCR}_{\mathrm{C}, \mathrm{n}}$ obtained in the operation with lactose $(1.65$ $\mathrm{molH}_{2} \cdot \mathrm{mol}^{-1}$ Lactose) was superior to those obtained in other studies using the same reactor configuration and sucrose as substrate. Phylogenetic analysis showed that the majority of the analyzed clones was similar to Clostridium. In addition, clones phylogenetically similar to Lactobacilaceae family, specifically Lactobacillus rhamnosus, were observed in a small proportion in the reactor, as well as clones with similar sequences of Acetobacter indonesiensis.

Keywords: Influent concentration, filling time, temperature, lactose, clostridium, stability. 


\section{SUMÁRIO}

Resumo xii

Abstract xiv

LISTA DE SÍMBOLOS E ABREVIAÇÕES ..................................................... xix

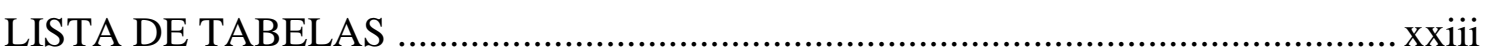

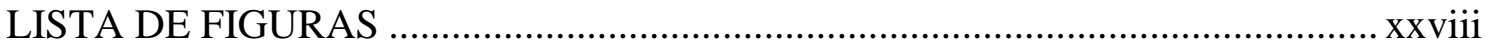

1. INTRODUÇÃ

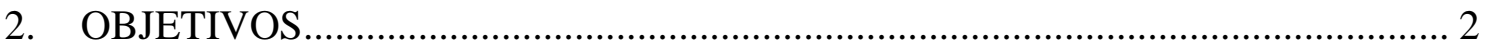

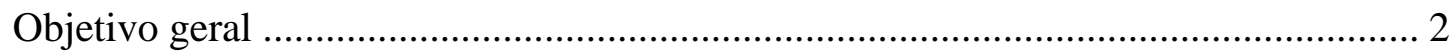

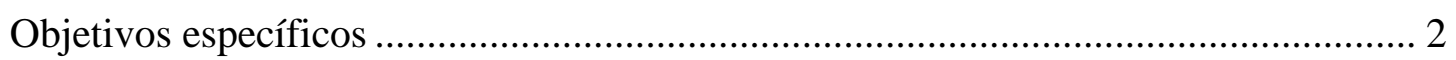

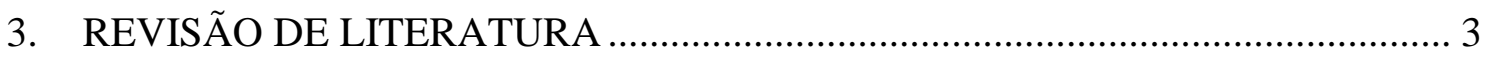

3.1. Produção biológica de hidrogênio ................................................................. 3

3.2. Reatores anaeróbios operados em batelada sequencial (AnSBBR)................. 6

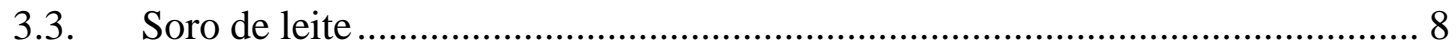

3.4. Fatores que influenciam a produção de hidrogênio em reatores anaeróbios .. 11

3.4.1. Influência da carga orgânica ............................................................. 11

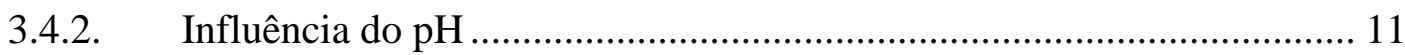

3.4.3. Influência da temperatura ................................................................ 12

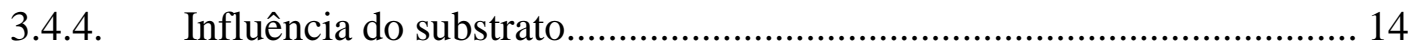

3.4.5. Influência dos microrganismos............................................................. 14

3.4.6. Influência da configuração do reator ................................................ 17

3.4.7. Influência do tempo de enchimento................................................... 19

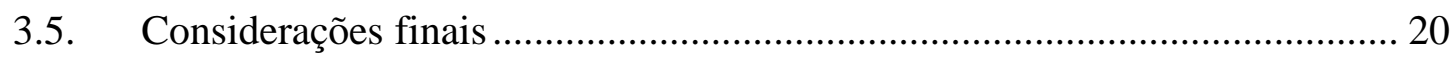

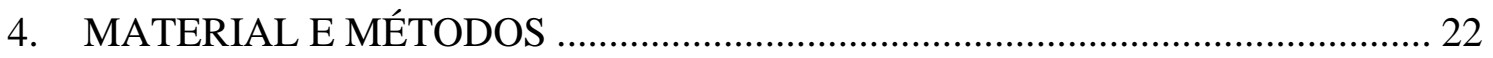

4.1. AnSBBR com biomassa imobilizada e recirculação ...................................... 22

4.2. AnSBBR com biomassa imobilizada e agitação mecânica ............................ 26

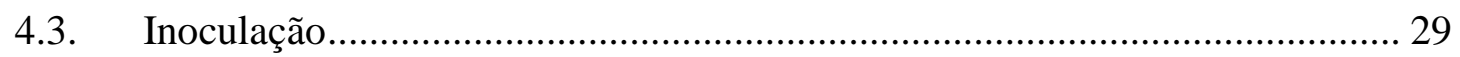

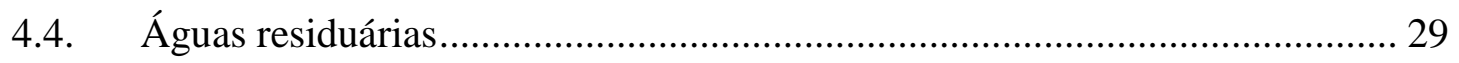

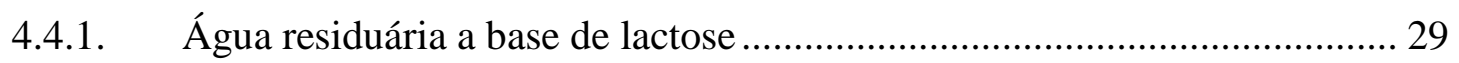

4.4.2. Água residuária a base de soro de leite................................................... 31

4.4.3. Água residuária a base de sacarose ......................................................... 31

4.4.4. Água residuária a base de leite desnatado tipo "longa-vida" ..................... 31

4.5. Suporte de imobilização da biomassa anaeróbia ............................................ 32 
4.6. Análises físico-químicas

4.7. Caracterização filogenética do consórcio microbiano do AnSBBR operado a $15{ }^{\circ} \mathrm{C}(\mathrm{C} 13)$ 37

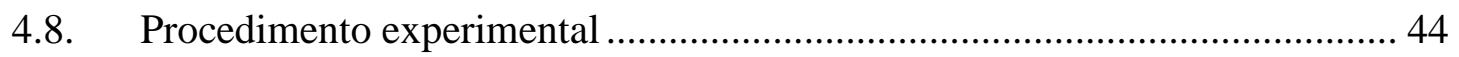

4.8.1. AnSBBR com recirculação da fase líquida …............................................. 37

4.8.2. AnSBBR com agitação mecânica.............................................................. 44

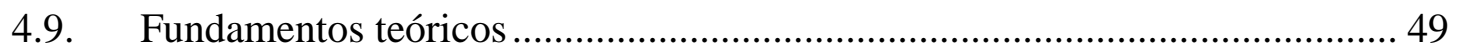

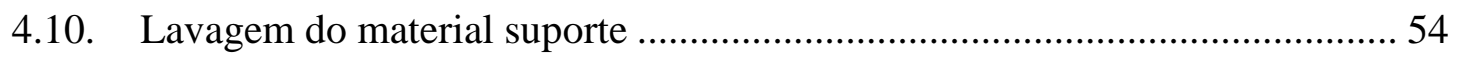

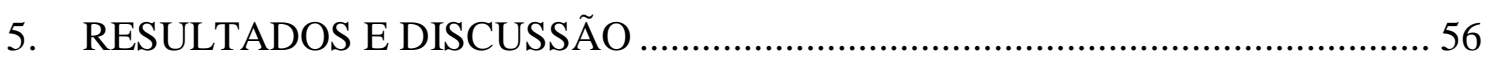

5.1. AnSBBR com recirculação da fase líquida - Primeira etapa (atingindo a

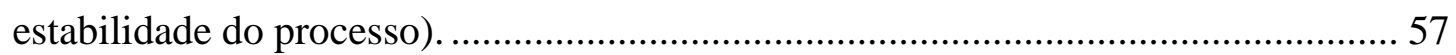

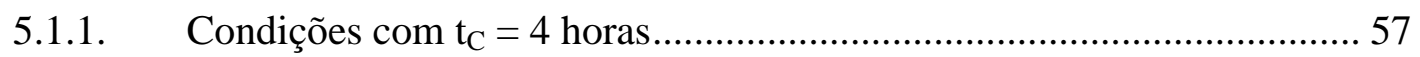

5.1.1.1. Condição 1 - Sem adaptação e afluente não refrigerado ........................ 57

5.1.1.2. Condição 2 - Adaptação com sacarose e afluente não refrigerado.......... 74

5.1.1.3. Condição 3 - Adaptação com lactose e afluente (não) refrigerado......... 93

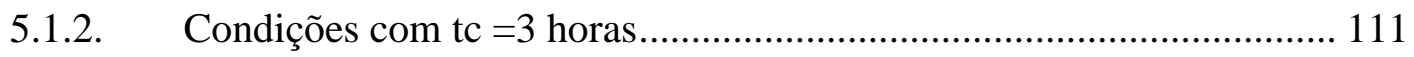

5.1.2.1. Condição 4 - Sem adaptação e afluente não refrigerado ....................... 111

5.1.2.2. Condição 5 - Sem adaptação e afluente refrigerado ............................ 129

5.1.2.3. Condição 6 - Adaptação com lactose e afluente refrigerado ................ 148

5.1.2.4. Condição 7 - Adaptação com lactose, alimentação com leite desnatado e afluente refrigerado

5.1.2.5. Condição 8 - Afluente (soro de leite) sem solução de nutrientes e ureia, com lavagem semanal e afluente $\left(\mathrm{t}_{\mathrm{c}}=3\right.$ horas, $\left.\mathrm{C}_{\mathrm{ST}}=4250 \mathrm{mgDQO} . \mathrm{L}^{-1}\right)$. 168

5.2. AnSBBR com recirculação da fase líquida - Efeito de importantes parâmetros operacionais (concentração afluente do substrato, tempo de enchimento e temperatura) na produção de biohidrogênio 186

5.2.1. Influência da concentração afluente do substrato................................ 186

5.2.1.1. Condição 9 - Soro de leite $\left(t_{c}=3\right.$ horas, $C_{S T}=6350$ mgDQO.L $\left.{ }^{-1}\right) \ldots . .186$

5.2.1.2. Condição 10 - Soro de leite $\left(t_{c}=3\right.$ horas, $C_{S T}=5500$ mgDQO.L $\left.{ }^{-1}\right) \ldots 204$

5.2.2. Influência da estratégia de alimentação (tempo de enchimento). 221

5.2.2.1. Condição $11-$ Soro de leite $\left(t_{c}=3\right.$ horas, $C_{S T}=5500 \mathrm{mgDQO} \cdot \mathrm{L}^{-1}-$ Batelada alimentada). 221

5.2.3. Influência da temperatura. 239

5.2.3.1. Condição 12 - Soro de leite $\left(t_{c}=3\right.$ horas, $C_{S T}=5500$ mgDQO.L $L^{-1}$, $\left.45^{\circ} \mathrm{C}\right) . \quad 239$ 
5.2.3.2. Condição $13-$ Soro de leite $\left(t_{c}=3\right.$ horas, $\left.\mathrm{C}_{\mathrm{ST}}=5500 \mathrm{mgDQO} \cdot \mathrm{L}^{-1}, 15^{\circ} \mathrm{C}\right)$ 249

5.3. AnSBBR com agitação mecânica e lactose como substrato.......................... 266

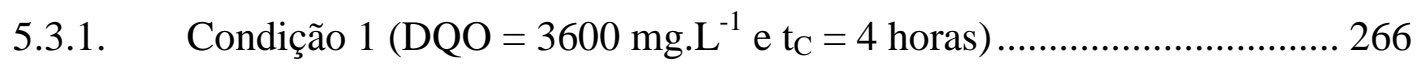

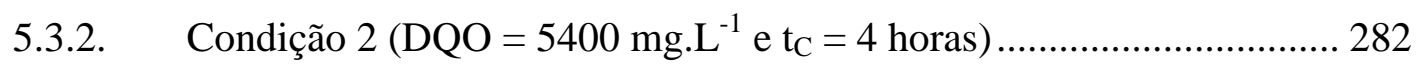

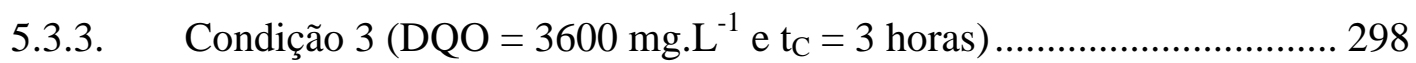

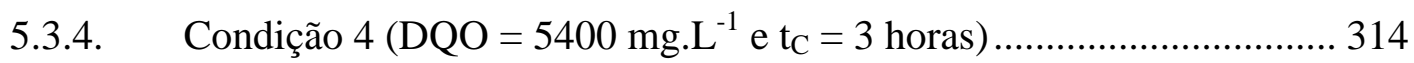

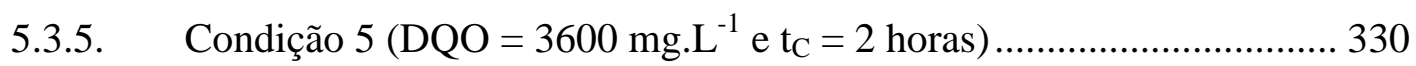

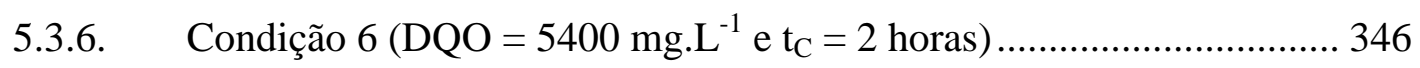

5.4. Análise comparativa das condições estudadas ........................................... 362

5.4.1. AnSBBR com recirculação da fase líquida - Primeira etapa (atingindo a estabilidade do processo).

5.4.2. AnSBBR com recirculação da fase líquida - Efeito de importantes parâmetros operacionais (concentração afluente do substrato, tempo de enchimento e temperatura) na produção de biohidrogênio 385

5.4.3. AnSBBR com agitação mecânica e lactose como substrato................. 410

5.5. Caracterização filogenética do consórcio microbiano do AnSBBR operado a $15{ }^{\circ} \mathrm{C}(\mathrm{C} 13)$. 426

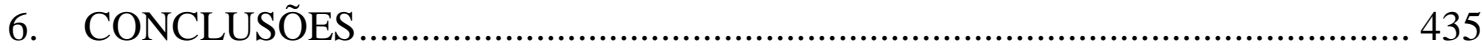

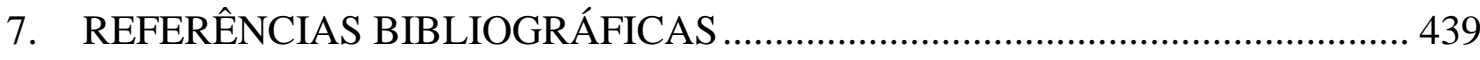




\section{LISTA DE SÍMBOLOS E ABREVIAÇÕES}

\begin{tabular}{|c|c|c|}
\hline Símbolo & Denominação & Unidade \\
\hline $\mathrm{C}_{\mathrm{ST}}$ & Concentração de matéria orgânica (amostras não filtradas) & {$\left[\mathrm{mgDQO} . \mathrm{L}^{-1}\right]$} \\
\hline $\mathrm{C}_{\mathrm{STA}}$ & Concentração de matéria orgânica afluente (amostras não filtradas) & {$\left[\mathrm{mgDQO} \cdot \mathrm{L}^{-1}\right]$} \\
\hline $\mathrm{C}_{\mathrm{STE}}$ & Concentração de matéria orgânica efluente (amostras não filtradas) & {$\left[\mathrm{mgDQO} \cdot \mathrm{L}^{-1}\right]$} \\
\hline $\mathrm{C}_{\mathrm{SF}}$ & Concentração de matéria orgânica (amostras filtradas) & {$\left[\mathrm{mgDQO} \cdot \mathrm{L}^{-1}\right]$} \\
\hline $\mathrm{C}_{\mathrm{SFE}}$ & Concentração de matéria orgânica efluente (amostras filtradas) & {$\left[\mathrm{mgDQO} \cdot \mathrm{L}^{-1}\right]$} \\
\hline$\varepsilon_{\mathrm{ST}}$ & Eficiência de remoção de matéria orgânica (amostras não filtradas) & {$[\%]$} \\
\hline$\varepsilon_{\mathrm{SF}}$ & Eficiência de remoção de matéria orgânica (amostras filtradas) & {$[\%]$} \\
\hline $\mathrm{C}_{\mathrm{C}}$ & Concentração de carboidratos & {$\left[\mathrm{mgCarboidrato.} \mathrm{L}^{-1}\right]$} \\
\hline $\mathrm{C}_{\mathrm{CT}}$ & Concentração de carboidratos (amostras não filtradas) & {$\left[\mathrm{mgCarboidrato.} \mathrm{L}^{-1}\right]$} \\
\hline $\mathrm{C}_{\mathrm{CTA}}$ & Concentração de carboidratos afluente (amostras não filtradas) & {$\left[\mathrm{mgCarboidrato} . \mathrm{L}^{-1}\right]$} \\
\hline $\mathrm{C}_{\mathrm{CTE}}$ & Concentração de carboidratos efluente (amostras não filtradas) & {$\left[\right.$ mgCarboidrato. $\left.\mathrm{L}^{-1}\right]$} \\
\hline $\mathrm{C}_{\mathrm{CF}}$ & Concentração de carboidratos (amostras não filtradas) & [mgCarboidrato. $\mathrm{L}^{-1}$ ] \\
\hline $\mathrm{C}_{\mathrm{CFE}}$ & Concentração de carboidratos efluente (amostras filtradas) & [mgCarboidrato. $\left.\mathrm{L}^{-1}\right]$ \\
\hline$\varepsilon_{\mathrm{CT}}$ & Eficiência de remoção de carboidratos (amostras não filtradas) & [\%] \\
\hline$\varepsilon_{\mathrm{CF}}$ & Eficiência de remoção de carboidratos (amostras filtradas) & {$[\%]$} \\
\hline AVT & Ácidos voláteis totais & {$\left[\operatorname{mgHAc} . \mathrm{L}^{-1}\right]$} \\
\hline AT & Alcalinidade total & {$\left[\mathrm{mgCaCO}_{3} \cdot \mathrm{L}^{-1}\right]$} \\
\hline AI & Alcalinidade intermediária & {$\left[\mathrm{mgCaCO}{ }_{3} \cdot \mathrm{L}^{-1}\right]$} \\
\hline $\mathrm{AP}$ & Alcalinidade parcial & {$\left[\mathrm{mgCaCO} 3 \cdot \mathrm{L}^{-1}\right]$} \\
\hline $\mathrm{AB}$ & Alcalinidade a bicarbonato & {$\left[\mathrm{mgCaCO}_{3} \cdot \mathrm{L}^{-1}\right]$} \\
\hline $\mathrm{pH}$ & Potencial hidrogeniônico & \\
\hline ST & Concentração de sólidos totais & {$\left[\mathrm{mg} . \mathrm{L}^{-1}\right]$} \\
\hline SVT & Concentração de sólidos voláteis totais & {$\left[\mathrm{mg} \cdot \mathrm{L}^{-1}\right]$} \\
\hline SST & Concentração de sólidos suspensos totais & {$\left[\mathrm{mg} . \mathrm{L}^{-1}\right]$} \\
\hline SSV & Concentração de sólidos suspensos voláteis & {$\left[\mathrm{mg} \cdot \mathrm{L}^{-1}\right]$} \\
\hline $\mathrm{C}_{\mathrm{MI}}$ & Concentração dos compostos intermediários & {$\left[\mathrm{mg} \cdot \mathrm{L}^{-1}\right]$} \\
\hline Ac & Acetona & {$\left[\mathrm{mg} \cdot \mathrm{L}^{-1}\right]$} \\
\hline $\mathrm{MeOH}$ & Metanol & {$\left[\mathrm{mg} \cdot \mathrm{L}^{-1}\right]$} \\
\hline $\mathrm{EtOH}$ & Etanol & {$\left[\mathrm{mg} \cdot \mathrm{L}^{-1}\right]$} \\
\hline $\mathrm{BuOH}$ & n-Butanol & {$\left[\mathrm{mg} \cdot \mathrm{L}^{-1}\right]$} \\
\hline HAc & Ácido Acético & {$\left[\mathrm{mg} \cdot \mathrm{L}^{-1}\right]$} \\
\hline
\end{tabular}




\begin{tabular}{|c|c|c|}
\hline $\mathrm{HPr}$ & Ácido Propiônico & {$\left[\mathrm{mg} \cdot \mathrm{L}^{-1}\right]$} \\
\hline $\mathrm{HIBu}$ & Ácido Isobutírico & {$\left[\mathrm{mg} . \mathrm{L}^{-1}\right]$} \\
\hline $\mathrm{HBu}$ & Ácido Butírico & {$\left[\mathrm{mg} . \mathrm{L}^{-1}\right]$} \\
\hline HIVa & Ácido Isovalérico & {$\left[\mathrm{mg} \cdot \mathrm{L}^{-1}\right]$} \\
\hline $\mathrm{HVa}$ & Ácido Valérico & {$\left[\mathrm{mg} \cdot \mathrm{L}^{-1}\right]$} \\
\hline $\mathrm{HCa}$ & Ácido Capróico & {$\left[\mathrm{mg} . \mathrm{L}^{-1}\right]$} \\
\hline $\mathrm{V}_{\mathrm{G}}$ & Volume total de biogás & [mL-CNTP] \\
\hline $\mathrm{Q}_{\mathrm{G}}$ & Vazão volumétrica do biogás & {$\left[\mathrm{mL} \cdot \mathrm{d}^{-1}\right]$} \\
\hline $\mathrm{C}_{\mathrm{CBG}}$ & Concentrações dos componentes do biogás & {$\left[\mathrm{mmol} \cdot \mathrm{L}^{-1}\right]$} \\
\hline $\mathrm{F}_{\mathrm{CBG}}$ & Fração molar dos componentes do biogás & {$[\%]$} \\
\hline $\mathrm{V}_{\mathrm{H} 2}$ & Volume de hidrogênio no biogás & {$[\mathrm{mL}-\mathrm{CNTP}]$} \\
\hline $\mathrm{V}_{\mathrm{CO} 2}$ & Volume de dióxido de carbono no biogás & [mL-CNTP] \\
\hline $\mathrm{V}_{\mathrm{CH} 4}$ & Volume de metano no biogás & [mL-CNTP] \\
\hline $\mathrm{C}_{\mathrm{H} 2}$ & Concentração de hidrogênio no biogás & {$\left[\mathrm{mmol} \cdot \mathrm{L}^{-1}\right]$} \\
\hline $\mathrm{C}_{\mathrm{CO} 2}$ & Concentração de dióxido de carbono no biogás & {$\left[\mathrm{mmol} \cdot \mathrm{L}^{-1}\right]$} \\
\hline $\mathrm{C}_{\mathrm{CH} 4}$ & Concentração de metano no biogás & {$\left[\mathrm{mmol} \cdot \mathrm{L}^{-1}\right]$} \\
\hline $\mathrm{n}_{\mathrm{H} 2}$ & Vazão molar de hidrogênio & {$\left[\mathrm{mmol} . \mathrm{d}^{-1}\right]$} \\
\hline $\mathrm{n}$ & Vazão molar de cada componente do biogás & {$\left[\mathrm{mmol} \cdot \mathrm{d}^{-1}\right]$} \\
\hline PrVH & Produção volumétrica de hidrogênio & {$\left[\mathrm{mLH}_{2} \cdot \mathrm{L}^{-1} \cdot \mathrm{d}^{-1}\right]$} \\
\hline $\mathrm{RMCR}_{\mathrm{C}, \mathrm{n}}$ & $\begin{array}{l}\text { Rendimento entre hidrogênio (molar) produzido e matéria orgânica } \\
\text { (molar) removida na forma de carboidratos }\end{array}$ & $\begin{array}{l}{\left[\mathrm{mmol} \mathrm{H}_{2 .} \mathrm{mmol}^{-1}\right.} \\
\text { Carboidrato }]\end{array}$ \\
\hline $\operatorname{PrM}$ & Produtividade molar de hidrogênio volumétrica & {$\left[\mathrm{mol} \cdot \mathrm{m}^{-3} \cdot \mathrm{d}^{-1}\right]$} \\
\hline PrME & Produtividade molar de hidrogênio específica & {$\left[\mathrm{mol} . \mathrm{kgSVT}^{-1} \cdot \mathrm{d}^{-1}\right]$} \\
\hline $\mathrm{RMCA}_{\mathrm{S}, \mathrm{m}}$ & $\begin{array}{l}\text { Rendimento entre hidrogênio (molar) produzido e matéria orgânica } \\
\qquad \text { (massa) aplicada na forma de DQO }\end{array}$ & {$\left[\right.$ mol.kgDQO $\left.{ }^{-1} \cdot \mathrm{d}^{-1}\right]$} \\
\hline $\mathrm{RMCA}_{\mathrm{C}, \mathrm{m}}$ & $\begin{array}{l}\text { Rendimento entre hidrogênio (molar) produzido e matéria orgânica } \\
\text { (massa) aplicada na forma de carboidratos }\end{array}$ & {$\left[\mathrm{mol} . \mathrm{kg}^{-1} \cdot \mathrm{d}^{-1}\right]$} \\
\hline $\mathrm{RMCR}_{\mathrm{S}, \mathrm{m}}$ & $\begin{array}{l}\text { Rendimento entre hidrogênio (molar) produzido e matéria orgânica } \\
\text { (massa) removida na forma de DQO }\end{array}$ & {$\left[\right.$ mol.kgDQO $\left.{ }^{-1} \cdot \mathrm{d}^{-1}\right]$} \\
\hline $\mathrm{RMCR}_{\mathrm{C}, \mathrm{m}}$ & $\begin{array}{l}\text { Rendimento entre hidrogênio (molar) produzido e matéria orgânica } \\
\text { (massa) removida na forma de carboidratos }\end{array}$ & {$\left[\mathrm{mol} . \mathrm{kg}^{-1} \cdot \mathrm{d}^{-1}\right]$} \\
\hline $\mathrm{t}_{\mathrm{C}}$ & Tempo de ciclo & [d] ou [dia] \\
\hline $\mathrm{t}$ & Tempo de ensaio/condição ou de monitoramento & [d] ou [dia] \\
\hline
\end{tabular}




\begin{tabular}{|c|c|c|}
\hline$t_{\mathrm{A}}$ & Tempo de alimentação & [h] ou [hora] \\
\hline $\mathrm{Q}_{\mathrm{R}}$ & Vazão de recirculação de meio líquido & {$\left[\mathrm{mL} \cdot \mathrm{s}^{-1}\right]$} \\
\hline $\mathrm{V}_{\mathrm{R}}$ & Volume total de meio líquido presente no biorreator & {$[\mathrm{mL}]$} \\
\hline $\mathrm{V}_{\mathrm{A}}$ & $\begin{array}{l}\text { Volume de meio líquido descarregado e alimentado a cada ciclo no } \\
\text { biorreator }\end{array}$ & {$[\mathrm{mL}]$} \\
\hline $\mathrm{V}_{\mathrm{D}}$ & $\begin{array}{l}\text { Volume descontado do biogás devido à alimentação durante a } \\
\text { batelada alimentada }\end{array}$ & {$[\mathrm{mL}]$} \\
\hline $\mathrm{COAV}_{\mathrm{S}}$ & $\begin{array}{c}\text { Carga orgânica aplicada volumétrica em termos de matéria } \\
\text { orgânica (amostras não filtradas) }\end{array}$ & {$\left[\mathrm{kgDQO} \cdot \mathrm{m}^{-3} \cdot \mathrm{d}^{-1}\right]$} \\
\hline $\mathrm{CORV}_{\mathrm{S}}$ & $\begin{array}{c}\text { Carga orgânica removida volumétrica em termos de matéria } \\
\text { orgânica (amostras filtradas) }\end{array}$ & {$\left[\mathrm{kgDQO} \cdot \mathrm{m}^{-3} \cdot \mathrm{d}^{-1}\right]$} \\
\hline $\mathrm{COAV}_{\mathrm{C}}$ & $\begin{array}{c}\text { Carga orgânica aplicada volumétrica em termos de carboidratos } \\
\qquad \text { (amostras não filtradas) }\end{array}$ & {$\left[\mathrm{kgCarboidrato} \cdot \mathrm{m}^{-3} \cdot \mathrm{d}^{-1}\right]$} \\
\hline $\mathrm{CORV}_{\mathrm{C}}$ & $\begin{array}{l}\text { Carga orgânica removida volumétrica em termos de carboidratos } \\
\text { (amostras filtradas) }\end{array}$ & {$\left[\mathrm{kgCarboidrato} \cdot \mathrm{m}^{-3} \cdot \mathrm{d}^{-1}\right]$} \\
\hline $\mathrm{COAE}_{\mathrm{S}}$ & $\begin{array}{c}\text { Carga orgânica aplicada específica em termos de matéria orgânica } \\
\qquad \text { (amostras não filtradas) }\end{array}$ & {$\left[\mathrm{kgDQO} \cdot \mathrm{m}^{-3} \cdot \mathrm{d}^{-1}\right]$} \\
\hline $\mathrm{CORE}_{\mathrm{S}}$ & $\begin{array}{c}\text { Carga orgânica removida específica em termos de matéria orgânica } \\
\text { (amostras filtradas) }\end{array}$ & {$\left[\mathrm{kgDQO} \cdot \mathrm{m}^{-3} \cdot \mathrm{d}^{-1}\right]$} \\
\hline $\mathrm{COAE}_{\mathrm{C}}$ & $\begin{array}{c}\text { Carga orgânica aplicada específica em termos de carboidratos } \\
\text { (amostras não filtradas) }\end{array}$ & {$\left[\mathrm{kgCarboidrato} \cdot \mathrm{m}^{-3} \cdot \mathrm{d}^{-1}\right]$} \\
\hline $\mathrm{CORE}_{\mathrm{C}}$ & $\begin{array}{l}\text { Carga orgânica removida específica em termos de carboidratos } \\
\qquad \text { (amostras filtradas) }\end{array}$ & {$\left[\mathrm{kgCarboidrato} \cdot \mathrm{m}^{-3} \cdot \mathrm{d}^{-1}\right]$} \\
\hline $\mathrm{m}_{\mathrm{BL} 1}$ & Quantidade de biomassa presente no líquido drenado do reator & [gSVT] \\
\hline $\mathrm{m}_{\mathrm{BL} 2}$ & $\begin{array}{l}\text { Quantidade de biomassa presente na água usada para lavagem do } \\
\text { sistema "material inerte + biomassa" }\end{array}$ & [gSVT] \\
\hline
\end{tabular}




\begin{tabular}{|c|c|c|}
\hline $\mathrm{CORE}_{\mathrm{C}}$ & $\begin{array}{l}\text { Carga orgânica removida específica em termos de carboidratos } \\
\qquad \text { (amostras filtradas) }\end{array}$ & {$\left[\mathrm{kgCarboidrato} . \mathrm{m}^{-3} \cdot \mathrm{d}^{-1}\right]$} \\
\hline $\mathrm{n}_{\mathrm{H} 2}$ & Fluxo molar diário de hidrogênio & {$\left[\mathrm{mol} . \mathrm{d}^{-1}\right]$} \\
\hline PrM & $\begin{array}{c}\text { Produtividade molar de hidrogênio em relação ao volume de meio } \\
\text { líquido presente no biorreator }\end{array}$ & {$\left[\mathrm{molH}_{2} \cdot \mathrm{m}^{-3} \cdot \mathrm{d}^{-1}\right]$} \\
\hline PrME & $\begin{array}{l}\text { Produtividade de hidrogênio em relação aos sólidos voláteis totais } \\
\text { presentes no biorreator }\end{array}$ & {$\left[\mathrm{molH}_{2} \cdot \mathrm{kgSVT}^{-1} \cdot \mathrm{d}^{-1}\right]$} \\
\hline $\mathrm{RMCA}_{\mathrm{C}, \mathrm{m}}$ & $\begin{array}{l}\text { Rendimento molar de hidrogênio em relação à carga aplicada de } \\
\text { carboidratos (amostras não filtradas) }\end{array}$ & {$\left[\mathrm{molH}_{2} \cdot \mathrm{kgCarboidrato}{ }^{-1}\right]$} \\
\hline $\mathrm{RMCA}_{\mathrm{S}, \mathrm{m}}$ & $\begin{array}{c}\text { Rendimento molar de hidrogênio em relação à carga aplicada de } \\
\text { matéria orgânica (amostras não filtradas) }\end{array}$ & {$\left[\mathrm{molH}_{2} \cdot \mathrm{kgDQO}^{-1}\right]$} \\
\hline $\mathrm{RMCR}_{\mathrm{C}, \mathrm{m}}$ & $\begin{array}{l}\text { Rendimento molar de hidrogênio em relação à carga removida de } \\
\text { carboidratos (amostras filtradas) }\end{array}$ & {$\left[\mathrm{molH}_{2} \cdot \mathrm{kgCarboidrato}{ }^{-1}\right]$} \\
\hline $\mathrm{RMCR}_{\mathrm{S}, \mathrm{m}}$ & $\begin{array}{l}\text { Rendimento molar de hidrogênio em relação à carga aplicada de } \\
\text { carboidratos (amostras filtradas) }\end{array}$ & {$\left[\mathrm{molH}_{2} \cdot \mathrm{kgDQO}^{-1}\right]$} \\
\hline $\mathrm{RMCR}_{\mathrm{C}, \mathrm{n}}$ & $\begin{array}{l}\text { Rendimento molar de hidrogênio em relação à carga aplicada de } \\
\text { carboidratos (amostras não filtradas) }\end{array}$ & {$\left[\mathrm{molH}_{2} \cdot\right.$ molCarboidrato $\left.^{-1}\right]$} \\
\hline $\mathrm{m}_{\mathrm{BL} 1}$ & Quantidade de biomassa presente no líquido drenado do reator & [gSVT] \\
\hline $\mathrm{m}_{\mathrm{BL} 2}$ & $\begin{array}{l}\text { Quantidade de biomassa presente na água usada para lavagem do } \\
\text { sistema "material inerte + biomassa" }\end{array}$ & [gSVT] \\
\hline
\end{tabular}

\begin{tabular}{cc}
\hline Abreviação & Denominação \\
\hline AnSBBR & Reator anaeróbio operado em batelada sequencial com biomassa \\
& imobilizada (anaerobic sequencing biofilm batch reactor) \\
DQO & Demanda Química de Oxigênio (matéria orgânica) \\
CNTP & Condições normais de temperatura e pressão $\left(0^{\circ} \mathrm{C}\right.$ e $\left.1 \mathrm{~atm}\right)$ \\
PEBD & Polietileno de baixa densidade \\
\hline
\end{tabular}




\section{LISTA DE TABELAS}

Tabela 3.1 - Rendimento máximo de açúcar a hidrogênio em processos fermentativos

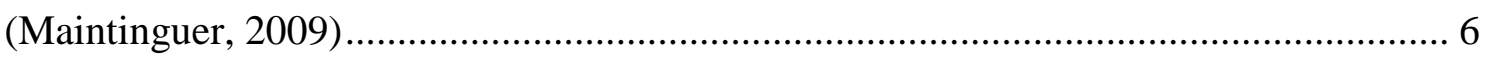

Tabela 4.1 - Composição da água residuária a base de lactose utilizada nos ensaios................ 30

Tabela 4.2 - Composição da água residuária a base de soro desidratado (em pó) comercial

(Marca Elegê) utilizada nos ensaios............................................................................. 31

Tabela 4.3 - Composição da água residuária a base de leite desnatado longa-vida utilizada nos

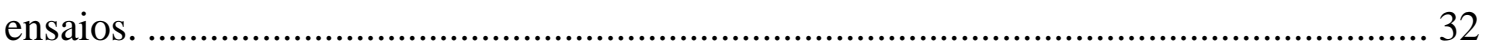

Tabela 4.4 - Resumo dos procedimentos analíticos e frequência de monitoramento. ............... 34

Tabela 4.5 - Resumos das condições experimentais do AnSBBR com recirculação................ 38

Tabela 4.6 - Resumo das condições experimentais estudadas no AnSBBR com agitação. ....... 45

Tabela 5.1 - Valores médios dos parâmetros monitorados na condição experimental 1 (Soro de

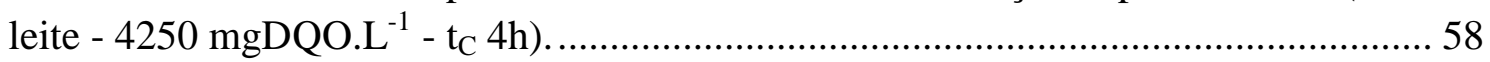

Tabela 5.2 - Concentração e distribuição dos compostos intermediários (AnSBBR com recirculação da fase líquida e soro de leite - Condição 1) ............................................. 64

Tabela 5.3 - Série de sólidos afluente e efluente (AnSBBR com recirculação da fase líquida e soro de leite - Condição 1).

Tabela 5.4 - Valores médios da produção, fração molar e os volumes individuais da mistura do biogás (AnSBBR com recirculação da fase líquida e soro de leite - Condição 1)........ 73

Tabela 5.5 - Valores médios dos parâmetros monitorados comuns a todas as etapas da condição experimental 2 (Soro de leite - $4250 \mathrm{mgDQO} . \mathrm{L}^{-1}-\mathrm{t}_{\mathrm{C}} 4 \mathrm{~h}$ ). ........................................ 76

Tabela 5.6 - Valores médios dos parâmetros exclusivos da primeira etapa da condição 2 (Soro

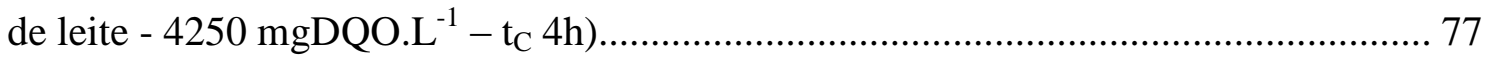

Tabela 5.7 - Concentração média e distribuição dos compostos intermediários (AnSBBR com recirculação da fase líquida e soro de leite - Condição 2).

Tabela 5.8 - Série de sólidos afluente e efluente (AnSBBR com recirculação da fase líquida e

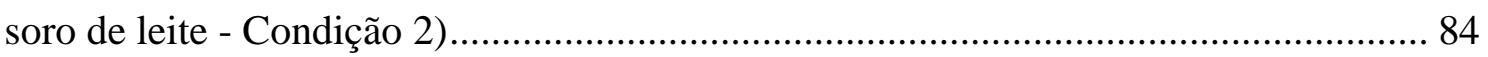

Tabela 5.9 - Valores médios da produção, fração molar e os volumes individuais da mistura do

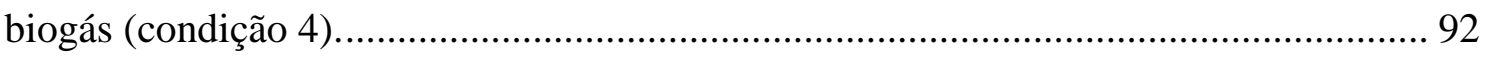

Tabela 5.10 - Valores médios dos parâmetros monitorados comuns a todas as etapas da condição experimental 3 (Soro de leite - 4250 mgDQO.L ${ }^{-1}-\mathrm{t}_{\mathrm{C}} 4 \mathrm{~h}$ )............................ 94

Tabela 5.11 - Valores médios dos parâmetros relacionados à carga orgânica e à produção de hidrogênio da condição 3 (Soro de leite - 4250 mgDQO.L ${ }^{-1}-t_{C} 4 h$ ) .......................... 95

Tabela 5.12 - Concentração média e distribuição dos compostos intermediários (AnSBBR com recirculação da fase líquida e soro de leite - Condição 3).

Tabela 5.13 - Série de sólidos afluente e efluente (AnSBBR com recirculação da fase líquida e soro de leite - Condição 3).

Tabela 5.14 - Valores médios da produção, fração molar e os volumes individuais da mistura do biogás (AnSBBR com recirculação da fase líquida e soro de leite - Condição 3). . 109

Tabela 5.15 - Valores médios dos parâmetros monitorados na condição experimental 4 (Soro de

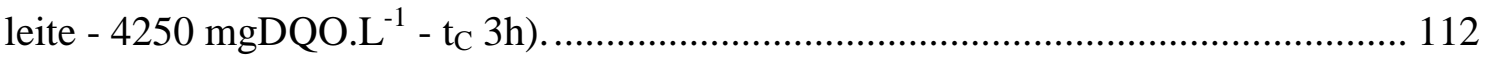

Tabela 5.16 - Concentração e distribuição dos compostos intermediários (AnSBBR com recirculação da fase líquida e soro de leite - Condição 4). 
Tabela 5.17 - Série de sólidos afluente e efluente (AnSBBR com recirculação da fase líquida e soro de leite - Condição 4).

Tabela 5.18 - Valores médios da produção, fração molar e os volumes individuais da mistura do biogás (AnSBBR com recirculação da fase líquida e soro de leite - Condição 4). 127

Tabela 5.19 - Valores médios dos parâmetros monitorados comuns a todas as etapas da condição experimental 5 (Soro de leite - $4250 \mathrm{mgDQO} . \mathrm{L}^{-1}-\mathrm{t}_{\mathrm{C}} 3 \mathrm{~h}$ ).

Tabela 5.20 - Valores médios dos parâmetros relacionados à carga orgânica e à produção de hidrogênio da condição 5 (Soro de leite - $4250 \mathrm{mgDQO}$. $^{-1}-\mathrm{t}_{\mathrm{C}} 3 \mathrm{~h}$ ). 132

Tabela 5.21 - Concentração média e distribuição dos compostos intermediários (AnSBBR com recirculação da fase líquida e soro de leite - Condição 5). 138

Tabela 5.22 - Série de sólidos afluente e efluente (AnSBBR com recirculação da fase líquida e soro de leite - Condição 5).

Tabela 5.23 - Valores médios da produção, fração molar e os volumes individuais da mistura do biogás (AnSBBR com recirculação da fase líquida e soro de leite - Condição 5). . 146

Tabela 5.24 - Valores médios dos parâmetros monitorados comuns a todas as etapas da condição experimental 6 (Soro de leite - 4250 mgDQO.L ${ }^{-1}-t_{C} 3 h$ ) .......................... 149

Tabela 5.25 - Concentração e distribuição dos compostos intermediários (AnSBBR com recirculação da fase líquida e soro de leite - Condição 6).

Tabela 5.26 - Série de sólidos afluente e efluente (AnSBBR com recirculação da fase líquida e soro de leite - Condição 6). 156

Tabela 5.27 - Valores médios dos parâmetros monitorados comuns a todas as etapas da condição experimental 7 (Leite desnatado longa vida - 4250 mgDQO.L $\mathrm{L}^{-1}-\mathrm{t}_{\mathrm{C}} 3 \mathrm{~h}$ ) ..... 160

Tabela 5.28 - Série de sólidos afluente e efluente (AnSBBR com recirculação da fase líquida e leite desnatado longa vida - Condição 7). 165

Tabela 5.29 - Valores médios dos parâmetros monitorados na condição experimental 8 (Soro de leite - $\left.4250 \mathrm{mgDQO} . \mathrm{L}^{-1}-\mathrm{t}_{\mathrm{C}} 3 \mathrm{~h}\right)$.

Tabela 5.30 - Concentração e distribuição dos compostos intermediários (AnSBBR com recirculação da fase líquida e soro de leite - Condição 8). 175

Tabela 5.31 - Série de sólidos afluente e efluente (AnSBBR com recirculação da fase líquida e soro de leite - Condição 8). 176

Tabela 5.32 - Lavagem do material suporte (AnSBBR com recirculação da fase líquida e soro de leite - Condição 8)

Tabela 5.33 - Valores médios da produção, fração molar e os volumes individuais da mistura do biogás (AnSBBR com recirculação da fase líquida e soro de leite - Condição 8). . 184

Tabela 5.34 - Valores médios dos parâmetros monitorados na condição experimental 9 (Soro de leite - $6350 \mathrm{mgDQO} . \mathrm{L}^{-1}-\mathrm{t}_{\mathrm{C}} 3 \mathrm{~h}$ ). 188

Tabela 5.35 - Concentração e distribuição dos compostos intermediários (AnSBBR com recirculação da fase líquida e soro de leite - Condição 9).

Tabela 5.36 - Série de sólidos afluente e efluente (AnSBBR com recirculação da fase líquida e soro de leite - Condição 9).

Tabela 5.37 - Lavagem do material suporte (AnSBBR com recirculação da fase líquida e soro de leite - Condição 9)

Tabela 5.38 - Valores médios da produção, fração molar e os volumes individuais da mistura do biogás (AnSBBR com recirculação da fase líquida e soro de leite - Condição 9). . 202 
Tabela 5.39 - Valores médios dos parâmetros monitorados na condição experimental 10 (Soro

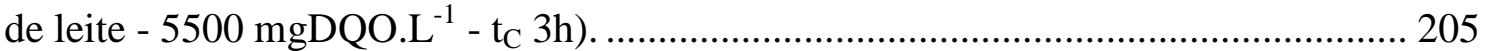

Tabela 5.40 - Concentração e distribuição dos compostos intermediários (AnSBBR com recirculação da fase líquida e soro de leite - Condição 10). 211

Tabela 5.41 - Série de sólidos afluente e efluente (AnSBBR com recirculação da fase líquida e soro de leite - Condição 10).

Tabela 5.42 - Lavagem do material suporte (AnSBBR com recirculação da fase líquida e soro de leite - Condição 10)

Tabela 5.43 - Valores médios da produção, fração molar e os volumes individuais da mistura do biogás (AnSBBR com recirculação da fase líquida e soro de leite - Condição 10). 220

Tabela 5.44 - Valores médios dos parâmetros monitorados na condição experimental 11 (Soro de leite - 5400 mgDQO. $\mathrm{L}^{-1}-\mathrm{t}_{\mathrm{C}} 3 \mathrm{~h}$ - Batelada alimentada)...................................... 222

Tabela 5.45 - Concentração e distribuição dos compostos intermediários (AnSBBR com recirculação da fase líquida e soro de leite - Condição 11)...................................... 228

Tabela 5.46 - Série de sólidos afluente e efluente (AnSBBR com recirculação da fase líquida e soro de leite - Condição 11)

Tabela 5.47 - Lavagem do material suporte (AnSBBR com recirculação da fase líquida e soro de leite - Condição 11)

Tabela 5.48 - Valores médios da produção, fração molar e os volumes individuais da mistura do biogás (AnSBBR com recirculação da fase líquida e soro de leite - Condição 9). . 238

Tabela 5.49 - Valores médios dos parâmetros monitorados na condição experimental $12\left(\mathrm{t}_{\mathrm{c}}=3\right.$ horas, $\mathrm{C}_{\mathrm{ST}}=5500 \mathrm{mgDQO} . \mathrm{L}^{-1}, 45^{\circ} \mathrm{C}$ ).

Tabela 5.50 - Série de sólidos afluente e efluente (AnSBBR com recirculação da fase líquida e soro de leite - Condição 12).

Tabela 5.51 - Lavagem do material suporte (AnSBBR com recirculação da fase líquida e soro de leite - Condição 12)

Tabela 5.52 - Valores médios dos parâmetros monitorados na condição experimental $13\left(\mathrm{t}_{\mathrm{c}}=3\right.$ horas, $\left.\mathrm{C}_{\mathrm{ST}}=5500 \mathrm{mgDQO} . \mathrm{L}^{-1}, 15^{\circ} \mathrm{C}\right)$ 250

Tabela 5.53 - Concentração e distribuição dos compostos intermediários (AnSBBR com recirculação da fase líquida e soro de leite - Condição 13).

Tabela 5.54 - Série de sólidos afluente e efluente (AnSBBR com recirculação da fase líquida e soro de leite - Condição 13)

Tabela 5.55 - Valores médios da produção, fração molar e os volumes individuais da mistura do biogás (AnSBBR com recirculação da fase líquida e soro de leite - Condição 13). 265

Tabela 5.56 - Valores médios dos parâmetros monitorados na condição 1 (Lactose - 3600 mgDQO.L $\left.\mathrm{L}^{-1}-\mathrm{t}_{\mathrm{C}} 4 \mathrm{~h}\right)$

Tabela 5.57 - Concentração e distribuição dos compostos intermediários (AnSBBR com agitação mecânica e lactose - Condição 1).

Tabela 5.58 - Série de sólidos afluente e efluente (AnSBBR com agitação mecânica e lactose Condição 1)

Tabela 5.59 - Valores médios da produção, fração molar e os volumes individuais da mistura do biogás (AnSBBR com agitação mecânica e lactose - Condição 1). 280

Tabela 5.60 - Valores médios dos parâmetros monitorados na condição experimental 2 (Lactose - $\left.5400 \mathrm{mgDQO} \cdot \mathrm{L}^{-1}-\mathrm{t}_{\mathrm{C}} 4 \mathrm{~h}\right)$. 283 
Tabela 5.61 - Concentração e distribuição dos compostos intermediários (AnSBBR com agitação mecânica e lactose - Condição 2)............................................................. 289

Tabela 5.62 - Série de sólidos afluente e efluente (AnSBBR com agitação mecânica e lactose Condição 2).

Tabela 5.63 - Valores médios da produção, fração molar e os volumes individuais da mistura do biogás (AnSBBR com agitação mecânica e lactose - Condição 2). 296

Tabela 5.64 - Valores médios dos parâmetros monitorados na condição experimental 3 (Lactose - $3600 \mathrm{mgDQO} . \mathrm{L}^{-1}-\mathrm{t}_{\mathrm{C}} 3 \mathrm{~h}$ ). 299

Tabela 5.65 - Concentração e distribuição dos compostos intermediários (AnSBBR com agitação mecânica e lactose - Condição 3). 305

Tabela 5.66 - Série de sólidos afluente e efluente (AnSBBR com agitação mecânica e lactose Condição 3). 306

Tabela 5.67 - Valores médios da produção, fração molar e os volumes individuais da mistura do biogás (AnSBBR com agitação mecânica e lactose - Condição 3).

Tabela 5.68 - Valores médios dos parâmetros monitorados na condição experimental 4 (Lactose - $\left.5400 \mathrm{mgDQO} . \mathrm{L}^{-1}-\mathrm{t}_{\mathrm{C}} 3 \mathrm{~h}\right)$. 315

Tabela 5.69 - Concentração e distribuição dos compostos intermediários (AnSBBR com agitação mecânica e lactose - Condição 4).

Tabela 5.70 - Série de sólidos afluente e efluente (AnSBBR com agitação mecânica e lactose Condição 4).

Tabela 5.71 - Valores médios da produção, fração molar e os volumes individuais da mistura do biogás (AnSBBR com agitação mecânica e lactose - Condição 4). 328

Tabela 5.72 - Valores médios dos parâmetros monitorados na condição 5 (Lactose - 3600 $\left.\operatorname{mgDQO} . \mathrm{L}^{-1}-\mathrm{t}_{\mathrm{C}} 2 \mathrm{~h}\right)$

Tabela 5.73 - Concentração e distribuição dos compostos intermediários (AnSBBR com agitação mecânica e lactose - Condição 5).

Tabela 5.74 - Série de sólidos afluente e efluente (AnSBBR com agitação mecânica e lactose Condição 5) 338

Tabela 5.75 - Valores médios da produção, fração molar e os volumes individuais da mistura do biogás (AnSBBR com agitação mecânica e lactose - Condição 5).

Tabela 5.76 - Valores médios dos parâmetros monitorados na condição experimental 6 (Lactose - $5400 \mathrm{mgDQO} . \mathrm{L}^{-1}-\mathrm{t}_{\mathrm{C}} 2 \mathrm{~h}$ ).

Tabela 5.77 - Concentração e distribuição dos compostos intermediários (AnSBBR com agitação mecânica e lactose - Condição 6).

Tabela 5.78 - Série de sólidos afluente e efluente (AnSBBR com agitação mecânica e lactose Condição 6).

Tabela 5.79 - Valores médios da produção, fração molar e os volumes individuais da mistura do biogás (AnSBBR com agitação mecânica e lactose - Condição 6). 360

Tabela 5.80 - Análises realizadas com o meio de alimentação sem refrigeração 381

Tabela 5.81 - Análises realizadas com o meio de alimentação com refrigeração 381

Tabela 5.82 - Indicadores de desempenho de produção de biohidrogênio nas condições com sacarose e lactose. 384 
Tabela 5.83 - Concentração e $\mathrm{COAV}_{\mathrm{SAT}}$ teóricas e reais, indicadores de produção de hidrogênio e quantidade de biomassa dentro do reator - influencia da concentração afluente. 401

Tabela 5.84 - Concentração e $\mathrm{COAV}_{\mathrm{SAT}}$ teóricas e reais, indicadores de produção de hidrogênio e quantidade de biomassa dentro do reator - influencia do tempo de enchimento. ..... 404

Tabela 5.85 - Concentração e $\mathrm{COAV}_{\mathrm{SAT}}$ teóricas e reais, indicadores de produção de hidrogênio e quantidade de biomassa dentro do reator - influência da temperatura. .. 406

Tabela 5.86 - Comparação entre diferentes configurações de reatores utilizando soro de leite como substrato. 409

Tabela 5.87 - Distribuição dos componentes do biogás em todas as condições (Lactose: $\mathrm{C} 1=$ $\mathrm{DQO}=3600 \mathrm{mg} \cdot \mathrm{L}^{-1}$ e $\mathrm{t}_{\mathrm{C}}=4$ horas; $\mathrm{C} 2=\mathrm{DQO}=5400 \mathrm{mg} \cdot \mathrm{L}^{-1}$ e $\mathrm{t}_{\mathrm{C}}=4$ horas; $\mathrm{C} 3=\mathrm{DQO}$ $=3600 \mathrm{mg} \cdot \mathrm{L}^{-1}$ e $\mathrm{t}_{\mathrm{C}}=3$ horas; $\mathrm{C} 4=\mathrm{DQO}=5400 \mathrm{mg} \cdot \mathrm{L}^{-1}$ e $\mathrm{t}_{\mathrm{C}}=3$ horas; $\mathrm{C} 5=\mathrm{DQO}=$ $3600 \mathrm{mg} . \mathrm{L}^{-1}$ e $\mathrm{t}_{\mathrm{C}}=2$ horas; $\mathrm{C} 6=\mathrm{DQO}=5400 \mathrm{mg} \cdot \mathrm{L}^{-1} \mathrm{e} \mathrm{t}_{\mathrm{C}}=2$ horas $)$.

Tabela 5.88 - Rendimentos na produção de biohidrogênio em todas as condições experimentais (Lactose: $\mathrm{C} 1=\mathrm{DQO}=3600 \mathrm{mg} \cdot \mathrm{L}^{-1}$ e $\mathrm{t}_{\mathrm{C}}=4$ horas; $\mathrm{C} 2=\mathrm{DQO}=5400 \mathrm{mg} . \mathrm{L}^{-1}$ e $_{\mathrm{C}}=4$ horas; $\mathrm{C} 3=\mathrm{DQO}=3600 \mathrm{mg} \cdot \mathrm{L}^{-1}$ e $\mathrm{t}_{\mathrm{C}}=3$ horas; $\mathrm{C} 4=\mathrm{DQO}=5400 \mathrm{mg} \cdot \mathrm{L}^{-1}$ e $\mathrm{t}_{\mathrm{C}}=3$ horas; $\mathrm{C} 5=\mathrm{DQO}=3600 \mathrm{mg} \cdot \mathrm{L}^{-1}$ e $\mathrm{t}_{\mathrm{C}}=2$ horas; $\mathrm{C} 6=\mathrm{DQO}=5400 \mathrm{mg} \cdot \mathrm{L}^{-1}$ e $\mathrm{t}_{\mathrm{C}}=2$ horas).

Tabela 5.89 - Produtividades em todas as condições experimentais (Lactose: $\mathrm{C} 1=\mathrm{DQO}=3600$

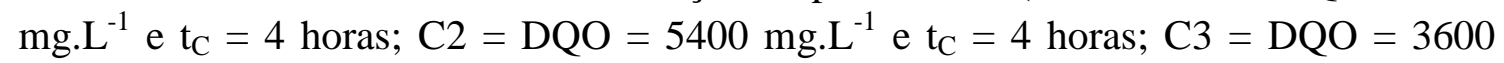
$\mathrm{mg} . \mathrm{L}^{-1}$ e $\mathrm{t}_{\mathrm{C}}=3$ horas; $\mathrm{C} 4=\mathrm{DQO}=5400 \mathrm{mg} . \mathrm{L}^{-1}$ e $\mathrm{t}_{\mathrm{C}}=3$ horas; $\mathrm{C} 5=\mathrm{DQO}=3600$ $\mathrm{mg} . \mathrm{L}^{-1} \mathrm{e} \mathrm{t}_{\mathrm{C}}=2$ horas; $\mathrm{C} 6=\mathrm{DQO}=5400 \mathrm{mg} \cdot \mathrm{L}^{-1}$ e $\mathrm{t}_{\mathrm{C}}=2$ horas $)$.

Tabela 5.90 - Quantidade de biomassa no interior do reator $\left(\mathrm{M}_{\mathrm{SVT}}\right)($ Lactose: $\mathrm{C} 1=\mathrm{DQO}=3600$

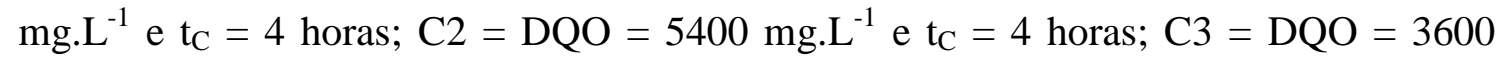
mg. $\mathrm{L}^{-1}$ e $\mathrm{t}_{\mathrm{C}}=3$ horas; $\mathrm{C} 4=\mathrm{DQO}=5400 \mathrm{mg} . \mathrm{L}^{-1}$ e $\mathrm{t}_{\mathrm{C}}=3$ horas; $\mathrm{C} 5=\mathrm{DQO}=3600$ mg. $\mathrm{L}^{-1}$ e $\mathrm{t}_{\mathrm{C}}=2$ horas; $\mathrm{C} 6=\mathrm{DQO}=5400 \mathrm{mg} \cdot \mathrm{L}^{-1}$ e $\mathrm{t}_{\mathrm{C}}=2$ horas)

Tabela 5.91 - Caracterização filogenética do consórcio microbiano proveniente do reator operado a $15^{\circ} \mathrm{C}$ alimentado como soro de leite. 434 


\section{LISTA DE FIGURAS}

Figura 3-1 - Processo de conversão anaeróbia da matéria orgânica................................. 4

Figura 4-1a - Esquema do (i) AnSBBR com recirculação utilizado nos ensaios e detalhes do (ii) reator, (iii) suporte da tela de aço, (iv) tela de aço e (v)

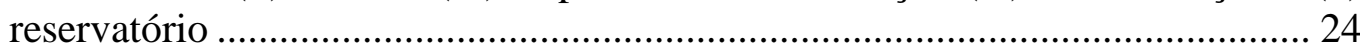

Figura 4-2 a - Esquema do AnSBBR com agitação utilizado nos ensaios ..................... 27

Figura 4-3 - Polietileno de baixa densidade (PEBD) utilizado como material suporte.. 33

Figura 4-4 - Esquema das condições experimentais estudadas no AnSBBR com recirculação: estabilidade do processo.............................................................. 41

Figura 4-5 - Esquema das condições experimentais estudadas no AnSBBR com recirculação: influência da concentração afluente, da estratégia de alimentação e da temperatura.

Figura 4-6 - Esquema utilizado para análise dos resultados do AnSBBR com agitação.

Figura 5-1 - Concentração de matéria orgânica (DQO): $\square$ - afluente não filtrada; $\Delta$ efluente não filtrada; o - efluente filtrada (AnSBBR com recirculação da fase líquida e soro de leite - Condição 1).

Figura 5-2 - Eficiência de remoção de matéria orgânica (DQO): $\diamond$ - não filtrada; filtrada (AnSBBR com recirculação da fase líquida e soro de leite - Condição 1).

Figura 5-3 - Concentração de carboidrato: $\square$ - afluente não filtrada; $\Delta$ - efluente não filtrada; ○ - efluente filtrada (AnSBBR com recirculação da fase líquida e soro de leite - Condição 1)

Figura 5-4 - Eficiência de remoção de carboidrato: $\diamond$ - não filtrada; - filtrada (AnSBBR com recirculação da fase líquida e soro de leite - Condição 1).

Figura 5-5 - Valores de pH: $\diamond$-afluente; - efluente (AnSBBR com recirculação da fase líquida e soro de leite - Condição 1).

Figura 5-6 - Alcalinidade total: $\diamond$-afluente; - efluente (AnSBBR com recirculação da fase líquida e soro de leite - Condição 1).

Figura 5-7 - Ácidos voláteis totais: $\diamond$-afluente; - efluente (AnSBBR com recirculação da fase líquida e soro de leite - Condição 1)

Figura 5-8 - Concentração dos compostos intermediários: $\square$ - ácido acético; $\Delta$ - etanol; ○ - ácido butírico; - ácido isobutírico; $\boldsymbol{\Delta}$ - ácido capróico; $\bullet$ - ácido valérico; * ácido propiônico; +butanol; - ácido isovalérico (AnSBBR com recirculação da fase líquida e soro de leite - Condição 1).

Figura 5-9 - Volume de biogás produzido por ciclo (AnSBBR com recirculação da fase líquida e soro de leite - Condição 1).

Figura 5-10 - Concentrações dos componentes do biogás no final do ciclo: $\square-\mathrm{CO}_{2} ; \Delta$ $\mathrm{H}_{2} ; 0-\mathrm{CH}_{4}$ (AnSBBR com recirculação da fase líquida e soro de leite Condição 1).

Figura 5-11 - Distribuições dos componentes do biogás no final do ciclo: $\square-\mathrm{CO}_{2} ; \Delta$ $\mathrm{H}_{2} ; \circ-\mathrm{CH}_{4}$ (AnSBBR com recirculação da fase líquida e soro de leite Condição 1)...

Figura 5-12 - Eixo da direita: Concentração de carboidrato $\diamond$ - do perfil 1, - do perfil 2 e - média dos dois perfis; Eixo da esquerda: * eficiência de degradação do carboidrato (AnSBBR com recirculação da fase líquida e soro de leite Condição 1)....

Figura 5-13 - Eixo da direita: Concentração de matéria orgânica (DQO) $\diamond$ - do perfil 1, - - do perfil 2 e — média dos dois perfis; Eixo da esquerda: $\star$ - eficiência de 
degradação da matéria orgânica (DQO) (AnSBBR com recirculação da fase líquida e soro de leite - Condição 1).

Figura 5-14 - Ácidos voláteis totais: $\diamond-$ do perfil 1 , - do perfil 2 e - média dos dois perfis (AnSBBR com recirculação da fase líquida e soro de leite - Condição 1).

Figura 5-15 - Concentração dos compostos intermediários ao longo do ciclo: $\square-$ ácido acético; $\Delta$ - etanol; ○ - ácido butírico; $\mathbf{\square}$ - ácido isobutírico; $\boldsymbol{\Delta}$ - ácido capróico; - - ácido valérico; ×-ácido propiônico; +butanol; — ácido isovalérico (AnSBBR com recirculação da fase líquida e soro de leite - Condição 1)......... 70

Figura 5-16 - Valores de pH: $\diamond$ - do perfil 1, - do perfil 2 e - média dos dois perfis (AnSBBR com recirculação da fase líquida e soro de leite - Condição 1)......... 71

Figura 5-17 - Alcalinidade total: $\diamond$ - do perfil 1 , - do perfil 2 e - média dos dois perfis (AnSBBR com recirculação da fase líquida e soro de leite - Condição 1).

Figura 5-18 - Produção volumétrica média acumulada do biogás, realizada com os valores dos perfis quantitativos mais consistentes obtidos durante a operação, juntamente com os desvios padrões (AnSBBR com recirculação da fase líquida e soro de leite - Condição 1).

Figura 5-19 - Volumes acumulados médios produzidos ao longo do ciclo: $\square-\mathrm{CO}_{2} ; \Delta-$ $\mathrm{H}_{2} ; 0-\mathrm{CH}_{4}$ (AnSBBR com recirculação da fase líquida e soro de leite Condição 1).

Figura 5-20 - Concentração de matéria orgânica (DQO): $\square$ - afluente não filtrada; $\Delta$ efluente não filtrada; O - efluente filtrada (AnSBBR com recirculação da fase líquida e soro de leite - Condição 2) ............................................................... 78

Figura 5-21 - Eficiência de remoção de matéria orgânica (DQO): $\diamond$ - não filtrada; filtrada (AnSBBR com recirculação da fase líquida e soro de leite - Condição 2).

Figura 5-22 - Concentração de carboidrato: $\square$ - afluente não filtrada; $\Delta$ - efluente não filtrada; O - efluente filtrada (AnSBBR com recirculação da fase líquida e soro de leite - Condição 2).

Figura 5-23 - Eficiência de remoção de carboidrato: $\diamond$ - não filtrada; - filtrada (AnSBBR com recirculação da fase líquida e soro de leite - Condição 2)......... 80

Figura 5-24 - Valores de pH: $\diamond$-afluente; - efluente (AnSBBR com recirculação da fase líquida e soro de leite - Condição 2)...................................................... 81

Figura 5-25 - Alcalinidade total: $\diamond$-afluente; - efluente (AnSBBR com recirculação da fase líquida e soro de leite - Condição 2).

Figura 5-26 - Ácidos voláteis totais: $\diamond$-afluente; - efluente (AnSBBR com recirculação da fase líquida e soro de leite - Condição 2).

Figura 5-27 - Concentração dos compostos intermediários durante o monitoramento: $\square$ - ácido acético; $\Delta$ - etanol; O - ácido butírico; $\mathbf{a}$ - ácido isobutírico; $\boldsymbol{\Delta}$ - ácido capróico; - - ácido valérico; - - ácido propiônico; + butanol; - ácido isovalérico (AnSBBR com recirculação da fase líquida e soro de leite - Condição 2). 83

Figura 5-28 - Volume de biogás produzido por ciclo (AnSBBR com recirculação da fase líquida e soro de leite - Condição 2).

Figura 5-29 - Concentrações dos componentes do biogás no final do ciclo: $\square-\mathrm{CO}_{2} ; \Delta$ $\mathrm{H}_{2} ;$ ○ $-\mathrm{CH}_{4}$ (AnSBBR com recirculação da fase líquida e soro de leite Condição 2). 
Figura 5-30 - Distribuições dos componentes do biogás no final do ciclo: $\square-\mathrm{CO}_{2} ; \Delta$ $\mathrm{H}_{2} ;$ O $-\mathrm{CH}_{4}$ (AnSBBR com recirculação da fase líquida e soro de leite Condição 2)...

Figura 5-31 - Eixo da direita: Concentração de matéria orgânica (DQO) $\diamond$ - do perfil 1, - - do perfil 2 e - média dos dois perfis; Eixo da esquerda: - - eficiência de degradação da matéria orgânica (DQO) (AnSBBR com recirculação da fase líquida e soro de leite - Condição 2).

Figura 5-32 - Eixo da direita: Concentração de carboidrato $\diamond$ - do perfil 1, - do perfil 2 e - média dos dois perfis; Eixo da esquerda: * eficiência de degradação do carboidrato (AnSBBR com recirculação da fase líquida e soro de leite Condição 2).

Figura 5-33 - Ácidos voláteis totais: $\diamond$-do perfil $1,-$ do perfil 2 e - média dos dois perfis (AnSBBR com recirculação da fase líquida e soro de leite - Condição 2).

Figura 5-34 - Concentração dos compostos intermediários ao longo do ciclo: $\square$ - ácido acético; $\Delta$ - etanol; O - ácido butírico; - ácido isobutírico; $\boldsymbol{\Delta}$ - ácido capróico; - - ácido valérico; - - ácido propiônico; + butanol; - ácido isovalérico (AnSBBR com recirculação da fase líquida e soro de leite - Condição 2)......... 89

Figura 5-35 - Valores de $\mathrm{pH}: \diamond-$ do perfil 1 , - do perfil 2 e - média dos dois perfis (AnSBBR com recirculação da fase líquida e soro de leite - Condição 2)......... 90

Figura 5-36 - Alcalinidade total: $\diamond$ - do perfil 1 , - do perfil 2 e - média dos dois perfis (AnSBBR com recirculação da fase líquida e soro de leite - Condição 2).

90

Figura 5-37 - Produção volumétrica média acumulada do biogás, realizada com os valores dos perfis quantitativos mais consistentes obtidos durante a operação, juntamente com os desvios padrões (AnSBBR com recirculação da fase líquida e soro de leite - Condição 2).

Figura 5-38 - Volumes acumulados médios produzidos ao longo do ciclo de: $\square-\mathrm{CO}_{2} ; \Delta$ - $\mathrm{H}_{2} ; 0-\mathrm{CH}_{4}$ (AnSBBR com recirculação da fase líquida e soro de leite Condição 2).

Figura 5-39 - Concentração de matéria orgânica (DQO): $\square$ - afluente não filtrada; $\Delta$ efluente não filtrada; o - efluente filtrada (AnSBBR com recirculação da fase líquida e soro de leite - Condição 3).

Figura 5-40 - Eficiência de remoção de matéria orgânica (DQO): $\diamond$ - não filtrada; filtrada (AnSBBR com recirculação da fase líquida e soro de leite - Condição 3).

Figura 5-41 - Concentração de carboidrato: $\square$ - afluente não filtrada; $\Delta$ - efluente não filtrada; $\bigcirc$ - efluente filtrada (AnSBBR com recirculação da fase líquida e soro de leite - Condição 3).

Figura 5-42 - Eficiência de remoção de carboidrato: $\diamond$ - não filtrada; - filtrada (AnSBBR com recirculação da fase líquida e soro de leite - Condição 3)......... 98

Figura 5-43 - Valores de pH: $\diamond$-afluente; - efluente (AnSBBR com recirculação da fase líquida e soro de leite - Condição 3). ......................................................... 99

Figura 5-44 - Alcalinidade total: $\diamond$-afluente; - efluente (AnSBBR com recirculação da fase líquida e soro de leite - Condição 3). ......................................................... 99

Figura 5-45 - Ácidos voláteis totais: $\diamond$-afluente; $\downarrow$ - efluente (AnSBBR com recirculação da fase líquida e soro de leite - Condição 3).

Figura 5-46 - Concentração dos compostos intermediários durante o monitoramento: $\square$ - ácido acético; $\Delta$ - etanol; ○ - ácido butírico; - ácido isobutírico; $\boldsymbol{\Delta}$ - ácido capróico; - - ácido valérico; - ácido propiônico; + butanol; - ácido 
isovalérico (AnSBBR com recirculação da fase líquida e soro de leite - Condição $3)$.

Figura 5-47 - Volume de biogás produzido por ciclo (AnSBBR com recirculação da fase líquida e soro de leite - Condição 3).

103

Figura 5-48 - Concentrações dos componentes do biogás no final do ciclo: $\square-\mathrm{CO}_{2} ; \Delta$ $\mathrm{H}_{2} ; \circ-\mathrm{CH}_{4}$ (AnSBBR com recirculação da fase líquida e soro de leite Condição 3). 103

Figura 5-49 - Distribuições dos componentes do biogás no final do ciclo: $\square-\mathrm{CO}_{2} ; \Delta$ $\mathrm{H}_{2} ;$ O $-\mathrm{CH}_{4}$ (AnSBBR com recirculação da fase líquida e soro de leite Condição 3)... 104

Figura 5-50 - Eixo da direita: Concentração de matéria orgânica (DQO) $\diamond$-do perfil 1, - - do perfil 2 e — média dos dois perfis; Eixo da esquerda: * eficiência de degradação da matéria orgânica (DQO) (AnSBBR com recirculação da fase líquida e soro de leite - Condição 3).

Figura 5-51 - Eixo da direita: Concentração de carboidrato $\diamond$-do perfil 1 , $\downarrow$ - do perfil 2 e - média dos dois perfis; Eixo da esquerda: * eficiência de degradação do carboidrato (AnSBBR com recirculação da fase líquida e soro de leite Condição 3). 106

Figura 5-52 - Ácidos voláteis totais: $\diamond$ - do perfil 1 , - do perfil 2 e - média dos dois perfis (AnSBBR com recirculação da fase líquida e soro de leite - Condição 3). 106

Figura 5-53 - Concentração dos compostos intermediários ao longo do ciclo: $\square$ - ácido acético; $\Delta$ - etanol; $\bigcirc$ - ácido butírico; - ácido isobutírico; $\boldsymbol{\Delta}$ - ácido capróico; - - ácido valérico; - - ácido propiônico; + butanol; - ácido isovalérico (AnSBBR com recirculação da fase líquida e soro de leite - Condição 3)....... 107

Figura 5-54 - Valores de pH: $\diamond$ - do perfil 1, - do perfil 2 e - média dos dois perfis (AnSBBR com recirculação da fase líquida e soro de leite - Condição 3)....... 108

Figura 5-55 - Alcalinidade total: $\diamond$ - do perfil 1, - do perfil 2 e - média dos dois perfis (AnSBBR com recirculação da fase líquida e soro de leite - Condição 3).

108

Figura 5-56 - Produção volumétrica média acumulada do biogás, realizada com os valores dos perfis quantitativos mais consistentes obtidos durante a operação, juntamente com os desvios padrões (AnSBBR com recirculação da fase líquida e soro de leite - Condição 3).

109

Figura 5-57 - Volumes acumulados médios produzidos ao longo do ciclo de: $\square-\mathrm{CO}_{2} ; \Delta$ - $\mathrm{H}_{2} ; \circ-\mathrm{CH}_{4}$ (AnSBBR com recirculação da fase líquida e soro de leite Condição 3). 110

Figura 5-58 - Concentração de matéria orgânica (DQO): $\square$ - afluente não filtrada; $\Delta$ efluente não filtrada; o - efluente filtrada (AnSBBR com recirculação da fase líquida e soro de leite - Condição 4).

Figura 5-59 - Eficiência de remoção de matéria orgânica (DQO): $\diamond$ - não filtrada; filtrada (AnSBBR com recirculação da fase líquida e soro de leite - Condição 4). 114

Figura 5-60 - Concentração de carboidrato: $\square$ - afluente não filtrada; $\Delta$ - efluente não filtrada; O - efluente filtrada (AnSBBR com recirculação da fase líquida e soro de leite - Condição 4). 115

Figura 5-61 - Eficiência de remoção de carboidrato: $\diamond$ - não filtrada; - filtrada (AnSBBR com recirculação da fase líquida e soro de leite - Condição 4)....... 115

Figura 5-62 - Valores de pH: $\diamond$-afluente; - efluente (AnSBBR com recirculação da fase líquida e soro de leite - Condição 4). 116 
Figura 5-63 - Alcalinidade total: $\diamond$-afluente; $\bullet$ - efluente (AnSBBR com recirculação da fase líquida e soro de leite - Condição 4).

Figura 5-64 - Ácidos voláteis totais: $\diamond$-afluente; - efluente (AnSBBR com recirculação da fase líquida e soro de leite - Condição 4).

Figura 5-65 - Concentração dos compostos intermediários: $\square$ - ácido acético; $\Delta$ - etanol; ○ - ácido butírico; - ácido isobutírico; $\boldsymbol{\Delta}$ - ácido capróico; $\bullet$ - ácido valérico; * ácido propiônico; +butanol; - ácido isovalérico (AnSBBR com recirculação da fase líquida e soro de leite - Condição 4). ................................ 118

Figura 5-66 - Volume de biogás produzido por ciclo (AnSBBR com recirculação da fase líquida e soro de leite - Condição 4). 120

Figura 5-67 - Concentrações dos componentes do biogás no final do ciclo: $\square-\mathrm{CO}_{2} ; \Delta$ $\mathrm{H}_{2} ;$ o $-\mathrm{CH}_{4}$ (AnSBBR com recirculação da fase líquida e soro de leite Condição 4).

121

Figura 5-68 - Distribuições dos componentes do biogás no final do ciclo: $\square-\mathrm{CO}_{2} ; \Delta-$ $\mathrm{H}_{2} ;$ o $-\mathrm{CH}_{4}$ (AnSBBR com recirculação da fase líquida e soro de leite Condição 4).

Figura 5-69 - Eixo da direita: Concentração de carboidrato $\diamond$ - do perfil 1, - do perfil 2 e - média dos dois perfis; Eixo da esquerda: * eficiência de degradação do carboidrato (AnSBBR com recirculação da fase líquida e soro de leite Condição 4).

Figura 5-70 - Eixo da direita: Concentração de matéria orgânica (DQO) $\diamond$ - do perfil 1, - - do perfil 2 e - média dos dois perfis; Eixo da esquerda: * eficiência de degradação da matéria orgânica (DQO) (AnSBBR com recirculação da fase líquida e soro de leite - Condição 4).

Figura 5-71 - Ácidos voláteis totais: $\diamond$ - do perfil $1, \downarrow$ - do perfil 2 e - média dos dois perfis (AnSBBR com recirculação da fase líquida e soro de leite - Condição 4).

Figura 5-72 - Concentração dos compostos intermediários ao longo do ciclo: $\square$ - ácido acético; $\Delta$ - etanol; ○ - ácido butírico; - ácido isobutírico; $\boldsymbol{\Delta}$ - ácido capróico; - - ácido valérico; - -ácido propiônico; +butanol; - ácido isovalérico (AnSBBR com recirculação da fase líquida e soro de leite - Condição 4)...... 125

Figura 5-73 - Valores de pH: $\diamond-$ do perfil 1 , - do perfil 2 e - média dos dois perfis (AnSBBR com recirculação da fase líquida e soro de leite - Condição 4)....... 126

Figura 5-74 - Alcalinidade total: $\diamond$ - do perfil 1 , - do perfil 2 e - média dos dois perfis (AnSBBR com recirculação da fase líquida e soro de leite - Condição 4). 126

Figura 5-75 - Produção volumétrica média acumulada do biogás, realizada com os valores dos perfis quantitativos mais consistentes obtidos durante a operação, juntamente com os desvios padrões (AnSBBR com recirculação da fase líquida e soro de leite - Condição 4).

Figura 5-76 - Volumes acumulados médios produzidos ao longo do ciclo: $\square-\mathrm{CO}_{2} ; \Delta$ $\mathrm{H}_{2} ; \circ-\mathrm{CH}_{4}$ (AnSBBR com recirculação da fase líquida e soro de leite Condição 4)........................................................................................ 128

Figura 5-77 - Concentração de matéria orgânica (DQO): $\square$ - afluente não filtrada; $\Delta$ efluente não filtrada; O - efluente filtrada (AnSBBR com recirculação da fase líquida e soro de leite - Condição 5).

Figura 5-78 - Eficiência de remoção de matéria orgânica (DQO): $\diamond$ - não filtrada; filtrada (AnSBBR com recirculação da fase líquida e soro de leite - Condição 5). 
Figura 5-79 - Concentração de carboidrato: $\square$ - afluente não filtrada; $\Delta$ - efluente não filtrada; ○ - efluente filtrada (AnSBBR com recirculação da fase líquida e soro de leite - Condição 5). 134

Figura 5-80 - Eficiência de remoção de carboidrato: $\diamond$ - não filtrada; - filtrada (AnSBBR com recirculação da fase líquida e soro de leite - Condição 5)....... 135

Figura 5-81 - Valores de pH: $\diamond$-afluente; $\downarrow$ - efluente (AnSBBR com recirculação da fase líquida e soro de leite - Condição 5). ........................................................ 136

Figura 5-82 - Alcalinidade total: $\diamond$-afluente; - efluente (AnSBBR com recirculação da fase líquida e soro de leite - Condição 5). ...................................................... 136

Figura 5-83 - Ácidos voláteis totais: $\diamond$-afluente; - - efluente (AnSBBR com recirculação da fase líquida e soro de leite - Condição 5).

Figura 5-84 - Concentração dos compostos intermediários durante o monitoramento: $\square$ - ácido acético; $\Delta$ - etanol; O - ácido butírico; $\mathbf{a}$ - ácido isobutírico; $\boldsymbol{\Delta}$ - ácido capróico; • - ácido valérico; * ácido propiônico; + butanol; — ácido isovalérico (AnSBBR com recirculação da fase líquida e soro de leite - Condição $5)$ 138

Figura 5-85 - Volume de biogás produzido por ciclo (AnSBBR com recirculação da fase líquida e soro de leite - Condição 5). 140

Figura 5-86 - Concentrações dos componentes do biogás no final do ciclo: $\square-\mathrm{CO}_{2} ; \Delta$ $\mathrm{H}_{2} ; 0-\mathrm{CH}_{4}$ (AnSBBR com recirculação da fase líquida e soro de leite Condição 5). 140

Figura 5-87 - Distribuições dos componentes do biogás no final do ciclo: $\square-\mathrm{CO}_{2} ; \Delta$ $\mathrm{H}_{2} ; 0-\mathrm{CH}_{4}$ (AnSBBR com recirculação da fase líquida e soro de leite Condição 5)...

Figura 5-88 - Eixo da direita: $\diamond$ - Concentração de matéria orgânica (DQO) do perfil; Eixo da esquerda: * eficiência de degradação da matéria orgânica (DQO) (AnSBBR com recirculação da fase líquida e soro de leite - Condição 5)....... 142

Figura 5-89 - Eixo da direita: $\diamond$ - Concentração de carboidrato do perfil; Eixo da esquerda: - - eficiência de degradação do carboidrato (AnSBBR com recirculação da fase líquida e soro de leite - Condição 5).

Figura 5-90 - $\diamond$ - Ácidos voláteis totais do perfil (AnSBBR com recirculação da fase líquida e soro de leite - Condição 5).

Figura 5-91 - Concentração dos compostos intermediários ao longo do ciclo: $\square$ - ácido acético; $\Delta$ - etanol; ○ - ácido butírico; $\boldsymbol{\square}$ - ácido isobutírico; $\boldsymbol{\Delta}$ - ácido capróico; - - ácido valérico; - - ácido propiônico; + butanol; - ácido isovalérico (AnSBBR com recirculação da fase líquida e soro de leite - Condição 5)....... 144

Figura 5-92 - $\diamond-$ Valores de $\mathrm{pH}$ do perfil (AnSBBR com recirculação da fase líquida e soro de leite - Condição 5).

Figura 5-93 - $\diamond$ - Alcalinidade total do perfil (AnSBBR com recirculação da fase líquida e soro de leite - Condição 5).

Figura 5-94 - Produção volumétrica média acumulada do biogás, realizada com os valores dos perfis quantitativos mais consistentes obtidos durante a operação, juntamente com os desvios padrões (AnSBBR com recirculação da fase líquida e soro de leite - Condição 5).

146

Figura 5-95 - Volumes acumulados médios produzidos ao longo do ciclo de: $\square-\mathrm{CO}_{2} ; \Delta$ - $\mathrm{H}_{2} ; 0-\mathrm{CH}_{4}$ (AnSBBR com recirculação da fase líquida e soro de leite Condição 5).

Figura 5-96 - Concentração de matéria orgânica (DQO): $\square$ - afluente não filtrada; $\Delta$ efluente não filtrada; o - efluente filtrada (AnSBBR com recirculação da fase líquida e soro de leite - Condição 6). 
Figura 5-97-Eficiência de remoção de matéria orgânica (DQO): $\diamond$ - não filtrada; filtrada (AnSBBR com recirculação da fase líquida e soro de leite - Condição 6).

151

Figura 5-98 - Concentração de carboidrato: $\square-$ afluente não filtrada; $\Delta$ - efluente não filtrada; O - efluente filtrada (AnSBBR com recirculação da fase líquida e soro de leite - Condição 6) 152

Figura 5-99 - Eficiência de remoção de carboidrato: $\diamond$ - não filtrada; - filtrada (AnSBBR com recirculação da fase líquida e soro de leite - Condição 6)....... 152

Figura 5-100 - Valores de pH: $\diamond$-afluente; - efluente (AnSBBR com recirculação da fase líquida e soro de leite - Condição 6).

Figura 5-101 - Alcalinidade total: $\diamond$-afluente; - efluente (AnSBBR com recirculação da fase líquida e soro de leite - Condição 6).................................................. 153

Figura 5-102 - Ácidos voláteis totais: $\diamond$-afluente; - efluente (AnSBBR com recirculação da fase líquida e soro de leite - Condição 6). ............................... 154

Figura 5-103 - Concentração dos compostos intermediários: $\square$ - ácido acético; $\Delta$ etanol; ○ - ácido butírico; - ácido isobutírico; $\boldsymbol{\Delta}$ - ácido capróico; $\bullet$ - ácido valérico; - a ácido propiônico; +butanol; - ácido isovalérico (AnSBBR com recirculação da fase líquida e soro de leite - Condição 6).

Figura 5-104 - Volume de biogás produzido por ciclo (AnSBBR com recirculação da fase líquida e soro de leite - Condição 6). 157

Figura 5-105 - Concentrações dos componentes do biogás no final do ciclo: $\square-\mathrm{CO}_{2} ; \Delta$ - $\mathrm{H}_{2}$; O $-\mathrm{CH}_{4}$ (AnSBBR com recirculação da fase líquida e soro de leite Condição 6). 157

Figura 5-106 - Distribuições dos componentes do biogás no final do ciclo: $\square-\mathrm{CO}_{2} ; \Delta$ $\mathrm{H}_{2} ; 0-\mathrm{CH}_{4}$ (AnSBBR com recirculação da fase líquida e soro de leite Condição 6)...... 158

Figura 5-107 - Concentração de matéria orgânica (DQO): $\square$ - afluente não filtrada; $\Delta$ efluente não filtrada; O - efluente filtrada (AnSBBR com recirculação da fase líquida e leite desnatado longa vida - Condição 7).

Figura 5-108-Eficiência de remoção de matéria orgânica (DQO): $\diamond$ - não filtrada; filtrada (AnSBBR com recirculação da fase líquida e leite desnatado longa vida Condição 7).....

Figura 5-109 - Concentração de carboidrato: $\square$ - afluente não filtrada; $\Delta$ - efluente não filtrada; O - efluente filtrada (AnSBBR com recirculação da fase líquida e leite desnatado longa vida - Condição 7).

Figura 5-110 - Eficiência de remoção de carboidrato: $\diamond$ - não filtrada; - filtrada (AnSBBR com recirculação da fase líquida e leite desnatado longa vida Condição 7).

Figura 5-111 - Valores de pH: $\diamond$-afluente; - efluente (AnSBBR com recirculação da fase líquida e leite desnatado longa vida - Condição 7). ................................. 164

Figura 5-112 - Alcalinidade total: $\diamond$-afluente; - efluente (AnSBBR com recirculação da fase líquida e leite desnatado longa vida - Condição 7).............................. 164

Figura 5-113 - Ácidos voláteis totais: $\diamond$-afluente; $\downarrow$ - efluente (AnSBBR com recirculação da fase líquida e leite desnatado longa vida - Condição 7)......... 165

Figura 5-114 - Volume de biogás produzido por ciclo (AnSBBR com recirculação da fase líquida e leite desnatado longa vida - Condição 7). .................................. 166

Figura 5-115 - Concentrações dos componentes do biogás no final do ciclo: $\square-\mathrm{CO}_{2} ; \Delta$ - $\mathrm{H}_{2} ; \circ-\mathrm{CH}_{4}$ (AnSBBR com recirculação da fase líquida e leite desnatado longa vida - Condição 7). 167 
Figura 5-116 - Distribuições dos componentes do biogás no final do ciclo: $\square-\mathrm{CO}_{2} ; \Delta$ $\mathrm{H}_{2} ; \mathrm{O}-\mathrm{CH}_{4}$ (AnSBBR com recirculação da fase líquida e leite desnatado longa vida - Condição 7).

Figura 5-117 - Concentração de matéria orgânica (DQO): $\square$ - afluente não filtrada; $\Delta$ efluente não filtrada; O - efluente filtrada (AnSBBR com recirculação da fase líquida e soro de leite - Condição 8)............................................................... 170

Figura 5-118 - Eficiência de remoção de matéria orgânica (DQO): $\diamond$ - não filtrada; filtrada (AnSBBR com recirculação da fase líquida e soro de leite - Condição 8).

Figura 5-119 - Concentração de carboidrato: $\square$ - afluente não filtrada; $\Delta$ - efluente não filtrada; O - efluente filtrada (AnSBBR com recirculação da fase líquida e soro de leite - Condição 8).

Figura 5-120 - Eficiência de remoção de carboidrato: $\diamond$ - não filtrada; - filtrada (AnSBBR com recirculação da fase líquida e soro de leite - Condição 8)....... 172

Figura 5-121 - Valores de pH: $\diamond$-afluente; - efluente (AnSBBR com recirculação da fase líquida e soro de leite - Condição 8).

Figura 5-122 - Alcalinidade total: $\diamond$-afluente; - efluente (AnSBBR com recirculação da fase líquida e soro de leite - Condição 8) 173

Figura 5-123 - Ácidos voláteis totais: $\diamond$-afluente; $\downarrow$ - efluente (AnSBBR com recirculação da fase líquida e soro de leite - Condição 8). 174

Figura 5-124 - Concentração dos compostos intermediários: $\square$ - ácido acético; $\Delta$ etanol; ○ - ácido butírico; $\mathbf{\square}$ - ácido isobutírico; $\boldsymbol{\Delta}$ - ácido capróico; $\bullet$ - ácido valérico; - a ácido propiônico; +butanol; - ácido isovalérico (AnSBBR com recirculação da fase líquida e soro de leite - Condição 8).

Figura 5-125 - Volume de biogás produzido por ciclo (AnSBBR com recirculação da fase líquida e soro de leite - Condição 8). 177

Figura 5-126 - Concentrações dos componentes do biogás no final do ciclo: $\square-\mathrm{CO}_{2} ; \Delta$ - $\mathrm{H}_{2}$; O $-\mathrm{CH}_{4}$ (AnSBBR com recirculação da fase líquida e soro de leite Condição 8).

Figura 5-127 - Distribuições dos componentes do biogás no final do ciclo: $\square-\mathrm{CO}_{2} ; \Delta$ $\mathrm{H}_{2} ;$ O $-\mathrm{CH}_{4}$ (AnSBBR com recirculação da fase líquida e soro de leite Condição 8).

Figura 5-128 - Concentração e eficiência de degradação de carboidrato: $\diamond$ - perfil e * eficiência (AnSBBR com recirculação da fase líquida e soro de leite - Condição $8)$.

Figura 5-129 - Concentração e eficiência de degradação de matéria orgânica: $\diamond$ - perfil e * eficiência (AnSBBR com recirculação da fase líquida e soro de leite Condição 8).....

Figura 5-130 - Ácidos voláteis totais $(\diamond)$ do perfil (AnSBBR com recirculação da fase líquida e soro de leite - Condição 8).

Figura 5-131 - Concentração dos compostos intermediários ao longo do ciclo: $\square$ - ácido acético; $\Delta$ - etanol; ○ - ácido butírico; $\mathbf{\square}$ - ácido isobutírico; $\boldsymbol{\Delta}$ - ácido capróico; - - ácido valérico; *ácido propiônico; +butanol; - ácido isovalérico (AnSBBR com recirculação da fase líquida e soro de leite - Condição 8)....... 182

Figura 5-132 - Valores de pH $(\diamond)$ do perfil (AnSBBR com recirculação da fase líquida e soro de leite - Condição 8).

Figura 5-133 - Alcalinidade total do perfil (AnSBBR com recirculação da fase líquida e soro de leite - Condição 8).

Figura 5-134 - Produção volumétrica média acumulada do biogás durante o ciclo (AnSBBR com recirculação da fase líquida e soro de leite - Condição 8). 184 
Figura 5-135 - Volumes acumulados médios produzidos ao longo do ciclo: $\square-\mathrm{CO}_{2} ; \Delta$ $\mathrm{H}_{2} ;$ O $-\mathrm{CH}_{4}$ (AnSBBR com recirculação da fase líquida e soro de leite Condição 8).

Figura 5-136 - Concentração de matéria orgânica (DQO): $\square$ - afluente não filtrada; $\Delta$ efluente não filtrada; O - efluente filtrada (AnSBBR com recirculação da fase líquida e soro de leite - Condição 9).

Figura 5-137 - Eficiência de remoção de matéria orgânica (DQO): $\diamond$ - não filtrada; filtrada (AnSBBR com recirculação da fase líquida e soro de leite - Condição 9).

Figura 5-138 - Concentração de carboidrato: $\square$ - afluente não filtrada; $\Delta$ - efluente não filtrada; O - efluente filtrada (AnSBBR com recirculação da fase líquida e soro de leite - Condição 9).

Figura 5-139 - Eficiência de remoção de carboidrato: $\diamond$ - não filtrada; - filtrada (AnSBBR com recirculação da fase líquida e soro de leite - Condição 9)....... 191

Figura 5-140 - Valores de pH: $\diamond$-afluente; - efluente (AnSBBR com recirculação da fase líquida e soro de leite - Condição 9).

Figura 5-141 - Alcalinidade total: $\diamond$-afluente; - efluente (AnSBBR com recirculação da fase líquida e soro de leite - Condição 9).

Figura 5-142 - Ácidos voláteis totais: $\diamond$-afluente; $\downarrow$ - efluente (AnSBBR com recirculação da fase líquida e soro de leite - Condição 9).

Figura 5-143 - Concentração dos compostos intermediários: $\square$ - ácido acético; $\Delta$ etanol; ○ - ácido butírico; $\mathbf{\square}$ - ácido isobutírico; $\boldsymbol{\Delta}$ - ácido capróico; $\bullet$ - ácido valérico; - a ácido propiônico; +butanol; - ácido isovalérico (AnSBBR com recirculação da fase líquida e soro de leite - Condição 9).

Figura 5-144 - Volume de biogás produzido por ciclo (AnSBBR com recirculação da fase líquida e soro de leite - Condição 9). 195

Figura 5-145 - Concentrações dos componentes do biogás no final do ciclo: $\square-\mathrm{CO}_{2} ; \Delta$ - $\mathrm{H}_{2} ; \circ-\mathrm{CH}_{4}$ (AnSBBR com recirculação da fase líquida e soro de leite Condição 9). 196

Figura 5-146 - Distribuições dos componentes do biogás no final do ciclo: $\square-\mathrm{CO}_{2} ; \Delta$ $\mathrm{H}_{2}$; O $-\mathrm{CH}_{4}$ (AnSBBR com recirculação da fase líquida e soro de leite Condição 9).

Figura 5-147 - Concentração e eficiência de degradação de carboidrato: $\diamond$ - perfil e * eficiência (AnSBBR com recirculação da fase líquida e soro de leite - Condição 9). 198

Figura 5-148 - Concentração e eficiência de degradação de matéria orgânica: $\diamond$ - perfil e * eficiência (AnSBBR com recirculação da fase líquida e soro de leite Condição 9).....

Figura 5-149 - Ácidos voláteis totais $(\diamond)$ do perfil (AnSBBR com recirculação da fase líquida e soro de leite - Condição 9).

Figura 5-150 - Concentração dos compostos intermediários ao longo do ciclo: $\square$ - ácido acético; $\Delta$ - etanol; ○ - ácido butírico; $\mathbf{\square}$ - ácido isobutírico; $\boldsymbol{\Delta}$ - ácido capróico; - - ácido valérico; - \#-ácido propiônico; +butanol; - ácido isovalérico (AnSBBR com recirculação da fase líquida e soro de leite - Condição 8)....... 200

Figura 5-151 - Valores de $\mathrm{pH}(\diamond)$ do perfil (AnSBBR com recirculação da fase líquida e soro de leite - Condição 9). 201

Figura 5-152 - Alcalinidade total do perfil (AnSBBR com recirculação da fase líquida e soro de leite - Condição 9).

Figura 5-153 - Produção volumétrica média acumulada do biogás durante o ciclo (AnSBBR com recirculação da fase líquida e soro de leite - Condição 9)...... 202 
Figura 5-154 - Volumes acumulados médios produzidos ao longo do ciclo: $\square-\mathrm{CO}_{2} ; \Delta$ $\mathrm{H}_{2} ;$ O $-\mathrm{CH}_{4}$ (AnSBBR com recirculação da fase líquida e soro de leite Condição 9)..... 203

Figura 5-155 - Concentração de matéria orgânica (DQO): $\square$ - afluente não filtrada; $\Delta$ efluente não filtrada; o - efluente filtrada (AnSBBR com recirculação da fase líquida e soro de leite - Condição 10)............................................................... 206

Figura 5-156 - Eficiência de remoção de matéria orgânica (DQO): $\diamond$ - não filtrada; filtrada (AnSBBR com recirculação da fase líquida e soro de leite - Condição $10)$. 207

Figura 5-157 - Concentração de carboidrato: $\square$ - afluente não filtrada; $\Delta$ - efluente não filtrada; O - efluente filtrada (AnSBBR com recirculação da fase líquida e soro de leite - Condição 10). 208

Figura 5-158 - Eficiência de remoção de carboidrato: $\diamond$ - não filtrada; - filtrada (AnSBBR com recirculação da fase líquida e soro de leite - Condição 10)..... 208

Figura 5-159 - Valores de pH: $\diamond$-afluente; - efluente (AnSBBR com recirculação da fase líquida e soro de leite - Condição 10). 209

Figura 5-160 - Alcalinidade total: $\diamond$-afluente; - efluente (AnSBBR com recirculação da fase líquida e soro de leite - Condição 10)..... 209

Figura 5-161 - Ácidos voláteis totais: $\diamond$-afluente; - efluente (AnSBBR com recirculação da fase líquida e soro de leite - Condição 10). 210

Figura 5-162 - Concentração dos compostos intermediários: $\square$ - ácido acético; $\Delta$ etanol; ○ - ácido butírico; $\mathbf{\square}$ - ácido isobutírico; $\boldsymbol{\Delta}$ - ácido capróico; $\bullet$ - ácido valérico; - ácido propiônico; +butanol; - ácido isovalérico (AnSBBR com recirculação da fase líquida e soro de leite - Condição 10).

Figura 5-163 - Volume de biogás produzido por ciclo (AnSBBR com recirculação da fase líquida e soro de leite - Condição 10). 212

Figura 5-164 - Concentrações dos componentes do biogás no final do ciclo: $\square-\mathrm{CO}_{2} ; \Delta$ - $\mathrm{H}_{2} ; \circ-\mathrm{CH}_{4}$ (AnSBBR com recirculação da fase líquida e soro de leite Condição 10).

Figura 5-165 - Distribuições dos componentes do biogás no final do ciclo: $\square-\mathrm{CO}_{2} ; \Delta$ $\mathrm{H}_{2} ;$ O $-\mathrm{CH}_{4}$ (AnSBBR com recirculação da fase líquida e soro de leite Condição 10). 213

Figura 5-166 - Concentração e eficiência de degradação de carboidrato: $\diamond$ - perfil e * eficiência (AnSBBR com recirculação da fase líquida e soro de leite - Condição $10)$. 215

Figura 5-167 - Concentração e eficiência de degradação de matéria orgânica: $\diamond$ - perfil e * eficiência (AnSBBR com recirculação da fase líquida e soro de leite Condição 10). 216

Figura 5-168 - Ácidos voláteis totais $(\diamond)$ do perfil (AnSBBR com recirculação da fase líquida e soro de leite - Condição 10). 216

Figura 5-169 - Concentração dos compostos intermediários ao longo do ciclo: $\square$ - ácido acético; $\Delta$ - etanol; ○ - ácido butírico; $\mathbf{\square}$ - ácido isobutírico; $\boldsymbol{\Delta}$ - ácido capróico; - - ácido valérico; *ácido propiônico; +butanol; - ácido isovalérico (AnSBBR com recirculação da fase líquida e soro de leite - Condição 10).... 217

Figura 5-170 - Valores de $\mathrm{pH}(\diamond)$ do perfil (AnSBBR com recirculação da fase líquida e soro de leite - Condição 10). 218

Figura 5-171 - Alcalinidade total do perfil (AnSBBR com recirculação da fase líquida e soro de leite - Condição 10).

Figura 5-172 - Produção volumétrica média acumulada do biogás durante o ciclo (AnSBBR com recirculação da fase líquida e soro de leite - Condição 10).... 219 
Figura 5-173 - Volumes acumulados médios produzidos ao longo do ciclo: $\square-\mathrm{CO}_{2} ; \Delta$ $\mathrm{H}_{2} ;$ O $-\mathrm{CH}_{4}$ (AnSBBR com recirculação da fase líquida e soro de leite Condição 10). 220

Figura 5-174 - Concentração de matéria orgânica (DQO): $\square$ - afluente não filtrada; $\Delta$ efluente não filtrada; O - efluente filtrada (AnSBBR com recirculação da fase líquida e soro de leite - Condição 11).

Figura 5-175 - Eficiência de remoção de matéria orgânica (DQO): $\diamond$ - não filtrada; filtrada (AnSBBR com recirculação da fase líquida e soro de leite - Condição $11)$.

Figura 5-176 - Concentração de carboidrato: $\square$ - afluente não filtrada; $\Delta$ - efluente não filtrada; O - efluente filtrada (AnSBBR com recirculação da fase líquida e soro de leite - Condição 11) 225

Figura 5-177 - Eficiência de remoção de carboidrato: $\diamond$ - não filtrada; - filtrada (AnSBBR com recirculação da fase líquida e soro de leite - Condição 11)..... 225

Figura 5-178 - Valores de pH: $\diamond$-afluente; - efluente (AnSBBR com recirculação da fase líquida e soro de leite - Condição 11). 226

Figura 5-179 - Alcalinidade total: $\diamond$-afluente; - efluente (AnSBBR com recirculação da fase líquida e soro de leite - Condição 11)................................................ 226

Figura 5-180 - Ácidos voláteis totais: $\diamond$-afluente; $\downarrow$ - efluente (AnSBBR com recirculação da fase líquida e soro de leite - Condição 11). ............................. 227

Figura 5-181 - Concentração dos compostos intermediários: $\square$ - ácido acético; $\Delta$ etanol; ○ - ácido butírico; $\mathbf{\square}$ - ácido isobutírico; $\boldsymbol{\Delta}$ - ácido capróico; $\bullet$ - ácido valérico; * ácido propiônico; +butanol; - ácido isovalérico (AnSBBR com recirculação da fase líquida e soro de leite - Condição 11)............................. 228

Figura 5-182 - Volume de biogás produzido por ciclo (AnSBBR com recirculação da fase líquida e soro de leite - Condição 11). 230

Figura 5-183 - Concentrações dos componentes do biogás no final do ciclo: $\square-\mathrm{CO}_{2} ; \Delta$ - $\mathrm{H}_{2} ; \circ-\mathrm{CH}_{4}$ (AnSBBR com recirculação da fase líquida e soro de leite Condição 11).

Figura 5-184 - Distribuições dos componentes do biogás no final do ciclo: $\square-\mathrm{CO}_{2} ; \Delta$ $\mathrm{H}_{2} ;$ O $-\mathrm{CH}_{4}$ (AnSBBR com recirculação da fase líquida e soro de leite Condição 11).

Figura 5-185 - Concentração e eficiência de degradação de carboidrato: $\diamond$ - perfil e * eficiência (AnSBBR com recirculação da fase líquida e soro de leite - Condição $11)$. 232

Figura 5-186 - Concentração e eficiência de degradação de matéria orgânica: $\diamond$ - perfil e * eficiência (AnSBBR com recirculação da fase líquida e soro de leite Condição 11).

Figura 5-187 - Ácidos voláteis totais $(\diamond)$ do perfil (AnSBBR com recirculação da fase líquida e soro de leite - Condição 11).

Figura 5-188 - Concentração dos compostos intermediários ao longo do ciclo: $\square$ - ácido acético; $\Delta$ - etanol; ○ - ácido butírico; $\mathbf{\square}$ - ácido isobutírico; $\boldsymbol{\Delta}$ - ácido capróico; - - ácido valérico; - \#-ácido propiônico; +butanol; - ácido isovalérico (AnSBBR com recirculação da fase líquida e soro de leite - Condição 11).... 234

Figura 5-189 - Valores de $\mathrm{pH}(\diamond)$ do perfil (AnSBBR com recirculação da fase líquida e soro de leite - Condição 11).

Figura 5-190 - Alcalinidade total do perfil (AnSBBR com recirculação da fase líquida e soro de leite - Condição 11).

Figura 5-191 - Produção volumétrica média acumulada do biogás durante o ciclo (AnSBBR com recirculação da fase líquida e soro de leite - Condição 11).... 237 
Figura 5-192 - Volumes acumulados médios produzidos ao longo do ciclo: $\square-\mathrm{CO}_{2} ; \Delta$ $\mathrm{H}_{2} ;$ O $-\mathrm{CH}_{4}$ (AnSBBR com recirculação da fase líquida e soro de leite Condição 11).... 238

Figura 5-193 - Concentração de matéria orgânica (DQO): $\square$ - afluente não filtrada; $\Delta$ efluente não filtrada; O - efluente filtrada (AnSBBR com recirculação da fase líquida e soro de leite - Condição 12).

Figura 5-194 - Eficiência de remoção de matéria orgânica (DQO): $\diamond$ - não filtrada; filtrada (AnSBBR com recirculação da fase líquida e soro de leite - Condição $12)$.

Figura 5-195 - Concentração de carboidrato: $\square$ - afluente não filtrada; $\Delta$ - efluente não filtrada; O - efluente filtrada (AnSBBR com recirculação da fase líquida e soro de leite - Condição 12). 243

Figura 5-196 - Eficiência de remoção de carboidrato: $\diamond$ - não filtrada; - filtrada (AnSBBR com recirculação da fase líquida e soro de leite - Condição 12)..... 243

Figura 5-197 - Valores de pH: $\diamond$-afluente; - efluente (AnSBBR com recirculação da fase líquida e soro de leite - Condição 12). 244

Figura 5-198 - Alcalinidade total: $\diamond$-afluente; - efluente (AnSBBR com recirculação da fase líquida e soro de leite - Condição 12)................................................ 244

Figura 5-199 - Ácidos voláteis totais: $\diamond$-afluente; $\downarrow$ - efluente (AnSBBR com recirculação da fase líquida e soro de leite - Condição 12). ............................ 245

Figura 5-200 - Volume de biogás produzido por ciclo (AnSBBR com recirculação da fase líquida e soro de leite - Condição 12). .................................................. 246

Figura 5-201 - Concentrações dos componentes do biogás no final do ciclo: $\square-\mathrm{CO}_{2} ; \Delta$ - $\mathrm{H}_{2} ; \mathrm{O}-\mathrm{CH}_{4}$ (AnSBBR com recirculação da fase líquida e soro de leite Condição 12).... 247

Figura 5-202 - Distribuições dos componentes do biogás no final do ciclo: $\square-\mathrm{CO}_{2} ; \Delta$ $\mathrm{H}_{2} ;$ O $-\mathrm{CH}_{4}$ (AnSBBR com recirculação da fase líquida e soro de leite Condição 12).....

Figura 5-203 - Concentração de matéria orgânica (DQO): $\square$ - afluente não filtrada; $\Delta$ efluente não filtrada; ○ - efluente filtrada (AnSBBR com recirculação da fase líquida e soro de leite - Condição 13).

Figura 5-204 - Eficiência de remoção de matéria orgânica (DQO): $\diamond$ - não filtrada; filtrada (AnSBBR com recirculação da fase líquida e soro de leite - Condição $13)$. 252

Figura 5-205 - Concentração de carboidrato: $\square$ - afluente não filtrada; $\Delta$ - efluente não filtrada; 0 - efluente filtrada (AnSBBR com recirculação da fase líquida e soro de leite - Condição 13).... 253

Figura 5-206 - Eficiência de remoção de carboidrato: $\diamond$ - não filtrada; • - filtrada (AnSBBR com recirculação da fase líquida e soro de leite - Condição 13)..... 253

Figura 5-207 - Valores de pH: $\diamond$-afluente; - efluente (AnSBBR com recirculação da fase líquida e soro de leite - Condição 13). 254

Figura 5-208 - Alcalinidade total: $\diamond$-afluente; - efluente (AnSBBR com recirculação da fase líquida e soro de leite - Condição 13)............................................... 255

Figura 5-209 - Ácidos voláteis totais: $\diamond$-afluente; - efluente (AnSBBR com recirculação da fase líquida e soro de leite - Condição 13)............................. 255

Figura 5-210 - Concentração dos compostos intermediários: $\square$ - ácido acético; $\Delta$ etanol; O - ácido butírico; - ácido isobutírico; $\boldsymbol{\Delta}$ - ácido capróico; • - ácido valérico; * ácido propiônico; +butanol; - ácido isovalérico (AnSBBR com recirculação da fase líquida e soro de leite - Condição 13). 256 
Figura 5-211 - Volume de biogás produzido por ciclo (AnSBBR com recirculação da fase líquida e soro de leite - Condição 13). .................................................... 258

Figura 5-212 - Concentrações dos componentes do biogás no final do ciclo: $\square-\mathrm{CO}_{2} ; \Delta$ - $\mathrm{H}_{2} ; \mathrm{O}-\mathrm{CH}_{4}$ (AnSBBR com recirculação da fase líquida e soro de leite Condição 13)..... 258

Figura 5-213 - Distribuições dos componentes do biogás no final do ciclo: $\square-\mathrm{CO}_{2} ; \Delta$ $\mathrm{H}_{2} ;$ o $-\mathrm{CH}_{4}$ (AnSBBR com recirculação da fase líquida e soro de leite Condição 13). 259

Figura 5-214 - Concentração e eficiência de degradação de carboidrato: $\diamond$ - perfil e * eficiência (AnSBBR com recirculação da fase líquida e soro de leite - Condição $13)$. 260

Figura 5-215 - Concentração e eficiência de degradação de matéria orgânica: $\diamond$ - perfil e * eficiência (AnSBBR com recirculação da fase líquida e soro de leite Condição 13)...... 261

Figura 5-216 - Ácidos voláteis totais $(\diamond)$ do perfil (AnSBBR com recirculação da fase líquida e soro de leite - Condição 13). 261

Figura 5-217 - Concentração dos compostos intermediários ao longo do ciclo: $\square$ - ácido acético; $\Delta$ - etanol; ○ - ácido butírico; $\mathbf{\square}$ - ácido isobutírico; $\boldsymbol{\Delta}$ - ácido capróico; - - ácido valérico; -ácido propiônico; +butanol; - ácido isovalérico (AnSBBR com recirculação da fase líquida e soro de leite - Condição 13)..... 262

Figura 5-218 - Valores de $\mathrm{pH}(\diamond)$ do perfil (AnSBBR com recirculação da fase líquida e soro de leite - Condição 13). 263

Figura 5-219 - Alcalinidade total do perfil (AnSBBR com recirculação da fase líquida e soro de leite - Condição 13). 263

Figura 5-220 - Produção volumétrica média acumulada do biogás durante o ciclo (AnSBBR com recirculação da fase líquida e soro de leite - Condição 13).... 264

Figura 5-221 - Volumes acumulados médios produzidos ao longo do ciclo: $\square-\mathrm{CO}_{2} ; \Delta$ $\mathrm{H}_{2} ;$ o $-\mathrm{CH}_{4}$ (AnSBBR com recirculação da fase líquida e soro de leite Condição 13). 265

Figura 5-222 - Concentração de matéria orgânica (DQO): $\square$ - afluente não filtrada; $\Delta$ efluente não filtrada; O - efluente filtrada (AnSBBR com agitação mecânica e lactose - Condição 1).

Figura 5-223-Eficiência de remoção de matéria orgânica (DQO): $\diamond$ - não filtrada; filtrada (AnSBBR com agitação mecânica e lactose - Condição 1). 269

Figura 5-224 - Concentração de carboidrato: $\square$ - afluente não filtrada; $\Delta$ - efluente não filtrada; O - efluente filtrada (AnSBBR com agitação mecânica e lactose Condição 1). 270

Figura 5-225 - Eficiência de remoção de carboidrato: $\diamond$ - não filtrada; - filtrada (AnSBBR com agitação mecânica e lactose - Condição 1)............................. 270

Figura 5-226 - Valores de pH: $\diamond$-afluente; - efluente (AnSBBR com agitação mecânica e lactose - Condição 1).

Figura 5-227 - Alcalinidade total: $\diamond$-afluente; - efluente (AnSBBR com agitação mecânica e lactose - Condição 1). 271

Figura 5-228 - Ácidos voláteis totais: $\diamond$-afluente; $\bullet$ - efluente (AnSBBR com agitação mecânica e lactose - Condição 1). 272

Figura 5-229 - Concentração dos compostos intermediários: $\square$ - ácido acético; $\Delta$ etanol; O - ácido butírico; - ácido isobutírico; $\boldsymbol{\Delta}$ - ácido capróico; • - ácido valérico; * ácido propiônico; +butanol; - ácido isovalérico (AnSBBR com agitação mecânica e lactose - Condição 1). 
Figura 5-230 - Volume de biogás produzido por ciclo (AnSBBR com agitação mecânica

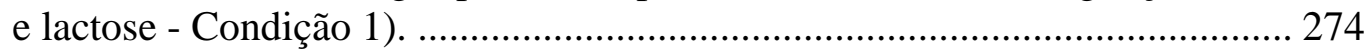

Figura 5-231 - Concentrações dos componentes do biogás no final do ciclo: $\square-\mathrm{CO}_{2} ; \Delta$ - $\mathrm{H}_{2} ; \mathrm{O}-\mathrm{CH}_{4}$ (AnSBBR com agitação mecânica e lactose - Condição 1)....... 275

Figura 5-232 - Distribuições dos componentes do biogás no final do ciclo: $\square-\mathrm{CO}_{2} ; \Delta$ $\mathrm{H}_{2} ; \circ-\mathrm{CH}_{4}($ AnSBBR com agitação mecânica e lactose - Condição 1)......... 275

Figura 5-233 - Concentração e eficiência de degradação de carboidrato: $\diamond$ - perfil e * eficiência (AnSBBR com agitação mecânica e lactose - Condição 1)............. 276

Figura 5-234 - Concentração e eficiência de degradação de matéria orgânica: $\diamond$ - perfil e * eficiência (AnSBBR com agitação mecânica e lactose - Condição 1).......... 277

Figura 5-235 - Ácidos voláteis totais $(\diamond)$ do perfil (AnSBBR com agitação mecânica e lactose - Condição 1).................................................................................. 277

Figura 5-236 - Concentração dos compostos intermediários ao longo do ciclo: $\square$ - ácido acético; $\Delta$ - etanol; ○ - ácido butírico; $\mathbf{\square}$ - ácido isobutírico; $\boldsymbol{\Delta}$ - ácido capróico; - - ácido valérico; - \#-ácido propiônico; +butanol; - ácido isovalérico (AnSBBR com agitação mecânica e lactose - Condição 1)............................. 278

Figura 5-237 - Valores de pH $(\diamond)$ do perfil (AnSBBR com agitação mecânica e lactose Condição 1).

Figura 5-238 - Alcalinidade total $(\diamond)$ do perfil (AnSBBR com agitação mecânica e lactose - Condição 1)..................................................................................... 279

Figura 5-239 - Produção volumétrica média acumulada do biogás durante o ciclo (AnSBBR com agitação mecânica e lactose - Condição 1)............................... 280

Figura 5-240 - Volumes acumulados médios produzidos ao longo do ciclo: $\square-\mathrm{CO}_{2} ; \Delta$ $\mathrm{H}_{2} ; \mathrm{O}-\mathrm{CH}_{4}($ AnSBBR com agitação mecânica e lactose - Condição 1)......... 281

Figura 5-241 - Concentração de matéria orgânica (DQO): $\square$ - afluente não filtrada; $\Delta$ efluente não filtrada; ○ - efluente filtrada (AnSBBR com agitação mecânica e lactose - Condição 2) ................................................................................. 284

Figura 5-242 - Eficiência de remoção de matéria orgânica (DQO): $\diamond$ - não filtrada; filtrada (AnSBBR com agitação mecânica e lactose - Condição 2)................. 285

Figura 5-243 - Concentração de carboidrato: $\square$ - afluente não filtrada; $\Delta$ - efluente não filtrada; 0 - efluente filtrada (AnSBBR com agitação mecânica e lactose Condição 2). 286

Figura 5-244 - Eficiência de remoção de carboidrato: $\diamond$ - não filtrada; - filtrada (AnSBBR com agitação mecânica e lactose - Condição 2)............................. 286

Figura 5-245 - Valores de pH: $\diamond$-afluente; $\bullet$ - efluente (AnSBBR com agitação mecânica e lactose - Condição 2). .................................................................. 287

Figura 5-246 - Alcalinidade total: $\diamond$-afluente; - efluente (AnSBBR com agitação mecânica e lactose - Condição 2). ................................................................. 287

Figura 5-247 - Ácidos voláteis totais: $\diamond$-afluente; - efluente (AnSBBR com agitação mecânica e lactose - Condição 2)............................................................... 288

Figura 5-248 - Concentração dos compostos intermediários: $\square$ - ácido acético; $\Delta$ etanol; ○ - ácido butírico; - ácido isobutírico; $\boldsymbol{\Delta}$ - ácido capróico; • - ácido valérico; * ácido propiônico; +butanol; - ácido isovalérico (AnSBBR com agitação mecânica e lactose - Condição 2).................................................. 289

Figura 5-249 - Volume de biogás produzido por ciclo (AnSBBR com agitação mecânica e lactose - Condição 2). 290

Figura 5-250 - Concentrações dos componentes do biogás no final do ciclo: $\square-\mathrm{CO}_{2} ; \Delta$ - $\mathrm{H}_{2}$; O - $\mathrm{CH}_{4}$ (AnSBBR com agitação mecânica e lactose - Condição 2)....... 291

Figura 5-251 - Distribuições dos componentes do biogás no final do ciclo: $\square-\mathrm{CO}_{2} ; \Delta$ $\mathrm{H}_{2} ;$ O $-\mathrm{CH}_{4}$ (AnSBBR com agitação mecânica e lactose - Condição 2)......... 291 
Figura 5-252 - Concentração e eficiência de degradação de carboidrato: $\diamond$ - perfil e * eficiência (AnSBBR com agitação mecânica e lactose - Condição 2). ............ 292

Figura 5-253 - Concentração e eficiência de degradação de matéria orgânica: $\diamond$ - perfil e * eficiência (AnSBBR com agitação mecânica e lactose - Condição 2). ......... 293

Figura 5-254 - Ácidos voláteis totais $(\diamond)$ do perfil (AnSBBR com agitação mecânica e lactose - Condição 2). 293

Figura 5-255 - Concentração dos compostos intermediários ao longo do ciclo: $\square-$ ácido acético; $\Delta$ - etanol; ○ - ácido butírico; $\mathbf{\square}$ - ácido isobutírico; $\boldsymbol{\Delta}$ - ácido capróico; - - ácido valérico; \#-ácido propiônico; +butanol; - ácido isovalérico (AnSBBR com agitação mecânica e lactose - Condição 2).

Figura 5-256 - Valores de pH $(\diamond)$ do perfil (AnSBBR com agitação mecânica e lactose Condição 2). 295

Figura 5-257 - Alcalinidade total $(\diamond)$ do perfil (AnSBBR com agitação mecânica e lactose - Condição 2). 295

Figura 5-258 - Produção volumétrica média acumulada do biogás durante o ciclo (AnSBBR com agitação mecânica e lactose - Condição 2). 296

Figura 5-259 - Volumes acumulados médios produzidos ao longo do ciclo: $\square-\mathrm{CO}_{2} ; \Delta$ $\mathrm{H}_{2} ;$ o - $\mathrm{CH}_{4}$ (AnSBBR com agitação mecânica e lactose - Condição 2)......... 297

Figura 5-260 - Concentração de matéria orgânica (DQO): $\square$ - afluente não filtrada; $\Delta$ efluente não filtrada; O - efluente filtrada (AnSBBR com agitação mecânica e lactose - Condição 3).

Figura 5-261 - Eficiência de remoção de matéria orgânica (DQO): $\diamond$ - não filtrada; filtrada (AnSBBR com agitação mecânica e lactose - Condição 3)................ 301

Figura 5-262 - Concentração de carboidrato: $\square$ - afluente não filtrada; $\Delta$ - efluente não filtrada; O - efluente filtrada (AnSBBR com agitação mecânica e lactose Condição 3). 302

Figura 5-263 - Eficiência de remoção de carboidrato: $\diamond$ - não filtrada; - filtrada (AnSBBR com agitação mecânica e lactose - Condição 3)............................. 302

Figura 5-264 - Valores de pH: $\diamond$-afluente; - efluente (AnSBBR com agitação mecânica e lactose - Condição 3).

Figura 5-265 - Alcalinidade total: $\diamond$-afluente; - efluente (AnSBBR com agitação mecânica e lactose - Condição 3). 303

Figura 5-266 - Ácidos voláteis totais: $\diamond$-afluente; $\bullet$ - efluente (AnSBBR com agitação mecânica e lactose - Condição 3). 304

Figura 5-267 - Concentração dos compostos intermediários: $\square$ - ácido acético; $\Delta$ etanol; O - ácido butírico; $\mathbf{- a ́ c i d o ~ i s o b u t i ́ r i c o ; ~} \boldsymbol{\Delta}$ - ácido capróico; • - ácido valérico; — ácido propiônico; +butanol; — ácido isovalérico (AnSBBR com agitação mecânica e lactose - Condição 3). 305

Figura 5-268 - Volume de biogás produzido por ciclo (AnSBBR com agitação mecânica e lactose - Condição 3). 306

Figura 5-269 - Concentrações dos componentes do biogás no final do ciclo: $\square-\mathrm{CO}_{2} ; \Delta$ - $\mathrm{H}_{2} ; \mathrm{O}-\mathrm{CH}_{4}$ (AnSBBR com agitação mecânica e lactose - Condição 3)....... 307

Figura 5-270 - Distribuições dos componentes do biogás no final do ciclo: $\square-\mathrm{CO}_{2} ; \Delta$ $\mathrm{H}_{2} ;$ o - $\mathrm{CH}_{4}$ (AnSBBR com agitação mecânica e lactose - Condição 3)......... 307

Figura 5-271 - Concentração e eficiência de degradação de carboidrato: $\diamond$ - perfil e * eficiência (AnSBBR com agitação mecânica e lactose - Condição 3)............. 308

Figura 5-272 - Concentração e eficiência de degradação de matéria orgânica: $\diamond$ - perfil e * eficiência (AnSBBR com agitação mecânica e lactose - Condição 3). ......... 309

Figura 5-273 - Ácidos voláteis totais $(\diamond)$ do perfil (AnSBBR com agitação mecânica e lactose - Condição 3). 309 
Figura 5-274 - Concentração dos compostos intermediários ao longo do ciclo: $\square$ - ácido acético; $\Delta$ - etanol; ○ - ácido butírico; $\mathbf{\square}$ - ácido isobutírico; $\boldsymbol{\Delta}$ - ácido capróico; - - ácido valérico; - \#-ácido propiônico; +butanol; - ácido isovalérico (AnSBBR com agitação mecânica e lactose - Condição 3). 310

Figura 5-275 - Valores de pH $(\diamond)$ do perfil (AnSBBR com agitação mecânica e lactose Condição 3) 311

Figura 5-276 - Alcalinidade total $(\diamond)$ do perfil (AnSBBR com agitação mecânica e lactose - Condição 3).

Figura 5-277 - Produção volumétrica média acumulada do biogás durante o ciclo (AnSBBR com agitação mecânica e lactose - Condição 3). 312

Figura 5-278 - Volumes acumulados médios produzidos ao longo do ciclo: $\square-\mathrm{CO}_{2}$; $\Delta$ $\mathrm{H}_{2} ; \mathrm{O}-\mathrm{CH}_{4}($ AnSBBR com agitação mecânica e lactose - Condição 3)......... 313

Figura 5-279 - Concentração de matéria orgânica (DQO): $\square$ - afluente não filtrada; $\Delta$ efluente não filtrada; O - efluente filtrada (AnSBBR com agitação mecânica e lactose - Condição 4).

Figura 5-280 - Eficiência de remoção de matéria orgânica (DQO): $\diamond$ - não filtrada; filtrada (AnSBBR com agitação mecânica e lactose - Condição 4).

Figura 5-281 - Concentração de carboidrato: $\square$ - afluente não filtrada; $\Delta$ - efluente não filtrada; O - efluente filtrada (AnSBBR com agitação mecânica e lactose Condição 4). 318

Figura 5-282 - Eficiência de remoção de carboidrato: $\diamond$ - não filtrada; - filtrada (AnSBBR com agitação mecânica e lactose - Condição 4).............................. 318

Figura 5-283 - Valores de pH: $\diamond$-afluente; - efluente (AnSBBR com agitação mecânica e lactose - Condição 4).

Figura 5-284 - Alcalinidade total: $\diamond$-afluente; - efluente (AnSBBR com agitação mecânica e lactose - Condição 4). 319

Figura 5-285 - Ácidos voláteis totais: $\diamond$-afluente; - efluente (AnSBBR com agitação mecânica e lactose - Condição 4).

Figura 5-286 - Concentração dos compostos intermediários: $\square$ - ácido acético; $\Delta$ etanol; ○ - ácido butírico; $\mathbf{\square}$ - ácido isobutírico; $\boldsymbol{\Delta}$ - ácido capróico; $\bullet$ - ácido valérico; - - ácido propiônico; +butanol; - ácido isovalérico (AnSBBR com agitação mecânica e lactose - Condição 4).

Figura 5-287 - Volume de biogás produzido por ciclo (AnSBBR com agitação mecânica e lactose - Condição 4). 322

Figura 5-288 - Concentrações dos componentes do biogás no final do ciclo: $\square-\mathrm{CO}_{2} ; \Delta$ - $\mathrm{H}_{2} ; \mathrm{O}-\mathrm{CH}_{4}$ (AnSBBR com agitação mecânica e lactose - Condição 4)....... 323

Figura 5-289 - Distribuições dos componentes do biogás no final do ciclo: $\square-\mathrm{CO}_{2}$; $\Delta$ $\mathrm{H}_{2} ; \mathrm{O}-\mathrm{CH}_{4}$ (AnSBBR com agitação mecânica e lactose - Condição 4)......... 323

Figura 5-290 - Concentração e eficiência de degradação de carboidrato: $\diamond$ - perfil e * eficiência (AnSBBR com agitação mecânica e lactose - Condição 4). ............ 324

Figura 5-291 - Concentração e eficiência de degradação de matéria orgânica: $\diamond$ - perfil e * eficiência (AnSBBR com agitação mecânica e lactose - Condição 4). ......... 325

Figura 5-292 - Ácidos voláteis totais $(\diamond)$ do perfil (AnSBBR com agitação mecânica e lactose - Condição 4). 325

Figura 5-293 - Concentração dos compostos intermediários ao longo do ciclo: $\square$ - ácido acético; $\Delta$ - etanol; ○ - ácido butírico; - ácido isobutírico; $\boldsymbol{\Delta}$ - ácido capróico; - - ácido valérico; ※ácido propiônico; +butanol; - ácido isovalérico (AnSBBR com agitação mecânica e lactose - Condição 4). 326

Figura 5-294 - Valores de pH $(\diamond)$ do perfil (AnSBBR com agitação mecânica e lactose Condição 4). 
Figura 5-295 - Alcalinidade total do perfil (AnSBBR com agitação mecânica e lactose Condição 4)

Figura 5-296 - Produção volumétrica média acumulada do biogás durante o ciclo (AnSBBR com agitação mecânica e lactose - Condição 4). 328

Figura 5-297 - Volumes acumulados médios produzidos ao longo do ciclo: $\square-\mathrm{CO}_{2} ; \Delta$ $\mathrm{H}_{2} ;$ ○ - $\mathrm{CH}_{4}$ (AnSBBR com agitação mecânica e lactose - Condição 4)......... 329

Figura 5-298 - Concentração de matéria orgânica (DQO): $\square$ - afluente não filtrada; $\Delta$ efluente não filtrada; O - efluente filtrada (AnSBBR com agitação mecânica e lactose - Condição 5).

Figura 5-299-Eficiência de remoção de matéria orgânica (DQO): $\diamond$ - não filtrada; filtrada (AnSBBR com agitação mecânica e lactose - Condição 5).

Figura 5-300 - Concentração de carboidrato: $\square$ - afluente não filtrada; $\Delta$ - efluente não filtrada; O - efluente filtrada (AnSBBR com agitação mecânica e lactose Condição 5)..... 334

Figura 5-301 - Eficiência de remoção de carboidrato: $\diamond$ - não filtrada; - filtrada (AnSBBR com agitação mecânica e lactose - Condição 5). 334

Figura 5-302 - Valores de pH: $\diamond$-afluente; • - efluente (AnSBBR com agitação mecânica e lactose - Condição 5).

Figura 5-303 - Alcalinidade total: $\diamond$-afluente; $\bullet$ - efluente (AnSBBR com agitação mecânica e lactose - Condição 5).

Figura 5-304 - Ácidos voláteis totais: $\diamond$-afluente; - efluente (AnSBBR com agitação mecânica e lactose - Condição 5). 336

Figura 5-305 - Concentração dos compostos intermediários: $\square$ - ácido acético; $\Delta$ etanol; O - ácido butírico; - ácido isobutírico; $\boldsymbol{\Delta}$ - ácido capróico; $\bullet$ - ácido valérico; - a ácido propiônico; +butanol; - ácido isovalérico (AnSBBR com agitação mecânica e lactose - Condição 5).

Figura 5-306 - Volume de biogás produzido por ciclo (AnSBBR com agitação mecânica e lactose - Condição 5). 338

Figura 5-307 - Concentrações dos componentes do biogás no final do ciclo: $\square-\mathrm{CO}_{2} ; \Delta$ - $\mathrm{H}_{2} ;$ ○ - $\mathrm{CH}_{4}$ (AnSBBR com agitação mecânica e lactose - Condição 5)....... 339

Figura 5-308 - Distribuições dos componentes do biogás no final do ciclo: $\square-\mathrm{CO}_{2} ; \Delta$ $\mathrm{H}_{2} ; \mathrm{O}-\mathrm{CH}_{4}$ (AnSBBR com agitação mecânica e lactose - Condição 5)......... 339

Figura 5-309 - Concentração e eficiência de degradação de carboidrato: $\diamond$ - perfil e $*$ eficiência (AnSBBR com agitação mecânica e lactose - Condição 5). 340

Figura 5-310 - Concentração e eficiência de degradação de matéria orgânica: $\diamond$ - perfil e * eficiência (AnSBBR com agitação mecânica e lactose - Condição 5).

Figura 5-311 - Ácidos voláteis totais $(\diamond)$ do perfil (AnSBBR com agitação mecânica e lactose - Condição 5). 341

Figura 5-312 - Concentração dos compostos intermediários ao longo do ciclo: $\square$ - ácido acético; $\Delta$ - etanol; O - ácido butírico; $\mathbf{\square}$ - ácido isobutírico; $\boldsymbol{\Delta}$ - ácido capróico; - - ácido valérico; - \#-ácido propiônico; †butanol; - ácido isovalérico (AnSBBR com agitação mecânica e lactose - Condição 5). 342

Figura 5-313 - Valores de $\mathrm{pH}(\diamond)$ do perfil (AnSBBR com agitação mecânica e lactose Condição 5).

Figura 5-314 - Alcalinidade total $(\diamond)$ do perfil (AnSBBR com agitação mecânica e lactose - Condição 5). 343

Figura 5-315 - Produção volumétrica média acumulada do biogás durante o ciclo (AnSBBR com agitação mecânica e lactose - Condição 5). 344

Figura 5-316 - Volumes acumulados médios produzidos ao longo do ciclo: $\square-\mathrm{CO}_{2} ; \Delta$ $\mathrm{H}_{2} ;$ ○ $-\mathrm{CH}_{4}$ (AnSBBR com agitação mecânica e lactose - Condição 5). 345 
Figura 5-317 - Concentração de matéria orgânica (DQO): $\square$ - afluente não filtrada; $\Delta$ efluente não filtrada; O - efluente filtrada (AnSBBR com agitação mecânica e lactose - Condição 6).

Figura 5-318 - Eficiência de remoção de matéria orgânica (DQO): $\diamond$ - não filtrada; filtrada (AnSBBR com agitação mecânica e lactose - Condição 6).

Figura 5-319 - Concentração de carboidrato: $\square$ - afluente não filtrada; $\Delta$ - efluente não filtrada; $\bigcirc$ - efluente filtrada (AnSBBR com agitação mecânica e lactose Condição 6). 350

Figura 5-320 - Eficiência de remoção de carboidrato: $\diamond$ - não filtrada; $\bullet$ - filtrada (AnSBBR com agitação mecânica e lactose - Condição 6).............................. 350

Figura 5-321 - Valores de pH: $\diamond$-afluente; - efluente (AnSBBR com agitação mecânica e lactose - Condição 6). 351

Figura 5-322 - Alcalinidade total: $\diamond$-afluente; - efluente (AnSBBR com agitação mecânica e lactose - Condição 6). 351

Figura 5-323 - Ácidos voláteis totais: $\diamond$-afluente; $\downarrow$ - efluente (AnSBBR com agitação mecânica e lactose - Condição 6). 352

Figura 5-324 - Concentração dos compostos intermediários: $\square$ - ácido acético; $\Delta$ etanol; O - ácido butírico; $\mathbf{\square}$ - ácido isobutírico; $\boldsymbol{\Delta}$ - ácido capróico; $\bullet$ - ácido valérico; - ácido propiônico; †butanol; - ácido isovalérico (AnSBBR com agitação mecânica e lactose - Condição 6). 353

Figura 5-325 - Volume de biogás produzido por ciclo (AnSBBR com agitação mecânica e lactose - Condição 6). 354

Figura 5-326 - Concentrações dos componentes do biogás no final do ciclo: $\square-\mathrm{CO}_{2} ; \Delta$ - $\mathrm{H}_{2} ;$ ○ - $\mathrm{CH}_{4}$ (AnSBBR com agitação mecânica e lactose - Condição 6)....... 355

Figura 5-327 - Distribuições dos componentes do biogás no final do ciclo: $\square-\mathrm{CO}_{2} ; \Delta-$ $\mathrm{H}_{2} ;$ ○ - $\mathrm{CH}_{4}$ (AnSBBR com agitação mecânica e lactose - Condição 6)......... 355

Figura 5-328 - Concentração e eficiência de degradação de carboidrato: $\diamond$ - perfil e * eficiência (AnSBBR com agitação mecânica e lactose - Condição 6). ............ 356

Figura 5-329 - Concentração e eficiência de degradação de matéria orgânica: $\diamond$ - perfil e * eficiência (AnSBBR com agitação mecânica e lactose - Condição 6). 357

Figura 5-330 - Ácidos voláteis totais $(\diamond)$ do perfil (AnSBBR com agitação mecânica e lactose - Condição 6). 357

Figura 5-331 - Concentração dos compostos intermediários ao longo do ciclo: $\square$ - ácido acético; $\Delta$ - etanol; ○ - ácido butírico; $\boldsymbol{\square}$ - ácido isobutírico; $\boldsymbol{\Delta}$ - ácido capróico; - - ácido valérico; - ácido propiônico; +butanol; - ácido isovalérico (AnSBBR com agitação mecânica e lactose - Condição 6). 358

Figura 5-332 - Valores de $\mathrm{pH}(\diamond)$ do perfil (AnSBBR com agitação mecânica e lactose Condição 6). 359

Figura 5-333 - Alcalinidade total $(\diamond)$ do perfil (AnSBBR com agitação mecânica e lactose - Condição 6).

Figura 5-334 - Produção volumétrica média acumulada do biogás durante o ciclo (AnSBBR com agitação mecânica e lactose - Condição 6).............................. 360

Figura 5-335 - Volumes acumulados médios produzidos ao longo do ciclo: $\square-\mathrm{CO}_{2} ; \Delta$ $\mathrm{H}_{2} ; \mathrm{O}-\mathrm{CH}_{4}$ (AnSBBR com agitação mecânica e lactose - Condição 6)......... 361

Figura 5-336 - Fluxograma das condições operadas na primeira fase do presente trabalho (AnSBBR com recirculação da fase líquida e soro de leite). 364

Figura 5-337 - Concentração de matéria orgânica (DQO): $\square$ - afluente não filtrada; $\Delta$ efluente não filtrada; $\circ$ - efluente filtrada (Soro de leite: $\mathrm{C} 1=$ Sem adaptação e afluente não refrigerado - 4250 mgDQO. $\mathrm{L}^{-1}-\mathrm{t}_{\mathrm{C}} 4 \mathrm{~h} ; \mathrm{C} 2$ = Adaptação com sacarose e afluente não refrigerado - $4250 \mathrm{mgDQO} . \mathrm{L}^{-1}-\mathrm{t}_{\mathrm{C}} 4 \mathrm{~h} ; \mathrm{C} 3=$ Adaptação 
com lactose e afluente (não) refrigerado - $4250 \mathrm{mgDQO} \cdot \mathrm{L}^{-1}-\mathrm{t}_{\mathrm{C}} 4 \mathrm{~h} ; \mathrm{C} 4=\mathrm{Sem}$ adaptação e afluente não refrigerado - $4250 \mathrm{mgDQO} . \mathrm{L}^{-1}-\mathrm{t}_{\mathrm{C}} 3 \mathrm{~h}$; C5 $=$ Sem adaptação e afluente refrigerado - $4250 \mathrm{mgDQO} \cdot \mathrm{L}^{-1}-\mathrm{t}_{\mathrm{C}} 3 \mathrm{~h}$; C6 = Adaptação com lactose e afluente refrigerado - $4250 \mathrm{mgDQO} . \mathrm{L}^{-1}-\mathrm{t}_{\mathrm{C}} 3 \mathrm{~h} ; \mathrm{C} 7=$ Adaptação com lactose, alimentação com leite desnatado e afluente refrigerado - 4250 $\operatorname{mgDQO} . \mathrm{L}^{-1}-\mathrm{t}_{\mathrm{C}} 3 \mathrm{~h}$; $\mathrm{C} 8=$ Afluente (soro de leite) sem solução de nutrientes e ureia, com lavagem semanal e afluente - $4250 \mathrm{mgDQO} . \mathrm{L}^{-1}-\mathrm{t}_{\mathrm{C}} 3 \mathrm{~h}$ ).. 366

Figura 5-338 - Eficiência de remoção de matéria orgânica (DQO): $\diamond$ - não filtrada; filtrada (Soro de leite: $\mathrm{C} 1$ = Sem adaptação e afluente não refrigerado - 4250 $\operatorname{mgDQO} . \mathrm{L}^{-1}-\mathrm{t}_{\mathrm{C}} 4 \mathrm{~h} ; \mathrm{C} 2$ = Adaptação com sacarose e afluente não refrigerado $4250 \mathrm{mgDQO} \cdot \mathrm{L}^{-1}-\mathrm{t}_{\mathrm{C}} 4 \mathrm{~h}$; $\mathrm{C} 3=$ Adaptação com lactose e afluente (não) refrigerado - $4250 \mathrm{mgDQO} . \mathrm{L}^{-1}-\mathrm{t}_{\mathrm{C}} 4 \mathrm{~h} ; \mathrm{C} 4=$ Sem adaptação e afluente não refrigerado - $4250 \mathrm{mgDQO} . \mathrm{L}^{-1}-\mathrm{t}_{\mathrm{C}} 3 \mathrm{~h} ; \mathrm{C} 5=$ Sem adaptação e afluente refrigerado - $4250 \mathrm{mgDQO} . \mathrm{L}^{-1}-\mathrm{t}_{\mathrm{C}} 3 \mathrm{~h}$; $\mathrm{C} 6=$ Adaptação com lactose e afluente refrigerado - $4250 \mathrm{mgDQO} \cdot \mathrm{L}^{-1}-\mathrm{t}_{\mathrm{C}} 3 \mathrm{~h} ; \mathrm{C} 7=$ Adaptação com lactose, alimentação com leite desnatado e afluente refrigerado - $4250 \mathrm{mgDQO} . \mathrm{L}^{-1}-\mathrm{t}_{\mathrm{C}}$ 3h; C8 = Afluente (soro de leite) sem solução de nutrientes e ureia, com lavagem semanal e afluente - $4250 \mathrm{mgDQO} . \mathrm{L}^{-1}-\mathrm{t}_{\mathrm{C}} 3 \mathrm{~h}$ ).

Figura 5-339 - Concentração de carboidrato: $\square-$ afluente não filtrada; $\Delta$ - efluente não filtrada; $\circ$ - efluente filtrada (Soro de leite: $\mathrm{C} 1=$ Sem adaptação e afluente não refrigerado - $4250 \mathrm{mgDQO} . \mathrm{L}^{-1}-\mathrm{t}_{\mathrm{C}} 4 \mathrm{~h} ; \mathrm{C} 2=$ Adaptação com sacarose e afluente não refrigerado - $4250 \mathrm{mgDQO} . \mathrm{L}^{-1}-\mathrm{t}_{\mathrm{C}} 4 \mathrm{~h} ; \mathrm{C} 3=$ Adaptação com lactose $\mathrm{e}$ afluente (não) refrigerado - $4250 \mathrm{mgDQO} \cdot \mathrm{L}^{-1}-\mathrm{t}_{\mathrm{C}} 4 \mathrm{~h}$; $\mathrm{C} 4=$ Sem adaptação e afluente não refrigerado - $4250 \mathrm{mgDQO} \cdot \mathrm{L}^{-1}-\mathrm{t}_{\mathrm{C}} 3 \mathrm{~h}$; C5 = Sem adaptação e afluente refrigerado - $4250 \mathrm{mgDQO} . \mathrm{L}^{-1}-\mathrm{t}_{\mathrm{C}} 3 \mathrm{~h}$; C6 = Adaptação com lactose e afluente refrigerado - $4250 \mathrm{mgDQO} . \mathrm{L}^{-1}-\mathrm{t}_{\mathrm{C}} 3 \mathrm{~h} ; \mathrm{C} 7=$ Adaptação com lactose, alimentação com leite desnatado e afluente refrigerado - $4250 \mathrm{mgDQO} . \mathrm{L}^{-1}-\mathrm{t}_{\mathrm{C}}$ 3h; $\mathrm{C} 8=$ Afluente (soro de leite) sem solução de nutrientes e ureia, com lavagem semanal e afluente - $4250 \mathrm{mgDQO} . \mathrm{L}^{-1}-\mathrm{t}_{\mathrm{C}} 3 \mathrm{~h}$ ).

Figura 5-340 - Eficiência de remoção de carboidrato: $\diamond$ - não filtrada; - filtrada (Soro de leite: $\mathrm{C} 1=$ Sem adaptação e afluente não refrigerado $-4250 \mathrm{mgDQO} . \mathrm{L}^{-1}-\mathrm{t}_{\mathrm{C}}$ 4h; C2 = Adaptação com sacarose e afluente não refrigerado - $4250 \mathrm{mgDQO} . \mathrm{L}^{-1}$ - $\mathrm{t}_{\mathrm{C}} 4 \mathrm{~h} ; \mathrm{C} 3$ = Adaptação com lactose e afluente (não) refrigerado - 4250 $\operatorname{mgDQO} . \mathrm{L}^{-1}-\mathrm{t}_{\mathrm{C}} 4 \mathrm{~h} ; \mathrm{C} 4$ = Sem adaptação e afluente não refrigerado - 4250 mgDQO. $L^{-1}-\mathrm{t}_{\mathrm{C}} 3 \mathrm{~h} ; \mathrm{C} 5=$ Sem adaptação e afluente refrigerado - 4250 mgDQO. $L^{-1}-t_{C} 3 h ; C 6=$ Adaptação com lactose e afluente refrigerado - 4250 mgDQO. $\mathrm{L}^{-1}-\mathrm{t}_{\mathrm{C}} 3 \mathrm{~h} ; \mathrm{C7}=$ Adaptação com lactose, alimentação com leite desnatado e afluente refrigerado - $4250 \mathrm{mgDQO} . \mathrm{L}^{-1}-\mathrm{t}_{\mathrm{C}} 3 \mathrm{~h} ; \mathrm{C} 8=$ Afluente (soro de leite) sem solução de nutrientes e ureia, com lavagem semanal e afluente $4250 \mathrm{mgDQO} . \mathrm{L}^{-1}-\mathrm{t}_{\mathrm{C}} 3 \mathrm{~h}$ ). 370

Figura 5-341 - Valores de pH: $\diamond$-afluente; - efluente (Soro de leite: $\mathrm{C} 1=$ Sem adaptação e afluente não refrigerado - $4250 \mathrm{mgDQO} \cdot \mathrm{L}^{-1}-\mathrm{t}_{\mathrm{C}} 4 \mathrm{~h} ; \mathrm{C} 2=$ Adaptação com sacarose e afluente não refrigerado - $4250 \mathrm{mgDQO} \cdot \mathrm{L}^{-1}-\mathrm{t}_{\mathrm{C}} 4 \mathrm{~h} ; \mathrm{C} 3=$ Adaptação com lactose e afluente (não) refrigerado - $4250 \mathrm{mgDQO} . \mathrm{L}^{-1}-\mathrm{t}_{\mathrm{C}} 4 \mathrm{~h}$; $\mathrm{C} 4=$ Sem adaptação e afluente não refrigerado $-4250 \mathrm{mgDQO} \cdot \mathrm{L}^{-1}-\mathrm{t}_{\mathrm{C}} 3 \mathrm{~h}$; $\mathrm{C} 5=$ Sem adaptação e afluente refrigerado - 4250 mgDQO.L $\mathrm{L}^{-1}-\mathrm{t}_{\mathrm{C}} 3 \mathrm{~h}$; C6 = Adaptação com lactose e afluente refrigerado - 4250 mgDQO.L ${ }^{-1}-\mathrm{t}_{\mathrm{C}} 3 \mathrm{~h} ; \mathrm{C} 7=$ Adaptação com lactose, alimentação com leite desnatado e afluente refrigerado $4250 \mathrm{mgDQO} . \mathrm{L}^{-1}-\mathrm{t}_{\mathrm{C}} 3 \mathrm{~h} ; \mathrm{C} 8=$ Afluente (soro de leite) sem solução de 
nutrientes e ureia, com lavagem semanal e afluente - $4250 \mathrm{mgDQO} . \mathrm{L}^{-1}-\mathrm{t}_{\mathrm{C}} 3 \mathrm{~h}$ ).

Figura 5-342 - Ácidos voláteis totais: $\diamond$-afluente; - efluente (Soro de leite: $\mathrm{C} 1=$ Sem adaptação e afluente não refrigerado - $4250 \mathrm{mgDQO} \cdot \mathrm{L}^{-1}-\mathrm{t}_{\mathrm{C}} 4 \mathrm{~h} ; \mathrm{C} 2$ = Adaptação com sacarose e afluente não refrigerado - $4250 \mathrm{mgDQO} \cdot \mathrm{L}^{-1}-\mathrm{t}_{\mathrm{C}} 4 \mathrm{~h} ; \mathrm{C} 3=$ Adaptação com lactose e afluente (não) refrigerado - $4250 \mathrm{mgDQO} . \mathrm{L}^{-1}-\mathrm{t}_{\mathrm{C}} 4 \mathrm{~h}$; $\mathrm{C} 4=$ Sem adaptação e afluente não refrigerado $-4250 \mathrm{mgDQO} . \mathrm{L}^{-1}-\mathrm{t}_{\mathrm{C}} 3 \mathrm{~h}$; $\mathrm{C} 5=$ Sem adaptação e afluente refrigerado - 4250 mgDQO. $\mathrm{L}^{-1}-\mathrm{t}_{\mathrm{C}} 3 \mathrm{~h}$; $\mathrm{C} 6=$ Adaptação com lactose e afluente refrigerado - 4250 mgDQO. $\mathrm{L}^{-1}-\mathrm{t}_{\mathrm{C}} 3 \mathrm{~h} ; \mathrm{C} 7=$ Adaptação com lactose, alimentação com leite desnatado e afluente refrigerado $4250 \mathrm{mgDQO} . \mathrm{L}^{-1}-\mathrm{t}_{\mathrm{C}} 3 \mathrm{~h} ; \mathrm{C} 8=$ Afluente (soro de leite) sem solução de nutrientes e ureia, com lavagem semanal e afluente $-4250 \mathrm{mgDQO} \cdot \mathrm{L}^{-1}-\mathrm{t}_{\mathrm{C}} 3 \mathrm{~h}$ )

Figura 5-343 - Concentração dos compostos intermediários durante o monitoramento: $\square$ - ácido acético; $\Delta$ - etanol; ○ - ácido butírico; - ácido isobutírico; $\boldsymbol{\Delta}$ - ácido capróico; - - ácido valérico; * ácido propiônico; +butanol; — ácido isovalérico (Soro de leite: $\mathrm{C} 1=$ Sem adaptação e afluente não refrigerado - 4250 $\operatorname{mgDQO} \mathrm{L}^{-1}-\mathrm{t}_{\mathrm{C}} 4 \mathrm{~h} ; \mathrm{C} 2$ = Adaptação com sacarose e afluente não refrigerado 4250 mgDQO.L $\mathrm{L}^{-1}-\mathrm{t}_{\mathrm{C}} 4 \mathrm{~h}$; $\mathrm{C} 3$ = Adaptação com lactose e afluente (não) refrigerado - $4250 \mathrm{mgDQO} . \mathrm{L}^{-1}-\mathrm{t}_{\mathrm{C}} 4 \mathrm{~h} ; \mathrm{C} 4=$ Sem adaptação e afluente não refrigerado - $4250 \mathrm{mgDQO} . \mathrm{L}^{-1}-\mathrm{t}_{\mathrm{C}} 3 \mathrm{~h} ; \mathrm{C} 5=$ Sem adaptação e afluente refrigerado - $4250 \mathrm{mgDQO} . \mathrm{L}^{-1}-\mathrm{t}_{\mathrm{C}} 3 \mathrm{~h}$; $\mathrm{C} 6$ = Adaptação com lactose e afluente refrigerado - $4250 \mathrm{mgDQO} \cdot \mathrm{L}^{-1}-\mathrm{t}_{\mathrm{C}} 3 \mathrm{~h} ; \mathrm{C} 7=$ Adaptação com lactose, alimentação com leite desnatado e afluente refrigerado - $4250 \mathrm{mgDQO} . \mathrm{L}^{-1}-\mathrm{t}_{\mathrm{C}}$ 3h; C8 = Afluente (soro de leite) sem solução de nutrientes e ureia, com lavagem semanal e afluente - $4250 \mathrm{mgDQO} . \mathrm{L}^{-1}-\mathrm{t}_{\mathrm{C}} 3 \mathrm{~h}$ ). 375

Figura 5-344 - Volume de biogás produzido por ciclo (Soro de leite: $\mathrm{C} 1=\mathrm{Sem}$ adaptação e afluente não refrigerado - $4250 \mathrm{mgDQO} \cdot \mathrm{L}^{-1}-\mathrm{t}_{\mathrm{C}} 4 \mathrm{~h} ; \mathrm{C} 2$ = Adaptação com sacarose e afluente não refrigerado - 4250 mgDQO. $\mathrm{L}^{-1}-\mathrm{t}_{\mathrm{C}} 4 \mathrm{~h} ; \mathrm{C} 3=$ Adaptação com lactose e afluente (não) refrigerado - $4250 \mathrm{mgDQO} \cdot \mathrm{L}^{-1}-\mathrm{t}_{\mathrm{C}} 4 \mathrm{~h}$; $\mathrm{C} 4=$ Sem adaptação e afluente não refrigerado $-4250 \mathrm{mgDQO} \cdot \mathrm{L}^{-1}-\mathrm{t}_{\mathrm{C}} 3 \mathrm{~h} ; \mathrm{C} 5=$ Sem adaptação e afluente refrigerado - 4250 mgDQO.L $\mathrm{L}^{-1}-\mathrm{t}_{\mathrm{C}} 3 \mathrm{~h}$; $\mathrm{C} 6=$ Adaptação com lactose e afluente refrigerado - 4250 mgDQO. $\mathrm{L}^{-1}-\mathrm{t}_{\mathrm{C}} 3 \mathrm{~h} ; \mathrm{C} 7=$ Adaptação com lactose, alimentação com leite desnatado e afluente refrigerado $4250 \mathrm{mgDQO} . \mathrm{L}^{-1}-\mathrm{t}_{\mathrm{C}} 3 \mathrm{~h} ; \mathrm{C} 8=$ Afluente (soro de leite) sem solução de nutrientes e ureia, com lavagem semanal e afluente -4250 mgDQO.L $\mathrm{L}^{-1}-\mathrm{t}_{\mathrm{C}} 3 \mathrm{~h}$ ).

Figura 5-345 - Concentrações dos componentes do biogás no final do ciclo: $\square-\mathrm{CO}_{2} ; \Delta$ $\mathrm{H}_{2} ;$ O $-\mathrm{CH}_{4}$ (Soro de leite: $\mathrm{C} 1=$ Sem adaptação e afluente não refrigerado $4250 \mathrm{mgDQO} . \mathrm{L}^{-1}-\mathrm{t}_{\mathrm{C}} 4 \mathrm{~h} ; \mathrm{C} 2$ = Adaptação com sacarose e afluente não refrigerado - $4250 \mathrm{mgDQO} . \mathrm{L}^{-1}-\mathrm{t}_{\mathrm{C}} 4 \mathrm{~h}$; $\mathrm{C} 3=$ Adaptação com lactose e afluente (não) refrigerado - $4250 \mathrm{mgDQO} . \mathrm{L}^{-1}-\mathrm{t}_{\mathrm{C}} 4 \mathrm{~h} ; \mathrm{C} 4=\mathrm{Sem}$ adaptação e afluente não refrigerado - $4250 \mathrm{mgDQO} . \mathrm{L}^{-1}-\mathrm{t}_{\mathrm{C}} 3 \mathrm{~h} ; \mathrm{C} 5=$ Sem adaptação e afluente refrigerado - $4250 \mathrm{mgDQO} . \mathrm{L}^{-1}-\mathrm{t}_{\mathrm{C}} 3 \mathrm{~h}$; $\mathrm{C} 6=$ Adaptação com lactose e afluente refrigerado - $4250 \mathrm{mgDQO} \cdot \mathrm{L}^{-1}-\mathrm{t}_{\mathrm{C}} 3 \mathrm{~h} ; \mathrm{C} 7=$ Adaptação com lactose, alimentação com leite desnatado e afluente refrigerado - $4250 \mathrm{mgDQO} . \mathrm{L}^{-1}-\mathrm{t}_{\mathrm{C}}$ 3h; C8 = Afluente (soro de leite) sem solução de nutrientes e ureia, com lavagem semanal e afluente - $4250 \mathrm{mgDQO} . \mathrm{L}^{-1}-\mathrm{t}_{\mathrm{C}} 3 \mathrm{~h}$ ). 378

Figura 5-346 - Distribuições dos componentes do biogás no final do ciclo: $\square-\mathrm{CO}_{2}$; $\Delta$ $\mathrm{H}_{2} ; \circ-\mathrm{CH}_{4}$ (Soro de leite: $\mathrm{C} 1=$ Sem adaptação e afluente não refrigerado - 
$4250 \mathrm{mgDQO} . \mathrm{L}^{-1}-\mathrm{t}_{\mathrm{C}} 4 \mathrm{~h} ; \mathrm{C} 2=$ Adaptação com sacarose e afluente não refrigerado - $4250 \mathrm{mgDQO} . \mathrm{L}^{-1}-\mathrm{t}_{\mathrm{C}} 4 \mathrm{~h}$; $\mathrm{C} 3=$ Adaptação com lactose e afluente (não) refrigerado - $4250 \mathrm{mgDQO} . \mathrm{L}^{-1}-\mathrm{t}_{\mathrm{C}} 4 \mathrm{~h} ; \mathrm{C} 4=\mathrm{Sem}$ adaptação e afluente não refrigerado - 4250 mgDQO. $L^{-1}-\mathrm{t}_{\mathrm{C}} 3 \mathrm{~h} ; \mathrm{C} 5=$ Sem adaptação e afluente refrigerado - $4250 \mathrm{mgDQO} . \mathrm{L}^{-1}-\mathrm{t}_{\mathrm{C}} 3 \mathrm{~h}$; C6 = Adaptação com lactose e afluente refrigerado - $4250 \mathrm{mgDQO} . \mathrm{L}^{-1}-\mathrm{t}_{\mathrm{C}} 3 \mathrm{~h} ; \mathrm{C} 7=$ Adaptação com lactose, alimentação com leite desnatado e afluente refrigerado - $4250 \mathrm{mgDQO} . \mathrm{L}^{-1}-\mathrm{t}_{\mathrm{C}}$ 3h; C8 = Afluente (soro de leite) sem solução de nutrientes e ureia, com lavagem semanal e afluente - $4250 \mathrm{mgDQO} . \mathrm{L}^{-1}-\mathrm{t}_{\mathrm{C}} 3 \mathrm{~h}$ ).

Figura 5-347 - Indícios de produção de $\mathrm{H}_{2} \mathrm{~S}$ nas mangueiras de recirculação. 382

Figura 5-348 - Concentração de matéria orgânica (DQO): $\square$ - afluente não filtrada; $\Delta$ efluente não filtrada; $\mathrm{O}-$ efluente filtrada (Soro de leite: $\mathrm{C} 8=\mathrm{t}_{\mathrm{C}}=3$ horas, $\mathrm{C}_{\mathrm{ST}}=$ $4250 \mathrm{mgDQO} . \mathrm{L}^{-1}-30^{\circ} \mathrm{C} ; \mathrm{C} 9=\mathrm{t}_{\mathrm{C}}=3$ horas, $\mathrm{C}_{\mathrm{ST}}=6350 \mathrm{mgDQO} \cdot \mathrm{L}^{-1}-30^{\circ} \mathrm{C}$; $\mathrm{C} 10=\mathrm{t}_{\mathrm{C}}=3$ horas, $\mathrm{C}_{\mathrm{ST}}=5500 \mathrm{mgDQO} \cdot \mathrm{L}^{-1}-30^{\circ} \mathrm{C} ; \mathrm{C} 11=\mathrm{t}_{\mathrm{C}}=3$ horas, $\mathrm{C}_{\mathrm{ST}}=$ $5500 \mathrm{mgDQO} \cdot \mathrm{L}^{-1}-30^{\circ} \mathrm{C}-$ Batelada alimentada $\left(\mathrm{t}_{\mathrm{A}}=0,5 . \mathrm{t}_{\mathrm{C}}=1,5\right.$ horas $) ; \mathrm{C} 12=$ $\mathrm{t}_{\mathrm{C}}=3$ horas, $\mathrm{C}_{\mathrm{ST}}=5500 \mathrm{mgDQO} \cdot \mathrm{L}^{-1}-45^{\circ} \mathrm{C} ; \mathrm{C} 13=\mathrm{t}_{\mathrm{C}}=3$ horas, $\mathrm{C}_{\mathrm{ST}}=5500$ $\left.\operatorname{mgDQO} . \mathrm{L}^{-1}-15^{\circ} \mathrm{C}\right)$.

Figura 5-349 - Eficiência de remoção de matéria orgânica (DQO): $\diamond$ - não filtrada; filtrada (Soro de leite: $\mathrm{C} 8=\mathrm{t}_{\mathrm{C}}=3$ horas, $\mathrm{C}_{\mathrm{ST}}=4250 \mathrm{mgDQO} \cdot \mathrm{L}^{-1}-30^{\circ} \mathrm{C}$; $\mathrm{C} 9=$ $\mathrm{t}_{\mathrm{C}}=3$ horas, $\mathrm{C}_{\mathrm{ST}}=6350 \mathrm{mgDQO} . \mathrm{L}^{-1}-30^{\circ} \mathrm{C} ; \mathrm{C} 10=\mathrm{t}_{\mathrm{C}}=3$ horas, $\mathrm{C}_{\mathrm{ST}}=5500$ $\operatorname{mgDQO} . \mathrm{L}^{-1}-30^{\circ} \mathrm{C} ; \mathrm{C} 11=\mathrm{t}_{\mathrm{C}}=3$ horas, $\mathrm{C}_{\mathrm{ST}}=5500 \mathrm{mgDQO} \cdot \mathrm{L}^{-1}-30^{\circ} \mathrm{C}-$ Batelada alimentada $\left(\mathrm{t}_{\mathrm{A}}=0,5 . \mathrm{t}_{\mathrm{C}}=1,5\right.$ horas $) ; \mathrm{C} 12=\mathrm{t}_{\mathrm{C}}=3$ horas, $\mathrm{C}_{\mathrm{ST}}=5500$ $\operatorname{mgDQO} . \mathrm{L}^{-1}-45^{\circ} \mathrm{C} ; \mathrm{C} 13=\mathrm{t}_{\mathrm{C}}=3$ horas, $\left.\mathrm{C}_{\mathrm{ST}}=5500 \mathrm{mgDQO} \cdot \mathrm{L}^{-1}-15^{\circ} \mathrm{C}\right) \ldots . .388$

Figura 5-350 - Concentração de carboidrato: $\square$ - afluente não filtrada; $\Delta$ - efluente não filtrada; $\bigcirc-$ efluente filtrada (Soro de leite: $\mathrm{C} 8=\mathrm{t}_{\mathrm{C}}=3$ horas, $\mathrm{C}_{\mathrm{ST}}=4250$ $\operatorname{mgDQO} . \mathrm{L}^{-1}-30^{\circ} \mathrm{C} ; \mathrm{C} 9=\mathrm{t}_{\mathrm{C}}=3$ horas, $\mathrm{C}_{\mathrm{ST}}=6350 \mathrm{mgDQO} \cdot \mathrm{L}^{-1}-30^{\circ} \mathrm{C} ; \mathrm{C} 10=$ $\mathrm{t}_{\mathrm{C}}=3$ horas, $\mathrm{C}_{\mathrm{ST}}=5500 \mathrm{mgDQO} . \mathrm{L}^{-1}-30^{\circ} \mathrm{C} ; \mathrm{C} 11=\mathrm{t}_{\mathrm{C}}=3$ horas, $\mathrm{C}_{\mathrm{ST}}=5500$ $\operatorname{mgDQO} . \mathrm{L}^{-1}-30^{\circ} \mathrm{C}-$ Batelada alimentada $\left(\mathrm{t}_{\mathrm{A}}=0,5 . \mathrm{t}_{\mathrm{C}}=1,5\right.$ horas $) ; \mathrm{C} 12=\mathrm{t}_{\mathrm{C}}=3$ horas, $\mathrm{C}_{\mathrm{ST}}=5500 \mathrm{mgDQO} . \mathrm{L}^{-1}-45^{\circ} \mathrm{C} ; \mathrm{C} 13=\mathrm{t}_{\mathrm{C}}=3$ horas, $\mathrm{C}_{\mathrm{ST}}=5500$ $\left.\operatorname{mgDQO} . \mathrm{L}^{-1}-15^{\circ} \mathrm{C}\right)$.

Figura 5-351 - Eficiência de remoção de carboidrato: $\diamond$ - não filtrada; - filtrada (Soro de leite: $\mathrm{C} 8=\mathrm{t}_{\mathrm{C}}=3$ horas, $\mathrm{C}_{\mathrm{ST}}=4250 \mathrm{mgDQO} \cdot \mathrm{L}^{-1}-30^{\circ} \mathrm{C} ; \mathrm{C} 9=\mathrm{t}_{\mathrm{C}}=3$ horas, $\mathrm{C}_{\mathrm{ST}}=6350 \mathrm{mgDQO} \cdot \mathrm{L}^{-1}-30^{\circ} \mathrm{C} ; \mathrm{C} 10=\mathrm{t}_{\mathrm{C}}=3$ horas, $\mathrm{C}_{\mathrm{ST}}=5500 \mathrm{mgDQO} . \mathrm{L}^{-1}-$ $30^{\circ} \mathrm{C} ; \mathrm{C} 11=\mathrm{t}_{\mathrm{C}}=3$ horas, $\mathrm{C}_{\mathrm{ST}}=5500 \mathrm{mgDQO} \cdot \mathrm{L}^{-1}-30^{\circ} \mathrm{C}-$ Batelada alimentada $\left(\mathrm{t}_{\mathrm{A}}=0,5 . \mathrm{t}_{\mathrm{C}}=1,5\right.$ horas$) ; \mathrm{C} 12=\mathrm{t}_{\mathrm{C}}=3$ horas, $\mathrm{C}_{\mathrm{ST}}=5500 \mathrm{mgDQO} . \mathrm{L}^{-1}-45^{\circ} \mathrm{C}$; $\mathrm{C} 13=\mathrm{t}_{\mathrm{C}}=3$ horas, $\left.\mathrm{C}_{\mathrm{ST}}=5500 \mathrm{mgDQO} \cdot \mathrm{L}^{-1}-15^{\circ} \mathrm{C}\right)$. 391

Figura 5-352 - Valores de pH: $\diamond$-afluente; - efluente (Soro de leite: $\mathrm{C} 8=\mathrm{t}_{\mathrm{C}}=3$ horas, $\mathrm{C}_{\mathrm{ST}}=4250 \mathrm{mgDQO} \cdot \mathrm{L}^{-1}-30^{\circ} \mathrm{C} ; \mathrm{C} 9=\mathrm{t}_{\mathrm{C}}=3$ horas, $\mathrm{C}_{\mathrm{ST}}=6350 \mathrm{mgDQO} . \mathrm{L}^{-1}-$ $30^{\circ} \mathrm{C} ; \mathrm{C} 10=\mathrm{t}_{\mathrm{C}}=3$ horas, $\mathrm{C}_{\mathrm{ST}}=5500 \mathrm{mgDQO} . \mathrm{L}^{-1}-30^{\circ} \mathrm{C} ; \mathrm{C} 11=\mathrm{t}_{\mathrm{C}}=3$ horas, $\mathrm{C}_{\mathrm{ST}}=5500 \mathrm{mgDQO} \cdot \mathrm{L}^{-1}-30^{\circ} \mathrm{C}-$ Batelada alimentada $\left(\mathrm{t}_{\mathrm{A}}=0,5 . \mathrm{t}_{\mathrm{C}}=1,5\right.$ horas$)$; $\mathrm{C} 12=\mathrm{t}_{\mathrm{C}}=3$ horas, $\mathrm{C}_{\mathrm{ST}}=5500 \mathrm{mgDQO} . \mathrm{L}^{-1}-45^{\circ} \mathrm{C} ; \mathrm{C} 13=\mathrm{t}_{\mathrm{C}}=3$ horas, $\mathrm{C}_{\mathrm{ST}}=$ $\left.5500 \mathrm{mgDQO} . \mathrm{L}^{-1}-15^{\circ} \mathrm{C}\right)$.

Figura 5-353 - Valores de $\mathrm{pH}: \diamond$-afluente; - efluente (Soro de leite: $\mathrm{C} 8=\mathrm{t}_{\mathrm{C}}=3$ horas, $\mathrm{C}_{\mathrm{ST}}=4250 \mathrm{mgDQO} . \mathrm{L}^{-1}-30^{\circ} \mathrm{C} ; \mathrm{C} 9=\mathrm{t}_{\mathrm{C}}=3$ horas, $\mathrm{C}_{\mathrm{ST}}=6350 \mathrm{mgDQO} . \mathrm{L}^{-1}-$ $30^{\circ} \mathrm{C} ; \mathrm{C} 10=\mathrm{t}_{\mathrm{C}}=3$ horas, $\mathrm{C}_{\mathrm{ST}}=5500 \mathrm{mgDQO} \cdot \mathrm{L}^{-1}-30^{\circ} \mathrm{C} ; \mathrm{C} 11=\mathrm{t}_{\mathrm{C}}=3$ horas, $\mathrm{C}_{\mathrm{ST}}=5500 \mathrm{mgDQO} \cdot \mathrm{L}^{-1}-30^{\circ} \mathrm{C}-$ Batelada alimentada $\left(\mathrm{t}_{\mathrm{A}}=0,5 \cdot \mathrm{t}_{\mathrm{C}}=1,5\right.$ horas $)$; $\mathrm{C} 12=\mathrm{t}_{\mathrm{C}}=3$ horas, $\mathrm{C}_{\mathrm{ST}}=5500 \mathrm{mgDQO} \cdot \mathrm{L}^{-1}-45^{\circ} \mathrm{C} ; \mathrm{C} 13=\mathrm{t}_{\mathrm{C}}=3$ horas, $\mathrm{C}_{\mathrm{ST}}=$ $\left.5500 \mathrm{mgDQO} . \mathrm{L}^{-1}-15^{\circ} \mathrm{C}\right)$. 394

Figura 5-354 - Concentração dos compostos intermediários durante o monitoramento: $\square$ - ácido acético; $\Delta$ - etanol; ○ - ácido butírico; - ácido isobutírico; $\boldsymbol{\Delta}$ - ácido 
capróico; • - ácido valérico; -X- ácido propiônico; -|-butanol; — ácido isovalérico (Soro de leite: $\mathrm{C} 8=\mathrm{t}_{\mathrm{C}}=3$ horas, $\mathrm{C}_{\mathrm{ST}}=4250 \mathrm{mgDQO} \cdot \mathrm{L}^{-1}-30^{\circ} \mathrm{C}$; $\mathrm{C}$ 9 $=\mathrm{t}_{\mathrm{C}}=3$ horas, $\mathrm{C}_{\mathrm{ST}}=6350 \mathrm{mgDQO} . \mathrm{L}^{-1}-30^{\circ} \mathrm{C} ; \mathrm{C} 10=\mathrm{t}_{\mathrm{C}}=3$ horas, $\mathrm{C}_{\mathrm{ST}}=5500$ $\operatorname{mgDQO} . \mathrm{L}^{-1}-30^{\circ} \mathrm{C} ; \mathrm{C} 11=\mathrm{t}_{\mathrm{C}}=3$ horas, $\mathrm{C}_{\mathrm{ST}}=5500 \mathrm{mgDQO} \cdot \mathrm{L}^{-1}-30^{\circ} \mathrm{C}-$ Batelada alimentada $\left(\mathrm{t}_{\mathrm{A}}=0,5 \cdot \mathrm{t}_{\mathrm{C}}=1,5\right.$ horas $) ; \mathrm{C} 12=\mathrm{t}_{\mathrm{C}}=3$ horas, $\mathrm{C}_{\mathrm{ST}}=5500$ $\operatorname{mgDQO} . \mathrm{L}^{-1}-45^{\circ} \mathrm{C} ; \mathrm{C} 13=\mathrm{t}_{\mathrm{C}}=3$ horas, $\left.\mathrm{C}_{\mathrm{ST}}=5500 \mathrm{mgDQO} . \mathrm{L}^{-1}-15^{\circ} \mathrm{C}\right) \ldots . .396$

Figura 5-355 - Vazão molar de cada componente do biogás $\left(\square-\mathrm{CO}_{2} ; \boldsymbol{\Delta}-\mathrm{H}_{2} ; \mathrm{O}-\mathrm{CH}_{4}\right)$ e vazão volumétrica do biogás (- -) (Soro de leite: $\mathrm{C} 8=\mathrm{t}_{\mathrm{C}}=3$ horas, $\mathrm{C}_{\mathrm{ST}}=4250$ $\operatorname{mgDQO} . \mathrm{L}^{-1}-30^{\circ} \mathrm{C} ; \mathrm{C} 9=\mathrm{t}_{\mathrm{C}}=3$ horas, $\mathrm{C}_{\mathrm{ST}}=6350 \mathrm{mgDQO} . \mathrm{L}^{-1}-30^{\circ} \mathrm{C} ; \mathrm{C} 10=$ $\mathrm{t}_{\mathrm{C}}=3$ horas, $\mathrm{C}_{\mathrm{ST}}=5500 \mathrm{mgDQO} . \mathrm{L}^{-1}-30^{\circ} \mathrm{C} ; \mathrm{C} 11=\mathrm{t}_{\mathrm{C}}=3$ horas, $\mathrm{C}_{\mathrm{ST}}=5500$ mgDQO. $\mathrm{L}^{-1}-30^{\circ} \mathrm{C}-$ Batelada alimentada $\left(\mathrm{t}_{\mathrm{A}}=0,5 . \mathrm{t}_{\mathrm{C}}=1,5\right.$ horas $) ; \mathrm{C} 12=\mathrm{t}_{\mathrm{C}}=3$ horas, $\mathrm{C}_{\mathrm{ST}}=5500 \mathrm{mgDQO} . \mathrm{L}^{-1}-45^{\circ} \mathrm{C} ; \mathrm{C} 13=\mathrm{t}_{\mathrm{C}}=3$ horas, $\mathrm{C}_{\mathrm{ST}}=5500$ $\left.\operatorname{mgDQO} . \mathrm{L}^{-1}-15^{\circ} \mathrm{C}\right)$.

Figura 5-356 - Volume de biogás produzido por dia (Lactose: $\mathrm{C} 1=\mathrm{DQO}=3600 \mathrm{mg} . \mathrm{L}^{-1}$ e $\mathrm{t}_{\mathrm{C}}=4$ horas; $\mathrm{C} 2=\mathrm{DQO}=5400 \mathrm{mg} . \mathrm{L}^{-1}$ e $\mathrm{t}_{\mathrm{C}}=4$ horas; $\mathrm{C} 3=\mathrm{DQO}=3600$ mg. $\mathrm{L}^{-1}$ e $\mathrm{t}_{\mathrm{C}}=3$ horas; $\mathrm{C} 4=\mathrm{DQO}=5400 \mathrm{mg} . \mathrm{L}^{-1}$ e $\mathrm{t}_{\mathrm{C}}=3$ horas; $\mathrm{C} 5=\mathrm{DQO}=$ $3600 \mathrm{mg} . \mathrm{L}^{-1} \mathrm{e} \mathrm{t}_{\mathrm{C}}=2$ horas; $\mathrm{C} 6=\mathrm{DQO}=5400 \mathrm{mg} \cdot \mathrm{L}^{-1} \mathrm{e} \mathrm{t}_{\mathrm{C}}=2$ horas$)$.

Figura 5-357 - Concentrações dos componentes do biogás em todas as condições: $\square-$ $\mathrm{CO}_{2} ; \Delta-\mathrm{H}_{2} ; \circ-\mathrm{CH}_{4}$ (Lactose: $\mathrm{C} 1=\mathrm{DQO}=3600 \mathrm{mg} . \mathrm{L}^{-1} \mathrm{e} \mathrm{t}_{\mathrm{C}}=4$ horas; $\mathrm{C} 2=$ $\mathrm{DQO}=5400 \mathrm{mg} \cdot \mathrm{L}^{-1} \mathrm{e} \mathrm{t}_{\mathrm{C}}=4$ horas $; \mathrm{C} 3=\mathrm{DQO}=3600 \mathrm{mg} \cdot \mathrm{L}^{-1} \mathrm{e} \mathrm{t}_{\mathrm{C}}=3$ horas; $\mathrm{C} 4$ $=\mathrm{DQO}=5400 \mathrm{mg} \cdot \mathrm{L}^{-1} \mathrm{e} \mathrm{t}_{\mathrm{C}}=3$ horas; $\mathrm{C} 5=\mathrm{DQO}=3600 \mathrm{mg} \cdot \mathrm{L}^{-1} \mathrm{e} \mathrm{t}_{\mathrm{C}}=2$ horas; $\mathrm{C} 6=\mathrm{DQO}=5400 \mathrm{mg} \cdot \mathrm{L}^{-1} \mathrm{e} \mathrm{t}_{\mathrm{C}}=2$ horas).

Figura 5-358 - Distribuições dos componentes do biogás em todas as condições: $\square-$ $\mathrm{CO}_{2} ; \Delta-\mathrm{H}_{2} ; \circ-\mathrm{CH}_{4}$ (Lactose: $\mathrm{C} 1=\mathrm{DQO}=3600 \mathrm{mg} . \mathrm{L}^{-1}$ e $\mathrm{t}_{\mathrm{C}}=4$ horas; $\mathrm{C} 2=$ $\mathrm{DQO}=5400 \mathrm{mg} . \mathrm{L}^{-1} \mathrm{e} \mathrm{t}_{\mathrm{C}}=4$ horas; $\mathrm{C} 3=\mathrm{DQO}=3600 \mathrm{mg} \cdot \mathrm{L}^{-1} \mathrm{e} \mathrm{t}_{\mathrm{C}}=3$ horas; $\mathrm{C} 4$ $=\mathrm{DQO}=5400 \mathrm{mg} \cdot \mathrm{L}^{-1} \mathrm{e} \mathrm{t}_{\mathrm{C}}=3$ horas; $\mathrm{C} 5=\mathrm{DQO}=3600 \mathrm{mg} \cdot \mathrm{L}^{-1} \mathrm{e} \mathrm{t}_{\mathrm{C}}=2$ horas; $\mathrm{C} 6=\mathrm{DQO}=5400 \mathrm{mg} \cdot \mathrm{L}^{-1} \mathrm{e} \mathrm{t}_{\mathrm{C}}=2$ horas). 414

Figura 5-359 - Eficiência de remoção de matéria orgânica (DQO): $\diamond$ - não filtrada; filtrada em todas as condições (Lactose: $\mathrm{C} 1=\mathrm{DQO}=3600 \mathrm{mg} \cdot \mathrm{L}^{-1}$ e $\mathrm{t}_{\mathrm{C}}=4$ horas; $\mathrm{C} 2=\mathrm{DQO}=5400 \mathrm{mg} \cdot \mathrm{L}^{-1} \mathrm{e} \mathrm{t}_{\mathrm{C}}=4$ horas; $\mathrm{C} 3=\mathrm{DQO}=3600 \mathrm{mg} \cdot \mathrm{L}^{-1}$ e $\mathrm{t}_{\mathrm{C}}=$ 3 horas; $\mathrm{C} 4=\mathrm{DQO}=5400 \mathrm{mg} . \mathrm{L}^{-1} \mathrm{e} \mathrm{t}_{\mathrm{C}}=3$ horas; $\mathrm{C} 5=\mathrm{DQO}=3600 \mathrm{mg} \cdot \mathrm{L}^{-1} \mathrm{e} \mathrm{t}_{\mathrm{C}}$ $=2$ horas; $\mathrm{C} 6=\mathrm{DQO}=5400 \mathrm{mg} \cdot \mathrm{L}^{-1} \mathrm{e} \mathrm{t}_{\mathrm{C}}=2$ horas)

Figura 5-360 - Eficiência de remoção de carboidrato: $\diamond$ - não filtrada; - filtrada em todas as condições (Lactose: $\mathrm{C} 1=\mathrm{DQO}=3600 \mathrm{mg} \cdot \mathrm{L}^{-1}$ e $_{\mathrm{C}}=4$ horas; $\mathrm{C} 2=$ $\mathrm{DQO}=5400 \mathrm{mg} \cdot \mathrm{L}^{-1} \mathrm{e} \mathrm{t}_{\mathrm{C}}=4$ horas; $\mathrm{C} 3=\mathrm{DQO}=3600 \mathrm{mg} \cdot \mathrm{L}^{-1} \mathrm{e} \mathrm{t}_{\mathrm{C}}=3$ horas; $\mathrm{C} 4$ $=\mathrm{DQO}=5400 \mathrm{mg} \cdot \mathrm{L}^{-1} \mathrm{e} \mathrm{t}_{\mathrm{C}}=3$ horas; $\mathrm{C} 5=\mathrm{DQO}=3600 \mathrm{mg} \cdot \mathrm{L}^{-1} \mathrm{e} \mathrm{t}_{\mathrm{C}}=2$ horas; $\mathrm{C} 6=\mathrm{DQO}=5400 \mathrm{mg} . \mathrm{L}^{-1} \mathrm{e} \mathrm{t}_{\mathrm{C}}=2$ horas $)$. 419

Figura 5-361 - Concentração dos compostos intermediários: $\square$ - ácido acético; $\Delta$ etanol; ○ - ácido butírico; $\mathbf{-}$ - ácido isobutírico; $\boldsymbol{\Delta}$ - ácido capróico; • - ácido valérico; * ácido propiônico; +butanol; - ácido isovalérico em todas as condições (Lactose: $\mathrm{C} 1=\mathrm{DQO}=3600 \mathrm{mg} . \mathrm{L}^{-1}$ e $\mathrm{t}_{\mathrm{C}}=4$ horas; $\mathrm{C} 2=\mathrm{DQO}=5400$ $\mathrm{mg} . \mathrm{L}^{-1}$ e $\mathrm{t}_{\mathrm{C}}=4$ horas; $\mathrm{C} 3=\mathrm{DQO}=3600 \mathrm{mg} \cdot \mathrm{L}^{-1}$ e $\mathrm{t}_{\mathrm{C}}=3$ horas; $\mathrm{C} 4=\mathrm{DQO}=$ $5400 \mathrm{mg} . \mathrm{L}^{-1}$ e $\mathrm{t}_{\mathrm{C}}=3$ horas; $\mathrm{C} 5=\mathrm{DQO}=3600 \mathrm{mg} \cdot \mathrm{L}^{-1}$ e $\mathrm{t}_{\mathrm{C}}=2$ horas; $\mathrm{C} 6=\mathrm{DQO}$ $=5400 \mathrm{mg} \cdot \mathrm{L}^{-1}$ e $\mathrm{t}_{\mathrm{C}}=2$ horas).

Figura 5-362 - Árvore filogenética construída a partir de distâncias evolutivas inferidas usando o método Neighbor-Joining (Saitou e Nei, 1987). 433 


\section{INTRODUÇÃO}

Os combustíveis fósseis são fontes não renováveis de energia, se tornando cada vez mais escassos, além de seus produtos de combustão serem responsáveis pelo crescente aquecimento global (Veziroglu e Sahin, 2008). O hidrogênio permanece como uma possibilidade por possuir características únicas em comparação com os outras opções: é um combustível limpo, pois gera na sua combustão água como produto, e apresenta 2,75 vezes mais energia (calor de combustão) do que os hidrocarbonetos (Lay et al., 1999). Uma alternativa para a obtenção de hidrogênio é a produção biológica deste utilizando a fração orgânica presente nas águas residuárias, sendo um processo não agressivo ao meio ambiente por não consumir combustíveis fósseis (Ren et al., 2007).

O reator operado em batelada seqüencial pode se constituir em uma opção tecnológica para a produção biológica de hidrogênio, pois sua aplicação em diversos estudos realizados por grupos de pesquisa da Escola de Engenharia de São Carlos da Universidade de São Paulo (EESC/USP) e da Escola de Engenharia Mauá do Instituto Mauá de Tecnologia (EEM/IMT) tem-se obtido resultados promissores, Desta forma, a possibilidade de produção de hidrogênio neste tipo de reator existe e é algo que apresenta bom potencial de implementação.

Dentre os diferentes resíduos que podem ser utilizadas como matéria-prima para a produção de hidrogênio, o soro de leite possui uma potencialidade de aplicação elevada, pois possui alta capacidade de degradação anaeróbia e, mesmo sendo um subproduto da indústria de laticínios, existe um grande excedente de soro que não é utilizado, principalmente em unidades produtoras de pequeno e médio porte. Assim, a utilização deste composto para a produção de hidrogênio seria uma alternativa conveniente por aliar produção de bioenergia à adequação ambiental deste resíduo, principalmente quando sua utilização como subproduto não for possível. 


\section{OBJETIVOS}

Objetivo geral

Estudar a aplicação do reator anaeróbio operado em batelada sequiencial com biomassa imobilizada em suporte inerte (AnSBBR) ao processo de produção de biohidrogênio a partir do soro de leite.

Objetivos específicos

- Avaliar a produção, a produtividade, o rendimento (entre biohidrogênio produzido e matéria orgânica consumida) e a velocidade de produção do biohidrogênio para diferentes cargas orgânicas aplicadas, implementadas modificando-se a concentração afluente, para diferentes tempos de enchimento e para diferentes temperaturas;

- Avaliar o comportamento do AnSBBR pela composição do biogás produzido (relação entre hidrogênio, metano e dióxido de carbono) e do efluente tratado (relação entre ácidos voláteis e alcoóis produzidos e consumo de matéria orgânica na forma de DQO e carboidratos);

- Avaliar a produção de biohidrogênio à partir de água residuária sintética à base de lactose, principal componente do soro de leite.

- Avaliar a composição do consórcio microbiano presente no interior do reator operado responsável pelo desenvolvimento do processo de produção de biohidrogênio. 


\section{REVISÃO DE LITERATURA}

\subsection{Produção biológica de hidrogênio}

Existem duas formas principais de produção biológica de hidrogênio por microrganismos: uma utiliza organismos fotossintéticos, como Oscillatoria sp. e Rhodopseudomonascapsulate, e a outra envolve organismos fermentativos, produtores de hidrogênio, como o Clostridium butyricum e a Escherichia coli (Tanisho e Wakao, 1987). Baseado nas tecnologias atuais não é economicamente viável cultivar bactérias fotossintéticas usando grandes foto-bioreatores e meios de cultura sintéticos (Rocha et al., 2001; Benemann, 1998), pois a produção de biohidrogênio por meio da fermentação anaeróbia de substratos orgânicos pode ser mais prática do que a conversão fotobiológica se um substrato de baixo ou nenhum custo for usado, tendo em vista que este tipo de fermentação não requer as grandes superfícies dos foto-bioreatores para utilizar a energia solar de forma eficiente (Benemann, 1998).

De acordo com Speece (1996), a digestão anaeróbia é um processo complexo que envolve diversos tipos de microrganismos e fases intermediárias. Os componentes orgânicos complexos (polímeros) contidos no substrato são hidrolisados em compostos mais simples (monômeros). Estes são metabolizados pelas bactérias fermentativas, sendo convertidos em ácidos voláteis, alcoóis, gás carbônico, hidrogênio, amônio/amônia e sulfeto. Os ácidos voláteis com mais de dois carbonos são convertidos em acetato e gás hidrogênio pelas bactérias acetogênicas. Por último, o acetato e o gás hidrogênio são convertidos em metano pelas arqueias metanogênicas acetoclásticas ou hidrogenotróficas, respectivamente. Quando existem sulfato e nitrato presentes no meio, as bactérias redutoras de sulfato e as bactérias redutoras de nitrato são capazes de 
utilizar o hidrogênio como doador de elétrons, formando sulfeto e amônia, respectivamente (Valdez-Vazquez et al., 2005). O processo anaeróbio de conversão da matéria orgânica está esquematizado de forma simplificada na Figura 3-1.

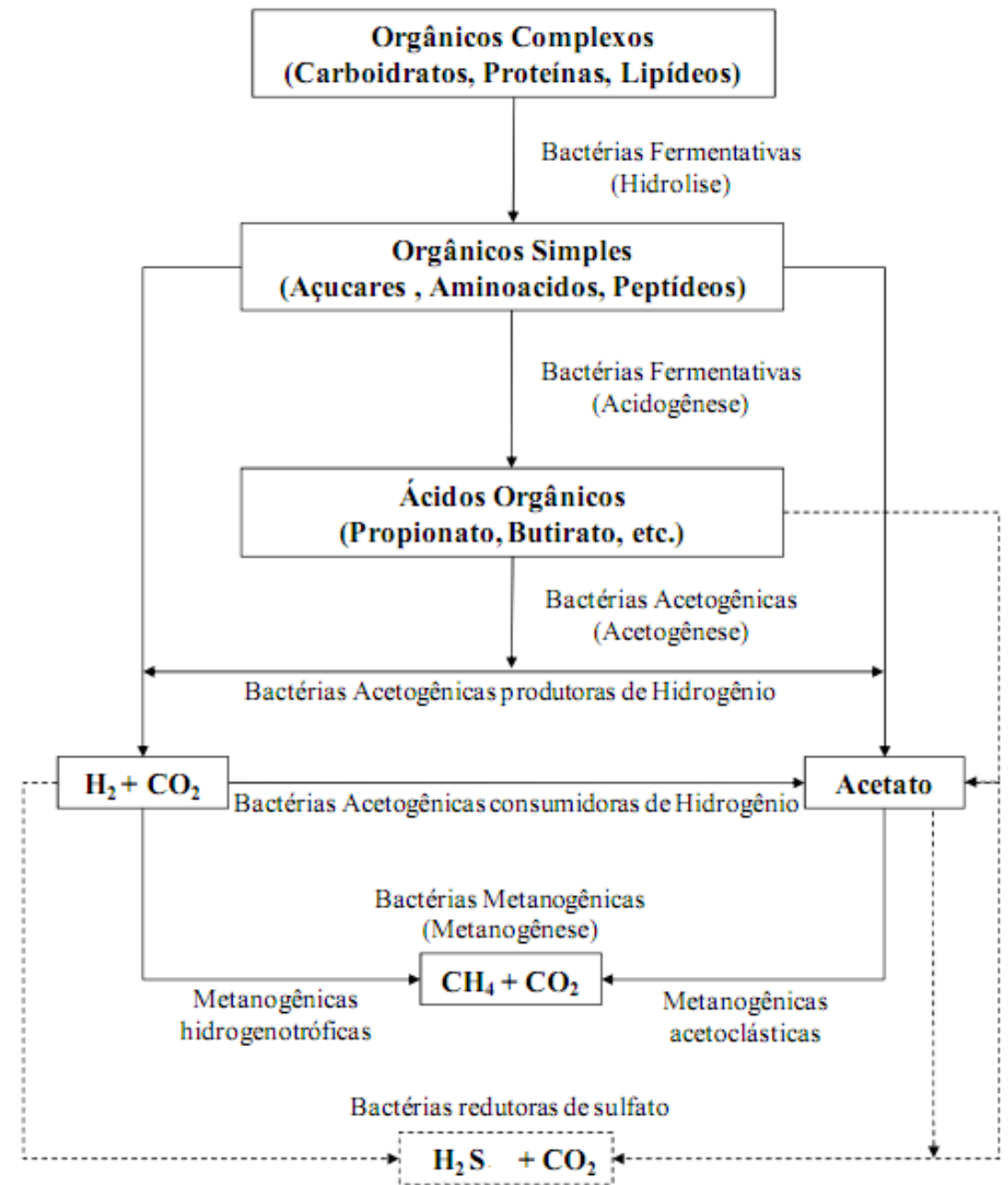

Figura 3-1 - Processo de conversão anaeróbia da matéria orgânica (Chernicharo, 1997; Speece, 1996).

No processo de digestão anaeróbica podem ser identificadas três rotas específicas de liberação de hidrogênio. A primeira é a decomposição do formiato. A segunda é a produção a partir da fermentação direta do etanol ou do butanol. E a terceira é a rota do NADH. A rota de produção de hidrogênio chamada de decomposição do formiato envolve diversas reações. O formiato é formado pela decomposição do piruvato em acetil-CoA (Acetila coenzima A). O acetil-CoA é levado ao acetato ou 
etanol. O formiato pela ação das enzimas hidrogenases entra em decomposição e forma hidrogênio e dióxido de carbono, liberando desta forma cerca de $50 \%$ da produção teórica de hidrogênio. $\mathrm{Na}$ produção a partir da fermentação do etanol e do butanol, o hidrogênio é produzido diretamente sem passar pela forma de formiato. A rota do NADH consiste na regeneração da coenzima NAD a partir da NADH que é produzida durante a conversão da glicose a piruvato no processo chamado de glicólise (Tanisho, 2001). A rota do NADH pode ser comprometida pelo consumo deste por reações concorrentes na formação de álcoois e ácidos. Estes fatos acerca das origens de geração do hidrogênio indicam que existem reações favoráveis que devem ser promovidas e desfavoráveis que devem ser limitadas, para que altas eficiências possam ser alcançadas. A única forma de intervir no metabolismo buscando favorecer a ocorrência de determinada rota é externamente, modificando as estratégias de operação do reator. De acordo com Tanisho (2001), o rendimento da produção de $\mathrm{H}_{2}$ varia de acordo com as bactérias envolvidas no processo. Na Tabela 3.1 são apresentados os rendimentos máximos de conversão de açúcares a hidrogênio nos processos fermentativos. 
Tabela 3.1 - Rendimento máximo de açúcar a hidrogênio em processos fermentativos (Maintinguer, 2009)

\begin{tabular}{|c|c|c|}
\hline Açúcar & Rota metabólica & $\mathrm{mol} \mathrm{H}_{2} \cdot \mathrm{mol} \mathrm{açúcar}^{-1}$ \\
\hline \multirow{2}{*}{ Glicose } & $\begin{array}{c}\mathrm{C}_{6} \mathrm{H}_{12} \mathrm{O}_{6}+2 \mathrm{H}_{2} \mathrm{O} \rightarrow 2 \mathrm{CH}_{3} \mathrm{COOH} \text { (ac. } \\
\text { acético })+2 \mathrm{CO}_{2}+4 \mathrm{H}_{2}\end{array}$ & 4 \\
\hline & $\begin{array}{c}\mathrm{C}_{6} \mathrm{H}_{12} \mathrm{O}_{6} \rightarrow \mathrm{CH}_{3} \mathrm{CH}_{2} \mathrm{CH}_{2} \mathrm{COOH} \text { (ac. } \\
\text { butírico) }+2 \mathrm{CO}_{2}+2 \mathrm{H}_{2}\end{array}$ & 2 \\
\hline \multirow{3}{*}{ Sacarose } & $\begin{array}{c}\mathrm{C}_{12} \mathrm{H}_{22} \mathrm{O}_{11}+5 \mathrm{H}_{2} \mathrm{O} \rightarrow 4 \mathrm{CH}_{3} \mathrm{COOH} \\
\text { (ac. acético) }+4 \mathrm{CO}_{2}+8 \mathrm{H}_{2}\end{array}$ & 8 \\
\hline & $\mathrm{C}_{12} \mathrm{H}_{22} \mathrm{O}_{11}+2 \mathrm{H}_{2} \mathrm{O} \rightarrow$ & \\
\hline & $\begin{array}{c}2 \mathrm{CH}_{3} \mathrm{CH}_{2} \mathrm{CH}_{2} \mathrm{COOH} \text { (ac. butírico) }+ \\
4 \mathrm{CO}_{2}+4 \mathrm{H}_{2}\end{array}$ & 4 \\
\hline \multirow{3}{*}{ Xilose } & $\begin{array}{c}\mathrm{C}_{5} \mathrm{H}_{10} \mathrm{O}_{5}+3 \mathrm{H}_{2} \mathrm{O} \rightarrow \mathrm{CH}_{3} \mathrm{COOH}(\mathrm{ac} . \\
\text { acético })+3 \mathrm{CO}_{2}+6 \mathrm{H}_{2}\end{array}$ & 6 \\
\hline & $\mathrm{C}_{5} \mathrm{H}_{10} \mathrm{O}_{5}+2 \mathrm{H}_{2} \mathrm{O} \rightarrow$ & \\
\hline & $\begin{array}{c}1 / 2 \mathrm{CH}_{3} \mathrm{CH}_{2} \mathrm{CH}_{2} \mathrm{COOH} \text { (ac. butírico) } \\
+3 \mathrm{CO}_{2}+5 \mathrm{H}_{2}\end{array}$ & 5 \\
\hline
\end{tabular}

\subsection{Reatores anaeróbios operados em batelada sequencial (AnSBBR)}

Os reatores anaeróbios operados em batelada seqüencial vêm sendo estudados por grupos da Escola de Engenharia de São Carlos da Universidade de São Paulo (EESC/USP) e da Escola de Engenharia Mauá do Instituto Mauá de Tecnologia (EEM/IMT), nas quais os projetos têm enfoque no estudo da otimização do biorreator convencional e de novas propostas de configurações para que a aplicação do sistema em escala plena se torne viável. Um ciclo típico do reator anaeróbio operado em batelada e batelada alimentada compreende quatro etapas: $(i)$ alimentação que pode ter o tempo de enchimento variável, definindo a estratégia de enchimento como batelada e/ou batelada alimentada; (ii) tratamento propriamente dito, por meio das biotransformações dos constituintes da água residuária por microrganismos; (iii) sedimentação, quando a biomassa se encontrar na forma granulada (ASBR), pois quando a biomassa se encontra na forma imobilizada em suporte inerte (AnSBBR) esta etapa não é necessária; e (iv) 
descarga, com retirada do líquido tratado e clarificado (Dague et al., 1992; Fernandes et al., 1993; Zaiat et al., 2001).

Os processos anaeróbios operados em bateladas sequenciais aparecem como uma solução de tratamento apropriada para casos específicos. Adéquam-se ao tratamento de efluentes industriais gerados intermitentemente, com compostos dificilmente degradáveis ou no caso de padrões de lançamento muito restritivos. Assim, implementando-se diferentes parâmetros de operação do reator, a remoção desejada pode ser garantida (Zaiat et al., 2001). Existem ainda outras vantagens relativas à configuração simples do reator, tais como: melhor controle da qualidade do efluente; ausência de curto circuito hidráulico; ausência da necessidade de estabilização do processo tendo em vista o caráter descontínuo do processo que ocorre em tanque único; bom controle do processo; alta velocidade de remoção de matéria orgânica; operação do sistema simples e estável; e ausência de sistema de distribuição do afluente.

Estudos sobre a influência de variáveis de processo sobre a eficiência e estabilidade do reator quando aplicado ao tratamento de diferentes efluentes têm sido encontrados em literatura, como os relacionados: $(i)$ ao tipo de mistura, a qual poderá ser implementada por recirculação da fase líquida (Brito et al., 1997; Camargo et al., 2002; Bergamo et al., 2009; Bezerra et al., 2009) ou por agitação mecânica (Angenent et al., 2002; Rodrigues et al., 2003 e 2004; Damasceno et al., 2008; Michelan et al., 2009); (ii) ao tempo de enchimento ou estratégia de alimentação (Bagley e Brodkorb, 1999; Shizas e Bagley, 2002; Borges et al., 2004; Orra et al., 2004; Zimmer et al., 2008; Albanez et al., 2009); e (iii) a carga orgânica (Ng, 1989; Chebel et al., 2006; Damasceno et al., 2007; Oliveira et al., 2008; Friedl et al., 2009; Novaes et al., 2010; Oliveira et al., 2009). 
A imobilização da biomassa em reatores ASBR foi proposta inicialmente por Ratusznei et al. (2000) usando espuma de poliuretano. Os autores estudaram a aplicabilidade desta nova configuração de reator ao tratamento de esgoto sanitário sintético e a denominaram de reator anaeróbio operado em bateladas sequenciais com biofilme aderido (“Anaerobic Sequencing Batch Biofilm Reactor: AnSBBR”). A matriz do meio suporte pode ser um material sólido natural (pedras, areia) ou artificial (plástico, pneus ralados, polímeros) ou constituído pela própria biomassa no caso do crescimento granulado. A interação entre células é promovida pela presença de moléculas de polímeros na parede celular e pela composição do meio. No biofilme ocorre uma dupla circulação dos compostos do metabolismo celular. Sólidos coloidais são hidrolisados pelas ações enzimáticas em moléculas de menores dimensões na superfície e micronutrientes liberados são adsorvidos e transportados através do biofilme. Os produtos resultantes do metabolismo celular circulam no sentido contrário e são evacuados na direção da fase líquida por difusão. Os biofilmes, além de favorecerem a cooperação entre os organismos associados reduzindo as distancias entre si, promovem uma forma de proteção contra fatores ambientais adversos. A criação destes microambientes favorece o conjunto, garantindo grande estabilidade às colônias (Carvalhinha et al., 2010).

\subsection{Soro de leite}

A indústria de queijo é responsável pela geração de três tipos de efluentes: o soro de leite (originado da produção de queijo, sendo o mais importante), o segundo soro de leite (originado da produção de queijo cottage) e o efluente de soro de leite (água de lavagem que contém diferentes frações de soro de leite e/ou segundo soro de 
leite). Efluentes da indústria de queijo representam um importante problema ambiental devido às suas características físico-químicas como minerais (0.46-10\%), sólidos suspensos totais $\left(0.1-22 \mathrm{~kg} . \mathrm{m}^{-3}\right), \mathrm{pH}(3.3-9.0)$, fósforo $\left(0.006-0.5 \mathrm{~kg} . \mathrm{m}^{-3}\right)$, Nitrogênio total Kjeldahl (NTK) (0.01-1.7 $\left.\mathrm{kg} \mathrm{m}^{-3}\right)$, carga orgânica $\left(0.6-102 \mathrm{~kg} . \mathrm{m}^{-3}\right)$, etc. As altas concentrações de matéria orgânica são causadas pela presença de lactose $(0.18-60$ kg.m ${ }^{3}$ ), proteínas $\left(1.4-33.5 \mathrm{~kg} \cdot \mathrm{m}^{-3}\right)$ e gorduras $\left(0.08-10.58 \mathrm{~kg} \cdot \mathrm{m}^{-3}\right)$. A matéria orgânica é aproximadamente $99 \%$ biodegradável (Ergüder et al., 2001).

A cor amarelada do soro de leite é causada pela presença de riboflavonoides (vitamina B2) (De Wit, 2001). A maior parte da lactose do leite permanece na principal fração constituinte do soro de leite $(90 \%)$. Gordura e proteínas são parcialmente responsáveis pela contaminação orgânica (Ghaly e Kamal, 2004).

O soro de leite é o resíduo mais contaminante gerado na produção do queijo (Rajeshwari et al., 2000). A caracterização do soro de leite dependerá da qualidade do leite utilizado (cabra, vaca, ovelha ou búfalo), o que dependerá da raça do animal, da alimentação, da saúde e do estágio de lactação (De Wit, 2001). O soro de leite pode causar excesso no consumo de oxigênio, impermeabilização, eutrofização, toxicidade, entre outros efeitos negativos nos ambientes receptores. Dentro deste contexto, para a produção de $1 \mathrm{~kg}$ de queijo são necessários $10 \mathrm{~kg}$ de leite, originando $9 \mathrm{~kg}$ de soro de leite. Assim, a escolha deste composto é motivada inicialmente pela grande produção, pois de acordo com Ghaly et al. (2000) estima-se que em 1998 cerca de 137,9 milhões de toneladas de soro foram produzidos em todo o mundo. De acordo com Tejayadi e Cheryan (1995), metade deste valor é produzida apenas nos Estados Unidos. A produção de soro de queijo no Brasil chegou a quase seis milhões de litros em 2010 (IBGE, 2012). 
Três diferentes opções de manejo dos efluentes do queijo são comumente utilizadas. A primeira é baseada na aplicação de tecnologias de valorização do rejeito. Estas tecnologias são aplicadas para recuperar compostos valiosos como proteínas e lactose. Cada litro de soro de queijo contém cerca de 50 gramas de lactose e 10 gramas de proteína com alto valor nutricional e funcional (Domingues et al., 1999). Atualmente, os processos de valorização aplicados ao soro de leite constituem a opção preferencial de tratamento deste rejeito. A segunda opção está relacionada à aplicação de tratamentos biológicos. Processos biológicos também podem ser usados como tecnologias de valorização. Por exemplo, a hidrólise da lactose e das proteínas levam à geração de monossacarídeos como glucose e galactose, peptídeos e aminoácidos. Processos de fermentação controlada estão sendo considerados na produção de ácido lático, ácido butírico, etanol, butanol, ácido acético, glicerol, acetona e hidrogênio (objetivo do presente trabalho). A terceira opção é a aplicação de tratamentos físicoquímicos como a coagulação/floculação, ozonização, precipitação térmica, isoelétrica, alcalina ou ácida, oxidação eletro-química, entre outras opções.

Mesmo existindo a possibilidade tecnológica de utilização deste composto como subproduto, a viabilidade econômica principalmente para o pequeno e médio produtor pode ser negativa, o que torna a disposição deste produto da indústria de laticínios um grave problema devido à sua elevada biodegradabilidade (Calli e Yukselen, 2004).

O uso do soro de leite em pó apresenta algumas vantagens quando comparado com o soro de leite in natura, principalmente com relação ao volume reduzido, maior estabilidade em longo prazo e maior facilidade de armazenamento e transporte (Kargi e Ozmihci, 2006). 


\subsection{Fatores que influenciam a produção de hidrogênio em reatores anaeróbios}

\subsubsection{Influência da carga orgânica}

A disponibilidade do substrato é avaliada pela carga orgânica volumétrica aplicada. Este parâmetro une o tempo de permanência do líquido no reator, o volume alimentado e a concentração afluente. Este fator foi o objeto de investigações diretas com foco na influência da carga orgânica na produção de hidrogênio em reatores operados em bateladas sequenciais (Venkata Mohan et al., 2007; Vijaya Bhaskar et al., 2008; Sreethawong et al., 2010; Mohanakrishna et al., 2011). Alguns autores, por outro lado, estudaram a produção de hidrogênio em função da variação de parâmetros inerentes à carga orgânica, como o efeito das concentrações iniciais (Buitrón e Carvajal, 2010), dos volumes afluentes (Badiei et al., 2011) ou dos tempos de permanência do líquido no reator (Cheong et al., 2007; Arooj et al., 2008; Chen. et al., 2009). Tais parâmetros foram estudados separadamente ou de maneira combinada, sem serem relacionados com as cargas orgânicas.

\subsubsection{Influência do $p H$}

$\mathrm{O}$ pH é um parâmetro fundamental nos reatores anaeróbios que pode influenciar na produção de hidrogênio e inibir a ação de microrganismos hidrogenotróficos, podendo afetar tanto a atividade da hidrogenase quanto as rotas metabólicas. Controlando o $\mathrm{pH}$ é possível inativar esses microrganismos, mesmo que o sistema apresente condições favoráveis para o aparecimento destes (Chen et al., 2008). 
Pesquisas mostram que o $\mathrm{pH}$ ótimo para produção de hidrogênio está na faixa entre 5,0 e 6,5 (Fang et al., 2002; Lin e Chang, 2004). Outras pesquisas apontam um valor único como ótimo, de 5,5 (Liu e Fang, 2002; Mu et al., 2007; Shin, 2007).

Investigações foram realizadas em estudo em batelada variando o $\mathrm{pH}$ inicial e medindo a produção de hidrogênio, sendo obtida a produção máxima para valores de pH 4,5 tratando efluente sintético a base de sacarose (Khanal et al., 2003), e de 6,0 tratando soro de queijo (Ferchichi et al., 2005). Pesquisas similares foram conduzidas usando reatores operados em bateladas sequenciais e um dispositivo de controle de $\mathrm{pH}$ ao longo do ciclo. Valores de $\mathrm{pH}$ ótimos foram de 4,9 tratando efluente sintético a base de sacarose (Chen et al., 2009) e de 5,0 tratando esterco de suínos (Wu et al., 2010).

Apesar das discordâncias com relações a valores ótimos, Lay et al. (1999) destacam que um pH muito abaixo de 4,5 é desfavorável para a produção de hidrogênio, tendo em vista que nessas condições ocorre a inibição da atividade da hidrogenase e de outras enzimas, com consequente alteração das rotas metabólicas envolvidas no processo.

\subsubsection{Influência da temperatura}

A temperatura tem uma influência importante na produção de hidrogênio. $\mathrm{Na}$ faixa entre $25^{\circ} \mathrm{C}$ e $40^{\circ} \mathrm{C}$ ocorrem as melhores eficiências do processo, principalmente em condições próximas da ideal $\left(35^{\circ} \mathrm{C}\right)$ para funcionamento dos catalisadores bioquímicos (Zhang e Shen, 2005).

Os microorganismos são classificados em algumas categorias de temperaturas, baseadas na faixa de temperatura que estes conseguem se desenvolver (psicrofílicos, mesofílicos e termofílicos). Variações significativas de temperatura devem ser previstas 
no tratamento de águas residuárias e o projeto deve fornecer flexibilidade suficiente para garantir a estabilidade do processo (Lettinga et al., 2001).

Diversos trabalhos têm sido realizados e têm demonstrado que há uma determinada faixa de temperatura entre $25^{\circ} \mathrm{C}$ e $60^{\circ} \mathrm{C}$ em que se nota alta capacidade das bactérias produtoras de hidrogênio em produzir este gás por meio da fermentação. No entanto, quando as temperaturas são elevadas pode ocorrer um decréscimo na produção (Wang e Wan, 2009).

Muitas pesquisas convergem para valores de temperaturas que variam entre $30^{\circ} \mathrm{C}$ e $36,8^{\circ} \mathrm{C}$, definindo estas como temperaturas ótimas para sistemas anaeróbios fermentativos produtores de hidrogênio (Fang et al., 2002; Lin e Chang, 2004).

Além da influência nos microrganismos a temperatura também tem influência direta na solubilidade do biogás oriundo da fermentação. Este é produzido em meio líquido e precisa se desprender para o meio gasoso, para só então se tornar disponível para o uso. O hidrogênio é um gás que apresenta baixa solubilidade em ambiente aquoso. Segundo Guwy et al. (1997), a solubilidade do hidrogênio é 0,017 $\mathrm{mLH}_{2} \cdot \mathrm{mL}^{-1}$ em água a 1 bar e $37^{\circ} \mathrm{C}$. Considerando-se a Lei de Henry, no qual a solubilidade é proporcional a pressão parcial do gás, quanto maior for a temperatura, menor será a solubilidade do hidrogênio. Consequentemente, menor será a interação dos microrganismos presentes no reator, desfavorecendo as rotas que consomem o hidrogênio produzido, como a metanogênica hidrtogenotrófica e a homoacteogênese (Hawkes et al., 2002). 


\subsubsection{Influência do substrato}

Diversos estudos buscando produzir hidrogênio à partir da fermentação anaeróbica tem sido desenvolvidos recentemente. Os substratos destas pesquisas tem sido tipicamente açúcares simples e amidos, que não são economicamente viáveis devido ao seu alto custo (Yang et al., 2007).

Diferentes águas residuárias têm sido utilizadas como substrato para a produção de biohidrogênio, nas quais a fonte de matéria orgânica carbonácea pode ser sacarose, amido de trigo, fração orgânica de resíduos sólidos, efluente de reatores biológicos, óleos vegetais, resíduos da produção de biodiesel e efluente da indústria de laticínios, especificamente o soro de leite. O objetivo comum de tais estudos tem sido a avaliação da produtividade em hidrogênio e a estabilidade operacional (Lin e Lay, 2004a-b, 2005; Ito et al., 2005; Alzate et al, 2007; Jeong et al., 2007; Nishio e Nakashimada, 2007; Argun et al., 2008; O-Thong et al., 2008; Oztekin et al., 2008; Sabourin-Provost et al., 2009). Além disso, tem sido investigada a melhoria da composição das águas residuárias em termos do equilíbrio de nutrientes no intuito de possibilitar um acréscimo de produtividade em hidrogênio e, assim, otimizar a aplicação desses diversos efluentes (Lin e Lay, 2005; Argun et al., 2008; Turcot et al., 2008).

\subsubsection{Influência dos microrganismos}

Existem diferentes microrganismos capazes de gerar hidrogênio biologicamente, tais como as algas verdes, cianobactérias, bactérias fotossintéticas e as bactérias fermentativas (Das e Veziroglu, 2001). Estes podem ser termofílicos ou mesofílicos, anaeróbios ou facultativos, desde que possuam enzimas hidrogenase ou nitrogenase. 
Como exemplos desses microrganismos pode-se citar Clostridium, Rumen bactéria, Thermoanaerobacter, Enterobacter, Escheicchia Coli, Citrobacter, Methanosarcina barkeri (Reith et al., 2003). Segundo Maintinguer (2008), as principais bactérias fermentativas conhecidas para a produção de hidrogênio incluem espécies de Enterobacter, Bacillus e Clostridium. Existem ainda os fungos, que também possuem enzimas hidrogenase e consequentemente são capazes de produzir hidrogênio, embora sejam pouco utilizados para essa finalidade (Boxma, 2005).

Os microrganismos pertencentes aos gêneros Clostridium são os mais importantes devido a seu alto potencial para produção de hidrogênio, pelo seu rápido metabolismo e sua capacidade de formar esporos. Esses organismos são capazes de produzir hidrogênio em condições mesofílicas ou termofílicas dentro de uma faixa de pH entre 5 e 6 (Krupp e Widmann, 2009). De acordo com Hawkes et al. (2002), o rendimento de hidrogênio a partir de espécies de Clostridium é geralmente maior do que aquele obtido por bactérias aeróbias facultativas como Enterobacter sp. Em seus estudos, Lay (2001) determinou que o gênero Clostridium é o produtor de hidrogênio predominante.

Em processos anaeróbios, o hidrogênio é produzido durante a fase exponencial de crescimento do Clostridium, com produção de solventes na fase estacionária. Isso acontece quando o pH cai para menos de 4,5. Aparentemente, o acúmulo de ácidos graxos voláteis e hidrogênio na fase de crescimento exponencial provocam essa mudança de rota. Os gêneros Clostridium podem produzir hidrogênio a partir da degradação de proteínas, aminoácidos ou carboidratos. O Clostridium acetobutyricum tem despertado grande interesse devido à sua capacidade de fermentar vários substratos em valiosos produtos finais como acetona, butanol e etanol (Mathews e Wang, 2009). Oh et al. (2004) utilizaram um reator anaeróbio de membrana (alimentado com glicose 
em $\mathrm{pH}$ 5,5) visando a produção de hidrogênio e encontraram bactérias filogeneticamente relacionadas com membros das Famílias Clostridiaceae e Flexibacteraceae, incluindo as espécies Clostridium acidisoli e Linmingia china. Iyer et al. (2004) avaliaram a influência de parâmetros operacionais (TDH e temperatura) na produção de $\mathrm{H}_{2}$ e na composição da comunidade microbiana presente em reator CSTR alimentado com glicose em $\mathrm{pH}$ 5,5. Maior diversidade microbiana foi encontrada para TDH de 30 horas (Bacillaceae, Clostridiaceae e Enterobacteriaceae) enquanto que em TDH de 10 horas somente representantes da Família Clostridiaceae foram encontrados. O aumento de temperatura de 30 para $37{ }^{\circ} \mathrm{C}$ causou notável alteração da população Clostridium acidisoli para populações de Clostridium acetobutylicum (Iyer et al., 2004). Microrganismos com elevada similaridade com Clostridium acidisoli também foram encontrados em reator CSTR aplicado a produção de hidrogênio e alimentado com melaço em pH 4-4,5 (Ren et al., 2007). Assim, sugere-se que independente do tipo de reator utilizado, as condições de cultivos, tais como disponibilidade de carboidrato, temperatura mesófila e condições anaeróbias parecem favorecer o crescimento e seleção de espécies de Clostridium.

O gênero Lactobacillus é o maior e mais diverso grupo de bactérias láticas agrupadas dentro do Filo Firmicutes. Os microrganismos deste gênero possuem morfologia de bacilos gram-positivos não formadores de endósporos, que, normalmente, não exibem motilidade e, ocasionalmente, são capazes de reduzir nitrato. De acordo com os produtos da fermentação da glicose, as bactérias láticas podem ser divididas em heteroláticas, que produzem ácido lático conjuntamente com $\mathrm{CO}_{2}$, etanol e ácido acético em quantidades equimolares; e as bactérias homoláticas, que produzem principalmente ácido lático (Zhang e Cai, 2014). A presença de bactérias láticas em reatores aplicados à produção de hidrogênio foi discutida detalhadamente por Sikora et 
al. (2013). Na maior parte dos relatos, a presença destes microorganismos teve influência negativa na produção de hidrogênio. Segundo os autores o efeito negativo da presença de bactérias láticas pode ser justificado (1) pela competição por substrato entre microrganismos produtores de $\mathrm{H}_{2}$ e as bactérias láticas ou (2) pela excreção de bacteriocinas pelas bactérias láticas, que inibem o crescimento de outros microrganismos, por exemplo, Clostridium. Segundo os autores, em reatores operados por longos períodos, ocorre a predominância de bactérias láticas em relação às produtoras de hidrogênio e, concomitante com a alteração da dinâmica microbiana ocorre também o aumento da produção de ácido lático ou etanol.

Os processos fermentativos que utilizam consórcios microbianos apresentam vantagens quando comparados com os que operam com culturas puras, pois a operação dos primeiros é mais simples, o controle do processo é mais fácil e pode-se utilizar ampla fonte de substrato, ao contrário das culturas puras, que apresentam uma faixa restrita de substrato. Porém, em um processo fermentativo com consócio microbiano, o hidrogênio produzido pelos microrganismos pode ser consumido pelos microrganismos consumidores de hidrogênio, podendo reduzir as velocidades de obtenção de hidrogênio (Hung et al., 2011).

\subsubsection{Influência da configuração do reator}

Muitas configurações de reatores foram testadas para produção de hidrogênio: reatores de leito fixo (Chang et al., 2002; Lee et al., 2003; Leite et al., 2008; Rojas, 2010; Fernandes, 2010; Peixoto, 2011; Fontes Lima, 2012; Penteado, 2012), reatores de manta de lodo (UASB) (Chang e Lin, 2004; Huang et al., 2004; Mohan et al., 2008), reatores de leito fluidizado (Wu et al., 2003; Amorim, 2009; Barros, 2010; Reis, 2011), 
reatores em batelada sequencial (Arooj et al., 2007; Cheong et al., 2007; Manssouri et al., 2013; Santos et al., 2014), reatores contínuos com agitação (Lin e Lay, 2005; Siriwongrungson et al., 2007).

Muitos autores buscaram comparar configurações de reatores com o intuito de encontrar qual teria melhor eficiência de produção de hidrogênio. Alzate-Gaviria et al. (2007) descreveram que reatores de fluxo contínuo apresentam maiores níveis e constância na produção de hidrogênio. Li et al. (2007) estudaram a produção de hidrogênio em reatores em batelada e contínuos com agitação, observando que o reator em batelada apresentou maior estabilidade de produção de $\mathrm{H}_{2}$ e melhor atividade microbiana.

Em seus estudos, Wu et al. (2002) compararam a produção de hidrogênio em reatores com células suspensas e com células imobilizadas em diversos suportes. Os autores observaram que a produção de hidrogênio foi maior nos reatores com células aderidas, com os reatores com células suspensas apresentando os piores resultados. De acordo com os autores, a produção biológica de hidrogênio em sistemas com células suspensas geralmente é ineficiente para reatores contínuos, pois apresenta problemas com o reciclo da biomassa, dificultando a obtenção de concentração celular suficiente para obtenção de alta produção de hidrogênio.

Lee et al. (2003) utilizaram reatores com leito empacotado aplicando como material suporte carvão ativado para produção anaeróbia de hidrogênio a partir de sacarose e utilizando como inóculo lodo de esgoto sanitário. Foi avaliada a produção de hidrogênio mediante o efeito da porosidade e do tempo de detenção hidráulica (TDH), sendo observado que a produção de hidrogênio é favorecida tanto pela eficiência de imobilização da biomassa em leitos fixos quanto pela manutenção de uma alta 
porosidade nos mesmos. Resultados similares foram obtidos por Fernandes (2010) em sua pesquisa.

\subsubsection{Influência do tempo de enchimento}

O tempo de enchimento é um parâmetro de projeto que exerce influência no desempenho e estabilidade do reator em batelada sequencial. A forma de alimentação pode ser realizada das seguintes formas: (i) batelada, com a alimentação sendo realizada em períodos extremamente curtos (alguns minutos) e antes da agitação do meio, mantendo separadamente as etapas de alimentação e reação do sistema; (ii) batelada alimentada, onde a alimentação é realizada em períodos de tempo longos em conjunto com a agitação do meio; e (iii) sistemas mistos, onde o reator funciona durante uma parte do ciclo em batelada e durante a outra parte em batelada alimentada. O tempo de enchimento é um parâmetro importante devido a sua capacidade de modificar a relação F/M (“food/microrganism”) (Zaiat et al., 2001).

Estudos sobre a influência da estratégia de alimentação em AnSBBR produzindo biohidrogênio ainda são poucos. Operando um AnSBBR com agitação mecânica alimentado com água residuária sintética a base de sacarose, Inoue et al. (2014) estudaram a influência do tempo de enchimento reproduzindo os experimentos de Manssouri et al. (2013), porém com um tempo de enchimento de 50\% o tempo de ciclo ao invés de 10 minutos. Assim, a estratégia de alimentação exerceu influência sobre o AnSBBR, sendo que o fornecimento gradual de substrato, através de tempos de enchimento mais longos, resultaram em melhores remoções de sacarose, $\mathrm{RMCR}_{\mathrm{C}, \mathrm{n}}, \operatorname{PrM}$ e PrME em todas as $\mathrm{COVA}_{\mathrm{S}}$ investigadas. 
Em reatores metanogênicos, essa variável tem sido analisada com melhor desempenho. Cheong e Hansen (2008) realizaram estudo em ASBR aplicado ao tratamento de água residuária sintética a base de glicose e produção de metano na verificação da influência do tempo de enchimento (tF) em relação ao tempo de ciclo (tC), verificando que o aumento da carga para os reatores em batelada resultou na queda da remoção de DQO, o que não aconteceu para os reatores em batelada alimentada. Os reatores com relação $\mathrm{tF} / \mathrm{tC}$ maior ou igual a 0,42 apresentaram rendimentos acima de 85\%. O mesmo comportamento foi observado pela produção volumétrica de metano, em que os reatores em batelada alimentada com $\mathrm{tF} / \mathrm{tC}$ maior ou igual a 0,42 apresentaram melhor desempenho, com o aumento da produção de metano quando submetido ao aumento da COVA. Dessa maneira, longos tempos de enchimento conferiram ao sistema uma maior estabilidade mesmo após o aumento da COVA, tendo em vista que os picos de ácidos orgânicos voláteis foram menores que os picos apresentados pelos reatores com tempos de enchimento mais curtos.

\subsection{Considerações finais}

A problemática da escassez e do potencial poluidor dos combustíveis fósseis impulsiona pesquisas por soluções alternativas para este problema. O hidrogênio é uma possibilidade limpa, que libera apenas água na sua combustão e apresenta uma alta eficiência energética. A produção biológica de hidrogênio tem se mostrado cada vez mais promissora, produzindo bioenergia a partir de rejeitos que agora passam a ser vistos como algo com valor agregado e não apenas um problema. Muitos estudos por todo o mundo têm sido desenvolvidos, avaliando-se os mais diversos parâmetros operacionais que afetam este tipo de produção de hidrogênio. 
Dentro deste contexto, o grupo de pesquisa resultante da parceria entre a EESC/USP e EEM/IMT tem obtido resultados interessantes. Após testes utilizando reatores anaeróbios de leito fixo, no ano de 2011 deu-se início ao estudo do AnSBBR para produção de hidrogênio. Foram realizados ensaios nesta configuração com agitação mecânica e recirculação da fase líquida, avaliando-se principalmente a carga orgânica aplicada volumétrica e o tempo de ciclo. O substrato utilizado, porém, era sintético à base de sacarose. Tendo em visto a facilidade operacional do AnSBBR, o que o torna uma ótima opção para uso em escala plena, fazem-se necessários estudos que utilizem águas residuárias reais. Assim, o presente trabalho se enquadra nesta realidade, utilizando soro de leite para produzir hidrogênio.

Desta forma, analisando-se a viabilidade da utilização de soro de leite como substrato para a produção biohidrogênio em AnSBBR a partir do estudo do efeito da carga orgânica aplicada (implementada pela definição de valores de concentração afluente e de tempo de ciclo), do tempo de enchimento e da temperatura, buscou-se otimizar o processo com o objetivo de contribuir para a sua aplicação em escala plena. 


\section{MATERIAL E MÉTODOS}

Para atingir o objetivo principal de produção de biohidrogênio à partir do soro de leite foram realizados diversos estudos utilizando diferentes águas residuárias (sacarose, lactose, leite desnatado e o próprio soro de leite) usando o AnSBBR com recirculação da fase líquida e com agitação mecânica, sempre buscando compreender o que estava ocorrendo no sistema. Após a estabilidade do processo em questão ser atingida com sucesso, analisou-se a influência de três parâmetros operacionais importantes: concentração afluente, tempo de alimentação e temperatura.

Estudos complementares utilizando o AnSBBR com agitação mecânica alimentado com lactose pura foram realizados devido ao fato deste ser o principal componente do soro de leite, buscando assim uma melhor compreensão da aplicação deste carboidrato para produção de biohidrogênio.

\subsection{AnSBBR com biomassa imobilizada e recirculação}

A Figura 4-1 mostra o sistema experimental proposto para a produção de biohidrogênio a partir do tratamento anaeróbio de soro de leite.

O reator constituiu-se por um frasco de acrílico cilíndrico com as seguintes dimensões: $540 \mathrm{~mm}$ de altura, $100 \mathrm{~mm}$ de diâmetro externo e 3,5 mm de espessura de parede. A parte inferior do reator foi composta por um compartimento de $40 \mathrm{~mm}$ de altura destinado a favorecer a distribuição da água residuária e, na parte superior, um compartimento com $60 \mathrm{~mm}$ de altura utilizado como câmara coletora de biogás $\left(\mathrm{H}_{2}\right.$, $\mathrm{CH}_{4}$ e $\mathrm{CO}_{2}$ ). Dessa forma, o volume total do reator foi de 4,3 $\mathrm{L}$ (volume vazio). 
O suporte de imobilização da biomassa foi acondicionado entre telas de aço Inox - 314, revestidas na parte superior por telas de PVC, dividindo a altura de $540 \mathrm{~mm}$ do reator em cinco compartimentos para evitar a compactação do leito e a passagem das partículas de suporte entre os compartimentos.

O sistema de recirculação foi composto (i) por um reservatório lateral, o qual continha um volume de 2,9 L (volume vazio), constituído por um frasco de acrílico cilíndrico com as seguintes dimensões: $430 \mathrm{~mm}$ de altura, $100 \mathrm{~mm}$ de diâmetro externo e 3,5 mm de espessura de parede; e (ii) por uma bomba peristáltica com vazão ajustável, marca Ismatec modelo MCP, com vazão máxima de 52,3 L.h ${ }^{-1}$. Um tubo graduado de $100 \mathrm{~mL}$ foi interligado ao sistema de recirculação para medidas da vazão de recirculação. Dessa forma, o volume total resultante da soma do volume do reator $(4,3$ L) e do reservatório (2,9 L) foi de 7,2 L.

Uma unidade de controle foi utilizada para automatizar as operações de carga, descarga e recirculação. A alimentação e descarga foram realizadas por bombas tipo

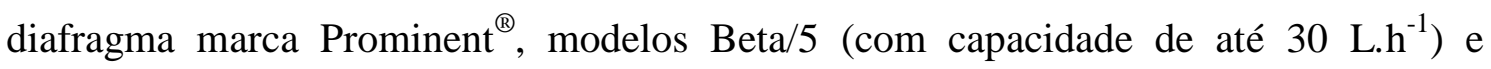

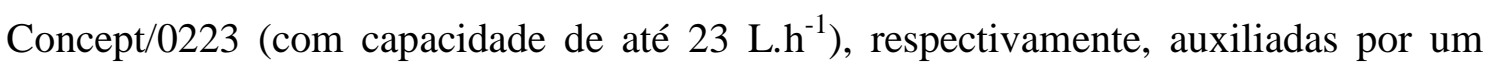
sistema de automação composto por temporizadores marca Coel ${ }^{\circledR}$, modelo RTST/20. 


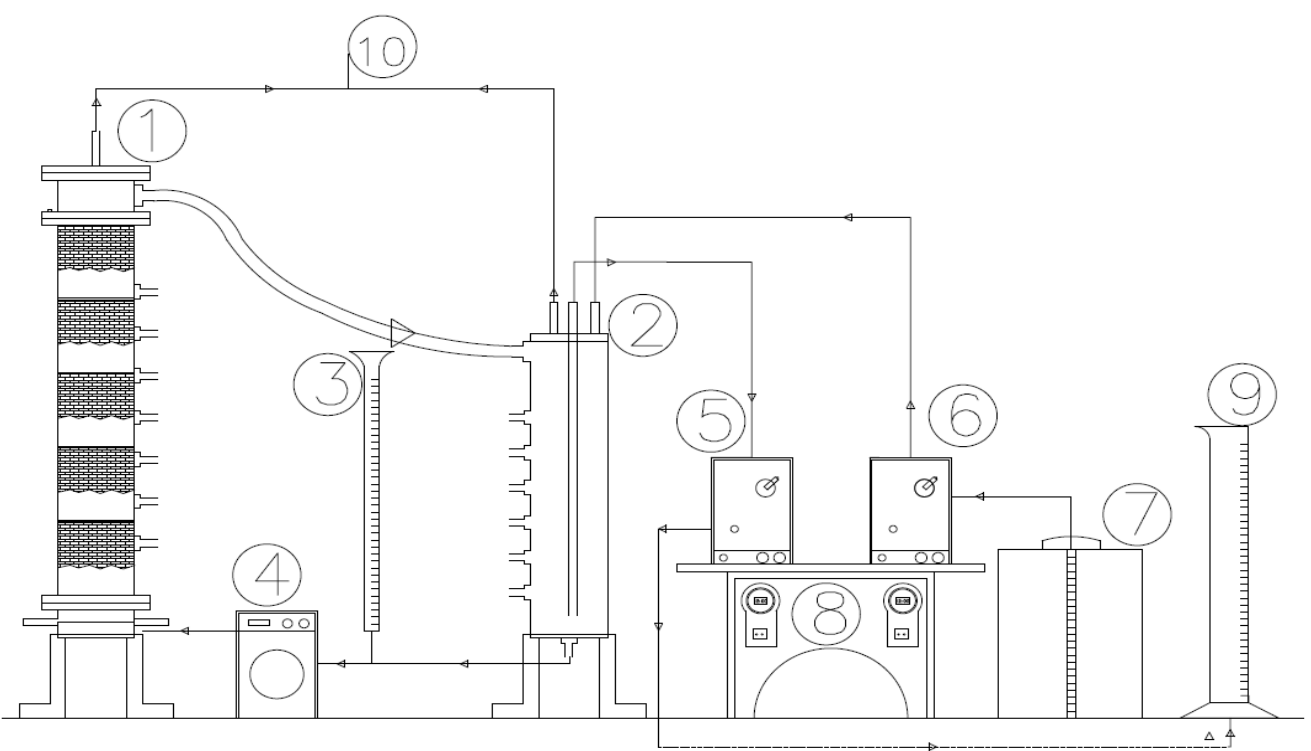

(i)
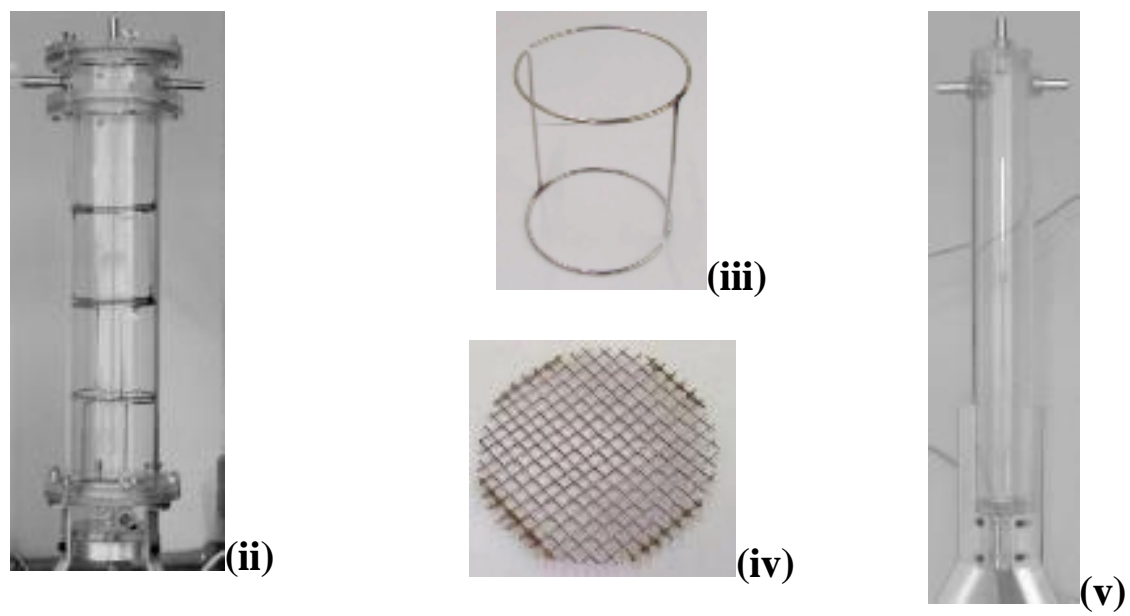

Figura 4-1a - Esquema do (i) AnSBBR com recirculação utilizado nos ensaios e detalhes do (ii) reator, (iii) suporte da tela de aço, (iv) tela de aço e (v) reservatório

[Notação: 1 - reator contendo biomassa imobilizada; 2 - reservatório lateral; 3 - medidor de vazão; 4 - bomba de recirculação; 5 - bomba de descarga; 6 - bomba de alimentação;

7 - reservatório de água residuária; 8 - unidades de controle; 9 - Proveta de coleta do efluente; 10 - saída do biogás]. 

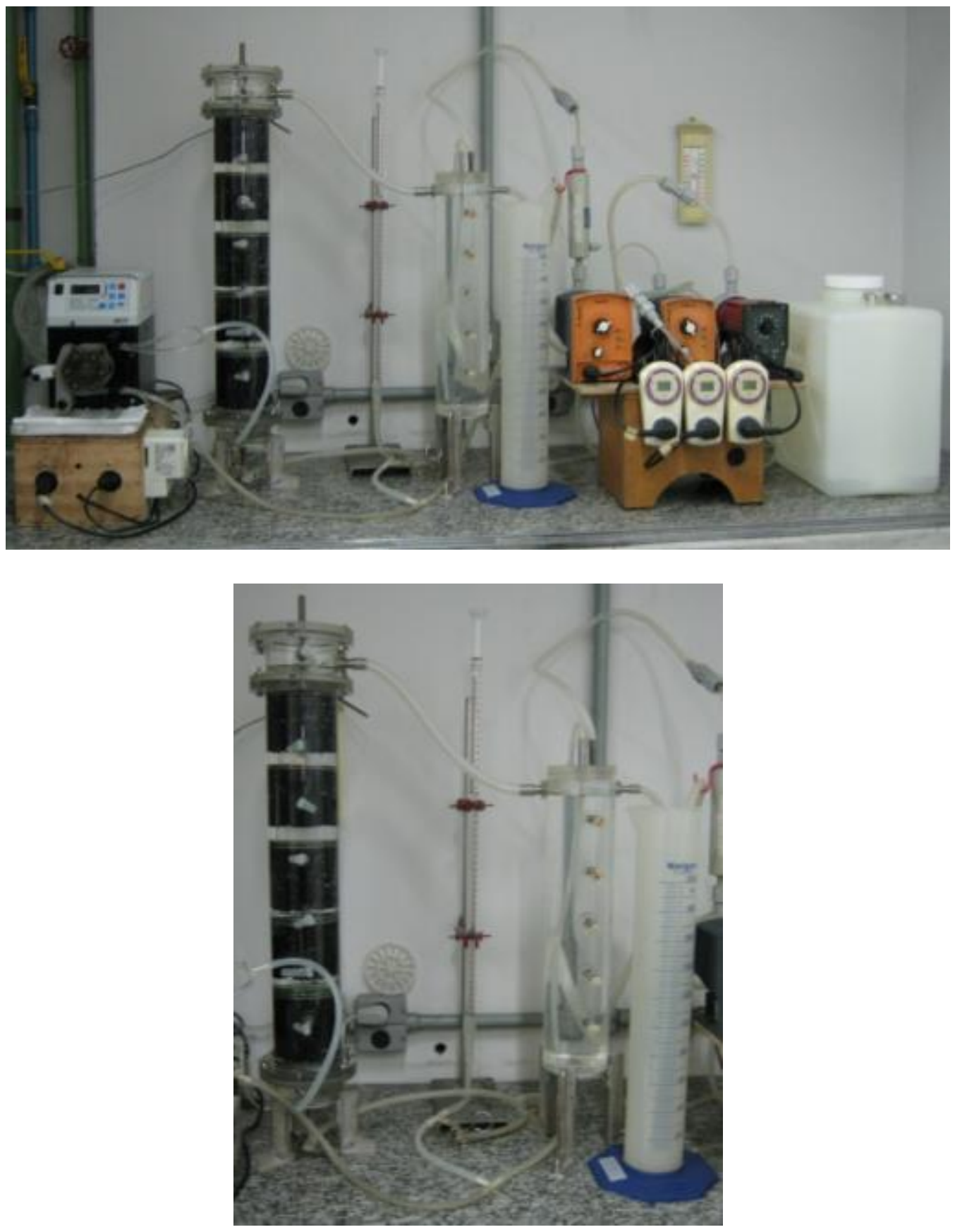

Figura 4.1b - Fotografia do AnSBBR com recirculação utilizado nos ensaios.

O reator foi colocado em uma câmara mantida a $30 \pm 1{ }^{\circ} \mathrm{C}$ durante os ensaios sobre a estabilidade na produção de biohidrogênio e nos estudos sobre a influência da concentração afluente, tempo de enchimento e da temperatura de $45 \pm 1{ }^{\circ} \mathrm{C}$, onde a manutenção da temperatura foi realizada por um sistema composto de sensor, controlador $\left(\right.$ Novus $^{\circledR}$, modelo N480), ventilador e resistência elétrica. Para a 
manutenção da temperatura no ensaio analisando $15 \pm 1^{\circ} \mathrm{C}$ o reator foi mantido dentro de um refrigerador.

\subsection{AnSBBR com biomassa imobilizada e agitação mecânica}

As Figura 4-2 a e b apresentam o esquema do biorreator com agitação mecânica (modelo Bioflo $110^{\circledR}$, fabricado pela New Brunswick Scientific Co.), constituído por um frasco de vidro de $20 \mathrm{~cm}$ de diâmetro e $30 \mathrm{~cm}$ de altura, com capacidade total de 7,5 L e capacidade útil de 5,60 L. O material suporte foi confinado em um cesto de aço Inox-316 perfurado de $18 \mathrm{~cm}$ de altura, $7 \mathrm{~cm}$ e $17,5 \mathrm{~cm}$ de diâmetros interno e externo, respectivamente.

A agitação fixa de $300 \mathrm{rpm}$ foi implementada por motor acoplado aos impelidores tipo turbina de $6 \mathrm{~cm}$ de diâmetro constituído por seis lâminas planas (padrão Rushton) e instalados a 8 e $16 \mathrm{~cm}$ do fundo do tanque (Michelan et al., 2009).

A alimentação e descarga foram realizadas por bombas tipo diafragma marca Prominent modelos $\beta$ e Concept, respectivamente. Um sistema de automação composto por temporizadores foi responsável pelo acionamento/parada das bombas e do agitador, de modo a implementar as etapas da operação em batelada sequencial: alimentação, reação e descarga. As temperaturas de $30 \pm 1^{\circ} \mathrm{C}$ e de $42 \pm 1^{\circ} \mathrm{C}$ foram controladas pela circulação de água na dupla parede externa (camisa) do reator, cuja temperatura foi regulada por um banho ultratermostatizado (marca Marconi modelo MA-184). 


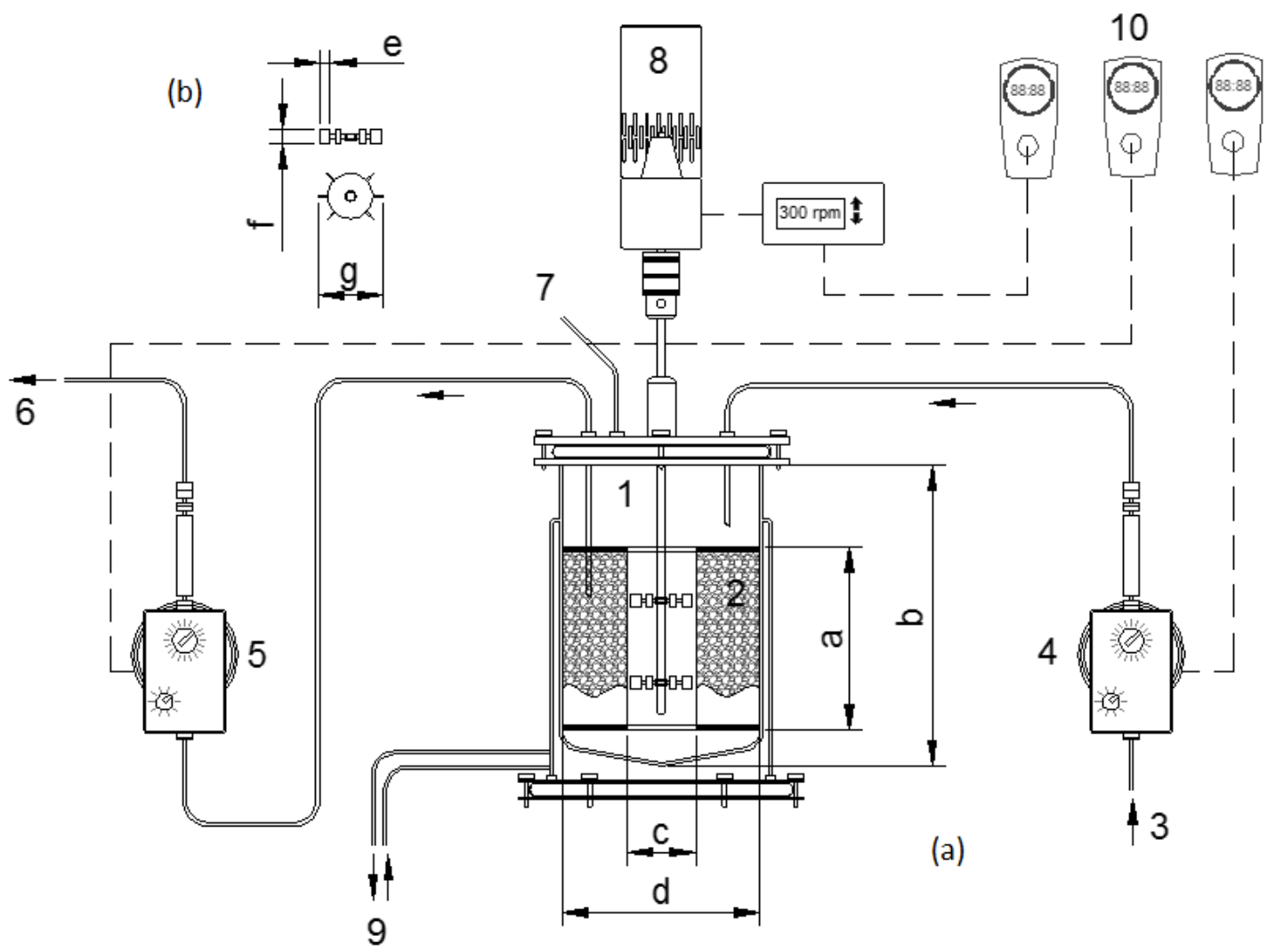

Figura 4-2 a - Esquema do AnSBBR com agitação utilizado nos ensaios

[Notação: (a) Reator 1 - Bioreator BIOFLO 110 (New Brunswick Scientific Co.) com capacidade de 7,5 L $(\mathrm{a}=29,5 \mathrm{~cm} ; \mathrm{b}=18 \mathrm{~cm} ; \mathrm{c}=18 \mathrm{~cm}) ; 2$ - Cesto de retenção e material suporte da biomassa $(b=18 \mathrm{~cm} ; d=7 \mathrm{~cm}) ; 3$ - Afluente; 4 - Bomba de alimentação;

5 -Bomba de descarga; 6 - Efluente; 7 - Saída de biogás; 8 - Sistema de agitação; 9 - Sistema de controle de temperatura (banho termostático); 10 - Sistema de automação;

(b) Detalhes dos impelidores tipo turbina com seis pás planas (e $=2 \mathrm{~cm} ; \mathrm{f}=1,5 \mathrm{~cm} ; \mathrm{g}=6 \mathrm{~cm})]$. 

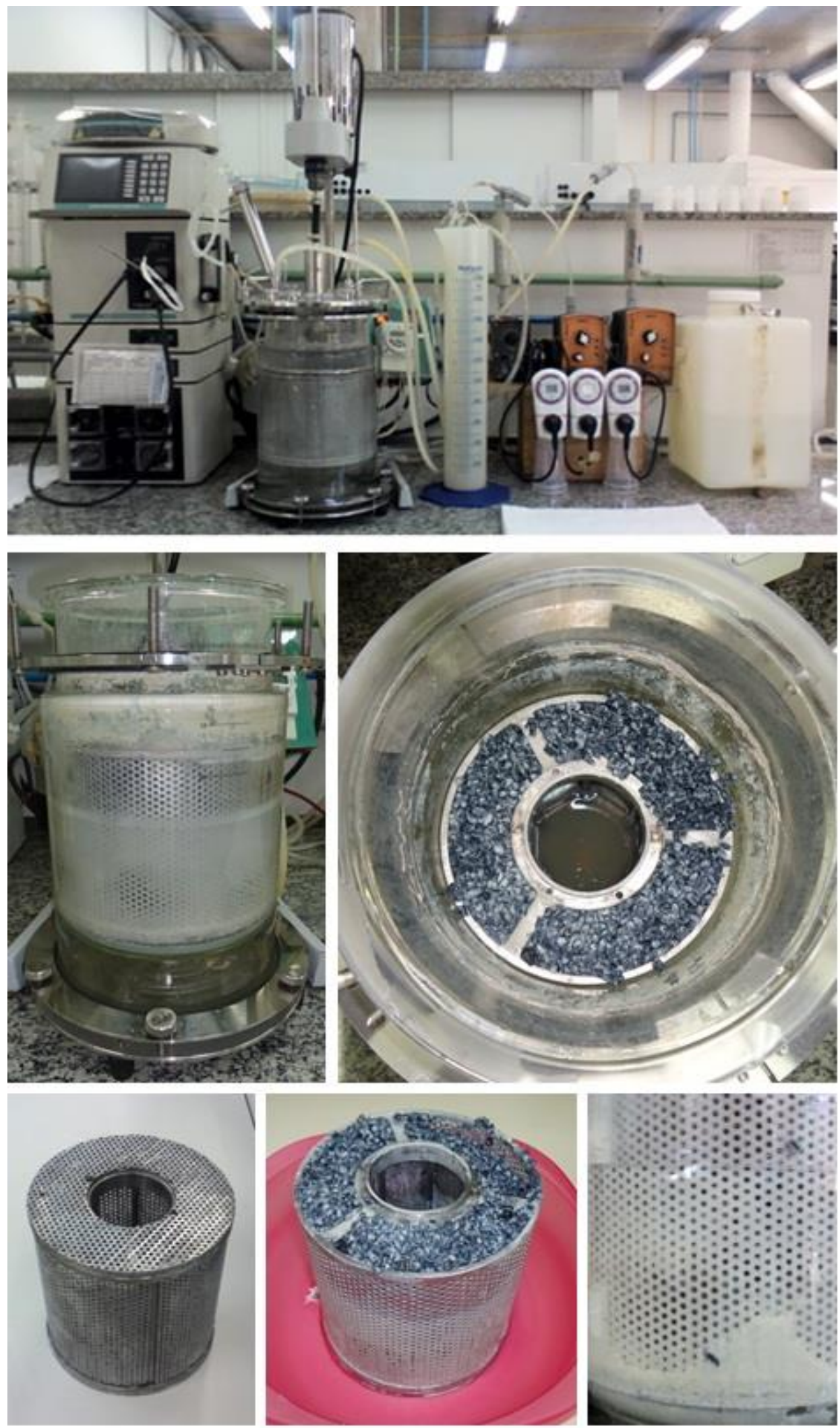

Figura 4.2 b - Fotografia do AnSBBR com agitação utilizado nos ensaios. 


\subsection{Inoculação}

Nos ensaios utilizando o soro de leite buscando a estabilidade do processo e nos ensaios com lactose o inóculo foi obtido de trabalhos anteriores de produção de hidrogênio realizados no laboratório (Manssouri, 2012; Santos, 2012). O material suporte junto com a biomassa que cresceu nos referidos reatores foram guardados em geladeira e usados no presente trabalho. Em uma das condições experimentais (Condição 5) utilizou-se uma forma diferente de inoculação. O inóculo foi obtido pelo processo de fermentação natural do meio de alimentação, preparado com água de abastecimento e mantido em repouso durante três dias, em recipiente aberto. Esse processo favorece a fermentação do meio através de microrganismos presentes na atmosfera e provenientes da água de abastecimento utilizada (Leite et al., 2008).

Nas demais condições utilizando soro de leite o inóculo foi obtido no presente trabalho de produção de hidrogênio em um AnSBBR com agitação mecânica alimentado com lactose.

\section{4. Águas residuárias}

\subsection{1. Água residuária a base de lactose}

Foram realizados ensaios para o AnSBBR com agitação e AnSBBR com recirculação utilizando água residuária formulada a base de lactose, fixando-se a razão entre a fonte de carbono e a fonte de nitrogênio $(\mathrm{C} / \mathrm{N})$ igual a $40, \mathrm{pH}$ igual a 6,0 e razão DQO/P menor que 500 (1000:2). A Tabela 4.1 descreve a composição da água 
residuária para uma concentração em termos de DQO igual a 1000 mg.L $\mathrm{L}^{-1}$ (adaptado de Del Nery, 1987).

A relação $\mathrm{C} / \mathrm{N}(\mathrm{g}-\mathrm{C} / \mathrm{g}-\mathrm{N})$ foi calculada de acordo com a porcentagem em massa de carbono e nitrogênio dos elementos lactose (glicose-galactose $-\mathrm{C}_{12} \mathrm{H}_{22} \mathrm{O}_{11}-144 \mathrm{~g}$ $\mathrm{C} / 342 \mathrm{~g}$-lactose $)$ e uréia $\left(\mathrm{CH}_{4} \mathrm{~N}_{2} \mathrm{O}-28 \mathrm{~g}-\mathrm{N} / 60 \mathrm{~g}\right.$-uréia), que constituíram parte do meio. Assim, a relação $\mathrm{C} / \mathrm{N}$ utilizada nesse estudo foi:

$$
893 / 20=(893 \cdot 144 / 342) /(20 \cdot 28 / 60)=376,0 / 9,33=40,3 \mathrm{~g}-\mathrm{C} / \mathrm{g}-\mathrm{N}
$$

A relação $\mathrm{C} / \mathrm{P}(\mathrm{g}-\mathrm{C} / \mathrm{g}-\mathrm{P})$ foi calculada de acordo com a porcentagem em massa de carbono e fósforo dos elementos lactose (glicose-galactose $-\mathrm{C}_{12} \mathrm{H}_{22} \mathrm{O}_{11}-144 \mathrm{~g}$ $\mathrm{C} / 342 \mathrm{~g}$-lactose $)$ e sais de fósforo $\left(\mathrm{KH}_{2} \mathrm{PO}_{4}-31 \mathrm{~g}-\mathrm{P} / 136 \mathrm{~g}-\mathrm{KH}_{2} \mathrm{PO}_{4} ; \mathrm{K}_{2} \mathrm{HPO}_{4}-31 \mathrm{~g}\right.$ $\mathrm{P} / 174 \mathrm{~g}-\mathrm{K}_{2} \mathrm{HPO}_{4} ; \mathrm{Na}_{2} \mathrm{HPO}_{4}-31 \mathrm{~g}-\mathrm{P} / 142 \mathrm{~g}-\mathrm{Na}_{2} \mathrm{HPO}_{4}$ ), que constituíram parte do meio. Assim, a relação C/P utilizada nesse estudo foi:

- em termos de C: $(893 \cdot 144 / 342) /(5,36 \bullet 31 / 136+1,30 \bullet 31 / 174+2,70 \bullet 31 / 142)$

$$
=376,0 / 2,04=184,3 \mathrm{~g}-\mathrm{C} / \mathrm{g}-\mathrm{P}
$$

- em termos de DQO: $(1000) /(5,36 \cdot 31 / 136+1,30 \bullet 31 / 174+2,70 \bullet 31 / 142)$

$$
=1000 / 2,04=490,2 \text { g-DQO/g-P }
$$

Tabela 4.1 - Composição da água residuária a base de lactose utilizada nos ensaios.

\begin{tabular}{cc}
\hline Composto & Concentração $(\mathrm{mg} / \mathrm{L})$ \\
\hline Lactose & 893,0 \\
(relação teórica: $1000 \mathrm{mg}-\mathrm{DQO}=893 \mathrm{mg}$-lactose) & $(1000 \mathrm{mgDQO} / \mathrm{L})$ \\
Uréia $\left(\mathrm{CH}_{4} \mathrm{~N}_{2} \mathrm{O}\right)$ & 20,0 \\
Sulfato de níquel $\left(\mathrm{NiSO}_{4} \cdot 6 \mathrm{H}_{2} \mathrm{O}\right)$ & 0,50 \\
Sulfato ferroso $\left(\mathrm{FeSO}_{4} \cdot 7 \mathrm{H}_{2} \mathrm{O}\right)$ & 2,50 \\
Cloreto férrico $\left(\mathrm{FeCl}_{3} \cdot 6 \mathrm{H}_{2} \mathrm{O}\right)$ & 0,25 \\
Cloreto de cálcio $\left(\mathrm{CaCl}_{2} \cdot 2 \mathrm{H}_{2} \mathrm{O}\right)$ & 2,06 \\
Cloreto de cobalto $\left(\mathrm{CoCl}_{2} \cdot 6 \mathrm{H}_{2} \mathrm{O}\right)$ & 0,04 \\
Dióxido de selênio $\left(\mathrm{SeO}_{2}\right)$ & 0,04 \\
Fosfato de potássio monobásico $\left(\mathrm{KH}_{2} \mathrm{PO}_{4}\right)$ & 5,36 \\
Fosfato de potássio dibásico $\left(\mathrm{K}_{2} \mathrm{HPO}_{4}\right)$ & 1,30 \\
Fosfato de sódio dibásico $\left(\mathrm{Na}_{2} \mathrm{HPO}_{4}\right)$ & 2,70 \\
Bicarbonato de sódio $\left(\mathrm{NaHCO}_{3}\right)$ & 500,0 \\
\hline
\end{tabular}




\subsection{2. Água residuária a base de soro de leite}

Foram realizados ensaios para o AnSBBR com recirculação utilizando água residuária formulada a base de soro desidratado (em pó) comercial a partir da dissolução com água de torneira cuja composição é mostrada na Tabela 4.2.

Tabela 4.2 - Composição da água residuária a base de soro desidratado (em pó) comercial (Marca Elegê) utilizada nos ensaios.

\begin{tabular}{cc}
\hline Composição & $\%$ \\
\hline Carboidrato & 73,1 \\
Proteína & 11,2 \\
Gorduras Totais & 2,0 \\
Fibra & 0,0 \\
Cálcio & 0,4 \\
Sódio & 0,7 \\
Outros minerais & 7,6 \\
Umidade & 5,0 \\
\hline Obs.: As quantidades de uréia e sais utilizadas nos ensaios que \\
contaram com a presença destes elementos foram as mesmas \\
\multicolumn{2}{c}{ descritas na Tabela 4.1. }
\end{tabular}

\subsection{3. Água residuária a base de sacarose}

Foram realizados ensaios para o AnSBBR com recirculação utilizando água residuária formulada a base de sacarose, utilizando-se os mesmos valores da Tabela 4.1, pois as massas moleculares da lactose e da sacarose são iguais.

\subsection{4. Água residuária a base de leite desnatado tipo "Ionga-vida"}

Foram realizados ensaios para o AnSBBR com recirculação utilizando água residuária formulada a base de leite desnatado longa-vida como fonte de carbono e 
energia, cuja composição é mostrada na Tabela 4.3, destacando-se a relação entre 3600 mgDQO/L e a concentração de carboidratos equivalente de $1430 \mathrm{mg} / \mathrm{L}$.

Tabela 4.3 - Composição da água residuária a base de leite desnatado longa-vida utilizada nos ensaios.

\begin{tabular}{cc}
\hline Análise & Resultado obtido \\
\hline Valor energético & $66 \mathrm{kcal}$ ou $275 \mathrm{~kJ}$ \\
Carboidratos & $9,9 \mathrm{~g}$ \\
Proteínas & $6,1 \mathrm{~g}$ \\
Gorduras totais & $0,0 \mathrm{~g}$ \\
Gorduras saturadas & $0,0 \mathrm{~g}$ \\
Gorduras trans & $0,0 \mathrm{~g}$ \\
Fibra alimentar & $0,0 \mathrm{~g}$ \\
Sódio & $263 \mathrm{mg}$ \\
Cálcio & $337 \mathrm{mg}$ \\
Colesterol & $0,0 \mathrm{mg}$ \\
\hline
\end{tabular}

\subsection{Suporte de imobilização da biomassa anaeróbia}

Como suporte de imobilização da biomassa foi utilizado polietileno de baixa densidade (PEBD), em detalhe na Figura 4-3, obtido como produto do processo de reciclagem de resíduos plásticos. As partículas possuíam aproximadamente $5 \mathrm{~mm}$ de comprimento por $3 \mathrm{~mm}$ de diâmetro.

Para maior caracterização do material suporte foi calculada a densidade aparente e real do material, através da imersão de uma massa conhecida do material em uma proveta graduada com volume de água conhecido, sendo encontrado a densidade aparente de 470 g.L $\mathrm{L}^{-1}$ e densidade real de 825 g.L $\mathrm{L}^{-1}$ Com esses valores da densidade foi realizado o cálculo da porosidade do leito, sendo obtido o valor de $43 \%$. 


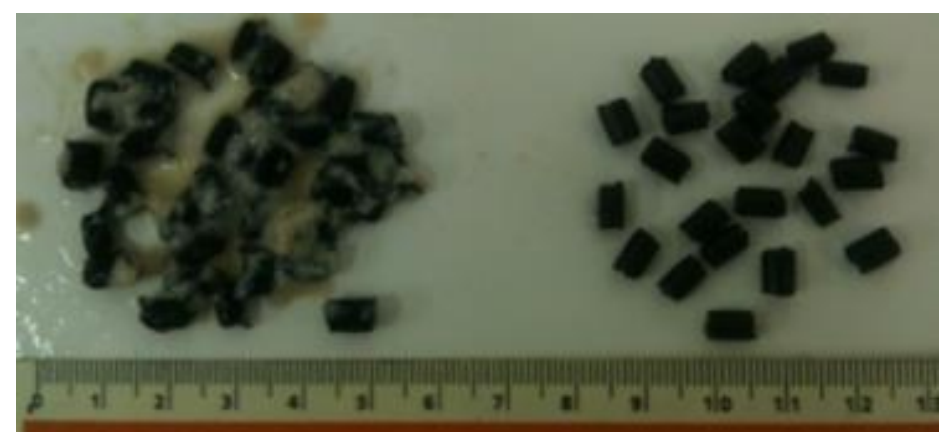

Figura 4-3 - Polietileno de baixa densidade (PEBD) utilizado como material suporte.

\subsection{Análises físico-químicas}

O monitoramento do reator foi efetuado medindo-se, em amostras do afluente e do efluente, as concentrações de matéria orgânica nas formas não filtrada $\left(\mathrm{C}_{\mathrm{ST}}\right)$ e filtrada $\left(\mathrm{C}_{\mathrm{SF}}\right)$ (como demanda química de oxigênio - DQO), alcalinidade parcial (AP), alcalinidade intermediária (AI), alcalinidade total (AT), alcalinidade a bicarbonato (AB), ácidos voláteis totais (AVT), sólidos totais (ST), sólidos totais voláteis (STV), sólidos suspensos totais (SST) e sólidos suspensos voláteis (SSV), além da medida do pH e do volume de meio alimentado/descarregado. Tais análises foram, realizadas de acordo com o Standard Methods for the Examination of Water and Wastewater (1995), considerando também o método proposto por Dilallo e Albertson (1961), o qual foi modificado por Ripley et al. (1986) na determinação da alcalinidade, e o método de Dubois (1956) para a determinação dos carboidratos totais (nas formas não filtrada $\mathrm{C}_{\mathrm{CT}}$ e filtrada $\mathrm{C}_{\mathrm{CF}}$ ). Esses parâmetros foram monitorados como mostrado na Tabela 4.4. 
Tabela 4.4 - Resumo dos procedimentos analíticos e frequência de monitoramento.

\begin{tabular}{cccc}
\hline Parâmetro & Amostra & $\begin{array}{c}\text { Frequência de } \\
\text { monitoramento }\end{array}$ & Método \\
\hline DQO & Afluente e efluente & 4vezes por semana & Standard Methods (1995) \\
Carboidratos & Afluente e efluente & 4vezes por semana & Dubois et. al., 1956 \\
Sólidos Suspensos & Afluente e efluente & 2 vezes por semana & Standard Methods (1995) \\
Volume de biogás & Saída de biogás & 2 vezes por semana & Medidor de gás Ritter \\
pH & Afluente e efluente & 4vezes por semana & Standard Methods (1995) \\
Alcalinidade & Afluente e efluente & 4vezes por semana & Standard Methods (1995) \\
Composição de biogás & Saída de biogás & 2 vezes por semana & Cromatografia gasosa \\
Ácidos voláteis & Efluente & 1vez por semana & Cromatografia gasosa \\
Alcoóis & Efluente & 1vez por semana & Cromatografia gasosa \\
Vazão recirculação & Tubo graduado & 1 vez por semana & Volumétrico \\
\hline
\end{tabular}

Os compostos intermediários do metabolismo anaeróbio (acetona, metanol, etanol, n-butanol, ácidos acético, propiônico, butírico, iso-butírico, valérico, iso-valérico e capróico) foram analisados por cromatografia em fase gasosa, pelo método "headspace", utilizando um cromatógrafo Agilent Technologies ${ }^{\circledR}$ modelo 7890 GC Systemcom injetor automático (fase líquida e "headspace”) GC Sampler 80, equipado com detector de ionização de chama e coluna HP-Innowax com $30 \mathrm{~m} \times 0,25 \mathrm{~mm} \times 0,25$ $\mu \mathrm{m}$ de espessura do filme. O gás de arraste utilizado foi o hidrogênio com vazão de 1,56 mL.min ${ }^{-1}$, a temperatura do injetor foi de $250^{\circ} \mathrm{C}$, a razão de "split" 10 e o volume de injeção de $1 \mu \mathrm{L}$. A temperatura do forno foi programada da seguinte forma: em $35^{\circ} \mathrm{C}$ por $0 \mathrm{~min}, 2^{\circ} \mathrm{C} \cdot \min ^{-1}$ até $38^{\circ} \mathrm{C} ; 10^{\circ} \mathrm{C} \cdot \mathrm{min}^{-1}$ até $75^{\circ} \mathrm{C} ; 35^{\circ} \mathrm{C} \cdot \mathrm{min}^{-1}$ até $120^{\circ} \mathrm{C}$ por 2 minutos; $10^{\circ} \mathrm{C} \cdot \mathrm{min}^{-1}$ até $170^{\circ} \mathrm{C}$ por 2 minutos. A temperatura do detector foi de $280^{\circ} \mathrm{C}$ com fluxo de ar sintético de $300 \mathrm{~mL} / \mathrm{min}$ e vazão de "makeup" de nitrogênio de 30mL/min.Foi utilizado nessa análise o método "head-space", utilizando como padrão interno o ácido crotônico (na determinação dos ácidos voláteis) e isobutanol (na determinação da acetona e alcoóis).

A composição do biogás formado pelo metabolismo anaeróbio (hidrogênio, 
metano e dióxido de carbono) foi analisada por cromatografia em fase gasosa utilizando-se um cromatógrafo Agilent Technologies ${ }^{\circledR}$ modelo 7890 GC System equipado com detector de condutividade térmica e coluna GS-Carbonplot Agilent com $30 \mathrm{~m} \times 0,53 \mathrm{~mm} \times 3,0 \mu \mathrm{m}$ de espessura do filme. O gás de arraste utilizado foi $\mathrm{o}$ argônio com vazão de 3,67 mL.min ${ }^{-1}$, a temperatura do injetor foi de $185^{\circ} \mathrm{C}$, a razão de "split" de 10 e o volume de injeção de $200 \mu \mathrm{L}$. A temperatura do forno foi programada da seguinte forma: em $40^{\circ} \mathrm{C}$ por $5 \mathrm{~min}$, de $40^{\circ} \mathrm{C}$ à $60^{\circ} \mathrm{C}$ em $5^{\circ} \mathrm{C} \cdot \min ^{-1}$, de $60^{\circ} \mathrm{C}$ à $95^{\circ} \mathrm{C}$ em $25^{\circ} \mathrm{C} \cdot \mathrm{min}^{-1}$, de $95^{\circ} \mathrm{C}$ à $200^{\circ} \mathrm{C}$ em $5^{\circ} \mathrm{C} \cdot \mathrm{min}^{-1}$. A temperatura do detector foi de $150^{\circ} \mathrm{C}$, com vazão de "makeup" de argônio de 8,33 mL.min ${ }^{-1}$.

O volume produzido foi medido por meio de medidor de gás Rittter modelo MilligasCounter.

Ao final de cada condição experimental foi realizada a quantificação da biomassa no interior do reator. Primeiramente foi feita a drenagem do sistema, sendo verificado o volume de meio líquido do reator $\left(\mathrm{V}_{\mathrm{R}}\right)$. Em seguida, todo o suporte inerte junto com a biomassa foi retirado do cesto de aço inox e quantificados $\left(\mathrm{M}_{\mathrm{T}-\mathrm{SI}+\mathrm{B}}\right)$, esse material foi homogeneizado para que fosse coletada uma amostra de suporte inerte com biomassa e quantificada $\left(\mathrm{M}_{\mathrm{A}-\mathrm{SI}+\mathrm{B}}\right)$. A partir dessa amostra foi realizada uma "lavagem" com água destilada do suporte inerte, dividindo essa amostra em duas partes, uma fase sólida apenas com os grânulos de PEBD e uma fase líquida contendo a biomassa do reator. Na fase sólida foi realizada a análise de ST e na fase líquida as análises de ST e SVT. A partir da quantidade de ST dos grânulos de PEBD $\left(\mathrm{M}_{\mathrm{A}-\mathrm{ST}}\right)$ e a quantidade de SVT da amostra $\left(\mathrm{M}_{\mathrm{A}-\mathrm{SVT}}\right)$, foi possível estimar a quantidade de biomassa do reator, sendo tal informação apresentada por três diferentes formas: 
(i) Quantidade total de biomassa do reator $\left(\mathrm{M}_{\mathrm{SVT}}\right.$ - Equação 4.1)

$$
\mathrm{M}_{\mathrm{SVT}}=\frac{\mathrm{M}_{\mathrm{A}-\mathrm{SVT}} \cdot \mathrm{M}_{\mathrm{T}-\mathrm{SI}+\mathrm{B}}}{\mathrm{M}_{\mathrm{A}-\mathrm{SI}+\mathrm{B}}}
$$

Pela quantidade total de biomassa do reator $\left(\mathrm{M}_{\mathrm{SVT}}\right)$ mede-se a capacidade do reator na retenção da biomassa, sendo essa variável importante também devido à sua utilização em outros indicadores utilizados na análise do reator, como a carga orgânica específica aplicada (COEA), a carga orgânica específica removida (COER) e a produtividade molar específica (PrME).

(ii) Relação entre a quantidade de biomassa e o volume de meio líquido do reator $\left(C_{X}-\right.$ Equação 4.2)

$$
C_{X}=\frac{M_{S V T}}{V_{R}}
$$

Pela concentração de biomassa no reator por volume de meio líquido tratado por ciclo $\left(\mathrm{C}_{\mathrm{X}}\right)$ mede-se a relação entre a quantidade de meio líquido disponível ao tratamento e a biomassa envolvida nas biotransformações inerentes ao processo biológico em estudo.

(iii) Relação entre a quantidade de biomassa e a quantidade de suporte inerte presente no reator $\left(\mathrm{C}_{\mathrm{X}^{\prime}}\right.$ - Equação (4.3) 


$$
\mathrm{C}_{\mathrm{X}}^{\prime}=\frac{\mathrm{M}_{\mathrm{A}-\mathrm{SVT}}}{\mathrm{M}_{\mathrm{A}-\mathrm{SI}}}
$$

Pela concentração de biomassa no reator por massa de suporte inerte presente no reator $\left(\mathrm{C}_{X}{ }^{\prime}\right)$ mede-se a relação entre a quantidade de suporte inerte disponível para a imobilização/retenção da biomassa e a biomassa envolvida nas biotransformações inerentes ao processo biológico em estudo.

\subsubsection{AnSBBR com recirculação da fase líquida}

Os ensaios realizados para o AnSBBR com recirculação são resumidos na Tabela 4.5. 
Tabela 4.5 - Resumos das condições experimentais do AnSBBR com recirculação.

\begin{tabular}{|c|c|c|c|c|c|c|}
\hline Ensaio & Substrato & $\begin{array}{c}\mathrm{C}_{\mathrm{STA}} \\
\left(\mathrm{mgDQO} \cdot \mathrm{L}^{-1}\right)\end{array}$ & $\begin{array}{l}\mathrm{t}_{\mathrm{C}} \\
(\mathrm{h})\end{array}$ & $\begin{array}{c}\text { COAV } \\
\left(\mathrm{mgDQO} \cdot \mathrm{L}^{-1} \cdot \mathrm{d}^{-1}\right)\end{array}$ & $\begin{array}{c}\text { Temperatura } \\
\left({ }^{\circ} \mathrm{C}\right)\end{array}$ & $\begin{array}{c}\text { Tipo de } \\
\text { alimentação }\end{array}$ \\
\hline 1 & Soro de leite & 4250 & 4,0 & 10,9 & $30 \pm 1$ & Batelada \\
\hline 2 & $\begin{array}{c}\text { Sacarose e Soro de } \\
\text { leite }\end{array}$ & 3600 e 4250 & 4,0 & 9,3 e 10,9 & $30 \pm 1$ & Batelada \\
\hline 3 & Lactose e Soro de leite & 3600 e 4250 & 4,0 & 9,3 e 10,9 & $30 \pm 1$ & Batelada \\
\hline 4 & Soro de leite & 4250 & 3,0 & 14,6 & $30 \pm 1$ & Batelada \\
\hline 5 & Soro de leite & 4250 & 3,0 & 14,6 & $30 \pm 1$ & Batelada \\
\hline 6 & Soro de leite & 4250 & 3,0 & 14,6 & $30 \pm 1$ & Batelada \\
\hline 7 & $\begin{array}{l}\text { Leite desnatado longa } \\
\text { vida }\end{array}$ & 4250 & 3,0 & 14,6 & $30 \pm 1$ & Batelada \\
\hline 8 & Soro de leite & 4250 & 3,0 & 14,6 & $30 \pm 1$ & Batelada \\
\hline 9 & Soro de leite & 6350 & 3,0 & 21,8 & $30 \pm 1$ & Batelada \\
\hline 10 & Soro de leite & 5400 & 3,0 & 18,5 & $30 \pm 1$ & Batelada \\
\hline 11 & Soro de leite & 5400 & 3,0 & 18,5 & $30 \pm 1$ & $\begin{array}{c}\text { Batelada } \\
\text { alimentada }\end{array}$ \\
\hline 12 & Soro de leite & 5400 & 3,0 & 18,5 & $45 \pm 1$ & Batelada \\
\hline 13 & Soro de leite & 5400 & 3,0 & 18,5 & $15 \pm 1$ & Batelada \\
\hline
\end{tabular}

A operação do reator foi realizada da seguinte maneira: no primeiro ciclo o sistema era alimentado com $3,5 \mathrm{~L}(2,0 \mathrm{~L}$ de meio no reator e $1,5 \mathrm{~L}$ de meio no reservatório) em $20 \mathrm{~min}$, sendo que o reator foi previamente preparado com o suporte inerte. Após o término da alimentação a vazão de recirculação era ligada (20 L.h ${ }^{-1}$ velocidade de recirculação de $0,2 \mathrm{~cm} \cdot \mathrm{s}^{-1}$ ). Ao final de um ciclo, a vazão de recirculação era desligada e eram descarregados $1,5 \mathrm{~L}$ de meio (em $10 \mathrm{~min}$ ), sendo mantidos no reator 2,0 L (denominado volume residual), ou seja, o volume total de meio líquido no sistema era de 3,5 L. Logo após essa descarga, um novo ciclo tinha início com a alimentação (com vazão constante) de 1,5 L de meio, em $10 \mathrm{~min}$, seguida pela recirculação da fase líquida. Ao término do ciclo, novamente a recirculação era interrompida e, em seguida, iniciava-se a descarga do reator. Assim, o ciclo era 
repetido, caracterizando as bateladas sequenciais.

Uma vez atingida a estabilidade nas condições experimentais, foram obtidos perfis ao longo do ciclo de operação de algumas das variáveis monitoradas. Aqui é importante definir o que é a estabilidade do processo em questão. Considerou-se, no presente trabalho, estabilidade do processo quando os indicadores de produção de hidrogênio apresentaram baixa variação de valores $( \pm 10 \%)$ durante pelos menos três dias após três semanas de operação. Nestes perfis foram retiradas amostras ao longo do tempo de operação de um ciclo. As variáveis de interesse foram: concentrações de matéria orgânica e carboidratos totais na forma filtrada, de alcalinidade a bicarbonato, de ácidos voláteis totais, de metabólitos intermediários (acetona, ácidos voláteis e alcoóis), de biogás (composição e produção), além do pH. As amostras retiradas para obtenção dos perfis anteriormente citados foram colhidas em intervalos de 20-30 min ao longo do ciclo. $\mathrm{O}$ volume total retirado nas amostragens foi de, no máximo, $350 \mathrm{~mL}$, ou seja, $10 \%$ do volume de meio reacional do sistema.

Os resultados experimentais obtidos no monitoramento do sistema e nos perfis ao longo de um ciclo, em cada condição operacional, foram analisados considerando-se a influência das variáveis estudadas sobre a estabilidade e o desempenho do processo, do fator de conversão entre hidrogênio formado e matéria orgânica consumida, e da relação entre hidrogênio, metano e dióxido de carbono formados.

A Figura 4-4 organiza a maneira como as condições experimentais estudadas foram realizadas na primeira parte dos experimentos com soro de leite (até atingir-se 
uma

produção

estável

de

hidrogênio).

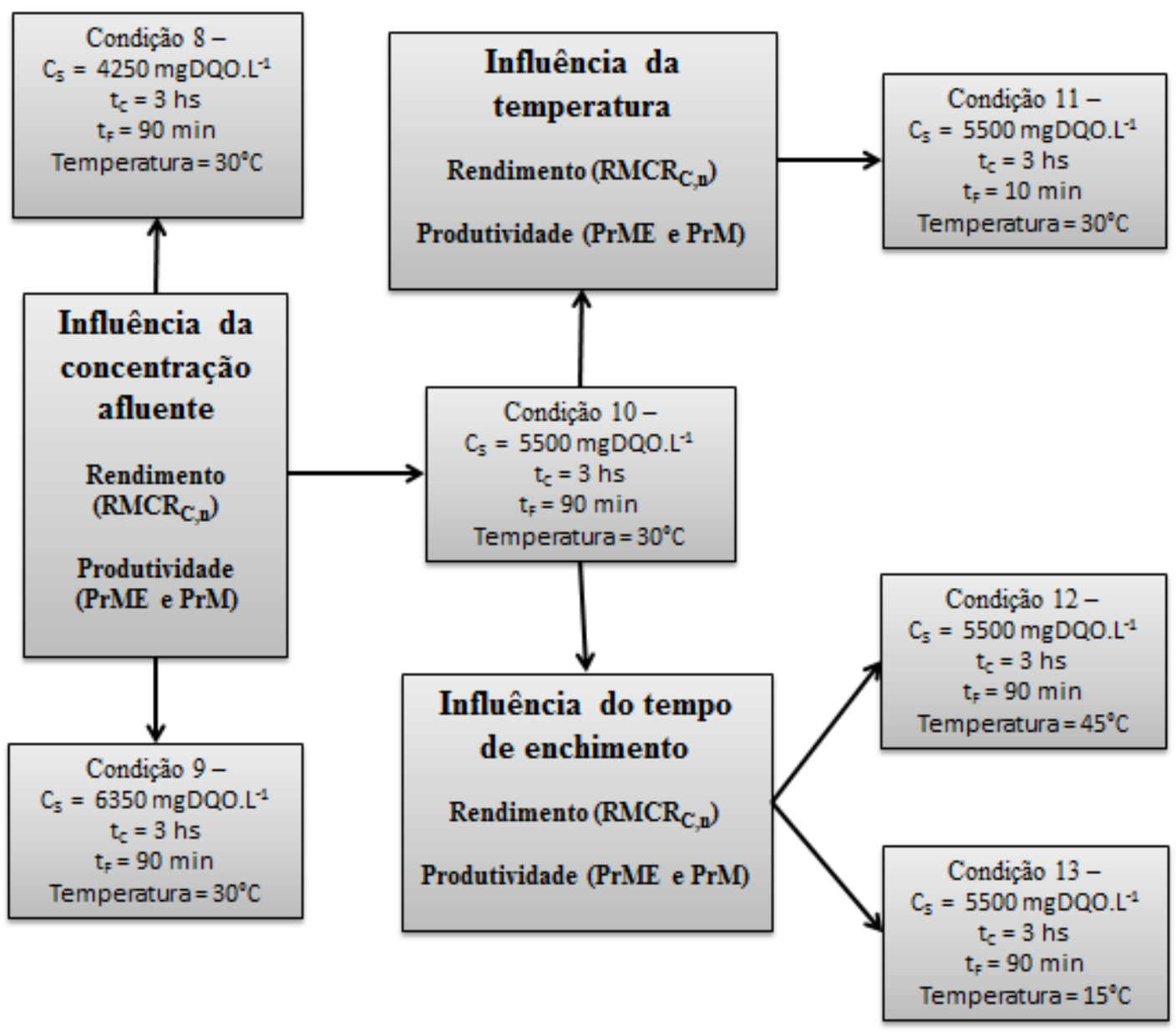

Figura 4-5 organiza a segunda parte dos experimentos, quando foi analisada a influência da concentração afluente, do tempo de enchimento e da temperatura na produção de biohidrogênio utilizando soro de leite como substrato. 


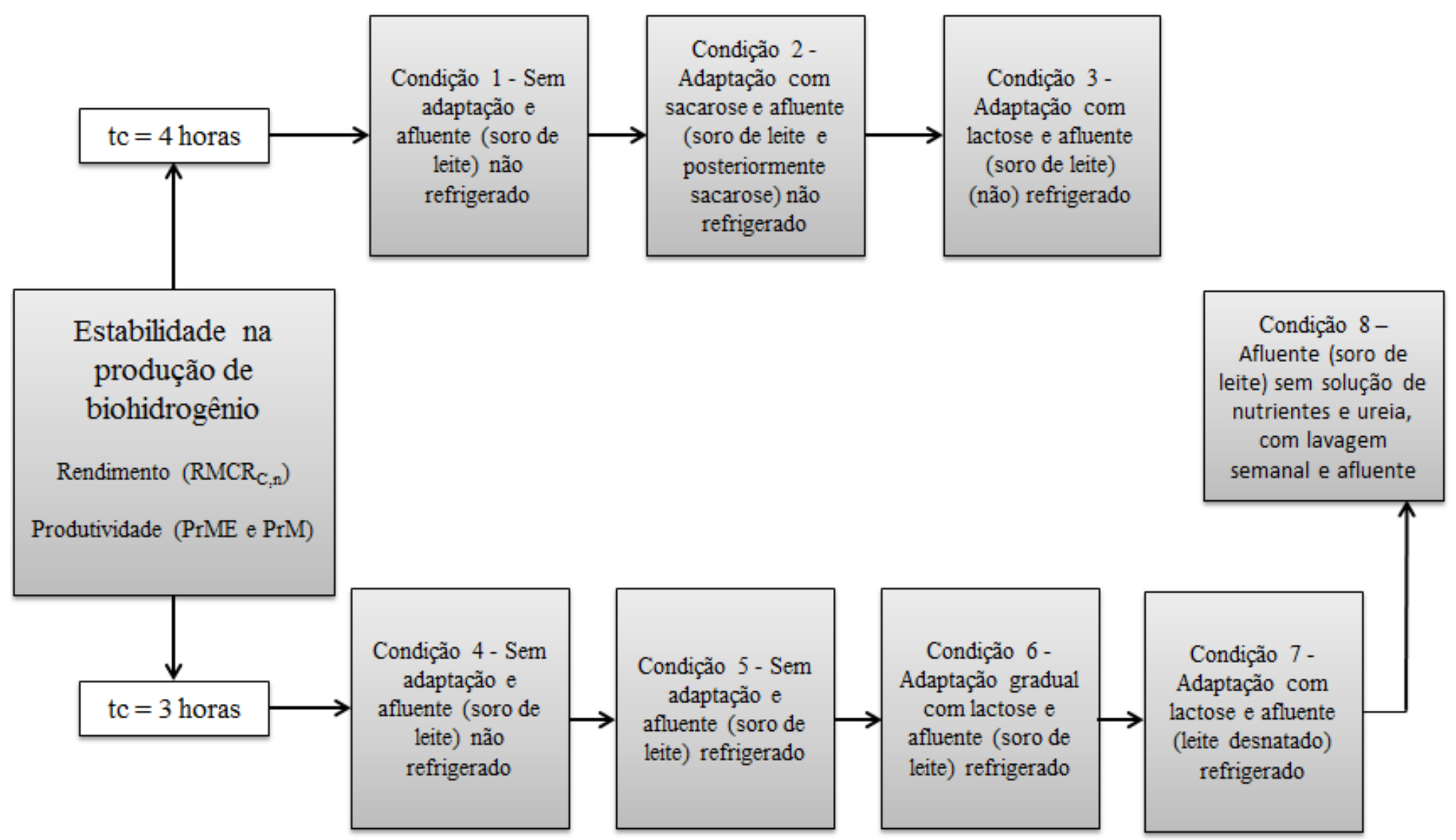

Figura 4-4 - Esquema das condições experimentais estudadas no AnSBBR com recirculação: estabilidade do processo. 


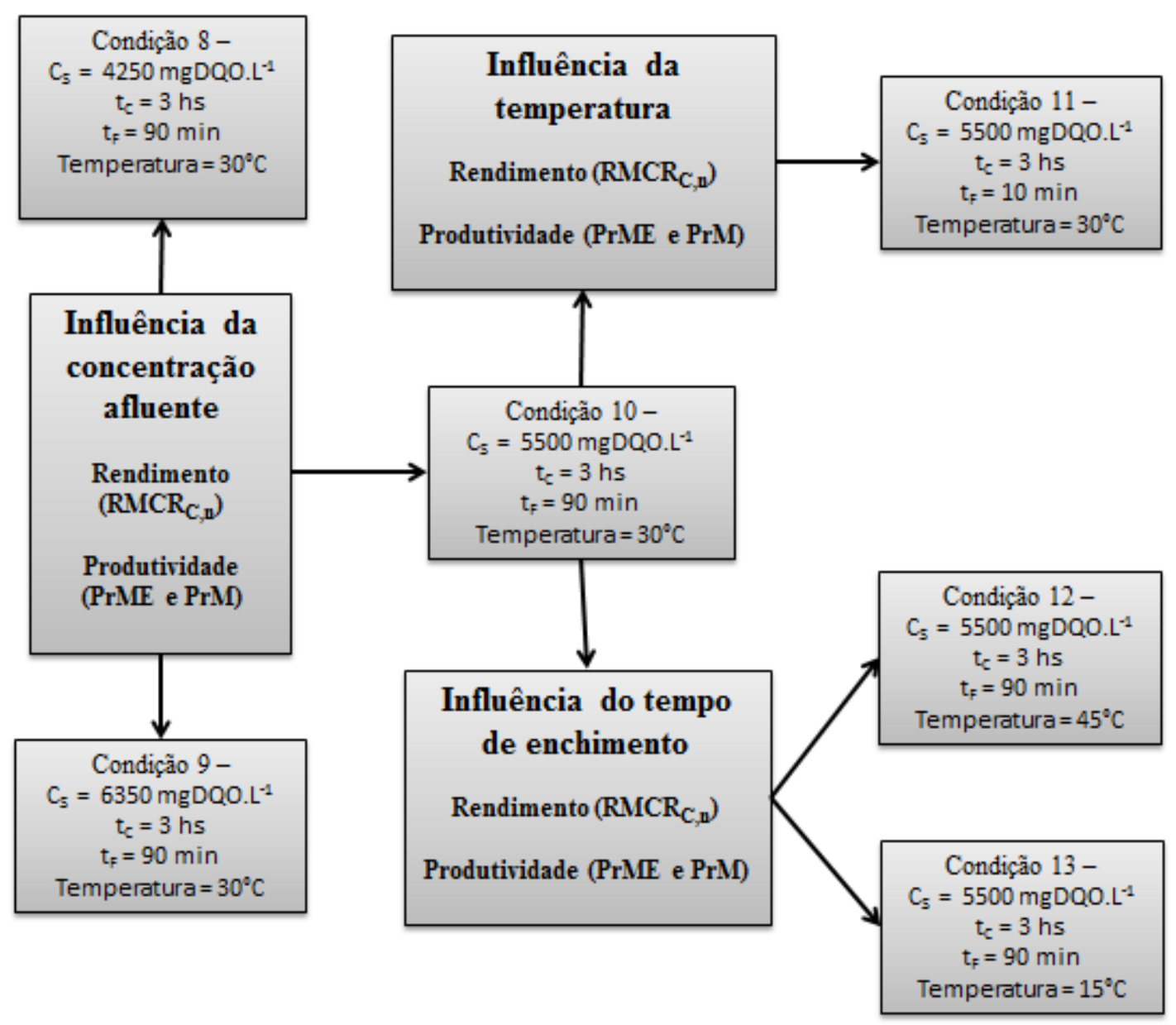

Figura 4-5 - Esquema das condições experimentais estudadas no AnSBBR com recirculação: influência da concentração afluente, da estratégia de alimentação e da temperatura.

\subsection{Caracterização filogenética do consórcio microbiano do AnSBBR operado a $15{ }^{\circ} \mathrm{C}(\mathbf{C 1 3})$}

Amostra de biomassa foi retirada do reator AnSBBR ao final do período operacional, centrifugada $(6.000 \mathrm{rpm}$ por $10 \mathrm{~min})$, congelada até o momento das análises de biologia molecular. O ácido nucléico foi extraído, amplificado por PCR $($ com set de primers 27F (AGAGTTTGATCMTGGCTCAG) e 1492R (TACGGYTACCTTGTTACGACTT)) (Lane, 1991), clonado em vetor apropriado (T- 
vector) e, posteriormente, os clones foram sequenciado em analisador automático de DNA modelo ABI3730XL (Applied Biosystems).

As sequências foram averiguadas manualmente com auxílio do software DNASTAR package (Lasergene Sequence Analysis). A presença de vetores e de quimeras nas sequências foi averiguada com o auxílio das ferramentas VECSCREEN (http://www.ncbi.nlm.nih.gov/tools/vecscreen/) e DECIPHER's FIND CHIMERAS (http://decipher.cee.wisc.edu/FindChimeras.html), respectivamente. As sequências verificadas foram então alinhadas usando-se a ferramenta ALIGNER e, agrupadas em Unidades Taxonômicas Operacionais (UTOs) usando-se a ferramenta COMPLETE LINKAGE CLUSTERING. Posteriormente, usou-se a ferramenta REPRESENTATIVE SEQUENCE para determinar a sequências representativas de cada UTO, as quais foram utilizadas para a análise filogenética. As sequências representativas de cada UTO foram comparadas com as sequências depositadas no banco de dados usando-se a ferramenta SEQMATCH. Todas as referidas análises foram realizadas usando-se ferramentas disponíveis no website Ribosomal Database Project (http://rdp.cme.msu.edu/).

A árvore filogenética foi construída com auxílio do software MEGA versão 6 (Tamura et al., 2013) usando o método Neighbor-Joining (Saitou e Nei, 1987). As distâncias evolutivas foram calculadas usando o método Jukes-Cantor (Jukes e Cantor, 1969). A confiabilidade da árvore foi avaliada pelo teste de bootstrap para 1000 repetições (Felsenstein, 1985). Escherichia coli (DQ118017) foi utilizada como espécie outgroup. As sequências representativas de cada UTO (UTO_1-KP702244, UTO_2KP702242，UTO_3-KP702243，UTO_4-KP702247, UTO_5-KP702245, UTO_6KP702246) foram depositadas na base de dados do NCBI. 


\subsection{Procedimento experimental}

\subsubsection{AnSBBR com agitação mecânica}

Para o AnSBBR com agitação mecânica, os ensaios foram realizados utilizandose diferentes cargas orgânicas volumétricas modificadas em função da concentração afluente, de 3600 e 5400 mgDQO.L ${ }^{-1}$, e do tempo de ciclo, de 4, 3 e 2 h, ou seja, 6,8 e 12 ciclos diários conforme mostra a Tabela 4.6. 
Tabela 4.6 - Resumo das condições experimentais estudadas no AnSBBR com agitação.

\begin{tabular}{cccccc}
\hline Condição & $\begin{array}{c}\text { Concentração afluente } \\
\left(\mathrm{mg} . \mathrm{L}^{-1}\right)\end{array}$ & $\begin{array}{c}\text { Tempo de ciclo } \\
(\mathrm{h})\end{array}$ & $\begin{array}{c}\text { Número de ciclos } \\
\left(\text { Ciclos.d }{ }^{-1}\right)\end{array}$ & $\begin{array}{c}\text { COAV } \\
\left(\mathrm{gDQO} . \mathrm{L}^{-1} \cdot \mathrm{d}^{-1}\right)\end{array}$ & $\begin{array}{c}\text { Temperatura } \\
\left({ }^{\circ} \mathrm{C}\right)\end{array}$ \\
\hline 1 & 3600 & 4 & 6 & 9,3 & $30 \pm 1$ \\
2 & 5400 & 4 & 6 & 13,9 & $30 \pm 1$ \\
3 & 3600 & 3 & 8 & 12,3 & $30 \pm 1$ \\
4 & 5400 & 3 & 8 & 18,5 & $30 \pm 1$ \\
5 & 3600 & 2 & 12 & 18,5 & $30 \pm 1$ \\
6 & 5400 & 2 & 12 & 27,8 & $30 \pm 1$ \\
\hline
\end{tabular}

O volume útil do reator $(5,6 \mathrm{~L})$ foi dividido em 3 partes: volume de meio tratado por ciclo de 1,5 L, volume residual de meio de 2,0 L e volume de suporte inerte com biomassa de 2,1 L (material suporte inerte e cesto). A operação do reator foi realizada da seguinte maneira: no primeiro ciclo foram alimentados 3,5 L ao reator em 20 min de meio ao reator, sendo que o reator foi previamente preparado pela colocação de $1,1 \mathrm{~kg}$ de suporte inerte (PEBD) contendo inóculo, com massa de sólidos voláteis totais por massa de material suporte $\left(\mathrm{C}_{\mathrm{X}^{\prime}}\right)$ de $0,02 \mathrm{~g} \cdot \mathrm{g}^{-1}$ (Manssouri, 2012).

Após o término da alimentação foi implementada uma agitação de $300 \mathrm{rpm}$. No final do ciclo, cuja duração foi em função da condição experimental em estudo, a agitação era desligada e eram descarregados 1,5 L de meio em 10 min, sendo que 2,0 L de volume residual ficavam mantidos no reator (além dos $2,1 \mathrm{~L}$ de suporte inerte e inóculo).

Logo após essa descarga, um novo ciclo tinha início, no qual, simultaneamente, havia a agitação do meio (300 rpm) e alimentação com vazão constante mas em tempos de enchimento diferentes em função da condição experimental. Ao término do ciclo, a agitação era interrompida e, em seguida, começava a descarga em 10 min e, assim, o ciclo era repetido, caracterizando as bateladas.

Uma vez atingida à estabilidade nas condições experimentais monitoradas no efluente descarregado nos finais dos ciclos, foram obtidos perfis ao longo do ciclo de 
operação de algumas das variáveis monitoradas. Nestes perfis foram retiradas amostras ao longo do tempo de operação de um ciclo. As variáveis de interesse foram: concentrações de matéria orgânica na forma filtrada (de carboidratos e de DQO), de alcalinidade a bicarbonato (AB), de ácidos voláteis totais (AVT), de metabólitos intermediários (solventes e ácidos voláteis), de biogás (composição e produção), além do $\mathrm{pH}$. O volume total retirado nas amostragens foi de no máximo $300 \mathrm{~mL}$, ou seja, $10 \%$ do volume de meio reacional do sistema.

O procedimento experimental foi conduzido dessa maneira para que não fosse feita apenas uma análise sobre o efeito da carga orgânica volumétrica aplicada, mas também na verificação da influência da concentração afluente e do tempo de ciclo, que são variáveis intrínsecas a carga orgânica volumétrica aplicada:

* A influência da carga orgânica volumétrica aplicada foi verificada pela análise das seis condições experimentais estudadas;

* A influência do tempo de ciclo foi realizada pela análise dos ensaios com tempos de ciclo de 4, 3 e 2 horas, sendo que a modificação foi realizada para uma concentração de 3600 mgDQO.L ${ }^{-1}$ (condições1, 3 e 5) e para uma concentração de $5400 \mathrm{mgDQO} . \mathrm{L}^{-1}$ (condições 2, 4 e 6);

* A influência da concentração afluente foi realizada pela análise dos ensaios realizados com concentrações de 3600 e 5400 mgDQO.L ${ }^{-1}$, sendo que a modificação foi realizada para um tempo de ciclo de 4 h (condições 1 e 2), para um tempo de ciclo de $3 \mathrm{~h}$ (condições 3 e 4) e para um tempo de ciclo de 2 h (condições 5 e 6);

* A análise sobre os ensaios com mesma carga orgânica volumétrica aplicada de 18,0 gDQO.L $\mathrm{L}^{-1} \mathrm{~d}^{-1}$, porém combinando tempos de ciclos e concentrações diferentes, ou seja, um ensaio com tempo de ciclo de 3 h e concentração de 
$5400 \mathrm{mgDQO} . \mathrm{L}^{-1}$ (condição 4) e outro ensaio com tempo de ciclo de $2 \mathrm{~h}$ e concentração de 3600 mgDQO.L ${ }^{-1}$ (condição 5).

A Figura 4-6 organiza a maneira com que as condições experimentais estudadas foram utilizadas na verificação da influência da carga orgânica volumétrica aplicada, do tempo de ciclo e da concentração afluente. Essas influências sobre o reator foram avaliadas quanto à estabilidade, ao fator de conversão (consumo de matéria orgânica nas formas de DQO e de carboidratos), ao rendimento entre hidrogênio produzido e substrato (na forma de carboidratos) consumido $\left(\mathrm{RMCR}_{\mathrm{C}, \mathrm{n}} \mathrm{em} \mathrm{molH}_{2} \cdot \mathrm{molSAC}^{-1}\right)$, e à produtividade do reator (PrME em molH $2 \cdot \mathrm{kgSVT}^{-1} \cdot \mathrm{d}^{-1}$ e PrM em molH $\left.2 \cdot \mathrm{m}^{-3} \cdot \mathrm{d}^{-1}\right)$. 


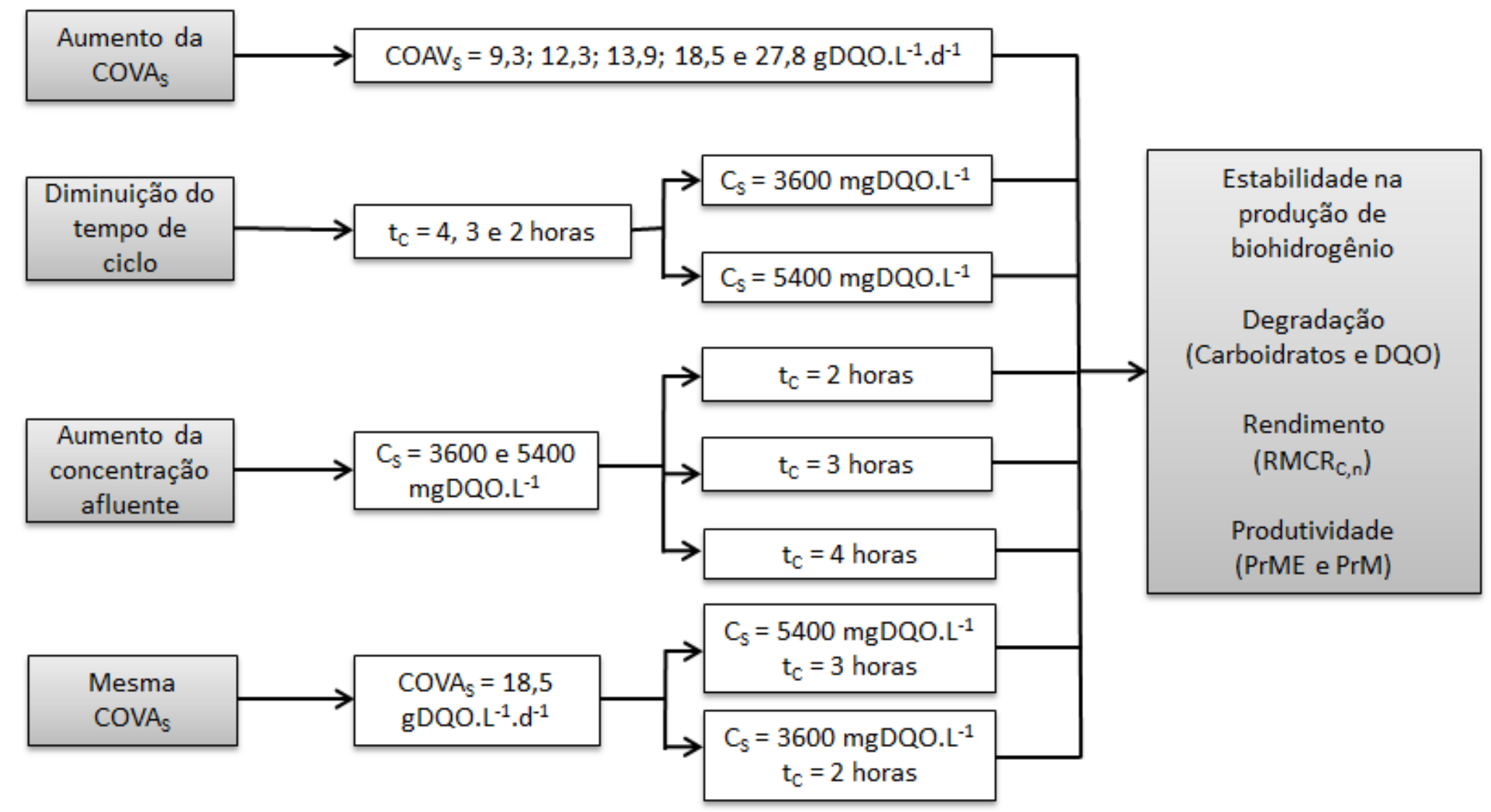

Figura 4-6 - Esquema utilizado para análise dos resultados do AnSBBR com agitação. 


\subsection{Fundamentos teóricos}

As eficiências de remoção de matéria orgânica e carboidrato não filtradas $\left(\varepsilon_{\mathrm{ST}} \mathrm{e}\right.$ $\left.\varepsilon_{\mathrm{CT}}\right)$ no sistema foram calculadas pelas Equações (4.4) e (4.5), nas quais $\mathrm{C}_{\mathrm{STA}}$ e $\mathrm{C}_{\mathrm{CTA}}$ são as concentrações de matéria orgânica e de carboidrato de amostras não filtradas no afluente e $\mathrm{C}_{\mathrm{STE}}$ e $\mathrm{C}_{\mathrm{CTE}}$ são as concentrações de matéria orgânica e carboidrato de amostras não filtradas no efluente.

$$
\begin{aligned}
& \varepsilon_{\mathrm{ST}}(\%)=\frac{\mathrm{C}_{\mathrm{STA}}-\mathrm{C}_{\mathrm{STE}}}{\mathrm{C}_{\mathrm{STA}}} \cdot 100 \\
& \varepsilon_{\mathrm{CT}}(\%)=\frac{\mathrm{C}_{\mathrm{CTA}}-\mathrm{C}_{\mathrm{CTE}}}{\mathrm{C}_{\mathrm{CTA}}} \cdot 100
\end{aligned}
$$

As eficiências de remoção de matéria orgânica e carboidrato filtradas ( $\varepsilon_{\mathrm{SF}}$ e $\left.\varepsilon_{\mathrm{CF}}\right)$ no sistema foram calculadas pelas Equações (4.6) e (4.7), nas quais $C_{S F E}$ e $C_{C F E}$ são as concentrações de matéria orgânica e carboidrato de amostras filtradas no efluente.

$$
\begin{aligned}
& \varepsilon_{\mathrm{SF}}(\%)=\frac{\mathrm{C}_{\mathrm{STA}}-\mathrm{C}_{\mathrm{SFE}}}{\mathrm{C}_{\mathrm{SFA}}} \cdot 100 \\
& \varepsilon_{\mathrm{CF}}(\%)=\frac{\mathrm{C}_{\mathrm{CTA}}-\mathrm{C}_{\mathrm{CFE}}}{\mathrm{C}_{\mathrm{CFA}}} \cdot 100
\end{aligned}
$$

As eficiências de remoção de matéria orgânica e carboidrato filtradas $\left(\varepsilon_{\mathrm{S}}\right.$ e $\left.\varepsilon_{\mathrm{C}}\right)$ para os perfis ao longo do ciclo foram calculadas pelas Equações (4.8) e (4.9), nas quais $\mathrm{C}_{\mathrm{STA} 0}$ e $\mathrm{C}_{\mathrm{CTA} 0}$ são as concentrações de matéria orgânica e de carboidratos filtrada no interior do reator no início do ciclo (tempo zero), ou seja, a concentração de matéria orgânica e de carboidrato no reator após a diluição inicial do afluente. 


$$
\begin{aligned}
& \varepsilon_{\mathrm{S}}(\%)=\frac{\mathrm{C}_{\mathrm{STA} 0}-\mathrm{C}_{\mathrm{SFE}}}{\mathrm{C}_{\mathrm{SFA}}} \cdot 100 \\
& \varepsilon_{\mathrm{C}}(\%)=\frac{\mathrm{C}_{\mathrm{CTA} 0}-\mathrm{C}_{\mathrm{CFE}}}{\mathrm{C}_{\mathrm{CFA}}} \cdot 100
\end{aligned}
$$

As cargas orgânicas aplicadas volumétricas $\left(\mathrm{COAV}_{\mathrm{S}}\right.$ e $\left.\mathrm{COAV}_{\mathrm{C}}\right)$, expressas em kgDQO. $\mathrm{m}^{-3} \cdot \mathrm{d}^{-1}$ e kgCarboidrato. $\mathrm{m}^{-3} \cdot \mathrm{d}^{-1}$, foram definidas como as quantidades de matéria orgânica e carboidrato aplicadas ao reator por unidade de tempo e por volume de meio do reator. Para reatores operados em batelada podem ser calculadas pelas Equações (4.10) e (4.11), nas quais $\mathrm{V}_{\mathrm{A}}$ é o volume de água residuária alimentada no ciclo, $\mathrm{N}$ é o número de ciclos por dia, e $\mathrm{V}_{\mathrm{R}}$ é o volume de água residuária no reator.

$$
\begin{aligned}
& \operatorname{COAV}_{\mathrm{S}}=\frac{\left(\mathrm{V}_{\mathrm{A}} \cdot \mathrm{N}\right) \cdot \mathrm{C}_{\mathrm{STA}}}{\mathrm{V}_{\mathrm{R}}} \\
& \operatorname{COAV}_{\mathrm{C}}=\frac{\left(\mathrm{V}_{\mathrm{A}} \cdot \mathrm{N}\right) \cdot \mathrm{C}_{\mathrm{CTA}}}{\mathrm{V}_{\mathrm{R}}}
\end{aligned}
$$

As cargas orgânicas aplicadas específicas $\left(\mathrm{COAE}_{\mathrm{S}}\right.$ e $\left.\mathrm{COAE}_{\mathrm{C}}\right)$, expressas em kgDQO.gSVT.d ${ }^{-1}$ e kgCarboidrato.gSVT.d ${ }^{-1}$, foram definidas como as quantidades de matéria orgânica e carboidrato aplicadas ao reator por unidade de tempo e por massa de sólidos totais voláteis no reator. Para reatores operados em batelada podem ser calculadas pelas Equações (4.12) e (4.13), nas quais $\mathrm{M}_{\mathrm{SvT}}$ é a massa de sólidos voláteis totais no interior do reator.

$$
\mathrm{COAE}_{\mathrm{STA}}=\frac{\left(\mathrm{V}_{\mathrm{A}} \cdot \mathrm{N}\right) \cdot \mathrm{C}_{\mathrm{STA}}}{\mathrm{M}_{\mathrm{SVT}}}
$$


$\mathrm{COAE}_{\mathrm{CTA}}=\frac{\left(\mathrm{V}_{\mathrm{A}} \cdot \mathrm{N}\right) \cdot \mathrm{C}_{\mathrm{CTA}}}{\mathrm{M}_{\mathrm{SVT}}}$

As cargas orgânicas removidas volumétricas $\left(\mathrm{CORV}_{\mathrm{S}}\right.$ e $\left.\mathrm{CORV}_{\mathrm{C}}\right)$, expressas em kgDQO. $\mathrm{m}^{-3} \cdot \mathrm{d}^{-1}$ e $\mathrm{kgCarboidrato} \cdot \mathrm{m}^{-3} \cdot \mathrm{d}^{-1}$, foram definidas como as quantidades de matéria orgânica e carboidrato removidas pelo reator por unidade de tempo e por volume de meio do reator. Para reatores operados em batelada podem ser calculadas pelas Equações (4.14) e (4.15).

$$
\begin{aligned}
& \operatorname{CORV}_{\mathrm{S}}=\frac{\left(\mathrm{V}_{\mathrm{A}} \cdot \mathrm{N}\right) \cdot\left(\mathrm{C}_{\mathrm{STA}}-\mathrm{C}_{\mathrm{SFE}}\right)}{\mathrm{V}_{\mathrm{R}}} \\
& \operatorname{CORV}_{\mathrm{C}}=\frac{\left(\mathrm{V}_{\mathrm{A}} \cdot \mathrm{N}\right) \cdot\left(\mathrm{C}_{\mathrm{CTA}}-\mathrm{C}_{\mathrm{CFE}}\right)}{\mathrm{V}_{\mathrm{R}}}
\end{aligned}
$$

As cargas orgânicas removidas específicas $\left(\mathrm{CORE}_{\mathrm{S}}\right.$ e $\left.\mathrm{CORE}_{\mathrm{C}}\right)$, expressas em kgDQO.gSVT.d ${ }^{-1}$ e kgCarboidrato.gSVT.d ${ }^{-1}$, foram definidas como as quantidades de matéria orgânica e carboidrato removidas reator por unidade de tempo e por massa de sólidos totais voláteis no reator. Para reatores operados em batelada podem ser calculadas pelas Equações (4.16) e (4.17).

$$
\begin{aligned}
& \operatorname{CORE}_{\mathrm{S}}=\frac{\left(\mathrm{V}_{\mathrm{A}} \cdot \mathrm{N}\right) \cdot\left(\mathrm{C}_{\mathrm{STA}}-\mathrm{C}_{\mathrm{SFE}}\right)}{\mathrm{M}_{\mathrm{SVT}}} \\
& \mathrm{CORE}_{\mathrm{C}}=\frac{\left(\mathrm{V}_{\mathrm{A}} \cdot \mathrm{N}\right) \cdot\left(\mathrm{C}_{\mathrm{CTA}}-\mathrm{C}_{\mathrm{CFE}}\right)}{\mathrm{M}_{\mathrm{SVT}}}
\end{aligned}
$$


A produtividade molar $(\mathrm{PrM})$, expressa em $\mathrm{molH}_{2} \cdot \mathrm{m}^{-3} \cdot \mathrm{d}^{-1}$, foi definida pela relação entre hidrogênio produzido por unidade de tempo e o volume de meio do reator. Para reatores operados em batelada pode ser calculada pela equação (4.18), na qual $\mathrm{n}_{\mathrm{H}_{2}}$ representa o número de moles de hidrogênio produzido por dia.

$$
\operatorname{Pr} M=\frac{n_{H_{2}}}{V_{R}}
$$

A produtividade molar específica (PrME), expressa em mol. $\mathrm{H}_{2} \cdot \mathrm{kgSVT}^{-1} \cdot \mathrm{d}^{-1}$, foi definida pela relação entre hidrogênio produzido por unidade de tempo e a massa de sólidos voláteis totais no interior do reator. Para reatores operados em batelada pode ser calculada pela equação (4.19).

$$
\operatorname{Pr} M E=\frac{n_{H_{2}}}{M_{S V T}}
$$

$\mathrm{O}$ rendimento molar por carga aplicada $\left(\mathrm{RMCA}_{\mathrm{S}, \mathrm{m}}\right)$, expresso em $\mathrm{molH}_{2} \cdot \mathrm{kgDQO}^{-1}$, foi definido pela relação entre hidrogênio produzido e matéria orgânica alimentada ao reator. Para reatores operados em batelada pode ser calculado pela equação (4.20).

$$
R M C A_{S, m}=\frac{n_{H_{2}}}{N \cdot V_{A} \cdot C_{S T A}}
$$


$\mathrm{O}$ rendimento molar por carga aplicada $\left(\mathrm{RMCA}_{\mathrm{C}, \mathrm{m}}\right)$, expresso em $\mathrm{molH}_{2} \cdot \mathrm{kgCarboidrato}^{-1}$, foi definido pela relação entre o hidrogênio produzido e carboidrato aplicado. Para reatores operados em batelada pode ser calculado pela equação (4.21).

$$
\operatorname{RMCA}_{\mathrm{C}, \mathrm{m}}=\frac{\mathrm{n}_{\mathrm{H}_{2}}}{\mathrm{~N} \cdot \mathrm{V}_{\mathrm{A}} \cdot \mathrm{C}_{\mathrm{CTA}}}
$$

$\mathrm{O}$ rendimento molar por carga removida $\left(\mathrm{RMCR}_{\mathrm{S}, \mathrm{m}}\right)$, expressa em $\mathrm{molH}_{2} \cdot \mathrm{kgDQO}^{-1}$, foi definido pela relação entre o hidrogênio produzido e matéria orgânica aplicada. Para reatores operados em batelada pode ser calculado pela equação (4.22).

$$
\mathrm{RMCR}_{\mathrm{s}, \mathrm{m}}=\frac{\mathrm{n}_{\mathrm{H}_{2}}}{\mathrm{~N} \cdot \mathrm{V}_{\mathrm{A}} \cdot\left(\mathrm{C}_{\mathrm{STA}}-\mathrm{C}_{\mathrm{SFE}}\right)}
$$

$\mathrm{O}$ rendimento molar por carga removida $\left(\mathrm{RMCR}_{\mathrm{C}, \mathrm{n}}\right)$, expressa em molH $_{2} \cdot$ molCarboidrato $^{-1}$, foi definido pela relação entre o hidrogênio produzido e carboidrato aplicado. Para reatores operados em batelada pode ser calculado pela equação (4.23).

$$
\mathrm{RMCR}_{\mathrm{C}, \mathrm{n}}=\frac{\mathrm{n}_{\mathrm{H}_{2}}}{\mathrm{~N} \cdot \mathrm{V}_{\mathrm{A}} \cdot\left(\mathrm{C}_{\mathrm{CTA}}-\mathrm{C}_{\mathrm{CFE}}\right)}
$$




\subsection{Lavagem do material suporte}

A partir da condição 8 na operação com soro de leite no AnSBBR com recirculação da fase líquida (condição na qual foi obtida a estabilidade na produção de biohidrogênio) foram realizadas lavagem sistemáticas do material suporte buscando um melhor controle do crescimento da biomassa. O objetivo deste procedimento é estabelecer um protocolo experimental de retirada desta biomassa que é gerada durante a operação do sistema, sendo este crescimento celular devido às características metabólicas dos microrganismos acidogênicos e à alta carga orgânica aplicada/removida (cinética de crescimento). Desta forma o intuito é melhorar a estabilidade e a eficiência do processo de produção de biohidrogênio.

O primeiro passo do procedimento foi descarregar todo o meio líquido contido no reator, medindo-se o volume e os sólidos totais e voláteis totais deste ( $\left.\mathrm{m}_{\mathrm{BL} 1}\right)$. Após, retirou-se todo o suporte inerte juntamente com a biomassa contidos dentro do reator, medindo-se esta massa total. Uma pequena amostra desta massa foi retirada com o intuito de calcular os valores de $\mathrm{C}_{\mathrm{x}}$ e de $\mathrm{C}_{\mathrm{x}}$ ' (indicadores da quantidade de biomassa por volume de meio reacional e por massa de material suporte, respectivamente) antes da lavagem do material suporte, de acordo com metodologia já descrita no item “4.6. Análises físico-químicas” do presente trabalho.

O passo seguinte foi realizar a lavagem propriamente dita do sistema "suporte inerte + bimassa", adicionando-se 1 litro de água de torneira e separando-se a água da lavagem do material suporte com o auxílio de uma peneira. Uma amostra de $50 \mathrm{~mL}$ foi retirada desta água de lavagem para análise de sólidos totais e voláteis totais no intuito de calcular a biomassa removida do sistema $\left(\mathrm{m}_{\mathrm{BL} 2}\right)$, da mesma forma que foi feito para o líquido descarregado no primeiro passo. 
A quantidade de biomassa removida com a lavagem (em gSVT) será a soma de m BL1 (calculado multiplicando a concentração SVT.L $^{-1}$ pelo volume de líquido descarregado do reator) com $\mathrm{m}_{\mathrm{BL} 2}$ (calculado multiplicando a concentração SVT.L ${ }^{-1}$ pelo volume de água usado para lavar o sistema "suporte inerte + biomassa", ou seja, 1 litro). Sabendo os valores de $\mathrm{C}_{\mathrm{x}}$ e de $\mathrm{C}_{\mathrm{x}}$, antes da presente lavagem e antes da lavagem seguinte é possível realizar uma comparação e analisar se a biomassa retornou à quantidade antes da lavagem ou se foi possível controlar o desenvolvimento dela com a lavagem. 


\section{RESULTADOS E DISCUSSÃO}

O estudo da produção de hidrogênio a partir de soro de leite em um AnSBBR com recirculação da fase líquida no presente trabalho constituiu-se de duas partes complementares, divididas assim com o intuito de tornar a compreensão dos resultados apresentados mais didática e simples. A primeira etapa do estudo (Condição 1 à Condição 8) refere-se à busca pela estabilidade do processo (principalmente dos indicadores de produção de hidrogênio) no estágio estacionário de operação do reator. Após esta estabilidade ser atingida teve início a segunda etapa do presente estudo (Condição 8 à Condição 13), a qual refere-se à avaliação de alguns importantes parâmetros operacionais (concentração afluente, tempo de enchimento e temperatura) na produção de hidrogênio utilizando a configuração de reator mencionada com o referido soro de leite. Devido aos diversos ensaios realizados, uma grande quantidade de dados e informações foi gerada e estes resultados são apresentados na integra, condição por condição aqui. O intuito de apresentar cada uma dessas condições é disponibilizar detalhes de cada uma, possibilitando futuras reproduções destas sem que fique alguma dúvida de como tudo foi feito, passo-a-passo.

Além do estudo da produção de hidrogênio em um AnSBBR com recirculação da fase líquida usando soro de leite, um estudo paralelo utilizando água sintética à base de lactose em um AnSBBR com agitação mecânica foi realizado tendo em vista que o principal componente do soro de leite é o referido carboidrato. Foram analisadas a influência da carga orgânica aplicada volumétrica modificando o tempo de ciclo e a concentração afluente (Condição 1 à Condição 6). 


\subsection{AnSBBR com recirculação da fase líquida - Primeira etapa (atingindo a estabilidade do processo).}

A produção de hidrogênio a partir de um AnSBBR com recirculação da fase líquida alimentado com soro de leite foi o objetivo principal do presente trabalho. A utilização de outros substratos como lactose, sacarose e leite desnatado fez parte de diversas tentativas de atingir uma produção estável de biohidrogênio, o que foi conseguido.

\subsubsection{Condições com $t_{C}=4$ horas}

\subsubsection{Condição 1-Sem adaptação e afluente não refrigerado}

A condição experimental 1 utilizando soro de leite como substrato apresentou uma COAV nominal de $10,9 \mathrm{kgDQO} \cdot \mathrm{m}^{-3} \cdot \mathrm{d}^{-1}$ e duração do ciclo de 4 horas, indo do dia 01 ao dia 36 (36 dias de operação). A Tabela 5.1 apresenta os valores médios dos parâmetros monitorados. 
Tabela 5.1 - Valores médios dos parâmetros monitorados na condição experimental 1 (Soro de leite - $4250 \mathrm{mgDQO} . \mathrm{L}^{-1}-\mathrm{t}_{\mathrm{C}} 4 \mathrm{~h}$ ).

\begin{tabular}{|c|c|c|c|c|c|c|c|c|c|}
\hline \multicolumn{2}{|r|}{ Parâmetro } & \multicolumn{4}{|c|}{ Afluente } & \multicolumn{4}{|c|}{ Efluente } \\
\hline $\mathrm{C}_{\mathrm{ST}}$ & $\left(\mathrm{mgDQO} \cdot \mathrm{L}^{-1}\right)$ & 3993 & \pm & 461 & $\left({ }^{16}\right.$ & ) 3393 & \pm 979 & $\left(^{16}\right.$ & ) \\
\hline $\mathrm{C}_{\mathrm{SF}}$ & $\left(m g D Q O . L^{-1}\right)$ & 4369 & \pm & 297 & $\left({ }^{3}\right.$ & ) 3111 & \pm 921 & $\left(\begin{array}{l}16 \\
0\end{array}\right.$ & ) \\
\hline$\varepsilon_{\mathrm{ST}}$ & $(\%)$ & - & & - & & 20 & \pm 14 & $(16$ & ) \\
\hline$\varepsilon_{\mathrm{SF}}$ & $(\%)$ & - & & - & & 26 & \pm 16 & $(16$ & ) \\
\hline $\mathrm{C}_{\mathrm{CT}}$ & (mgCarboidrato. $\mathrm{L}^{-1}$ ) & 3681 & \pm & 430 & $\left({ }^{16}\right.$ & ) 127 & \pm 77 & $(16$ & ) \\
\hline $\mathrm{C}_{\mathrm{CF}}$ & (mgCarboidrato. $\left.\mathrm{L}^{-1}\right)$ & 4058 & \pm & 238 & $\left(^{3}\right.$ & ) 83 & \pm 79 & $(16$ & ) \\
\hline$\varepsilon_{\mathrm{CT}}$ & $(\%)$ & - & & - & & 97 & \pm 2 & $(16$ & ) \\
\hline$\varepsilon_{\mathrm{CF}}$ & $(\%)$ & - & & - & & 98 & \pm 2 & $(16$ & ) \\
\hline $\mathrm{pH}$ & (u) & 7,00 & \pm & 1,07 & $\left({ }^{16}\right.$ & ) 4,51 & $\pm 0,44$ & $(16$ & ) \\
\hline AVT & $\left(\mathrm{mgHAc} . \mathrm{L}^{-1}\right)$ & 118 & \pm & 22 & $\left({ }^{16}\right.$ & ) 1515 & \pm 209 & $(16$ & ) \\
\hline AT & $\left(\mathrm{mgCaCO}{ }_{3} \cdot \mathrm{L}^{-1}\right)$ & 322 & \pm & 184 & $(16$ & ) 226 & \pm 183 & $(16$ & ) \\
\hline $\mathrm{AP}$ & $\left(\mathrm{mgCaCO}_{3} \cdot \mathrm{L}^{-1}\right)$ & 215 & \pm & 151 & $\left({ }^{16}\right.$ & ) 0 & \pm 0 & $(16$ & ) \\
\hline AI & $\left(\mathrm{mgCaCO}_{3} \cdot \mathrm{L}^{-1}\right)$ & 107 & \pm & 36 & $(16$ & ) 226 & \pm 183 & $(16$ & ) \\
\hline $\mathrm{AB}$ & $\left(\mathrm{mgCaCO}_{3} \cdot \mathrm{L}^{-1}\right)$ & 245 & \pm & 172 & $\left({ }^{16}\right.$ & ) 0 & \pm 0 & $\left(\begin{array}{l}16 \\
0\end{array}\right.$ & ) \\
\hline ST & $\left(\mathrm{mg} \cdot \mathrm{L}^{-1}\right)$ & 4065,75 & \pm & 462 & $\left(^{8}\right.$ & ) 2646 & \pm 319 & $\left(^{8}\right.$ & ) \\
\hline STV & $\left(\mathrm{mg} . \mathrm{L}^{-1}\right)$ & 3412,5 & \pm & 464 & $\left(^{8}\right.$ & ) 1989 & \pm 281 & $\left(^{8}\right.$ & ) \\
\hline SST & $\left(\mathrm{mg} . \mathrm{L}^{-1}\right)$ & 115,75 & \pm & 64 & $\left({ }^{8}\right.$ & ) 165 & \pm 77 & $\left(^{8}\right.$ & ) \\
\hline SSV & $\left(\mathrm{mg} \cdot \mathrm{L}^{-1}\right)$ & 124,42 & \pm & 35 & $(8$ & ) 194 & \pm 39 & $\left(^{8}\right.$ & ) \\
\hline $\mathrm{M}_{\mathrm{STV}}$ & (g) & - & & - & & 63,0 & - & & \\
\hline $\mathrm{C}_{\mathrm{X}}$ & $\left(\mathrm{g} \cdot \mathrm{L}^{-1}\right)$ & - & & - & & 17,40 & - & & \\
\hline $\mathrm{C}_{\mathrm{X}}^{\prime}$ & $\left(\right.$ g.gsuporte $\left.{ }^{-1}\right)$ & - & & - & & 0,042 & - & & \\
\hline $\mathrm{V}_{\mathrm{G}}$ & (mL-CNTP) & - & & - & & 549 & \pm 44 & $\left({ }^{6}\right.$ & ) \\
\hline $\mathrm{V}_{\mathrm{H} 2}$ & (mL-CNTP) & - & & - & & 1 & \pm 1 & $\left(^{3}\right.$ & ) \\
\hline $\mathrm{COAV}_{\mathrm{STA}}$ & $\left(\mathrm{kgDQO} \cdot \mathrm{m}^{-3} \cdot \mathrm{d}^{-1}\right)$ & 10,3 & & - & & - & - & & \\
\hline $\mathrm{CORV}_{\mathrm{SFE}}$ & $\left(\operatorname{kgDQO} \cdot \mathrm{m}^{-3} \cdot \mathrm{d}^{-1}\right)$ & - & & - & & 2,3 & - & & \\
\hline $\mathrm{COAV}_{\mathrm{CTA}}$ & $\left(\right.$ kgCarboidrato. $\left.\mathrm{m}^{-3} \cdot \mathrm{d}^{-1}\right)$ & 9,5 & & - & & - & - & & \\
\hline $\mathrm{CORV}_{\mathrm{CFE}}$ & $\left(\right.$ kgCarboidrato. $\left.\mathrm{m}^{-3} \cdot \mathrm{d}^{-1}\right)$ & - & & - & & 9,3 & - & & \\
\hline $\mathrm{COAE}_{\mathrm{STA}}$ & $\left(\operatorname{kgDQO} \cdot k g S T V^{-1} \cdot d^{-1}\right)$ & 0,6 & & - & & - & - & & \\
\hline $\mathrm{CORE}_{\mathrm{SFE}}$ & $\left(\mathrm{kgDQO} \cdot \mathrm{kgSTV}^{-1} \cdot \mathrm{d}^{-1}\right)$ & - & & - & & 0,1 & - & & \\
\hline $\mathrm{COAE}_{\mathrm{CTA}}$ & $\left(\mathrm{kgCarboidrato} \mathrm{kgSTV}^{-1} \cdot \mathrm{d}^{-1}\right)$ & 0,5 & & - & & - & - & & \\
\hline $\mathrm{CORE}_{\mathrm{CFE}}$ & $\left(\mathrm{kgCarboidrato} \mathrm{kgSTV}^{-1} \cdot \mathrm{d}^{-1}\right)$ & - & & - & & 0,5 & - & & \\
\hline $\mathrm{RMCR}_{\mathrm{C}, \mathrm{n}}$ & $\left(\mathrm{molH}_{2}\right.$ molCarboidrato $\left.^{-1}\right)$ & - & & - & & 0,0015 & - & & \\
\hline $\mathrm{n}_{\mathrm{H} 2}$ & $\left(\mathrm{molH}_{2} \cdot \mathrm{d}^{-1}\right)$ & - & & - & & 0,0001 & - & & \\
\hline PrM & $\left(\mathrm{molH}_{2} \cdot \mathrm{m}^{-3} \cdot \mathrm{d}^{-1}\right)$ & - & & - & & 0,04 & - & & \\
\hline PrME & $\left(\mathrm{molH}_{2} \cdot \mathrm{kgSVT}^{-1} \cdot \mathrm{d}^{-1}\right)$ & - & & - & & 0,00 & - & & \\
\hline $\mathrm{RMCA}_{\mathrm{S}, \mathrm{m}}$ & $\left(\mathrm{molH}_{2} \cdot \mathrm{kgDQO}^{-1} \cdot \mathrm{d}^{-1}\right)$ & 0,00 & & - & & - & - & & \\
\hline $\mathrm{RMCA}_{\mathrm{C}, \mathrm{m}}$ & $\left(\mathrm{molH}_{2} \cdot \mathrm{kg}^{-1} \cdot \mathrm{d}^{-1}\right)$ & 0,00 & & - & & - & - & & \\
\hline $\mathrm{RMCR}_{\mathrm{S}, \mathrm{m}}$ & $\left(\mathrm{molH}_{2} \cdot \mathrm{kgDQO}^{-1} \cdot \mathrm{d}^{-1}\right)$ & - & & - & & 0,02 & 一 & & \\
\hline $\mathrm{RMCR}_{\mathrm{C}, \mathrm{m}}$ & $\left(\mathrm{molH}_{2} \cdot \mathrm{kg}^{-1} \cdot \mathrm{d}^{-1}\right)$ & - & & - & & 0,00 & - & & \\
\hline $\mathrm{V}_{\mathrm{R}}$ & $(\mathrm{mL})$ & 2000 & & & & & & & \\
\hline $\mathrm{V}_{\mathrm{A}}$ & $(\mathrm{mL})$ & 1430 & \pm & $45\left(^{12}\right)$ & & & & & \\
\hline $\mathrm{Q}_{\mathrm{R}}$ & $\left(\mathrm{mL} \cdot \mathrm{s}^{-1}\right)$ & 6 & \pm & $0\left(^{3}\right)$ & & & & & \\
\hline
\end{tabular}


A Figura 5-1 apresenta os valores da concentração afluente (não filtrada) e efluente (não filtrada e filtrada) de matéria orgânica (DQO) no sistema, enquanto que a Figura 5-2 apresenta a eficiência de remoção do mesmo parâmetro durante o monitoramento diário. Esta eficiência atingiu, em média, 26\% para as amostras filtradas e $20 \%$ para amostras não filtradas. A média de concentração afluente não filtrada do substrato foi de $3993 \mathrm{mgDQO} . \mathrm{L}^{-1}$ e de $3393 \mathrm{mgDQO} . \mathrm{L}^{-1}$ e $3111 \mathrm{mgDQO} . \mathrm{L}^{-1}$ para amostras de efluente não filtrado e filtrado, respectivamente.

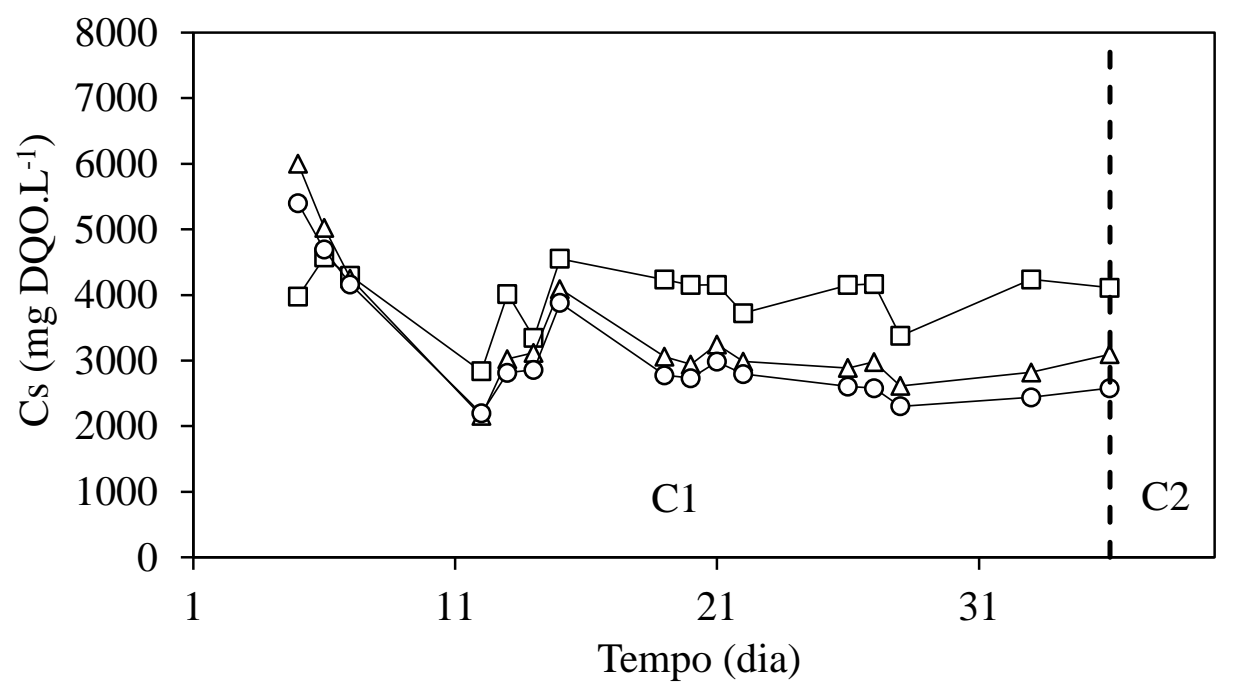

Figura 5-1 - Concentração de matéria orgânica (DQO): $\square$ - afluente não filtrada; $\Delta$ efluente não filtrada; o - efluente filtrada (AnSBBR com recirculação da fase líquida e soro de leite - Condição 1). 


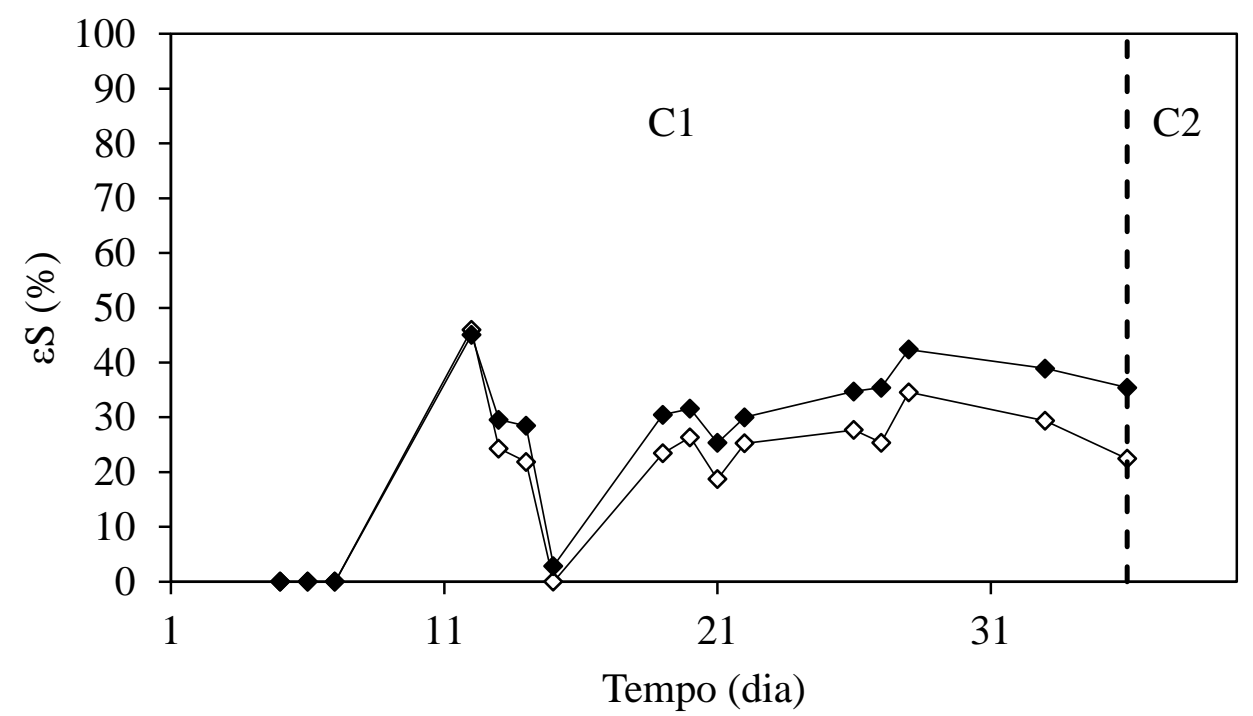

Figura 5-2 - Eficiência de remoção de matéria orgânica (DQO): $\diamond$ - não filtrada; filtrada (AnSBBR com recirculação da fase líquida e soro de leite - Condição 1).

A Figura 5-3 apresenta os valores da concentração de carboidratos afluente e efluente (para amostras filtradas e não filtradas), enquanto a Figura 5-4 mostra a eficiência de remoção do mesmo parâmetro (bruto e filtrado) durante o monitoramento diário. A média da concentração afluente foi de $3681 \mathrm{mgCarboidrato.} \mathrm{L}^{-1}$, enquanto que a concentração residual (amostras não filtradas) foi de 127 mgCarboidrato. $\mathrm{L}^{-1}$ e 83 mgCarboidrato. $\mathrm{L}^{-1}$ para a concentração residual filtrada. A eficiência de remoção de sacarose foi, em média, de $98 \%$ e $97 \%$ para as amostras filtradas e não filtradas, respectivamente. A condição apresentou uma alta eficiência de remoção de carboidrato. 


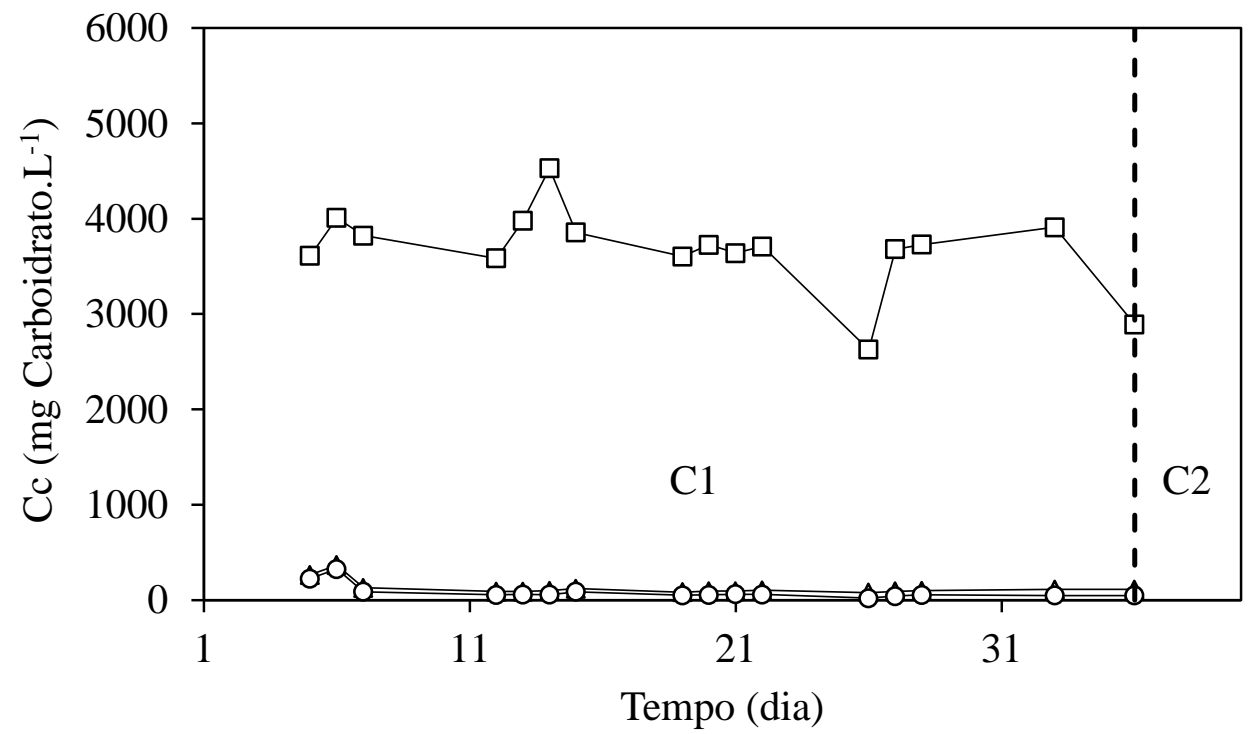

Figura 5-3 - Concentração de carboidrato: $\square$ - afluente não filtrada; $\Delta$ - efluente não filtrada; ○ - efluente filtrada (AnSBBR com recirculação da fase líquida e soro de leite Condição 1).

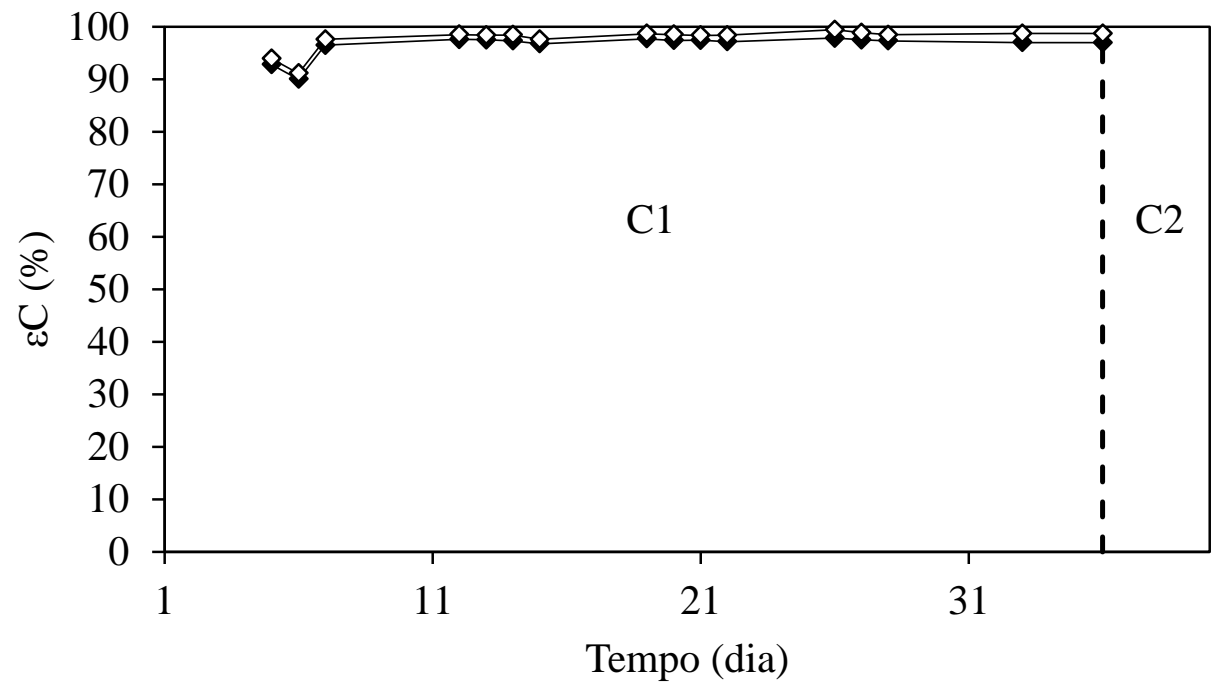

Figura 5-4 - Eficiência de remoção de carboidrato: $\diamond$ - não filtrada; - filtrada (AnSBBR com recirculação da fase líquida e soro de leite - Condição 1).

As Figura 5-5, Figura 5-6 e Figura 5-7 apresentam os perfis temporais, tanto para o afluente quanto para o efluente, do $\mathrm{pH}$, da alcalinidade total e dos ácidos voláteis totais por titulação, respectivamente. A média dos valores de $\mathrm{pH}$ afluente durante a Condição 1 foi de 7,00 e de pH efluente foi de 4,51. A média da alcalinidade total foi de 
322 e $226 \mathrm{mgCaCO}_{3} \cdot \mathrm{L}^{-1}$ para o afluente e efluente, respectivamente. O valor médio da concentração de ácidos voláteis totais afluente foi de $118 \mathrm{mgHAc} . \mathrm{L}^{-1}$ e efluente de 1515 mgHAc. $L^{-1}$. A partir do $22^{\circ}$ dia de operação começou-se a adicionar ácido clorídrico concentrado $12 \mathrm{M}$ (na proporção de 7,5 $\mathrm{mL}$ para cada 11 litros de afluente) buscando resolver o problema de não produção de $\mathrm{H}_{2}$ apresentado nesta condição operacional. Com isso o pH afluente foi reduzido para próximo de 5,0.

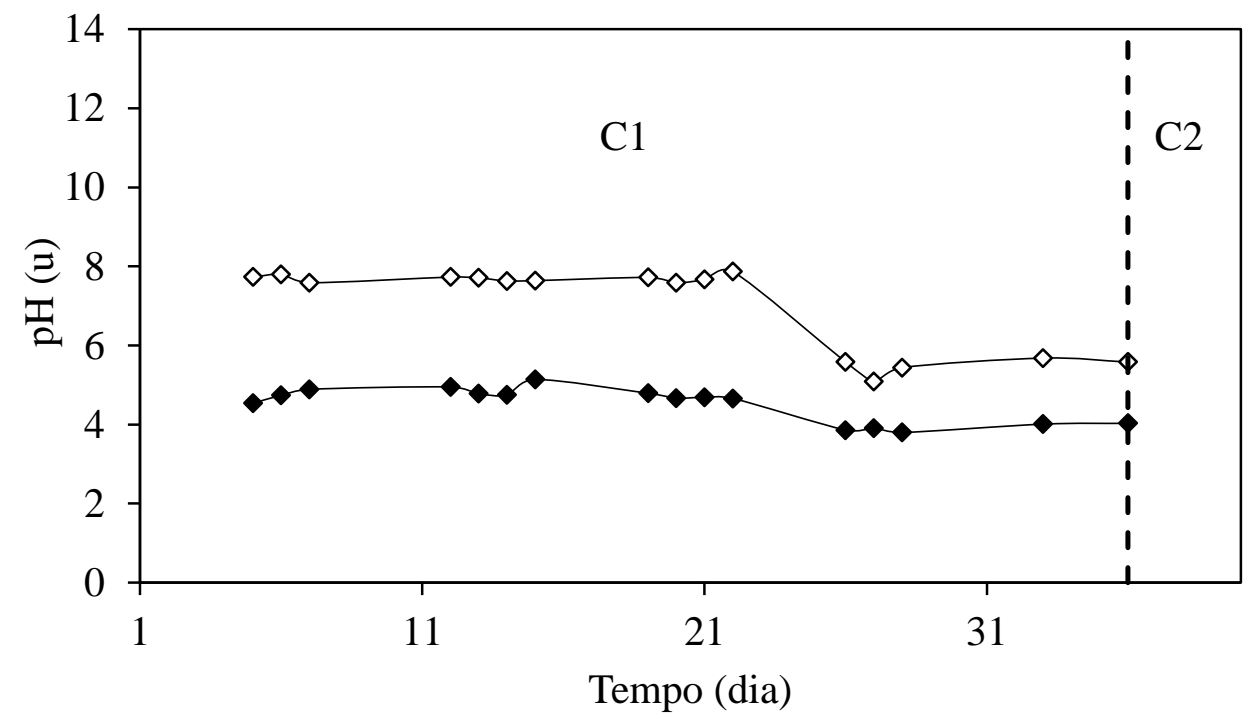

Figura 5-5 - Valores de pH: $\diamond$-afluente; - efluente (AnSBBR com recirculação da fase líquida e soro de leite - Condição 1). 


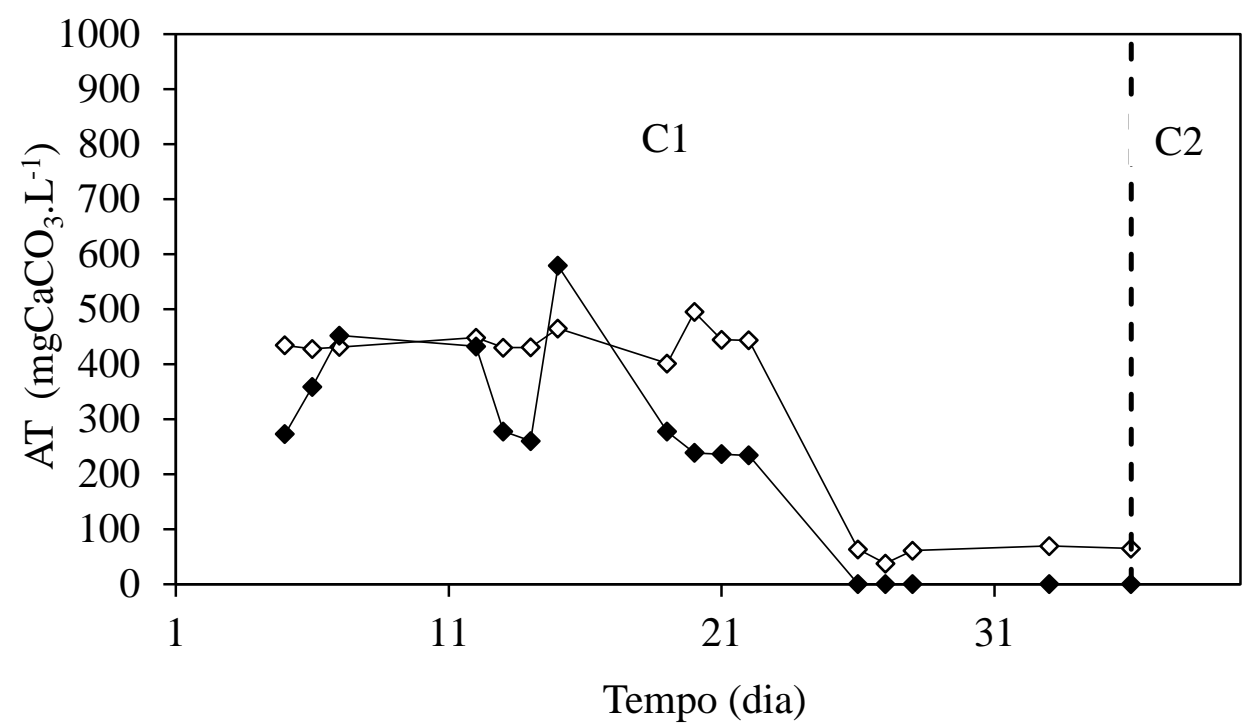

Figura 5-6 - Alcalinidade total: $\diamond$-afluente; $\downarrow$ - efluente (AnSBBR com recirculação da fase líquida e soro de leite - Condição 1).

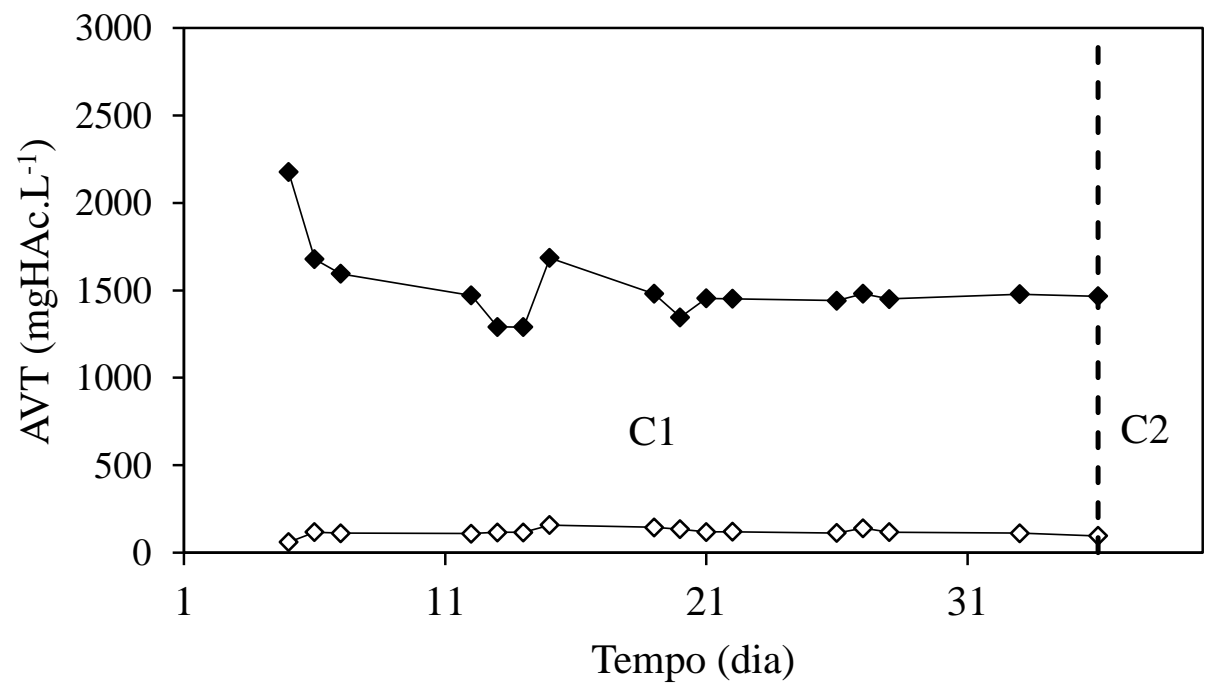

Figura 5-7 - Ácidos voláteis totais: $\diamond$-afluente; - efluente (AnSBBR com recirculação da fase líquida e soro de leite - Condição 1).

A Figura 5-8 apresenta o monitoramento dos compostos intermediários contidos no efluente do sistema, enquanto que a Tabela 5.2 apresenta os valores da concentração média destes produtos. O método cromatográfico aplicado não detectou a presença de acetona e metanol. Dentre os ácidos voláteis, o ácido acético predominou seguido pelo 
ácido butírico representando respectivamente $72,84 \%$ e $12,07 \%$ dos compostos intermediários. Os demais produtos apresentaram concentrações abaixo de 100 mg.L ${ }^{-1}$.

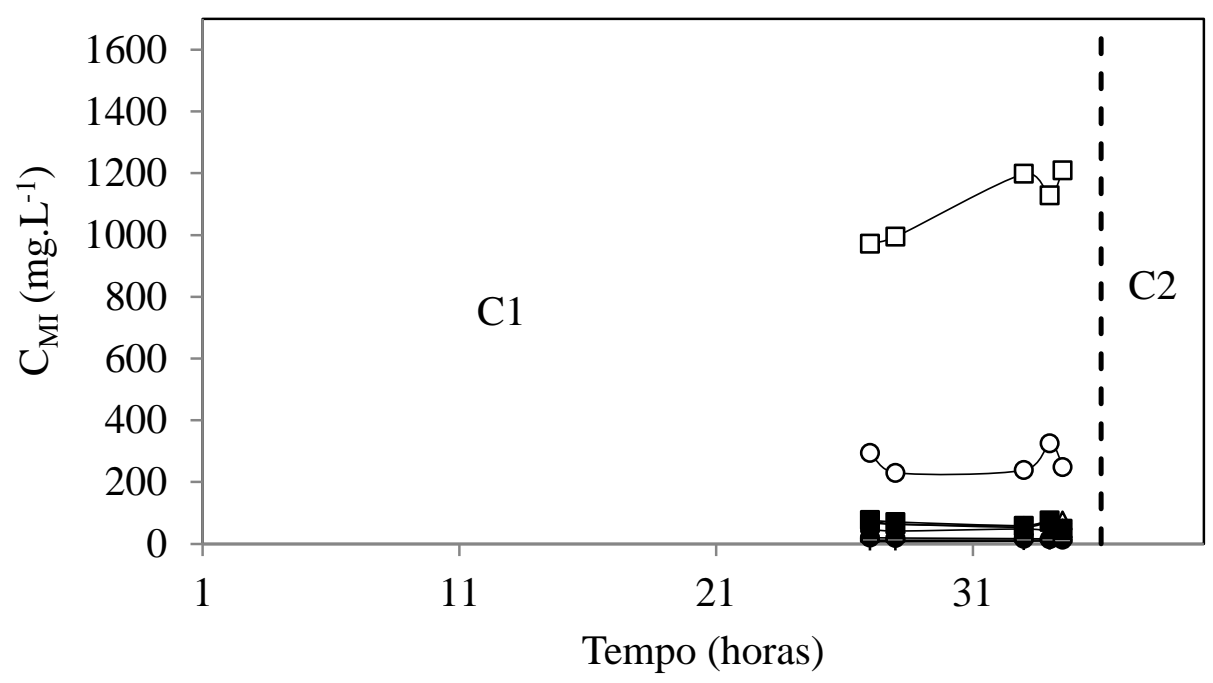

Figura 5-8 - Concentração dos compostos intermediários: $\square$ - ácido acético; $\Delta$ - etanol; ○ - ácido butírico; $\mathbf{\square}$ - ácido isobutírico; $\boldsymbol{\Delta}$ - ácido capróico; $\bullet$ - ácido valérico; - ácido propiônico; +butanol; - ácido isovalérico (AnSBBR com recirculação da fase líquida e soro de leite - Condição 1).

Tabela 5.2 - Concentração e distribuição dos compostos intermediários (AnSBBR com recirculação da fase líquida e soro de leite - Condição 1).

\begin{tabular}{cccccccc}
\hline $\begin{array}{c}\text { Produtos } \\
\text { intermediários }\end{array}$ & \multicolumn{5}{c}{ Concentrações médias } & & Distribuição \\
$\left(\mathrm{mg} . \mathrm{L}^{-1}\right)$ & \multicolumn{3}{c}{$\left(\mathrm{mmol} . \mathrm{L}^{-1}\right)$} & $(\%)$ \\
\hline Acetona & 0,0 & \pm & 0,0 & 0,0 & \pm & 0,0 & 0,0 \\
Metanol & 0,0 & \pm & 0,0 & 0,0 & \pm & 0,0 & 0,0 \\
Etanol & 67,4 & \pm & 7,1 & 1,5 & \pm & 0,2 & 5,8 \\
n-Butanol & 8,4 & \pm & 1,6 & 0,1 & \pm & 0,0 & 0,5 \\
Acético & 1100,2 & \pm & 111,9 & 18,3 & \pm & 1,9 & 72,8 \\
Porpiônico & 43,2 & \pm & 3,7 & 0,6 & \pm & 0,1 & 2,3 \\
Isobutírico & 66,0 & \pm & 12,1 & 0,8 & \pm & 0,1 & 3,0 \\
Butírico & 267,4 & \pm & 40,9 & 3,0 & \pm & 0,5 & 12,1 \\
Isovalérico & 11,3 & \pm & 1,2 & 0,1 & \pm & 0,0 & 0,4 \\
Valérico & 16,8 & \pm & 2,5 & 0,2 & \pm & 0,0 & 0,7 \\
Capróico & 62,3 & \pm & 10,3 & 0,6 & \pm & 0,1 & 2,4 \\
\hline
\end{tabular}


O monitoramento da série de sólidos é mostrado na Tabela 5.3, cujos valores apresentam um baixo teor de SSV no efluente e afluente, indicando mais uma vez a boa capacidade do reator em reter biomassa.

Tabela 5.3 - Série de sólidos afluente e efluente (AnSBBR com recirculação da fase líquida e soro de leite - Condição 1).

\begin{tabular}{lcccc}
\hline & $\begin{array}{c}\text { ST } \\
\left(\mathrm{mg} . \mathrm{L}^{-1}\right)\end{array}$ & $\begin{array}{c}\text { SVT } \\
\left(\mathrm{mg} . \mathrm{L}^{-1}\right)\end{array}$ & $\begin{array}{c}\text { SST } \\
\left(\mathrm{mg} . \mathrm{L}^{-1}\right)\end{array}$ & $\begin{array}{c}\text { SSV } \\
\left(\mathrm{mg} . \mathrm{L}^{-1}\right)\end{array}$ \\
\hline Afluente & $4066 \pm 462$ & $3413 \pm 464$ & $116 \pm 64$ & $124 \pm 35$ \\
Efluente & $2646 \pm 319$ & $1989 \pm 281$ & $166 \pm 777$ & $194 \pm 39$ \\
\hline
\end{tabular}

$*$ Número de amostras consideradas $=8$.

A produção do biogás por ciclo, em aspecto quantitativo, pode ser observada na Figura 5-9. A produção média foi de $471 \mathrm{~mL}$ (CNTP). A Figura 5-10 apresenta o monitoramento das concentrações dos componentes do biogás no final do ciclo, enquanto que a Figura 5-11 apresenta a distribuição destes mesmos componentes. Os valores médios de concentração de $\mathrm{H}_{2}, \mathrm{CH}_{4}$ e $\mathrm{CO}_{2}$ foram $0,41,3,13$ e 5,79 mmol.L ${ }^{-1}$, respectivamente. Além disso, a distribuição percentual média de $\mathrm{H}_{2}$ foi de $4,9 \%$, a de $\mathrm{CH}_{4}$ foi de $30,5 \%$ e a de $\mathrm{CO}_{2}$ foi de $64,6 \%$. Apesar de ainda apresentar uma baixa produção de hidrogênio, este valor médio foi mascarado devido a uma produção pontual alta no dia 15. No final da operação, onde o reator deveria estar estável, a produção de hidrogênio inexistiu, com produção de metano e gás carbônico, apenas. Este foi o motivo para a adição do ácido clorídrico, buscando atingir-se um pH que supostamente inibisse a ação dos microrganismos metanogênicos. Porém o biogás produzido continuou a apresentar apenas $\mathrm{CH}_{4}$ e $\mathrm{CO}_{2}$ em sua composição. 


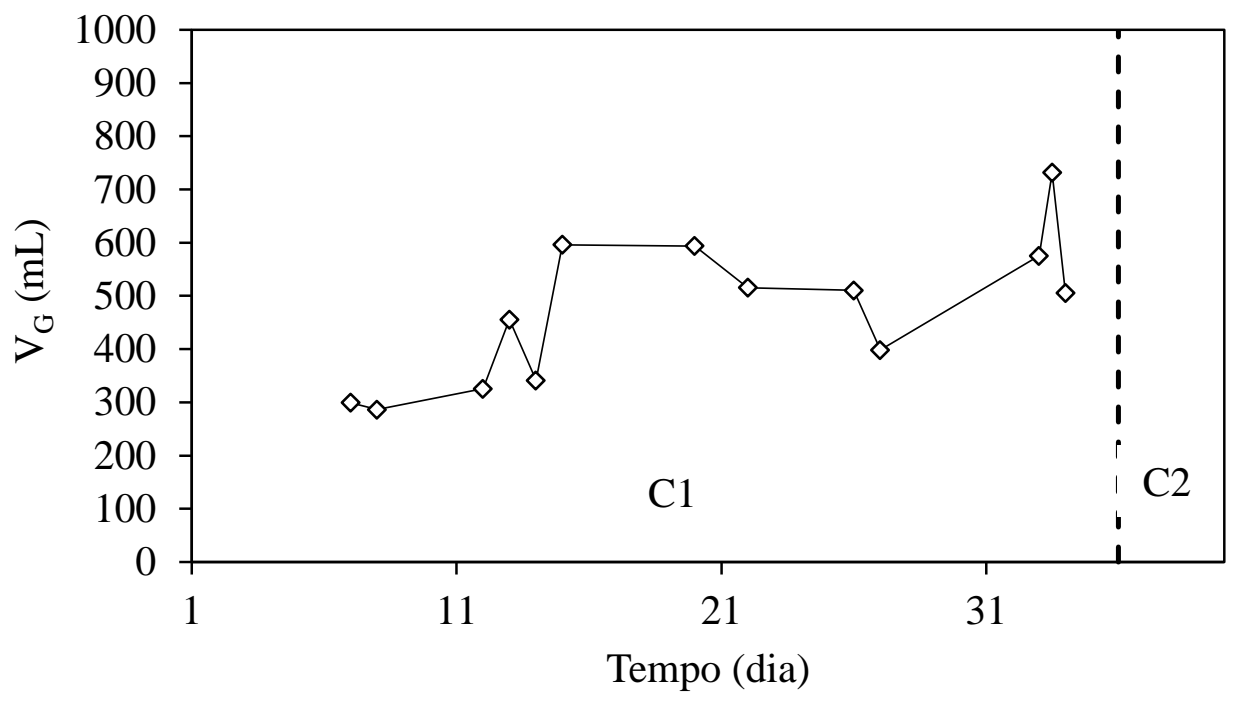

Figura 5-9 - Volume de biogás produzido por ciclo (AnSBBR com recirculação da fase líquida e soro de leite - Condição 1).

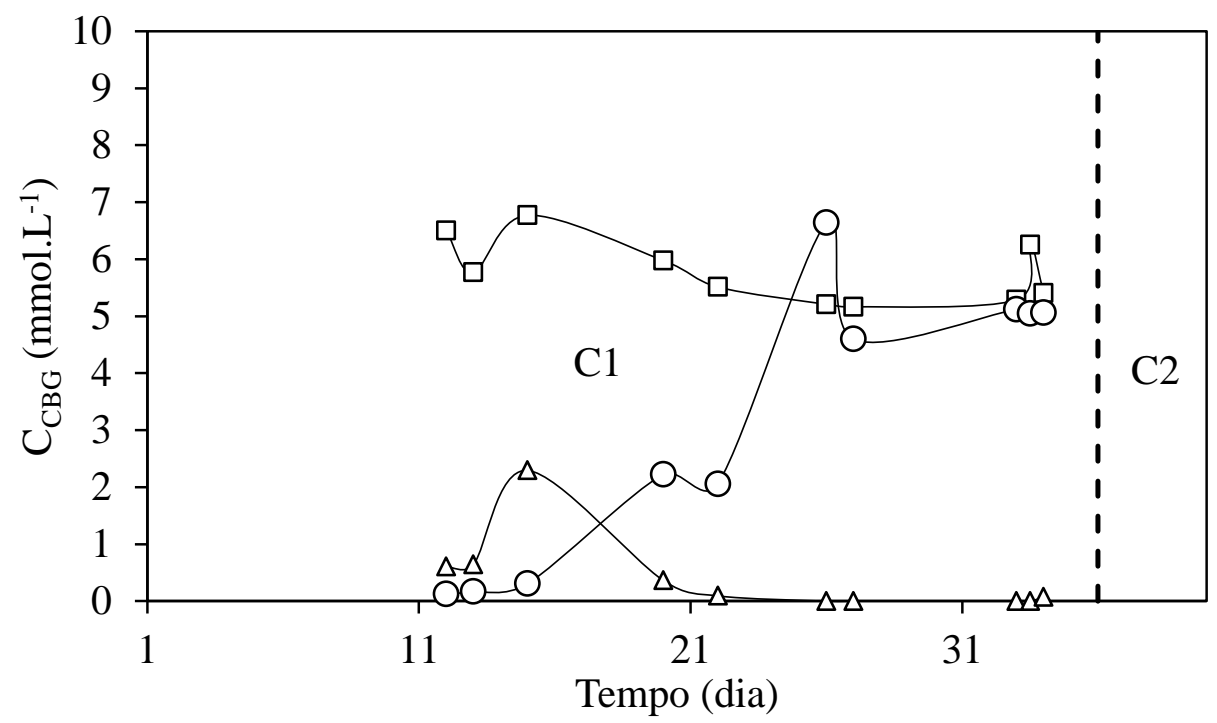

Figura 5-10 - Concentrações dos componentes do biogás no final do ciclo: $\square-\mathrm{CO}_{2} ; \Delta-$ $\mathrm{H}_{2} ;$ O $-\mathrm{CH}_{4}$ (AnSBBR com recirculação da fase líquida e soro de leite - Condição 1). 


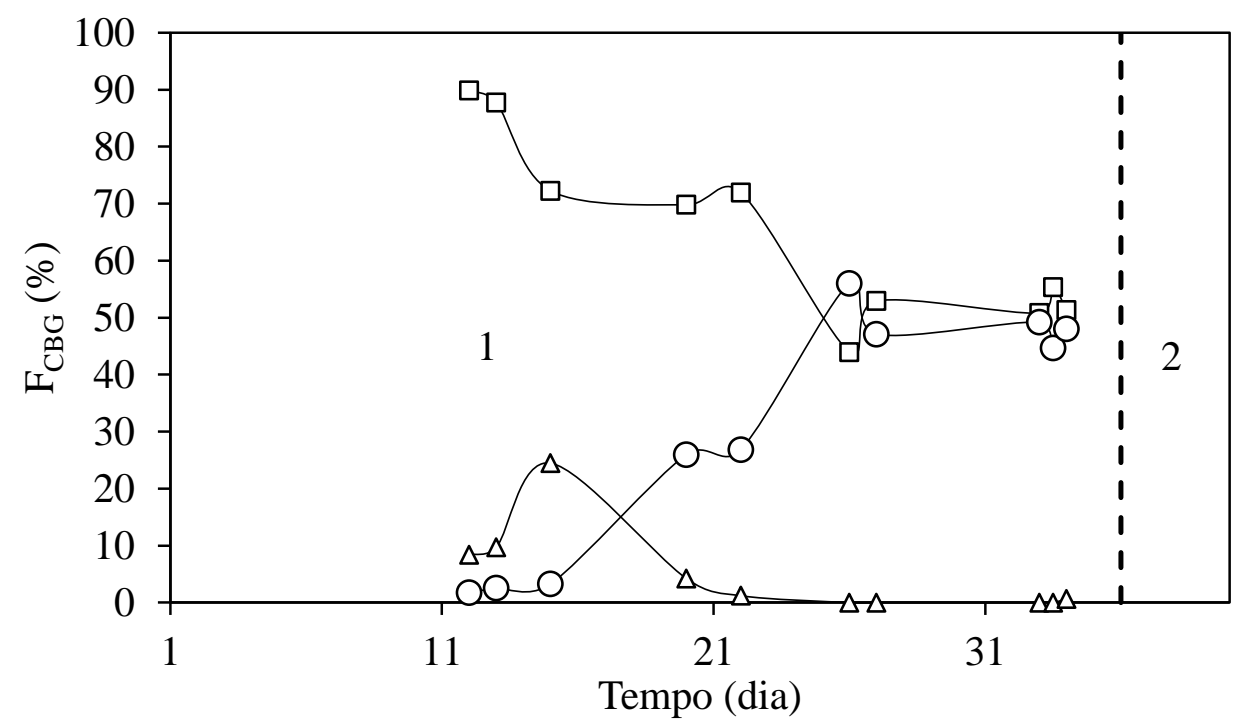

Figura 5-11 - Distribuições dos componentes do biogás no final do ciclo: $\square-\mathrm{CO}_{2} ; \Delta$ $\mathrm{H}_{2} ; \mathrm{O}-\mathrm{CH}_{4}$ (AnSBBR com recirculação da fase líquida e soro de leite - Condição 1).

No final da operação foi realizado o perfil temporal, com o intuito de entender melhor como os parâmetros indicativos de eficiência do sistema se comportavam durante um ciclo completo. A Figura 5-12 apresenta a evolução da concentração de carboidrato ao longo do ciclo e a eficiência de remoção do mesmo. Ao inicio do ciclo (tempo zero) o volume afluente é diluído no volume residual resultando em uma concentração em sacarose da ordem de $1800 \mathrm{mg} \cdot \mathrm{L}^{-1}$. A conversão da sacarose se faz de maneira progressiva ao longo do ciclo, atingindo valores na ordem de $99 \%$ no final do mesmo, com um residual aproximado de $50 \mathrm{mg} . \mathrm{L}^{-1}$. 


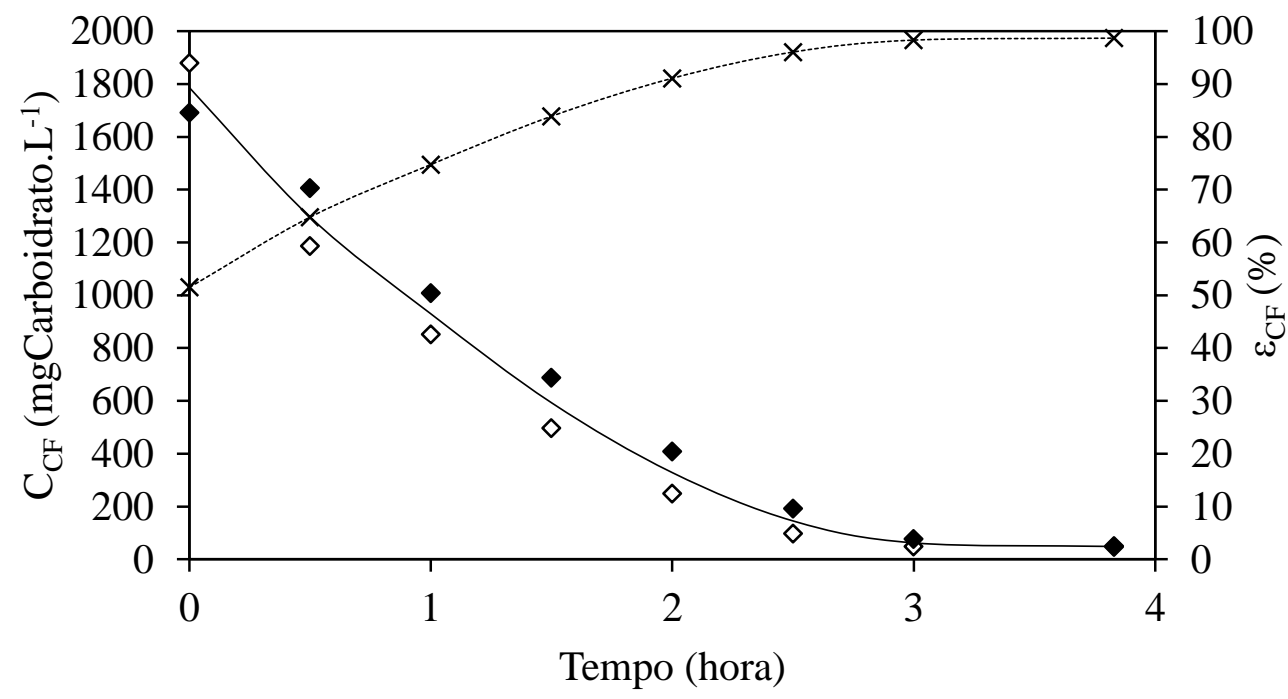

Figura 5-12 - Eixo da direita: Concentração de carboidrato $\diamond$ - do perfil 1 , - do perfil 2 e - média dos dois perfis; Eixo da esquerda: - $¥$ - eficiência de degradação do carboidrato (AnSBBR com recirculação da fase líquida e soro de leite - Condição 1).

A Figura 5-13 apresenta a evolução da concentração de matéria orgânica ao longo do ciclo. Observa-se uma baixa remoção da DQO, levando a uma alta concentração da mesma no volume residual. Assim, no inicio do ciclo, a diluição do volume carregado pelo volume residual é realizada em proporção bem menor do que no caso dos carboidratos totais, tendo em vista que as concentrações afluente e residual são muito próximas. No inicio do ciclo, a concentração é da ordem de $3100 \mathrm{mg} . \mathrm{L}^{-1}$ atingindo valores próximos a $2500 \mathrm{mg} . \mathrm{L}^{-1}$ no último ponto do ciclo. 


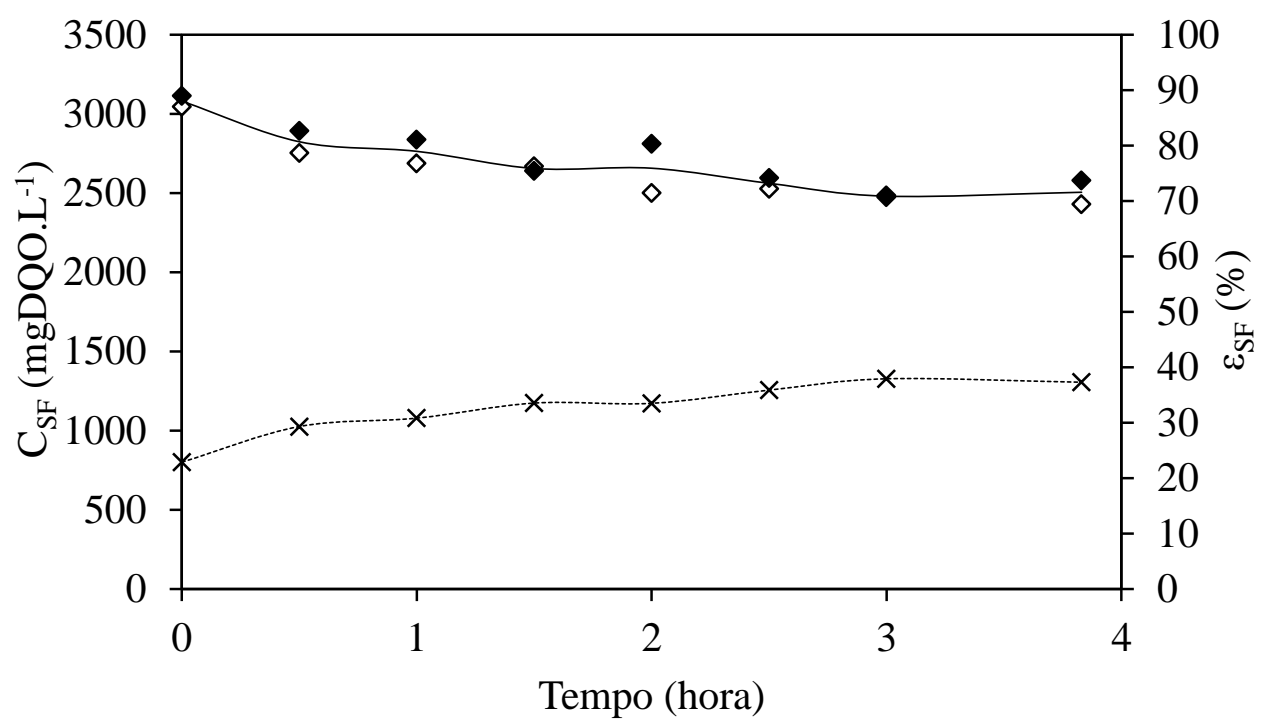

Figura 5-13 - Eixo da direita: Concentração de matéria orgânica (DQO) $\diamond$ - do perfil 1, - - do perfil 2 e - média dos dois perfis; Eixo da esquerda: - - eficiência de degradação da matéria orgânica (DQO) (AnSBBR com recirculação da fase líquida e soro de leite - Condição 1).

O acúmulo de ácidos voláteis totais por titulação ao longo do ciclo pode ser observado na Figura 5-14. A concentração destes aumenta claramente durante a fase de reação para atingir um máximo no final do ciclo na ordem de $1500 \mathrm{mgHAc} . \mathrm{L}^{-1}$.

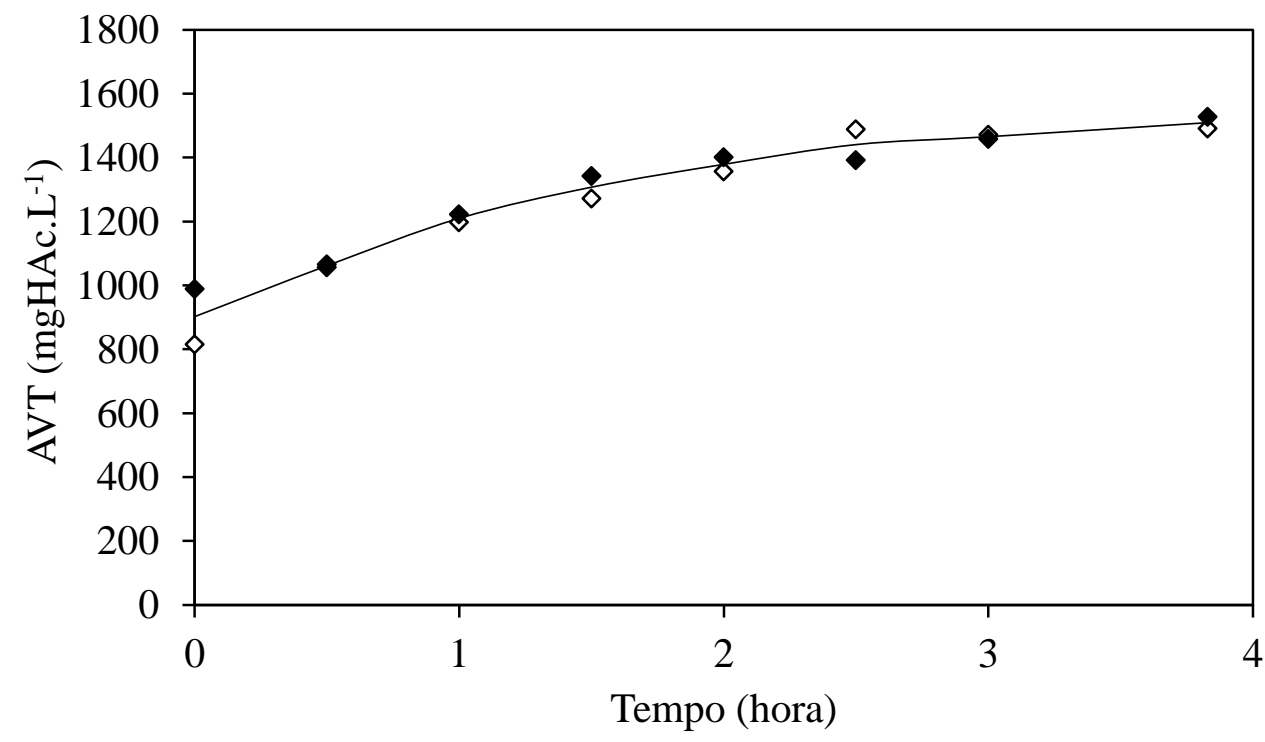

Figura 5-14 - Ácidos voláteis totais: $\diamond$ - do perfil 1 , - do perfil 2 e - média dos dois perfis (AnSBBR com recirculação da fase líquida e soro de leite - Condição 1). 
Os resultados dos compostos intermediários por cromatografia gasosa são apresentados na Figura 5-15. Observa-se um aumento destacado das quantidades de ácido acético, passando de uma concentração inicial de 594,1 mg.L $\mathrm{L}^{-1}$ até $1209,4 \mathrm{mg} . \mathrm{L}^{-1}$ no final do ciclo. O ácido butírico apresentou-se estável durante todo o perfil, com concentrações próximas a $250 \mathrm{mg} \cdot \mathrm{L}^{-1}$. Os demais produtos, assim como o ácido butírico, também apresentaram produção estável, porém com concentrações sempre abaixo de $100 \mathrm{mg} \cdot \mathrm{L}^{-1}$.

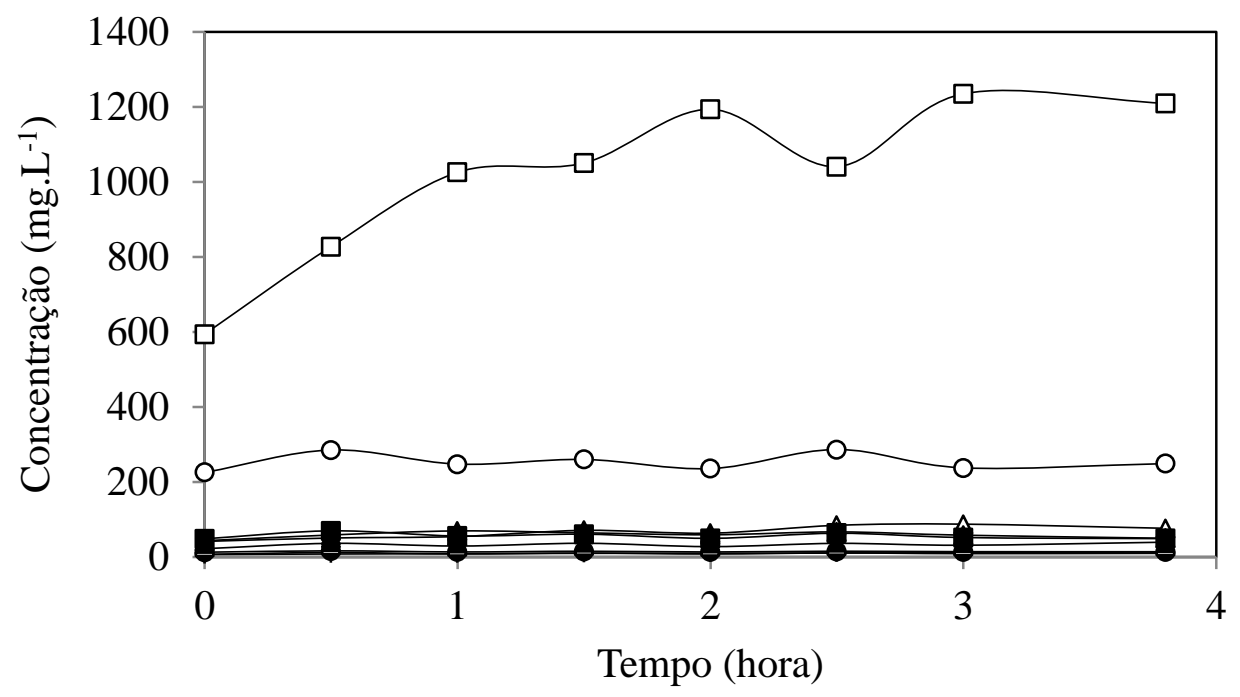

Figura 5-15 - Concentração dos compostos intermediários ao longo do ciclo: $\square$ - ácido acético; $\Delta$ - etanol; ○ - ácido butírico; $\mathbf{\square}$ - ácido isobutírico; $\boldsymbol{\Delta}$ - ácido capróico; • ácido valérico; - -ácido propiônico; +butanol; — ácido isovalérico (AnSBBR com recirculação da fase líquida e soro de leite - Condição 1).

$\mathrm{O}$ pH diminuiu instantaneamente em relação ao afluente devido à diluição do mesmo com o volume residual no inicio do ciclo (alimentação do reator em 10 minutos) e permaneceu estável ao longo da operação conforme a Figura 5-16. A estabilidade do pH porém, não condiz com a produção de ácidos voláteis, tendo em vista que o sistema não apresentava no momento do monitoramento do perfil capacidade de tamponamento. 
Isto porque a alcalinidade total era consumida antes de entrar no reator, no galão de alimentação, devido à adição do ácido clorídrico concentrado, como pode ser observado na Figura 5-17.

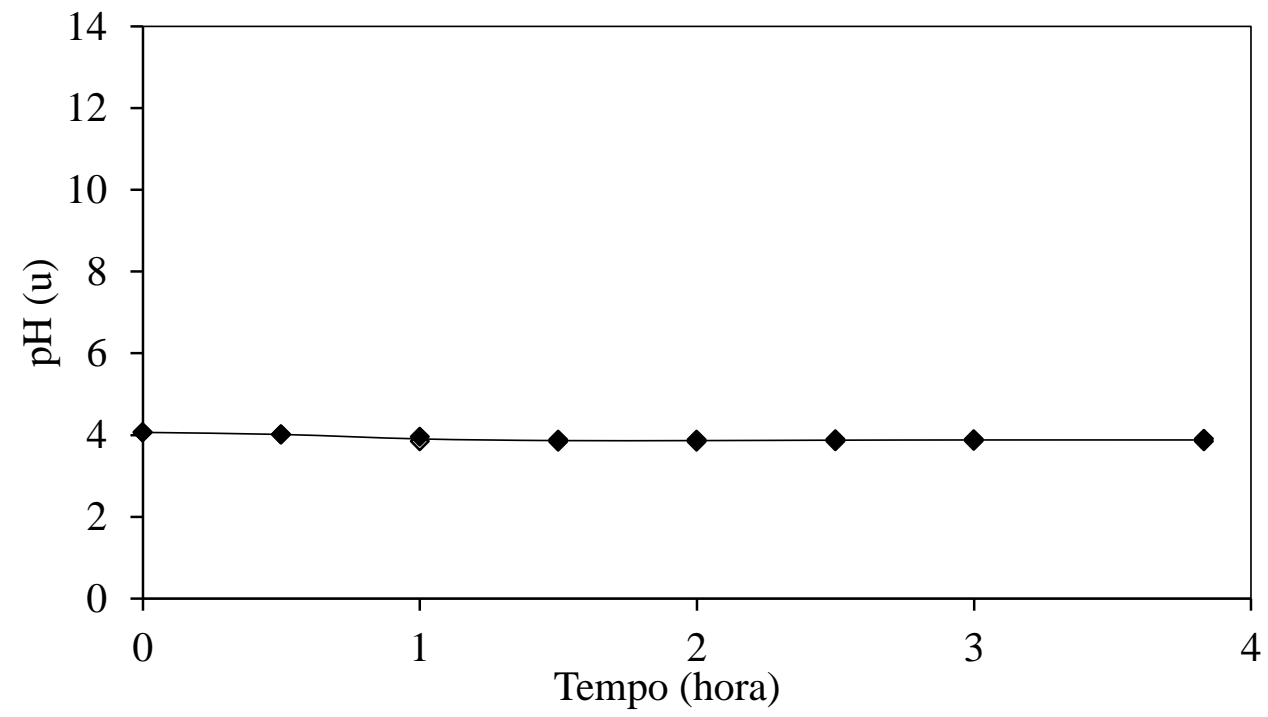

Figura 5-16 - Valores de $\mathrm{pH}: \diamond-$ do perfil 1 , - do perfil 2 e — média dos dois perfis (AnSBBR com recirculação da fase líquida e soro de leite - Condição 1).

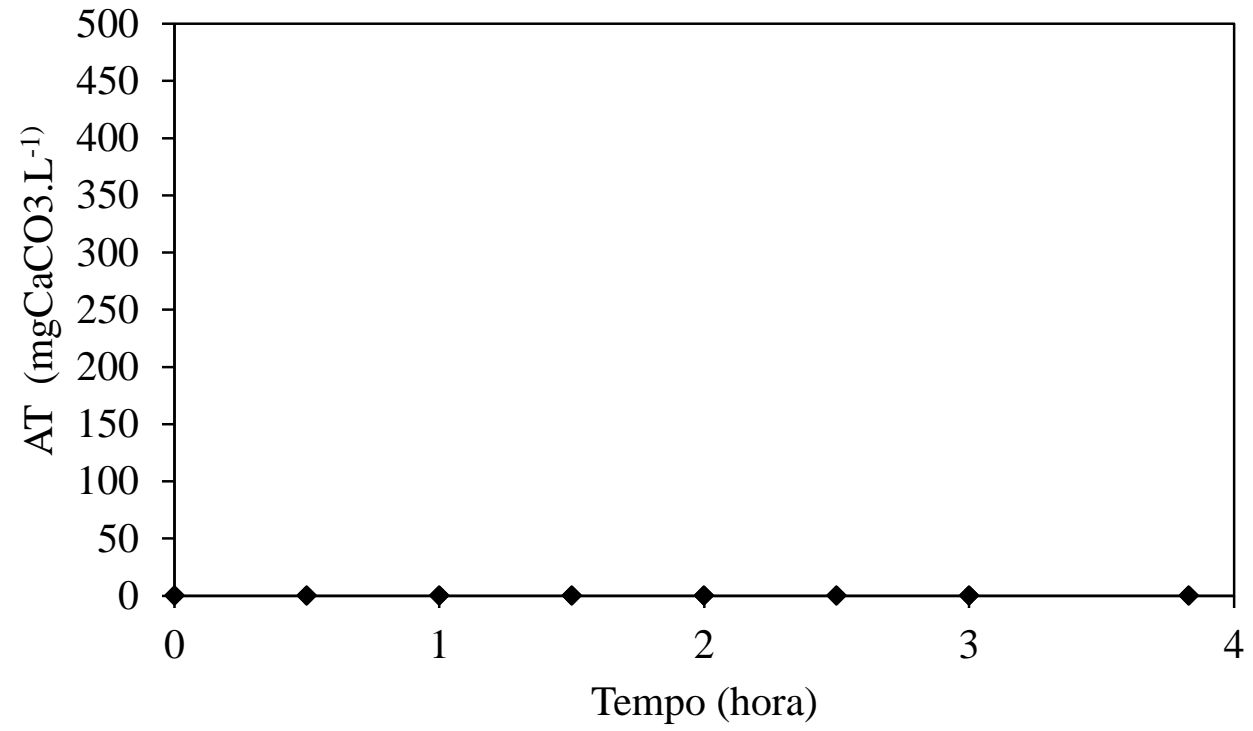

Figura 5-17 - Alcalinidade total: $\diamond$-do perfil 1, - do perfil 2 e - média dos dois perfis (AnSBBR com recirculação da fase líquida e soro de leite - Condição 1). 
A produção volumétrica média acumulada do biogás, realizada com os valores dos perfis quantitativos mais consistentes obtidos durante a operação, juntamente com os desvios padrões encontram-se na Figura 5-18. A maior parte da produção ocorre no inicio do ciclo, até a metade do mesmo, e tem uma tendência a se estabilizar no final. A Tabela 5.4 resume os valores médios da produção, fração molar e os volumes individuais da mistura do biogás. A Figura 5-19 apresenta os volumes acumulados médios dos perfis de $\mathrm{H}_{2}, \mathrm{CO}_{2}$ e $\mathrm{CH}_{4}$ produzidos durante o ciclo.

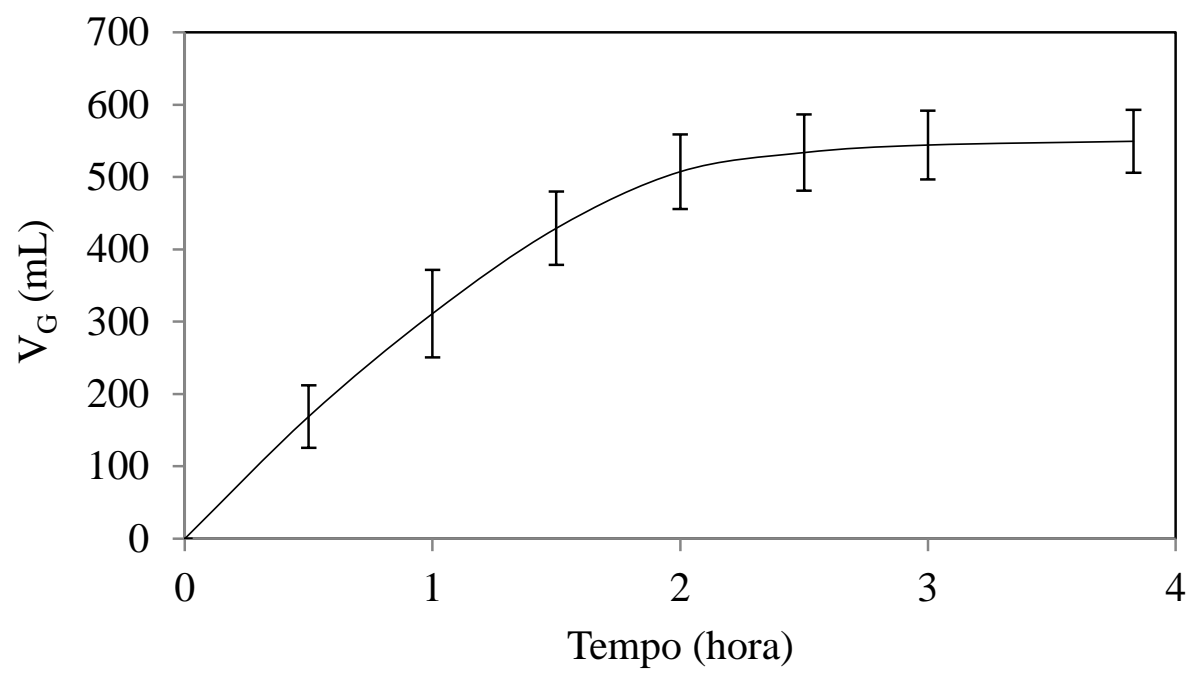

Figura 5-18 - Produção volumétrica média acumulada do biogás, realizada com os valores dos perfis quantitativos mais consistentes obtidos durante a operação, juntamente com os desvios padrões (AnSBBR com recirculação da fase líquida e soro de leite - Condição 1). 
Tabela 5.4 - Valores médios da produção, fração molar e os volumes individuais da mistura do biogás (AnSBBR com recirculação da fase líquida e soro de leite - Condição 1).

\begin{tabular}{ccccccccccc}
$\begin{array}{c}\text { Tempo } \\
(\mathrm{h})\end{array}$ & $\begin{array}{c}\mathrm{V}_{\mathrm{G}} \\
(\mathrm{mL}-\mathrm{CNTP})\end{array}$ & \multicolumn{3}{c}{$\mathrm{C}_{\mathrm{G}}\left(\mathrm{mmol} . \mathrm{L}^{-1}\right)$} & \multicolumn{3}{c}{ Fração Molar $(\%)$} & \multicolumn{3}{c}{ Volume (mL - CNTP) } \\
& & $\mathrm{H}_{2}$ & $\mathrm{CO}_{2}$ & $\mathrm{CH}_{4}$ & $\mathrm{H}_{2}$ & $\mathrm{CO}_{2}$ & $\mathrm{CH}_{4}$ & $\mathrm{H}_{2}$ & $\mathrm{CO}_{2}$ & $\mathrm{CH}_{4}$ \\
\hline 0,0 & 0,0 & 0,0 & 0,0 & 0,0 & 0,0 & 0,0 & 0,0 & 0,0 & 0,0 & 0,0 \\
0,5 & 168,8 & 0,0 & 2,0 & 0,5 & 0,0 & 81,8 & 18,2 & 0,0 & 138,1 & 30,7 \\
1,0 & 311,1 & 0,0 & 3,1 & 1,3 & 0,0 & 70,4 & 29,6 & 0,0 & 238,3 & 72,8 \\
1,5 & 429,2 & 0,0 & 4,0 & 2,2 & 0,2 & 64,1 & 35,7 & 0,2 & 313,9 & 115,0 \\
2,0 & 507,3 & 0,0 & 4,6 & 3,1 & 0,2 & 60,2 & 39,6 & 0,4 & 360,9 & 145,9 \\
2,5 & 533,8 & 0,0 & 5,0 & 3,7 & 0,2 & 57,8 & 42,0 & 0,5 & 376,2 & 157,0 \\
3,0 & 544,2 & 0,0 & 5,2 & 4,1 & 0,2 & 55,9 & 43,9 & 0,5 & 382,0 & 161,6 \\
3,7 & 549,4 & 0,0 & 5,3 & 4,9 & 0,2 & 51,6 & 48,2 & 0,5 & 384,7 & 164,1 \\
\hline
\end{tabular}

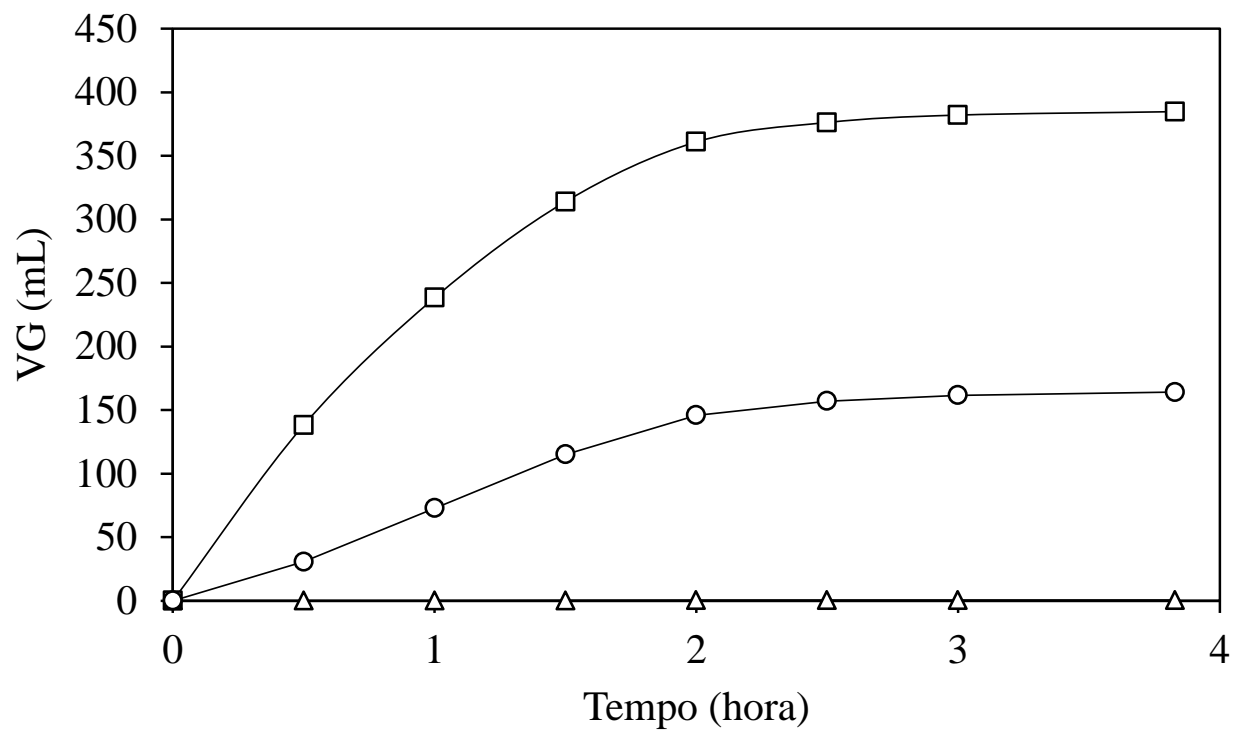

Figura 5-19 - Volumes acumulados médios produzidos ao longo do ciclo: $\square-\mathrm{CO}_{2} ; \Delta$ $\mathrm{H}_{2} ; \mathrm{O}-\mathrm{CH}_{4}$ (AnSBBR com recirculação da fase líquida e soro de leite - Condição 1). 


\subsubsection{Condição 2 - Adaptação com sacarose e afluente não refrigerado}

Levando em consideração o insucesso em produzir biohidrogênio a partir de soro de leite na primeira condição, optou-se por uma nova estratégia de operação. A condição 2 foi composta por 3 etapas. Na primeira etapa, desmontou-se o reator, todo o material suporte foi completamente limpo, iniciando-se uma nova operação usando sacarose como substrato, buscando aclimatar a biomassa com um substrato que produziu exclusivamente hidrogênio em trabalhos anteriores (Manssouri, 2012; Santos, 2012). Foi utilizada uma COAV nominal de $9,3 \mathrm{kgDQO} \cdot \mathrm{m}^{-3} \cdot \mathrm{d}^{-1}$ e duração do ciclo de 4 horas por um período de 22 dias (do dia 37 ao dia 58). Na segunda etapa após condicionar a biomassa com sacarose e garantir que a produção do biogás com este substrato era composto apenas por $\mathrm{H}_{2}$ e $\mathrm{CO}_{2}$, sem a presença de $\mathrm{CH}_{4}$, retornou-se à alimentação com soro de leite em condições idênticas à condição experimental 1, com COAV nominal de $10,1 \mathrm{kgDQO} \cdot \mathrm{m}^{-3} \cdot \mathrm{d}^{-1}$ e duração do ciclo de 4 horas por um período de 13 dias, indo do dia 58 ao dia 70. Na terceira etapa o reator voltou a ser alimentado com sacarose, de forma idêntica à segunda etapa. $\mathrm{O}$ inicio da operação se deu sem limpar o material suporte com biomassa da etapa anterior, o que fez com que ocorresse uma produção concomitante e estável de $\mathrm{H}_{2}$ e $\mathrm{CH}_{4}$. Desmontou-se então o reator, lavando todo o material suporte e reiniciando a operação com sacarose, o que acabou por eliminar novamente a presença de metano da composição do biogás produzido, dando um indicativo que possivelmente o soro de leite poderia ser o responsável pelo desenvolvimento de microrganismos metanogênicos no sistema. Esta última etapa da presente condição foi operada, antes e depois de lavar o material suporte, com COAV nominal de 9,3 kgDQO. $\mathrm{m}^{-3} \cdot \mathrm{d}^{-1}$ e duração do ciclo de 4 horas por um período de 18 dias 
(10 dias sem lavar o material suporte e 8 dias após a lavagem do material suporte), indo do dia 71 ao dia 88 .

A Tabela 5.5 apresenta as variáveis monitoradas e seus respectivos valores médios comuns a todas as etapas, enquanto que a Tabela 5.6 mostra os parâmetros exclusivos da primeira etapa da condição (única para a qual foi realizado perfil). 
Tabela 5.5 - Valores médios dos parâmetros monitorados comuns a todas as etapas da condição experimental 2 (Soro de leite - 4250 mgDQO.L ${ }^{-1}$

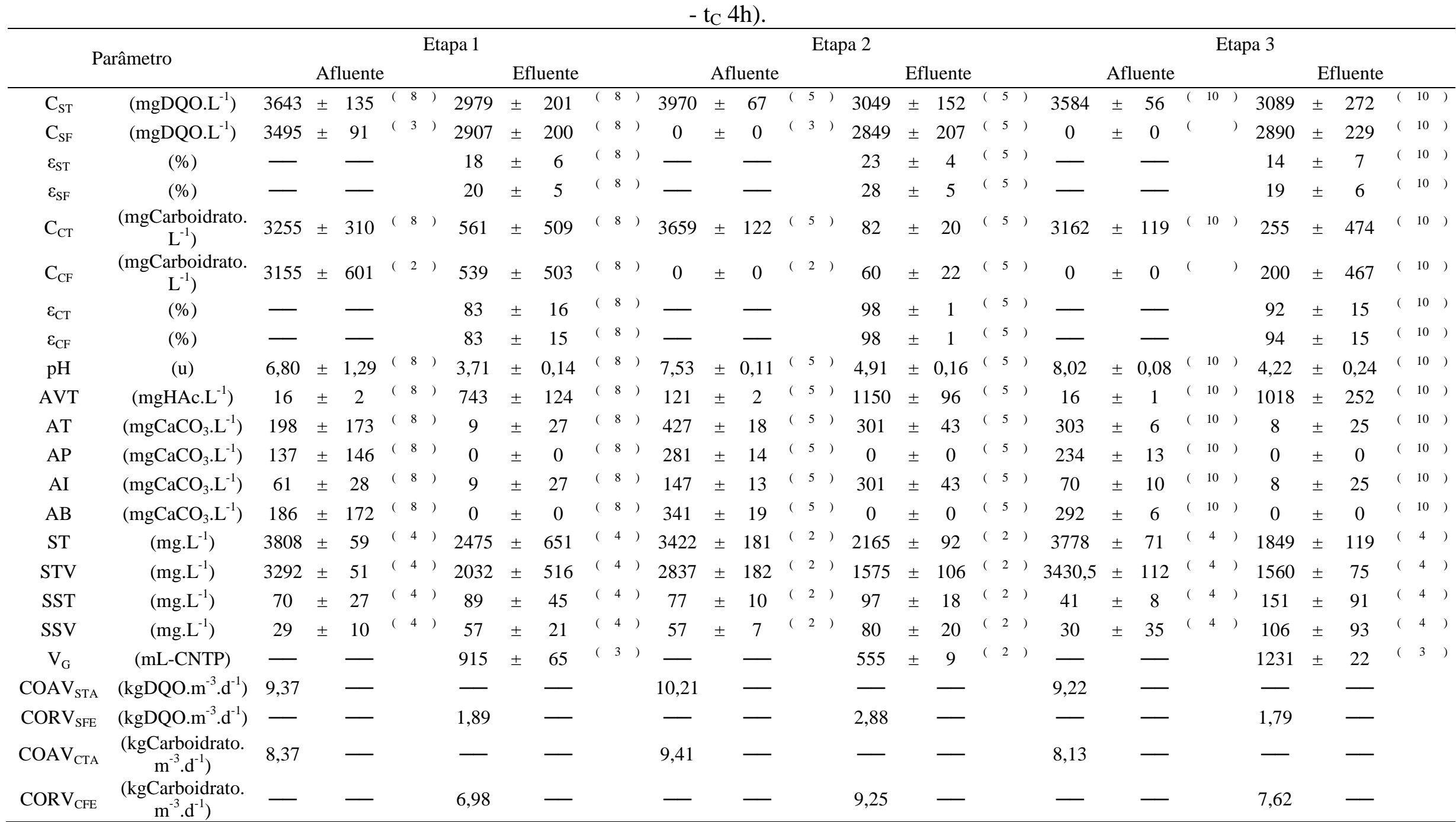

(*) Entre parêntese o número de amostras considerado no cálculo da média. 
Tabela 5.6 - Valores médios dos parâmetros exclusivos da primeira etapa da condição 2 (Soro de leite $-4250 \mathrm{mgDQO} . \mathrm{L}^{-1}-\mathrm{t}_{\mathrm{C}} 4 \mathrm{~h}$ ).

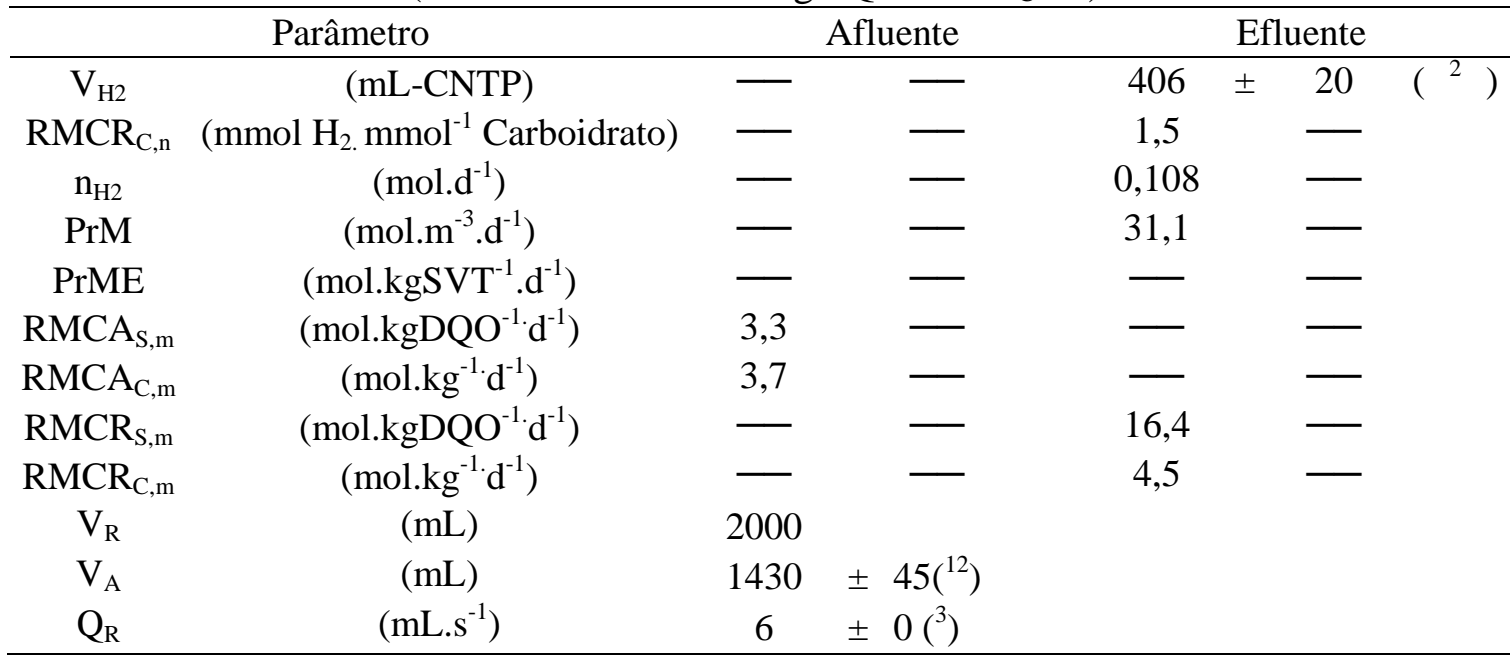

(*) Entre parêntese o número de amostras considerado no cálculo da média.

A Figura 5-20 apresenta os valores da concentração afluente (não filtrada) e efluente (não filtrada e filtrada) de matéria orgânica (DQO) nos sistema, enquanto que a Figura 5-21 apresenta a eficiência de remoção do mesmo parâmetro durante o monitoramento diário. Esta eficiência atingiu, em média, 18, 23 e 14\% para as amostras não filtradas e 20, 28 e $19 \%$ para amostras filtradas (para as etapas 1, 2 e 3 respectivamente). Para a primeira etapa, a média de concentração afluente (amostras não filtradas) do substrato foi de $3643 \mathrm{mgDQO} . \mathrm{L}^{-1}$ e de $2979 \mathrm{mgDQO} . \mathrm{L}^{-1}$ e 2907 mgDQO. $L^{-1}$ para amostras de efluente não filtrada e filtrada, respectivamente. Para a segunda etapa, a média de concentração afluente (amostras não filtradas) do substrato foi de $3970 \mathrm{mgDQO} . \mathrm{L}^{-1}$ e de $3049 \mathrm{mgDQO} . \mathrm{L}^{-1}$ e $2849 \mathrm{mgDQO} . \mathrm{L}^{-1}$ para amostras de efluente não filtrada e filtrada, respectivamente. Para a terceira etapa, a média de concentração afluente (amostras não filtradas) do substrato foi de $3584 \mathrm{mgDQO} . \mathrm{L}^{-1}$ e de $3089 \mathrm{mgDQO} . \mathrm{L}^{-1}$ e $2890 \mathrm{mgDQO} . \mathrm{L}^{-1}$ para amostras de efluente não filtrada e filtrada, respectivamente. 


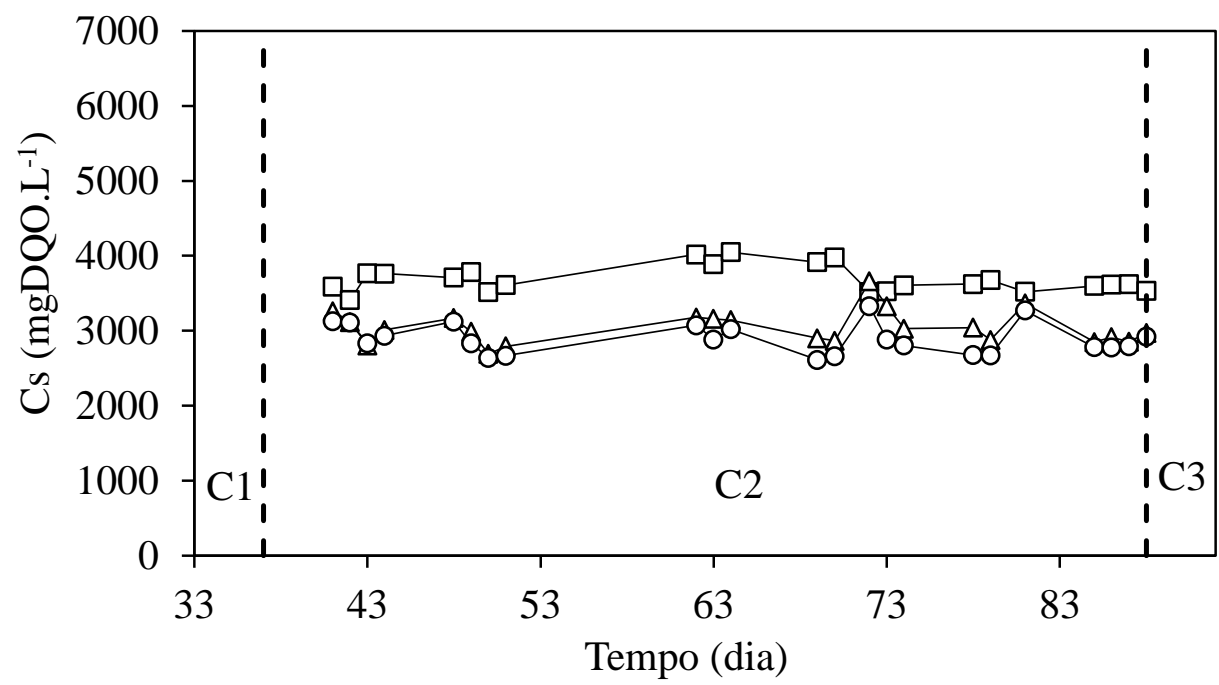

Figura 5-20 - Concentração de matéria orgânica (DQO): $\square$ - afluente não filtrada; $\Delta$ efluente não filtrada; o - efluente filtrada (AnSBBR com recirculação da fase líquida e soro de leite - Condição 2).

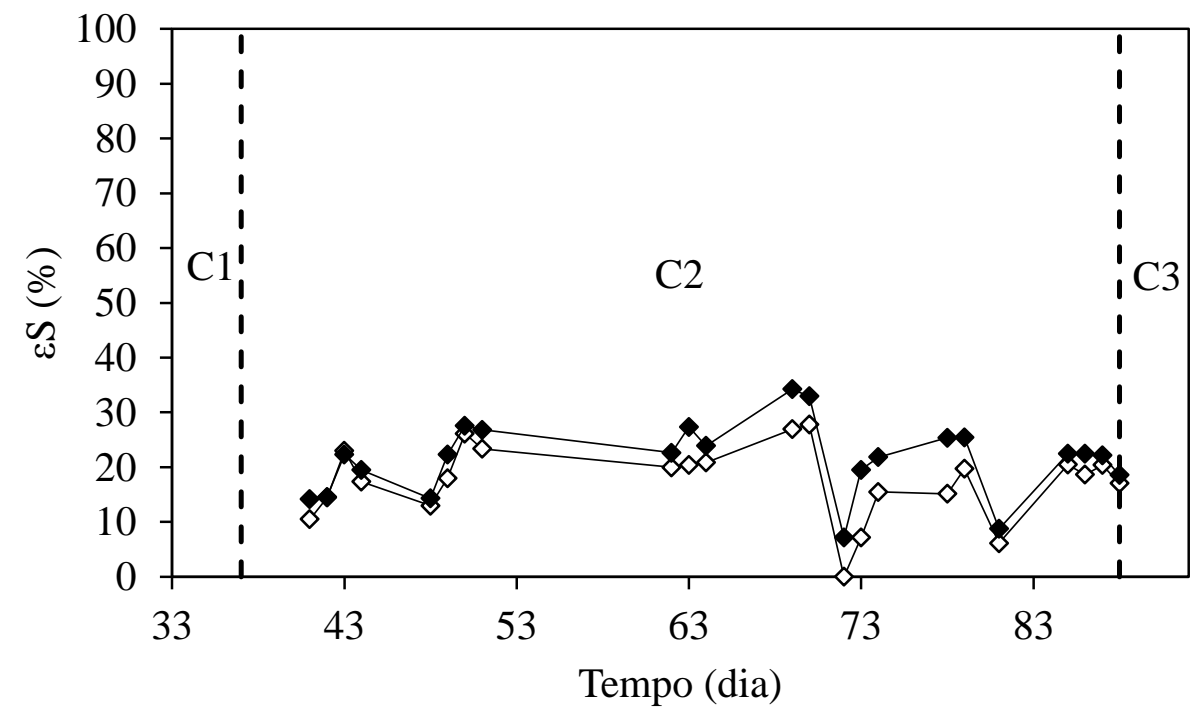

Figura 5-21 - Eficiência de remoção de matéria orgânica (DQO): $\diamond$ - não filtrada; filtrada (AnSBBR com recirculação da fase líquida e soro de leite - Condição 2).

A Figura 5-22 apresenta os valores da concentração de carboidratos afluente e efluente (para amostras filtradas e não filtradas). A Figura 5-23 apresenta a eficiência de remoção do mesmo parâmetro (não filtrada e filtrada) durante o monitoramento diário.. Esta eficiência atingiu, em média, 83, 98 e 92\% para as amostras não filtradas e 83, 98 e 
94\% para amostras filtradas (para as etapas 1, 2 e 3 respectivamente). Para a primeira etapa, a média de concentração afluente (amostras não filtradas) do substrato foi de 3255 mgCarboidrato. $\mathrm{L}^{-1}$ e de $561 \mathrm{mgCarboidrato.L^{-1 }}$ e $539 \mathrm{mgCarboidrato.L^{-1 }}$ para amostras de efluente não filtrada e filtrada, respectivamente. Para a segunda etapa, a média de concentração afluente (amostras não filtradas) do substrato foi de 3659 mgCarboidrato. $\mathrm{L}^{-1}$ e de $82 \mathrm{mgCarboidrato.} \mathrm{L}^{-1}$ e $60 \mathrm{mgCarboidrato.} \mathrm{L}^{-1}$ para amostras de efluente não filtrada e filtrada, respectivamente. Para a terceira etapa, a média de concentração afluente (amostras não filtradas) do substrato foi de $200 \mathrm{mgCarboidrato.L^{- }}$ ${ }^{1}$ e de 92 mgCarboidrato. $\mathrm{L}^{-1}$ e $2890 \mathrm{mgCarboidrato.L^{-1 }}$ para amostras de efluente não filtrada e filtrada, respectivamente. As quedas pontuais foram causadas pelas mudanças do substrato na alimentação.

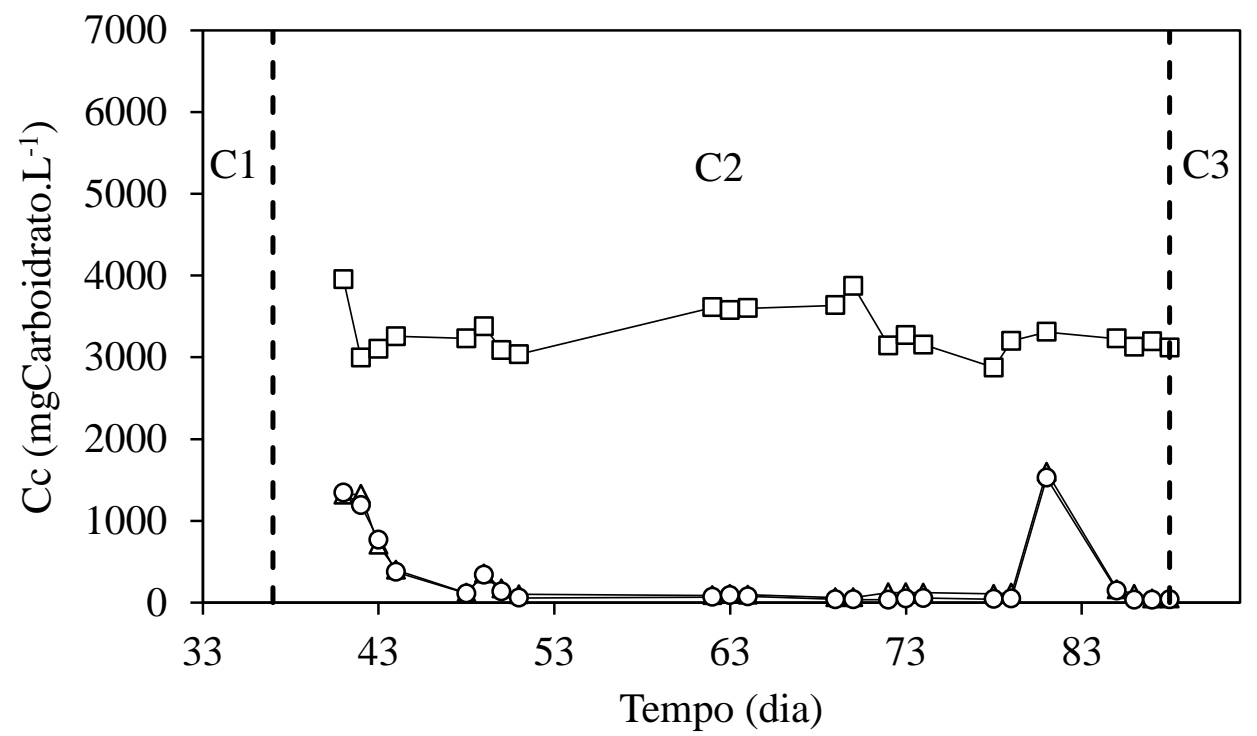

Figura 5-22 - Concentração de carboidrato: $\square-$ afluente não filtrada; $\Delta$ - efluente não filtrada; ○ - efluente filtrada (AnSBBR com recirculação da fase líquida e soro de leite Condição 2). 


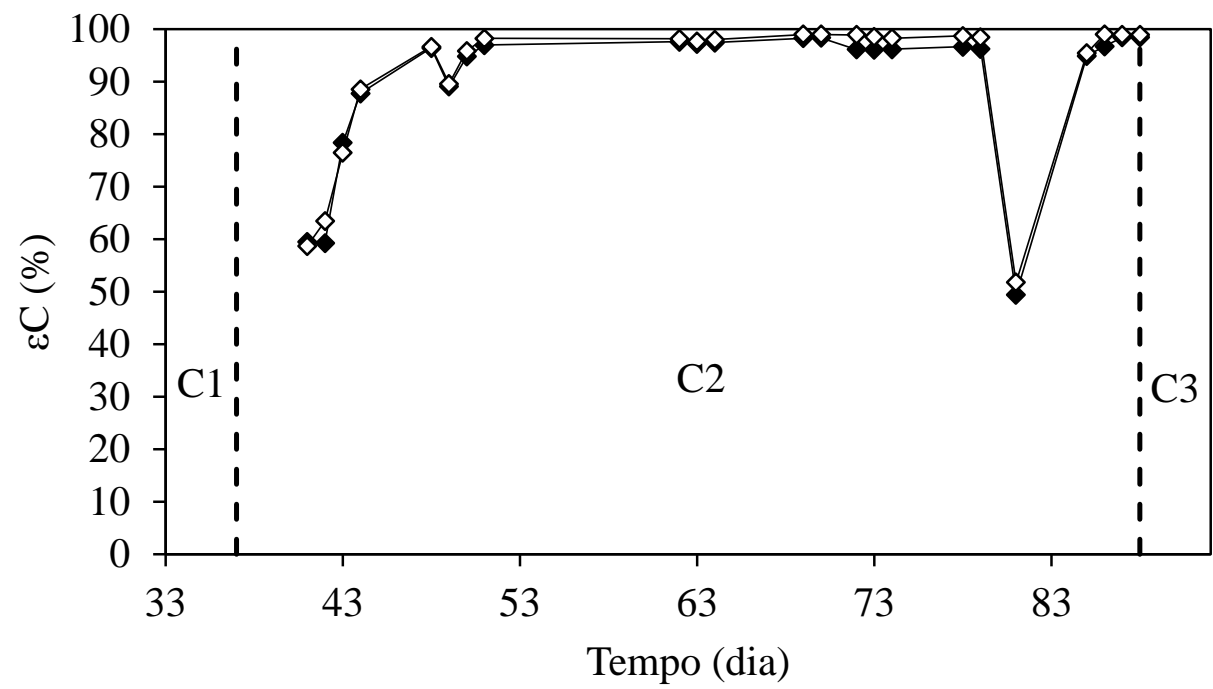

Figura 5-23 - Eficiência de remoção de carboidrato: $\diamond$ - não filtrada; $\downarrow$ - filtrada (AnSBBR com recirculação da fase líquida e soro de leite - Condição 2).

As Figura 5-24, Figura 5-25 e Figura 5-26 apresentam o monitoramento diário, tanto para o afluente quanto para o efluente, do $\mathrm{pH}$, da alcalinidade total e dos ácidos voláteis totais, respectivamente. A média dos valores de $\mathrm{pH}$ afluente foi de $6,80,7,53 \mathrm{e}$ 8,02 e de pH efluente foi de 3,71, 4,91 e 4,22 (para as etapas 1, 2 e 3 respectivamente). A média da alcalinidade total afluente foi de 198,427 e $303 \mathrm{mgCaCO}_{3} \cdot \mathrm{L}^{-1}$ e efluente de 9, 301 e $8 \mathrm{mgCaCO}_{3} \cdot \mathrm{L}^{-1}$ (para as etapas 1,2 e 3 respectivamente). O valor médio da concentração de ácidos voláteis totais afluente foi de 16, 121 e 16 mgHAc.L $\mathrm{L}^{-1}$ e efluente de 743, 1150 e 1018 mgHAc.L ${ }^{-1}$ (para es etapas 1, 2 e 3 respectivamente). Como pode ser observado na Figura 5-24 a etapa 1 da condição foi iniciada com a adição de ácido clorídrico concentrado $12 \mathrm{M}$ (na proporção de 7,5 mL para cada 11 litros de afluente), porém sem implicações nos demais parâmetros de monitoramento, além do consumo da alcalinidade total afluente. 


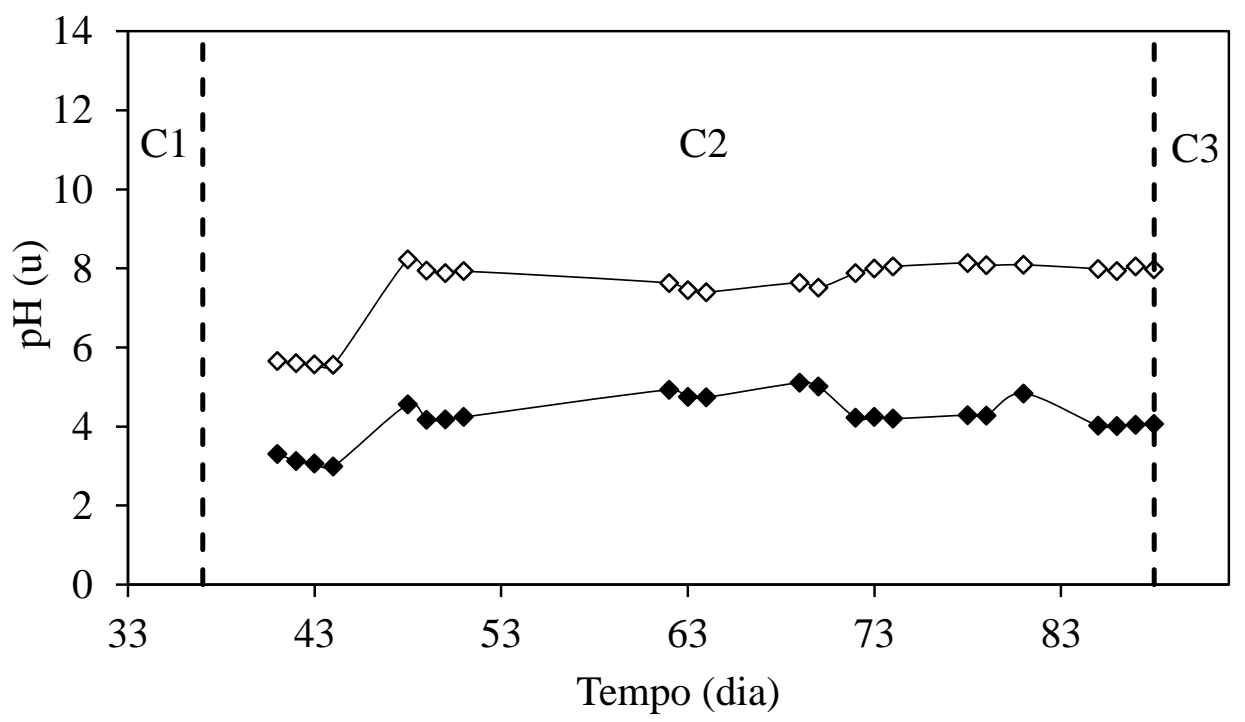

Figura 5-24 - Valores de pH: $\diamond$-afluente; $\downarrow$ - efluente (AnSBBR com recirculação da fase líquida e soro de leite - Condição 2).

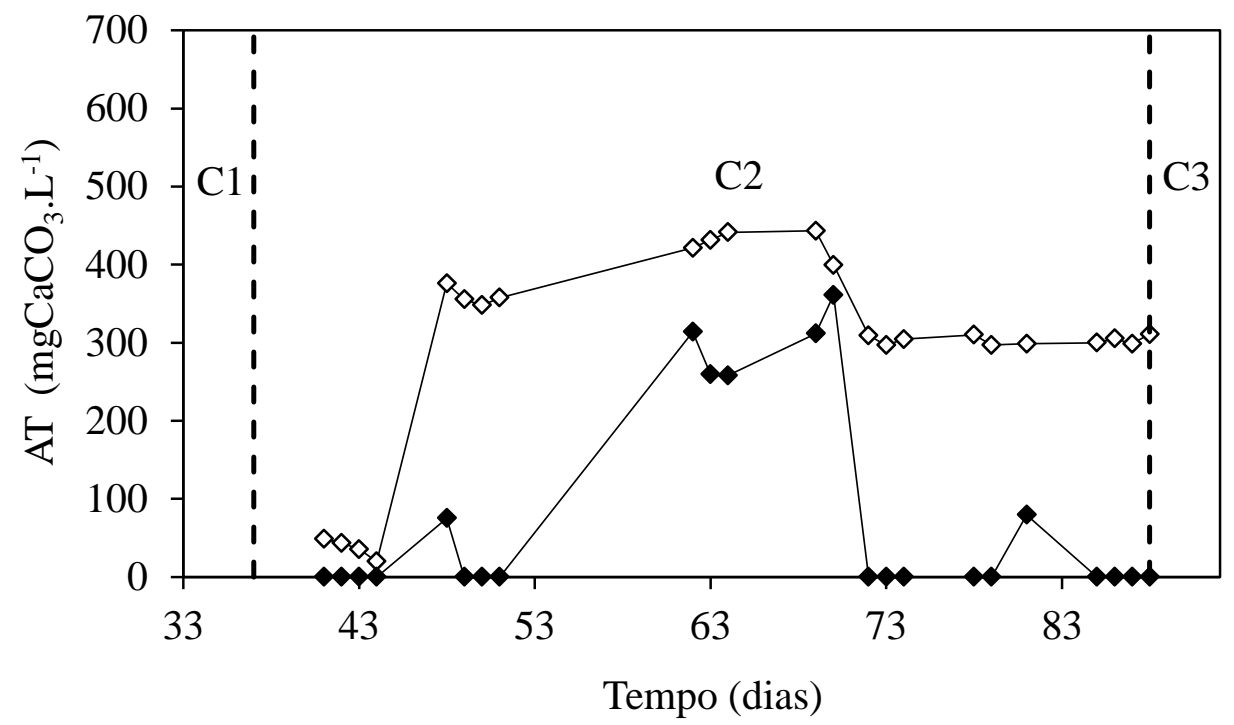

Figura 5-25 - Alcalinidade total: $\diamond$-afluente; $\diamond$ - efluente (AnSBBR com recirculação da fase líquida e soro de leite - Condição 2). 


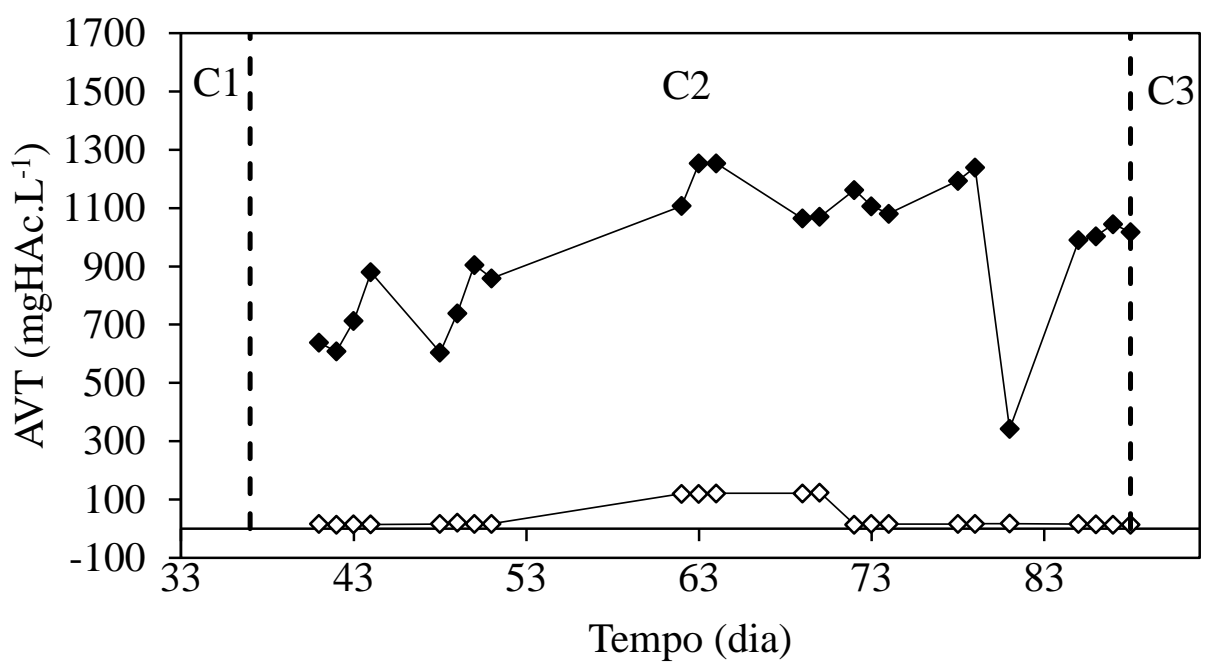

Figura 5-26 - Ácidos voláteis totais: $\diamond$-afluente; - efluente (AnSBBR com recirculação da fase líquida e soro de leite - Condição 2).

A Figura 5-27 apresenta o monitoramento dos compostos intermediários contidos no efluente do sistema, enquanto que a Tabela 5.7 apresenta os valores da concentração média destes produto. Este monitoramento foi realizado apenas para a etapa 1. O método cromatográfico utilizado novamente não detectou a presença de acetona e metanol. Entre os ácidos voláteis, a presença do ácido acético predominou (45,79\% dos compostos intermediários), com algum destaque, além disso, para o ácido butírico $(4,80 \%$ dos compostos intermediários) e para o ácido propiônico $(2,99 \%$ dos compostos intermediários). O maior diferencial com as condições anteriores, porém, está na produção de etanol, representando 44,52\% dos compostos intermediários. Os demais produtos apresentaram concentrações abaixo de $50 \mathrm{mg} \cdot \mathrm{L}^{-1}$. 


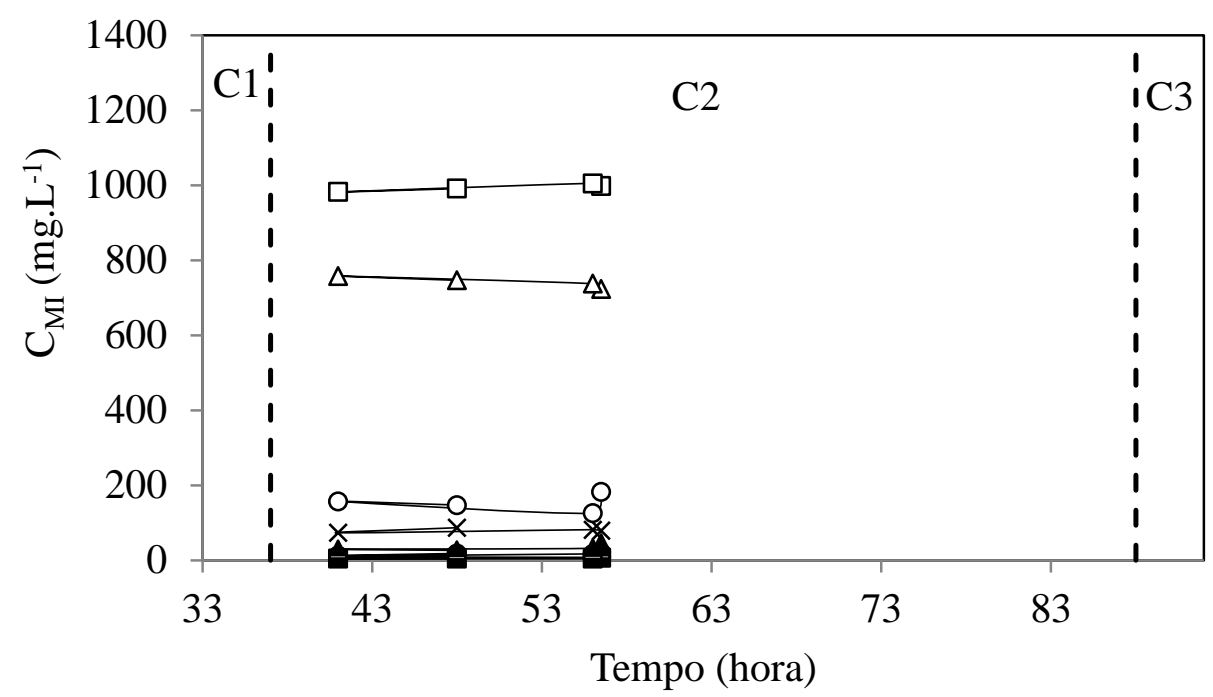

Figura 5-27 - Concentração dos compostos intermediários durante o monitoramento: - ácido acético; $\Delta$ - etanol; $\bigcirc$ - ácido butírico; - ácido isobutírico; $\boldsymbol{\Delta}$ - ácido capróico; • - ácido valérico; - * ácido propiônico; † butanol; — ácido isovalérico (AnSBBR com recirculação da fase líquida e soro de leite - Condição 2).

Tabela 5.7 - Concentração média e distribuição dos compostos intermediários (AnSBBR com recirculação da fase líquida e soro de leite - Condição 2).

\begin{tabular}{cccccccc}
\hline $\begin{array}{c}\text { Produtos } \\
\text { intermediários }\end{array}$ & \multicolumn{5}{c}{ Concentrações média } & \multicolumn{3}{c}{$\begin{array}{c}\text { Distribuição } \\
\left(\mathrm{mg} . \mathrm{L}^{-1}\right)\end{array}$} & \multicolumn{1}{c}{$\left.\mathrm{mmol}_{\mathrm{L}}^{-1}\right)$} & $(\%)$ \\
\hline Acetona & 0,0 & \pm & 0,0 & 0,0 & \pm & 0,0 & 0,0 \\
Metanol & 0,0 & \pm & 0,0 & 0,0 & \pm & 0,0 & 0,0 \\
Etanol & 741,5 & \pm & 14,4 & 16,1 & \pm & 0,3 & 44,5 \\
n-Butanol & 4,5 & \pm & 0,4 & 0,06 & \pm & 0,2 & 0,2 \\
Acético & 994,1 & \pm & 9,9 & 16,6 & \pm & 0,2 & 45,8 \\
Propiônico & 80,1 & \pm & 5,6 & 1,1 & \pm & 0,1 & 3,0 \\
Isobutírico & 5,2 & \pm & 1,4 & 0,1 & \pm & 0,1 & 0,2 \\
Butírico & 152,9 & \pm & 23,7 & 1,7 & \pm & 0,3 & 4,8 \\
Isovalérico & 8,1 & \pm & 1,1 & 0,1 & \pm & 0,1 & 0,2 \\
Valérico & 16,8 & \pm & 3,6 & 0,2 & \pm & 0,1 & 0,5 \\
Capróico & 33,2 & \pm & 8,5 & 0,3 & \pm & 0,1 & 0,9 \\
\hline
\end{tabular}

O monitoramento da série de sólidos é mostrado na Tabela 5.8, cujos valores apresentam um baixo teor de SSV no efluente e afluente, indicando a boa capacidade do reator em reter biomassa, mesmo no começo da operação. 
Tabela 5.8 - Série de sólidos afluente e efluente (AnSBBR com recirculação da fase líquida e soro de leite - Condição 2)

\begin{tabular}{|c|c|c|c|c|c|c|}
\hline & & $\begin{array}{c}\mathrm{ST} \\
\left(\mathrm{mg} \cdot \mathrm{L}^{-1}\right)\end{array}$ & $\begin{array}{r}\mathrm{SV} \\
(\mathrm{mg} .\end{array}$ & & $\begin{array}{c}\text { SST } \\
\left(\mathrm{mg} . \mathrm{L}^{-1}\right)\end{array}$ & $\begin{array}{c}\text { SSV } \\
\left(\mathrm{mg} \cdot \mathrm{L}^{-1}\right)\end{array}$ \\
\hline \multirow{2}{*}{ Etapa 1} & Afluente & $808,0 \pm 59,0$ & 3292,0 & $\pm 51,5$ & $70,0 \pm 27,4$ & $29,0 \pm 9,6$ \\
\hline & Efluente & $2475,0 \pm 650,6$ & 2032,5 & $\pm 515,6$ & $89,5 \pm 45,1$ & $57,0 \pm 20,9$ \\
\hline \multirow[b]{2}{*}{ Etapa 2} & Afluente & $3422,0 \pm 181,0$ & 2837,0 & $\pm 182,4$ & $77,0 \pm 9,9$ & $57,0 \pm 7,1$ \\
\hline & Efluente & $2165,0 \pm 91,9$ & 1575,0 & $\pm 106,1$ & $97,0 \pm 18,4$ & $80,0 \pm 19,8$ \\
\hline \multirow{2}{*}{ Etapa 3} & Afluente & $3778,0 \pm-70,6$ & 3430,5 & $\pm 111,8$ & $41,0 \pm 8,4$ & $30,0 \pm 35,2$ \\
\hline & Efluente & $1849,0 \pm 119,0$ & 1559,5 & $\pm 75,2$ & $151,5 \pm 91,4$ & $106,0 \pm 93,1$ \\
\hline
\end{tabular}

*Número de amostras consideradas $=4,2$ e 4 (etapa 1, 2 e 3 respectivamente).

A produção quantitativa do biogás por ciclo é apresentada na Figura 5-28. A produção média foi de $810 \mathrm{~mL}$ (CNTP). A Figura 5-29 apresenta o monitoramento das concentrações dos componentes do biogás no final do ciclo, enquanto que a Figura 5-30 apresenta a distribuição destes mesmos componentes. Os valores médios de concentração de $\mathrm{H}_{2}$ foram, para as etapas 1, 2 e 3 respectivamente, 9,8, 0,9 e 7,9 mmol.L ${ }^{-1}$, Para o $\mathrm{CH}_{4}$ os valores médios de concentração foram, para as etapas 1,2 e 3 respectivamente, $0,0,1,1$ e 1,9 mmol. $\mathrm{L}^{-1}$. Por ultimo, Os valores médios de concentração de $\mathrm{CO}_{2}$ foram 8,6, 7,0 e 8,6 mmol.L ${ }^{-1}$ para as etapas 1,2 e 3 respectivamente. Além disso, a distribuição percentual média de $\mathrm{H}_{2}$ foi de 53,2, 9,7 e $32,1 \%$ (para as etapas 1, 2 e 3 respectivamente), a de $\mathrm{CH}_{4}$ foi de 0,0, 10,6 e 16,3\% (para as etapas 1,2 e 3 respectivamente) e a de $\mathrm{CO}_{2}$ foi de 46,8, 79,8 e 51,6\% (para as etapas 1,2 e 3 respectivamente). Na primeira etapa a mudança de substrato surtiu efeito e o reator passou a produzir $\mathrm{H}_{2}$, sem a presença de metano. $\mathrm{Na}$ segunda etapa, porém, mesmo com o condicionamento com sacarose na etapa anterior e com um curto período de operação, foi possível observar a queda na produção de $\mathrm{H}_{2}$ (praticamente zero) e a volta da produção de $\mathrm{CH}_{4}$. Na terceira etapa, com a substituição do soro de leite pela sacarose mantendo a biomassa desenvolvida na segunda etapa não foi possível retomar 
os resultados obtidos na primeira etapa (produção de hidrogênio sem produção de metano), ocorrendo uma estabilização da composição do biogás contendo $\mathrm{H}_{2}, \mathrm{CH}_{4} \mathrm{e}$ $\mathrm{CO}_{2}$. A alimentação com sacarose após a lavagem do sistema, porém, encerrou a produção de metano, retomando os resultados obtidos na primeira etapa, dando um indicativo que possivelmente o soro de leite pode ser o responsável pelo desenvolvimento de microrganismos metanogênicos no sistema.

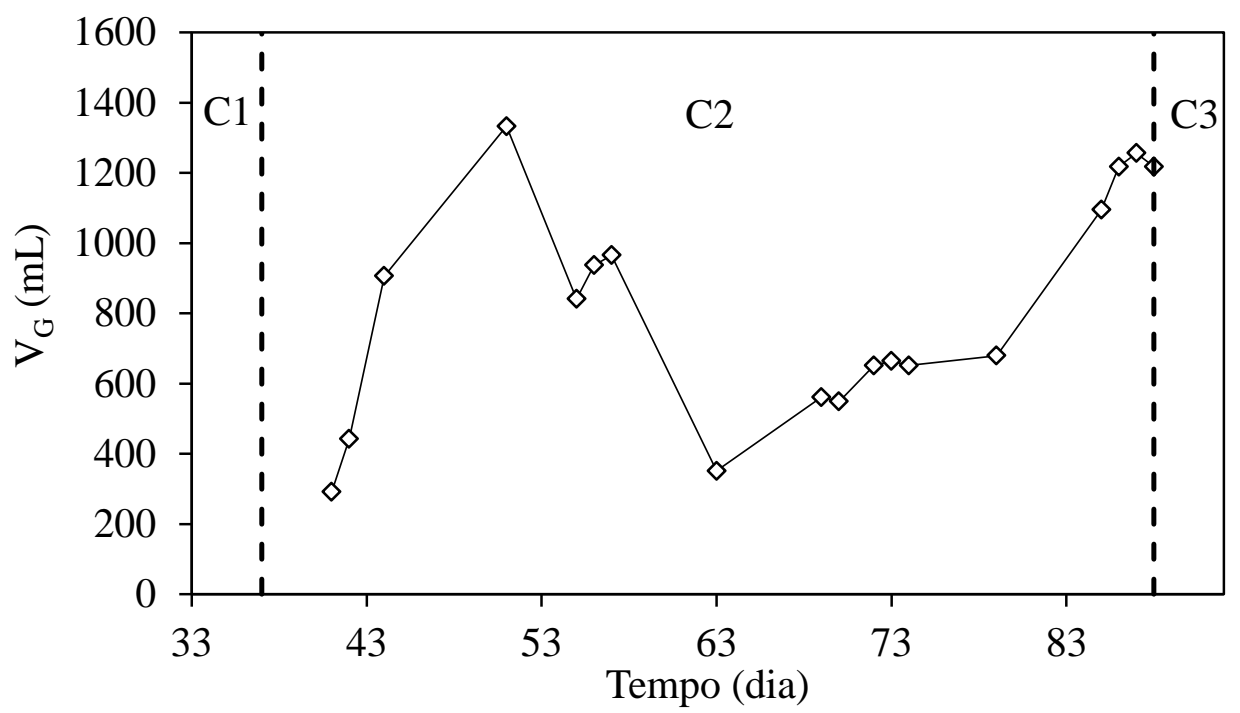

Figura 5-28 - Volume de biogás produzido por ciclo (AnSBBR com recirculação da fase líquida e soro de leite - Condição 2). 


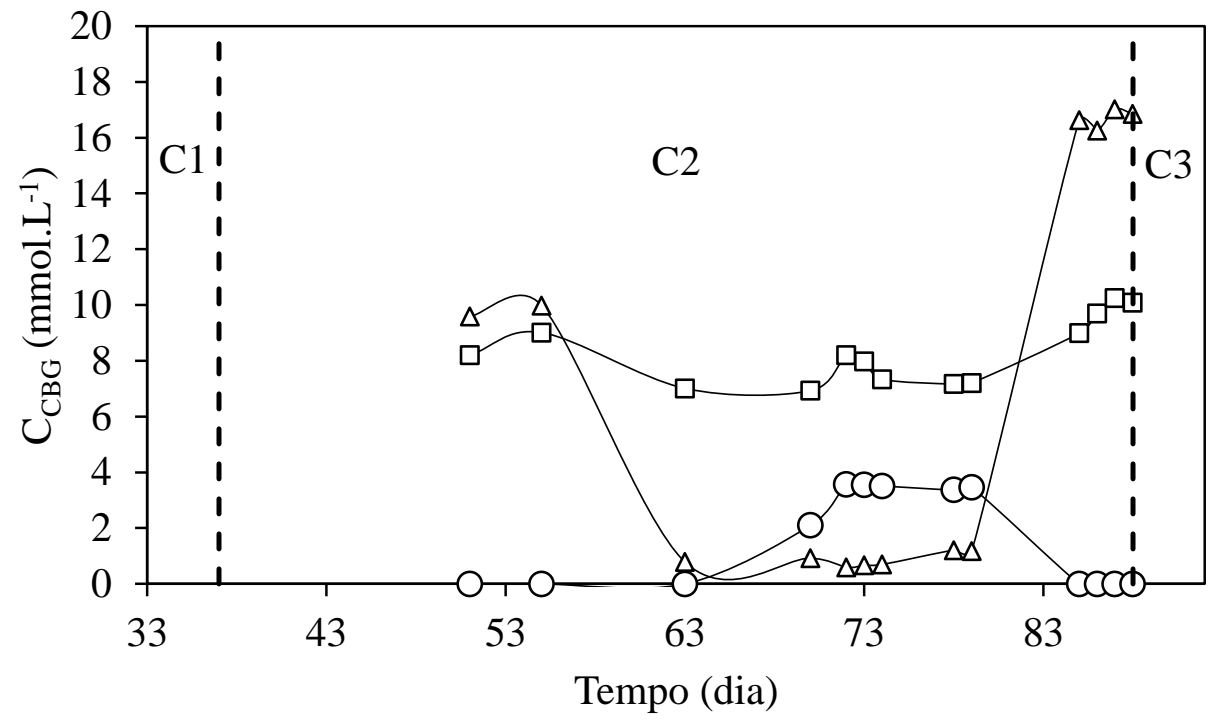

Figura 5-29 - Concentrações dos componentes do biogás no final do ciclo: $\square-\mathrm{CO}_{2} ; \Delta$ $\mathrm{H}_{2} ; \circ-\mathrm{CH}_{4}$ (AnSBBR com recirculação da fase líquida e soro de leite - Condição 2).

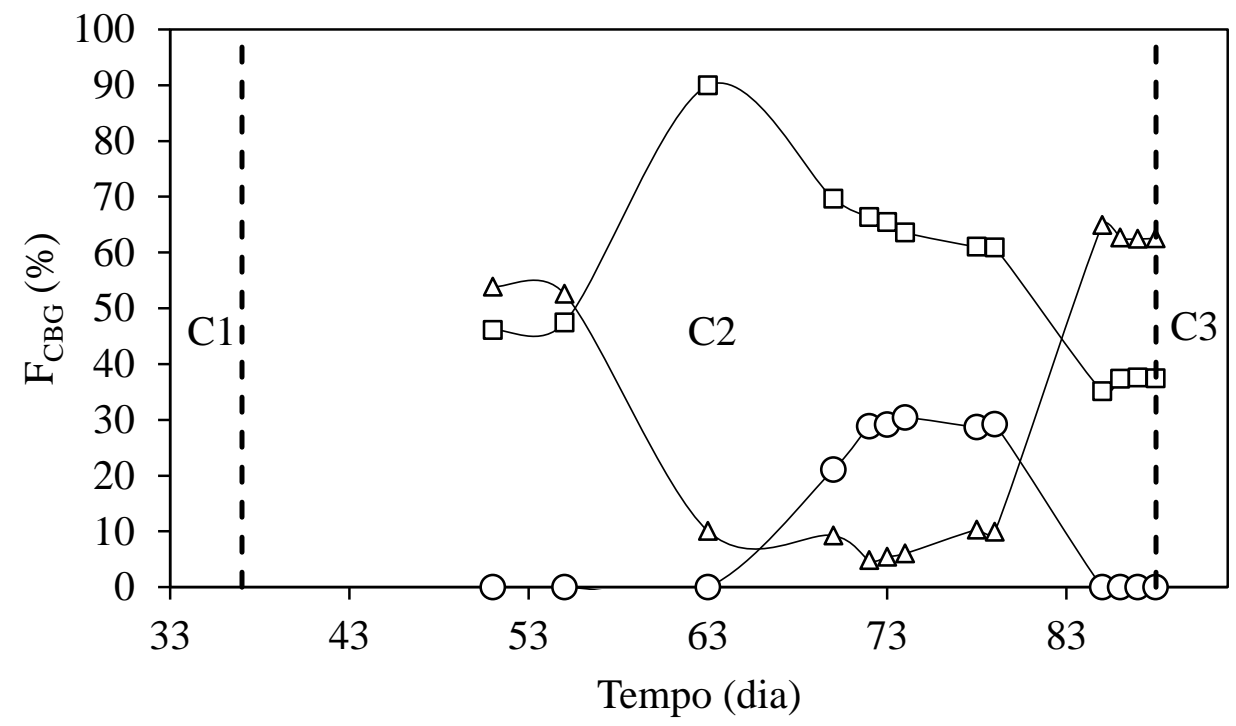

Figura 5-30 - Distribuições dos componentes do biogás no final do ciclo: $\square-\mathrm{CO}_{2} ; \Delta$ $\mathrm{H}_{2} ;$ O - $\mathrm{CH}_{4}$ (AnSBBR com recirculação da fase líquida e soro de leite - Condição 2).

O perfil temporal foi realizado apenas no final da primeira etapa da Condição 2.

A Figura 5-31 apresenta a evolução da concentração de matéria orgânica ao longo do ciclo. Observa-se uma baixa remoção da DQO, levando a uma alta concentração da mesma no volume residual. Desta forma no inicio do ciclo a diluição do volume 
carregado pelo volume residual é realizada em proporção baixa, tendo em vista que as concentrações afluente e residual são próximas. No inicio do ciclo, a concentração é da ordem de $3300 \mathrm{mg} . \mathrm{L}^{-1}$ atingindo valores próximos a $3015 \mathrm{mg} . \mathrm{L}^{-1}$ no último ponto do ciclo.

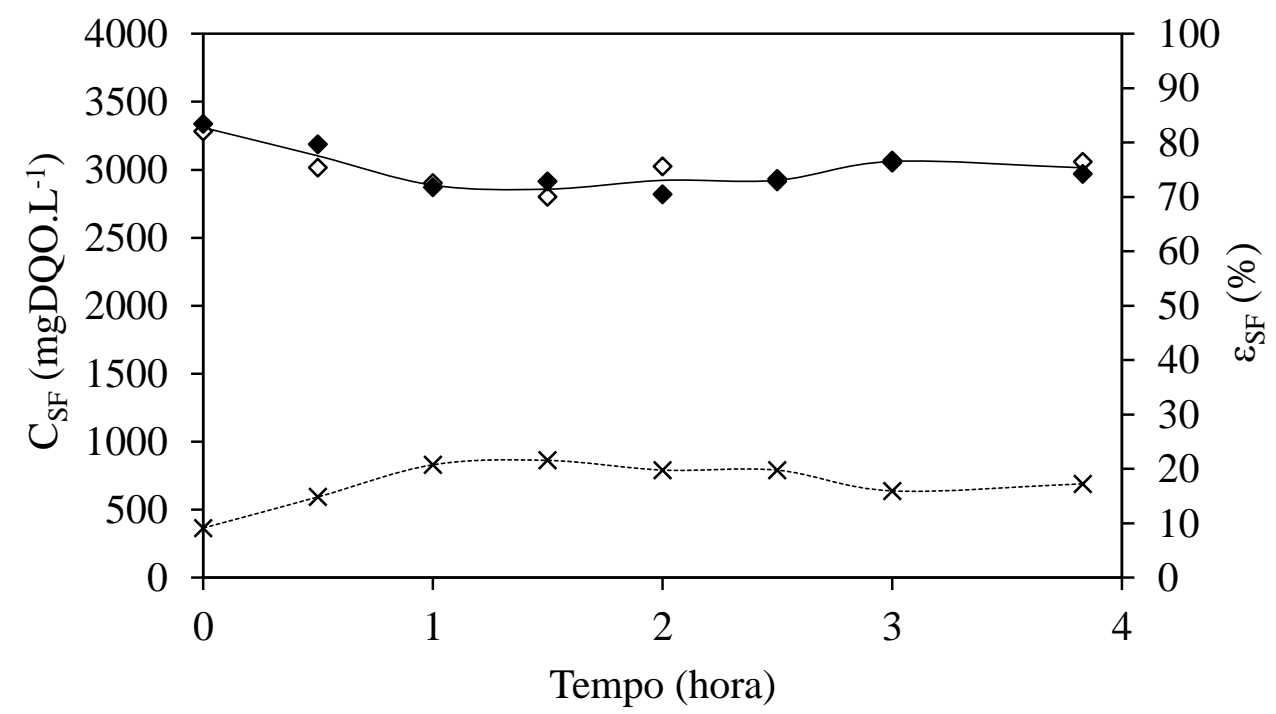

Figura 5-31 - Eixo da direita: Concentração de matéria orgânica (DQO) $\diamond$ - do perfil 1, - - do perfil 2 e - média dos dois perfis; Eixo da esquerda: - - eficiência de degradação da matéria orgânica (DQO) (AnSBBR com recirculação da fase líquida e soro de leite - Condição 2).

A Figura 5-32 apresenta a evolução da concentração de carboidrato ao longo do ciclo e a eficiência de remoção do mesmo. No inicio do ciclo o volume afluente é diluído no volume residual resultando em uma concentração em sacarose da ordem de 1500 $\mathrm{mg} \cdot \mathrm{L}^{-1}$. A conversão desta sacarose se faz de maneira progressiva ao longo do ciclo, atingindo valores na ordem de $99 \%$ no final do mesmo, com um residual aproximado de $37 \mathrm{mg} \cdot \mathrm{L}^{-1}$. 


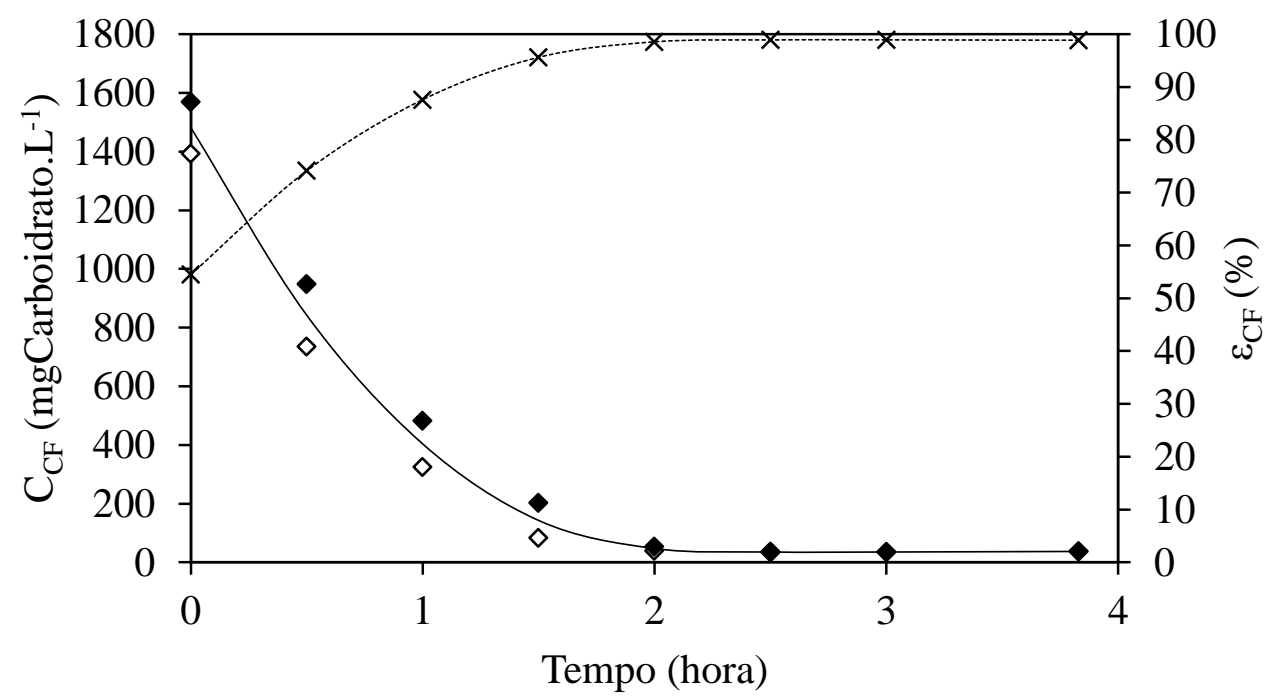

Figura 5-32 - Eixo da direita: Concentração de carboidrato $\diamond$ - do perfil 1 , - do perfil 2 e - média dos dois perfis; Eixo da esquerda: - - eficiência de degradação do carboidrato (AnSBBR com recirculação da fase líquida e soro de leite - Condição 2).

O acúmulo de ácidos voláteis totais por titulação ao longo do ciclo é apresentado na Figura 5-33. A concentração destes aumenta claramente durante a fase de reação para atingir um valor médio máximo no final do ciclo na ordem de $950 \mathrm{mgHAc} . \mathrm{L}^{-1}$.

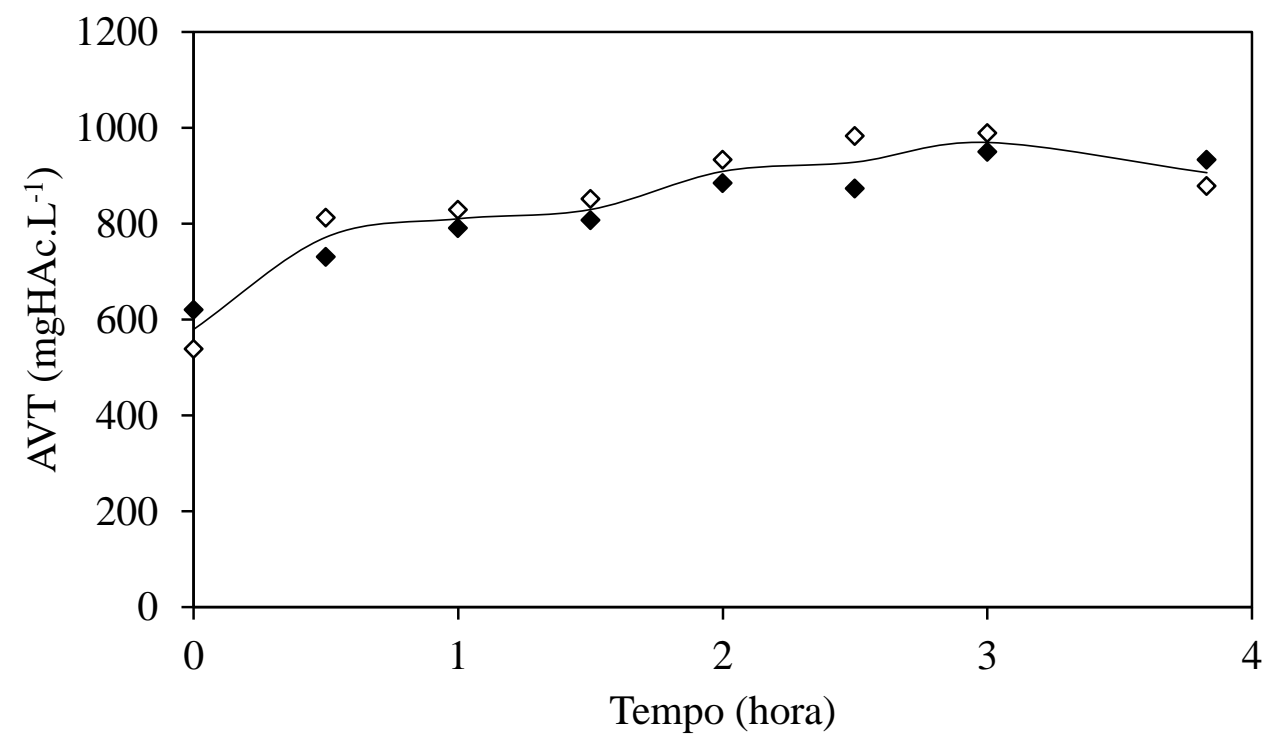

Figura 5-33 - Ácidos voláteis totais: $\diamond$ - do perfil 1 , - do perfil $2 \mathrm{e}$ - média dos dois perfis (AnSBBR com recirculação da fase líquida e soro de leite - Condição 2). 
As concentrações dos metabólitos intermediários por cromatografia gasosa são apresentadas na Figura 5-34. Observa-se uma produção crescente de ácido acético e etanol, passando de uma concentração inicial de $602,2 \mathrm{mg} . \mathrm{L}^{-1}$ até $997,9 \mathrm{mg} . \mathrm{L}^{-1}$ no final do ciclo para o ácido e de uma concentração inicial de 495,8 mg. $\mathrm{L}^{-1}$ até $724,0 \mathrm{mg} . \mathrm{L}^{-1}$ no final do ciclo para o álcool. Além destes, o ácido butírico mereceu algum destaque se apresentando estável durante todo o perfil, com concentrações próximas a $125 \mathrm{mg} . \mathrm{L}^{-1}$. Os demais produtos também apresentaram produção estável, porém com concentrações sempre abaixo de $100 \mathrm{mg} . \mathrm{L}^{-1}$.

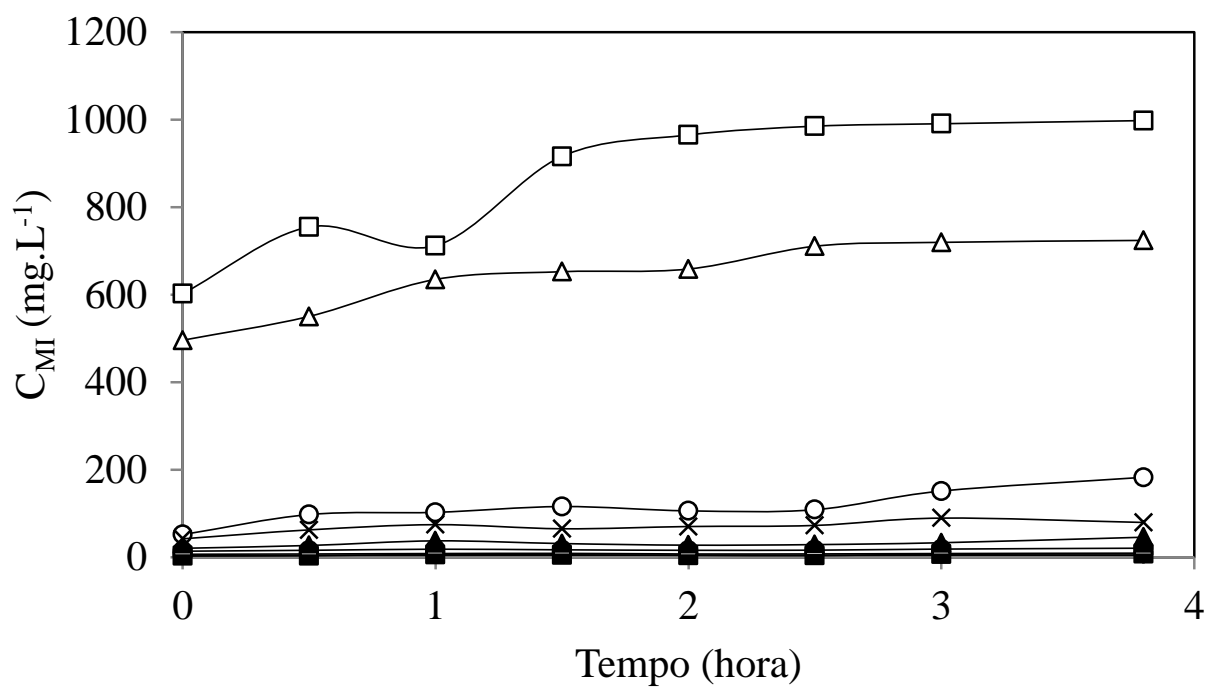

Figura 5-34 - Concentração dos compostos intermediários ao longo do ciclo: $\square$ - ácido acético; $\Delta$ - etanol; $\bigcirc$ - ácido butírico; $\boldsymbol{-}$ - ácido isobutírico; $\boldsymbol{\Delta}$ - ácido capróico; $\bullet-$ ácido valérico; * ácido propiônico; + butanol; - ácido isovalérico (AnSBBR com recirculação da fase líquida e soro de leite - Condição 2).

$\mathrm{O}$ pH diminuiu instantaneamente em relação ao afluente devido à diluição do mesmo com o volume residual no inicio do ciclo (alimentação do reator em 10 minutos) e permaneceu estável ao longo da operação conforme a Figura 5-35. A estabilidade do pH mesmo com a produção de ácidos voláteis se deu devido ao tamponamento do 
sistema pelo consumo de alcalinidade ao longo do ciclo. A Figura 5-36 apresenta a evolução da alcalinidade total no reator ao longo do ciclo.

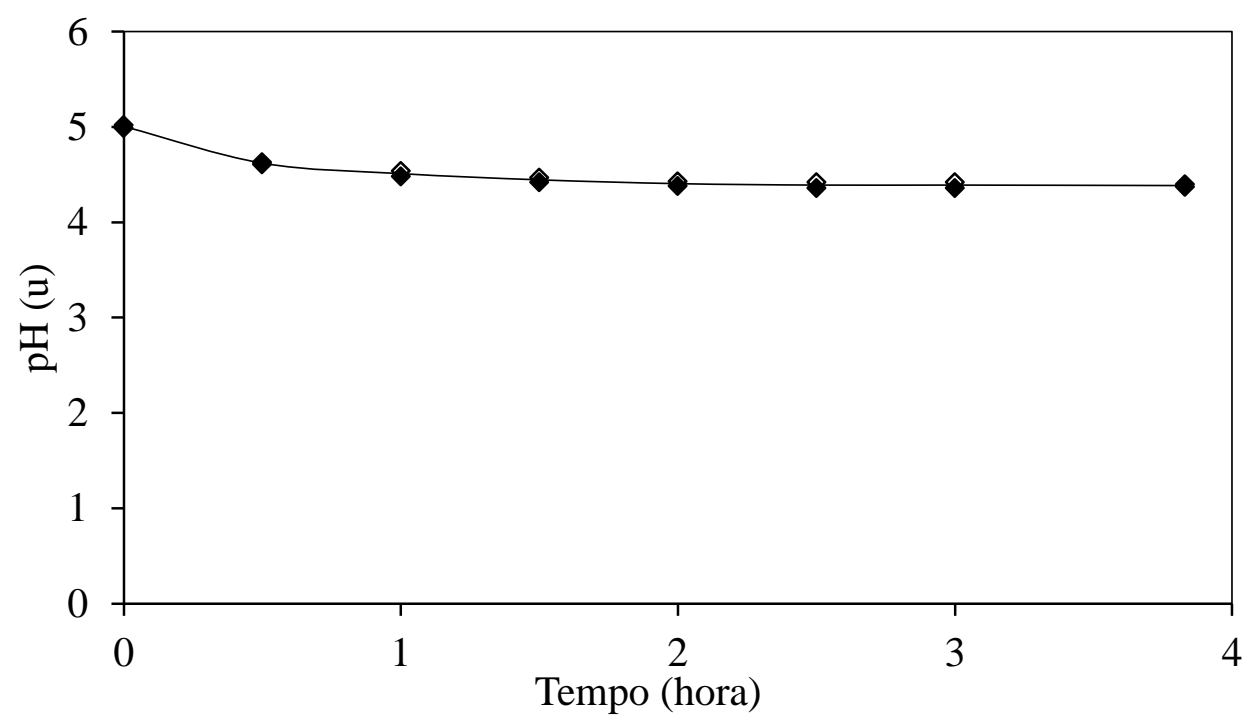

Figura 5-35 - Valores de pH: $\diamond-$ do perfil 1 , - do perfil 2 e - média dos dois perfis (AnSBBR com recirculação da fase líquida e soro de leite - Condição 2).

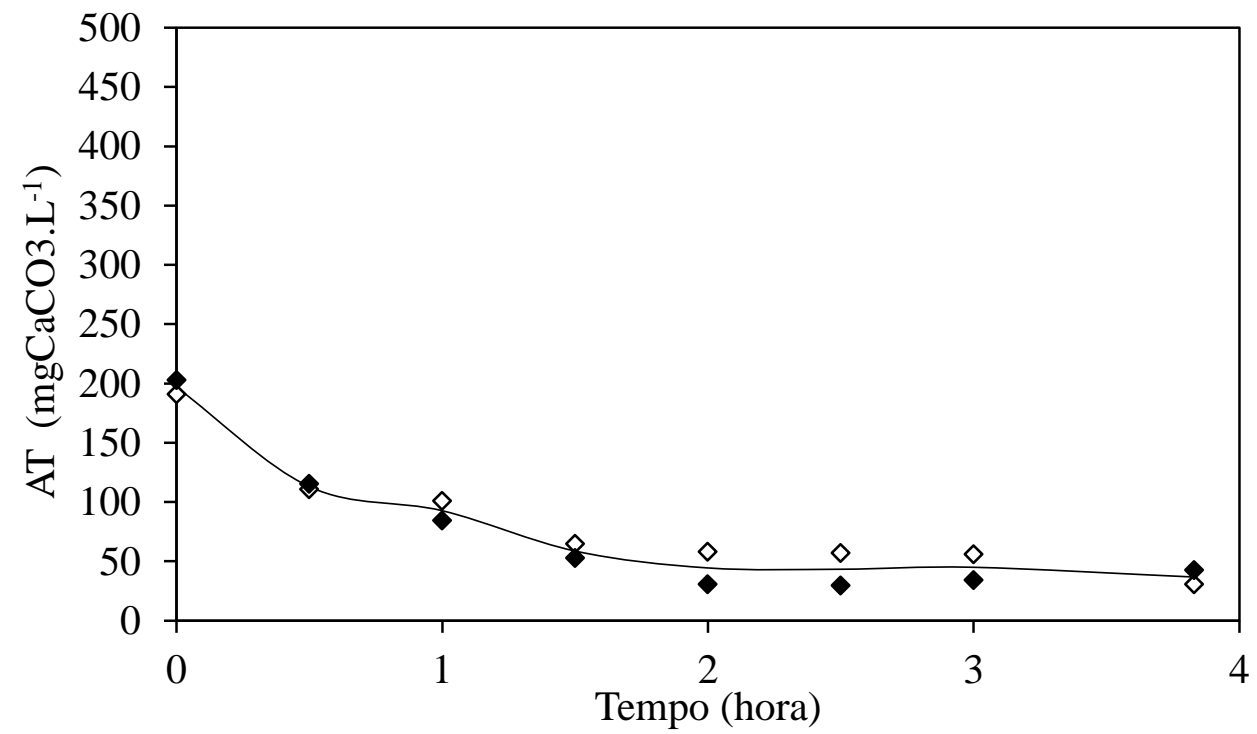

Figura 5-36 - Alcalinidade total: $\diamond$ - do perfil 1, - do perfil $2 \mathrm{e}-$ média dos dois perfis (AnSBBR com recirculação da fase líquida e soro de leite - Condição 2). 
A produção volumétrica média acumulada do biogás, realizada com os valores dos perfis quantitativos mais consistentes obtidos durante a operação, juntamente com os desvios padrões encontram-se na Figura 5-37. A maior parte da produção ocorre no inicio do ciclo, até a metade do mesmo, e tende a se estabilizar no final. A Tabela 5.9 resume os valores médios da produção, fração molar e os volumes individuais da mistura do biogás. A Figura 5-38 apresenta os volumes acumulados médios dos perfis de $\mathrm{H}_{2}, \mathrm{CO}_{2}$ e $\mathrm{CH}_{4}$ produzidos durante o ciclo.

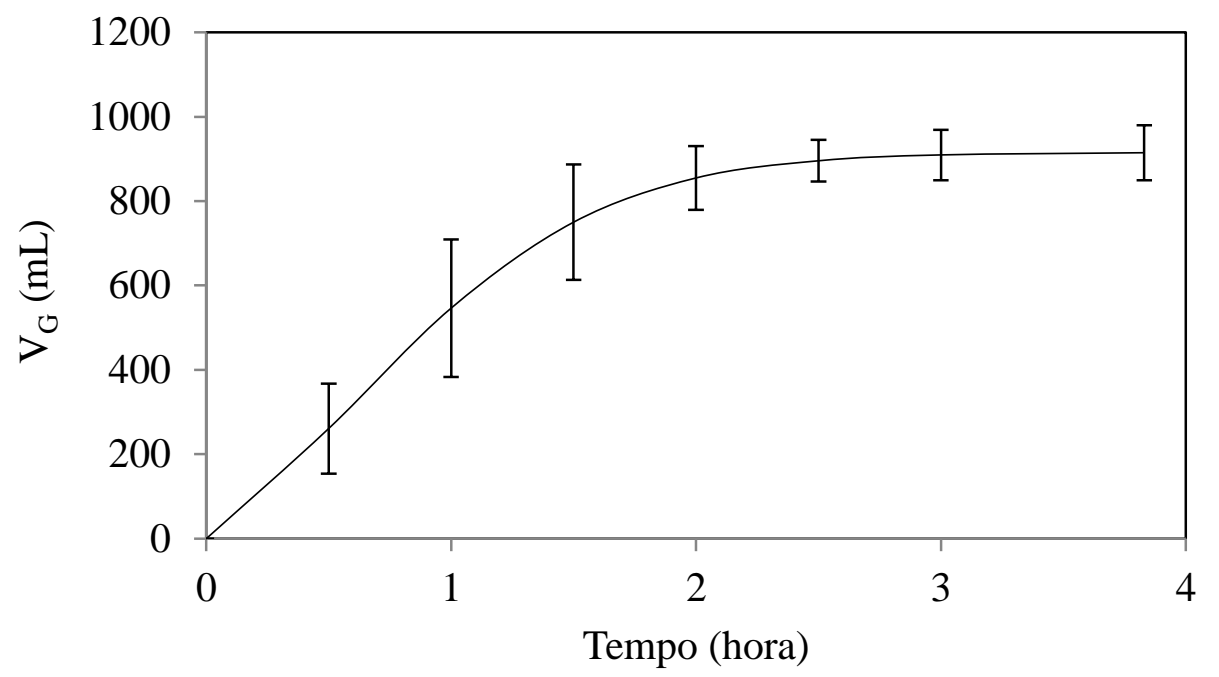

Figura 5-37 - Produção volumétrica média acumulada do biogás, realizada com os valores dos perfis quantitativos mais consistentes obtidos durante a operação, juntamente com os desvios padrões (AnSBBR com recirculação da fase líquida e soro de leite - Condição 2). 
Tabela 5.9 - Valores médios da produção, fração molar e os volumes individuais da mistura do biogás (condição 4).

\begin{tabular}{|c|c|c|c|c|c|c|c|c|c|c|}
\hline \multirow{2}{*}{$\begin{array}{l}\text { Tempo } \\
\text { (h) }\end{array}$} & \multirow{2}{*}{$\begin{array}{c}\mathrm{V}_{\mathrm{G}} \\
(\mathrm{mL}-\mathrm{CNTP})\end{array}$} & \multicolumn{3}{|c|}{$\mathrm{C}_{\mathrm{G}}\left(\mathrm{mmol} \cdot \mathrm{L}^{-1}\right)$} & \multicolumn{3}{|c|}{ Fração Molar (\%) } & \multicolumn{3}{|c|}{ Volume $(\mathrm{mL}-\mathrm{CNTP})$} \\
\hline & & $\mathrm{H}_{2}$ & $\mathrm{CO}_{2}$ & $\mathrm{CH}_{4}$ & $\mathrm{H}_{2}$ & $\mathrm{CO}_{2}$ & $\mathrm{CH}_{4}$ & $\mathrm{H}_{2}$ & $\mathrm{CO}_{2}$ & $\mathrm{CH}_{4}$ \\
\hline 0,0 & 0,0 & 0,0 & 0,0 & 0,0 & 0,0 & 0,0 & 0,0 & 0,0 & 0,0 & 0,0 \\
\hline 0,5 & 261,1 & 1,71 & 3,38 & 0,0 & 33,7 & 66,3 & 0,0 & 88,1 & 173,0 & 0,0 \\
\hline 1,0 & 546,4 & 4,64 & 5,62 & 0,0 & 45,2 & 54,8 & 0,0 & 217,0 & 329,4 & 0,0 \\
\hline 1,5 & 750,1 & 6,77 & 6,59 & 0,0 & 50,7 & 49,3 & 0,0 & 320,2 & 429,9 & 0,0 \\
\hline 2,0 & 854,9 & 7,91 & 7,40 & 0,0 & 51,7 & 48,3 & 0,0 & 374,4 & 480,5 & 0,0 \\
\hline 2,5 & 895,6 & 9,11 & 7,85 & 0,0 & 53,7 & 46,3 & 0,0 & 396,2 & 499,4 & 0,0 \\
\hline 3,0 & 909,4 & 9,54 & 8,32 & 0,0 & 53,4 & 46,6 & 0,0 & 403,6 & 505,8 & 0,0 \\
\hline 3,8 & 914,6 & 9,78 & 8,61 & 0,0 & 53,2 & 46,8 & 0,0 & 406,4 & 508,2 & 0,0 \\
\hline
\end{tabular}

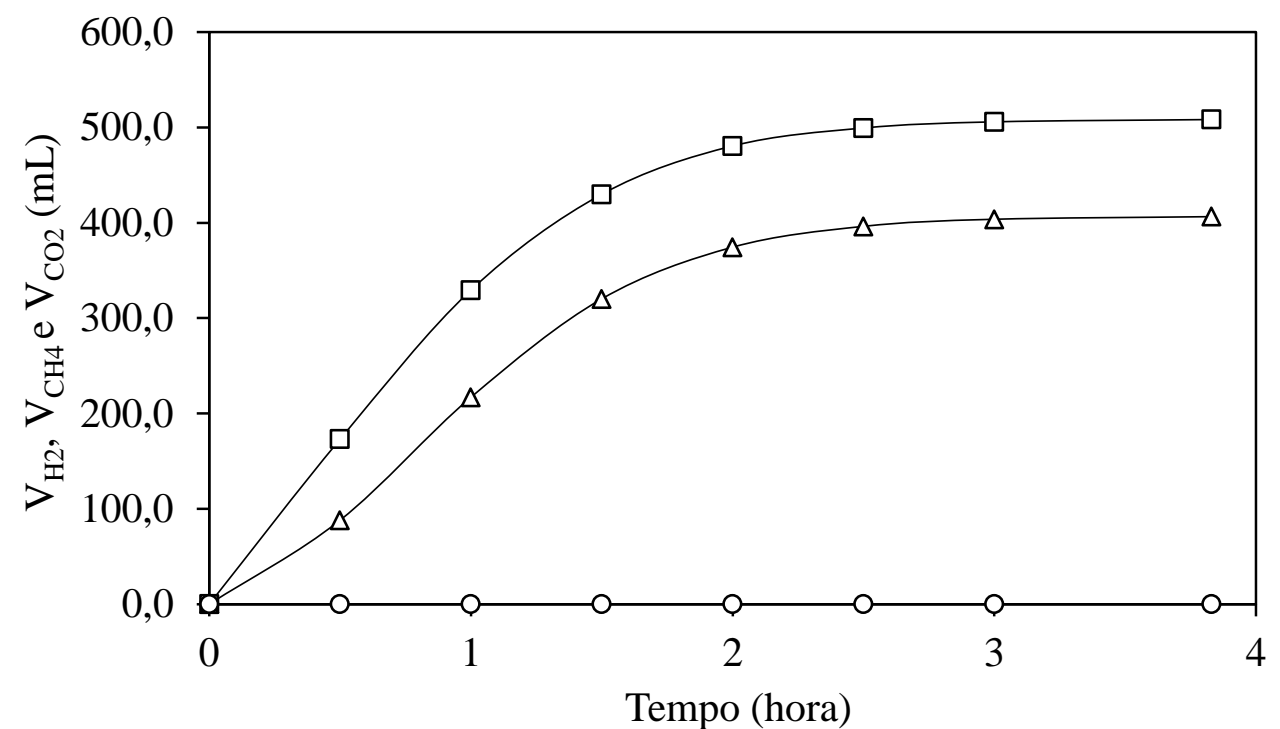

Figura 5-38 - Volumes acumulados médios produzidos ao longo do ciclo de: $\square-\mathrm{CO}_{2} ; \Delta$ $-\mathrm{H}_{2} ; \circ-\mathrm{CH}_{4}$ (AnSBBR com recirculação da fase líquida e soro de leite - Condição 2). 


\subsubsection{Condição 3 - Adaptação com lactose e afluente (não) refrigerado}

Na primeira etapa da Condição 3 optou-se por alimentar o reator com lactose pura, com COAV nominal de 9,3 kgDQO. $\mathrm{m}^{-3} \cdot \mathrm{d}^{-1}$ e duração do ciclo de 4 horas por um período de 34 dias (dia 88 ao dia 121), buscando entender se o problema na produção do biohidrogênio estava no carboidrato do soro de leite ou em algum outro detalhe.

A segunda etapa da Condição 3 foi operada utilizando o soro de leite, com COAV nominal de 10,9 kgDQO. $\mathrm{m}^{-3} \cdot \mathrm{d}^{-1}$ e duração do ciclo de 4 horas por um período de 24 dias (dia 122 ao dia 145). O afluente foi mantido refrigerado em geladeira a $4^{\circ} \mathrm{C}$. Durante os primeiros 10 dias de operação desta etapa o reator foi alimentado com os componentes usuais. Observou-se, porém, uma queda na produção do $\mathrm{H}_{2}$ (que não chegou a atingir valores próximos a zero) e um ligeiro aumento na produção de $\mathrm{CH}_{4}$. Buscando reverter este problema, adicionou-se $\mathrm{HCl}$ no meio de alimentação durante 8 dias, porém sem sucesso. Assim, optou-se por mais um teste durante a esta parte da operação e retirou-se tanto o $\mathrm{HCl}$ quanto o bicarbonato da alimentação. Este teste durou 6 dias e no final da operação a produção de $\mathrm{H}_{2}$ zerou e a de metano aumentou significativamente.

A Tabela 5.10 apresenta as variáveis monitoradas e seus respectivos valores médios comuns a todas as etapas, enquanto que a Tabela 5.11 mostra os parâmetros relacionados à carga orgânica e à produção de hidrogênio. 
Tabela 5.10 - Valores médios dos parâmetros monitorados comuns a todas as etapas da condição experimental 3 (Soro de leite - 4250 mgDQO.L

\begin{tabular}{|c|c|c|c|c|c|c|c|c|c|c|c|c|c|c|c|c|c|c|c|c|c|c|}
\hline & \multirow{2}{*}{ Parâmetro } & \multicolumn{10}{|c|}{ Etapa 1} & \multicolumn{11}{|c|}{ Etapa 2} \\
\hline & & \multicolumn{5}{|c|}{ Afluente } & \multicolumn{5}{|c|}{ Efluente } & \multicolumn{5}{|c|}{ Afluente } & \multicolumn{6}{|c|}{ Efluente } \\
\hline $\mathrm{C}_{\mathrm{ST}}$ & $\left(\mathrm{mgDQO} \cdot \mathrm{L}^{-1}\right)$ & 3485 & \pm & 152 & & $14)$ & 2984 & \pm & 89 & & $14 \quad$ & 3856 & \pm & 116 & & $\overline{14)}$ & 3007 & \pm & 226 & ( & 14 & ) \\
\hline $\mathrm{C}_{\mathrm{SF}}$ & $\left(\mathrm{mgDQO} \cdot \mathrm{L}^{-1}\right)$ & - & \pm & - & ( & $3)$ & 2886 & \pm & 118 & & $14)$ & 0 & \pm & 0 & & $3)$ & 2809 & \pm & 223 & ( & & \\
\hline$\varepsilon_{\mathrm{ST}}$ & $(\%)$ & - & & - & & & 14 & \pm & 3 & & $14)$ & - & & - & & & 22 & \pm & 6 & ( & 14 & ) \\
\hline$\varepsilon_{\mathrm{SF}}$ & $(\%)$ & - & & - & & & 17 & \pm & 3 & & $14)$ & - & & - & & & 27 & \pm & 6 & ( & 14 & \\
\hline $\mathrm{C}_{\mathrm{CT}}$ & (mgCarboidrato.L $\left.\mathrm{L}^{-1}\right)$ & 3170 & \pm & 241 & ( & $14)$ & 235 & \pm & 333 & & $14)$ & 3695 & \pm & 214 & ( & $14)$ & 57 & \pm & 27 & ( & 14 & \\
\hline $\mathrm{C}_{\mathrm{CF}}$ & (mgCarboidrato.L $\mathrm{L}^{-1}$ ) & - & \pm & - & ( & ) & 221 & \pm & 343 & & 14 ) & 0 & \pm & 0 & ( & $3)$ & 41 & \pm & 30 & ( & & \\
\hline$\varepsilon_{\mathrm{CT}}$ & $(\%)$ & - & & - & & & 93 & \pm & 10 & & $14)$ & - & & - & & & 98 & \pm & 1 & ( & 14 & ) \\
\hline$\varepsilon_{\mathrm{CF}}$ & $(\%)$ & $\longrightarrow$ & & - & & & 93 & \pm & 11 & & $14)$ & - & & - & & & 99 & \pm & 1 & ( & 14 & ) \\
\hline $\mathrm{pH}$ & (u) & 8,03 & \pm & 0,10 & ( & $14)$ & 4,66 & \pm & 0,22 & & $14)$ & 7,04 & \pm & 0,88 & ( & $14)$ & 4,50 & \pm & 0,32 & ( & 14 & ) \\
\hline AVT & $\left(\mathrm{mgHAc} . \mathrm{L}^{-1}\right)$ & 16 & \pm & 2 & ( & $14)$ & 751 & \pm & 168 & & $14)$ & 549 & \pm & 727 & ( & $14)$ & 1129 & \pm & 157 & ( & 14 & ) \\
\hline $\mathrm{AT}$ & $\left(\mathrm{mgCaCO}_{3} \cdot \mathrm{L}^{-1}\right)$ & 328 & \pm & 41 & ( & $14)$ & 114 & \pm & 43 & & $14)$ & 277 & \pm & 153 & ( & $14)$ & 121 & \pm & 135 & ( & 14 & ) \\
\hline $\mathrm{AP}$ & $\left(\mathrm{mgCaCO}_{3} \cdot \mathrm{L}^{-1}\right)$ & 257 & \pm & 45 & ( & $14)$ & 0 & \pm & 0 & $(1$ & $14)$ & 177 & \pm & 123 & ( & $14)$ & 0 & \pm & 0 & ( & 14 & ) \\
\hline AI & $\left(\mathrm{mgCaCO}_{3} \cdot \mathrm{L}^{-1}\right)$ & 71 & \pm & 10 & ( & $14)$ & 114 & \pm & 43 & $(1$ & $14)$ & 100 & \pm & 36 & ( & $14)$ & 121 & \pm & 135 & ( & 14 & ) \\
\hline $\mathrm{AB}$ & $\left(\mathrm{mgCaCO}_{3} \cdot \mathrm{L}^{-1}\right)$ & 317 & \pm & 40 & ( & $14)$ & 0 & \pm & 0 & $(1$ & $14)$ & 171 & \pm & 161 & ( & $14)$ & 0 & \pm & 0 & ( & 14 & ) \\
\hline $\mathrm{ST}$ & $\left(\mathrm{mg} . \mathrm{L}^{-1}\right)$ & 2822 & \pm & 223 & ( & $7)$ & 1635 & \pm & 274 & $(7$ & 7 ) & 3511 & \pm & 217 & ( & $6)$ & 2306 & \pm & 137 & ( & 6 & ) \\
\hline STV & $\left(\mathrm{mg} \cdot \mathrm{L}^{-1}\right)$ & 245 & \pm & 283 & ( & $7)$ & 1062 & \pm & 667 & $(7$ & 7 ) & 2807 & \pm & 146 & ( & $6)$ & 1620 & \pm & 148 & ( & 6 & ) \\
\hline $\mathrm{SST}$ & $\left(\mathrm{mg} \cdot \mathrm{L}^{-1}\right)$ & 53 & \pm & 55 & ( & $7)$ & 63 & \pm & 26 & $(7$ & 7 ) & 147 & \pm & 76 & ( & $6)$ & 163 & \pm & 58 & ( & 6 & ) \\
\hline SSV & $\left(\mathrm{mg} \cdot \mathrm{L}^{-1}\right)$ & 21 & \pm & 10 & & $7)$ & 57 & \pm & 19 & $(7$ & 7 ) & 142 & \pm & 35 & ( & $6)$ & 138 & \pm & 48 & & 6 & ) \\
\hline $\mathrm{M}_{\mathrm{STV}}$ & (g) & - & & - & & & 17,94 & & - & & & - & & - & & & 42 & & - & & & \\
\hline $\mathrm{C}_{\mathrm{X}}$ & $\left(\mathrm{g} . \mathrm{L}^{-1}\right)$ & $\longrightarrow$ & & - & & & 5,04 & & - & & & - & & - & & & 12,74 & & - & & & \\
\hline $\mathrm{C}_{\mathrm{X}}^{\prime}$ & (g.gsuporte ${ }^{-1}$ ) & - & & - & & & 0,0114 & & - & & & - & & - & & & 0,03 & & - & & & \\
\hline $\mathrm{V}_{\mathrm{G}}$ & (mL-CNTP) & - & & - & & & 673 & \pm & 14 & & 4 ) & - & & - & & & 517 & \pm & 15 & & $4)$ & ) \\
\hline $\mathrm{V}_{\mathrm{H} 2}$ & (mL-CNTP) & - & & - & & & 139 & \pm & 5 & & 2 ) & $\longrightarrow$ & & - & & & - & \pm & - & & & \\
\hline
\end{tabular}

(*) Entre parêntese o número de amostras considerado no cálculo da média. 
Tabela 5.11 - Valores médios dos parâmetros relacionados à carga orgânica e à produção de hidrogênio da condição 3 (Soro de leite - $4250 \mathrm{mgDQO} \cdot \mathrm{L}^{-1}-\mathrm{t}_{\mathrm{C}} 4 \mathrm{~h}$ ).

\begin{tabular}{|c|c|c|c|c|c|c|}
\hline \multirow{2}{*}{ Parâmetro } & & \multicolumn{3}{|c|}{ Etapa 1} & \multicolumn{2}{|c|}{ Etapa 2} \\
\hline & & Afluent & & Efluente & Afluente & Efluente \\
\hline COAV $_{\text {STA }}$ & $\left(\mathrm{kgDQO} \cdot \mathrm{m}^{-3} \cdot \mathrm{d}^{-1}\right)$ & 8,9 & & - & 9,9 & - \\
\hline $\mathrm{CORV}_{\mathrm{SFE}}$ & $\left(\mathrm{kgDQO} \cdot \mathrm{m}^{-3} \cdot \mathrm{d}^{-1}\right)$ & - & & 1,5 & - & 2,7 \\
\hline $\mathrm{COAV}_{\text {СТА }}$ & $\left(\mathrm{kgCarboidrato} \cdot \mathrm{m}^{-3} \cdot \mathrm{d}^{-1}\right)$ & 8,2 & & - & 9,5 & - \\
\hline $\mathrm{CORV}_{\mathrm{CFE}}$ & $\left(\right.$ kgCarboidrato. $\left.\mathrm{m}^{-3} \cdot \mathrm{d}^{-1}\right)$ & - & & 7,6 & - & 9,4 \\
\hline $\mathrm{COAE}_{\mathrm{STA}}$ & $\left(\mathrm{kgDQO} \cdot \mathrm{kgSTV}^{-1} \cdot \mathrm{d}^{-1}\right)$ & 1,8 & & - & 0,8 & - \\
\hline $\mathrm{CORE}_{\mathrm{SFE}}$ & $\left(\mathrm{kgDQO} \cdot \mathrm{kgSTV}^{-1} \cdot \mathrm{d}^{-1}\right)$ & - & & 0,3 & - & 0,2 \\
\hline $\mathrm{COAE}_{\mathrm{CTA}}$ & $\left(\mathrm{kgCarboidrato.kgSTV}^{-1} \cdot \mathrm{d}^{-1}\right)$ & 1,6 & & - & 0,8 & - \\
\hline $\mathrm{CORE}_{\mathrm{CFE}}$ & $\left(\mathrm{kgCarboidrato.kgSTV}^{-1} \cdot \mathrm{d}^{-1}\right)$ & - & & 1,5 & - & 0,8 \\
\hline $\mathrm{RMCR}_{\mathrm{C}, \mathrm{n}}$ & $\left(\mathrm{molH}_{2 .}\right.$ molCarboidrato $\left.^{-1}\right)$ & - & & 0,5 & - & - \\
\hline $\mathrm{n}_{\mathrm{H} 2}$ & $\left(\mathrm{molH}_{2} \cdot \mathrm{d}^{-1}\right)$ & - & & 0,04 & - & - \\
\hline PrM & $\left(\mathrm{molH}_{2} \cdot \mathrm{m}^{-3} \cdot \mathrm{d}^{-1}\right)$ & - & & 10,5 & - & - \\
\hline PrME & $\left(\mathrm{molH}_{2} \cdot \mathrm{kgSVT}^{-1} \cdot \mathrm{d}^{-1}\right)$ & - & & 2,1 & - & - \\
\hline $\mathrm{RMCA}_{\mathrm{S}, \mathrm{m}}$ & $\left(\mathrm{molH}_{2} \cdot \mathrm{kgDQO}^{-1} \cdot \mathrm{d}^{-1}\right)$ & 1,2 & & - & - & - \\
\hline $\mathrm{RMCA}_{\mathrm{C}, \mathrm{m}}$ & $\left(\mathrm{molH}_{2} \cdot \mathrm{kg}^{-1} \cdot \mathrm{d}^{-1}\right)$ & 1,3 & & - & - & - \\
\hline $\mathrm{RMCR}_{\mathrm{S}, \mathrm{m}}$ & $\left(\mathrm{molH}_{2} \cdot \mathrm{kgDQO}^{-1} \cdot \mathrm{d}^{-1}\right)$ & - & & 6,9 & - & - \\
\hline $\mathrm{RMCR}_{\mathrm{C}, \mathrm{m}}$ & $\left(\mathrm{molH}_{2} \cdot \mathrm{kg}^{-1} \cdot \mathrm{d}^{-1}\right)$ & - & & 1,4 & - & - \\
\hline $\mathrm{V}_{\mathrm{R}}$ & $(\mathrm{mL})$ & 2000 & & & & \\
\hline $\mathrm{V}_{\mathrm{A}}$ & $(\mathrm{mL})$ & 1430 & $\pm 45\left(^{12}\right)$ & & & \\
\hline $\mathrm{Q}_{\mathrm{R}}$ & $\left(\mathrm{mL} \cdot \mathrm{s}^{-1}\right)$ & 6 & $\pm 0\left(\left(^{3}\right)\right.$ & & & \\
\hline
\end{tabular}

(*) Entre parêntese o número de amostras considerado no cálculo da média.

A Figura 5-39 apresenta os valores da concentração afluente (não filtrada) e efluente (não filtrada e filtrada) de matéria orgânica (DQO) nos sistema, enquanto que a Figura 5-40 apresenta a eficiência de remoção do mesmo parâmetro durante o monitoramento diário. Esta eficiência atingiu, em média, 14 e 22\% para as amostras não filtradas e 17 e $27 \%$ para amostras filtradas (para as etapas 1 e 2 respectivamente). Para a primeira etapa, a média de concentração afluente (amostras não filtradas) do substrato foi de $3485 \mathrm{mgDQO} . \mathrm{L}^{-1}$ e de $2984 \mathrm{mgDQO} . \mathrm{L}^{-1}$ e $2886 \mathrm{mgDQO} . \mathrm{L}^{-1}$ para amostras de efluente não filtrada e filtrada, respectivamente. Para a segunda etapa, a média de concentração afluente (amostras não filtradas) do substrato foi de $3856 \mathrm{mgDQO} . \mathrm{L}^{-1}$ e de $3007 \mathrm{mgDQO} . \mathrm{L}^{-1}$ e $2809 \mathrm{mgDQO} . \mathrm{L}^{-1}$ para amostras de efluente não filtrada e filtrada, respectivamente. 


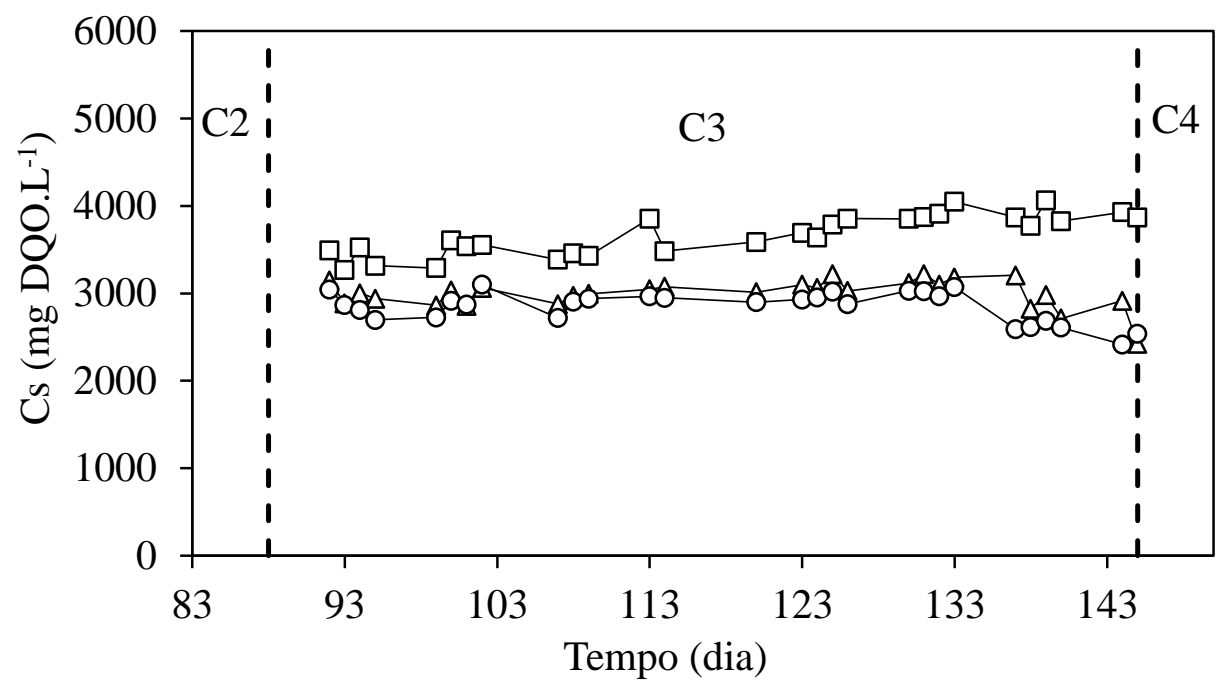

Figura 5-39 - Concentração de matéria orgânica (DQO): $\square$ - afluente não filtrada; $\Delta$ efluente não filtrada; o - efluente filtrada (AnSBBR com recirculação da fase líquida e soro de leite - Condição 3).

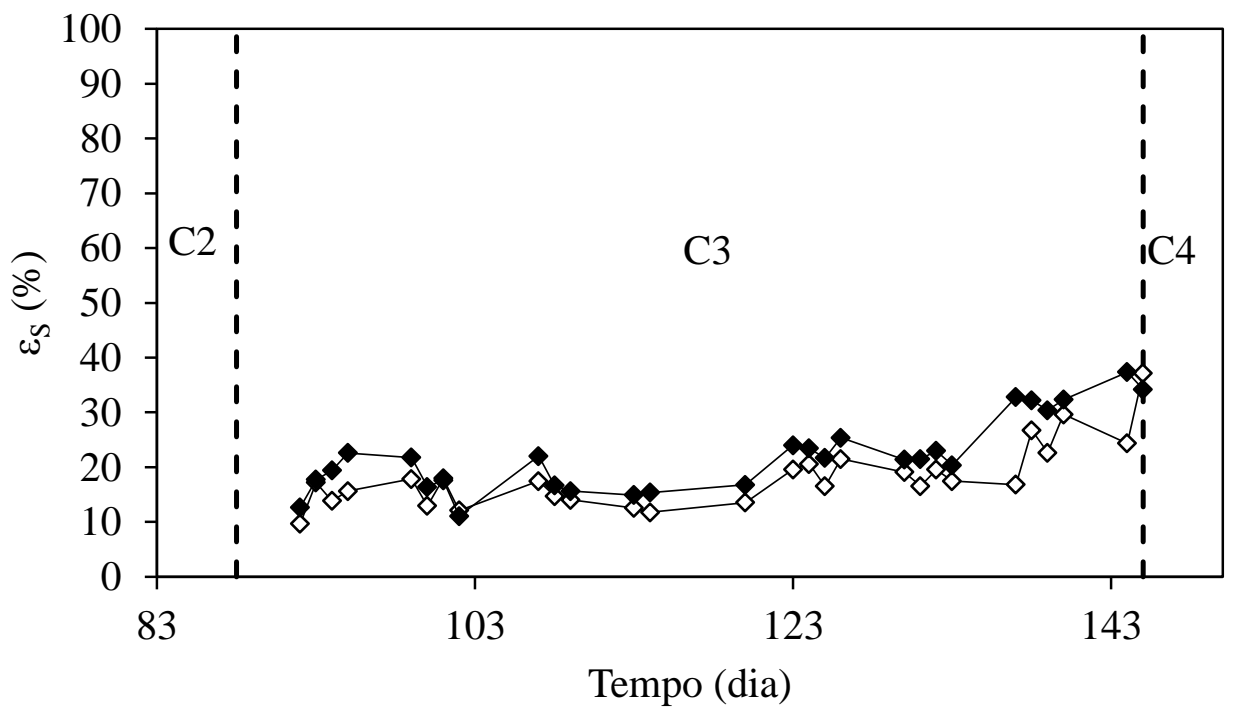

Figura 5-40 - Eficiência de remoção de matéria orgânica (DQO): $\diamond$ - não filtrada; filtrada (AnSBBR com recirculação da fase líquida e soro de leite - Condição 3).

A Figura 5-41 apresenta os valores da concentração de carboidratos afluente e efluente (para amostras filtradas e não filtradas). A Figura 5-42 apresenta a eficiência de remoção do mesmo parâmetro (não filtrada e filtrada) durante o monitoramento diário. Esta eficiência atingiu, em média, 93 e $98 \%$ para as amostras não filtradas e 93 e 99\% 
para amostras filtradas (para as etapas 1 e 2 respectivamente). Para a primeira etapa, a média de concentração afluente (amostras não filtradas) do substrato foi de 3170 mgCarboidrato. $\mathrm{L}^{-1}$ e de $235 \mathrm{mgCarboidrato.} \mathrm{L}^{-1}$ e $221 \mathrm{mgCarboidrato.} \mathrm{L}^{-1}$ para amostras de efluente não filtrada e filtrada, respectivamente. Para a segunda etapa, a média de concentração afluente (amostras não filtradas) do substrato foi de 3695 mgCarboidrato. $\mathrm{L}^{-1}$ e de $57 \mathrm{mgCarboidrato.} \mathrm{L}^{-1}$ e $41 \mathrm{mgCarboidrato.} \mathrm{L}^{-1}$ para amostras de efluente não filtrada e filtrada, respectivamente.

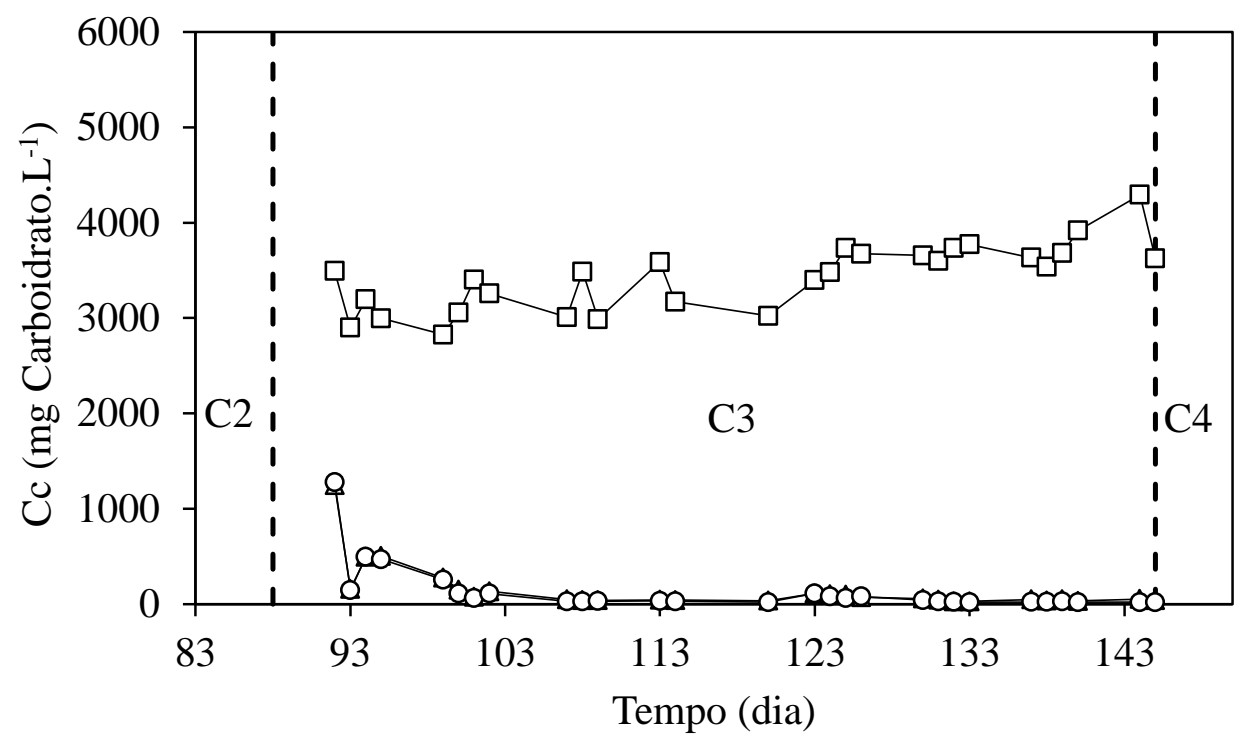

Figura 5-41 - Concentração de carboidrato: $\square-$ afluente não filtrada; $\Delta$ - efluente não filtrada; ○ - efluente filtrada (AnSBBR com recirculação da fase líquida e soro de leite Condição 3). 


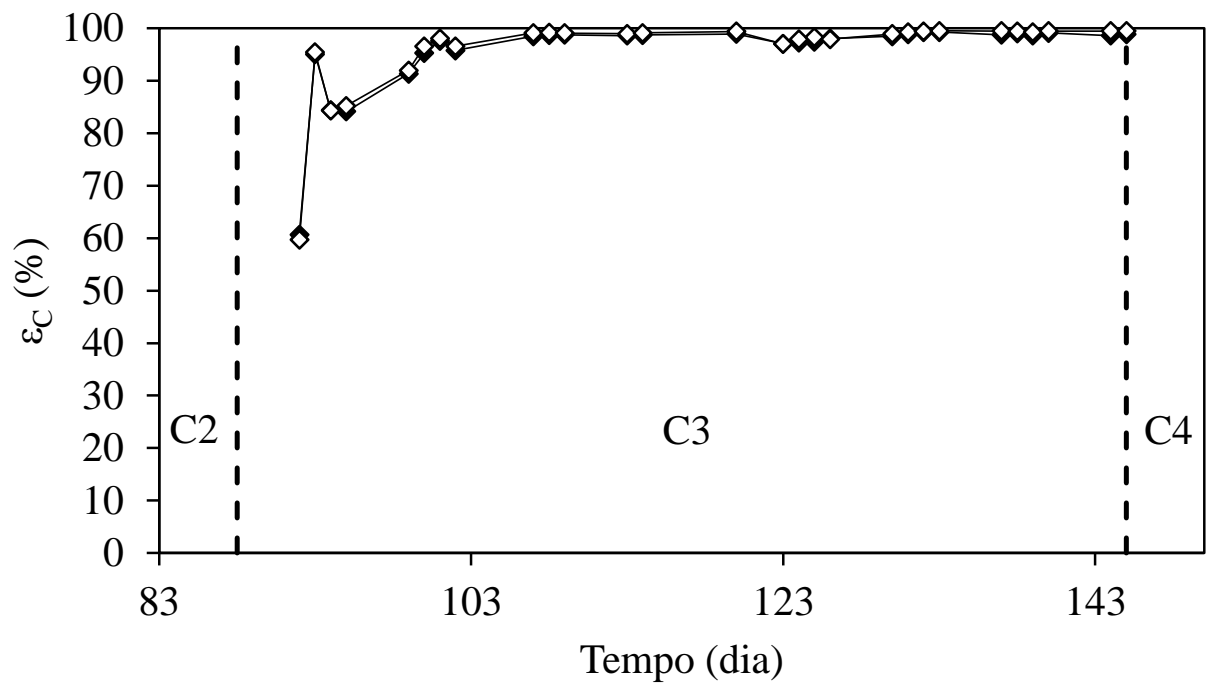

Figura 5-42 - Eficiência de remoção de carboidrato: $\diamond$ - não filtrada; $\downarrow$ - filtrada (AnSBBR com recirculação da fase líquida e soro de leite - Condição 3).

As Figura 5-43, Figura 5-44 e Figura 5-45 apresentam o monitoramento diário, tanto para o afluente quanto para o efluente, do $\mathrm{pH}$, da alcalinidade total e dos ácidos voláteis totais, respectivamente. A média dos valores de $\mathrm{pH}$ afluente foi de 8,03 e 7,04 e de $\mathrm{pH}$ efluente foi de 4,66 e 4,50 (para as etapas 1 e 2 respectivamente). A média da alcalinidade total afluente foi de 328 e $277 \mathrm{mgCaCO}_{3} \cdot \mathrm{L}^{-1}$ e efluente de 114 e 121 $\mathrm{mgCaCO}_{3} \cdot \mathrm{L}^{-1}$ (para as etapas 1 e 2 respectivamente). O valor médio da concentração de ácidos voláteis totais afluente foi de 16 e 549 mgHAc. $\mathrm{L}^{-1}$ e efluente de 751 e 1129 mgHAc. $L^{-1}$ (para as etapas 1 e 2 respectivamente). Como pode ser observado na Figura 5-43 durante a etapa 2 da condição foi adicionado ácido clorídrico concentrado $12 \mathrm{M}$ (na proporção de 7,5 mL para cada 11 litros de afluente), porém sem implicações nos demais parâmetros de monitoramento, além do consumo da alcalinidade total afluente e ácidos voláteis totais afluente. 


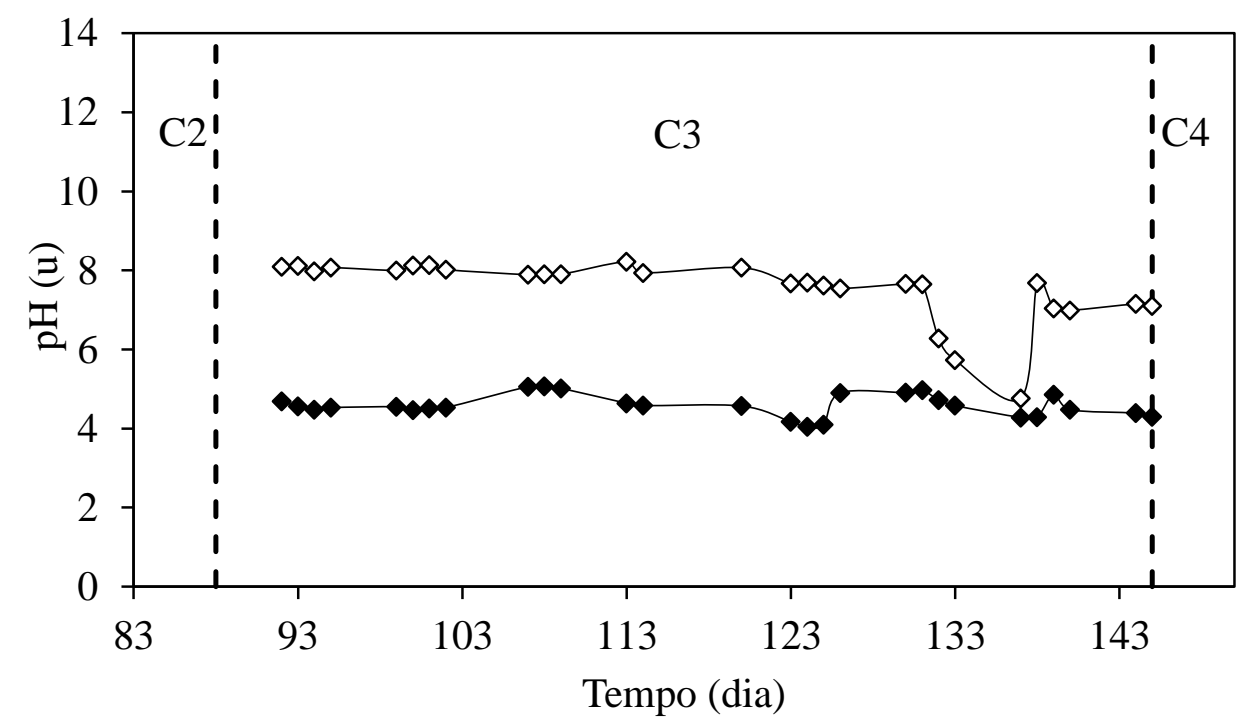

Figura 5-43 - Valores de pH: $\diamond$-afluente; $\downarrow$ - efluente (AnSBBR com recirculação da fase líquida e soro de leite - Condição 3).

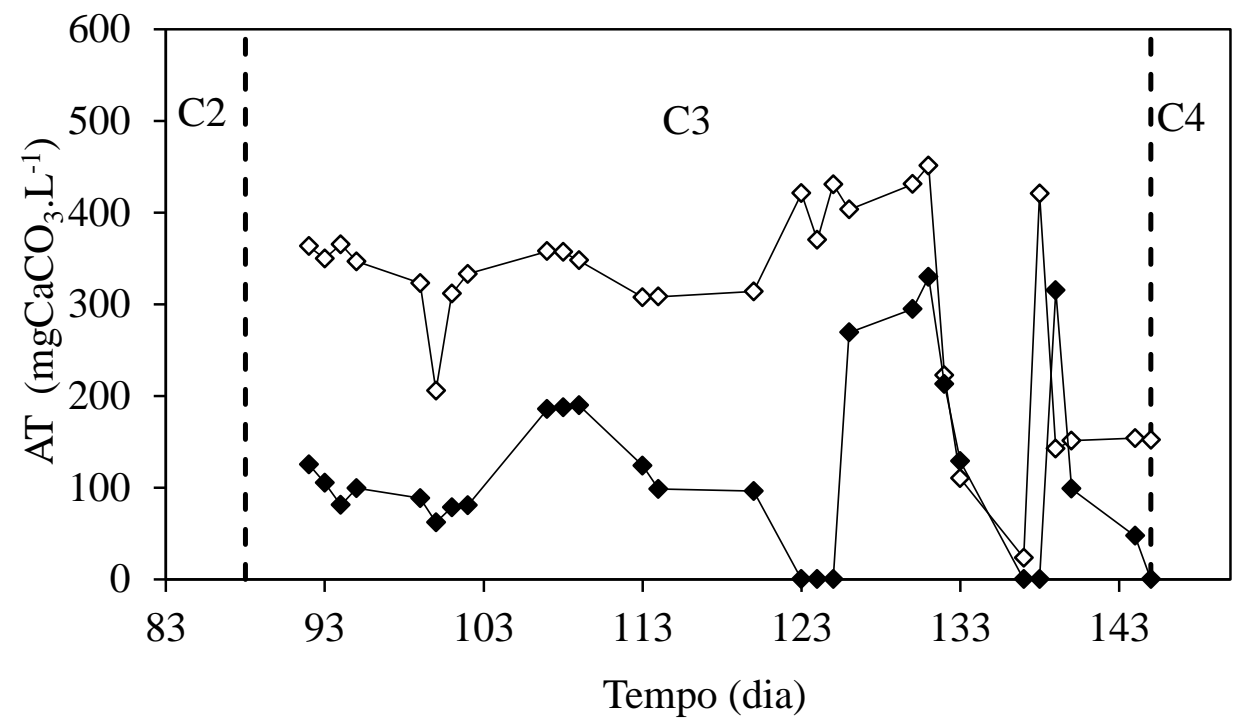

Figura 5-44 - Alcalinidade total: $\diamond$-afluente; $\diamond$ - efluente (AnSBBR com recirculação da fase líquida e soro de leite - Condição 3). 


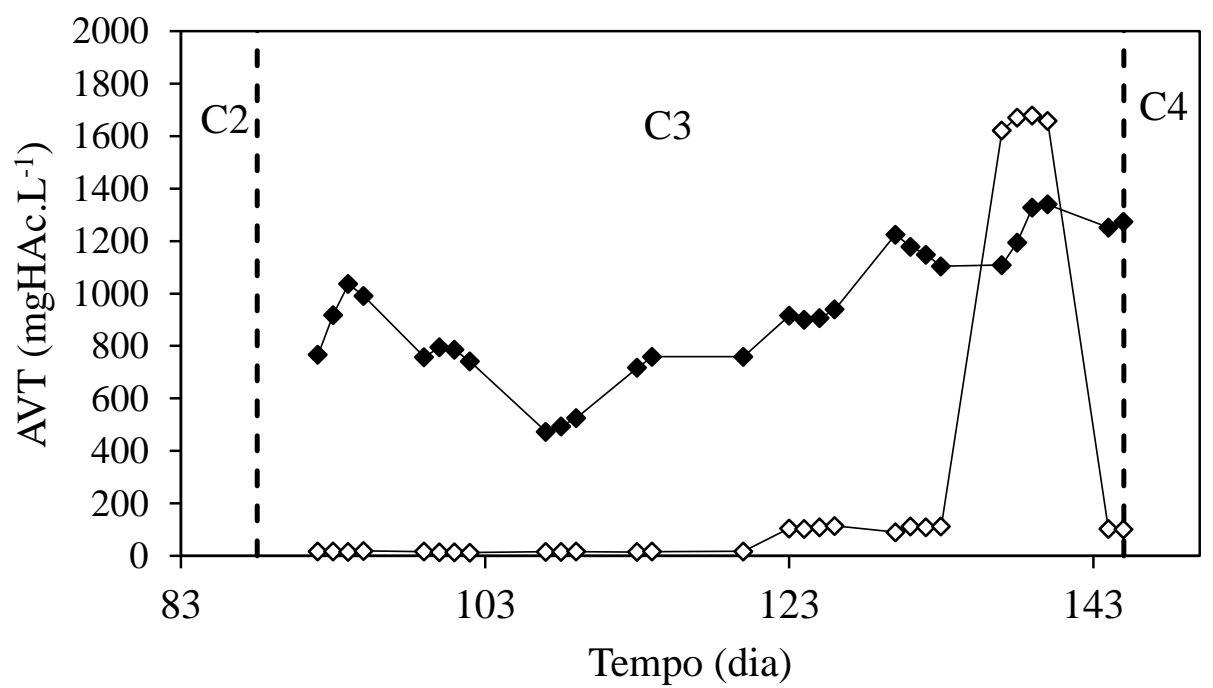

Figura 5-45 - Ácidos voláteis totais: $\diamond$-afluente; - efluente (AnSBBR com recirculação da fase líquida e soro de leite - Condição 3).

A Figura 5-46 apresenta o monitoramento dos compostos intermediários contidos no efluente do sistema, enquanto que a Tabela 5.12 apresenta os valores da concentração média destes produto. $\mathrm{O}$ método cromatográfico utilizado novamente não detectou a presença de acetona e metanol. Na etapa 1 predominou a presença do etanol e do ácido acético (47,5\% e 35,4\% dos compostos intermediários, respectivamente). $\mathrm{Na}$ etapa 2 a ordem de predominancia dos dois compostos se inverteu $(57,6 \%$ de ácido acético e $17,9 \%$ etanol). 


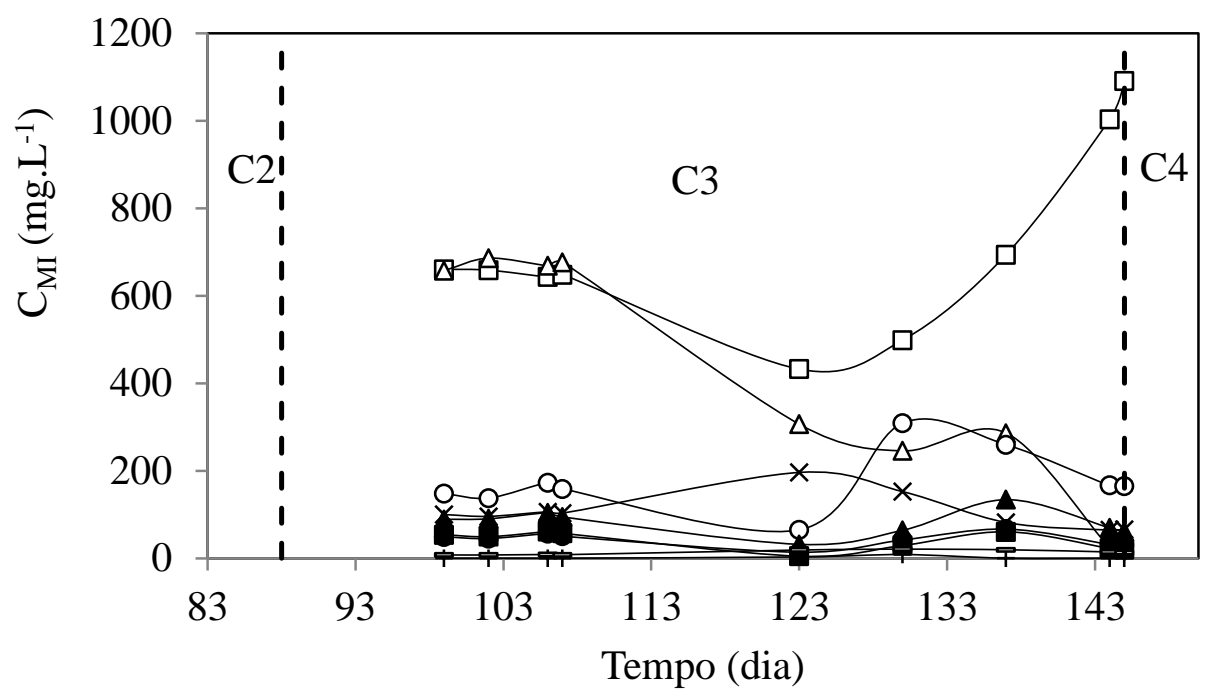

Figura 5-46 - Concentração dos compostos intermediários durante o monitoramento: - ácido acético; $\Delta$ - etanol; O - ácido butírico; $\square$-ácido isobutírico; $\boldsymbol{\Delta}$ - ácido capróico; • - ácido valérico; - * ácido propiônico; † butanol; — ácido isovalérico (AnSBBR com recirculação da fase líquida e soro de leite - Condição 3).

Tabela 5.12 - Concentração média e distribuição dos compostos intermediários (AnSBBR com recirculação da fase líquida e soro de leite - Condição 3).

\begin{tabular}{|c|c|c|c|c|c|c|c|c|c|c|c|c|c|}
\hline \multirow{4}{*}{$\begin{array}{c}\begin{array}{c}\text { Produtos } \\
\text { intermediários }\end{array} \\
\text { Acetona }\end{array}$} & \multicolumn{7}{|c|}{ Etapa 1} & \multicolumn{6}{|c|}{ Etapa 2} \\
\hline & \multicolumn{6}{|c|}{ Concentrações média } & \multirow{3}{*}{$\begin{array}{c}\text { Distribuição } \\
(\%) \\
0,00\end{array}$} & \multicolumn{5}{|c|}{ Concentrações média } & \multirow{3}{*}{$\begin{array}{c}\begin{array}{c}\text { Distribuição } \\
(\%)\end{array} \\
0,00\end{array}$} \\
\hline & \multicolumn{3}{|c|}{$\left(\mathrm{mg} \cdot \mathrm{L}^{-1}\right)$} & \multicolumn{3}{|c|}{$\left(\mathrm{mmol} . \mathrm{L}^{-1}\right)$} & & \multicolumn{3}{|c|}{$\left(\mathrm{mg} \cdot \mathrm{L}^{-1}\right)$} & \multicolumn{2}{|c|}{$\left(\mathrm{mmol} . \mathrm{L}^{-1}\right)$} & \\
\hline & 0,00 & \pm & 0,00 & 0,00 & \pm & 0,00 & & 0,00 & \pm & 0,00 & 0,00 & $\pm 0,00$ & \\
\hline Metanol & 0,00 & \pm & 0,00 & 0,00 & \pm & 0,00 & 0,00 & 0,00 & \pm & 0,00 & 0,00 & $\pm 0,00$ & 0,00 \\
\hline Etanol & 672,3 & \pm & 12,0 & 14,6 & \pm & 0,3 & 47,5 & 178,0 & \pm & 140,5 & 3,9 & $\pm 3,1$ & 17,9 \\
\hline n-Butanol & 0,0 & \pm & 0,0 & 0,0 & \pm & 0,0 & 0,0 & 2,3 & \pm & 3,7 & 0,0 & $\pm 0,0$ & 0,1 \\
\hline Acético & 652,7 & \pm & 8,3 & 10,9 & \pm & 0,1 & 35,4 & 744,0 & \pm & 294,9 & 12,4 & $\pm 4,9$ & 57,6 \\
\hline Porpiônico & 101,2 & \pm & 4,5 & 1,4 & \pm & 0,1 & 4,4 & 112,1 & \pm & 59,2 & 1,5 & $\pm 0,8$ & 7,0 \\
\hline Isobutírico & 55,1 & \pm & 4,9 & 0,6 & \pm & 0,1 & 2,0 & 27,3 & \pm & 20,6 & 0,3 & $\pm 0,2$ & 1,4 \\
\hline Butírico & 154,1 & \pm & 15,1 & 1,7 & \pm & 0,2 & 5,7 & 192,9 & \pm & 94,5 & 2,2 & $\pm 1,1$ & 10,2 \\
\hline Isovalérico & 7,9 & \pm & 0,5 & 0,1 & \pm & 0,0 & 0,3 & 17,3 & \pm & 3,2 & 0,2 & $\pm 0,0$ & 0,8 \\
\hline Valérico & 50,1 & \pm & 4,6 & 0,5 & \pm & 0,0 & 1,6 & 36,6 & \pm & 19,6 & 0,4 & $\pm 0,2$ & 1,7 \\
\hline Capróico & 94,3 & \pm & 6,8 & 0,9 & \pm & 0,1 & 3,0 & 72,0 & \pm & 37,6 & 0,7 & $\pm 0,4$ & 3,3 \\
\hline
\end{tabular}

O monitoramento da série de sólidos é mostrado na Tabela 5.13, cujos valores apresentam um baixo teor de SSV no efluente e afluente, indicando a boa capacidade do reator em reter biomassa, mesmo no começo da operação. 
Tabela 5.13 - Série de sólidos afluente e efluente (AnSBBR com recirculação da fase líquida e soro de leite - Condição 3)

\begin{tabular}{llcccc}
\hline & \multicolumn{1}{c}{$\begin{array}{c}\text { ST } \\
\left(\mathrm{mg} . \mathrm{L}^{-1}\right)\end{array}$} & $\begin{array}{c}\text { SVT } \\
\left(\mathrm{mg} . \mathrm{L}^{-1}\right)\end{array}$ & $\begin{array}{c}\text { SST } \\
\left(\mathrm{mg} . \mathrm{L}^{-1}\right)\end{array}$ & $\begin{array}{c}\text { SSV } \\
\left(\mathrm{mg} . \mathrm{L}^{-1}\right)\end{array}$ \\
\hline \multirow{2}{*}{ Etapa 1 } & Afluente & $2823 \pm 224$ & $2451 \pm 283$ & $53 \pm 55$ & $21 \pm 10$ \\
& Efluente & $1635 \pm 274$ & $1348 \pm 333$ & $63 \pm 26$ & $57 \pm 19$ \\
\multirow{2}{*}{ Etapa 2 } & Afluente & $3511 \pm 217$ & $2808 \pm 146$ & $148 \pm 76$ & $143 \pm 35$ \\
& Efluente & $2306 \pm 138$ & $1620 \pm 148$ & $163 \pm 58$ & $138 \pm 48$ \\
\hline
\end{tabular}

*Número de amostras consideradas $=7$ e 6 (etapa 1 e 2 respectivamente).

A produção quantitativa do biogás por ciclo é apresentada na Figura 5-47. A produção média foi de $510 \mathrm{~mL}(\mathrm{CNTP})$. A Figura 5-48 apresenta o monitoramento das concentrações dos componentes do biogás no final do ciclo, enquanto que a Figura 5-49 apresenta a distribuição destes mesmos componentes. Os valores médios de concentração de $\mathrm{H}_{2}$ foram, para as etapas 1 e 2 respectivamente, 6,0 e 1,7 mmol.L ${ }^{-1}$, Para o $\mathrm{CH}_{4}$ os valores médios de concentração foram, para as etapas 1 e 2 respectivamente, 0,0 e 1,6 mmol. $\mathrm{L}^{-1}$. Por ultimo, Os valores médios de concentração de $\mathrm{CO}_{2}$ foram 8,2 e 7,3 mmol. $\mathrm{L}^{-1}$ para as etapas 1 e 2 respectivamente. Além disso, a distribuição percentual média de $\mathrm{H}_{2}$ foi de 41,7 e 17,1\% (para as etapas 1 e 2 respectivamente), a de $\mathrm{CH}_{4}$ foi de 10,6 e $11,0 \%$ (para as etapas 1 e 2 respectivamente) e a de $\mathrm{CO}_{2}$ foi de 58,3 e 71,9\% (para as etapas 1 e 2 respectivamente). Os resultados obtidos na primeira e na segunda etapa da condição 3 mostraram que a queda na produção de hidrogênio e o aumento na produção de metano não estava relacionado com o tipo de carboidrato utilizado (lactose), mas provavelmente com algum componente do soro de leite. 


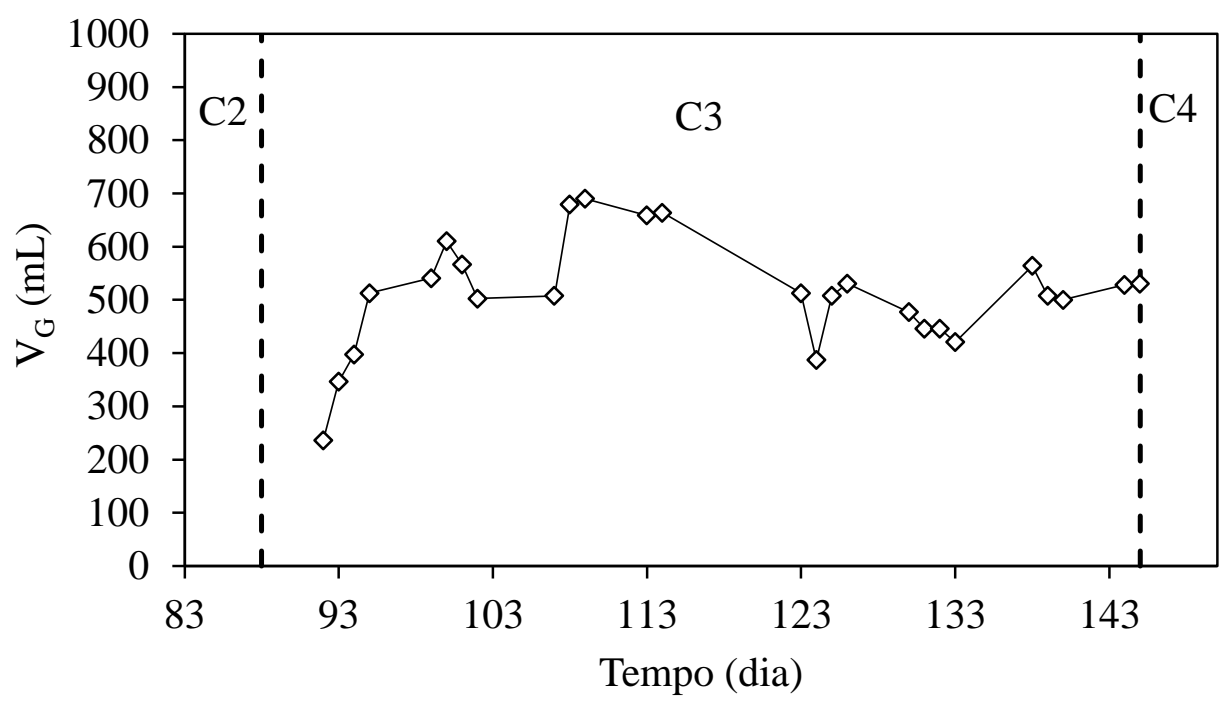

Figura 5-47 - Volume de biogás produzido por ciclo (AnSBBR com recirculação da fase líquida e soro de leite - Condição 3).

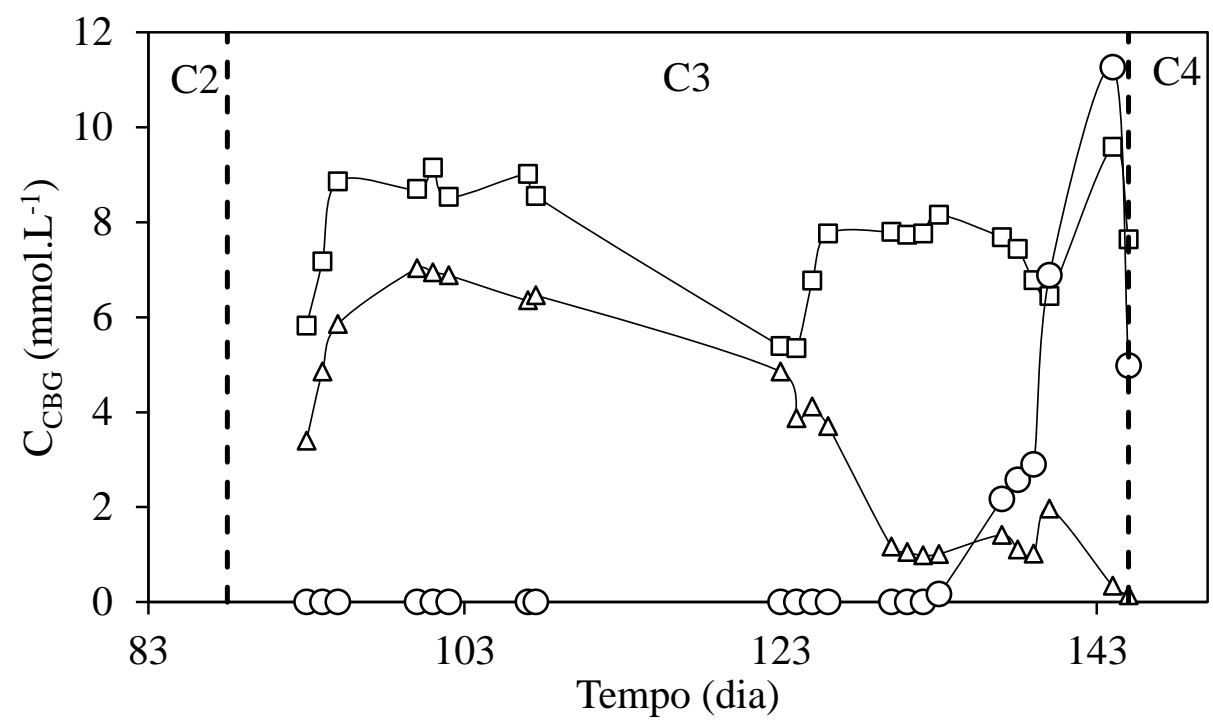

Figura 5-48 - Concentrações dos componentes do biogás no final do ciclo: $\square-\mathrm{CO}_{2} ; \Delta$ $\mathrm{H}_{2} ; \mathrm{O}-\mathrm{CH}_{4}$ (AnSBBR com recirculação da fase líquida e soro de leite - Condição 3). 


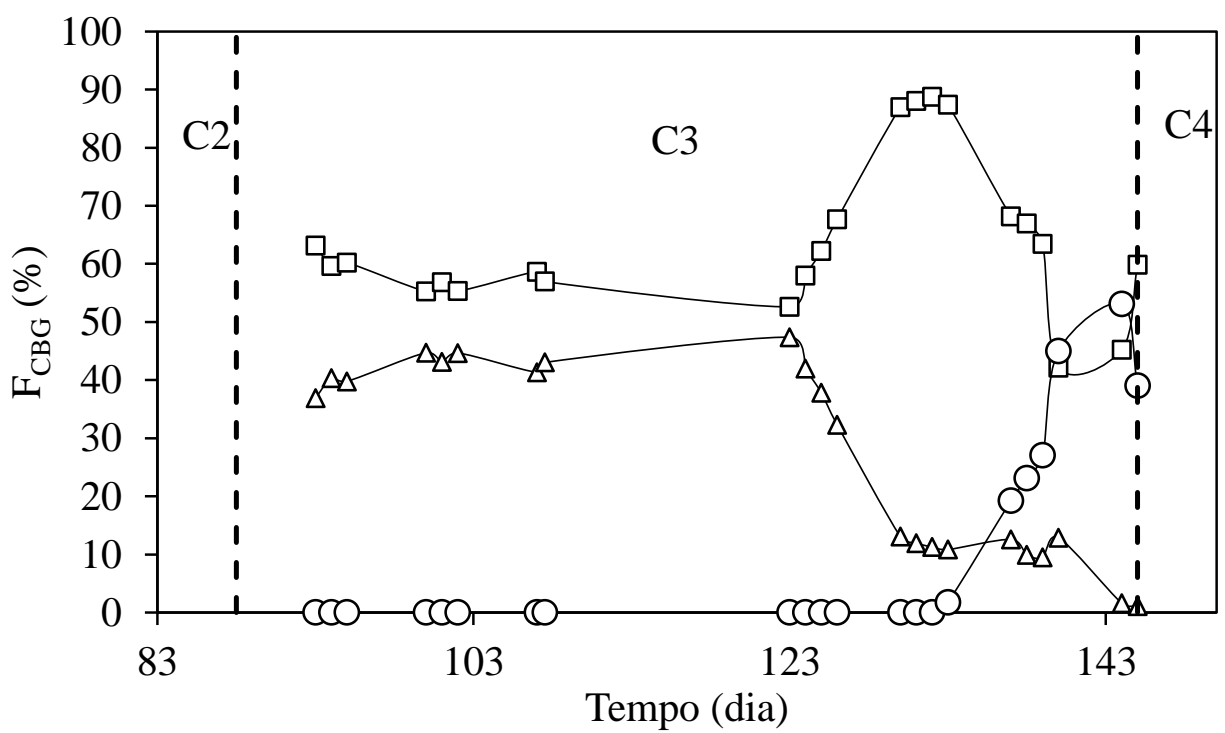

Figura 5-49 - Distribuições dos componentes do biogás no final do ciclo: $\square-\mathrm{CO}_{2} ; \Delta$ $\mathrm{H}_{2} ;$ ○ $-\mathrm{CH}_{4}$ (AnSBBR com recirculação da fase líquida e soro de leite - Condição 3 ).

O perfil temporal foi realizado apenas no final da primeira etapa da Condição 3. A Figura 5-50 apresenta a evolução da concentração de matéria orgânica ao longo do ciclo. Observa-se uma baixa remoção da DQO, levando a uma alta concentração da mesma no volume residual. Desta forma no inicio do ciclo a diluição do volume carregado pelo volume residual é realizada em proporção baixa, tendo em vista que as concentrações afluente e residual são próximas. No inicio do ciclo, a concentração média é da ordem de $3100 \mathrm{mg} . \mathrm{L}^{-1}$ atingindo valores próximos a $3000 \mathrm{mg} . \mathrm{L}^{-1}$ no último ponto do ciclo. 


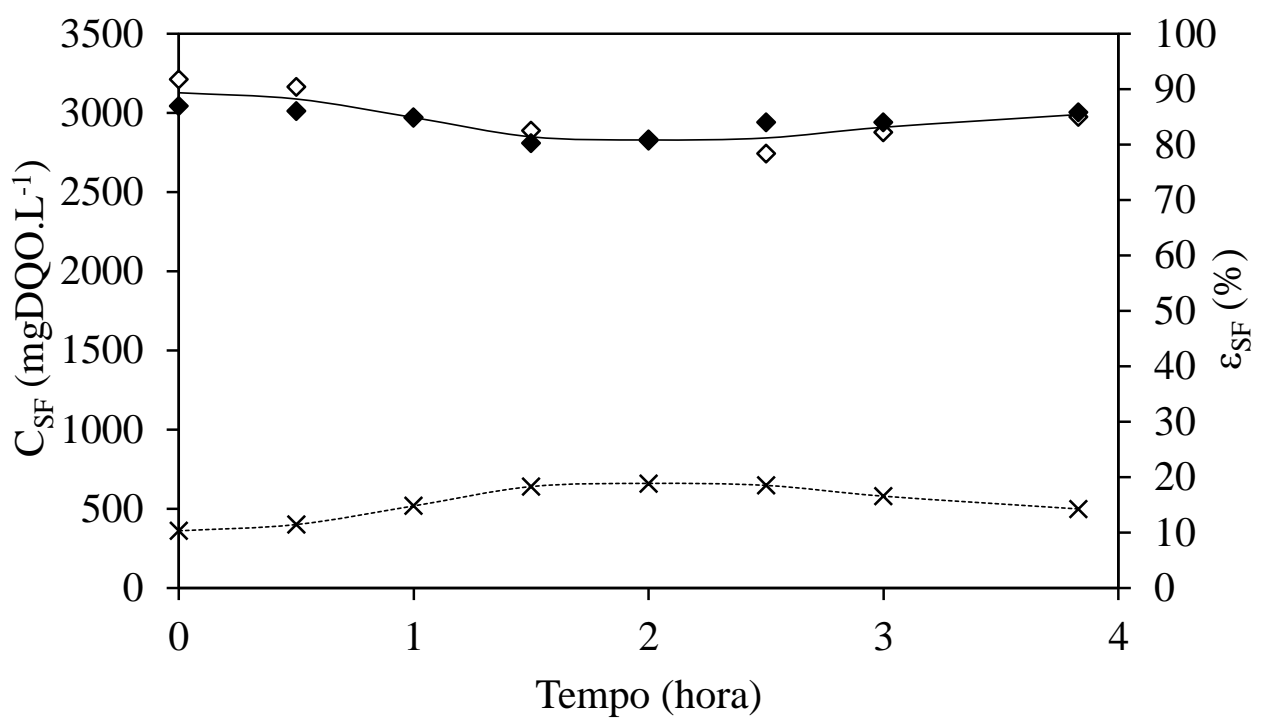

Figura 5-50 - Eixo da direita: Concentração de matéria orgânica (DQO) $\diamond$ - do perfil 1, - - do perfil 2 e - média dos dois perfis; Eixo da esquerda: - - eficiência de degradação da matéria orgânica (DQO) (AnSBBR com recirculação da fase líquida e soro de leite - Condição 3).

A Figura 5-51 apresenta a evolução da concentração de carboidrato ao longo do ciclo e a eficiência de remoção do mesmo. No inicio do ciclo o volume afluente é diluído no volume residual resultando em uma concentração em sacarose da ordem de $850 \mathrm{mg} . \mathrm{L}^{-1}$. A conversão desta sacarose se faz de maneira progressiva ao longo do ciclo, atingindo valores na ordem de $99 \%$ no final do mesmo, com um residual aproximado de $30 \mathrm{mg} \cdot \mathrm{L}^{-1}$. 


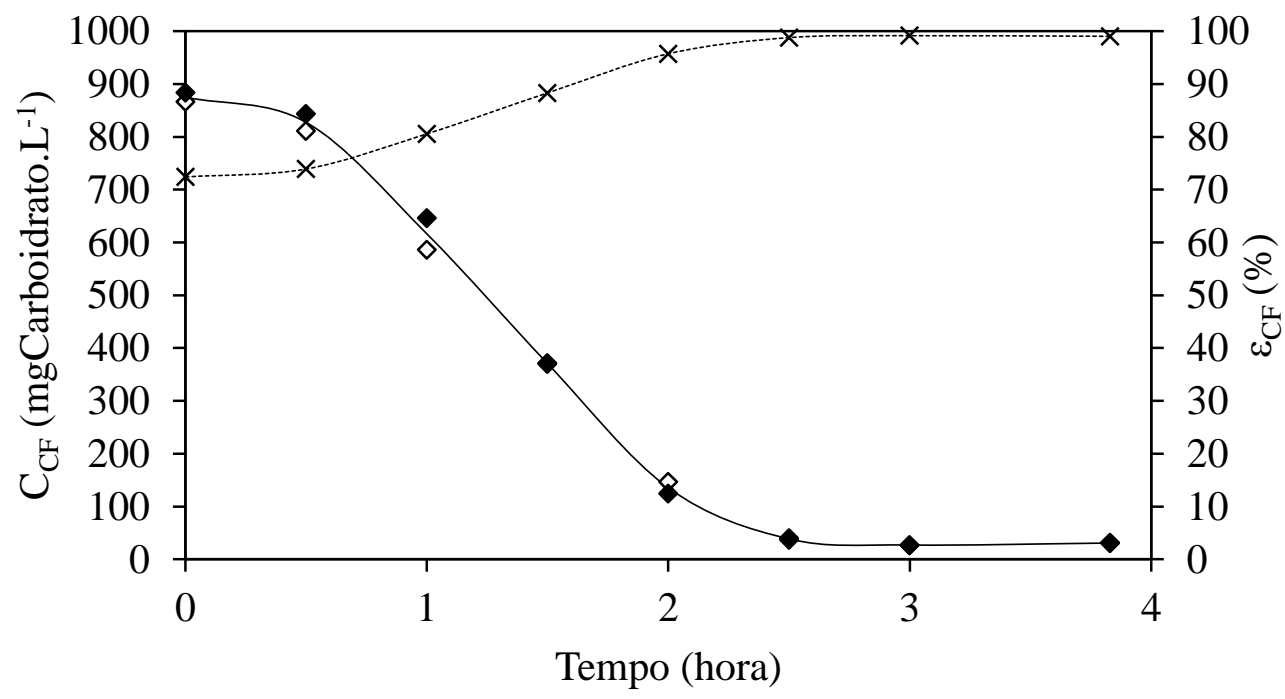

Figura 5-51 - Eixo da direita: Concentração de carboidrato $\diamond$ - do perfil 1 , - do perfil 2 e - média dos dois perfis; Eixo da esquerda: - - eficiência de degradação do carboidrato (AnSBBR com recirculação da fase líquida e soro de leite - Condição 3).

O acúmulo de ácidos voláteis totais por titulação ao longo do ciclo é apresentado na Figura 5-52. A concentração destes aumenta claramente durante a fase de reação para atingir um valor médio máximo no final do ciclo na ordem de $480 \mathrm{mgHAc} . \mathrm{L}^{-1}$.

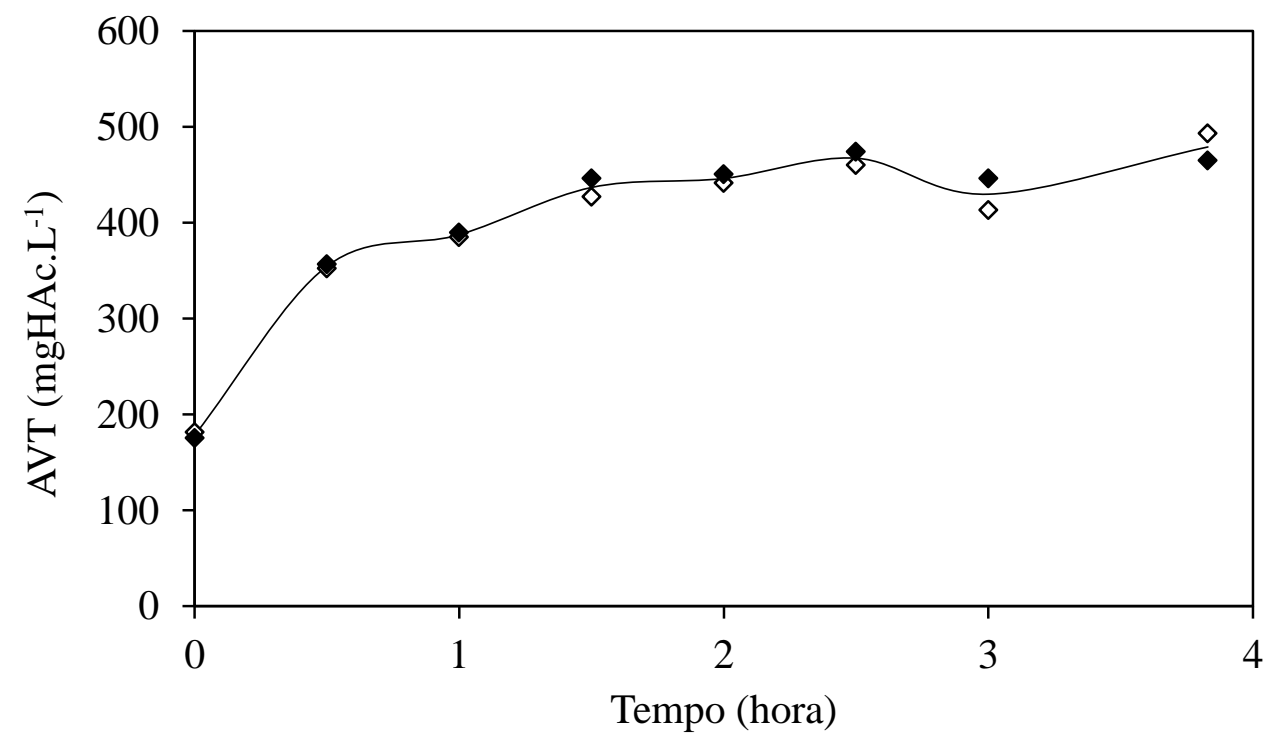

Figura 5-52 - Ácidos voláteis totais: $\diamond$ - do perfil 1 , - do perfil 2 e - média dos dois perfis (AnSBBR com recirculação da fase líquida e soro de leite - Condição 3). 
As concentrações dos metabólitos intermediários por cromatografia gasosa são apresentadas na Figura 5-53, que permaneceram estáveis durante todo o ciclo. O maior destaque foi para o ácido acético e o etanol, que apresentaram concentrações acima de $500 \mathrm{mg} . \mathrm{L}^{-1}$ durante todo ciclo.

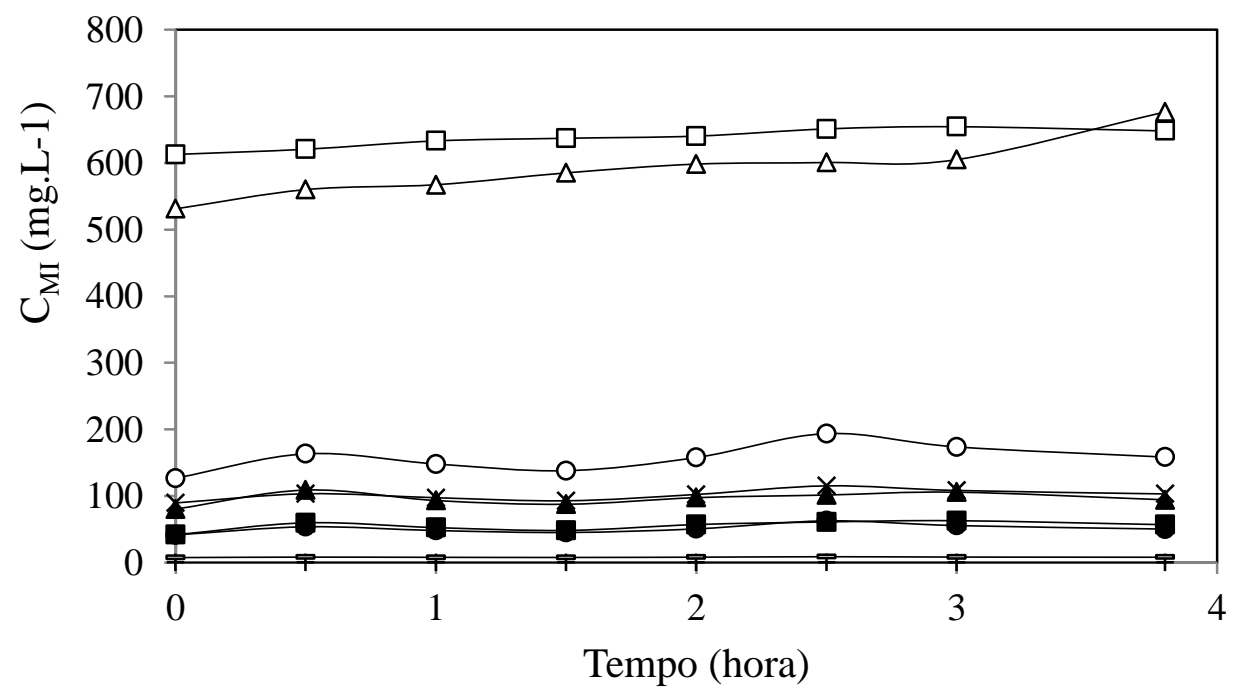

Figura 5-53 - Concentração dos compostos intermediários ao longo do ciclo: $\square$ - ácido acético; $\Delta$ - etanol; $\bigcirc$ - ácido butírico; $\mathbf{\square}$ - ácido isobutírico; $\boldsymbol{\Delta}$ - ácido capróico; $\bullet-$ ácido valérico; - - ácido propiônico; + butanol; - ácido isovalérico (AnSBBR com recirculação da fase líquida e soro de leite - Condição 3).

$\mathrm{O}$ pH diminuiu instantaneamente em relação ao afluente devido à diluição do mesmo com o volume residual no inicio do ciclo (alimentação do reator em 10 minutos) e permaneceu estável ao longo da operação conforme a Figura 5-54. A estabilidade do pH mesmo com a produção de ácidos voláteis se deu devido ao tamponamento do sistema pelo consumo de alcalinidade ao longo do ciclo. A Figura 5-55 apresenta a evolução da alcalinidade total no reator ao longo do ciclo. 


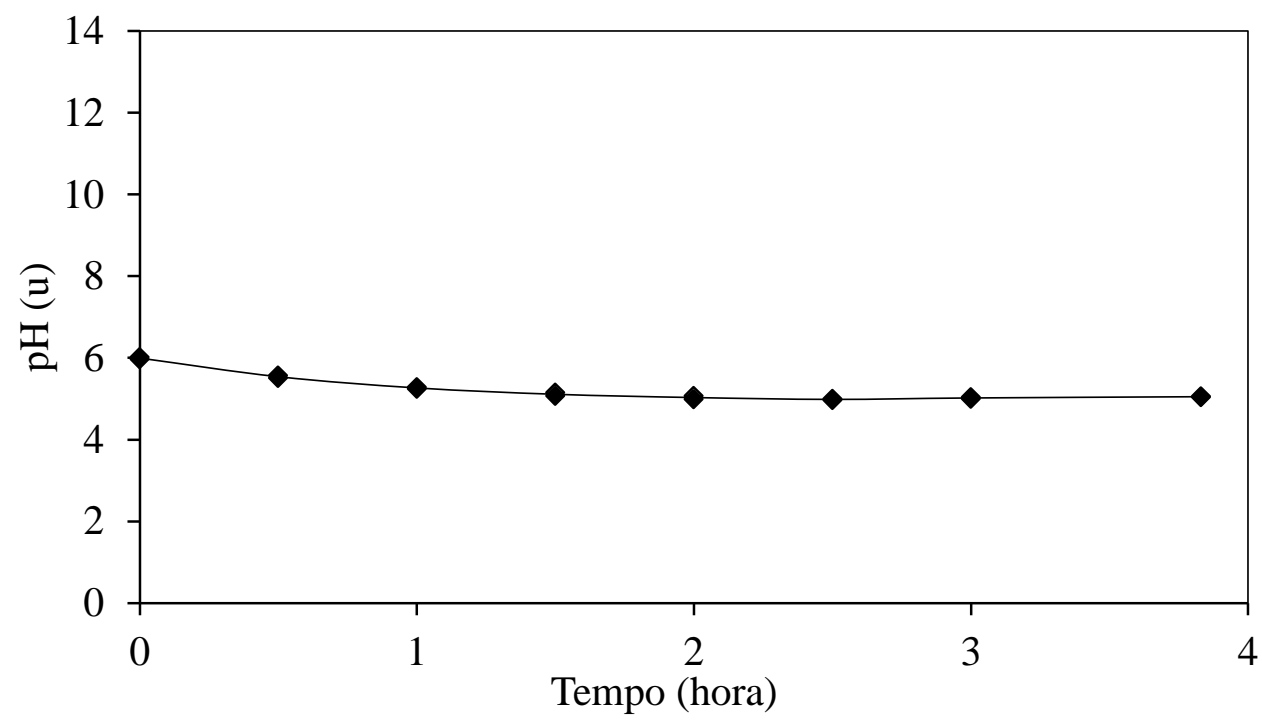

Figura 5-54 - Valores de pH: $\diamond$ - do perfil 1, - do perfil 2 e — média dos dois perfis (AnSBBR com recirculação da fase líquida e soro de leite - Condição 3).

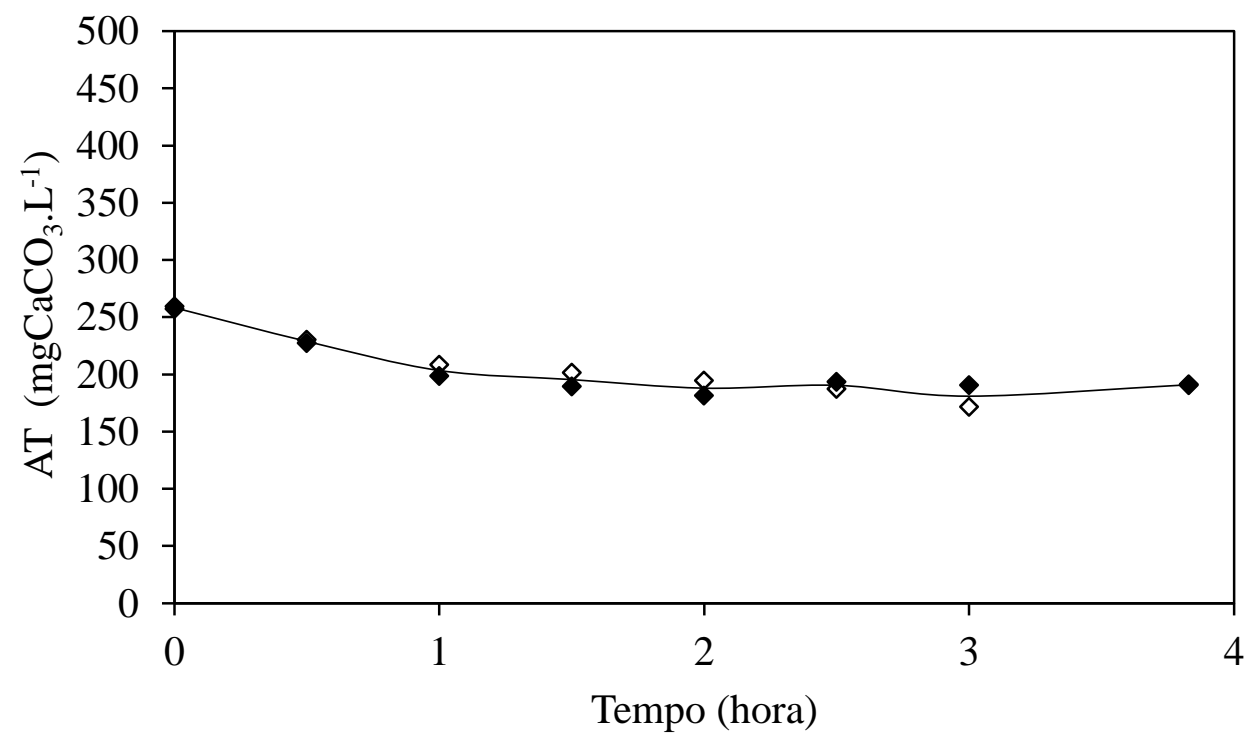

Figura 5-55 - Alcalinidade total: $\diamond$ - do perfil 1, - do perfil 2 e - média dos dois perfis (AnSBBR com recirculação da fase líquida e soro de leite - Condição 3).

A produção volumétrica média acumulada do biogás, realizada com os valores dos perfis quantitativos mais consistentes obtidos durante a operação, juntamente com os desvios padrões encontram-se na Figura 5-56. A maior parte da produção ocorre no inicio do ciclo, até a metade do mesmo, e tende a se estabilizar no final. A Tabela 5.14 
resume os valores médios da produção, fração molar e os volumes individuais da mistura do biogás. A Figura 5-57 apresenta os volumes acumulados médios dos perfis de $\mathrm{H}_{2}, \mathrm{CO}_{2}$ e $\mathrm{CH}_{4}$ produzidos durante o ciclo.

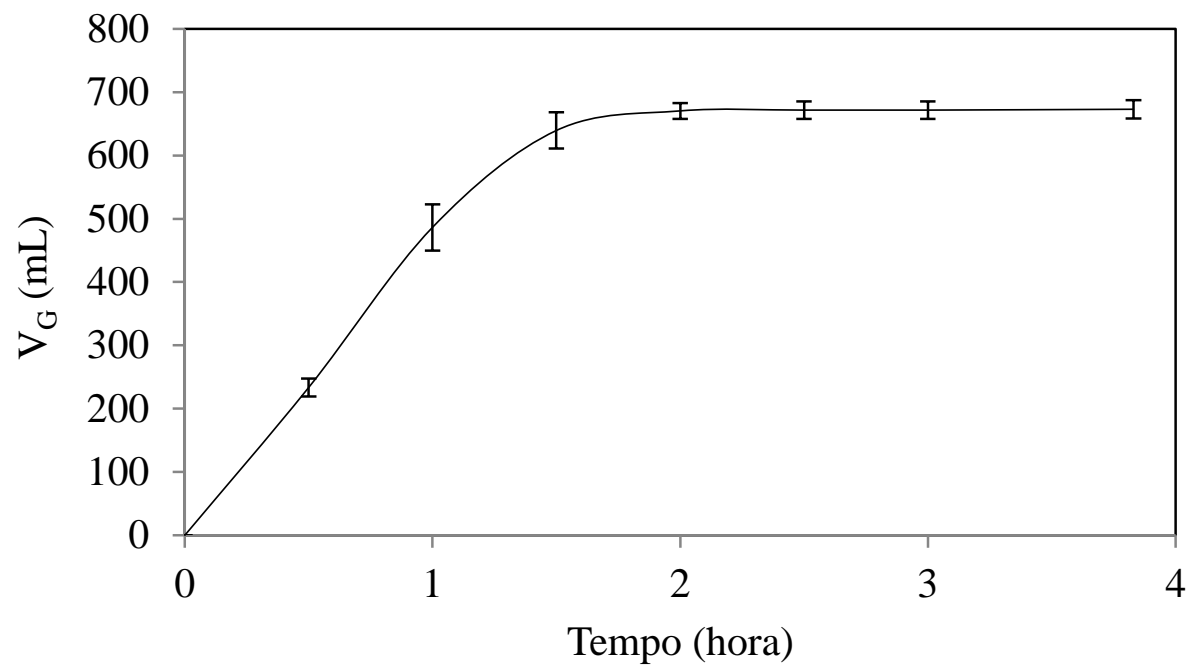

Figura 5-56 - Produção volumétrica média acumulada do biogás, realizada com os valores dos perfis quantitativos mais consistentes obtidos durante a operação, juntamente com os desvios padrões (AnSBBR com recirculação da fase líquida e soro de leite - Condição 3).

Tabela 5.14 - Valores médios da produção, fração molar e os volumes individuais da mistura do biogás (AnSBBR com recirculação da fase líquida e soro de leite - Condição 3).

\begin{tabular}{ccccccccccc}
\hline \multirow{2}{*}{$\begin{array}{c}\text { Tempo } \\
(\mathrm{h})\end{array}$} & \multirow{2}{*}{$\mathrm{V}_{\mathrm{G}}$} & \multicolumn{3}{c}{$\mathrm{C}_{\mathrm{G}}\left(\mathrm{mmol} \cdot \mathrm{L}^{-1}\right)$} & \multicolumn{3}{c}{ Fração Molar (\%) } & \multicolumn{3}{c}{ Volume $(\mathrm{mL}-\mathrm{CNTP})$} \\
& & $\mathrm{H}_{2}$ & $\mathrm{CO}_{2}$ & $\mathrm{CH}_{4}$ & $\mathrm{H}_{2}$ & $\mathrm{CO}_{2}$ & $\mathrm{CH}_{4}$ & $\mathrm{H}_{2}$ & $\mathrm{CO}_{2}$ & $\mathrm{CH}_{4}$ \\
\hline 0,0 & 0,0 & 0,0 & 0,0 & 0,0 & 0,0 & 0,0 & 0,0 & 0,0 & 0 & 0,0 \\
0,5 & 233,5 & 0,2 & 2,3 & 0,0 & 9,2 & 90,8 & 0,0 & 21,5 & 212,0 & 0,0 \\
1,0 & 486,5 & 1,1 & 3,9 & 0,0 & 21,2 & 78,8 & 0,0 & 75,2 & 411,3 & 0,0 \\
1,5 & 639,5 & 3,5 & 6,8 & 0,0 & 34,0 & 66,0 & 0,0 & 127,2 & 512,3 & 0,0 \\
2,0 & 670,4 & 4,6 & 8,2 & 0,0 & 36,1 & 63,9 & 0,0 & 138,4 & 532,0 & 0,0 \\
2,5 & 671,7 & 5,8 & 8,6 & 0,0 & 40,4 & 59,6 & 0,0 & 138,9 & 532,8 & 0,0 \\
3,0 & 671,7 & 6,4 & 8,7 & 0,0 & 42,2 & 57,8 & 0,0 & 138,9 & 532,8 & 0,0 \\
3,8 & 673,0 & 6,4 & 8,8 & 0,0 & 42,2 & 57,8 & 0,0 & 139,5 & 533,6 & 0,0 \\
\hline
\end{tabular}




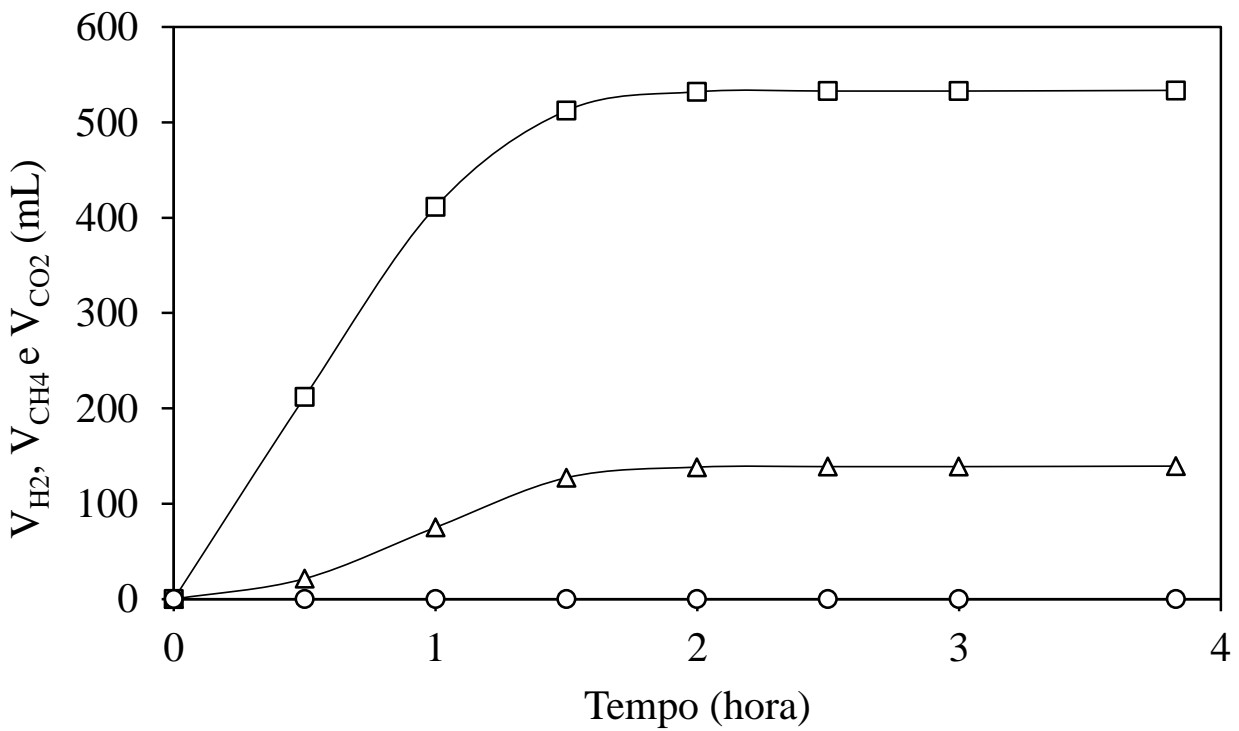

Figura 5-57 - Volumes acumulados médios produzidos ao longo do ciclo de: $\square-\mathrm{CO}_{2} ; \Delta$ - $\mathrm{H}_{2} ; \circ-\mathrm{CH}_{4}$ (AnSBBR com recirculação da fase líquida e soro de leite - Condição 3 ). 
5.1.2. Condições com $t c=3$ horas

\subsubsection{Condição 4 - Sem adaptação e afluente não refrigerado}

A condição experimental 4 utilizando soro de leite como substrato apresentou uma COAV nominal de 14,6 kgDQO.m-3.d-1e duração do ciclo de 3 horas, indo do dia 146 ao dia 174 (29 dias de operação). A Tabela 5.15 apresenta os valores médios dos parâmetros monitorados. Iniciou-se esta condição de operação adicionando ácido clorídrico para deixar o $\mathrm{pH}$ afluente próximo a 5,0, com o intuito de estudar um pouco mais a influência desta faixa baixa de $\mathrm{pH}$ no processo. 
Tabela 5.15 - Valores médios dos parâmetros monitorados na condição experimental 4 (Soro de leite - $4250 \mathrm{mgDQO} \cdot \mathrm{L}^{-1}-\mathrm{t}_{\mathrm{C}} 3 \mathrm{~h}$ ).

\begin{tabular}{|c|c|c|c|c|c|c|c|c|c|c|c|}
\hline \multicolumn{2}{|r|}{ Parâmetro } & \multicolumn{5}{|c|}{ Afluente } & \multicolumn{5}{|c|}{ Efluente } \\
\hline $\mathrm{C}_{\mathrm{ST}}$ & $\left(\mathrm{mgDQO} \cdot \mathrm{L}^{-1}\right)$ & 4095 & \pm & 332 & ( & 10 & ) 2960 & \pm 328 & ( & 10 & ) \\
\hline $\mathrm{C}_{\mathrm{SF}}$ & $\left(m g D Q O . L^{-1}\right)$ & - & & - & & & 2579 & \pm 147 & ( & 10 & ) \\
\hline$\varepsilon_{\mathrm{ST}}$ & $(\%)$ & - & & - & & & 28 & \pm 8 & ( & 10 & ) \\
\hline$\varepsilon_{\mathrm{SF}}$ & $(\%)$ & - & & - & & & 37 & \pm 4 & ( & 10 & ) \\
\hline $\mathrm{C}_{\mathrm{CT}}$ & (mgCarboidrato. $\mathrm{L}^{-1}$ ) & 3784 & \pm & 278 & ( & 10 & ) 118 & \pm 53 & ( & 10 & ) \\
\hline $\mathrm{C}_{\mathrm{CF}}$ & (mgCarboidrato. $\left.\mathrm{L}^{-1}\right)$ & - & & - & & & 49 & \pm 10 & ( & 10 & ) \\
\hline$\varepsilon_{\mathrm{CT}}$ & $(\%)$ & - & & - & & & 97 & \pm 1 & ( & 10 & ) \\
\hline$\varepsilon_{\mathrm{CF}}$ & $(\%)$ & - & & - & & & 99 & \pm 0 & ( & 10 & ) \\
\hline $\mathrm{pH}$ & (u) & 6,57 & \pm & 1,43 & ( & 10 & ) 4,43 & $\pm 0,50$ & ( & 10 & ) \\
\hline AVT & $\left(\mathrm{mgHAc} . \mathrm{L}^{-1}\right)$ & 121 & \pm & 12 & ( & 10 & ) 1247 & \pm 68 & ( & 10 & ) \\
\hline $\mathrm{AT}$ & $\left(\mathrm{mgCaCO}_{3} \cdot \mathrm{L}^{-1}\right)$ & 292 & \pm & 219 & ( & 10 & 184 & \pm 165 & ( & 10 & ) \\
\hline $\mathrm{AP}$ & $\left(\mathrm{mgCaCO}_{3} \cdot \mathrm{L}^{-1}\right)$ & 200 & \pm & 173 & ( & 10 & ) 0 & \pm 0 & ( & 10 & ) \\
\hline AI & $\left(\mathrm{mgCaCO}_{3} \cdot \mathrm{L}^{-1}\right)$ & 92 & \pm & 48 & ( & 10 & ) 184 & \pm 165 & ( & 10 & ) \\
\hline $\mathrm{AB}$ & $\left(\mathrm{mgCaCO}_{3} \cdot \mathrm{L}^{-1}\right)$ & 224 & \pm & 194 & ( & 10 & ) 0 & \pm 0 & ( & 10 & ) \\
\hline ST & $\left(\mathrm{mg} \cdot \mathrm{L}^{-1}\right)$ & 3638 & \pm & 846 & ( & 4 & ) 2249 & \pm 136 & ( & 4 & ) \\
\hline STV & $\left(\mathrm{mg} . \mathrm{L}^{-1}\right)$ & 2962 & \pm & 765 & ( & 4 & ) 1600 & \pm 223 & ( & 4 & ) \\
\hline SST & $\left(\mathrm{mg} . \mathrm{L}^{-1}\right)$ & 112 & \pm & 85 & ( & 4 & 323 & \pm 220 & ( & 4 & ) \\
\hline SSV & $\left(\mathrm{mg} \cdot \mathrm{L}^{-1}\right)$ & 95 & \pm & 55 & ( & 4 & ) 255 & \pm 177 & ( & 4 & ) \\
\hline $\mathrm{M}_{\mathrm{STV}}$ & (g) & - & & - & & & 48,77 & - & & & \\
\hline $\mathrm{C}_{\mathrm{X}}$ & $\left(\mathrm{g} \cdot \mathrm{L}^{-1}\right)$ & - & & - & & & 13,94 & - & & & \\
\hline $\mathrm{C}_{\mathrm{X}}^{\prime}$ & (g.gsuporte ${ }^{-1}$ ) & - & & - & & & 0,0333 & - & & & \\
\hline $\mathrm{V}_{\mathrm{G}}$ & (mL-CNTP) & - & & - & & & 562 & \pm 6 & & 3 & ) \\
\hline $\mathrm{V}_{\mathrm{H} 2}$ & (mL-CNTP) & - & & - & & & 0 & \pm 1 & & 2 & ) \\
\hline $\mathrm{COAV}_{\mathrm{STA}}$ & $\left(\mathrm{kgDQO} \cdot \mathrm{m}^{-3} \cdot \mathrm{d}^{-1}\right)$ & 14,0 & & - & & & - & - & & & \\
\hline $\mathrm{CORV}_{\mathrm{SFE}}$ & $\left(\operatorname{kgDQO} \cdot \mathrm{m}^{-3} \cdot \mathrm{d}^{-1}\right)$ & - & & - & & & 5,2 & - & & & \\
\hline $\mathrm{COAV}_{\mathrm{CTA}}$ & $\left(\right.$ kgCarboidrato. $\left.\mathrm{m}^{-3} \cdot \mathrm{d}^{-1}\right)$ & 12,9 & & - & & & - & - & & & \\
\hline $\mathrm{CORV}_{\mathrm{CFE}}$ & $\left(\right.$ kgCarboidrato. $\left.\mathrm{m}^{-3} \cdot \mathrm{d}^{-1}\right)$ & - & & - & & & 12,8 & - & & & \\
\hline $\mathrm{COAE}_{\mathrm{STA}}$ & $\left(\operatorname{kgDQO} \cdot k g S T V^{-1} \cdot d^{-1}\right)$ & 1,0 & & - & & & - & - & & & \\
\hline $\mathrm{CORE}_{\mathrm{SFE}}$ & $\left(\mathrm{kgDQO} \cdot \mathrm{kgSTV}^{-1} \cdot \mathrm{d}^{-1}\right)$ & - & & - & & & 0,3 & - & & & \\
\hline $\mathrm{COAE}_{\mathrm{CTA}}$ & $\left(\mathrm{kgCarboidrato} \mathrm{kgSTV}^{-1} \cdot \mathrm{d}^{-1}\right)$ & 0,9 & & - & & & - & - & & & \\
\hline $\mathrm{CORE}_{\mathrm{CFE}}$ & $\left(\mathrm{kgCarboidrato} \mathrm{kgSTV}^{-1} \cdot \mathrm{d}^{-1}\right)$ & - & & - & & & 0,9 & - & & & \\
\hline $\mathrm{RMCR}_{\mathrm{C}, \mathrm{n}}$ & $\left(\mathrm{molH}_{2}\right.$ molCarboidrato $\left.^{-1}\right)$ & - & & - & & & 0,0012 & - & & & \\
\hline $\mathrm{n}_{\mathrm{H} 2}$ & $\left(\mathrm{molH}_{2} \cdot \mathrm{d}^{-1}\right)$ & - & & - & & & 0,0002 & - & & & \\
\hline PrM & $\left(\mathrm{molH}_{2} \cdot \mathrm{m}^{-3} \cdot \mathrm{d}^{-1}\right)$ & - & & - & & & 0,05 & - & & & \\
\hline PrME & $\left(\mathrm{molH}_{2} \cdot \mathrm{kgSVT}^{-1} \cdot \mathrm{d}^{-1}\right)$ & - & & - & & & 0,00 & - & & & \\
\hline $\mathrm{RMCA}_{\mathrm{S}, \mathrm{m}}$ & $\left(\mathrm{molH}_{2} \cdot \mathrm{kgDQO}^{-1} \cdot \mathrm{d}^{-1}\right)$ & 0,0 & & - & & & - & - & & & \\
\hline $\mathrm{RMCA}_{\mathrm{C}, \mathrm{m}}$ & $\left(\mathrm{molH}_{2} \cdot \mathrm{kg}^{-1} \cdot \mathrm{d}^{-1}\right)$ & 0,0 & & - & & & - & - & & & \\
\hline $\mathrm{RMCR}_{\mathrm{S}, \mathrm{m}}$ & $\left(\mathrm{molH}_{2} \cdot \mathrm{kgDQO}^{-1} \cdot \mathrm{d}^{-1}\right)$ & - & & - & & & 0,0 & - & & & \\
\hline $\mathrm{RMCR}_{\mathrm{C}, \mathrm{m}}$ & $\left(\mathrm{molH}_{2} \cdot \mathrm{kg}^{-1} \cdot \mathrm{d}^{-1}\right)$ & - & & - & & & 0,0 & - & & & \\
\hline $\mathrm{V}_{\mathrm{R}}$ & $(\mathrm{mL})$ & 2000 & & & & & & & & & \\
\hline $\mathrm{V}_{\mathrm{A}}$ & $(\mathrm{mL})$ & 1430 & \pm & $45\left(^{12}\right)$ & & & & & & & \\
\hline $\mathrm{Q}_{\mathrm{R}}$ & $\left(\mathrm{mL} \cdot \mathrm{s}^{-1}\right)$ & 6 & \pm & $0\left(^{3}\right)$ & & & & & & & \\
\hline
\end{tabular}


A Figura 5-58 apresenta os valores da concentração afluente (não filtrada) e efluente (não filtrada e filtrada) de matéria orgânica (DQO) no sistema, enquanto que a Figura 5-59 apresenta a eficiência de remoção do mesmo parâmetro durante o monitoramento diário. Esta eficiência atingiu, em média, 37\% para as amostras filtradas e $28 \%$ para amostras não filtradas. A média de concentração afluente não filtrada do substrato foi de $4095 \mathrm{mgDQO} . \mathrm{L}^{-1}$ e de $2960 \mathrm{mgDQO} . \mathrm{L}^{-1}$ e $2579 \mathrm{mgDQO} . \mathrm{L}^{-1}$ para amostras de efluente não filtrado e filtrado, respectivamente.

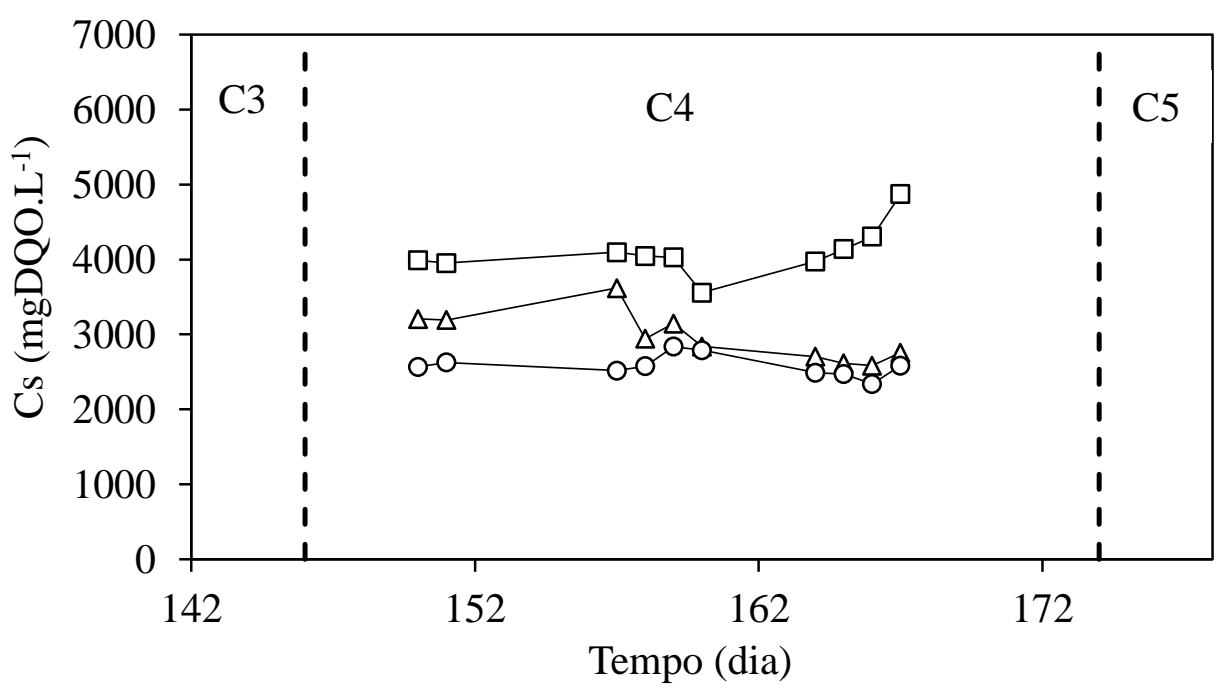

Figura 5-58 - Concentração de matéria orgânica (DQO): $\square$ - afluente não filtrada; $\Delta$ efluente não filtrada; o - efluente filtrada (AnSBBR com recirculação da fase líquida e soro de leite - Condição 4). 


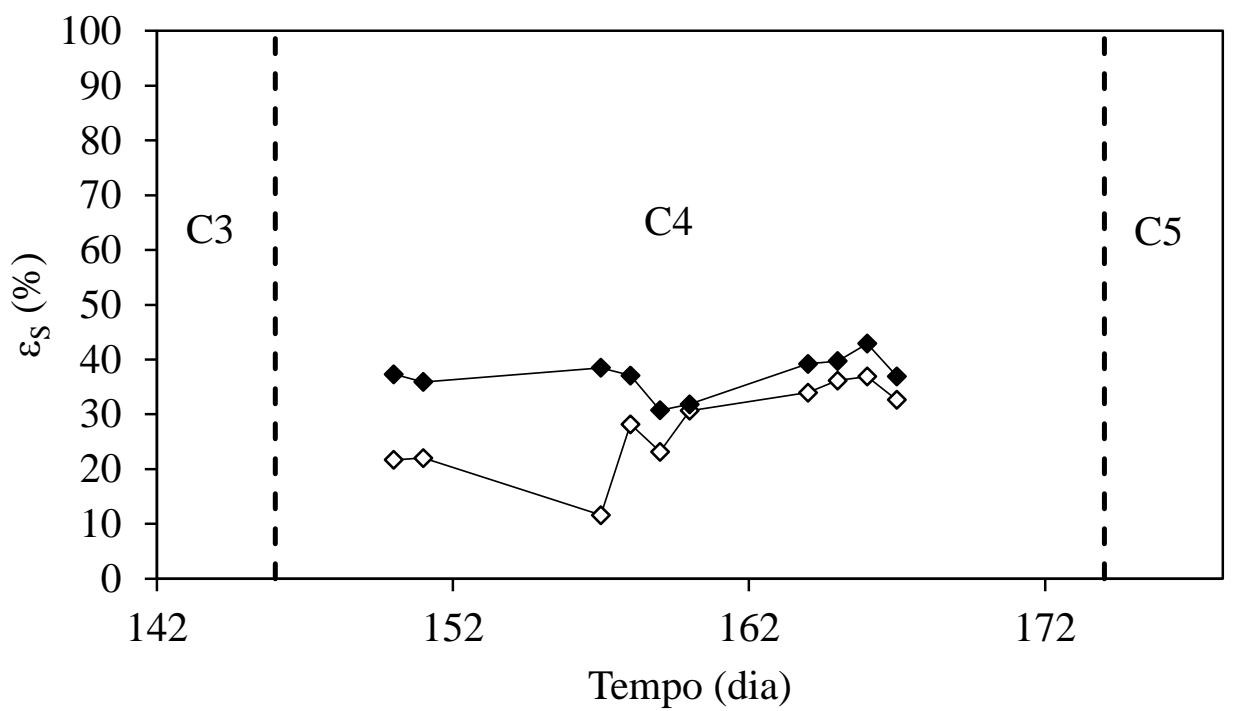

Figura 5-59 - Eficiência de remoção de matéria orgânica (DQO): $\diamond$ - não filtrada; filtrada (AnSBBR com recirculação da fase líquida e soro de leite - Condição 4).

A Figura 5-60 apresenta os valores da concentração de carboidratos afluente e efluente (para amostras filtradas e não filtradas), enquanto a Figura 5-61 mostra a eficiência de remoção do mesmo parâmetro (bruto e filtrado) durante o monitoramento diário. A média da concentração afluente foi de $3784 \mathrm{mgCarboidrato.} \mathrm{L}^{-1}$, enquanto que a concentração residual (amostras não filtradas) foi de $118 \mathrm{mgCarboidrato.L^{-1 }}$ e 49 mgCarboidrato. $\mathrm{L}^{-1}$ para a concentração residual filtrada. A eficiência de remoção de sacarose foi, em média, de $97 \%$ e $99 \%$ para as amostras filtradas e não filtradas, respectivamente. A condição apresentou uma alta eficiência de remoção de carboidrato. 


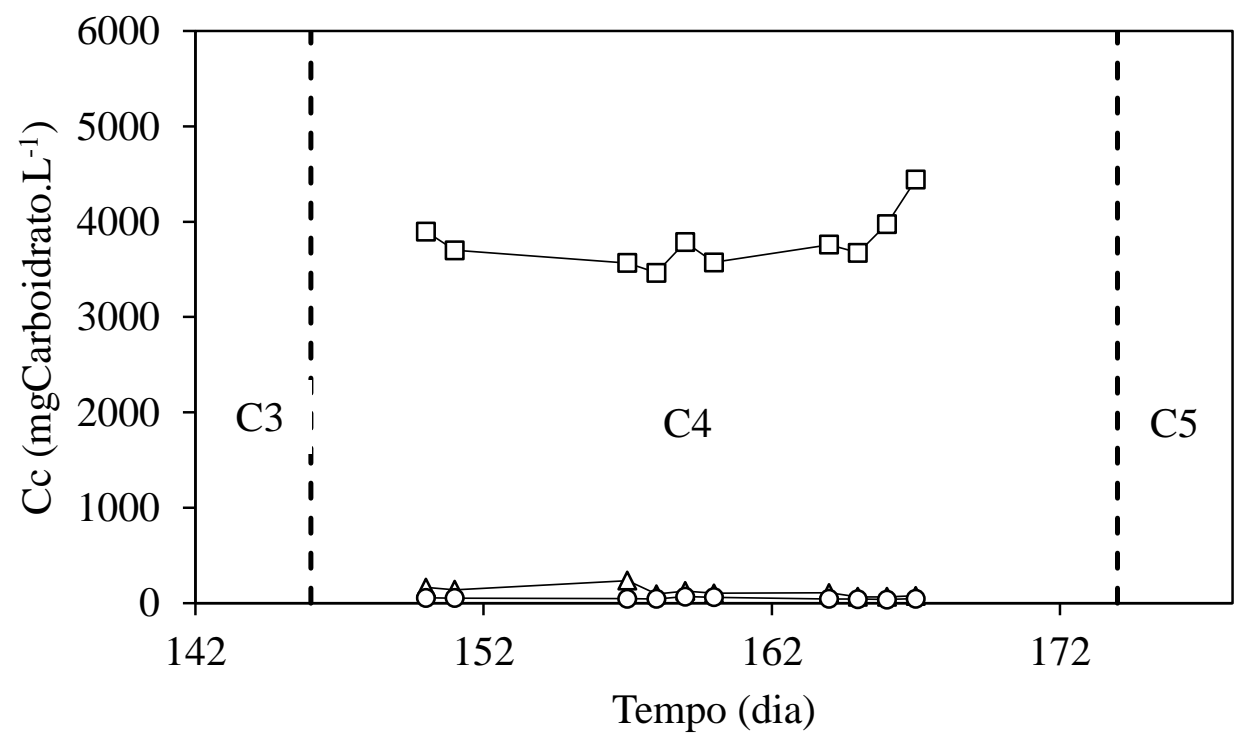

Figura 5-60 - Concentração de carboidrato: $\square-$ afluente não filtrada; $\Delta$ - efluente não filtrada; ○ - efluente filtrada (AnSBBR com recirculação da fase líquida e soro de leite Condição 4).

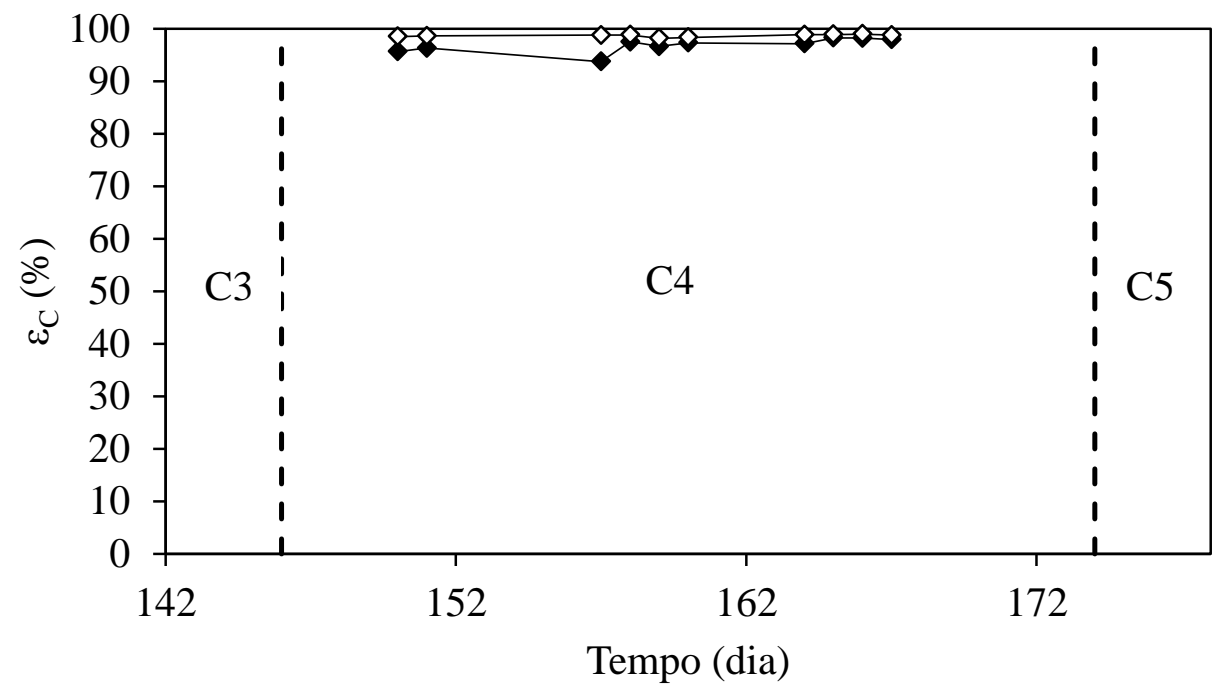

Figura 5-61 - Eficiência de remoção de carboidrato: $\diamond$ - não filtrada; $\downarrow$ - filtrada (AnSBBR com recirculação da fase líquida e soro de leite - Condição 4).

As Figura 5-62, Figura 5-63 e Figura 5-64 apresentam os perfis temporais, tanto para o afluente quanto para o efluente, do $\mathrm{pH}$, da alcalinidade total e dos ácidos voláteis totais por titulação, respectivamente. A média dos valores de $\mathrm{pH}$ afluente durante a Condição 1 foi de 6,57 e de pH efluente foi de 4,43. A média da alcalinidade total foi de 
292 e $184 \mathrm{mgCaCO}_{3} \cdot \mathrm{L}^{-1}$ para o afluente e efluente, respectivamente. O valor médio da concentração de ácidos voláteis totais afluente foi de $121 \mathrm{mgHAc} . \mathrm{L}^{-1}$ e efluente de 1247 mgHAc. $L^{-1}$. Como pode ser observado na Figura 5-62 iniciou-se a operação da Condição 2 adicionando ácido clorídrico concentrado $12 \mathrm{M}$ (na proporção de 7,5 mL para cada 11 litros de afluente) objetivando testar um pouco mais a influência de baixas faixas de $\mathrm{pH}$ na produção de $\mathrm{H}_{2}$ utilizando este tipo de substrato.

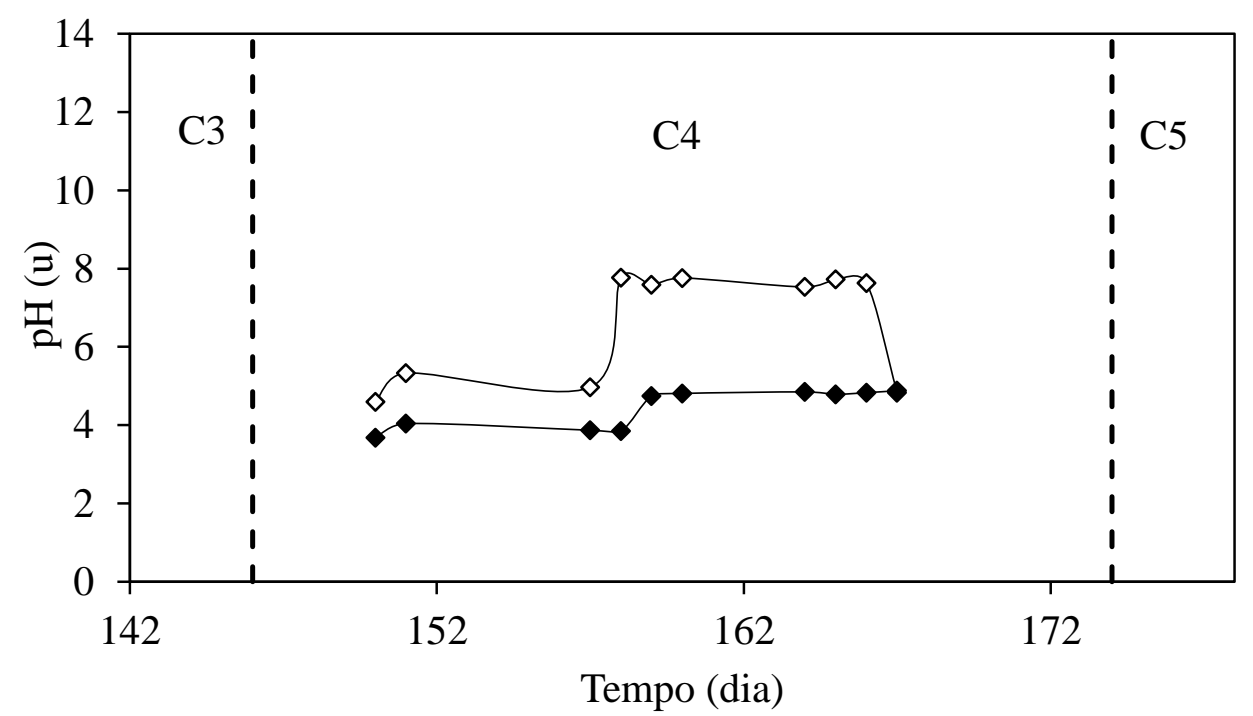

Figura 5-62 - Valores de pH: $\diamond$-afluente; - efluente (AnSBBR com recirculação da fase líquida e soro de leite - Condição 4). 


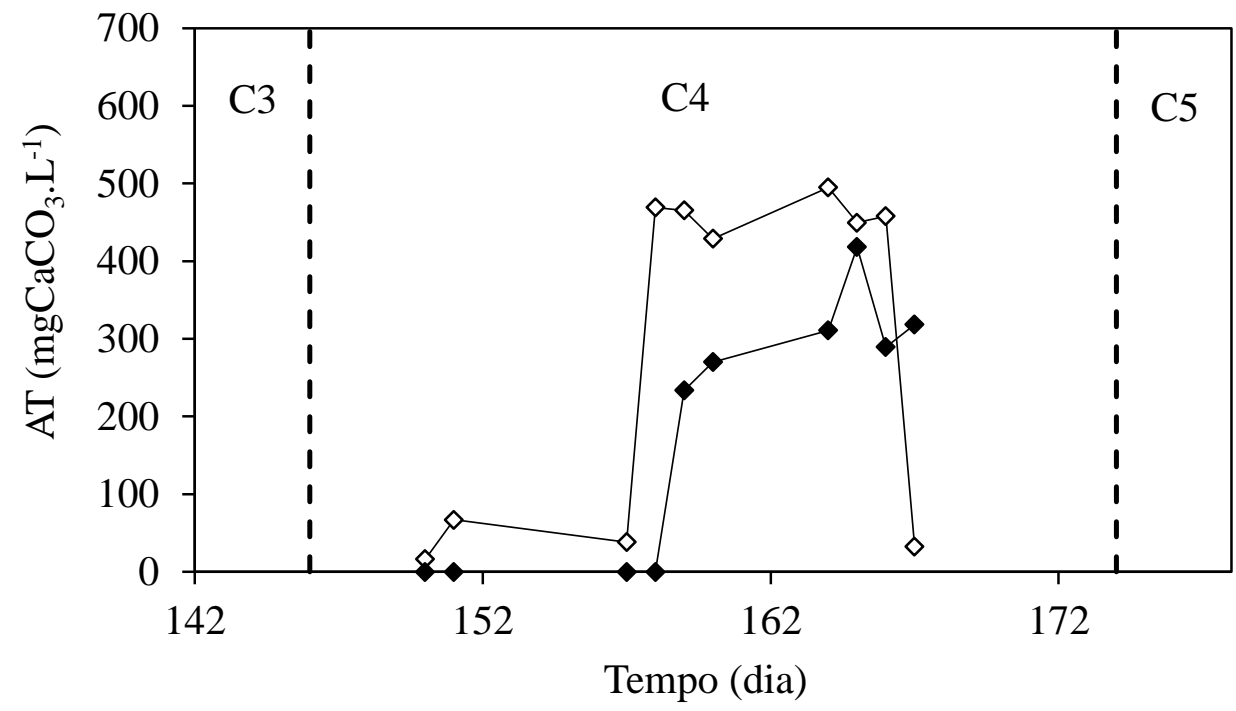

Figura 5-63 - Alcalinidade total: $\diamond$-afluente; $\downarrow$ - efluente (AnSBBR com recirculação da fase líquida e soro de leite - Condição 4).

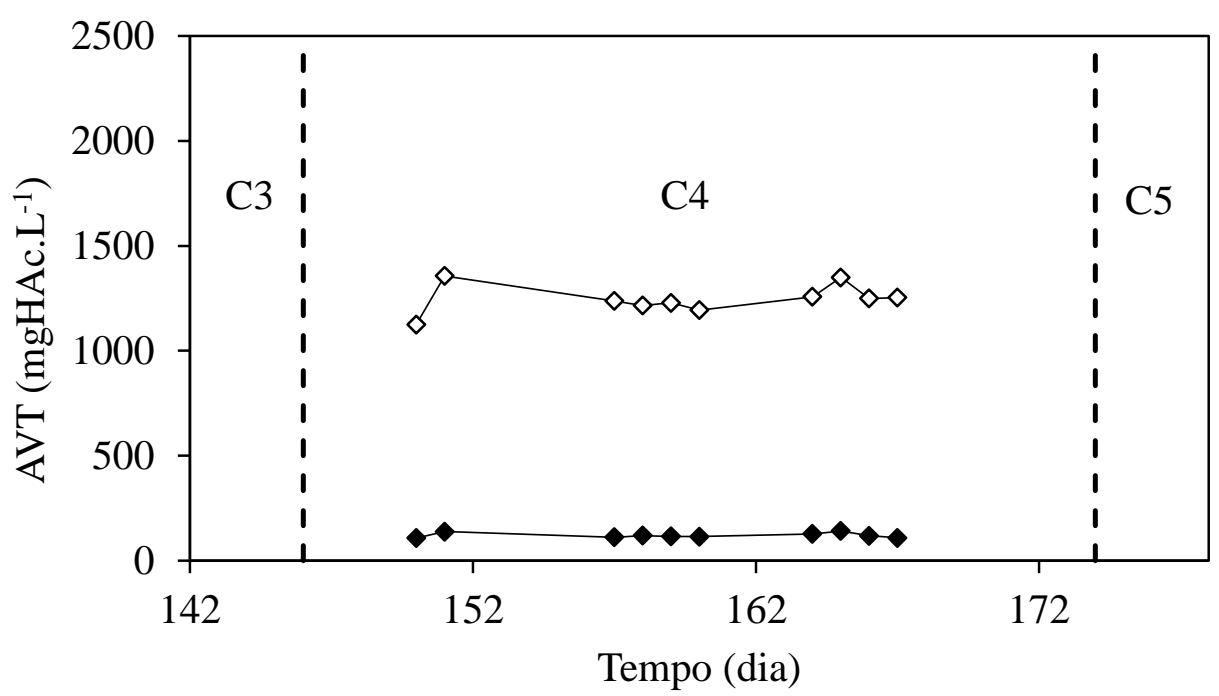

Figura 5-64 - Ácidos voláteis totais: $\diamond$-afluente; - efluente (AnSBBR com recirculação da fase líquida e soro de leite - Condição 4).

A Figura 5-65 apresenta o monitoramento dos compostos intermediários contidos no efluente do sistema, enquanto que a Tabela 5.16 apresenta os valores da concentração média destes produtos. O método cromatográfico utilizado mais uma vez não detectou a presença de acetona e metanol. Mais uma vez, entre os ácidos voláteis, a 
presença do ácido acético predominou seguida pelo ácido butírico representando respectivamente $59,5 \%$ e $21,1 \%$ dos compostos intermediários. Porém nesta condição a presença do ácido capróico também merece destaque, sendo responsável por 9,7\% dos metabólitos no meio líquido. Os demais produtos apresentaram concentrações abaixo de 100 mg. $\mathrm{L}^{-1}$.

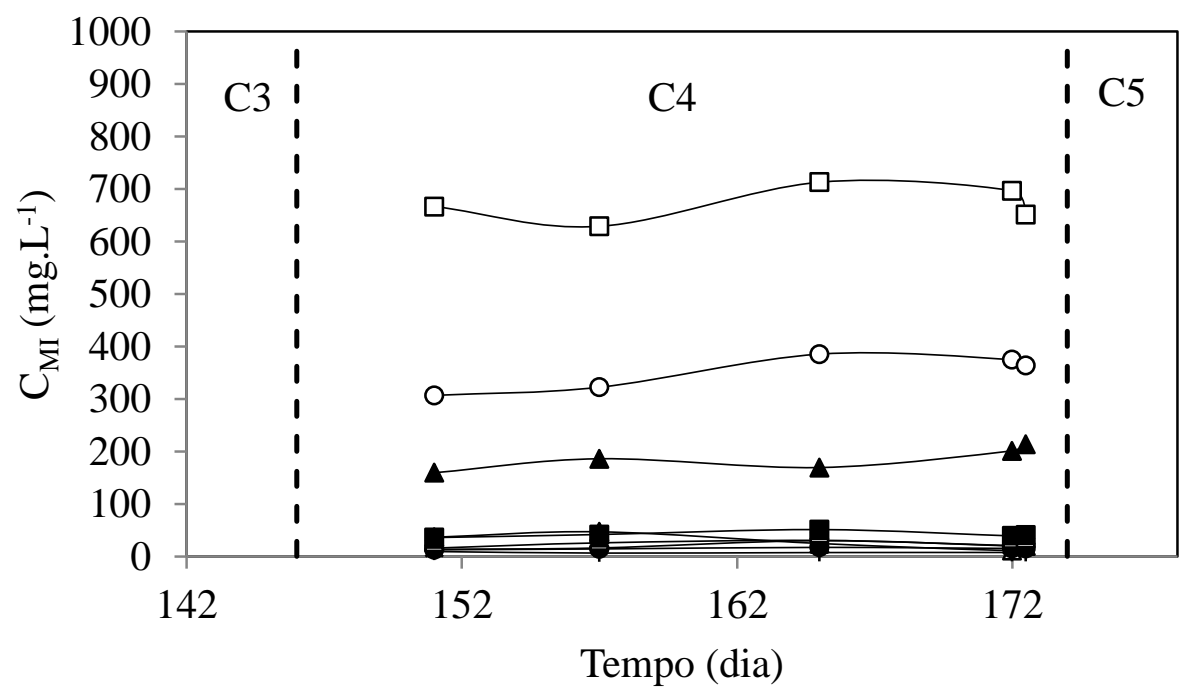

Figura 5-65 - Concentração dos compostos intermediários: $\square$ - ácido acético; $\Delta$ - etanol; ○ - ácido butírico; - ácido isobutírico; $\boldsymbol{\Lambda}$ - ácido capróico; $\bullet$ - ácido valérico; - ácido propiônico; +butanol; - ácido isovalérico (AnSBBR com recirculação da fase líquida e soro de leite - Condição 4). 
Tabela 5.16 - Concentração e distribuição dos compostos intermediários (AnSBBR com recirculação da fase líquida e soro de leite - Condição 4).

\begin{tabular}{cccccccc}
\hline $\begin{array}{c}\text { Produtos } \\
\text { intermediários }\end{array}$ & \multicolumn{9}{c}{ Concentrações média } & \multicolumn{3}{c}{$\begin{array}{c}\text { Distribuição } \\
\left(\mathrm{mg} . \mathrm{L}^{-1}\right)\end{array}$} & \multicolumn{1}{c}{$\left.\mathrm{mmol}_{\mathrm{L}}^{-1}\right)$} & $(\%)$ \\
\hline Acetona & 0,0 & \pm & 0,0 & 0,0 & \pm & 0,0 & 0,0 \\
Metanol & 0,0 & \pm & 0,0 & 0,0 & \pm & 0,0 & 0,0 \\
Etanol & 27,7 & \pm & 14,02 & 0,6 & \pm & 0,3 & 3,2 \\
n-Butanol & 7,4 & \pm & 1,10 & 0,1 & \pm & 0,0 & 0,5 \\
Acético & 671,1 & \pm & 33,97 & 11,2 & \pm & 0,6 & 59,5 \\
Porpiônico & 22,3 & \pm & 5,75 & 0,3 & \pm & 0,1 & 1,6 \\
Isobutírico & 41,6 & \pm & 5,70 & 0,5 & \pm & 0,1 & 2,5 \\
Butírico & 350,4 & \pm & 34,20 & 4,0 & \pm & 0,4 & 21,2 \\
Isovalérico & 20,0 & \pm & 6,36 & 0,2 & \pm & 0,1 & 1,0 \\
Valérico & 14,7 & \pm & 1,66 & 0,1 & \pm & 0,0 & 0,8 \\
Capróico & 185,8 & \pm & 22,18 & 1,8 & \pm & 0,2 & 9,7 \\
\hline
\end{tabular}

O monitoramento da série de sólidos é mostrado na Tabela 5.17, cujos valores apresentam um baixo teor de SSV no efluente e afluente, indicando mais uma vez a boa capacidade do reator em reter biomassa.

Tabela 5.17 - Série de sólidos afluente e efluente (AnSBBR com recirculação da fase líquida e soro de leite - Condição 4).

\begin{tabular}{lcccc}
\hline & $\begin{array}{c}\text { ST } \\
\left(\mathrm{mg} . \mathrm{L}^{-1}\right)\end{array}$ & $\begin{array}{c}\text { SVT } \\
\left(\mathrm{mg} . \mathrm{L}^{-1}\right)\end{array}$ & $\begin{array}{c}\text { SST } \\
\left(\mathrm{mg} . \mathrm{L}^{-1}\right)\end{array}$ & $\begin{array}{c}\text { SSV } \\
\left(\mathrm{mg} . \mathrm{L}^{-1}\right)\end{array}$ \\
\hline Afluente & $3639 \pm 846$ & $2962 \pm 765$ & $113 \pm 86$ & $96 \pm 55$ \\
Efluente & $2249 \pm 136$ & $1600 \pm 223$ & $323 \pm 220$ & $255 \pm 177$ \\
\hline \multicolumn{5}{c}{ *Número de amostras consideradas $=4}$.
\end{tabular}

A produção do biogás por ciclo, em aspecto quantitativo, pode ser observada na Figura 5-66. A produção média foi de $642 \mathrm{~mL}$ (CNTP). A Figura 5-67 apresenta o monitoramento das concentrações dos componentes do biogás no final do ciclo, enquanto que a Figura 5-68 apresenta a distribuição destes mesmos componentes. Os valores médios de concentração de $\mathrm{H}_{2}, \mathrm{CH}_{4}$ e $\mathrm{CO}_{2}$ foram 0,56, 3,73 e 7,08 mmol.L ${ }^{-1}$, respectivamente. Além disso, a distribuição percentual média de $\mathrm{H}_{2}$ foi de $4,6 \%$, a de 
$\mathrm{CH}_{4}$ foi de $33,2 \%$ e a de $\mathrm{CO}_{2}$ foi de $62,3 \%$. Apesar de ainda apresentar uma baixa produção de hidrogênio, esta produção ocorreu apenas no inicio da operação. Novamente, no final da operação, onde o reator deveria estar estável, a produção de hidrogênio inexistiu, com produção de metano e gás carbônico, apenas.

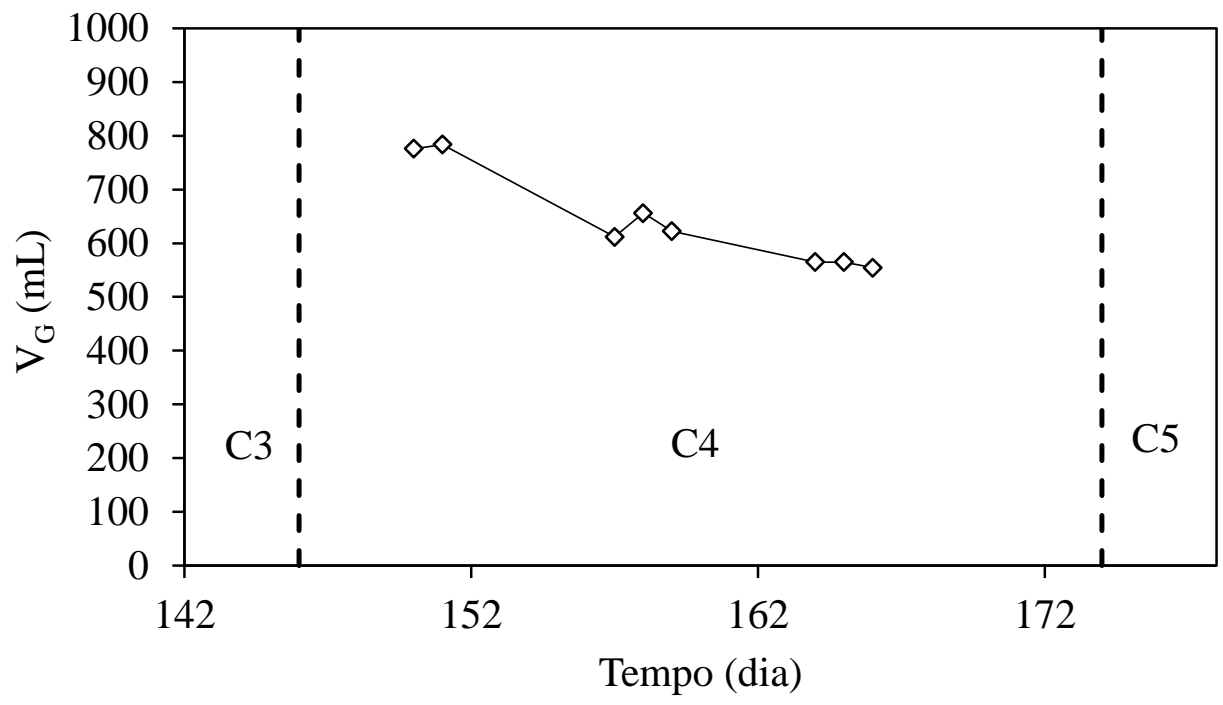

Figura 5-66 - Volume de biogás produzido por ciclo (AnSBBR com recirculação da fase líquida e soro de leite - Condição 4). 


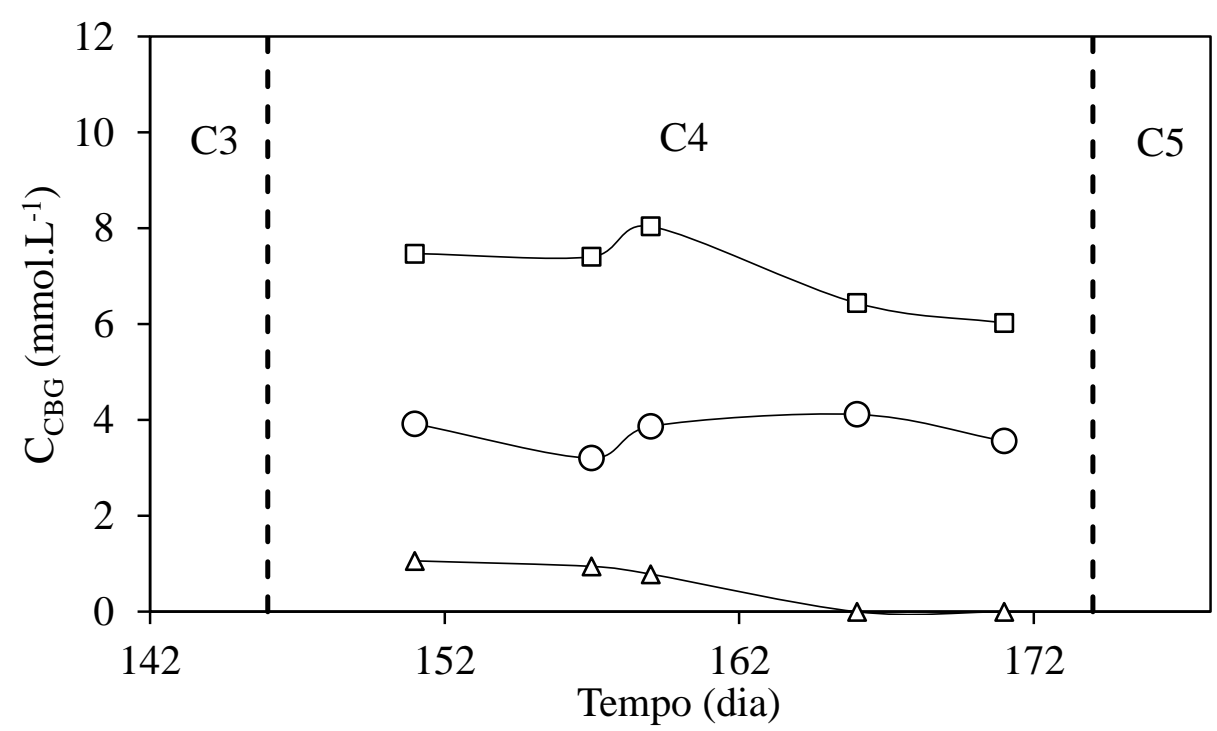

Figura 5-67 - Concentrações dos componentes do biogás no final do ciclo: $\square-\mathrm{CO}_{2} ; \Delta-$ $\mathrm{H}_{2} ;$ O $-\mathrm{CH}_{4}$ (AnSBBR com recirculação da fase líquida e soro de leite - Condição 4).

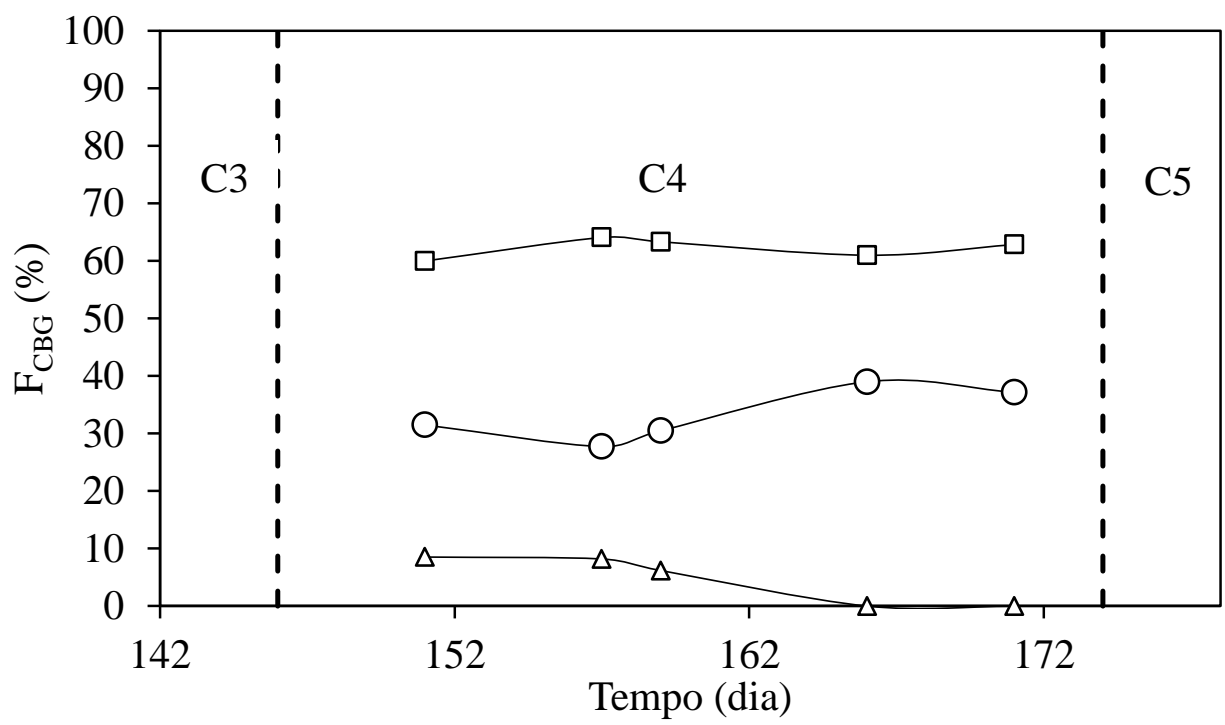

Figura 5-68 - Distribuições dos componentes do biogás no final do ciclo: $\square-\mathrm{CO}_{2} ; \Delta$ $\mathrm{H}_{2} ;$ o - $\mathrm{CH}_{4}$ (AnSBBR com recirculação da fase líquida e soro de leite - Condição 4).

No final da operação foi realizado o perfil temporal, com o intuito de entender melhor como os parâmetros indicativos de eficiência do sistema se comportavam durante um ciclo completo. A Figura 5-69 apresenta a evolução da concentração de carboidrato ao longo do ciclo e a eficiência de remoção do mesmo. Ao inicio do ciclo 
(tempo zero) o volume afluente é diluído no volume residual resultando em uma concentração de carboidrato da ordem de $1600 \mathrm{mg} \cdot \mathrm{L}^{-1}$. A conversão deste se faz de maneira progressiva ao longo do ciclo, atingindo valores na ordem de $99 \%$ no final do mesmo, com um residual aproximado de $30 \mathrm{mg} \cdot \mathrm{L}^{-1}$.

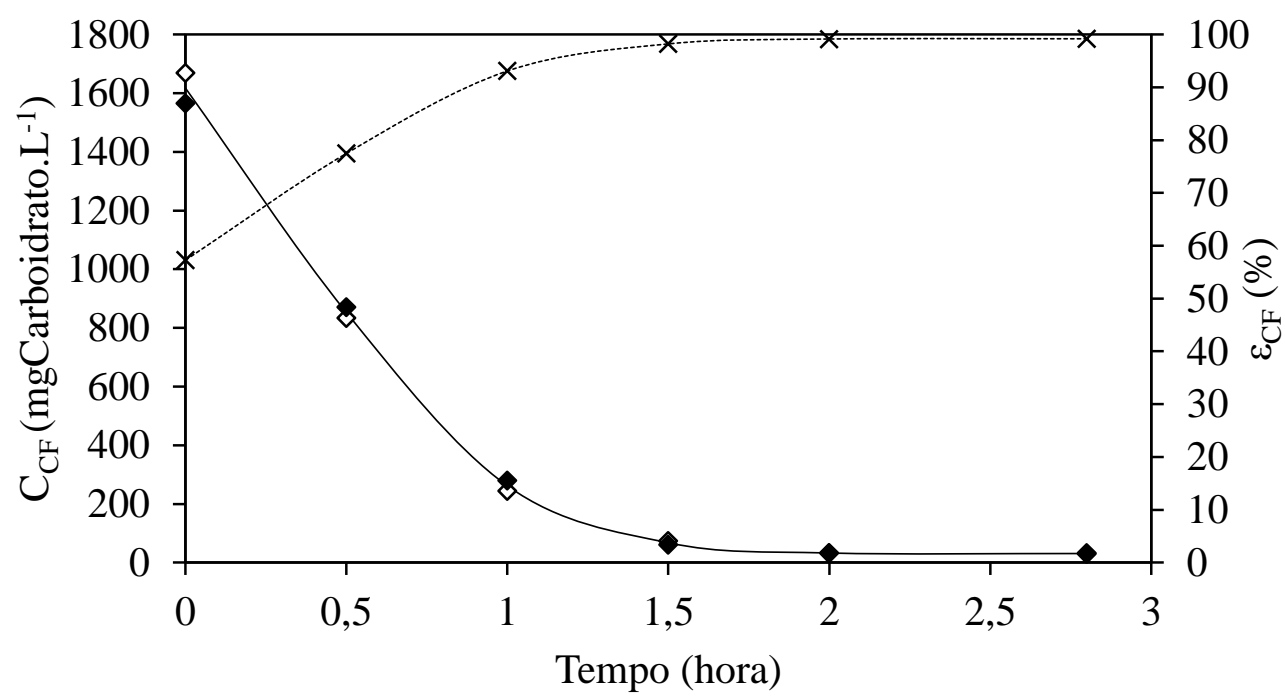

Figura 5-69 - Eixo da direita: Concentração de carboidrato $\diamond$ - do perfil 1 , - do perfil 2 e - média dos dois perfis; Eixo da esquerda: * eficiência de degradação do carboidrato (AnSBBR com recirculação da fase líquida e soro de leite - Condição 4).

A Figura 5-70 apresenta a evolução da concentração de matéria orgânica ao longo do ciclo. Mais uma vez observa-se uma baixa remoção da DQO, levando a uma alta concentração da mesma no volume residual. De tal modo, no inicio do ciclo, a diluição do volume carregado pelo volume residual é realizada em proporção bem menor do que no caso dos carboidratos totais, tendo em vista que as concentrações afluente e residual são próximas. No inicio do ciclo, a concentração é da ordem de 2900 mg. $\mathrm{L}^{-1}$ atingindo valores próximos a $2350 \mathrm{mg} . \mathrm{L}^{-1}$ no último ponto do ciclo. 


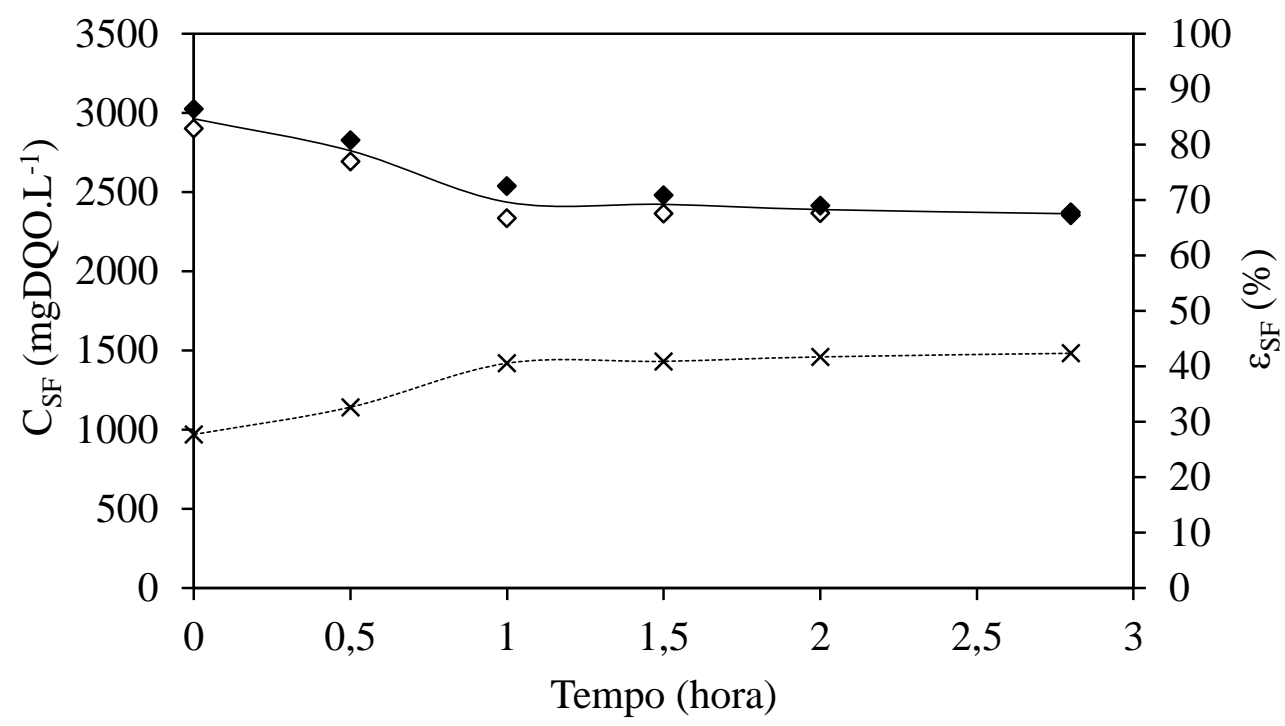

Figura 5-70 - Eixo da direita: Concentração de matéria orgânica (DQO) $\diamond$ - do perfil 1, - - do perfil 2 e - média dos dois perfis; Eixo da esquerda: * eficiência de degradação da matéria orgânica (DQO) (AnSBBR com recirculação da fase líquida e soro de leite - Condição 4).

O acúmulo de ácidos voláteis totais por titulação ao longo do ciclo pode ser observado na Figura 5-71. A concentração destes aumenta claramente durante a fase de reação para atingir um valor médio máximo no final do ciclo na ordem de 1000 $\operatorname{mgHAc} . \mathrm{L}^{-1}$. 


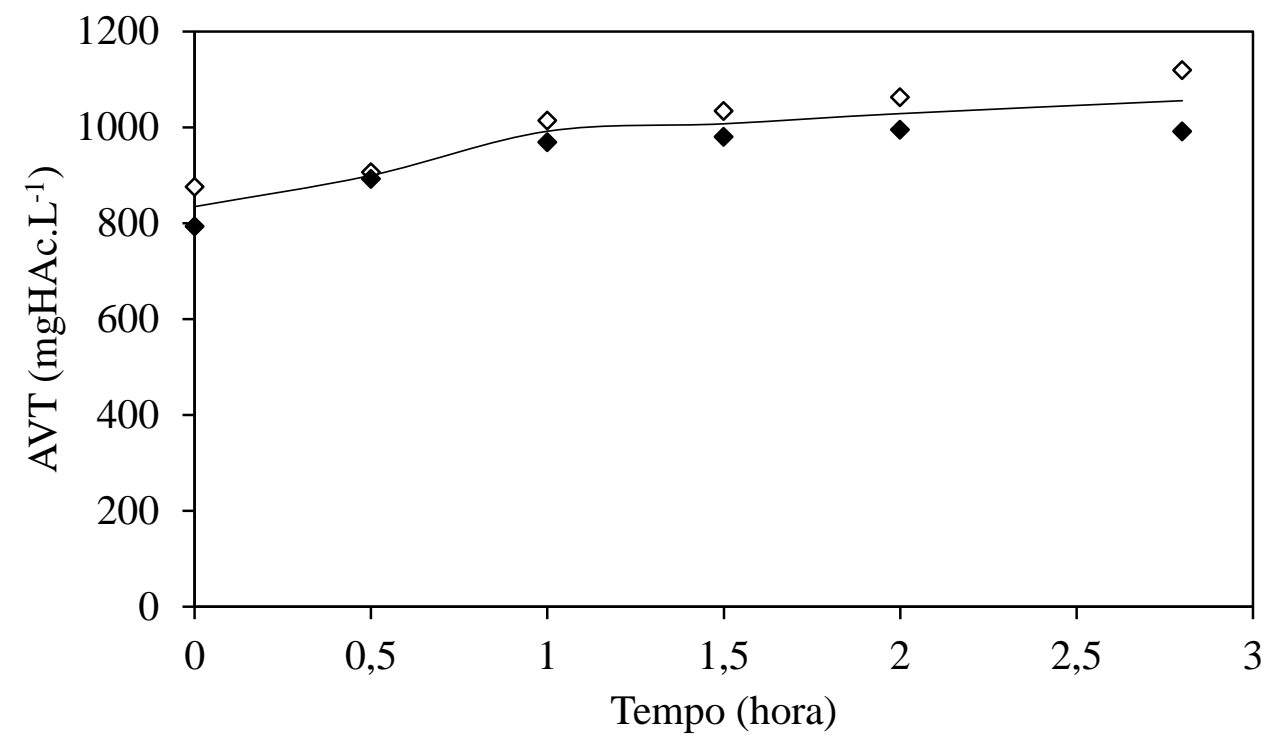

Figura 5-71 - Ácidos voláteis totais: $\diamond$ - do perfil 1 , - do perfil 2 e — média dos dois perfis (AnSBBR com recirculação da fase líquida e soro de leite - Condição 4).

Os resultados dos compostos intermediários por cromatografia gasosa são apresentados na Figura 5-72. Observa-se uma produção destacada de ácido acético, passando de uma concentração inicial de 515,6 mg. $\mathrm{L}^{-1}$ até $650,7 \mathrm{mg} . \mathrm{L}^{-1}$ no final do ciclo. O ácido butírico também se apresentou estável durante todo o perfil, com concentrações próximas a $300 \mathrm{mg} \cdot \mathrm{L}^{-1}$. Outro metabólito com produção relevante foi o ácido capróico, com valores estáveis próximos a $160 \mathrm{mg} \cdot \mathrm{L}^{-1}$, o que não aconteceu na condição 1. Os demais produtos também apresentaram produção estável, porém com concentrações sempre abaixo de $100 \mathrm{mg} \cdot \mathrm{L}^{-1}$. 


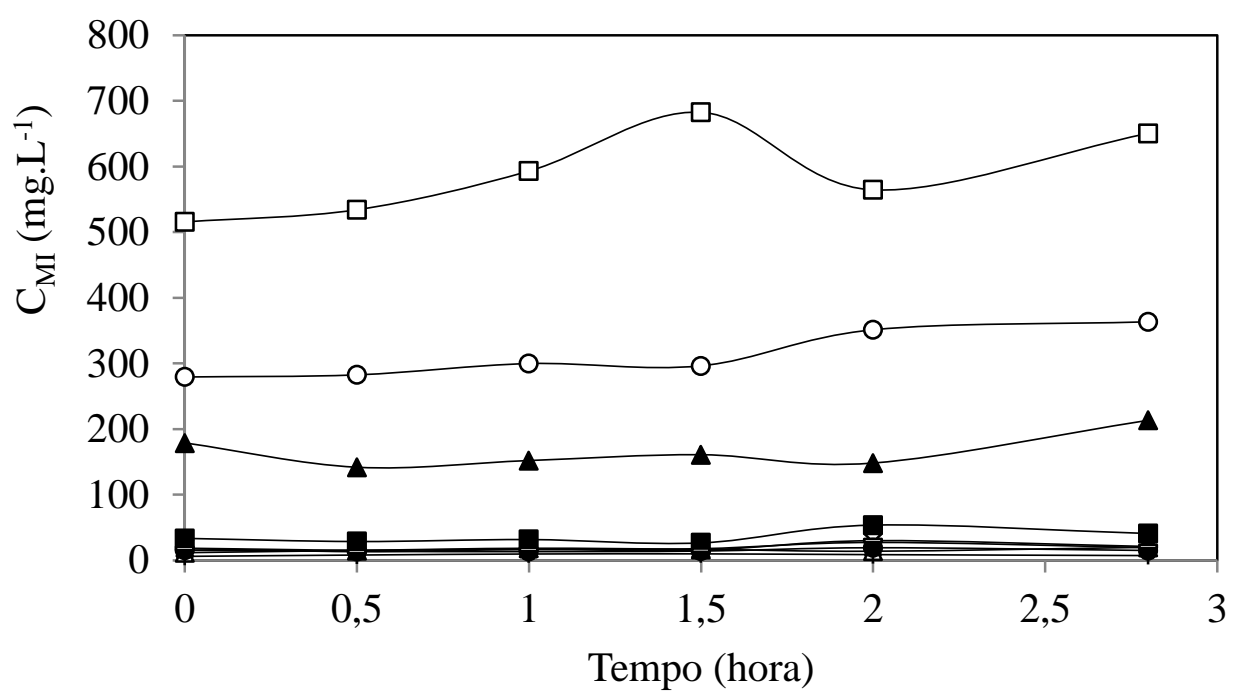

Figura 5-72 - Concentração dos compostos intermediários ao longo do ciclo: $\square$ - ácido acético; $\Delta$ - etanol; $\bigcirc$ - ácido butírico; $\boldsymbol{\square}$-ácido isobutírico; $\boldsymbol{\Delta}$ - ácido capróico; • ácido valérico; - -ácido propiônico; +butanol; — ácido isovalérico (AnSBBR com recirculação da fase líquida e soro de leite - Condição 4).

$\mathrm{O}$ pH diminuiu instantaneamente em relação ao afluente devido à diluição do mesmo com o volume residual no inicio do ciclo (alimentação do reator em 10 minutos) e permaneceu estável ao longo da operação conforme a Figura 5-73. A estabilidade do pH porém, não condiz com a produção de ácidos voláteis, tendo em vista que o sistema não apresentava no momento do monitoramento do perfil capacidade de tamponamento (apesar de a segunda parte da condição 4 ter sido realizada sem adição de ácido clorídrico, o perfil desta condição foi realizado com adição do mesmo para fins de comparação com a condição 1). Da mesma forma a alcalinidade total era consumida antes de entrar no reator, no galão de alimentação, devido à adição do ácido clorídrico concentrado, como pode ser observado na Figura 5-74. 


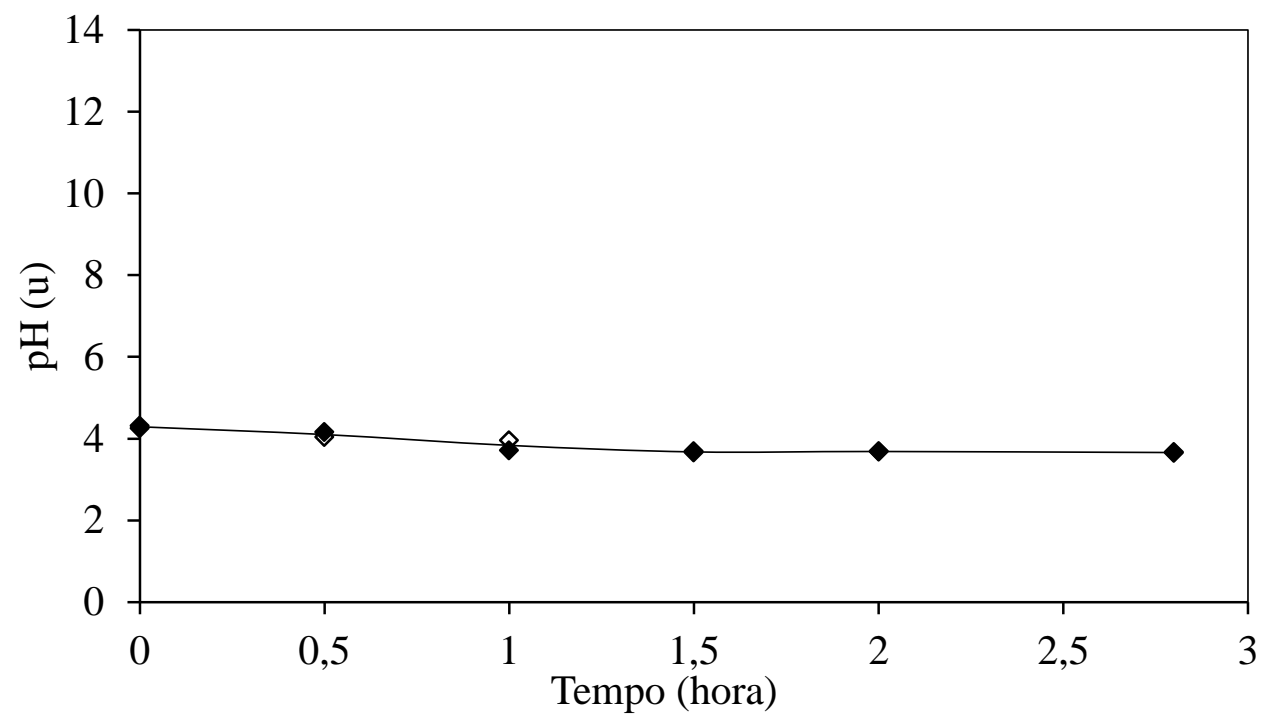

Figura 5-73 - Valores de pH: $\diamond$ - do perfil 1 , - do perfil 2 e - média dos dois perfis (AnSBBR com recirculação da fase líquida e soro de leite - Condição 4).

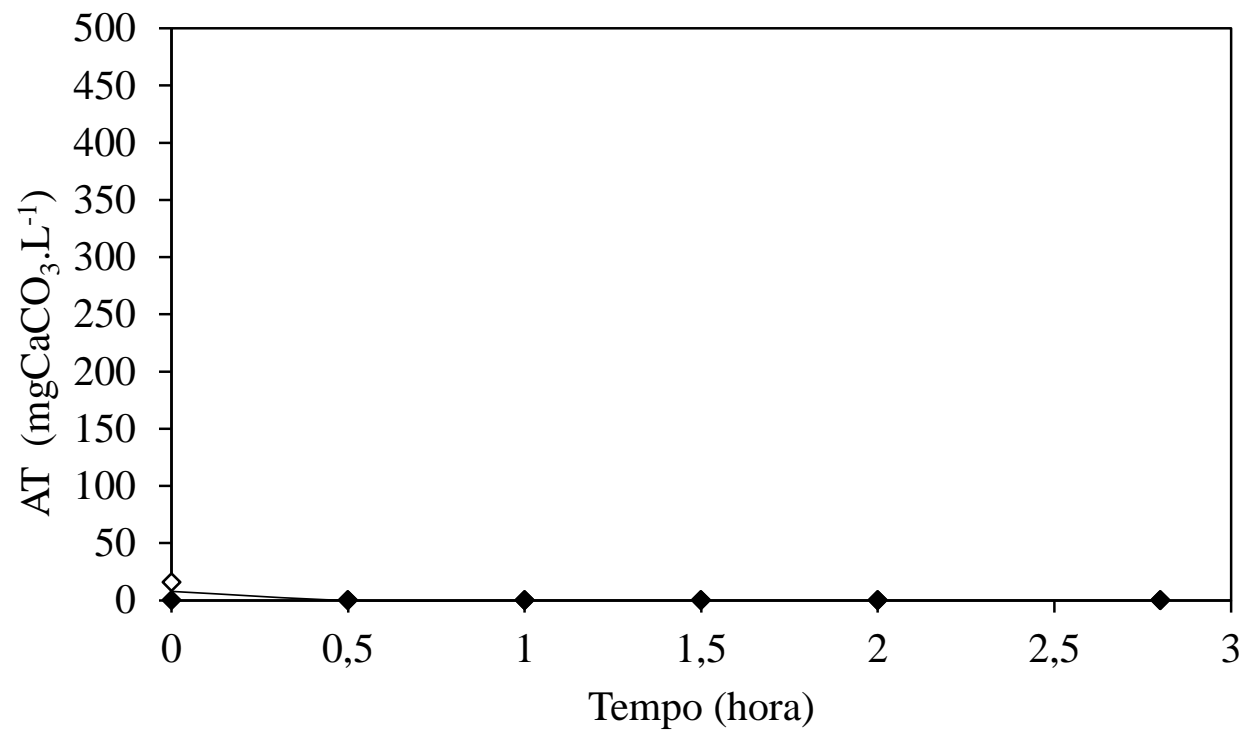

Figura 5-74 - Alcalinidade total: $\diamond$ - do perfil 1, - do perfil $2 \mathrm{e}$ - média dos dois perfis (AnSBBR com recirculação da fase líquida e soro de leite - Condição 4).

A produção volumétrica média acumulada do biogás, realizada com os valores dos perfis quantitativos mais consistentes obtidos durante a operação, juntamente com os desvios padrões encontram-se na Figura 5-75. A maior parte da produção ocorre no inicio do ciclo, até a metade do mesmo, e tem uma tendência a se estabilizar no final. A Tabela 5.18 resume os valores médios da produção, fração molar e os volumes 
individuais da mistura do biogás. A Figura 5-76 apresenta os volumes acumulados médios dos perfis de $\mathrm{H}_{2}, \mathrm{CO}_{2}$ e $\mathrm{CH}_{4}$ produzidos durante o ciclo.

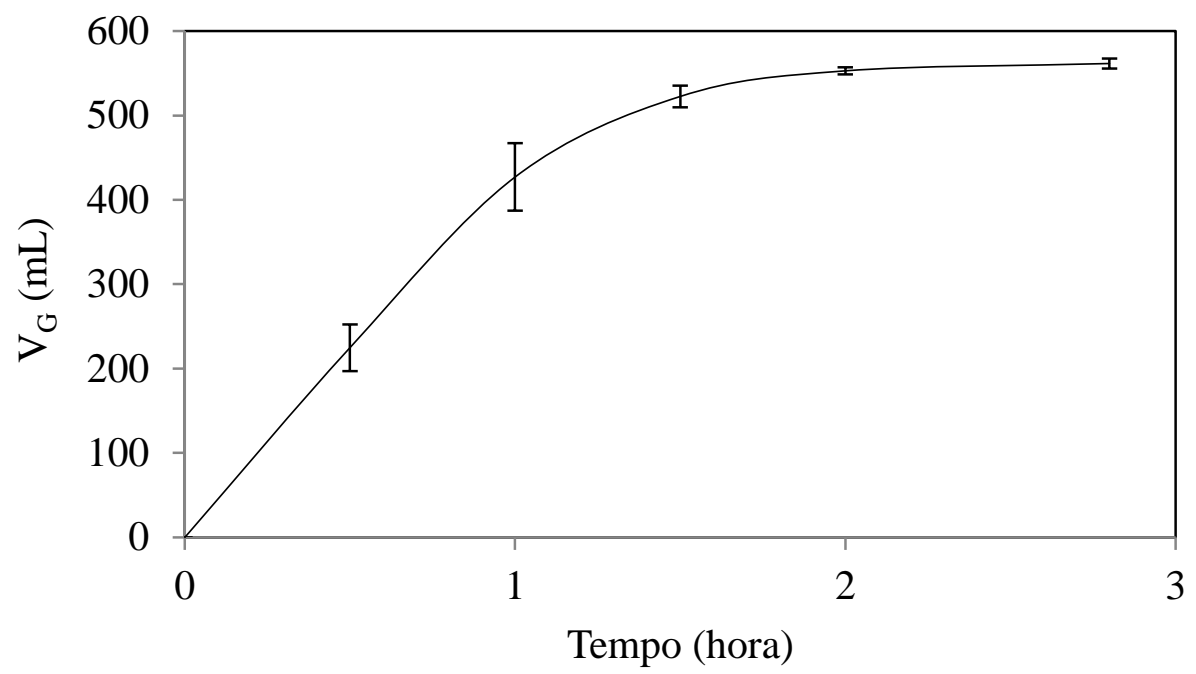

Figura 5-75 - Produção volumétrica média acumulada do biogás, realizada com os valores dos perfis quantitativos mais consistentes obtidos durante a operação, juntamente com os desvios padrões (AnSBBR com recirculação da fase líquida e soro de leite - Condição 4).

Tabela 5.18 - Valores médios da produção, fração molar e os volumes individuais da mistura do biogás (AnSBBR com recirculação da fase líquida e soro de leite - Condição 4).

\begin{tabular}{ccccccccccc}
\hline $\begin{array}{c}\text { Tempo } \\
(\mathrm{h})\end{array}$ & $\begin{array}{c}\mathrm{V}_{\mathrm{G}} \\
(\mathrm{mL}-\mathrm{CNTP})\end{array}$ & \multicolumn{3}{c}{$\mathrm{C}_{\mathrm{G}}\left(\mathrm{mmol} . \mathrm{L}^{-1}\right)$} & \multicolumn{3}{c}{ Fração Molar (\%) } & \multicolumn{3}{c}{ Volume $(\mathrm{mL}-\mathrm{CNTP})$} \\
& & $\mathrm{H}_{2}$ & $\mathrm{CO}_{2}$ & $\mathrm{CH}_{4}$ & $\mathrm{H}_{2}$ & $\mathrm{CO}_{2}$ & $\mathrm{CH}_{4}$ & $\mathrm{H}_{2}$ & $\mathrm{CO}_{2}$ & $\mathrm{CH}_{4}$ \\
\hline 0,0 & 0,0 & 0,0 & 0,0 & 0,0 & 0,0 & 0,0 & 0,0 & 0,0 & 0,0 & 0,0 \\
0,5 & 224,8 & 0,0 & 3,3 & 0,9 & 0,0 & 78,3 & 21,7 & 0,0 & 175,9 & 48,9 \\
1,0 & 427,0 & 0,0 & 5,0 & 2,2 & 0,0 & 69,2 & 30,6 & 0,0 & 315,9 & 110,8 \\
1,5 & 522,5 & 0,0 & 5,8 & 3,0 & 0,0 & 65,9 & 34,0 & 0,0 & 378,8 & 143,2 \\
2,0 & 552,8 & 0,0 & 6,1 & 3,5 & 0,0 & 63,5 & 36,5 & 0,0 & 398,1 & 154,3 \\
2,5 & 561,5 & 0,0 & 6,2 & 3,8 & 0,0 & 61,9 & 38,1 & 0,0 & 403,5 & 157,6 \\
3,0 & 0,0 & 0,0 & 0,0 & 0,0 & 0,0 & 0,0 & 0,0 & 0,0 & 0,0 & 0,0 \\
3,7 & 224,8 & 0,0 & 3,3 & 0,9 & 0,0 & 78,3 & 21,7 & 0,0 & 175,9 & 48,9 \\
\hline
\end{tabular}




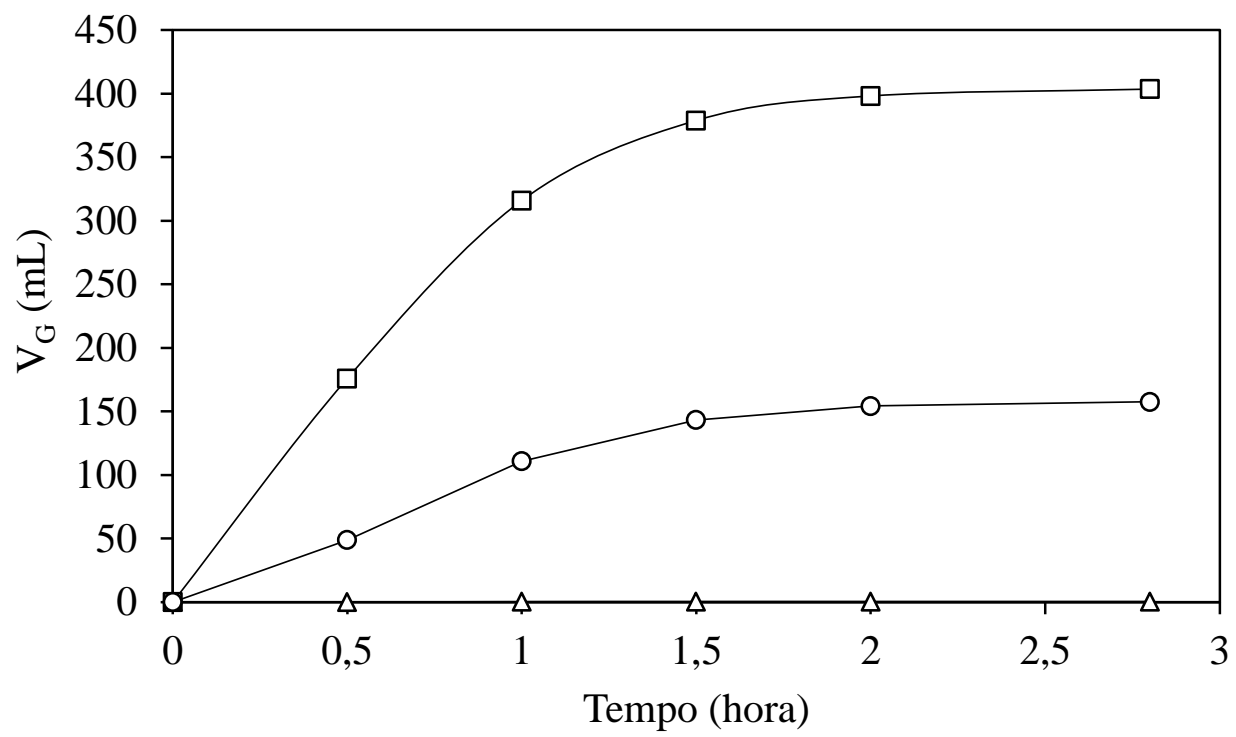

Figura 5-76 - Volumes acumulados médios produzidos ao longo do ciclo: $\square-\mathrm{CO}_{2} ; \Delta$ $\mathrm{H}_{2} ; \circ-\mathrm{CH}_{4}$ (AnSBBR com recirculação da fase líquida e soro de leite - Condição 4). 


\subsubsection{Condição 5 - Sem adaptação e afluente refrigerado}

A Condição 5 caracterizou-se por duas etapas. Na primeira etapa da Condição 5 o reator foi alimentado com soro de leite com COAV nominal de $14,6 \mathrm{kgDQO} \cdot \mathrm{m}^{-3} \cdot \mathrm{d}^{-1} \mathrm{e}$ duração do ciclo de 3 horas por um período de 24 dias (dia 175 ao dia 198). Esta foi a segunda condição onde o meio de alimentação foi mantido refrigerado a $4^{\circ} \mathrm{C}$. Como durante a Condição 3 (a primeira condição na qual o meio de alimentação foi mantido refrigerado) foram realizados alguns pequenos testes (adição de ácido clorídrico, retirada do bicarbonato de sódio e retirada do ácido clorídrico), optou-se por realizar uma operação completa com o meio refrigerado sem fazer nenhuma mudança durante o decorrer deste experimento, buscando, assim, compreender a real influência da refrigeração do afluente. A concentração afluente foi mantida, mudando-se apenas o tempo de ciclo.

Na segunda etapa da Condição 5 o reator continuou sendo alimentado com soro de leite, com a mesma COAV nominal e tempo de ciclo (14,6 kgDQO. $\mathrm{m}^{-3} \cdot \mathrm{d}^{-1}$ e 3 horas) por um período de 20 dias (dia 198 ao dia 217). A diferença desta etapa foi a forma de inoculação utilizada. Optou-se por realizar a fermentação natural do meio de alimentação, de acordo com metodologia proposta por Leite et al. (2008). Quatro litros de meio de alimentação à base de soro com DQO de $4250 \mathrm{mg} / \mathrm{L}$ foram preparados no dia 196 e deixados em contato com o ar fermentando. Após a lavagem e esterilização do material suporte e lavagem do reator, encheu-se este com o meio fermentado no dia 198 deixando este recirculando durante todo final de semana. No dia 201 foi retomada a alimentação normal com meio fresco à base de soro de leite. 
A Tabela 5.19 apresenta as variáveis monitoradas e seus respectivos valores médios comuns a todas as etapas, enquanto que a Tabela 5.20 mostra os parâmetros relacionados à carga orgânica e à produção de hidrogênio. 
Tabela 5.19 - Valores médios dos parâmetros monitorados comuns a todas as etapas da condição experimental 5 (Soro de leite - 4250 mgDQO.L

\begin{tabular}{|c|c|c|c|c|c|c|c|c|c|c|c|c|c|c|c|c|c|c|c|c|c|c|}
\hline & \multirow{2}{*}{ Parâmetro } & \multicolumn{10}{|c|}{ Etapa 1} & \multicolumn{11}{|c|}{ Etapa 2} \\
\hline & & \multicolumn{5}{|c|}{ Afluente } & \multicolumn{5}{|c|}{ Efluente } & \multicolumn{5}{|c|}{ Afluente } & \multicolumn{6}{|c|}{ Efluente } \\
\hline $\mathrm{C}_{\mathrm{ST}}$ & $\left(\mathrm{mgDQO} \cdot \mathrm{L}^{-1}\right)$ & 3765 & \pm & 246 & & & 3216 & \pm & 251 & & $13)$ & 3784 & \pm & 364 & & $10)$ & 3184 & \pm & 276 & & 10 & \\
\hline $\mathrm{C}_{\mathrm{SF}}$ & $\left(\mathrm{mgDQO} \cdot \mathrm{L}^{-1}\right)$ & - & \pm & - & $(3$ & 3 ) & 2916 & \pm & 240 & & $13)$ & - & \pm & - & ( & 3 ) & 3088 & \pm & 184 & & 10 & ) \\
\hline$\varepsilon_{\mathrm{ST}}$ & $(\%)$ & - & & - & & & 15 & \pm & 7 & & $13)$ & - & & - & & & 16 & \pm & 7 & ( & 10 & ) \\
\hline$\varepsilon_{\mathrm{SF}}$ & $(\%)$ & - & & - & & & 23 & \pm & 6 & & $13)$ & - & & - & & & 18 & \pm & 5 & ( & 10 & ) \\
\hline $\mathrm{C}_{\mathrm{CT}}$ & (mgCarboidrato. $\mathrm{L}^{-1}$ ) & 3509 & \pm & 357 & $(1)$ & $13)$ & 257 & \pm & 429 & & $13)$ & 3786 & \pm & 114 & ( & $9 \quad)$ & 466 & \pm & 500 & ( & 9 & ) \\
\hline $\mathrm{C}_{\mathrm{CF}}$ & (mgCarboidrato.L $\mathrm{L}^{-1}$ ) & - & \pm & - & ( & & 342 & \pm & 396 & & $13)$ & - & \pm & - & ( & ) & 448 & \pm & 498 & ( & 9 & ) \\
\hline$\varepsilon_{\mathrm{CT}}$ & $(\%)$ & - & & - & & & 92 & \pm & 12 & ( & $13)$ & - & & - & & & 88 & \pm & 13 & ( & 9 & ) \\
\hline$\varepsilon_{\mathrm{CF}}$ & $(\%)$ & - & & - & & & 90 & \pm & 11 & & $13)$ & - & & - & & & 88 & \pm & 13 & ( & 9 & ) \\
\hline $\mathrm{pH}$ & (u) & 7,70 & \pm & 0,05 & $(1)$ & 13 ) & 4,71 & \pm & 0,36 & ( & $13)$ & 7,76 & \pm & 0,17 & $(1$ & $10)$ & 4,38 & \pm & 0,42 & ( & 10 & ) \\
\hline AVT & $\left(\right.$ mgHAc. $\left.L^{-1}\right)$ & 110 & \pm & 6 & $(1)$ & $13)$ & 1263 & \pm & 385 & & $13)$ & 116 & \pm & 6 & $(1$ & $10)$ & 1064 & \pm & 315 & ( & 10 & ) \\
\hline AT & $\left(\mathrm{mgCaCO}_{3} \cdot \mathrm{L}^{-1}\right)$ & 435 & \pm & 17 & $(1)$ & 13 ) & 269 & \pm & 128 & & $13)$ & 435 & \pm & 10 & $(1$ & $10)$ & 129 & \pm & 113 & ( & 10 & ) \\
\hline $\mathrm{AP}$ & $\left(\mathrm{mgCaCO}{ }_{3} \cdot \mathrm{L}^{-1}\right)$ & 313 & \pm & 15 & $(1)$ & $13)$ & 0 & \pm & 0 & & $13)$ & 310 & \pm & 9 & $(1$ & $10)$ & 0 & \pm & 0 & ( & 10 & ) \\
\hline $\mathrm{AI}$ & $\left(\mathrm{mgCaCO}{ }_{3} \cdot \mathrm{L}^{-1}\right)$ & 122 & \pm & 11 & $(1)$ & $13)$ & 269 & \pm & 128 & & $13)$ & 125 & \pm & 10 & $(1$ & $10)$ & 129 & \pm & 113 & ( & 10 & ) \\
\hline $\mathrm{AB}$ & $\left(\mathrm{mgCaCO}{ }_{3} \cdot \mathrm{L}^{-1}\right)$ & 357 & \pm & 15 & $(1)$ & $13)$ & 0 & \pm & 0 & & $13)$ & 353 & \pm & 11 & $(1$ & $10)$ & 0 & \pm & 0 & ( & 10 & ) \\
\hline ST & $\left(\mathrm{mg} . \mathrm{L}^{-1}\right)$ & 3239 & \pm & 80 & ( 4 & 4 ) & 2441 & \pm & 162 & & $4)$ & 3415 & \pm & 175 & ( & $4 \quad)$ & 2593 & \pm & 367 & ( & 4 & ) \\
\hline STV & $\left(\mathrm{mg} \cdot \mathrm{L}^{-1}\right)$ & 2512 & \pm & 29 & ( 4 & 4 ) & 1748 & \pm & 161 & ( & $4)$ & 2699 & \pm & 221 & ( & $4 \quad)$ & 1921 & \pm & 297 & ( & 4 & ) \\
\hline $\mathrm{SST}$ & $\left(\mathrm{mg} \cdot \mathrm{L}^{-1}\right)$ & 176 & \pm & 18 & ( 4 & 4 ) & 220 & \pm & 70 & ( & 4 ) & 183,5 & \pm & 15 & ( & $4 \quad)$ & 115 & \pm & 67 & ( & 4 & ) \\
\hline SSV & $\left(\mathrm{mg} \cdot \mathrm{L}^{-1}\right)$ & 138,5 & \pm & 12 & ( 4 & 4 ) & 161 & \pm & 55 & ( & $4)$ & 146,5 & \pm & 13 & ( & $4 \quad)$ & 84 & \pm & 69 & ( & 4 & ) \\
\hline $\mathrm{M}_{\mathrm{STV}}$ & (g) & $\longrightarrow$ & & - & & & 39,24 & & - & & & - & & - & & & 30 & & - & & & \\
\hline $\mathrm{C}_{\mathrm{X}}$ & $\left(\mathrm{g} \cdot \mathrm{L}^{-1}\right)$ & - & & - & & & 11,41 & & - & & & - & & - & & & 8,25 & & - & & & \\
\hline $\mathrm{C}_{\mathrm{X}}^{\prime}$ & (g.gsuporte ${ }^{-1}$ ) & $\longrightarrow$ & & - & & & 0,0278 & & - & & & - & & - & & & 0,02 & & - & & & \\
\hline $\mathrm{V}_{\mathrm{G}}$ & (mL-CNTP) & - & & - & & & 541 & \pm & 14 & ( & $3)$ & - & & - & & & 332 & \pm & 3 & ( & 3 & ) \\
\hline $\mathrm{V}_{\mathrm{H} 2}$ & (mL-CNTP) & - & & - & & & 26 & \pm & - & ( & $1)$ & - & & - & & & - & & - & & & \\
\hline
\end{tabular}

(*) Entre parêntese o número de amostras considerado no cálculo da média. 
Tabela 5.20 - Valores médios dos parâmetros relacionados à carga orgânica e à produção de hidrogênio da condição 5 (Soro de leite - $4250 \mathrm{mgDQO} \mathrm{L}^{-1}-\mathrm{t}_{\mathrm{C}} 3 \mathrm{~h}$ ).

\begin{tabular}{|c|c|c|c|c|c|c|}
\hline & \multirow{2}{*}{ Parâmetro } & \multicolumn{3}{|c|}{ Etapa 1} & \multicolumn{2}{|c|}{ Etapa 2} \\
\hline & & Afluen & & Efluente & Afluente & Efluente \\
\hline COAV $_{\text {STA }}$ & $\left(\operatorname{kgDQO} \cdot \mathrm{m}^{-3} \cdot \mathrm{d}^{-1}\right)$ & 12,91 & & - & 12,97 & - \\
\hline $\mathrm{CORV}_{\mathrm{SFE}}$ & $\left(\right.$ kgDQO. $\left.m^{-3} \cdot d^{-1}\right)$ & - & & 2,91 & - & 2,38 \\
\hline COAV $_{\text {СТA }}$ & $\left(\mathrm{kgCarboidrato} \cdot \mathrm{m}^{-3} \cdot \mathrm{d}^{-1}\right)$ & 12,03 & & - & 12,98 & - \\
\hline $\mathrm{CORV}_{\mathrm{CFE}}$ & $\left(\right.$ kgCarboidrato. $\left.\mathrm{m}^{-3} \cdot \mathrm{d}^{-1}\right)$ & $\longrightarrow$ & & 10,86 & - & 11,44 \\
\hline $\mathrm{COAE}_{\mathrm{STA}}$ & $\left(\mathrm{kgDQO} \cdot \mathrm{kgSTV}^{-1} \cdot \mathrm{d}^{-1}\right)$ & 1,15 & & - & 1,52 & - \\
\hline $\mathrm{CORE}_{\mathrm{SFE}}$ & $\left(\mathrm{kgDQO} \cdot \mathrm{kgSTV}^{-1} \cdot \mathrm{d}^{-1}\right)$ & $\longrightarrow$ & & 0,26 & - & 0,28 \\
\hline COAE $_{\text {СTA }}$ & $\left(\mathrm{kgCarboidrato} \mathrm{kgSTV}^{-1} \cdot \mathrm{d}^{-1}\right)$ & 1,07 & & - & 1,52 & - \\
\hline $\mathrm{CORE}_{\mathrm{CFE}}$ & $\left(\mathrm{kgCarboidrato.kgSTV}^{-1} \cdot \mathrm{d}^{-1}\right)$ & - & & 0,97 & - & 1,34 \\
\hline $\mathrm{RMCR}_{\mathrm{C}, \mathrm{n}}$ & $\left(\mathrm{molH}_{2 .}\right.$ molCarboidrato $\left.^{-1}\right)$ & - & & 0,08 & - & - \\
\hline $\mathrm{n}_{\mathrm{H} 2}$ & $\left(\mathrm{molH}_{2} \cdot \mathrm{d}^{-1}\right)$ & - & & 0,01 & - & - \\
\hline PrM & $\left(\mathrm{molH}_{2} \cdot \mathrm{m}^{-3} \cdot \mathrm{d}^{-1}\right)$ & - & & 2,66 & - & - \\
\hline PrME & $\left(\mathrm{molH}_{2} \cdot \mathrm{kgSVT}^{-1} \cdot \mathrm{d}^{-1}\right)$ & $\longrightarrow$ & & 0,23 & - & - \\
\hline $\mathrm{RMCA}_{\mathrm{S}, \mathrm{m}}$ & $\left(\mathrm{molH}_{2} \cdot \mathrm{kgDQO}^{-1} \cdot \mathrm{d}^{-1}\right)$ & 0,20 & & - & - & - \\
\hline $\mathrm{RMCA}_{\mathrm{C}, \mathrm{m}}$ & $\left(\mathrm{molH}_{2} \cdot \mathrm{kg}^{-1} \cdot \mathrm{d}^{-1}\right)$ & 0,22 & & - & - & - \\
\hline $\mathrm{RMCR}_{\mathrm{S}, \mathrm{m}}$ & $\left(\mathrm{molH}_{2} \cdot \mathrm{kgDQO}^{-1} \cdot \mathrm{d}^{-1}\right)$ & - & & 0,90 & - & - \\
\hline $\mathrm{RMCR}_{\mathrm{C}, \mathrm{m}}$ & $\left(\mathrm{molH}_{2} \cdot \mathrm{kg}^{-1} \cdot \mathrm{d}^{-1}\right)$ & - & & 0,24 & - & - \\
\hline$V_{R}$ & $(\mathrm{~mL})$ & 2000 & & & 2000 & \\
\hline $\mathrm{V}_{\mathrm{A}}$ & $(\mathrm{mL})$ & 1430 & $\pm 45\left(^{12}\right)$ & - & $1488 \pm 45\left({ }^{10}\right)$ & - \\
\hline $\mathrm{Q}_{\mathrm{R}}$ & $\left(\mathrm{mL} \cdot \mathrm{s}^{-1}\right)$ & 6 & $\pm 0\left(^{3}\right)$ & - & $6,34 \pm 00\left(^{2}\right)$ & 一 \\
\hline
\end{tabular}

(*) Entre parêntese o número de amostras considerado no cálculo da média.

A Figura 5-77 apresenta os valores da concentração afluente (não filtrada) e efluente (não filtrada e filtrada) de matéria orgânica (DQO) no sistema, enquanto que a Figura 5-78 apresenta a eficiência de remoção do mesmo parâmetro durante o monitoramento diário. Esta eficiência atingiu, em média, 15 e 16\% para as amostras não filtradas e 23 e $18 \%$ para amostras filtradas (para as etapas 1 e 2 respectivamente). Para a primeira etapa da Condição 5, a média de concentração afluente (amostras não filtradas) do substrato foi de $3765 \mathrm{mgDQO} . \mathrm{L}^{-1}$ e de $3216 \mathrm{mgDQO} . \mathrm{L}^{-1}$ e 2916 $\operatorname{mgDQO} . \mathrm{L}^{-1}$ para amostras de efluente não filtrada e filtrada, respectivamente. Para a segunda etapa da Condição 5, a média de concentração afluente (amostras não filtradas) do substrato foi de $3784 \mathrm{mgDQO} . \mathrm{L}^{-1}$ e de $3184 \mathrm{mgDQO} . \mathrm{L}^{-1}$ e $3088 \mathrm{mgDQO} . \mathrm{L}^{-1}$ para amostras de efluente não filtrada e filtrada, respectivamente. 


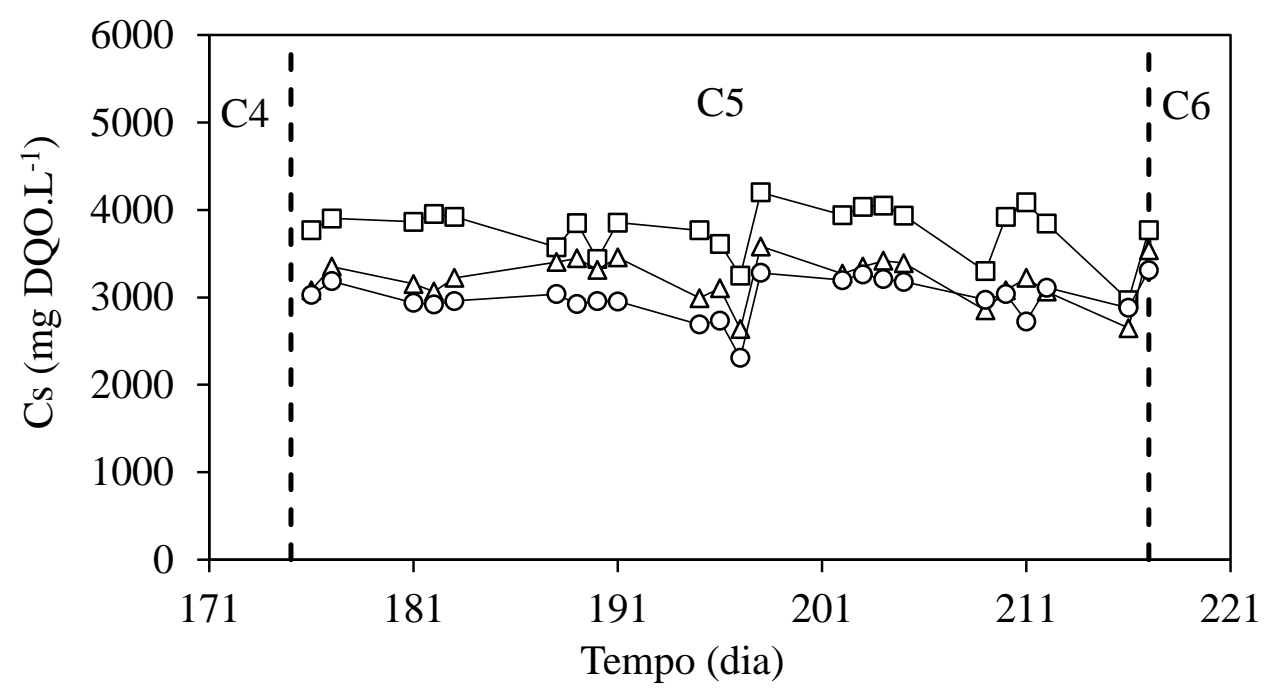

Figura 5-77 - Concentração de matéria orgânica (DQO): $\square$ - afluente não filtrada; $\Delta$ efluente não filtrada; $\bigcirc$ - efluente filtrada (AnSBBR com recirculação da fase líquida e soro de leite - Condição 5).

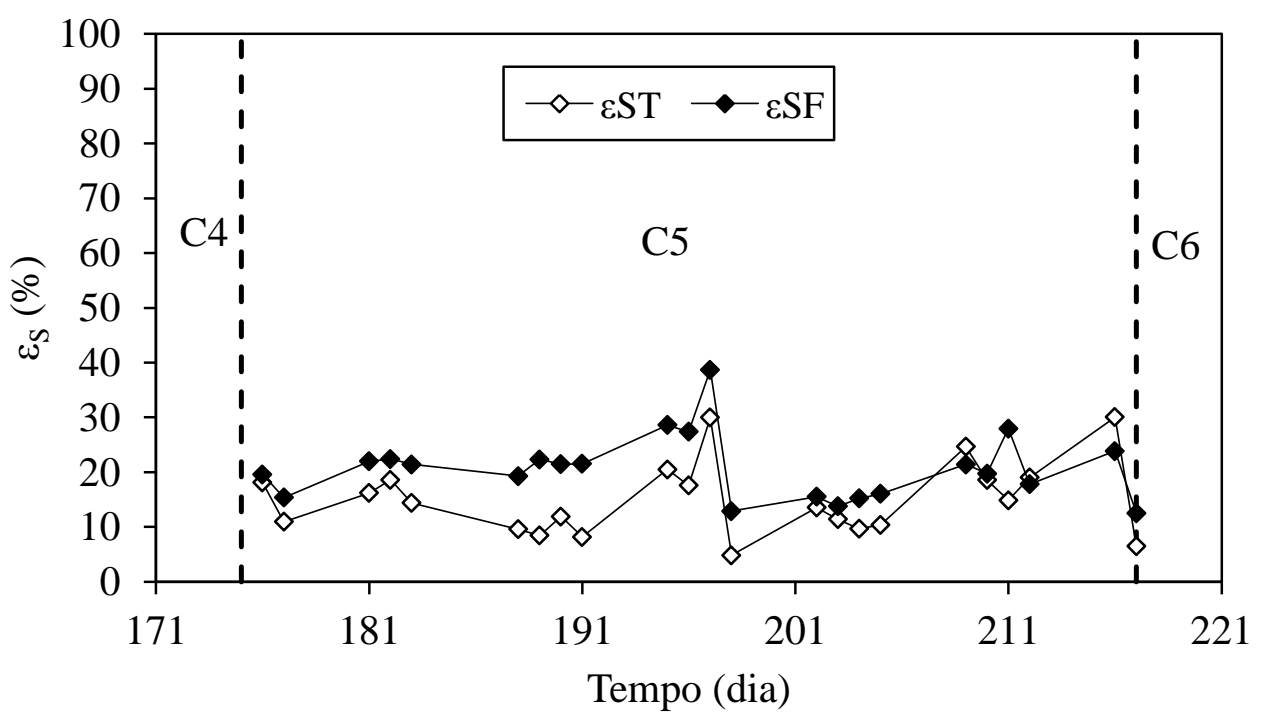

Figura 5-78 - Eficiência de remoção de matéria orgânica (DQO): $\diamond$ - não filtrada; filtrada (AnSBBR com recirculação da fase líquida e soro de leite - Condição 5).

A Figura 5-79 apresenta os valores da concentração de carboidratos afluente e efluente (para amostras filtradas e não filtradas). A Figura 5-80 apresenta a eficiência de remoção do mesmo parâmetro (não filtrada e filtrada) durante o monitoramento diário. Esta eficiência atingiu, em média, 93 e $88 \%$ para as amostras não filtradas e 94 e $88 \%$ 
para amostras filtradas (para as etapas 1 e 2 respectivamente). Para a primeira etapa da Condição 5, a média de concentração afluente para amostras não filtradas do substrato foi de 3509 mgCarboidrato. $\mathrm{L}^{-1}$ e de $257 \mathrm{mgCarboidrato.} \mathrm{L}^{-1}$ e $198 \mathrm{mgCarboidrato.} \mathrm{L}^{-1}$ para amostras de efluente não filtrada e filtrada, respectivamente. Para a segunda etapa da Condição 5, a média de concentração afluente para amostras não filtradas do substrato foi de $3786 \mathrm{mgCarboidrato.L^{-1 }}$ e de 466 mgCarboidrato. $\mathrm{L}^{-1}$ e 448 mgCarboidrato. $\mathrm{L}^{-1}$ para amostras de efluente não filtrada e filtrada, respectivamente.

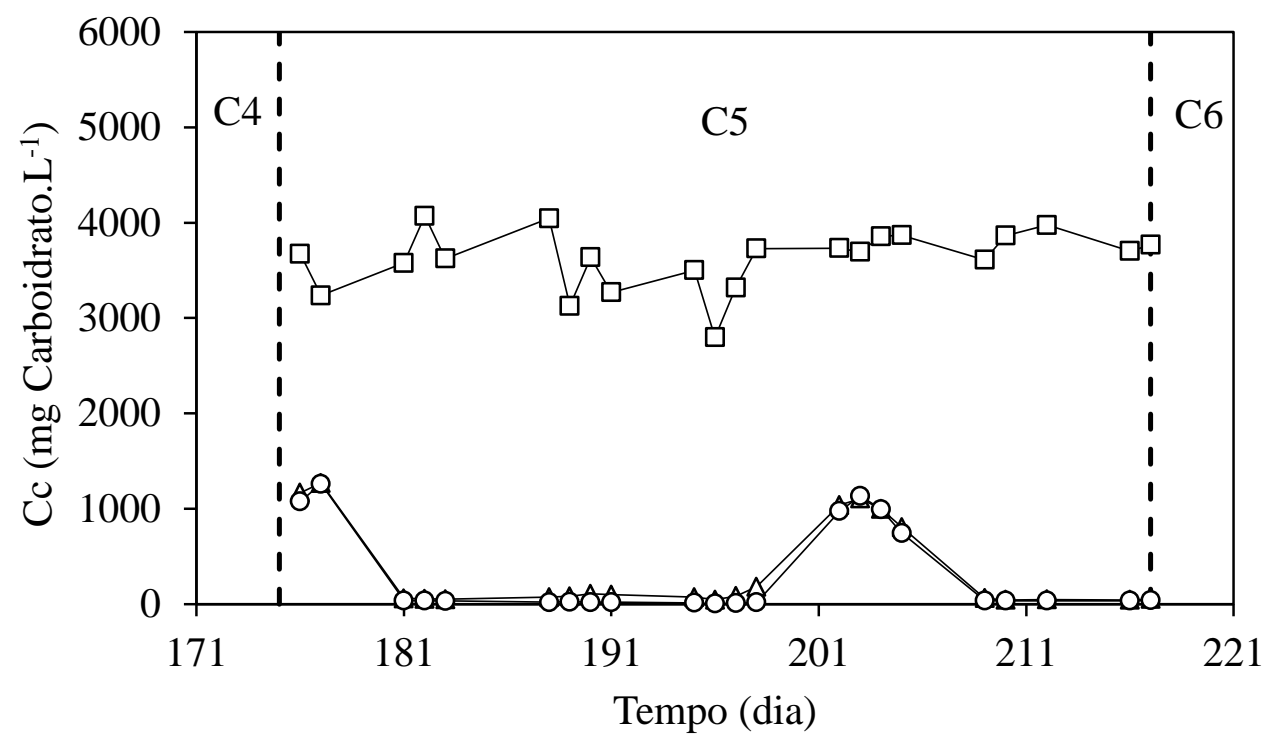

Figura 5-79 - Concentração de carboidrato: $\square-$ afluente não filtrada; $\Delta$ - efluente não filtrada; ○ - efluente filtrada (AnSBBR com recirculação da fase líquida e soro de leite Condição 5). 


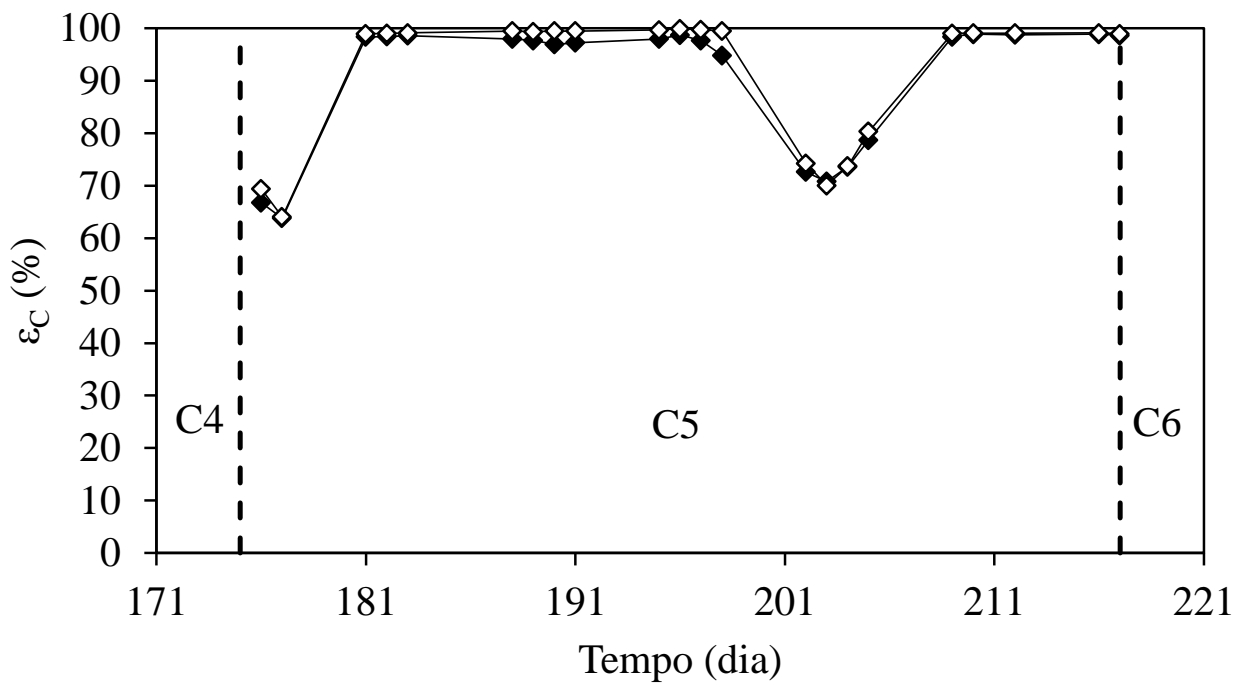

Figura 5-80 - Eficiência de remoção de carboidrato: $\diamond$ - não filtrada; - filtrada (AnSBBR com recirculação da fase líquida e soro de leite - Condição 5).

As Figura 5-81, Figura 5-82 e Figura 5-83 apresentam o monitoramento diário, tanto para o afluente quanto para o efluente, do $\mathrm{pH}$, da alcalinidade total e dos ácidos voláteis totais, respectivamente. A média dos valores de $\mathrm{pH}$ afluente foi de 7,70 e 7,76 e de $\mathrm{pH}$ efluente foi de 4,71 e 4,38 (para as etapas 1 e 2 respectivamente). A média da alcalinidade total afluente foi de 453 e $435 \mathrm{mgCaCO}_{3} \cdot \mathrm{L}^{-1}$ e efluente de 269 e 129 $\mathrm{mgCaCO}_{3} \cdot \mathrm{L}^{-1}$ (para as etapas 1 e 2 respectivamente). O valor médio da concentração de ácidos voláteis totais afluente foi de 110 e 116 mgHAc. $\mathrm{L}^{-1}$ e efluente de 1263 e 1064 $\operatorname{mgHAc} . \mathrm{L}^{-1}$ (para as etapas 1 e 2 respectivamente). 


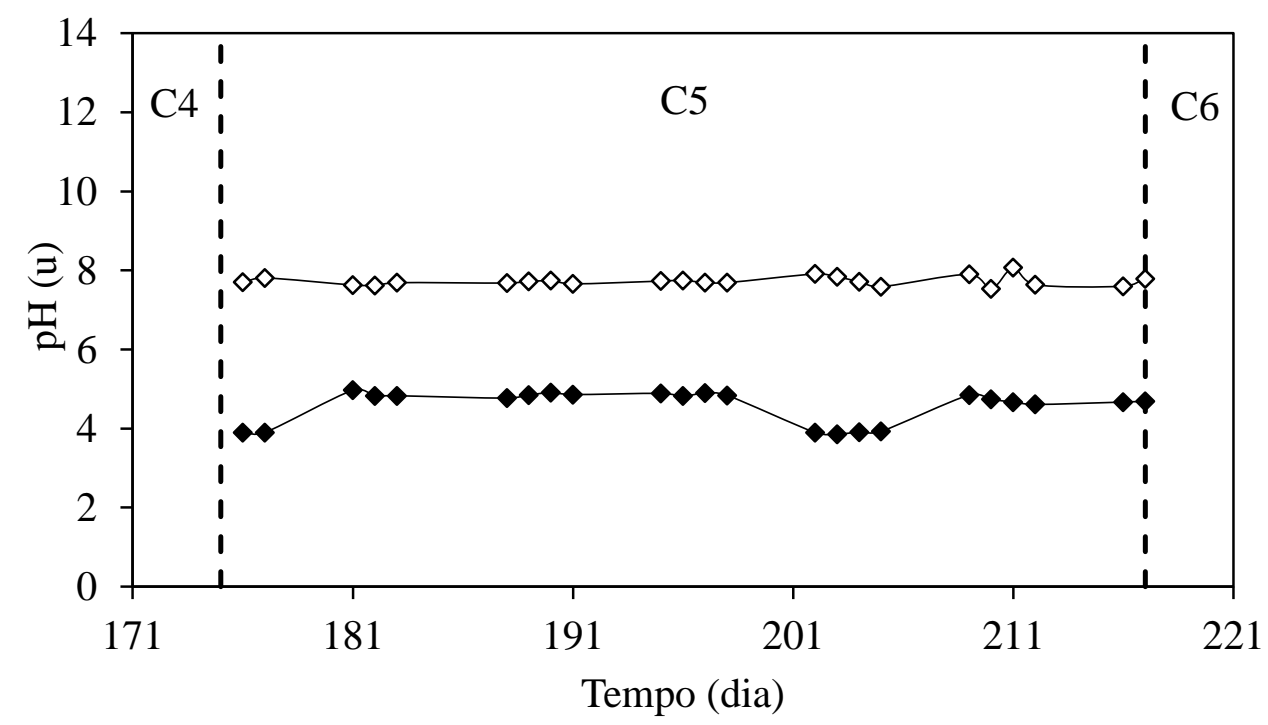

Figura 5-81 - Valores de pH: $\diamond$-afluente; $\downarrow$ - efluente (AnSBBR com recirculação da fase líquida e soro de leite - Condição 5).

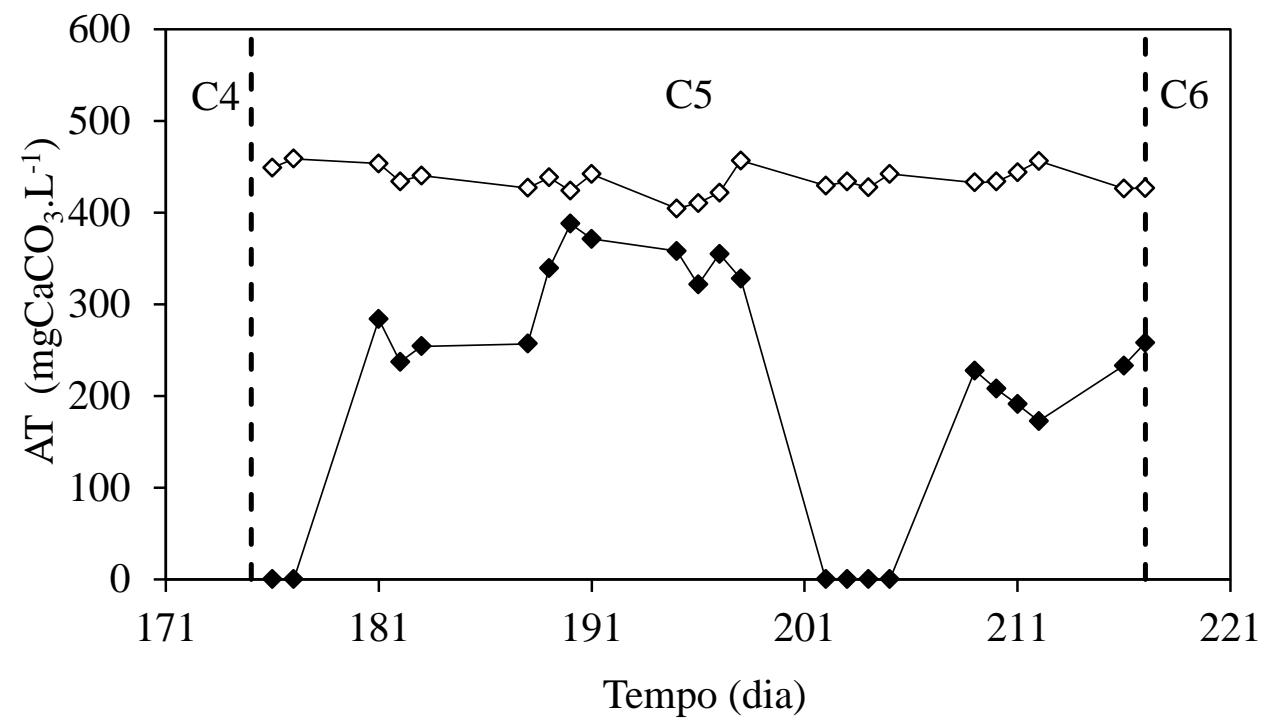

Figura 5-82 - Alcalinidade total: $\diamond$-afluente; $\downarrow$ - efluente (AnSBBR com recirculação da fase líquida e soro de leite - Condição 5). 


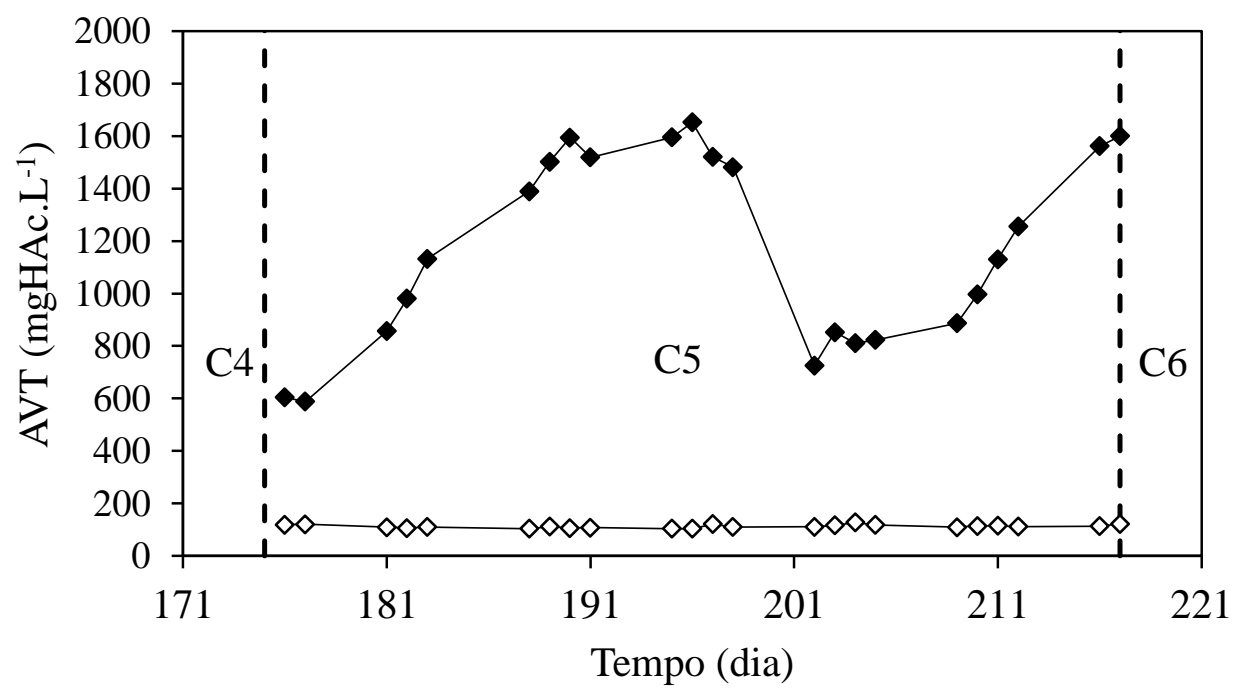

Figura 5-83 - Ácidos voláteis totais: $\diamond$-afluente; - efluente (AnSBBR com recirculação da fase líquida e soro de leite - Condição 5).

A Figura 5-84 apresenta o monitoramento dos compostos intermediários contidos no efluente do sistema, enquanto que a Tabela 5.21 apresenta os valores da concentração média destes produto. Em ambas as etapas predominou a presença do ácido acético $(29,1 \%$ e 66,9\% dos compostos intermediários, para a etapa 1 e 2 respectivamente). 


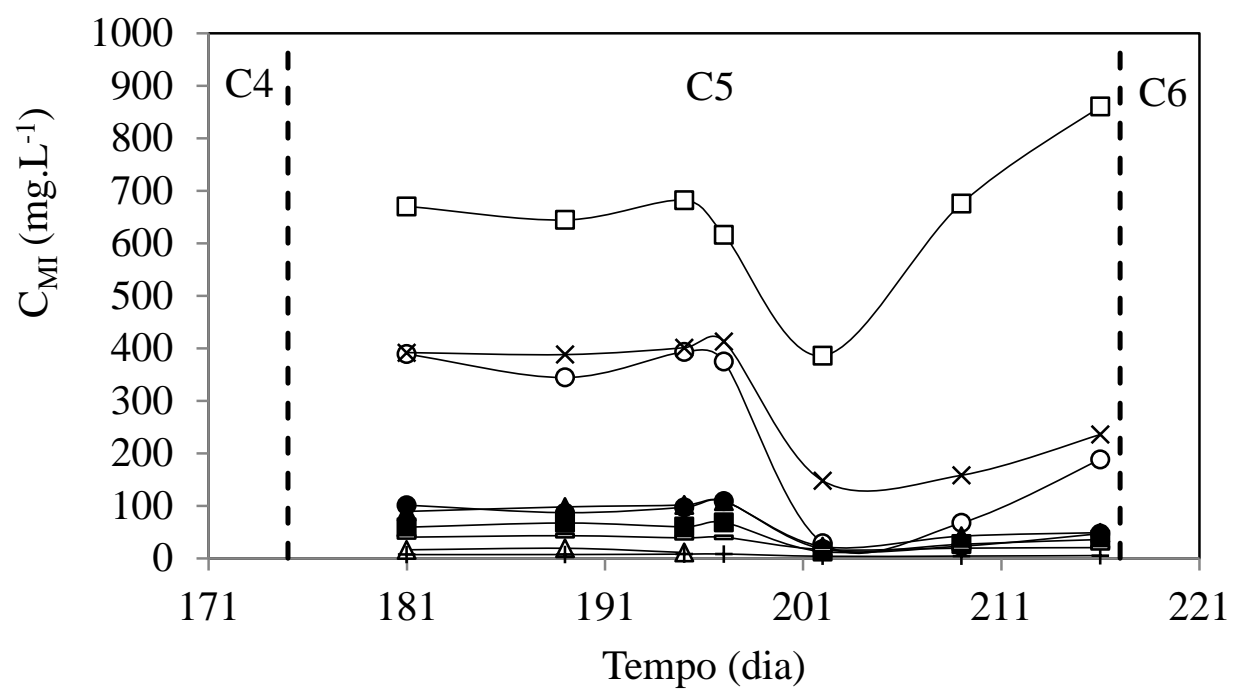

Figura 5-84 - Concentração dos compostos intermediários durante o monitoramento: - ácido acético; $\Delta$ - etanol; O - ácido butírico; - ácido isobutírico; $\boldsymbol{\Delta}$ - ácido capróico; • - ácido valérico; - * ácido propiônico; † butanol; — ácido isovalérico (AnSBBR com recirculação da fase líquida e soro de leite - Condição 5).

Tabela 5.21 - Concentração média e distribuição dos compostos intermediários (AnSBBR com recirculação da fase líquida e soro de leite - Condição 5).

\begin{tabular}{|c|c|c|c|c|c|c|c|c|c|c|c|c|c|}
\hline \multirow{4}{*}{$\begin{array}{c}\begin{array}{c}\text { Produtos } \\
\text { intermediários }\end{array} \\
\text { Acetona }\end{array}$} & \multicolumn{7}{|c|}{ Etapa 1} & \multicolumn{6}{|c|}{ Etapa 2} \\
\hline & \multicolumn{6}{|c|}{ Concentrações média } & \multirow{3}{*}{$\begin{array}{c}\text { Distribuição } \\
(\%) \\
0,00\end{array}$} & \multicolumn{5}{|c|}{ Concentrações média } & \multirow{3}{*}{$\begin{array}{c}\begin{array}{c}\text { Distribuição } \\
(\%)\end{array} \\
0,00\end{array}$} \\
\hline & \multicolumn{3}{|c|}{$\left(\mathrm{mg} \cdot \mathrm{L}^{-1}\right)$} & \multicolumn{3}{|c|}{$\left(\mathrm{mmol} . \mathrm{L}^{-1}\right)$} & & \multicolumn{3}{|c|}{$\left(\mathrm{mg} \cdot \mathrm{L}^{-1}\right)$} & \multicolumn{2}{|c|}{$\left(\mathrm{mmol} . \mathrm{L}^{-1}\right)$} & \\
\hline & 0,00 & \pm & 0,00 & 0,00 & \pm & 0,00 & & 0,00 & \pm & 0,00 & 0,00 & $\pm 0,00$ & \\
\hline Metanol & 0,00 & \pm & 0,00 & 0,00 & \pm & 0,00 & 0,00 & 0,00 & \pm & 0,00 & 0,00 & $\pm 0,00$ & 0,00 \\
\hline Etanol & 14,9 & \pm & 3,4 & 0,3 & \pm & 0,1 & 1,3 & 34,4 & \pm & 7,1 & 0,7 & $\pm 0,2$ & 4,6 \\
\hline n-Butanol & 7,5 & \pm & 0,6 & 0,1 & \pm & 0,0 & 0,4 & 4,3 & \pm & 0,7 & 0,1 & $\pm 0,0$ & 0,4 \\
\hline Acético & 653,3 & \pm & 29,1 & 10,9 & \pm & 0,5 & 45,3 & 640,7 & \pm & 239,3 & 10,7 & $\pm 4,0$ & 66,3 \\
\hline Porpiônico & 398,5 & \pm & 11,3 & 5,4 & \pm & 0,2 & 22,4 & 180,4 & \pm & 48,2 & 2,4 & $\pm 0,7$ & 15,1 \\
\hline Isobutírico & 63,6 & \pm & 4,7 & 0,7 & \pm & 0,1 & 3,0 & 24,9 & \pm & 11,7 & 0,3 & $\pm 0,1$ & 1,8 \\
\hline Butírico & 375,4 & \pm & 27,1 & 4,3 & \pm & 0,3 & 17,7 & 94,9 & \pm & 83,2 & 1,1 & $\pm 0,9$ & 6,7 \\
\hline Isovalérico & 40,4 & \pm & 1,8 & 0,4 & \pm & 0,0 & 1,6 & 18,6 & \pm & 1,9 & 0,2 & $\pm 0,0$ & 1,1 \\
\hline Valérico & 98,5 & \pm & 9,2 & 1,0 & \pm & 0,1 & 4,0 & 29,2 & \pm & 15,6 & 0,3 & $\pm 0,2$ & 1,8 \\
\hline Capróico & 99,3 & \pm & 8,1 & 1,0 & \pm & 0,1 & 4,1 & 37,7 & \pm & 13,8 & 0,4 & $\pm 0,1$ & 2,3 \\
\hline
\end{tabular}

O monitoramento da série de sólidos é mostrado na Tabela 5.22, cujos valores apresentam um baixo teor de SSV no efluente e afluente, indicando a boa capacidade do reator em reter biomassa, mesmo no começo da operação. 
Tabela 5.22 - Série de sólidos afluente e efluente (AnSBBR com recirculação da fase líquida e soro de leite - Condição 5)

\begin{tabular}{llcccc}
\hline & & $\begin{array}{c}\text { ST } \\
\left(\mathrm{mg} . \mathrm{L}^{-1}\right)\end{array}$ & $\begin{array}{c}\text { SVT } \\
\left(\mathrm{mg} . \mathrm{L}^{-1}\right)\end{array}$ & $\begin{array}{c}\text { SST } \\
\left(\mathrm{mg} . \mathrm{L}^{-1}\right)\end{array}$ & $\begin{array}{c}\text { SSV } \\
\left(\mathrm{mg} . \mathrm{L}^{-1}\right)\end{array}$ \\
\hline \multirow{2}{*}{ Etapa 1 } & Afluente & $3239 \pm 80$ & $2512 \pm 29$ & $176 \pm 18$ & $139 \pm 12$ \\
& Efluente & $2441 \pm 162$ & $1748 \pm 161$ & $220 \pm 70$ & $161 \pm 55$ \\
\multirow{2}{*}{ Etapa 2 } & Afluente & $3415 \pm 175$ & $2699 \pm 221$ & $184 \pm 15$ & $147 \pm 13$ \\
& Efluente & $2593 \pm 368$ & $1921 \pm 297$ & $115 \pm 67$ & $84 \pm 69$ \\
\hline
\end{tabular}

*Número de amostras consideradas $=4$ para ambas as etapas.

A produção quantitativa do biogás por ciclo é apresentada na Figura 5-85. A produção média foi de $402 \mathrm{~mL}$ (CNTP). A Figura 5-86 apresenta o monitoramento das concentrações dos componentes do biogás no final do ciclo, enquanto que a Figura 5-87 apresenta a distribuição destes mesmos componentes. Os valores médios de concentração de $\mathrm{H}_{2}$ foram, para as etapas 1 e 2 respectivamente, 0,4 e 0,9 mmol.L $\mathrm{L}^{-1}$, Para o $\mathrm{CH}_{4}$ os valores médios de concentração foram, para as etapas 1 e 2 respectivamente, 4,3 e 0,1 mmol. $\mathrm{L}^{-1}$. Por último, os valores médios de concentração de $\mathrm{CO}_{2}$ foram 9,5 e 6,6 mmol. $\mathrm{L}^{-1}$ para as etapas 1 e 2 respectivamente. Além disso, a distribuição percentual média de $\mathrm{H}_{2}$ foi de 2,7 e 10,8\% (para as etapas 1 e 2 respectivamente), a de $\mathrm{CH}_{4}$ foi de 30,3 e 0,5\% (para as etapas 1 e 2 respectivamente) e a de $\mathrm{CO}_{2}$ foi de 67,1 e $88,7 \%$ (para as etapas 1 e 2 respectivamente).

Apesar dos valores de concentração de $\mathrm{H}_{2}$ na segunda etapa não terem propriamente zerado, optou-se por interromper a Condição 5 devido à queda acentuada na produção de hidrogênio junto com o aparecimento de metano. Na operação desta condição, realizada com refrigeração do meio, existiram indícios de produção de $\mathrm{H}_{2} \mathrm{~S}$ (odor característico e formação de substância branca recobrindo o exterior das mangueiras de alimentação) por possível ação de bactérias redutoras de sulfato (BRS), apesar de análises específicas para detecção deste composto não terem sido realizadas. 
Isto explicaria a queda na produção de hidrogênio sem concomitante aumento do metano.

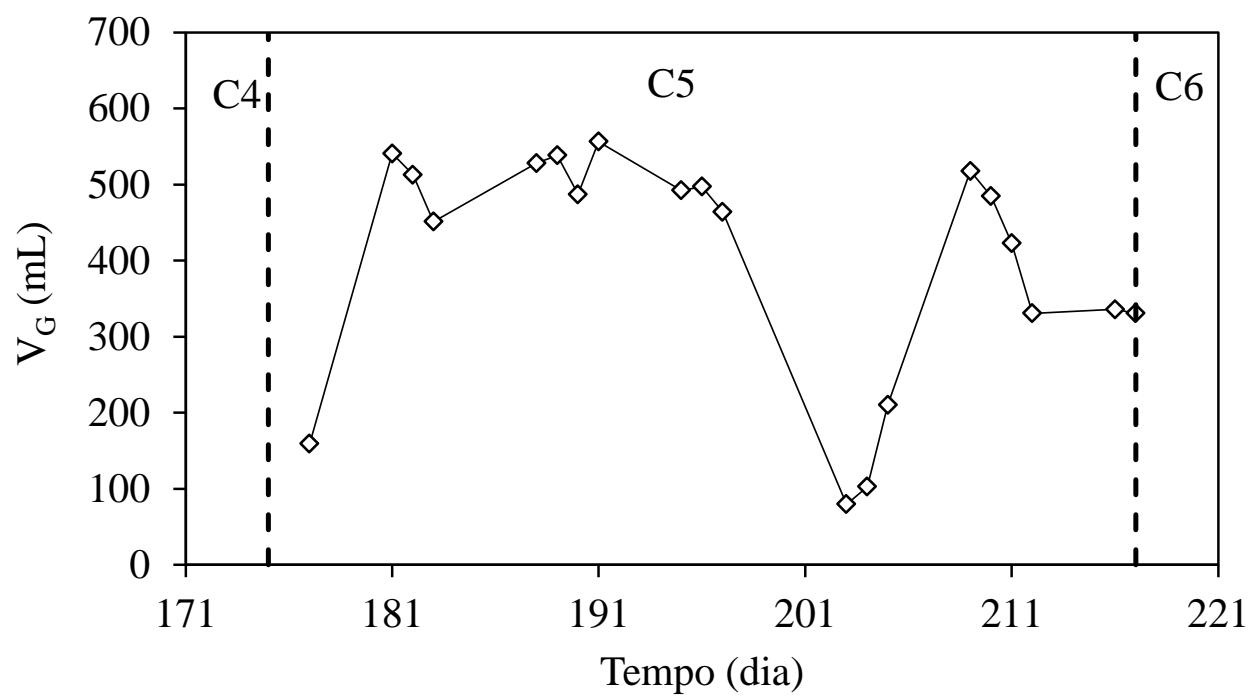

Figura 5-85 - Volume de biogás produzido por ciclo (AnSBBR com recirculação da fase líquida e soro de leite - Condição 5).

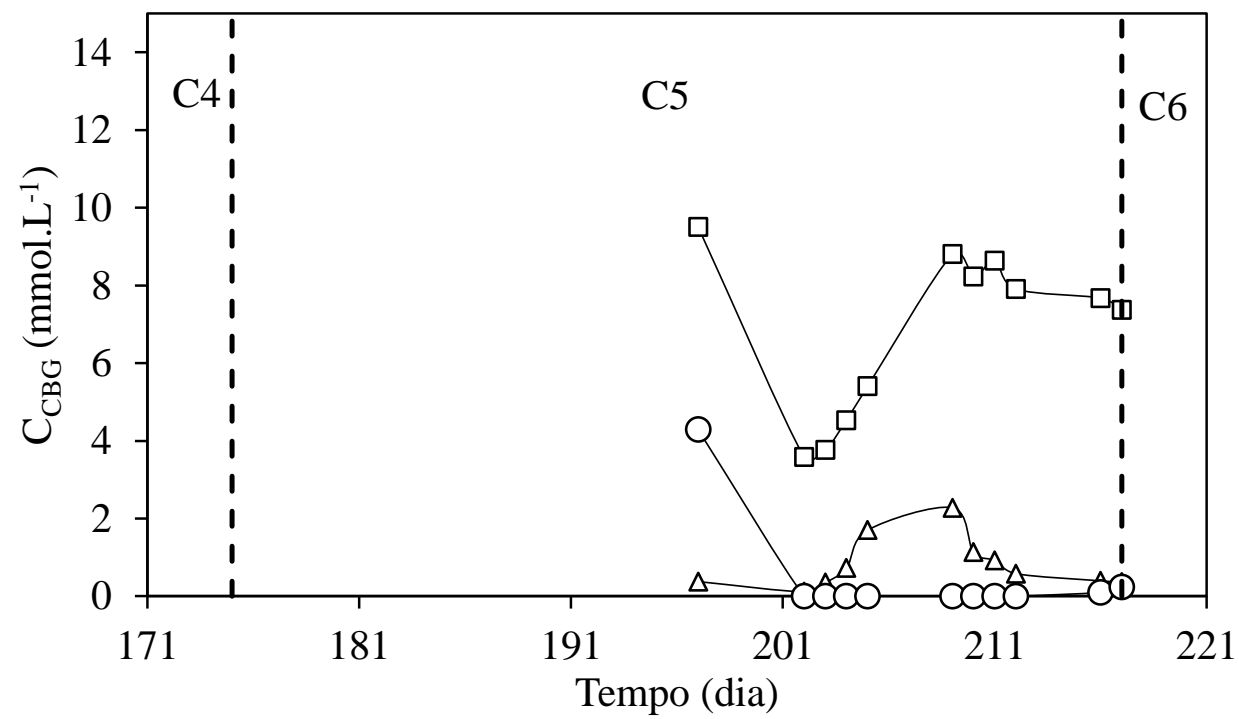

Figura 5-86 - Concentrações dos componentes do biogás no final do ciclo: $\square-\mathrm{CO}_{2} ; \Delta$ $\mathrm{H}_{2} ; \circ-\mathrm{CH}_{4}$ (AnSBBR com recirculação da fase líquida e soro de leite - Condição 5). 


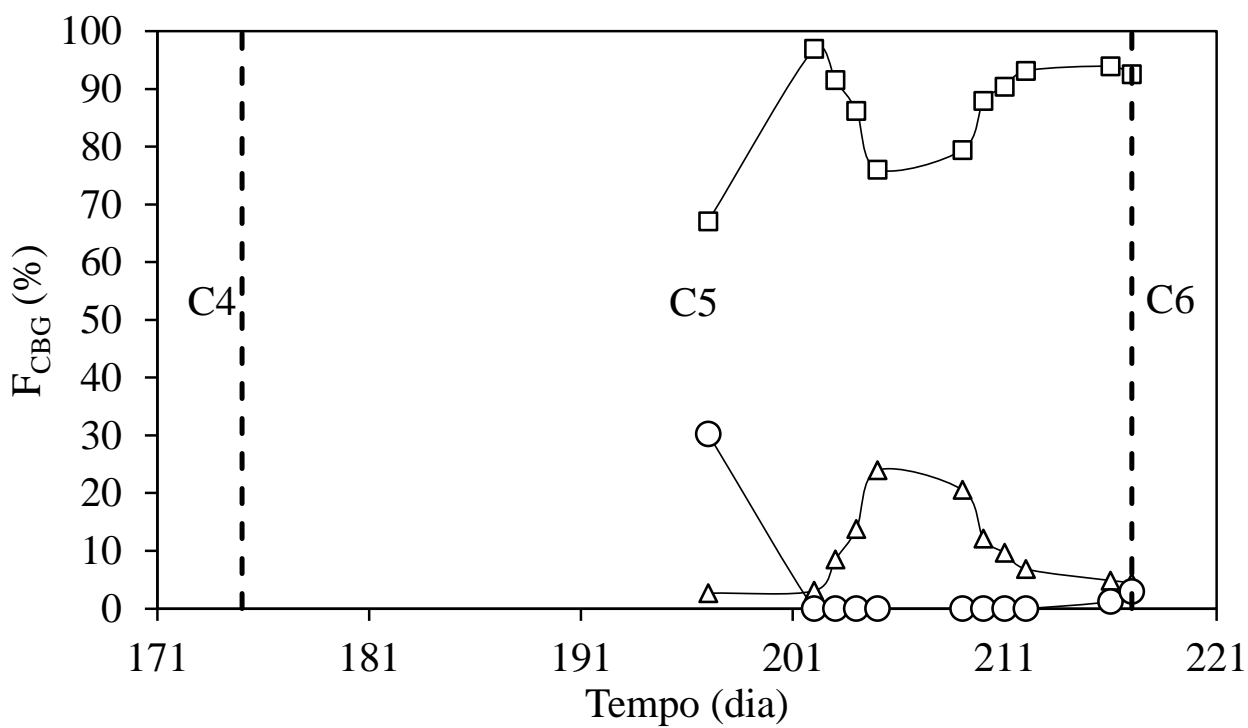

Figura 5-87 - Distribuições dos componentes do biogás no final do ciclo: $\square-\mathrm{CO}_{2} ; \Delta$ $\mathrm{H}_{2} ;$ ○ - $\mathrm{CH}_{4}$ (AnSBBR com recirculação da fase líquida e soro de leite - Condição 5).

O perfil temporal foi realizado apenas no final da primeira etapa da Condição 5. A Figura 5-88 apresenta a evolução da concentração de matéria orgânica ao longo do ciclo. Observa-se uma baixa remoção da DQO, levando a uma alta concentração da mesma no volume residual. Desta forma no inicio do ciclo a diluição do volume carregado pelo volume residual é realizada em proporção baixa, tendo em vista que as concentrações afluente e residual são próximas. No inicio do ciclo, a concentração média é da ordem de $3200 \mathrm{mg} . \mathrm{L}^{-1}$ atingindo valores próximos a $2800 \mathrm{mg} . \mathrm{L}^{-1}$ no último ponto do ciclo. 


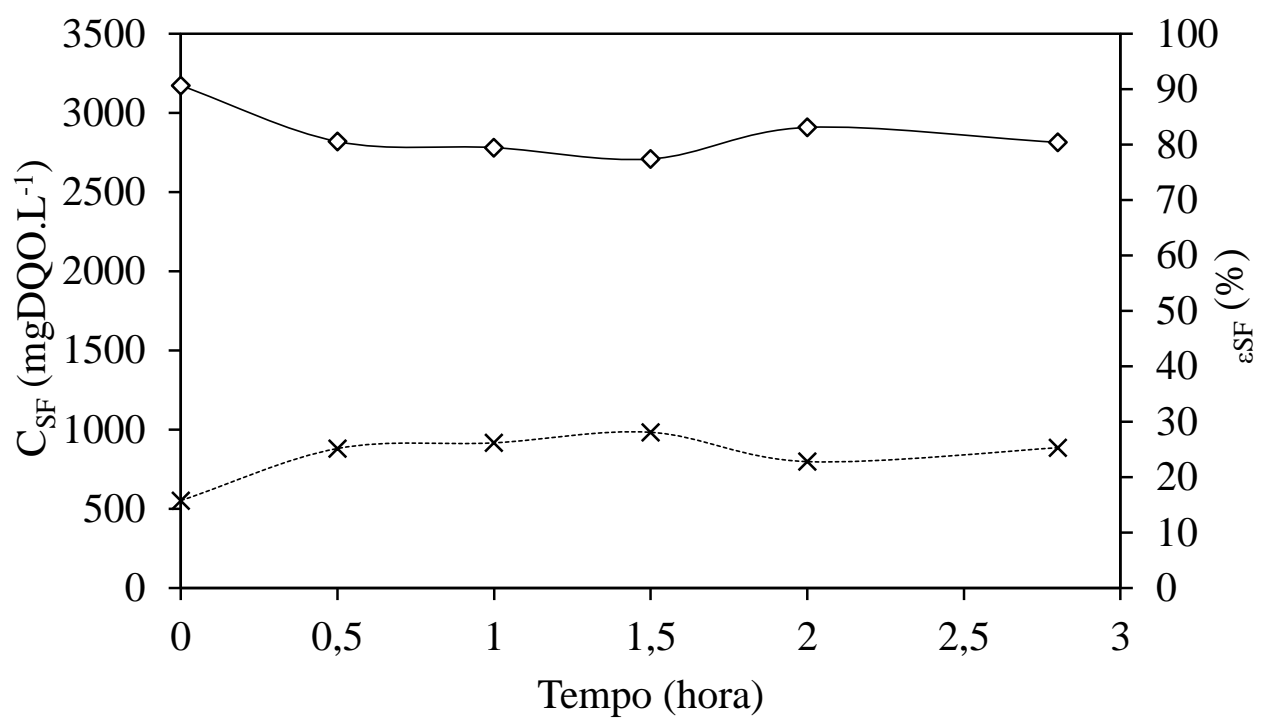

Figura 5-88 - Eixo da direita: $\diamond$ - Concentração de matéria orgânica (DQO) do perfil; Eixo da esquerda: * eficiência de degradação da matéria orgânica (DQO) (AnSBBR com recirculação da fase líquida e soro de leite - Condição 5).

A Figura 5-89 apresenta a evolução da concentração de carboidrato ao longo do ciclo e a eficiência de remoção do mesmo. No inicio do ciclo o volume afluente é diluído no volume residual resultando em uma concentração em sacarose da ordem de $1700 \mathrm{mg} \cdot \mathrm{L}^{-1}$. A conversão desta sacarose se faz de maneira progressiva ao longo do ciclo, atingindo valores na ordem de $99 \%$ no final do mesmo, com um residual aproximado de $12 \mathrm{mg} \cdot \mathrm{L}^{-1}$. 


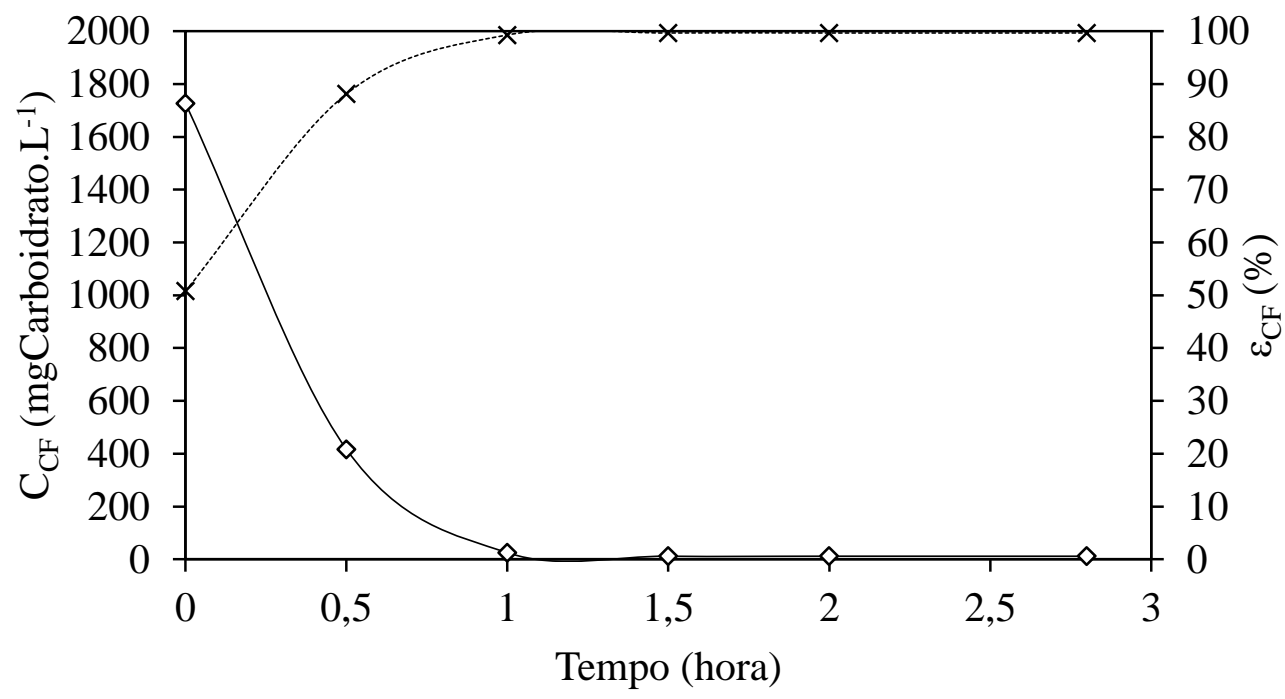

Figura 5-89 - Eixo da direita: $\diamond$ - Concentração de carboidrato do perfil; Eixo da esquerda: * eficiência de degradação do carboidrato (AnSBBR com recirculação da fase líquida e soro de leite - Condição 5).

O acúmulo de ácidos voláteis totais por titulação ao longo do ciclo é apresentado na Figura 5-90. A concentração destes aumenta claramente durante a fase de reação para atingir um valor médio máximo no final do ciclo de $1180 \mathrm{mgHAc} . \mathrm{L}^{-1}$.

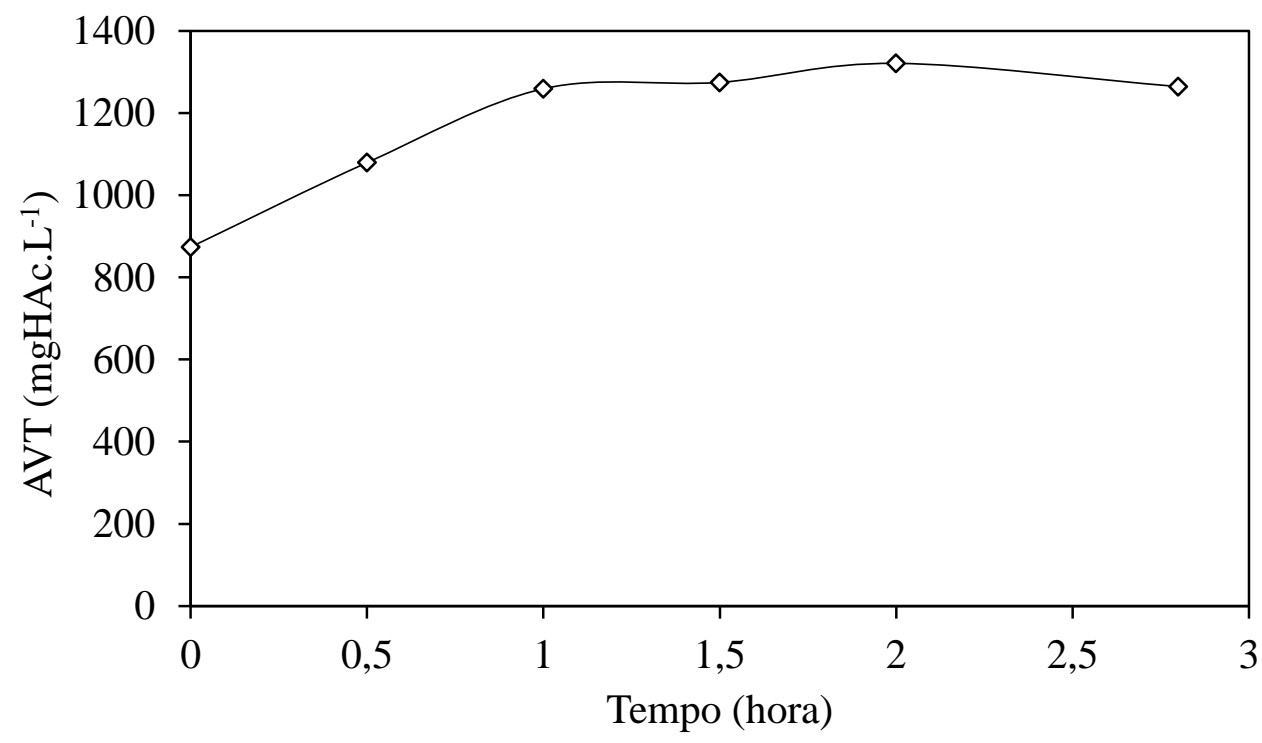

Figura 5-90 - $\diamond$ - Ácidos voláteis totais do perfil (AnSBBR com recirculação da fase líquida e soro de leite - Condição 5). 
As concentrações dos metabólitos intermediários por cromatografia gasosa são apresentadas na Figura 5-91, que permaneceram estáveis durante todo o ciclo, com exceção dos ácidos acético, butírico e propiônico que apresentaram variações das suas concentrações ao longo do ciclo.

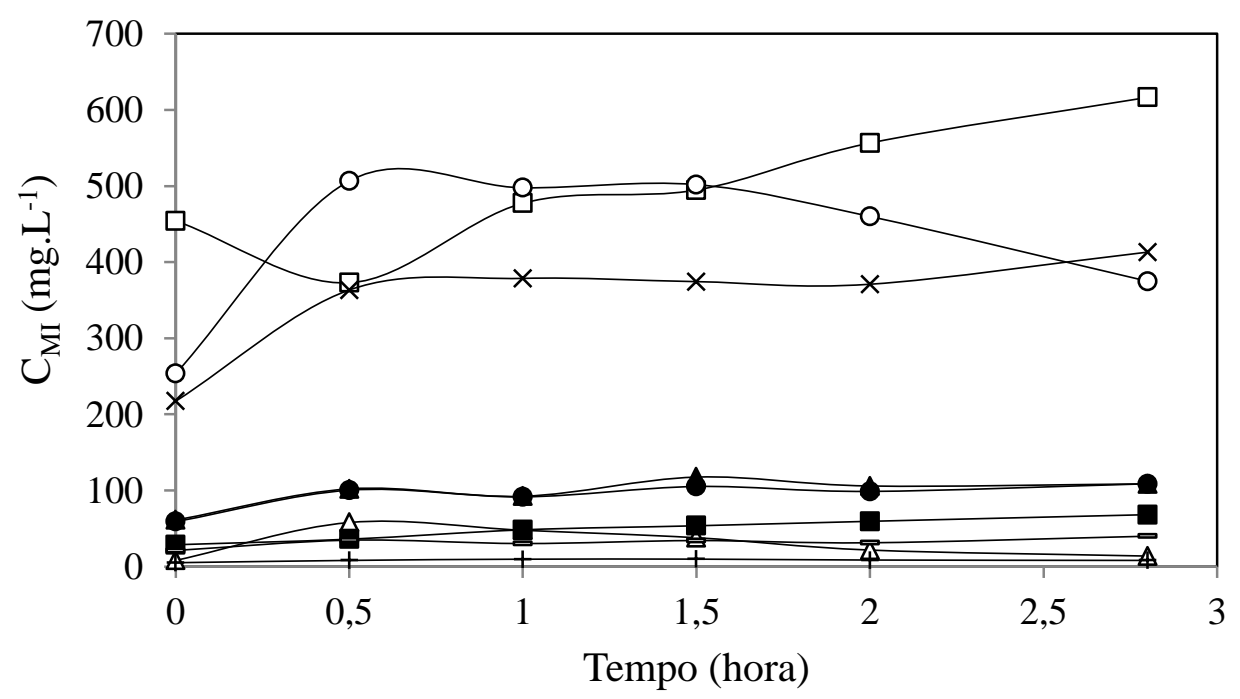

Figura 5-91 - Concentração dos compostos intermediários ao longo do ciclo: $\square$ - ácido acético; $\Delta$ - etanol; ○ - ácido butírico; $\mathbf{\square}$ - ácido isobutírico; $\boldsymbol{\Delta}$ - ácido capróico; • ácido valérico; - - ácido propiônico; + butanol; - ácido isovalérico (AnSBBR com recirculação da fase líquida e soro de leite - Condição 5).

$\mathrm{O}$ pH diminuiu instantaneamente em relação ao afluente devido à diluição do mesmo com o volume residual no inicio do ciclo (alimentação do reator em 10 minutos) e permaneceu estável ao longo da operação conforme a Figura 5-92. A estabilidade do pH mesmo com a produção de ácidos voláteis se deu devido ao tamponamento do sistema pelo consumo de alcalinidade ao longo do ciclo. A Figura 5-93 apresenta a evolução da alcalinidade total no reator ao longo do ciclo. 


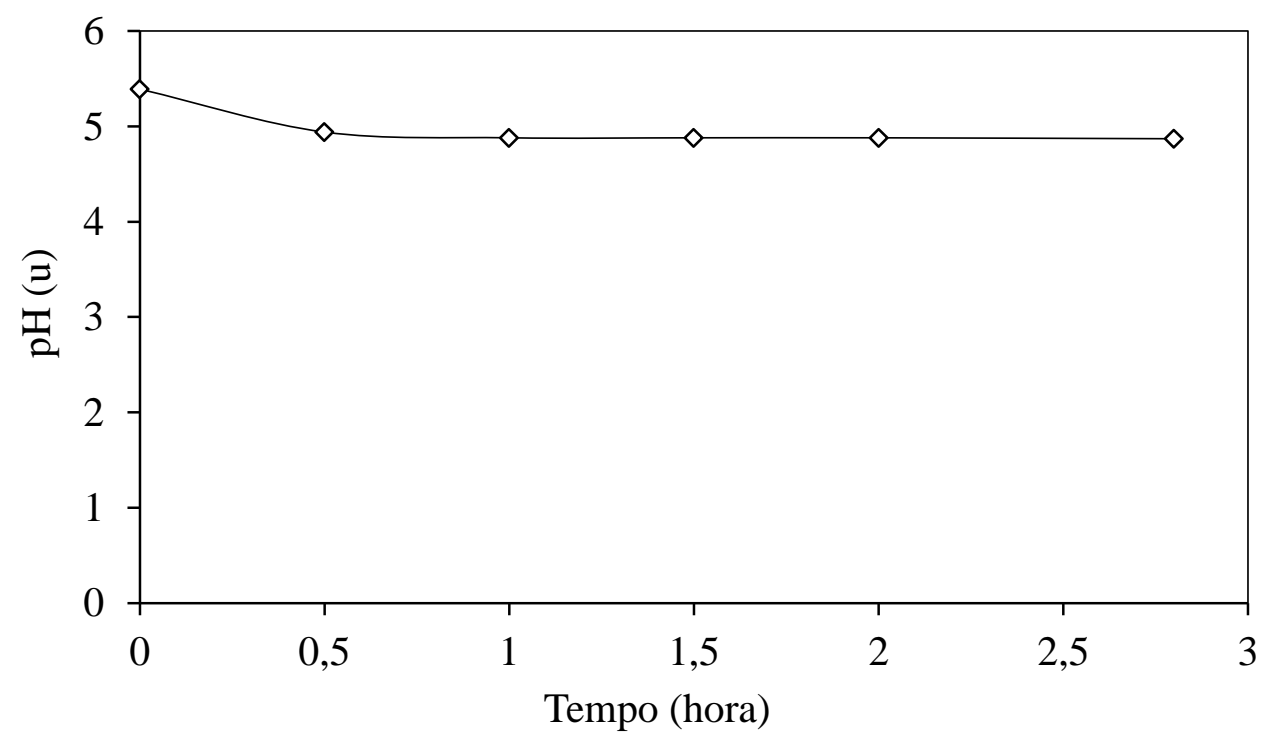

Figura 5-92 - $\diamond-$ Valores de pH do perfil (AnSBBR com recirculação da fase líquida e soro de leite - Condição 5).

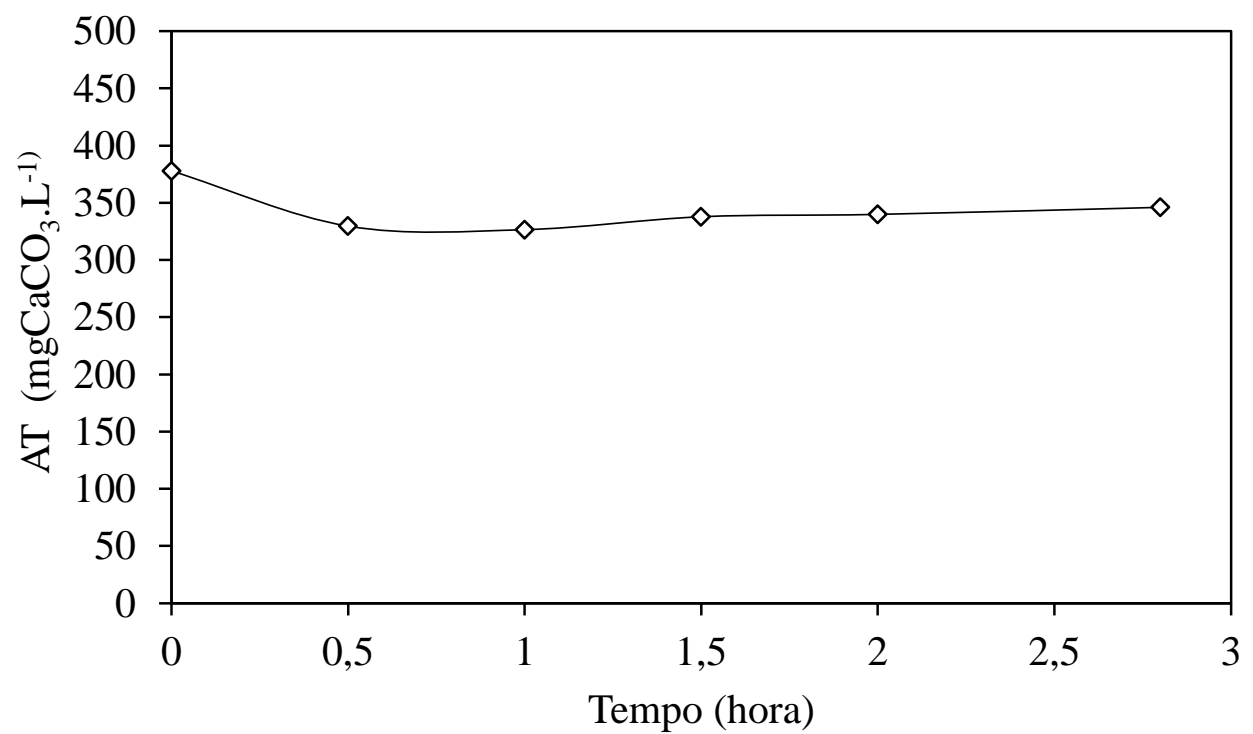

Figura 5-93 - $\diamond$ - Alcalinidade total do perfil (AnSBBR com recirculação da fase líquida e soro de leite - Condição 5).

A produção volumétrica média acumulada do biogás, realizada com os valores dos perfis quantitativos mais consistentes obtidos durante a operação, juntamente com os desvios padrões encontram-se na Figura 5-94. A maior parte da produção ocorre no inicio do ciclo, até a metade do mesmo, e tende a se estabilizar no final. A Tabela 5.23 
resume os valores médios da produção, fração molar e os volumes individuais da mistura do biogás. A Figura 5-95 apresenta os volumes acumulados médios dos perfis de $\mathrm{H}_{2}, \mathrm{CO}_{2}$ e $\mathrm{CH}_{4}$ produzidos durante o ciclo.

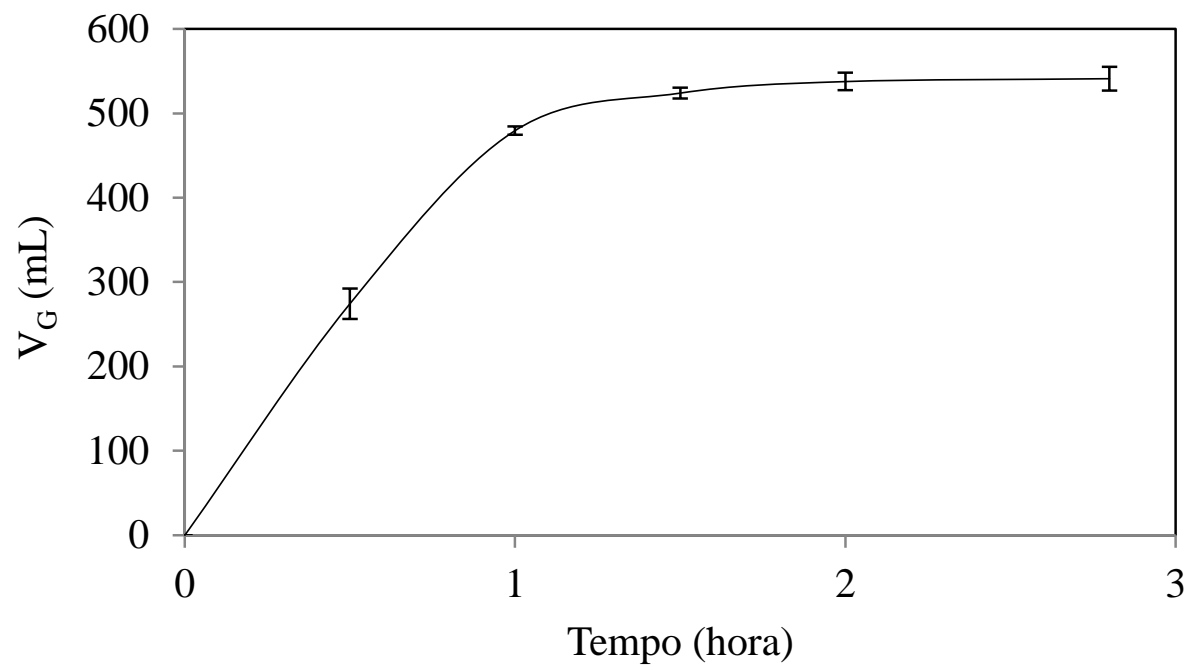

Figura 5-94 - Produção volumétrica média acumulada do biogás, realizada com os valores dos perfis quantitativos mais consistentes obtidos durante a operação, juntamente com os desvios padrões (AnSBBR com recirculação da fase líquida e soro de leite - Condição 5).

Tabela 5.23 - Valores médios da produção, fração molar e os volumes individuais da mistura do biogás (AnSBBR com recirculação da fase líquida e soro de leite - Condição 5).

\begin{tabular}{ccccccccccc}
\hline \multirow{2}{*}{$\begin{array}{c}\text { Tempo } \\
(\mathrm{h})\end{array}$} & \multirow{2}{*}{$\mathrm{V}_{\mathrm{G}}$} & \multicolumn{3}{c}{$\mathrm{C}_{\mathrm{G}}\left(\mathrm{mmol} \cdot \mathrm{L}^{-1}\right)$} & \multicolumn{3}{c}{ Fração Molar $(\%)$} & \multicolumn{3}{c}{ Volume (mL - CNTP) } \\
& & $\mathrm{H}_{2}$ & $\mathrm{CO}_{2}$ & $\mathrm{CH}_{4}$ & $\mathrm{H}_{2}$ & $\mathrm{CO}_{2}$ & $\mathrm{CH}_{4}$ & $\mathrm{H}_{2}$ & $\mathrm{CO}_{2}$ & $\mathrm{CH}_{4}$ \\
\hline 0,0 & 0,0 & 0,0 & 0,0 & 0,0 & 0,0 & 0,0 & 0,0 & 0,0 & 0,0 & 0,0 \\
0,5 & 274,3 & 0,3 & 5,0 & 1,7 & 4,3 & 71,4 & 24,4 & 11,7 & 195,8 & 66,8 \\
1,0 & 479,5 & 0,7 & 8,4 & 3,9 & 5,6 & 64,4 & 30,0 & 23,2 & 327,8 & 128,5 \\
1,5 & 523,9 & 0,6 & 9,0 & 4,0 & 4,3 & 66,2 & 29,6 & 25,1 & 357,2 & 141,6 \\
2,0 & 537,6 & 0,5 & 9,2 & 4,2 & 3,3 & 66,4 & 30,3 & 25,5 & 366,3 & 145,7 \\
2,5 & 541,0 & 0,4 & 9,5 & 4,3 & 2,7 & 67,1 & 30,3 & 25,6 & 368,6 & 146,8 \\
\hline
\end{tabular}




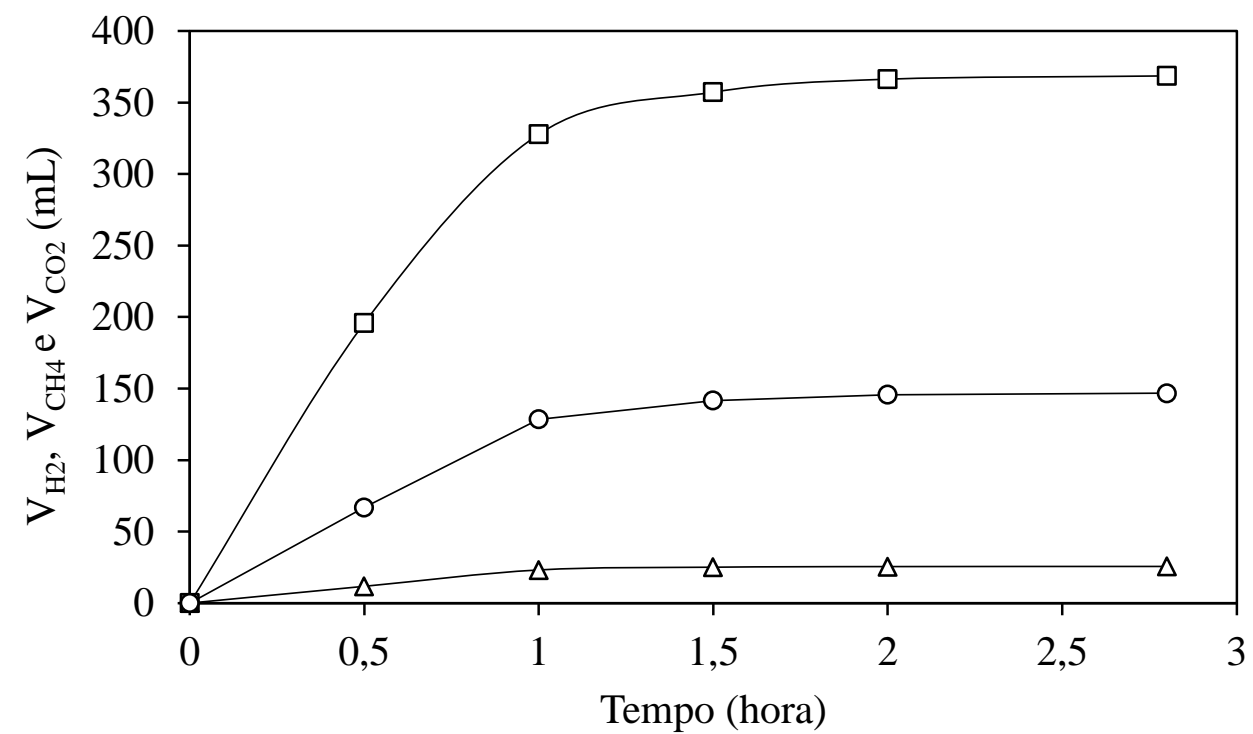

Figura 5-95 - Volumes acumulados médios produzidos ao longo do ciclo de: $\square-\mathrm{CO}_{2} ; \Delta$ - $\mathrm{H}_{2} ; \circ-\mathrm{CH}_{4}$ (AnSBBR com recirculação da fase líquida e soro de leite - Condição 5). 


\subsubsection{Condição 6 - Adaptação com lactose e afluente refrigerado}

A condição 6 com COAV nominal de 14,6 kgDQO. $\mathrm{m}^{-3} \cdot \mathrm{d}^{-1} \mathrm{e}$ duração do ciclo de 3 horas durou do dia 217 ao dia 265 (49 dias de operação). A alimentação nesta condição foi realizada de início com lactose e gradualmente este substrato foi sendo substituído pelo soro de leite. Esta substituição foi realizada da seguinte forma: Do dia 217 ao dia 226 (10 dias de operação) o meio de alimentação foi composto completamente por lactose; Do dia 226 ao dia 233 (8 dias) o meio de alimentação foi composto por $25 \%$ de soro de leite e $75 \%$ de lactose; Do dia 233 ao dia 240 ( 8 dias) o meio de alimentação foi composto por $50 \%$ de soro de leite e $50 \%$ de lactose; Do dia 240 ao dia 247 (8 dias) o meio de alimentação foi composto por75\% de soro de leite e 25\% de lactose; por ultimo, do dia 247 ao dia 264 (18 dias) o meio de alimentação foi composto completamente por soro de leite. Com esta estratégia de operação buscou-se uma adaptação diferente da biomassa e uma produção estável do hidrogênio. A Tabela 5.24 apresenta os valores médios dos parâmetros monitorados. 
Tabela 5.24 - Valores médios dos parâmetros monitorados comuns a todas as etapas da condição experimental 6 (Soro de leite - 4250 mgDQO.L ${ }^{-1}-t_{C} 3 h$ )

\begin{tabular}{|c|c|c|c|c|c|c|c|c|c|}
\hline \multicolumn{2}{|r|}{ Parâmetro } & \multicolumn{4}{|c|}{ Afluente } & \multicolumn{4}{|c|}{ Efluente } \\
\hline $\mathrm{C}_{\mathrm{ST}}$ & $\left(\mathrm{mgDQO} \cdot \mathrm{L}^{-1}\right)$ & 3857 & \pm & 243 & $(20)$ & 3159 & \pm & 185 & $(20)$ \\
\hline $\mathrm{C}_{\mathrm{SF}}$ & $\left(\mathrm{mgDQO} \cdot \mathrm{L}^{-1}\right)$ & - & \pm & - & $(3)$ & 3059 & \pm & 301 & $(20)$ \\
\hline$\varepsilon_{\mathrm{ST}}$ & $(\%)$ & - & & - & & 18 & \pm & 5 & $(20)$ \\
\hline$\varepsilon_{\mathrm{SF}}$ & $(\%)$ & - & & - & & 21 & \pm & 8 & $(20)$ \\
\hline $\mathrm{C}_{\mathrm{CT}}$ & $\left(\right.$ mgCarboidrato. $\left.L^{-1}\right)$ & 3705 & \pm & 308 & $(20)$ & 165 & \pm & 473 & $(20)$ \\
\hline $\mathrm{C}_{\mathrm{CF}}$ & (mgCarboidrato. $\mathrm{L}^{-1}$ ) & - & \pm & - & $(\quad)$ & 146 & \pm & 472 & $(20)$ \\
\hline$\varepsilon_{\mathrm{CT}}$ & $(\%)$ & - & & - & & 96 & \pm & 13 & $(20)$ \\
\hline$\varepsilon_{\mathrm{CF}}$ & $(\%)$ & - & & - & & 96 & \pm & 13 & $(20)$ \\
\hline $\mathrm{pH}$ & (u) & 7,73 & \pm & 0,19 & $(20)$ & 4,54 & \pm & 0,24 & $(20)$ \\
\hline AVT & $\left(\mathrm{mgHAc} . \mathrm{L}^{-1}\right)$ & 73 & \pm & 37 & $(20)$ & 1283 & \pm & 277 & $(20)$ \\
\hline $\mathrm{AT}$ & $\left(\mathrm{mgCaCO}_{3} \cdot \mathrm{L}^{-1}\right)$ & 415 & \pm & 31 & $(20)$ & 119 & \pm & 73 & $(20)$ \\
\hline $\mathrm{AP}$ & $\left(\mathrm{mgCaCO}_{3} \cdot \mathrm{L}^{-1}\right)$ & 311 & \pm & 20 & $(20)$ & 0 & \pm & 0 & $(20)$ \\
\hline AI & $\left(\mathrm{mgCaCO}_{3} \cdot \mathrm{L}^{-1}\right)$ & 105 & \pm & 25 & $(20)$ & 119 & \pm & 73 & $(20)$ \\
\hline $\mathrm{AB}$ & $\left(\mathrm{mgCaCO}_{3} \cdot \mathrm{L}^{-1}\right)$ & 364 & \pm & 17 & $(20)$ & 0 & \pm & 0 & $(20)$ \\
\hline ST & $\left(\mathrm{mg} \cdot \mathrm{L}^{-1}\right)$ & 3438,29 & \pm & 311 & $(7)$ & 2161 & \pm & 435 & $(7)$ \\
\hline STV & $\left(\mathrm{mg} \cdot \mathrm{L}^{-1}\right)$ & 2781,43 & \pm & 234 & $(7)$ & 1535 & \pm & 267 & $(7)$ \\
\hline SST & $\left(\mathrm{mg} \cdot \mathrm{L}^{-1}\right)$ & 120,28 & \pm & 66 & $(7)$ & 100 & \pm & 63 & $(7)$ \\
\hline SSV & $\left(\mathrm{mg} \cdot \mathrm{L}^{-1}\right)$ & 59,714 & \pm & 54 & $(7)$ & 60 & \pm & 53 & $(7)$ \\
\hline $\mathrm{M}_{\mathrm{STV}}$ & (g) & - & & - & & - & & - & \\
\hline $\mathrm{C}_{\mathrm{X}}$ & $\left(\mathrm{g} \cdot \mathrm{L}^{-1}\right)$ & - & & - & & - & & - & \\
\hline $\mathrm{C}_{\mathrm{X}}^{\prime}$ & (g.gsuporte ${ }^{-1}$ ) & - & & - & & - & & - & \\
\hline $\mathrm{V}_{\mathrm{G}}$ & (mL-CNTP) & - & & - & & 301 & \pm & 45 & $\left(\begin{array}{ll}2\end{array}\right)$ \\
\hline $\mathrm{V}_{\mathrm{H} 2}$ & (mL-CNTP) & - & & - & & - & & - & \\
\hline $\mathrm{COAV}_{\mathrm{STA}}$ & $\left(\mathrm{kgDQO} \cdot \mathrm{m}^{-3} \cdot \mathrm{d}^{-1}\right)$ & 13,2 & & - & & - & & - & \\
\hline $\mathrm{CORV}_{\mathrm{SFE}}$ & $\left(\mathrm{kgDQO} \cdot \mathrm{m}^{-3} \cdot \mathrm{d}^{-1}\right)$ & - & & - & & 2,7 & & - & \\
\hline $\mathrm{COAV}_{\text {СТА }}$ & $\left(\right.$ kgCarboidrato. $\left.\mathrm{m}^{-3} \cdot \mathrm{d}^{-1}\right)$ & 12,7 & & - & & - & & - & \\
\hline $\mathrm{CORV}_{\mathrm{CFE}}$ & $\left(\mathrm{kgCarboidrato} \cdot \mathrm{m}^{-3} \cdot \mathrm{d}^{-1}\right)$ & - & & - & & 12,2 & & - & \\
\hline $\mathrm{COAE}_{\mathrm{STA}}$ & $\left(\mathrm{kgDQO} \cdot \mathrm{kgSTV}^{-1} \cdot \mathrm{d}^{-1}\right)$ & - & & - & & - & & - & \\
\hline $\mathrm{CORE}_{\mathrm{SFE}}$ & $\left(\mathrm{kgDQO} \cdot \mathrm{kgSTV}^{-1} \cdot \mathrm{d}^{-1}\right)$ & - & & - & & - & & - & \\
\hline $\mathrm{COAE}_{\mathrm{CTA}}$ & $\left(\mathrm{kgCarboidrato.kgSTV}^{-1} \cdot \mathrm{d}^{-1}\right)$ & - & & - & & - & & - & \\
\hline $\mathrm{CORE}_{\mathrm{CFE}}$ & $\left(\mathrm{kgCarboidrato.kgSTV}^{-1} \cdot \mathrm{d}^{-1}\right)$ & - & & - & & - & & - & \\
\hline $\mathrm{RMCR}_{\mathrm{C}, \mathrm{n}}$ & $\left(\mathrm{molH}_{2}\right.$ molCarboidrato $\left.^{-1}\right)$ & - & & - & & - & & - & \\
\hline $\mathrm{n}_{\mathrm{H} 2}$ & $\left(\mathrm{molH}_{2} \cdot \mathrm{d}^{-1}\right)$ & 一 & & - & & - & & - & \\
\hline PrM & $\left(\mathrm{molH}_{2} \cdot \mathrm{m}^{-3} \cdot \mathrm{d}^{-1}\right)$ & - & & - & & - & & - & \\
\hline PrME & $\left(\mathrm{molH}_{2} \cdot \mathrm{kgSVT}^{-1} \cdot \mathrm{d}^{-1}\right)$ & - & & - & & - & & - & \\
\hline $\mathrm{RMCA}_{\mathrm{S}, \mathrm{m}}$ & $\left(\mathrm{molH}_{2} \cdot \mathrm{kgDQO}^{-1} \cdot \mathrm{d}^{-1}\right)$ & - & & - & & - & & - & \\
\hline $\mathrm{RMCA}_{\mathrm{C}, \mathrm{m}}$ & $\left(\mathrm{molH}_{2} \cdot \mathrm{kg}^{-1} \cdot \mathrm{d}^{-1}\right)$ & - & & - & & - & & - & \\
\hline $\mathrm{RMCR}_{\mathrm{S}, \mathrm{m}}$ & $\left(\mathrm{molH}_{2} \cdot \mathrm{kgDQO}^{-1} \cdot \mathrm{d}^{-1}\right)$ & - & & - & & - & & - & \\
\hline $\mathrm{RMCR}_{\mathrm{C}, \mathrm{m}}$ & $\left(\mathrm{molH}_{2} \cdot \mathrm{kg}^{-1} \cdot \mathrm{d}^{-1}\right)$ & - & & - & & - & & - & \\
\hline $\mathrm{V}_{\mathrm{R}}$ & $(\mathrm{mL})$ & 2000 & & & & & & & \\
\hline $\mathrm{V}_{\mathrm{A}}$ & $(\mathrm{mL})$ & 1456 & \pm & 33 & ( 21 ) & 一 & & - & \\
\hline $\mathrm{Q}_{\mathrm{R}}$ & $\left(\mathrm{mL} \cdot \mathrm{s}^{-1}\right)$ & 6 & \pm & 0 & $\left({ }^{4}\right)$ & - & & - & \\
\hline
\end{tabular}

(*) Entre parêntese o número de amostras considerado no cálculo da média 
A Figura 5-96 apresenta os valores da concentração afluente (amostras não filtradas) e efluente (amostras não filtradas e filtradas) de matéria orgânica (DQO) nos sistema, enquanto que a Figura 5-97 apresenta a eficiência de remoção do mesmo parâmetro durante o monitoramento diário. Esta eficiência atingiu, em média, 21\% para as amostras filtradas e $18 \%$ para amostras não filtradas. A média de concentração afluente para amostras não filtradas do substrato foi de $3857 \mathrm{mgDQO} . \mathrm{L}^{-1}$ e de 3159 mgDQO. $\mathrm{L}^{-1}$ e $3059 \mathrm{mgDQO} . \mathrm{L}^{-1}$ para amostras de efluente não filtradas e filtradas, respectivamente.

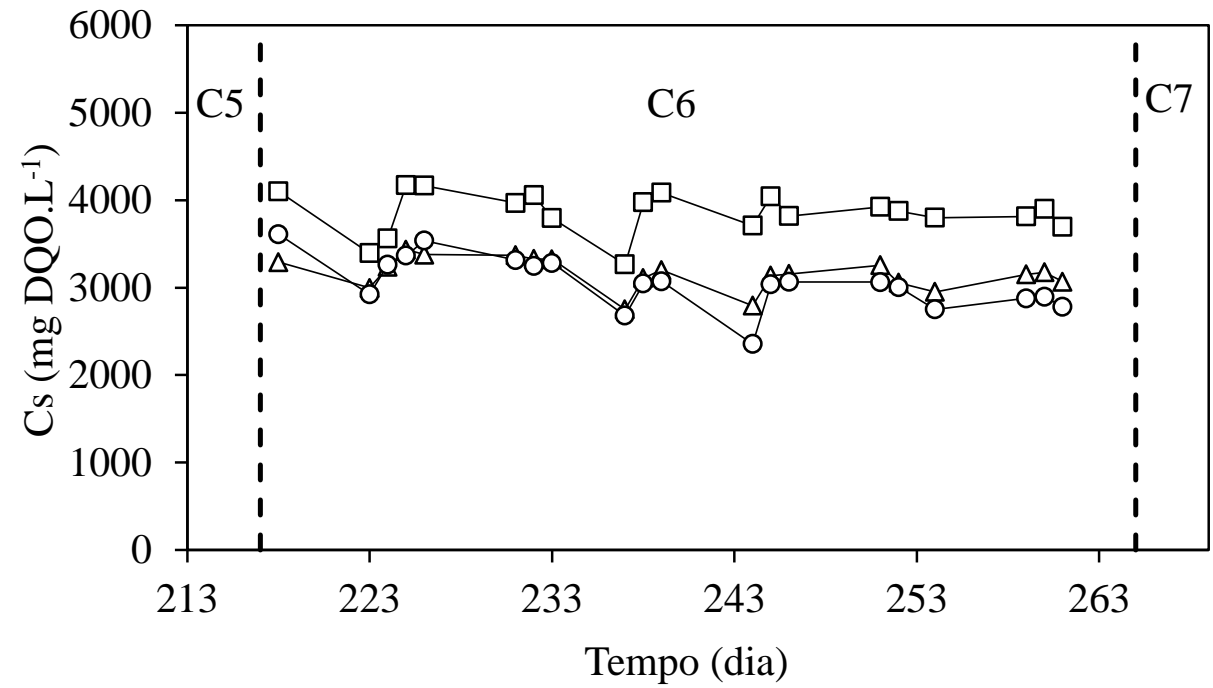

Figura 5-96 - Concentração de matéria orgânica (DQO): $\square$ - afluente não filtrada; $\Delta$ efluente não filtrada; o - efluente filtrada (AnSBBR com recirculação da fase líquida e soro de leite - Condição 6). 


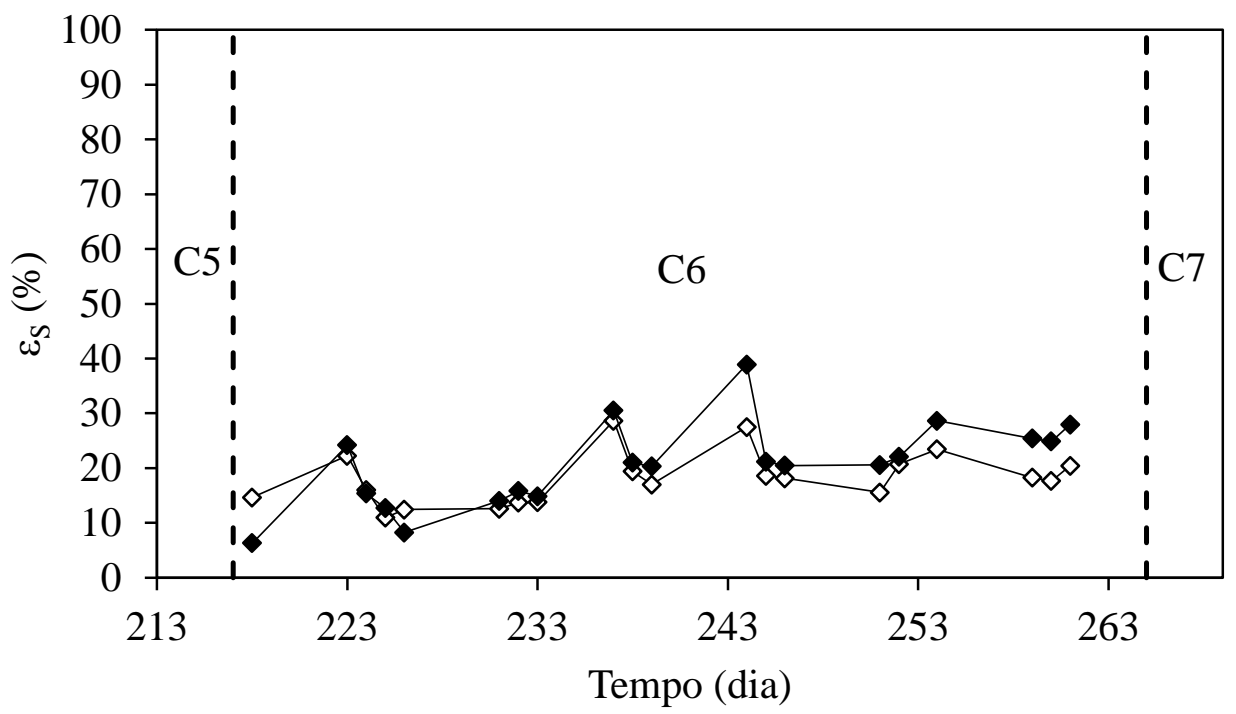

Figura 5-97-Eficiência de remoção de matéria orgânica (DQO): $\diamond$ - não filtrada; filtrada (AnSBBR com recirculação da fase líquida e soro de leite - Condição 6).

A Figura 5-98 mostra os valores da concentração de carboidratos afluente e efluente (para amostras filtradas e não filtradas). A Figura 5-99 apresenta a eficiência de remoção do mesmo parâmetro (para amostras filtradas e não filtradas) durante o monitoramento diário. A média da concentração afluente foi de 3705 mgCarboidrato. $\mathrm{L}^{-}$ ${ }^{1}$, enquanto que a concentração residual não filtrada foi de $165 \mathrm{mgCarboidrato.} \mathrm{L}^{-1}$ e 146 mgCarboidrato. $\mathrm{L}^{-1}$ para a concentração residual filtrada. A eficiência de remoção de lactose foi, em média, de $96 \%$ para ambas as amostras (filtradas e não filtradas). 


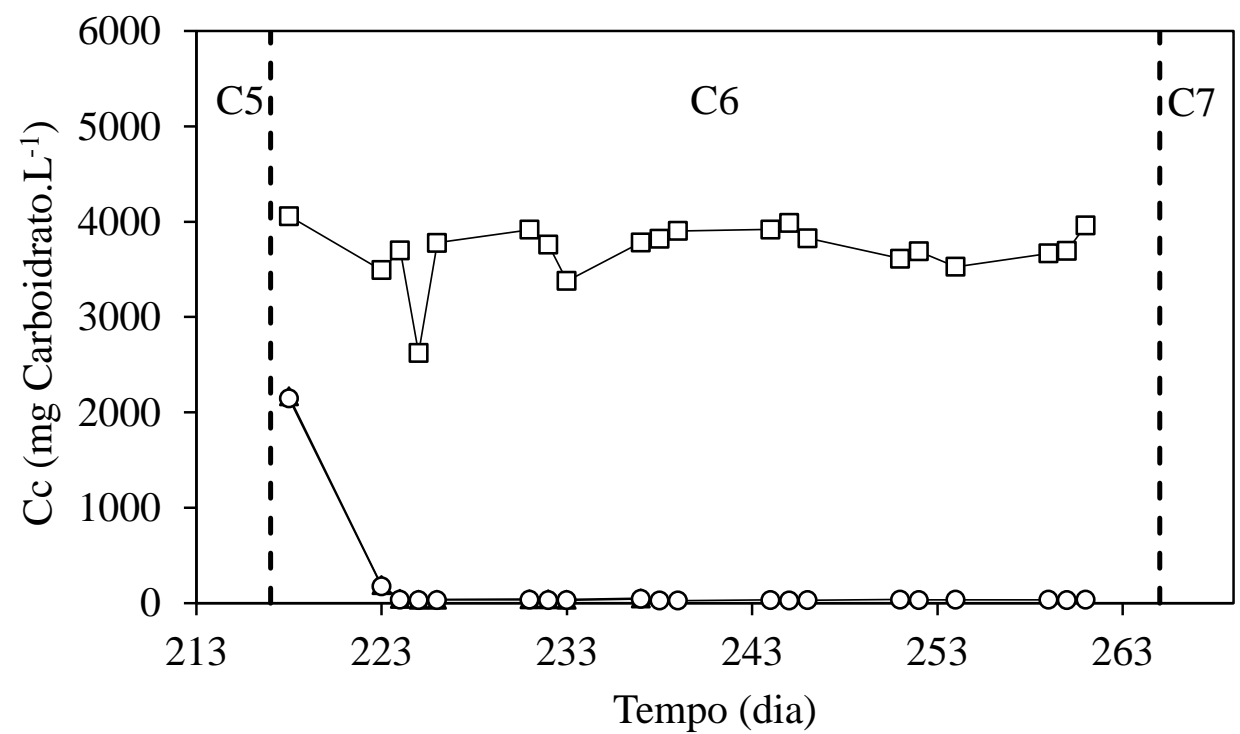

Figura 5-98 - Concentração de carboidrato: $\square-$ afluente não filtrada; $\Delta$ - efluente não filtrada; ○ - efluente filtrada (AnSBBR com recirculação da fase líquida e soro de leite Condição 6).

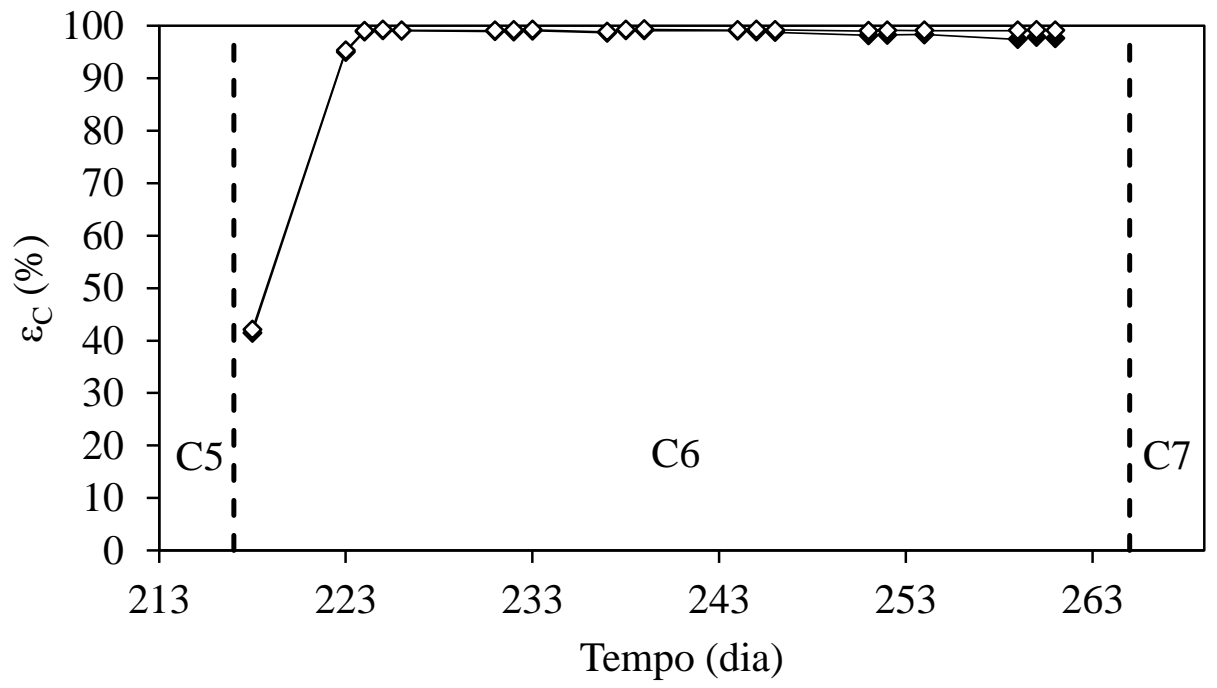

Figura 5-99 - Eficiência de remoção de carboidrato: $\diamond$ - não filtrada; $\downarrow$ - filtrada (AnSBBR com recirculação da fase líquida e soro de leite - Condição 6).

As Figura 5-100, Figura 5-101 e Figura 5-102 apresentam os perfis temporais, tanto para o afluente quanto para o efluente, do $\mathrm{pH}$, da alcalinidade total e dos ácidos voláteis totais, respectivamente. A média dos valores de $\mathrm{pH}$ afluente durante esta primeira fase foi de 7,73 e de $\mathrm{pH}$ efluente foi de 4,54. A média da alcalinidade total foi de 415 e $119 \mathrm{mgCaCO}_{3} \cdot \mathrm{L}^{-1}$ para o afluente e efluente, respectivamente. O valor médio 
da concentração de ácidos voláteis totais afluente foi de 73 mgHAc. $\mathrm{L}^{-1}$ e efluente de 1283 mgHAc. $L^{-1}$. A queda do pH efluente está relacionada com a alta produção de ácidos voláteis totais.

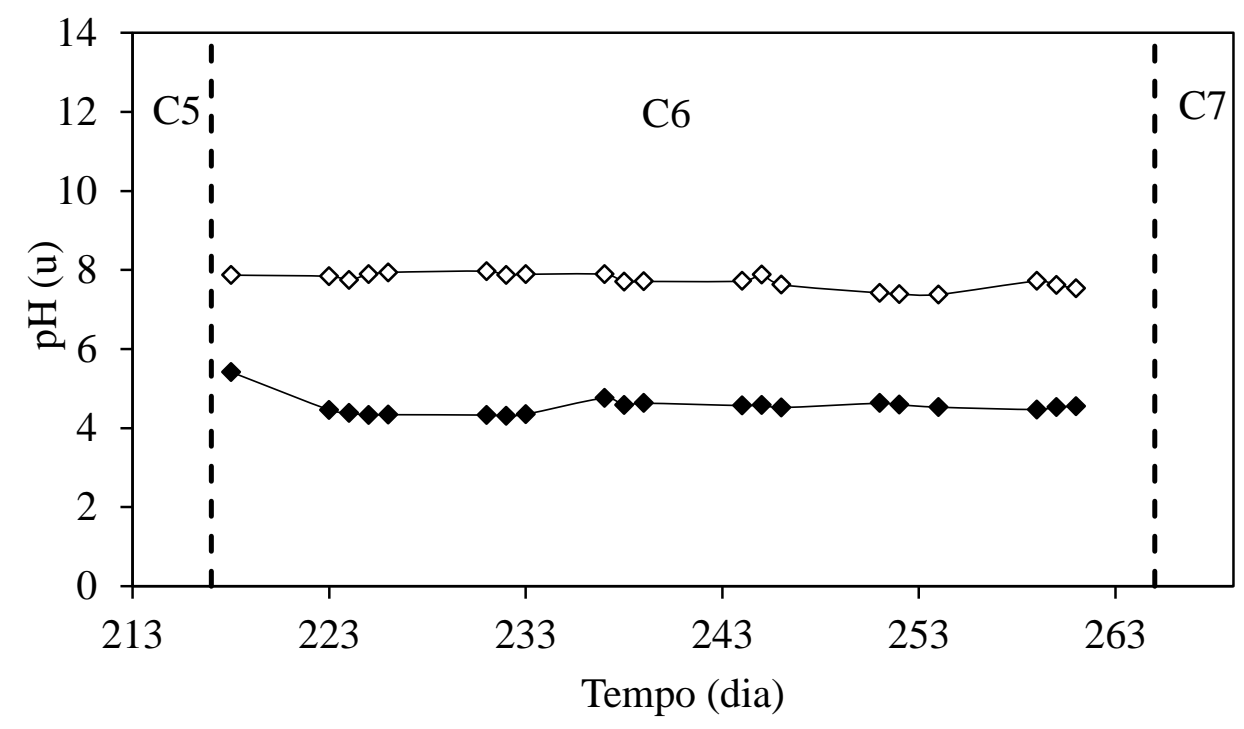

Figura 5-100 - Valores de pH: $\diamond$-afluente; - efluente (AnSBBR com recirculação da fase líquida e soro de leite - Condição 6).

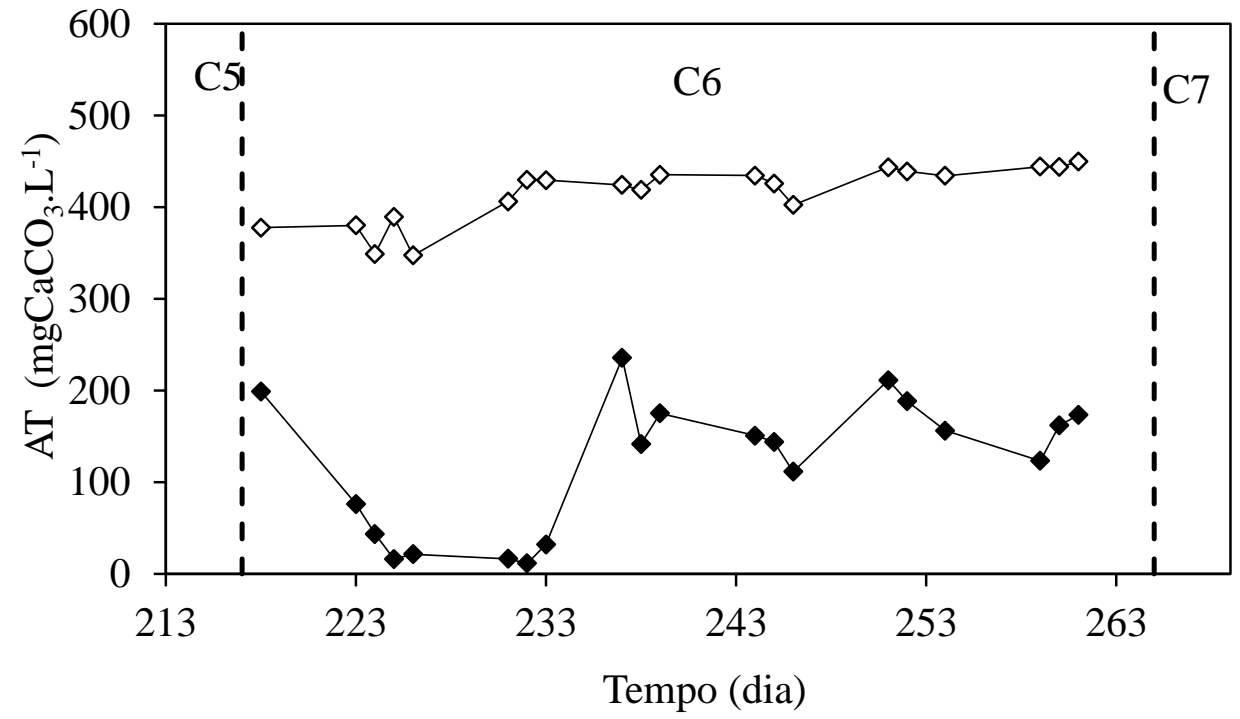

Figura 5-101 - Alcalinidade total: $\diamond$-afluente; - efluente (AnSBBR com recirculação da fase líquida e soro de leite - Condição 6). 


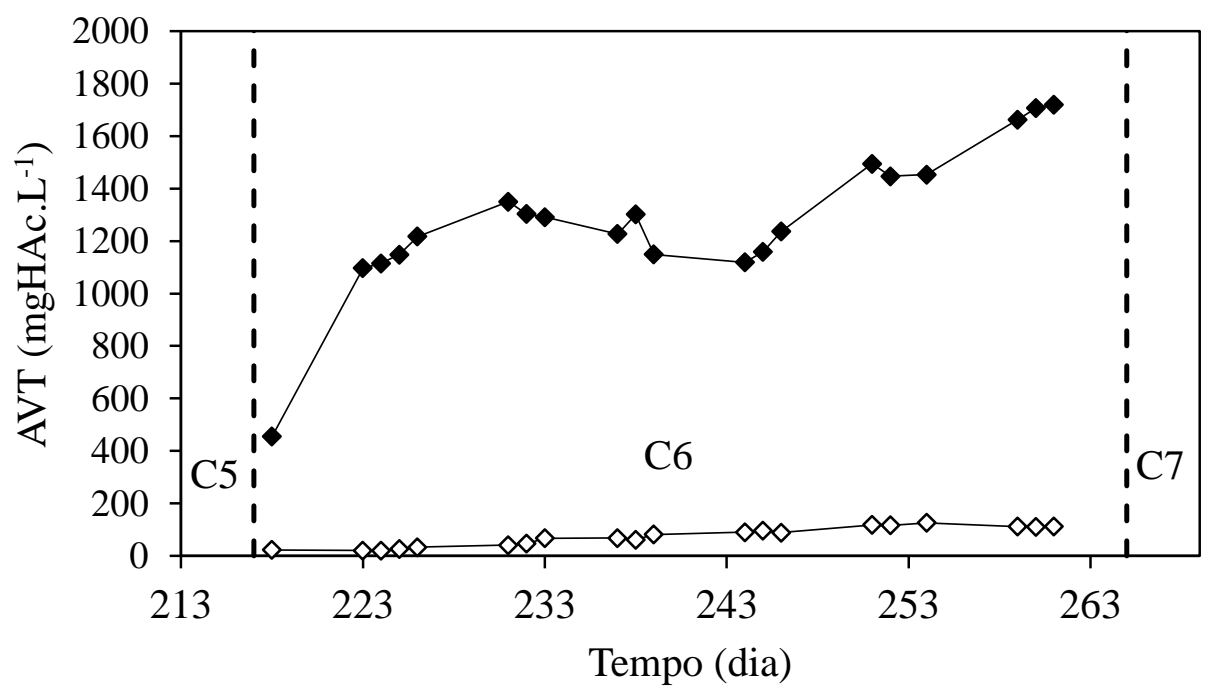

Figura 5-102 - Ácidos voláteis totais: $\diamond$-afluente; - efluente (AnSBBR com recirculação da fase líquida e soro de leite - Condição 6).

A Figura 5-103 apresenta o monitoramento dos compostos intermediários contidos no efluente do sistema, enquanto que a Tabela 5.25 apresenta os valores da concentração média destes produtos. A instabilidade entre as concentrações ao longo da operação pode ser atribuída à mudança do substrato e consequentemente à mudança da rota metabólica usada. Mesmo com esta instabilidade, o produto intermediário com maiores concentrações foi o ácido acético. 


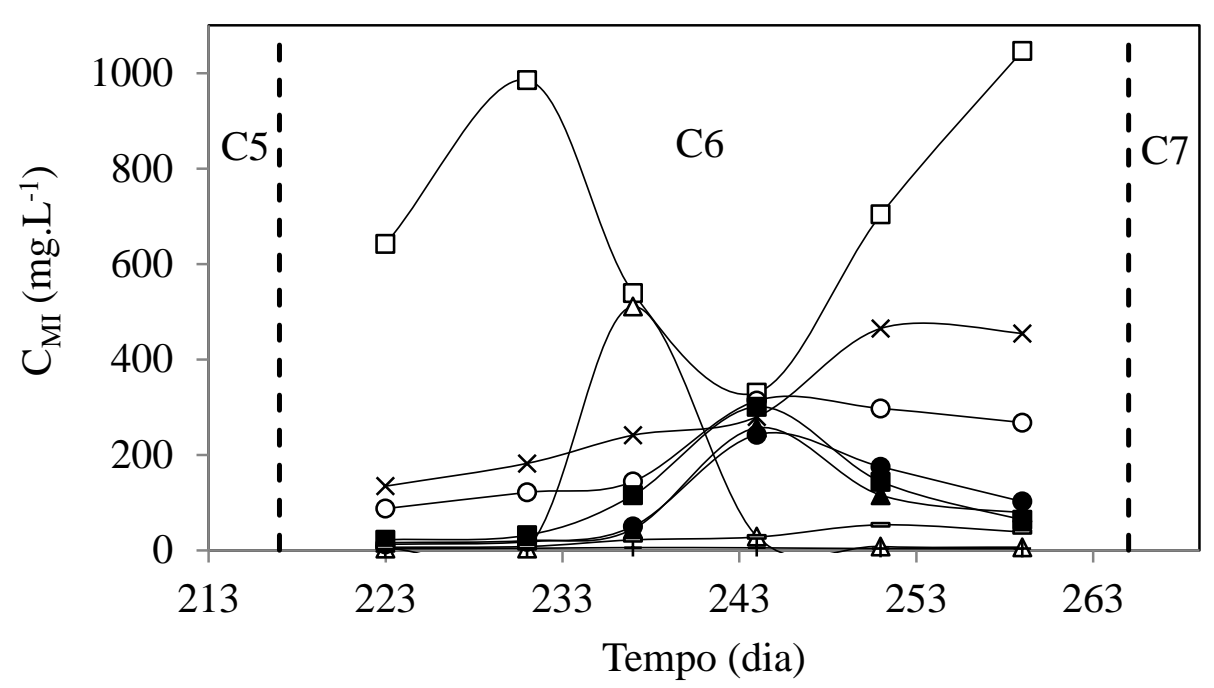

Figura 5-103 - Concentração dos compostos intermediários: $\square$ - ácido acético; $\Delta$ etanol; ○-ácido butírico; - ácido isobutírico; $\boldsymbol{\Delta}$ - ácido capróico; $\bullet$ - ácido valérico; * ácido propiônico; +butanol; - ácido isovalérico (AnSBBR com recirculação da fase líquida e soro de leite - Condição 6).

Tabela 5.25 - Concentração e distribuição dos compostos intermediários (AnSBBR com recirculação da fase líquida e soro de leite - Condição 6).

\begin{tabular}{cccccccc}
\hline $\begin{array}{c}\text { Produtos } \\
\text { intermediários }\end{array}$ & \multicolumn{5}{c}{ Concentrações médias } & \multicolumn{3}{c}{$\begin{array}{c}\text { Distribuição } \\
\left(\mathrm{mg} . \mathrm{L}^{-1}\right)\end{array}$} & \multicolumn{1}{c}{$\left(\mathrm{mmol. \textrm {L } ^ { - 1 } )}\right.$} & $(\%)$ \\
\hline Acetona & 0,0 & \pm & 0,0 & 0,0 & \pm & 0,0 & 0,0 \\
Metanol & 0,0 & \pm & 0,0 & 0,0 & \pm & 0,0 & 0,0 \\
Etanol & 93,5 & \pm & 204,6 & 2,0 & \pm & 4,4 & 8,6 \\
n-Butanol & 4,0 & \pm & 1,0 & 0,1 & \pm & 0,0 & 0,2 \\
Acético & 707,8 & \pm & 270,8 & 11,8 & \pm & 4,5 & 50,1 \\
Porpiônico & 292,8 & \pm & 138,6 & 4,0 & \pm & 1,9 & 16,8 \\
Isobutírico & 112,7 & \pm & 103,5 & 1,3 & \pm & 1,2 & 5,4 \\
Butírico & 205,1 & \pm & 98,7 & 2,3 & \pm & 1,1 & 9,9 \\
Isovalérico & 25,8 & \pm & 18,1 & 0,3 & \pm & 0,2 & 1,1 \\
Valérico & 99,9 & \pm & 92,5 & 1,0 & \pm & 0,9 & 4,2 \\
Capróico & 88,4 & \pm & 90,4 & 0,9 & \pm & 0,9 & 3,7 \\
\hline
\end{tabular}

O monitoramento da série de sólidos é mostrado na Tabela 5.26, cujos valores apresentam um baixo teor de SSV no efluente e afluente, indicando a boa capacidade do reator em reter biomassa, mesmo no começo da operação. 
Tabela 5.26 - Série de sólidos afluente e efluente (AnSBBR com recirculação da fase líquida e soro de leite - Condição 6)

\begin{tabular}{lcccc}
\hline & $\begin{array}{c}\text { ST } \\
\left(\mathrm{mg} . L^{-1}\right)\end{array}$ & $\begin{array}{c}\text { SVT } \\
\left(\mathrm{mg} . L^{-1}\right)\end{array}$ & $\begin{array}{c}\text { SST } \\
\left(\mathrm{mg} . L^{-1}\right)\end{array}$ & $\begin{array}{c}\text { SSV } \\
\left(\mathrm{mg} . L^{-1}\right)\end{array}$ \\
\hline Afluente & $3438 \pm 311$ & $2781 \pm 234$ & $120 \pm 66$ & $60 \pm 54$ \\
Efluente & $2161 \pm 435$ & $1535 \pm 267$ & $100 \pm 64$ & $60 \pm 53$ \\
\hline
\end{tabular}

A produção do biogás por ciclo, em aspecto quantitativo, pode ser observada na Figura 5-104. A produção média foi de $440 \mathrm{~mL}$ (CNTP). A Figura 5-105 apresenta o monitoramento das concentrações dos componentes do biogás no final do ciclo, enquanto que a Figura 5-106 apresenta a distribuição destes mesmos componentes. Os valores médios de concentração de $\mathrm{H}_{2}, \mathrm{CH}_{4}$ e $\mathrm{CO}_{2}$ foram 2,3, 1,2 e 7,9 mmol.L ${ }^{-1}$, respectivamente. Além disso, a distribuição percentual média de $\mathrm{H}_{2}$ foi de $13,7 \%$, a de $\mathrm{CH}_{4}$ foi de $12,8 \%$ e a de $\mathrm{CO}_{2}$ foi de $73,5 \%$. A estratégia de adaptação da biomassa, com substituição gradual de um substrato que comprovadamente produz hidrogênio (lactose) pelo substrato que apresenta problemas na produção de $\mathrm{H}_{2}$ (soro de leite), não apresentou os resultados esperados, falhando em manter uma produção estável do biohidrogênio e em eliminar a produção de metano. Os indícios de produção de $\mathrm{H}_{2} \mathrm{~S}$ (odor característico e formação de substância branca recobrindo o exterior das mangueiras de alimentação) por possível ação de bactérias redutoras de sulfato (BRS) continuaram presentes nesta condição. 


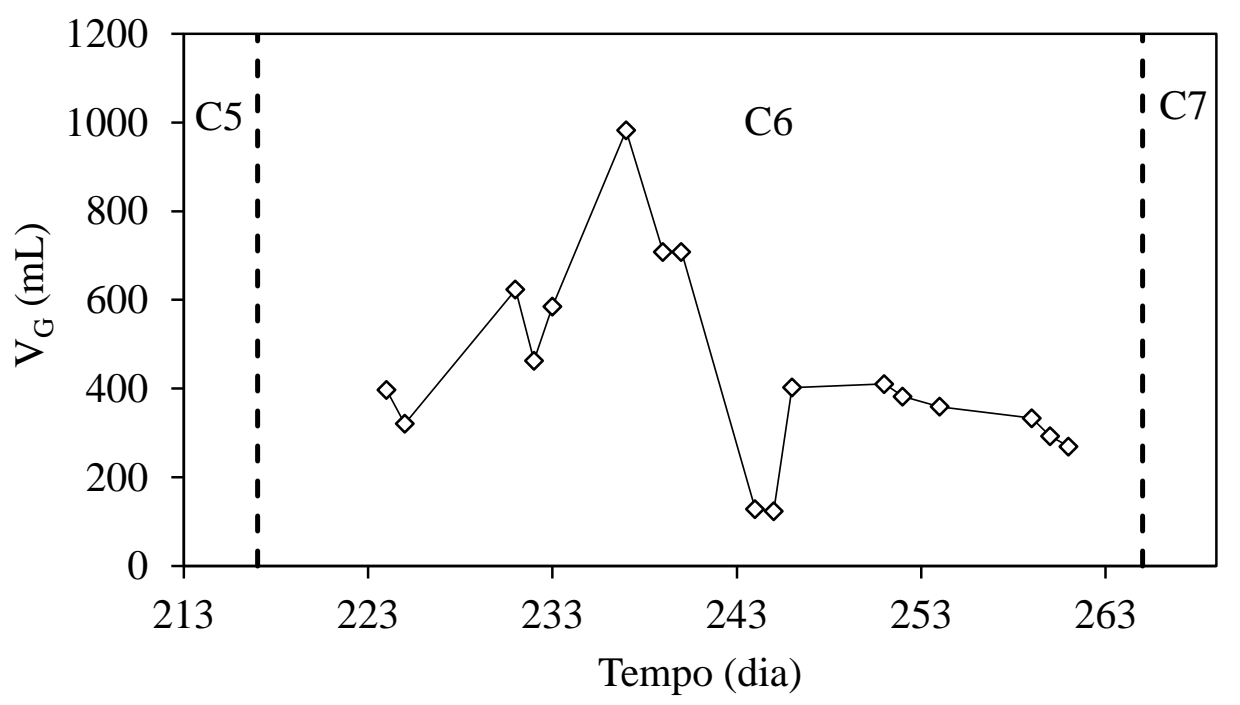

Figura 5-104 - Volume de biogás produzido por ciclo (AnSBBR com recirculação da fase líquida e soro de leite - Condição 6).

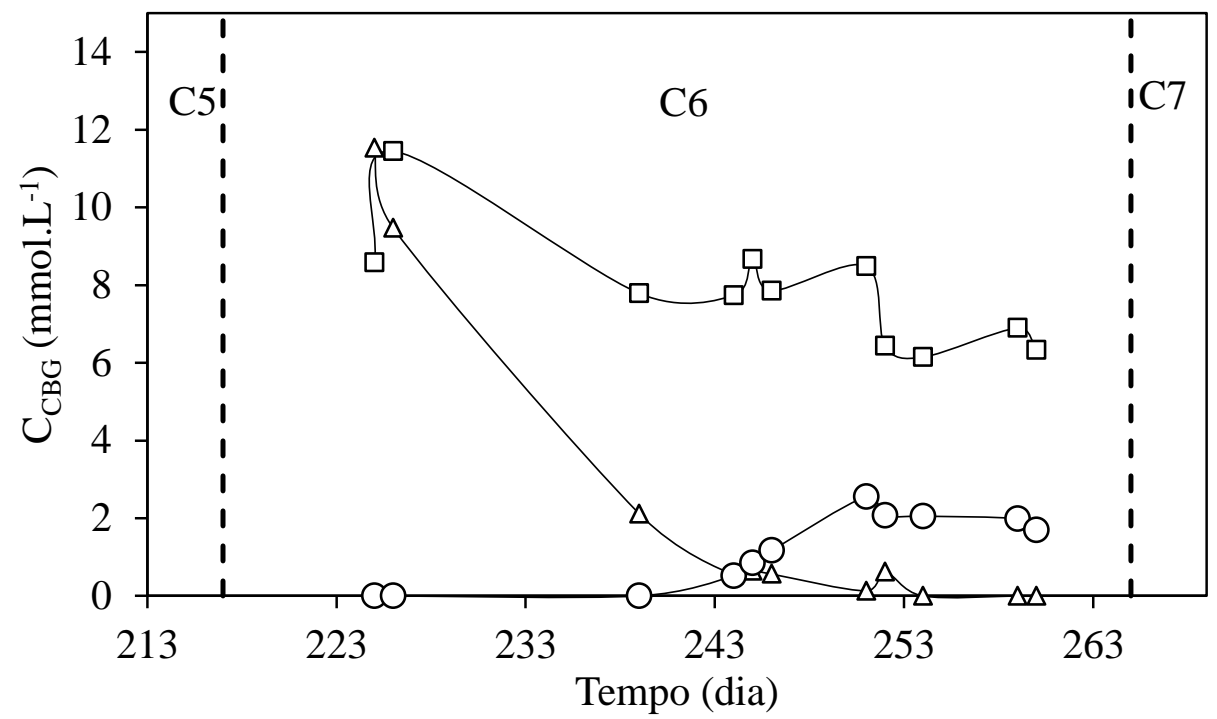

Figura 5-105 - Concentrações dos componentes do biogás no final do ciclo: $\square-\mathrm{CO}_{2} ; \Delta$ $-\mathrm{H}_{2} ; \circ-\mathrm{CH}_{4}$ (AnSBBR com recirculação da fase líquida e soro de leite - Condição 6). 


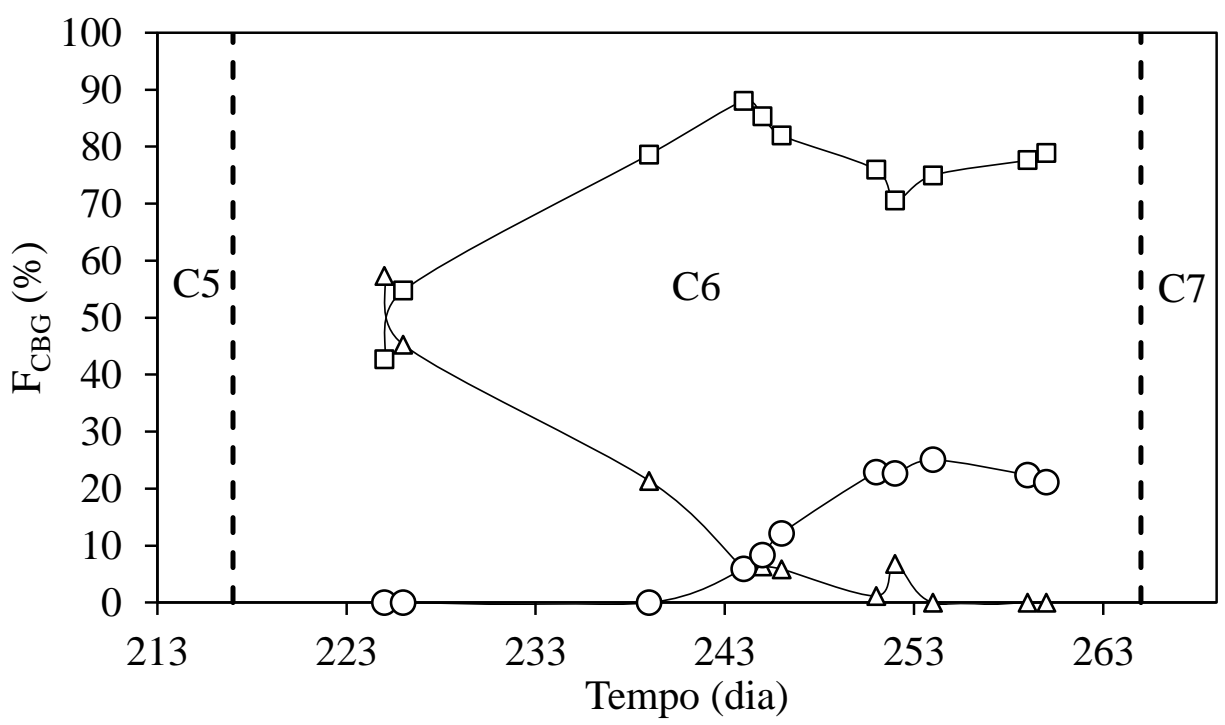

Figura 5-106 - Distribuições dos componentes do biogás no final do ciclo: $\square-\mathrm{CO}_{2} ; \Delta-$ $\mathrm{H}_{2} ; \circ-\mathrm{CH}_{4}$ (AnSBBR com recirculação da fase líquida e soro de leite - Condição 6). 


\subsubsection{Condição 7-Adaptação com lactose, alimentação com leite desnatado e afluente refrigerado}

Continuando na tentativa de entender os motivos para a instabilidade na produção de hidrogênio à partir do soro, operou-se a condição 7 alimentando o reator com leite desnatado longa vida. Esta condição apresentou COAV nominal de 14,6 kgDQO. $m^{-3} \cdot d^{-1}$ e duração do ciclo de 3 horas, durando do dia 266 ao dia 295 (30 dias de operação). Uma breve adaptação da biomassa foi realizada no começo da operação (do dia 266 ao dia 279 - 14 dias de operação), alimentando-se o reator com lactose durante este período. $\mathrm{O}$ intuito desta operação foi verificar se o problema na produção de hidrogênio com o soro de leite como substrato estava relacionado com alguma possível contaminação (isto seria confirmado caso uma produção de $\mathrm{H}_{2}$ estável fosse atingida, tendo em vista que o leite longa vida é esterilizado). A Tabela 5.27 apresenta os valores médios dos parâmetros monitorados. 
Tabela 5.27 - Valores médios dos parâmetros monitorados comuns a todas as etapas da condição experimental 7 (Leite desnatado longa vida - 4250 mgDQO.L ${ }^{-1}-t_{C} 3 h$ )

\begin{tabular}{|c|c|c|c|c|c|c|c|c|c|}
\hline \multicolumn{2}{|r|}{ Parâmetro } & \multicolumn{4}{|c|}{ Afluente } & \multicolumn{4}{|c|}{ Efluente } \\
\hline $\mathrm{C}_{\mathrm{ST}}$ & $\left(\mathrm{mgDQO} \cdot \mathrm{L}^{-1}\right)$ & 3237 & \pm & 295 & $\left({ }^{13}\right)$ & 2575 & \pm & 316 & $\left({ }^{13}\right)$ \\
\hline $\mathrm{C}_{\mathrm{SF}}$ & $\left(\mathrm{mgDQO} \cdot \mathrm{L}^{-1}\right)$ & - & \pm & - & $\left({ }^{3}\right)$ & 2496 & \pm & 343 & $\left(\begin{array}{l}13 \\
\end{array}\right)$ \\
\hline$\varepsilon_{\mathrm{ST}}$ & $(\%)$ & - & & - & & 21 & \pm & 9 & $\left(\begin{array}{l}13 \\
\end{array}\right)$ \\
\hline$\varepsilon_{\mathrm{SF}}$ & $(\%)$ & - & & - & & 23 & \pm & 10 & $\left(\begin{array}{l}13 \\
\end{array}\right)$ \\
\hline $\mathrm{C}_{\mathrm{CT}}$ & $\left(\mathrm{mgCarboidrato} . \mathrm{L}^{-1}\right)$ & 1961 & \pm & 823 & $\left({ }^{13}\right)$ & 82 & \pm & 182 & $\left(\begin{array}{l}13 \\
\end{array}\right)$ \\
\hline $\mathrm{C}_{\mathrm{CF}}$ & (mgCarboidrato. $\mathrm{L}^{-1}$ ) & - & \pm & - & $(\quad)$ & 65 & \pm & 143 & $\left(\begin{array}{l}13 \\
\end{array}\right)$ \\
\hline$\varepsilon_{\mathrm{CT}}$ & $(\%)$ & - & & - & & 96 & \pm & 9 & $\left(\begin{array}{l}13 \\
\end{array}\right)$ \\
\hline$\varepsilon_{\mathrm{CF}}$ & $(\%)$ & - & & - & & 97 & \pm & 7 & $\left(\begin{array}{l}13 \\
)\end{array}\right.$ \\
\hline $\mathrm{pH}$ & (u) & 7,72 & \pm & 0,21 & $\left({ }^{13}\right)$ & 5,54 & \pm & 0,71 & $\left(\begin{array}{l}13 \\
\end{array}\right)$ \\
\hline AVT & $\left(\mathrm{mgHAc} . \mathrm{L}^{-1}\right)$ & 87 & \pm & 43 & $\left({ }^{13}\right)$ & 1067 & \pm & 121 & $\left(\begin{array}{l}13 \\
\end{array}\right)$ \\
\hline AT & $\left(\mathrm{mgCaCO}_{3} \cdot \mathrm{L}^{-1}\right)$ & 470 & \pm & 34 & $\left({ }^{13}\right)$ & 415 & \pm & 218 & $\left({ }^{13}\right)$ \\
\hline $\mathrm{AP}$ & $\left(\mathrm{mgCaCO}_{3} \cdot \mathrm{L}^{-1}\right)$ & 326 & \pm & 26 & $\left({ }^{13}\right)$ & 28 & \pm & 25 & $\left(\begin{array}{l}13 \\
\end{array}\right)$ \\
\hline AI & $\left(\mathrm{mgCaCO}_{3} \cdot \mathrm{L}^{-1}\right)$ & 144 & \pm & 33 & $\left({ }^{13}\right)$ & 387 & \pm & 199 & $(13)$ \\
\hline $\mathrm{AB}$ & $\left(\mathrm{mgCaCO}_{3} \cdot \mathrm{L}^{-1}\right)$ & 408 & \pm & 35 & $\left({ }^{13}\right)$ & 0 & \pm & 0 & $\left(\begin{array}{l}13 \\
\end{array}\right)$ \\
\hline ST & $\left(\mathrm{mg} \cdot \mathrm{L}^{-1}\right)$ & 3046,6 & \pm & 197 & $\left({ }^{6}\right)$ & 2014 & \pm & 264 & $\left({ }^{6}\right)$ \\
\hline STV & $\left(\mathrm{mg} \cdot \mathrm{L}^{-1}\right)$ & 2396,6 & \pm & 198 & $\left({ }^{6}\right)$ & 1418 & \pm & 142 & $\left(\begin{array}{l}6 \\
\end{array}\right)$ \\
\hline SST & $\left(\mathrm{mg} \cdot \mathrm{L}^{-1}\right)$ & 55,3 & \pm & 23 & $\left({ }^{6}\right)$ & 92 & \pm & 22 & $\left({ }^{6}\right)$ \\
\hline SSV & $\left(\mathrm{mg} \cdot \mathrm{L}^{-1}\right)$ & 41,3 & \pm & 19 & $\left({ }^{6}\right)$ & 78 & \pm & 19 & $\left(\begin{array}{l}6 \\
\end{array}\right)$ \\
\hline $\mathrm{M}_{\mathrm{STV}}$ & (g) & - & & - & & - & & - & \\
\hline $\mathrm{C}_{\mathrm{X}}$ & $\left(\mathrm{g} . \mathrm{L}^{-1}\right)$ & - & & - & & - & & - & \\
\hline $\mathrm{C}_{\mathrm{X}}{ }^{\prime}$ & $\left(\right.$ g.gsuporte $\left.{ }^{-1}\right)$ & - & & - & & - & & - & \\
\hline $\mathrm{V}_{\mathrm{G}}$ & (mL-CNTP) & - & & - & & 317 & \pm & 5 & $(3)$ \\
\hline $\mathrm{V}_{\mathrm{H} 2}$ & (mL-CNTP) & - & & - & & - & & - & \\
\hline $\mathrm{COAV}_{\mathrm{STA}}$ & $\left(\operatorname{kgDQO} \cdot \mathrm{m}^{-3} \cdot \mathrm{d}^{-1}\right)$ & 11,1 & & - & & - & & - & \\
\hline $\mathrm{CORV}_{\mathrm{SFE}}$ & $\left(\operatorname{kgDQO} \cdot \mathrm{m}^{-3} \cdot \mathrm{d}^{-1}\right)$ & - & & - & & 2,5 & & - & \\
\hline $\mathrm{COAV}_{\mathrm{CTA}}$ & $\left(\right.$ kgCarboidrato. $\left.\mathrm{m}^{-3} \cdot \mathrm{d}^{-1}\right)$ & 6,7 & & - & & - & & - & \\
\hline $\mathrm{CORV}_{\mathrm{CFE}}$ & $\left(\right.$ kgCarboidrato. $\left.\mathrm{m}^{-3} \cdot \mathrm{d}^{-1}\right)$ & - & & - & & 6,5 & & - & \\
\hline $\mathrm{COAE}_{\mathrm{STA}}$ & $\left(\operatorname{kgDQO} \cdot \mathrm{kgSTV}^{-1} \cdot \mathrm{d}^{-1}\right)$ & - & & - & & - & & - & \\
\hline $\mathrm{CORE}_{\mathrm{SFE}}$ & $\left(\operatorname{kgDQO} \cdot k g S T V^{-1} \cdot d^{-1}\right)$ & - & & - & & - & & - & \\
\hline $\mathrm{COAE}_{\mathrm{CTA}}$ & $\left(\right.$ kgCarboidrato.kgSTV $\left.^{-1} \cdot \mathrm{d}^{-1}\right)$ & - & & - & & - & & - & \\
\hline $\mathrm{CORE}_{\mathrm{CFE}}$ & $\left(\mathrm{kgCarboidrato} \mathrm{kgSTV}^{-1} \cdot \mathrm{d}^{-1}\right)$ & - & & - & & - & & - & \\
\hline $\mathrm{RMCR}_{\mathrm{C}, \mathrm{n}}$ & $\left(\mathrm{molH}_{2}\right.$ molCarboidrato $\left.^{-1}\right)$ & - & & - & & - & & - & \\
\hline $\mathrm{n}_{\mathrm{H} 2}$ & $\left(\mathrm{molH}_{2} \cdot \mathrm{d}^{-1}\right)$ & - & & - & & - & & - & \\
\hline PrM & $\left(\mathrm{molH}_{2} \cdot \mathrm{m}^{-3} \cdot \mathrm{d}^{-1}\right)$ & - & & - & & - & & - & \\
\hline PrME & $\left(\mathrm{molH}_{2} \cdot \mathrm{kgSVT}^{-1} \cdot \mathrm{d}^{-1}\right)$ & - & & - & & - & & - & \\
\hline $\mathrm{RMCA}_{\mathrm{S}, \mathrm{m}}$ & $\left(\mathrm{molH}_{2} \cdot \mathrm{kgDQO}^{-1} \cdot \mathrm{d}^{-1}\right)$ & - & & - & & - & & - & \\
\hline $\mathrm{RMCA}_{\mathrm{C}, \mathrm{m}}$ & $\left(\mathrm{molH}_{2} \cdot \mathrm{kg}^{-1} \cdot \mathrm{d}^{-1}\right)$ & $\longrightarrow$ & & - & & - & & - & \\
\hline $\mathrm{RMCR}_{\mathrm{S}, \mathrm{m}}$ & $\left(\mathrm{molH}_{2} \cdot \mathrm{kgDQO}^{-1} \cdot \mathrm{d}^{-1}\right)$ & - & & - & & - & & - & \\
\hline $\mathrm{RMCR}_{\mathrm{C}, \mathrm{m}}$ & $\left(\mathrm{molH}_{2} \cdot \mathrm{kg}^{-1} \cdot \mathrm{d}^{-1}\right)$ & - & & - & & - & & - & \\
\hline $\mathrm{V}_{\mathrm{R}}$ & $(\mathrm{mL})$ & 2000 & & & & & & & \\
\hline $\mathrm{V}_{\mathrm{A}}$ & $(\mathrm{mL})$ & 1495 & \pm & 39 & $\left({ }^{12}\right)$ & - & & - & \\
\hline $\mathrm{Q}_{\mathrm{R}}$ & $\left(\mathrm{mL} \cdot \mathrm{s}^{-1}\right)$ & 6 & \pm & - & $\left({ }^{1}\right)$ & - & & - & \\
\hline
\end{tabular}

(*) Entre parêntese o número de amostras considerado no cálculo da média 
A Figura 5-107 apresenta os valores da concentração afluente (amostras não filtradas) e efluente (amostras não filtradas e filtradas) de matéria orgânica (DQO) nos sistema, enquanto que a Figura 5-108 apresenta a eficiência de remoção do mesmo parâmetro durante o monitoramento diário. Esta eficiência atingiu, em média, 23\% para as amostras filtradas e $21 \%$ para amostras não filtradas. A média de concentração afluente para amostras não filtradas do substrato foi de $3237 \mathrm{mgDQO} . \mathrm{L}^{-1}$ e de 2575 mgDQO. $L^{-1}$ e 2496 mgDQO.L $L^{-1}$ para amostras de efluente não filtradas e filtradas, respectivamente.

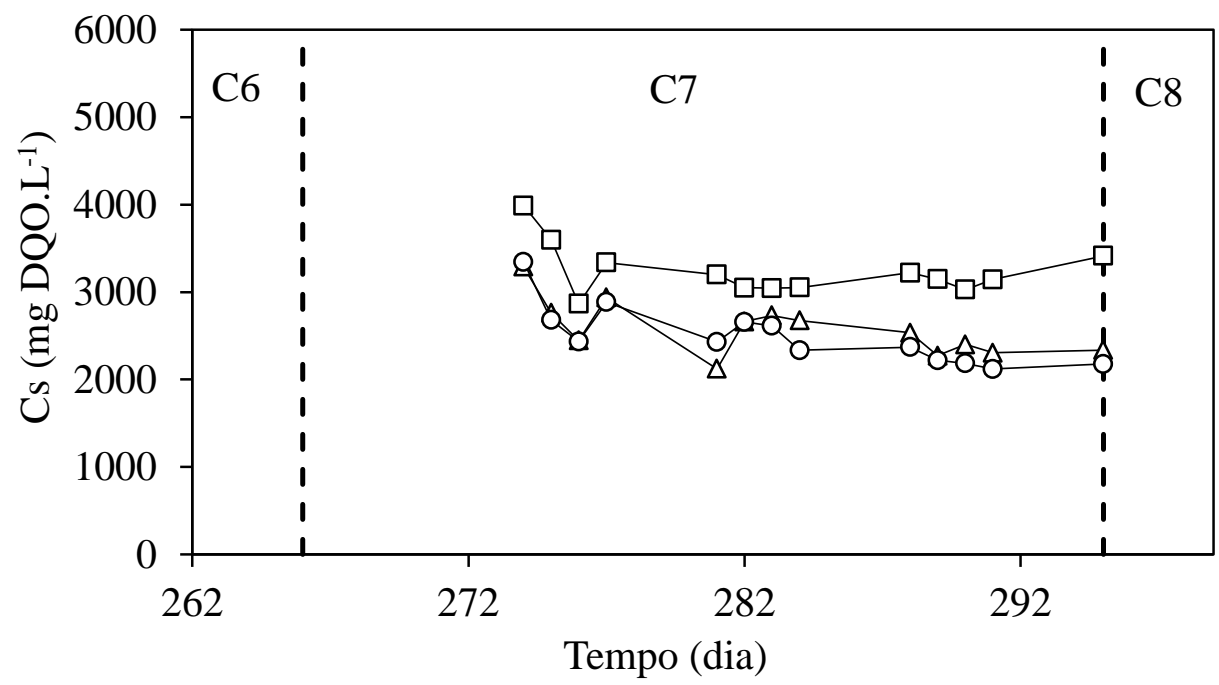

Figura 5-107 - Concentração de matéria orgânica (DQO): $\square$ - afluente não filtrada; $\Delta$ efluente não filtrada; o - efluente filtrada (AnSBBR com recirculação da fase líquida e leite desnatado longa vida - Condição 7). 


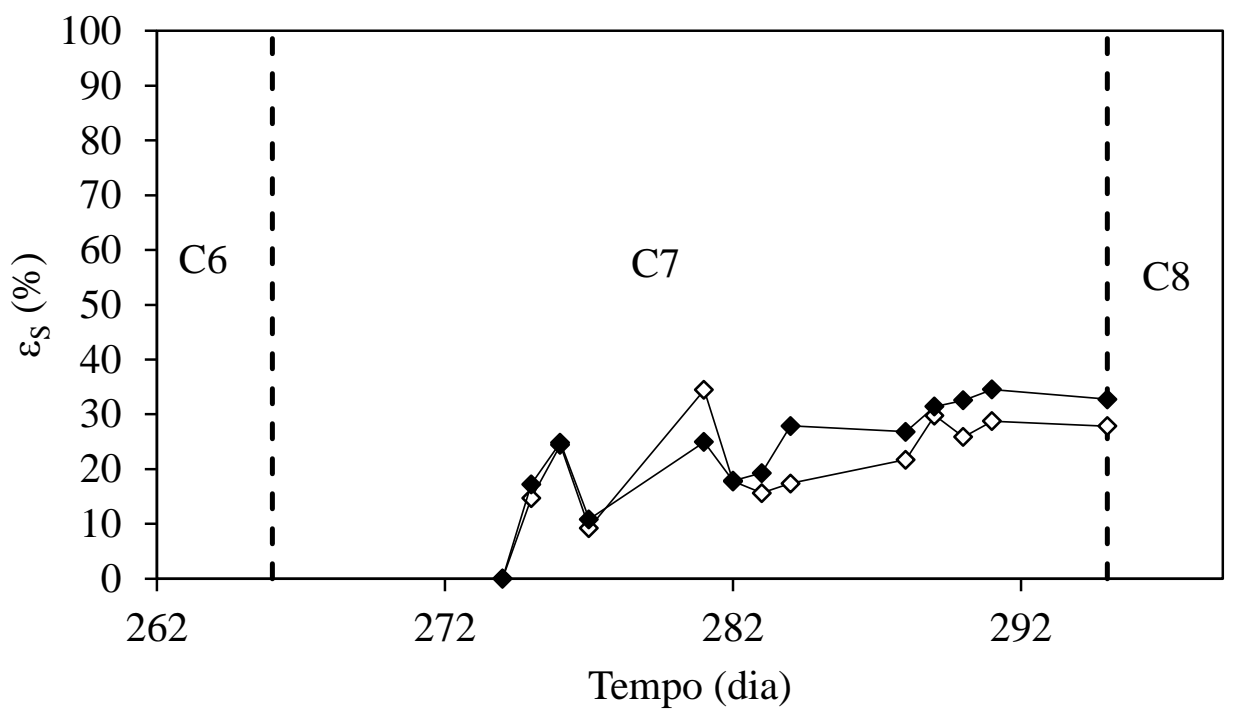

Figura 5-108-Eficiência de remoção de matéria orgânica (DQO): $\diamond$ - não filtrada; filtrada (AnSBBR com recirculação da fase líquida e leite desnatado longa vida Condição 7).

A Figura 5-109 mostra os valores da concentração de carboidratos afluente e efluente (para amostras filtradas e não filtradas). A Figura 5-110 apresenta a eficiência de remoção do mesmo parâmetro (para amostras filtradas e não filtradas) durante o monitoramento diário. A média da concentração afluente foi de $1961 \mathrm{mgCarboidrato.L^{- }}$ ${ }^{1}$, enquanto que a concentração residual não filtrada foi de $82 \mathrm{mgCarboidrato.} \mathrm{L}^{-1}$ e 65 mgCarboidrato. $\mathrm{L}^{-1}$ para a concentração residual filtrada. A eficiência de remoção de lactose foi, em média, de $97 \%$ para as amostras filtradas e de $96 \%$ para as amostras não filtradas. 


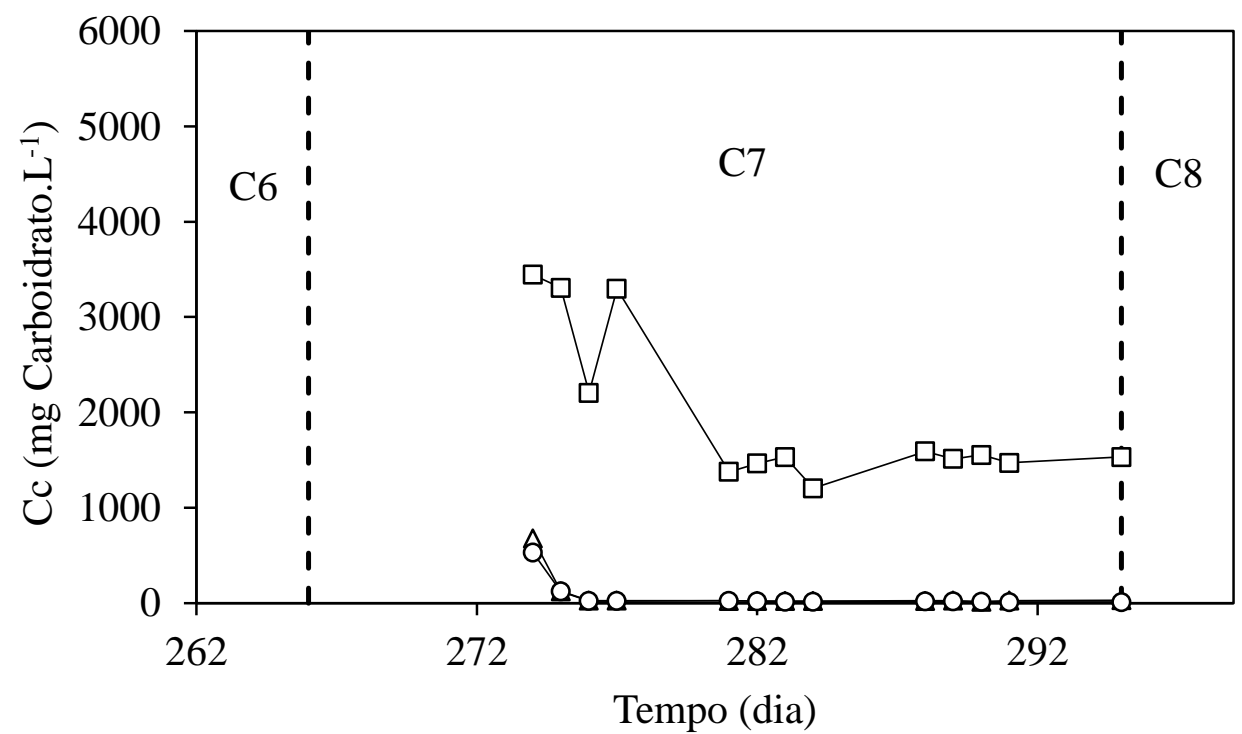

Figura 5-109 - Concentração de carboidrato: $\square$ - afluente não filtrada; $\Delta$ - efluente não filtrada; $\bigcirc-$ efluente filtrada (AnSBBR com recirculação da fase líquida e leite desnatado longa vida - Condição 7).

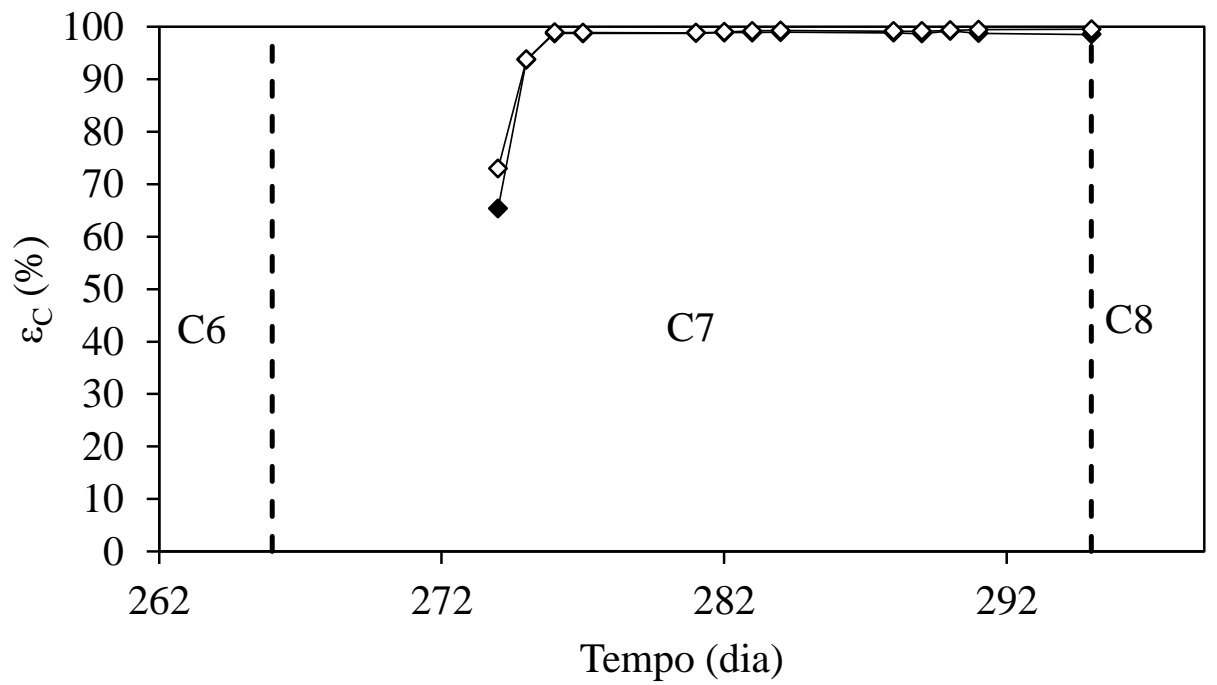

Figura 5-110 - Eficiência de remoção de carboidrato: $\diamond$ - não filtrada; $\downarrow$ - filtrada (AnSBBR com recirculação da fase líquida e leite desnatado longa vida - Condição 7).

As Figura 5-111, Figura 5-112 e Figura 5-113 apresentam os perfis temporais, tanto para o afluente quanto para o efluente, do $\mathrm{pH}$, da alcalinidade total e dos ácidos voláteis totais, respectivamente. A média dos valores de $\mathrm{pH}$ afluente durante esta primeira fase foi de 7,72 e de $\mathrm{pH}$ efluente foi de 5,54. A média da alcalinidade total foi de 470 e $415 \mathrm{mgCaCO}_{3} \cdot \mathrm{L}^{-1}$ para o afluente e efluente, respectivamente. $\mathrm{O}$ valor médio 
da concentração de ácidos voláteis totais afluente foi de $87 \mathrm{mgHAc} . \mathrm{L}^{-1}$ e efluente de 1067 mgHAc. $L^{-1}$. A queda do pH efluente está relacionada com a alta produção de ácidos voláteis totais.

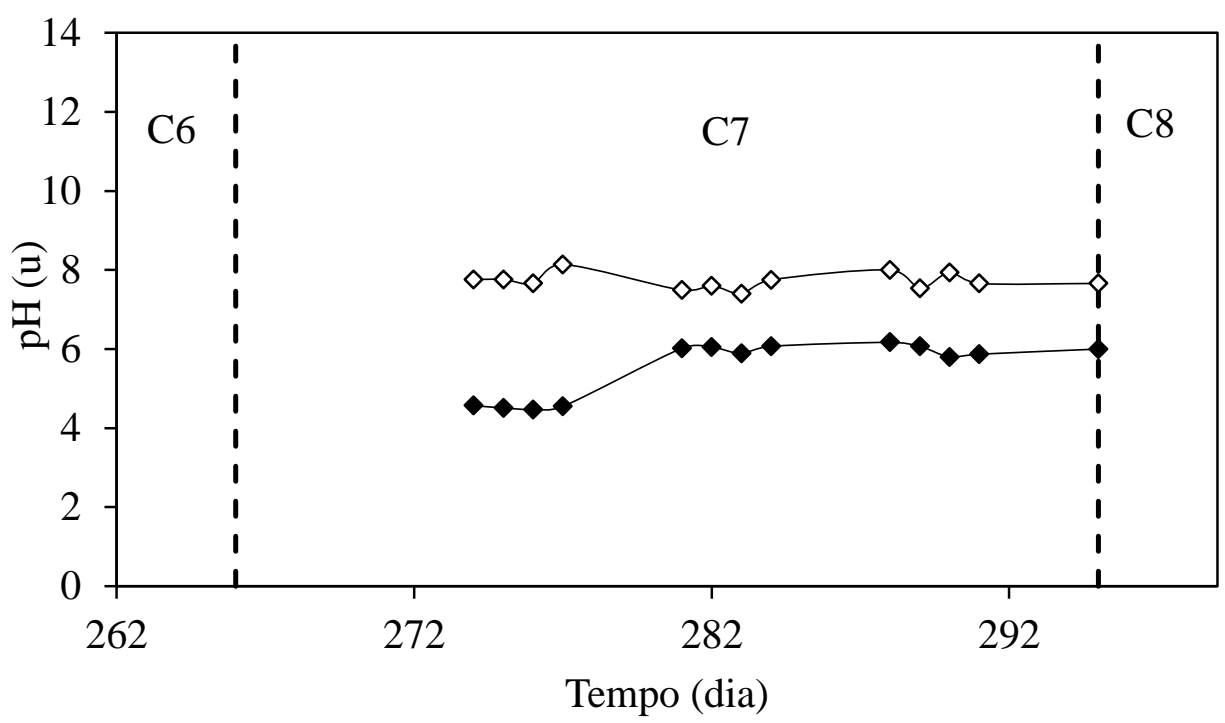

Figura 5-111 - Valores de pH: $\diamond$-afluente; - efluente (AnSBBR com recirculação da fase líquida e leite desnatado longa vida - Condição 7).

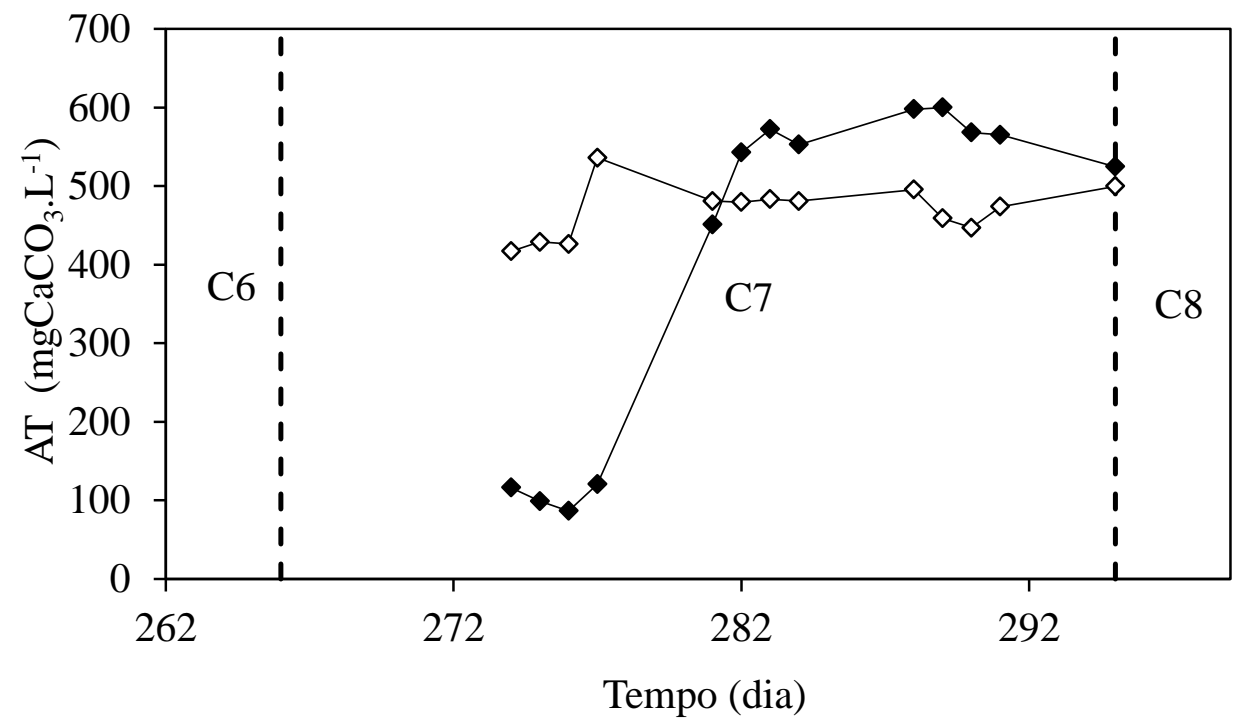

Figura 5-112 - Alcalinidade total: $\diamond$-afluente; - efluente (AnSBBR com recirculação da fase líquida e leite desnatado longa vida - Condição 7). 


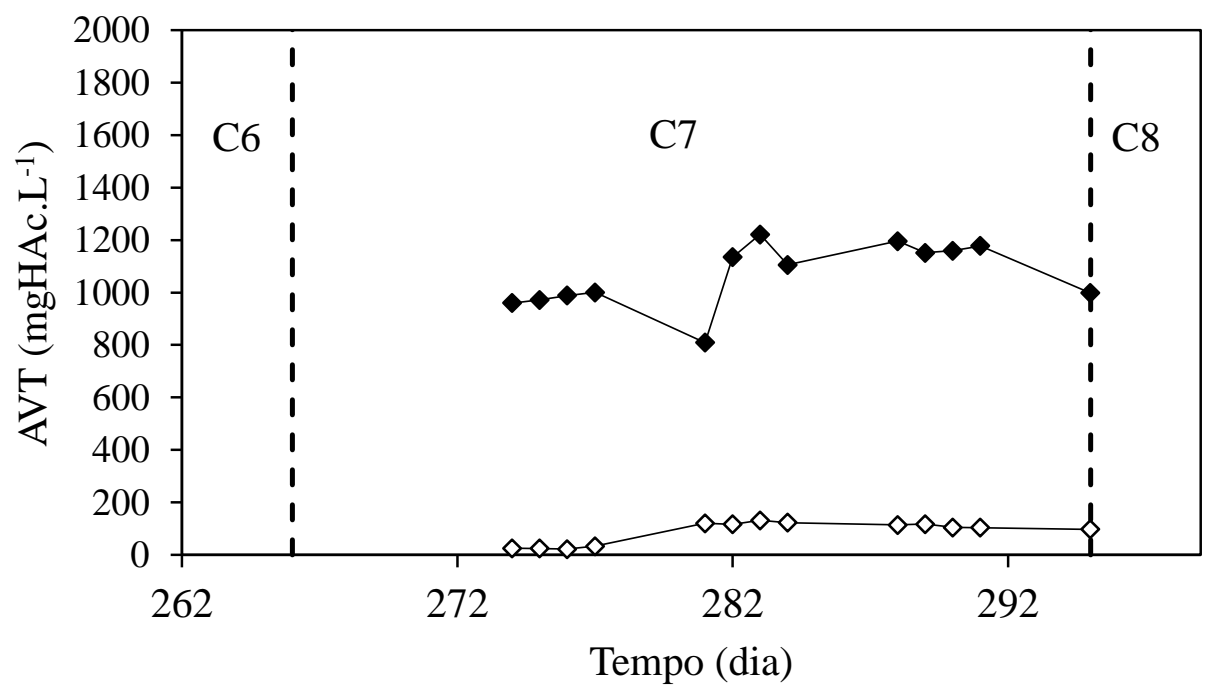

Figura 5-113 - Ácidos voláteis totais: $\diamond$-afluente; - efluente (AnSBBR com recirculação da fase líquida e leite desnatado longa vida - Condição 7).

O monitoramento da série de sólidos é mostrado na Tabela 5.28, cujos valores apresentam um baixo teor de SSV no efluente e afluente, indicando a boa capacidade do reator em reter biomassa, mesmo no começo da operação.

Tabela 5.28 - Série de sólidos afluente e efluente (AnSBBR com recirculação da fase líquida e leite desnatado longa vida - Condição 7)

\begin{tabular}{lcccc}
\hline & $\begin{array}{c}\text { ST } \\
\left(\mathrm{mg} . L^{-1}\right)\end{array}$ & $\begin{array}{c}\text { SVT } \\
\left(\mathrm{mg} . L^{-1}\right)\end{array}$ & $\begin{array}{c}\text { SST } \\
\left(\mathrm{mg} . L^{-1}\right)\end{array}$ & $\begin{array}{c}\text { SSV } \\
\left(\mathrm{mg} . \mathrm{L}^{-1}\right)\end{array}$ \\
\hline Afluente & $3047 \pm 197$ & $2397 \pm 198$ & $55 \pm 23$ & $41 \pm 264$ \\
Efluente & $2014 \pm 264$ & $1418 \pm 142$ & $92 \pm 22$ & $78 \pm 19$ \\
\hline
\end{tabular}

*Número de amostras consideradas $=6$.

A produção do biogás por ciclo, em aspecto quantitativo, pode ser observada na Figura 5-114. A produção média foi de $465 \mathrm{~mL}$ (CNTP). A Figura 5-115 apresenta o monitoramento das concentrações dos componentes do biogás no final do ciclo, enquanto que a Figura 5-116 apresenta a distribuição destes mesmos componentes. Os valores médios de concentração de $\mathrm{H}_{2}, \mathrm{CH}_{4}$ e $\mathrm{CO}_{2}$ foram 2,8, 0,9 e 7,8 mmol.L ${ }^{-1}$, respectivamente. Além disso, a distribuição percentual média de $\mathrm{H}_{2}$ foi de $16,1 \%$, a de 
$\mathrm{CH}_{4}$ foi de $9,7 \%$ e a de $\mathrm{CO}_{2}$ foi de $74,2 \%$. Vale ressaltar que as quantidades de hidrogênio e metano retratadas pelos valores médios estão levando em consideração os valores obtidos na adaptação com lactose (altas concentrações de hidrogênio e sem produção de metano). A operação com leite desnatado longa vida atingiu valores de concentração de $\mathrm{H}_{2}$ iguais a zero no final da operação, dando indícios que a instabilidade na produção de hidrogênio com o soro de leite não foi ocasionada por alguma contaminação. Mais uma vez, foram presenciados indícios de produção de $\mathrm{H}_{2} \mathrm{~S}$ (odor característico e formação de substância branca recobrindo o exterior das mangueiras de alimentação) por possível ação de bactérias redutoras de sulfato (BRS).

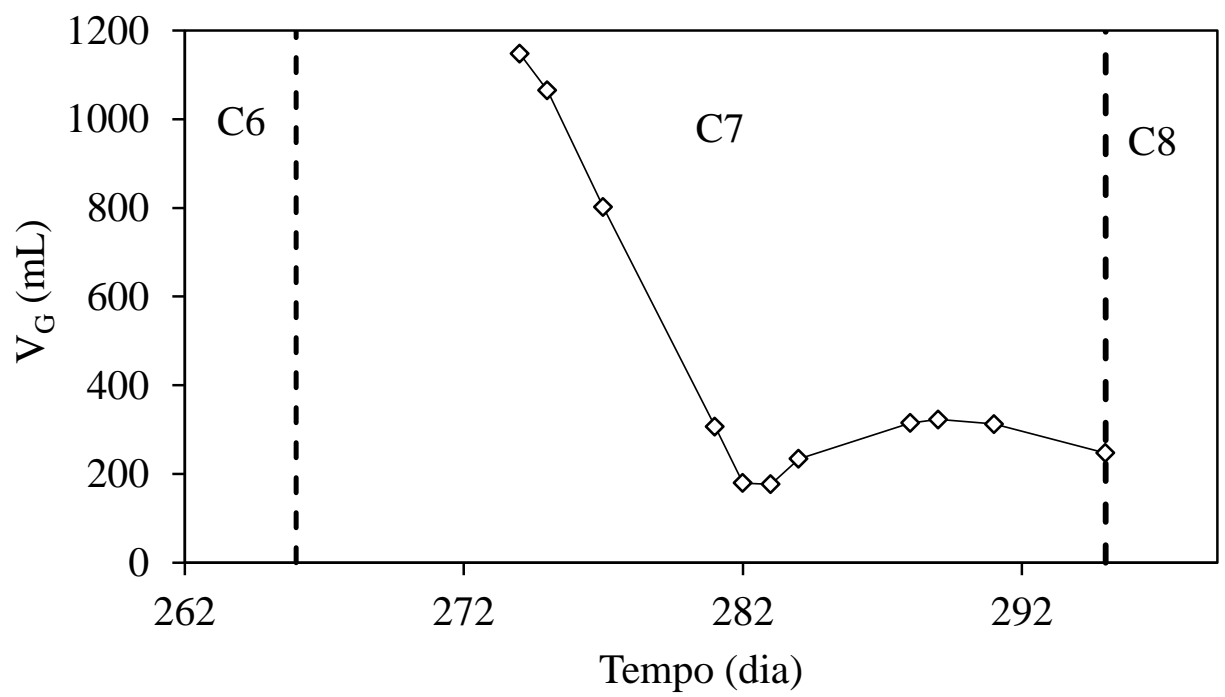

Figura 5-114 - Volume de biogás produzido por ciclo (AnSBBR com recirculação da fase líquida e leite desnatado longa vida - Condição 7). 


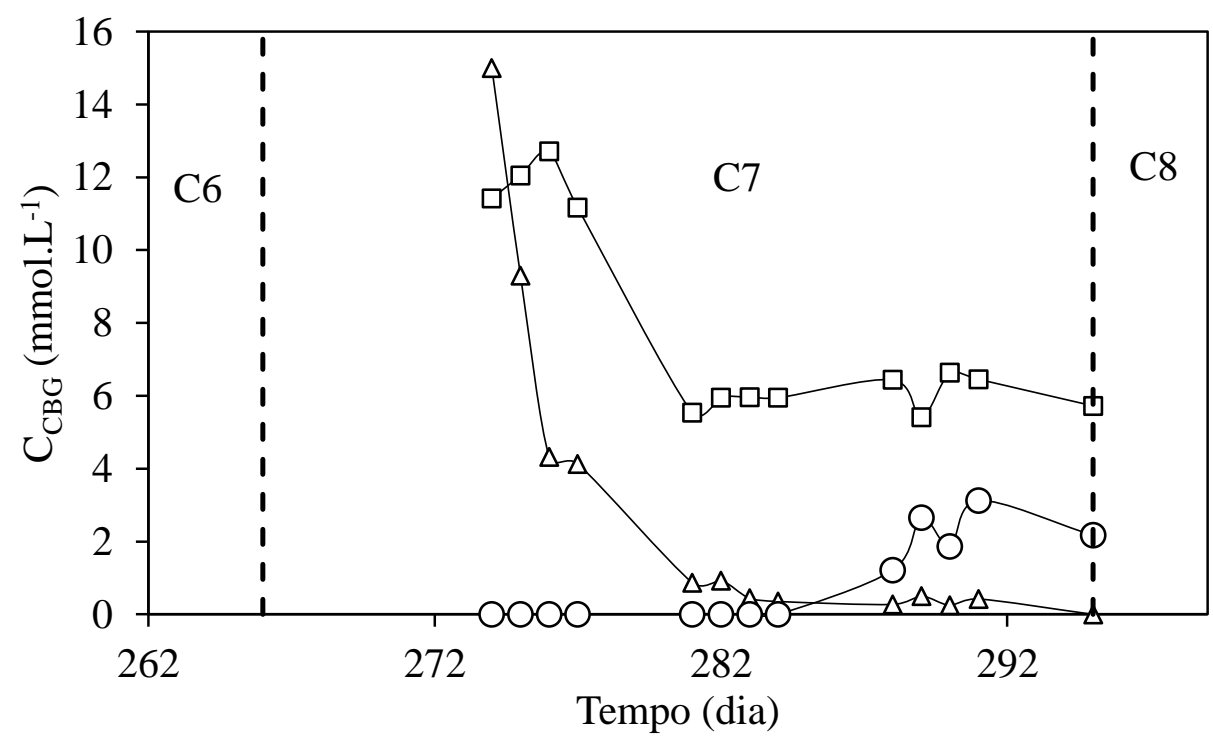

Figura 5-115 - Concentrações dos componentes do biogás no final do ciclo: $\square-\mathrm{CO}_{2} ; \Delta$ - $\mathrm{H}_{2} ; \mathrm{O}-\mathrm{CH}_{4}$ (AnSBBR com recirculação da fase líquida e leite desnatado longa vida Condição 7).

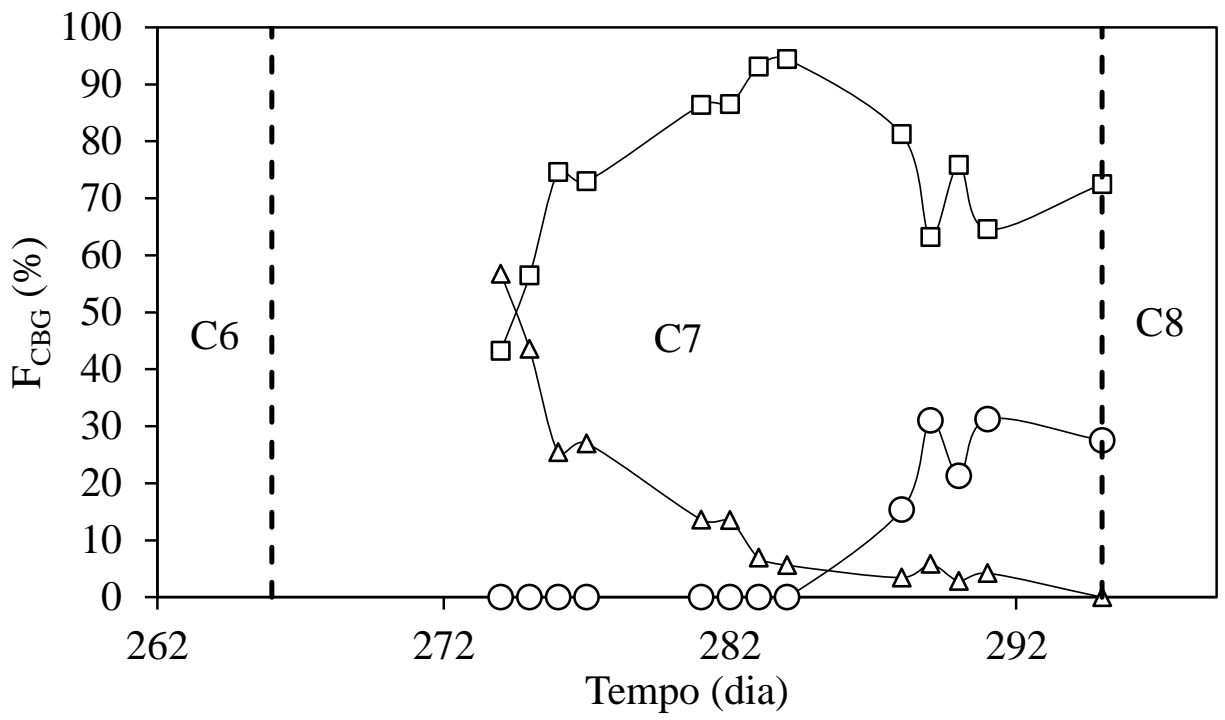

Figura 5-116 - Distribuições dos componentes do biogás no final do ciclo: $\square-\mathrm{CO}_{2} ; \Delta-$ $\mathrm{H}_{2} ; \mathrm{O}-\mathrm{CH}_{4}$ (AnSBBR com recirculação da fase líquida e leite desnatado longa vida Condição 7). 
5.1.2.5. Condição 8-Afluente (soro de leite) sem solução de nutrientes e ureia, com lavagem semanal e afluente ( $t_{c}=3$ horas, $C_{S T}=4250$ $\left.m g D Q O \cdot L^{-1}\right)$

A condição experimental 8 apresentou uma COAV nominal de 14,6 kgDQO.m ${ }^{3} \cdot \mathrm{d}^{-1}$ e duração do ciclo de 3 horas, indo do dia 296 ao dia 332 (37 dias de operação). Tendo em vista os indícios de produção de $\mathrm{H}_{2} \mathrm{~S}$ (odor característico e formação de substância branca recobrindo o exterior das mangueiras de alimentação) por possível ação de bactérias redutoras de sulfato (BRS), nesta condição optou-se por alimentar o reator apenas com soro de leite e bicarbonato de sódio, retirando-se a uréia e a complementação de nutrientes. Esta solução de nutrientes, adaptado de Del Nery (1987) continha uma quantidade aproximada de $13 \mathrm{mgSO}_{4} \cdot \mathrm{L}^{-1}$ de meio de alimentação (provenientes do sulfato de níquel e do sulfato ferroso), quantidade que pode ser considerada alta para um nutriente que é requisitado em pequenas quantidades para o crescimento celular. Além disso, lavagens do material suporte foram realizadas buscando um maior controle da biomassa dentro do reator.

A Tabela 5.29 apresenta os valores médios dos parâmetros monitorados. 
Tabela 5.29 - Valores médios dos parâmetros monitorados na condição experimental 8 (Soro de leite - $4250 \mathrm{mgDQO} . \mathrm{L}^{-1}-\mathrm{t}_{\mathrm{C}} 3 \mathrm{~h}$ ).

\begin{tabular}{|c|c|c|c|c|c|c|c|c|c|}
\hline \multicolumn{2}{|r|}{ Parâmetro } & \multicolumn{5}{|c|}{ Afluente } & \multicolumn{3}{|c|}{ Efluente } \\
\hline $\mathrm{C}_{\mathrm{ST}}$ & $\left(\mathrm{mgDQO} \cdot \mathrm{L}^{-1}\right)$ & 4067 & \pm & 396 & $\left({ }^{1}\right.$ & ) & 3124 & \pm 233 & $\left({ }^{15}\right.$ \\
\hline $\mathrm{C}_{\mathrm{SF}}$ & $\left(\mathrm{mgDQO} \cdot \mathrm{L}^{-1}\right)$ & - & \pm & - & 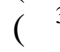 & ) & 2833 & \pm 166 & $(15$ \\
\hline$\varepsilon_{\mathrm{ST}}$ & $(\%)$ & - & & - & & & 23 & \pm & $(15$ \\
\hline$\varepsilon_{\mathrm{SF}}$ & $(\%)$ & - & & - & & & 30 & $\pm \quad 4$ & $(15$ \\
\hline $\mathrm{C}_{\mathrm{CT}}$ & (mgCarboidrato. $\left.\mathrm{L}^{-1}\right)$ & 3237 & \pm & 308 & $\left(\begin{array}{l}1 \\
-1\end{array}\right.$ & ) & 90 & \pm 145 & $(17$ \\
\hline $\mathrm{C}_{\mathrm{CF}}$ & $\left(\right.$ mgCarboidrato. $\left.\mathrm{L}^{-1}\right)$ & - & \pm & - & & & 51 & \pm 131 & $(17$ \\
\hline$\varepsilon_{\mathrm{CT}}$ & $(\%)$ & - & & - & & & 97 & \pm 4 & $(17$ \\
\hline$\varepsilon_{\mathrm{CF}}$ & $(\%)$ & - & & - & & & 98 & $\pm \quad 4$ & $(17$ \\
\hline $\mathrm{pH}$ & (u) & 7,74 & \pm & 0,15 & $\left({ }^{1}\right.$ & ) & 4,27 & $\pm 0,19$ & $(17$ \\
\hline AVT & $\left(\mathrm{mgHAc} . \mathrm{L}^{-1}\right)$ & 118 & \pm & 13 & $(1$ & ) & 1408 & \pm 362 & $(17$ \\
\hline AT & $\left(\mathrm{mgCaCO}_{3} \cdot \mathrm{L}^{-1}\right)$ & 381 & \pm & 33 & $(1$ & ) & 30 & \pm 50 & $(17$ \\
\hline AP & $\left(\mathrm{mgCaCO}_{3} \cdot \mathrm{L}^{-1}\right)$ & 259 & \pm & 31 & $\left({ }^{1}\right.$ & ) & 0 & \pm 0 & $\left({ }^{17}\right)$ \\
\hline AI & $\left(\mathrm{mgCaCO}_{3} \cdot \mathrm{L}^{-1}\right)$ & 123 & \pm & 12 & $\left({ }^{1}\right.$ & ) & 30 & \pm 50 & $(17)$ \\
\hline $\mathrm{AB}$ & $\left(\mathrm{mgCaCO}_{3} \cdot \mathrm{L}^{-1}\right)$ & 298 & \pm & 33 & $(1$ & ) & 0 & \pm 0 & $(17)$ \\
\hline ST & $\left(\mathrm{mg} \cdot \mathrm{L}^{-1}\right)$ & 3757 & \pm & 439 & ( & ) & 2616 & \pm 572 & $\left(^{8}\right.$ \\
\hline STV & $\left(\mathrm{mg} \cdot \mathrm{L}^{-1}\right)$ & 3028 & \pm & 394 & ( & ) & 1914 & \pm 542 & $8)$ \\
\hline SST & $\left(\mathrm{mg} \cdot \mathrm{L}^{-1}\right)$ & 132 & \pm & 30 & ( & ) & 121 & \pm 67 & $\left(^{8}\right.$ \\
\hline SSV & $\left(\mathrm{mg} \cdot \mathrm{L}^{-1}\right)$ & 112 & \pm & 23 & ( & ) & 118 & \pm 56 & $\left({ }^{8}\right)$ \\
\hline $\mathrm{M}_{\mathrm{STV}}$ & (g) & - & & - & & & 15,5 & - & \\
\hline $\mathrm{C}_{\mathrm{X}}$ & $\left(\mathrm{g} . \mathrm{L}^{-1}\right)$ & - & & - & & & 4,2 & - & \\
\hline $\mathrm{C}_{\mathrm{X}}^{\prime}$ & (g.gsuporte ${ }^{-1}$ ) & - & & - & & & 0,010 & - & \\
\hline $\mathrm{V}_{\mathrm{G}}$ & (mL-CNTP) & - & & - & & & 526 & \pm 20 & $\left({ }^{4}\right.$ \\
\hline $\mathrm{V}_{\mathrm{H} 2}$ & (mL-CNTP) & - & & - & & & 187 & \pm & $\left({ }^{1}\right.$ \\
\hline $\mathrm{COAV}_{\mathrm{S}}$ & $\left(\mathrm{kgDQO} \cdot \mathrm{m}^{-3} \cdot \mathrm{d}^{-1}\right)$ & 13,9 & & - & & & - & - & \\
\hline $\mathrm{CORV}_{\mathrm{S}}$ & $\left(\right.$ kgDQO. $\left.\mathrm{m}^{-3} \cdot \mathrm{d}^{-1}\right)$ & - & & - & & & 4,2 & - & \\
\hline $\mathrm{COAV}_{\mathrm{C}}$ & $\left(\right.$ kgCarboidrato. $\left.\mathrm{m}^{-3} \cdot \mathrm{d}^{-1}\right)$ & 11,1 & & - & & & - & - & \\
\hline $\mathrm{CORV}_{\mathrm{C}}$ & $\left(\right.$ kgCarboidrato. $\left.\mathrm{m}^{-3} \cdot \mathrm{d}^{-1}\right)$ & - & & - & & & 10,9 & - & \\
\hline $\mathrm{COAE}_{\mathrm{S}}$ & $\left(\mathrm{kgDQO} \cdot \mathrm{kgSTV}^{-1} \cdot \mathrm{d}^{-1}\right)$ & 3,2 & & - & & & - & - & \\
\hline $\mathrm{CORE}_{\mathrm{S}}$ & $\left(\mathrm{kgDQO} \mathrm{kgSTV}^{-1} \cdot \mathrm{d}^{-1}\right)$ & - & & - & & & 1,0 & - & \\
\hline $\mathrm{COAE}_{\mathrm{C}}$ & $\left(\mathrm{kgCarboidrato} \mathrm{kgSTV}^{-1} \cdot \mathrm{d}^{-1}\right)$ & 2,5 & & - & & & - & - & \\
\hline $\mathrm{CORE}_{\mathrm{C}}$ & $\left(\mathrm{kgCarboidrato} \mathrm{kgSTV}^{-1} \cdot \mathrm{d}^{-1}\right)$ & - & & - & & & 2,5 & - & \\
\hline $\mathrm{RMCR}_{\mathrm{C}, \mathrm{n}}$ & $\left(\right.$ molH $_{2 .}$ molCarboidrato $\left.^{-1}\right)$ & 一 & & - & & & 0,6 & - & \\
\hline $\mathrm{n}_{\mathrm{H} 2}$ & $\left(\mathrm{molH}_{2} \cdot \mathrm{d}^{-1}\right)$ & - & & - & & & 0,067 & - & \\
\hline PrVH & $\left(\mathrm{mLH}_{2} \cdot \mathrm{L}^{-1} \cdot \mathrm{d}^{-1}\right)$ & - & & - & & & 406,2 & - & \\
\hline PrM & $\left(\mathrm{molH}_{2} \cdot \mathrm{m}^{-3} \cdot \mathrm{d}^{-1}\right)$ & - & & - & & & 18,1 & - & \\
\hline PrME & $\left(\mathrm{molH}_{2} \cdot \mathrm{kgSVT}^{-1} \cdot \mathrm{d}^{-1}\right)$ & - & & - & & & 4,3 & - & \\
\hline $\mathrm{RMCA}_{\mathrm{S}, \mathrm{m}}$ & $\left(\mathrm{molH}_{2} \cdot \mathrm{kgDQO}^{-1} \cdot \mathrm{d}^{-1}\right)$ & 1,4 & & - & & & - & - & \\
\hline $\mathrm{RMCA}_{\mathrm{C}, \mathrm{m}}$ & $\left(\mathrm{molH}_{2} \cdot \mathrm{kg}^{-1} \cdot \mathrm{d}^{-1}\right)$ & 1,7 & & - & & & - & - & \\
\hline $\mathrm{RMCR}_{\mathrm{S}, \mathrm{m}}$ & $\left(\mathrm{molH}_{2} \cdot \mathrm{kgDQO}^{-1} \cdot \mathrm{d}^{-1}\right)$ & - & & - & & & 4,5 & - & \\
\hline $\mathrm{RMCR}_{\mathrm{C}, \mathrm{m}}$ & $\left(\mathrm{molH}_{2} \cdot \mathrm{kg}^{-1} \cdot \mathrm{d}^{-1}\right)$ & - & & - & & & 1,7 & - & \\
\hline $\mathrm{V}_{\mathrm{R}}$ & $(\mathrm{mL})$ & 2180 & & & & & - & - & \\
\hline $\mathrm{V}_{\mathrm{A}}$ & $(\mathrm{mL})$ & 1465 & \pm & 40 & & & $\longrightarrow$ & - & \\
\hline $\mathrm{Q}_{\mathrm{R}}$ & $\left(\mathrm{mL} \cdot \mathrm{s}^{-1}\right)$ & 7 & \pm & 0 & ( & ) & - & - & \\
\hline
\end{tabular}

(*) Entre parêntese o número de amostras considerado no cálculo da média 
A Figura 5-117 apresenta os valores da concentração afluente (amostras não filtradas) e efluente (amostras não filtradas e filtradas) de matéria orgânica (DQO) nos sistema. A Figura 5-118 apresenta a eficiência de remoção do mesmo parâmetro durante o monitoramento diário. Esta eficiência atingiu, em média, 30\% para as amostras filtradas e $23 \%$ para mostras não filtradas. A média de concentração afluente não filtrada do substrato foi de $4067 \mathrm{mgDQO} . \mathrm{L}^{-1}$ e de $3124 \mathrm{mgDQO} . \mathrm{L}^{-1}$ e $2833 \mathrm{mgDQO} . \mathrm{L}^{-1}$ para amostras de efluente não filtradas e filtradas, respectivamente.

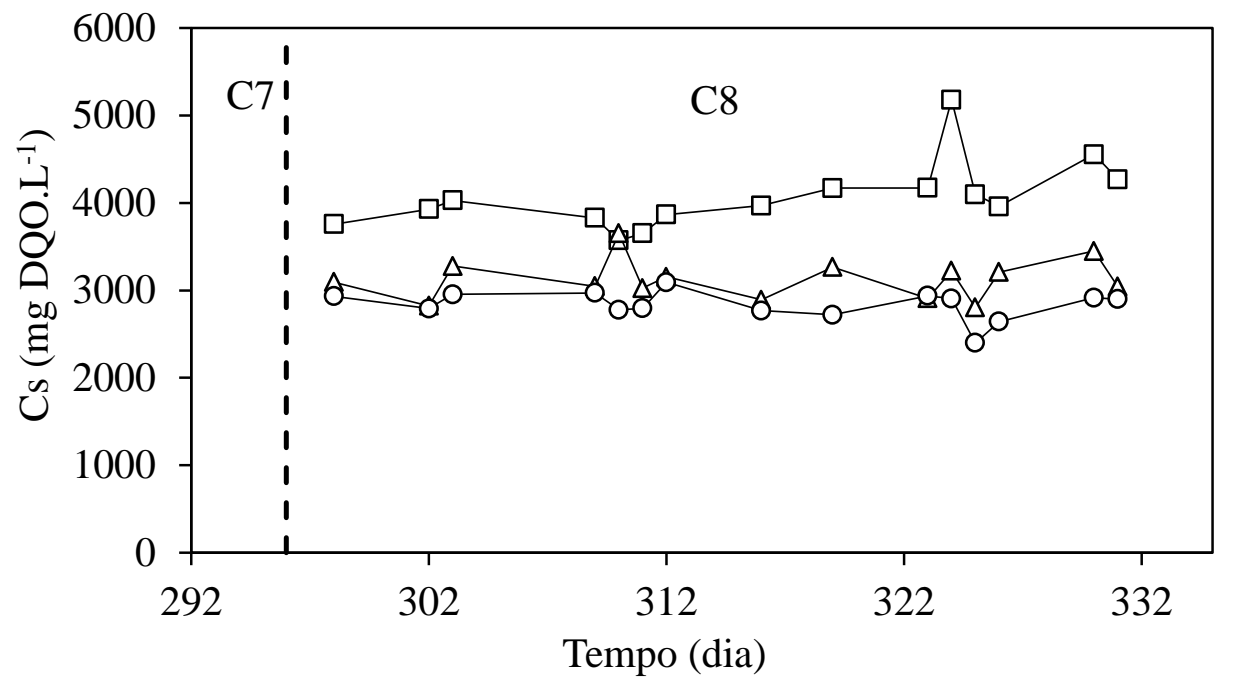

Figura 5-117 - Concentração de matéria orgânica (DQO): $\square$ - afluente não filtrada; $\Delta$ efluente não filtrada; o - efluente filtrada (AnSBBR com recirculação da fase líquida e soro de leite - Condição 8). 


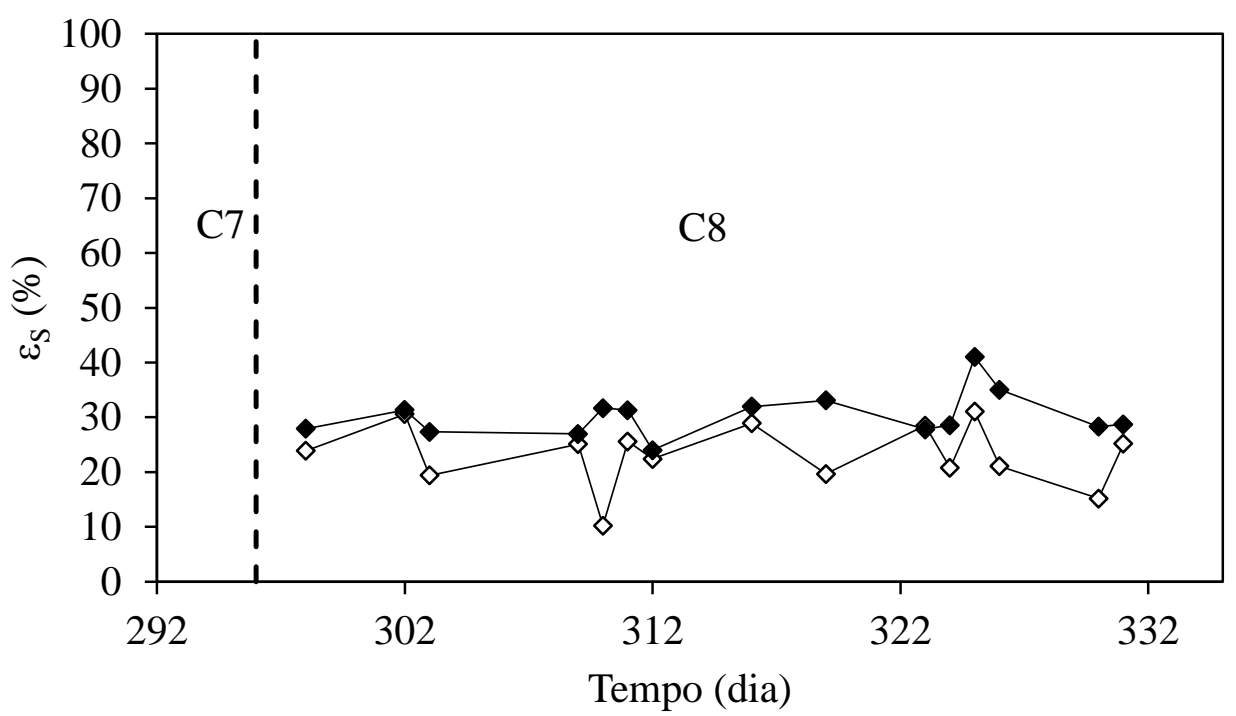

Figura 5-118 - Eficiência de remoção de matéria orgânica (DQO): $\diamond$ - não filtrada; filtrada (AnSBBR com recirculação da fase líquida e soro de leite - Condição 8).

A Figura 5-119 apresenta os valores da concentração de carboidratos afluente e efluente (para amostras filtradas e não filtradas) e Figura 5-120 apresenta a eficiência de remoção do mesmo parâmetro (não filtrada e filtrada) durante o monitoramento diário. A média da concentração afluente foi de $3237 \mathrm{mgCarboidrato.} \mathrm{L}^{-1}$, enquanto que a concentração residual (amostras não filtradas) foi de $90 \mathrm{mgCarboidrato.}^{-1}$ e 51 mgCarboidrato. $\mathrm{L}^{-1}$ para a concentração residual filtrada durante toda a operação e de 58 mgCarboidrato. $\mathrm{L}^{-1}$ e $18 \mathrm{mgCarboidrato.L^{-1 }}$ durante a fase estacionária. A eficiência de remoção de carboidrato foi, em média, de $98 \%$ para as amostras filtradas e $97 \%$ para mostras não filtradas durante toda a operação e de $99 \%$ para as amostras filtradas e $98 \%$ para mostras não filtradas durante a fase estacionária. 


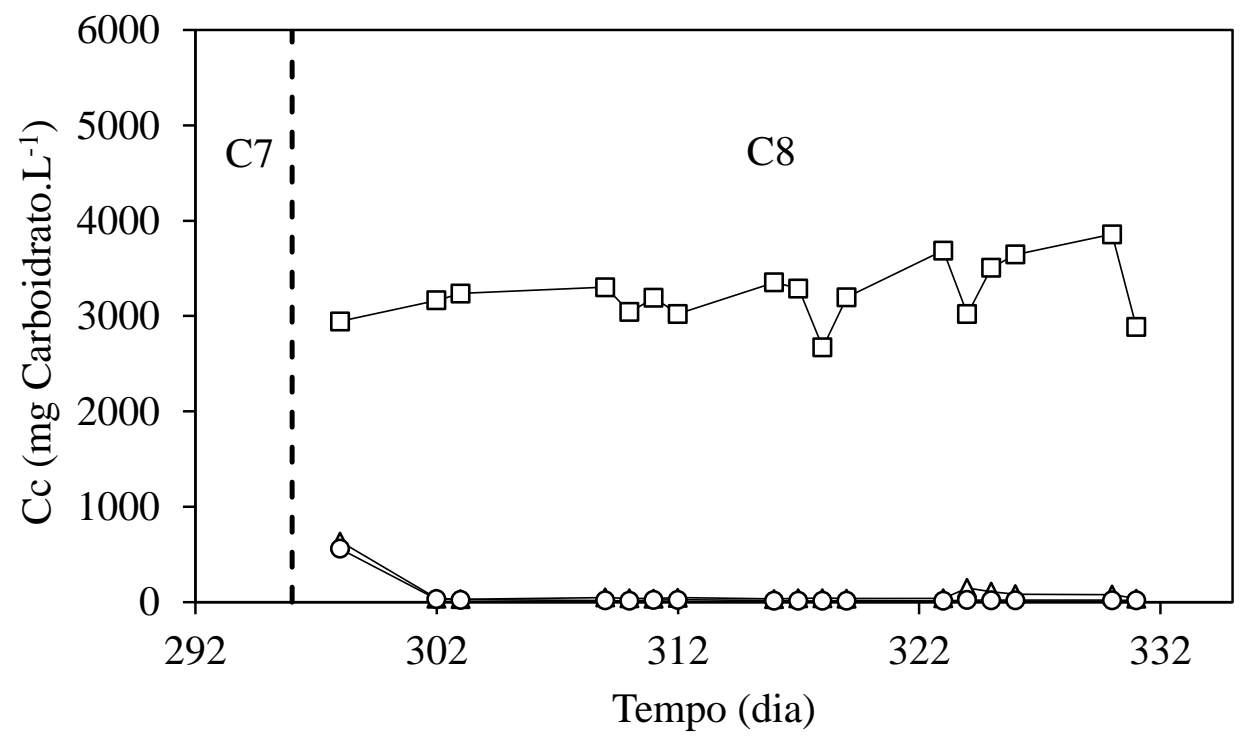

Figura 5-119 - Concentração de carboidrato: $\square$ - afluente não filtrada; $\Delta$ - efluente não filtrada; O - efluente filtrada (AnSBBR com recirculação da fase líquida e soro de leite Condição 8).

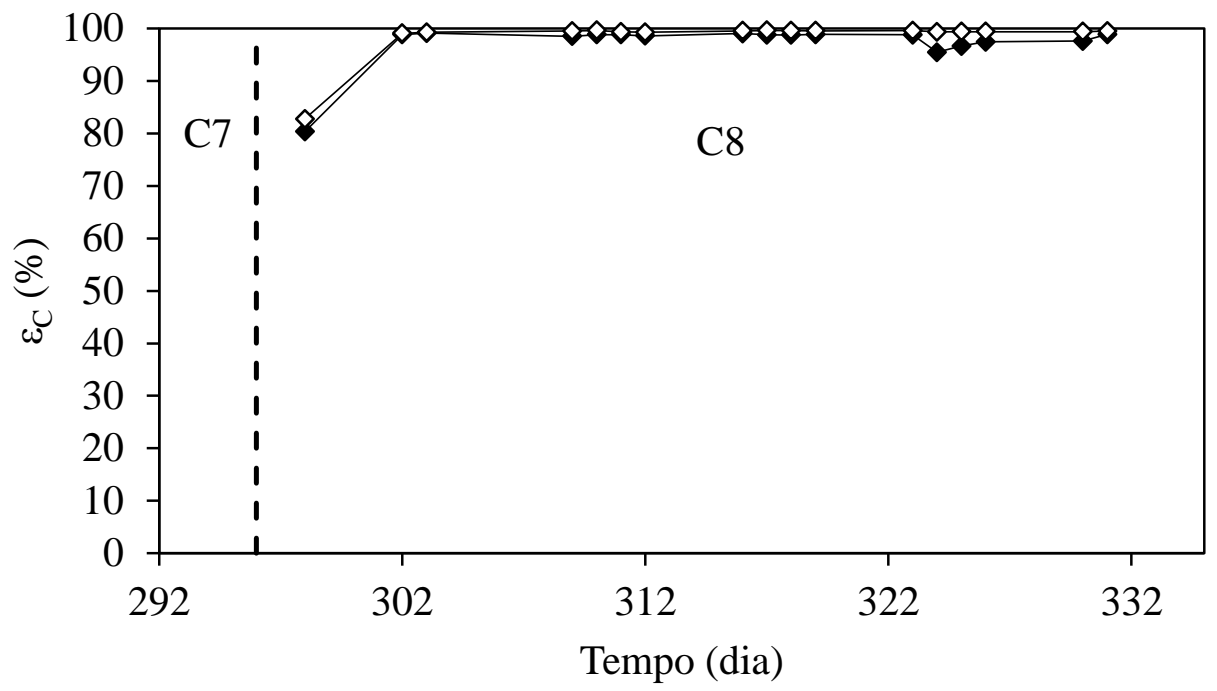

Figura 5-120 - Eficiência de remoção de carboidrato: $\diamond$ - não filtrada; $\downarrow$ - filtrada (AnSBBR com recirculação da fase líquida e soro de leite - Condição 8).

As Figura 5-121, Figura 5-122 e Figura 5-123 apresentam os perfis temporais (afluente e efluente) do $\mathrm{pH}$, da alcalinidade total e dos ácidos voláteis totais por titulação, respectivamente. A média dos valores de $\mathrm{pH}$ afluente durante a Condição 8 foi de 7,74 e de $\mathrm{pH}$ efluente foi de 4,27. A média da alcalinidade total foi de 381 
$\mathrm{mgCaCO} 3 \cdot \mathrm{L}^{-1}$ para o afluente e de $30 \mathrm{mgCaCO}_{3} \cdot \mathrm{L}^{-1}$ para o efluente. O valor médio da concentração de ácidos voláteis totais afluente foi de $118 \mathrm{mgHAc} . \mathrm{L}^{-1}$ e efluente de 1408 $\operatorname{mgHAc} . \mathrm{L}^{-1}$.

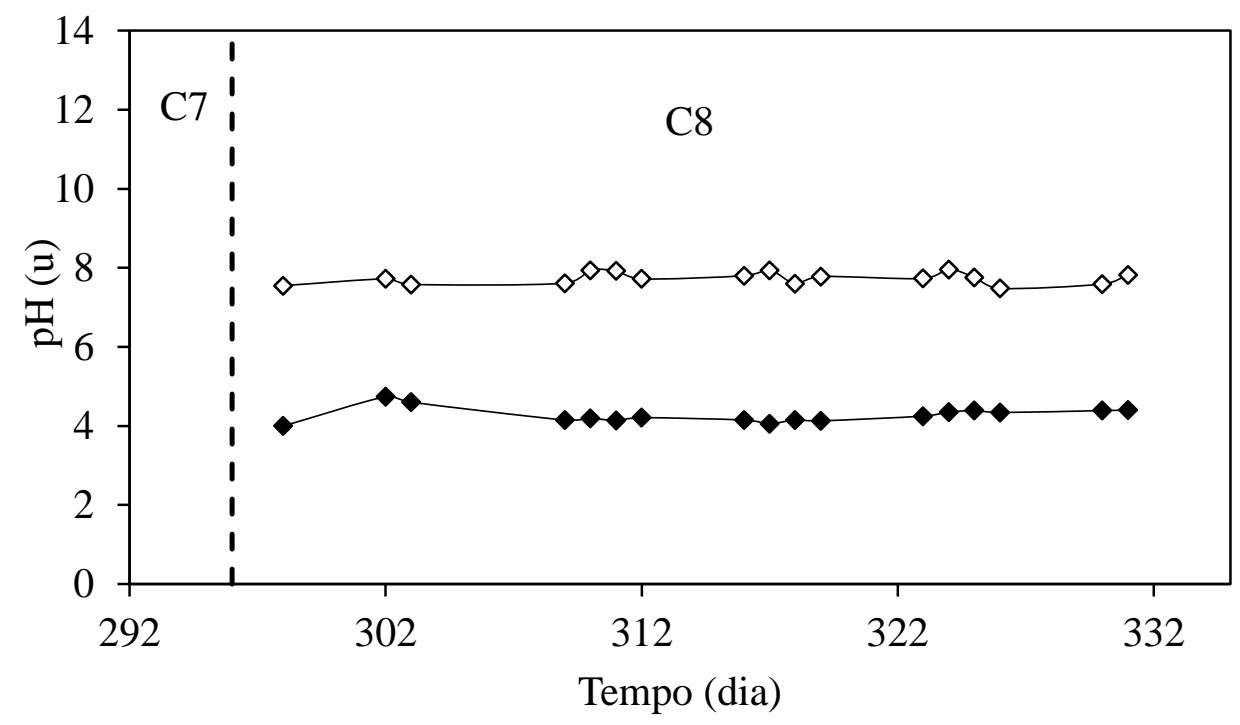

Figura 5-121 - Valores de pH: $\diamond$-afluente; - efluente (AnSBBR com recirculação da fase líquida e soro de leite - Condição 8).

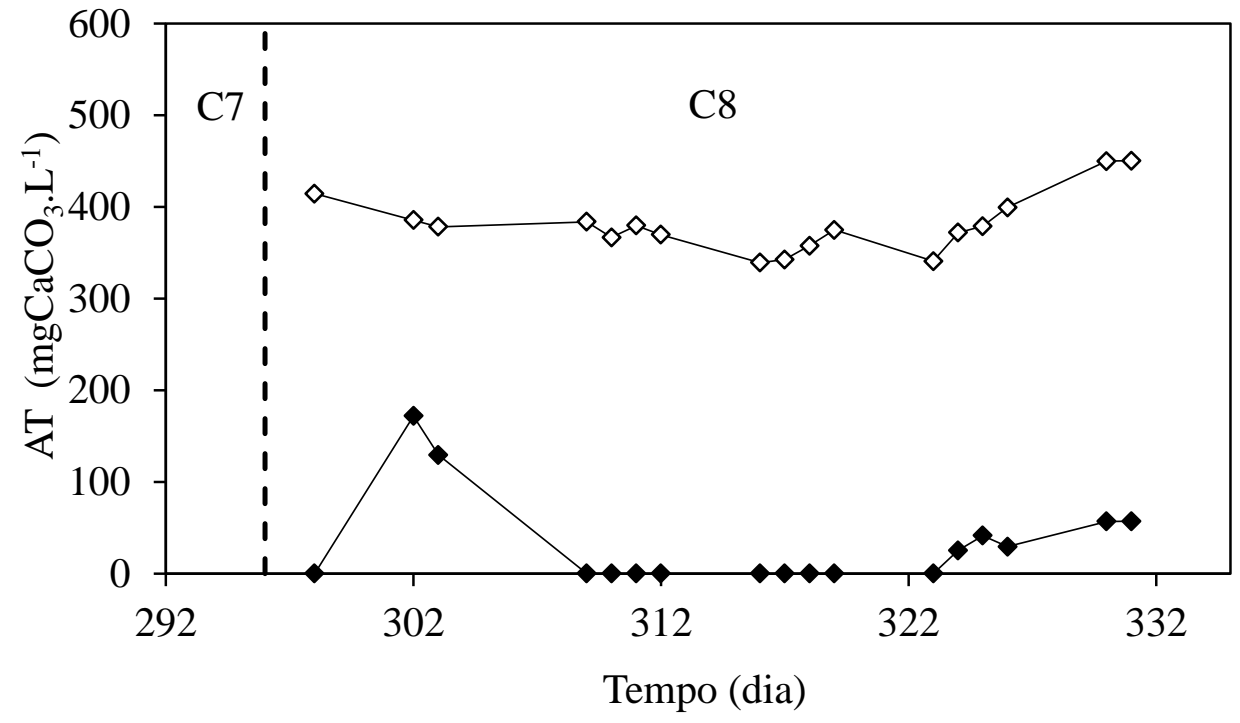

Figura 5-122 - Alcalinidade total: $\diamond$-afluente; - efluente (AnSBBR com recirculação da fase líquida e soro de leite - Condição 8). 


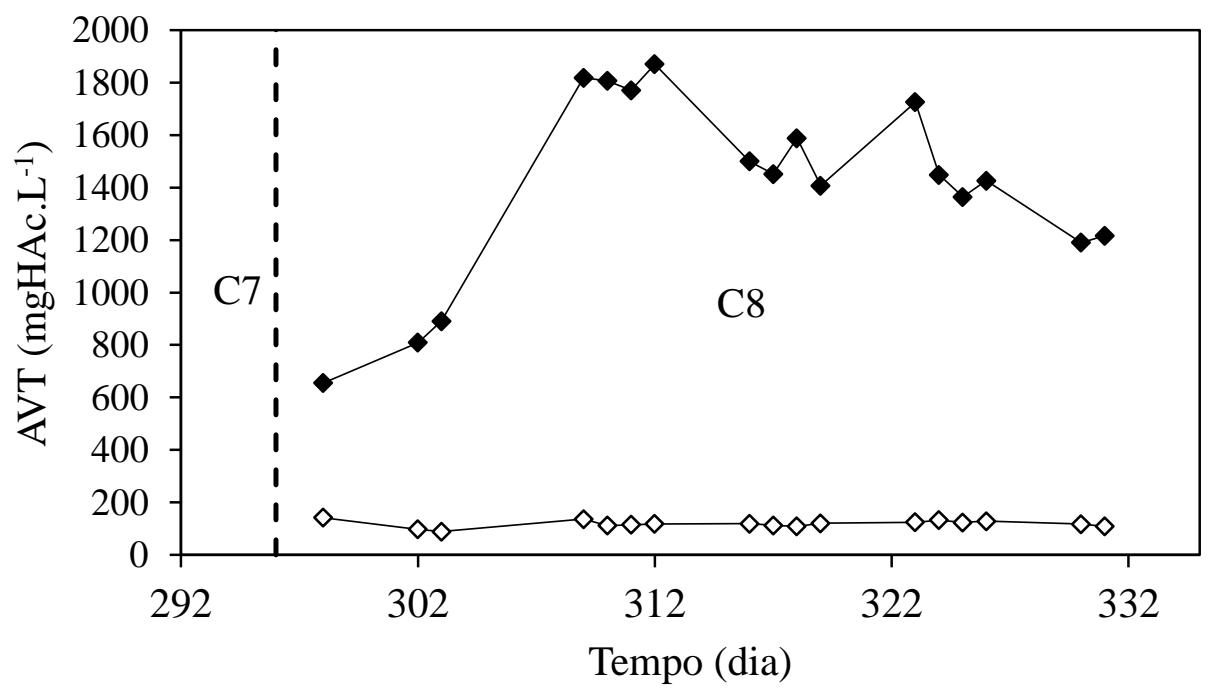

Figura 5-123 - Ácidos voláteis totais: $\diamond$-afluente; - efluente (AnSBBR com recirculação da fase líquida e soro de leite - Condição 8).

A Figura 5-124 apresenta o monitoramento dos compostos intermediários contidos no efluente do sistema, enquanto que a Tabela 5.30 apresenta os valores da concentração média destes produto. $\mathrm{O}$ método cromatográfico utilizado mais uma vez não detectou a presença de acetona e metanol. O ácido acético, o ácido butírico e o etanol foram os maiores destaques, representando juntos aproximadamente $90 \%$ dos produtos intermediários $(59,4 \%, 14,6 \%$ e $16,4 \%$, respectivamente). 


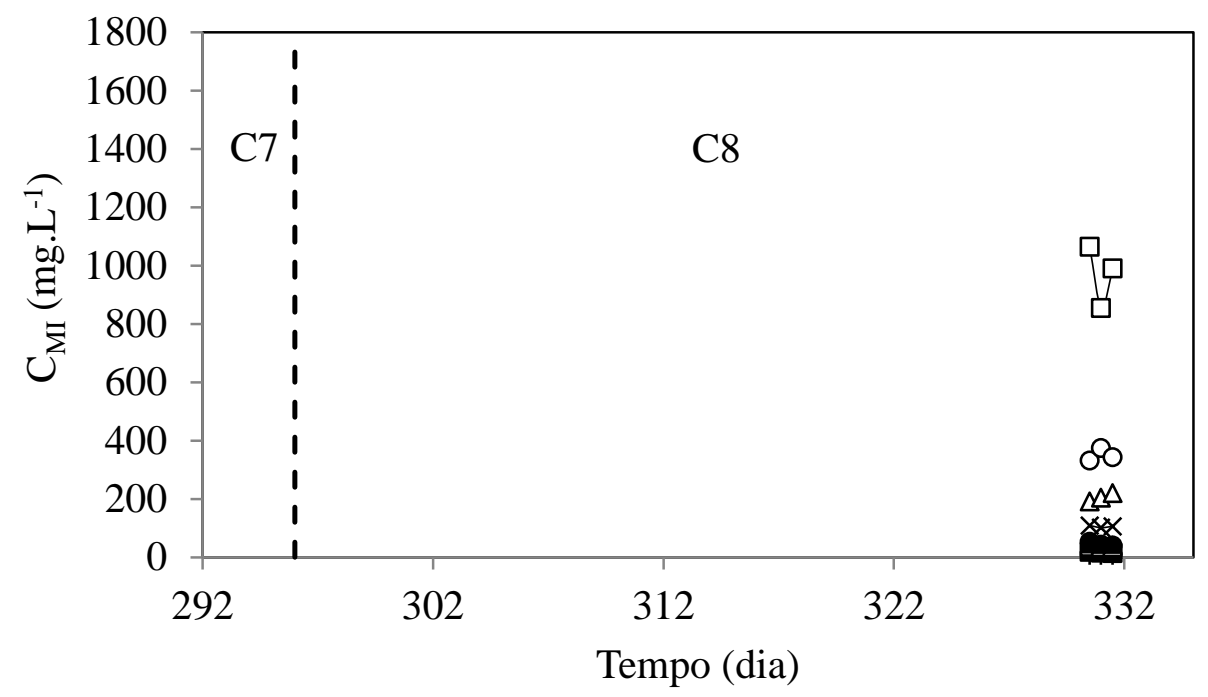

Figura 5-124 - Concentração dos compostos intermediários: $\square$ - ácido acético; $\Delta$ etanol; ○-ácido butírico; - ácido isobutírico; $\boldsymbol{\Delta}$ - ácido capróico; $\bullet$ - ácido valérico; * ácido propiônico; +butanol; - ácido isovalérico (AnSBBR com recirculação da fase líquida e soro de leite - Condição 8).

Tabela 5.30 - Concentração e distribuição dos compostos intermediários (AnSBBR com recirculação da fase líquida e soro de leite - Condição 8).

\begin{tabular}{cccccccc}
\hline $\begin{array}{c}\text { Produtos } \\
\text { intermediários }\end{array}$ & \multicolumn{5}{c}{ Concentrações médias } \\
$\left(\mathrm{mg} . \mathrm{L}^{-1}\right)$ & \multicolumn{3}{c}{$\begin{array}{c}\text { Distribuição } \\
\left(\mathrm{mmol.L^{-1 }}\right)\end{array}$} \\
\hline Acetona & 0,0 & \pm & 0,0 & 0,0 & \pm & 0,0 & 0,0 \\
Metanol & 0,0 & \pm & 0,0 & 0,0 & \pm & 0,0 & 0,0 \\
Etanol & 205,2 & \pm & 14,4 & 4,5 & \pm & 0,3 & 16,4 \\
n-Butanol & 4,4 & \pm & 0,4 & 0,1 & \pm & 0,0 & 0,2 \\
Acético & 970,3 & \pm & 106,8 & 16,2 & \pm & 1,8 & 59,4 \\
Porpiônico & 105,4 & \pm & 3,7 & 1,4 & \pm & 0,1 & 5,2 \\
Isobutírico & 16,4 & \pm & 1,8 & 0,2 & \pm & 0,0 & 0,7 \\
Butírico & 349,8 & \pm & 22,6 & 4,0 & \pm & 0,3 & 14,6 \\
Isovalérico & 10,7 & \pm & 1,0 & 0,1 & \pm & 0,0 & 0,4 \\
Valérico & 45,1 & \pm & 6,2 & 0,4 & \pm & 0,1 & 1,6 \\
Capróico & 39,6 & \pm & 8,5 & 0,4 & \pm & 0,1 & 1,4 \\
\hline
\end{tabular}

O monitoramento da série de sólidos é mostrado na Tabela 5.31, cujos valores apresentam um baixo teor de SSV no efluente e afluente, indicando a boa capacidade do reator em reter biomassa. 
Tabela 5.31 - Série de sólidos afluente e efluente (AnSBBR com recirculação da fase líquida e soro de leite - Condição 8).

\begin{tabular}{lcccc}
\hline & $\begin{array}{c}\text { ST } \\
\left(\mathrm{mg} . \mathrm{L}^{-1}\right)\end{array}$ & $\begin{array}{c}\text { SVT } \\
\left(\mathrm{mg} . \mathrm{L}^{-1}\right)\end{array}$ & $\begin{array}{c}\text { SST } \\
\left(\mathrm{mg} . \mathrm{L}^{-1}\right)\end{array}$ & $\begin{array}{c}\text { SSV } \\
\left(\mathrm{mg} . \mathrm{L}^{-1}\right)\end{array}$ \\
\hline Afluente & $3757 \pm 439$ & $3028 \pm 394$ & $132 \pm 30$ & $112 \pm 23$ \\
Efluente & $2616 \pm 572$ & $1914 \pm 542$ & $122 \pm 67$ & $119 \pm 56$ \\
\hline
\end{tabular}

*Número de amostras consideradas $=8$.

A produção quantitativa do biogás por ciclo é apresentada na Figura 5-125. A produção média foi de $393 \mathrm{~mL}$ (CNTP) durante toda a operação e $526 \mathrm{~mL}$ (CNTP) no estado estacionário. A Figura 5-126 apresenta o monitoramento das concentrações dos componentes do biogás no final do ciclo, enquanto que a Figura 5-127 apresenta a distribuição destes mesmos componentes. Os valores médios de concentração de $\mathrm{H}_{2}$, $\mathrm{CH}_{4}$ e $\mathrm{CO}_{2}$ foram 3,1, 0,1 e 7,0 mmol.L $\mathrm{L}^{-1}$, respectivamente. Além disso, a distribuição percentual média de $\mathrm{H}_{2}$ foi de $25,2 \%$, a de $\mathrm{CH}_{4}$ foi de $0,5 \%$ e a de $\mathrm{CO}_{2}$ foi de $74,3 \%$.

A nova estratégia de operação surtiu efeito, eliminando os indícios de produção de $\mathrm{H}_{2} \mathrm{~S}$ (odor característico e formação de substância branca recobrindo o exterior das mangueiras de alimentação) por possível ação de bactérias redutoras de sulfato (BRS), que provavelmente estavam consumindo o hidrogênio na presença do sulfato em excesso de acordo com a reação:

$$
\mathrm{SO}_{4}^{2-}+4 \mathrm{H}_{2} \rightarrow \mathrm{H}_{2} \mathrm{~S}+2 \mathrm{H}_{2} \mathrm{O}+2 \mathrm{OH}^{-}(\Delta \mathrm{G}=-154 \mathrm{KJ})
$$

Em conjunto com a lavagem periódica do material suporte, atingiu-se uma estabilidade na produção de hidrogênio, como pode ser observado entre os dias 324 e 331 da Figura 5-126 e da Figura 5-127. 


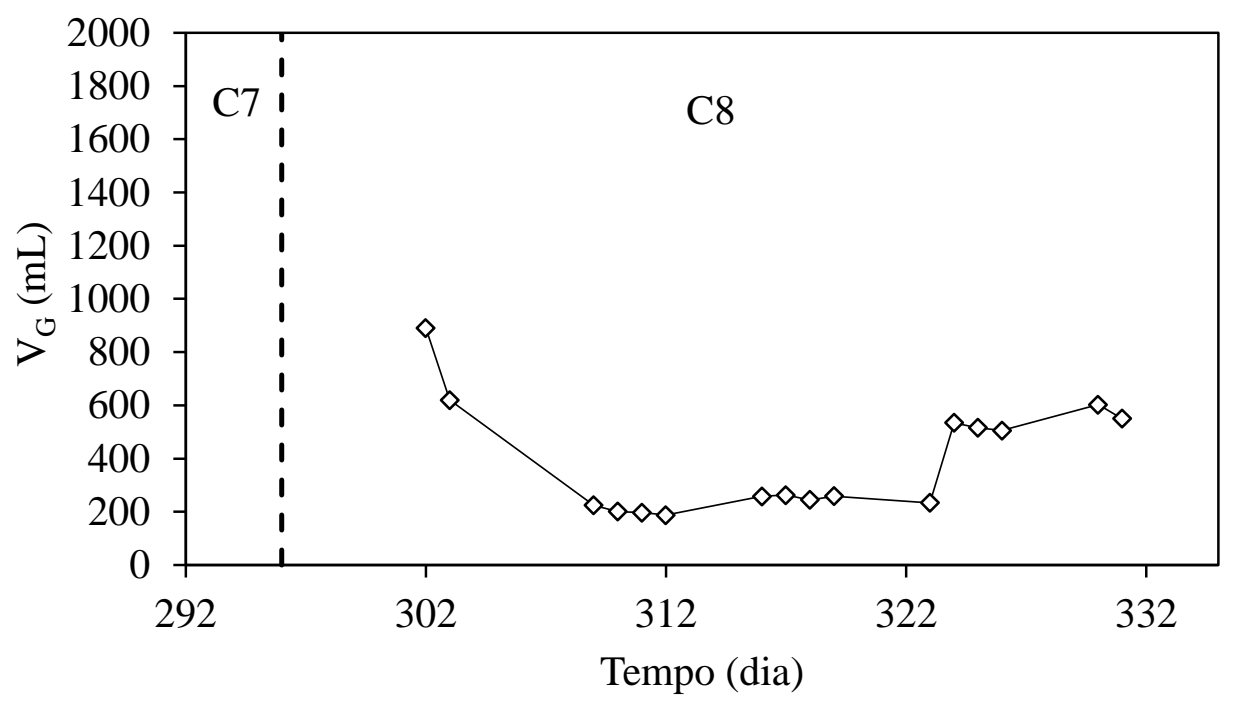

Figura 5-125 - Volume de biogás produzido por ciclo (AnSBBR com recirculação da fase líquida e soro de leite - Condição 8).

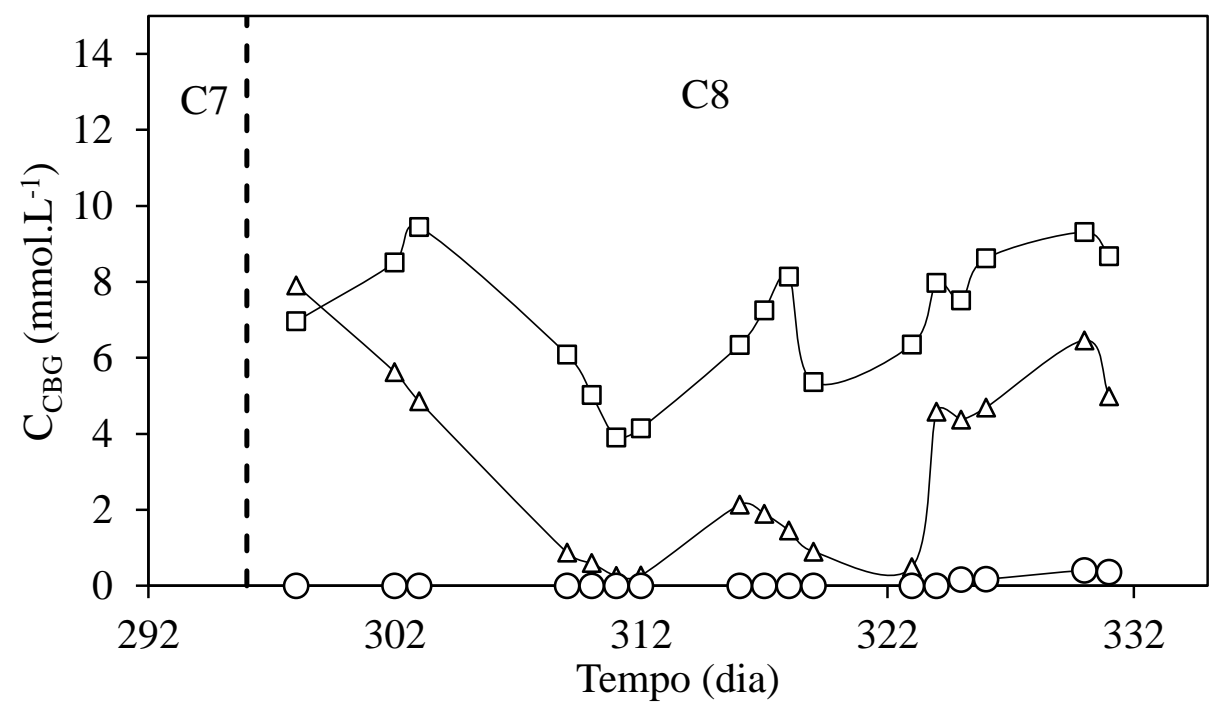

Figura 5-126 - Concentrações dos componentes do biogás no final do ciclo: $\square-\mathrm{CO}_{2} ; \Delta$ - $\mathrm{H}_{2} ;$ ○ - $\mathrm{CH}_{4}$ (AnSBBR com recirculação da fase líquida e soro de leite - Condição 8). 


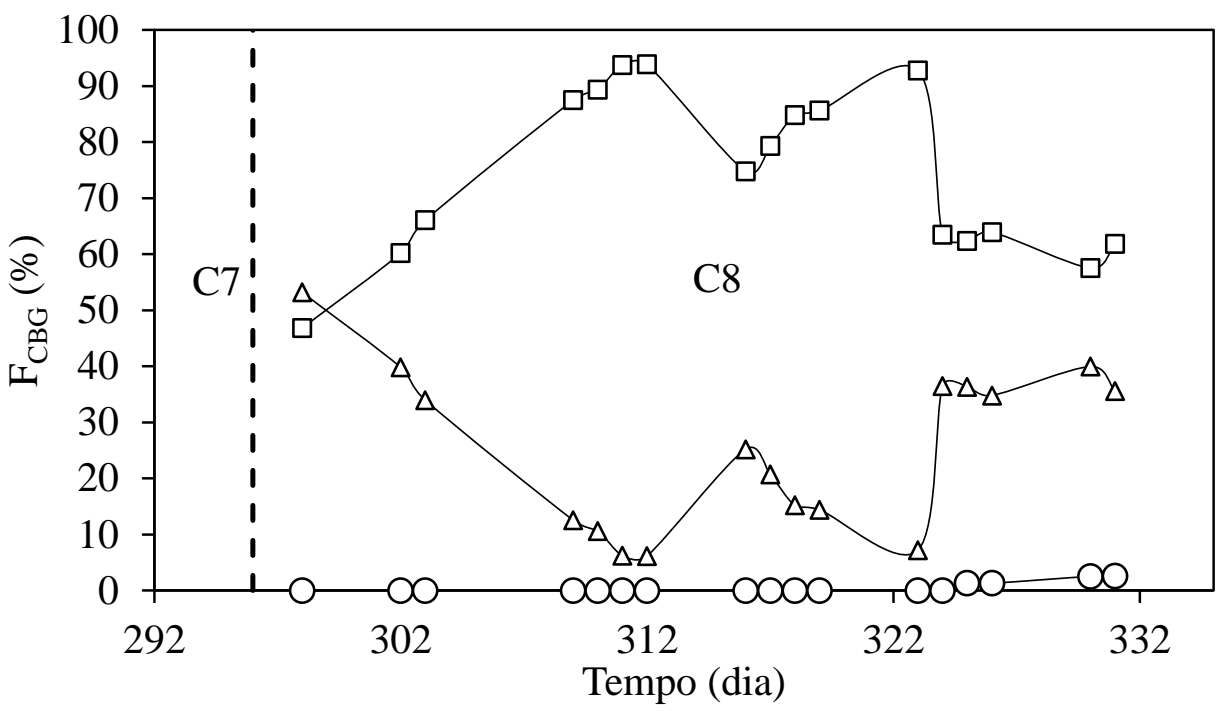

Figura 5-127 - Distribuições dos componentes do biogás no final do ciclo: $\square-\mathrm{CO}_{2} ; \Delta-$ $\mathrm{H}_{2} ;$ ○ $-\mathrm{CH}_{4}$ (AnSBBR com recirculação da fase líquida e soro de leite - Condição 8).

A Tabela 5.32 apresenta um resumo das lavagens do material suporte realizadas na condição 8. Como pode ser observada, a lavagem surtiu efeito no crescimento celular dentro do reator, sendo removidas cada vez menos quantidades de biomassa (massa de SVT) e apresentando valores de $\mathrm{C}_{\mathrm{x}}$ e de $\mathrm{C}_{\mathrm{x}}$, (que são os indicadores da quantidade de biomassa por volume de meio reacional e por massa de material suporte, respectivamente) cada vez menores com o passar do tempo de operação. A exceção está no dia 319, quando uma forma de lavagem alternativa foi realizada. Nela drenou-se apenas o líquido de dentro do reator sem lavar o material suporte com 1 litro de água. Esta alternativa, apesar de mais prática, não surtiu o mesmo efeito da lavagem proposta inicialmente, ocorrendo um acúmulo grande de biomassa dentro do reator tanto no material suporte quanto no meio reacional. Analisando ainda a quantificação de $C_{x}$ e de $\mathrm{C}_{\mathrm{x}}$ ' realizada antes da desmontagem do reator, é possível observar que os valores obtidos (4,2 g.L. $\mathrm{L}^{-1}$ e 0,010 g.gsuporte ${ }^{-1}$, respectivamente) foram ainda menores do que os obtidos durante as lavagens durante a operação, provando que estas tiveram resultados 
positivos no controle da biomassa e consequentemente na produção estável do hidrogênio.

Tabela 5.32 - Lavagem do material suporte (AnSBBR com recirculação da fase líquida e soro de leite - Condição 8)

\begin{tabular}{cccc}
\hline Tempo & $\begin{array}{c}\text { Quantidade de } \\
\text { biomassa removida } \\
\text { do sistema } \\
(\mathrm{gSVT})\end{array}$ & $\begin{array}{c}\mathrm{C}_{\mathrm{X}} \text { antes da } \\
\text { lavagem } \\
\left(\mathrm{gSVT} . \mathrm{L}^{-1}\right)\end{array}$ & $\begin{array}{c}\mathrm{C}_{\mathrm{X}}{ }^{\prime} \text { antes da } \\
\text { lavagem } \\
\left(\mathrm{gSVT}_{\text {dia }} \text { gsuporte }\right.\end{array}$ \\
\hline 312 & 41,2 & 9,0 & 0,018 \\
319 & 17,5 & - & - \\
323 & 33,7 & 10,5 & 0,022 \\
329 & 23,3 & 6,6 & 0,014 \\
\hline
\end{tabular}

O perfil temporal foi realizado no final da operação, com o intuito de entender melhor como os parâmetros indicativos de eficiência do sistema se comportavam durante um ciclo completo. A Figura 5-128 apresenta a evolução da concentração de carboidrato ao longo do ciclo e a eficiência de remoção do mesmo. Ao inicio do ciclo (tempo zero) o volume afluente é diluído no volume residual resultando em uma concentração em sacarose da ordem de $1360 \mathrm{mg} \cdot \mathrm{L}^{-1}$. A conversão de carboidrato se faz de maneira progressiva ao longo do ciclo, atingindo valores na ordem de $99 \%$ no final do mesmo, com um residual aproximado de $16 \mathrm{mg} . \mathrm{L}^{-1}$. 


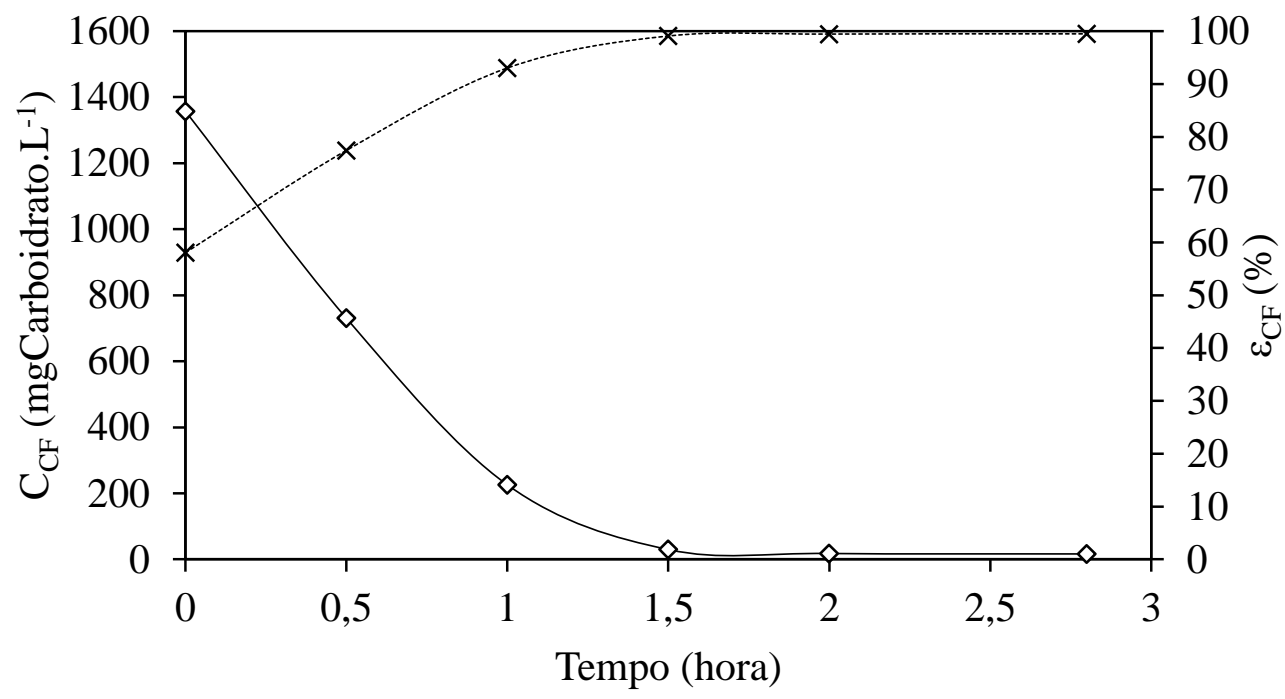

Figura 5-128 - Concentração e eficiência de degradação de carboidrato: $\diamond$ - perfil e * eficiência (AnSBBR com recirculação da fase líquida e soro de leite - Condição 8).

A Figura 5-129 apresenta a evolução da concentração de matéria orgânica ao longo do ciclo. Observa-se uma baixa remoção da DQO, levando a uma alta concentração da mesma no volume residual. Assim, no inicio do ciclo, a diluição do volume carregado pelo volume residual é realizada em proporção bem menor do que no caso dos carboidratos totais, tendo em vista que as concentrações afluente e residual são muito próximas. No inicio do ciclo, a concentração é da ordem de $3360 \mathrm{mg} . \mathrm{L}^{-1}$ atingindo valores próximos a $2980 \mathrm{mg} . \mathrm{L}^{-1}$ no último ponto do ciclo. 


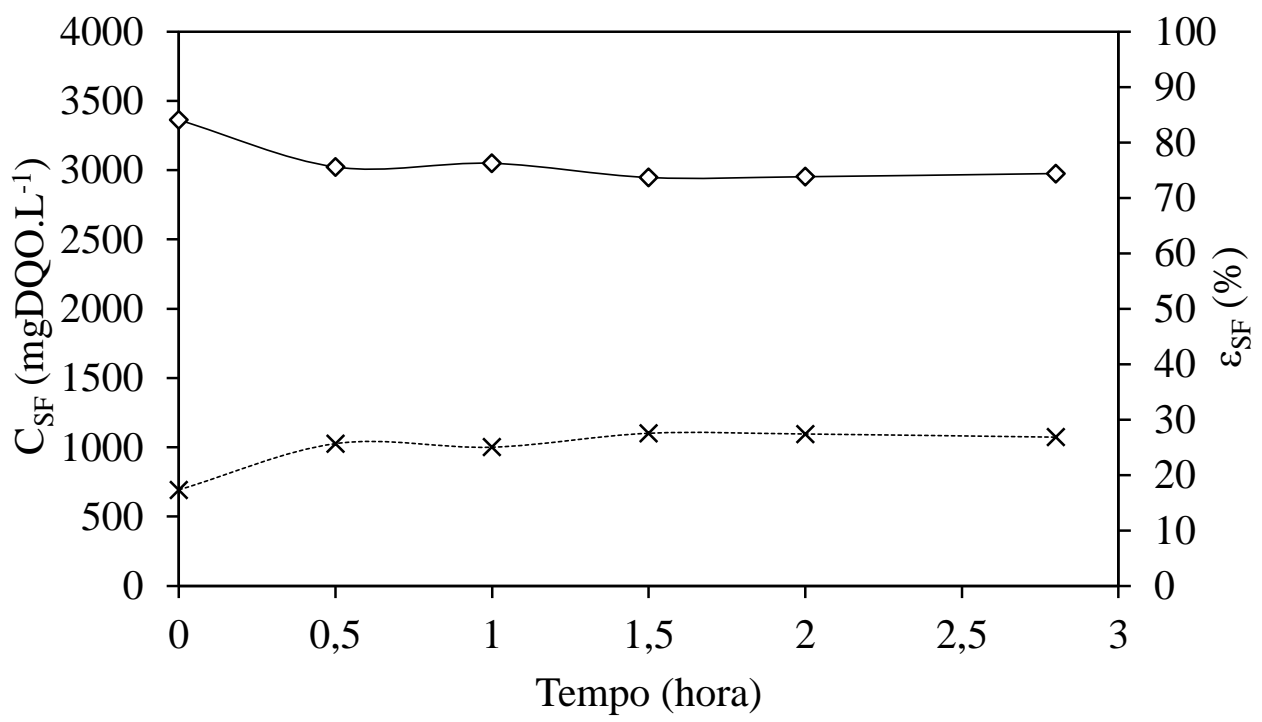

Figura 5-129 - Concentração e eficiência de degradação de matéria orgânica: $\diamond$ - perfil e * eficiência (AnSBBR com recirculação da fase líquida e soro de leite - Condição 8).

O acúmulo de ácidos voláteis totais por titulação ao longo do ciclo pode ser observado na Figura 5-130. A concentração destes aumenta claramente durante a fase de reação para atingir um máximo no final do ciclo na ordem de $1230 \mathrm{mgHAc} . \mathrm{L}^{-1}$.

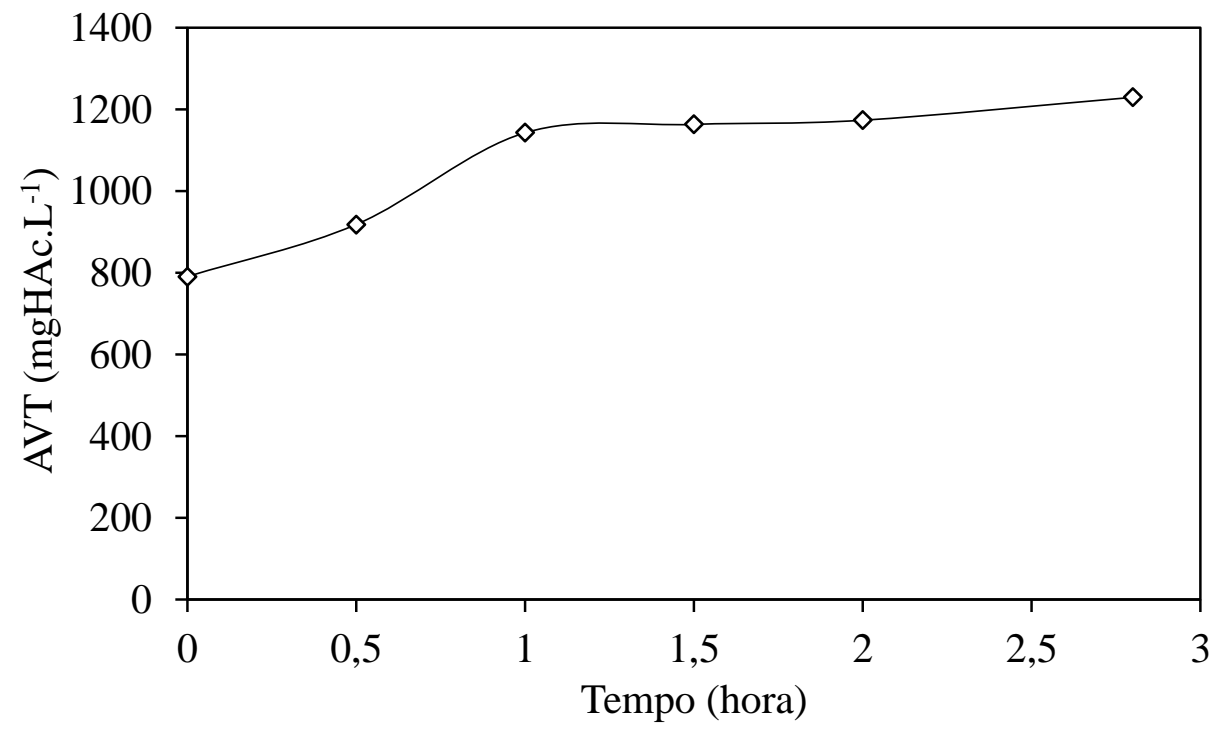

Figura 5-130 - Ácidos voláteis totais $(\diamond)$ do perfil (AnSBBR com recirculação da fase líquida e soro de leite - Condição 8). 
Os resultados dos compostos intermediários por cromatografia gasosa são apresentados na Figura 5-131. O ácido acético apresentou o maior crescimento durante o ciclo. Os demais apresentaram ligeiros aumentos.

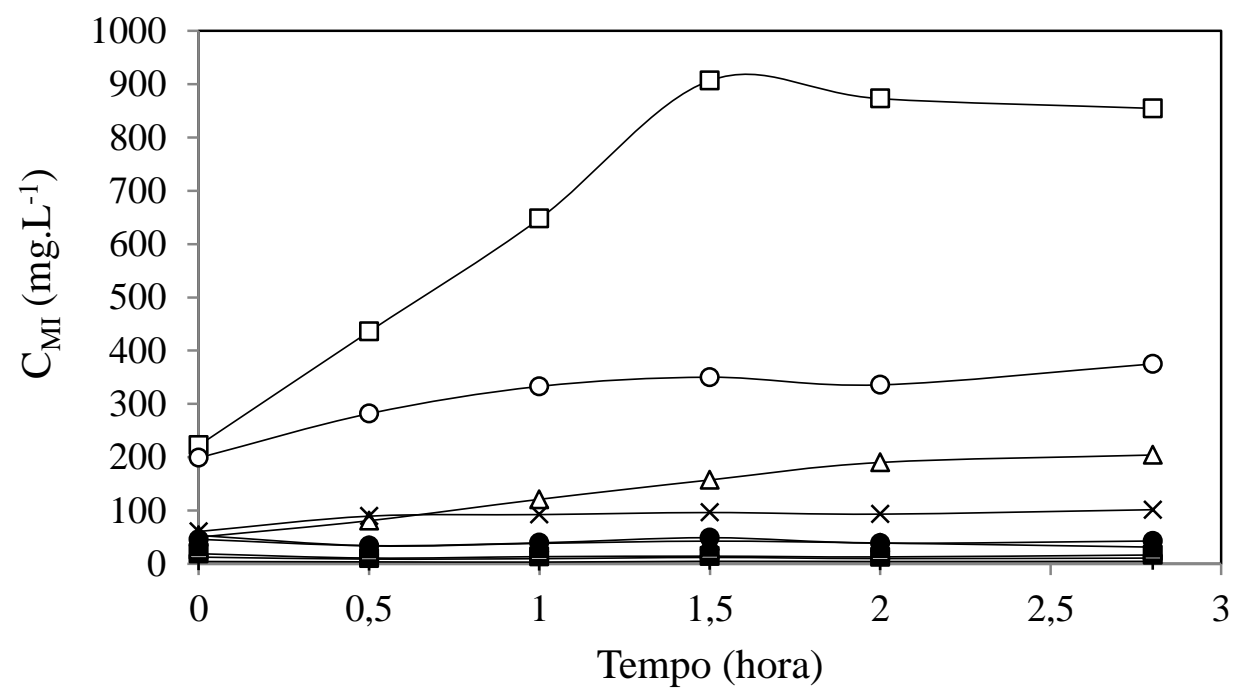

Figura 5-131 - Concentração dos compostos intermediários ao longo do ciclo: $\square$ - ácido acético; $\Delta$ - etanol; ○ - ácido butírico; - ácido isobutírico; $\boldsymbol{\Delta}$ - ácido capróico; $\bullet-$ ácido valérico; - \#-ácido propiônico; +butanol; — ácido isovalérico (AnSBBR com recirculação da fase líquida e soro de leite - Condição 8).

$\mathrm{O}$ pH diminuiu instantaneamente em relação ao afluente devido à diluição do mesmo com o volume residual no inicio do ciclo e permaneceu estável ao longo da operação conforme a Figura 5-132. A estabilidade do $\mathrm{pH}$ foi mantida, como pode ser visto na Figura 5-133, devido a alcalinidade que, mesmo apresentando uma queda no início, não foi completamente consumida durante o ciclo. 


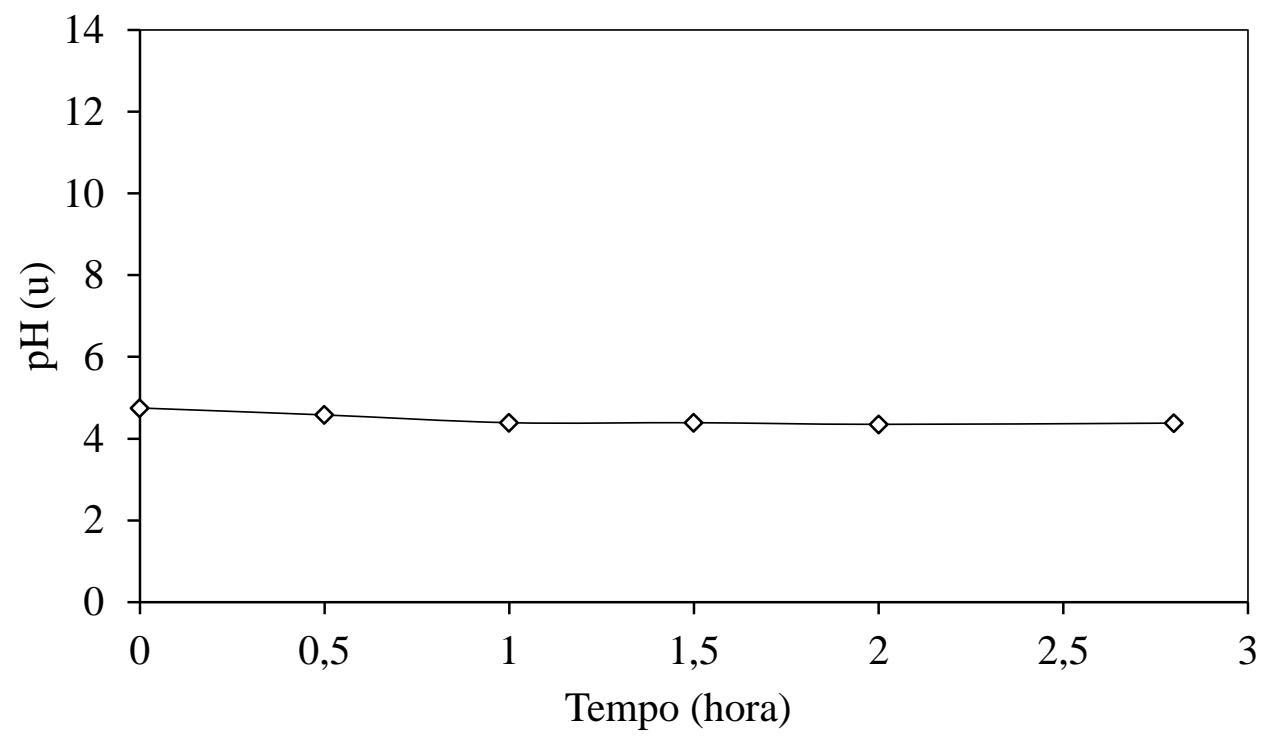

Figura 5-132 - Valores de pH $(\diamond)$ do perfil (AnSBBR com recirculação da fase líquida e soro de leite - Condição 8).

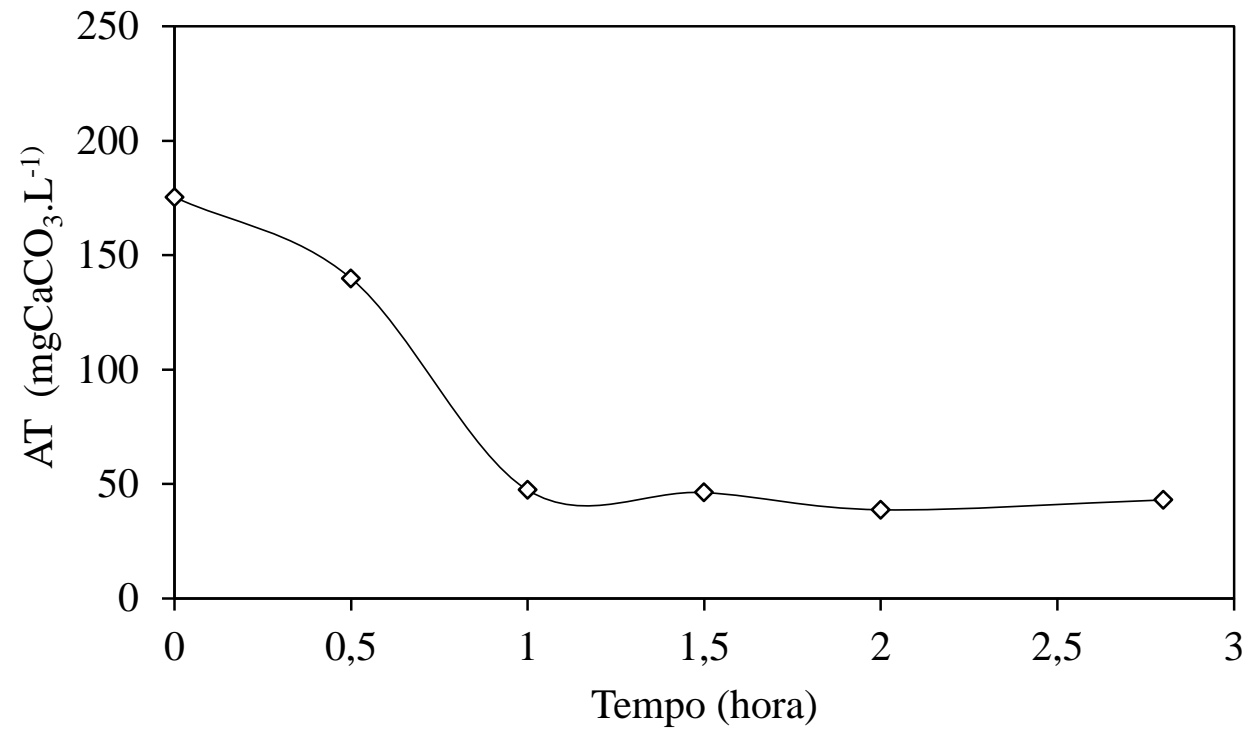

Figura 5-133 - Alcalinidade total do perfil (AnSBBR com recirculação da fase líquida e soro de leite - Condição 8).

A produção volumétrica média acumulada do biogás, realizada com os valores dos perfis quantitativos mais consistentes obtidos durante a operação, juntamente com os desvios padrões encontram-se na Figura 5-134. A maior parte da produção ocorre no inicio do ciclo, sendo realizada até o final do mesmo em quantidades menores. A Tabela 5.33 resume os valores médios da produção, fração molar e os volumes individuais da 
mistura do biogás. A Figura 5-135 apresenta os volumes acumulados médios dos perfis de $\mathrm{H}_{2}, \mathrm{CO}_{2}$ e $\mathrm{CH}_{4}$ produzidos durante o ciclo. Foi produzido metano em baixíssima quantidade apenas no final da condição, além do hidrogênio e do gás carbônico.

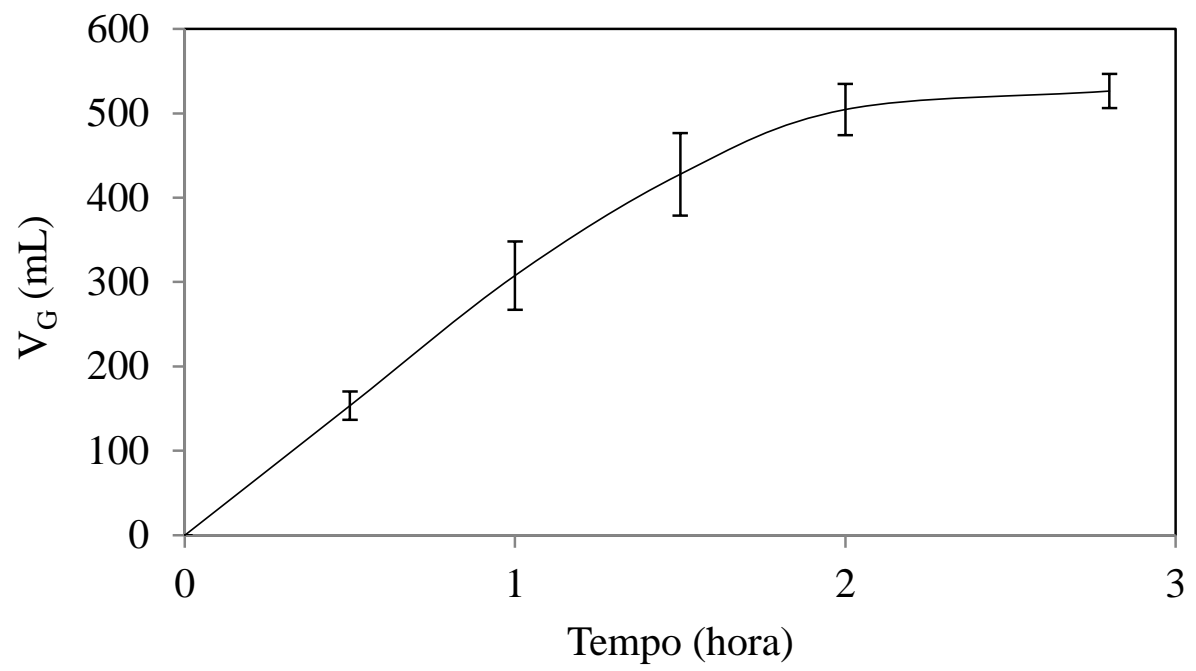

Figura 5-134 - Produção volumétrica média acumulada do biogás durante o ciclo (AnSBBR com recirculação da fase líquida e soro de leite - Condição 8).

Tabela 5.33 - Valores médios da produção, fração molar e os volumes individuais da mistura do biogás (AnSBBR com recirculação da fase líquida e soro de leite - Condição 8).

\begin{tabular}{ccccccccccc}
\hline $\begin{array}{c}\text { Tempo } \\
(\mathrm{h})\end{array}$ & $\begin{array}{c}\mathrm{V}_{\mathrm{G}} \\
(\mathrm{mL}-\mathrm{CNTP})\end{array}$ & \multicolumn{3}{c}{$\mathrm{C}_{\mathrm{G}}\left(\mathrm{mmol} . \mathrm{L}^{-1}\right)$} & \multicolumn{3}{c}{ Fração Molar $(\%)$} & \multicolumn{3}{c}{ Volume $(\mathrm{mL}-\mathrm{CNTP})$} \\
& & $\mathrm{H}_{2}$ & $\mathrm{CO}_{2}$ & $\mathrm{CH}_{4}$ & $\mathrm{H}_{2}$ & $\mathrm{CO}_{2}$ & $\mathrm{CH}_{4}$ & $\mathrm{H}_{2}$ & $\mathrm{CO}_{2}$ & $\mathrm{CH}_{4}$ \\
\hline 0,0 & 0,0 & 0,0 & 0,0 & 0,0 & 0,0 & 0,0 & 0,0 & 0,0 & 0,0 & 0,0 \\
0,5 & 153,6 & 1,4 & 2,7 & 0,0 & 34,0 & 66,0 & 0,0 & 52,3 & 101,3 & 0,0 \\
1,0 & 307,8 & 3,4 & 5,0 & 0,3 & 38,7 & 57,7 & 3,5 & 112,0 & 190,3 & 5,4 \\
1,5 & 427,7 & 4,1 & 7,8 & 0,3 & 33,3 & 63,9 & 2,7 & 152,0 & 267,0 & 8,7 \\
2,0 & 504,4 & 4,8 & 8,5 & 0,3 & 35,3 & 62,2 & 2,5 & 179,0 & 314,7 & 10,7 \\
2,8 & 526,4 & 5,0 & 8,7 & 0,4 & 35,6 & 61,8 & 2,6 & 186,8 & 328,3 & 11,2 \\
\hline
\end{tabular}




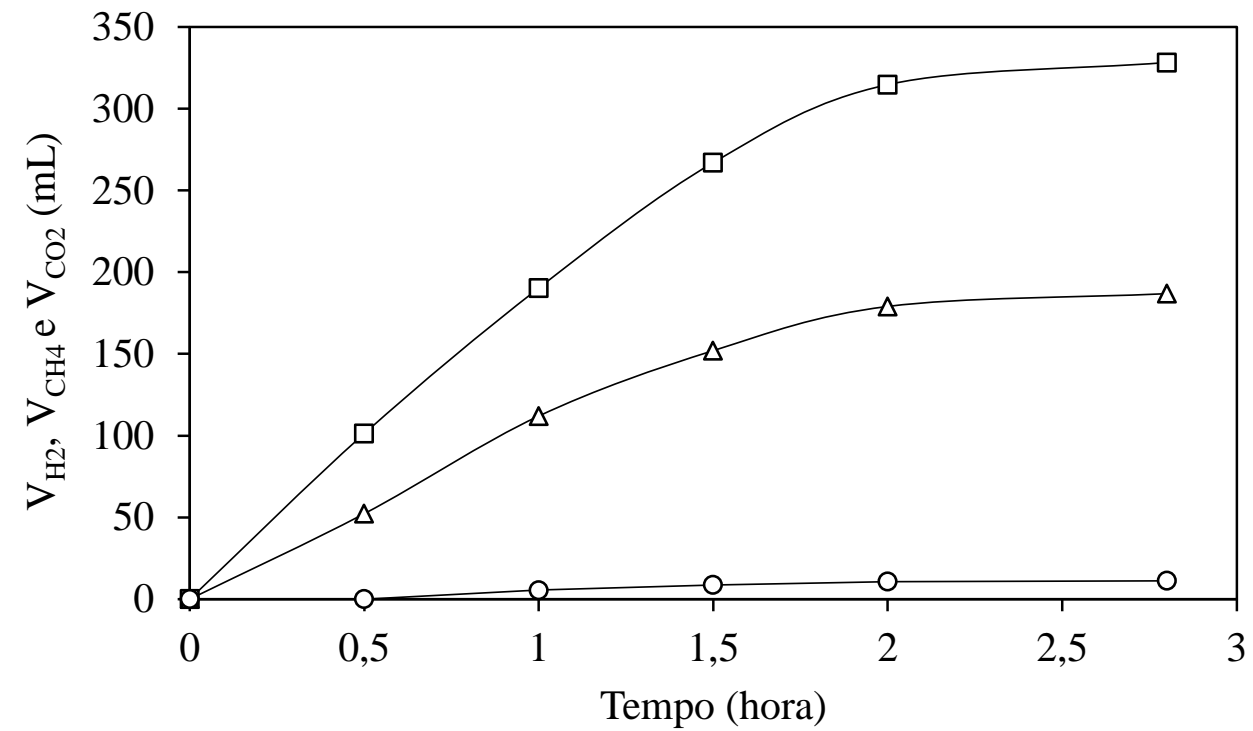

Figura 5-135 - Volumes acumulados médios produzidos ao longo do ciclo: $\square-\mathrm{CO}_{2} ; \Delta$ $\mathrm{H}_{2}$; ○ $-\mathrm{CH}_{4}$ (AnSBBR com recirculação da fase líquida e soro de leite - Condição 8). 


\subsection{AnSBBR com recirculação da fase líquida - Efeito de importantes parâmetros operacionais (concentração afluente do substrato, tempo de enchimento e temperatura) na produção de biohidrogênio.}

Após a estabilidade na produção de hidrogênio a partir de um AnSBBR com recirculação da fase líquida alimentado com soro de leite ter sido atingida, deu-se início à segunda parte do trabalho, na qual três importantes parâmetros operacionais foram avaliados: concentração afluente do substrato, tempo de enchimento do reator e temperatura. A condição base para estes estudos foi a Condição 8 na qual a estabilidade do processo foi atingida. Desta forma, todas as condições desta parte do trabalho mantiveram as mesmas características da referida condição base (tempo de ciclo de 3 horas, polietileno como material suporte, etc), mudando-se apenas o parâmetro operacional em estudo.

\subsubsection{Influência da concentração afluente do substrato.}

Três condições concentrações afluente do substrato foram testadas $(4250,5500$ e $6350 \mathrm{mgDQO} . \mathrm{L}^{-1}$ ), sendo que para a a concentração mais baixa foram considerados os resultados da Condição 8. Assim, com a Condição 9 avaliou-se a concentração afluente de 6350 mgDQO.L $\mathrm{L}^{-1}$ e com a Condição 10 a concentração afluente de 5400 mgDQO.L ${ }^{-}$ 1 .

5.2.1.1. Condição 9 -Soro de leite $\left(t_{c}=3\right.$ horas, $\left.C_{S T}=6350 \mathrm{mgDQO} . \mathrm{L}^{-1}\right)$ 
A condição experimental 9 apresentou uma COAV nominal de 21,8 kgDQO.m ${ }^{-}$ ${ }^{3}$. $\mathrm{d}^{-1}$ e duração do ciclo de 3 horas, indo do dia 333 ao dia 359 (27 dias de operação). A Tabela 5.34 apresenta os valores médios dos parâmetros monitorados. 
Tabela 5.34 - Valores médios dos parâmetros monitorados na condição experimental 9 (Soro de leite - $6350 \mathrm{mgDQO} . \mathrm{L}^{-1}-\mathrm{t}_{\mathrm{C}} 3 \mathrm{~h}$ ).

\begin{tabular}{|c|c|c|c|c|c|c|c|c|c|c|c|}
\hline \multicolumn{2}{|r|}{ Parâmetro } & \multicolumn{5}{|c|}{ Afluente } & & \multicolumn{4}{|c|}{ Efluente } \\
\hline $\mathrm{C}_{\mathrm{ST}}$ & $\left(\mathrm{mgDQO} \cdot \mathrm{L}^{-1}\right)$ & 5811 & \pm & 381 & & 11 & & 5013 & \pm 381 & & $11)$ \\
\hline $\mathrm{C}_{\mathrm{SF}}$ & $\left(\mathrm{mgDQO} \cdot \mathrm{L}^{-1}\right)$ & - & \pm & - & ( & 3 & & 4454 & \pm 401 & $(1)$ & $11)$ \\
\hline$\varepsilon_{\mathrm{ST}}$ & $(\%)$ & - & & - & & & & 12 & \pm 7 & & $11)$ \\
\hline$\varepsilon_{\mathrm{SF}}$ & $(\%)$ & - & & - & & & & 22 & $\pm \quad 7$ & & $11 \quad$ \\
\hline $\mathrm{C}_{\mathrm{CT}}$ & $\left(\mathrm{mgCarboidrato} . \mathrm{L}^{-1}\right)$ & 4428 & \pm & 554 & ( & 11 & & 215 & \pm 330 & $(1)$ & $11)$ \\
\hline $\mathrm{C}_{\mathrm{CF}}$ & (mgCarboidrato. $\left.\mathrm{L}^{-1}\right)$ & - & \pm & - & & & & 63 & \pm 122 & $(11)$ & $11)$ \\
\hline$\varepsilon_{\mathrm{CT}}$ & $(\%)$ & - & & - & & & & 95 & \pm 7 & & $11)$ \\
\hline$\varepsilon_{\mathrm{CF}}$ & $(\%)$ & - & & - & & & & 99 & \pm 3 & $(11$ & $11)$ \\
\hline $\mathrm{pH}$ & (u) & 7,66 & \pm & 0,10 & ( & 11 & ) & 4,09 & $\pm 0,06$ & $(11$ & $11)$ \\
\hline AVT & $\left(\mathrm{mgHAc} . \mathrm{L}^{-1}\right)$ & 156 & \pm & 12 & ( & 11 & & 1844 & \pm 217 & ( 11 & $11)$ \\
\hline AT & $\left(\mathrm{mgCaCO}_{3} \cdot \mathrm{L}^{-1}\right)$ & 446 & \pm & 14 & ( & 11 & ) & 0 & \pm 0 & & 11 \\
\hline $\mathrm{AP}$ & $\left(\mathrm{mgCaCO}_{3} \cdot \mathrm{L}^{-1}\right)$ & 283 & \pm & 17 & ( & 11 & & 0 & \pm & $(11$ & $11)$ \\
\hline AI & $\left(\mathrm{mgCaCO}_{3} \cdot \mathrm{L}^{-1}\right)$ & 164 & \pm & 15 & ( & 11 & ) & 0 & \pm & & $11)$ \\
\hline $\mathrm{AB}$ & $\left(\mathrm{mgCaCO}_{3} \cdot \mathrm{L}^{-1}\right)$ & 335 & \pm & 16 & ( & 11 & ) & 0 & \pm & & $11 \quad)$ \\
\hline ST & $\left(\mathrm{mg} \cdot \mathrm{L}^{-1}\right)$ & 5112 & \pm & 241 & ( & 6 & ) & 3477 & $\pm \quad 77$ & & $6)$ \\
\hline STV & $\left(\mathrm{mg} \cdot \mathrm{L}^{-1}\right)$ & 4245 & \pm & 217 & ( & 6 & ) & 2577 & \pm 109 & & 6 \\
\hline SST & $\left(\mathrm{mg} \cdot \mathrm{L}^{-1}\right)$ & 174 & \pm & 20 & ( & 6 & 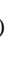 & 454 & \pm 116 & ( 6 & 6 \\
\hline SSV & $\left(\mathrm{mg} \cdot \mathrm{L}^{-1}\right)$ & 143 & \pm & 21 & ( & 6 & & 430 & $\pm \quad 98$ & & 6 \\
\hline $\mathrm{M}_{\mathrm{STV}}$ & (g) & - & & - & & & & 33,9 & - & & \\
\hline $\mathrm{C}_{\mathrm{X}}$ & $\left(\mathrm{g} . \mathrm{L}^{-1}\right)$ & - & & - & & & & 9,5 & - & & \\
\hline $\mathrm{C}_{\mathrm{X}}^{\prime}$ & $\left(\right.$ g.gsuporte $\left.{ }^{-1}\right)$ & - & & - & & & & 0,021 & - & & \\
\hline $\mathrm{V}_{\mathrm{G}}$ & (mL-CNTP) & - & & - & & & & 769 & \pm 87 & & $2)$ \\
\hline $\mathrm{V}_{\mathrm{H} 2}$ & (mL-CNTP) & - & & - & & & & 159 & \pm & & $1 \quad)$ \\
\hline $\mathrm{COAV}_{\mathrm{S}}$ & $\left(\operatorname{kgDQO} \cdot \mathrm{m}^{-3} \cdot \mathrm{d}^{-1}\right)$ & 19,6 & & - & & & & - & - & & \\
\hline $\mathrm{CORV}_{\mathrm{S}}$ & $\left(\mathrm{kgDQO} \cdot \mathrm{m}^{-3} \cdot \mathrm{d}^{-1}\right)$ & - & & - & & & & 4,3 & - & & \\
\hline $\mathrm{COAV}_{\mathrm{C}}$ & $\left(\mathrm{kgCarboidrato} \cdot \mathrm{m}^{-3} \cdot \mathrm{d}^{-1}\right)$ & 15,2 & & - & & & & - & - & & \\
\hline $\mathrm{CORV}_{\mathrm{C}}$ & $\left(\mathrm{kgCarboidrato} \cdot \mathrm{m}^{-3} \cdot \mathrm{d}^{-1}\right)$ & - & & 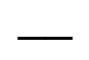 & & & & 15,0 & - & & \\
\hline $\mathrm{COAE}_{\mathrm{S}}$ & $\left(\mathrm{kgDQO} \mathrm{kgSTV}^{-1} \cdot \mathrm{d}^{-1}\right)$ & 2,0 & & 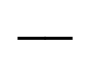 & & & & $\underline{10,0}$ & - & & \\
\hline $\mathrm{CORE}_{\mathrm{S}}$ & $\left(\operatorname{kgDQO} \mathrm{kgSTV}^{-1} \cdot \mathrm{d}^{-1}\right)$ & - & & - & & & & 0,4 & - & & \\
\hline $\mathrm{COAE}_{\mathrm{C}}$ & $\left(\mathrm{kgCarboidrato.kgSTV}{ }^{-1} \cdot \mathrm{d}^{-1}\right)$ & 1,6 & & $\underline{-}$ & & & & - & - & & \\
\hline $\mathrm{CORE}_{\mathrm{C}}$ & $\left(\mathrm{kgCarboidrato.kgSTV}^{-1} \cdot \mathrm{d}^{-1}\right)$ & - & & - & & & & 1,5 & - & & \\
\hline $\mathrm{RMCR}_{\mathrm{C}, \mathrm{n}}$ & $\left(\mathrm{molH}_{2 .}\right.$ molCarboidrato $\left.^{-1}\right)$ & - & & - & & & & 0,37 & - & & \\
\hline $\mathrm{n}_{\mathrm{H} 2}$ & $\left(\mathrm{molH}_{2} \cdot \mathrm{d}^{-1}\right)$ & - & & - & & & & 0,057 & - & & \\
\hline PrVH & $\left(\mathrm{mLH}_{2} \cdot \mathrm{L}^{-1} \cdot \mathrm{d}^{-1}\right)$ & - & & - & & & & 357,2 & - & & \\
\hline PrM & $\left(\mathrm{molH}_{2} \cdot \mathrm{m}^{-3} \cdot \mathrm{d}^{-1}\right)$ & - & & - & & & & 15,9 & - & & \\
\hline PrME & $\left(\mathrm{molH}_{2} \cdot \mathrm{kgSVT}^{-1} \cdot \mathrm{d}^{-1}\right)$ & - & & - & & & & 1,7 & - & & \\
\hline $\mathrm{RMCA}_{\mathrm{S}, \mathrm{m}}$ & $\left(\mathrm{molH}_{2} \cdot \mathrm{kgDQO}^{-1} \cdot \mathrm{d}^{-1}\right)$ & 0,8 & & - & & & & - & - & & \\
\hline $\mathrm{RMCA}_{\mathrm{C}, \mathrm{m}}$ & $\left(\mathrm{molH}_{2} \cdot \mathrm{kg}^{-1} \cdot \mathrm{d}^{-1}\right)$ & 1,1 & & 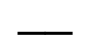 & & & & - & - & & \\
\hline $\mathrm{RMCR}_{\mathrm{S}, \mathrm{m}}$ & $\left(\mathrm{molH}_{2} \cdot \mathrm{kgDQO}^{-1} \cdot \mathrm{d}^{-1}\right)$ & - & & - & & & & 3,8 & - & & \\
\hline $\mathrm{RMCR}_{\mathrm{C}, \mathrm{m}}$ & $\left(\mathrm{molH}_{2} \cdot \mathrm{kg}^{-1} \cdot \mathrm{d}^{-1}\right)$ & - & & - & & & & 1,1 & - & & \\
\hline $\mathrm{V}_{\mathrm{d}}$ & $(\mathrm{mL})$ & 1484 & \pm & 38 & ( & 12 & & - & - & & \\
\hline $\mathrm{Q}_{\mathrm{R}}$ & $\left(\mathrm{mL} \cdot \mathrm{s}^{-1}\right)$ & 7 & \pm & 0 & ( & & & - & - & & \\
\hline
\end{tabular}

(*) Entre parêntese o número de amostras considerado no cálculo da média

A Figura 5-136 apresenta os valores da concentração afluente (amostras não filtradas) e efluente (amostras não filtradas e filtradas) de matéria orgânica (DQO) nos 
sistema. A Figura 5-137 apresenta a eficiência de remoção do mesmo parâmetro durante o monitoramento diário. Esta eficiência atingiu, em média, 23\% para as amostras filtradas e $14 \%$ para mostras não filtradas. A média de concentração afluente não filtrada do substrato foi de $5810 \mathrm{mgDQO} . \mathrm{L}^{-1}$ e de $5018 \mathrm{mgDQO} . \mathrm{L}^{-1}$ e $4454 \mathrm{mgDQO} . \mathrm{L}^{-1}$ para amostras de efluente não filtradas e filtradas, respectivamente.

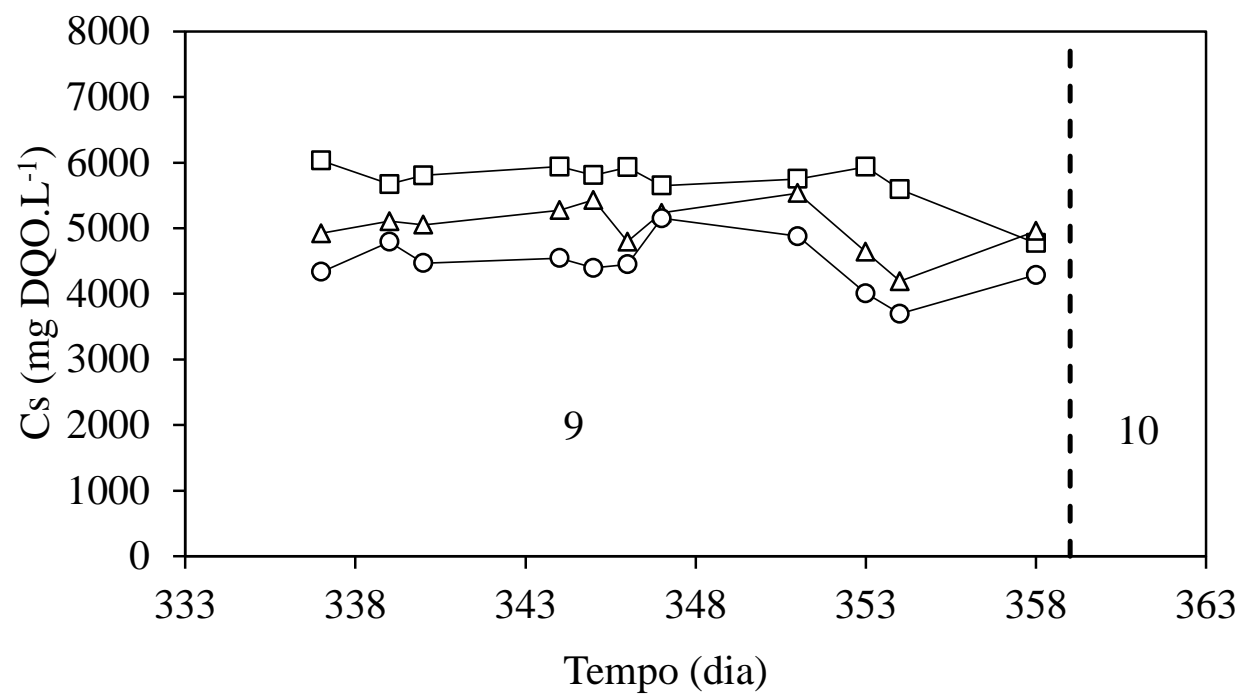

Figura 5-136 - Concentração de matéria orgânica (DQO): $\square$ - afluente não filtrada; $\Delta$ efluente não filtrada; 0 - efluente filtrada (AnSBBR com recirculação da fase líquida e soro de leite - Condição 9).

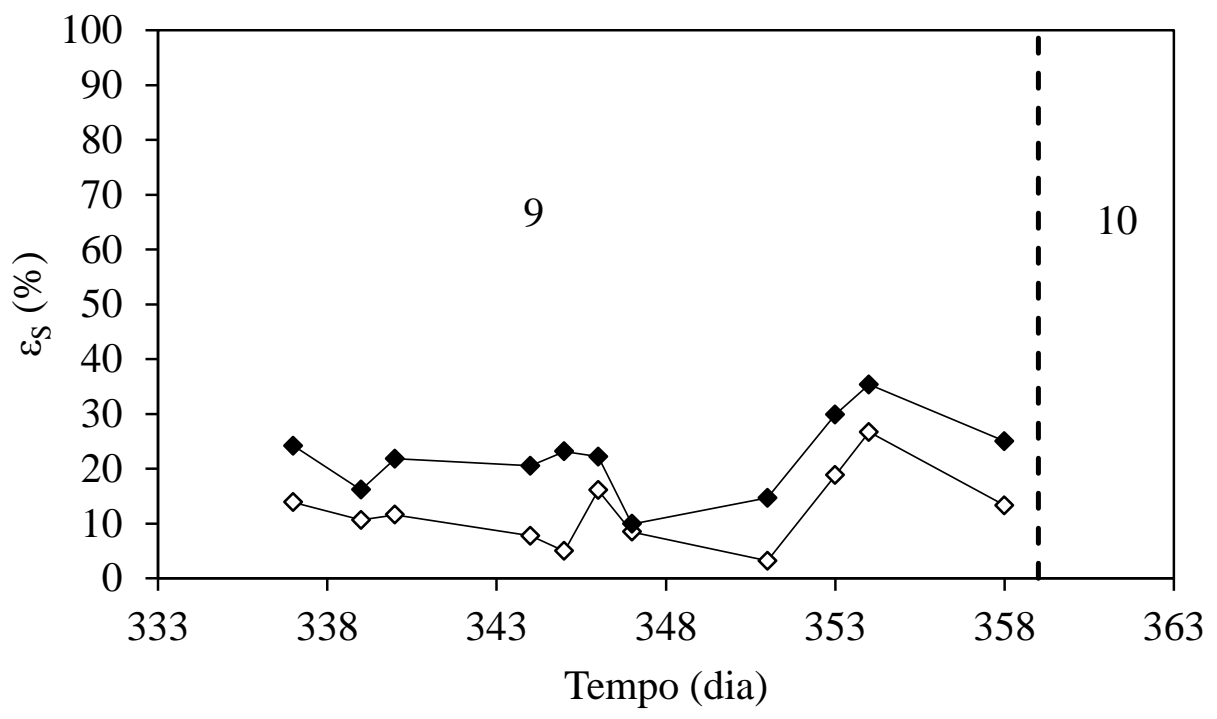

Figura 5-137 - Eficiência de remoção de matéria orgânica (DQO): $\diamond$ - não filtrada; filtrada (AnSBBR com recirculação da fase líquida e soro de leite - Condição 9). 
A Figura 5-138 apresenta os valores da concentração de carboidratos afluente e efluente (para amostras filtradas e não filtradas) e Figura 5-139 apresenta a eficiência de remoção do mesmo parâmetro (não filtrada e filtrada) durante o monitoramento diário. A média da concentração afluente foi de $3237 \mathrm{mgCarboidrato.} \mathrm{L}^{-1}$, enquanto que a concentração residual (amostras não filtradas) foi de 90 mgCarboidrato. $\mathrm{L}^{-1}$ e 51 mgCarboidrato. $\mathrm{L}^{-1}$ para a concentração residual filtrada durante toda a operação e de 90 mgCarboidrato. $\mathrm{L}^{-1}$ e $51 \mathrm{mgCarboidrato.} \mathrm{L}^{-1}$ durante a fase estacionária. A eficiência de remoção de carboidrato foi, em média, de $98 \%$ para as amostras filtradas e $97 \%$ para mostras não filtradas durante toda a operação e de $98 \%$ para as amostras filtradas e $97 \%$ para as amostras não filtradas durante a fase estacionária.

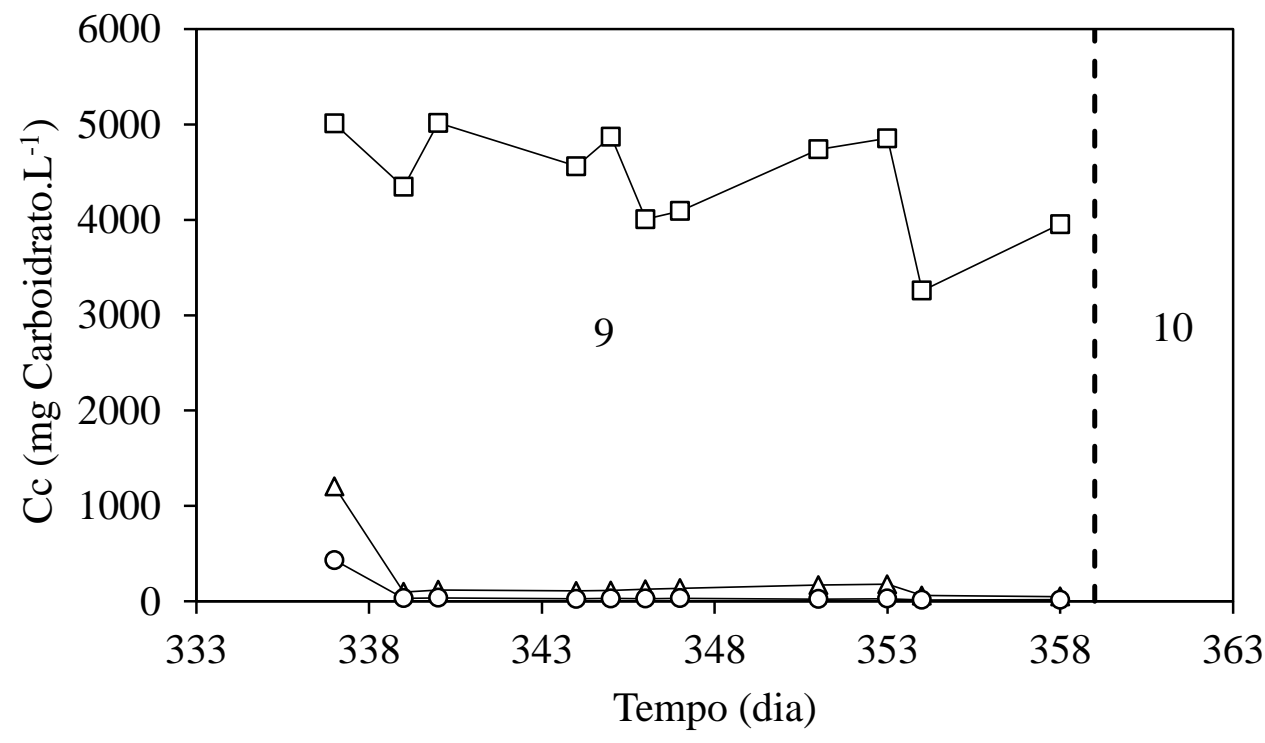

Figura 5-138 - Concentração de carboidrato: $\square$ - afluente não filtrada; $\Delta$ - efluente não filtrada; O - efluente filtrada (AnSBBR com recirculação da fase líquida e soro de leite Condição 9). 


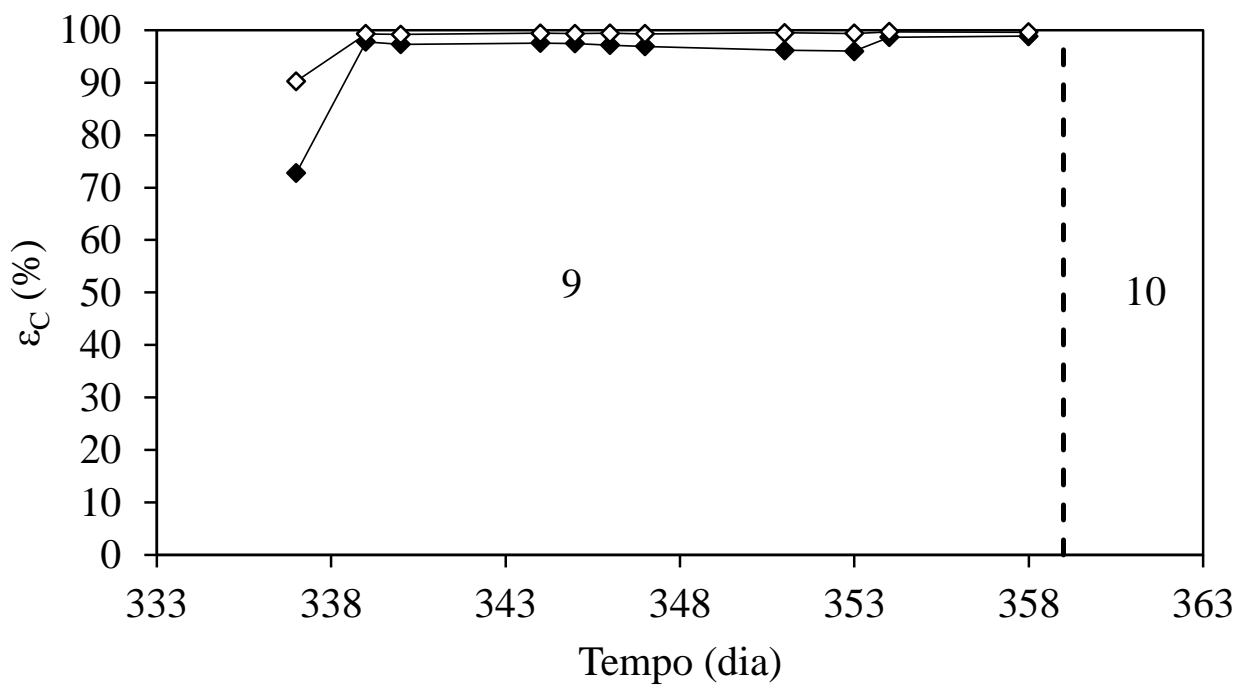

Figura 5-139 - Eficiência de remoção de carboidrato: $\diamond$ - não filltrada; $\bullet$ filtrada (AnSBBR com recirculação da fase líquida e soro de leite - Condição 9).

As Figura 5-140, Figura 5-141 e Figura 5-142 apresentam os perfis temporais (afluente e efluente) do $\mathrm{pH}$, da alcalinidade total e dos ácidos voláteis totais por titulação, respectivamente. A média dos valores de $\mathrm{pH}$ afluente durante a Condição 9 foi de 7,66 e de $\mathrm{pH}$ efluente foi de 4,09. A média da alcalinidade total foi de 446 $\mathrm{mgCaCO}_{3} \cdot \mathrm{L}^{-1}$ para o afluente, sem alcalinidade total no efluente. O valor médio da concentração de ácidos voláteis totais afluente foi de $156 \mathrm{mgHAc} . \mathrm{L}^{-1}$ e efluente de 1845 $\operatorname{mgHAc} . \mathrm{L}^{-1}$. 


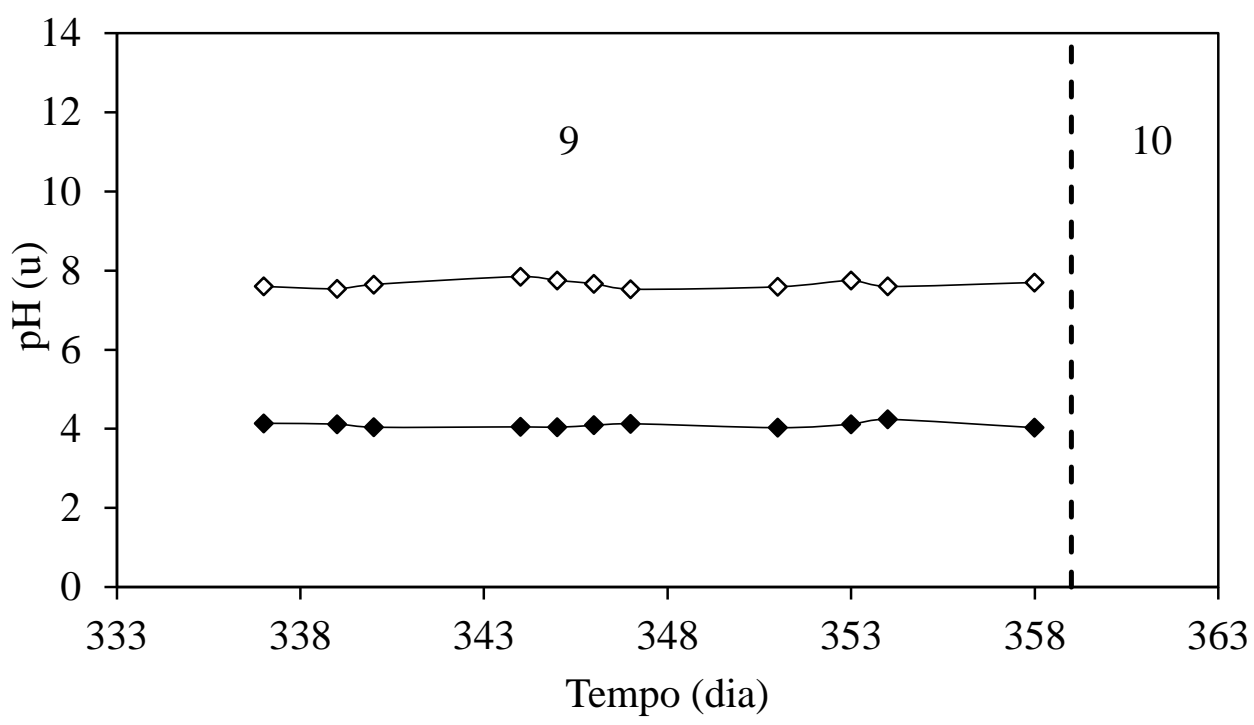

Figura 5-140 - Valores de pH: $\diamond$-afluente; - efluente (AnSBBR com recirculação da fase líquida e soro de leite - Condição 9).

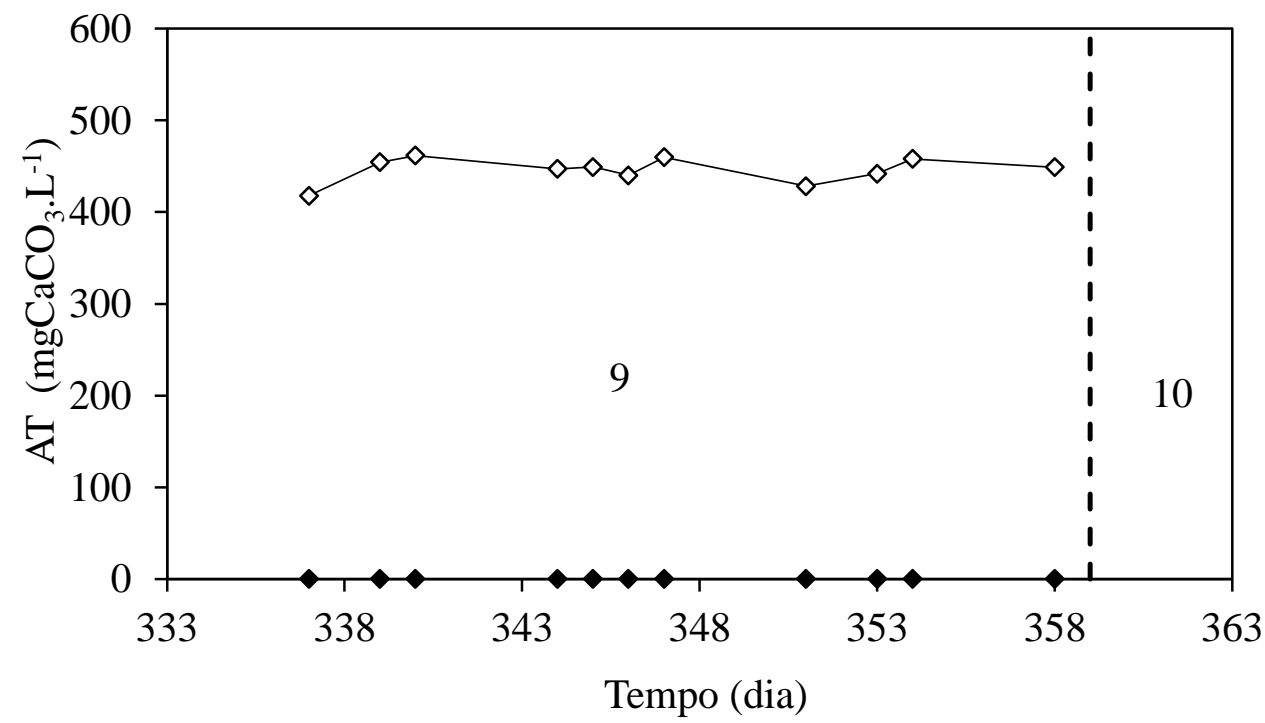

Figura 5-141 - Alcalinidade total: $\diamond$-afluente; - efluente (AnSBBR com recirculação da fase líquida e soro de leite - Condição 9). 


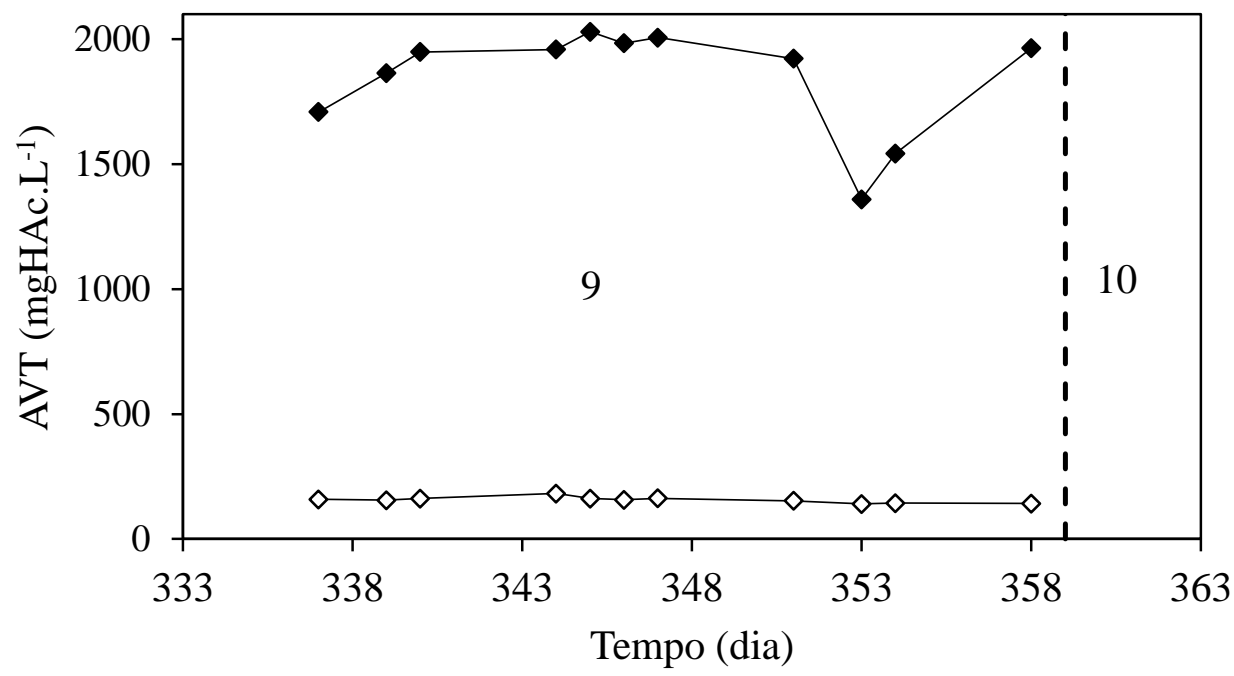

Figura 5-142 - Ácidos voláteis totais: $\diamond$-afluente; - efluente (AnSBBR com recirculação da fase líquida e soro de leite - Condição 9).

A Figura 5-143 apresenta o monitoramento dos compostos intermediários contidos no efluente do sistema. Já a Tabela 5.35 apresenta os valores da concentração média destes mesmos produtos. O método cromatográfico utilizado novamente não detectou a presença de acetona e metanol. $\mathrm{O}$ ácido acético e o ácido butírico foram os principais metabólitos, representando juntos aproximadamente $88 \%$ dos produtos intermediários $(63,8 \%$ e 24,2\%, respectivamente). 


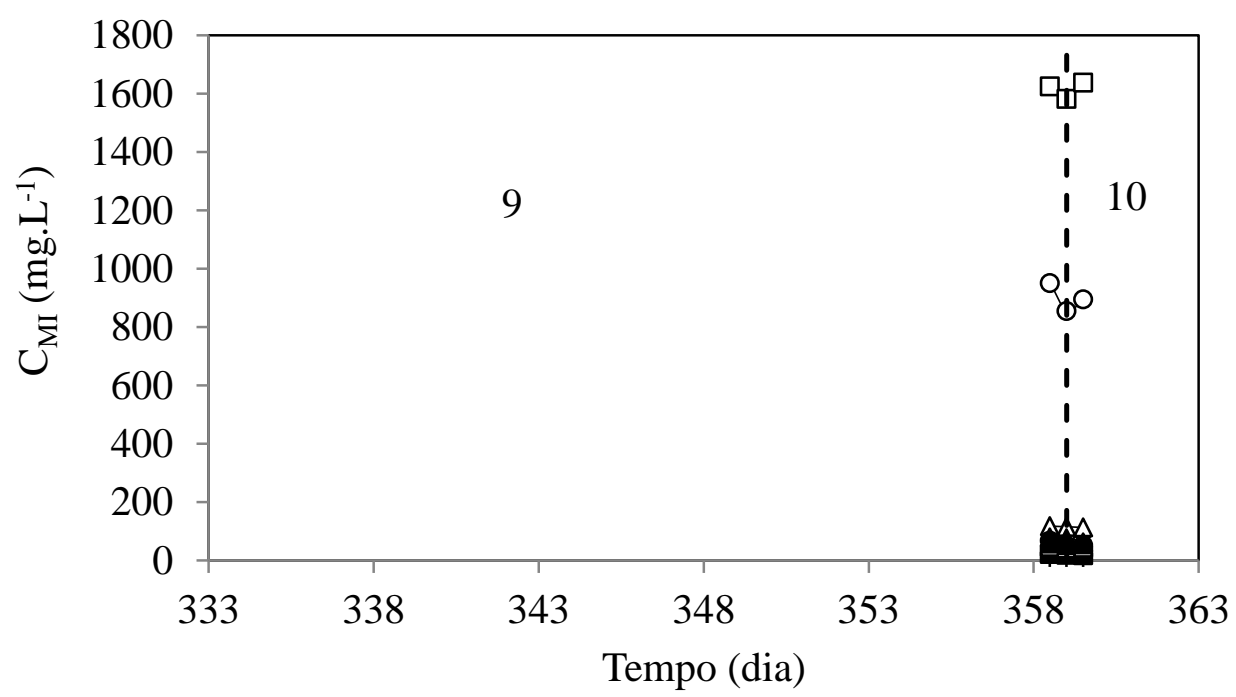

Figura 5-143 - Concentração dos compostos intermediários: $\square$ - ácido acético; $\Delta$ etanol; ○-ácido butírico; - ácido isobutírico; $\boldsymbol{\Delta}$ - ácido capróico; $\bullet$ - ácido valérico; * ácido propiônico; +butanol; - ácido isovalérico (AnSBBR com recirculação da fase líquida e soro de leite - Condição 9).

Tabela 5.35 - Concentração e distribuição dos compostos intermediários (AnSBBR com recirculação da fase líquida e soro de leite - Condição 9).

\begin{tabular}{cccccccc}
\hline $\begin{array}{c}\text { Produtos } \\
\text { intermediários }\end{array}$ & \multicolumn{5}{c}{ Concentrações médias } \\
$\left(\mathrm{mg} . \mathrm{L}^{-1}\right)$ & \multicolumn{3}{c}{$\begin{array}{c}\text { Distribuição } \\
\left(\mathrm{mmol} . \mathrm{L}^{-1}\right)\end{array}$} \\
\hline Acetona & 0,0 & \pm & 0,0 & 0,0 & \pm & 0,0 & 0,0 \\
Metanol & 0,0 & \pm & 0,0 & 0,0 & \pm & 0,0 & 0,0 \\
Etanol & 115,2 & \pm & 2,3 & 2,5 & \pm & 0,0 & 5,9 \\
n-Butanol & 7,6 & \pm & 0,3 & 0,1 & \pm & 0,0 & 0,2 \\
Acético & 1615,4 & \pm & 29,3 & 26,9 & \pm & 0,5 & 63,8 \\
Porpiônico & 57,1 & \pm & 4,7 & 0,8 & \pm & 0,1 & 1,8 \\
Isobutírico & 19,9 & \pm & 1,9 & 0,2 & \pm & 0,0 & 0,5 \\
Butírico & 900,3 & \pm & 47,7 & 10,2 & \pm & 0,5 & 24,2 \\
Isovalérico & 19,4 & \pm & 3,1 & 0,2 & \pm & 0,0 & 0,5 \\
Valérico & 56,5 & \pm & 10,3 & 0,6 & \pm & 0,1 & 1,3 \\
Capróico & 72,7 & \pm & 8,7 & 0,7 & \pm & 0,1 & 1,7 \\
\hline
\end{tabular}

O monitoramento da série de sólidos é mostrado na Tabela 5.36, cujos valores apresentam um baixo teor de SSV no efluente e afluente, indicando a boa capacidade do reator em reter biomassa. 
Tabela 5.36 - Série de sólidos afluente e efluente (AnSBBR com recirculação da fase líquida e soro de leite - Condição 9).

\begin{tabular}{lcccc}
\hline & $\begin{array}{c}\text { ST } \\
\left(\mathrm{mg} . L^{-1}\right)\end{array}$ & $\begin{array}{c}\text { SVT } \\
\left(\mathrm{mg} . L^{-1}\right)\end{array}$ & $\begin{array}{c}\text { SST } \\
\left(\mathrm{mg} . L^{-1}\right)\end{array}$ & $\begin{array}{c}\text { SSV } \\
\left(\mathrm{mg} . L^{-1}\right)\end{array}$ \\
\hline Afluente & $5112 \pm 241$ & $4245 \pm 217$ & $174 \pm 20$ & $143 \pm 21$ \\
Efluente & $3477 \pm 77$ & $2577 \pm 109$ & $454 \pm 116$ & $430 \pm 98$ \\
\hline
\end{tabular}

*Número de amostras consideradas $=6$.

A produção quantitativa do biogás por ciclo é mostrada na Figura 5-144. A produção média foi de $525 \mathrm{~mL}$ (CNTP) durante toda a operação e $769 \mathrm{~mL}$ (CNTP) no estado estacionário, valores superiores aos obtidos na Condição 8. Isto, porém, já era esperado, tendo em vista que este é um parâmetro extensivo. A Figura 5-145 apresenta o monitoramento das concentrações dos componentes do biogás no final do ciclo, enquanto que a Figura 5-146 apresenta a distribuição destes mesmos componentes. Os valores médios de concentração de $\mathrm{H}_{2}, \mathrm{CH}_{4}$ e $\mathrm{CO}_{2}$ durante toda a operação foram 3,0, 0,1 e 8,3 mmol. $\mathrm{L}^{-1}$, respectivamente. Além disso, a distribuição percentual média de $\mathrm{H}_{2}$ foi de $25,0 \%$, a de $\mathrm{CH}_{4}$ foi de $0,8 \%$ e a de $\mathrm{CO}_{2}$ foi de $74,2 \%$.

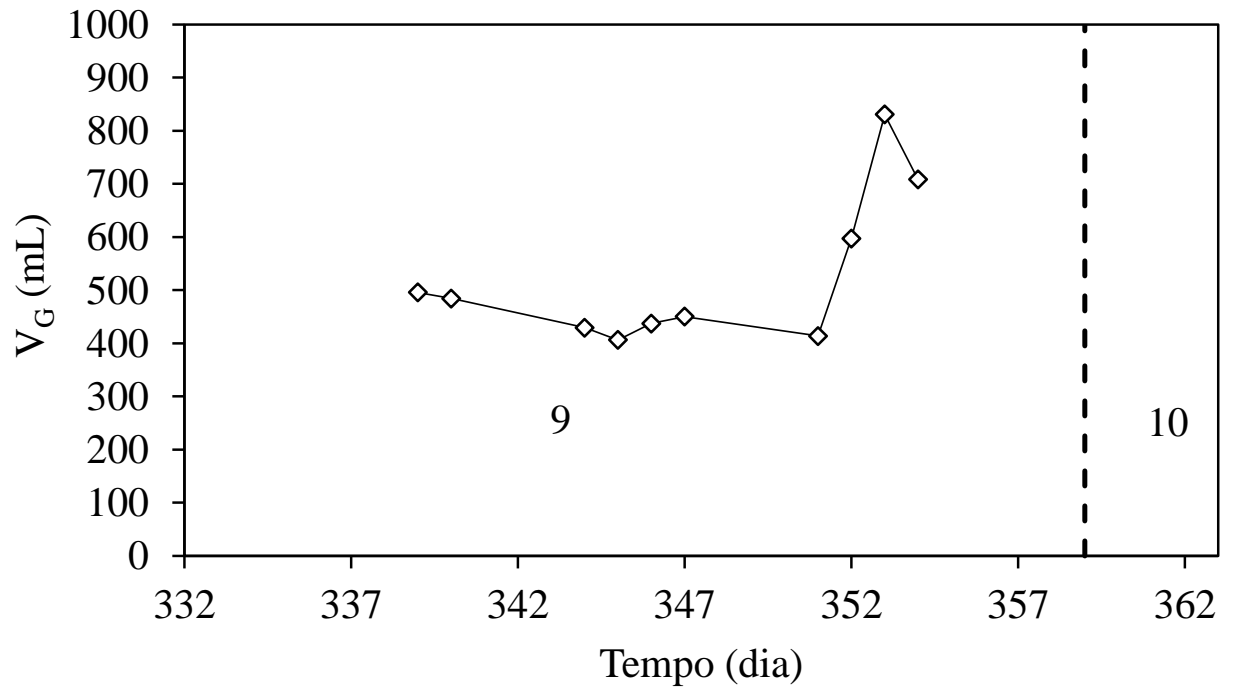

Figura 5-144 - Volume de biogás produzido por ciclo (AnSBBR com recirculação da fase líquida e soro de leite - Condição 9). 


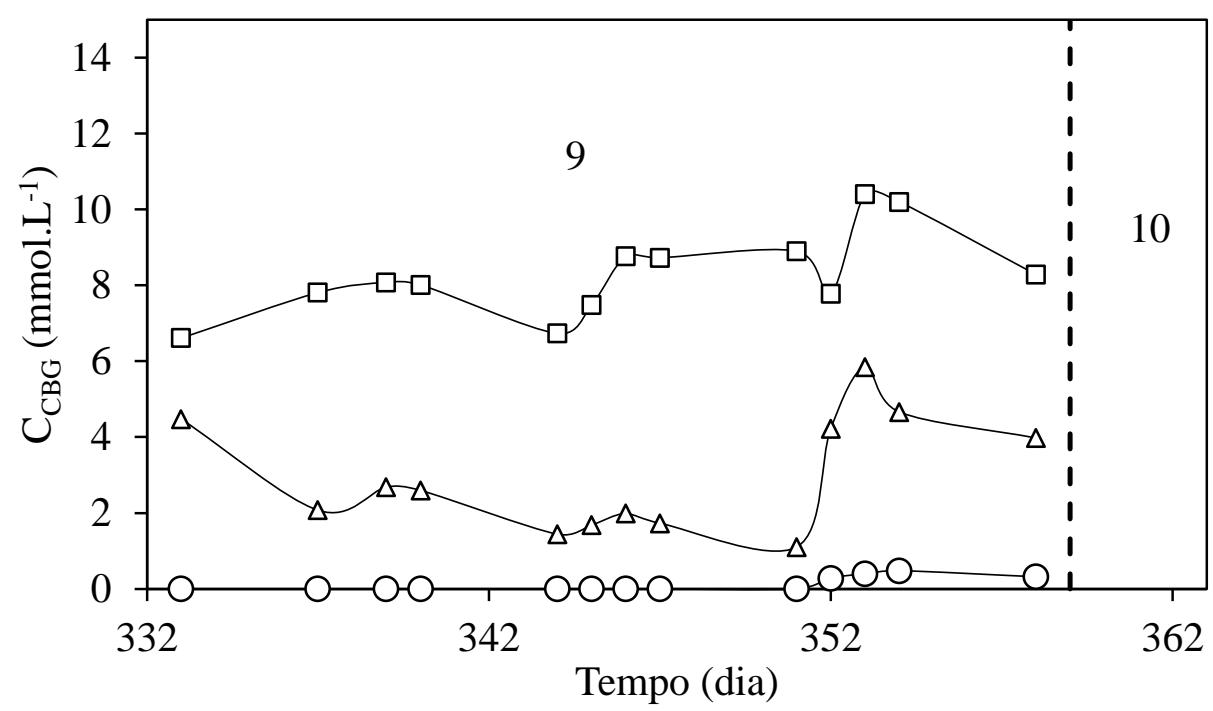

Figura 5-145 - Concentrações dos componentes do biogás no final do ciclo: $\square-\mathrm{CO}_{2} ; \Delta$ - $\mathrm{H}_{2} ; \circ-\mathrm{CH}_{4}$ (AnSBBR com recirculação da fase líquida e soro de leite - Condição 9).

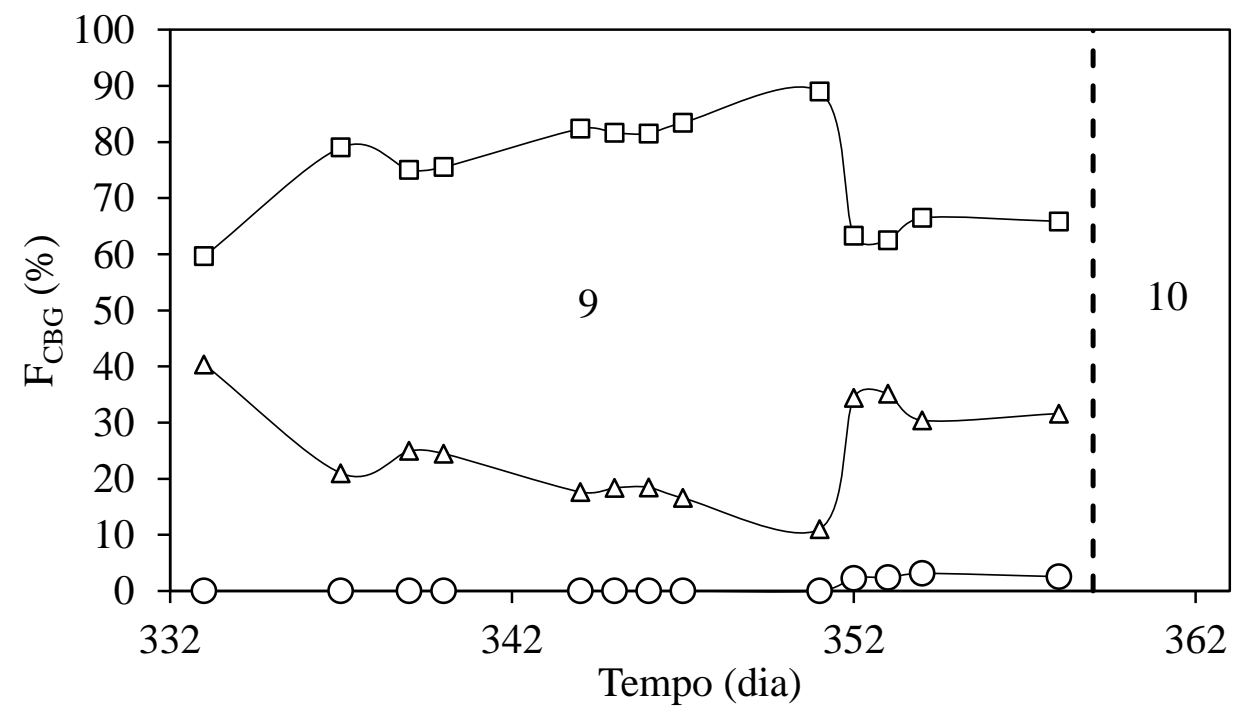

Figura 5-146 - Distribuições dos componentes do biogás no final do ciclo: $\square-\mathrm{CO}_{2} ; \Delta-$ $\mathrm{H}_{2} ; \mathrm{O}-\mathrm{CH}_{4}$ (AnSBBR com recirculação da fase líquida e soro de leite - Condição 9).

A lavagem periódica do material suporte continuou a ser realizada, buscando-se manter a estabilidade na produção de hidrogênio. A Tabela 5.37 apresenta um resumo das lavagens do material suporte realizadas na condição 9. Apenas uma lavagem foi realizada nesta condição, com esta surtindo, novamente, efeito no crescimento celular dentro do reator. 
Tabela 5.37 - Lavagem do material suporte (AnSBBR com recirculação da fase líquida e soro de leite - Condição 9)

\begin{tabular}{cccc}
\hline Tempo & $\begin{array}{c}\text { Quantidade de } \\
\text { biomassa removida } \\
\text { do sistema } \\
(\mathrm{gSVT})\end{array}$ & $\begin{array}{c}\mathrm{C}_{\mathrm{X}} \text { antes da } \\
\text { lavagem } \\
\left(\mathrm{gSVT}^{-1}\right)\end{array}$ & $\begin{array}{c}\mathrm{C}_{\mathrm{X}}{ }^{\prime} \text { antes da } \\
\text { lavagem } \\
\left(\mathrm{gSVT} . \mathrm{gsuporte}^{-1}\right)\end{array}$ \\
\hline 351 & 53,7 & 10,3 & 0,021 \\
\hline
\end{tabular}

O perfil temporal foi realizado no final da operação, com o intuito de entender melhor como os parâmetros indicativos de eficiência do sistema se comportavam durante um ciclo completo. A Figura 5-147 apresenta a evolução da concentração de carboidrato ao longo do ciclo e a eficiência de remoção do mesmo. Ao inicio do ciclo (tempo zero) o volume afluente é diluído no volume residual resultando em uma concentração em carboidrato da ordem de $1490 \mathrm{mg} . \mathrm{L}^{-1}$. A conversão de carboidrato se faz de maneira progressiva ao longo do ciclo, atingindo valores na ordem de $99 \%$ no final do mesmo, com um residual aproximado de $16 \mathrm{mg} \cdot \mathrm{L}^{-1}$. A máxima degradação é atingida mais rapidamente nesta condição (1 hora) do que na condição anterior $(1,5$ horas). 


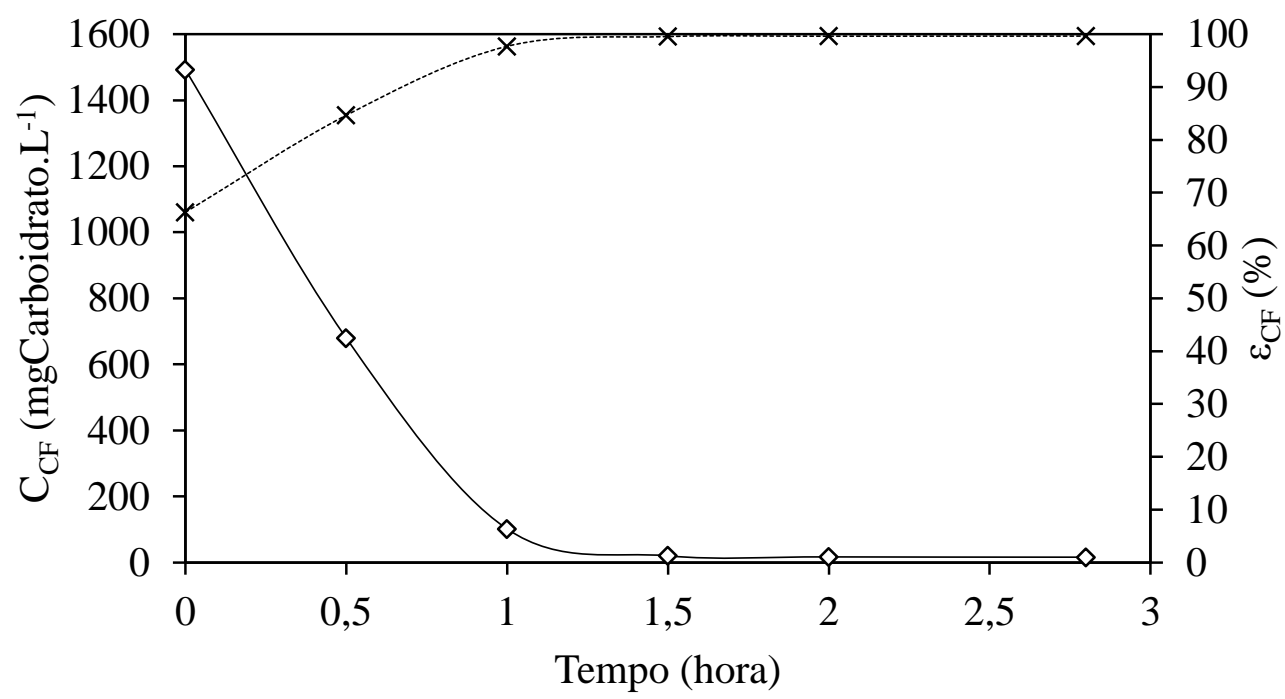

Figura 5-147 - Concentração e eficiência de degradação de carboidrato: $\diamond$ - perfil e * eficiência (AnSBBR com recirculação da fase líquida e soro de leite - Condição 9).

A Figura 5-148 apresenta a evolução da concentração de matéria orgânica ao longo do ciclo. Observa-se uma baixa remoção da DQO, levando a uma alta concentração da mesma no volume residual. Assim, no inicio do ciclo, novamente a diluição do volume carregado pelo volume residual é realizada em proporção bem menor do que no caso dos carboidratos totais, tendo em vista que as concentrações afluente e residual são muito próximas. No inicio do ciclo, a concentração é da ordem de $4750 \mathrm{mg} . \mathrm{L}^{-1}$ atingindo valores próximos a $4515 \mathrm{mg} . \mathrm{L}^{-1}$ no último ponto do ciclo. 


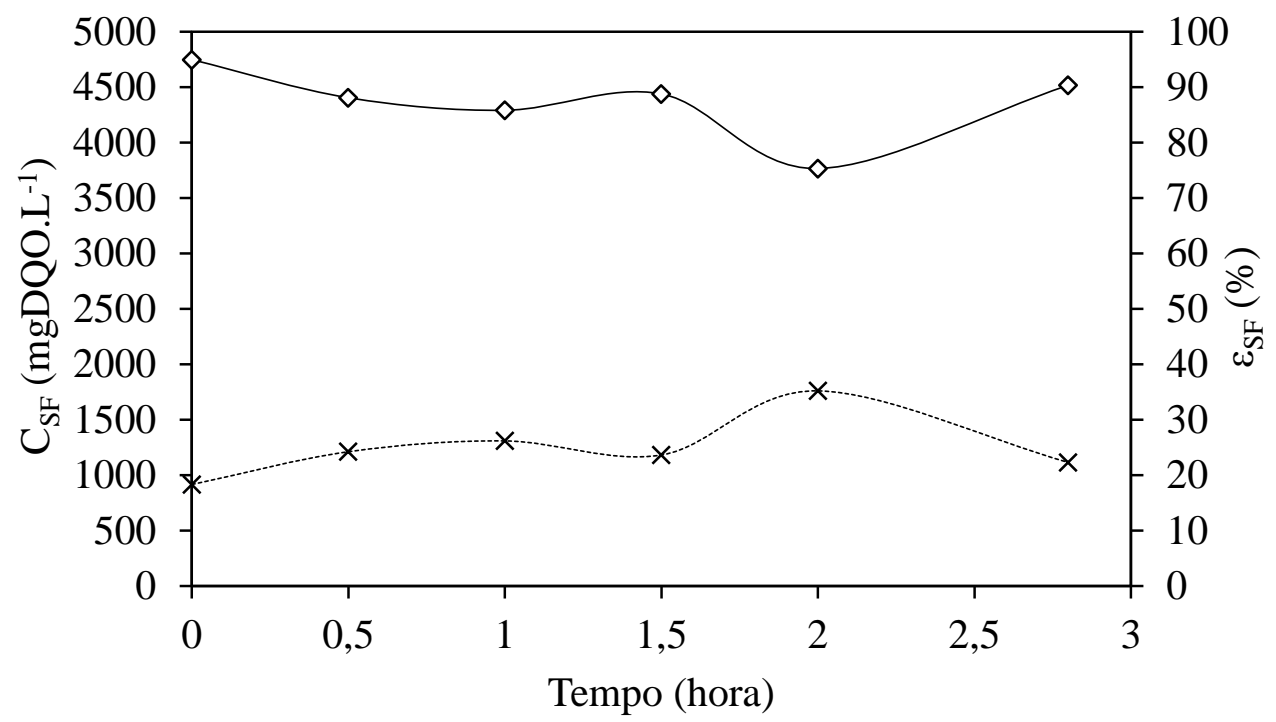

Figura 5-148 - Concentração e eficiência de degradação de matéria orgânica: $\diamond$ - perfil e * eficiência (AnSBBR com recirculação da fase líquida e soro de leite - Condição 9).

O acúmulo de ácidos voláteis totais por titulação ao longo do ciclo pode ser observado na Figura 5-149. A concentração destes apresentou um claro aumento durante a fase de reação para atingir um máximo no final do ciclo na ordem de 1890 $\operatorname{mgHAc} . \mathrm{L}^{-1}$.

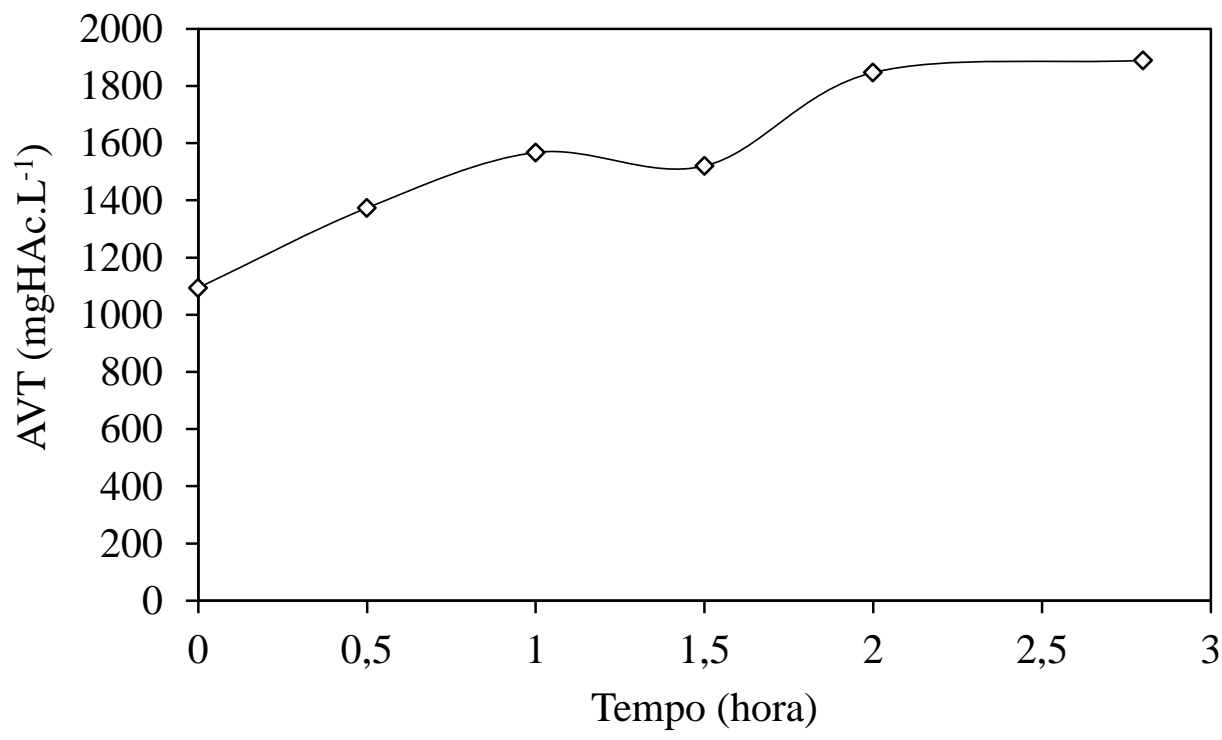

Figura 5-149 - Ácidos voláteis totais $(\diamond)$ do perfil (AnSBBR com recirculação da fase líquida e soro de leite - Condição 9). 
Os resultados dos compostos intermediários por cromatografia gasosa são apresentados na Figura 5-150. Todos os componentes apresentaram concentrações praticamente constantes ao longo do ciclo, exceto o ácido acético que apresentou um crescimento significativo.

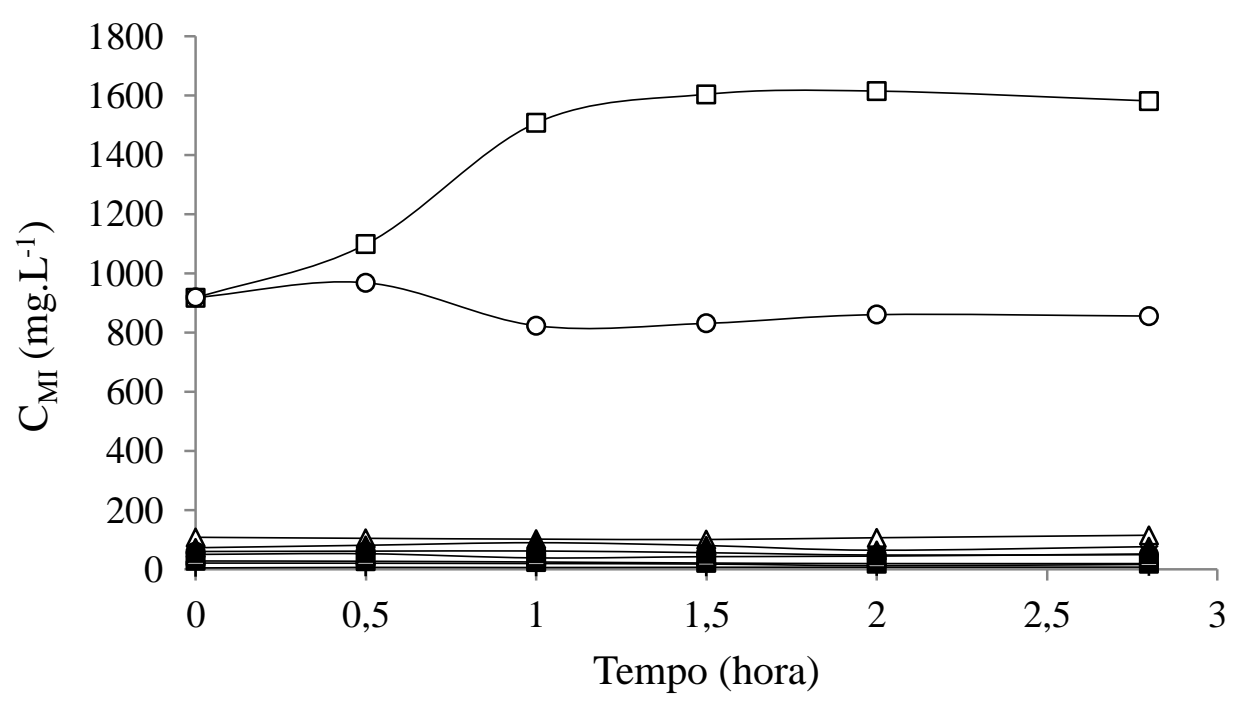

Figura 5-150 - Concentração dos compostos intermediários ao longo do ciclo: $\square$ - ácido

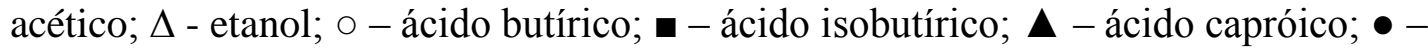
ácido valérico; - *ácido propiônico; +butanol; - ácido isovalérico (AnSBBR com recirculação da fase líquida e soro de leite - Condição 8).

$\mathrm{O}$ pH diminuiu instantaneamente em relação ao afluente devido à diluição do mesmo com o volume residual no inicio do ciclo e permaneceu estável ao longo da operação conforme a Figura 5-151. A estabilidade do pH foi mantida, como pode ser visto na Figura 5-152, mesmo com o sistema não apresentando nenhuma alcalinidade desde o início do ciclo. 


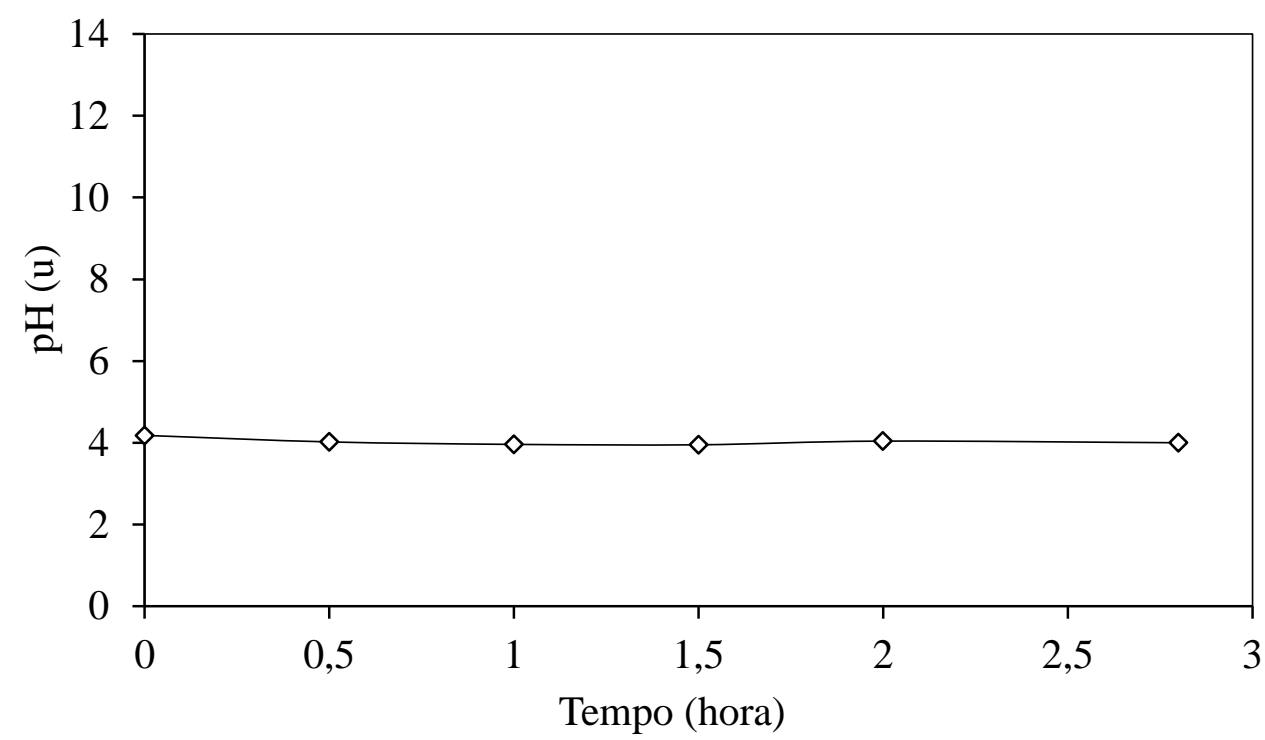

Figura 5-151 - Valores de pH $(\diamond)$ do perfil (AnSBBR com recirculação da fase líquida e soro de leite - Condição 9).

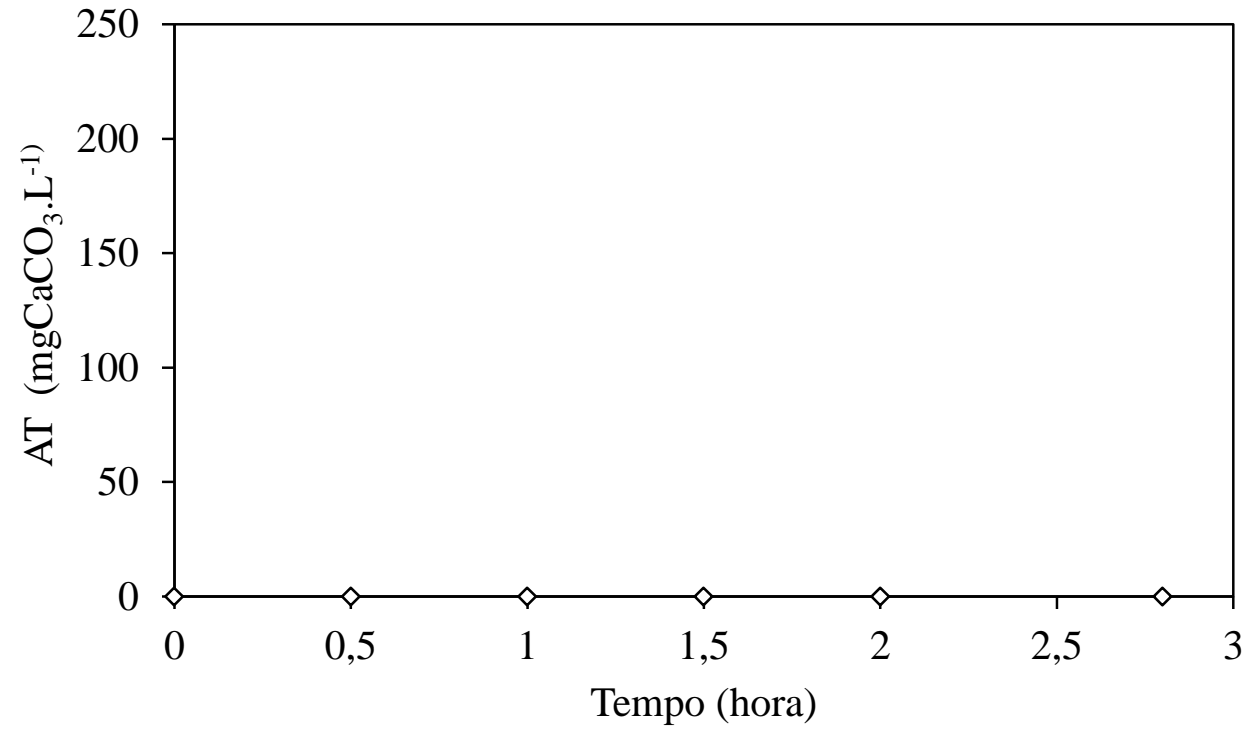

Figura 5-152 - Alcalinidade total do perfil (AnSBBR com recirculação da fase líquida e soro de leite - Condição 9).

A produção volumétrica média acumulada do biogás, realizada com os valores dos perfis quantitativos mais consistentes obtidos durante a operação, juntamente com os desvios padrões encontram-se na Figura 5-153. A produção quase em sua totalidade ocorre nas duas primeiras horas do ciclo, sendo realizada no final do mesmo em quantidades menores. A Tabela 5.38 resume os valores médios da produção, fração 
molar e os volumes individuais da mistura do biogás. A Figura 5-154 apresenta os volumes acumulados médios dos perfis de $\mathrm{H}_{2}, \mathrm{CO}_{2}$ e $\mathrm{CH}_{4}$ produzidos durante o ciclo. Assim como ocorreu na Condição 8 , foi produzido metano em baixíssima quantidade apenas no final da condição, além do hidrogênio e do gás carbônico. Os indicadores de produção de hidrogênio, calculados com os dados obtidos no perfil, apresentaram melhores resultados na Condição 8, mesmo com a Condição 9 apresentando uma maior produção volumétrica de biogás (Tabela 5.34).

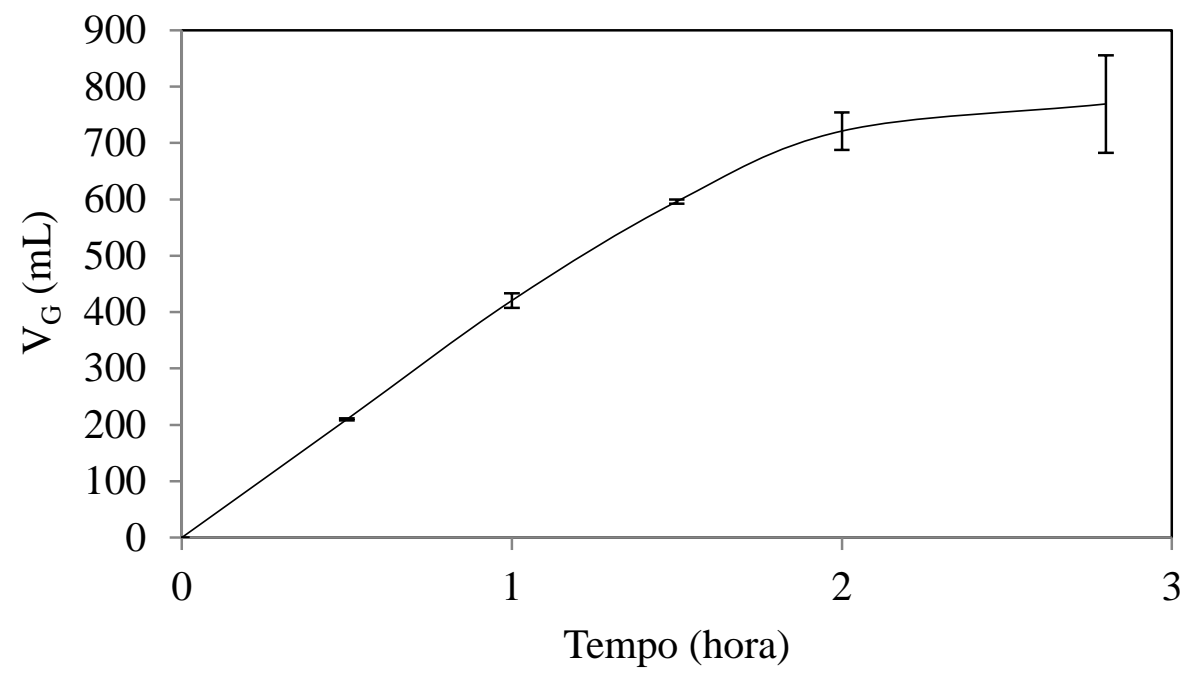

Figura 5-153 - Produção volumétrica média acumulada do biogás durante o ciclo (AnSBBR com recirculação da fase líquida e soro de leite - Condição 9).

Tabela 5.38 - Valores médios da produção, fração molar e os volumes individuais da mistura do biogás (AnSBBR com recirculação da fase líquida e soro de leite - Condição 9).

\begin{tabular}{ccccccccccc}
\hline $\begin{array}{c}\text { Tempo } \\
(\mathrm{h})\end{array}$ & \multirow{2}{*}{$\mathrm{V}_{\mathrm{G}}$} & \multicolumn{3}{c}{$\mathrm{C}_{\mathrm{G}}\left(\mathrm{mmol} \cdot \mathrm{L}^{-1}\right)$} & \multicolumn{3}{c}{ Fração Molar (\%) } & \multicolumn{3}{c}{ Volume $(\mathrm{mL}-\mathrm{CNTP})$} \\
& & $\mathrm{H}_{2}$ & $\mathrm{CO}_{2}$ & $\mathrm{CH}_{4}$ & $\mathrm{H}_{2}$ & $\mathrm{CO}_{2}$ & $\mathrm{CH}_{4}$ & $\mathrm{H}_{2}$ & $\mathrm{CO}_{2}$ & $\mathrm{CH}_{4}$ \\
\hline 0,0 & 0,0 & 0,0 & 0,0 & 0,0 & 0,0 & 0,0 & 0,0 & 0,0 & 0,0 & 0,0 \\
0,5 & 209,6 & 0,4 & 2,9 & 0,0 & 12,5 & 0,0 & 87,5 & 26,2 & 183,4 & 0,0 \\
1,0 & 420,5 & 1,2 & 5,3 & 0,2 & 17,9 & 2,6 & 79,5 & 63,9 & 351,1 & 5,5 \\
1,5 & 596,2 & 2,7 & 8,0 & 0,2 & 24,8 & 2,3 & 73,0 & 107,4 & 479,4 & 9,4 \\
2,0 & 721,2 & 3,5 & 8,2 & 0,3 & 29,4 & 2,5 & 68,1 & 144,2 & 564,5 & 12,6 \\
2,8 & 769,4 & 4,0 & 8,3 & 0,3 & 31,6 & 2,5 & 65,9 & 159,4 & 596,2 & 13,8 \\
\hline
\end{tabular}




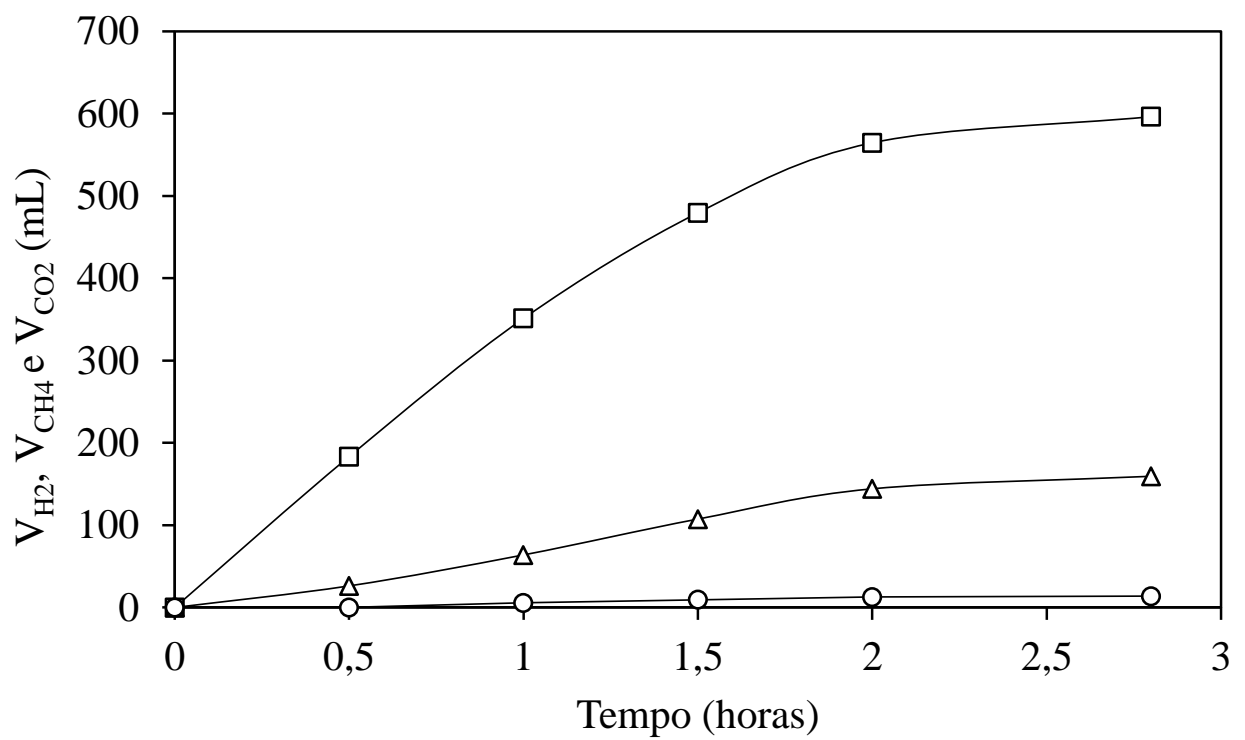

Figura 5-154 - Volumes acumulados médios produzidos ao longo do ciclo: $\square-\mathrm{CO}_{2}$; $\Delta$ $\mathrm{H}_{2} ;$ ○ - $\mathrm{CH}_{4}$ (AnSBBR com recirculação da fase líquida e soro de leite - Condição 9). 
5.2.1.2. Condição $10-$ Soro de leite $\left(t_{c}=3\right.$ horas, $C_{S T}=5500 \mathrm{mgDQO} \mathrm{L}^{-}$ 1)

A condição experimental 10 apresentou uma COAV nominal de 18,5 kgDQO.m ${ }^{-}$ ${ }^{3} \cdot \mathrm{d}^{-1} \mathrm{e}$ duração do ciclo de 3 horas, com duração do dia 360 ao dia 385 (26 dias de operação). A Tabela 5.39 apresenta os valores médios dos parâmetros monitorados. 
Tabela 5.39 - Valores médios dos parâmetros monitorados na condição experimental 10 (Soro de leite - $5500 \mathrm{mgDQO} . \mathrm{L}^{-1}-\mathrm{t}_{\mathrm{C}} 3 \mathrm{~h}$ ).

\begin{tabular}{|c|c|c|c|c|c|c|c|c|c|c|c|}
\hline \multicolumn{2}{|r|}{ Parâmetro } & \multicolumn{5}{|c|}{ Afluente } & & \multicolumn{4}{|c|}{ Efluente } \\
\hline $\mathrm{C}_{\mathrm{ST}}$ & $\left(\mathrm{mgDQO} \cdot \mathrm{L}^{-1}\right)$ & 5025 & \pm & 341 & & 11 & & 4155 & \pm 403 & & \\
\hline $\mathrm{C}_{\mathrm{SF}}$ & $\left(\mathrm{mgDQO} \cdot \mathrm{L}^{-1}\right)$ & - & \pm & - & ( & 3 & & 3695 & \pm 256 & ( 11 & \\
\hline$\varepsilon_{\mathrm{ST}}$ & $(\%)$ & - & & - & & & & 18 & \pm 7 & ( 11 & \\
\hline$\varepsilon_{\mathrm{SF}}$ & $(\%)$ & - & & - & & & & 26 & \pm & $(11$ & \\
\hline $\mathrm{C}_{\mathrm{CT}}$ & $\left(\mathrm{mgCarboidrato} . \mathrm{L}^{-1}\right)$ & 4012 & \pm & 590 & $(1$ & 11 & & 257 & \pm 481 & ( 11 & \\
\hline $\mathrm{C}_{\mathrm{CF}}$ & (mgCarboidrato. $\left.\mathrm{L}^{-1}\right)$ & - & \pm & - & & & & 233 & \pm 498 & ( 11 & \\
\hline$\varepsilon_{\mathrm{CT}}$ & $(\%)$ & - & & - & & & & 94 & \pm 12 & ( 11 & \\
\hline$\varepsilon_{\mathrm{CF}}$ & $(\%)$ & - & & - & & & & 94 & $\pm \quad 12$ & ( 11 & \\
\hline $\mathrm{pH}$ & (u) & 7,86 & \pm & 0,10 & ( & 11 & ) & 4,43 & $\pm 0,12$ & ( 11 & \\
\hline AVT & $\left(\mathrm{mgHAc} . \mathrm{L}^{-1}\right)$ & 144 & \pm & 11 & ( & 11 & & 1489 & \pm 379 & ( 11 & \\
\hline AT & $\left(\mathrm{mgCaCO}_{3} \cdot \mathrm{L}^{-1}\right)$ & 441 & \pm & 19 & ( & 11 & ) & 89 & \pm 72 & ( 11 & \\
\hline $\mathrm{AP}$ & $\left(\mathrm{mgCaCO}_{3} \cdot \mathrm{L}^{-1}\right)$ & 300 & \pm & 20 & ( & 11 & & 0 & \pm & ( 11 & \\
\hline AI & $\left(\mathrm{mgCaCO}_{3} \cdot \mathrm{L}^{-1}\right)$ & 141 & \pm & 11 & ( & 11 & ) & 89 & $\pm \quad 72$ & ( 11 & \\
\hline $\mathrm{AB}$ & $\left(\mathrm{mgCaCO}_{3} \cdot \mathrm{L}^{-1}\right)$ & 339 & \pm & 23 & $(1$ & 11 & ) & 0 & \pm 0 & ( 11 & \\
\hline ST & $\left(\mathrm{mg} \cdot \mathrm{L}^{-1}\right)$ & 4540 & \pm & 121 & ( & 4 & ) & 1994 & \pm 199 & ( 4 & \\
\hline STV & $\left(\mathrm{mg} \cdot \mathrm{L}^{-1}\right)$ & 3785 & \pm & 148 & ( & 4 & ) & 1346 & \pm 125 & $(4$ & \\
\hline SST & $\left(\mathrm{mg} \cdot \mathrm{L}^{-1}\right)$ & 152 & \pm & 18 & ( & 4 & & 215 & $\pm \quad 95$ & ( 4 & \\
\hline SSV & $\left(\mathrm{mg} \cdot \mathrm{L}^{-1}\right)$ & 143 & \pm & 25 & ( & 4 & & 207 & $\pm \quad 88$ & ( 4 & \\
\hline $\mathrm{M}_{\mathrm{STV}}$ & (g) & - & & - & & & & 17,8 & - & & \\
\hline $\mathrm{C}_{\mathrm{X}}$ & $\left(\mathrm{g} . \mathrm{L}^{-1}\right)$ & - & & - & & & & 4,7 & - & & \\
\hline $\mathrm{C}_{\mathrm{X}}^{\prime}$ & $\left(\right.$ g.gsuporte $\left.{ }^{-1}\right)$ & - & & - & & & & 0,011 & - & & \\
\hline $\mathrm{V}_{\mathrm{G}}$ & (mL-CNTP) & - & & - & & & & 883 & \pm 18 & $(2$ & \\
\hline $\mathrm{V}_{\mathrm{H} 2}$ & (mL-CNTP) & - & & - & & & & 311 & \pm- & $(1$ & \\
\hline $\mathrm{COAV}_{\mathrm{S}}$ & $\left(\operatorname{kgDQO} \cdot \mathrm{m}^{-3} \cdot \mathrm{d}^{-1}\right)$ & 17,2 & & - & & & & - & - & & \\
\hline $\mathrm{CORV}_{\mathrm{S}}$ & $\left(\mathrm{kgDQO} \cdot \mathrm{m}^{-3} \cdot \mathrm{d}^{-1}\right)$ & $\underline{11,2}$ & & - & & & & 4,6 & - & & \\
\hline $\mathrm{COAV}_{\mathrm{C}}$ & $\left(\mathrm{kgCarboidrato} \cdot \mathrm{m}^{-3} \cdot \mathrm{d}^{-1}\right)$ & 13,8 & & - & & & & - & - & & \\
\hline $\mathrm{CORV}_{\mathrm{C}}$ & $\left(\mathrm{kgCarboidrato} \cdot \mathrm{m}^{-3} \cdot \mathrm{d}^{-1}\right)$ & - & & - & & & & 13,0 & - & & \\
\hline $\mathrm{COAE}_{\mathrm{S}}$ & $\left(\mathrm{kgDQO} \cdot \mathrm{kgSTV}^{-1} \cdot \mathrm{d}^{-1}\right)$ & 3,4 & & - & & & & $\underline{10,0}$ & - & & \\
\hline $\mathrm{CORE}_{\mathrm{S}}$ & $\left(\operatorname{kgDQO} \mathrm{kgSTV}^{-1} \cdot \mathrm{d}^{-1}\right)$ & - & & - & & & & 0,9 & - & & \\
\hline $\mathrm{COAE}_{\mathrm{C}}$ & $\left(\mathrm{kgCarboidrato.kgSTV}{ }^{-1} \cdot \mathrm{d}^{-1}\right)$ & 2,7 & & - & & & & 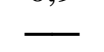 & - & & \\
\hline $\mathrm{CORE}_{\mathrm{C}}$ & $\left(\mathrm{kgCarboidrato.kgSTV}^{-1} \cdot \mathrm{d}^{-1}\right)$ & - & & - & & & & 2,6 & - & & \\
\hline $\mathrm{RMCR}_{\mathrm{C}, \mathrm{n}}$ & $\left(\mathrm{molH}_{2 .}\right.$ molCarboidrato $\left.^{-1}\right)$ & - & & - & & & & 0,80 & - & & \\
\hline $\mathrm{n}_{\mathrm{H} 2}$ & $\left(\mathrm{molH}_{2} \cdot \mathrm{d}^{-1}\right)$ & - & & - & & & & 0,111 & - & & \\
\hline PrVH & $\left(\mathrm{mLH}_{2} \cdot \mathrm{L}^{-1} \cdot \mathrm{d}^{-1}\right)$ & - & & - & & & & 657,6 & - & & \\
\hline PrM & $\left(\mathrm{molH}_{2} \cdot \mathrm{m}^{-3} \cdot \mathrm{d}^{-1}\right)$ & - & & - & & & & 29,3 & - & & \\
\hline PrME & $\left(\mathrm{molH}_{2} \cdot \mathrm{kgSVT}^{-1} \cdot \mathrm{d}^{-1}\right)$ & - & & - & & & & 6,2 & - & & \\
\hline $\mathrm{RMCA}_{\mathrm{S}, \mathrm{m}}$ & $\left(\mathrm{molH}_{2} \cdot \mathrm{kgDQO}^{-1} \cdot \mathrm{d}^{-1}\right)$ & 1,8 & & - & & & & - & - & & \\
\hline $\mathrm{RMCA}_{\mathrm{C}, \mathrm{m}}$ & $\left(\mathrm{molH}_{2} \cdot \mathrm{kg}^{-1} \cdot \mathrm{d}^{-1}\right)$ & 2,3 & & - & & & & - & - & & \\
\hline $\mathrm{RMCR}_{\mathrm{S}, \mathrm{m}}$ & $\left(\mathrm{molH}_{2} \cdot \mathrm{kgDQO}^{-1} \cdot \mathrm{d}^{-1}\right)$ & - & & - & & & & 7,0 & - & & \\
\hline $\mathrm{RMCR}_{\mathrm{C}, \mathrm{m}}$ & $\left(\mathrm{molH}_{2} \cdot \mathrm{kg}^{-1} \cdot \mathrm{d}^{-1}\right)$ & - & & - & & & & 2,3 & - & & \\
\hline $\mathrm{V}_{\mathrm{d}}$ & $(\mathrm{mL})$ & 1493 & \pm & 33 & ( & 10 & & - & - & & \\
\hline $\mathrm{Q}_{\mathrm{R}}$ & $\left(\mathrm{mL} \cdot \mathrm{s}^{-1}\right)$ & 7 & \pm & 0 & ( & & & - & - & & \\
\hline
\end{tabular}

(*) Entre parêntese o número de amostras considerado no cálculo da média

A Figura 5-155 apresenta os valores da concentração afluente (amostras não filtradas) e efluente (amostras não filtradas e filtradas) de matéria orgânica (DQO) nos 
sistema. A Figura 5-156 apresenta a eficiência de remoção do mesmo parâmetro durante o monitoramento diário. Esta eficiência atingiu, em média, 26\% para as amostras filtradas e $17 \%$ para mostras não filtradas. A média de concentração afluente não filtrada do substrato foi de $5025 \mathrm{mgDQO} . \mathrm{L}^{-1}$ e de $4155 \mathrm{mgDQO} . \mathrm{L}^{-1}$ e $3695 \mathrm{mgDQO} . \mathrm{L}^{-1}$ para amostras de efluente não filtradas e filtradas, respectivamente.

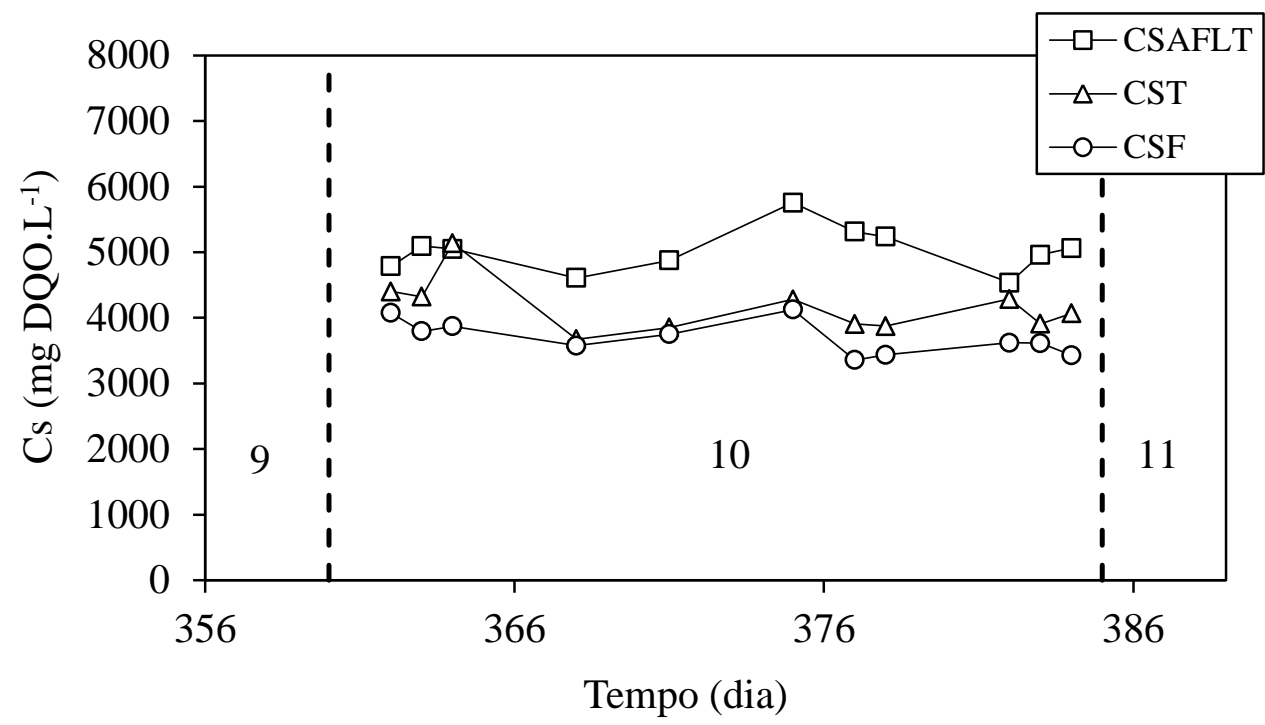

Figura 5-155 - Concentração de matéria orgânica (DQO): $\square$ - afluente não filtrada; $\Delta$ efluente não filtrada; o - efluente filtrada (AnSBBR com recirculação da fase líquida e soro de leite - Condição 10). 


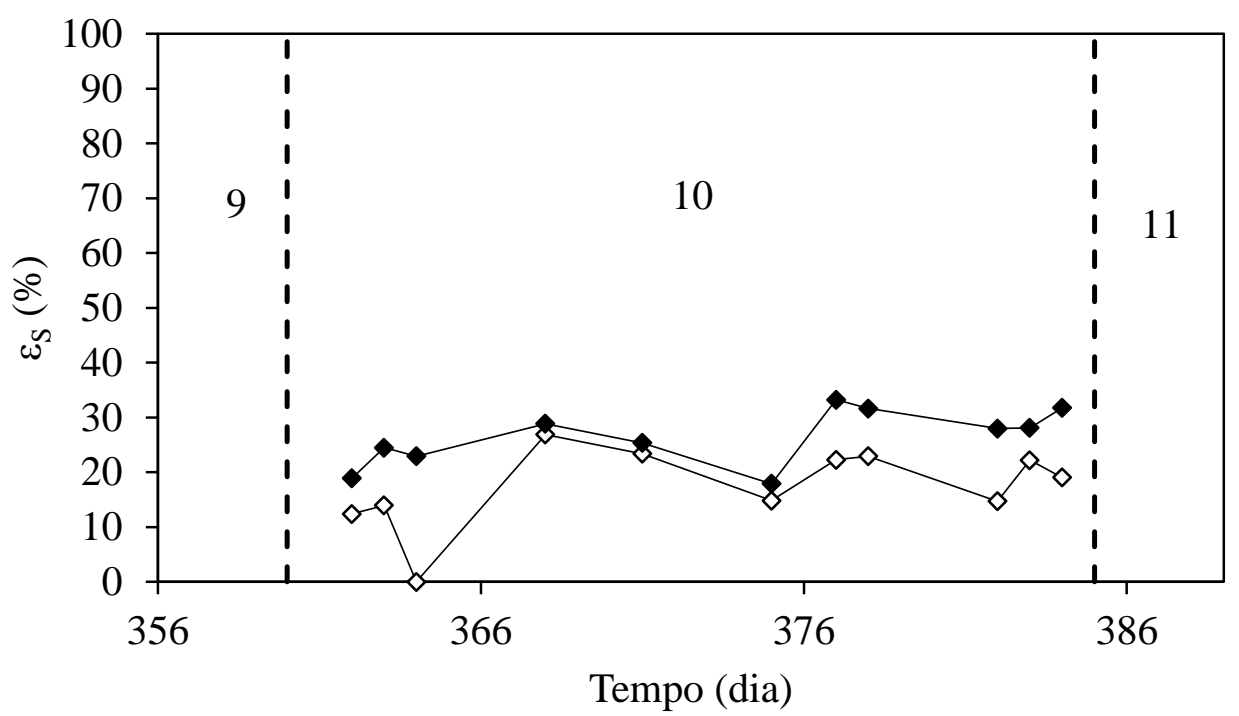

Figura 5-156 - Eficiência de remoção de matéria orgânica (DQO): $\diamond$ - não filtrada; filtrada (AnSBBR com recirculação da fase líquida e soro de leite - Condição 10).

A Figura 5-157 apresenta os valores da concentração de carboidratos afluente e efluente (para amostras filtradas e não filtradas) e Figura 5-158 apresenta a eficiência de remoção do mesmo parâmetro (não filtrada e filtrada) durante o monitoramento diário. A média da concentração afluente foi de $4112 \mathrm{mgCarboidrato.} \mathrm{L}^{-1}$, enquanto que a concentração residual (amostras não filtradas) foi de 257 mgCarboidrato. $\mathrm{L}^{-1}$ e 233 mgCarboidrato. $\mathrm{L}^{-1}$ para a concentração residual filtrada durante toda a operação e de 42 mgCarboidrato. $\mathrm{L}^{-1}$ e $17 \mathrm{mgCarboidrato.} \mathrm{L}^{-1}$ durante a fase estacionária. A eficiência de remoção de carboidrato foi, em média, de $94 \%$ para as amostras filtradas e não filtradas durante toda a operação e de $99 \%$ para as amostras filtradas e não filtradas durante a fase estacionária. 


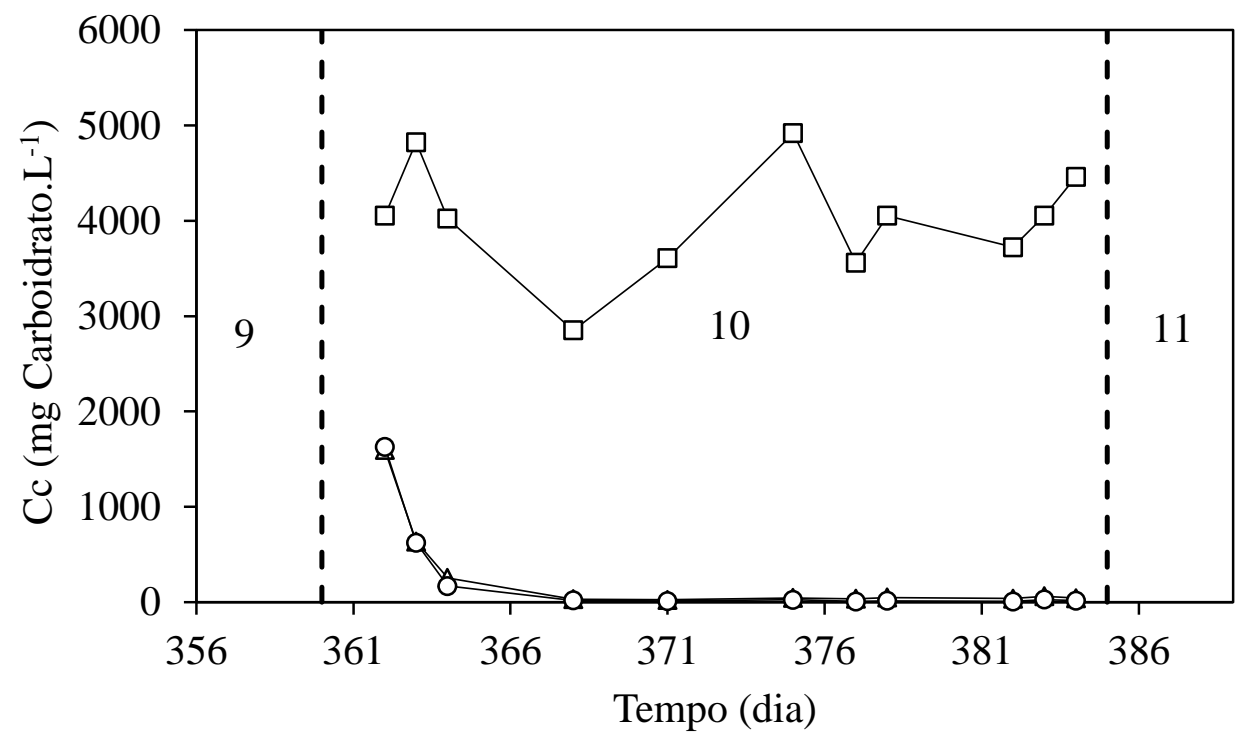

Figura 5-157 - Concentração de carboidrato: $\square$ - afluente não filtrada; $\Delta$ - efluente não filtrada; O - efluente filtrada (AnSBBR com recirculação da fase líquida e soro de leite Condição 10).

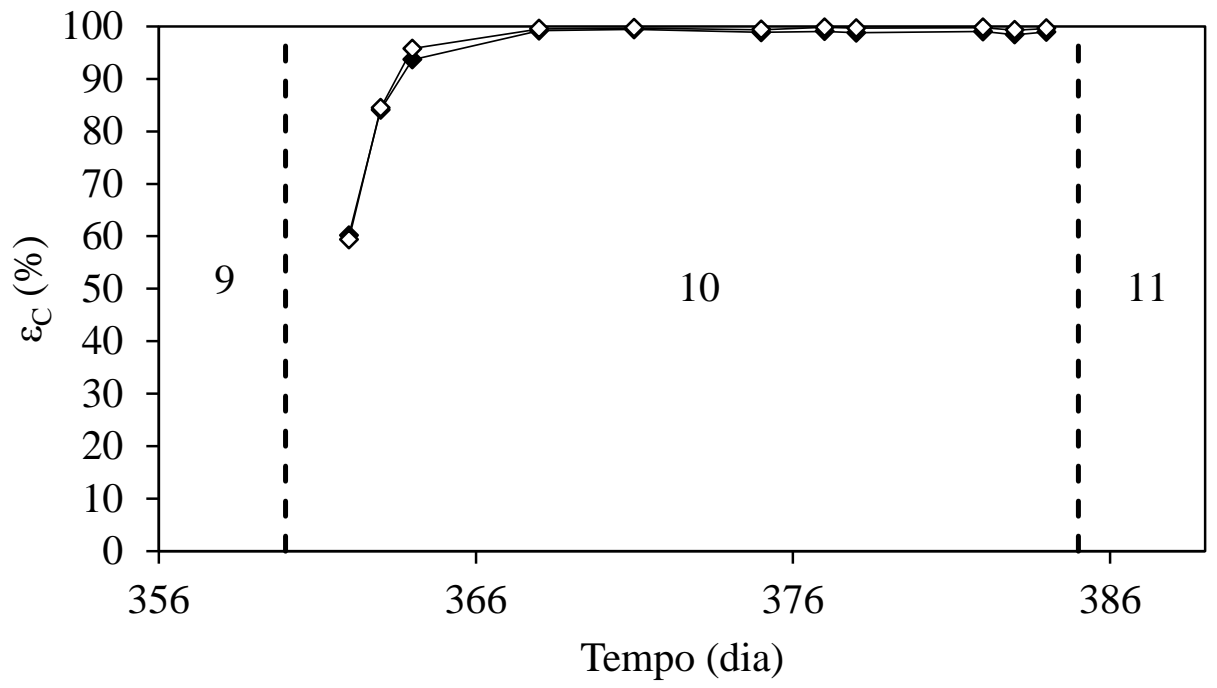

Figura 5-158 - Eficiência de remoção de carboidrato: $\diamond$ - não filtrada; $\downarrow$ - filtrada (AnSBBR com recirculação da fase líquida e soro de leite - Condição 10).

As Figura 5-159, Figura 5-160 e Figura 5-161 apresentam os perfis temporais (afluente e efluente) do $\mathrm{pH}$, da alcalinidade total e dos ácidos voláteis totais por titulação, respectivamente. A média dos valores de $\mathrm{pH}$ afluente durante a Condição 4 foi de 7,86 e de $\mathrm{pH}$ efluente foi de 4,43. A média da alcalinidade total foi de 441 
$\mathrm{mgCaCO} 3 . \mathrm{L}^{-1}$ para o afluente e de $89 \mathrm{mgCaCO}_{3} \cdot \mathrm{L}^{-1}$ para o efluente. O valor médio da concentração de ácidos voláteis totais afluente foi de $144 \mathrm{mgHAc} . \mathrm{L}^{-1}$ e efluente de 1489 $\operatorname{mgHAc} . \mathrm{L}^{-1}$.

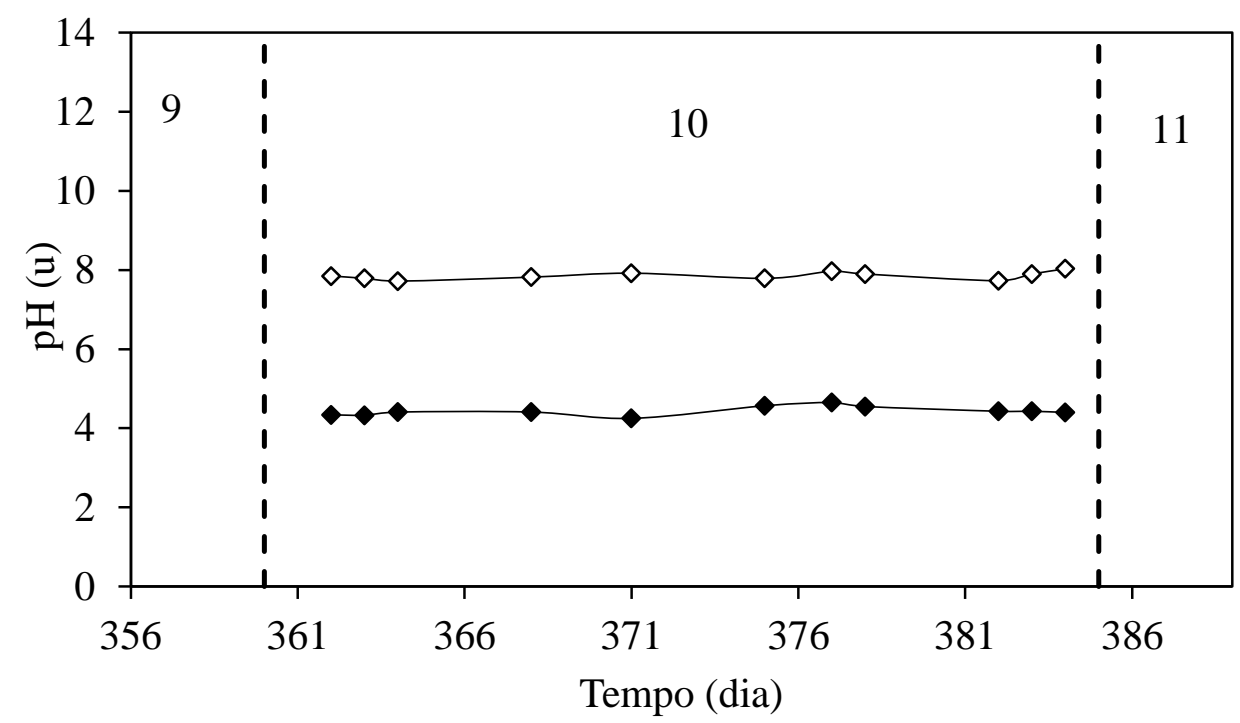

Figura 5-159 - Valores de pH: $\diamond$-afluente; - efluente (AnSBBR com recirculação da fase líquida e soro de leite - Condição 10).

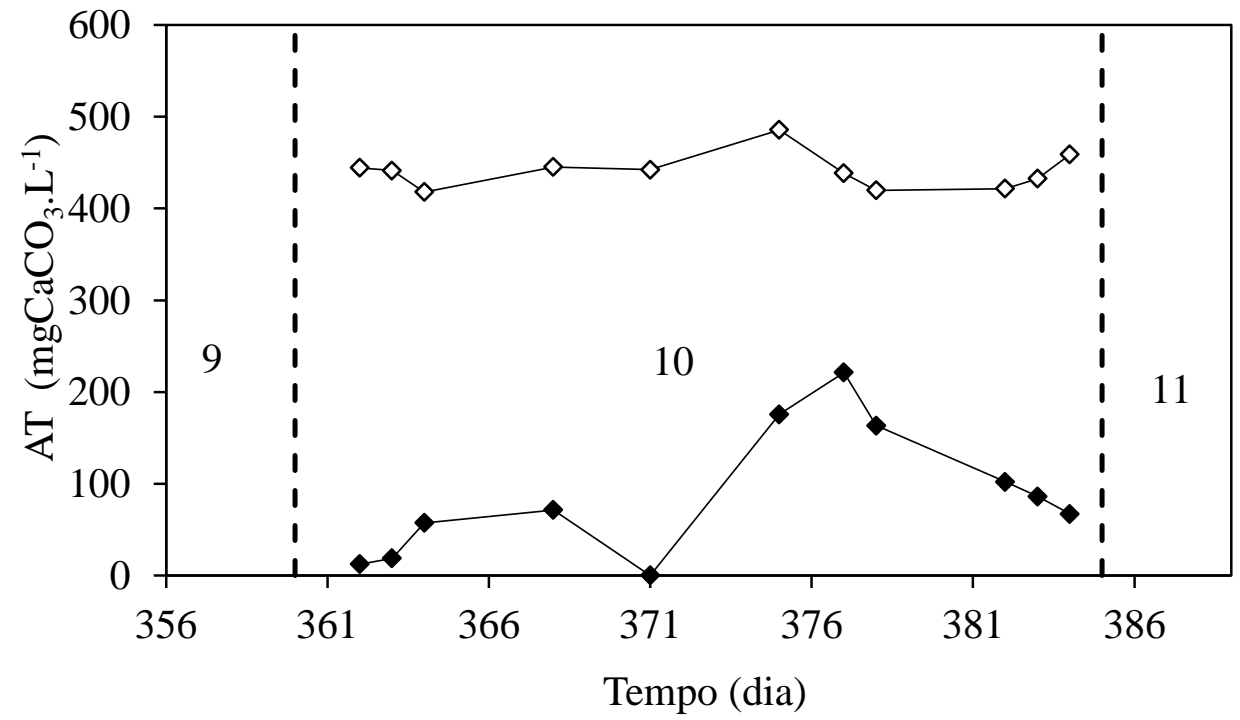

Figura 5-160 - Alcalinidade total: $\diamond$-afluente; - efluente (AnSBBR com recirculação da fase líquida e soro de leite - Condição 10). 


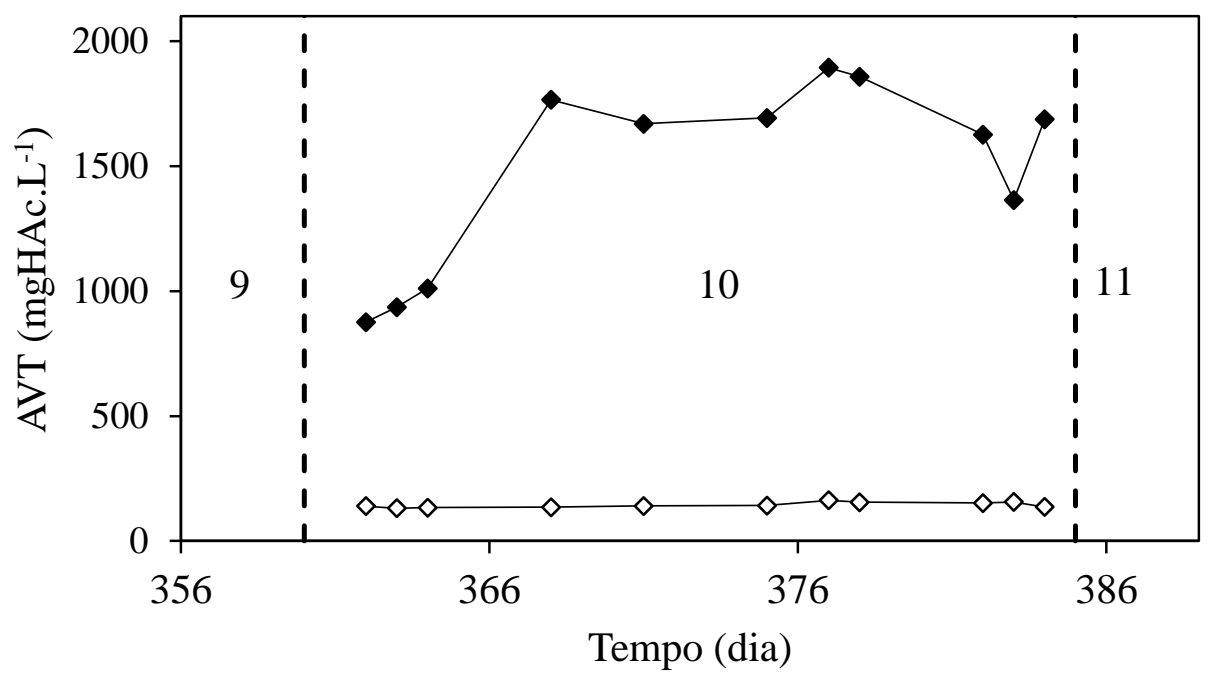

Figura 5-161 - Ácidos voláteis totais: $\diamond$-afluente; - efluente (AnSBBR com recirculação da fase líquida e soro de leite - Condição 10).

A Figura 5-162 apresenta o monitoramento dos compostos intermediários contidos no efluente do sistema, enquanto que a Tabela 5.40 apresenta os valores da concentração média destes produto. O ácido acético, o ácido butírico e o etanol foram os maiores destaques, representando juntos aproximadamente $91 \%$ dos produtos intermediários $(37,2 \%, 30,0 \%$ e $24,0 \%$, respectivamente). 


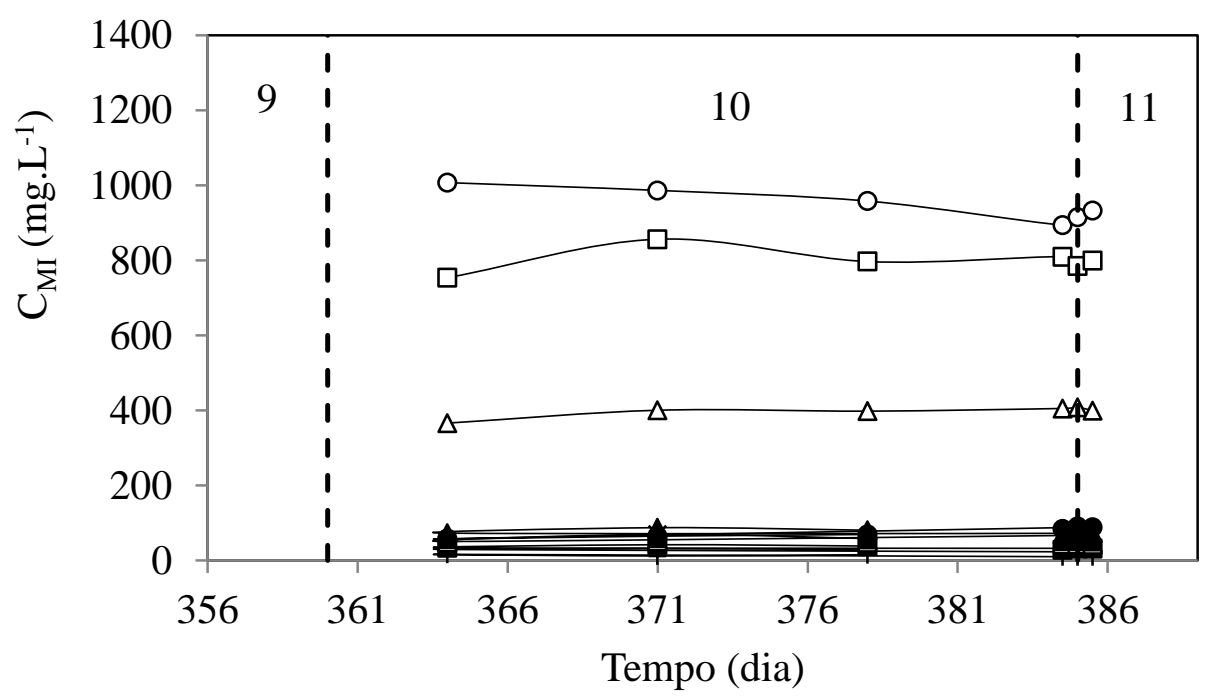

Figura 5-162 - Concentração dos compostos intermediários: $\square$ - ácido acético; $\Delta$ etanol; ○-ácido butírico; - ácido isobutírico; $\boldsymbol{\Delta}$ - ácido capróico; $\bullet$ - ácido valérico; * ácido propiônico; +butanol; - ácido isovalérico (AnSBBR com recirculação da fase líquida e soro de leite - Condição 10).

Tabela 5.40 - Concentração e distribuição dos compostos intermediários (AnSBBR com recirculação da fase líquida e soro de leite - Condição 10).

\begin{tabular}{cccccccc}
\hline $\begin{array}{c}\text { Produtos } \\
\text { intermediários }\end{array}$ & \multicolumn{4}{c}{$\begin{array}{c}\text { Concentrações médias } \\
\left(\mathrm{mg} . \mathrm{L}^{-1}\right)\end{array}$} & \multicolumn{3}{c}{$\begin{array}{c}\text { Distribuição } \\
\left(\mathrm{mmol} . \mathrm{L}^{-1}\right)\end{array}$} \\
\hline Acetona & 0,0 & \pm & 0,0 & 0,0 & \pm & 0,0 & 0,0 \\
Metanol & 0,0 & \pm & 0,0 & 0,0 & \pm & 0,0 & 0,0 \\
Etanol & 396,1 & \pm & 15,2 & 8,6 & \pm & 0,3 & 24,0 \\
n-Butanol & 12,0 & \pm & 3,1 & 0,2 & \pm & 0,0 & 0,4 \\
Acético & 800,2 & \pm & 33,5 & 13,3 & \pm & 0,6 & 37,2 \\
Porpiônico & 62,9 & \pm & 7,2 & 0,8 & \pm & 0,1 & 2,4 \\
Isobutírico & 34,2 & \pm & 5,0 & 0,4 & \pm & 0,1 & 1,1 \\
Butírico & 949,1 & \pm & 43,1 & 10,8 & \pm & 0,5 & 30,0 \\
Isovalérico & 26,5 & \pm & 3,7 & 0,3 & \pm & 0,0 & 0,7 \\
Valérico & 75,8 & \pm & 13,7 & 0,7 & \pm & 0,1 & 2,1 \\
Capróico & 76,6 & \pm & 6,4 & 0,7 & \pm & 0,1 & 2,1 \\
\hline
\end{tabular}

O monitoramento da série de sólidos é mostrado na Tabela 5.41, cujos valores apresentam um baixo teor de SSV no efluente e afluente, indicando a boa capacidade do reator em reter biomassa. 
Tabela 5.41 - Série de sólidos afluente e efluente (AnSBBR com recirculação da fase líquida e soro de leite - Condição 10).

\begin{tabular}{lcccc}
\hline & $\begin{array}{c}\text { ST } \\
\left(\mathrm{mg}^{-1}\right)\end{array}$ & $\begin{array}{c}\text { SVT } \\
\left(\mathrm{mg} . L^{-1}\right)\end{array}$ & $\begin{array}{c}\text { SST } \\
\left(\mathrm{mg} . L^{-1}\right)\end{array}$ & $\begin{array}{c}\text { SSV } \\
\left(\mathrm{mg} . \mathrm{L}^{-1}\right)\end{array}$ \\
\hline Afluente & $4540 \pm 121$ & $3785 \pm 148$ & $152 \pm 18$ & $143 \pm 25$ \\
Efluente & $1994 \pm 199$ & $1346 \pm 125$ & $215 \pm 95$ & $207 \pm 88$ \\
\hline
\end{tabular}

*Número de amostras consideradas $=4$.

A produção quantitativa do biogás por ciclo é apresentada na Figura 5-163. A produção média foi de $792 \mathrm{~mL}(\mathrm{CNTP})$ durante toda a operação e $883 \mathrm{~mL}$ (CNTP) no estado estacionário. A Figura 5-164 apresenta o monitoramento das concentrações dos componentes do biogás no final do ciclo, enquanto que a Figura 5-165 apresenta a distribuição destes mesmos componentes. Os valores médios de concentração de $\mathrm{H}_{2}$, $\mathrm{CH}_{4}$ e $\mathrm{CO}_{2}$ foram 5,6, 0,0 e 8,4 mmol.L ${ }^{-1}$, respectivamente. Além disso, a distribuição percentual média de $\mathrm{H}_{2}$ foi de $36,1 \%$, a de $\mathrm{CH}_{4}$ foi de $0,0 \%$ e a de $\mathrm{CO}_{2}$ foi de $63,9 \%$.

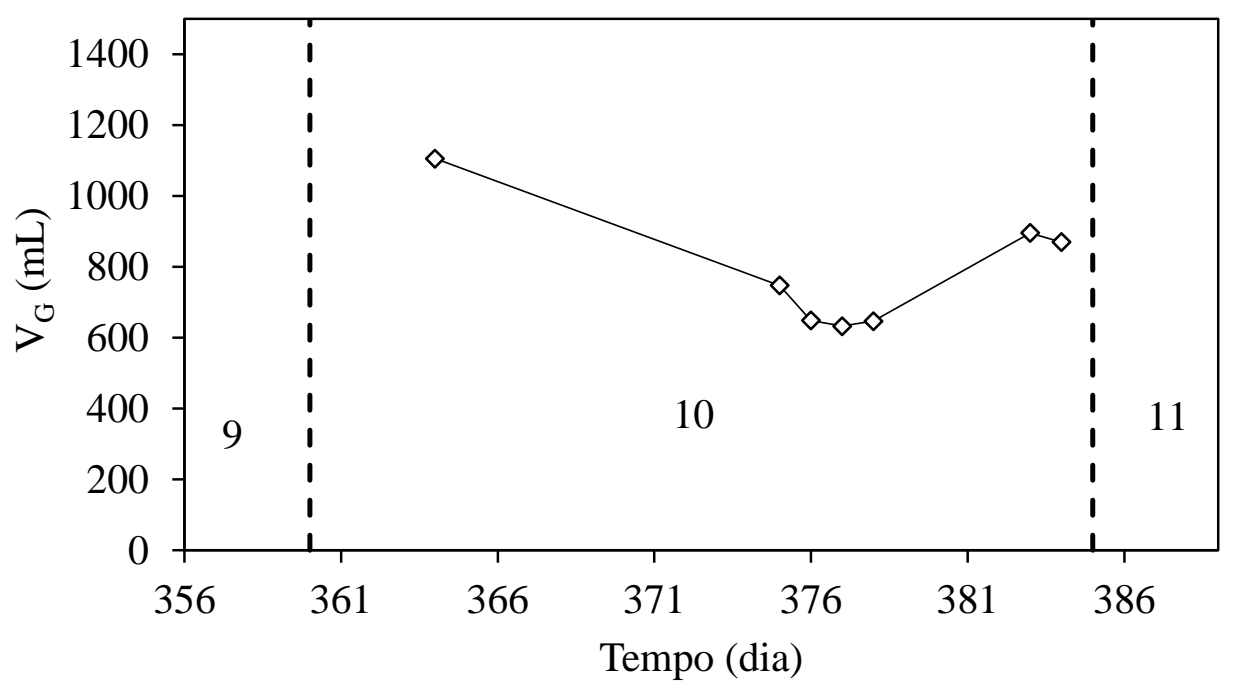

Figura 5-163 - Volume de biogás produzido por ciclo (AnSBBR com recirculação da fase líquida e soro de leite - Condição 10). 


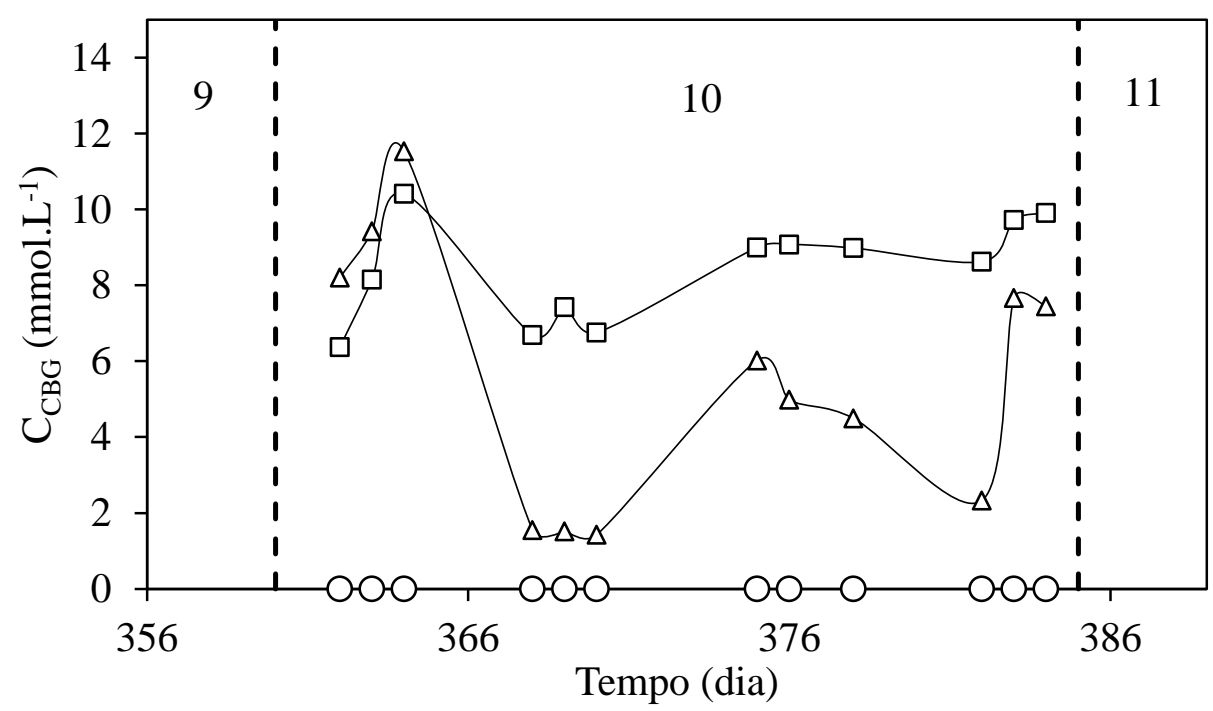

Figura 5-164 - Concentrações dos componentes do biogás no final do ciclo: $\square-\mathrm{CO}_{2} ; \Delta$ - $\mathrm{H}_{2} ; \circ-\mathrm{CH}_{4}$ (AnSBBR com recirculação da fase líquida e soro de leite - Condição 10).

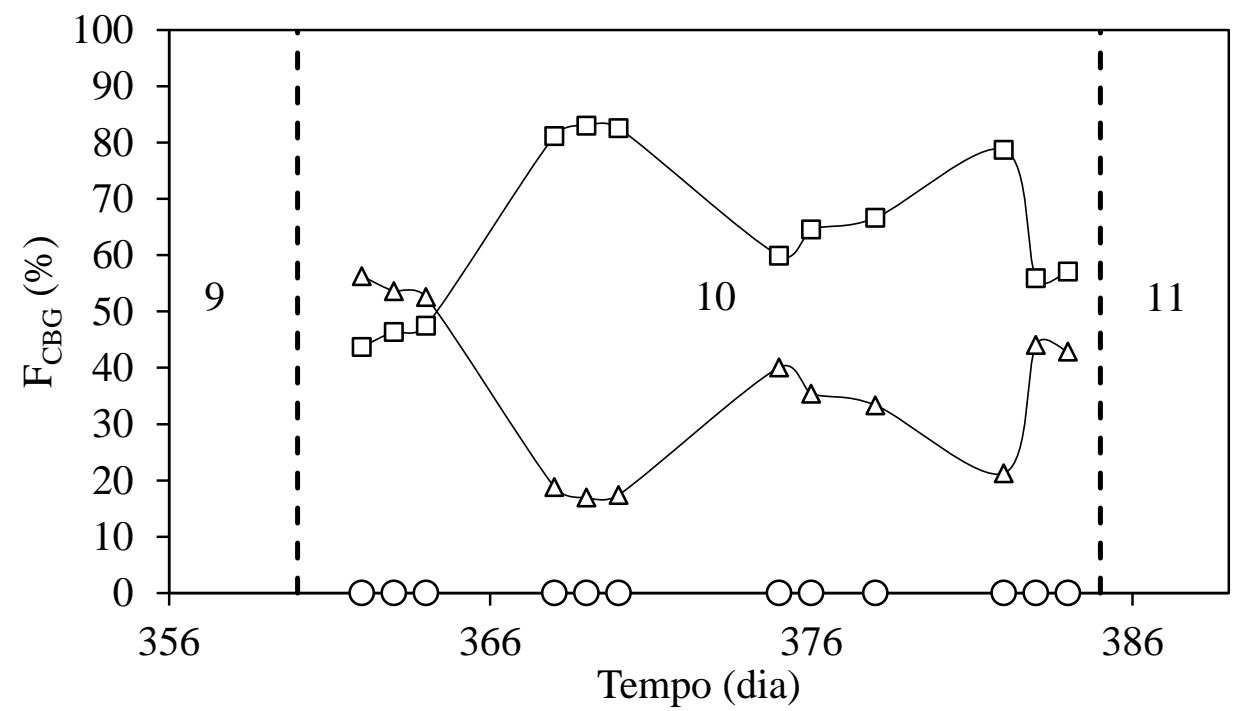

Figura 5-165 - Distribuições dos componentes do biogás no final do ciclo: $\square-\mathrm{CO}_{2} ; \Delta-$ $\mathrm{H}_{2} ;$ ○ - $\mathrm{CH}_{4}$ (AnSBBR com recirculação da fase líquida e soro de leite - Condição 10).

A lavagem periódica do material suporte continuou a ser realizada na presente condição. A Tabela 5.42 apresenta um resumo das lavagens do material suporte realizadas na condição 10. Duas lavagens foram realizadas nesta condição, com estas surtindo, novamente, efeito no crescimento celular dentro do reator, sendo removidas 
cada vez menos quantidades de biomassa (massa de SVT) e apresentando valores de $\mathrm{C}_{\mathrm{x}}$ e de $C_{\mathrm{x}}{ }^{\prime}$ cada vez menores com o passar do tempo de operação.

Tabela 5.42 - Lavagem do material suporte (AnSBBR com recirculação da fase líquida e soro de leite - Condição 10)

\begin{tabular}{cccc}
\hline Tempo & $\begin{array}{c}\text { Quantidade de } \\
\text { biomassa removida } \\
\text { do sistema } \\
(\mathrm{gSVT})\end{array}$ & $\begin{array}{c}\mathrm{C}_{\mathrm{X}} \text { antes da } \\
\text { lavagem } \\
\left(\mathrm{gSVT} . \mathrm{L}^{-1}\right)\end{array}$ & $\begin{array}{c}\mathrm{C}_{\mathrm{X}}{ }^{\prime} \text { antes da } \\
\text { lavagem } \\
\left(\mathrm{gSVT} . \text { gsuporte }^{-1}\right)\end{array}$ \\
\hline 374 & 39,2 & 12,7 & 0,032 \\
382 & 34,0 & 9,9 & 0,023 \\
\hline
\end{tabular}

O perfil temporal foi realizado no final da operação, com o intuito de entender melhor como os parâmetros indicativos de eficiência do sistema se comportavam durante um ciclo completo. A Figura 5-166 apresenta a evolução da concentração de carboidrato ao longo do ciclo e a eficiência de remoção do mesmo. Ao inicio do ciclo (tempo zero) o volume afluente é diluído no volume residual resultando em uma concentração em sacarose da ordem de $1700 \mathrm{mg} . \mathrm{L}^{-1}$. A conversão de carboidrato se faz de maneira progressiva ao longo do ciclo, atingindo valores na ordem de $99 \%$ no final do mesmo, com um residual aproximado de $14 \mathrm{mg} \cdot \mathrm{L}^{-1}$. 


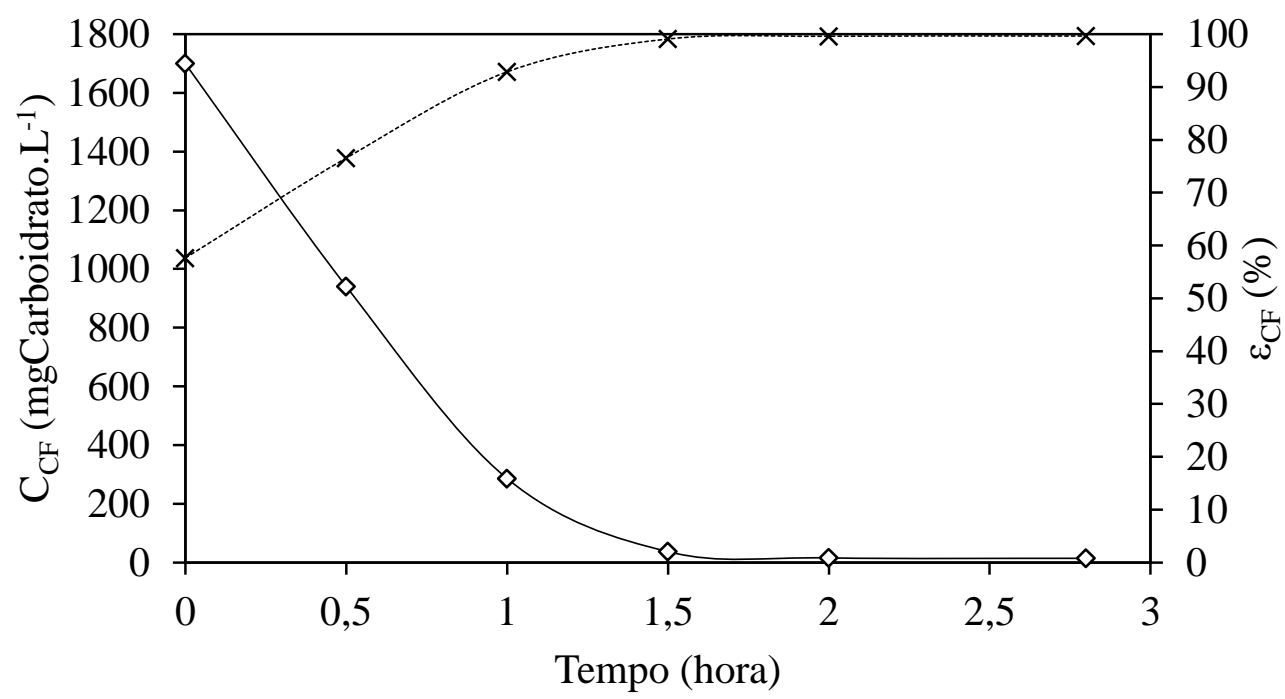

Figura 5-166 - Concentração e eficiência de degradação de carboidrato: $\diamond$ - perfil e * eficiência (AnSBBR com recirculação da fase líquida e soro de leite - Condição 10).

A Figura 5-167 apresenta a evolução da concentração de matéria orgânica ao longo do ciclo. Observa-se uma baixa remoção da DQO, levando a uma alta concentração da mesma no volume residual. Assim, no inicio do ciclo, a diluição do volume carregado pelo volume residual é realizada em proporção bem menor do que no caso dos carboidratos totais, tendo em vista que as concentrações afluente e residual são muito próximas. No inicio do ciclo, a concentração é da ordem de $3960 \mathrm{mg} . \mathrm{L}^{-1}$, permanecendo em valores próximos a este durante todo o ciclo. 


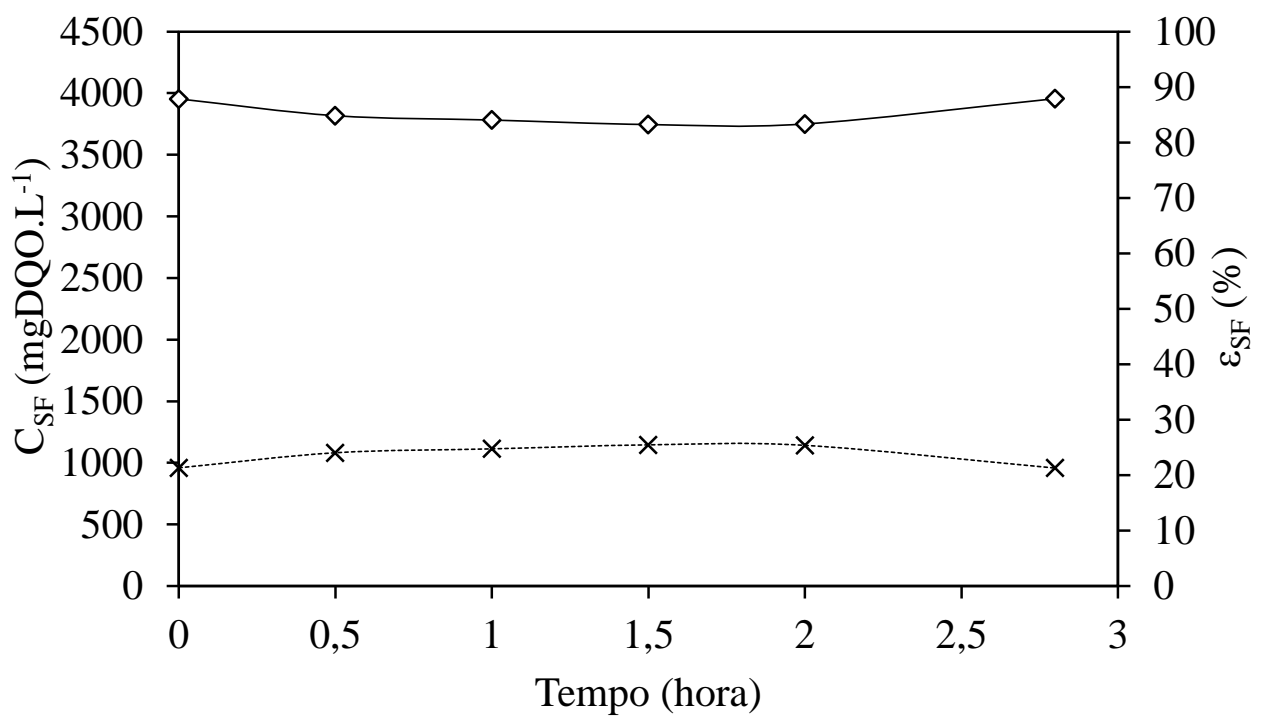

Figura 5-167 - Concentração e eficiência de degradação de matéria orgânica: $\diamond$ - perfil e * eficiência (AnSBBR com recirculação da fase líquida e soro de leite - Condição 10).

O acúmulo de ácidos voláteis totais por titulação ao longo do ciclo pode ser observado na Figura 5-168. A concentração destes aumenta até metade do ciclo permanecendo praticamente constante, atingindo um valor no final do ciclo na ordem de 1710 mgHAc. $\mathrm{L}^{-1}$.

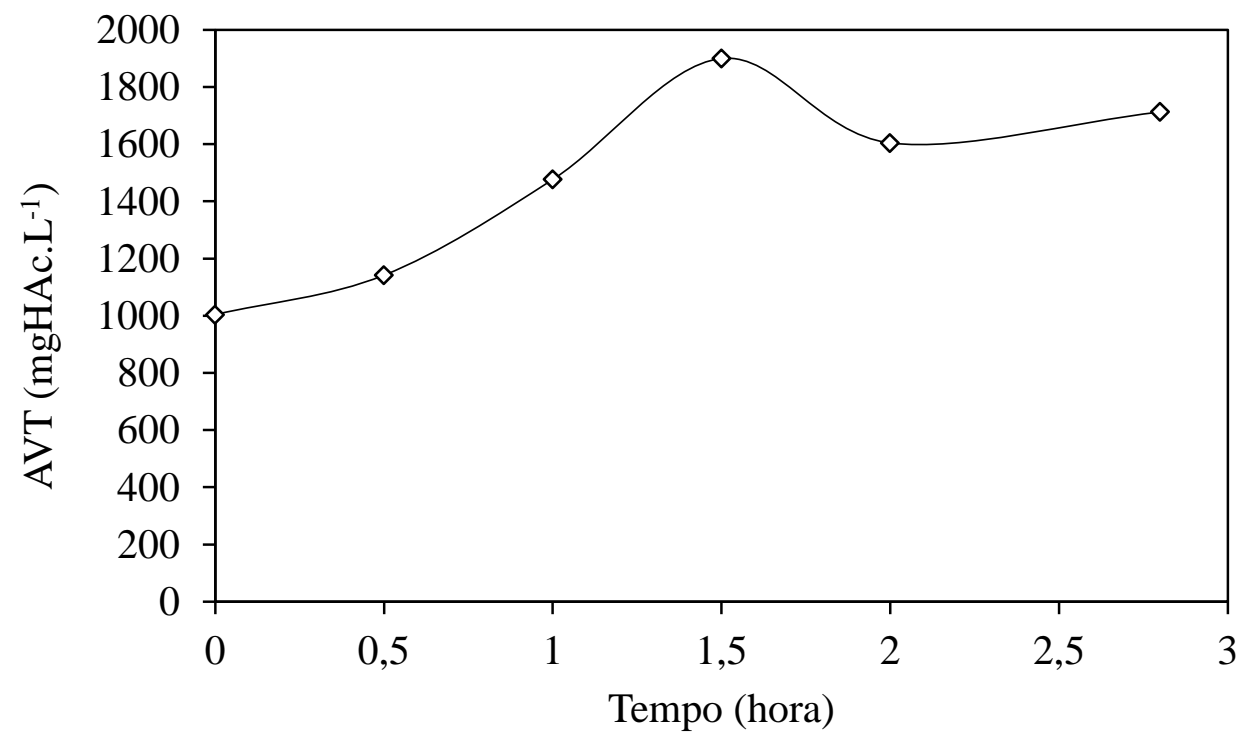

Figura 5-168 - Ácidos voláteis totais $(\diamond)$ do perfil (AnSBBR com recirculação da fase líquida e soro de leite - Condição 10). 
Os resultados dos compostos intermediários por cromatografia gasosa são apresentados na Figura 5-169. O ácido butírico apresentou o crescimento mais acentuado durante o ciclo, com os demais apresentando ligeiros aumentos.

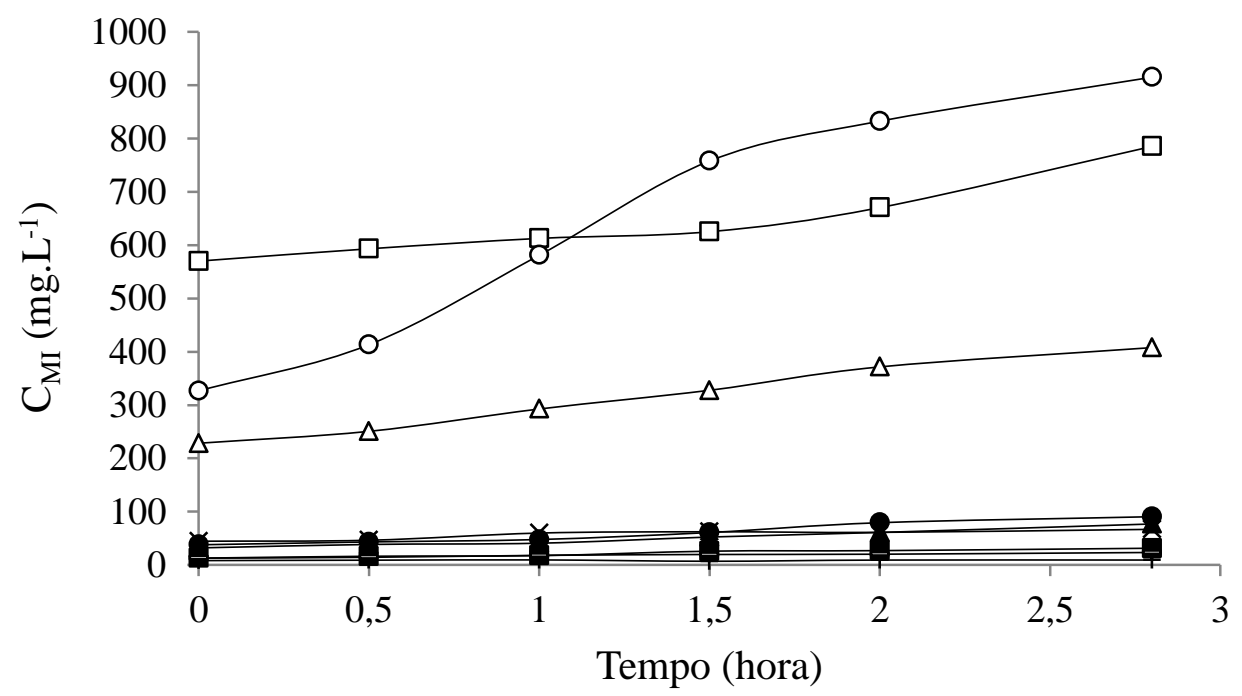

Figura 5-169 - Concentração dos compostos intermediários ao longo do ciclo: $\square$ - ácido acético; $\Delta$ - etanol; O - ácido butírico; $\mathbf{\square}$ - ácido isobutírico; $\boldsymbol{\Delta}$ - ácido capróico; $\bullet-$ ácido valérico; - *ácido propiônico; +butanol; — ácido isovalérico (AnSBBR com recirculação da fase líquida e soro de leite - Condição 10).

$\mathrm{O}$ pH diminuiu instantaneamente em relação ao afluente devido à diluição do mesmo com o volume residual no inicio do ciclo e permaneceu estável ao longo da operação conforme a Figura 5-170. A estabilidade do pH foi mantida, como pode ser visto na Figura 5-171, devido a alcalinidade que, mesmo apresentando uma queda no início, não foi completamente consumida durante o ciclo. 


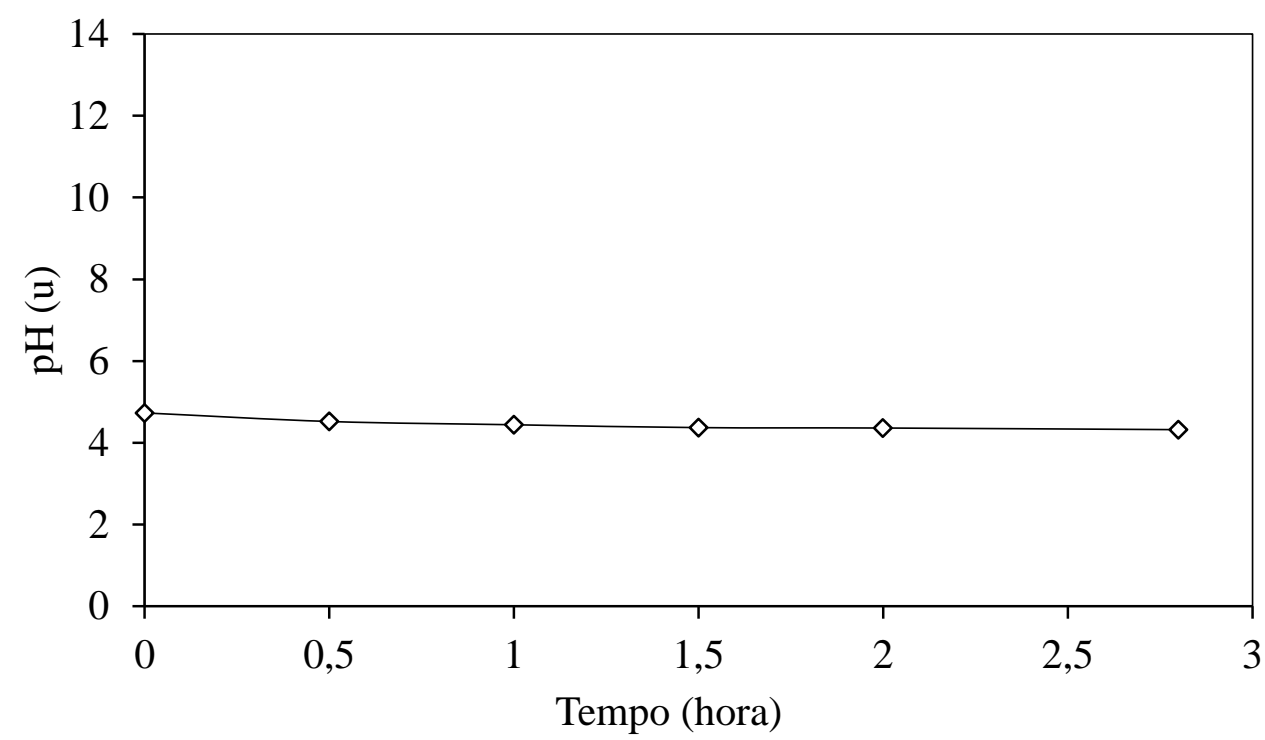

Figura 5-170 - Valores de pH $(\diamond)$ do perfil (AnSBBR com recirculação da fase líquida e soro de leite - Condição 10).

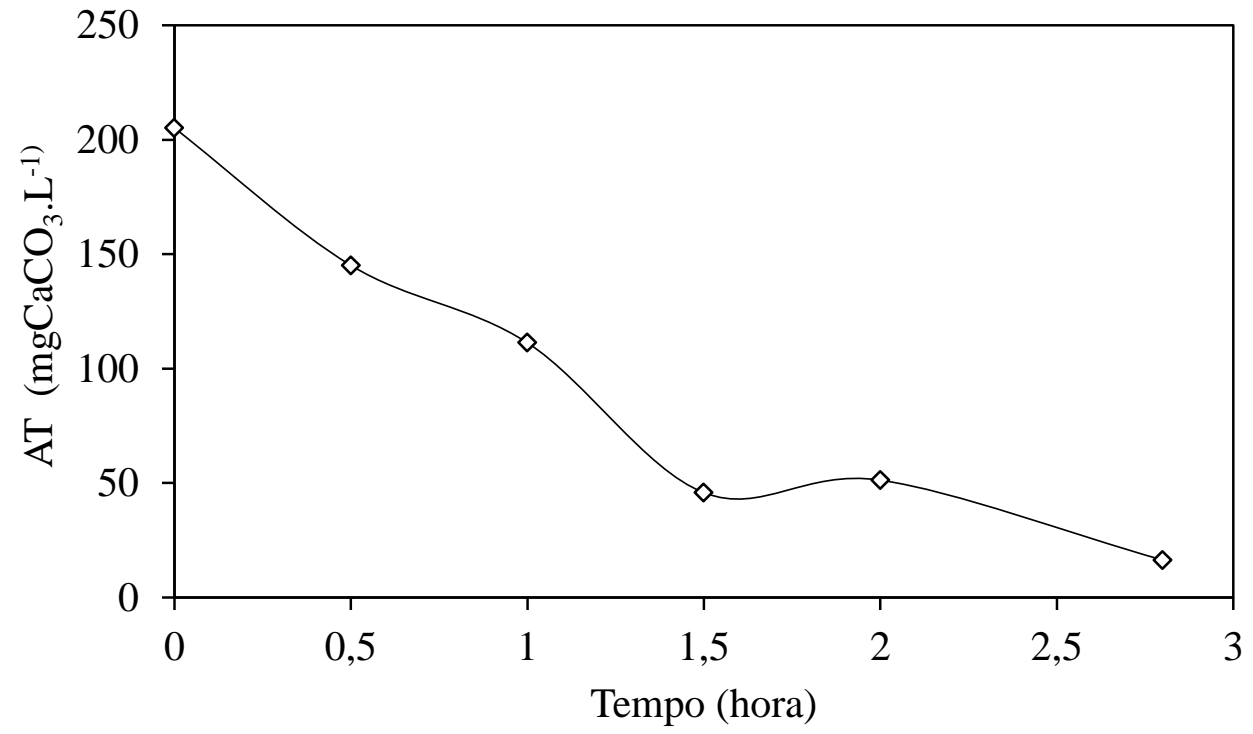

Figura 5-171 - Alcalinidade total do perfil (AnSBBR com recirculação da fase líquida e soro de leite - Condição 10).

A produção volumétrica média acumulada do biogás, realizada com os valores dos perfis quantitativos mais consistentes obtidos durante a operação, juntamente com os desvios padrões encontram-se na Figura 5-172. Assim como nas condições 8 e 9, a maior parte da produção ocorre no inicio do ciclo, sendo realizada até o final do mesmo em quantidades menores. A Tabela 5.43 resume os valores médios da produção, fração 
molar e os volumes individuais da mistura do biogás. A Figura 5-173 apresenta os volumes acumulados médios dos perfis de $\mathrm{H}_{2}, \mathrm{CO}_{2}$ e $\mathrm{CH}_{4}$ produzidos durante o ciclo. Ao contrário das condições 8 e 9, não ocorreu produção de metano. A condição 10 com a concentração intermediária (5500 mgDQO.L $\mathrm{L}^{-1}$ ) apresentou-se como um ponto de ótimo, atingindo tanto os melhores indicadores de produção de hidrogênio calculados com os dados obtidos no perfil quanto a melhor produção volumétrica de biogás em comparação com as condições 8 e 9. Este ponto de ótimo médio atingido, ao invés de um esperado aumento da produção de hidrogênio e de biogás com o aumento da concentração afluente, pode ser explicado pelo fato de que o aumento da concentração de alimentação aumenta o acúmulo dos produtos intermediários do processo como o hidrogênio, os ácidos orgânicos e álcoois, podendo ocasionar a inibição do processo (Sreethawong et al., 2010). Podemos destacar, entre estes produtos intermediários, a pressão parcial de $\mathrm{H}_{2}$, que pode atingir altos valores ocasionados pela rápida formação deste gás em concentrações altas.

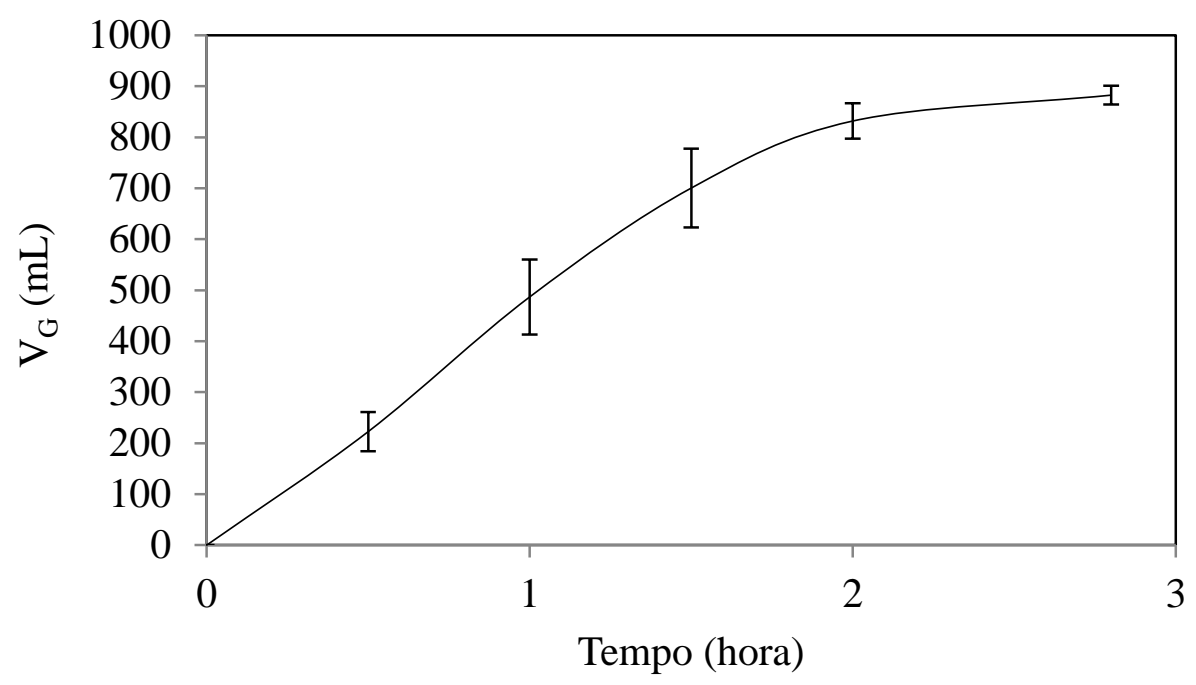

Figura 5-172 - Produção volumétrica média acumulada do biogás durante o ciclo (AnSBBR com recirculação da fase líquida e soro de leite - Condição 10). 
Tabela 5.43 - Valores médios da produção, fração molar e os volumes individuais da mistura do biogás (AnSBBR com recirculação da fase líquida e soro de leite - Condição 10).

\begin{tabular}{ccccccccccc}
$\begin{array}{c}\text { Tempo } \\
(\mathrm{h})\end{array}$ & $\begin{array}{c}\mathrm{V}_{\mathrm{G}} \\
(\mathrm{mL}-\mathrm{CNTP})\end{array}$ & \multicolumn{3}{c}{$\mathrm{C}_{\mathrm{G}}\left(\mathrm{mmol} \cdot \mathrm{L}^{-1}\right)$} & \multicolumn{3}{c}{ Fração Molar (\%) } & \multicolumn{3}{c}{ Volume (mL $-\mathrm{CNTP})$} \\
& & $\mathrm{H}_{2}$ & $\mathrm{CO}_{2}$ & $\mathrm{CH}_{4}$ & $\mathrm{H}_{2}$ & $\mathrm{CO}_{2}$ & $\mathrm{CH}_{4}$ & $\mathrm{H}_{2}$ & $\mathrm{CO}_{2}$ & $\mathrm{CH}_{4}$ \\
\hline 0,0 & 0,0 & 0,0 & 0,0 & 0,0 & 0,0 & 0,0 & 0,0 & 0,0 & 0,0 & 0,0 \\
0,5 & 222,6 & 1,2 & 4,3 & 0,0 & 22,6 & 77,4 & 0,0 & 50,2 & 172,4 & 0,0 \\
1,0 & 486,9 & 4,2 & 7,3 & 0,0 & 36,7 & 63,3 & 0,0 & 147,3 & 339,6 & 0,0 \\
1,5 & 700,4 & 5,4 & 8,2 & 0,0 & 39,6 & 60,4 & 0,0 & 231,9 & 468,5 & 0,0 \\
2,0 & 831,9 & 6,7 & 8,8 & 0,0 & 43,0 & 57,0 & 0,0 & 288,4 & 543,5 & 0,0 \\
2,8 & 882,6 & 7,2 & 9,2 & 0,0 & 44,0 & 56,0 & 0,0 & 310,7 & 571,9 & 0,0 \\
\hline
\end{tabular}

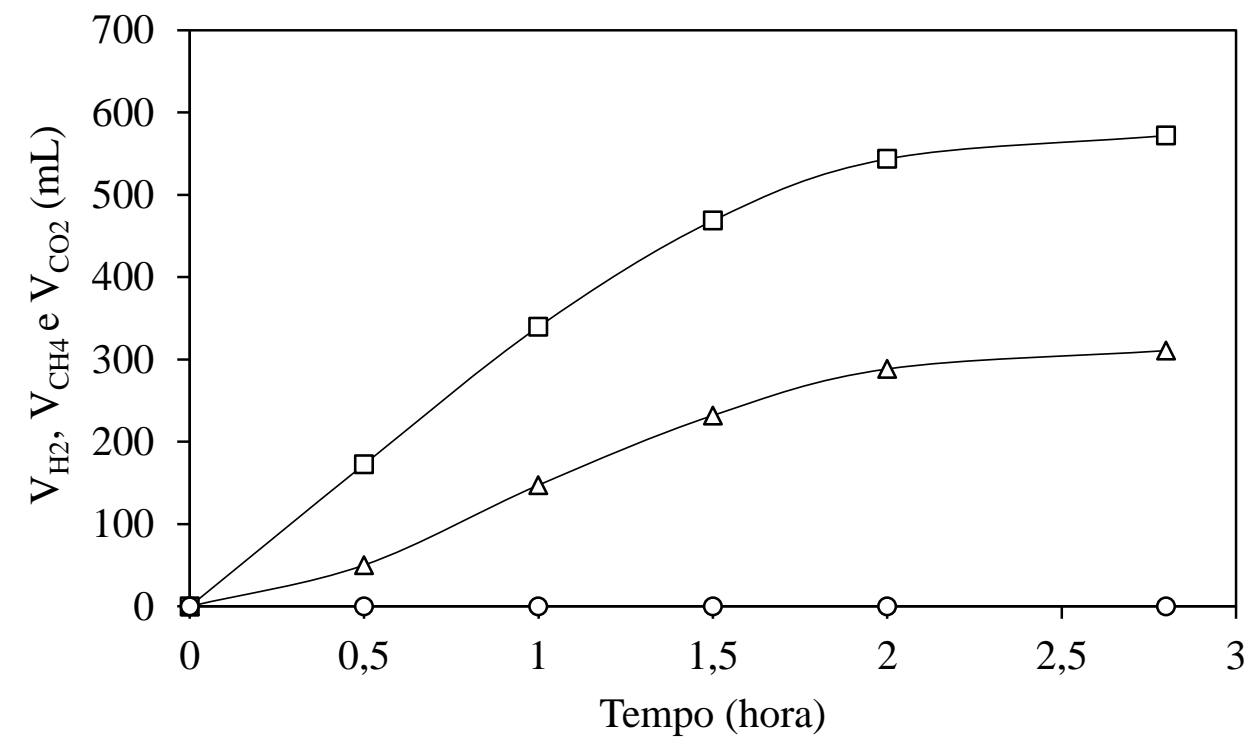

Figura 5-173 - Volumes acumulados médios produzidos ao longo do ciclo: $\square-\mathrm{CO}_{2} ; \Delta$ $\mathrm{H}_{2} ;$ o - $\mathrm{CH}_{4}$ (AnSBBR com recirculação da fase líquida e soro de leite - Condição 10). 


\subsubsection{Influência da estratégia de alimentação (tempo de enchimento).}

Após avaliar a concentração afluente, passou-se para o estudo da estratégia de alimentação na produção de hidrogênio em um AnSBBR alimentado com soro. A nova base de operação para estes ensaios foi a Condição 10 que apresentou os melhores indicadores de produção de hidrogênio. Desta forma, a Condição 11 foi uma repetição da condição prévia (concentração afluente de $5400 \mathrm{mgDQO} \cdot \mathrm{L}^{-1}$ e tempo de ciclo de 3 horas) com apenas uma mudança: ao invés do reator ser alimentado em 10 minutos no início de cada ciclo, ele foi alimentado em 90 minutos (50\% do tempo de ciclo de 3 horas).

\subsubsection{Condição $11-$ Soro de leite $\left(t_{c}=3\right.$ horas, $C_{S T}=5500 \mathrm{mgDQO} \cdot \mathrm{L}^{-}$ ${ }^{1}$ - Batelada alimentada).}

A condição experimental 11 apresentou uma COAV nominal de 18,5 kgDQO.m ${ }^{3} \cdot \mathrm{d}^{-1}$ e duração do ciclo de 3 horas, indo do dia 386 ao dia 421 (36 dias de operação). A Tabela 5.44 apresenta os valores médios dos parâmetros monitorados. 
Tabela 5.44 - Valores médios dos parâmetros monitorados na condição experimental 11 (Soro de leite - $5400 \mathrm{mgDQO} . \mathrm{L}^{-1}-\mathrm{t}_{\mathrm{C}} 3 \mathrm{~h}$ - Batelada alimentada).

\begin{tabular}{|c|c|c|c|c|c|c|c|c|c|c|}
\hline \multicolumn{2}{|r|}{ Parâmetro } & \multicolumn{5}{|c|}{ Afluente } & & \multicolumn{3}{|c|}{ Efluente } \\
\hline $\mathrm{C}_{\mathrm{ST}}$ & $\left(\mathrm{mgDQO} \cdot \mathrm{L}^{-1}\right)$ & 4761 & \pm & 155 & & & & 3917 & \pm 345 & $\left(\begin{array}{ll}(17\end{array}\right)$ \\
\hline $\mathrm{C}_{\mathrm{SF}}$ & $\left(\mathrm{mgDQO} \cdot \mathrm{L}^{-1}\right)$ & - & $\overline{ \pm}$ & - & ( & 3 & ) & 3541 & \pm 350 & $\left(\begin{array}{ll}17\end{array}\right)$ \\
\hline$\varepsilon_{\mathrm{ST}}$ & $(\%)$ & - & & - & & & & 18 & \pm 7 & $\left(\begin{array}{ll}17 & 17\end{array}\right)$ \\
\hline$\varepsilon_{\mathrm{SF}}$ & $(\%)$ & - & & - & & & & 26 & \pm & $\left(\begin{array}{ll}17 & 17\end{array}\right)$ \\
\hline $\mathrm{C}_{\mathrm{CT}}$ & (mgCarboidrato. $\mathrm{L}^{-1}$ ) & 3689 & \pm & 325 & ( & 17 & ) & 222 & \pm 505 & $\left(\begin{array}{ll}17 & 17\end{array}\right)$ \\
\hline $\mathrm{C}_{\mathrm{CF}}$ & $\left(\mathrm{mgCarboidrato} . \mathrm{L}^{-1}\right)$ & - & \pm & - & & & & 198 & \pm 512 & $\left(\begin{array}{ll}17\end{array}\right)$ \\
\hline$\varepsilon_{\mathrm{CT}}$ & $(\%)$ & - & & - & & & & 94 & \pm 14 & $\left(\begin{array}{ll}17 & 17\end{array}\right)$ \\
\hline$\varepsilon_{\mathrm{CF}}$ & $(\%)$ & - & & - & & & & 95 & \pm 14 & $\left(\begin{array}{ll}17 & 17\end{array}\right)$ \\
\hline $\mathrm{pH}$ & (u) & 7,80 & \pm & 0,20 & ( & 17 & ) & 4,56 & $\pm 0,20$ & $\left(\begin{array}{ll}17 & 17\end{array}\right)$ \\
\hline AVT & $\left(\mathrm{mgHAc} . \mathrm{L}^{-1}\right)$ & 141 & \pm & 11 & ( & 17 & 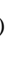 & 1356 & \pm 224 & $\left(\begin{array}{ll}17\end{array}\right)$ \\
\hline AT & $\left(\mathrm{mgCaCO}_{3} \cdot \mathrm{L}^{-1}\right)$ & 495 & \pm & 28 & ( & 17 & ) & 184 & \pm 84 & $\left(\begin{array}{ll}17\end{array}\right)$ \\
\hline $\mathrm{AP}$ & $\left(\mathrm{mgCaCO}_{3} \cdot \mathrm{L}^{-1}\right)$ & 348 & \pm & 20 & ( & 17 & ) & 0 & \pm & $\left(\begin{array}{ll}17\end{array}\right)$ \\
\hline AI & $\left(\mathrm{mgCaCO}_{3} \cdot \mathrm{L}^{-1}\right)$ & 147 & \pm & 13 & ( & 17 & ) & 184 & $\pm \quad 84$ & $\left(\begin{array}{ll}17\end{array}\right)$ \\
\hline $\mathrm{AB}$ & $\left(\mathrm{mgCaCO}_{3} \cdot \mathrm{L}^{-1}\right)$ & 395 & \pm & 29 & ( & 17 & ) & 0 & \pm & $\left(\begin{array}{ll}17\end{array}\right)$ \\
\hline ST & $\left(\mathrm{mg} \cdot \mathrm{L}^{-1}\right)$ & 4242 & \pm & 257 & ( & 9 & ) & 2402 & \pm 425 & $\left(\begin{array}{ll}9 & )\end{array}\right.$ \\
\hline STV & $\left(\mathrm{mg} \cdot \mathrm{L}^{-1}\right)$ & 3424 & \pm & 264 & ( & 9 & ) & 1582 & \pm 421 & $\left(\begin{array}{ll}9 & )\end{array}\right.$ \\
\hline SST & $\left(\mathrm{mg} . \mathrm{L}^{-1}\right)$ & 173 & \pm & 41 & ( & 9 & ) & 182 & \pm 68 & $\left(\begin{array}{ll}9 & )\end{array}\right.$ \\
\hline SSV & $\left(\mathrm{mg} \cdot \mathrm{L}^{-1}\right)$ & 142 & \pm & 30 & ( & 9 & ) & 162 & \pm 77 & $\left(\begin{array}{ll}9 & )\end{array}\right.$ \\
\hline $\mathrm{M}_{\mathrm{STV}}$ & (g) & - & & - & & & & 35,7 & - & \\
\hline $\mathrm{C}_{\mathrm{X}}$ & $\left(\mathrm{g} . \mathrm{L}^{-1}\right)$ & - & & - & & & & 10,7 & - & \\
\hline $\mathrm{C}_{\mathrm{X}}^{\prime}$ & $\left(\right.$ g.gsuporte $\left.{ }^{-1}\right)$ & - & & - & & & & 0,021 & - & \\
\hline $\mathrm{V}_{\mathrm{G}}$ & (mL-CNTP) & - & & - & & & & 877 & \pm 117 & $\left(\begin{array}{ll}4 & )\end{array}\right.$ \\
\hline $\mathrm{V}_{\mathrm{H} 2}$ & (mL-CNTP) & - & & - & & & & 308 & \pm- & $\left(\begin{array}{ll}1 & 1\end{array}\right)$ \\
\hline $\mathrm{COAV}_{\mathrm{S}}$ & $\left(\operatorname{kgDQO} \cdot \mathrm{m}^{-3} \cdot \mathrm{d}^{-1}\right)$ & 16,3 & & - & & & & - & - & \\
\hline $\mathrm{CORV}_{\mathrm{S}}$ & $\left(\mathrm{kgDQO} \cdot \mathrm{m}^{-3} \cdot \mathrm{d}^{-1}\right)$ & - & & - & & & & 4,2 & - & \\
\hline $\mathrm{COAV}_{\mathrm{C}}$ & $\left(\mathrm{kgCarboidrato} . \mathrm{m}^{-3} \cdot \mathrm{d}^{-1}\right)$ & 12,6 & & - & & & & - & - & \\
\hline $\mathrm{CORV}_{\mathrm{C}}$ & (kgCarboidrato. $\left.\mathrm{m}^{-3} \cdot \mathrm{d}^{-1}\right)$ & - & & - & & & & 12,0 & - & \\
\hline $\mathrm{COAE}_{\mathrm{S}}$ & $\left(\mathrm{kgDQO} \mathrm{kgSTV}^{-1} \cdot \mathrm{d}^{-1}\right)$ & 1,6 & & - & & & & $\underline{12,0}$ & - & \\
\hline $\mathrm{CORE}_{S}$ & $\left(\mathrm{kgDQO} \mathrm{kgSTV}^{-1} \cdot \mathrm{d}^{-1}\right)$ & - & & - & & & & 0,4 & - & \\
\hline $\mathrm{COAE}_{\mathrm{C}}$ & $\left(\mathrm{kgCarboidrato.kgSTV}^{-1} \cdot \mathrm{d}^{-1}\right)$ & 1,2 & & - & & & & - & - & \\
\hline $\mathrm{CORE}_{\mathrm{C}}$ & $\left(\mathrm{kgCarboidrato.kgSTV}^{-1} \cdot \mathrm{d}^{-1}\right)$ & - & & - & & & & 1,2 & - & \\
\hline $\mathrm{RMCR}_{\mathrm{C}, \mathrm{n}}$ & $\left(\mathrm{molH}_{2}\right.$ molCarboidrato $\left.^{-1}\right)$ & - & & - & & & & 0,86 & - & \\
\hline $\mathrm{n}_{\mathrm{H} 2}$ & $\left(\mathrm{molH}_{2} \cdot \mathrm{d}^{-1}\right)$ & - & & - & & & & 0,110 & - & \\
\hline $\mathrm{PrVH}$ & $\left(\mathrm{mLH}_{2} \cdot \mathrm{L}^{-1} \cdot \mathrm{d}^{-1}\right)$ & - & & - & & & & 736,8 & - & \\
\hline PrM & $\left(\mathrm{molH}_{2} \cdot \mathrm{m}^{-3} \cdot \mathrm{d}^{-1}\right)$ & - & & - & & & & 32,9 & - & \\
\hline PrME & $\left(\mathrm{molH}_{2} \cdot \mathrm{kgSVT}^{-1} \cdot \mathrm{d}^{-1}\right)$ & - & & - & & & & 3,1 & - & \\
\hline $\mathrm{RMCA}_{\mathrm{S}, \mathrm{m}}$ & $\left(\mathrm{molH}_{2} \cdot \mathrm{kgDQO}^{-1} \cdot \mathrm{d}^{-1}\right)$ & 1,9 & & - & & & & 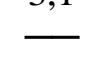 & - & \\
\hline $\mathrm{RMCA}_{\mathrm{C}, \mathrm{m}}$ & $\left(\mathrm{molH}_{2} \cdot \mathrm{kg}^{-1} \cdot \mathrm{d}^{-1}\right)$ & 2,5 & & 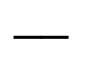 & & & & - & - & \\
\hline $\mathrm{RMCR}_{\mathrm{S}, \mathrm{m}}$ & $\left(\mathrm{molH}_{2} \cdot \mathrm{kgDQO}^{-1} \cdot \mathrm{d}^{-1}\right)$ & - & & - & & & & 7,5 & - & \\
\hline $\mathrm{RMCR}_{\mathrm{C}, \mathrm{m}}$ & $\left(\mathrm{molH}_{2} \cdot \mathrm{kg}^{-1} \cdot \mathrm{d}^{-1}\right)$ & - & & - & & & & 2,5 & - & \\
\hline $\mathrm{V}_{\mathrm{d}}$ & $(\mathrm{mL})$ & 1499 & \pm & 40 & ( & 17 & ) & - & - & \\
\hline $\mathrm{Q}_{\mathrm{R}}$ & $\left(\mathrm{mL} \cdot \mathrm{s}^{-1}\right)$ & 7 & \pm & 0 & ( & & & - & - & \\
\hline
\end{tabular}

(*) Entre parêntese o número de amostras considerado no cálculo da média

A Figura 5-174 apresenta os valores da concentração afluente (amostras não filtradas) e efluente (amostras não filtradas e filtradas) de matéria orgânica (DQO) nos 
sistema. A Figura 5-175 apresenta a eficiência de remoção do mesmo parâmetro durante o monitoramento diário. Esta eficiência atingiu, em média, 26\% para as amostras filtradas e $18 \%$ para mostras não filtradas. A média de concentração afluente não filtrada do substrato foi de $4761 \mathrm{mgDQO} . \mathrm{L}^{-1}$ e de $3917 \mathrm{mgDQO} . \mathrm{L}^{-1}$ e $3541 \mathrm{mgDQO} . \mathrm{L}^{-1}$ para amostras de efluente não filtradas e filtradas, respectivamente.

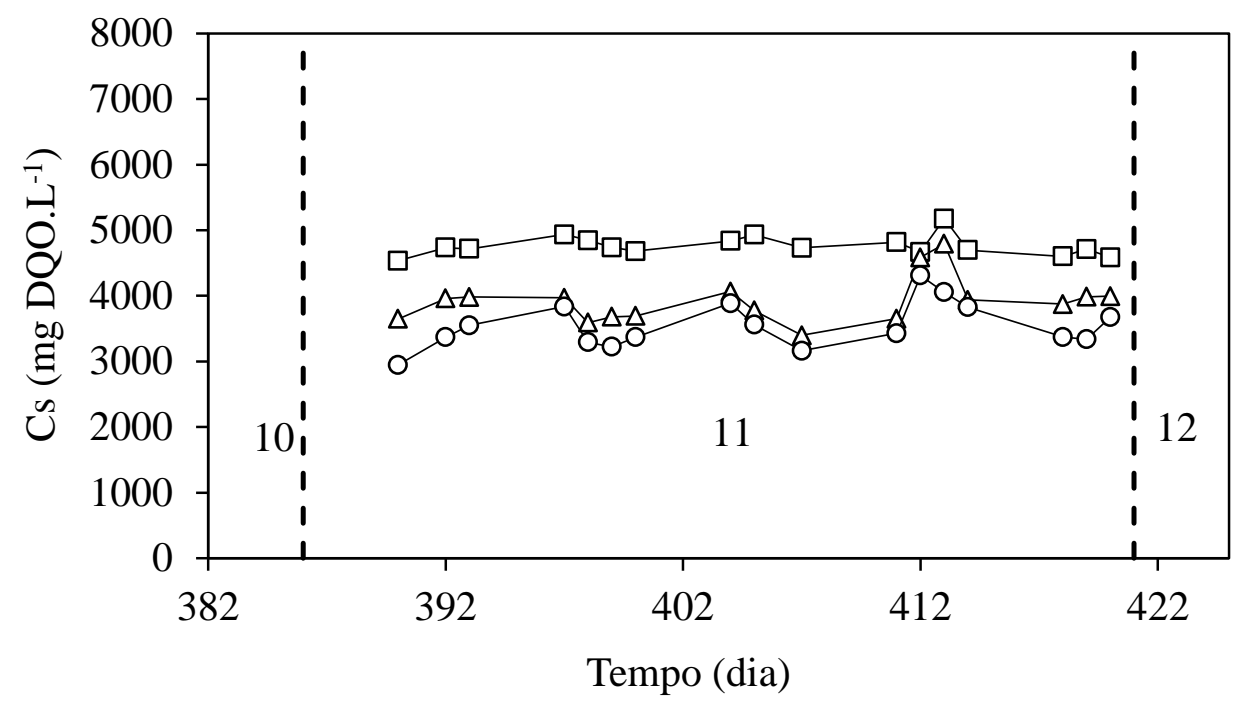

Figura 5-174 - Concentração de matéria orgânica (DQO): $\square$ - afluente não filtrada; $\Delta$ efluente não filtrada; o - efluente filtrada (AnSBBR com recirculação da fase líquida e soro de leite - Condição 11). 


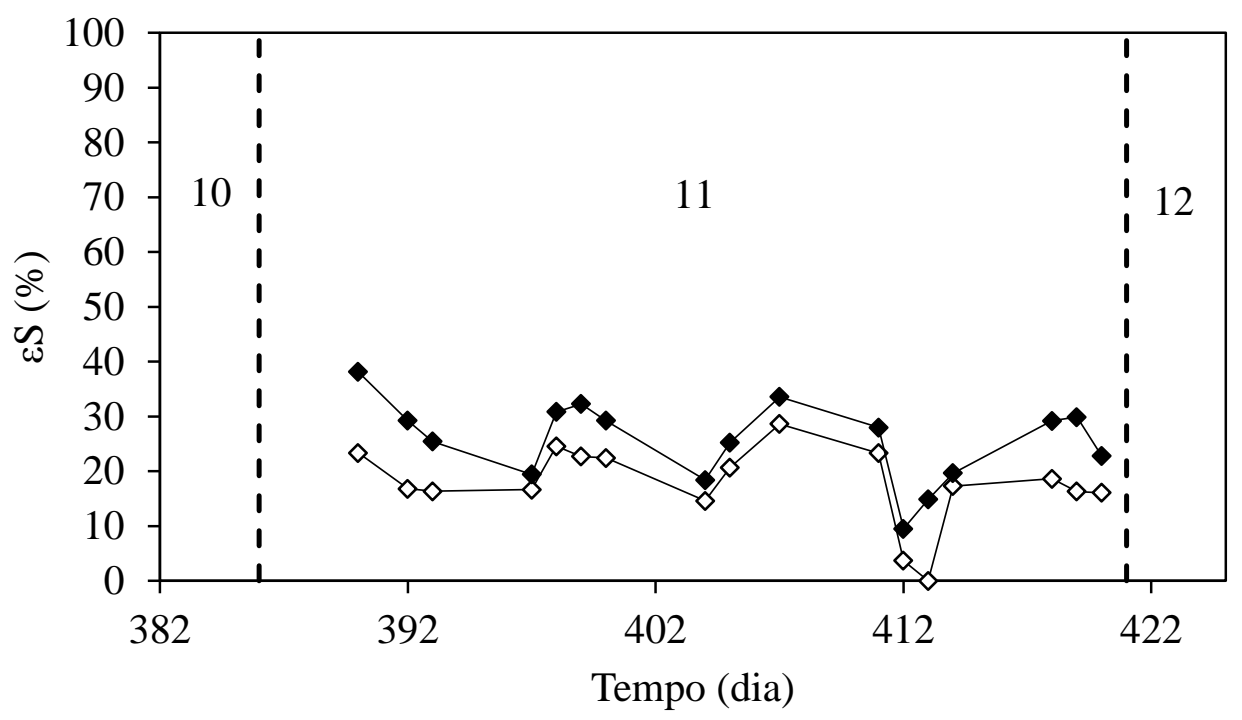

Figura 5-175 - Eficiência de remoção de matéria orgânica (DQO): $\diamond$ - não filtrada; filtrada (AnSBBR com recirculação da fase líquida e soro de leite - Condição 11).

A Figura 5-176 apresenta os valores da concentração de carboidratos afluente e efluente (para amostras filtradas e não filtradas) e Figura 5-177 apresenta a eficiência de remoção do mesmo parâmetro (não filtrada e filtrada) durante o monitoramento diário. A média da concentração afluente foi de $3689 \mathrm{mgCarboidrato.} \mathrm{L}^{-1}$, enquanto que a concentração residual (amostras não filtradas) foi de $222 \mathrm{mgCarboidrato.} \mathrm{L}^{-1}$ e 198 mgCarboidrato. $\mathrm{L}^{-1}$ para a concentração residual filtrada durante toda a operação e de 39 mgCarboidrato. $\mathrm{L}^{-1}$ e $16 \mathrm{mgCarboidrato.} \mathrm{L}^{-1}$ durante a fase estacionária. A eficiência de remoção de carboidrato foi, em média, de $95 \%$ para as amostras filtradas e $94 \%$ para mostras não filtradas durante toda a operação e de $99 \%$ para as amostras filtradas e não filtradas durante a fase estacionária. 


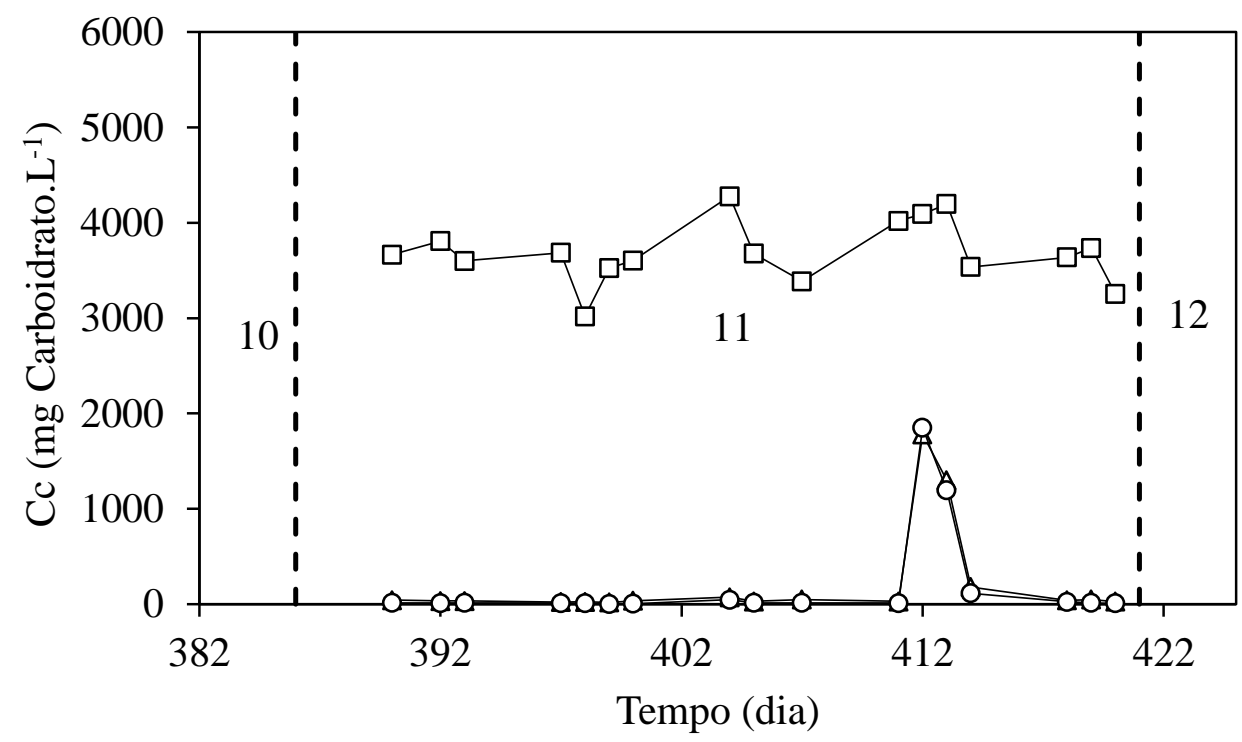

Figura 5-176 - Concentração de carboidrato: $\square$ - afluente não filtrada; $\Delta$ - efluente não filtrada; ○ - efluente filtrada (AnSBBR com recirculação da fase líquida e soro de leite Condição 11).

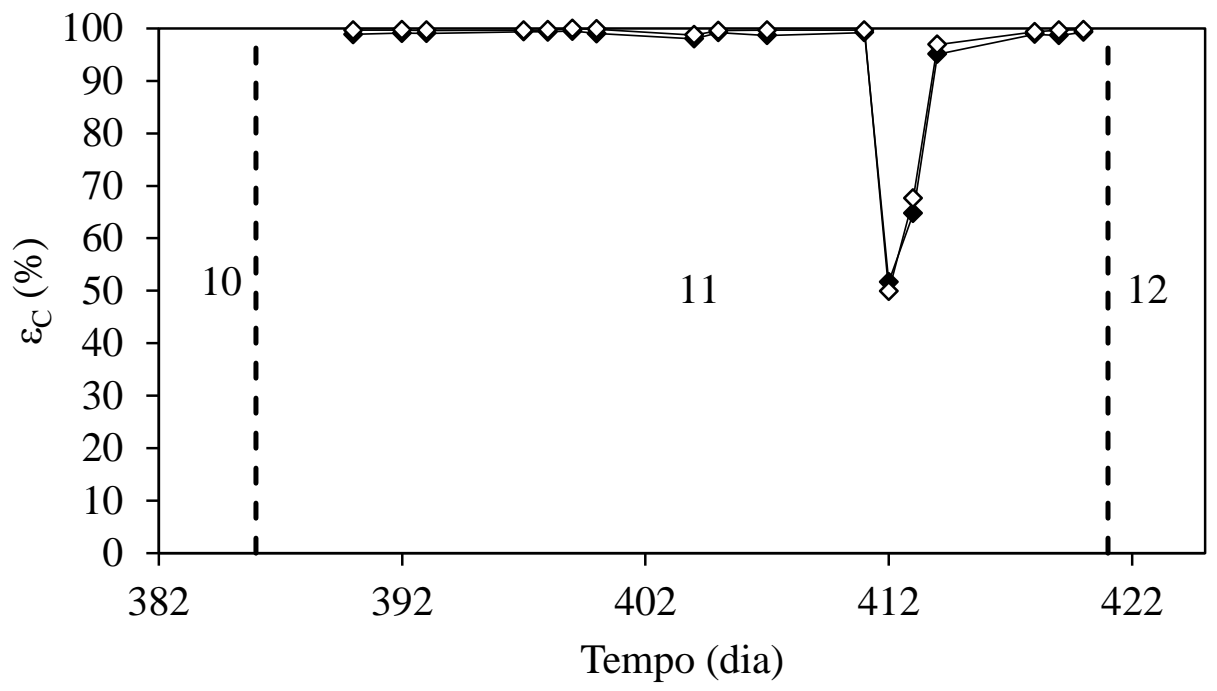

Figura 5-177 - Eficiência de remoção de carboidrato: $\diamond$ - não filtrada; $\downarrow$ - filtrada (AnSBBR com recirculação da fase líquida e soro de leite - Condição 11).

As Figura 5-178, Figura 5-179 e Figura 5-180 apresentam os perfis temporais (afluente e efluente) do $\mathrm{pH}$, da alcalinidade total e dos ácidos voláteis totais por titulação, respectivamente. A média dos valores de $\mathrm{pH}$ afluente durante a Condição 9 foi de 7,80 e de $\mathrm{pH}$ efluente foi de 4,56. A média da alcalinidade total foi de 495 
$\operatorname{mgCaCO} 3 \cdot \mathrm{L}^{-1}$ para o afluente e de $184 \mathrm{mgCaCO}_{3} \cdot \mathrm{L}^{-1}$ no efluente. $\mathrm{O}$ valor médio da concentração de ácidos voláteis totais afluente foi de $141 \mathrm{mgHAc} . \mathrm{L}^{-1}$ e efluente de 1356 $\operatorname{mgHAc} \cdot \mathrm{L}^{-1}$.

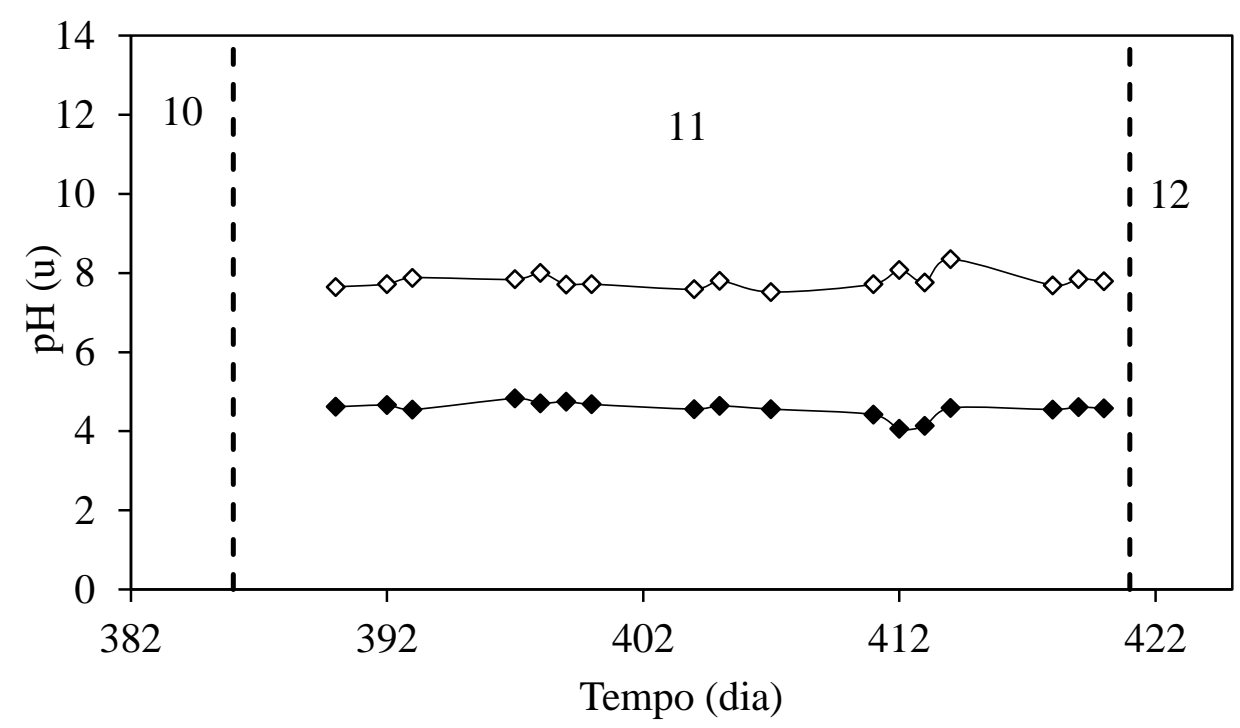

Figura 5-178 - Valores de pH: $\diamond$-afluente; - efluente (AnSBBR com recirculação da fase líquida e soro de leite - Condição 11).

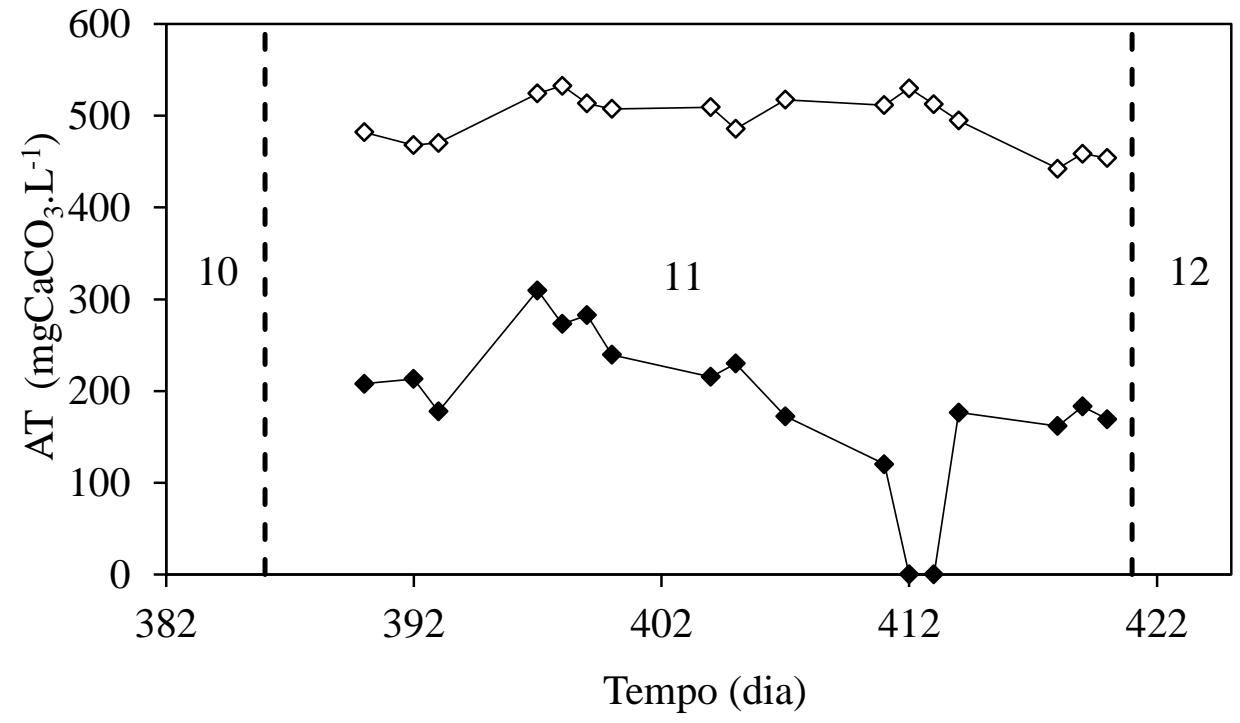

Figura 5-179 - Alcalinidade total: $\diamond$-afluente; - efluente (AnSBBR com recirculação da fase líquida e soro de leite - Condição 11). 


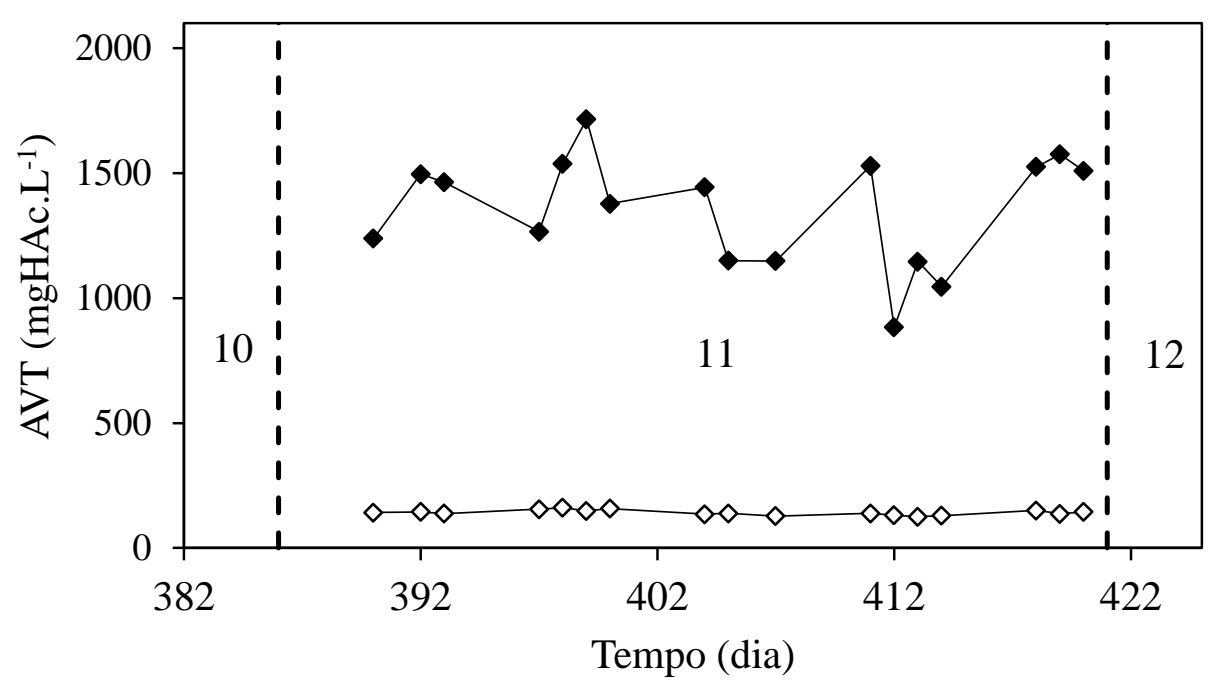

Figura 5-180 - Ácidos voláteis totais: $\diamond$-afluente; - efluente (AnSBBR com recirculação da fase líquida e soro de leite - Condição 11).

A Figura 5-181 apresenta o monitoramento dos compostos intermediários contidos no efluente do sistema. Já a Tabela 5.45 apresenta os valores da concentração média destes mesmos produtos. O método cromatográfico utilizado novamente não detectou a presença de acetona e metanol. O ácido acético, o etanol e o ácido butírico foram os principais metabólitos, representando juntos aproximadamente $93 \%$ dos produtos intermediários $(43,9 \%, 25 \%$ e $24,0 \%$, respectivamente). 


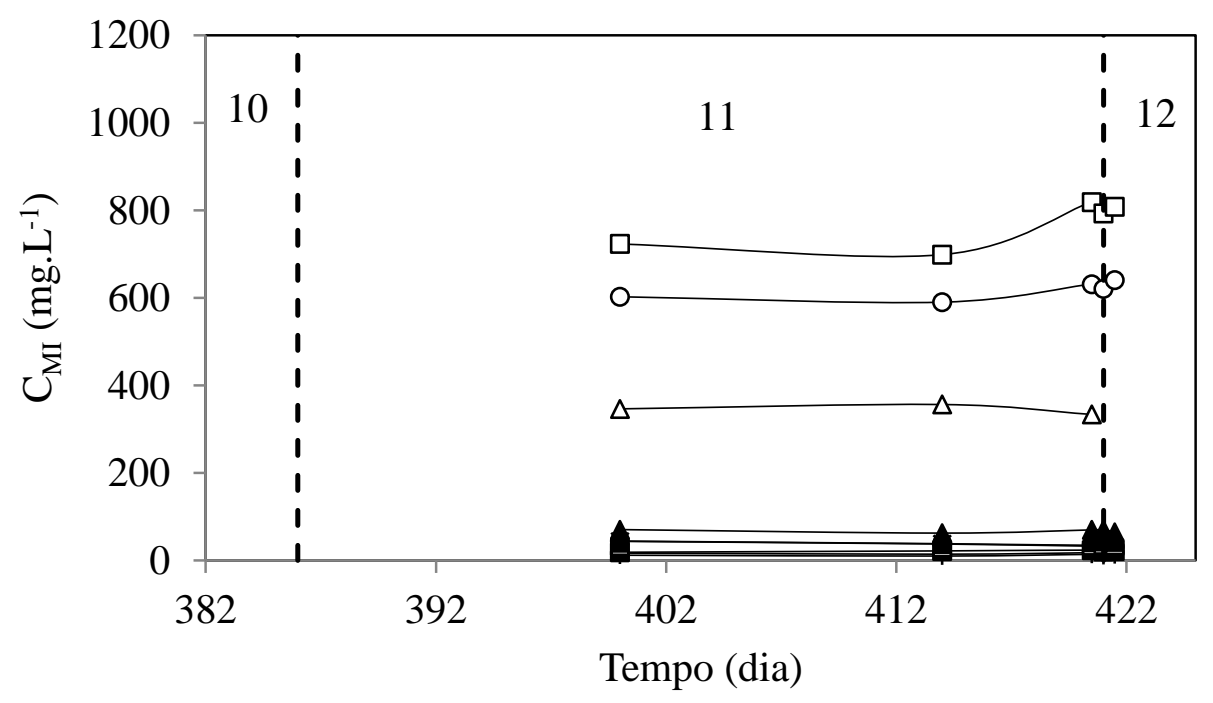

Figura 5-181 - Concentração dos compostos intermediários: $\square$ - ácido acético; $\Delta$ etanol; ○ - ácido butírico; $\mathbf{\square}$ - ácido isobutírico; $\boldsymbol{\Delta}$ - ácido capróico; $\bullet$ - ácido valérico; * ácido propiônico; +butanol; - ácido isovalérico (AnSBBR com recirculação da fase líquida e soro de leite - Condição 11).

Tabela 5.45 - Concentração e distribuição dos compostos intermediários (AnSBBR com recirculação da fase líquida e soro de leite - Condição 11).

\begin{tabular}{cccccccc}
\hline $\begin{array}{c}\text { Produtos } \\
\text { intermediários }\end{array}$ & \multicolumn{4}{c}{$\begin{array}{c}\text { Concentrações médias } \\
\left(\mathrm{mg} . \mathrm{L}^{-1}\right)\end{array}$} & \multicolumn{3}{c}{$\begin{array}{c}\text { Distribuição } \\
\left(\mathrm{mmol} . \mathrm{L}^{-1}\right)\end{array}$} \\
\hline Acetona & 0,0 & \pm & 0,0 & 0,0 & \pm & 0,0 & 0,0 \\
Metanol & 0,0 & \pm & 0,0 & 0,0 & \pm & 0,0 & 0,0 \\
Etanol & 336,3 & \pm & 14,9 & 7,3 & \pm & 0,3 & 25,0 \\
n-Butanol & 11,9 & \pm & 1,5 & 0,2 & \pm & 0,0 & 0,5 \\
Acético & 768,3 & \pm & 53,9 & 12,8 & \pm & 0,9 & 43,9 \\
Porpiônico & 35,6 & \pm & 5,1 & 0,5 & \pm & 0,1 & 1,6 \\
Isobutírico & 21,0 & \pm & 1,8 & 0,2 & \pm & 0,0 & 0,8 \\
Butírico & 616,9 & \pm & 20,5 & 7,0 & \pm & 0,2 & 24,0 \\
Isovalérico & 17,3 & \pm & 2,0 & 0,2 & \pm & 0,0 & 0,6 \\
Valérico & 37,2 & \pm & 4,9 & 0,4 & \pm & 0,0 & 1,2 \\
Capróico & 67,4 & \pm & 3,7 & 0,7 & \pm & 0,0 & 2,3 \\
\hline
\end{tabular}

O monitoramento da série de sólidos é mostrado na Tabela 5.46, cujos valores apresentam um baixo teor de SSV no efluente e afluente. 
Tabela 5.46 - Série de sólidos afluente e efluente (AnSBBR com recirculação da fase líquida e soro de leite - Condição 11).

\begin{tabular}{lcccc}
\hline & $\begin{array}{c}\text { ST } \\
\left(\mathrm{mg} . L^{-1}\right)\end{array}$ & $\begin{array}{c}\text { SVT } \\
\left(\mathrm{mg} . L^{-1}\right)\end{array}$ & $\begin{array}{c}\text { SST } \\
\left(\mathrm{mg} . L^{-1}\right)\end{array}$ & $\begin{array}{c}\text { SSV } \\
\left(\mathrm{mg} . L^{-1}\right)\end{array}$ \\
\hline Afluente & $4242 \pm 257$ & $3424 \pm 264$ & $173 \pm 41$ & $142 \pm 30$ \\
Efluente & $2402 \pm 423$ & $1582 \pm 421$ & $182 \pm 68$ & $162 \pm 77$ \\
\hline
\end{tabular}

$*$ Número de amostras consideradas $=9$.

A produção quantitativa do biogás por ciclo é mostrada na Figura 5-182. A produção média foi de $618 \mathrm{~mL}(\mathrm{CNTP})$ durante toda a operação e $877 \mathrm{~mL}(\mathrm{CNTP})$ no estado estacionário, valores ligeiramente inferiores aos obtidos na Condição 10. A Figura 5-183 apresenta o monitoramento das concentrações dos componentes do biogás no final do ciclo, enquanto que a Figura 5-184 apresenta a distribuição destes mesmos componentes. Os valores médios de concentração de $\mathrm{H}_{2}, \mathrm{CH}_{4}$ e $\mathrm{CO}_{2}$ durante toda a operação foram 5,9, 0,7 e 9,6 mmol. $\mathrm{L}^{-1}$, respectivamente. Além disso, a distribuição percentual média de $\mathrm{H}_{2}$ foi de $36,6 \%$, a de $\mathrm{CH}_{4}$ foi de $3,8 \%$ e a de $\mathrm{CO}_{2}$ foi de $59,6 \%$. É possível perceber desta forma que ocorreu presença de metano no processo em baixas condições, enquanto que a Condição 10 apresentou um biogás livre deste componente em sua composição. 


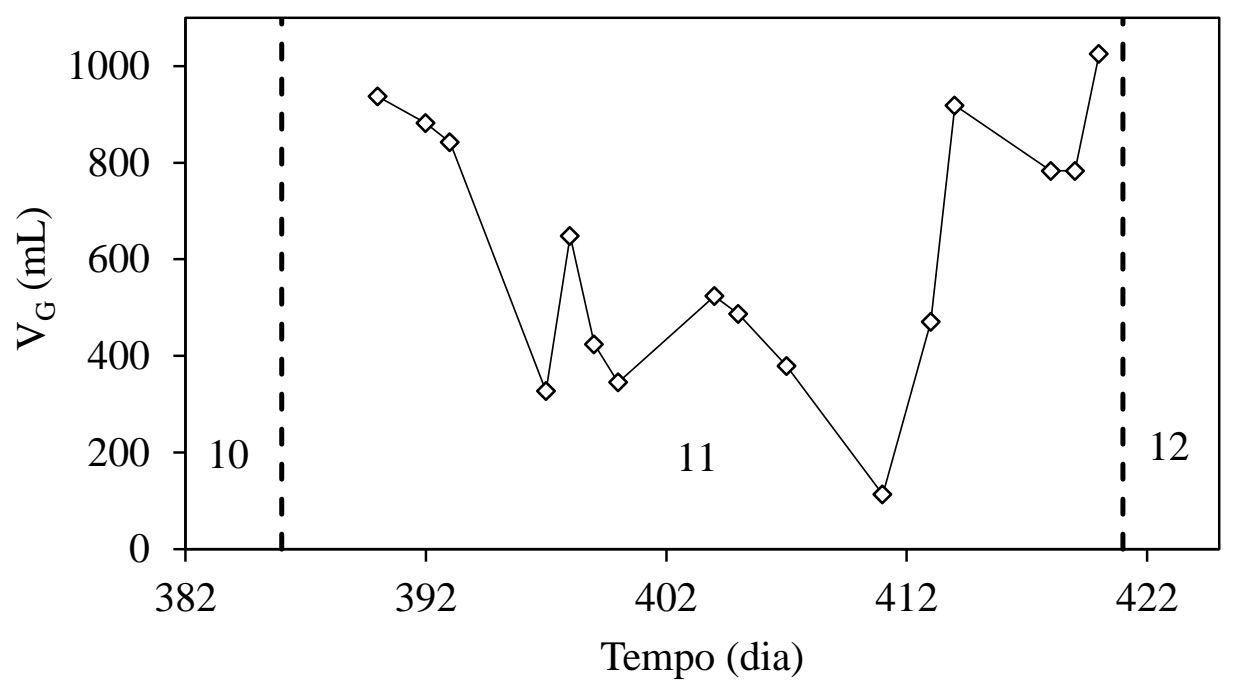

Figura 5-182 - Volume de biogás produzido por ciclo (AnSBBR com recirculação da fase líquida e soro de leite - Condição 11).

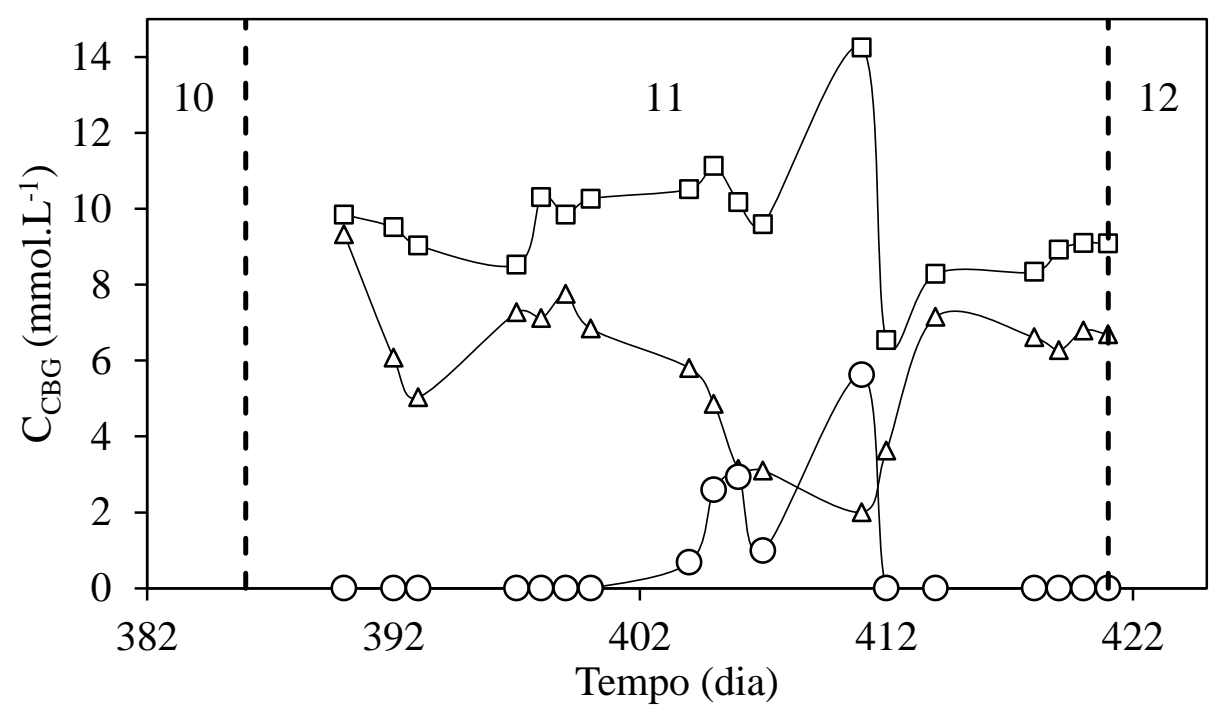

Figura 5-183 - Concentrações dos componentes do biogás no final do ciclo: $\square-\mathrm{CO}_{2} ; \Delta$ - $\mathrm{H}_{2} ; \circ-\mathrm{CH}_{4}$ (AnSBBR com recirculação da fase líquida e soro de leite - Condição 11). 


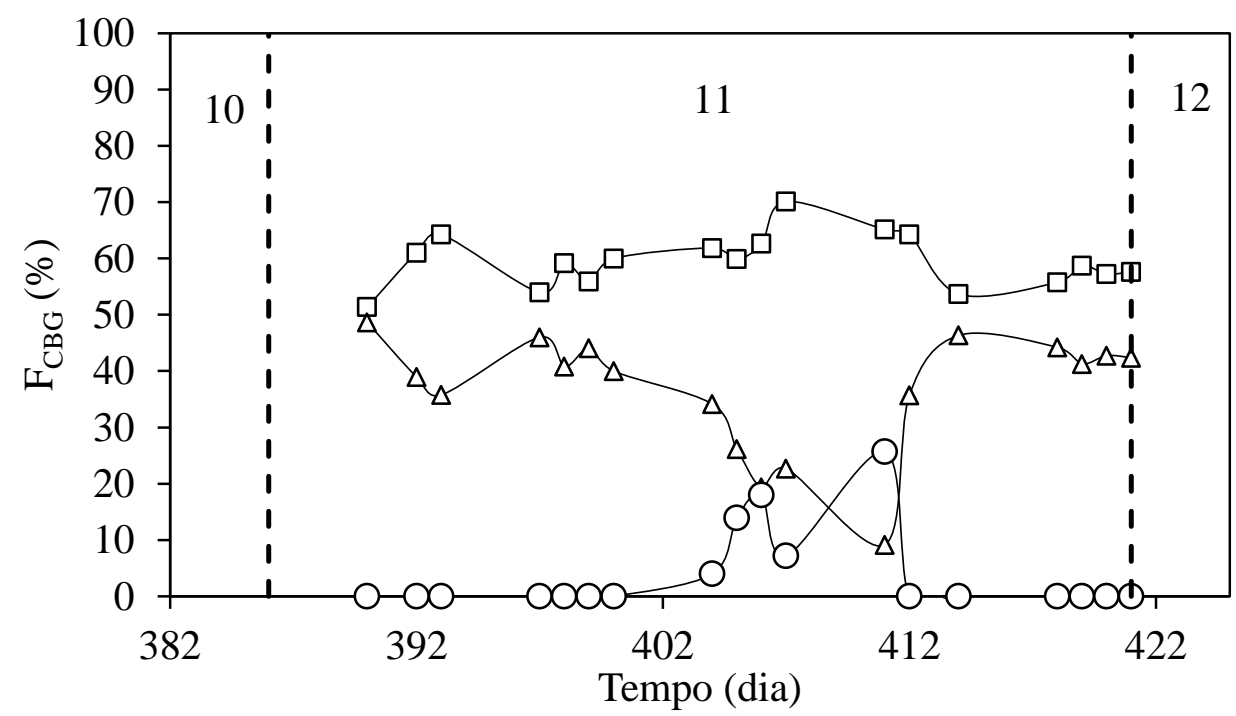

Figura 5-184 - Distribuições dos componentes do biogás no final do ciclo: $\square-\mathrm{CO}_{2} ; \Delta$ $\mathrm{H}_{2} ;$ ○ $-\mathrm{CH}_{4}$ (AnSBBR com recirculação da fase líquida e soro de leite - Condição 11).

A lavagem periódica do material suporte continuou a ser realizada, buscando-se manter a estabilidade na produção de hidrogênio. A Tabela 5.47 apresenta um resumo das lavagens do material suporte realizadas na condição 11. A lavagem nesta condição apresentou um efeito mais ameno do que nas condições anteriores, proporcionando um maior crescimento da biomassa.

Tabela 5.47 - Lavagem do material suporte (AnSBBR com recirculação da fase líquida e soro de leite - Condição 11)

\begin{tabular}{cccc}
\hline Tempo & $\begin{array}{c}\text { Quantidade de } \\
\text { biomassa removida } \\
\text { do sistema } \\
(\mathrm{gSVT})\end{array}$ & $\begin{array}{c}\mathrm{C}_{\mathrm{X}} \text { antes da } \\
\text { lavagem } \\
\left(\mathrm{gSVT} . \mathrm{L}^{-1}\right)\end{array}$ & $\begin{array}{c}\mathrm{C}_{\mathrm{X}}{ }^{\prime} \text { antes da } \\
\text { lavagem } \\
\left(\mathrm{gSVT} . \mathrm{gsuporte}^{-1}\right)\end{array}$ \\
\hline 397 & 30,6 & 10,9 & 0,021 \\
406 & 29,7 & 10,2 & 0,020 \\
\hline
\end{tabular}

O perfil temporal foi realizado no final da operação, com o intuito de entender melhor como os parâmetros indicativos de eficiência do sistema se comportavam durante um ciclo completo. A Figura 5-185 apresenta a evolução da concentração de 
carboidrato ao longo do ciclo e a eficiência de remoção do mesmo. A dinâmica de degradação no processo em batelada alimentada apresenta-se de forma do processo em batelada. O primeiro ponto do ciclo, representando um tempo muito próximo a zero, apresenta uma concentração baixíssima, resultado da batelada anterior. Durante o processo de alimentação contínua a concentração de carboidratos vai aumentando mostrando que a degradação destes é mais lenta do que a entrada. Desta forma é possível notar um aumento nas concentrações de lactose dentro do interior até 1 hora e meia de ciclo, quando a concentração começa a cair, atingindo no final do ciclo um valor residual aproximado de $14 \mathrm{mg} . \mathrm{L}^{-1}$ e uma degradação na ordem de $99 \%$.

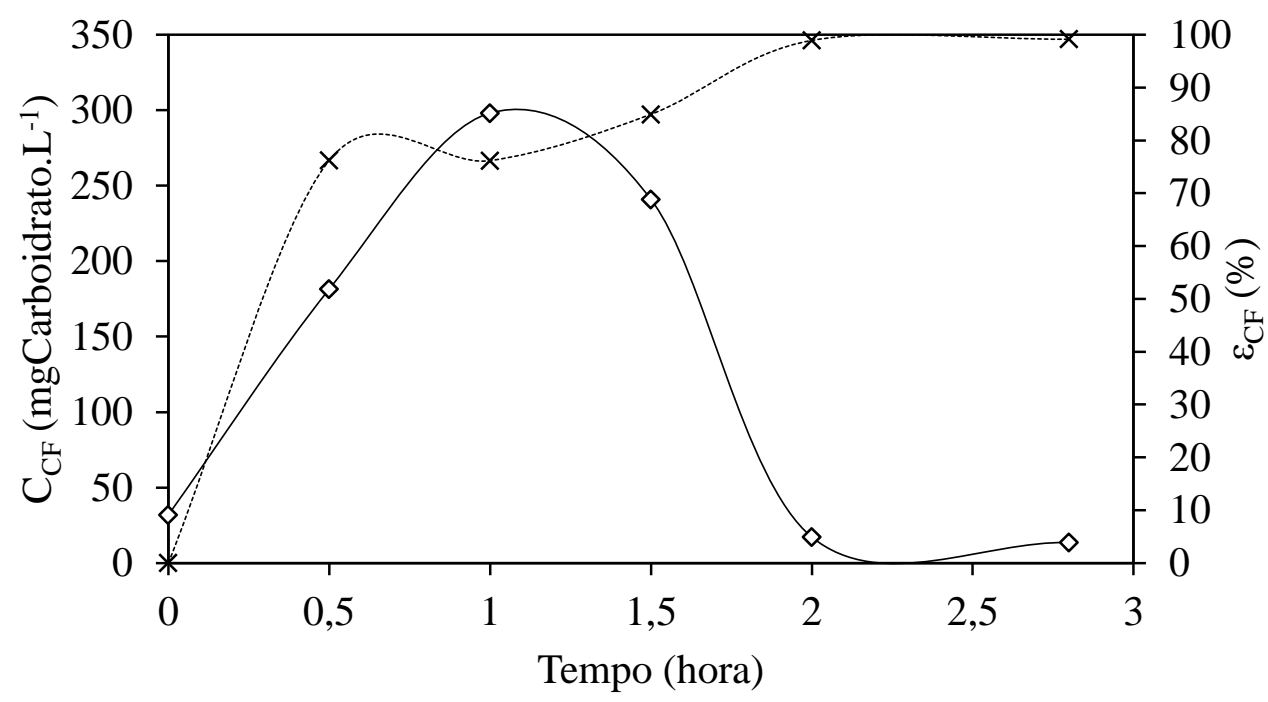

Figura 5-185 - Concentração e eficiência de degradação de carboidrato: $\diamond$ - perfil e * eficiência (AnSBBR com recirculação da fase líquida e soro de leite - Condição 11).

A Figura 5-186 apresenta a evolução da concentração de matéria orgânica ao longo do ciclo. Observa-se uma baixa remoção da DQO, levando a uma alta concentração da mesma no volume residual. Assim, no inicio do ciclo, novamente a diluição do volume carregado pelo volume residual é realizada em proporção bem menor do que no caso dos carboidratos totais, tendo em vista que as concentrações 
afluente e residual são muito próximas. No inicio do ciclo, a concentração é da ordem de $3560 \mathrm{mg} . \mathrm{L}^{-1}$ atingindo valores próximos a $3410 \mathrm{mg} . \mathrm{L}^{-1}$ no último ponto do ciclo.

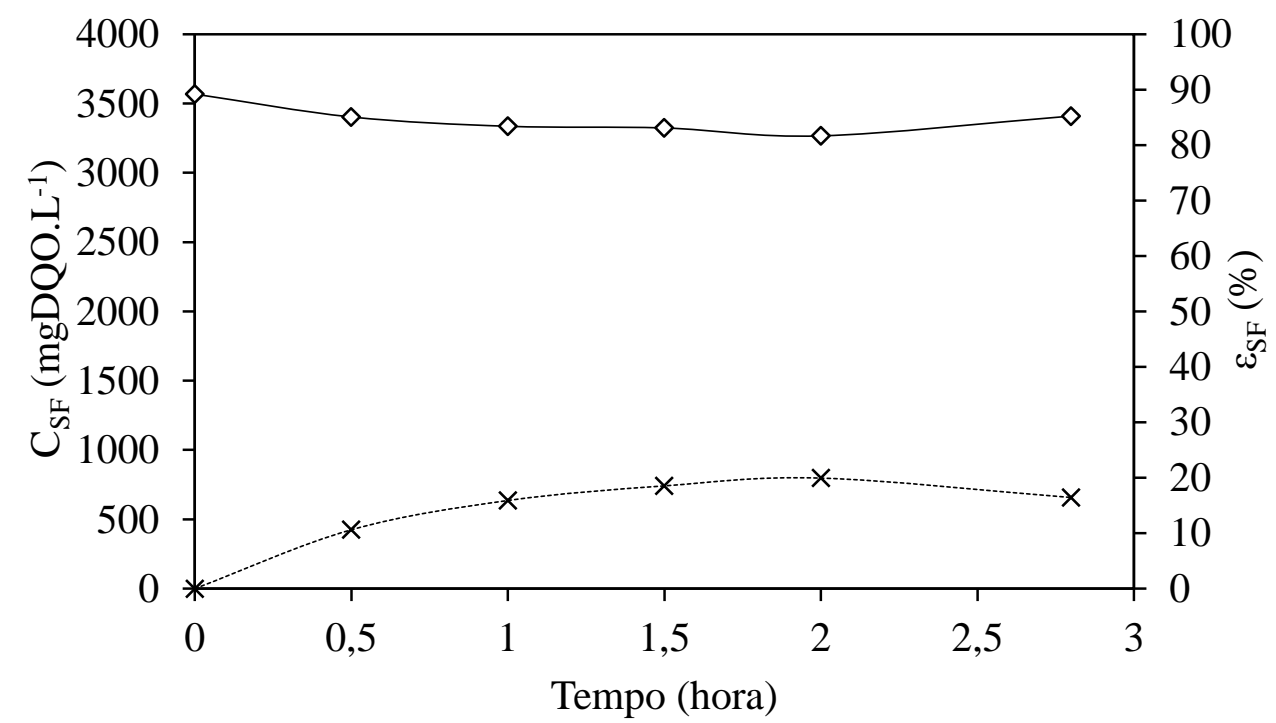

Figura 5-186 - Concentração e eficiência de degradação de matéria orgânica: $\diamond$ - perfil e * eficiência (AnSBBR com recirculação da fase líquida e soro de leite - Condição 11).

O acúmulo de ácidos voláteis totais por titulação ao longo do ciclo pode ser observado na Figura 5-187. A concentração destes permaneceu praticamente constante durante a fase de reação para atingir um valor na ordem de $1460 \mathrm{mgHAc} . \mathrm{L}^{-1}$ no final do ciclo. 


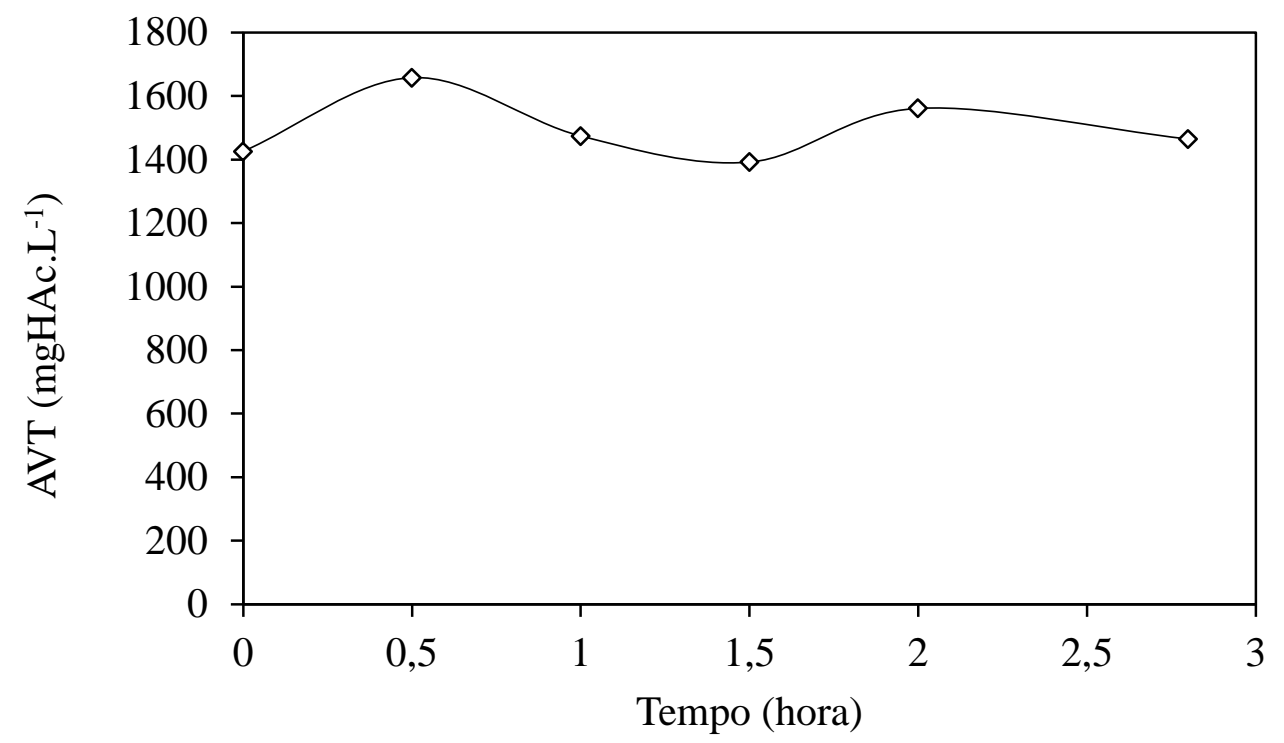

Figura 5-187 - Ácidos voláteis totais $(\diamond)$ do perfil (AnSBBR com recirculação da fase líquida e soro de leite - Condição 11).

Os resultados dos compostos intermediários por cromatografia gasosa são apresentados na Figura 5-188. Todos os componentes apresentaram concentrações praticamente constantes ao longo do ciclo.

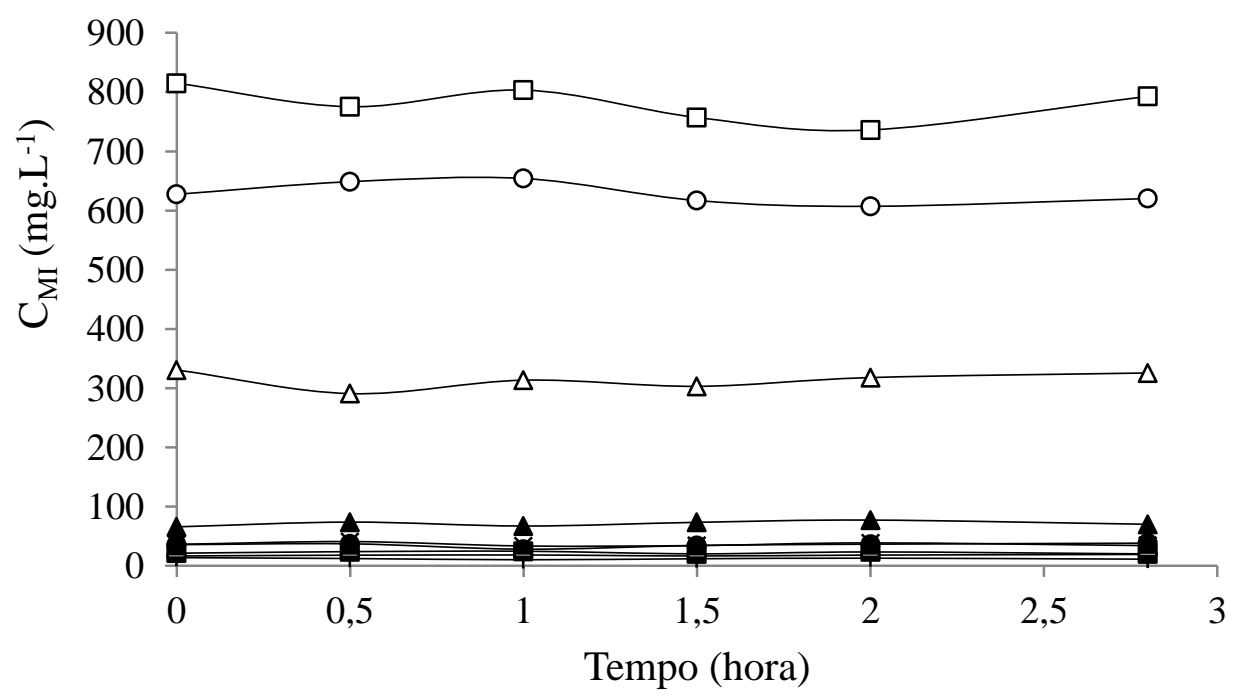

Figura 5-188 - Concentração dos compostos intermediários ao longo do ciclo: $\square$ - ácido acético; $\Delta$ - etanol; $\bigcirc$ - ácido butírico; $\mathbf{\square}$ - ácido isobutírico; $\boldsymbol{\Delta}$ - ácido capróico; • ácido valérico; - *ácido propiônico; +butanol; - ácido isovalérico (AnSBBR com recirculação da fase líquida e soro de leite - Condição 11). 
$\mathrm{O}$ pH diminuiu instantaneamente em relação ao afluente devido à diluição do mesmo com o volume residual no inicio do ciclo e permaneceu estável ao longo da operação conforme a Figura 5-189. A estabilidade do $\mathrm{pH}$ foi mantida, como pode ser visto na Figura 5-190, devido a alcalinidade que foi consumida lentamente durante o ciclo.

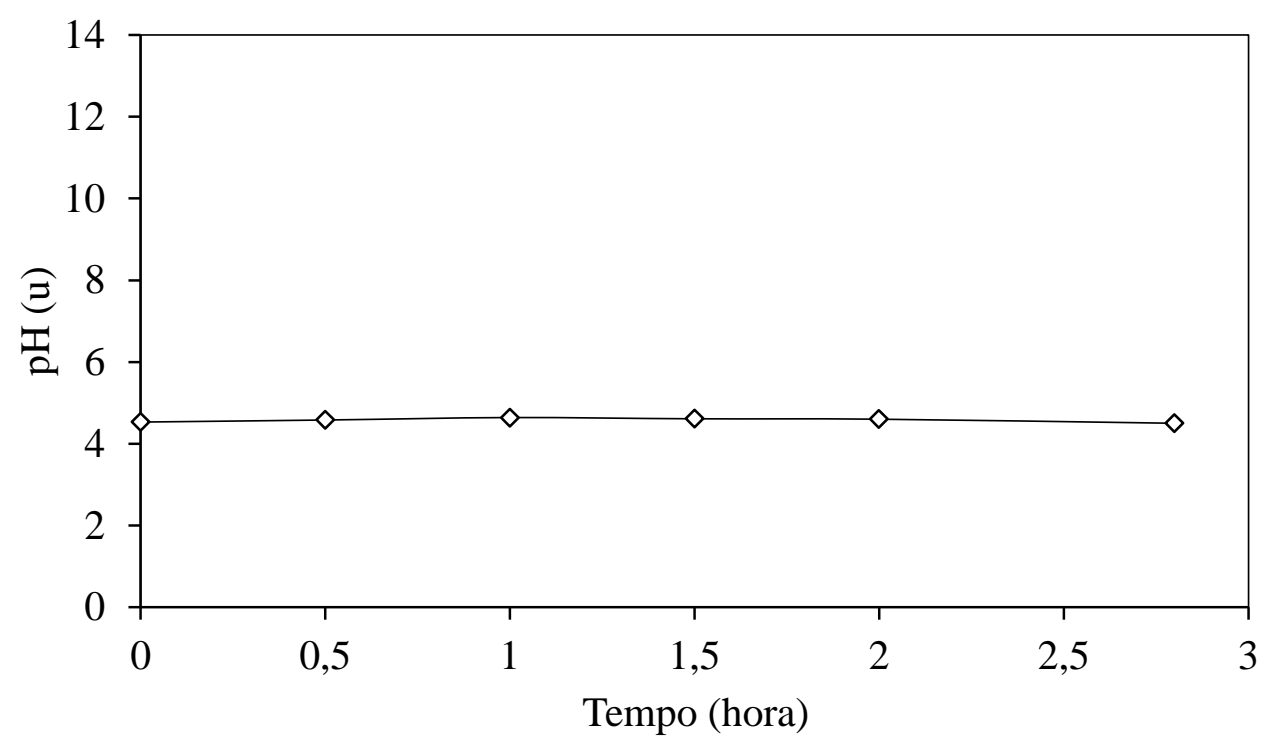

Figura 5-189 - Valores de pH $(\diamond)$ do perfil (AnSBBR com recirculação da fase líquida e soro de leite - Condição 11). 


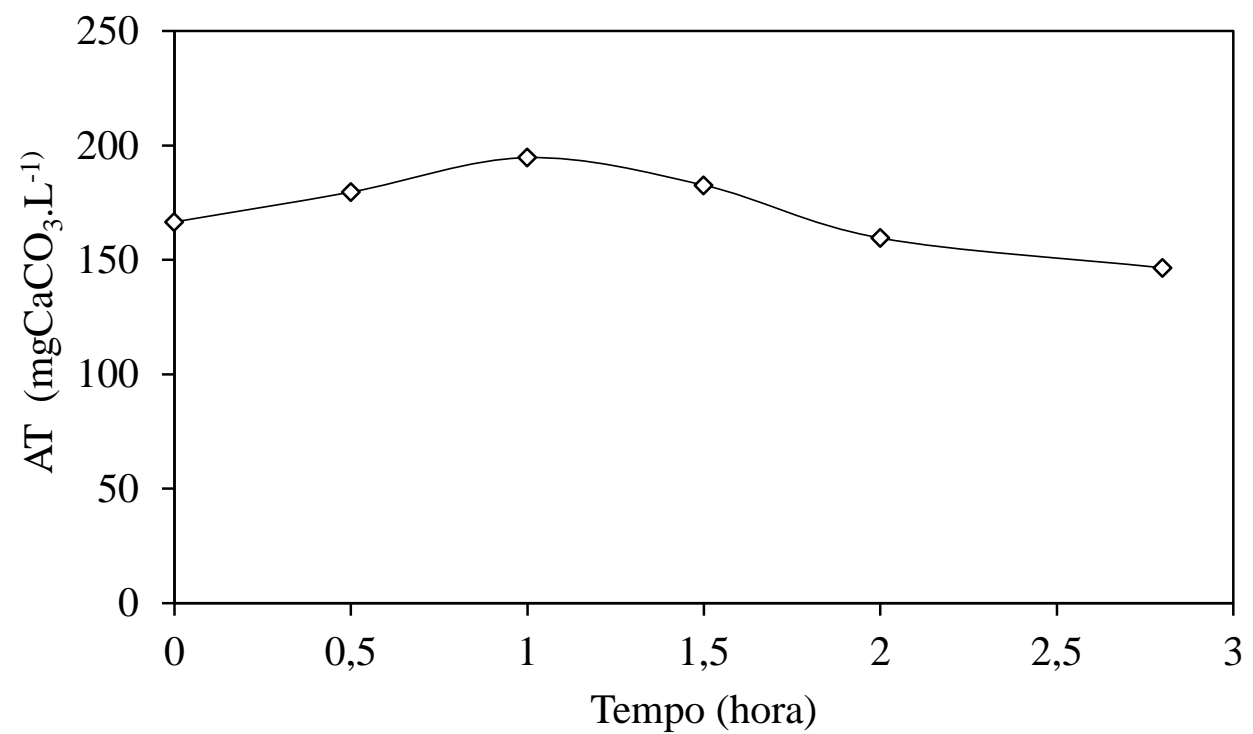

Figura 5-190 - Alcalinidade total do perfil (AnSBBR com recirculação da fase líquida e soro de leite - Condição 11).

A produção volumétrica média acumulada do biogás, realizada com os valores dos perfis quantitativos mais consistentes obtidos durante a operação, juntamente com os desvios padrões encontram-se na Figura 5-191. A produção quase em sua totalidade ocorre na primeira hora e meia do ciclo, sendo realizada no final do mesmo em quantidades menores. A Tabela 5.48 resume os valores médios da produção, fração molar e os volumes individuais da mistura do biogás. A Figura 5-192 apresenta os volumes acumulados médios dos perfis de $\mathrm{H}_{2}, \mathrm{CO}_{2}$ e $\mathrm{CH}_{4}$ produzidos durante o ciclo. Assim como ocorreu na Condição 10, não foi produzido metano. Era esperado que a batelada alimentada apresentasse os melhores resultados de produção de $\mathrm{H}_{2}$, já que ocorreria uma influencia direta na relação F/M, com um fornecimento gradual de substrato e uma disponibilização mais lenta deste aos microrganismos, melhorando assim a assimilação e o rendimento pelas rotas metabólicas produtoras de hidrogênio, como foi observado por Inoue (2013). Porém os resultados obtidos, como pôde ser observado anteriormente, foram bastante similares, não permitindo definir qual tipo de alimentação foi melhor para a produção de biohidrogênio. O único indicador que 
apresentou uma maior discrepância foi a PrME (mol.kg $\left.{ }^{-1} \mathrm{SVT} . \mathrm{d}^{-1}\right)$, devido ao maior crescimento da biomassa no interior do reator $(17,7$ e 35,7 gSVT em C10 e C11, respectivamente). $\mathrm{O}$ fato da forma de alimentação não ter surtido um efeito perceptível no processo pode estar relacionado com o tipo de substrato utilizado tendo em vista que Inoue (2013) utilizou sacarose, um substrato de fácil degradação e assimilação, enquanto que o presente trabalho utilizou soro de leite, substrato complexo que provavelmente é lentamente degradado e assimilado mesmo quando disponibilizado rapidamente.

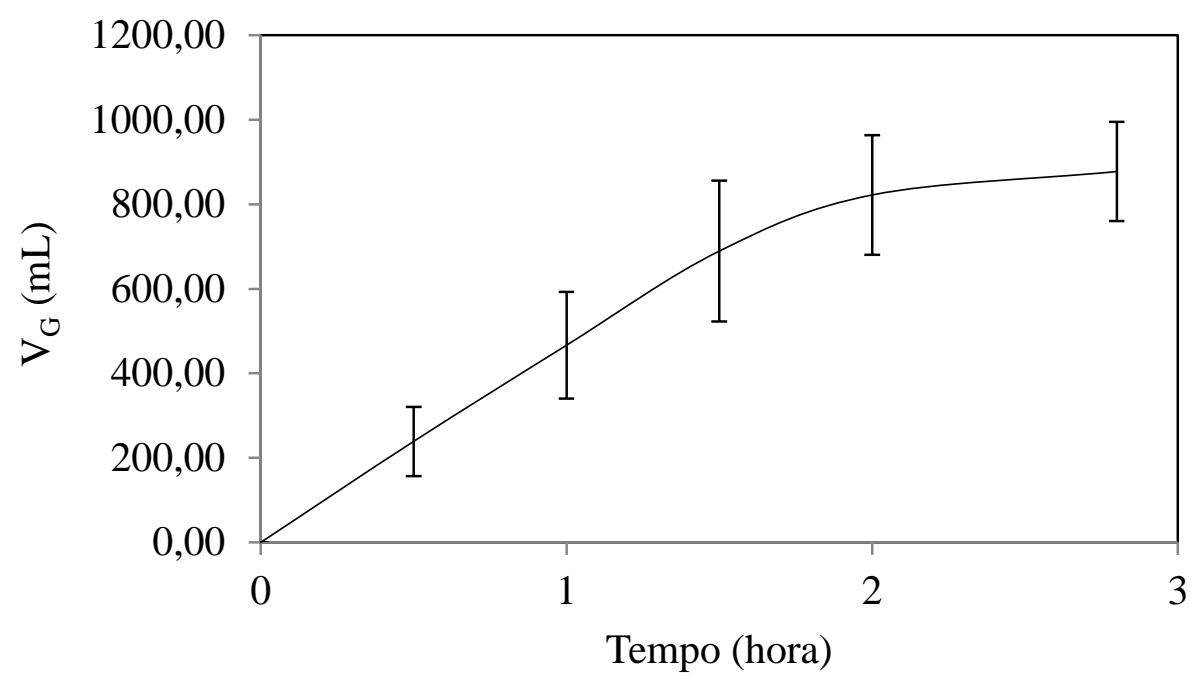

Figura 5-191 - Produção volumétrica média acumulada do biogás durante o ciclo (AnSBBR com recirculação da fase líquida e soro de leite - Condição 11). 
Tabela 5.48 - Valores médios da produção, fração molar e os volumes individuais da mistura do biogás (AnSBBR com recirculação da fase líquida e soro de leite - Condição 9).

\begin{tabular}{ccccccccccc}
$\begin{array}{c}\text { Tempo } \\
(\mathrm{h})\end{array}$ & $\begin{array}{c}\mathrm{V}_{\mathrm{G}} \\
(\mathrm{mL}-\mathrm{CNTP})\end{array}$ & \multicolumn{3}{c}{$\mathrm{C}_{\mathrm{G}}\left(\mathrm{mmol} \cdot \mathrm{L}^{-1}\right)$} & \multicolumn{3}{c}{ Fração Molar (\%) } & \multicolumn{3}{c}{ Volume (mL $-\mathrm{CNTP})$} \\
\hline 0,0 & 0,0 & 0,0 & 0,0 & 0,0 & 0,0 & 0,0 & 0,0 & 0,0 & 0,0 & 0,0 \\
0,5 & 238,9 & 64,5 & 174,4 & 0,0 & 27,0 & 73,0 & 0,0 & 1,4 & 3,8 & 0,0 \\
1,0 & 466,4 & 142,3 & 324,1 & 0,0 & 34,2 & 65,8 & 0,0 & 3,0 & 5,7 & 0,0 \\
1,5 & 689,2 & 230,8 & 458,4 & 0,0 & 39,7 & 60,3 & 0,0 & 4,9 & 7,4 & 0,0 \\
2,0 & 822,0 & 284,2 & 537,8 & 0,0 & 40,2 & 59,8 & 0,0 & 6,0 & 8,9 & 0,0 \\
2,8 & 877,3 & 307,6 & 569,7 & 0,0 & 42,4 & 57,6 & 0,0 & 6,7 & 9,1 & 0,0 \\
\hline
\end{tabular}

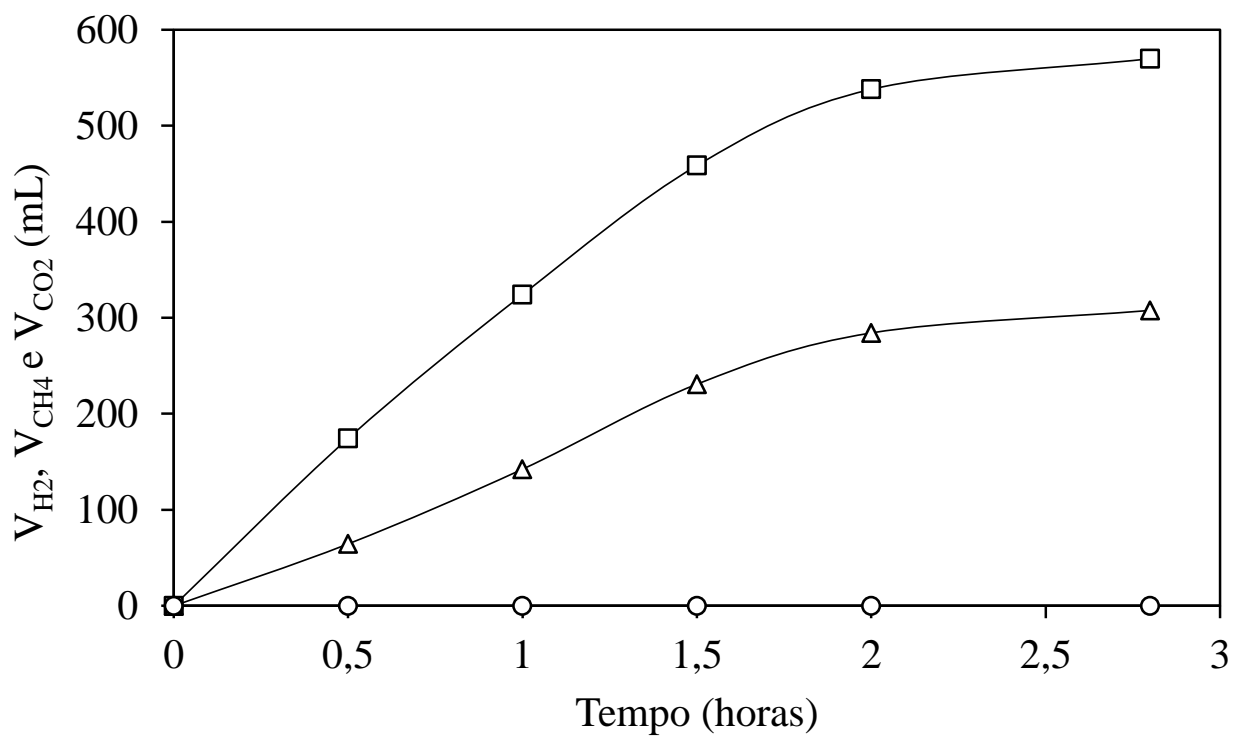

Figura 5-192 - Volumes acumulados médios produzidos ao longo do ciclo: $\square-\mathrm{CO}_{2} ; \Delta-$ $\mathrm{H}_{2} ;$ o $-\mathrm{CH}_{4}$ (AnSBBR com recirculação da fase líquida e soro de leite - Condição 11). 


\subsubsection{Influência da temperatura.}

Após avaliar a concentração afluente e o tempo de enchimento, passou-se para o último estudo desta fase, a avaliação da influência da temperatura na produção de hidrogênio em um AnSBBR alimentado com soro de leite. Tendo em vista que a forma de alimentação não apresentou uma diferença significativa na produção de hidrogênio, manteve-se a Condição 10 como base de operação para os novos ensaios devido à simplicidade e facilidade de operação da batelada em comparação com a batelada alimentada. Desta forma, as Condições 12 e 13 foram uma repetição da Condição 10 (concentração afluente de $5400 \mathrm{mgDQO} . \mathrm{L}^{-1}$ e tempo de ciclo de 3 horas) alterando a temperatura. Ao invés do reator ser a $30^{\circ} \mathrm{C}$, ele foi mantido a $45^{\circ} \mathrm{C}$ (Condição 12 ) e a $15^{\circ} \mathrm{C}$ (Condição 13).

5.2.3.1. Condição $12-$ Soro de leite $\left(t_{c}=3\right.$ horas, $C_{S T}=5500 \mathrm{mgDQO} . \mathrm{L}^{-}$ $\left.{ }^{1}, 45^{\circ} \mathrm{C}\right)$.

A condição experimental 12 apresentou uma COAV nominal de 18,5 kgDQO.m ${ }^{3} \cdot \mathrm{d}^{-1}$ e duração do ciclo de 3 horas, indo do dia 421 ao dia 439 (19 dias de operação). A Tabela 5.49 apresenta os valores médios dos parâmetros monitorados. 
Tabela 5.49 - Valores médios dos parâmetros monitorados na condição experimental 12

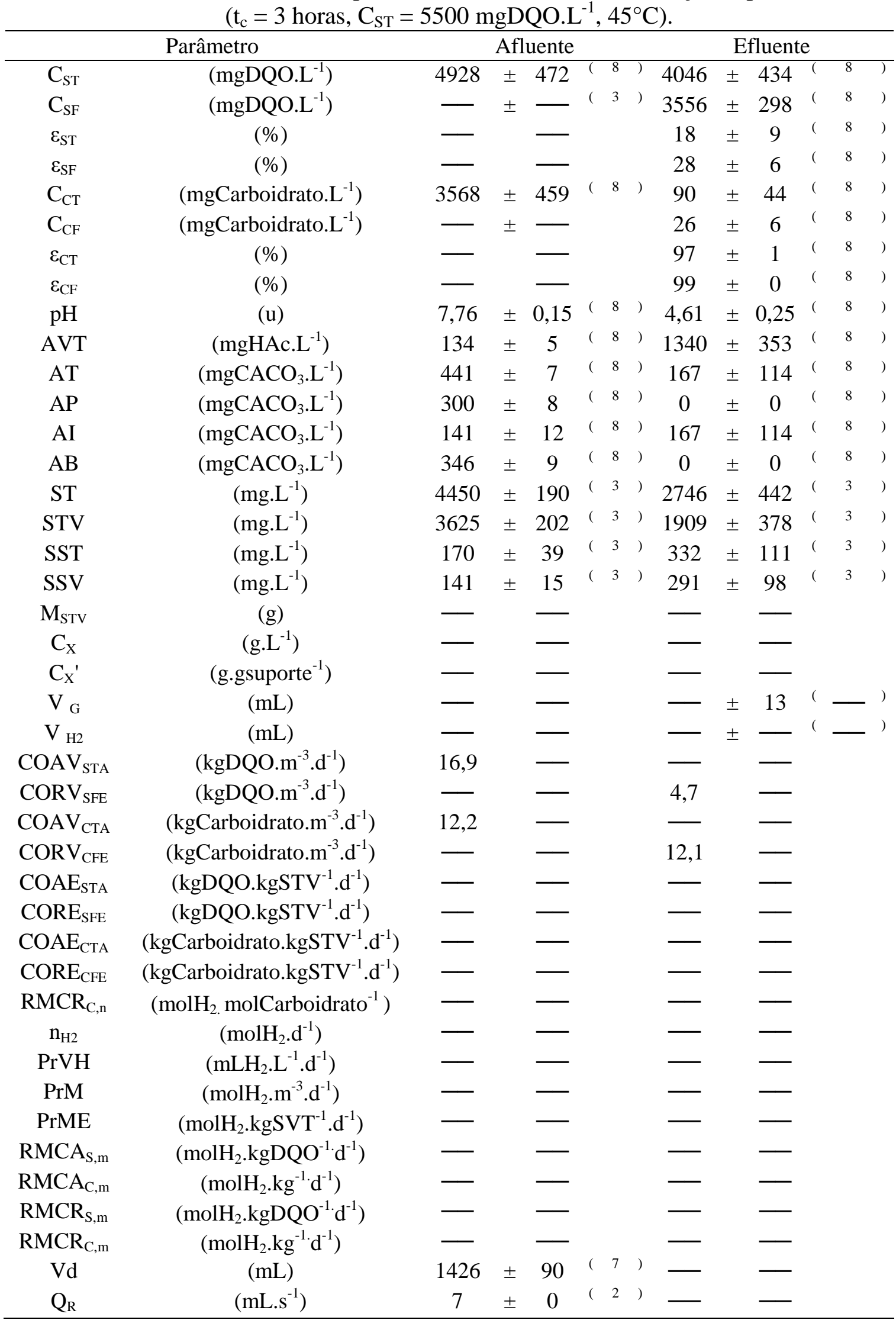

(*) Entre parêntese o número de amostras considerado no cálculo da média 
A Figura 5-193 apresenta os valores da concentração afluente (amostras não filtradas) e efluente (amostras não filtradas e filtradas) de matéria orgânica (DQO) nos sistema. A Figura 5-194 apresenta a eficiência de remoção do mesmo parâmetro durante o monitoramento diário. Esta eficiência atingiu, em média, 28\% para as amostras filtradas e $18 \%$ para mostras não filtradas. A média de concentração afluente não filtrada do substrato foi de $4928 \mathrm{mgDQO} . \mathrm{L}^{-1}$ e de $4046 \mathrm{mgDQO} . \mathrm{L}^{-1}$ e $3556 \mathrm{mgDQO} . \mathrm{L}^{-1}$ para amostras de efluente não filtradas e filtradas, respectivamente.

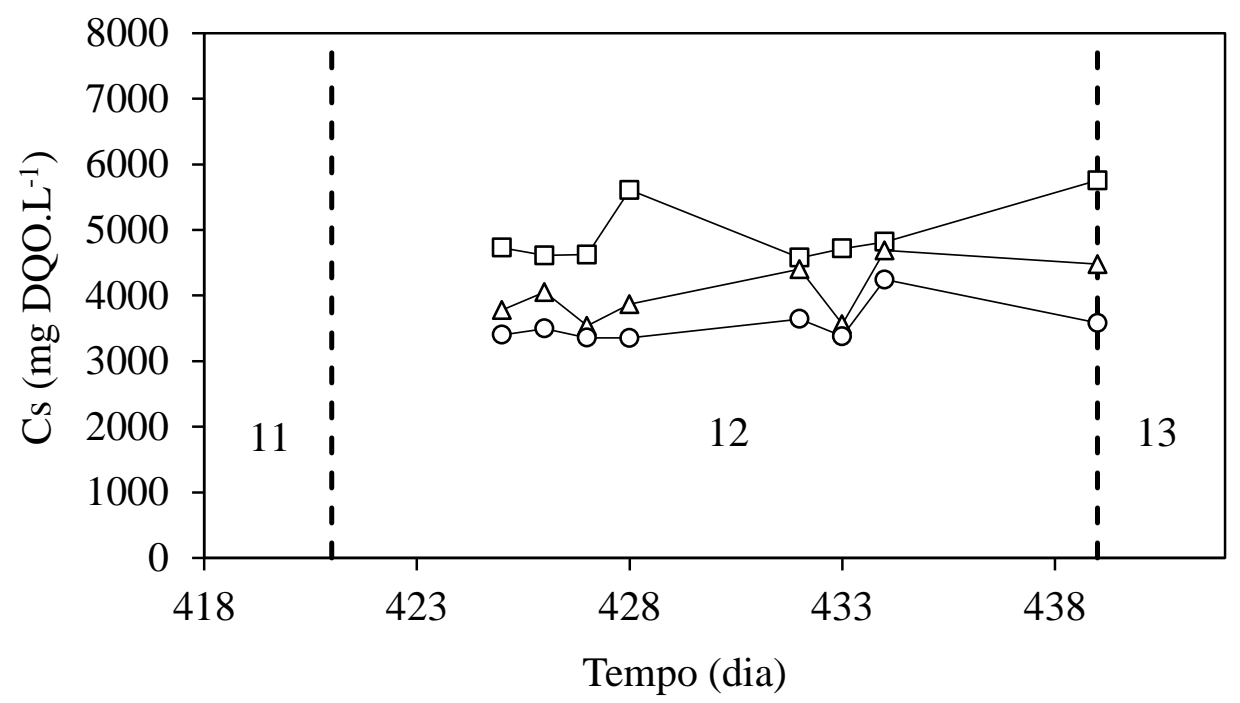

Figura 5-193 - Concentração de matéria orgânica (DQO): $\square-$ afluente não filtrada; $\Delta$ efluente não filtrada; $\bigcirc$ - efluente filtrada (AnSBBR com recirculação da fase líquida e soro de leite - Condição 12). 


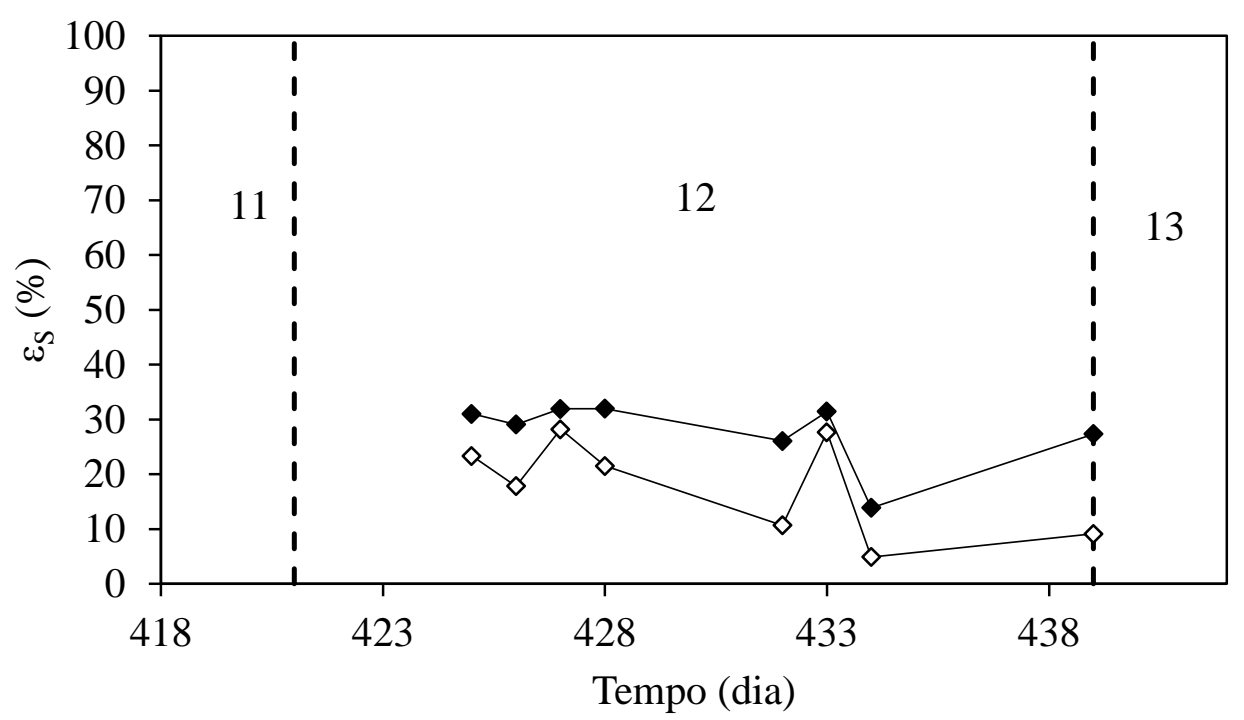

Figura 5-194 - Eficiência de remoção de matéria orgânica (DQO): $\diamond$ - não filtrada; filtrada (AnSBBR com recirculação da fase líquida e soro de leite - Condição 12).

A Figura 5-195 apresenta os valores da concentração de carboidratos afluente e efluente (para amostras filtradas e não filtradas) e Figura 5-196 apresenta a eficiência de remoção do mesmo parâmetro (não filtrada e filtrada) durante o monitoramento diário. A média da concentração afluente foi de $3568 \mathrm{mgCarboidrato.} \mathrm{L}^{-1}$, enquanto que a concentração residual (amostras não filtradas) foi de $90 \mathrm{mgCarboidrato.}^{-1}$ e 26 mgCarboidrato. $\mathrm{L}^{-1}$ para a concentração residual filtrada durante toda a operação. A eficiência de remoção de carboidrato foi, em média, de $99 \%$ para as amostras filtradas e 97\% para mostras não filtradas durante toda a operação. 


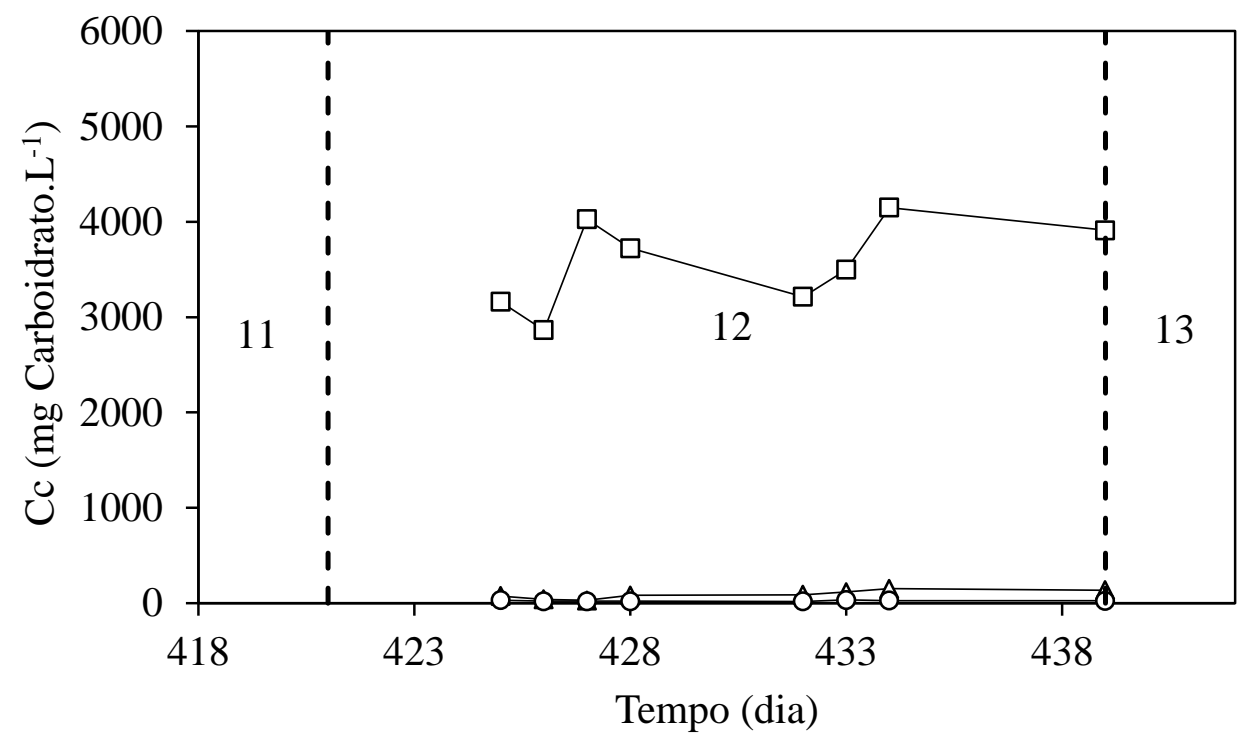

Figura 5-195 - Concentração de carboidrato: $\square$ - afluente não filtrada; $\Delta$ - efluente não filtrada; O - efluente filtrada (AnSBBR com recirculação da fase líquida e soro de leite Condição 12).

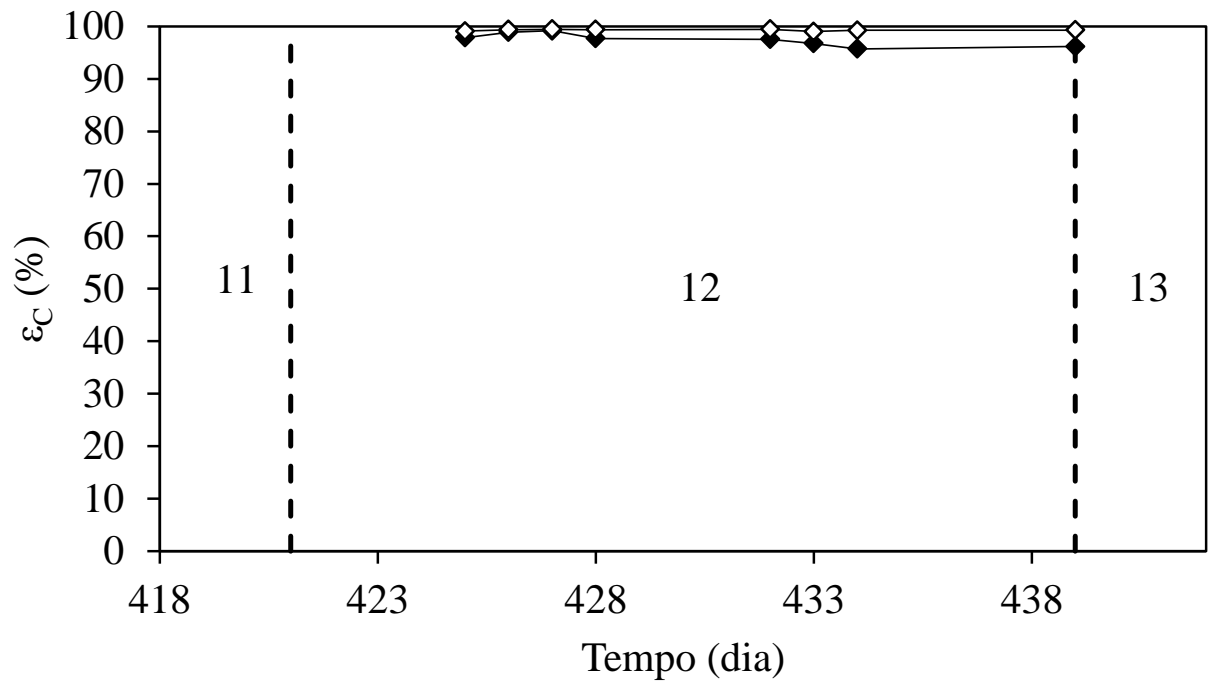

Figura 5-196 - Eficiência de remoção de carboidrato: $\diamond$ - não filtrada; $\downarrow$ - filtrada (AnSBBR com recirculação da fase líquida e soro de leite - Condição 12).

As Figura 5-197, Figura 5-198 e Figura 5-199 apresentam os perfis temporais (afluente e efluente) do $\mathrm{pH}$, da alcalinidade total e dos ácidos voláteis totais por titulação, respectivamente. A média dos valores de $\mathrm{pH}$ afluente durante a Condição 12 foi de 7,76 e de $\mathrm{pH}$ efluente foi de 4,41. A média da alcalinidade total foi de 441 
$\mathrm{mgCaCO} 3 \cdot \mathrm{L}^{-1}$ para o afluente e de $167 \mathrm{mgCaCO}_{3} \cdot \mathrm{L}^{-1}$ no efluente. O valor médio da concentração de ácidos voláteis totais afluente foi de $134 \mathrm{mgHAc} . \mathrm{L}^{-1}$ e efluente de 1340 $\operatorname{mgHAc} . \mathrm{L}^{-1}$.

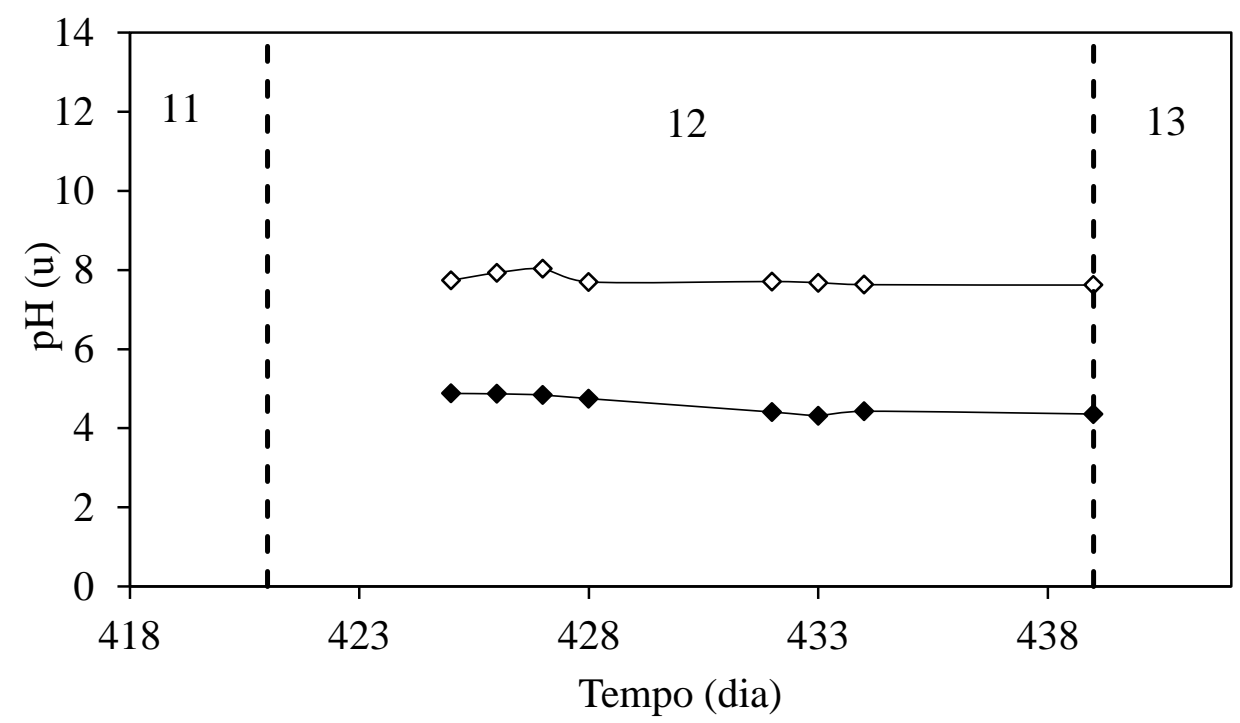

Figura 5-197 - Valores de pH: $\diamond$-afluente; - efluente (AnSBBR com recirculação da fase líquida e soro de leite - Condição 12).

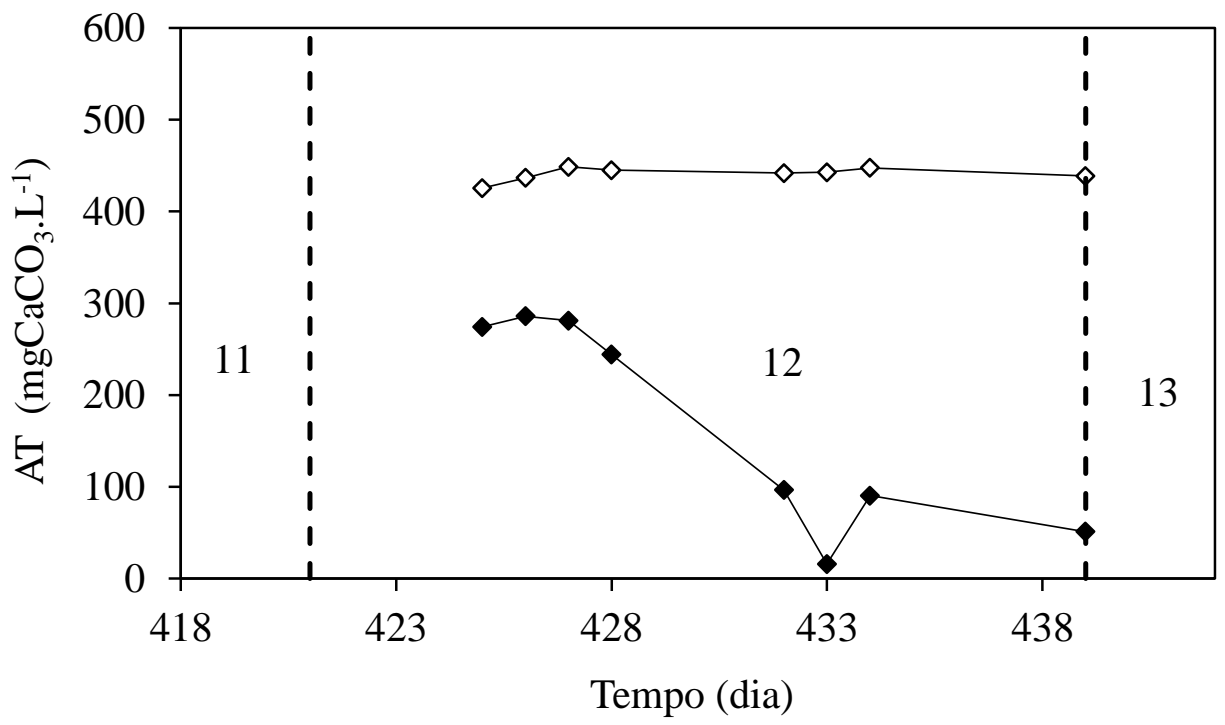

Figura 5-198 - Alcalinidade total: $\diamond$-afluente; - efluente (AnSBBR com recirculação da fase líquida e soro de leite - Condição 12). 


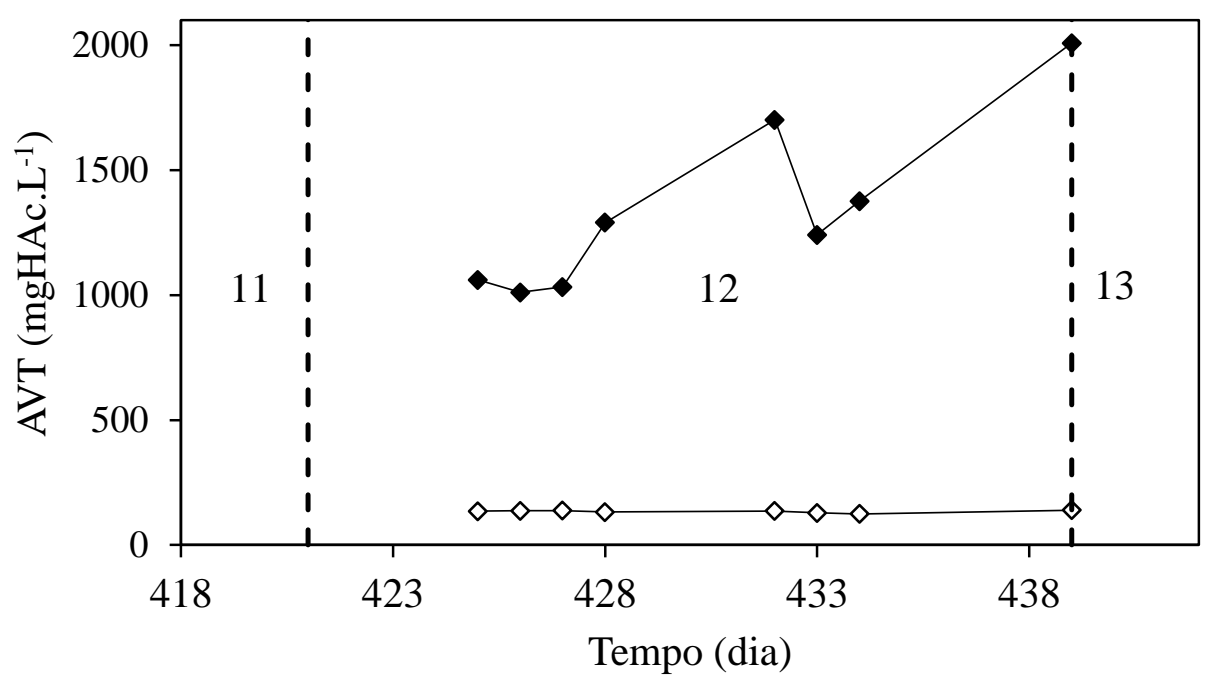

Figura 5-199 - Ácidos voláteis totais: $\diamond$-afluente; - efluente (AnSBBR com recirculação da fase líquida e soro de leite - Condição 12).

Tendo em vista que o sistema parou de produzir hidrogênio, não foi realizado o monitoramento dos compostos intermediários.

O monitoramento da série de sólidos é mostrado na Tabela 5.50, cujos valores apresentam um baixo teor de SSV no efluente e afluente.

Tabela 5.50 - Série de sólidos afluente e efluente (AnSBBR com recirculação da fase líquida e soro de leite - Condição 12).

\begin{tabular}{lcccc}
\hline & $\begin{array}{c}\text { ST } \\
\left(\mathrm{mg} . \mathrm{L}^{-1}\right)\end{array}$ & $\begin{array}{c}\text { SVT } \\
\left(\mathrm{mg} . \mathrm{L}^{-1}\right)\end{array}$ & $\begin{array}{c}\text { SST } \\
\left(\mathrm{mg} . \mathrm{L}^{-1}\right)\end{array}$ & $\begin{array}{c}\text { SSV } \\
\left(\mathrm{mg} . \mathrm{L}^{-1}\right)\end{array}$ \\
\hline Afluente & $4450 \pm 190$ & $3625 \pm 202$ & $170 \pm 39$ & $141 \pm 15$ \\
Efluente & $2746 \pm 442$ & $1909 \pm 378$ & $332 \pm 112$ & $291 \pm 98$ \\
\hline \multicolumn{5}{c}{ *Número de amostras consideradas $=3}$.
\end{tabular}

A produção quantitativa do biogás por ciclo é mostrada na Figura 5-200. A produção média foi de $485 \mathrm{~mL}$ (CNTP). A Figura 5-201 apresenta o monitoramento das concentrações dos componentes do biogás no final do ciclo, enquanto que a Figura 5-202 apresenta a distribuição destes mesmos componentes. Os valores médios de concentração de $\mathrm{H}_{2}, \mathrm{CH}_{4}$ e $\mathrm{CO}_{2}$ durante toda a operação foram 3,0, 2,2 e 8,7 mmol.L ${ }^{-1}$, 
respectivamente. Além disso, a distribuição percentual média de $\mathrm{H}_{2}$ foi de $20,1 \%$, a de $\mathrm{CH}_{4}$ foi de $17,0 \%$ e a de $\mathrm{CO}_{2}$ foi de $62,9 \%$. Porém no último dia de operação os valores de concentração obtidos para $\mathrm{H}_{2}, \mathrm{CH}_{4}$ e $\mathrm{CO}_{2}$ foram 0,0 , 3,6 e 6,8 mmol.L ${ }^{-1}$, enquanto que a distribuição percentual foi de $0,0 \%, 34,7 \%$ e $65,3 \%$ para $\mathrm{H}_{2}, \mathrm{CH}_{4}$ e $\mathrm{CO}_{2}$, respectivamente, mostrando que o processo de produção de hidrogênio entrou em falha com o decorrer do tempo quando operado em uma temperatura de $45^{\circ} \mathrm{C}$.

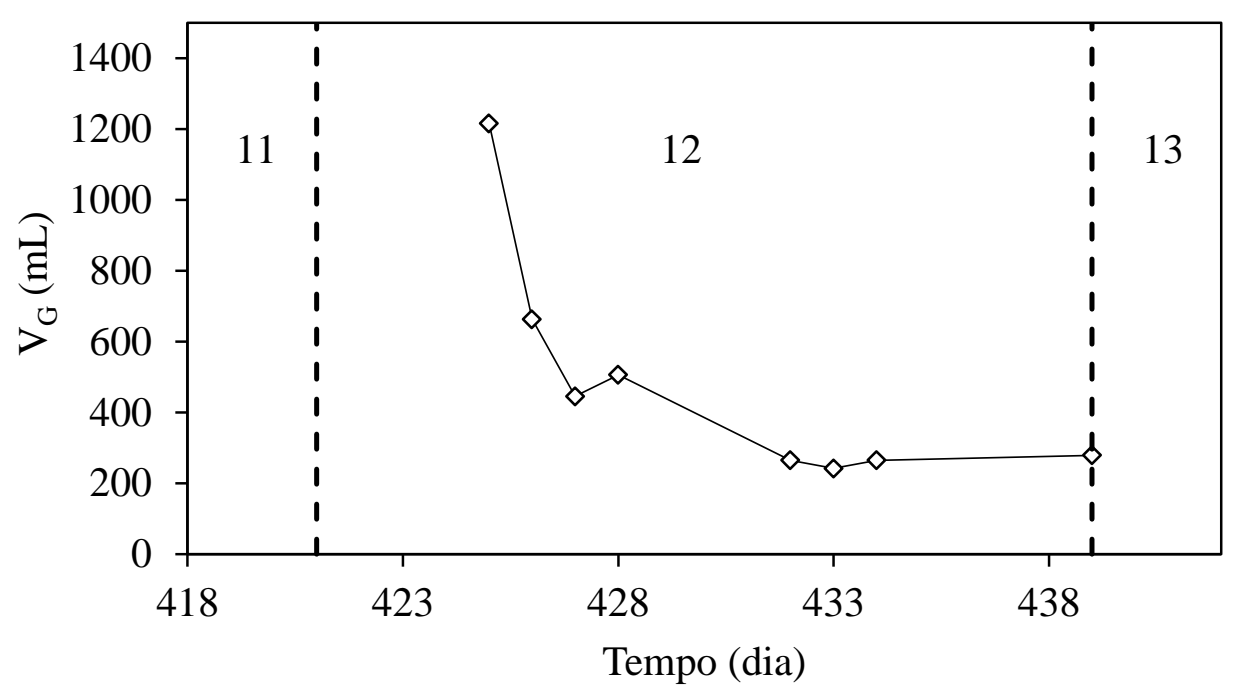

Figura 5-200 - Volume de biogás produzido por ciclo (AnSBBR com recirculação da fase líquida e soro de leite - Condição 12). 


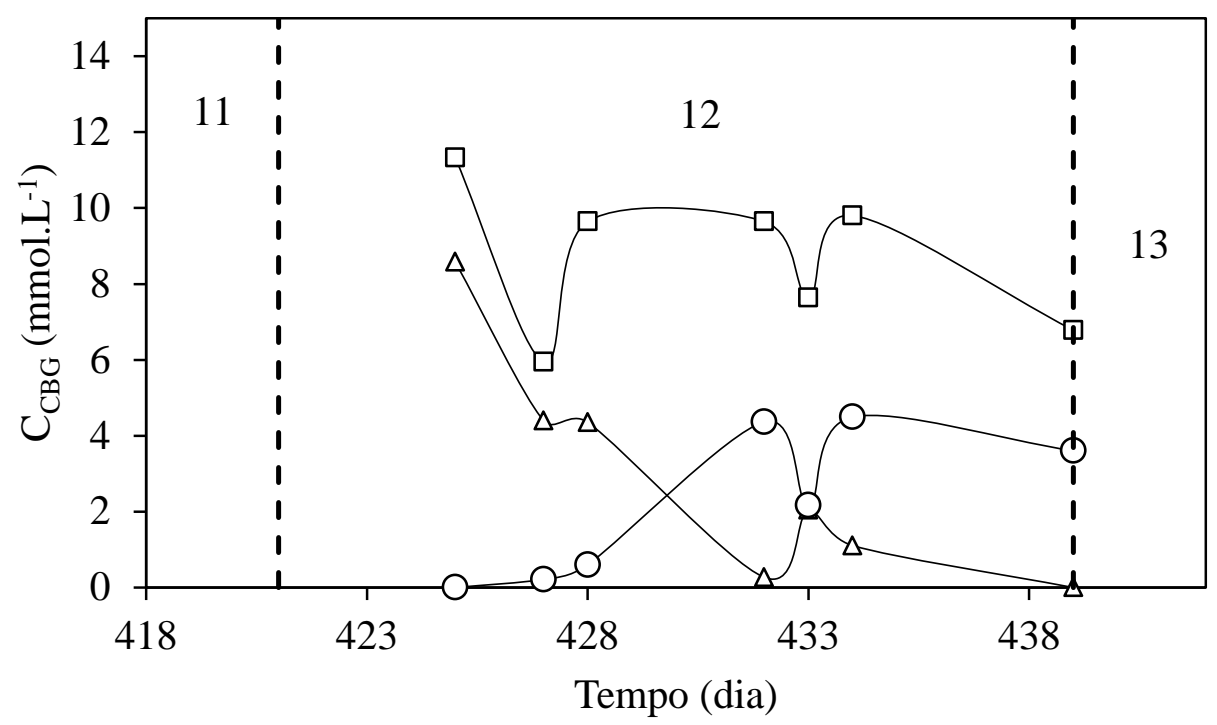

Figura 5-201 - Concentrações dos componentes do biogás no final do ciclo: $\square-\mathrm{CO}_{2} ; \Delta$ - $\mathrm{H}_{2} ; \circ-\mathrm{CH}_{4}$ (AnSBBR com recirculação da fase líquida e soro de leite - Condição 12).

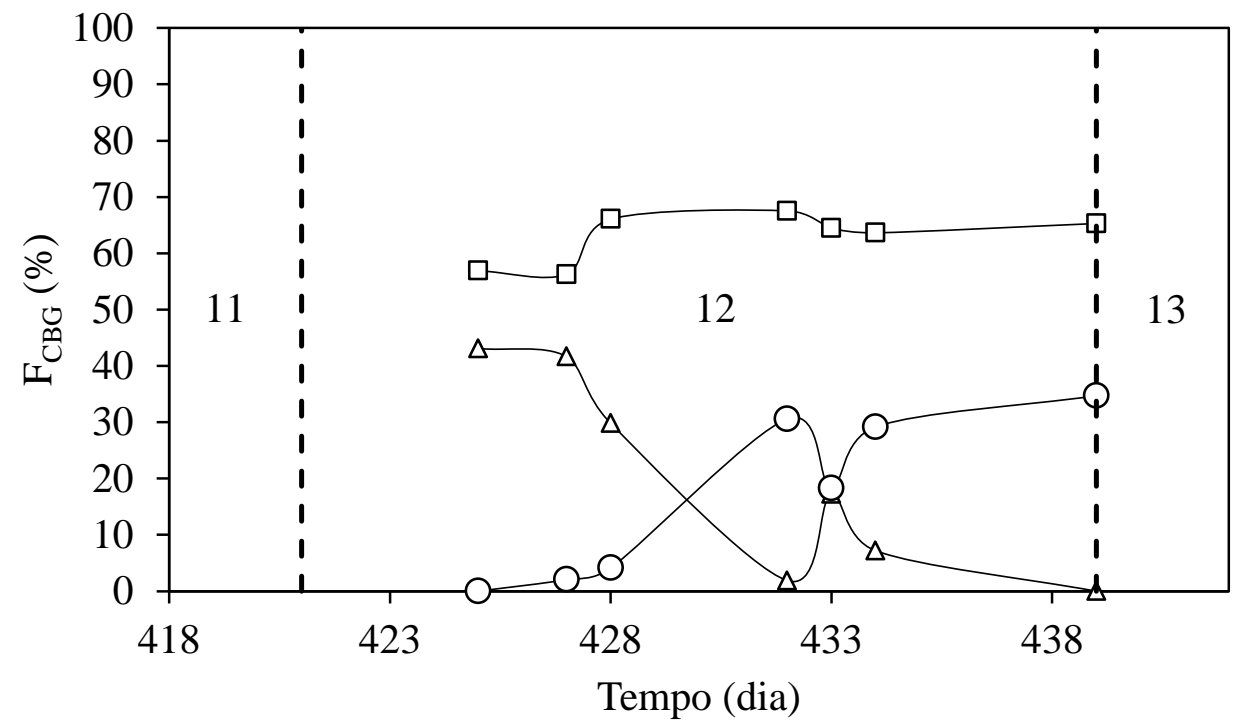

Figura 5-202 - Distribuições dos componentes do biogás no final do ciclo: $\square-\mathrm{CO}_{2}$; $\Delta$ $\mathrm{H}_{2} ;$ ○ $-\mathrm{CH}_{4}$ (AnSBBR com recirculação da fase líquida e soro de leite - Condição 12).

A lavagem periódica do material suporte foi realizada apenas uma vez nesta condição, como pode ser observado na Tabela 5.51. Porem esta lavagem não apresentou o efeito esperado de melhorar a produção de hidrogênio como aconteceu nas condições 
anteriores nas quais ocorreu lavagem do material suporte. Pode-se supor que quando uma comunidade microbiana consumidora de hidrogênio consegue se consolidar no meio de reação é difícil reverter este processo.

Tabela 5.51 - Lavagem do material suporte (AnSBBR com recirculação da fase líquida e soro de leite - Condição 12)

\begin{tabular}{cccc}
\hline Tempo & $\begin{array}{c}\text { Quantidade de } \\
\text { biomassa removida } \\
\text { do sistema } \\
\text { (gSVT) }\end{array}$ & $\begin{array}{c}\mathrm{C}_{\mathrm{X}} \text { antes da } \\
\text { lavagem } \\
\left(\mathrm{gSVT}^{-1}\right)\end{array}$ & $\begin{array}{c}\mathrm{C}_{\mathrm{X}}{ }^{\prime} \text { antes da } \\
\text { lavagem } \\
\left(\mathrm{gSVT} . \text { gsuporte }^{-1}\right)\end{array}$ \\
\hline 432 & 27,4 & 6,8 & 0,013 \\
\hline
\end{tabular}

Tendo em vista que não ocorreu produção de hidrogênio no final da operação, não foi realizado perfil temporal para esta condição. 
5.2.3.2. Condição $13-$ Soro de leite $\left(t_{c}=3\right.$ horas, $C_{S T}=5500 \mathrm{mgDQO} \cdot \mathrm{L}^{-}$ $\left.{ }^{1}, 15^{\circ} \mathrm{C}\right)$

A condição experimental 13 apresentou uma COAV nominal de 18,5 kgDQO.m ${ }^{3} \cdot \mathrm{d}^{-1}$ e duração do ciclo de 3 horas, com duração do dia 439 ao dia 461 (23 dias de operação). A Tabela 5.52 apresenta os valores médios dos parâmetros monitorados. 
Tabela 5.52 - Valores médios dos parâmetros monitorados na condição experimental 13

\begin{tabular}{|c|c|c|c|c|c|c|c|c|c|c|}
\hline & Parâmetro & & Afl & dente & & & & Efluente & & \\
\hline $\mathrm{C}_{\mathrm{ST}}$ & $\left(\mathrm{mgDQO} . \mathrm{L}^{-1}\right)$ & 4896 & \pm & 362 & $(12)$ & & 4181 & \pm 268 & & \\
\hline $\mathrm{C}_{\mathrm{SF}}$ & $\left(\mathrm{mgDQO} \cdot \mathrm{L}^{-1}\right)$ & - & \pm & - & & & 3817 & \pm 249 & $(12$ & \\
\hline$\varepsilon_{\mathrm{ST}}$ & $(\%)$ & - & & - & & & 15 & \pm & $(12$ & 2 \\
\hline$\varepsilon_{\mathrm{SF}}$ & $(\%)$ & - & & - & & & 22 & \pm & & \\
\hline $\mathrm{C}_{\mathrm{CT}}$ & $\left(\right.$ mgCarboidrato. $\left.\mathrm{L}^{-1}\right)$ & 3879 & \pm & 460 & ( 12 & 12 & 1052 & \pm 909 & ( 12 & \\
\hline $\mathrm{C}_{\mathrm{CF}}$ & (mgCarboidrato. $\mathrm{L}^{-1}$ ) & - & \pm & - & & & 762 & \pm 1053 & $(12$ & 2 \\
\hline$\varepsilon_{\mathrm{CT}}$ & $(\%)$ & - & & - & & & 73 & \pm 23 & $(12$ & 2 \\
\hline$\varepsilon_{\mathrm{CF}}$ & $(\%)$ & - & & - & & & 80 & \pm 27 & & \\
\hline $\mathrm{pH}$ & (u) & 7,91 & \pm & 0,09 & $(1)$ & 11 & 4,42 & $\pm 0,18$ & ( 11 & \\
\hline AVT & $\left(\mathrm{mgHAc} \cdot \mathrm{L}^{-1}\right)$ & 138 & \pm & 5 & ( 1 & 11 & 1052 & \pm 286 & ( 11 & \\
\hline AT & $\left(\mathrm{mgCaCO}_{3} \cdot \mathrm{L}^{-1}\right)$ & 416 & \pm & 26 & $(1)$ & 11 & 71 & 55 & ( 11 & \\
\hline AP & $\left(\mathrm{mgCaCO}_{3} \cdot \mathrm{L}^{-1}\right)$ & 290 & \pm & 27 & ( 1 & 11 & 0 & \pm & ( 11 & \\
\hline AI & $\left(\mathrm{mgCaCO}_{3} \cdot \mathrm{L}^{-1}\right)$ & 127 & \pm & 8 & ( 1 & 11 & 71 & \pm & ( 11 & \\
\hline $\mathrm{AB}$ & $\left(\mathrm{mgCaCO}_{3} \cdot \mathrm{L}^{-1}\right)$ & 318 & \pm & 25 & ( 1 & 11 & 0 & \pm & ( 11 & 1) \\
\hline ST & $\left(\mathrm{mg} . \mathrm{L}^{-1}\right)$ & 4263 & \pm & 99 & ( 5 & 5 & ) 3020 & \pm 570 & ( 5 & \\
\hline STV & $\left(\mathrm{mg} \cdot \mathrm{L}^{-1}\right)$ & 3576 & \pm & 90 & ( 5 & 5 & 2262 & \pm 499 & ( 5 & ) \\
\hline SST & $\left(\mathrm{mg} \cdot \mathrm{L}^{-1}\right)$ & 90 & \pm & 38 & ( 5 & 5 & 305 & \pm & ( 5 & \\
\hline SSV & $\left(\mathrm{mg} \cdot \mathrm{L}^{-1}\right)$ & 77 & \pm & 4 & ( 5 & 5 & 292 & 99 & ( 5 & ) \\
\hline $\mathrm{M}_{\mathrm{STV}}$ & (g) & - & & - & & & 56,7 & - & & \\
\hline $\mathrm{C}_{\mathrm{X}}$ & $\left(\mathrm{g} \cdot \mathrm{L}^{-1}\right)$ & - & & - & & & 19,4 & - & & \\
\hline $\mathrm{C}_{\mathrm{X}}^{\prime}$ & (g.gsuporte ${ }^{-1}$ ) & - & & - & & & 0,034 & - & & \\
\hline $\mathrm{V}_{\mathrm{G}}$ & (mL-CNTP) & - & & - & & & 638 & $\pm \quad 11$ & $(3$ & \\
\hline $\mathrm{V}_{\mathrm{H} 2}$ & (mL-CNTP) & - & & - & & & 396 & \pm- & ( 1 & \\
\hline $\mathrm{COAV}_{\mathrm{S}}$ & $\left(\mathrm{kgDQO} \cdot \mathrm{m}^{-3} \cdot \mathrm{d}^{-1}\right)$ & 16,8 & & - & & & - & - & & \\
\hline $\mathrm{CORV}_{\mathrm{S}}$ & $\left(\mathrm{kgDQO} \cdot \mathrm{m}^{-3} \cdot \mathrm{d}^{-1}\right)$ & - & & - & & & 3,7 & - & & \\
\hline $\mathrm{COAV}_{\mathrm{C}}$ & $\left(\right.$ kgCarboidrato.m $\left.\mathrm{m}^{-3} \cdot \mathrm{d}^{-1}\right)$ & 13,3 & & - & & & - & - & & \\
\hline $\mathrm{CORV}_{\mathrm{C}}$ & $\left(\right.$ kgCarboidrato.m $\left.\mathrm{m}^{-3} \cdot \mathrm{d}^{-1}\right)$ & - & & - & & & 10,7 & - & & \\
\hline $\mathrm{COAE}_{\mathrm{S}}$ & $\left(\mathrm{kgDQO} \cdot \mathrm{kgSTV}^{-1} \cdot \mathrm{d}^{-1}\right)$ & 1,0 & & - & & & - & - & & \\
\hline $\mathrm{CORE}_{\mathrm{S}}$ & $\left(\mathrm{kgDQO} \mathrm{kgSTV}{ }^{-1} \cdot \mathrm{d}^{-1}\right)$ & - & & - & & & 0,2 & - & & \\
\hline $\mathrm{COAE}_{\mathrm{C}}$ & $\left(\mathrm{kgCarboidrato} \mathrm{kgSTV}^{-1} \cdot \mathrm{d}^{-1}\right)$ & 0,8 & & - & & & - & - & & \\
\hline $\mathrm{CORE}_{\mathrm{C}}$ & $\left(\mathrm{kgCarboidrato} \mathrm{kgSTV}^{-1} \cdot \mathrm{d}^{-1}\right)$ & & & - & & & 0,7 & - & & \\
\hline $\mathrm{RMCR}_{\mathrm{C}, \mathrm{n}}$ & $\left(\mathrm{molH}_{2}\right.$ molCarboidrato $\left.^{-1}\right)$ & - & & - & & & 1,12 & - & & \\
\hline $\mathrm{n}_{\mathrm{H} 2}$ & $\left(\mathrm{molH}_{2} \cdot \mathrm{d}^{-1}\right)$ & - & & - & & & 0,141 & - & & \\
\hline $\mathrm{PrVH}$ & $\left(\mathrm{mLH}_{2} \cdot \mathrm{L}^{-1} \cdot \mathrm{d}^{-1}\right)$ & - & & - & & & 1084,8 & - & & \\
\hline PrM & $\left(\mathrm{molH}_{2} \cdot \mathrm{m}^{-3} \cdot \mathrm{d}^{-1}\right)$ & 一 & & - & & & 48,4 & - & & \\
\hline PrME & $\left(\mathrm{molH}_{2} \cdot \mathrm{kgSVT}^{-1} \cdot \mathrm{d}^{-1}\right)$ & 一 & & - & & & 2,5 & - & & \\
\hline $\mathrm{RMCA}_{\mathrm{S}, \mathrm{m}}$ & $\left(\mathrm{molH}_{2} \cdot \mathrm{kgDQO}^{-1} \cdot \mathrm{d}^{-1}\right)$ & 2,4 & & - & & & - & - & & \\
\hline $\mathrm{RMCA}_{\mathrm{C}, \mathrm{m}}$ & $\left(\mathrm{molH}_{2} \cdot \mathrm{kg}^{-1} \cdot \mathrm{d}^{-1}\right)$ & 3,0 & & - & & & 一 & - & & \\
\hline $\mathrm{RMCR}_{\mathrm{S}, \mathrm{m}}$ & $\left(\mathrm{molH}_{2} \cdot \mathrm{kgDQO}^{-1} \cdot \mathrm{d}^{-1}\right)$ & 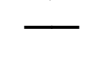 & & - & & & 10,9 & - & & \\
\hline $\mathrm{RMCR}_{\mathrm{C}, \mathrm{m}}$ & $\left(\mathrm{molH}_{2} \cdot \mathrm{kg}^{-1} \cdot \mathrm{d}^{-1}\right)$ & 一 & & - & & & 3,2 & - & & \\
\hline $\mathrm{V}_{\mathrm{d}}$ & $(\mathrm{mL})$ & 1449 & \pm & 48 & $(1)$ & 10 & - & - & & \\
\hline $\mathrm{Q}_{\mathrm{R}}$ & $\left(\mathrm{mL} \cdot \mathrm{s}^{-1}\right)$ & 7 & \pm & 0 & $(1$ & & - & - & & \\
\hline
\end{tabular}

(*) Entre parêntese o número de amostras considerado no cálculo da média

A Figura 5-203 apresenta os valores da concentração afluente (amostras não filtradas) e efluente (amostras não filtradas e filtradas) de matéria orgânica (DQO) nos 
sistema. A Figura 5-204 apresenta a eficiência de remoção do mesmo parâmetro durante o monitoramento diário. Esta eficiência atingiu, em média, 22\% para as amostras filtradas e $15 \%$ para mostras não filtradas. A média de concentração afluente não filtrada do substrato foi de $4896 \mathrm{mgDQO} . \mathrm{L}^{-1}$ e de $4181 \mathrm{mgDQO} . \mathrm{L}^{-1}$ e $3817 \mathrm{mgDQO} . \mathrm{L}^{-1}$ para amostras de efluente não filtradas e filtradas, respectivamente.

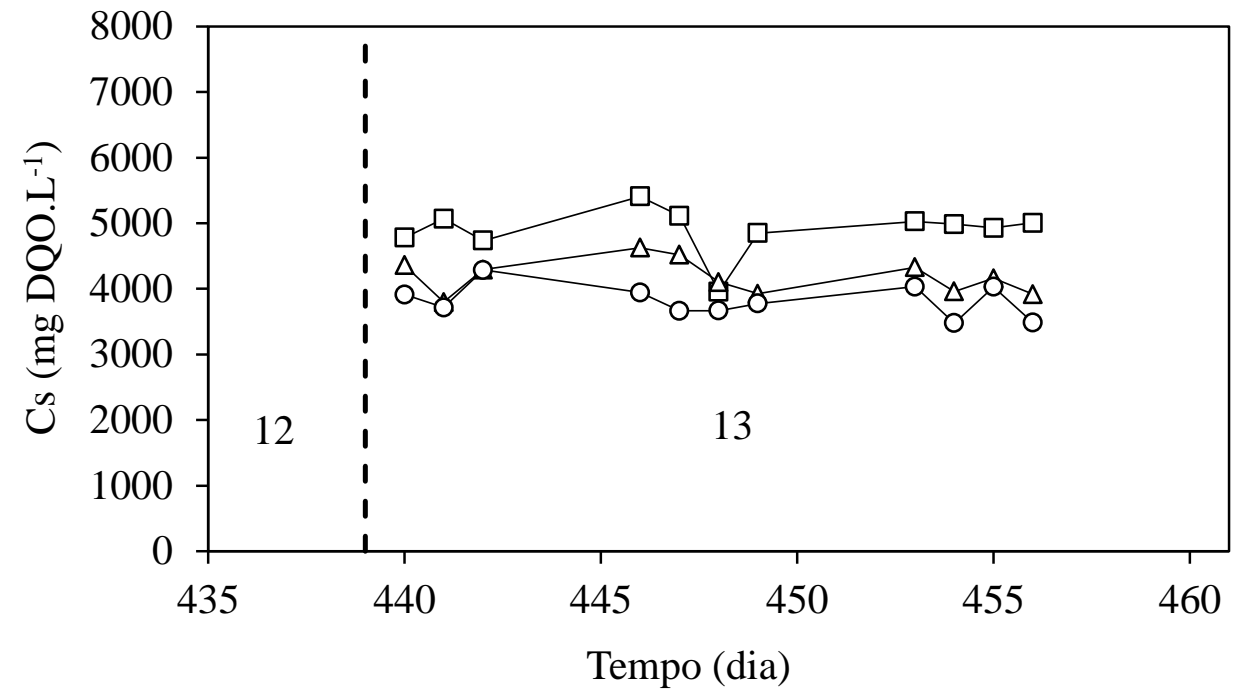

Figura 5-203 - Concentração de matéria orgânica (DQO): $\square$ - afluente não filtrada; $\Delta$ efluente não filtrada; o - efluente filtrada (AnSBBR com recirculação da fase líquida e soro de leite - Condição 13). 


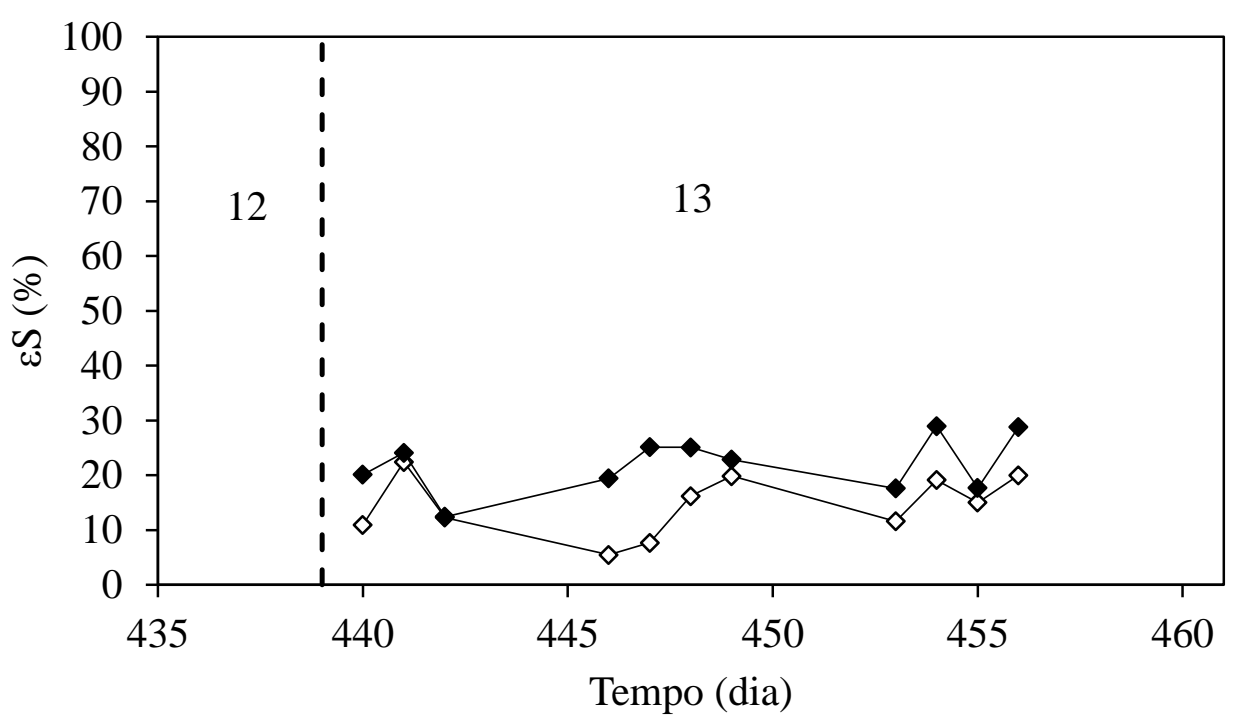

Figura 5-204 - Eficiência de remoção de matéria orgânica (DQO): $\diamond$ - não filtrada; filtrada (AnSBBR com recirculação da fase líquida e soro de leite - Condição 13).

A Figura 5-205 apresenta os valores da concentração de carboidratos afluente e efluente (para amostras filtradas e não filtradas) e Figura 5-206 apresenta a eficiência de remoção do mesmo parâmetro (não filtrada e filtrada) durante o monitoramento diário. A média da concentração afluente foi de $3879 \mathrm{mgCarboidrato.} \mathrm{L}^{-1}$, enquanto que a concentração residual (amostras não filtradas) foi de 1052 mgCarboidrato.L ${ }^{-1}$ e 762 mgCarboidrato. $\mathrm{L}^{-1}$ para a concentração residual não-filtrada e filtrada durante toda a operação e de 268 mgCarboidrato. $\mathrm{L}^{-1}$ e 246 mgCarboidrato. $\mathrm{L}^{-1}$ durante a fase estacionária. A eficiência de remoção de carboidrato foi, em média, de $80 \%$ para as amostras filtradas e de $73 \%$ para as amostras não-filtradas durante toda a operação e de 94\% para as amostras filtradas e de $93 \%$ para as amostras não-filtradas durante a fase estacionária. A remoção de carboidratos ilustra muito bem a forma como o processo biológico em uma temperatura baixa ocorreu de forma bastante lenta, o que pode ter sido benéfico para a produção de hidrogênio como será melhor explicado posteriormente. Ao contrário das demais condições, onde a remoção já se apresentava 
acima de 90\% logo nos primeiros dias de operação, a Condição 13 levou mais de 10 dias para atingir os mesmos $90 \%$ de remoção de lactose.

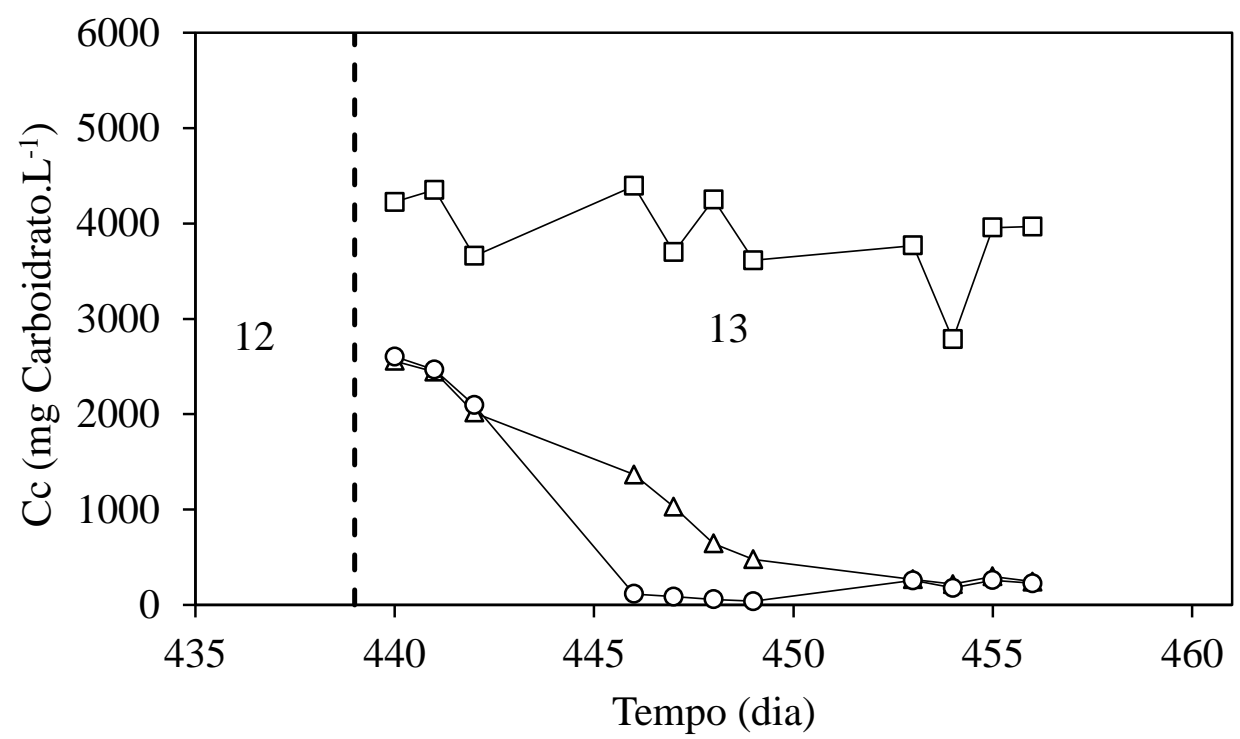

Figura 5-205 - Concentração de carboidrato: $\square$ - afluente não filtrada; $\Delta$ - efluente não filtrada; ○ - efluente filtrada (AnSBBR com recirculação da fase líquida e soro de leite Condição 13).

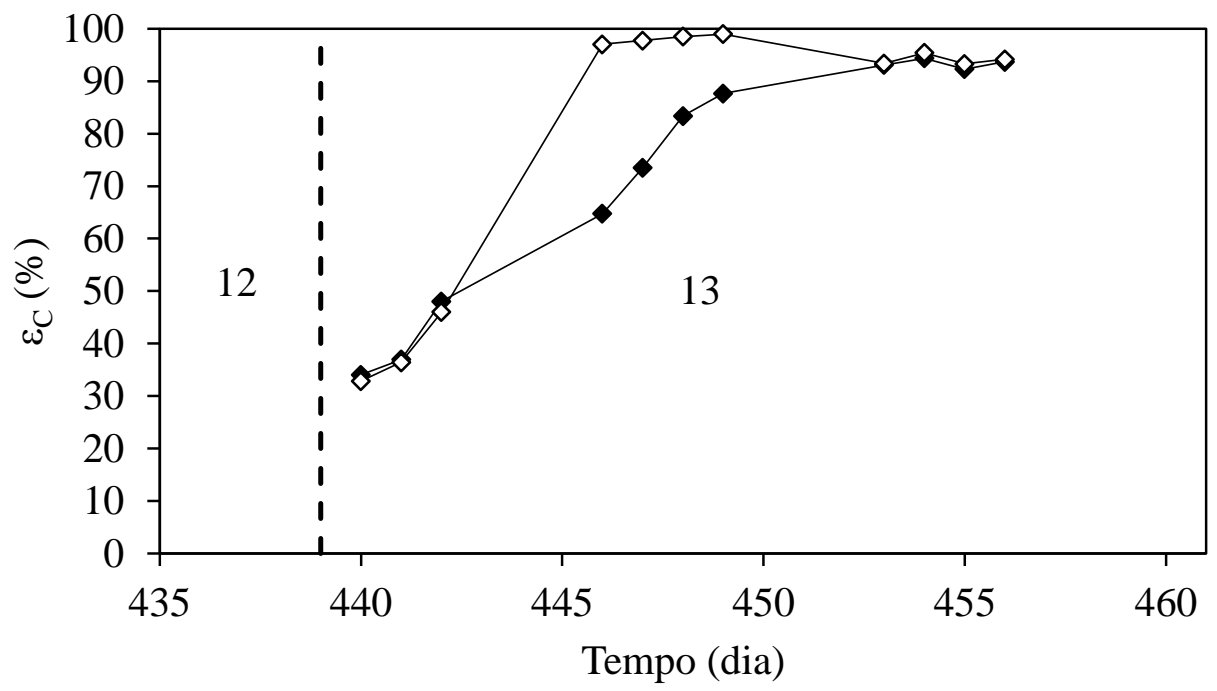

Figura 5-206 - Eficiência de remoção de carboidrato: $\diamond$ - não filltrada; $\bullet$ filtrada (AnSBBR com recirculação da fase líquida e soro de leite - Condição 13). 
As Figura 5-207, Figura 5-208 e Figura 5-209 apresentam os perfis temporais durante toda a operação (afluente e efluente) do $\mathrm{pH}$, da alcalinidade total e dos ácidos voláteis totais por titulação, respectivamente. A média dos valores de $\mathrm{pH}$ afluente durante a Condição 4 foi de 7,91 e de pH efluente foi de 4,40. A média da alcalinidade total foi de $416 \mathrm{mgCaCO}_{3} \cdot \mathrm{L}^{-1}$ para o afluente e de $71 \mathrm{mgCaCO}_{3} \cdot \mathrm{L}^{-1}$ para o efluente. $\mathrm{O}$ valor médio da concentração de ácidos voláteis totais afluente foi de $138 \mathrm{mgHAc} . \mathrm{L}^{-1} \mathrm{e}$ efluente de $1052 \mathrm{mgHAc} . \mathrm{L}^{-1}$.

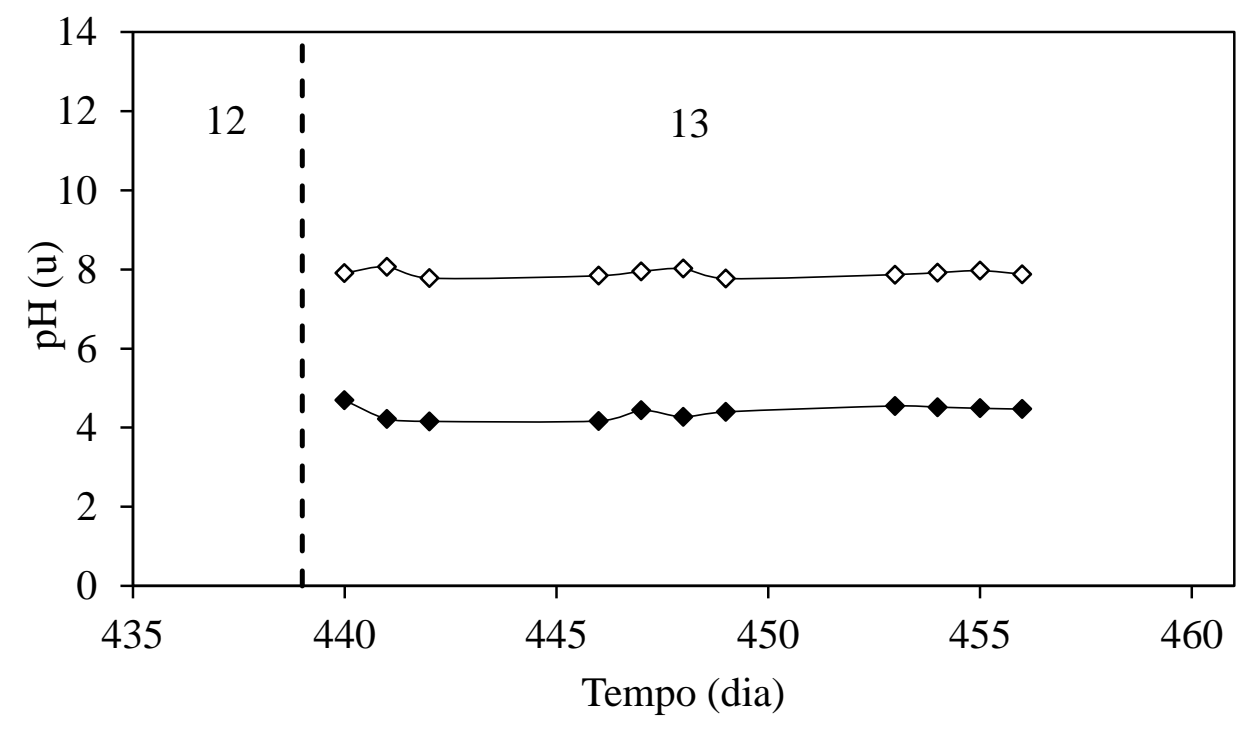

Figura 5-207 - Valores de pH: $\diamond$-afluente; - efluente (AnSBBR com recirculação da fase líquida e soro de leite - Condição 13). 


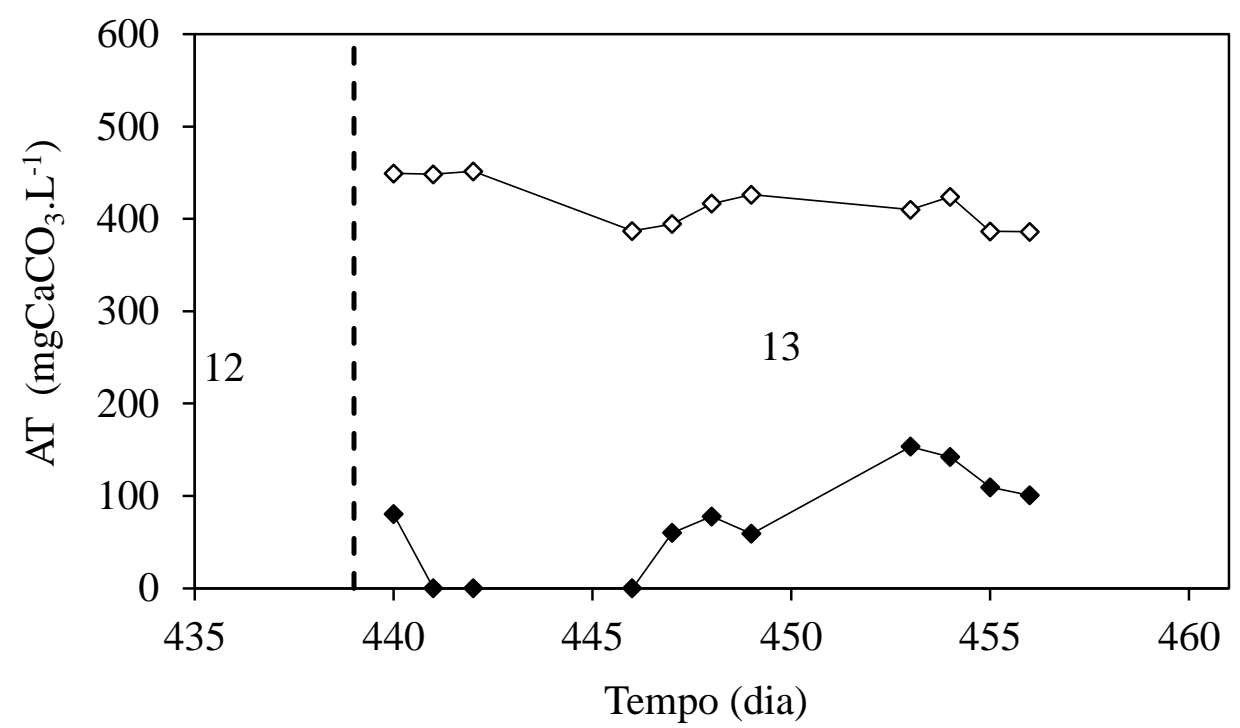

Figura 5-208 - Alcalinidade total: $\diamond$-afluente; - efluente (AnSBBR com recirculação da fase líquida e soro de leite - Condição 13).

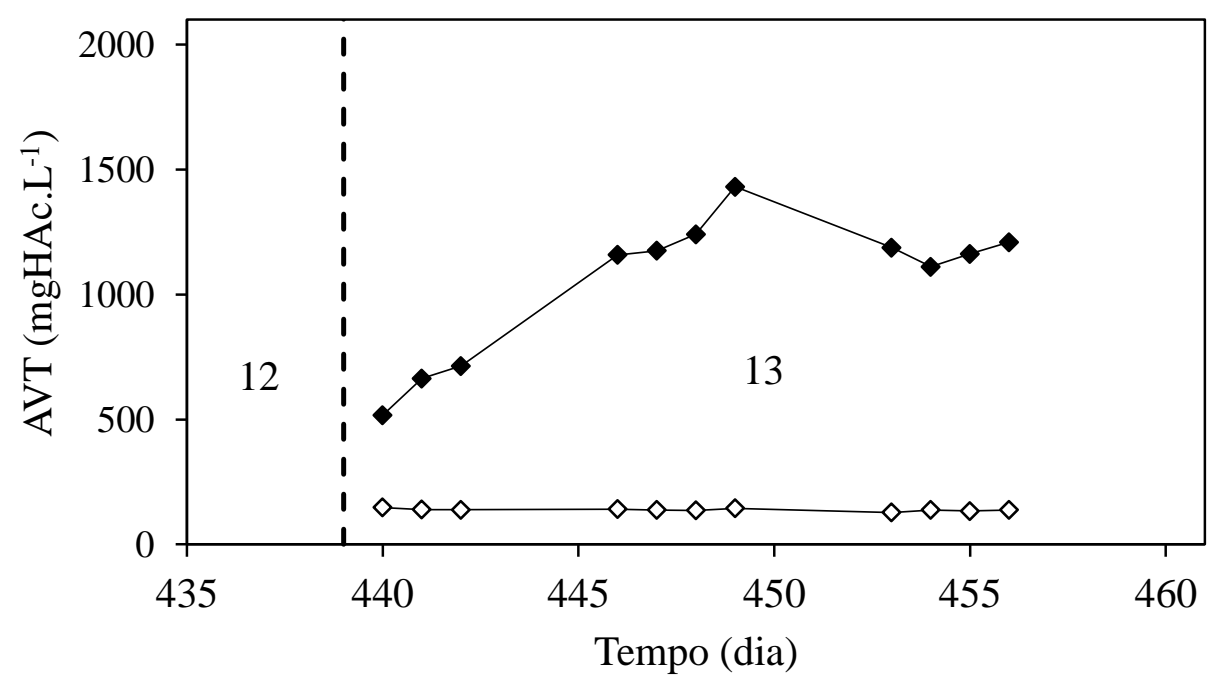

Figura 5-209 - Ácidos voláteis totais: $\diamond$-afluente; - efluente (AnSBBR com recirculação da fase líquida e soro de leite - Condição 13).

A Figura 5-210 apresenta o monitoramento dos compostos intermediários contidos no efluente do sistema, enquanto que a Tabela 5.53 apresenta os valores da concentração média destes produto. $\mathrm{O}$ ácido acético e o ácido butírico foram os maiores destaques, representando juntos aproximadamente $83 \%$ dos produtos intermediários 
(50,4\% e 32,1\%, respectivamente). Exatamente estes dois metabólitos estão ligados às rotas clássicas de produção de hidrogênio.

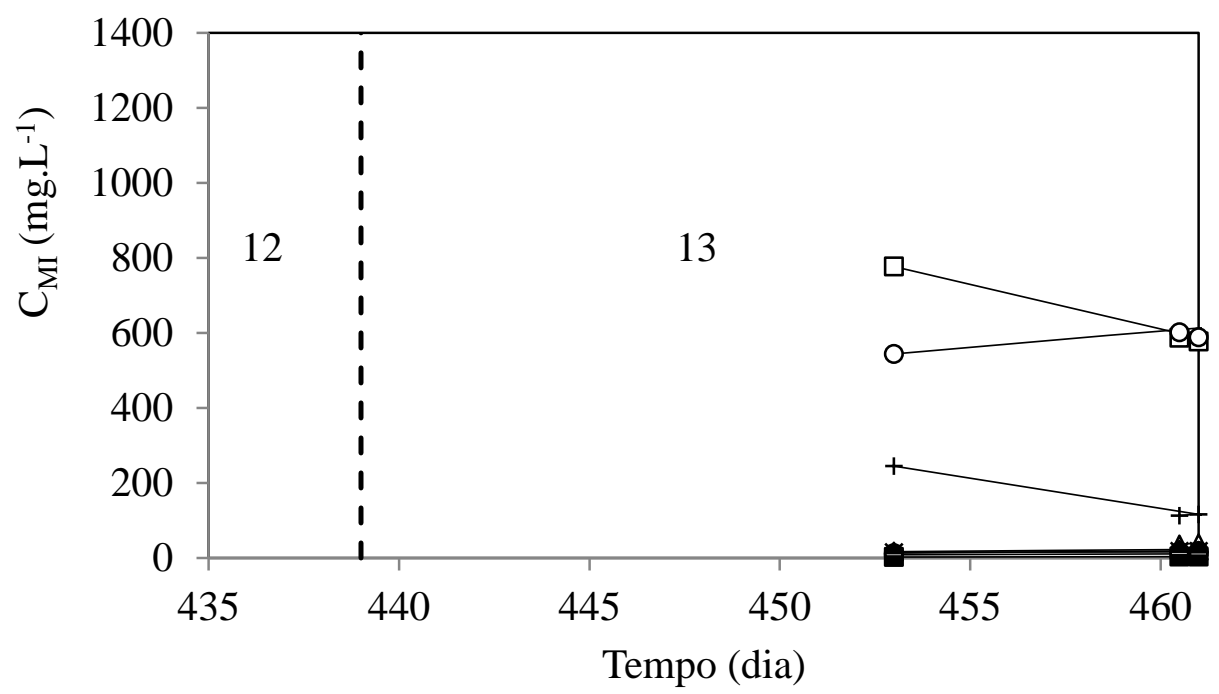

Figura 5-210 - Concentração dos compostos intermediários: $\square$ - ácido acético; $\Delta$ etanol; ○ - ácido butírico; $\mathbf{\square}$ - ácido isobutírico; $\boldsymbol{\Delta}$ - ácido capróico; $\bullet$ - ácido valérico; * ácido propiônico; +butanol; - ácido isovalérico (AnSBBR com recirculação da fase líquida e soro de leite - Condição 13).

Tabela 5.53 - Concentração e distribuição dos compostos intermediários (AnSBBR com recirculação da fase líquida e soro de leite - Condição 13).

\begin{tabular}{cccccccc}
\hline $\begin{array}{c}\text { Produtos } \\
\text { intermediários }\end{array}$ & \multicolumn{5}{c}{ Concentrações médias } & \multicolumn{3}{c}{$\begin{array}{c}\text { Distribuição } \\
\left(\mathrm{mg} . \mathrm{L}^{-1}\right)\end{array}$} & \multicolumn{1}{c}{$\left.\mathrm{mmol}_{\mathrm{L}}^{-1}\right)$} & $(\%)$ \\
\hline Acetona & 0,0 & \pm & 0,0 & 0,0 & \pm & 0,0 & 0,0 \\
Metanol & 0,0 & \pm & 0,0 & 0,0 & \pm & 0,0 & 0,0 \\
Etanol & 42,5 & \pm & 12,0 & 0,9 & \pm & 0,3 & 4,4 \\
n-Butanol & 145,5 & \pm & 66,3 & 2,0 & \pm & 0,9 & 9,5 \\
Acético & 628,7 & \pm & 98,9 & 10,5 & \pm & 1,6 & 50,4 \\
Porpiônico & 16,9 & \pm & 1,3 & 0,2 & \pm & 0,0 & 1,1 \\
Isobutírico & 3,6 & \pm & 0,8 & 0,0 & \pm & 0,0 & 0,2 \\
Butírico & 587,4 & \pm & 31,2 & 6,7 & \pm & 0,4 & 32,1 \\
Isovalérico & 10,3 & \pm & 1,4 & 0,1 & \pm & 0,0 & 0,5 \\
Valérico & 17,0 & \pm & 2,9 & 0,2 & \pm & 0,0 & 0,8 \\
Capróico & 20,5 & \pm & 3,0 & 0,2 & \pm & 0,0 & 1,0 \\
\hline
\end{tabular}


O monitoramento da série de sólidos é mostrado na Tabela 5.54, cujos valores apresentam um baixo teor de SSV no efluente e afluente, indicando a boa capacidade do reator em reter biomassa.

Tabela 5.54 - Série de sólidos afluente e efluente (AnSBBR com recirculação da fase líquida e soro de leite - Condição 13).

\begin{tabular}{lcccc}
\hline & $\begin{array}{c}\text { ST } \\
\left(\mathrm{mg} . \mathrm{L}^{-1}\right)\end{array}$ & $\begin{array}{c}\text { SVT } \\
\left(\mathrm{mg} . \mathrm{L}^{-1}\right)\end{array}$ & $\begin{array}{c}\text { SST } \\
\left(\mathrm{mg} . \mathrm{L}^{-1}\right)\end{array}$ & $\begin{array}{c}\text { SSV } \\
\left(\mathrm{mg} . \mathrm{L}^{-1}\right)\end{array}$ \\
\hline Afluente & $4263 \pm 99$ & $3576 \pm 90$ & $90 \pm 38$ & $77 \pm 4$ \\
Efluente & $3020 \pm 570$ & $2262 \pm 499$ & $305 \pm 79$ & $292 \pm 99$ \\
\hline
\end{tabular}

A produção quantitativa do biogás por ciclo é apresentada na Figura 5-211. A produção média foi de $502 \mathrm{~mL}$ (CNTP) durante toda a operação e $638 \mathrm{~mL}$ (CNTP) no estado estacionário. A Figura 5-212 apresenta o monitoramento das concentrações dos componentes do biogás no final do ciclo, enquanto que a Figura 5-213 apresenta a distribuição destes mesmos componentes. Os valores médios de concentração de $\mathrm{H}_{2}$, $\mathrm{CH}_{4}$ e $\mathrm{CO}_{2}$ foram 9,8, 0,0 e 6,7 mmol.L $\mathrm{L}^{-1}$, respectivamente. Além disso, a distribuição percentual média durante toda a operação para o $\mathrm{H}_{2}$ foi de $49,9 \%$, para o $\mathrm{CH}_{4}$ foi de 0,0 $\%$ e para o $\mathrm{CO}_{2}$ foi de $50,1 \%$. 


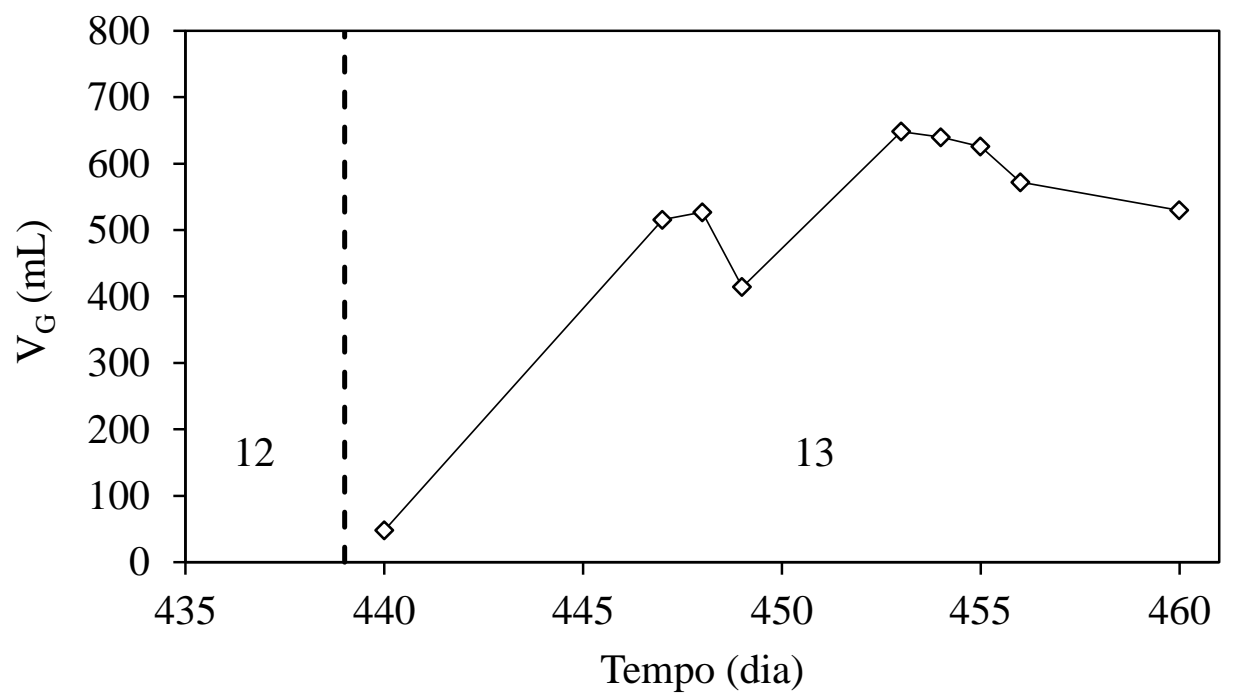

Figura 5-211 - Volume de biogás produzido por ciclo (AnSBBR com recirculação da fase líquida e soro de leite - Condição 13).

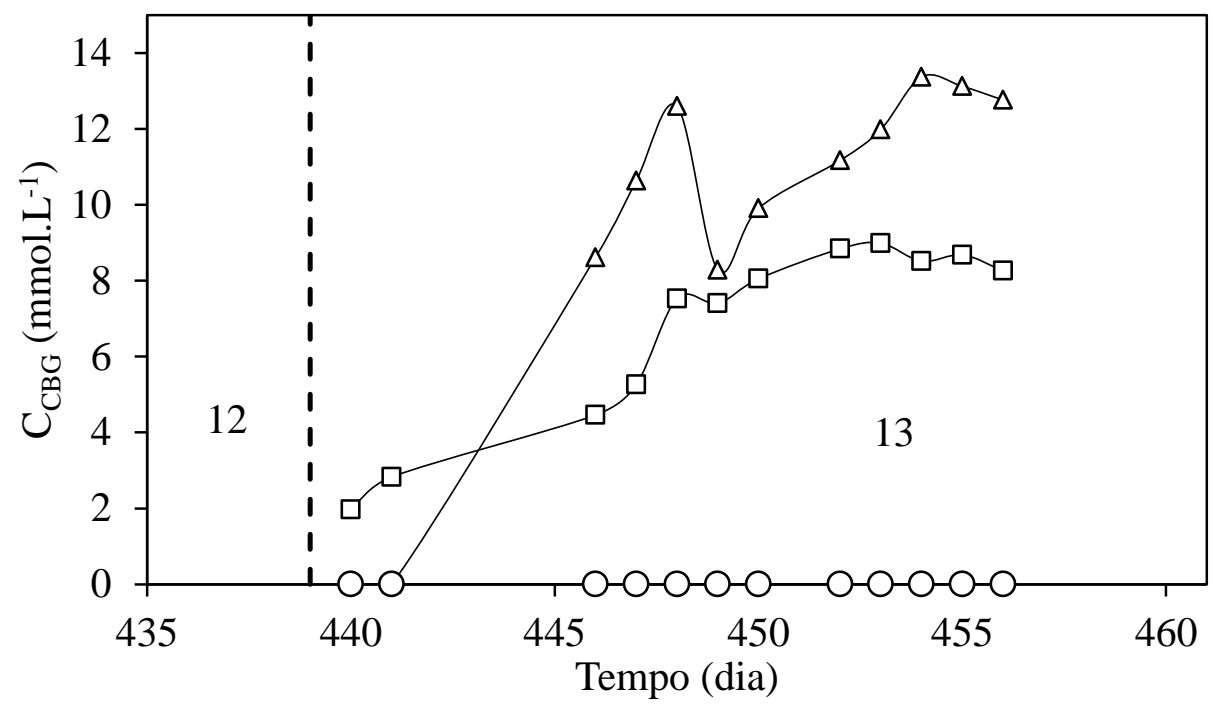

Figura 5-212 - Concentrações dos componentes do biogás no final do ciclo: $\square-\mathrm{CO}_{2} ; \Delta$ - $\mathrm{H}_{2} ; \circ-\mathrm{CH}_{4}$ (AnSBBR com recirculação da fase líquida e soro de leite - Condição 13). 


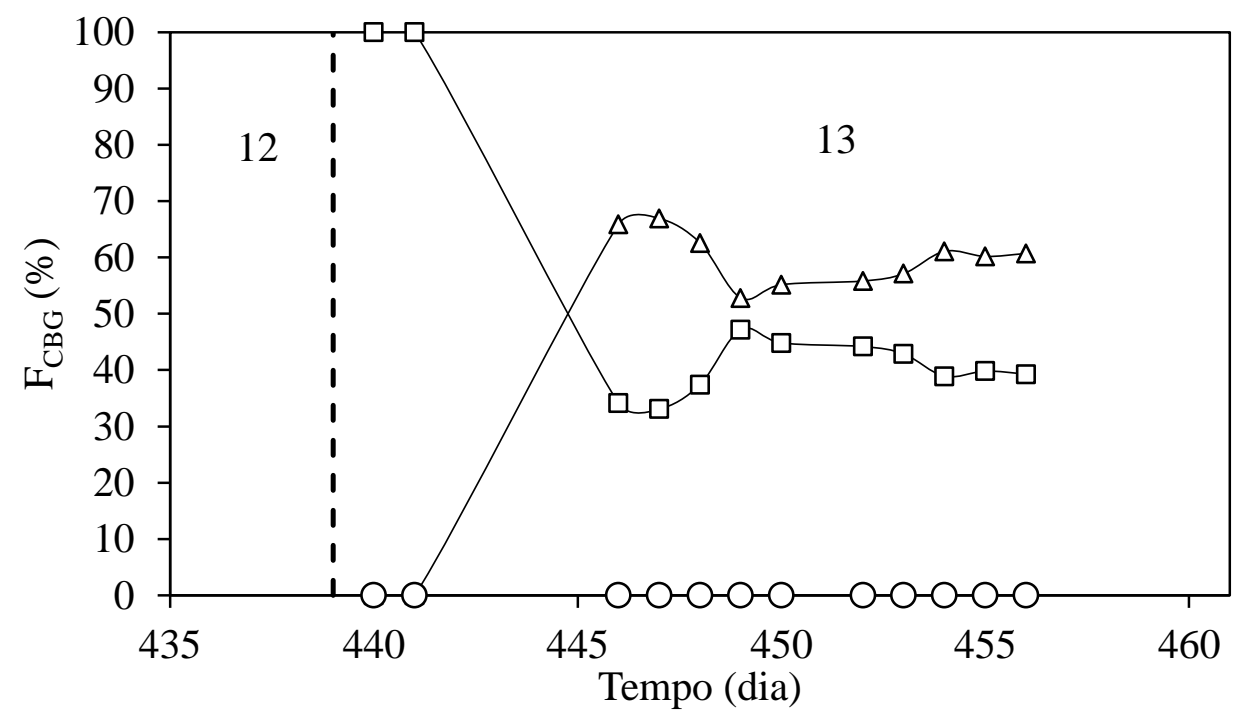

Figura 5-213 - Distribuições dos componentes do biogás no final do ciclo: $\square-\mathrm{CO}_{2} ; \Delta-$ $\mathrm{H}_{2} ;$ ○ $-\mathrm{CH}_{4}$ (AnSBBR com recirculação da fase líquida e soro de leite - Condição 13).

A lavagem periódica do material suporte não precisou ser realizada na presente condição. O principal objetivo destas lavagens nas condições anteriores foi de controlar o alto crescimento dos microrganismos dentro do reator. Porém com a baixa temperatura de operação ocorreu um controle natural do crescimento microbiano, não sendo necessária assim nenhuma lavagem para melhorar a produção de hidrogênio.

O perfil temporal foi realizado no final da operação. A Figura 5-214 apresenta a evolução da concentração de carboidrato ao longo do ciclo e a eficiência de remoção do mesmo. Ao inicio do ciclo (tempo zero) o volume afluente é diluído no volume residual resultando em uma concentração em sacarose da ordem de $2150 \mathrm{mg} \cdot \mathrm{L}^{-1}$. A conversão de carboidrato se faz de maneira progressiva ao longo do ciclo, atingindo valores na ordem de $96 \%$ no final do mesmo, com um residual aproximado de 170 mg. $\mathrm{L}^{-1}$. 


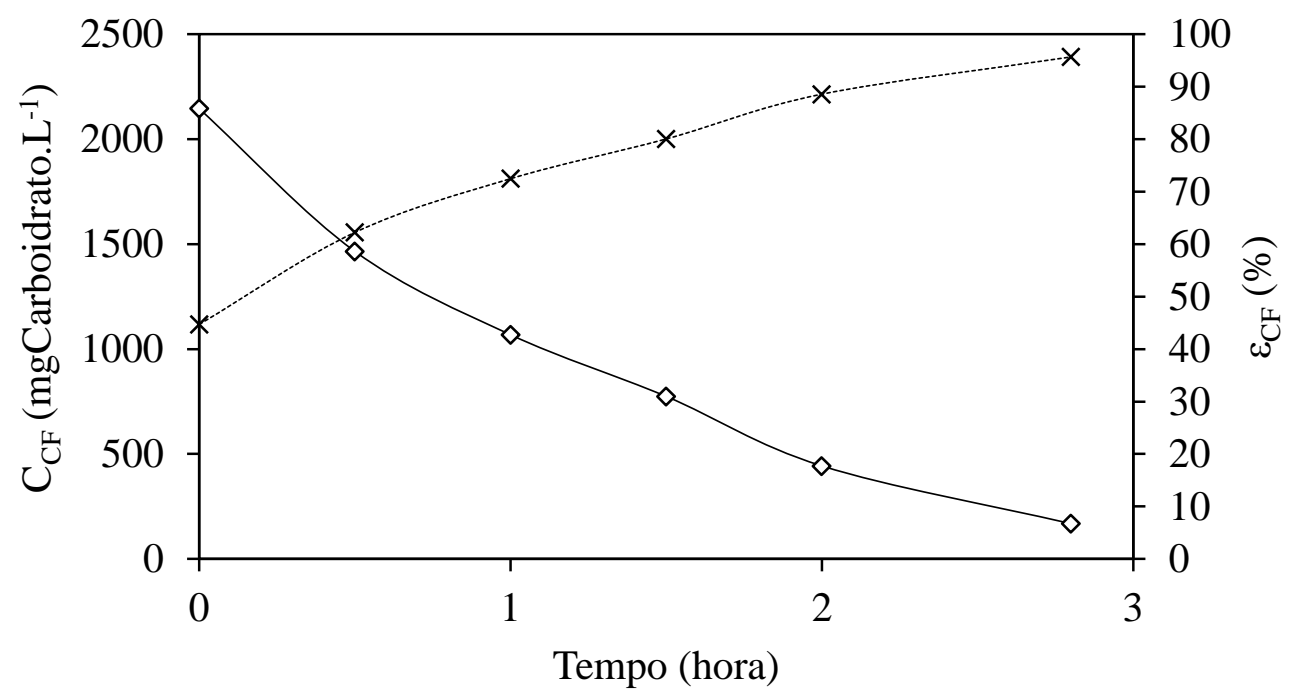

Figura 5-214 - Concentração e eficiência de degradação de carboidrato: $\diamond$ - perfil e * eficiência (AnSBBR com recirculação da fase líquida e soro de leite - Condição 13).

A Figura 5-215 apresenta a evolução da concentração de matéria orgânica ao longo do ciclo. Observa-se uma baixa remoção da DQO como esperado, levando a uma alta concentração da mesma no volume residual. Assim, no inicio do ciclo, a diluição do volume carregado pelo volume residual é realizada em proporção bem menor do que no caso dos carboidratos totais, tendo em vista que as concentrações afluente e residual são muito próximas. Porém nesta condição é possível se observar uma diminuição mais acentuada da concentração de matéria orgânica na forma de DQO, apresentando no inicio do ciclo um valor na ordem de $4480 \mathrm{mg} . \mathrm{L}^{-1}$ e no final na ordem de $3840 \mathrm{mg} . \mathrm{L}^{-1}$. 


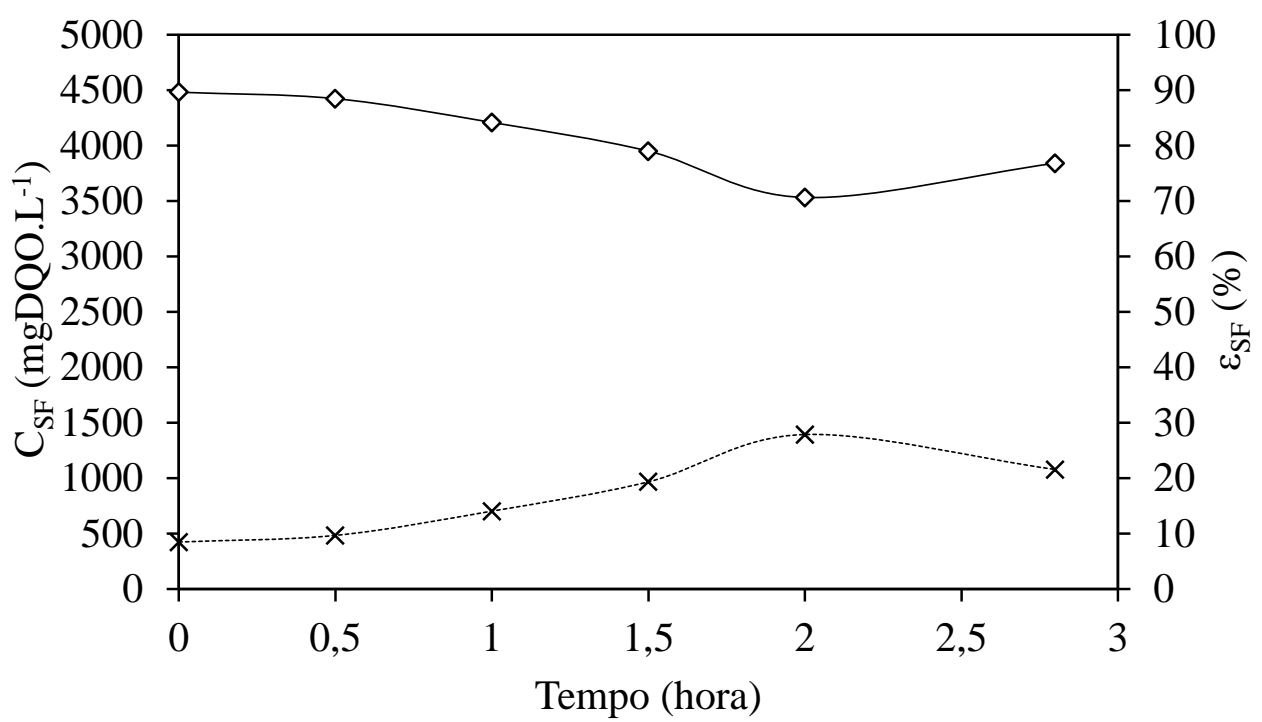

Figura 5-215 - Concentração e eficiência de degradação de matéria orgânica: $\diamond$ - perfil e * eficiência (AnSBBR com recirculação da fase líquida e soro de leite - Condição 13).

O acúmulo de ácidos voláteis totais por titulação ao longo do ciclo pode ser observado na Figura 5-216, ocorrendo um aumento nas primeiras duas horas de ciclo para então atingir um valor praticamente constante na última hora do ciclo de aproximadamente $1400 \mathrm{mgHAc} . \mathrm{L}^{-1}$.

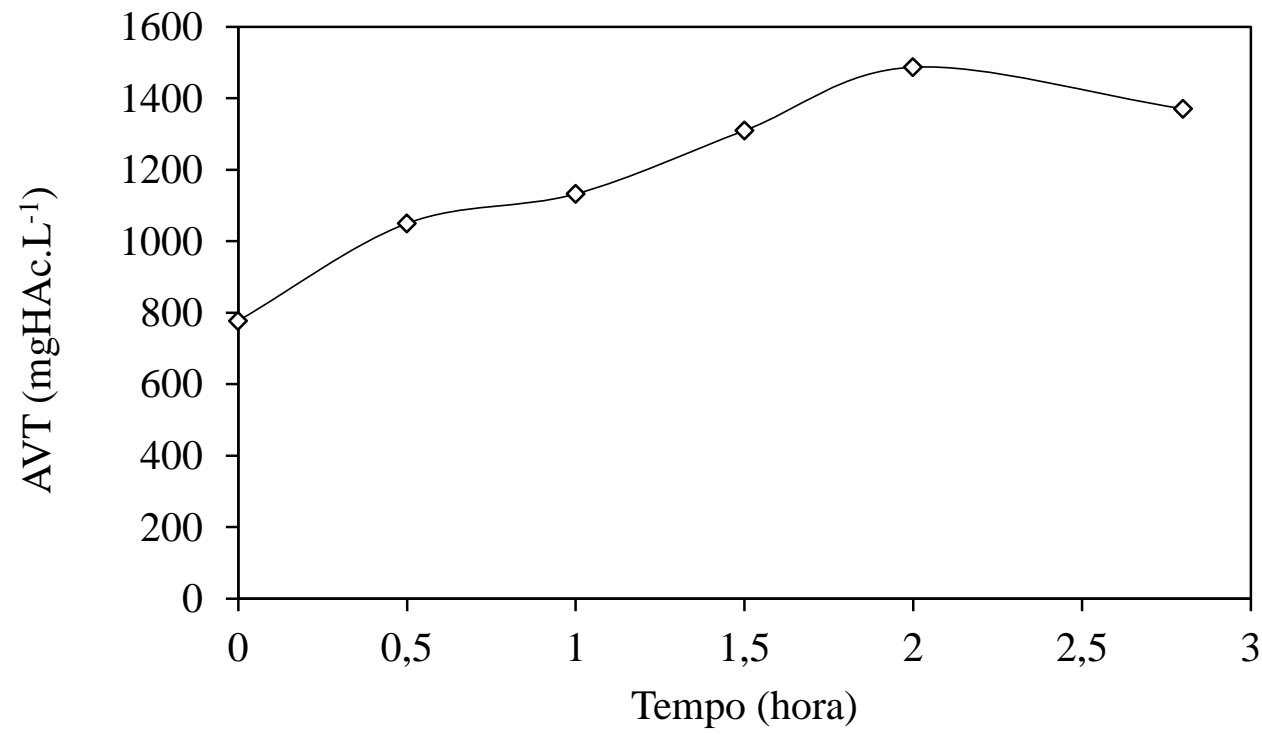

Figura 5-216 - Ácidos voláteis totais $(\diamond)$ do perfil (AnSBBR com recirculação da fase líquida e soro de leite - Condição 13). 
Os resultados dos compostos intermediários por cromatografia gasosa são apresentados na Figura 5-217. O ácido butírico apresentou o crescimento mais acentuado durante o ciclo, com os demais apresentando uma concentração praticamente constante.

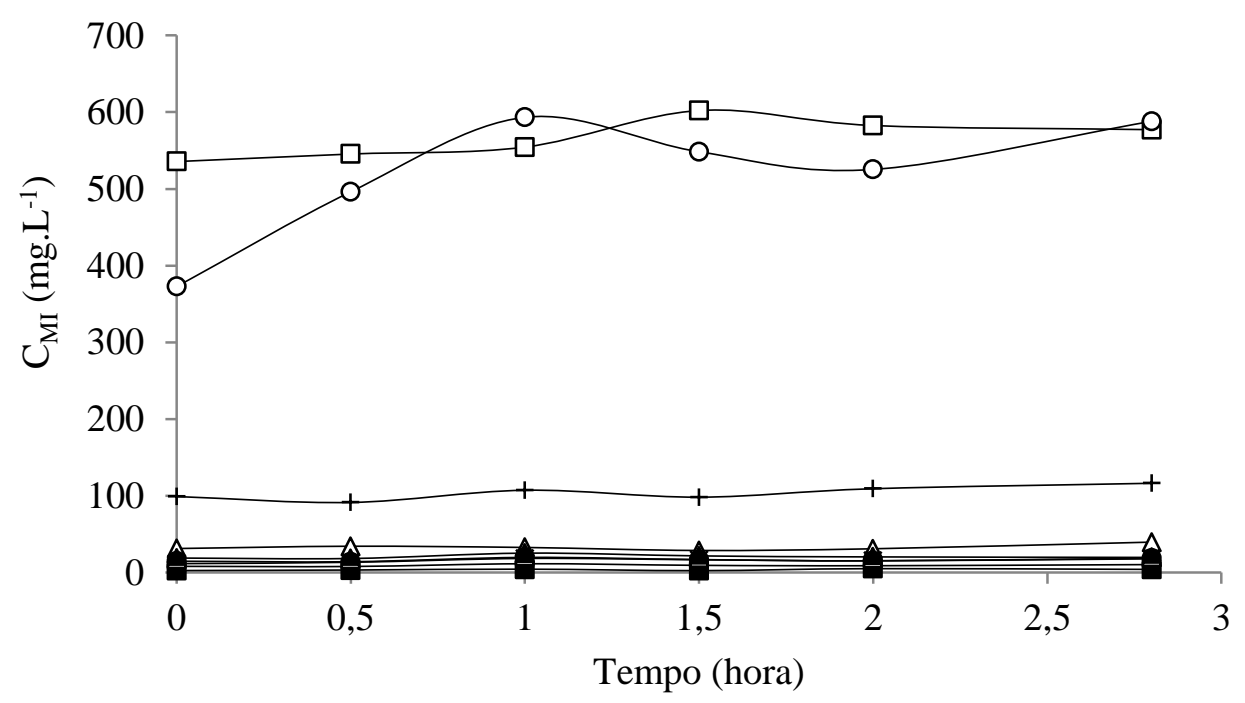

Figura 5-217 - Concentração dos compostos intermediários ao longo do ciclo: $\square-$ ácido acético; $\Delta$ - etanol; $\bigcirc$ - ácido butírico; $\mathbf{\square}$ - ácido isobutírico; $\boldsymbol{\Delta}$ - ácido capróico; $\bullet-$ ácido valérico; - -ácido propiônico; +butanol; - ácido isovalérico (AnSBBR com recirculação da fase líquida e soro de leite - Condição 13).

$\mathrm{O}$ pH diminuiu instantaneamente em relação ao afluente devido à diluição do mesmo com o volume residual no inicio do ciclo e permaneceu estável ao longo da operação conforme a Figura 5-218. A estabilidade do pH foi mantida, como pode ser visto na Figura 5-219, devido a alcalinidade que, mesmo apresentando uma queda constante, não foi completamente consumida durante o ciclo. 


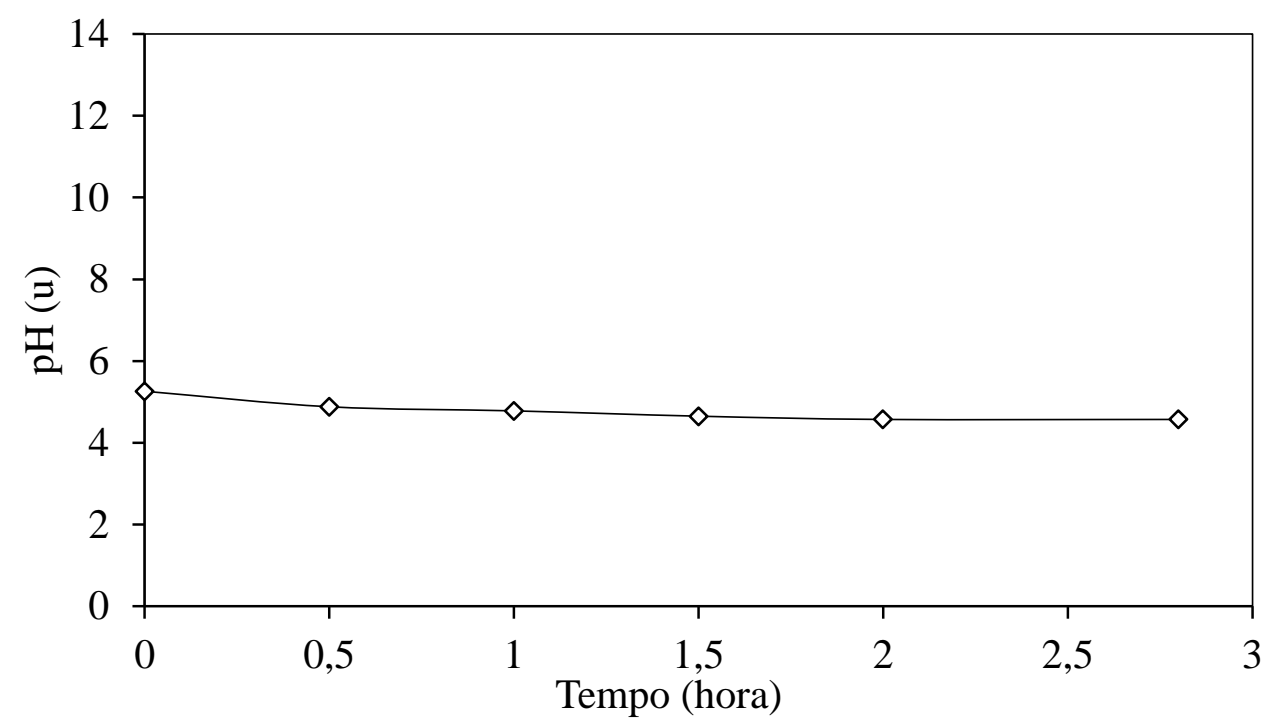

Figura 5-218 - Valores de pH $(\diamond)$ do perfil (AnSBBR com recirculação da fase líquida e soro de leite - Condição 13).

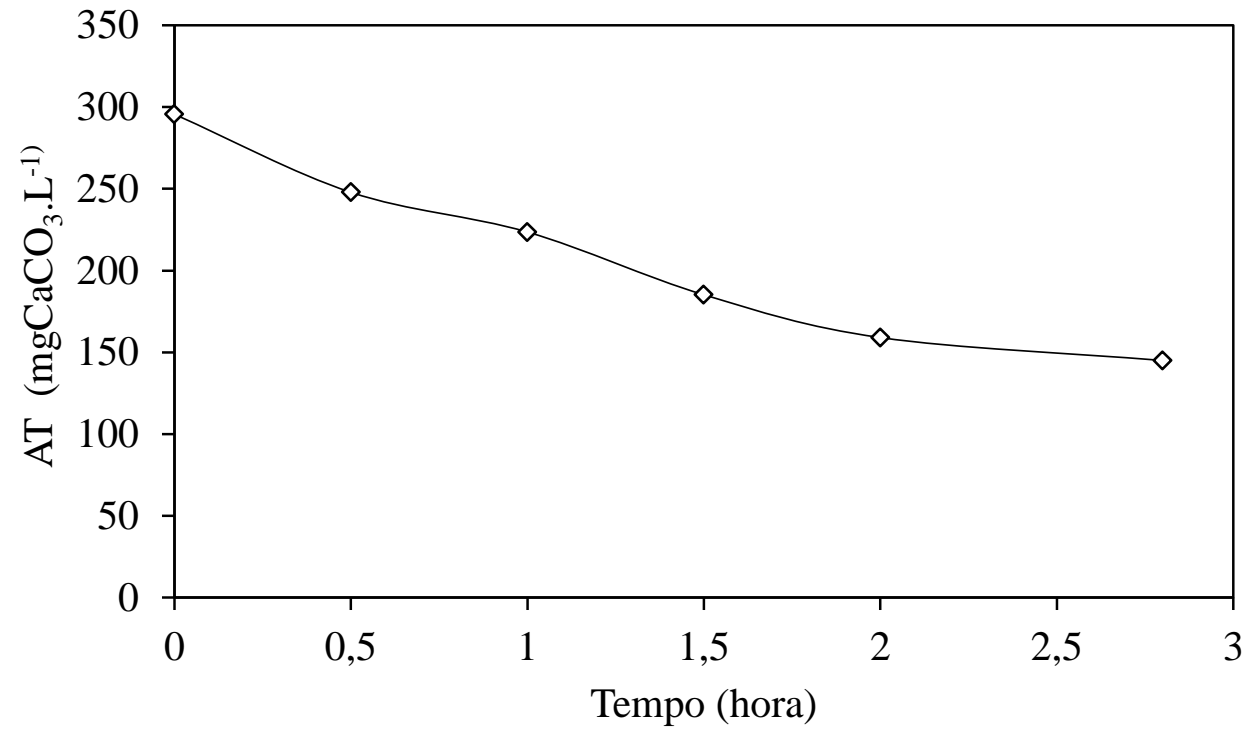

Figura 5-219 - Alcalinidade total do perfil (AnSBBR com recirculação da fase líquida e soro de leite - Condição 13).

A produção volumétrica média acumulada do biogás, realizada com os valores dos perfis quantitativos mais consistentes obtidos durante a operação, juntamente com os desvios padrões encontram-se na Figura 5-220. Ao contrário das condições anteriores, a Condição 13 apresentou uma produção crescente de biogás durante o ciclo, com uma ligeira diminuição na última hora. A Tabela 5.55 resume os valores médios da 
produção, fração molar e os volumes individuais da mistura do biogás. A Figura 5-221 apresenta os volumes acumulados médios dos perfis de $\mathrm{H}_{2}, \mathrm{CO}_{2}$ e $\mathrm{CH}_{4}$ produzidos durante o ciclo. É possível observar que não ocorreu produção de metano. Os resultados obtidos para todos os indicadores de produção de hidrogênio com a temperatura de operação mais baixa estudada foram os melhores comparados com todas as condições analisadas. Uma possível explicação para estes resultados pode estar no fato de que a temperatura baixa inibiria a ação dos microorganismos competidores como os metanogênicos e os homoacetogênicos. Os microrganismos acidogênicos por possuírem uma velocidade de crescimento maior teriam a vantagem de se desenvolver sem uma competição mais forte, mesmo em uma condição desfavorável como a apresentada na temperatura de $15^{\circ} \mathrm{C}$.

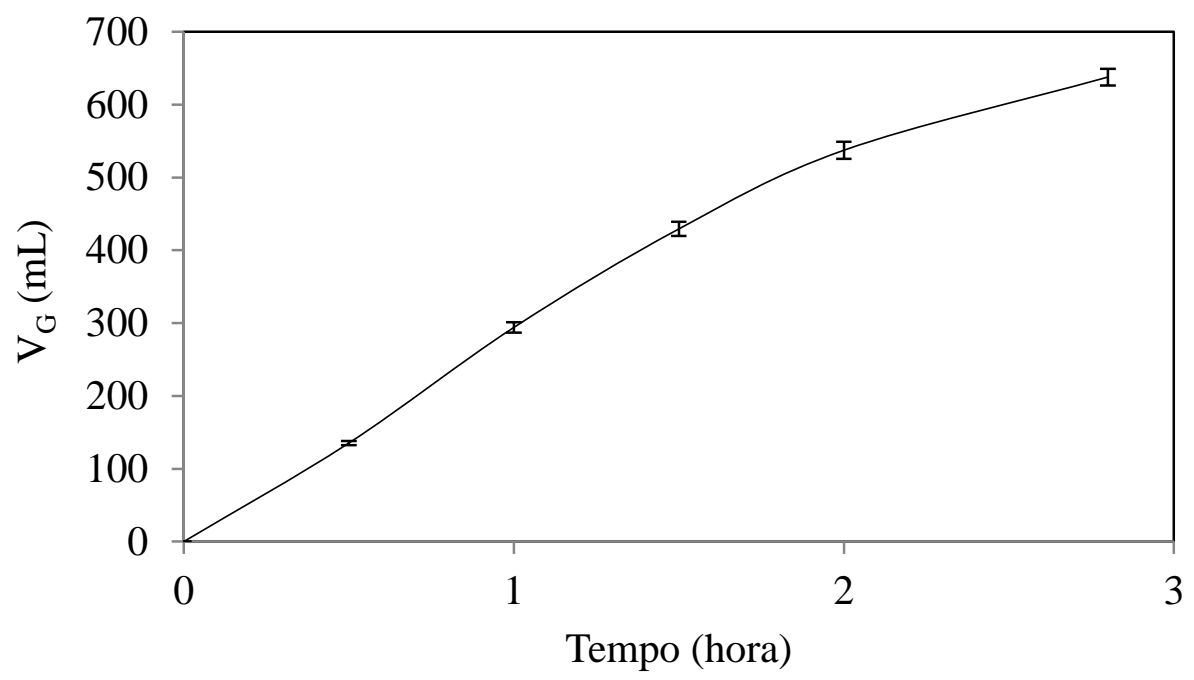

Figura 5-220 - Produção volumétrica média acumulada do biogás durante o ciclo (AnSBBR com recirculação da fase líquida e soro de leite - Condição 13). 
Tabela 5.55 - Valores médios da produção, fração molar e os volumes individuais da mistura do biogás (AnSBBR com recirculação da fase líquida e soro de leite - Condição 13).

\begin{tabular}{ccccccccccc}
$\begin{array}{c}\text { Tempo } \\
(\mathrm{h})\end{array}$ & $\begin{array}{c}\mathrm{V}_{\mathrm{G}} \\
(\mathrm{mL}-\mathrm{CNTP})\end{array}$ & \multicolumn{3}{c}{$\mathrm{C}_{\mathrm{G}}\left(\mathrm{mmol} \cdot \mathrm{L}^{-1}\right)$} & \multicolumn{3}{c}{ Fração Molar (\%) } & \multicolumn{3}{c}{ Volume (mL $-\mathrm{CNTP})$} \\
& & $\mathrm{H}_{2}$ & $\mathrm{CO}_{2}$ & $\mathrm{CH}_{4}$ & $\mathrm{H}_{2}$ & $\mathrm{CO}_{2}$ & $\mathrm{CH}_{4}$ & $\mathrm{H}_{2}$ & $\mathrm{CO}_{2}$ & $\mathrm{CH}_{4}$ \\
\hline 0,0 & 0,0 & 0,0 & 0,0 & 0,0 & 0,0 & 0,0 & 0,0 & 0,0 & 0,0 & 0,0 \\
0,5 & 135,3 & 6,2 & 3,4 & 0,0 & 64,5 & 35,5 & 0,0 & 87,3 & 48,0 & 0,0 \\
1,0 & 294,0 & 9,0 & 5,7 & 0,0 & 61,4 & 38,6 & 0,0 & 184,7 & 109,2 & 0,0 \\
1,5 & 429,2 & 12,4 & 7,7 & 0,0 & 61,6 & 38,4 & 0,0 & 268,0 & 161,2 & 0,0 \\
2,0 & 537,3 & 12,8 & 8,1 & 0,0 & 61,2 & 38,8 & 0,0 & 334,1 & 203,1 & 0,0 \\
2,8 & 637,8 & 13,1 & 8,2 & 0,0 & 61,5 & 38,5 & 0,0 & 395,9 & 241,8 & 0,0 \\
\hline
\end{tabular}

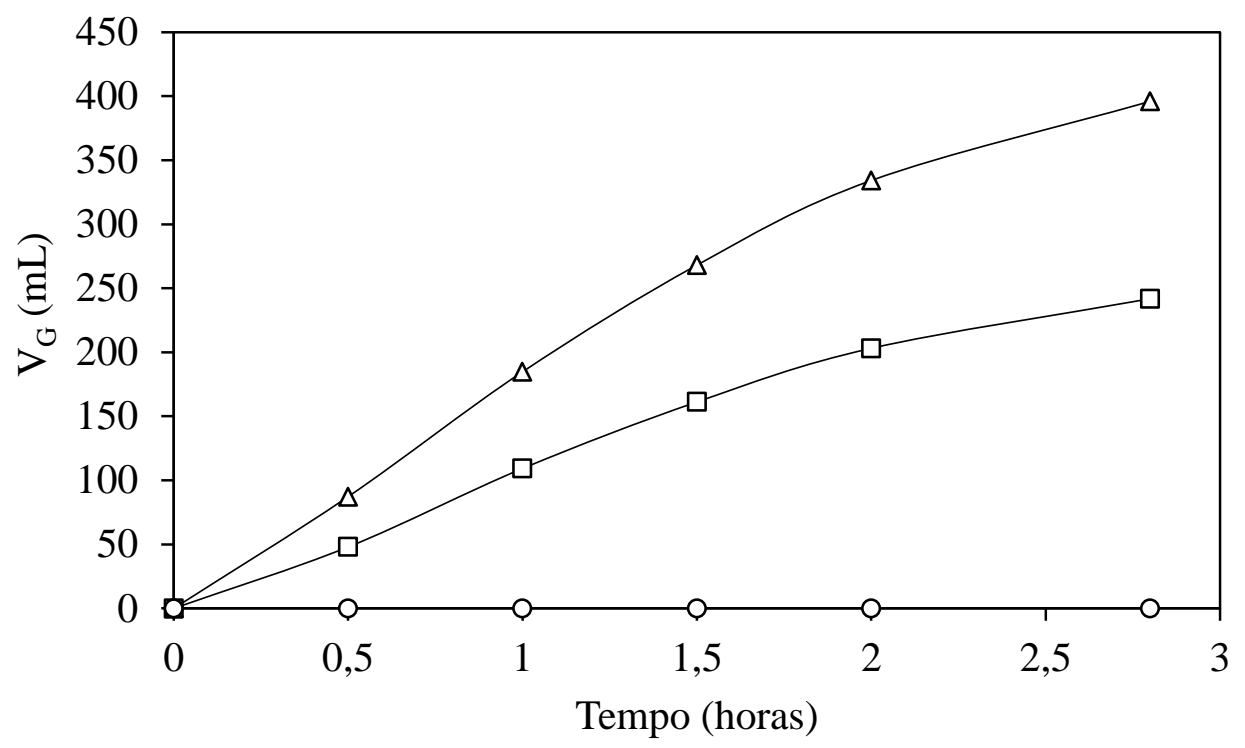

Figura 5-221 - Volumes acumulados médios produzidos ao longo do ciclo: $\square-\mathrm{CO}_{2} ; \Delta$ $\mathrm{H}_{2} ;$ o - $\mathrm{CH}_{4}$ (AnSBBR com recirculação da fase líquida e soro de leite - Condição 13). 


\subsection{AnSBBR com agitação mecânica e lactose como substrato}

O AnSBBR com agitação mecânica alimentado com lactose pura foi utilizado para estudos complementares devido ao fato do referido carboidrato ser o principal componente do soro de leite, buscando deste forma uma melhor compreensão da aplicação deste para produção de biohidrogênio.

5.3.1. Condição $1\left(D Q O=3600 \mathrm{mg}^{-L^{-1}}\right.$ e $t_{C}=4$ horas $)$

A condição experimental 1, com COAV nominal de 9,3 $\mathrm{kgDQO} \cdot \mathrm{m}^{-3} \cdot \mathrm{d}^{-1} \mathrm{e}$ duração do ciclo de 4 horas, durou do dia 01 ao dia 23 (23 dias de operação). A Tabela 5.56 apresenta os valores médios dos parâmetros monitorados. 
Tabela 5.56 - Valores médios dos parâmetros monitorados na condição 1 (Lactose $\left.3600 \mathrm{mgDQO} . \mathrm{L}^{-1}-\mathrm{t}_{\mathrm{C}} 4 \mathrm{~h}\right)$

\begin{tabular}{|c|c|c|c|c|c|c|c|c|c|c|}
\hline \multicolumn{2}{|r|}{ Parâmetro } & \multicolumn{5}{|c|}{ Afluente } & \multicolumn{4}{|c|}{ Efluente } \\
\hline $\mathrm{C}_{\mathrm{ST}}$ & $\left(\mathrm{mgDQO} \cdot \mathrm{L}^{-1}\right)$ & 3392 & \pm & 305 & & $9 \quad$ & 2890 & \pm & 186 & $(9$ \\
\hline $\mathrm{C}_{\mathrm{SF}}$ & $\left(\mathrm{mgDQO} \cdot \mathrm{L}^{-1}\right)$ & - & \pm & - & ( & 3 ) & 2692 & \pm & 447 & $(9)$ \\
\hline$\varepsilon_{\mathrm{ST}}$ & $(\%)$ & - & & - & & & 15 & \pm & 5 & $(9)$ \\
\hline$\varepsilon_{\mathrm{SF}}$ & $(\%)$ & - & & - & & & 21 & \pm & 13 & $(9$ \\
\hline $\mathrm{C}_{\mathrm{CT}}$ & $\left(\mathrm{mgCarboidrato} . \mathrm{L}^{-1}\right)$ & 3121 & \pm & 423 & $(1$ & $1)$ & 62 & \pm & 150 & $(11)$ \\
\hline $\mathrm{C}_{\mathrm{CF}}$ & $\left(\mathrm{mgCarboidrato} . \mathrm{L}^{-1}\right)$ & - & \pm & - & & & 48 & \pm & 115 & $(11)$ \\
\hline$\varepsilon_{\mathrm{CT}}$ & $(\%)$ & - & & - & & & 98 & \pm & 4 & $(11)$ \\
\hline$\varepsilon_{\mathrm{CF}}$ & $(\%)$ & - & & - & & & 98 & \pm & 3 & $(11)$ \\
\hline $\mathrm{pH}$ & (u) & 7,80 & \pm & 0,04 & $(1$ & $1)$ & 4,27 & \pm & 0,13 & $(11$ \\
\hline AVT & $\left(\mathrm{mgHAc} . \mathrm{L}^{-1}\right)$ & 23 & \pm & 5 & $(1$ & 1 ) & 1031 & \pm & 92 & $(11$ \\
\hline AT & $\left(\mathrm{mgCaCO}_{3} \cdot \mathrm{L}^{-1}\right)$ & 317 & \pm & 29 & $(1$ & $1)$ & 18 & \pm & 16 & $(11$ \\
\hline $\mathrm{AP}$ & $\left(\mathrm{mgCaCO}_{3} \cdot \mathrm{L}^{-1}\right)$ & 232 & \pm & 27 & $(1$ & 1 ) & 0 & \pm & 0 & $(11$ \\
\hline AI & $\left(\mathrm{mgCaCO}_{3} \cdot \mathrm{L}^{-1}\right)$ & 85 & \pm & 17 & $(1$ & $1)$ & 18 & \pm & 16 & $(11$ \\
\hline $\mathrm{AB}$ & $\left(\mathrm{mgCaCO}_{3} \cdot \mathrm{L}^{-1}\right)$ & 301 & \pm & 27 & $(1$ & $1)$ & 0 & \pm & 0 & $(11)$ \\
\hline ST & $\left(\mathrm{mg} \cdot \mathrm{L}^{-1}\right)$ & 3011 & \pm & 68 & ( & $5)$ & 1699 & \pm & 97 & $(5)$ \\
\hline STV & $\left(\mathrm{mg} \cdot \mathrm{L}^{-1}\right)$ & 258 & \pm & 66 & ( & $5)$ & 1344 & \pm & 77 & $(5)$ \\
\hline SST & $\left(\mathrm{mg} \cdot \mathrm{L}^{-1}\right)$ & 30 & \pm & 34 & ( & $5)$ & 69 & \pm & 38 & $\left(\begin{array}{l}5 \\
)\end{array}\right)$ \\
\hline SSV & $\left(\mathrm{mg} \cdot \mathrm{L}^{-1}\right)$ & 12 & \pm & 16 & ( & $5)$ & 63 & \pm & 6 & $(5$ \\
\hline $\mathrm{M}_{\mathrm{STV}}$ & (g) & - & & - & & & 17,9 & & - & \\
\hline $\mathrm{C}_{\mathrm{X}}$ & $\left(\mathrm{g} \cdot \mathrm{L}^{-1}\right)$ & - & & - & & & 4,6 & & - & \\
\hline $\mathrm{C}_{\mathrm{X}}{ }^{\prime}$ & $\left(\right.$ g.gsuporte $\left.{ }^{-1}\right)$ & - & & - & & & 0,018 & & - & \\
\hline $\mathrm{V}_{\mathrm{G}}$ & (mL-CNTP) & - & & - & & & 747 & \pm & 39 & $(3$ \\
\hline $\mathrm{V}_{\mathrm{H} 2}$ & (mL-CNTP) & - & & - & & & 149 & \pm & - & $(1$ \\
\hline $\mathrm{COAV}_{\mathrm{STA}}$ & $\left(\mathrm{kgDQO} \cdot \mathrm{m}^{-3} \cdot \mathrm{d}^{-1}\right)$ & 8,7 & & - & & & - & & - & \\
\hline $\mathrm{CORV}_{\mathrm{SFE}}$ & $\left(\mathrm{kgDQO} \cdot \mathrm{m}^{-3} \cdot \mathrm{d}^{-1}\right)$ & - & & - & & & 1,8 & & - & \\
\hline $\operatorname{COAV}_{\mathrm{CTA}}$ & $\left(\right.$ kgCarboidrato. $\left.\mathrm{m}^{-3} \cdot \mathrm{d}^{-1}\right)$ & 8,0 & & - & & & - & & - & \\
\hline $\mathrm{CORV}_{\mathrm{CFE}}$ & $\left(\right.$ kgCarboidrato. $\left.\mathrm{m}^{-3} \cdot \mathrm{d}^{-1}\right)$ & - & & - & & & 7,9 & & - & \\
\hline $\mathrm{COAE}_{\mathrm{STA}}$ & $\left(\mathrm{kgDQO} \cdot \mathrm{kgSTV}^{-1} \cdot \mathrm{d}^{-1}\right)$ & 1,7 & & - & & & - & & - & \\
\hline $\mathrm{CORE}_{\mathrm{SFE}}$ & $\left(\mathrm{kgDQO} \cdot \mathrm{kgSTV}^{-1} \cdot \mathrm{d}^{-1}\right)$ & - & & - & & & 0,35 & & - & \\
\hline $\mathrm{COAE}_{\mathrm{CTA}}$ & $\left(\mathrm{kgCarboidrato} \mathrm{kgSTV}^{-1} \cdot \mathrm{d}^{-1}\right)$ & 1,6 & & - & & & - & & - & \\
\hline $\mathrm{CORE}_{\mathrm{CFE}}$ & $\left(\mathrm{kgCarboidrato} \mathrm{kgSTV}^{-1} \cdot \mathrm{d}^{-1}\right)$ & - & & - & & & 1,6 & & - & \\
\hline $\mathrm{RMCR}_{\mathrm{C}, \mathrm{n}}$ & $\left(\mathrm{molH}_{2}\right.$ molCarboidrato $\left.^{-1}\right)$ & - & & - & & & 0,49 & & - & \\
\hline $\mathrm{n}_{\mathrm{H} 2}$ & $\left(\mathrm{molH}_{2} \cdot \mathrm{d}^{-1}\right)$ & - & & - & & & 0,040 & & - & \\
\hline PrM & $\left(\mathrm{molH}_{2} \cdot \mathrm{m}^{-3} \cdot \mathrm{d}^{-1}\right)$ & - & & - & & & 10,2 & & - & \\
\hline PrME & $\left(\mathrm{molH}_{2} \cdot \mathrm{kgSVT}^{-1} \cdot \mathrm{d}^{-1}\right)$ & - & & - & & & 2,2 & & - & \\
\hline $\mathrm{RMCA}_{\mathrm{S}, \mathrm{m}}$ & $\left(\mathrm{molH}_{2} \cdot \mathrm{kgDQO}^{-1} \cdot \mathrm{d}^{-1}\right)$ & 1,3 & & - & & & - & & - & \\
\hline $\mathrm{RMCA}_{\mathrm{C}, \mathrm{m}}$ & $\left(\mathrm{molH}_{2} \cdot \mathrm{kg}^{-1} \cdot \mathrm{d}^{-1}\right)$ & 1,4 & & - & & & - & & - & \\
\hline $\mathrm{RMCR}_{\mathrm{S}, \mathrm{m}}$ & $\left(\mathrm{molH}_{2} \cdot \mathrm{kgDQO}^{-1} \cdot \mathrm{d}^{-1}\right)$ & - & & - & & & 6,3 & & - & \\
\hline $\mathrm{RMCR}_{\mathrm{C}, \mathrm{m}}$ & $\left(\mathrm{molH}_{2} \cdot \mathrm{kg}^{-1} \cdot \mathrm{d}^{-1}\right)$ & - & & - & & & 1,4 & & - & \\
\hline $\mathrm{V}_{\mathrm{R}}$ & $(\mathrm{mL})$ & 2420 & \pm & - & ( & ) & - & & - & \\
\hline $\mathrm{V}_{\mathrm{A}}$ & $(\mathrm{mL})$ & 1516 & \pm & 32 & & $0 \quad)$ & - & & - & \\
\hline
\end{tabular}

(*) Entre parêntese o número de amostras considerado no cálculo da média 
A Figura 5-222 apresenta os valores da concentração afluente (amostras não filtradas) e efluente (amostras não filtradas e filtradas) de matéria orgânica (DQO) nos sistema, enquanto que a Figura 5-223 apresenta a eficiência de remoção do mesmo parâmetro durante o monitoramento diário. Esta eficiência atingiu, em média, 17\% para as amostras filtradas e $13 \%$ para amostras não filtradas. A média de concentração afluente para amostras não filtradas do substrato foi de $3392 \mathrm{mgDQO} . \mathrm{L}^{-1}$ e de 2980 mgDQO. $L^{-1}$ e $2692 \mathrm{mgDQO} . \mathrm{L}^{-1}$ para amostras de efluente não filtradas e filtradas, respectivamente. A baixa eficiência de remoção de DQO é algo esperado no processo de produção de hidrogênio, tendo em vista que ocorre a formação de ácidos e solventes.

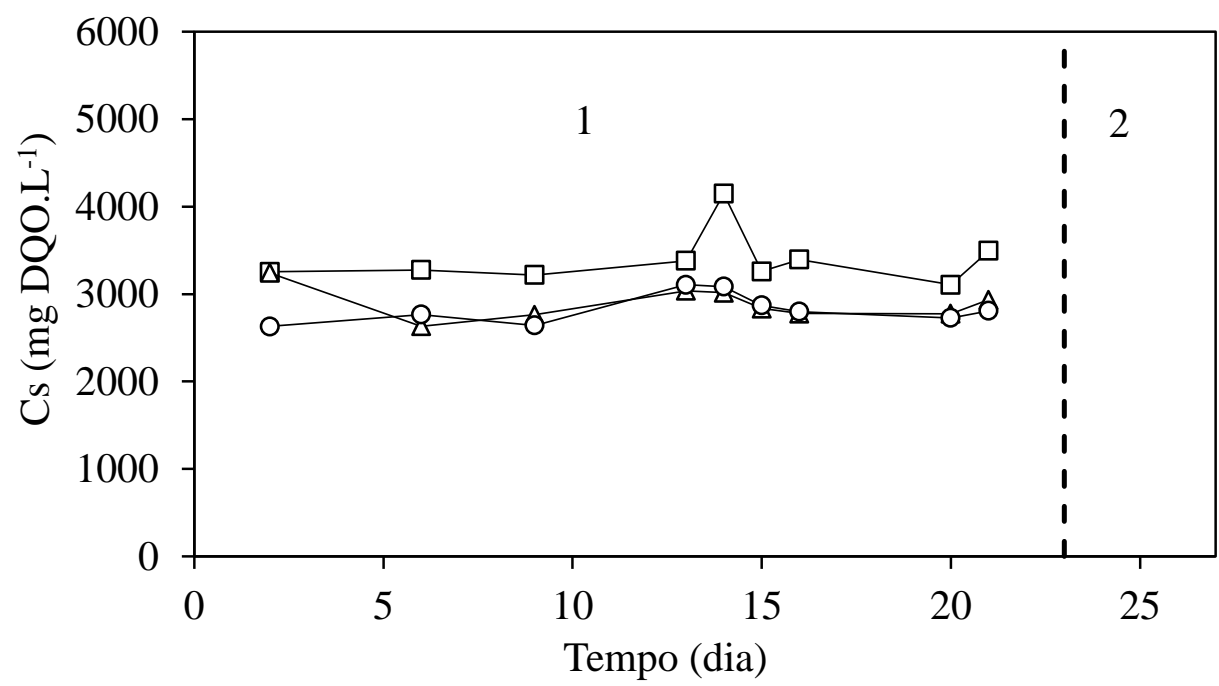

Figura 5-222 - Concentração de matéria orgânica (DQO): $\square$ - afluente não filtrada; $\Delta$ efluente não filtrada; o - efluente filtrada (AnSBBR com agitação mecânica e lactose Condição 1). 


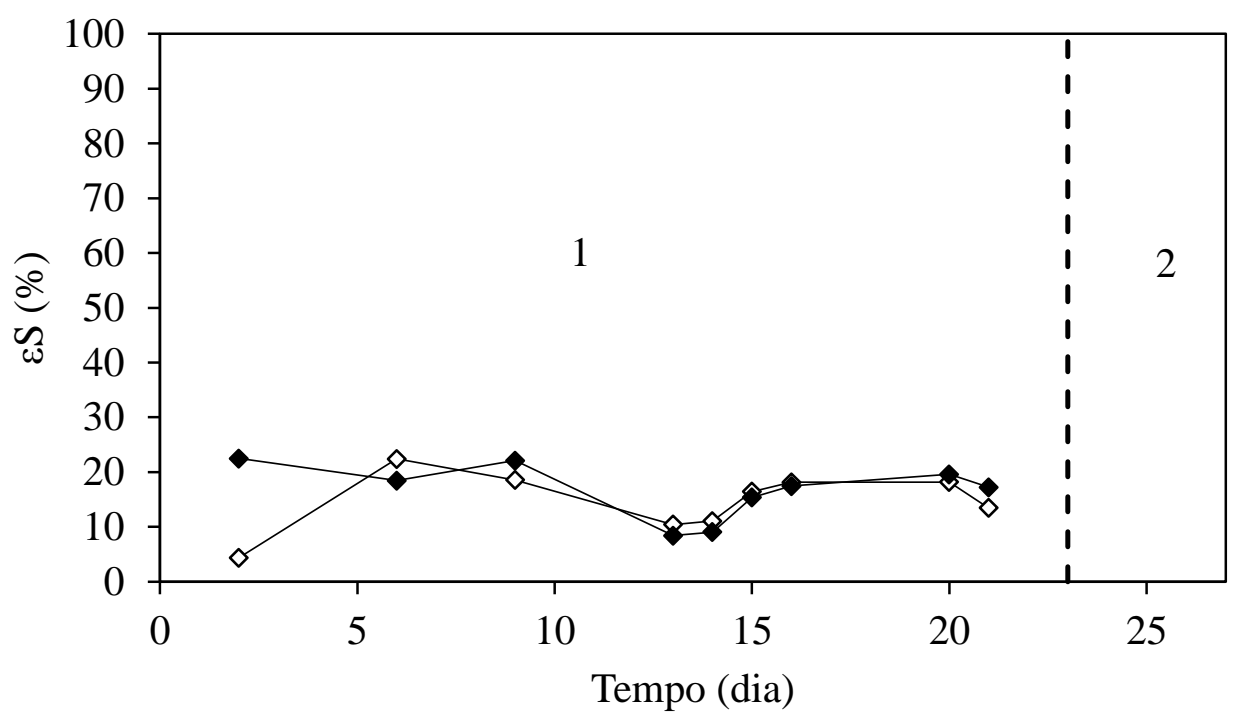

Figura 5-223-Eficiência de remoção de matéria orgânica (DQO): $\diamond$ - não filtrada; filtrada (AnSBBR com agitação mecânica e lactose - Condição 1).

A Figura 5-224 mostra os valores da concentração de carboidratos afluente e efluente (para amostras filtradas e não filtradas). A Figura 5-225 apresenta a eficiência de remoção do mesmo parâmetro (para amostras filtradas e não filtradas) durante o monitoramento diário. A média da concentração afluente foi de $3121 \mathrm{mgCarboidrato.L^{- }}$ ${ }^{1}$, enquanto que a concentração residual não filtrada foi de $62 \mathrm{mgCarboidrato.}^{-1}$ e 48 mgCarboidrato. $\mathrm{L}^{-1}$ para a concentração residual filtrada. A eficiência de remoção de lactose foi, em média, de $98 \%$ para ambas as amostras (filtradas e não filtradas). 


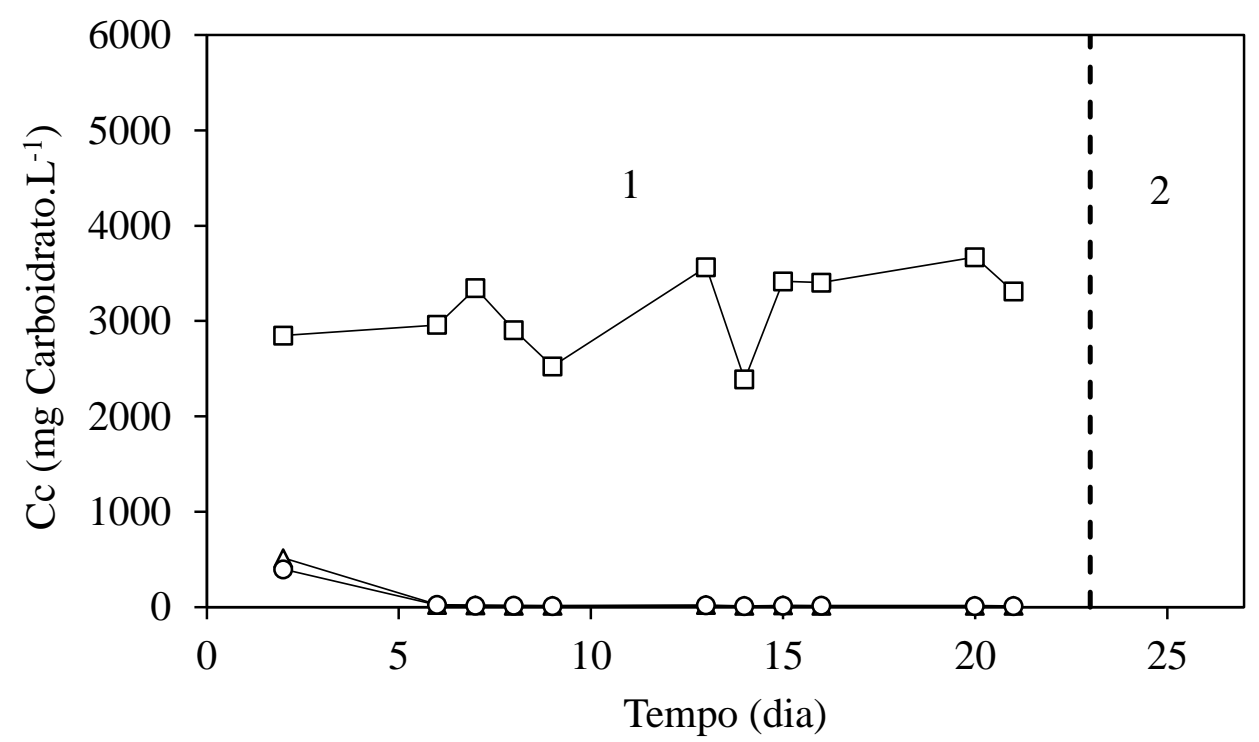

Figura 5-224 - Concentração de carboidrato: $\square$ - afluente não filtrada; $\Delta$ - efluente não filtrada; ○ - efluente filtrada (AnSBBR com agitação mecânica e lactose - Condição 1).

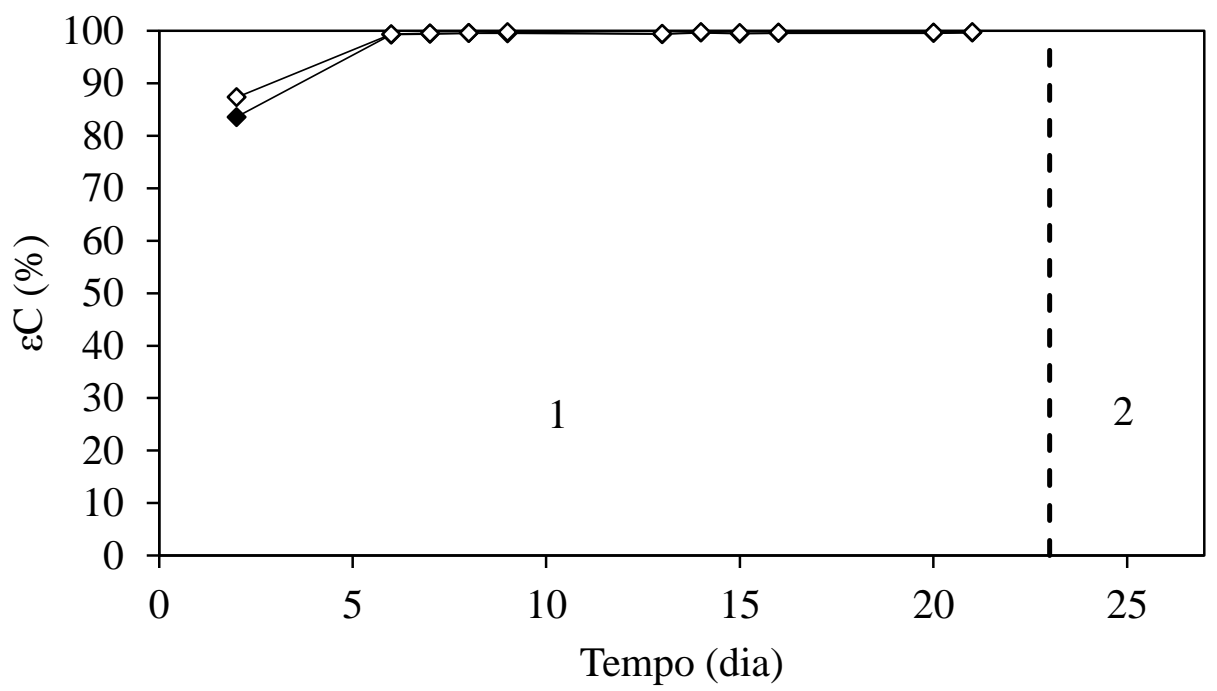

Figura 5-225 - Eficiência de remoção de carboidrato: $\diamond$ - não filtrada; $\downarrow$ - filtrada (AnSBBR com agitação mecânica e lactose - Condição 1).

As Figura 5-226, Figura 5-227 e Figura 5-228 apresentam os perfis temporais, tanto para o afluente quanto para o efluente, do $\mathrm{pH}$, da alcalinidade total e dos ácidos voláteis totais, respectivamente. A média dos valores de $\mathrm{pH}$ afluente durante esta primeira fase foi de 7,80 e de pH efluente foi de 4,27. A média da alcalinidade total foi de 317 e $18 \mathrm{mgCaCO}_{3} \cdot \mathrm{L}^{-1}$ para o afluente e efluente, respectivamente. O valor médio da 
concentração de ácidos voláteis totais afluente foi de $23 \mathrm{mgHAc} . \mathrm{L}^{-1}$ e efluente de 1031 mgHAc. $\mathrm{L}^{-1}$. A queda do pH efluente está relacionada com a alta produção de ácidos voláteis totais.

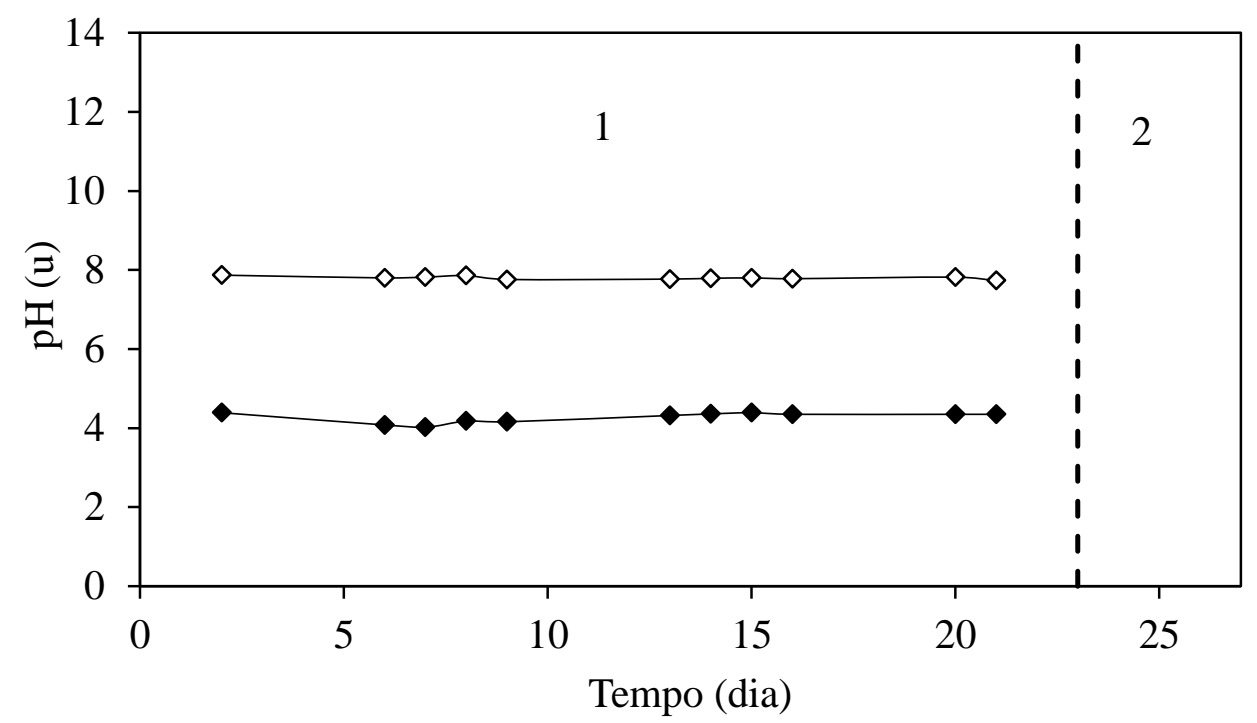

Figura 5-226 - Valores de pH: $\diamond$-afluente; - efluente (AnSBBR com agitação mecânica e lactose - Condição 1).

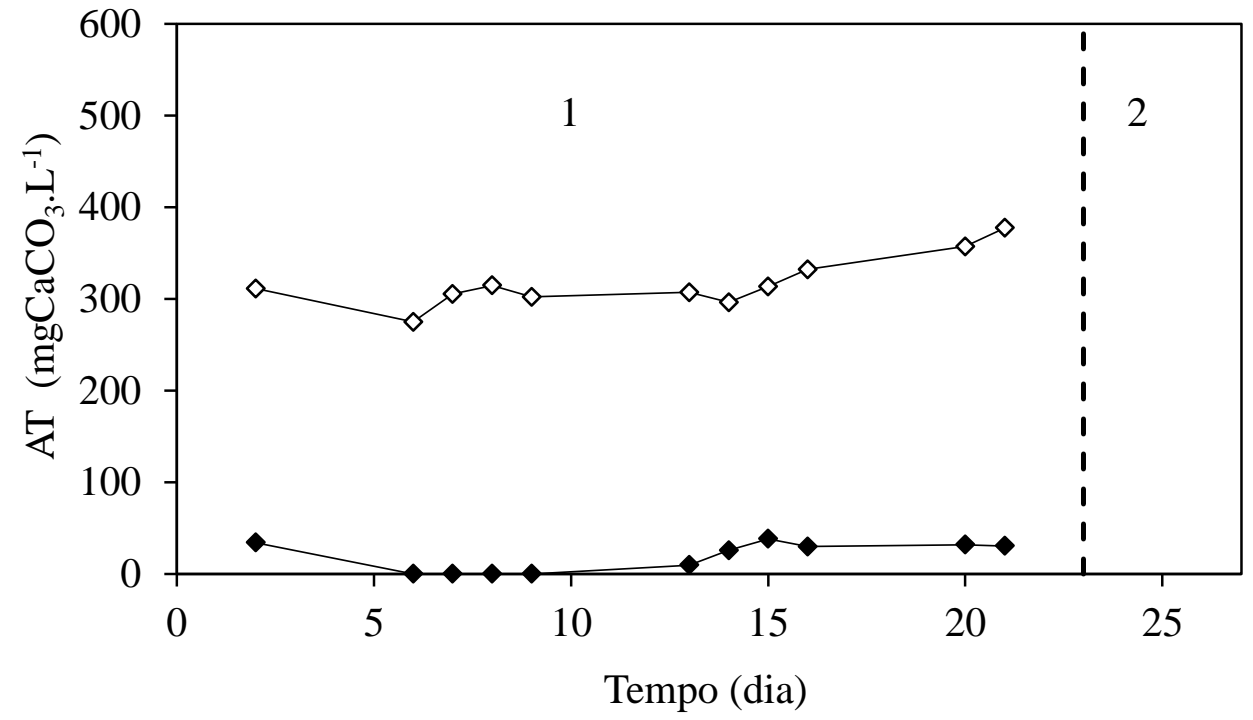

Figura 5-227 - Alcalinidade total: $\diamond$-afluente; - efluente (AnSBBR com agitação mecânica e lactose - Condição 1). 


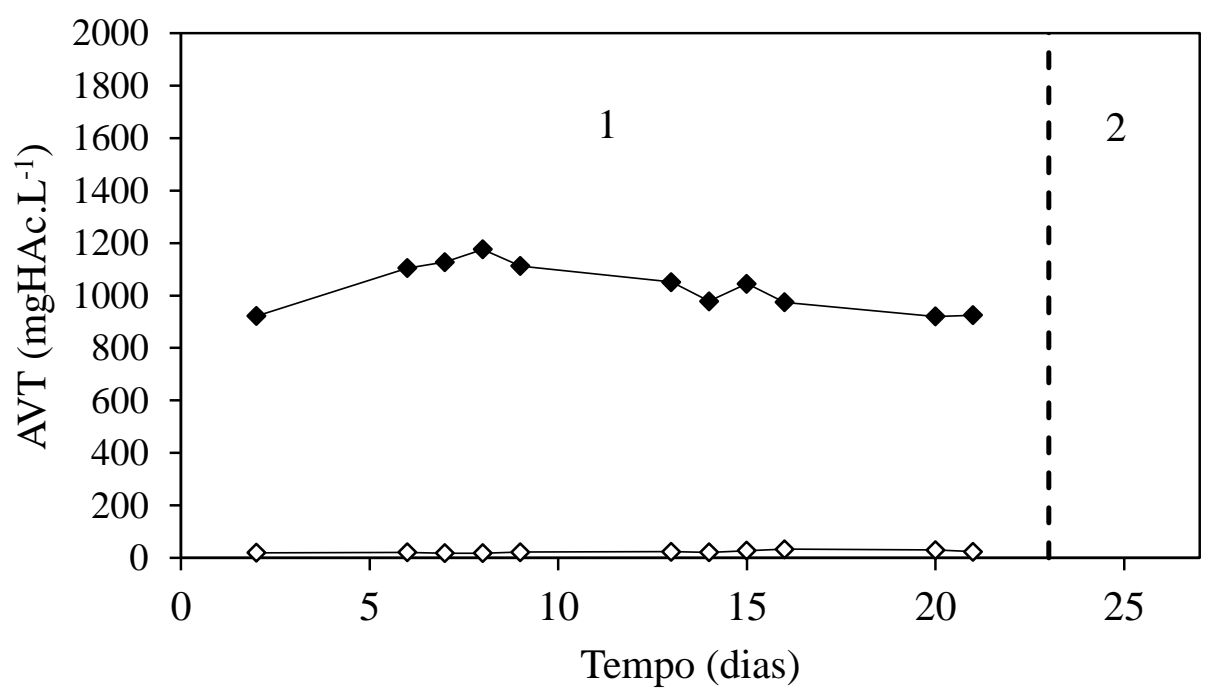

Figura 5-228 - Ácidos voláteis totais: $\diamond$-afluente; - efluente (AnSBBR com agitação mecânica e lactose - Condição 1).

A Figura 5-229 apresenta o monitoramento dos compostos intermediários contidos no efluente do sistema, enquanto que a Tabela 5.61 apresenta os valores da concentração média destes produtos. As amostras para análise destes compostos foram coletadas no dia do perfil temporal da condição (no descarte antes do ciclo do perfil, no ultimo ponto do perfil e no descarte após o ciclo do perfil). O método cromatográfico aplicado não detectou a presença de acetona e metanol. Dentre os ácidos voláteis, o ácido acético predominou seguido pelo ácido isobutírico e pelo ácido butírico representando respectivamente $27,1 \%, 12,3 \%$ e $12,0 \%$ dos compostos intermediários. O etanol também foi produzido em alta quantidade, representando $24,4 \%$ dos compostos. 


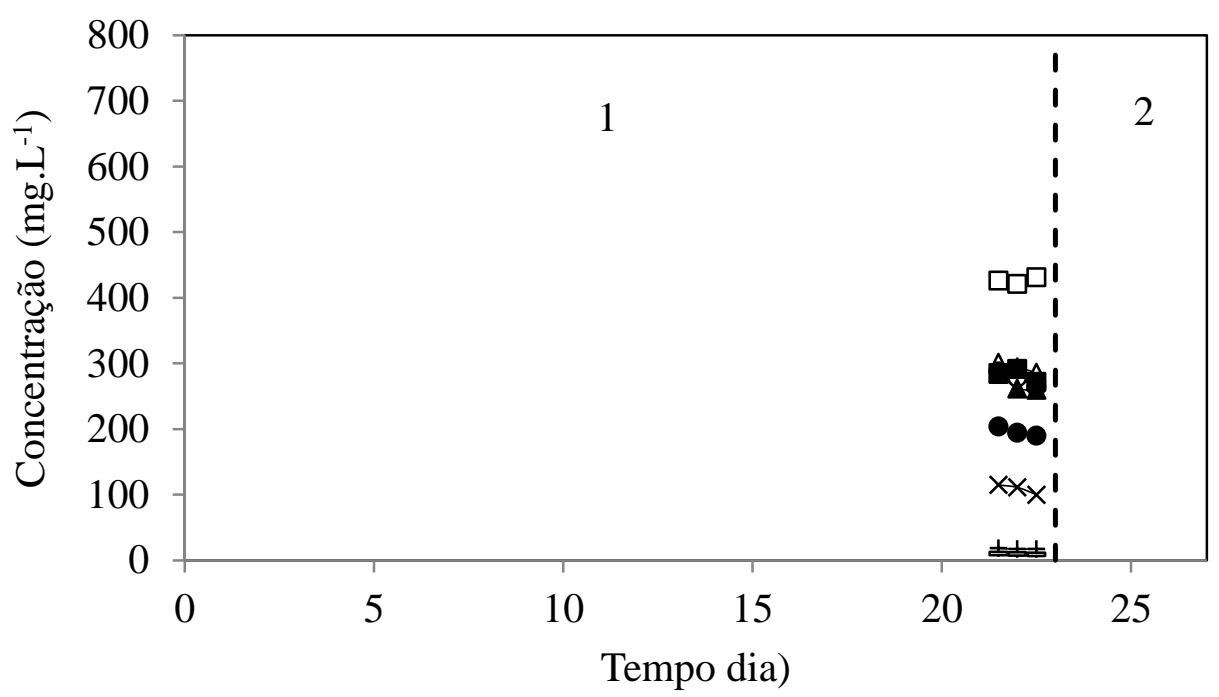

Figura 5-229 - Concentração dos compostos intermediários: $\square$ - ácido acético; $\Delta$ etanol; ○ - ácido butírico; $\mathbf{-}$ - ácido isobutírico; $\boldsymbol{\Delta}$ - ácido capróico; • - ácido valérico; * ácido propiônico; +butanol; — ácido isovalérico (AnSBBR com agitação mecânica e lactose - Condição 1).

Tabela 5.57 - Concentração e distribuição dos compostos intermediários (AnSBBR com agitação mecânica e lactose - Condição 1).

\begin{tabular}{cccccccc}
\hline $\begin{array}{c}\text { Produtos } \\
\text { intermediários }\end{array}$ & \multicolumn{5}{c}{ Concentrações médias } & \multicolumn{3}{c}{$\begin{array}{c}\text { Distribuição } \\
\left(\mathrm{mg} . \mathrm{L}^{-1}\right)\end{array}$} & \multicolumn{1}{c}{$\left(\mathrm{mmol} . \mathrm{L}^{-1}\right)$} & $(\%)$ \\
\hline Acetona & 0,0 & \pm & 0,0 & 0,0 & \pm & 0,0 & 0,0 \\
Metanol & 0,0 & \pm & 0,0 & 0,0 & \pm & 0,0 & 0,0 \\
Etanol & 293,7 & \pm & 7,8 & 6,4 & \pm & 0,2 & 24,4 \\
n-Butanol & 17,5 & \pm & 0,7 & 0,2 & \pm & 0,0 & 0,9 \\
Acético & 426,3 & \pm & 5,4 & 7,1 & \pm & 0,1 & 27,1 \\
Porpiônico & 108,5 & \pm & 7,7 & 1,5 & \pm & 0,1 & 5,6 \\
Isobutírico & 282,9 & \pm & 10,1 & 3,2 & \pm & 0,1 & 12,3 \\
Butírico & 276,6 & \pm & 11,8 & 3,1 & \pm & 0,1 & 12,0 \\
Isovalérico & 9,6 & \pm & 0,7 & 0,1 & \pm & 0,0 & 0,4 \\
Valérico & 196,1 & \pm & 7,3 & 1,9 & \pm & 0,1 & 7,3 \\
Capróico & 268,6 & \pm & 13,5 & 2,6 & \pm & 0,1 & 10,1 \\
\hline
\end{tabular}


O monitoramento da série de sólidos é mostrado na Tabela 5.58, cujos valores apresentam um baixo teor de SSV no efluente e afluente, indicando a boa capacidade do reator em reter biomassa, mesmo no começo da operação.

Tabela 5.58 - Série de sólidos afluente e efluente (AnSBBR com agitação mecânica e lactose - Condição 1)

\begin{tabular}{lcccc}
\hline & $\begin{array}{c}\mathrm{ST} \\
\left(\mathrm{mg} . \mathrm{L}^{-1}\right)\end{array}$ & $\begin{array}{c}\mathrm{SVT} \\
\left(\mathrm{mg} . \mathrm{L}^{-1}\right)\end{array}$ & $\begin{array}{c}\mathrm{SST} \\
\left(\mathrm{mg} . \mathrm{L}^{-1}\right)\end{array}$ & $\begin{array}{c}\mathrm{SSV} \\
\left(\mathrm{mg} . \mathrm{L}^{-1}\right)\end{array}$ \\
\hline Afluente & $3011,0 \pm 68,5$ & $2585,2 \pm 65,7$ & $29,6 \pm 34,3$ & $11,6 \pm 15,7$ \\
Efluente & $1698,8 \pm 96,6$ & $1344,4 \pm 77,4$ & $69,2 \pm 38,5$ & $63,2 \pm 6,1$ \\
\hline \multicolumn{5}{c}{ *Número de amostras consideradas $=5}$.
\end{tabular}

A produção do biogás por ciclo, em aspecto quantitativo, pode ser observada na Figura 5-230. A produção média foi de $789 \mathrm{~mL}$ (CNTP). A Figura 5-231 apresenta o monitoramento das concentrações dos componentes do biogás no final do ciclo, enquanto que a Figura 5-232 apresenta a distribuição destes mesmos componentes. Os valores médios de concentração de $\mathrm{H}_{2}, \mathrm{CH}_{4}$ e $\mathrm{CO}_{2}$ foram 3,0, 0,0 e 9,7 mmol.L ${ }^{-1}$, respectivamente. Além disso, a distribuição percentual média de $\mathrm{H}_{2}$ foi de $22,4 \%$, a de $\mathrm{CH}_{4}$ foi de $0,0 \%$ e a de $\mathrm{CO}_{2}$ foi de $77,6 \%$.

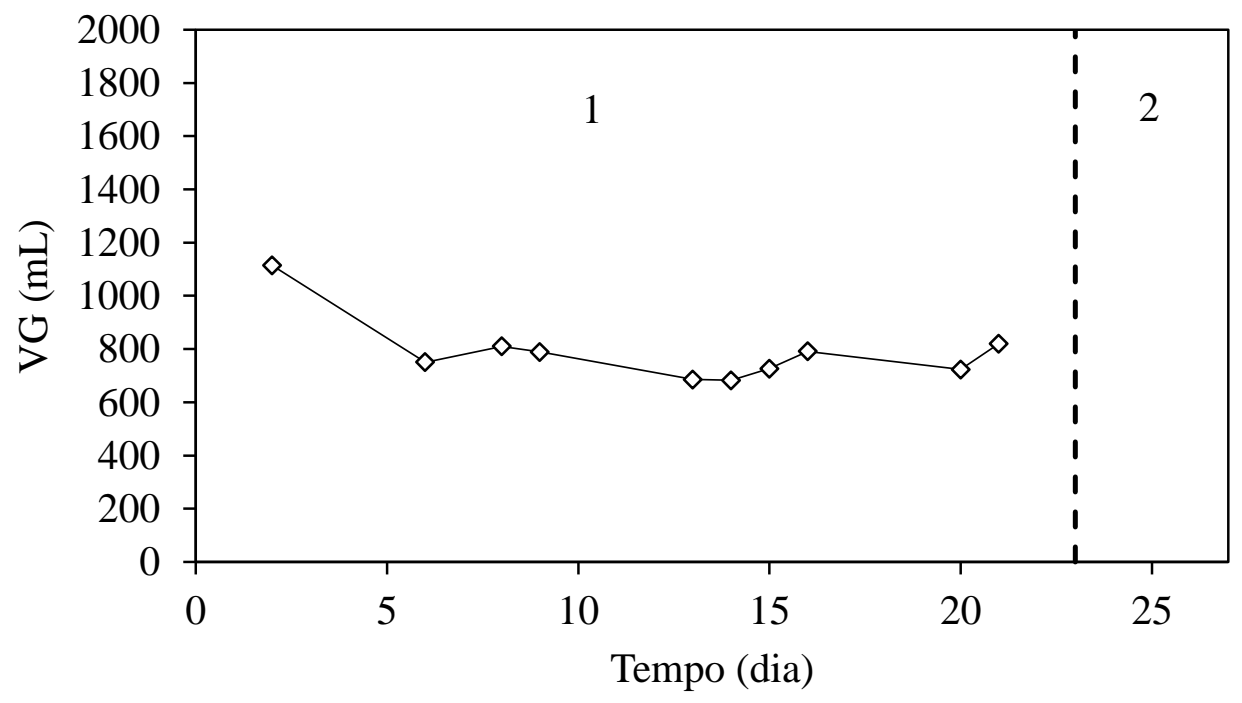

Figura 5-230 - Volume de biogás produzido por ciclo (AnSBBR com agitação mecânica e lactose - Condição 1). 


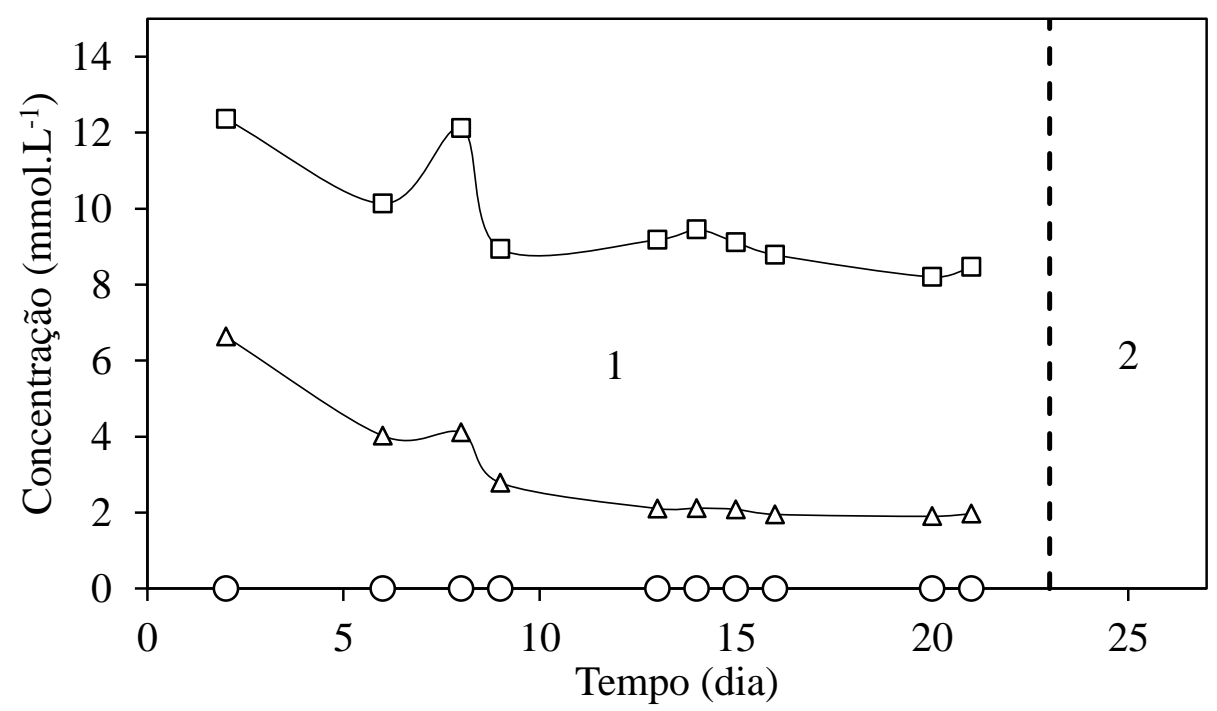

Figura 5-231 - Concentrações dos componentes do biogás no final do ciclo: $\square-\mathrm{CO}_{2} ; \Delta$ - $\mathrm{H}_{2} ; \circ-\mathrm{CH}_{4}$ (AnSBBR com agitação mecânica e lactose - Condição 1).

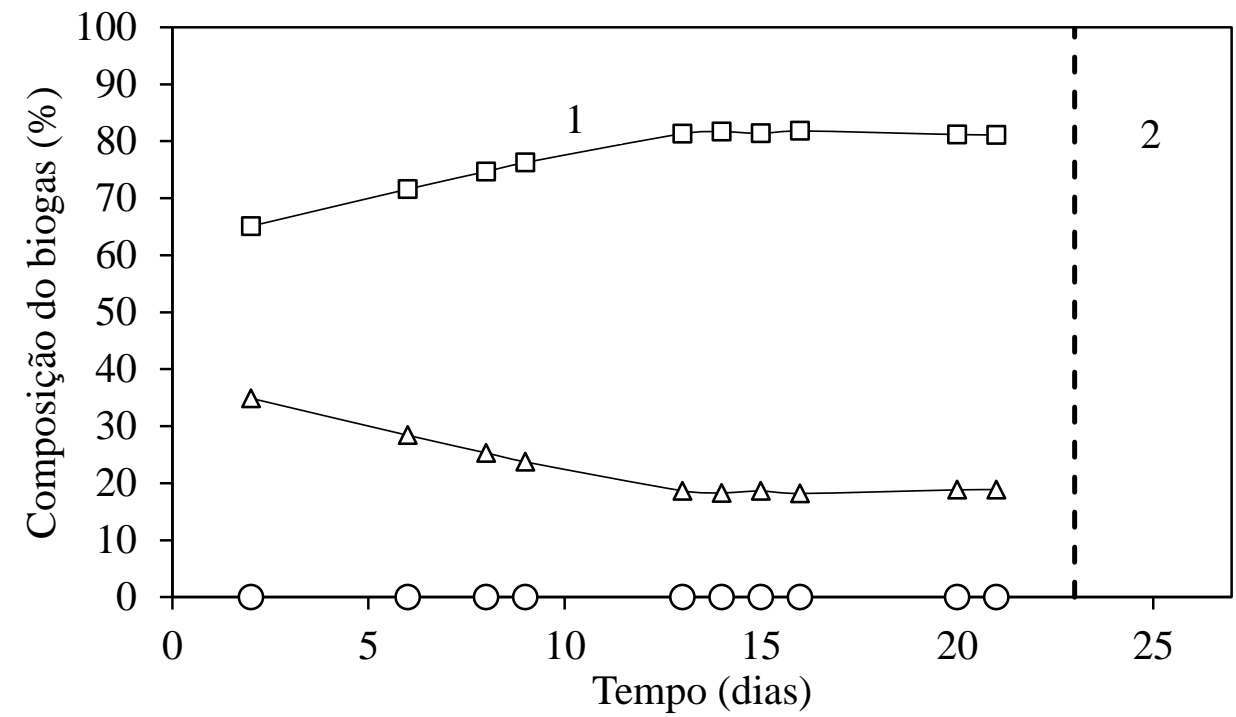

Figura 5-232 - Distribuições dos componentes do biogás no final do ciclo: $\square-\mathrm{CO}_{2} ; \Delta-$ $\mathrm{H}_{2} ;$ ○ $-\mathrm{CH}_{4}$ (AnSBBR com agitação mecânica e lactose - Condição 1).

No final da operação foi realizado o perfil temporal, com o intuito de entender melhor como os parâmetros indicativos de eficiência do sistema se comportavam durante um ciclo completo. A Figura 5-233 apresenta a evolução da concentração de carboidrato ao longo do ciclo e a eficiência de remoção do mesmo. Ao inicio do ciclo 
(tempo zero) o volume afluente é diluído no volume residual resultando em uma concentração em sacarose da ordem de $1090 \mathrm{mg} \cdot \mathrm{L}^{-1}$. A conversão de carboidrato se faz de maneira progressiva ao longo do ciclo, atingindo valores na ordem de $99 \%$ no final do mesmo, com um residual aproximado de $11 \mathrm{mg} \cdot \mathrm{L}^{-1}$.

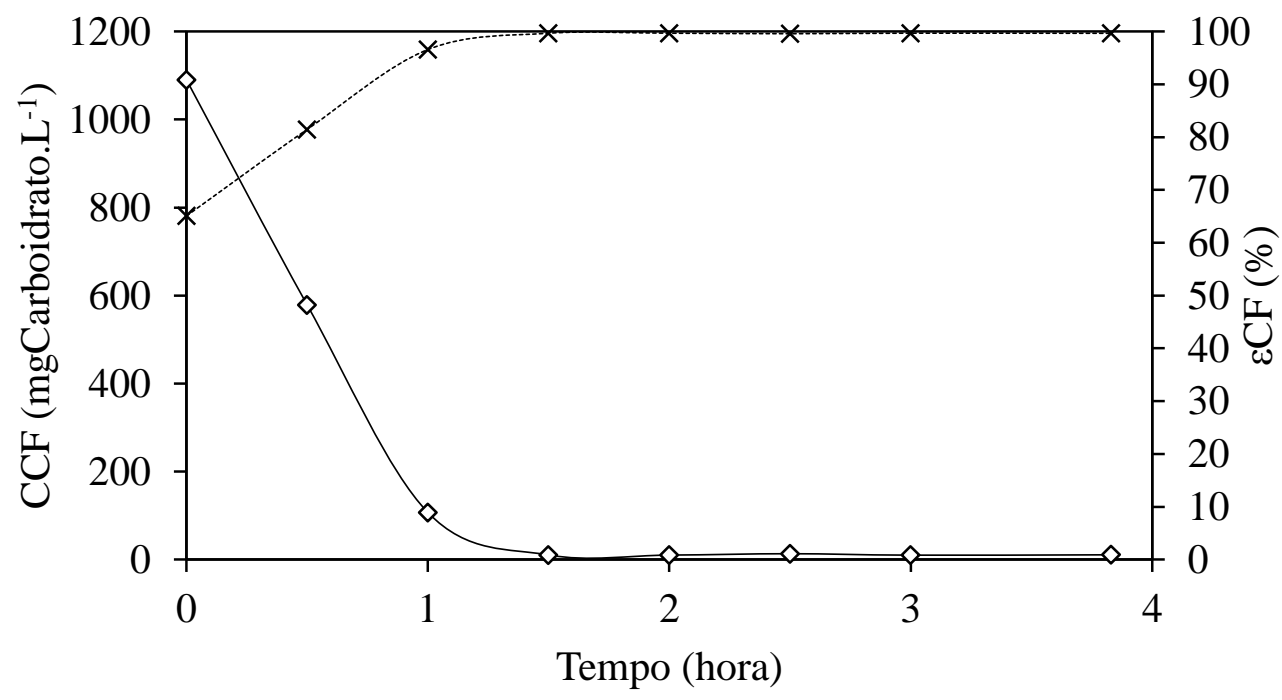

Figura 5-233 - Concentração e eficiência de degradação de carboidrato: $\diamond$ - perfil e * eficiência (AnSBBR com agitação mecânica e lactose - Condição 1).

A Figura 5-234 apresenta a evolução da concentração de matéria orgânica ao longo do ciclo. Observa-se uma baixa remoção da DQO, levando a uma alta concentração da mesma no volume residual. Assim, no inicio do ciclo, a diluição do volume carregado pelo volume residual é realizada em proporção bem menor do que no caso dos carboidratos totais, tendo em vista que as concentrações afluente e residual são muito próximas. No inicio do ciclo, a concentração é da ordem de $3100 \mathrm{mg} . \mathrm{L}^{-1}$ atingindo valores próximos a $3050 \mathrm{mg} . \mathrm{L}^{-1}$ no último ponto do ciclo. 


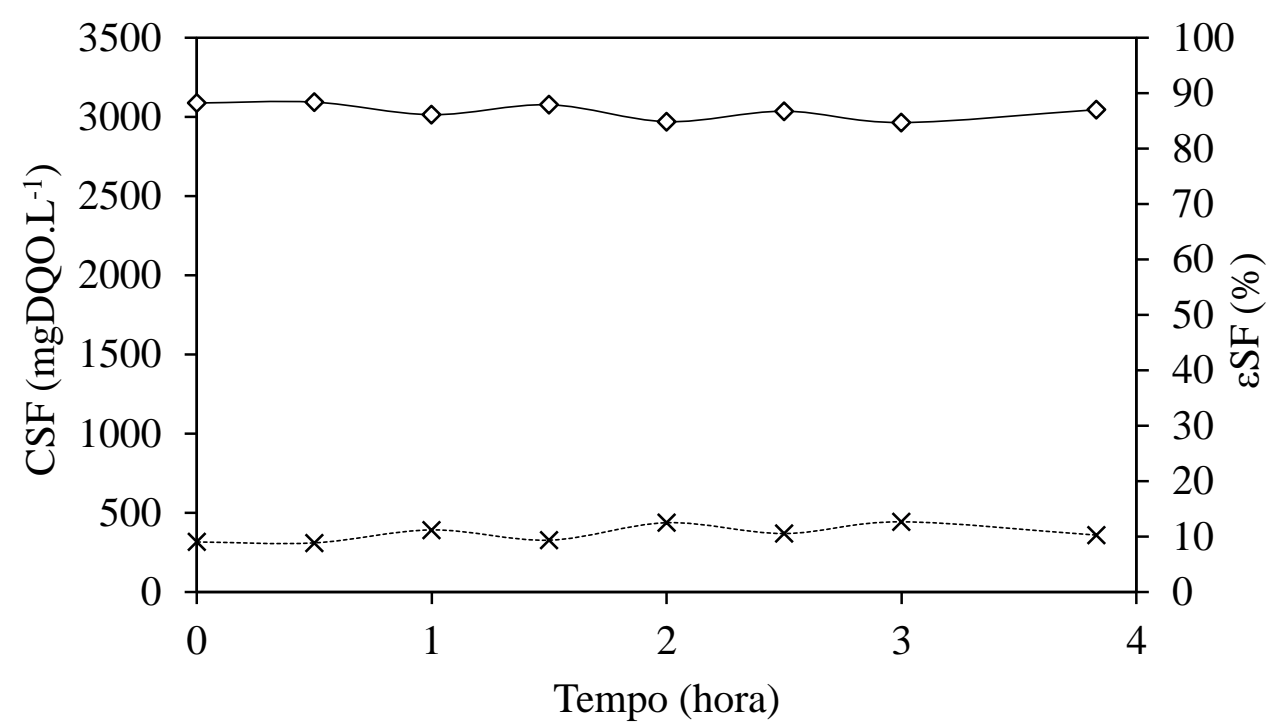

Figura 5-234 - Concentração e eficiência de degradação de matéria orgânica: $\diamond$ - perfil e * eficiência (AnSBBR com agitação mecânica e lactose - Condição 1).

O acúmulo de ácidos voláteis totais por titulação ao longo do ciclo pode ser observado na Figura 5-235. A concentração destes aumenta claramente durante a fase de reação para atingir um máximo no final do ciclo na ordem de 740 mgHAc. $\mathrm{L}^{-1}$.

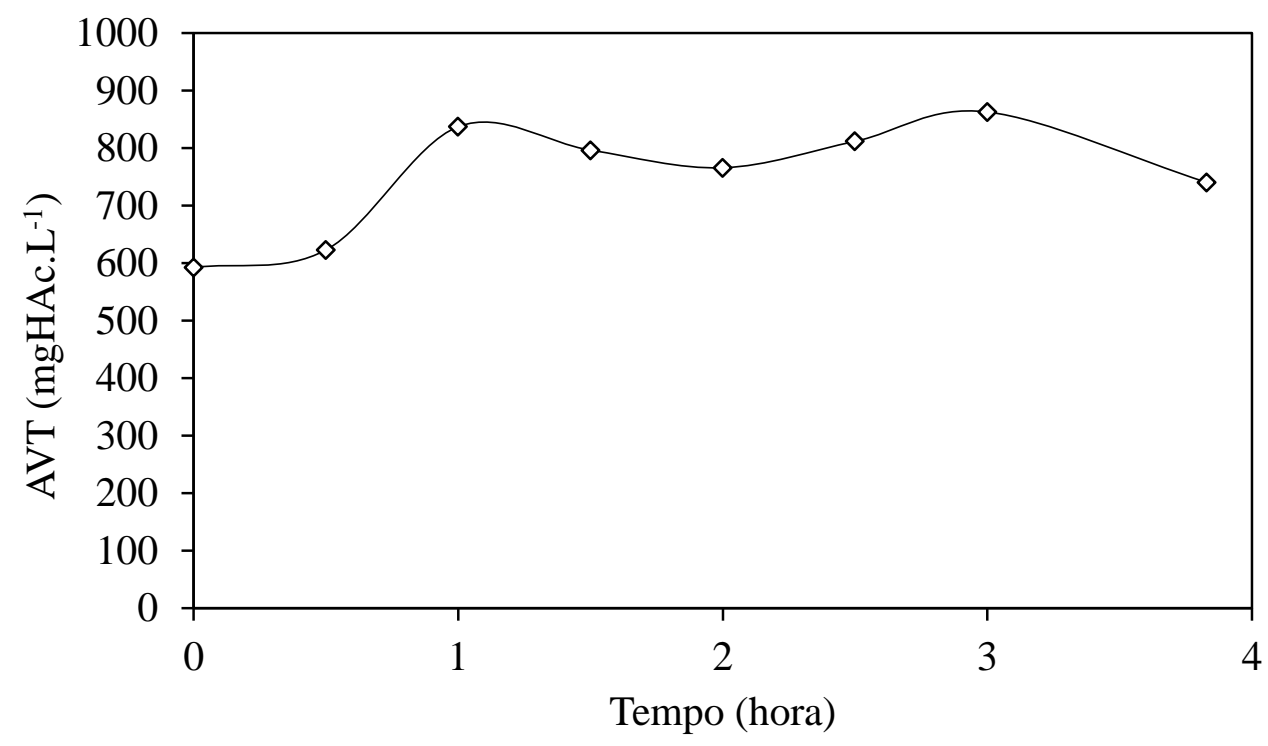

Figura 5-235 - Ácidos voláteis totais $(\diamond)$ do perfil (AnSBBR com agitação mecânica e lactose - Condição 1). 
Os resultados dos compostos intermediários por cromatografia gasosa são apresentados na Figura 5-236. Estes permaneceram praticamente estáveis durante todo o perfil. Os ácidos butírico, isobutírico e capróico foram os intermediários que apresentaram o maior aumento praticamente triplicando suas concentrações. O etanol apresentou em um primeiro momento um aumento seguido por uma queda e estabilização da concentração no final de ciclo.

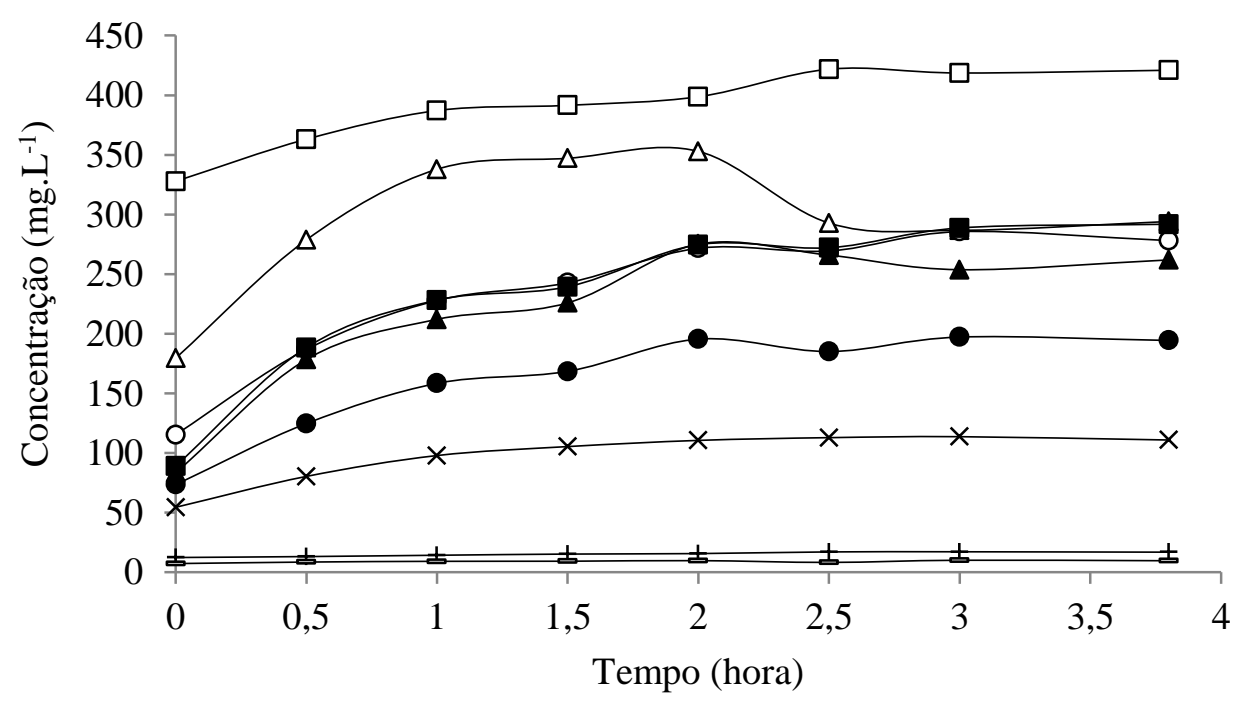

Figura 5-236 - Concentração dos compostos intermediários ao longo do ciclo: $\square$ - ácido acético; $\Delta$ - etanol; O - ácido butírico; $\mathbf{- a ́}$ - ádo isobutírico; $\boldsymbol{\Delta}$ - ácido capróico; $\bullet-$ ácido valérico; - ※ácido propiônico; +butanol; - ácido isovalérico (AnSBBR com agitação mecânica e lactose - Condição 1).

$\mathrm{O}$ pH diminuiu instantaneamente em relação ao afluente devido à diluição do mesmo com o volume residual no inicio do ciclo (alimentação do reator em 10 minutos) e permaneceu estável ao longo da operação com uma ligeira queda nos primeiros pontos do perfil, conforme a Figura 5-237. Esta estabilidade do pH era esperada pois, como pode ser visto na Figura 5-238, o meio de alimentação possuía alcalinidade suficiente para tamponar o sistema que foi consumida durante o ciclo. 


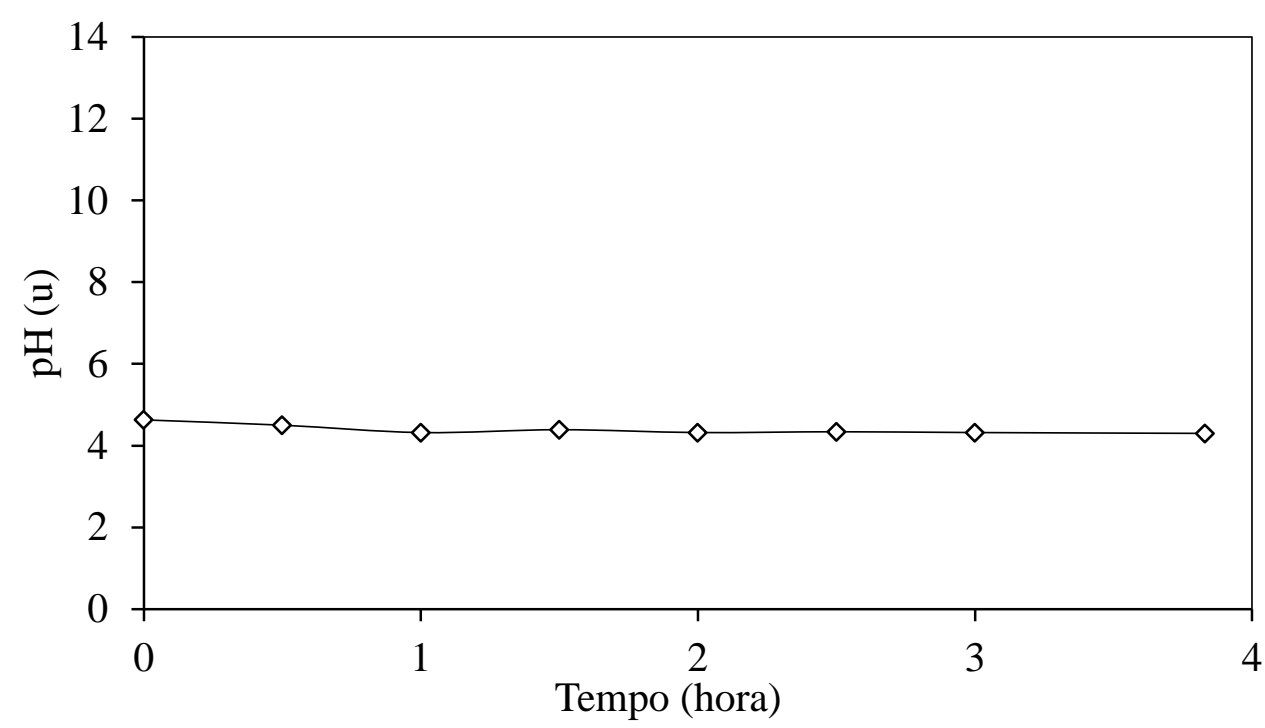

Figura 5-237 - Valores de pH $(\diamond)$ do perfil (AnSBBR com agitação mecânica e lactose Condição 1).

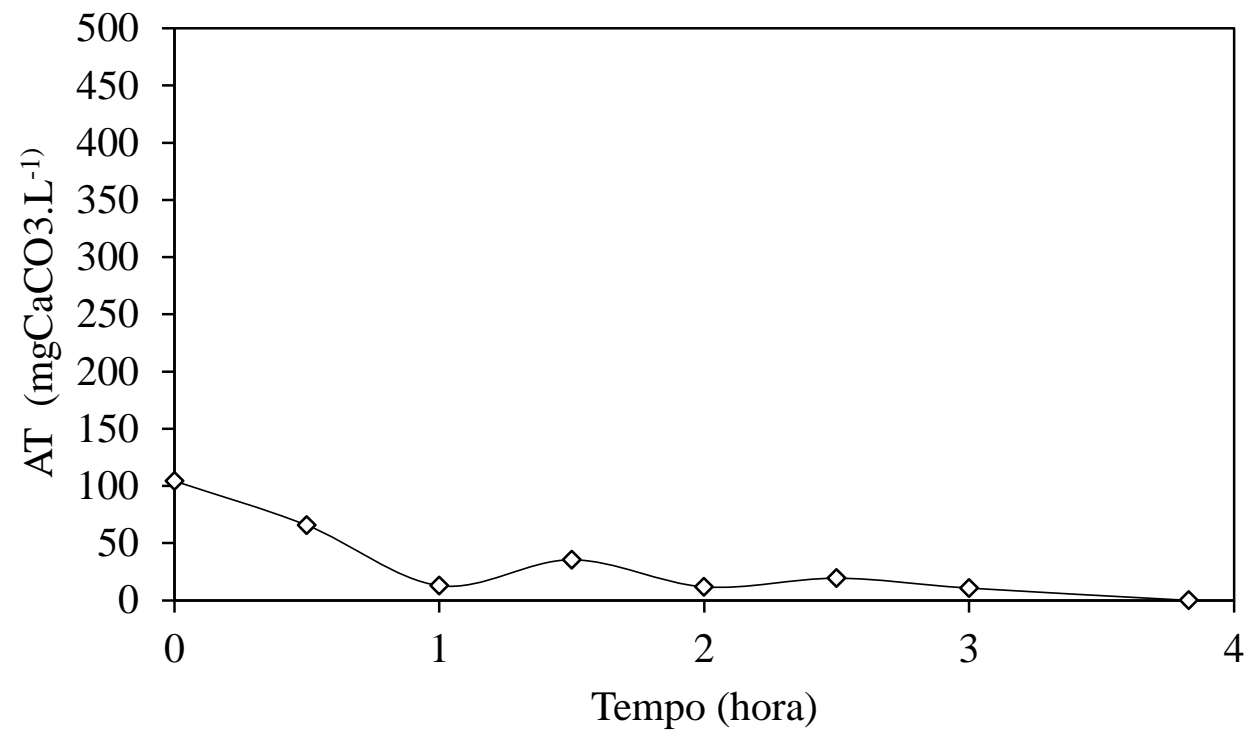

Figura 5-238 - Alcalinidade total $(\diamond)$ do perfil (AnSBBR com agitação mecânica e lactose - Condição 1).

A produção volumétrica média acumulada do biogás, realizada com os valores dos perfis quantitativos mais consistentes obtidos durante a operação, juntamente com os desvios padrões encontram-se na Figura 5-239. Toda produção ocorre nas primeiras uma hora e meia do ciclo. A Tabela 5.59 resume os valores médios da produção, fração molar e os volumes individuais da mistura do biogás. A Figura 5-271 apresenta os 
volumes acumulados médios dos perfis de $\mathrm{H}_{2}, \mathrm{CO}_{2}$ e $\mathrm{CH}_{4}$ produzidos durante o ciclo. Apenas $\mathrm{H}_{2}$ e $\mathrm{CO}_{2}$ foram produzidos, sem a presença de $\mathrm{CH}_{4}$.

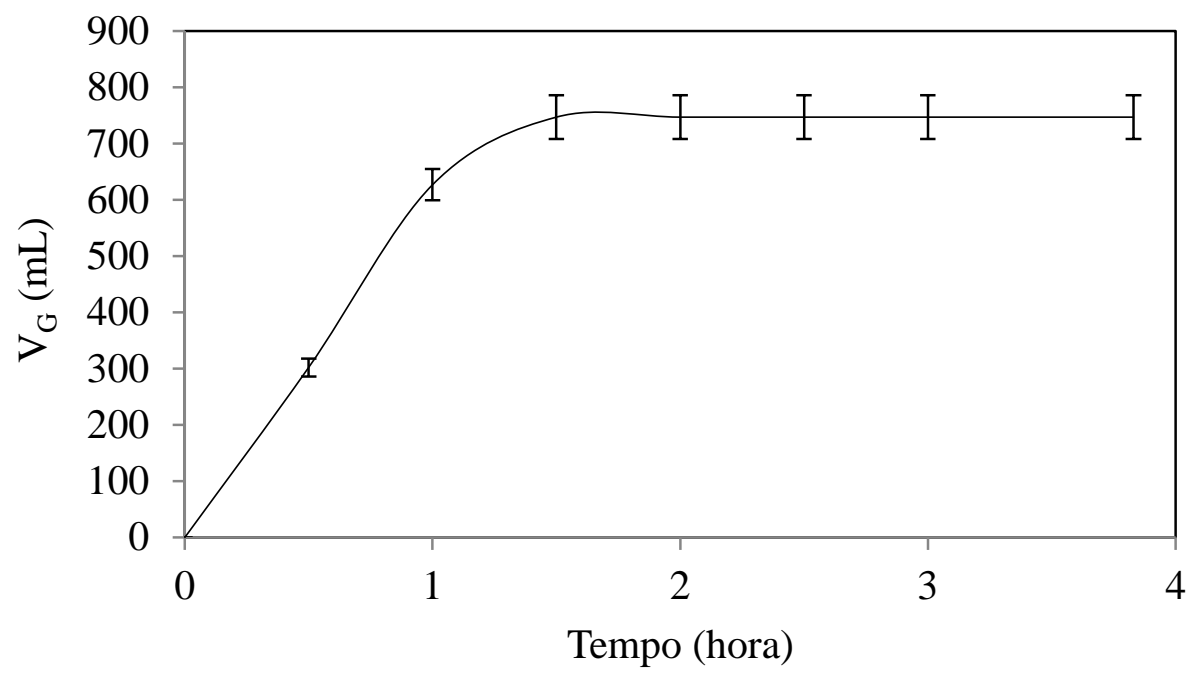

Figura 5-239 - Produção volumétrica média acumulada do biogás durante o ciclo (AnSBBR com agitação mecânica e lactose - Condição 1).

Tabela 5.59 - Valores médios da produção, fração molar e os volumes individuais da mistura do biogás (AnSBBR com agitação mecânica e lactose - Condição 1).

\begin{tabular}{ccccccccccc}
\hline $\begin{array}{c}\text { Tempo } \\
(\mathrm{h})\end{array}$ & $\begin{array}{c}\mathrm{V}_{\mathrm{G}} \\
(\mathrm{mL}-\mathrm{CNTP})\end{array}$ & \multicolumn{3}{c}{$\mathrm{C}_{\mathrm{G}}\left(\mathrm{mmol} . \mathrm{L}^{-1}\right)$} & \multicolumn{3}{c}{ Fração Molar (\%) } & \multicolumn{3}{c}{ Volume (mL - CNTP) } \\
& $\mathrm{H}_{2}$ & $\mathrm{CO}_{2}$ & $\mathrm{CH}_{4}$ & $\mathrm{H}_{2}$ & $\mathrm{CO}_{2}$ & $\mathrm{CH}_{4}$ & $\mathrm{H}_{2}$ & $\mathrm{CO}_{2}$ & $\mathrm{CH}_{4}$ \\
\hline 0,0 & 0,0 & 0,0 & 0,0 & 0,0 & 0,0 & 0,0 & 0,0 & 0,0 & 0,0 & 0,0 \\
0,5 & 302,2 & 0,8 & 3,3 & 0,0 & 18,7 & 81,3 & 0,0 & 56,4 & 245,7 & 0,0 \\
1,0 & 626,8 & 1,5 & 5,8 & 0,0 & 20,9 & 79,1 & 0,0 & 124,4 & 502,5 & 0,0 \\
1,5 & 747,0 & 1,9 & 7,4 & 0,0 & 20,4 & 79,6 & 0,0 & 148,9 & 598,1 & 0,0 \\
2,0 & 747,0 & 1,9 & 8,2 & 0,0 & 19,0 & 81,0 & 0,0 & 148,9 & 598,1 & 0,0 \\
2,5 & 747,0 & 2,0 & 8,3 & 0,0 & 19,2 & 80,8 & 0,0 & 148,9 & 598,1 & 0,0 \\
3,0 & 747,0 & 1,9 & 8,4 & 0,0 & 18,7 & 81,3 & 0,0 & 148,9 & 598,1 & 0,0 \\
3,7 & 747,0 & 2,0 & 8,5 & 0,0 & 18,9 & 81,1 & 0,0 & 148,9 & 598,1 & 0,0 \\
\hline
\end{tabular}




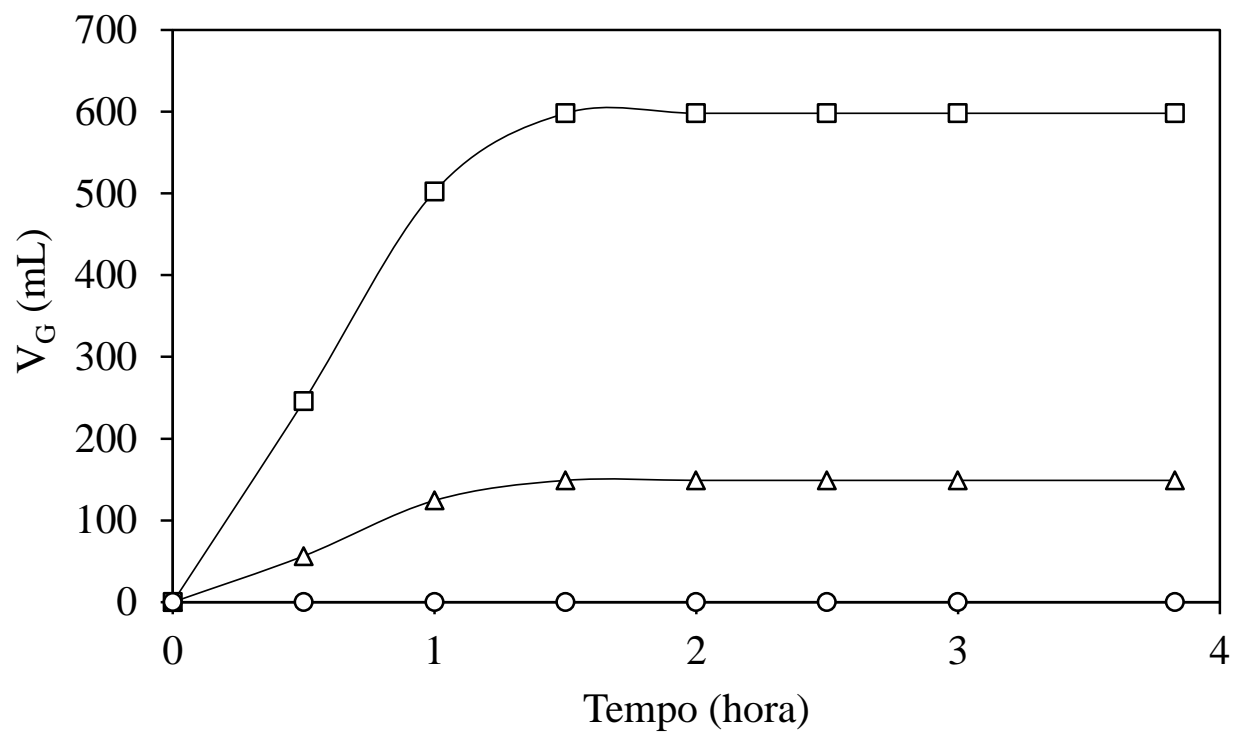

Figura 5-240 - Volumes acumulados médios produzidos ao longo do ciclo: $\square-\mathrm{CO}_{2} ; \Delta$ $\mathrm{H}_{2} ;$ ○ $-\mathrm{CH}_{4}$ (AnSBBR com agitação mecânica e lactose - Condição 1). 
5.3.2. Condição $2\left(D Q O=5400 \mathrm{mg}^{-L^{-1}}\right.$ e $t_{C}=4$ horas $)$

A condição experimental 2 apresentou uma COAV nominal de 13,9 kgDQO.m ${ }^{3} \cdot \mathrm{d}^{-1}$ e duração do ciclo de 4 horas, indo do dia 23 ao dia 46 (24 dias de operação). A Tabela 5.60 apresenta os valores médios dos parâmetros monitorados. 
Tabela 5.60 - Valores médios dos parâmetros monitorados na condição experimental 2 (Lactose - $5400 \mathrm{mgDQO} . \mathrm{L}^{-1}-\mathrm{t}_{\mathrm{C}} 4 \mathrm{~h}$ ).

\begin{tabular}{|c|c|c|c|c|c|c|c|c|c|c|c|}
\hline \multicolumn{2}{|r|}{ Parâmetro } & \multicolumn{5}{|c|}{ Afluente } & \multicolumn{5}{|c|}{ Efluente } \\
\hline $\mathrm{C}_{\mathrm{ST}}$ & $\left(\mathrm{mgDQO} . \mathrm{L}^{-1}\right)$ & 4846 & \pm & 398 & $(10$ & $\overline{0}$ & 3958 & \pm & 242 & $(10$ & \\
\hline $\mathrm{C}_{\mathrm{SF}}$ & $\left(\mathrm{mgDQO} \cdot \mathrm{L}^{-1}\right)$ & - & \pm & - & $(3$ & & 4100 & \pm & 283 & $(10$ & ) \\
\hline$\varepsilon_{\mathrm{ST}}$ & $(\%)$ & - & & - & & & 18 & \pm & 5 & $(10$ & \\
\hline$\varepsilon_{\mathrm{SF}}$ & $(\%)$ & - & & - & & & 15 & \pm & 6 & $(10$ & \\
\hline $\mathrm{C}_{\mathrm{CT}}$ & (mgCarboidrato. $\mathrm{L}^{-1}$ ) & 4579 & \pm & 403 & $(10$ & 0 & 305 & \pm & 490 & $(10$ & ) \\
\hline $\mathrm{C}_{\mathrm{CF}}$ & (mgCarboidrato. $\mathrm{L}^{-1}$ ) & - & \pm & - & & & 287 & \pm & 480 & $(10$ & ) \\
\hline$\varepsilon_{\mathrm{CT}}$ & $(\%)$ & - & & - & & & 93 & \pm & 11 & $(10$ & ) \\
\hline$\varepsilon_{\mathrm{CF}}$ & $(\%)$ & - & & - & & & 94 & \pm & 10 & $(10$ & \\
\hline $\mathrm{pH}$ & (u) & 7,93 & \pm & 0,14 & $(10$ & 0 & 4,20 & \pm & 0,11 & $(10$ & ) \\
\hline AVT & $\left(\mathrm{mgHAc} . \mathrm{L}^{-1}\right)$ & 25 & \pm & 4 & $(10$ & 0 & 1561 & \pm & 158 & ( 10 & ) \\
\hline AT & $\left(\mathrm{mgCaCO}_{3} \cdot \mathrm{L}^{-1}\right)$ & 375 & \pm & 26 & $(10$ & 0 & 6 & \pm & 19 & ( 10 & ) \\
\hline AP & $\left(\mathrm{mgCaCO}_{3} \cdot \mathrm{L}^{-1}\right)$ & 295 & \pm & 22 & $(10$ & 0 & 0 & \pm & 0 & ( 10 & \\
\hline AI & $\left(\mathrm{mgCaCO}_{3} \cdot \mathrm{L}^{-1}\right)$ & 79 & \pm & 12 & $(10$ & 0 & 6 & \pm & 19 & $(10$ & ) \\
\hline $\mathrm{AB}$ & $\left(\mathrm{mgCaCO}_{3} \cdot \mathrm{L}^{-1}\right)$ & 357 & \pm & 25 & $(10$ & 0 & 0 & \pm & 0 & ( 10 & ) \\
\hline ST & $\left(\mathrm{mg} \cdot \mathrm{L}^{-1}\right)$ & 3803 & \pm & 239 & $(3$ & & 2295 & \pm & 138 & $(3$ & ) \\
\hline STV & $\left(\mathrm{mg} \cdot \mathrm{L}^{-1}\right)$ & 3343 & \pm & 305 & $(3$ & & 1813 & \pm & 174 & $(3$ & ) \\
\hline SST & $\left(\mathrm{mg} \cdot \mathrm{L}^{-1}\right)$ & 57 & \pm & 12 & $(3$ & & 142 & \pm & 23 & $(3$ & ) \\
\hline SSV & $\left(\mathrm{mg} \cdot \mathrm{L}^{-1}\right)$ & 22 & \pm & 17 & $(3$ & & 108 & \pm & 12 & $(3$ & ) \\
\hline $\mathrm{M}_{\mathrm{STV}}$ & (g) & - & & - & & & 11,7 & & - & & \\
\hline $\mathrm{C}_{\mathrm{X}}$ & $\left(\mathrm{g} . \mathrm{L}^{-1}\right)$ & 一 & & - & & & 3,2 & & - & & \\
\hline $\mathrm{C}_{\mathrm{X}}^{\prime}$ & (g.gsuporte ${ }^{-1}$ ) & - & & - & & & 0,014 & & - & & \\
\hline $\mathrm{V}_{\mathrm{G}}$ & (mL-CNTP) & - & & - & & & 1622 & \pm & 111 & $(4$ & ) \\
\hline $\mathrm{V}_{\mathrm{H} 2}$ & (mL-CNTP) & - & & - & & & 694 & \pm & - & $(1$ & \\
\hline $\mathrm{COAV}_{\mathrm{STA}}$ & $\left(\mathrm{kgDQO} \cdot \mathrm{m}^{-3} \cdot \mathrm{d}^{-1}\right)$ & 12,5 & & - & & & - & & - & & \\
\hline $\mathrm{CORV}_{\mathrm{SFE}}$ & $\left(\mathrm{kgDQO} \cdot \mathrm{m}^{-3} \cdot \mathrm{d}^{-1}\right)$ & - & & - & & & 1,9 & & - & & \\
\hline $\mathrm{COAV}_{\mathrm{CTA}}$ & $\left(\mathrm{kgCarboidrato} \cdot \mathrm{m}^{-3} \cdot \mathrm{d}^{-1}\right)$ & 11,8 & & - & & & - & & - & & \\
\hline $\mathrm{CORV}_{\mathrm{CFE}}$ & $\left(\right.$ kgCarboidrato. $\left.\mathrm{m}^{-3} \cdot \mathrm{d}^{-1}\right)$ & - & & - & & & 11,1 & & - & & \\
\hline $\mathrm{COAE}_{\mathrm{STA}}$ & $\left(\operatorname{kgDQO} \cdot k g S T V^{-1} \cdot d^{-1}\right)$ & 3,7 & & - & & & - & & - & & \\
\hline $\mathrm{CORE}_{\mathrm{SFE}}$ & $\left(\mathrm{kgDQO} \cdot \mathrm{kgSTV}^{-1} \cdot \mathrm{d}^{-1}\right)$ & - & & - & & & 0,6 & & - & & \\
\hline $\mathrm{COAE}_{\mathrm{CTA}}$ & $\left(\mathrm{kgCarboidrato} \mathrm{kgSTV}^{-1} \cdot \mathrm{d}^{-1}\right)$ & 3,5 & & - & & & - & & - & & \\
\hline $\mathrm{CORE}_{\mathrm{CFE}}$ & $\left(\mathrm{kgCarboidrato} \mathrm{kgSTV}^{-1} \cdot \mathrm{d}^{-1}\right)$ & - & & - & & & 3,3 & & - & & \\
\hline $\mathrm{RMCR}_{\mathrm{C}, \mathrm{n}}$ & $\left(\mathrm{molH}_{2}\right.$ molCarboidrato $\left.^{-1}\right)$ & - & & - & & & 1,65 & & - & & \\
\hline $\mathrm{n}_{\mathrm{H} 2}$ & $\left(\mathrm{molH}_{2} \cdot \mathrm{d}^{-1}\right)$ & - & & - & & & 0,186 & & - & & \\
\hline PrM & $\left(\mathrm{molH}_{2} \cdot \mathrm{m}^{-3} \cdot \mathrm{d}^{-1}\right)$ & - & & - & & & 50,3 & & - & & \\
\hline PrME & $\left(\mathrm{molH}_{2} \cdot \mathrm{kgSVT}^{-1} \cdot \mathrm{d}^{-1}\right)$ & - & & - & & & 15,8 & & - & & \\
\hline $\mathrm{RMCA}_{\mathrm{S}, \mathrm{m}}$ & $\left(\mathrm{molH}_{2} \cdot \mathrm{kgDQO}^{-1} \cdot \mathrm{d}^{-1}\right)$ & 4,3 & & - & & & - & & - & & \\
\hline $\mathrm{RMCA}_{\mathrm{C}, \mathrm{m}}$ & $\left(\mathrm{molH}_{2} \cdot \mathrm{kg}^{-1} \cdot \mathrm{d}^{-1}\right)$ & 4,5 & & $\longrightarrow$ & & & - & & - & & \\
\hline $\mathrm{RMCR}_{\mathrm{S}, \mathrm{m}}$ & $\left(\mathrm{molH}_{2} \cdot \mathrm{kgDQO}^{-1} \cdot \mathrm{d}^{-1}\right)$ & - & & - & & & 27,7 & & - & & \\
\hline $\mathrm{RMCR}_{\mathrm{C}, \mathrm{m}}$ & $\left(\mathrm{molH}_{2} \cdot \mathrm{kg}^{-1} \cdot \mathrm{d}^{-1}\right)$ & - & & - & & & 4,8 & & - & & \\
\hline $\mathrm{V}_{\mathrm{R}}$ & $(\mathrm{mL})$ & 2190 & & & & & 一 & & - & & \\
\hline $\mathrm{V}_{\mathrm{A}}$ & $(\mathrm{mL})$ & 1505 & \pm & 12 & $(12$ & 2 & & & & & \\
\hline
\end{tabular}

(*) Entre parêntese o número de amostras considerado no cálculo da média 
A Figura 5-241 apresenta os valores da concentração afluente (não filtrada) e efluente (não filtrada e filtrada) de matéria orgânica (DQO) no sistema, enquanto que a Figura 5-242 apresenta a eficiência de remoção do mesmo parâmetro durante o monitoramento diário. Esta eficiência atingiu, em média, 15\% para as amostras filtradas e $18 \%$ para amostras não filtradas. A média de concentração afluente não filtrada do substrato foi de $4846 \mathrm{mgDQO} . \mathrm{L}^{-1}$ e de $3957 \mathrm{mgDQO} . \mathrm{L}^{-1}$ e $4100 \mathrm{mgDQO} . \mathrm{L}^{-1}$ para amostras de efluente não filtrado e filtrado, respectivamente.

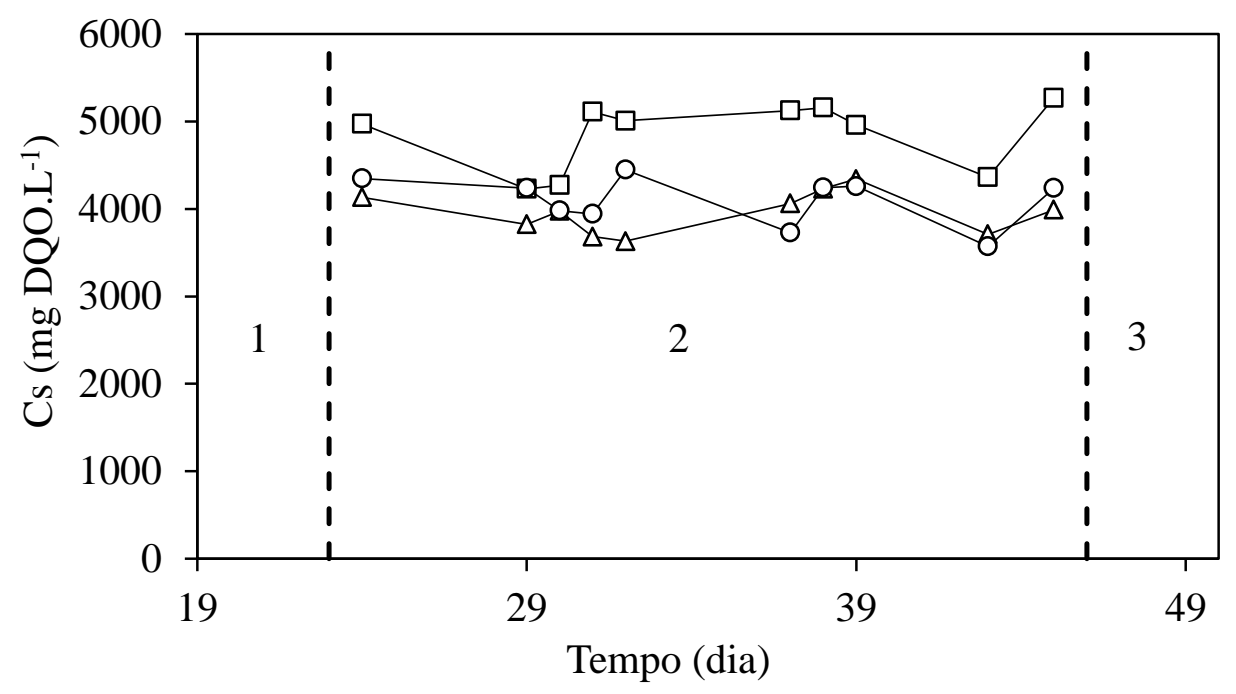

Figura 5-241 - Concentração de matéria orgânica (DQO): $\square-$ afluente não filtrada; $\Delta$ efluente não filtrada; $\bigcirc$ - efluente filtrada (AnSBBR com agitação mecânica e lactose Condição 2). 


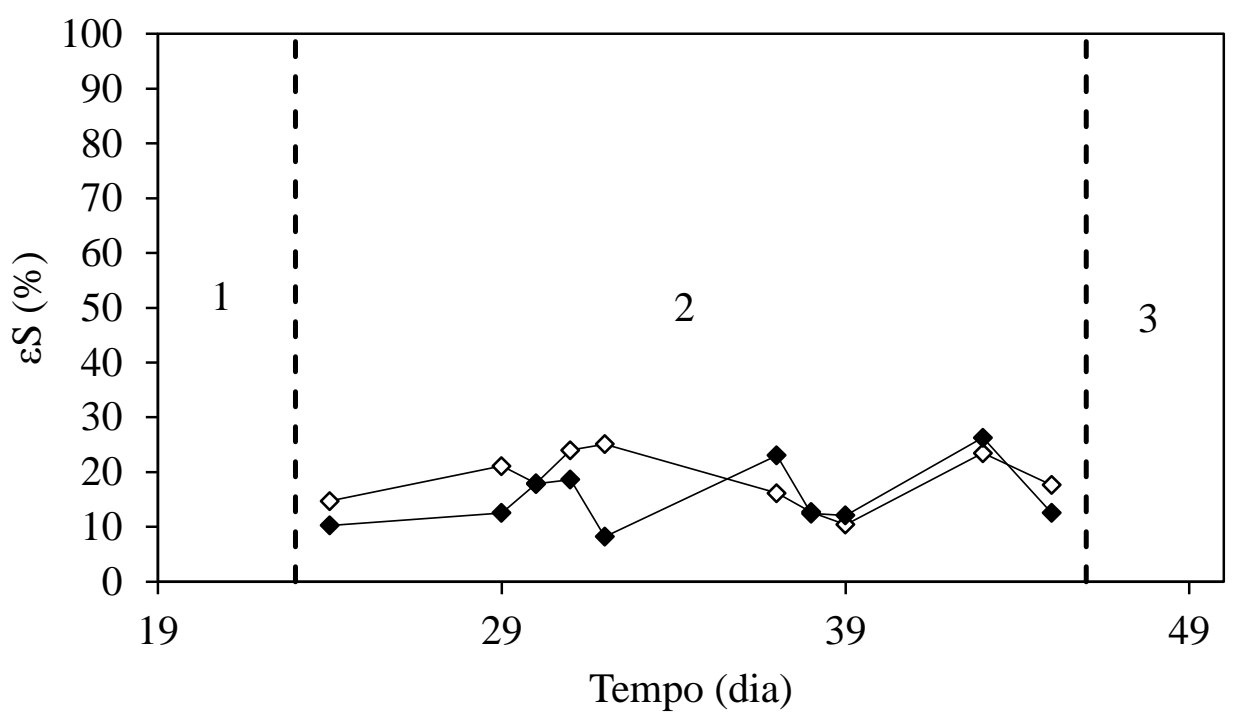

Figura 5-242 - Eficiência de remoção de matéria orgânica (DQO): $\diamond$ - não filtrada; filtrada (AnSBBR com agitação mecânica e lactose - Condição 2).

A Figura 5-243 apresenta os valores da concentração de carboidratos afluente e efluente (para amostras filtradas e não filtradas), enquanto a Figura 5-244 mostra a eficiência de remoção do mesmo parâmetro (não filtrada e filtrada) durante o monitoramento diário. A média da concentração afluente foi de 4579 mgCarboidrato.: ${ }^{-}$ ${ }^{1}$, enquanto que a concentração residual não filtrada foi de $305 \mathrm{mgCarboidrato.} \mathrm{L}^{-1}$ e 287 mgCarboidrato. $\mathrm{L}^{-1}$ para a concentração residual filtrada. A eficiência de remoção de lactose foi, em média, de $94 \%$ e $93 \%$ para as amostras filtradas e não filtradas, respectivamente. A alta eficiência de remoção foi mantida nesta condição. 


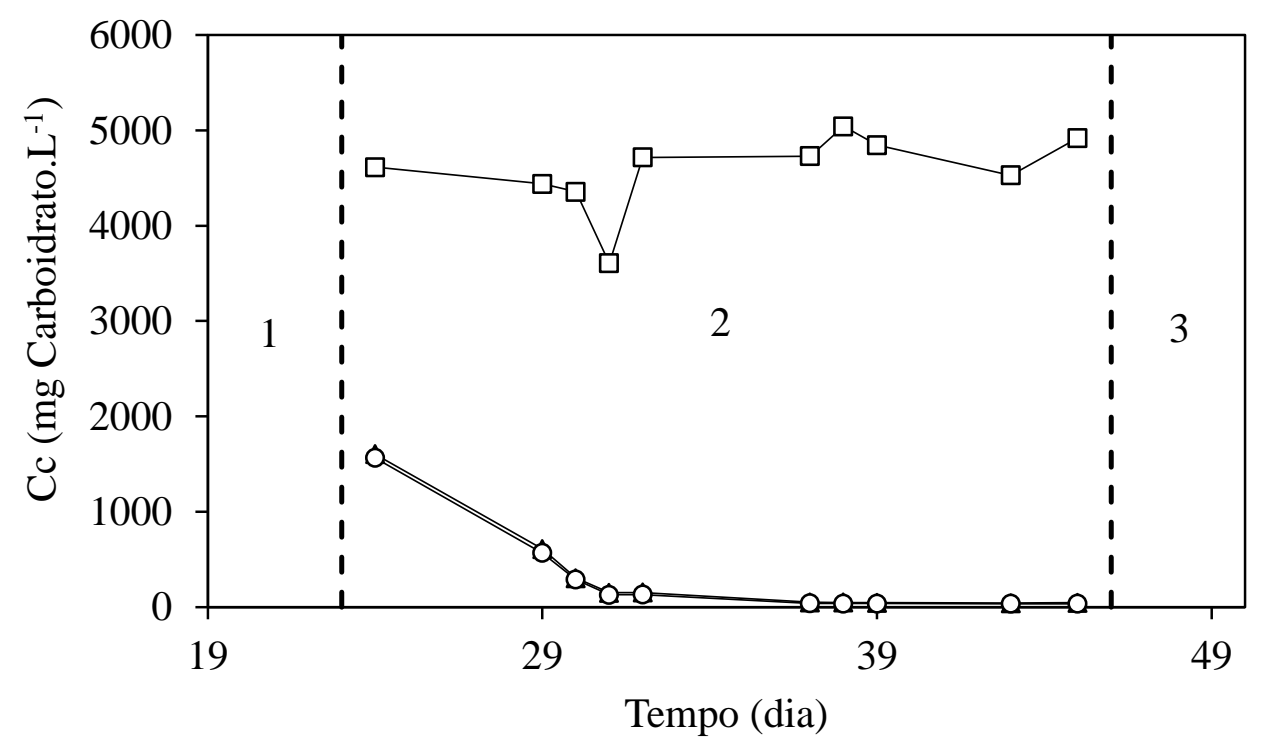

Figura 5-243 - Concentração de carboidrato: $\square$ - afluente não filtrada; $\Delta$ - efluente não filtrada; ○ - efluente filtrada (AnSBBR com agitação mecânica e lactose - Condição 2).

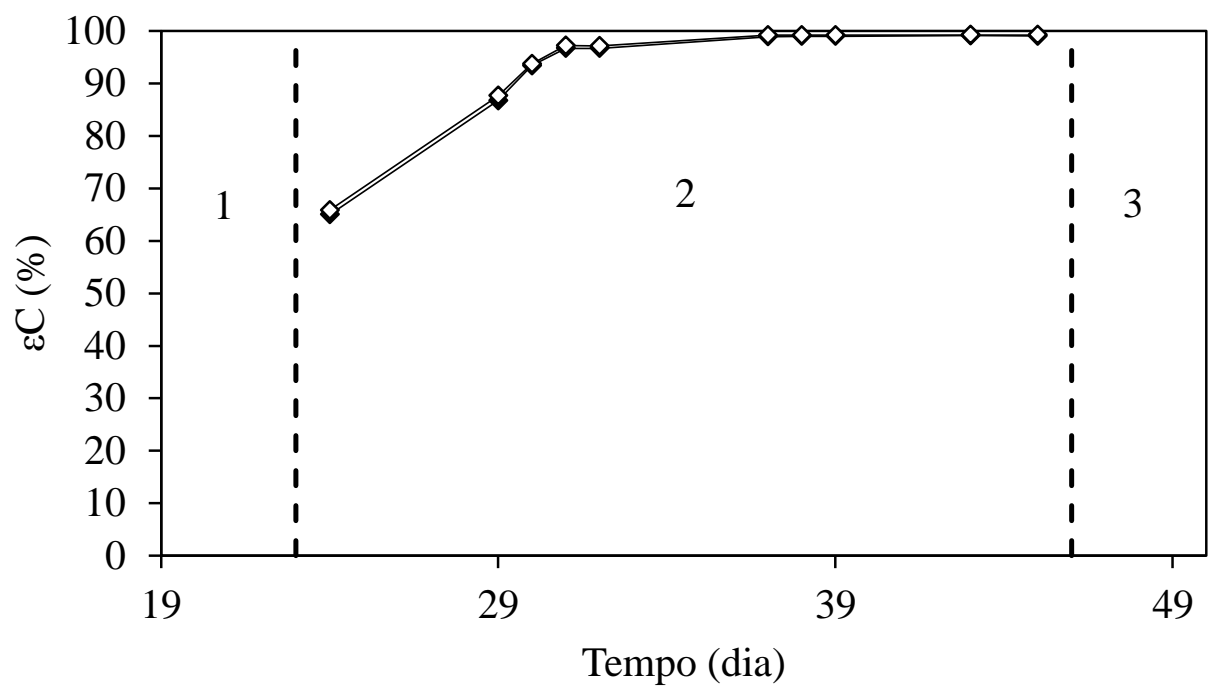

Figura 5-244 - Eficiência de remoção de carboidrato: $\diamond$ - não filtrada; $\downarrow$ - filtrada (AnSBBR com agitação mecânica e lactose - Condição 2).

As Figura 5-245, Figura 5-246 e Figura 5-247 apresentam os valores, tanto para o afluente quanto para o efluente, do $\mathrm{pH}$, da alcalinidade total e dos ácidos voláteis totais por titulação, respectivamente. A média dos valores de $\mathrm{pH}$ afluente durante a Condição 1 foi de 7,93 e de pH efluente foi de 4,20. A média da alcalinidade total foi de 375 e $6 \mathrm{mgCaCO}_{3} \cdot \mathrm{L}^{-1}$ para o afluente e efluente, respectivamente. O valor médio da 
concentração de ácidos voláteis totais afluente foi de $25 \mathrm{mgHAc} . \mathrm{L}^{-1}$ e efluente de 1561 mgHAc. $\mathrm{L}^{-1}$. Novamente a queda no pH está relacionada com a alta produção de ácidos voláteis totais.

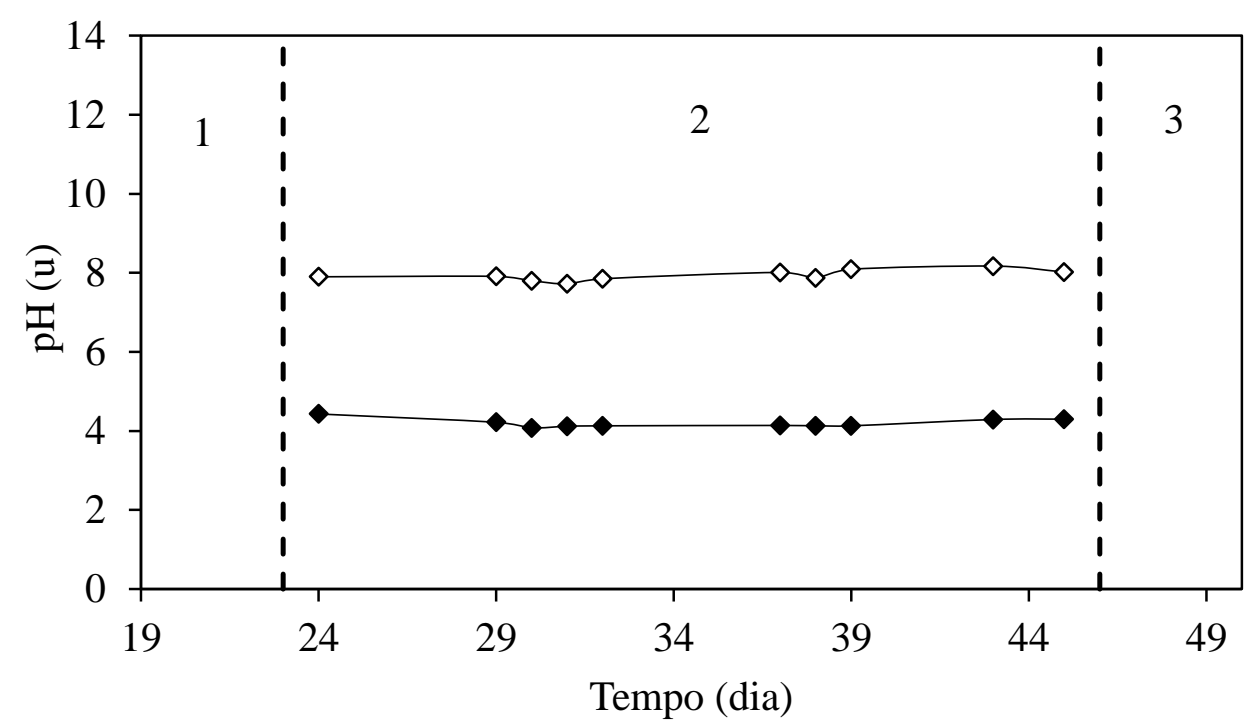

Figura 5-245 - Valores de pH: $\diamond$-afluente; - efluente (AnSBBR com agitação mecânica e lactose - Condição 2).

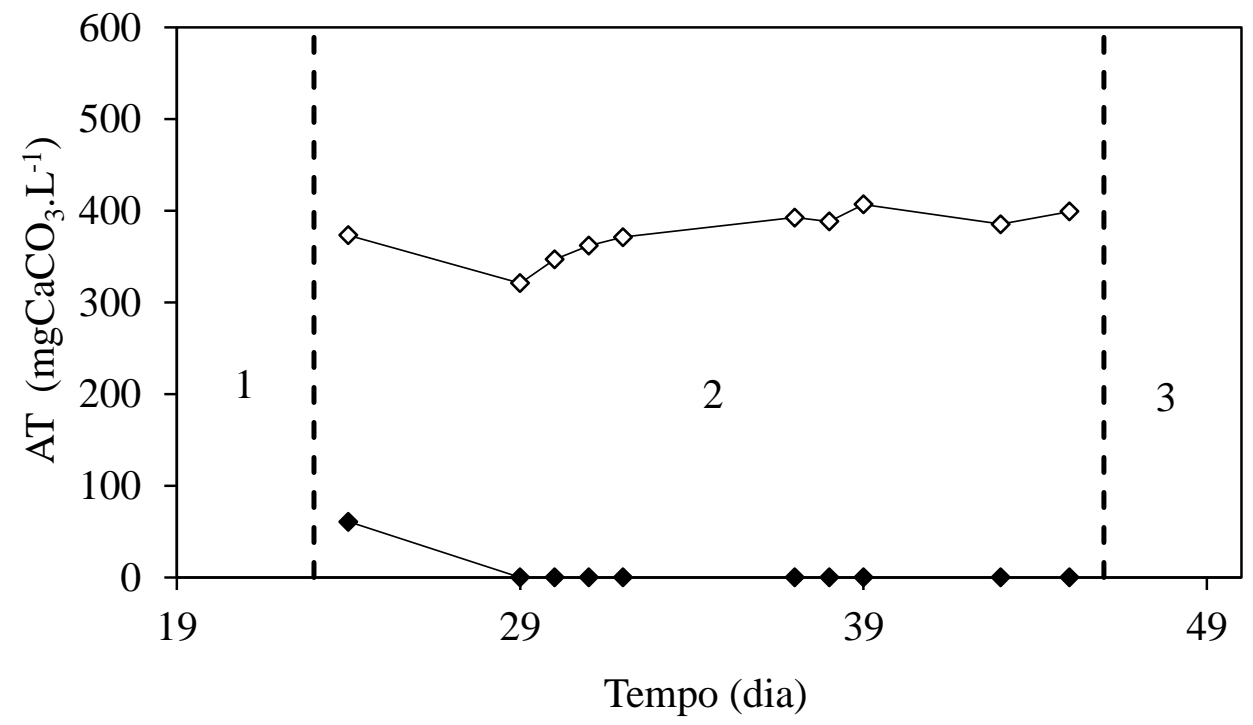

Figura 5-246 - Alcalinidade total: $\diamond$-afluente; $\downarrow$ - efluente (AnSBBR com agitação mecânica e lactose - Condição 2). 


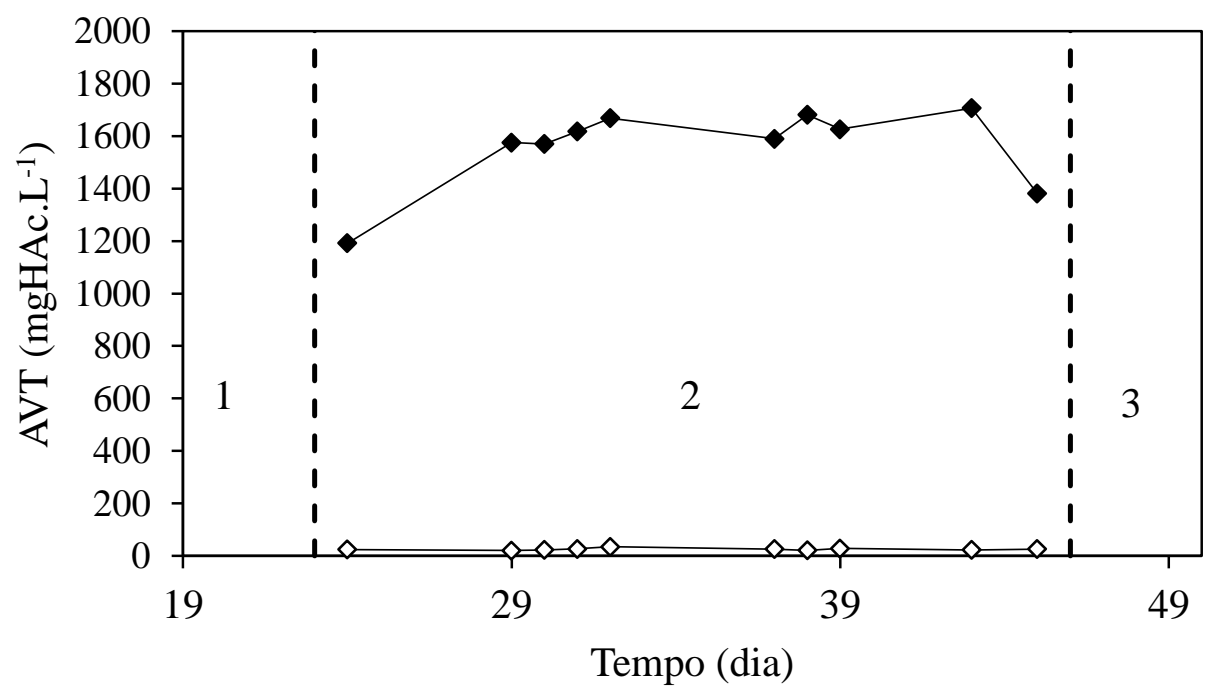

Figura 5-247 - Ácidos voláteis totais: $\diamond$-afluente; - efluente (AnSBBR com agitação mecânica e lactose - Condição 2).

A Figura 5-236 apresenta o monitoramento dos compostos intermediários contidos no efluente do sistema, enquanto que a Tabela 5.61 apresenta os valores da concentração média destes produtos. As amostras para análise destes compostos foram coletadas no dia do perfil temporal da condição (no descarte antes do ciclo do perfil, no ultimo ponto do perfil e no descarte após o ciclo do perfil). O método cromatográfico aplicado não detectou a presença de acetona e metanol. Dentre os ácidos voláteis, o ácido acético predominou seguido pelo ácido propiônico e pelo ácido butírico representando respectivamente $32,8 \%, 7,9 \%$ e $5,1 \%$ dos compostos intermediários. $\mathrm{O}$ maior destaque entre os produtos intermediários, porém, foi o etanol representando 47,5\% dos compostos. Os demais produtos apresentaram concentrações abaixo de 130 mg. $\mathrm{L}^{-1}$. 


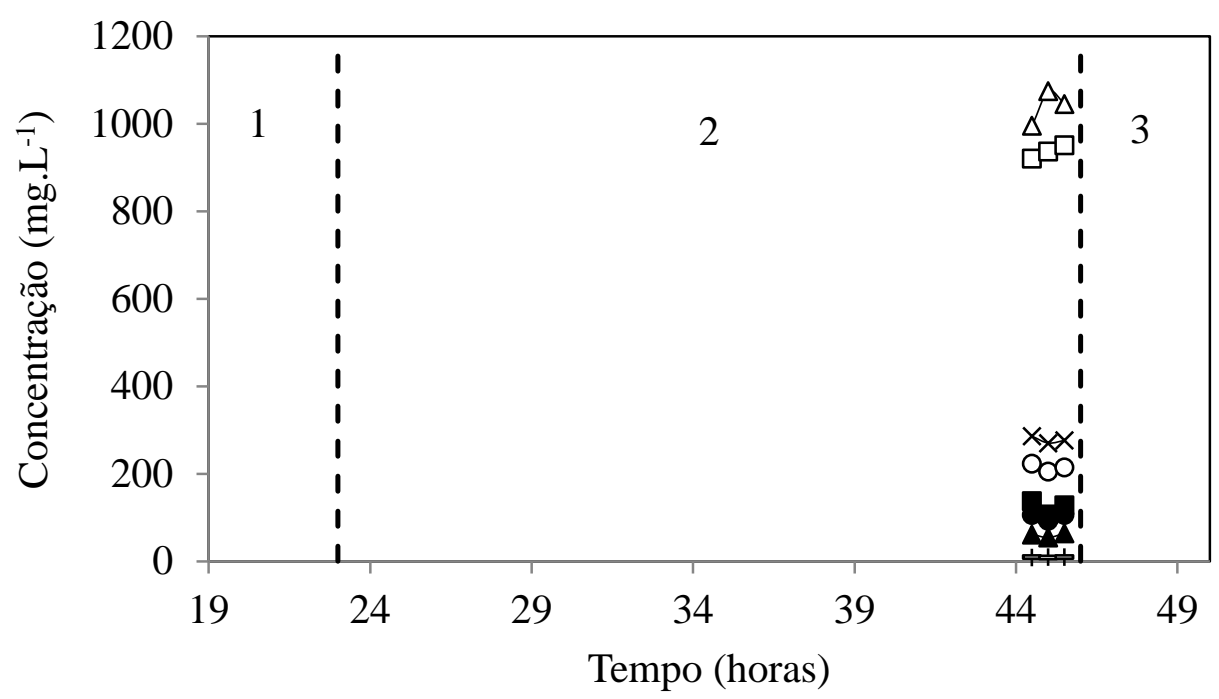

Figura 5-248 - Concentração dos compostos intermediários: $\square$ - ácido acético; $\Delta$ etanol; ○ - ácido butírico; $\mathbf{-}$ - ácido isobutírico; $\boldsymbol{\Delta}$ - ácido capróico; • - ácido valérico; * ácido propiônico; +butanol; — ácido isovalérico (AnSBBR com agitação mecânica e lactose - Condição 2).

Tabela 5.61 - Concentração e distribuição dos compostos intermediários (AnSBBR com agitação mecânica e lactose - Condição 2).

\begin{tabular}{cccccccc}
\hline $\begin{array}{c}\text { Produtos } \\
\text { intermediários }\end{array}$ & \multicolumn{5}{c}{ Concentrações médias } & & Distribuição \\
& \multicolumn{3}{c}{$\left(\mathrm{mg} . \mathrm{L}^{-1}\right)$} & \multicolumn{3}{c}{$\left(\mathrm{mmol. \textrm {L } ^ { - 1 } )}\right.$} & $(\%)$ \\
\hline Acetona & 0,0 & \pm & 0,0 & 0,0 & \pm & 0,0 & 0,0 \\
Metanol & 0,0 & \pm & 0,0 & 0,0 & \pm & 0,0 & 0,0 \\
Etanol & 1038,6 & \pm & 39,9 & 22,5 & \pm & 0,9 & 47,5 \\
n-Butanol & 9,1 & \pm & 0,2 & 0,1 & \pm & 0,0 & 0,3 \\
Acético & 936,0 & \pm & 15,0 & 15,6 & \pm & 0,3 & 32,8 \\
Porpiônico & 277,4 & \pm & 7,8 & 3,7 & \pm & 0,1 & 7,9 \\
Isobutírico & 124,1 & \pm & 15,6 & 1,4 & \pm & 0,2 & 3,0 \\
Butírico & 214,1 & \pm & 9,2 & 2,4 & \pm & 0,1 & 5,1 \\
Isovalérico & 9,4 & \pm & 0,5 & 0,1 & \pm & 0,0 & 0,2 \\
Valérico & 101,5 & \pm & 7,6 & 1,0 & \pm & 0,1 & 2,1 \\
Capróico & 59,9 & \pm & 5,3 & 0,6 & \pm & 0,1 & 1,2 \\
\hline
\end{tabular}

O monitoramento da série de sólidos é mostrado na Tabela 5.62, cujos valores apresentam um baixo teor de SSV no efluente e afluente, indicando mais uma vez a boa capacidade do reator em reter biomassa. 
Tabela 5.62 - Série de sólidos afluente e efluente (AnSBBR com agitação mecânica e lactose - Condição 2).

\begin{tabular}{lcccr}
\hline & $\begin{array}{c}\text { ST } \\
\left(\mathrm{mg} . L^{-1}\right)\end{array}$ & $\begin{array}{c}\text { SVT } \\
\left(\mathrm{mg} . L^{-1}\right)\end{array}$ & $\begin{array}{c}\text { SST } \\
\left(\mathrm{mg} . L^{-1}\right)\end{array}$ & \multicolumn{1}{c}{$\begin{array}{c}\text { SSV } \\
\left(\mathrm{mg} . L^{-1}\right)\end{array}$} \\
\hline Afluente & $3803 \pm 239$ & $3343 \pm 305$ & $57 \pm 12$ & $22 \pm 17$ \\
Efluente & $2295 \pm 138$ & $1813 \pm 174$ & $142 \pm 23$ & $108 \pm 13$ \\
\hline
\end{tabular}

*Número de amostras consideradas $=3$.

A produção do biogás por ciclo, em aspecto quantitativo, pode ser observada na Figura 5-249. A produção média foi de $1695 \mathrm{~mL}$ (CNTP). A Figura 5-250 apresenta o monitoramento das concentrações dos componentes do biogás no final do ciclo, enquanto que a Figura 5-251 apresenta a distribuição destes mesmos componentes. Os valores médios de concentração de $\mathrm{H}_{2}, \mathrm{CH}_{4}$ e $\mathrm{CO}_{2}$ foram 9,4, 0,0 e 15,0 mmol.L ${ }^{-1}$, respectivamente. Além disso, a distribuição percentual média de $\mathrm{H}_{2}$ foi de $38,8 \%$, a de $\mathrm{CH}_{4}$ foi de $0,0 \%$ e a de $\mathrm{CO}_{2}$ foi de $61,2 \%$.

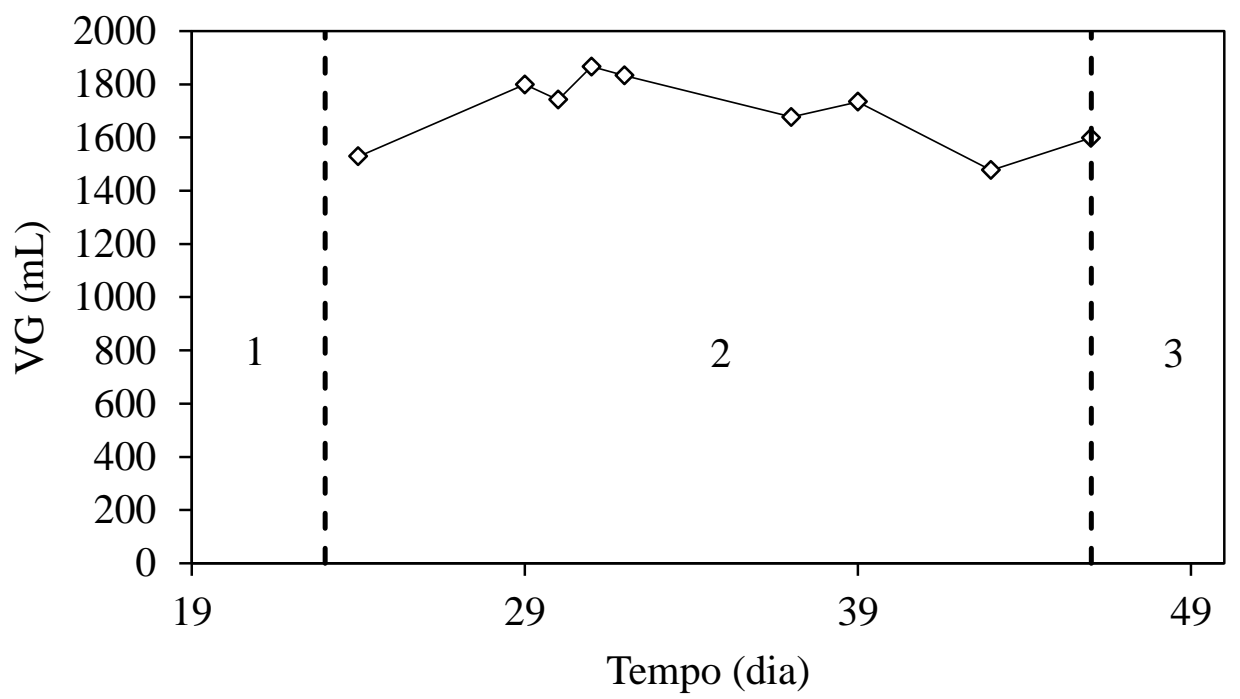

Figura 5-249 - Volume de biogás produzido por ciclo (AnSBBR com agitação mecânica e lactose - Condição 2). 


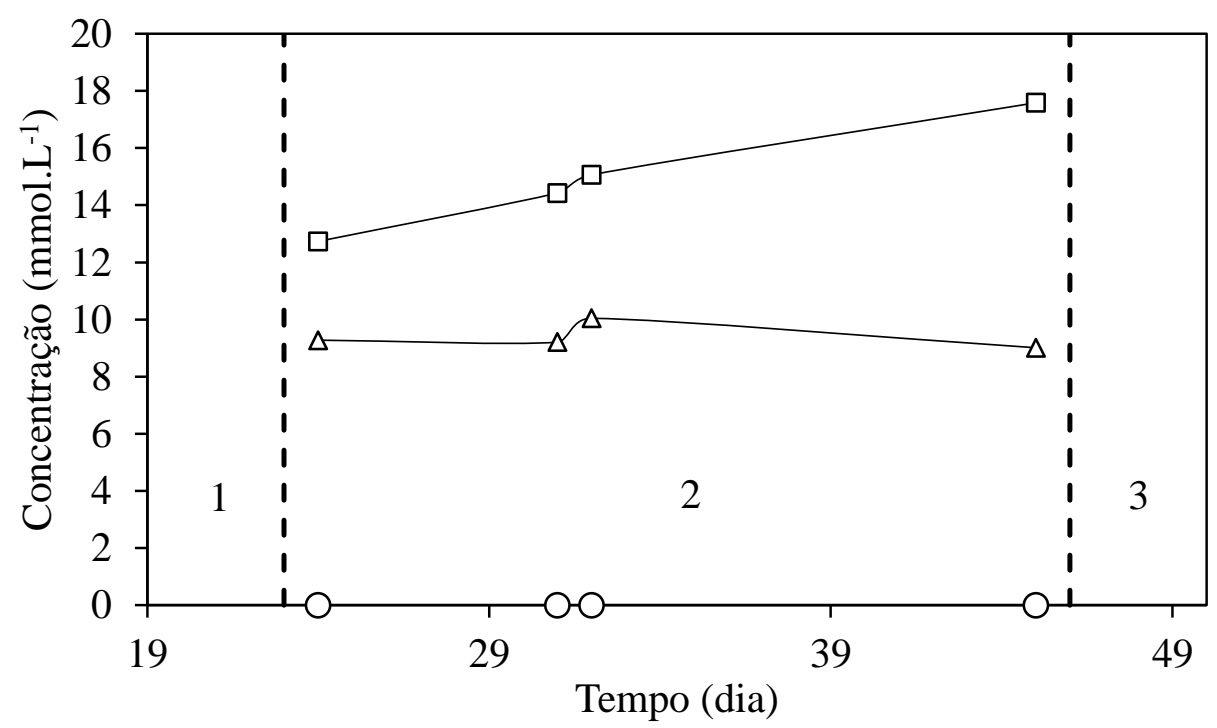

Figura 5-250 - Concentrações dos componentes do biogás no final do ciclo: $\square-\mathrm{CO}_{2} ; \Delta$ - $\mathrm{H}_{2} ;$ ○ - $\mathrm{CH}_{4}$ (AnSBBR com agitação mecânica e lactose - Condição 2).

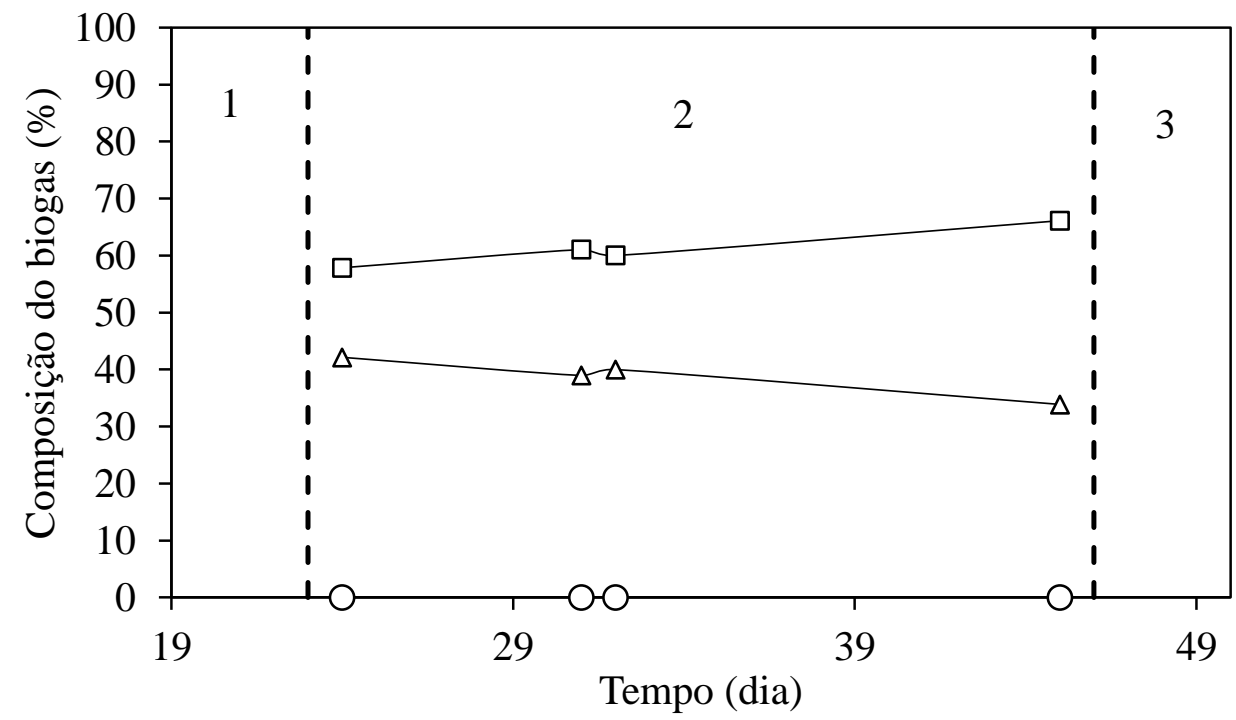

Figura 5-251 - Distribuições dos componentes do biogás no final do ciclo: $\square-\mathrm{CO}_{2} ; \Delta$ $\mathrm{H}_{2} ; \circ-\mathrm{CH}_{4}$ (AnSBBR com agitação mecânica e lactose - Condição 2).

No final da operação foi realizado o perfil temporal, com o intuito de entender melhor como os parâmetros indicativos de eficiência do sistema se comportavam durante um ciclo completo. A Figura 5-283 apresenta a evolução da concentração de carboidrato ao longo do ciclo e a eficiência de remoção do mesmo. Ao inicio do ciclo (tempo zero) o volume afluente foi diluído no volume residual resultando em uma 
concentração de sacarose da ordem de $1540 \mathrm{mg} \cdot \mathrm{L}^{-1}$. A conversão de carboidrato se faz de maneira progressiva ao longo do ciclo, atingindo valores na ordem de $99 \%$ no final do mesmo, com um residual aproximado de $31 \mathrm{mg} \cdot \mathrm{L}^{-1}$.

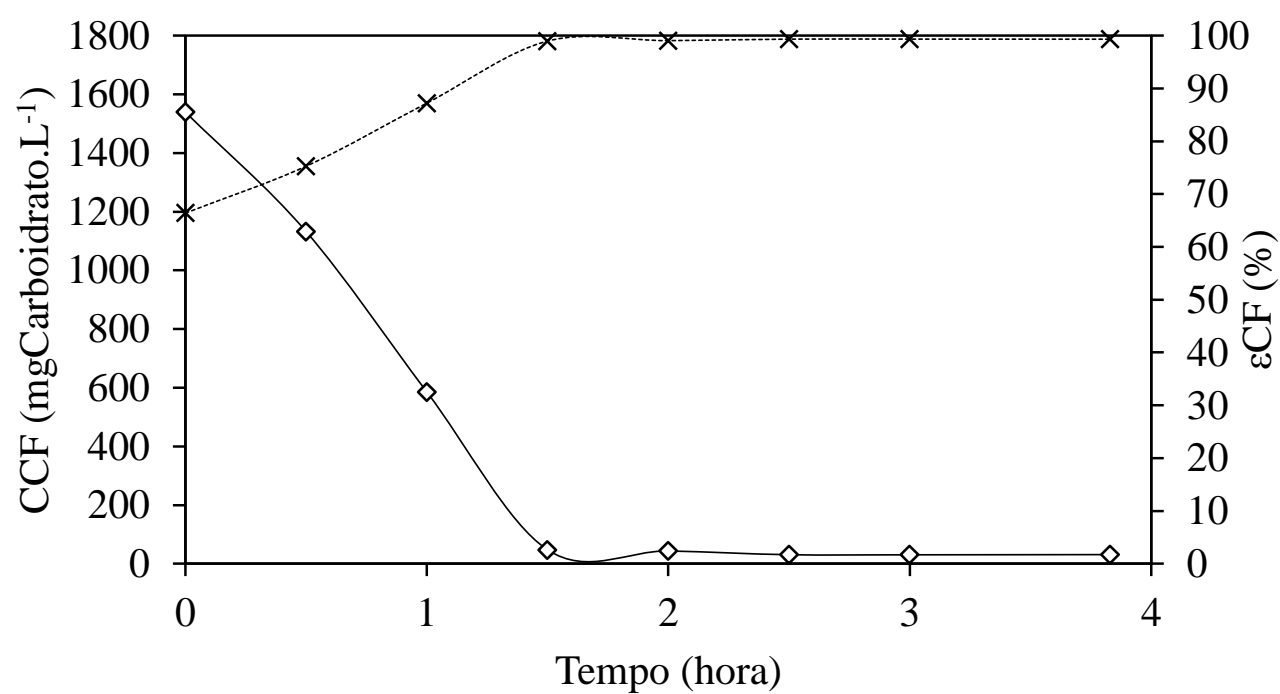

Figura 5-252 - Concentração e eficiência de degradação de carboidrato: $\diamond$ - perfil e * eficiência (AnSBBR com agitação mecânica e lactose - Condição 2).

A Figura 5-253 apresenta a evolução da concentração de matéria orgânica ao longo do ciclo. Observa-se uma baixa remoção da DQO, levando a uma alta concentração da mesma no volume residual. Assim, no inicio do ciclo, a diluição do volume carregado pelo volume residual é realizada mais uma vez em proporção bem menor do que no caso dos carboidratos totais, tendo em vista que as concentrações afluente e residual são muito próximas. No inicio do ciclo, a concentração é da ordem de $4580 \mathrm{mg} . \mathrm{L}^{-1}$ atingindo valores próximos a $4510 \mathrm{mg} . \mathrm{L}^{-1}$ no último ponto do ciclo. 


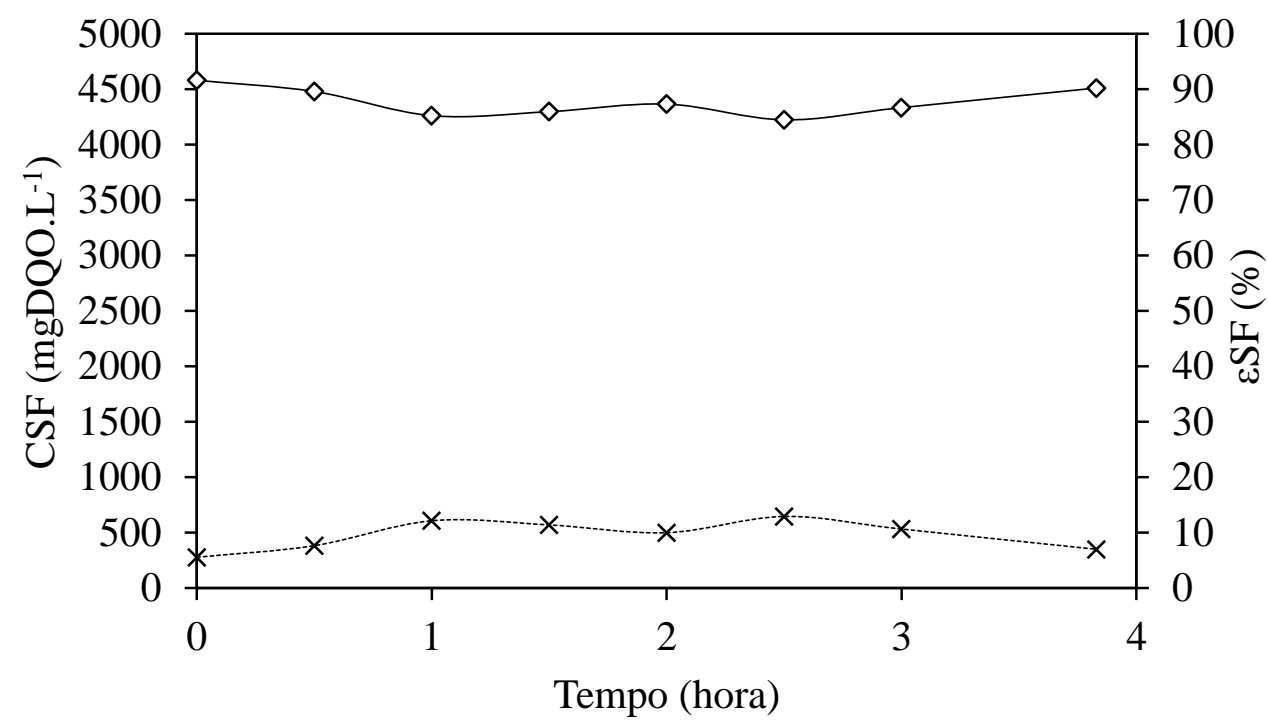

Figura 5-253 - Concentração e eficiência de degradação de matéria orgânica: $\diamond$ - perfil e * eficiência (AnSBBR com agitação mecânica e lactose - Condição 2).

O acúmulo de ácidos voláteis totais por titulação ao longo do ciclo pode ser observado na Figura 5-254. A concentração destes aumenta claramente durante a fase de reação para atingir um máximo no final do ciclo na ordem de $1250 \mathrm{mgHAc} . \mathrm{L}^{-1}$.

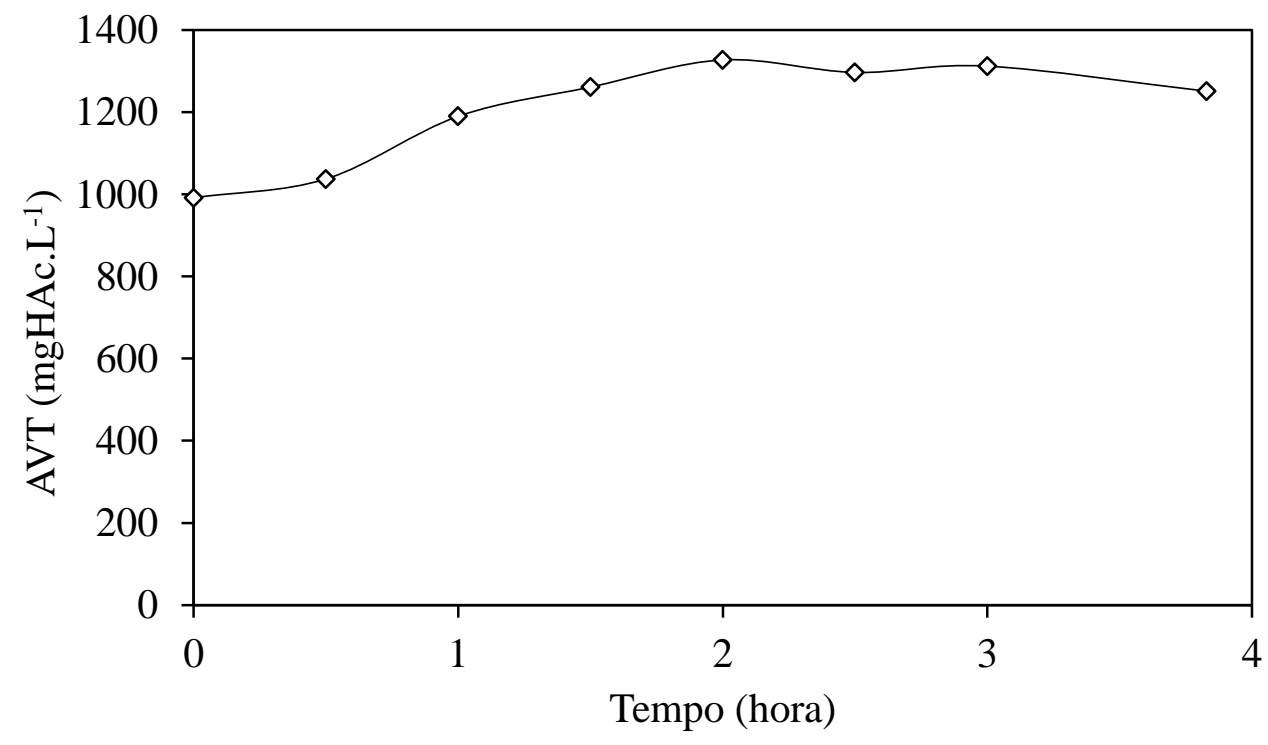

Figura 5-254 - Ácidos voláteis totais $(\diamond)$ do perfil (AnSBBR com agitação mecânica e lactose - Condição 2). 
Os resultados dos compostos intermediários por cromatografia gasosa são apresentados na Figura 5-255. Estes permaneceram estáveis durante todo o perfil. Uma ressalva pode ser feita para o etanol e o ácido acético, que apresentaram aumentos significativos em suas concentrações, indo de $676,5 \mathrm{mg} . \mathrm{L}^{-1}$ no início do ciclo até 1074,6 mg. $\mathrm{L}^{-1}$ no final do ciclo e de 472,4 até 936,6 mg.L ${ }^{-1}$, respectivamente.

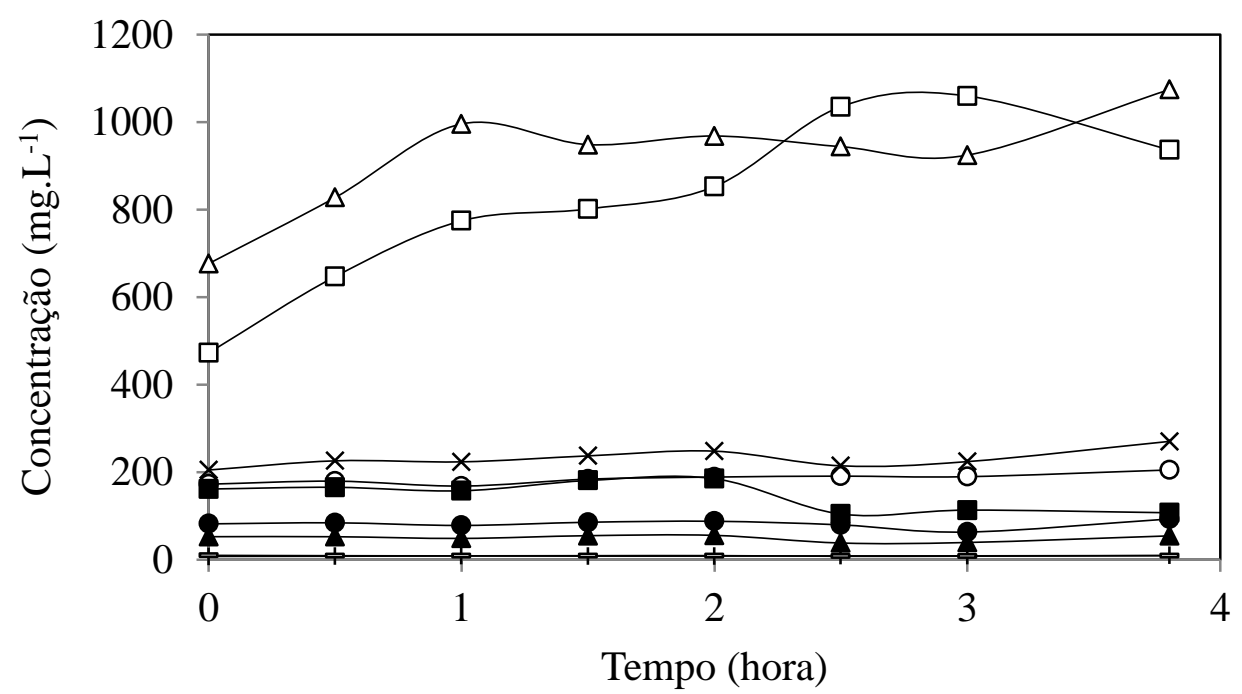

Figura 5-255 - Concentração dos compostos intermediários ao longo do ciclo: $\square$ - ácido acético; $\Delta$ - etanol; $\bigcirc$ - ácido butírico; $\mathbf{\square}$ - ácido isobutírico; $\boldsymbol{\Delta}$ - ácido capróico; $\bullet-$ ácido valérico; - *ácido propiônico; +butanol; - ácido isovalérico (AnSBBR com agitação mecânica e lactose - Condição 2).

$\mathrm{O}$ pH diminuiu instantaneamente em relação ao afluente devido à diluição do mesmo com o volume residual no inicio do ciclo (alimentação do reator em 10 minutos) e permaneceu estável ao longo da operação, conforme a Figura 5-256. Esta estabilidade do $\mathrm{pH}$ foi mantida mesmo com a alcalinidade do sistema sendo completamente consumida na primeira hora de ciclo, como pode ser visto na Figura 5-257. 


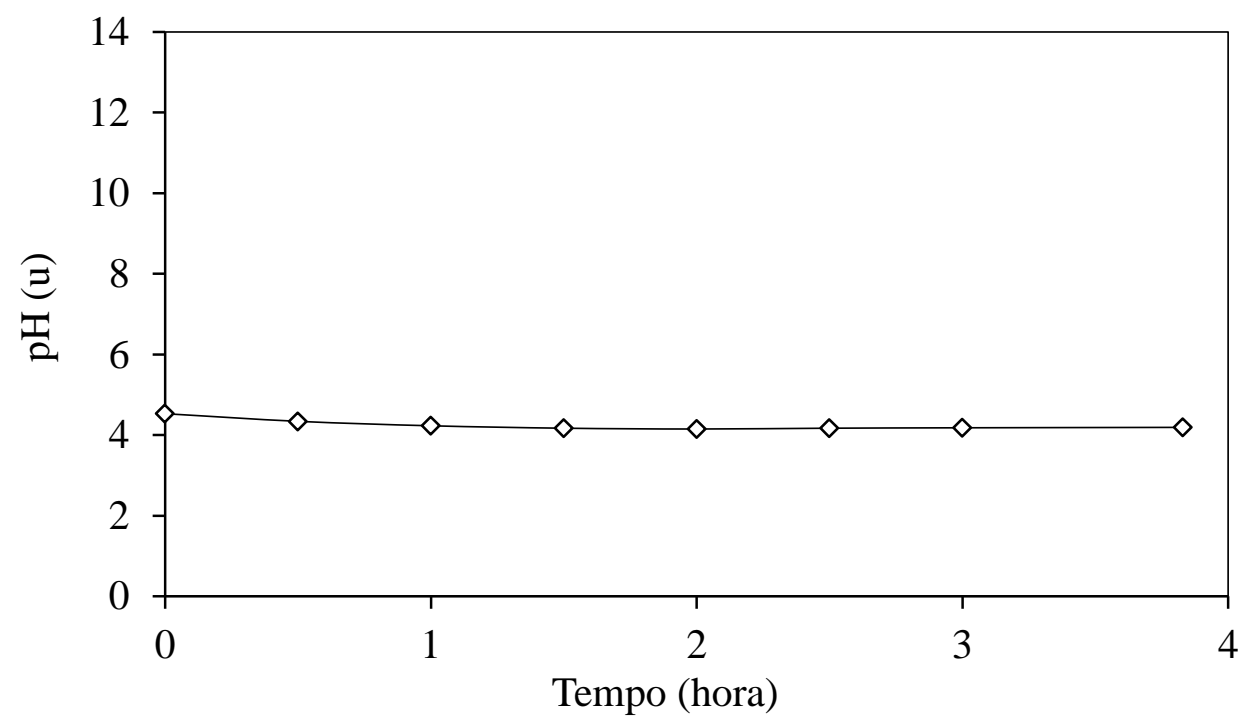

Figura 5-256 - Valores de pH $(\diamond)$ do perfil (AnSBBR com agitação mecânica e lactose Condição 2).

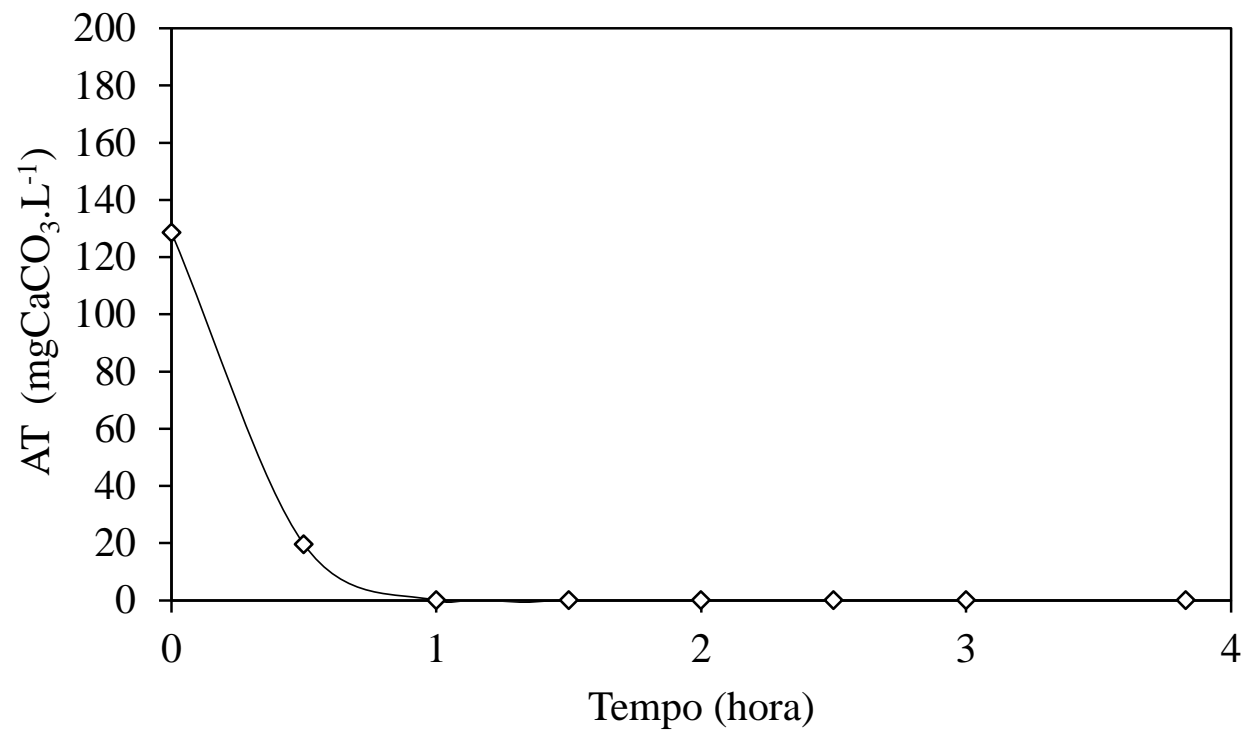

Figura 5-257 - Alcalinidade total $(\diamond)$ do perfil (AnSBBR com agitação mecânica e lactose - Condição 2).

A produção volumétrica média acumulada do biogás, realizada com os valores dos perfis quantitativos mais consistentes obtidos durante a operação, juntamente com os desvios padrões encontram-se na Figura 5-258. A maior parte da produção ocorre no inicio do ciclo, com esta produção acontecendo até o final do ciclo, porém em menor escala. A Tabela 5.63 resume os valores médios da produção, fração molar e os volumes 
individuais da mistura do biogás. A Figura 5-259 apresenta os volumes acumulados médios dos perfis de $\mathrm{H}_{2}, \mathrm{CO}_{2}$ e $\mathrm{CH}_{4}$ produzidos durante o ciclo. Apenas hidrogênio e gás carbônico foram produzidos, sem a presença de metano.

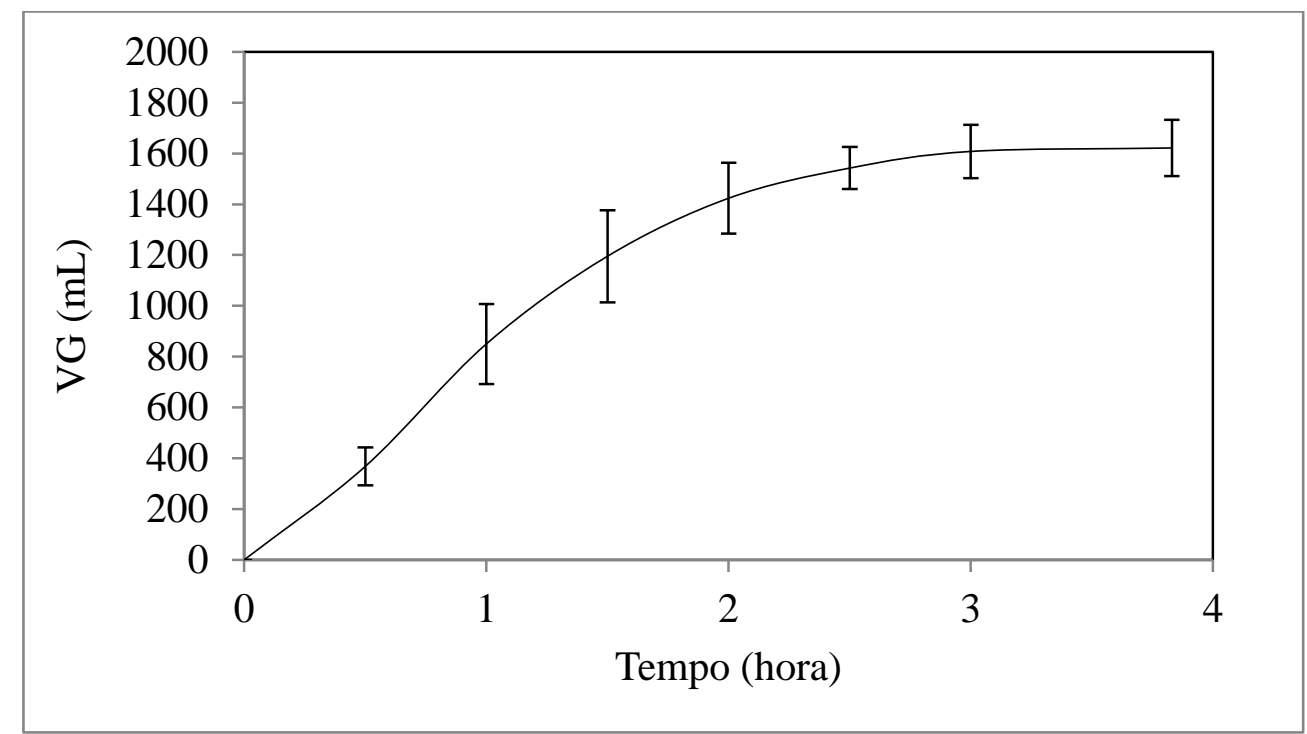

Figura 5-258 - Produção volumétrica média acumulada do biogás durante o ciclo (AnSBBR com agitação mecânica e lactose - Condição 2).

Tabela 5.63 - Valores médios da produção, fração molar e os volumes individuais da mistura do biogás (AnSBBR com agitação mecânica e lactose - Condição 2).

\begin{tabular}{ccccccccccc}
\hline $\begin{array}{c}\text { Tempo } \\
(\mathrm{h})\end{array}$ & \multirow{2}{*}{$\mathrm{V}_{\mathrm{G}}$} & \multicolumn{3}{c}{$\mathrm{C}_{\mathrm{G}}\left(\mathrm{mmol} . \mathrm{L}^{-1}\right)$} & \multicolumn{3}{c}{ Fração Molar (\%) } & \multicolumn{3}{c}{ Volume (mL - CNTP) } \\
& $(\mathrm{mL}-\mathrm{CNTP})$ & $\mathrm{H}_{2}$ & $\mathrm{CO}_{2}$ & $\mathrm{CH}_{4}$ & $\mathrm{H}_{2}$ & $\mathrm{CO}_{2}$ & $\mathrm{CH}_{4}$ & $\mathrm{H}_{2}$ & $\mathrm{CO}_{2}$ & $\mathrm{CH}_{4}$ \\
\hline 0,0 & 0,0 & 0,0 & 0,0 & 0,0 & 0,0 & 0,0 & 0,0 & 0,0 & 0,0 & 0,0 \\
0,5 & 367,9 & 145,3 & 222,6 & 0,0 & 39,5 & 60,5 & 0,0 & 2,5 & 3,8 & 0,0 \\
1,0 & 850,1 & 357,6 & 492,5 & 0,0 & 44,0 & 56,0 & 0,0 & 4,2 & 5,4 & 0,0 \\
1,5 & 1195,3 & 509,6 & 685,8 & 0,0 & 44,0 & 56,0 & 0,0 & 5,8 & 7,4 & 0,0 \\
2,0 & 1423,8 & 605,7 & 818,1 & 0,0 & 42,1 & 57,9 & 0,0 & 6,8 & 9,4 & 0,0 \\
2,5 & 1542,5 & 657,8 & 884,7 & 0,0 & 43,8 & 56,2 & 0,0 & 8,0 & 10,3 & 0,0 \\
3,0 & 1608,1 & 687,6 & 920,4 & 0,0 & 45,6 & 54,4 & 0,0 & 9,4 & 11,2 & 0,0 \\
3,7 & 1621,7 & 693,9 & 927,8 & 0,0 & 45,8 & 54,2 & 0,0 & 9,5 & 11,3 & 0,0 \\
\hline
\end{tabular}




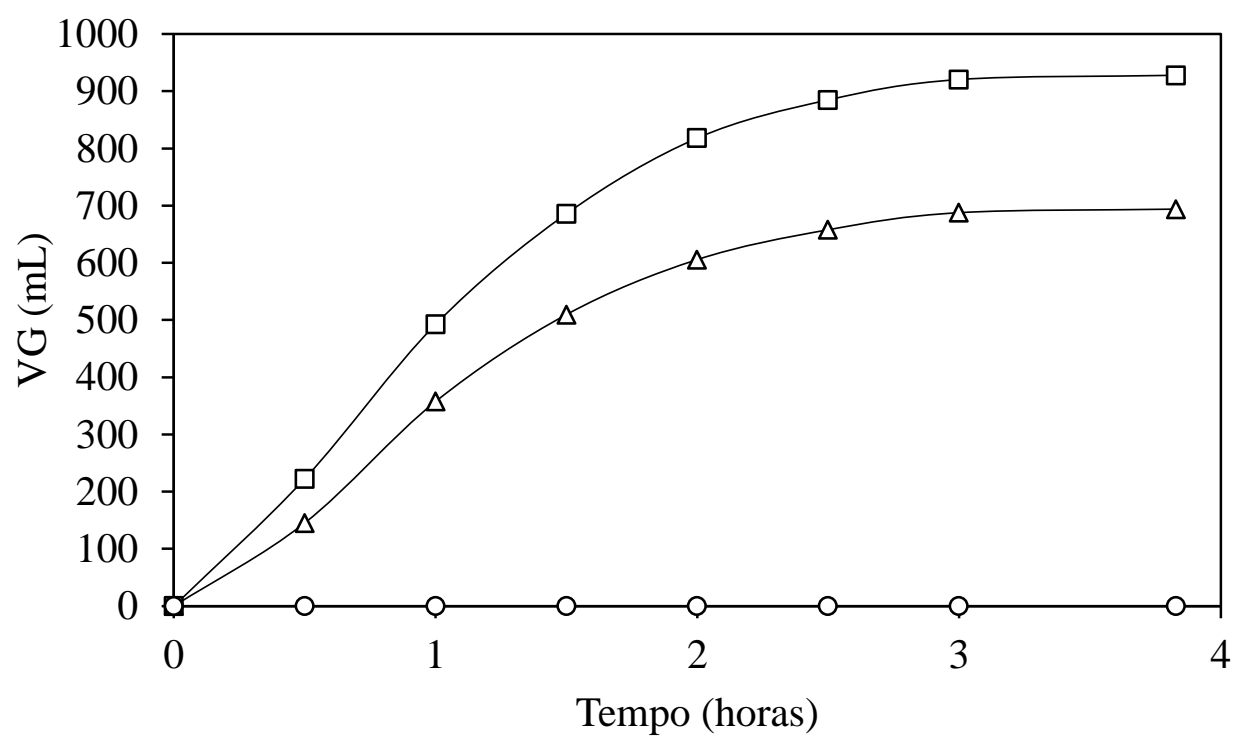

Figura 5-259 - Volumes acumulados médios produzidos ao longo do ciclo: $\square-\mathrm{CO}_{2} ; \Delta$ $\mathrm{H}_{2} ;$ ○ - $\mathrm{CH}_{4}$ (AnSBBR com agitação mecânica e lactose - Condição 2). 
5.3.3. Condição $3\left(D Q O=3600 \mathrm{mg}^{-L^{-1}}\right.$ e $t_{C}=3$ horas $)$

A condição experimental 3 apresentou uma COAV nominal de 12,3 kgDQO.m ${ }^{3} \cdot \mathrm{d}^{-1}$ e duração do ciclo de 3 horas, indo do dia 46 ao dia 67 (22 dias de operação). A Tabela 5.64 apresenta os valores médios dos parâmetros monitorados. 
Tabela 5.64 - Valores médios dos parâmetros monitorados na condição experimental 3 (Lactose - $3600 \mathrm{mgDQO} . \mathrm{L}^{-1}-\mathrm{t}_{\mathrm{C}} 3 \mathrm{~h}$ ).

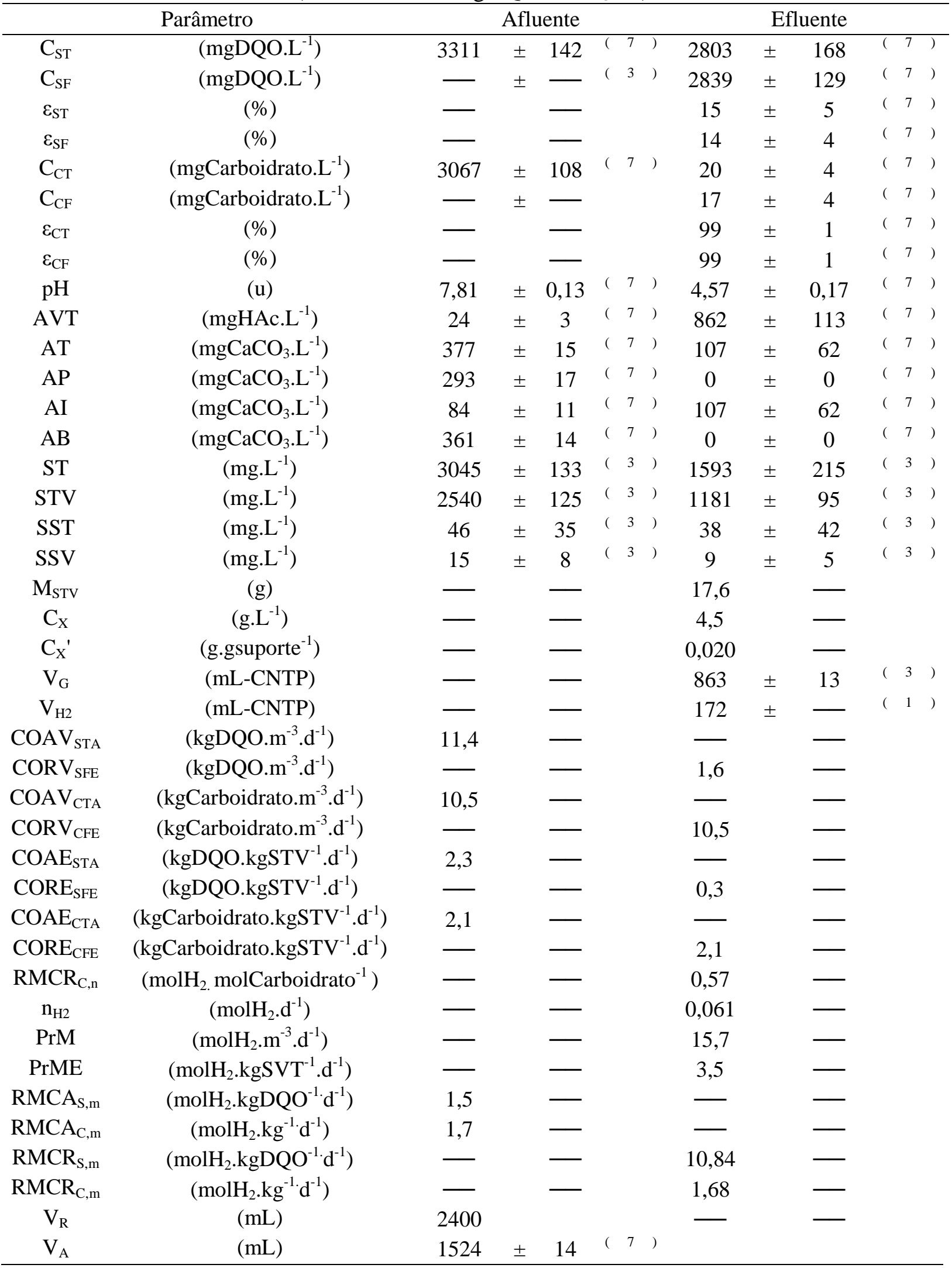

(*) Entre parêntese o número de amostras considerado no cálculo da média 
A Figura 5-260 apresenta os valores da concentração afluente (não filtrada) e efluente (não filtrada e filtrada) de matéria orgânica (DQO) no sistema, enquanto que a Figura 5-261 apresenta a eficiência de remoção do mesmo parâmetro durante o monitoramento diário. Esta eficiência atingiu, em média, 14\% para as amostras filtradas e $15 \%$ para amostras não filtradas. A média de concentração afluente não filtrada do substrato foi de $3311 \mathrm{mgDQO} . \mathrm{L}^{-1}$ e de $2803 \mathrm{mgDQO} . \mathrm{L}^{-1}$ e $2839 \mathrm{mgDQO} . \mathrm{L}^{-1}$ para amostras de efluente não filtrado e filtrado, respectivamente.

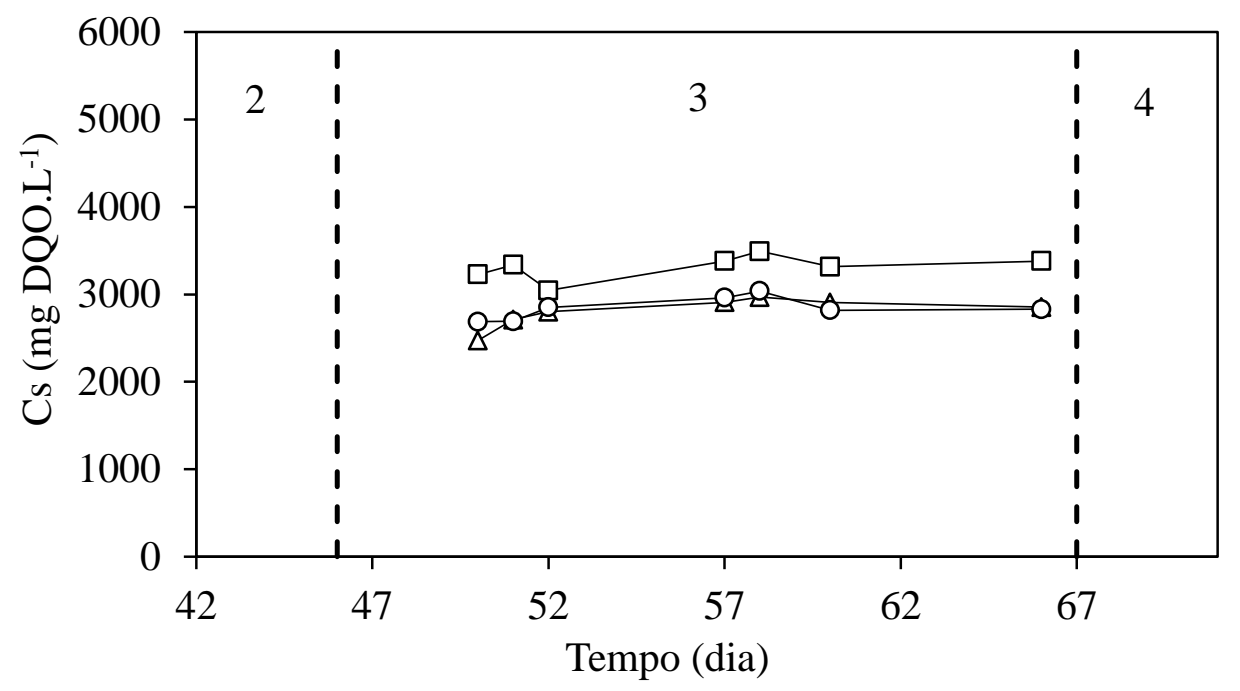

Figura 5-260 - Concentração de matéria orgânica (DQO): $\square-$ afluente não filtrada; $\Delta$ efluente não filtrada; $\bigcirc$ - efluente filtrada (AnSBBR com agitação mecânica e lactose Condição 3). 


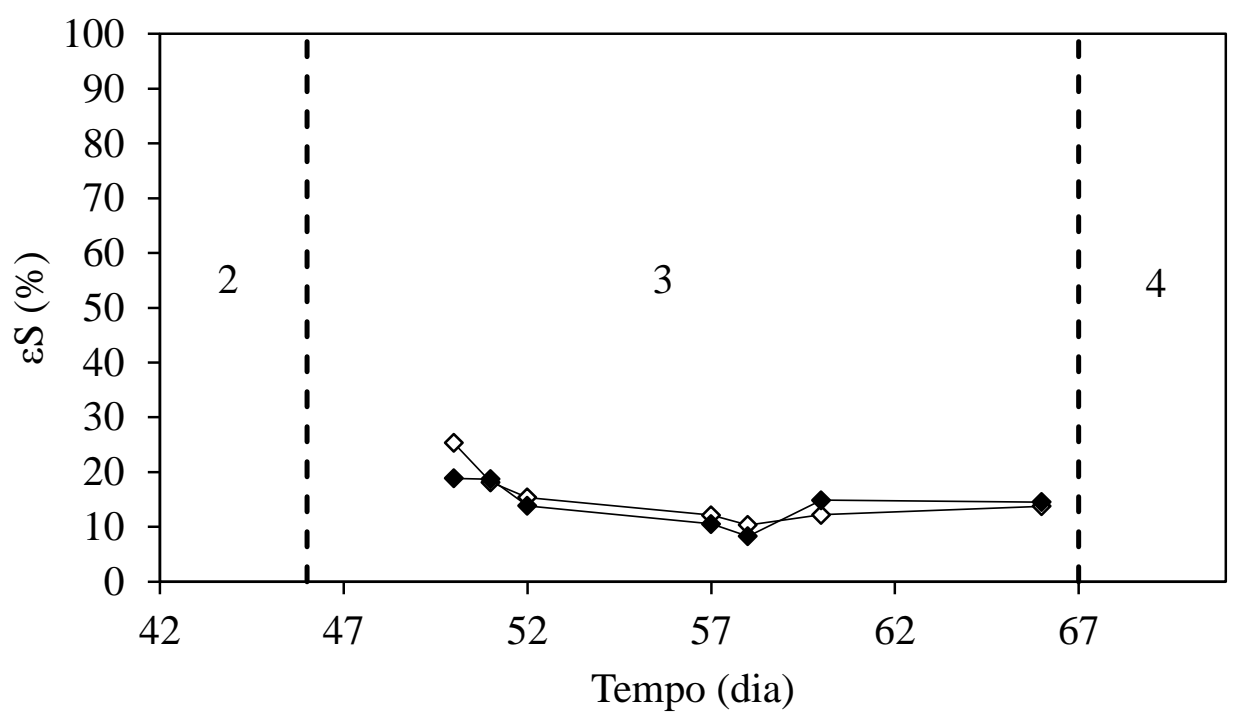

Figura 5-261 - Eficiência de remoção de matéria orgânica (DQO): $\diamond$ - não filtrada; filtrada (AnSBBR com agitação mecânica e lactose - Condição 3).

A Figura 5-262 apresenta os valores da concentração de carboidratos afluente e efluente (para amostras filtradas e não filtradas), enquanto a Figura 5-263 mostra a eficiência de remoção do mesmo parâmetro (não filtrada e filtrada) durante o monitoramento diário. A média da concentração afluente foi de 3067 mgCarboidrato.L ${ }^{-}$ 1, enquanto que a concentração residual não filtrada foi de 20 mgCarboidrato. $\mathrm{L}^{-1}$ e 17 mgCarboidrato. $\mathrm{L}^{-1}$ para a concentração residual filtrada. A eficiência de remoção de sacarose foi, em média, de 99\% para ambas as amostras. 


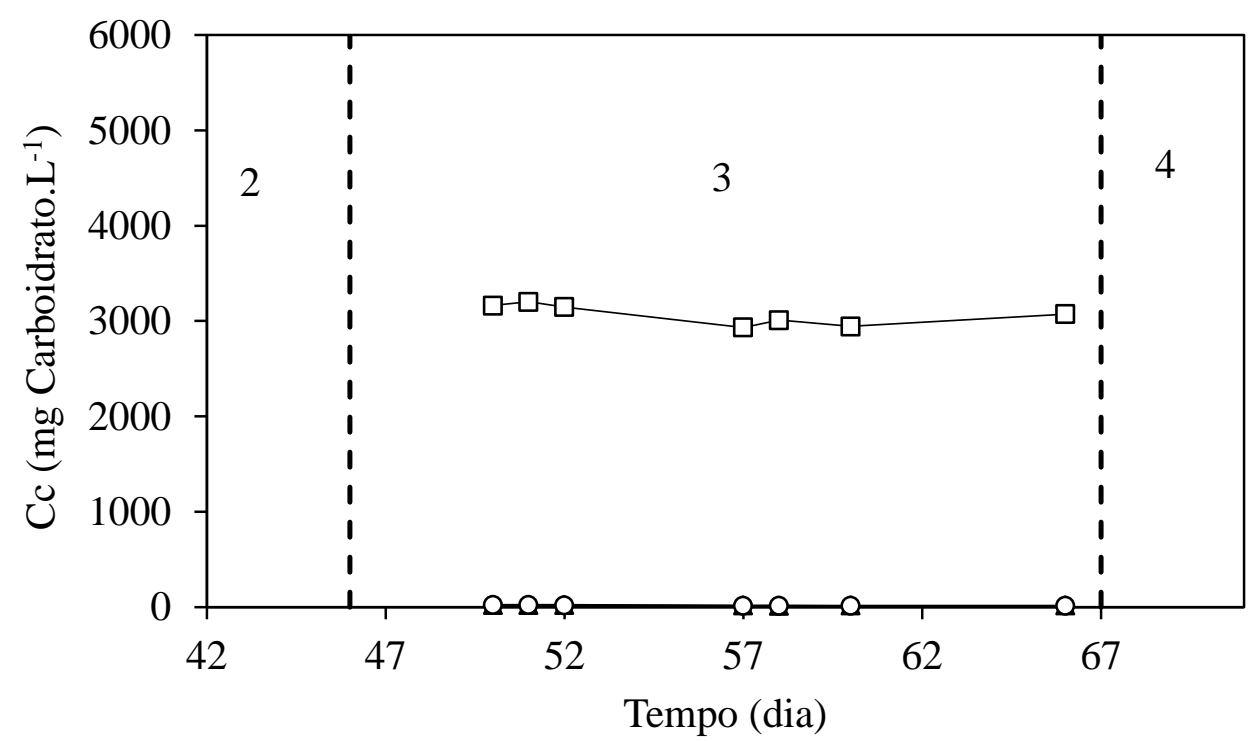

Figura 5-262 - Concentração de carboidrato: $\square$ - afluente não filtrada; $\Delta$ - efluente não filtrada; O - efluente filtrada (AnSBBR com agitação mecânica e lactose - Condição 3).

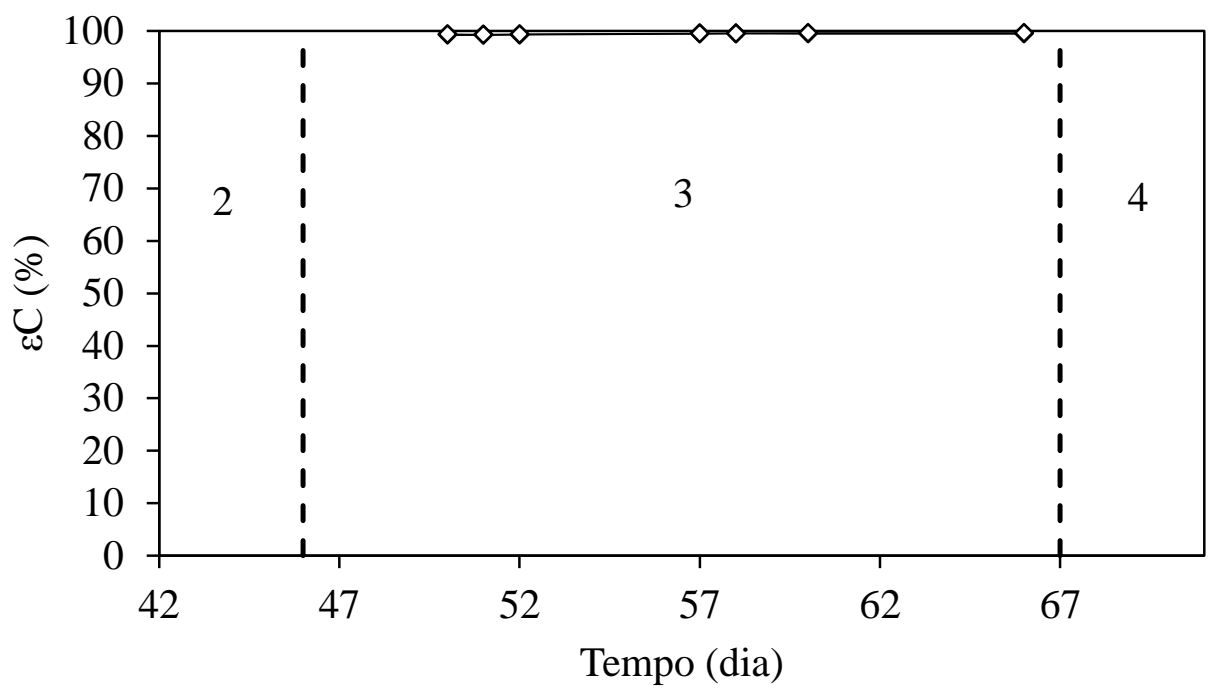

Figura 5-263 - Eficiência de remoção de carboidrato: $\diamond$ - não filtrada; $\downarrow$ - filtrada (AnSBBR com agitação mecânica e lactose - Condição 3).

As Figura 5-264, Figura 5-265 e Figura 5-266 apresentam os valores, tanto para o afluente quanto para o efluente, do $\mathrm{pH}$, da alcalinidade total e dos ácidos voláteis totais por titulação, respectivamente. A média dos valores de $\mathrm{pH}$ afluente durante a Condição 3 foi de 7,81 e de pH efluente foi de 4,57. A média da alcalinidade total foi de 377 e $107 \mathrm{mgCaCO}_{3} \cdot \mathrm{L}^{-1}$ para o afluente e efluente, respectivamente. O valor médio da 
concentração de ácidos voláteis totais afluente foi de $24 \mathrm{mgHAc} . \mathrm{L}^{-1}$ e efluente de 862 $\operatorname{mgHAc} . \mathrm{L}^{-1}$.

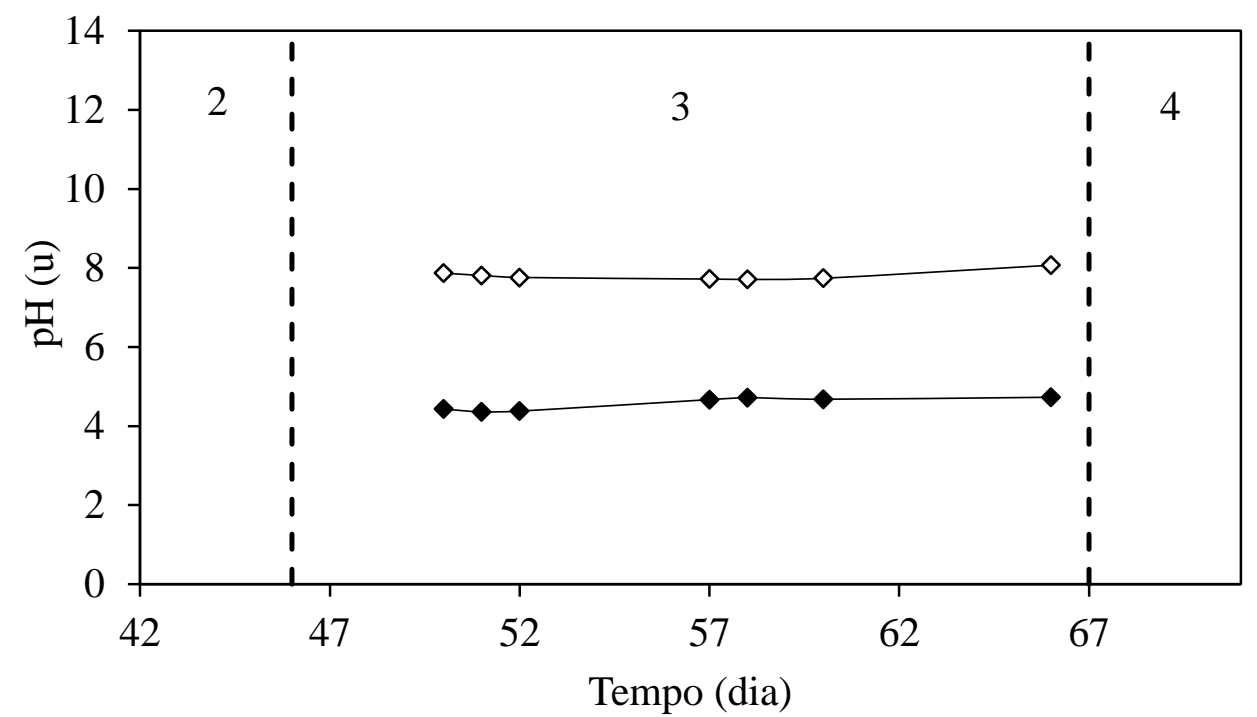

Figura 5-264 - Valores de pH: $\diamond$-afluente; - efluente (AnSBBR com agitação mecânica e lactose - Condição 3).

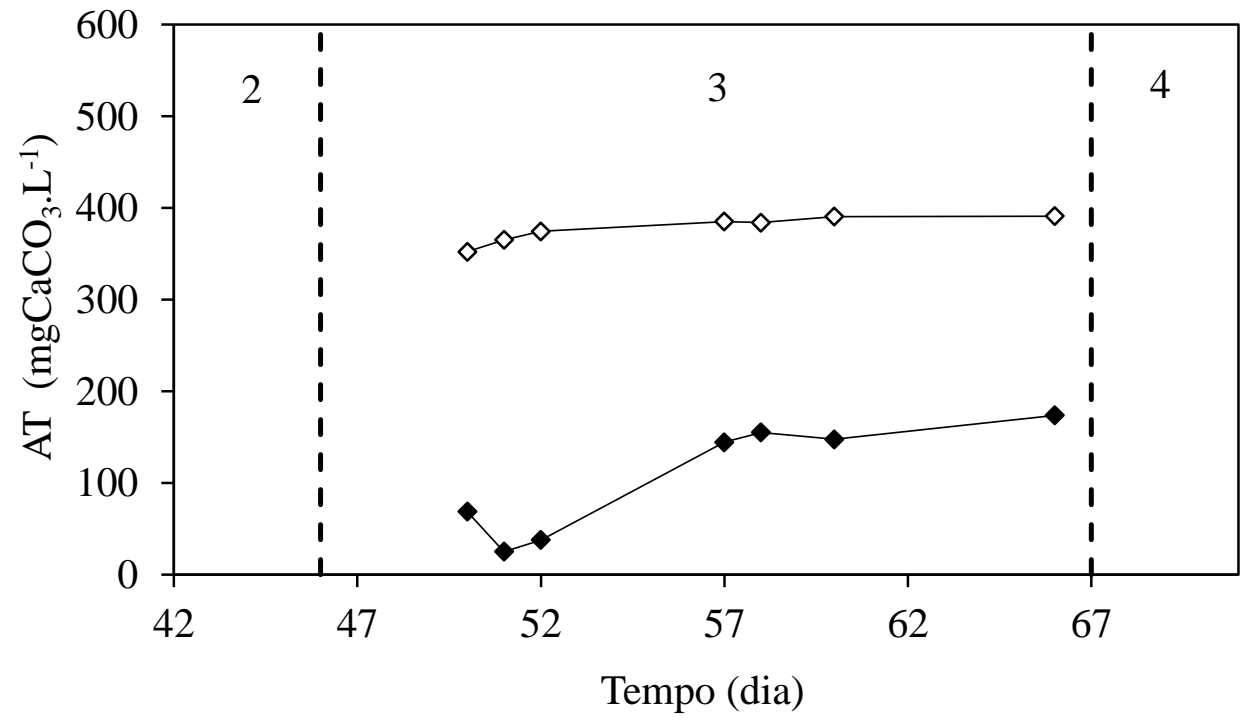

Figura 5-265 - Alcalinidade total: $\diamond$-afluente; $\downarrow$ - efluente (AnSBBR com agitação mecânica e lactose - Condição 3). 


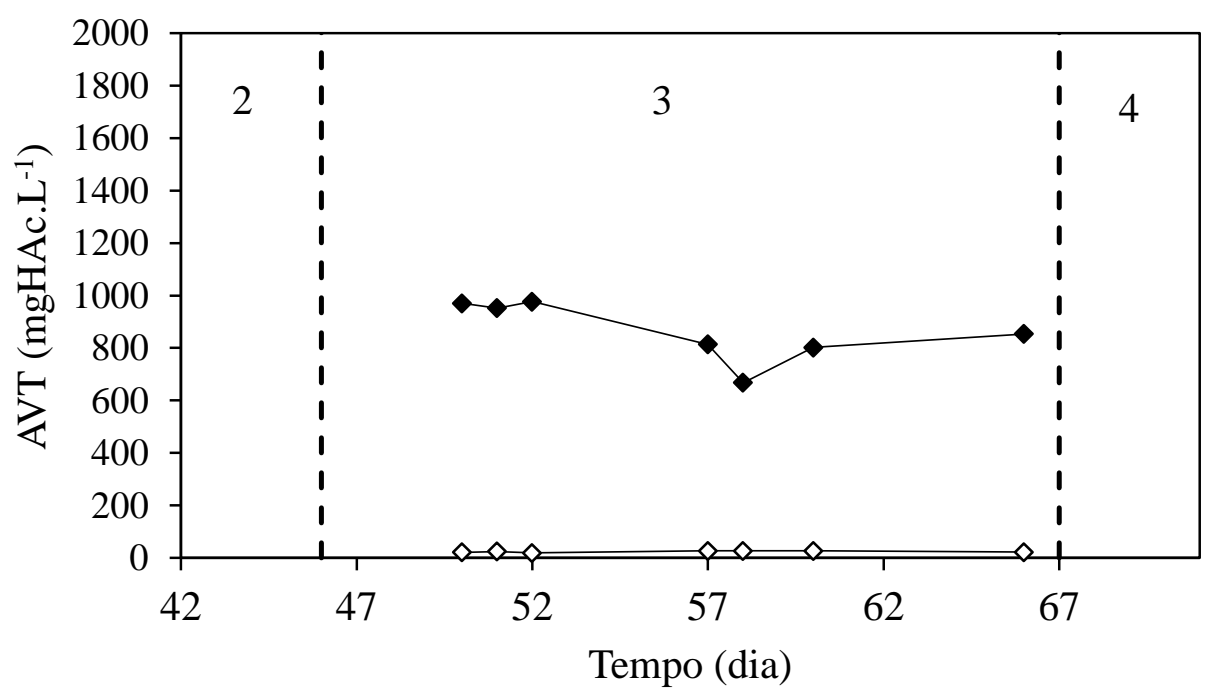

Figura 5-266 - Ácidos voláteis totais: $\diamond$-afluente; - efluente (AnSBBR com agitação mecânica e lactose - Condição 3).

A Figura 5-267 apresenta o monitoramento dos compostos intermediários contidos no efluente do sistema, enquanto que a Tabela 5.65 apresenta os valores da concentração média destes produtos. As amostras para análise destes compostos foram coletadas no dia do perfil temporal da condição (no descarte antes do ciclo do perfil, no ultimo ponto do perfil e no descarte após o ciclo do perfil). O método cromatográfico aplicado não detectou, mais uma vez, a presença de acetona e metanol. Dentre os ácidos voláteis, o ácido acético predominou seguido pelo ácido isobutírico e pelo ácido butírico representando respectivamente $25,2 \%, 12,6 \%$ e $10,4 \%$ dos compostos intermediários. O maior destaque entre os produtos intermediários novamente foi o etanol representando $36,6 \%$ dos compostos. 


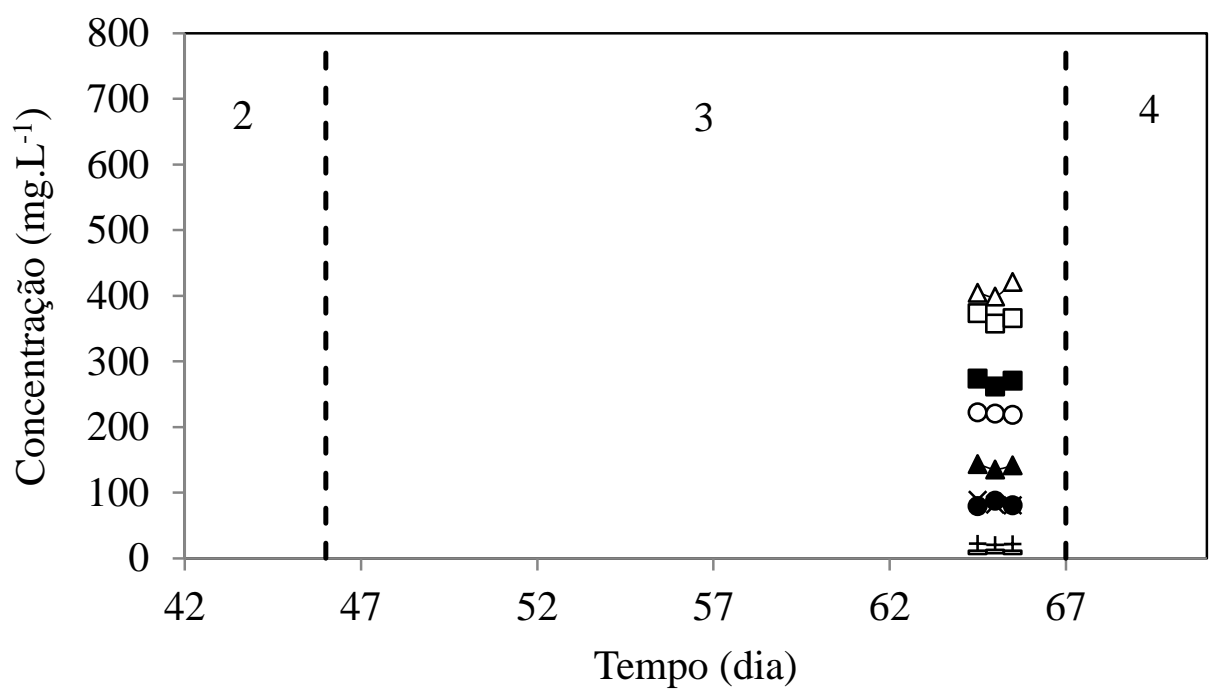

Figura 5-267 - Concentração dos compostos intermediários: $\square$ - ácido acético; $\Delta$ etanol; ○ - ácido butírico; - ácido isobutírico; $\boldsymbol{\Delta}$ - ácido capróico; $\bullet$ - ácido valérico; * ácido propiônico; +butanol; - ácido isovalérico (AnSBBR com agitação mecânica e lactose - Condição 3).

Tabela 5.65 - Concentração e distribuição dos compostos intermediários (AnSBBR com agitação mecânica e lactose - Condição 3).

\begin{tabular}{cccccccc}
\hline $\begin{array}{c}\text { Produtos } \\
\text { intermediários }\end{array}$ & \multicolumn{5}{c}{ Concentrações médias } & & Distribuição \\
& \multicolumn{3}{c}{$\left(\mathrm{mg} . \mathrm{L}^{-1}\right)$} & \multicolumn{3}{c}{$\left(\mathrm{mmol} . \mathrm{L}^{-1}\right)$} & $(\%)$ \\
\hline Acetona & 0,0 & \pm & 0,0 & 0,0 & \pm & 0,0 & 0,0 \\
Metanol & 0,0 & \pm & 0,0 & 0,0 & \pm & 0,0 & 0,0 \\
Etanol & 408,3 & \pm & 11,6 & 8,9 & \pm & 0,3 & 36,6 \\
n-Butanol & 21,2 & \pm & 0,9 & 0,3 & \pm & 0,0 & 1,2 \\
Acético & 365,8 & \pm & 8,1 & 6,1 & \pm & 0,1 & 25,2 \\
Porpiônico & 83,9 & \pm & 4,3 & 1,1 & \pm & 0,1 & 4,7 \\
Isobutírico & 268,6 & \pm & 6,0 & 3,1 & \pm & 0,1 & 12,6 \\
Butírico & 220,6 & \pm & 1,9 & 2,5 & \pm & 0,0 & 10,4 \\
Isovalérico & 9,5 & \pm & 0,6 & 0,1 & \pm & 0,0 & 0,4 \\
Valérico & 82,7 & \pm & 4,5 & 0,8 & \pm & 0,0 & 3,3 \\
Capróico & 140,1 & \pm & 4,1 & 1,4 & \pm & 0,0 & 5,7 \\
\hline
\end{tabular}

O monitoramento da série de sólidos é mostrado na Tabela 5.6, cujos valores apresentam um baixo teor de SSV no efluente e afluente, indicando mais uma vez a boa capacidade do reator em reter biomassa. 
Tabela 5.66 - Série de sólidos afluente e efluente (AnSBBR com agitação mecânica e lactose - Condição 3).

\begin{tabular}{lcccc}
\hline & $\begin{array}{c}\text { ST } \\
\left(\mathrm{mg}^{-1}\right)\end{array}$ & $\begin{array}{c}\text { SVT } \\
\left(\mathrm{mg} . L^{-1}\right)\end{array}$ & $\begin{array}{c}\text { SST } \\
\left(\mathrm{mg} . L^{-1}\right)\end{array}$ & $\begin{array}{c}\text { SSV } \\
\left(\mathrm{mg} . \mathrm{L}^{-1}\right)\end{array}$ \\
\hline Afluente & $3054 \pm 133$ & $2540 \pm 125$ & $46 \pm 35$ & $15 \pm 8$ \\
Efluente & $1593 \pm 215$ & $1181 \pm 95$ & $38 \pm 42$ & $9 \pm 5$ \\
\hline
\end{tabular}

*Número de amostras consideradas $=3$.

A produção do biogás por ciclo, em aspecto quantitativo, pode ser observada na Figura 5-268. A produção média foi de $987 \mathrm{~mL}$ (CNTP). A Figura 5-269 apresenta o monitoramento das concentrações dos componentes do biogás no final do ciclo, enquanto que a Figura 5-270 apresenta a distribuição destes mesmos componentes. Os valores médios de concentração de $\mathrm{H}_{2}, \mathrm{CH}_{4}$ e $\mathrm{CO}_{2}$ foram 5,1, 0,0 e 11,8 mmol.L ${ }^{-1}$, respectivamente. Além disso, a distribuição percentual média de $\mathrm{H}_{2}$ foi de $29,1 \%$, a de $\mathrm{CH}_{4}$ foi de $0,0 \%$ e a de $\mathrm{CO}_{2}$ foi de $70,9 \%$.

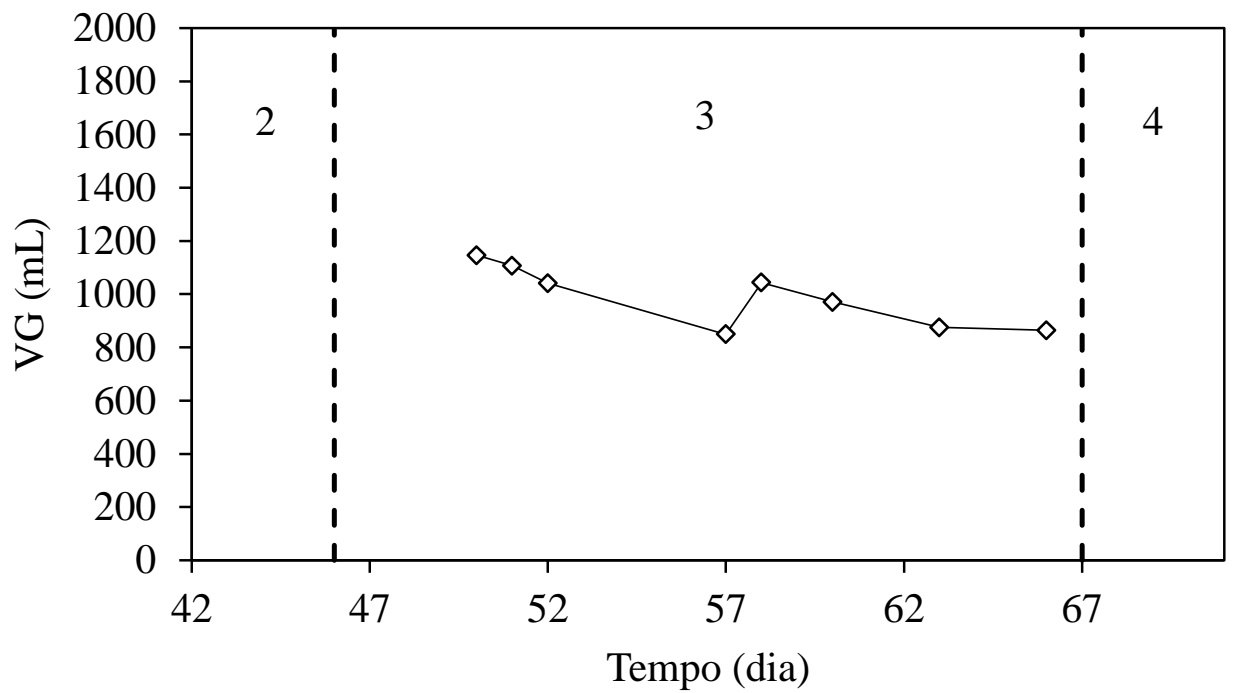

Figura 5-268 - Volume de biogás produzido por ciclo (AnSBBR com agitação mecânica e lactose - Condição 3). 


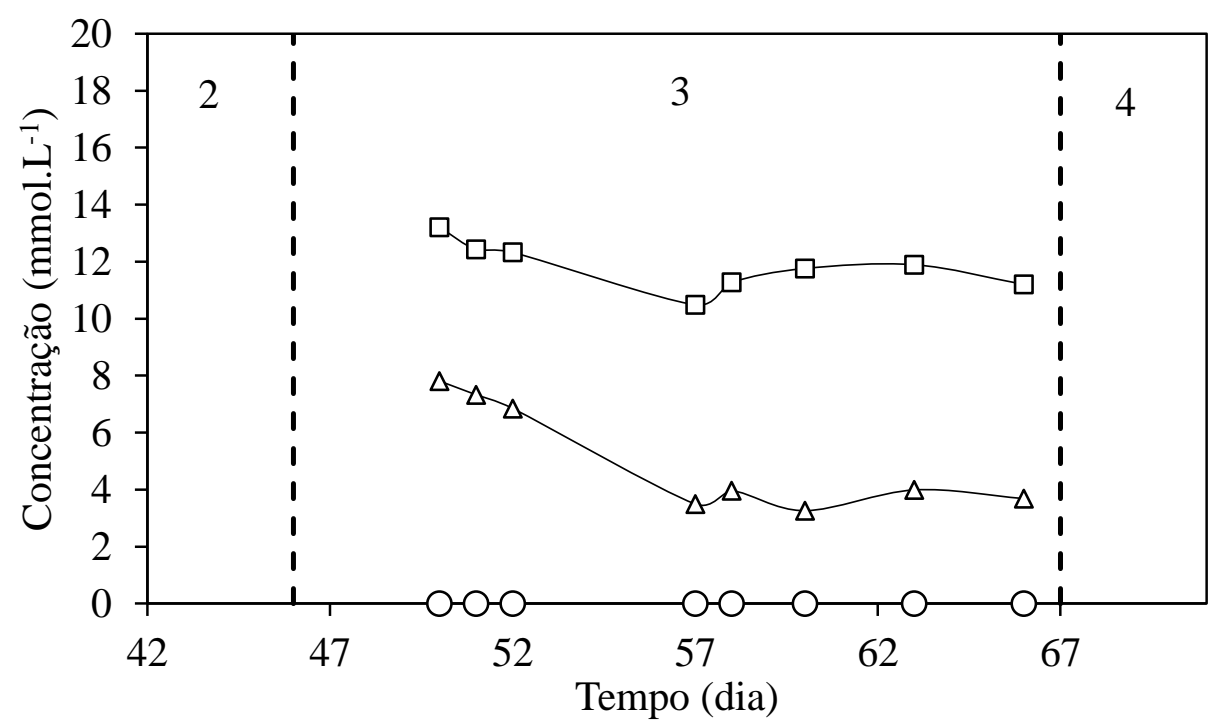

Figura 5-269 - Concentrações dos componentes do biogás no final do ciclo: $\square-\mathrm{CO}_{2} ; \Delta$ - $\mathrm{H}_{2} ; \circ-\mathrm{CH}_{4}$ (AnSBBR com agitação mecânica e lactose - Condição 3).

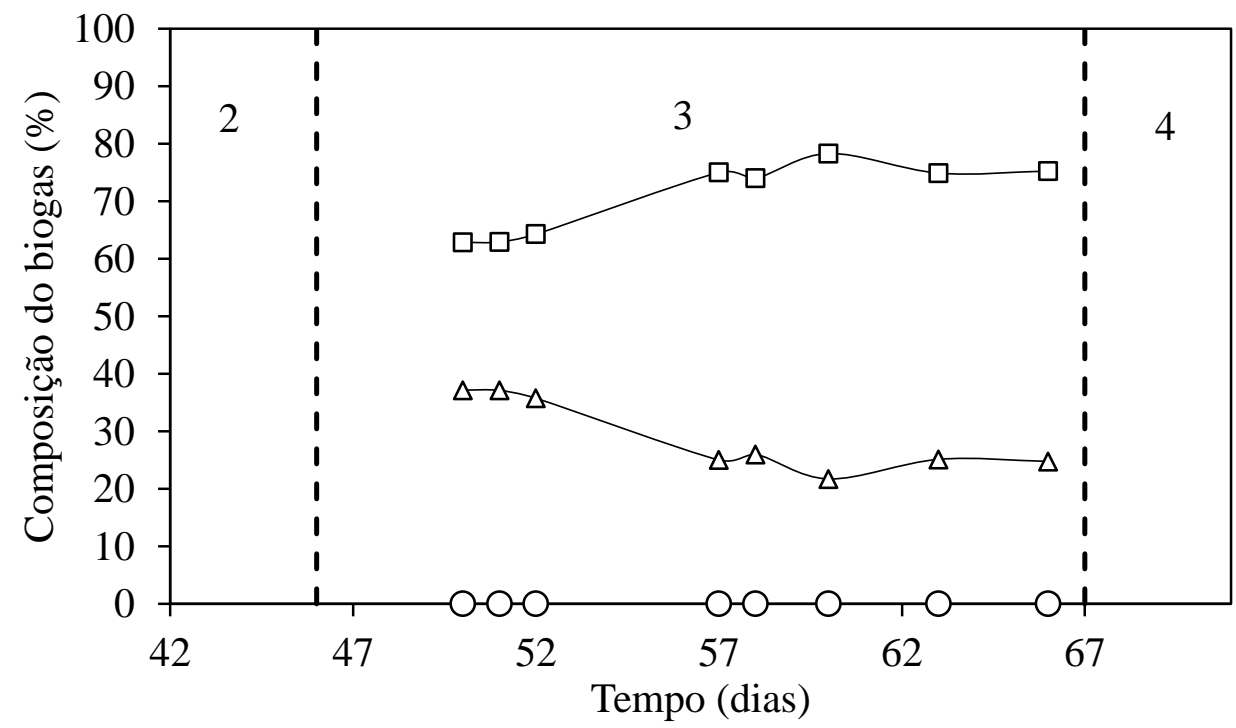

Figura 5-270 - Distribuições dos componentes do biogás no final do ciclo: $\square-\mathrm{CO}_{2} ; \Delta$ $\mathrm{H}_{2} ; \circ-\mathrm{CH}_{4}$ (AnSBBR com agitação mecânica e lactose - Condição 3).

Realizou-se o perfil temporal no final da operação, com o intuito de entender melhor como os parâmetros indicativos de eficiência do sistema se comportavam durante um ciclo completo. A Figura 5-271 apresenta a evolução da concentração de carboidrato ao longo do ciclo e a eficiência de remoção do mesmo. Ao inicio do ciclo (tempo zero) o volume afluente é diluído no volume residual resultando em uma 
concentração em sacarose da ordem de $970 \mathrm{mg} . \mathrm{L}^{-1}$. A conversão de carboidrato se faz de maneira progressiva ao longo do ciclo, atingindo valores na ordem de $99 \%$ no final do mesmo, com um residual aproximado de $15 \mathrm{mg} \cdot \mathrm{L}^{-1}$.

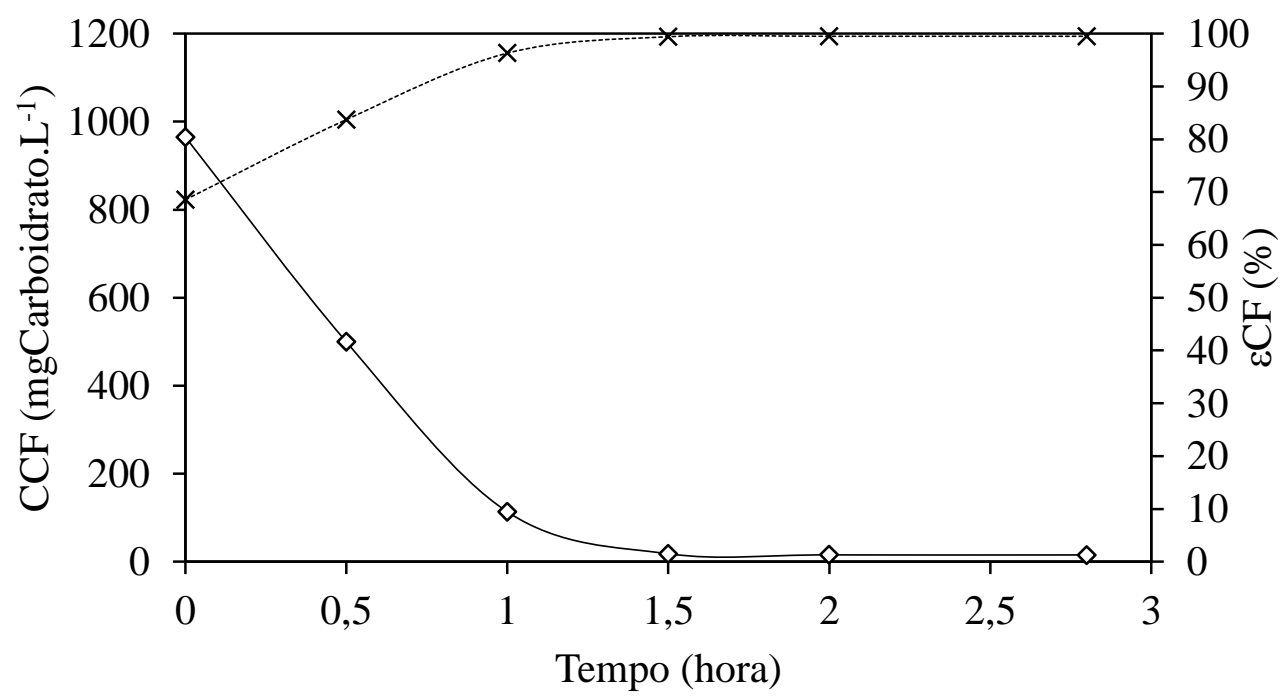

Figura 5-271 - Concentração e eficiência de degradação de carboidrato: $\diamond$ - perfil e * eficiência (AnSBBR com agitação mecânica e lactose - Condição 3).

A Figura 5-25 apresenta a evolução da concentração de matéria orgânica ao longo do ciclo. Observa-se uma baixa remoção da DQO, levando a uma alta concentração da mesma no volume residual. Assim, no inicio do ciclo, a diluição do volume carregado pelo volume residual é realizada em proporção bem menor do que no caso dos carboidratos totais, tendo em vista que as concentrações afluente e residual são muito próximas. No inicio do ciclo, a concentração é da ordem de $3000 \mathrm{mg} . \mathrm{L}^{-1}$ atingindo valores próximos a $2900 \mathrm{mg} . \mathrm{L}^{-1}$ no último ponto do ciclo. 


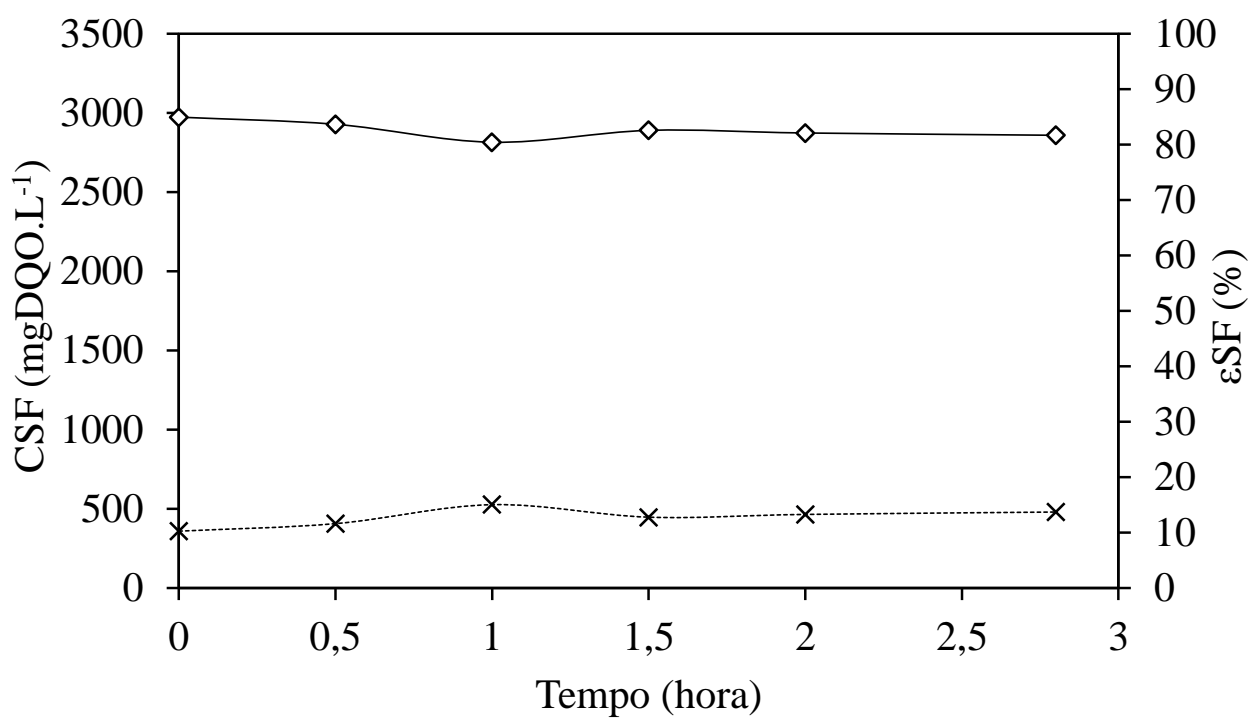

Figura 5-272 - Concentração e eficiência de degradação de matéria orgânica: $\diamond$ - perfil e * eficiência (AnSBBR com agitação mecânica e lactose - Condição 3).

O acúmulo de ácidos voláteis totais por titulação ao longo do ciclo pode ser observado na Figura 5-26. A concentração destes aumenta claramente durante a fase de reação para atingir um máximo no final do ciclo na ordem de $850 \mathrm{mgHAc} . \mathrm{L}^{-1}$.

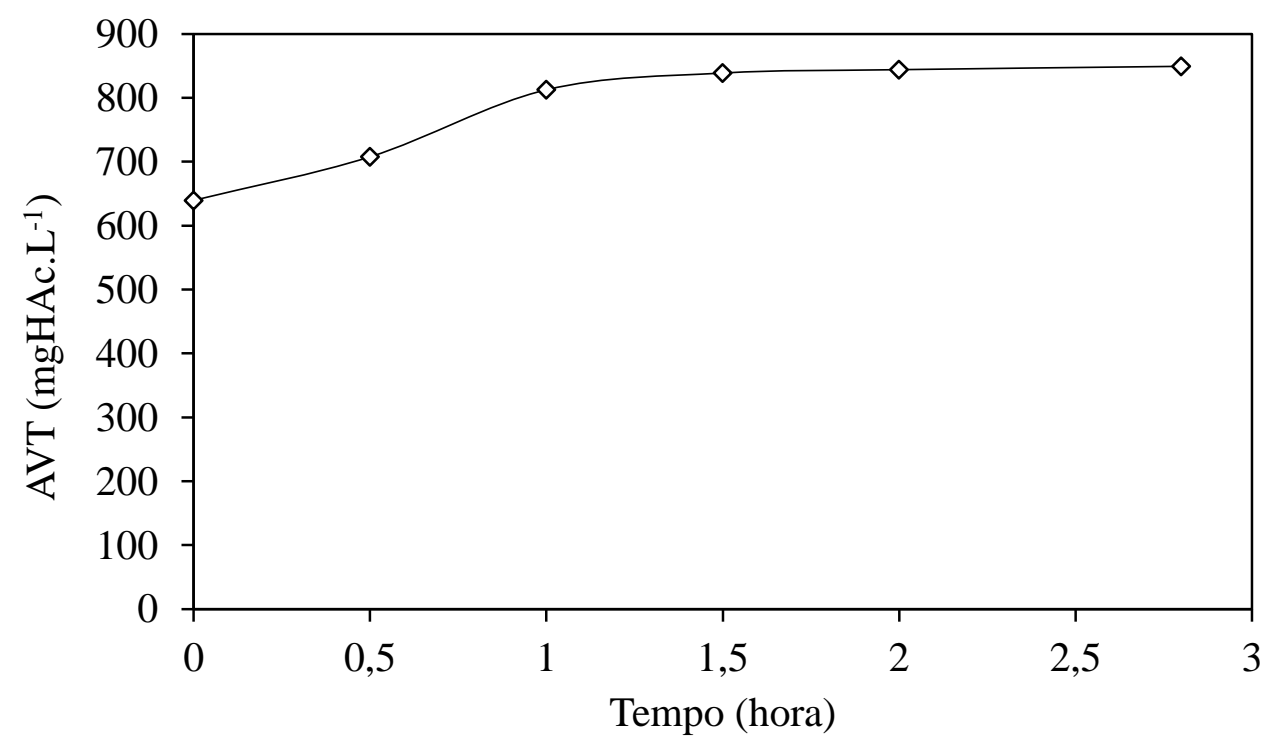

Figura 5-273 - Ácidos voláteis totais $(\diamond)$ do perfil (AnSBBR com agitação mecânica e lactose - Condição 3). 
Os resultados dos compostos intermediários por cromatografia gasosa são apresentados na Figura 5-28. Estes se apresentaram estáveis, com exceção do etanol que apresentou uma queda na última hora de ciclo.

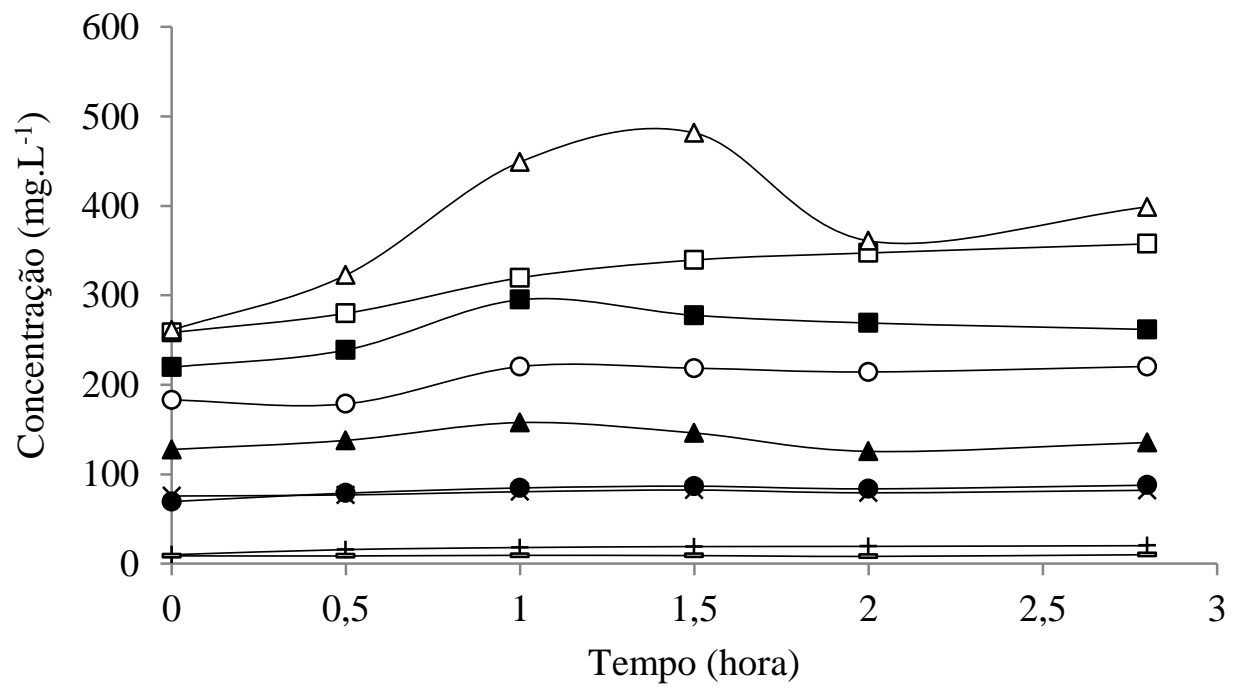

Figura 5-274 - Concentração dos compostos intermediários ao longo do ciclo: $\square$ - ácido acético; $\Delta$ - etanol; $\bigcirc$ - ácido butírico; - ácido isobutírico; $\boldsymbol{\Delta}$ - ácido capróico; $\bullet-$ ácido valérico; - *ácido propiônico; +butanol; — ácido isovalérico (AnSBBR com agitação mecânica e lactose - Condição 3).

$\mathrm{O}$ pH diminuiu instantaneamente em relação ao afluente devido à diluição do mesmo com o volume residual no inicio do ciclo e permaneceu estável ao longo da operação conforme a Figura 5-29. Esta estabilidade do pH era esperada pois, como pode ser visto na Figura 5-276, o meio de alimentação possuía alcalinidade suficiente para tamponar o sistema. 


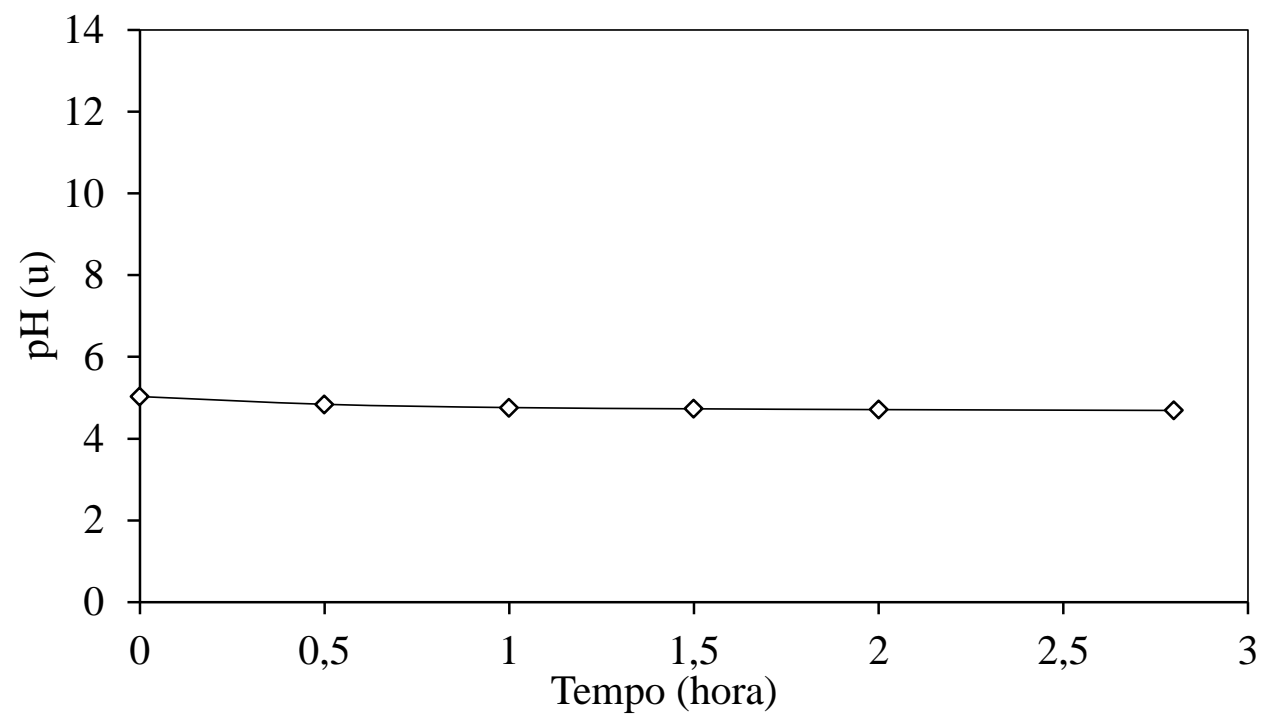

Figura 5-275 - Valores de pH $(\diamond)$ do perfil (AnSBBR com agitação mecânica e lactose Condição 3).

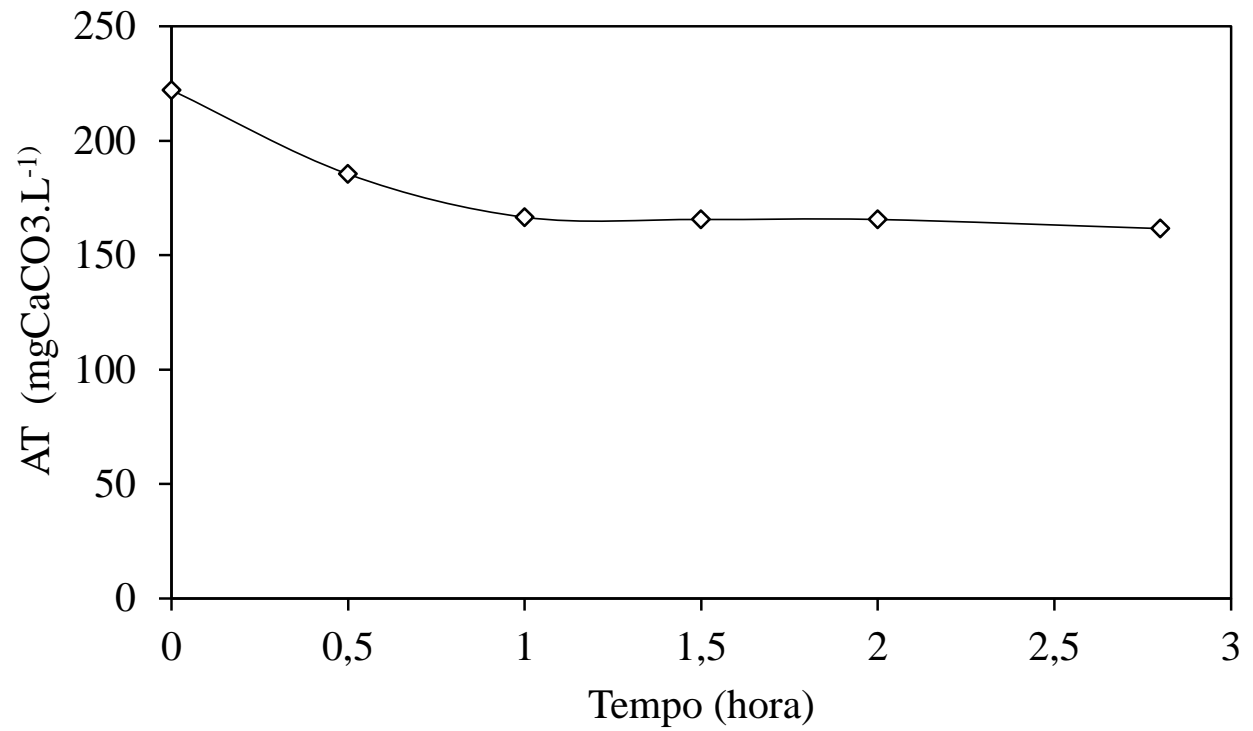

Figura 5-276 - Alcalinidade total $(\diamond)$ do perfil (AnSBBR com agitação mecânica e lactose - Condição 3).

A produção volumétrica média acumulada do biogás, realizada com os valores dos perfis quantitativos mais consistentes obtidos durante a operação, juntamente com os desvios padrões encontram-se na Figura 5-277. A maior parte da produção ocorre no inicio do ciclo, durante a primeira hora do mesmo, e tem uma tendência a se estabilizar nas duas horas finais. A Tabela 5.8 resume os valores médios da produção, fração molar 
e os volumes individuais da mistura do biogás. A Figura 5-278 apresenta os volumes acumulados médios dos perfis de $\mathrm{H}_{2}, \mathrm{CO}_{2}$ e $\mathrm{CH}_{4}$ produzidos durante o ciclo. Novamente apenas hidrogênio e gás carbônico foram produzidos, sem a presença de metano.

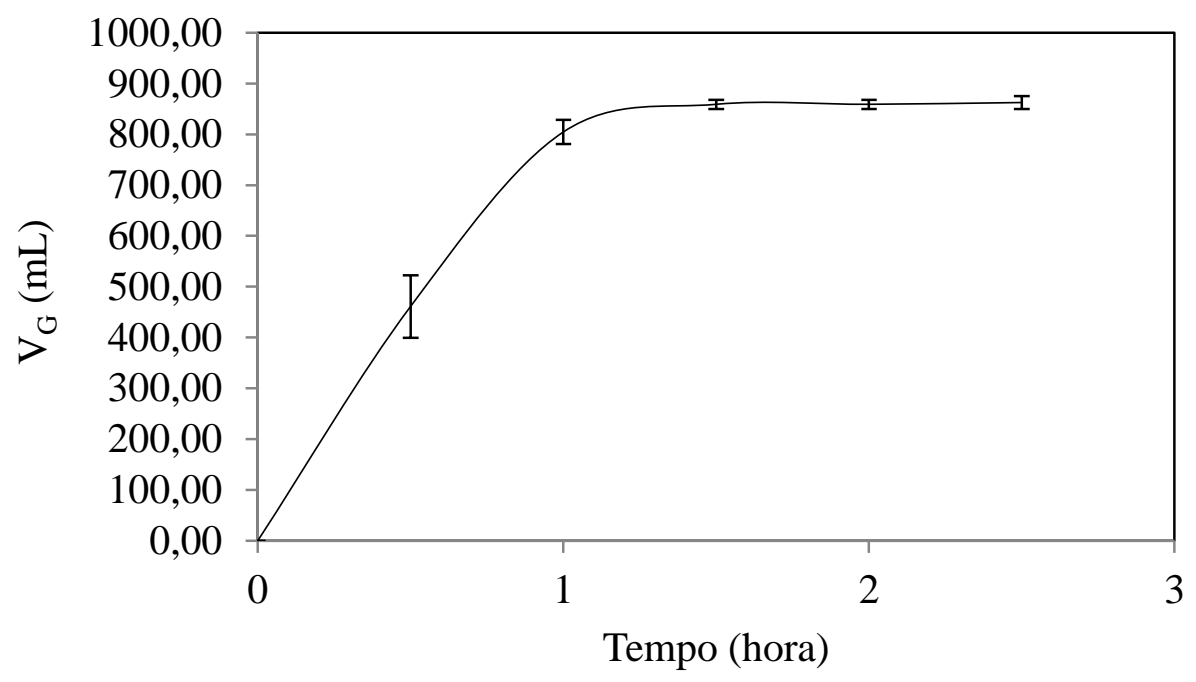

Figura 5-277 - Produção volumétrica média acumulada do biogás durante o ciclo (AnSBBR com agitação mecânica e lactose - Condição 3).

Tabela 5.67 - Valores médios da produção, fração molar e os volumes individuais da mistura do biogás (AnSBBR com agitação mecânica e lactose - Condição 3).

\begin{tabular}{|c|c|c|c|c|c|c|c|c|c|c|}
\hline \multirow{2}{*}{$\begin{array}{l}\text { Tempo } \\
\text { (h) }\end{array}$} & \multirow{2}{*}{$\begin{array}{c}\mathrm{V}_{\mathrm{G}} \\
(\mathrm{mL}-\mathrm{CNTP})\end{array}$} & \multicolumn{3}{|c|}{$\mathrm{C}_{\mathrm{G}}\left(\mathrm{mmol} \cdot \mathrm{L}^{-1}\right)$} & \multicolumn{3}{|c|}{ Fração Molar (\%) } & \multicolumn{3}{|c|}{ Volume $(\mathrm{mL}-\mathrm{CNTP})$} \\
\hline & & $\mathrm{H}_{2}$ & $\mathrm{CO}_{2}$ & $\mathrm{CH}_{4}$ & $\mathrm{H}_{2}$ & $\mathrm{CO}_{2}$ & $\mathrm{CH}_{4}$ & $\mathrm{H}_{2}$ & $\mathrm{CO}_{2}$ & $\mathrm{CH}_{4}$ \\
\hline 0,0 & 0 & 0,0 & 0,0 & 0,0 & 0,0 & 0,0 & 0,0 & 0,0 & 0,0 & 0,0 \\
\hline 0,5 & 461 & 1,0 & 4,4 & 0,0 & 19,1 & 80,9 & 0,0 & 88,3 & 372,9 & 0,0 \\
\hline 1,0 & 805 & 2,2 & 8,4 & 0,0 & 20,5 & 79,5 & 0,0 & 158,6 & 646,1 & 0,0 \\
\hline 1,5 & 859 & 3,5 & 11,7 & 0,0 & 22,8 & 77,2 & 0,0 & 171,0 & 688,2 & 0,0 \\
\hline 2,0 & 859 & 3,9 & 11,7 & 0,0 & 24,9 & 75,1 & 0,0 & 171,0 & 688,2 & 0,0 \\
\hline 2,8 & 863 & 4,0 & 11,9 & 0,0 & 25,1 & 74,9 & 0,0 & 171,9 & 690,8 & 0,0 \\
\hline
\end{tabular}




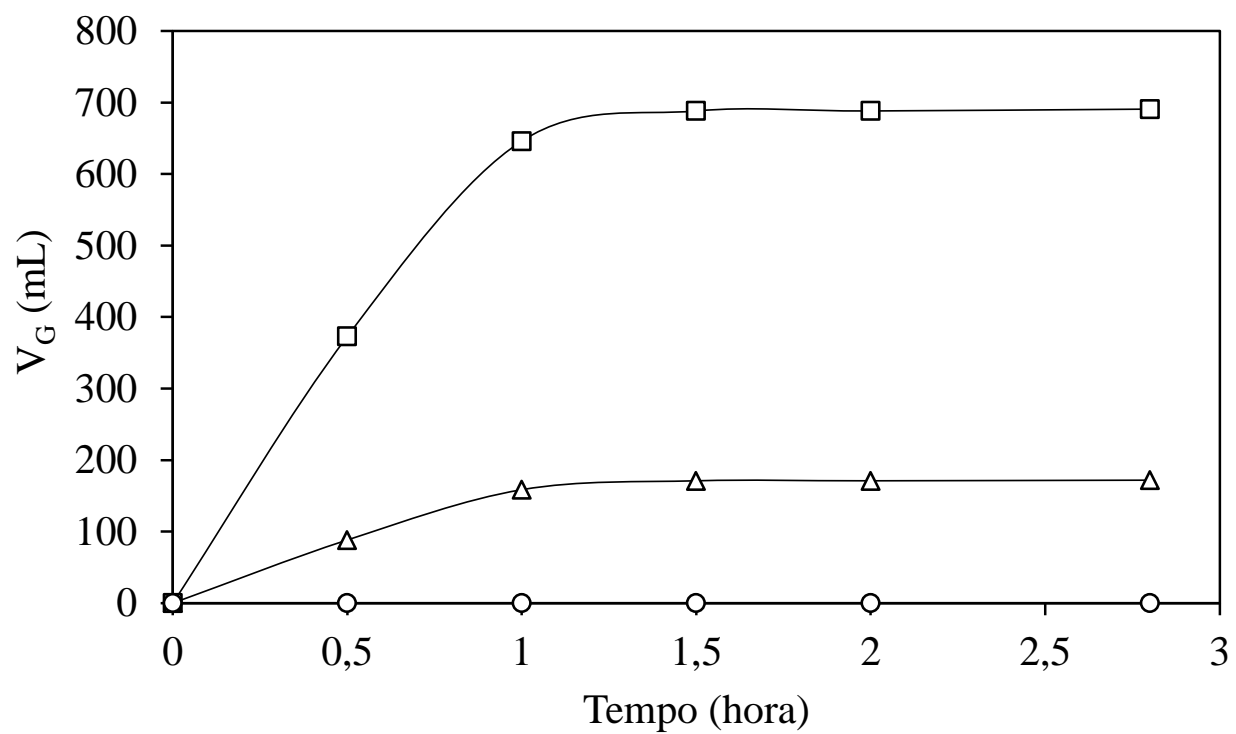

Figura 5-278 - Volumes acumulados médios produzidos ao longo do ciclo: $\square-\mathrm{CO}_{2} ; \Delta$ $\mathrm{H}_{2} ;$ ○ - $\mathrm{CH}_{4}$ (AnSBBR com agitação mecânica e lactose - Condição 3). 
5.3.4. Condição $4\left(D Q O=5400 \mathrm{mg}^{-L^{-1}}\right.$ e $t_{C}=3$ horas $)$

A condição experimental 4 apresentou uma COAV nominal de 18,5 kgDQO.m ${ }^{3} \cdot \mathrm{d}^{-1}$ e duração do ciclo de 3 horas, indo do dia 67 ao dia 88 (21 dias de operação). A Tabela 5.68 apresenta os valores médios dos parâmetros monitorados. 
Tabela 5.68 - Valores médios dos parâmetros monitorados na condição experimental 4 (Lactose - $5400 \mathrm{mgDQO} . \mathrm{L}^{-1}-\mathrm{t}_{\mathrm{C}} 3 \mathrm{~h}$ ).

\begin{tabular}{|c|c|c|c|c|c|c|c|c|c|c|}
\hline \multicolumn{2}{|r|}{ Parâmetro } & \multicolumn{5}{|c|}{ Afluente } & & \multicolumn{3}{|c|}{ Efluente } \\
\hline $\mathrm{C}_{\mathrm{ST}}$ & $\left(\mathrm{mgDQO} \cdot \mathrm{L}^{-1}\right)$ & 5285 & \pm & 234 & & 9 & & 4508 & \pm 240 & $(9)$ \\
\hline $\mathrm{C}_{\mathrm{SF}}$ & $\left(\mathrm{mgDQO} \cdot \mathrm{L}^{-1}\right)$ & - & \pm & - & ( & 3 & & 4370 & \pm 310 & $(9)$ \\
\hline$\varepsilon_{\mathrm{ST}}$ & $(\%)$ & - & & - & & & & 15 & \pm & $(9)$ \\
\hline$\varepsilon_{\mathrm{SF}}$ & $(\%)$ & - & & - & & & & 17 & \pm 6 & $(9)$ \\
\hline $\mathrm{C}_{\mathrm{CT}}$ & (mgCarboidrato. $\mathrm{L}^{-1}$ ) & 4974 & \pm & 252 & ( & 9 & & 112 & \pm 112 & $(9)$ \\
\hline $\mathrm{C}_{\mathrm{CF}}$ & (mgCarboidrato. $\mathrm{L}^{-1}$ ) & - & \pm & - & & & & 97 & \pm 118 & $(9)$ \\
\hline$\varepsilon_{\mathrm{CT}}$ & $(\%)$ & - & & - & & & & 98 & \pm & $(9)$ \\
\hline$\varepsilon_{\mathrm{CF}}$ & $(\%)$ & - & & - & & & & 98 & \pm & $(9)$ \\
\hline $\mathrm{pH}$ & (u) & 7,98 & \pm & 0,06 & ( & 9 & 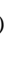 & 3,94 & $\pm 0,06$ & $(9)$ \\
\hline AVT & $\left(\mathrm{mgHAc} . \mathrm{L}^{-1}\right)$ & 35 & \pm & 6 & ( & 9 & 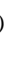 & 1651 & \pm 99 & $(9)$ \\
\hline AT & $\left(\mathrm{mgCaCO} 3 \cdot \mathrm{L}^{-1}\right)$ & 403 & \pm & 8 & ( & 9 & ) & 0 & \pm & $(9)$ \\
\hline AP & $\left(\mathrm{mgCaCO}_{3} \cdot \mathrm{L}^{-1}\right)$ & 309 & \pm & 15 & ( & 9 & 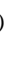 & 0 & \pm & $(9)$ \\
\hline AI & $\left(\mathrm{mgCaCO}_{3} \cdot \mathrm{L}^{-1}\right)$ & 94 & \pm & 19 & ( & 9 & 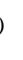 & 0 & \pm & $(9)$ \\
\hline $\mathrm{AB}$ & $\left(\mathrm{mgCaCO}_{3} \cdot \mathrm{L}^{-1}\right)$ & 378 & \pm & 8 & ( & 9 & 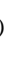 & 0 & \pm & $(9)$ \\
\hline ST & $\left(\mathrm{mg} \cdot \mathrm{L}^{-1}\right)$ & 5165 & \pm & 2205 & ( & 4 & 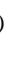 & 2368 & \pm 256 & $(4)$ \\
\hline STV & $\left(\mathrm{mg} \cdot \mathrm{L}^{-1}\right)$ & 4530 & \pm & 2244 & ( & 4 & 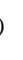 & 1932 & \pm 117 & $(4)$ \\
\hline SST & $\left(\mathrm{mg} \cdot \mathrm{L}^{-1}\right)$ & 70 & \pm & 31 & ( & 4 & 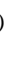 & 118 & $\pm \quad 37$ & $(4)$ \\
\hline SSV & $\left(\mathrm{mg} \cdot \mathrm{L}^{-1}\right)$ & 36 & \pm & 9 & ( & 4 & 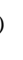 & 99 & \pm 27 & $(4)$ \\
\hline $\mathrm{M}_{\mathrm{STV}}$ & $(\mathrm{g})$ & - & & - & & & & 19,3 & - & \\
\hline $\mathrm{C}_{\mathrm{X}}$ & $\left(\right.$ g. $\left.\mathrm{L}^{-1}\right)$ & - & & - & & & & 5,1 & - & \\
\hline $\mathrm{C}_{\mathrm{X}}^{\prime}$ & $\left(\right.$ g.gsuporte ${ }^{-1}$ ) & - & & - & & & & 0,023 & - & \\
\hline $\mathrm{V}_{\mathrm{G}}$ & (mL-CNTP) & - & & - & & & & 1005 & \pm 38 & $(3)$ \\
\hline $\mathrm{V}_{\mathrm{H} 2}$ & (mL-CNTP) & - & & - & & & & 160 & \pm- & $\left(\begin{array}{l}1 \\
1\end{array}\right)$ \\
\hline $\mathrm{COAV}_{\mathrm{STA}}$ & $\left(\mathrm{kgDQO} \cdot \mathrm{m}^{-3} \cdot \mathrm{d}^{-1}\right)$ & 18,1 & & - & & & & - & - & \\
\hline $\mathrm{CORV}_{\mathrm{SFE}}$ & $\left(\operatorname{kgDQO} \cdot \mathrm{m}^{-3} \cdot \mathrm{d}^{-1}\right)$ & - & & - & & & & 3,1 & - & \\
\hline $\mathrm{COAV}_{\text {СТА }}$ & $\left(\right.$ kgCarboidrato. $\left.\mathrm{m}^{-3} \cdot \mathrm{d}^{-1}\right)$ & 17,1 & & - & & & & - & - & \\
\hline $\mathrm{CORV}_{\mathrm{CFE}}$ & $\left(\right.$ kgCarboidrato. $\left.\mathrm{m}^{-3} \cdot \mathrm{d}^{-1}\right)$ & - & & - & & & & 16,7 & - & \\
\hline $\mathrm{COAE}_{\mathrm{STA}}$ & $\left(\mathrm{kgDQO} \cdot \mathrm{kgSTV}^{-1} \cdot \mathrm{d}^{-1}\right)$ & 3,3 & & - & & & & - & - & \\
\hline $\mathrm{CORE}_{\mathrm{SFE}}$ & $\left(\mathrm{kgDQO} \cdot \mathrm{kgSTV}^{-1} \cdot \mathrm{d}^{-1}\right)$ & - & & - & & & & 0,6 & - & \\
\hline $\mathrm{COAE}_{\mathrm{CTA}}$ & $\left(\mathrm{kgCarboidrato} \mathrm{kgSTV}^{-1} \cdot \mathrm{d}^{-1}\right)$ & 3,1 & & - & & & & - & - & \\
\hline $\mathrm{CORE}_{\mathrm{CFE}}$ & $\left(\mathrm{kgCarboidrato} \mathrm{kgSTV}^{-1} \cdot \mathrm{d}^{-1}\right)$ & - & & - & & & & 3,0 & - & \\
\hline $\mathrm{RMCR}_{\mathrm{C}, \mathrm{n}}$ & $\left(\right.$ molH $_{2 .}$ molCarboidrato $\left.^{-1}\right)$ & - & & - & & & & 0,33 & - & \\
\hline $\mathrm{n}_{\mathrm{H} 2}$ & $\left(\mathrm{molH}_{2} \cdot \mathrm{d}^{-1}\right)$ & - & & 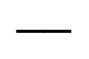 & & & & 0,0570 & 一 & \\
\hline PrM & $\left(\mathrm{molH}_{2} \cdot \mathrm{m}^{-3} \cdot \mathrm{d}^{-1}\right)$ & - & & - & & & & 14,9 & 一 & \\
\hline PrME & $\left(\mathrm{molH}_{2} \cdot \mathrm{kgSVT}^{-1} \cdot \mathrm{d}^{-1}\right)$ & - & & - & & & & 3,0 & - & \\
\hline $\mathrm{RMCA}_{\mathrm{S}, \mathrm{m}}$ & $\left(\mathrm{molH}_{2} \cdot \mathrm{kgDQO}^{-1} \cdot \mathrm{d}^{-1}\right)$ & 0,9 & & - & & & & - & - & \\
\hline $\mathrm{RMCA}_{\mathrm{C}, \mathrm{m}}$ & $\left(\mathrm{molH}_{2} \cdot \mathrm{kg}^{-1} \cdot \mathrm{d}^{-1}\right)$ & 1,0 & & - & & & & - & - & \\
\hline $\mathrm{RMCR}_{\mathrm{S}, \mathrm{m}}$ & $\left(\mathrm{molH}_{2} \cdot \mathrm{kgDQO}^{-1} \cdot \mathrm{d}^{-1}\right)$ & - & & - & & & & 5,19 & - & \\
\hline $\mathrm{RMCR}_{\mathrm{C}, \mathrm{m}}$ & $\left(\mathrm{molH}_{2} \cdot \mathrm{kg}^{-1} \cdot \mathrm{d}^{-1}\right)$ & - & & - & & & & 0,97 & - & \\
\hline $\mathrm{V}_{\mathrm{R}}$ & $(\mathrm{mL})$ & 2320 & & & & & & - & - & \\
\hline $\mathrm{V}_{\mathrm{A}}$ & $(\mathrm{mL})$ & 1509 & \pm & 12 & ( & 10 & & & & \\
\hline
\end{tabular}

(*) Entre parêntese o número de amostras considerado no cálculo da média 
A Figura 5-279 apresenta os valores da concentração afluente (amostras não filtradas) e efluente (amostras não filtradas e filtradas) de matéria orgânica (DQO) nos sistema. A Figura 5-280 apresenta a eficiência de remoção do mesmo parâmetro durante o monitoramento diário. Esta eficiência atingiu, em média, 17\% para as amostras filtradas e $15 \%$ para mostras não filtradas. A média de concentração afluente não filtrada do substrato foi de $5285 \mathrm{mgDQO} . \mathrm{L}^{-1}$ e de $4508 \mathrm{mgDQO} . \mathrm{L}^{-1}$ e $4370 \mathrm{mgDQO} . \mathrm{L}^{-1}$ para amostras de efluente não filtradas e filtradas, respectivamente.

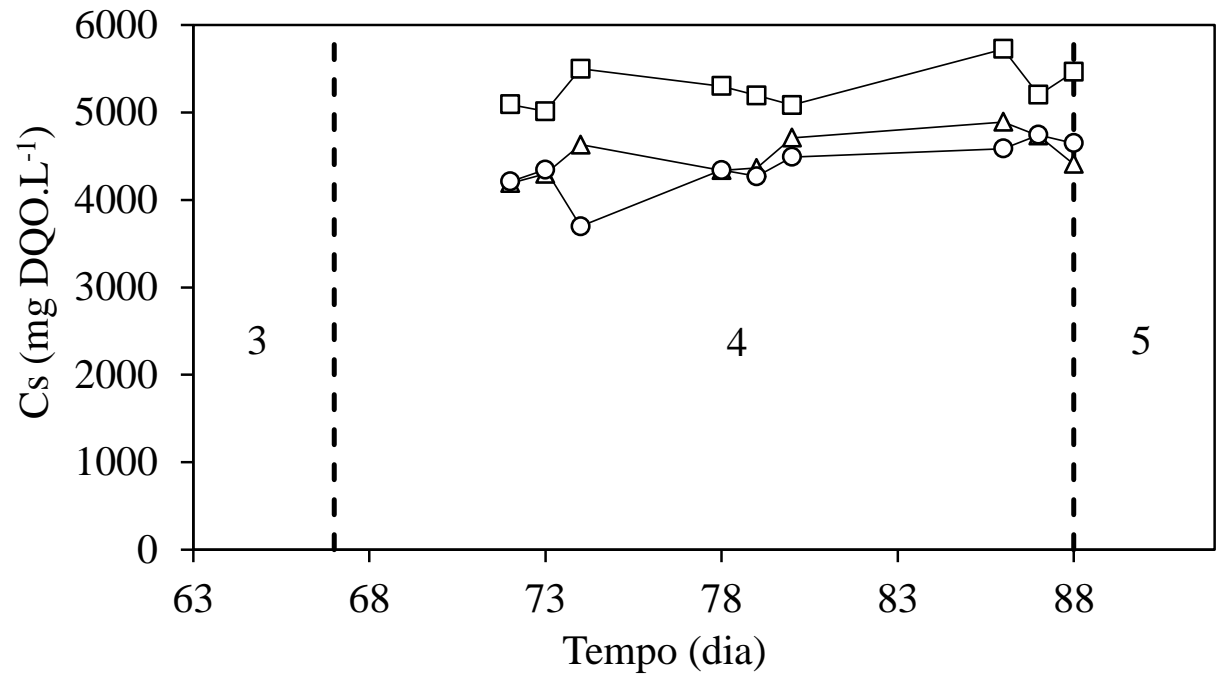

Figura 5-279 - Concentração de matéria orgânica (DQO): $\square$ - afluente não filtrada; $\Delta$ efluente não filtrada; o - efluente filtrada (AnSBBR com agitação mecânica e lactose Condição 4). 


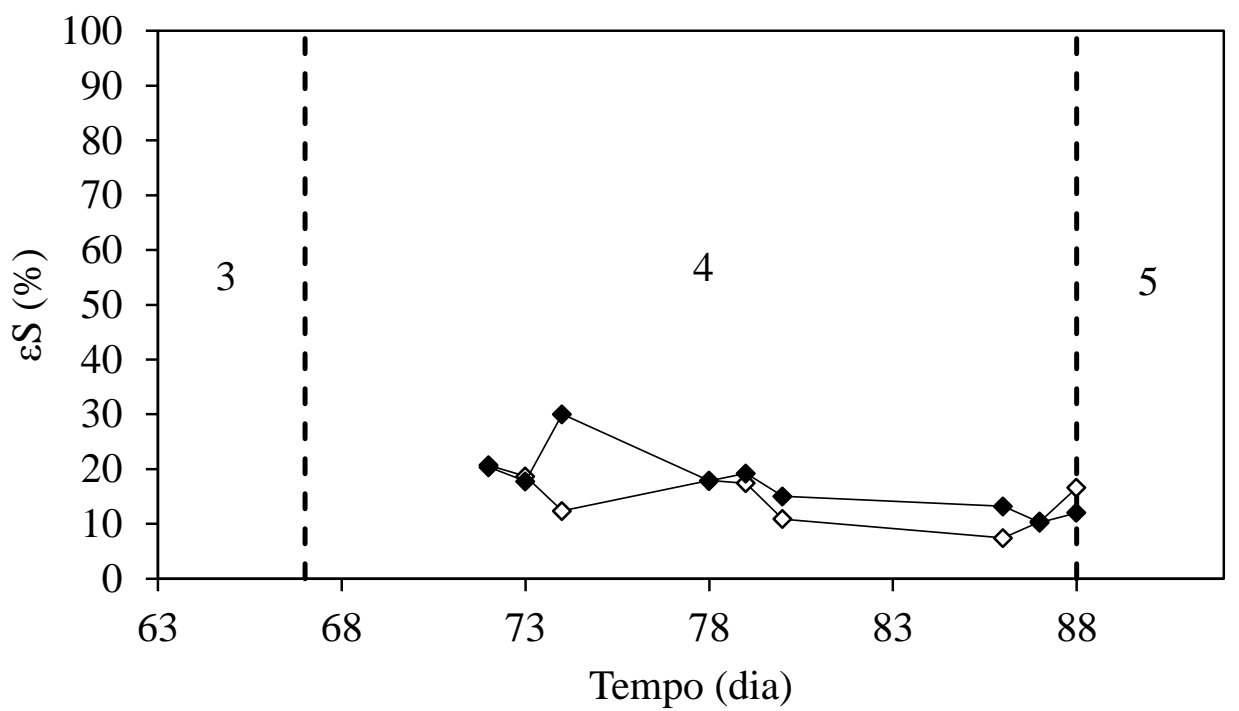

Figura 5-280 - Eficiência de remoção de matéria orgânica (DQO): $\diamond$ - não filtrada; filtrada (AnSBBR com agitação mecânica e lactose - Condição 4).

A Figura 5-281 apresenta os valores da concentração de carboidratos afluente e efluente (para amostras filtradas e não filtradas) e Figura 5-282 apresenta a eficiência de remoção do mesmo parâmetro (não filtrada e filtrada) durante o monitoramento diário. A média da concentração afluente foi de $4974 \mathrm{mgCarboidrato.} \mathrm{L}^{-1}$, enquanto que a concentração residual (amostras não filtradas) foi de 112 mgCarboidrato.L $\mathrm{L}^{-1}$ e 97 mgCarboidrato. $\mathrm{L}^{-1}$ para a concentração residual filtrada. A eficiência de remoção de carboidrato foi, em média, de $98 \%$ para ambas as amostras. 


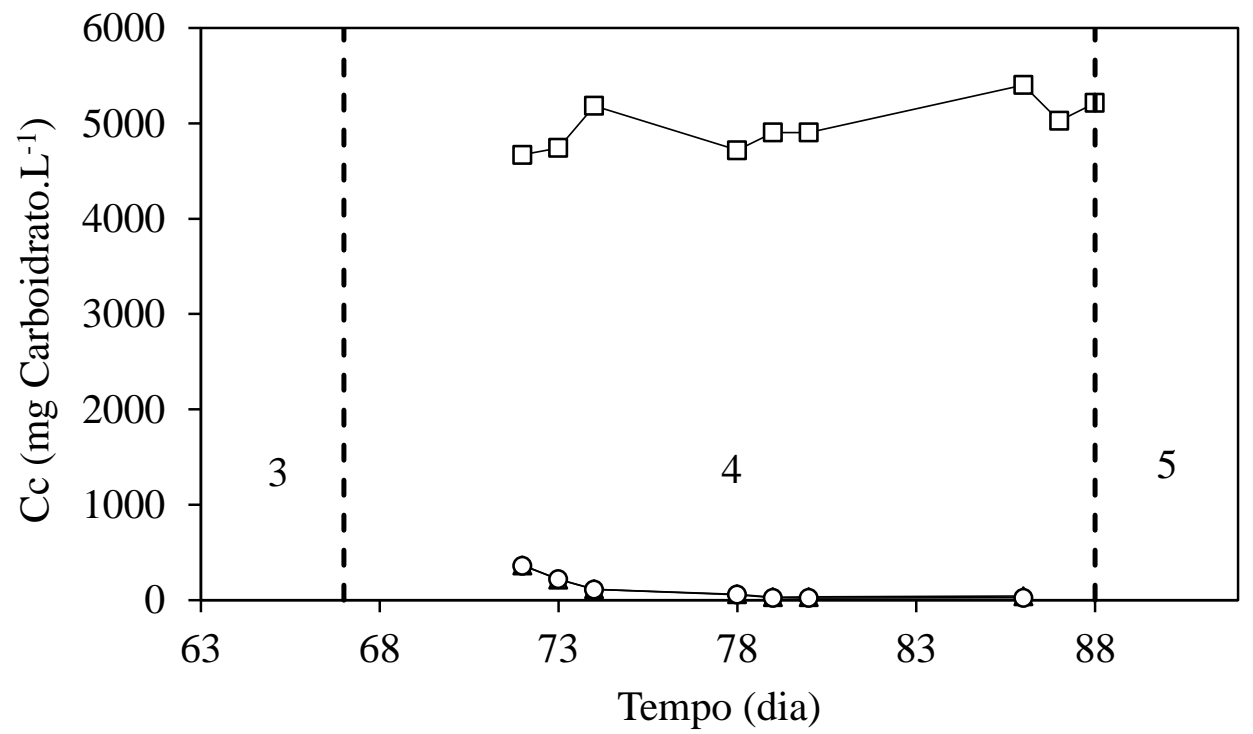

Figura 5-281 - Concentração de carboidrato: $\square$ - afluente não filtrada; $\Delta$ - efluente não filtrada; ○ - efluente filtrada (AnSBBR com agitação mecânica e lactose - Condição 4).

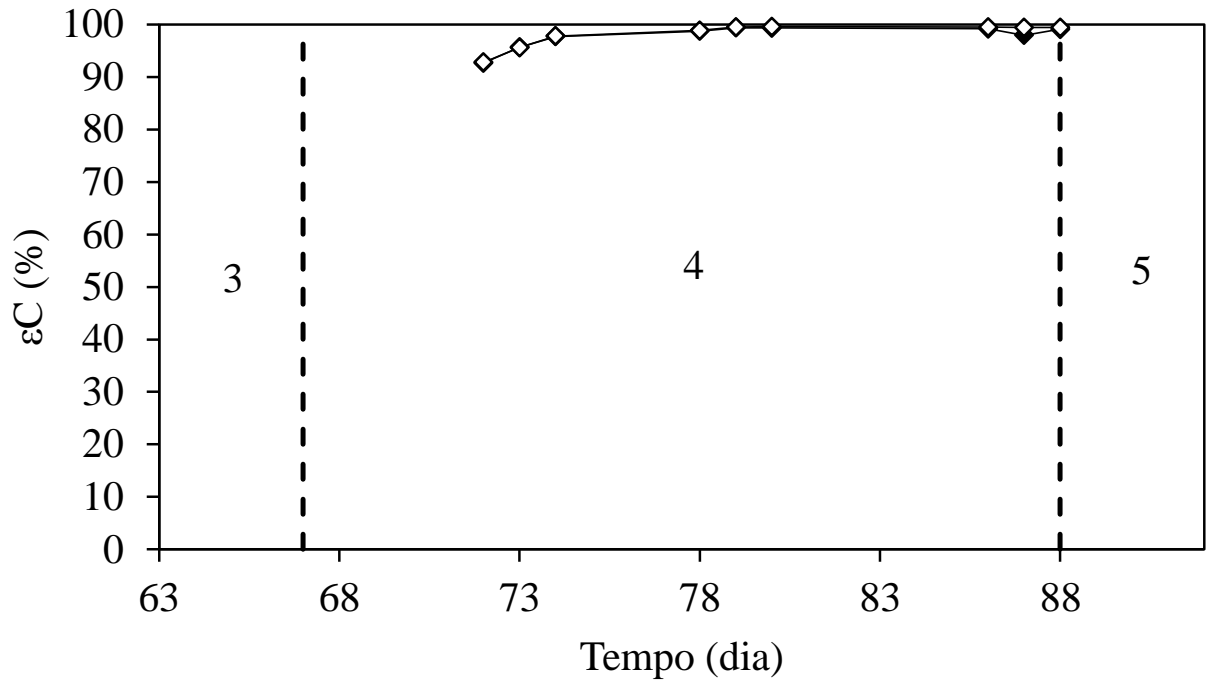

Figura 5-282 - Eficiência de remoção de carboidrato: $\diamond$ - não filtrada; $\downarrow$ - filtrada (AnSBBR com agitação mecânica e lactose - Condição 4).

As Figura 5-283, Figura 5-284 e Figura 5-285 apresentam os perfis temporais (afluente e efluente) do $\mathrm{pH}$, da alcalinidade total e dos ácidos voláteis totais por titulação, respectivamente. A média dos valores de $\mathrm{pH}$ afluente durante a Condição 4 foi de 7,98 e de $\mathrm{pH}$ efluente foi de 3,94. A média da alcalinidade total foi de 403 
$\mathrm{mgCaCO} 3 \cdot \mathrm{L}^{-1}$ para o afluente, enquanto que o efluente não apresentou alcalinidade total durante esta condição. O valor médio da concentração de ácidos voláteis totais afluente foi de $35 \mathrm{mgHAc} . \mathrm{L}^{-1}$ e efluente de $1651 \mathrm{mgHAc} . \mathrm{L}^{-1}$.

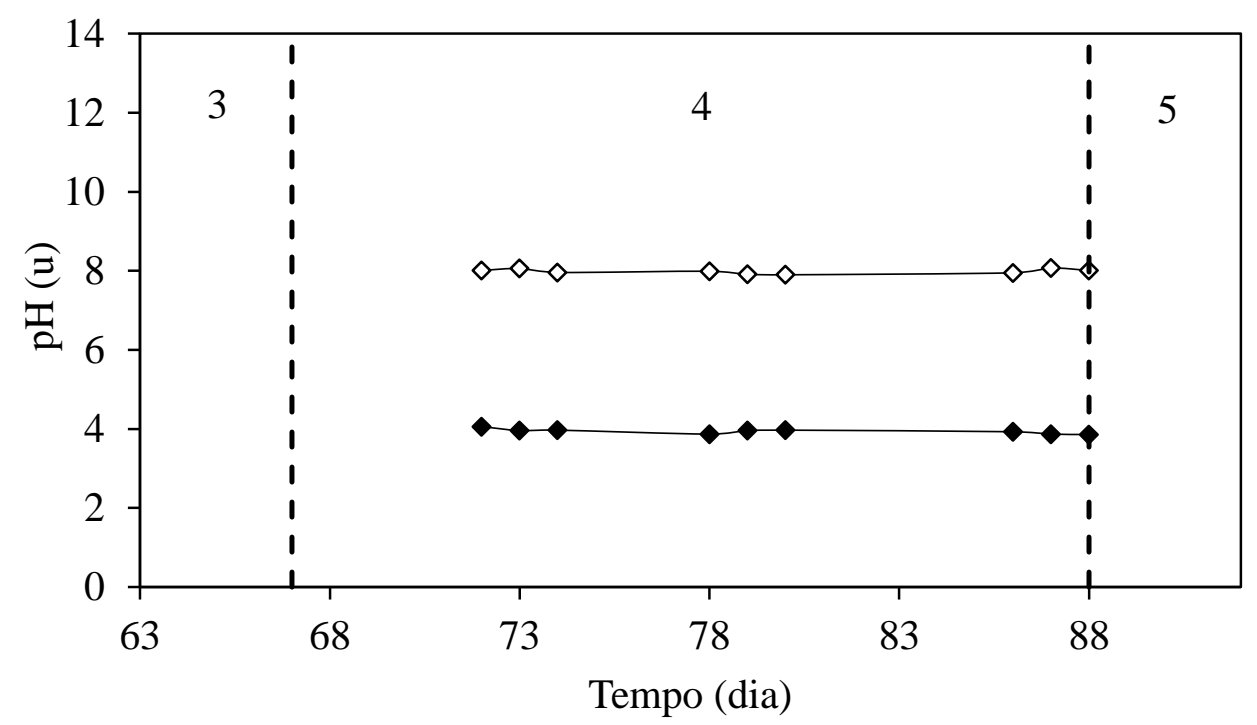

Figura 5-283 - Valores de pH: $\diamond$-afluente; - efluente (AnSBBR com agitação mecânica e lactose - Condição 4).

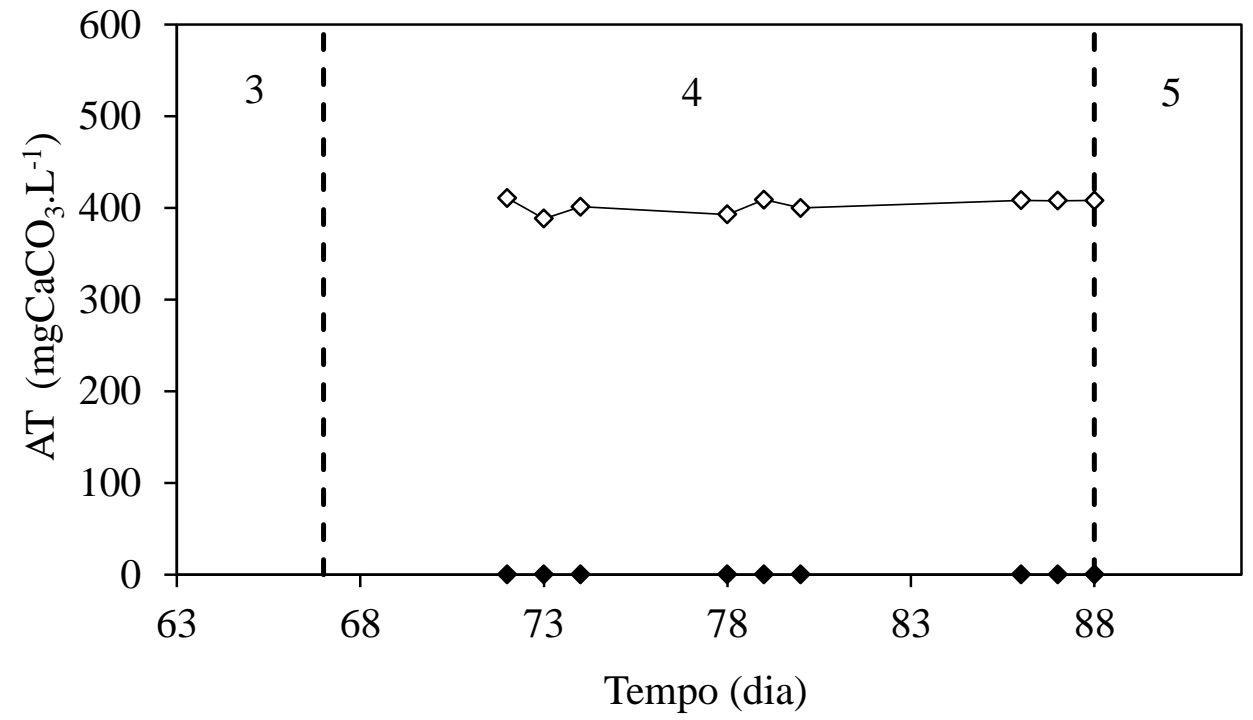

Figura 5-284 - Alcalinidade total: $\diamond$-afluente; - efluente (AnSBBR com agitação mecânica e lactose - Condição 4). 


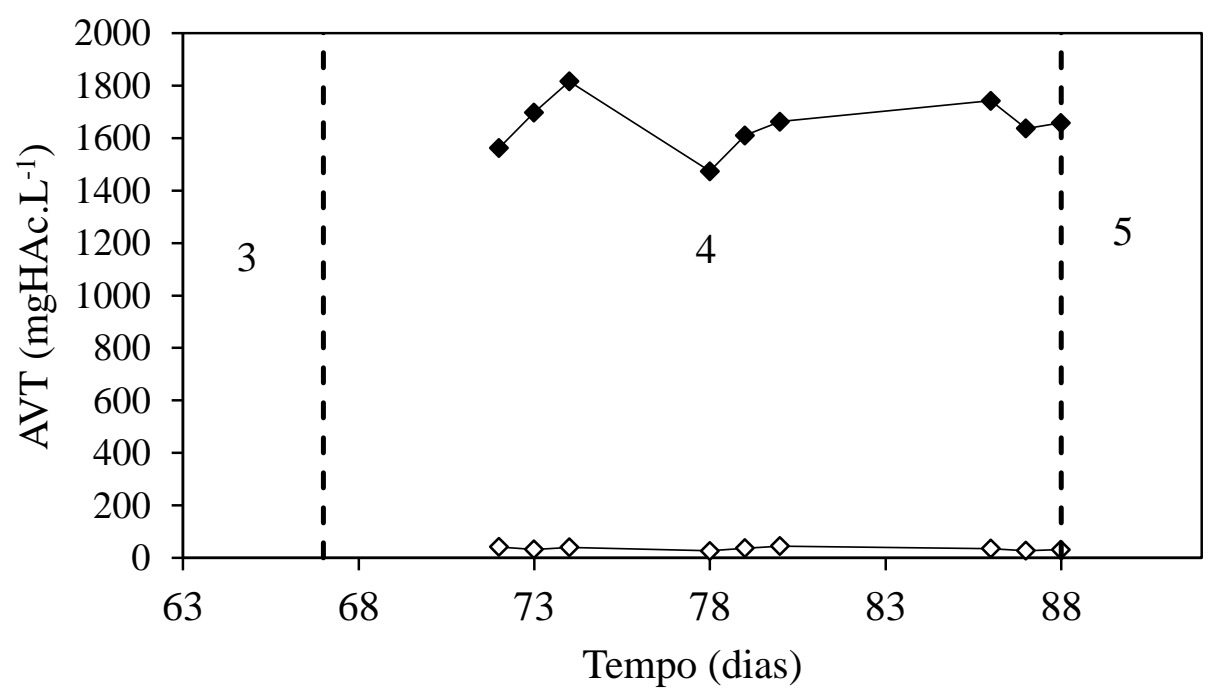

Figura 5-285 - Ácidos voláteis totais: $\diamond$-afluente; - efluente (AnSBBR com agitação mecânica e lactose - Condição 4).

A Figura 5-286 apresenta o monitoramento dos compostos intermediários contidos no efluente do sistema, enquanto que a Tabela 5.69 apresenta os valores da concentração média destes produto. $\mathrm{O}$ método cromatográfico utilizado mais uma vez não detectou a presença de acetona e metanol. O ácido acético e o etanol foram os maiores destaques, representando juntos $86 \%$ dos produtos intermediários $(54,4 \%$ e $32,0 \%$, respectivamente). 


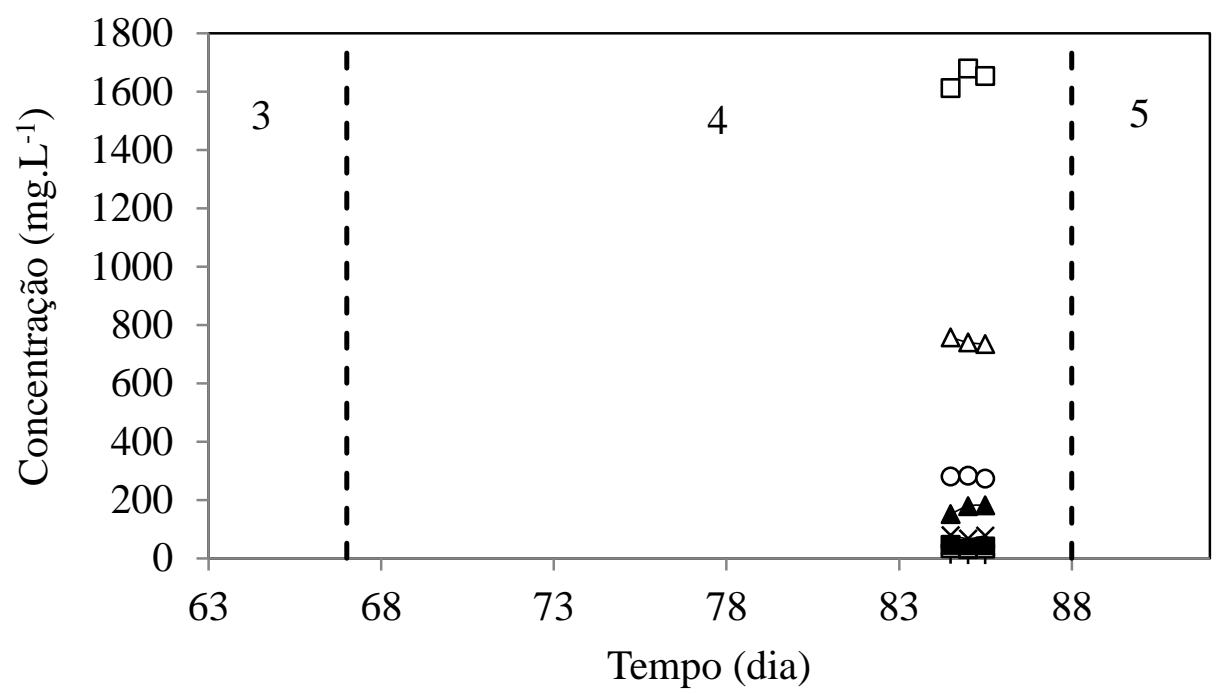

Figura 5-286 - Concentração dos compostos intermediários: $\square$ - ácido acético; $\Delta$ etanol; ○ - ácido butírico; - ácido isobutírico; $\boldsymbol{\Delta}$ - ácido capróico; $\bullet$ - ácido valérico; * ácido propiônico; +butanol; - ácido isovalérico (AnSBBR com agitação mecânica e lactose - Condição 4).

Tabela 5.69 - Concentração e distribuição dos compostos intermediários (AnSBBR com agitação mecânica e lactose - Condição 4).

\begin{tabular}{cccccccc}
\hline $\begin{array}{c}\text { Produtos } \\
\text { intermediários }\end{array}$ & \multicolumn{5}{c}{ Concentrações médias } \\
& \multicolumn{3}{c}{$\left(\mathrm{mg} . \mathrm{L}^{-1}\right)$} & \multicolumn{3}{c}{$\begin{array}{c}\text { Distribuição } \\
\left(\mathrm{mmol} . \mathrm{L}^{-1}\right)\end{array}$} & $(\%)$ \\
\hline Acetona & 0,0 & \pm & 0,0 & 0,0 & \pm & 0,0 & 0,0 \\
Metanol & 0,0 & \pm & 0,0 & 0,0 & \pm & 0,0 & 0,0 \\
Etanol & 743,7 & \pm & 12,1 & 16,1 & \pm & 0,3 & 32,0 \\
n-Butanol & 10,8 & \pm & 0,3 & 0,2 & \pm & 0,0 & 0,3 \\
Acético & 1648,2 & \pm & 34,1 & 27,5 & \pm & 0,6 & 54,4 \\
Porpiônico & 74,5 & \pm & 6,5 & 1,0 & \pm & 0,1 & 2,0 \\
Isobutírico & 39,13 & \pm & 7,3 & 0,4 & \pm & 0,1 & 0,9 \\
Butírico & 278,6 & \pm & 5,1 & 3,2 & \pm & 0,1 & 6,3 \\
Isovalérico & 8,9 & \pm & 0,5 & 0,1 & \pm & 0,0 & 0,2 \\
Valérico & 38,0 & \pm & 4,2 & 0,4 & \pm & 0,0 & 0,7 \\
Capróico & 170,9 & \pm & 16,5 & 1,7 & \pm & 0,2 & 3,3 \\
\hline
\end{tabular}

O monitoramento da série de sólidos é mostrado naTabela 5.70, cujos valores apresentam um baixo teor de SSV no efluente e afluente, indicando a boa capacidade do reator em reter biomassa. 
Tabela 5.70 - Série de sólidos afluente e efluente (AnSBBR com agitação mecânica e lactose - Condição 4).

\begin{tabular}{lcccl}
\hline & $\begin{array}{c}\text { ST } \\
\left(\mathrm{mg} . L^{-1}\right)\end{array}$ & $\begin{array}{c}\text { SVT } \\
\left(\mathrm{mg} \cdot \mathrm{L}^{-1}\right)\end{array}$ & $\begin{array}{c}\text { SST } \\
\left(\mathrm{mg} . \mathrm{L}^{-1}\right)\end{array}$ & $\begin{array}{c}\text { SSV } \\
\left(\mathrm{mg} . \mathrm{L}^{-1}\right)\end{array}$ \\
\hline Afluente & $5166 \pm 2205$ & $4351 \pm 2244$ & $71 \pm 31$ & $36 \pm 9$ \\
Efluente & $2369 \pm 256$ & $1932 \pm 117$ & $118 \pm 37$ & $99 \pm 27$ \\
\hline
\end{tabular}

*Número de amostras consideradas $=4$.

A produção quantitativa do biogás por ciclo é apresentada na Figura 5-287. A produção média foi de $1138 \mathrm{~mL}$ (CNTP). A Figura 5-288 apresenta o monitoramento das concentrações dos componentes do biogás no final do ciclo, enquanto que a Figura 5-289 apresenta a distribuição destes mesmos componentes. Os valores médios de concentração de $\mathrm{H}_{2}, \mathrm{CH}_{4}$ e $\mathrm{CO}_{2}$ foram 5,5, 0,1 e 14,9 mmol.L $\mathrm{L}^{-1}$, respectivamente. Além disso, a distribuição percentual média de $\mathrm{H}_{2}$ foi de $26,0 \%$, a de $\mathrm{CH}_{4}$ foi de $0,5 \%$ e a de $\mathrm{CO}_{2}$ foi de $73,5 \%$.

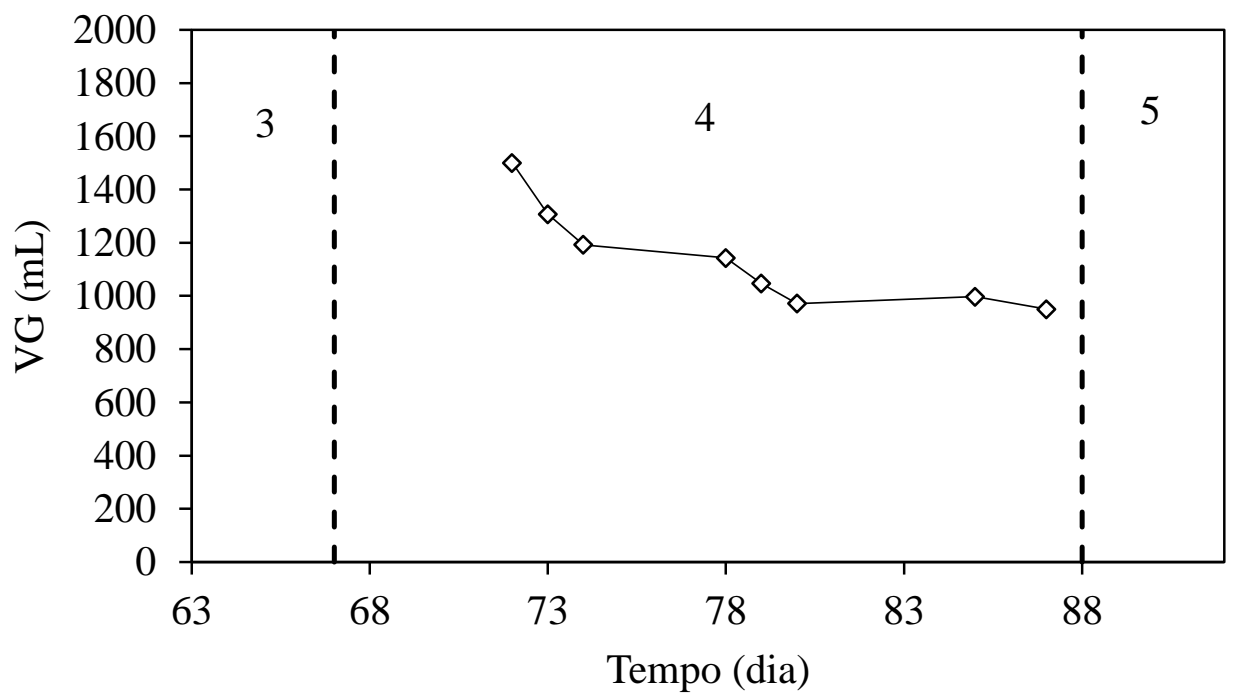

Figura 5-287 - Volume de biogás produzido por ciclo (AnSBBR com agitação mecânica e lactose - Condição 4). 


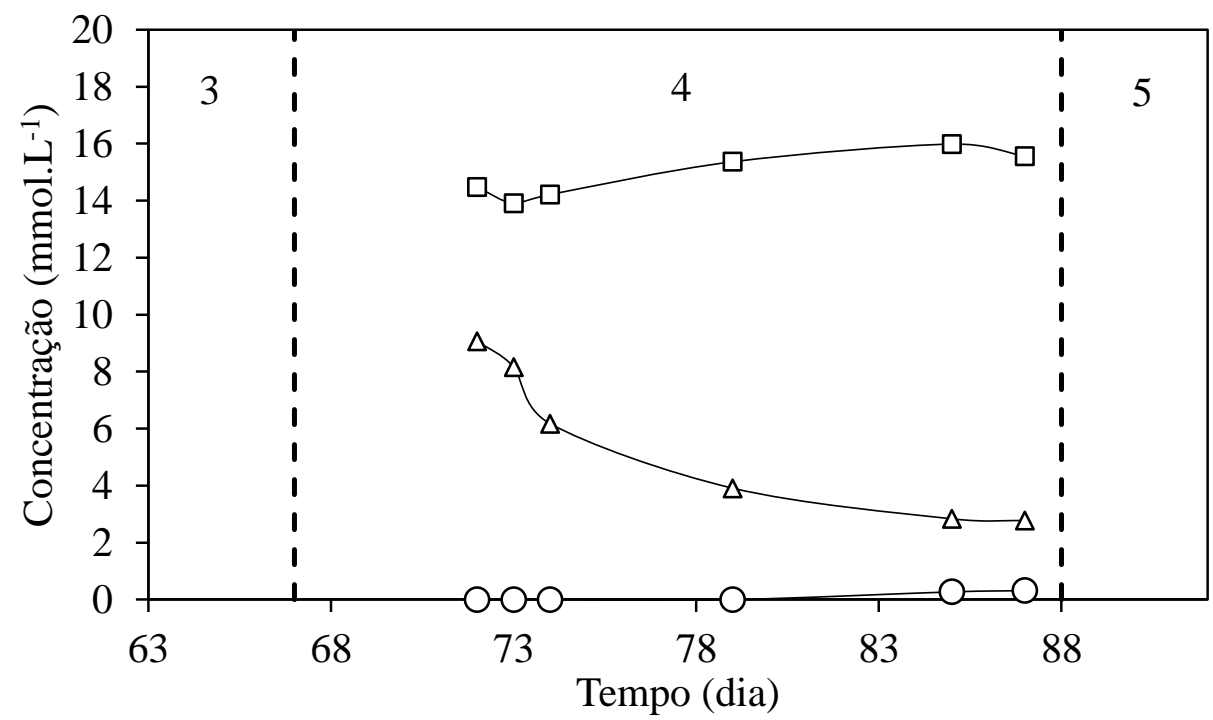

Figura 5-288 - Concentrações dos componentes do biogás no final do ciclo: $\square-\mathrm{CO}_{2} ; \Delta$ - $\mathrm{H}_{2} ; \circ-\mathrm{CH}_{4}$ (AnSBBR com agitação mecânica e lactose - Condição 4).

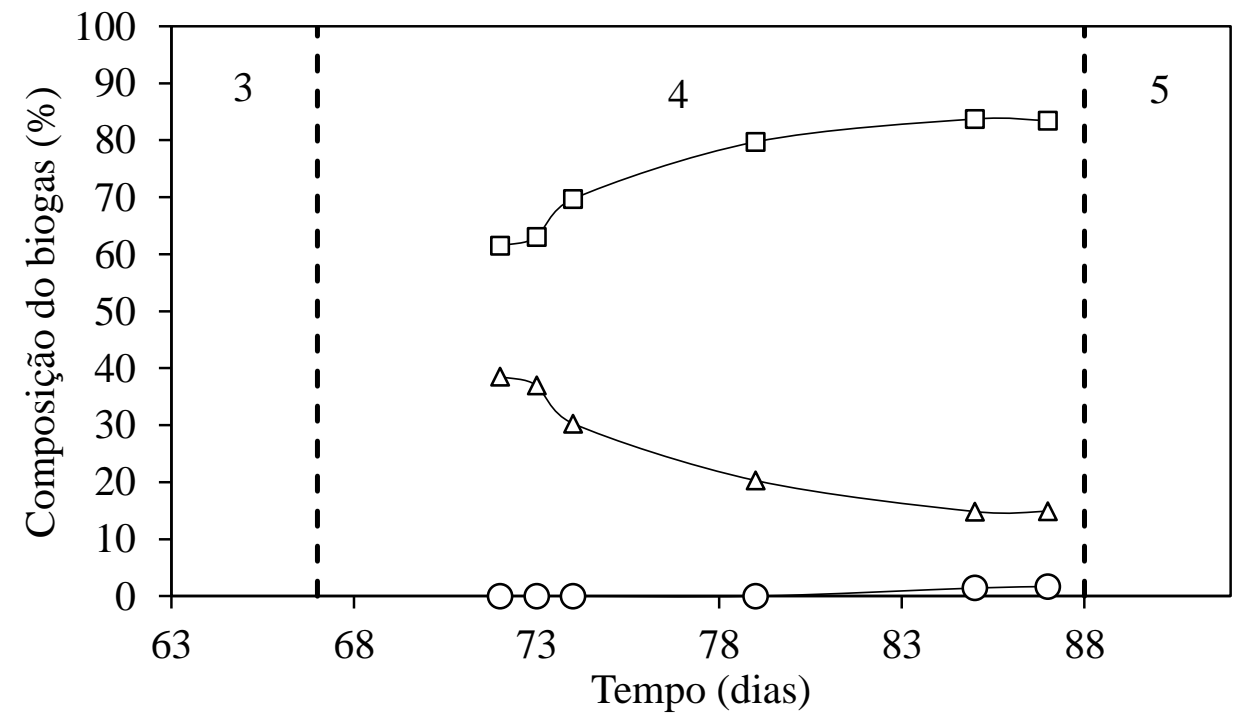

Figura 5-289 - Distribuições dos componentes do biogás no final do ciclo: $\square-\mathrm{CO}_{2} ; \Delta$ $\mathrm{H}_{2} ;$ ○ $-\mathrm{CH}_{4}$ (AnSBBR com agitação mecânica e lactose - Condição 4).

O perfil temporal foi realizado no final da operação, com o intuito de entender melhor como os parâmetros indicativos de eficiência do sistema se comportavam durante um ciclo completo. A Figura 5-290 apresenta a evolução da concentração de carboidrato ao longo do ciclo e a eficiência de remoção do mesmo. Ao inicio do ciclo (tempo zero) o volume afluente é diluído no volume residual resultando em uma 
concentração em sacarose da ordem de $1580 \mathrm{mg} \cdot \mathrm{L}^{-1}$. A conversão de carboidrato se faz de maneira progressiva ao longo do ciclo, atingindo valores na ordem de $99 \%$ no final do mesmo, com um residual aproximado de $25 \mathrm{mg} \cdot \mathrm{L}^{-1}$.

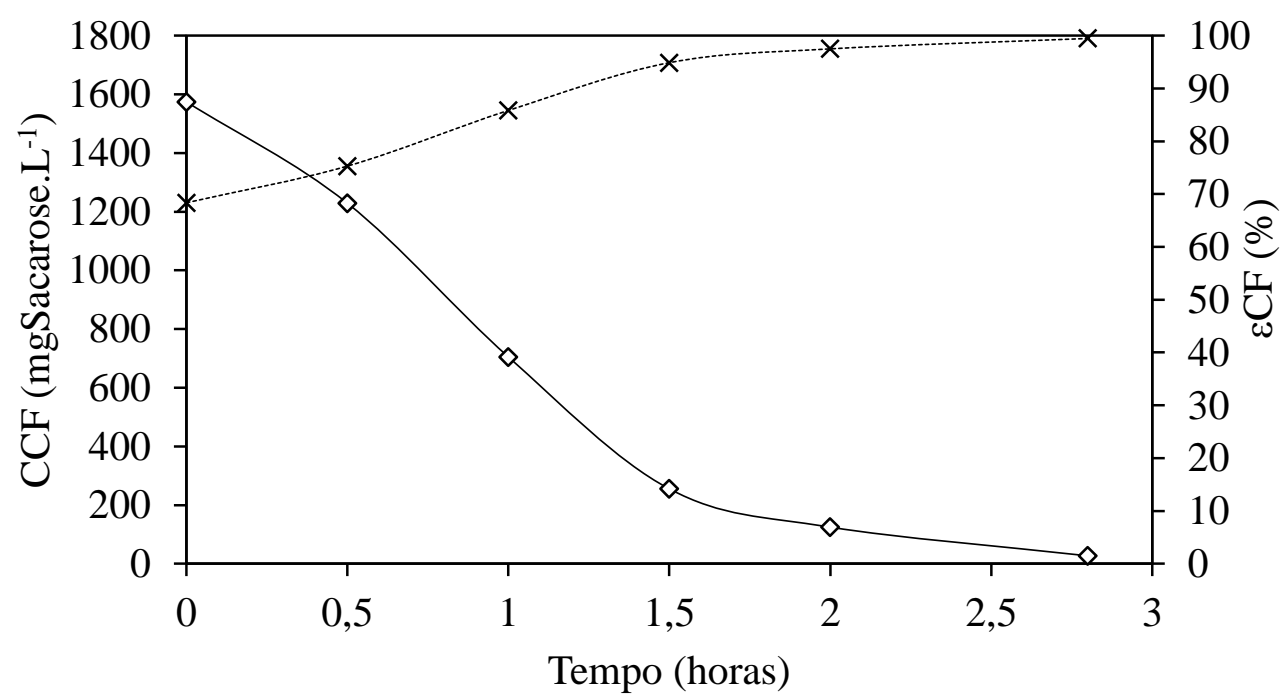

Figura 5-290 - Concentração e eficiência de degradação de carboidrato: $\diamond$ - perfil e * eficiência (AnSBBR com agitação mecânica e lactose - Condição 4).

A Figura 5-291 apresenta a evolução da concentração de matéria orgânica ao longo do ciclo. Observa-se uma baixa remoção da DQO, levando a uma alta concentração da mesma no volume residual. Assim, no inicio do ciclo, a diluição do volume carregado pelo volume residual é realizada em proporção bem menor do que no caso dos carboidratos totais, tendo em vista que as concentrações afluente e residual são muito próximas. No inicio do ciclo, a concentração é da ordem de $4980 \mathrm{mg} . \mathrm{L}^{-1}$ atingindo valores próximos a $4705 \mathrm{mg} . \mathrm{L}^{-1}$ no último ponto do ciclo. 


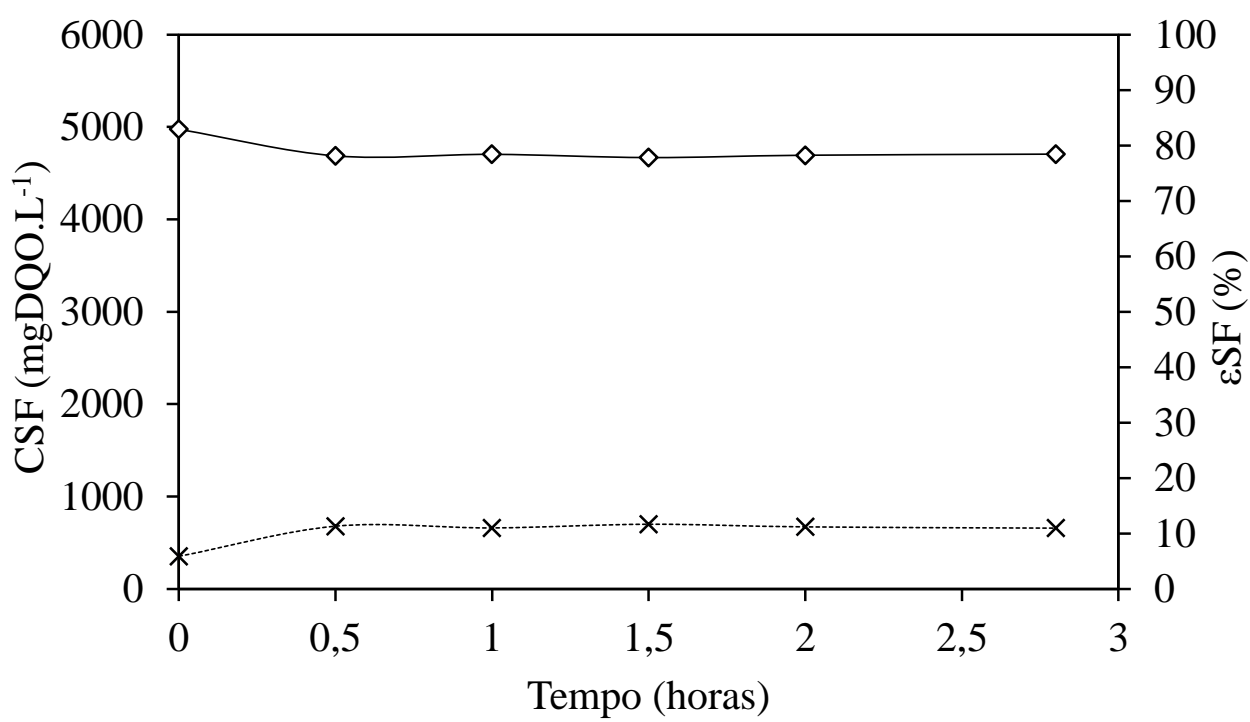

Figura 5-291 - Concentração e eficiência de degradação de matéria orgânica: $\diamond$ - perfil e * eficiência (AnSBBR com agitação mecânica e lactose - Condição 4).

O acúmulo de ácidos voláteis totais por titulação ao longo do ciclo pode ser observado na Figura 5-292. A concentração destes aumenta claramente durante a fase de reação para atingir um máximo no final do ciclo na ordem de 1470 mgHAc. $\mathrm{L}^{-1}$.

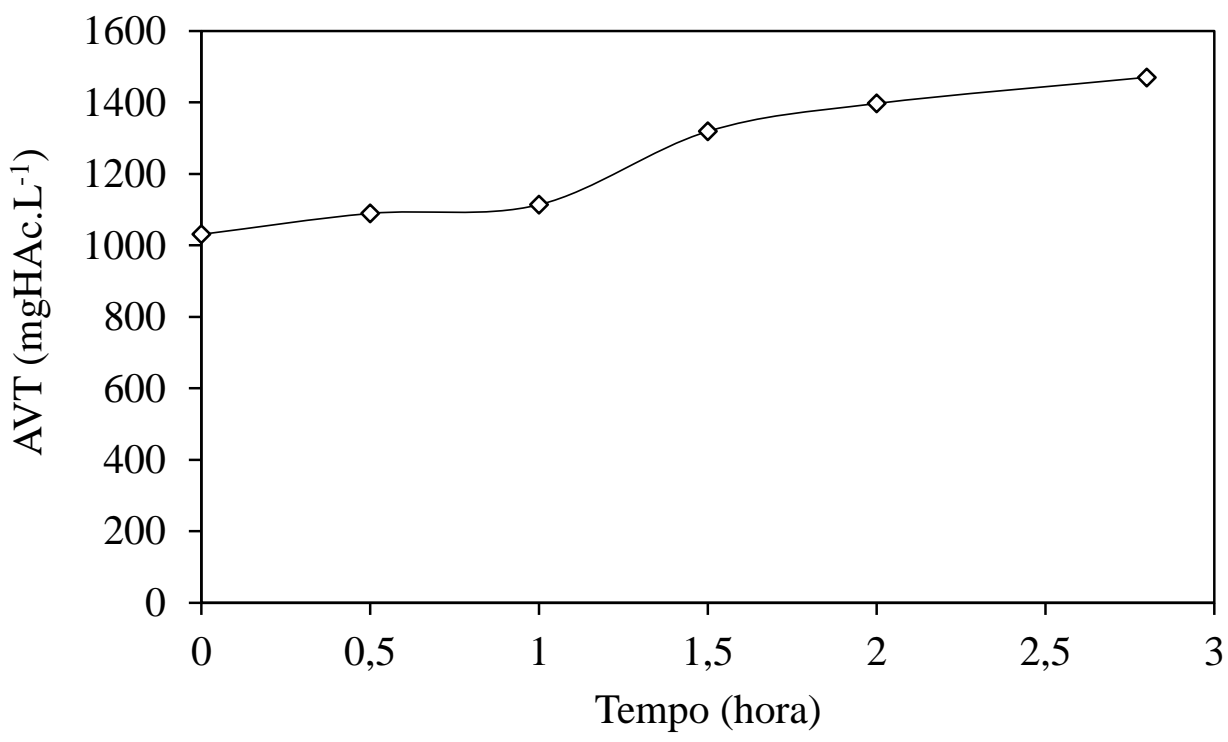

Figura 5-292 - Ácidos voláteis totais $(\diamond)$ do perfil (AnSBBR com agitação mecânica e lactose - Condição 4). 
Os resultados dos compostos intermediários por cromatografia gasosa são apresentados na Figura 5-293. Estes se apresentaram estáveis, com exceção do ácido acético que apresentou um crescimento durante o perfil e do etanol que apresentou uma queda na última hora de ciclo.

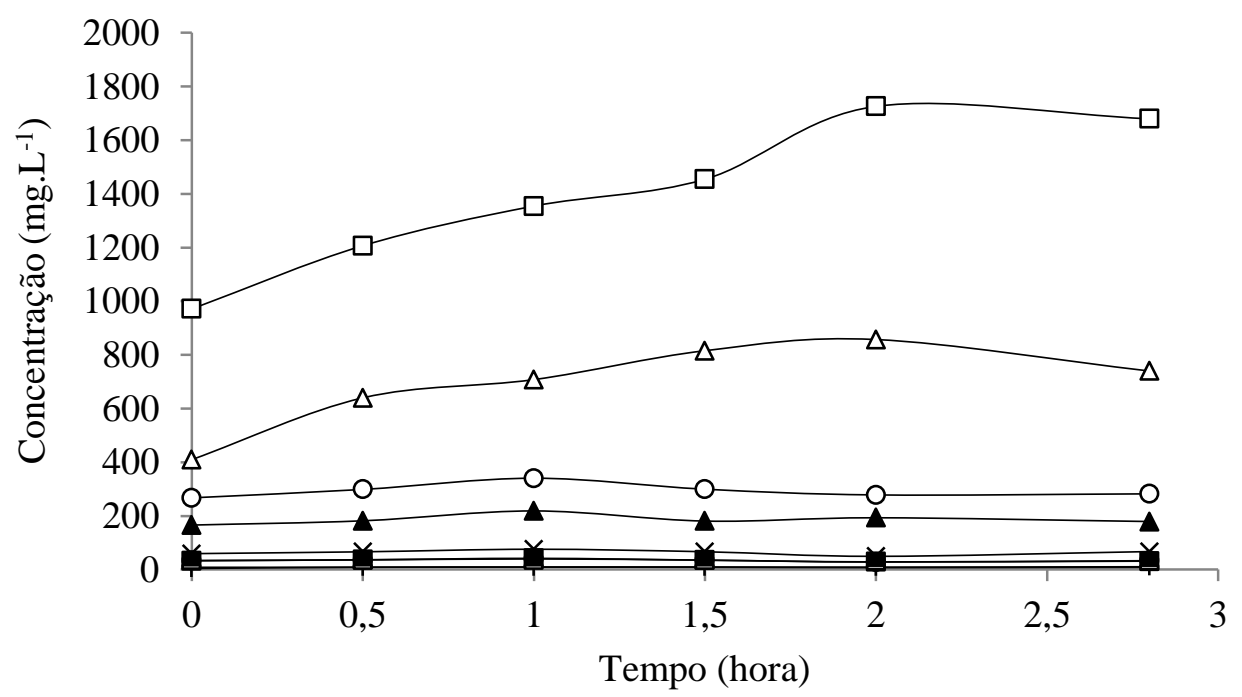

Figura 5-293 - Concentração dos compostos intermediários ao longo do ciclo: $\square$ - ácido acético; $\Delta$ - etanol; $\bigcirc$ - ácido butírico; $\boldsymbol{- a ́ c i d o ~ i s o b u t i ́ r i c o ; ~} \boldsymbol{\Delta}$ - ácido capróico; $\bullet-$ ácido valérico; - *ácido propiônico; +butanol; - ácido isovalérico (AnSBBR com agitação mecânica e lactose - Condição 4).

$\mathrm{O}$ pH diminuiu instantaneamente em relação ao afluente devido à diluição do mesmo com o volume residual no inicio do ciclo e permaneceu estável ao longo da operação conforme a Figura 5-294. A estabilidade do $\mathrm{pH}$ foi mantida, como pode ser visto na Figura 5-295, mesmo com o meio de alimentação não possuindo nenhuma alcalinidade durante todo o tempo de perfil. 


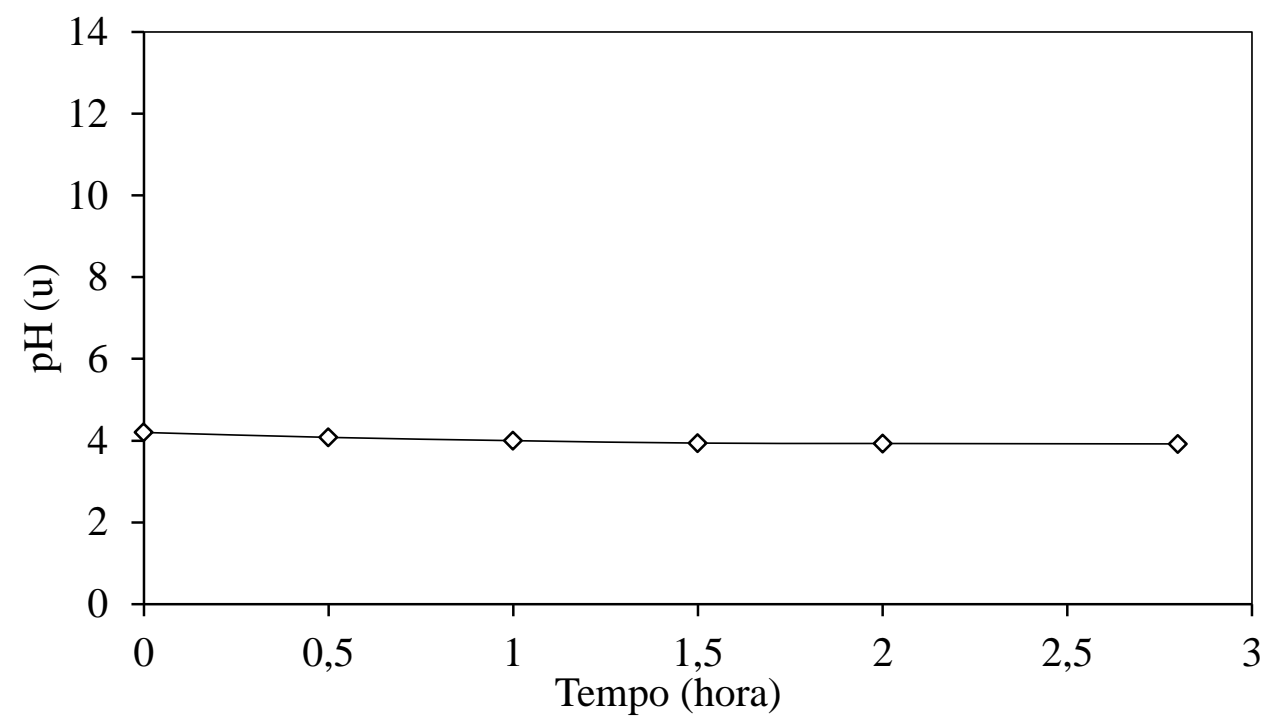

Figura 5-294 - Valores de pH $(\diamond)$ do perfil (AnSBBR com agitação mecânica e lactose Condição 4).

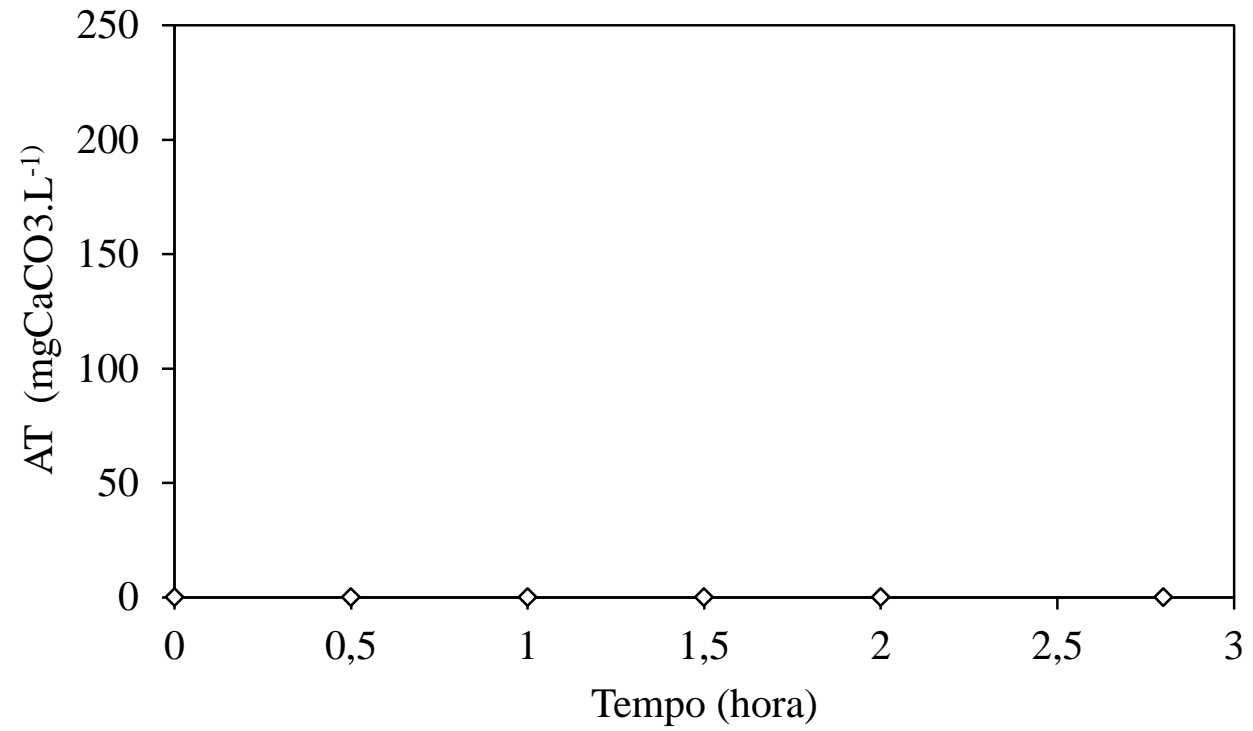

Figura 5-295 - Alcalinidade total do perfil (AnSBBR com agitação mecânica e lactose Condição 4).

A produção volumétrica média acumulada do biogás, realizada com os valores dos perfis quantitativos mais consistentes obtidos durante a operação, juntamente com os desvios padrões encontram-se na Figura 5-296. A maior parte da produção ocorre no inicio do ciclo, durante a primeira hora do mesmo, e apresentou uma tendência a se estabilizar na hora final do ciclo. A Tabela 5.71 resume os valores médios da produção, 
fração molar e os volumes individuais da mistura do biogás. A Figura 5-297 apresenta os volumes acumulados médios dos perfis de $\mathrm{H}_{2}, \mathrm{CO}_{2}$ e $\mathrm{CH}_{4}$ produzidos durante o ciclo. Foi produzido metano em baiíssima quantidade nesta condição, além do hidrogênio e do gás carbônico.

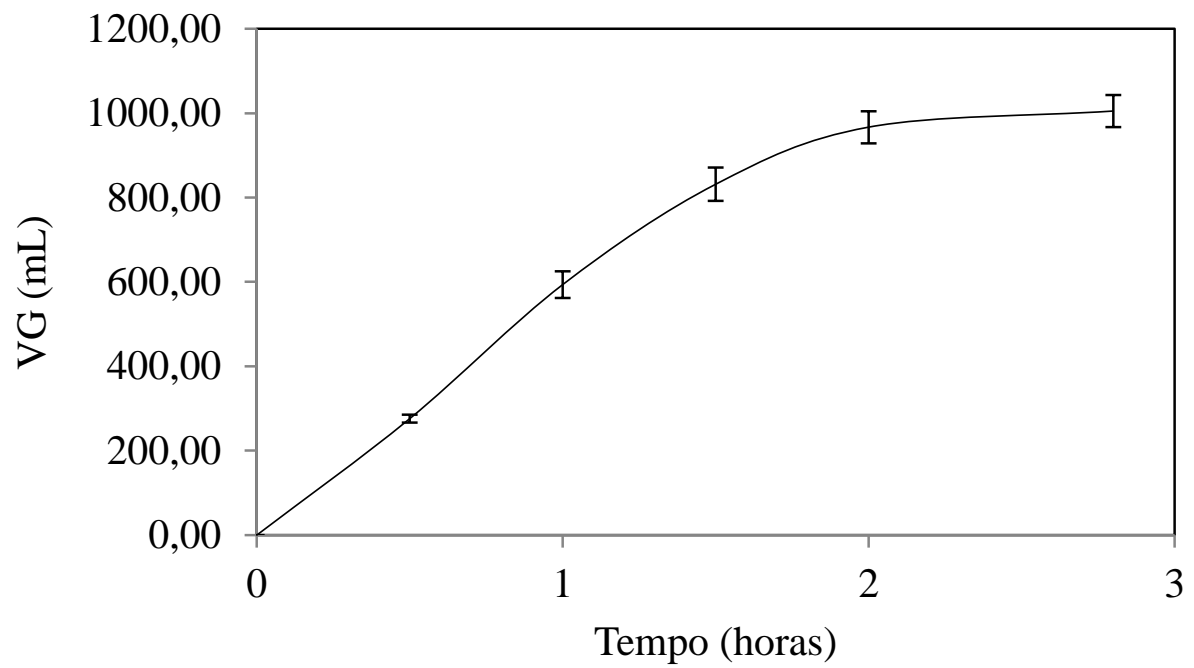

Figura 5-296 - Produção volumétrica média acumulada do biogás durante o ciclo (AnSBBR com agitação mecânica e lactose - Condição 4).

Tabela 5.71 - Valores médios da produção, fração molar e os volumes individuais da mistura do biogás (AnSBBR com agitação mecânica e lactose - Condição 4).

\begin{tabular}{ccccccccccc}
\hline $\begin{array}{c}\text { Tempo } \\
(\mathrm{h})\end{array}$ & \multirow{2}{*}{$\mathrm{V}_{\mathrm{G}}$} & \multicolumn{3}{c}{$\mathrm{C}_{\mathrm{G}}\left(\mathrm{mmol} \cdot \mathrm{L}^{-1}\right)$} & \multicolumn{3}{c}{ Fração Molar $(\%)$} & \multicolumn{3}{c}{ Volume (mL - CNTP) } \\
& & $\mathrm{H}_{2}$ & $\mathrm{CO}_{2}$ & $\mathrm{CH}_{4}$ & $\mathrm{H}_{2}$ & $\mathrm{CO}_{2}$ & $\mathrm{CH}_{4}$ & $\mathrm{H}_{2}$ & $\mathrm{CO}_{2}$ & $\mathrm{CH}_{4}$ \\
\hline 0,0 & 0 & 0,0 & 0,0 & 0,0 & 0,0 & 0,0 & 0,0 & 0,0 & 0,0 & 0,0 \\
0,5 & 276 & 1,1 & 4,9 & 0,1 & 18,3 & 80,4 & 1,3 & 50,4 & 222,0 & 3,5 \\
1,0 & 594 & 1,7 & 9,6 & 0,2 & 14,7 & 83,8 & 1,5 & 97,2 & 488,2 & 8,2 \\
1,5 & 831 & 2,3 & 12,0 & 0,2 & 15,9 & 82,5 & 1,6 & 134,9 & 684,4 & 12,1 \\
2,0 & 967 & 2,6 & 15,7 & 0,3 & 14,0 & 84,4 & 1,5 & 153,9 & 198,7 & 14,2 \\
2,8 & 1005 & 2,9 & 16,1 & 0,3 & 15,0 & 83,5 & 1,5 & 159,7 & 830,6 & 14,7 \\
\hline
\end{tabular}




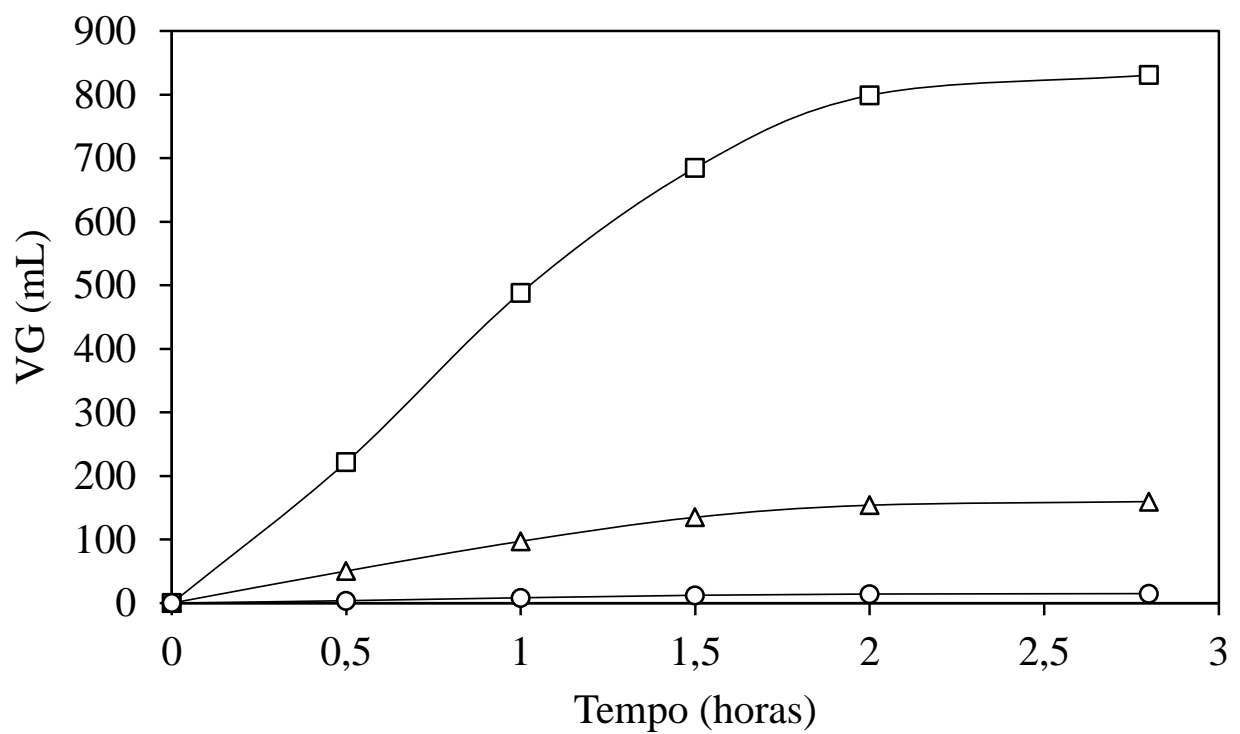

Figura 5-297 - Volumes acumulados médios produzidos ao longo do ciclo: $\square-\mathrm{CO}_{2} ; \Delta$ $\mathrm{H}_{2} ;$ O $-\mathrm{CH}_{4}$ (AnSBBR com agitação mecânica e lactose - Condição 4). 
5.3.5. Condição $5\left(D Q O=3600 \mathrm{mg}^{-L^{-1}}\right.$ e $t_{C}=2$ horas $)$

A condição experimental 5, com COAV nominal de 18,5 $\mathrm{kgDQO} \cdot \mathrm{m}^{-3} \cdot \mathrm{d}^{-1} \mathrm{e}$ duração do ciclo de 2 horas, durou do dia 89 ao dia 113 ( 25 dias de operação). A Tabela 5.72 apresenta os valores médios dos parâmetros monitorados. 
Tabela 5.72 - Valores médios dos parâmetros monitorados na condição 5 (Lactose $\left.3600 \mathrm{mgDQO} . \mathrm{L}^{-1}-\mathrm{t}_{\mathrm{C}} 2 \mathrm{~h}\right)$

\begin{tabular}{|c|c|c|c|c|c|c|c|c|c|c|}
\hline \multicolumn{2}{|r|}{ Parâmetro } & \multicolumn{5}{|c|}{ Afluente } & \multicolumn{4}{|c|}{ Efluente } \\
\hline $\mathrm{C}_{\mathrm{ST}}$ & $\left(\mathrm{mgDQO} \cdot \mathrm{L}^{-1}\right)$ & 3458 & \pm & 182 & ( & 9 & 2848 & \pm & 132 & $\left({ }^{9}\right)$ \\
\hline $\mathrm{C}_{\mathrm{SF}}$ & $\left(\mathrm{mgDQO} . \mathrm{L}^{-1}\right)$ & - & \pm & - & ( & 3 & 2809 & \pm & 233 & $\left({ }^{9}\right)$ \\
\hline$\varepsilon_{\mathrm{ST}}$ & $(\%)$ & - & & - & & & 18 & \pm & 4 & $\left({ }^{9}\right)$ \\
\hline$\varepsilon_{\mathrm{SF}}$ & $(\%)$ & - & & - & & & 19 & \pm & 7 & $\left({ }^{9}\right)$ \\
\hline $\mathrm{C}_{\mathrm{CT}}$ & $\left(\right.$ mgCarboidrato. $\left.L^{-1}\right)$ & 3050 & \pm & 359 & ( & 8 & 40 & \pm & 54 & $\left({ }^{8}\right)$ \\
\hline $\mathrm{C}_{\mathrm{CF}}$ & (mgCarboidrato. $\mathrm{L}^{-1}$ ) & - & \pm & - & & & 36 & \pm & 49 & $\left({ }^{8}\right)$ \\
\hline$\varepsilon_{\mathrm{CT}}$ & $(\%)$ & - & & - & & & 99 & \pm & 2 & $\left({ }^{8}\right)$ \\
\hline$\varepsilon_{\mathrm{CF}}$ & $(\%)$ & - & & - & & & 99 & \pm & 2 & $\left({ }^{8}\right)$ \\
\hline $\mathrm{pH}$ & (u) & 7,99 & \pm & 0,12 & ( & 9 & 4,53 & \pm & 0,02 & $\left({ }^{9}\right)$ \\
\hline AVT & $\left(\mathrm{mgHAc} . \mathrm{L}^{-1}\right)$ & 30 & \pm & 10 & ( & 9 & 934 & \pm & 53 & $\left({ }^{9}\right)$ \\
\hline $\mathrm{AT}$ & $\left(\mathrm{mgCaCO}_{3} \cdot \mathrm{L}^{-1}\right)$ & 415 & \pm & 29 & ( & 9 & 105 & \pm & 10 & $\left({ }^{9}\right)$ \\
\hline $\mathrm{AP}$ & $\left(\mathrm{mgCaCO}_{3} \cdot \mathrm{L}^{-1}\right)$ & 307 & \pm & 23 & ( & 9 & 0 & \pm & 0 & $\left({ }^{9}\right)$ \\
\hline AI & $\left(\mathrm{mgCaCO}_{3} \cdot \mathrm{L}^{-1}\right)$ & 108 & \pm & 24 & ( & 9 & 105 & \pm & 10 & $\left({ }^{9}\right)$ \\
\hline $\mathrm{AB}$ & $\left(\mathrm{mgCaCO}_{3} \cdot \mathrm{L}^{-1}\right)$ & 394 & \pm & 34 & ( & 9 & 0 & \pm & 0 & $\left({ }^{9}\right)$ \\
\hline ST & $\left(\mathrm{mg} \cdot \mathrm{L}^{-1}\right)$ & 3158 & \pm & 219 & ( & 5 & 1592 & \pm & 95 & $\left({ }^{5}\right)$ \\
\hline STV & $\left(\mathrm{mg} \cdot \mathrm{L}^{-1}\right)$ & 2699 & \pm & 177 & ( & 5 & 1191 & \pm & 41 & $\left({ }^{5}\right)$ \\
\hline SST & $\left(\mathrm{mg} \cdot \mathrm{L}^{-1}\right)$ & 36 & \pm & 10 & ( & 5 & 61 & \pm & 27 & $\left({ }^{5}\right)$ \\
\hline SSV & $\left(\mathrm{mg} \cdot \mathrm{L}^{-1}\right)$ & 22 & \pm & 14 & ( & 5 & 54 & \pm & 27 & $\left({ }^{5}\right)$ \\
\hline $\mathrm{M}_{\mathrm{STV}}$ & (g) & - & & - & & & 17,4 & & - & \\
\hline $\mathrm{C}_{\mathrm{X}}$ & $\left(\mathrm{g} \cdot \mathrm{L}^{-1}\right)$ & - & & - & & & 5,0 & & - & \\
\hline $\mathrm{C}_{\mathrm{X}}^{\prime}$ & (g.gsuporte ${ }^{-1}$ ) & - & & - & & & 0,017 & & - & \\
\hline $\mathrm{V}_{\mathrm{G}}$ & (mL-CNTP) & - & & - & & & 863 & \pm & 25 & $\left({ }^{4}\right)$ \\
\hline $\mathrm{V}_{\mathrm{H} 2}$ & (mL-CNTP) & - & & - & & & 173 & \pm & - & $\left({ }^{1}\right)$ \\
\hline $\mathrm{COAV}_{\mathrm{STA}}$ & $\left(\operatorname{kgDQO} \cdot \mathrm{m}^{-3} \cdot \mathrm{d}^{-1}\right)$ & 17,8 & & - & & & - & & - & \\
\hline $\mathrm{CORV}_{\mathrm{SFE}}$ & $\left(\operatorname{kgDQO} \cdot \mathrm{m}^{-3} \cdot \mathrm{d}^{-1}\right)$ & - & & - & & & 3,3 & & - & \\
\hline $\mathrm{COAV}_{\mathrm{CTA}}$ & $\left(\right.$ kgCarboidrato. $\left.\mathrm{m}^{-3} \cdot \mathrm{d}^{-1}\right)$ & 15,7 & & - & & & - & & - & \\
\hline $\mathrm{CORV}_{\mathrm{CFE}}$ & (kgCarboidrato. $\mathrm{m}^{-3} \cdot \mathrm{d}^{-1}$ ) & - & & - & & & 15,5 & & - & \\
\hline $\mathrm{COAE}_{\mathrm{STA}}$ & $\left(\mathrm{kgDQO} \cdot \mathrm{kgSTV}^{-1} \cdot \mathrm{d}^{-1}\right)$ & 3,6 & & - & & & - & & - & \\
\hline $\mathrm{CORE}_{\mathrm{SFE}}$ & $\left(\mathrm{kgDQO} \cdot \mathrm{kgSTV}^{-1} \cdot \mathrm{d}^{-1}\right)$ & - & & - & & & 0,7 & & - & \\
\hline $\mathrm{COAE}_{\mathrm{CTA}}$ & $\left(\mathrm{kgCarboidrato} \mathrm{kgSTV}^{-1} \cdot \mathrm{d}^{-1}\right)$ & 3,2 & & - & & & - & & - & \\
\hline $\mathrm{CORE}_{\mathrm{CFE}}$ & $\left(\mathrm{kgCarboidrato} \mathrm{kgSTV}^{-1} \cdot \mathrm{d}^{-1}\right)$ & - & & - & & & 3,1 & & - & \\
\hline $\mathrm{RMCR}_{\mathrm{C}, \mathrm{n}}$ & $\left(\mathrm{molH}_{2}\right.$ molCarboidrato $\left.^{-1}\right)$ & - & & - & & & 0,59 & & - & \\
\hline $\mathrm{n}_{\mathrm{H} 2}$ & $\left(\mathrm{molH}_{2} \cdot \mathrm{d}^{-1}\right)$ & - & & $\longrightarrow$ & & & 0,093 & & - & \\
\hline PrM & $\left(\mathrm{molH}_{2} \cdot \mathrm{m}^{-3} \cdot \mathrm{d}^{-1}\right)$ & - & & - & & & 26,5 & & - & \\
\hline PrME & $\left(\mathrm{molH}_{2} \cdot \mathrm{kgSVT}^{-1} \cdot \mathrm{d}^{-1}\right)$ & - & & - & & & 5,4 & & - & \\
\hline $\mathrm{RMCA}_{\mathrm{S}, \mathrm{m}}$ & $\left(\mathrm{molH}_{2} \cdot \mathrm{kgDQO}^{-1} \cdot \mathrm{d}^{-1}\right)$ & 1,5 & & - & & & 一 & & - & \\
\hline $\mathrm{RMCA}_{\mathrm{C}, \mathrm{m}}$ & $\left(\mathrm{molH}_{2} \cdot \mathrm{kg}^{-1} \cdot \mathrm{d}^{-1}\right)$ & 1,7 & & - & & & 一 & & - & \\
\hline $\mathrm{RMCR}_{\mathrm{S}, \mathrm{m}}$ & $\left(\mathrm{molH}_{2} \cdot \mathrm{kgDQO}^{-1} \cdot \mathrm{d}^{-1}\right)$ & - & & - & & & 8,0 & & - & \\
\hline $\mathrm{RMCR}_{\mathrm{C}, \mathrm{m}}$ & $\left(\mathrm{molH}_{2} \cdot \mathrm{kg}^{-1} \cdot \mathrm{d}^{-1}\right)$ & - & & - & & & 1,7 & & - & \\
\hline $\mathrm{V}_{\mathrm{R}}$ & $(\mathrm{mL})$ & 2000 & & & & & 一 & & - & \\
\hline $\mathrm{V}_{\mathrm{A}}$ & $(\mathrm{mL})$ & 1509 & \pm & 12 & & , & & & & \\
\hline
\end{tabular}

(*) Entre parêntese o número de amostras considerado no cálculo da média 
A Figura 5-298 apresenta os valores da concentração afluente (amostras não filtradas) e efluente (amostras não filtradas e filtradas) de matéria orgânica (DQO) nos sistema, enquanto que a Figura 5-299 apresenta a eficiência de remoção do mesmo parâmetro durante o monitoramento diário. Esta eficiência atingiu, em média, 19\% para as amostras filtradas e $18 \%$ para mostras não filtradas. A média de concentração afluente para amostras não filtradas do substrato foi de $3458 \mathrm{mgDQO} . \mathrm{L}^{-1}$ e de 2848 mgDQO.L ${ }^{-1}$ e 2808 mgDQO.L ${ }^{-1}$ para amostras de efluente para amostras não filtradas e filtradas, respectivamente.

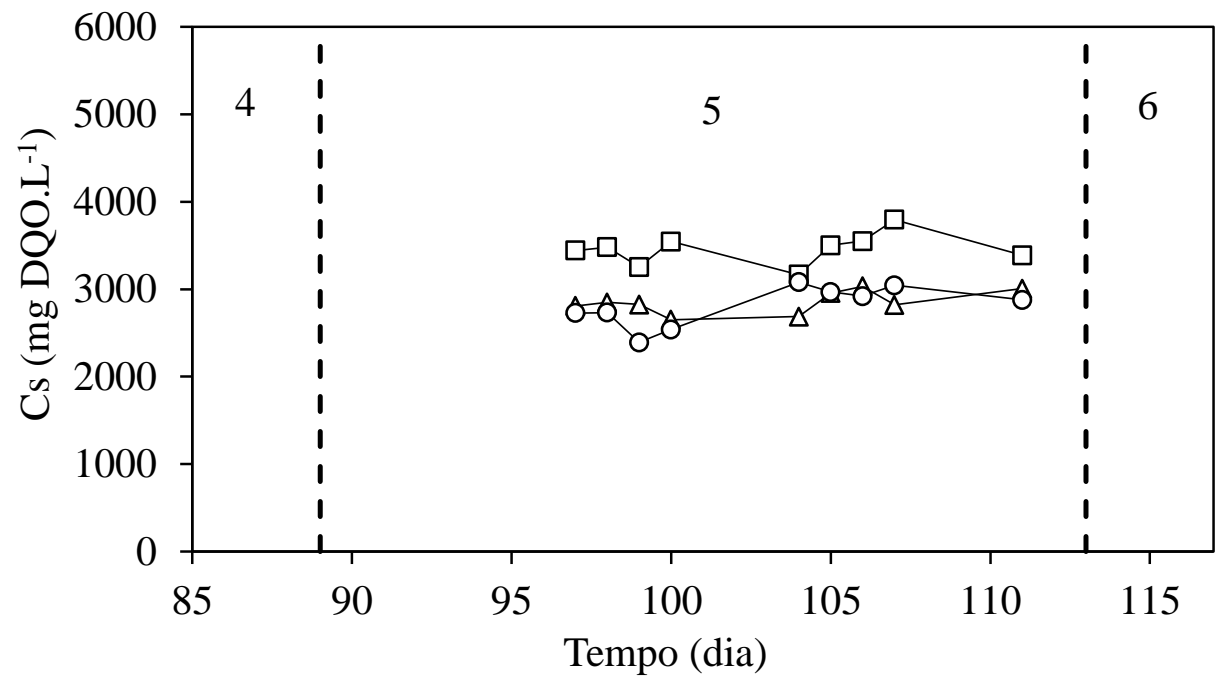

Figura 5-298 - Concentração de matéria orgânica (DQO): $\square$ - afluente não filtrada; $\Delta$ efluente não filtrada; $\bigcirc$ - efluente filtrada (AnSBBR com agitação mecânica e lactose Condição 5). 


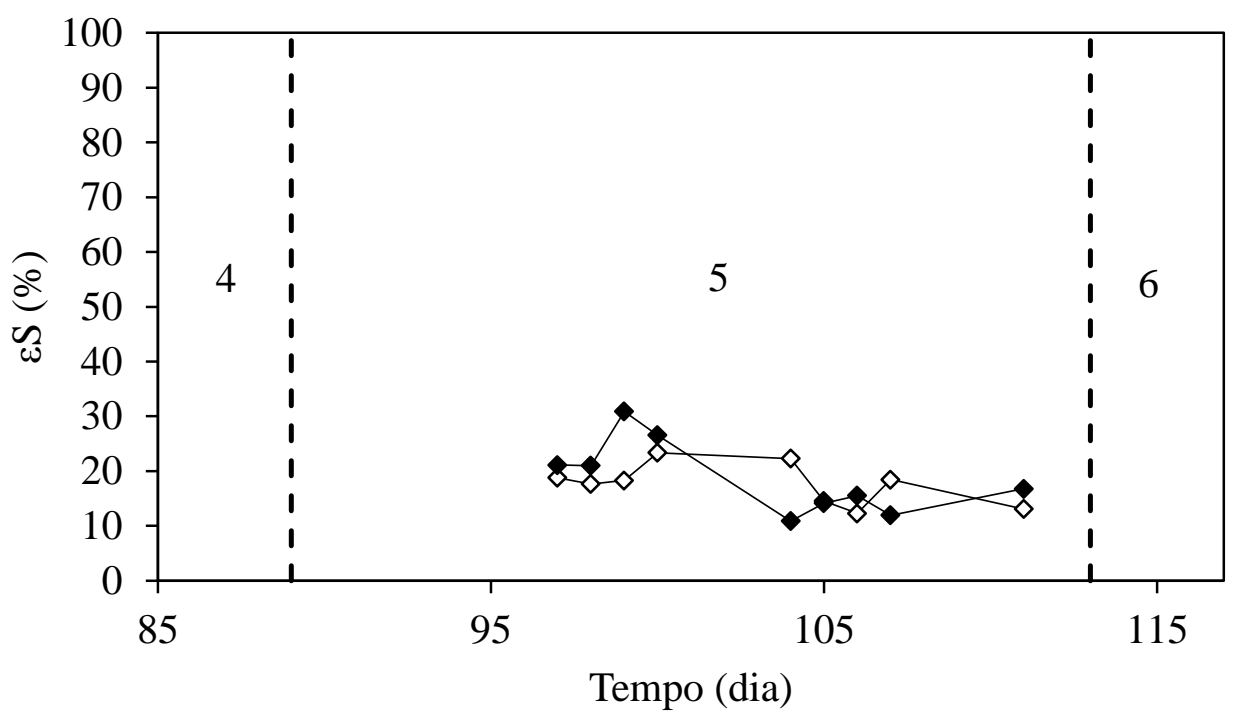

Figura 5-299-Eficiência de remoção de matéria orgânica (DQO): $\diamond$ - não filtrada; filtrada (AnSBBR com agitação mecânica e lactose - Condição 5).

A Figura 5-300 mostra os valores da concentração de carboidratos afluente e efluente (para amostras filtradas e não filtradas). A Figura 5-301 apresenta a eficiência de remoção do mesmo parâmetro (para amostras filtradas e não filtradas) durante o monitoramento diário. A média da concentração afluente foi de $3050 \mathrm{mgCarboidrato.L^{- }}$ ${ }^{1}$, enquanto que a concentração residual não filtrada foi de $40 \mathrm{mgCarboidrato.}^{-1}$ e 36 mgCarboidrato. $\mathrm{L}^{-1}$ para a concentração residual filtrada. A eficiência de remoção de lactose foi, em média, de 99\% para ambas as amostras (filtradas e não filtradas). 


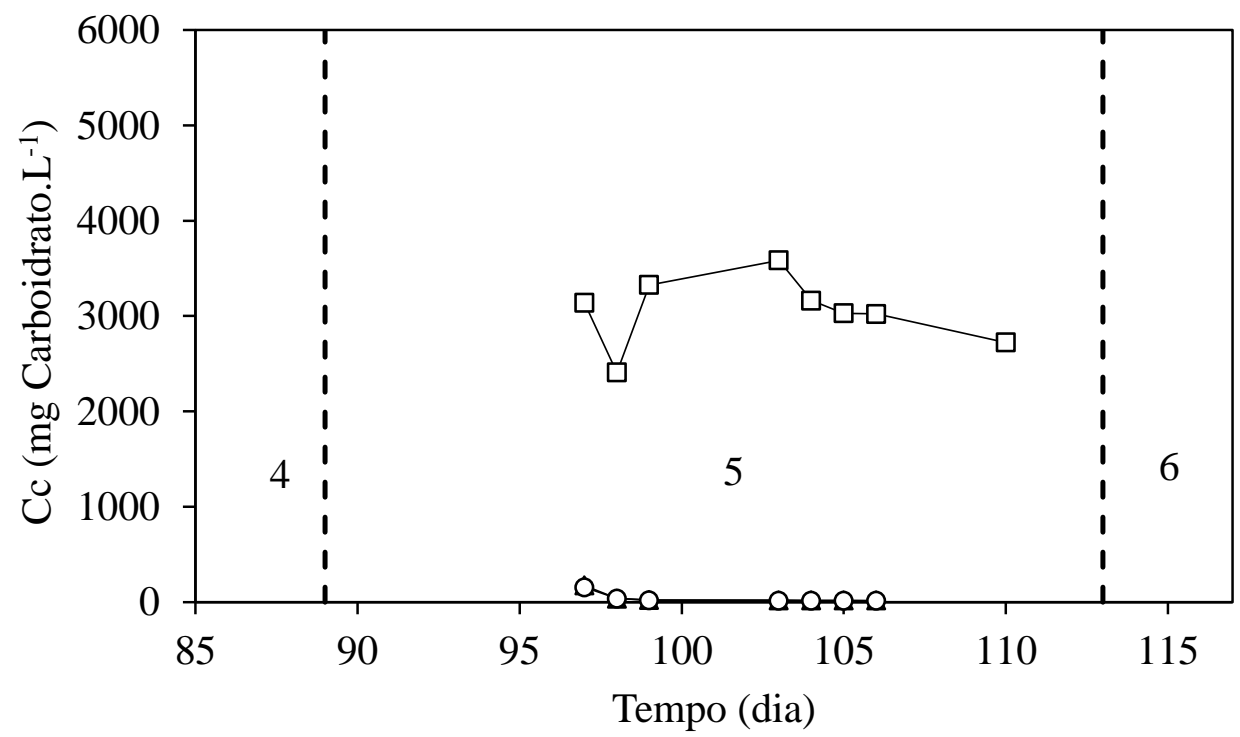

Figura 5-300 - Concentração de carboidrato: $\square$ - afluente não filtrada; $\Delta$ - efluente não filtrada; ○ - efluente filtrada (AnSBBR com agitação mecânica e lactose - Condição 5).

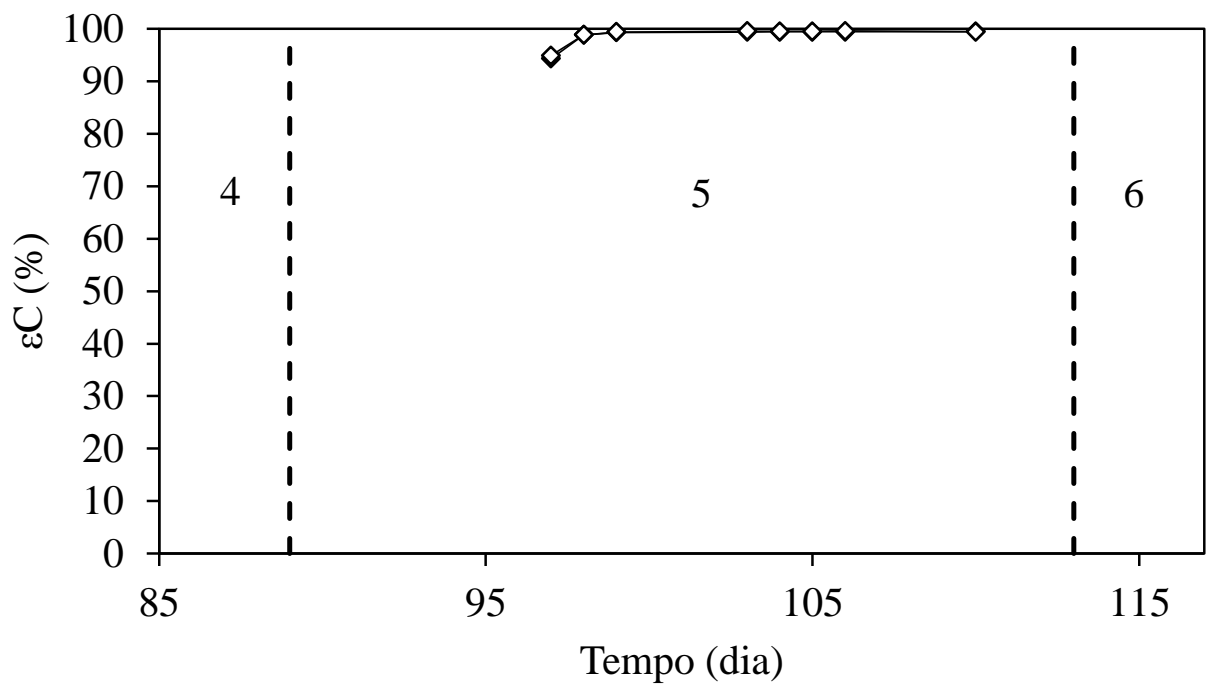

Figura 5-301 - Eficiência de remoção de carboidrato: $\diamond$ - não filtrada; - filtrada (AnSBBR com agitação mecânica e lactose - Condição 5).

As Figura 5-302, Figura 5-303 e Figura 5-304 apresentam os perfis temporais, tanto para o afluente quanto para o efluente, do $\mathrm{pH}$, da alcalinidade total e dos ácidos voláteis totais, respectivamente. A média dos valores de $\mathrm{pH}$ afluente durante esta primeira fase foi de 7,99 e de $\mathrm{pH}$ efluente foi de 4,53. A média da alcalinidade total foi de 415 e $105 \mathrm{mgCaCO}_{3} \cdot \mathrm{L}^{-1}$ para o afluente e efluente, respectivamente. O valor médio 
da concentração de ácidos voláteis totais afluente foi de $30 \mathrm{mgHAc} . \mathrm{L}^{-1}$ e efluente de 934 mgHAc. $\mathrm{L}^{-1}$. A queda do pH efluente está relacionada com a alta produção de ácidos voláteis totais.

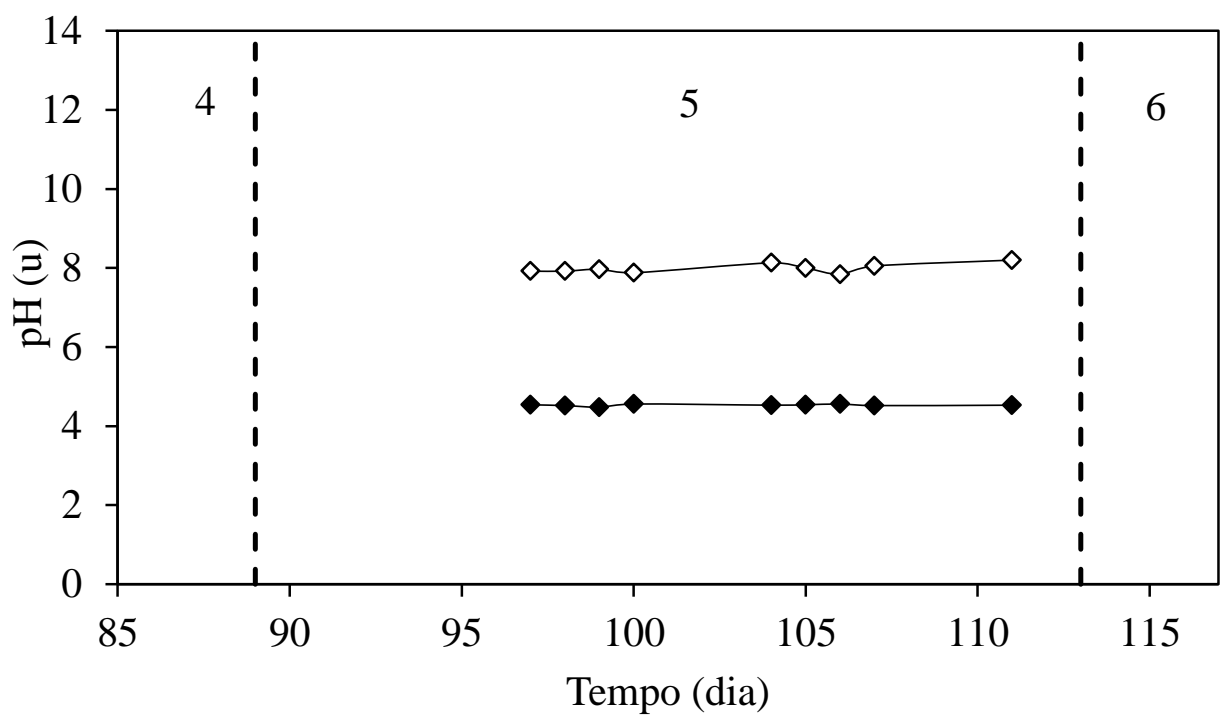

Figura 5-302 - Valores de pH: $\diamond$-afluente; - efluente (AnSBBR com agitação mecânica e lactose - Condição 5).

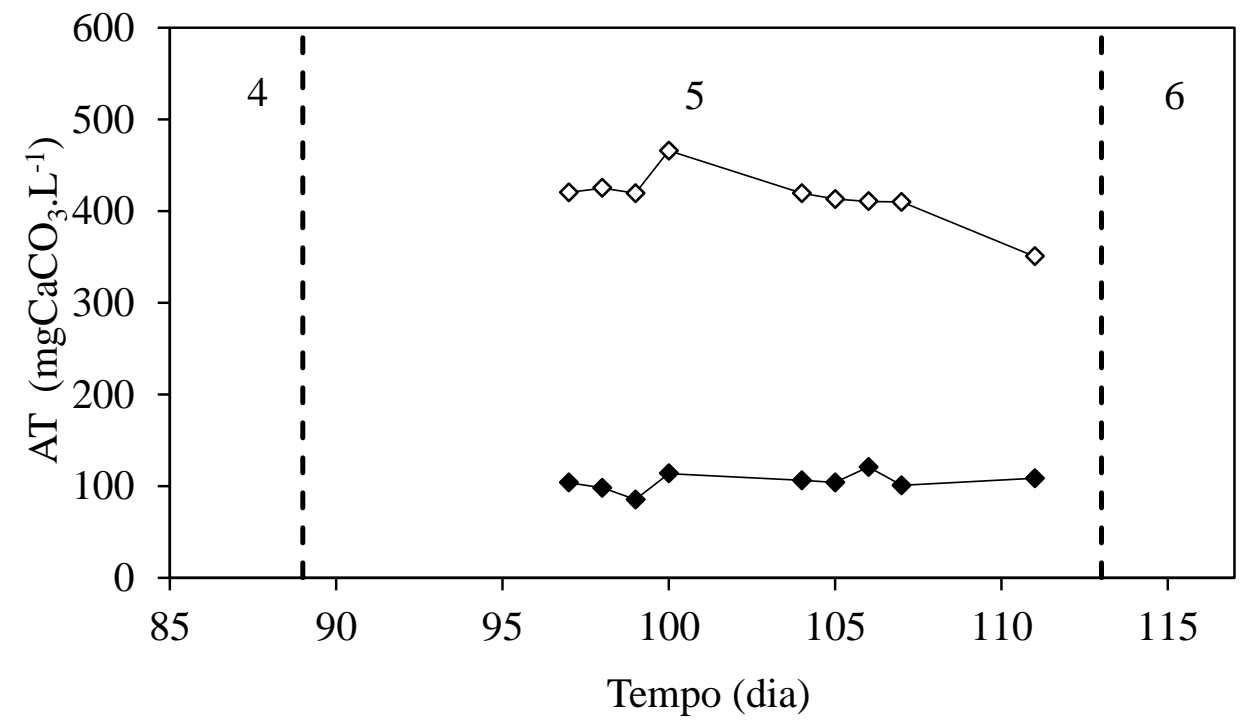

Figura 5-303 - Alcalinidade total: $\diamond$-afluente; - efluente (AnSBBR com agitação mecânica e lactose - Condição 5). 


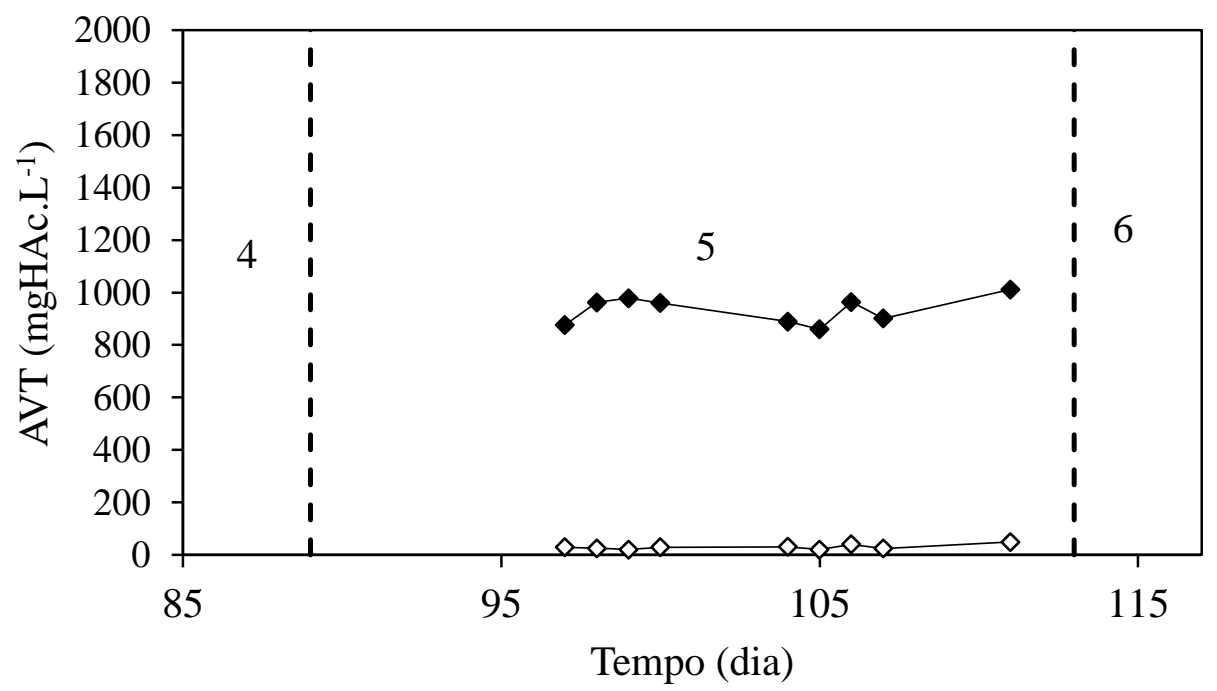

Figura 5-304 - Ácidos voláteis totais: $\diamond$-afluente; - efluente (AnSBBR com agitação mecânica e lactose - Condição 5).

A Figura 5-305 apresenta o monitoramento dos compostos intermediários contidos no efluente do sistema, enquanto que a Tabela 5.73 apresenta os valores da concentração média destes produtos. As amostras para análise destes compostos foram coletadas no dia do perfil temporal da condição (no descarte antes do ciclo do perfil, no ultimo ponto do perfil e no descarte após o ciclo do perfil). O método cromatográfico aplicado não detectou a presença de acetona e metanol. Dentre os ácidos voláteis, o ácido acético predominou seguido pelo ácido butírico e pelo ácido isobutírico representando respectivamente $35,8 \%, 9,3 \%$ e $8,9 \%$ dos compostos intermediários. O etanol também foi produzido em alta quantidade, representando $34,8 \%$ dos compostos. 


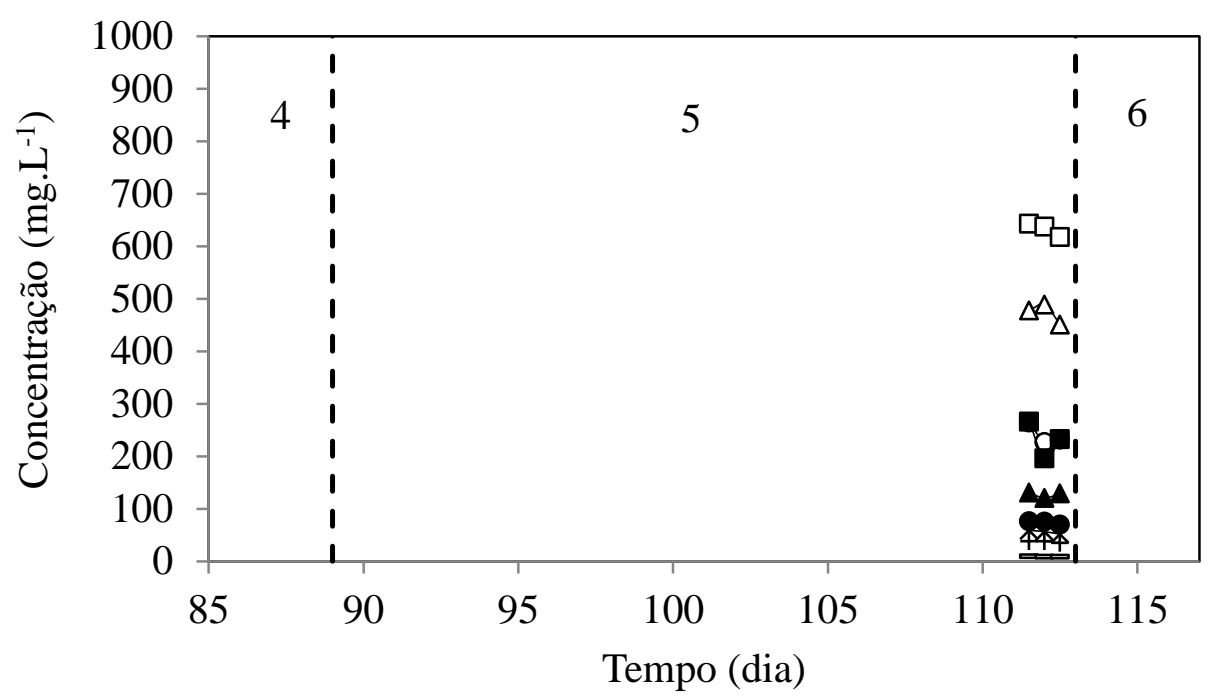

Figura 5-305 - Concentração dos compostos intermediários: $\square$ - ácido acético; $\Delta$ etanol; ○ - ácido butírico; $\mathbf{-}$ - ácido isobutírico; $\boldsymbol{\Delta}$ - ácido capróico; • - ácido valérico; * ácido propiônico; +butanol; - ácido isovalérico (AnSBBR com agitação mecânica e lactose - Condição 5).

Tabela 5.73 - Concentração e distribuição dos compostos intermediários (AnSBBR com agitação mecânica e lactose - Condição 5).

\begin{tabular}{cccccccc}
\hline $\begin{array}{c}\text { Produtos } \\
\text { intermediários }\end{array}$ & \multicolumn{5}{c}{ Concentrações médias } & \multicolumn{3}{c}{$\begin{array}{c}\text { Distribuição } \\
\left(\mathrm{mg} . \mathrm{L}^{-1}\right)\end{array}$} & \multicolumn{2}{c}{$\left(\mathrm{mmol}_{\mathrm{L}} \mathrm{L}^{-1}\right)$} & $(\%)$ \\
\hline Acetona & 0,0 & \pm & 0,0 & 0,0 & \pm & 0,0 & 0,0 \\
Metanol & 0,0 & \pm & 0,0 & 0,0 & \pm & 0,0 & 0,0 \\
Etanol & 472,7 & \pm & 19,4 & 10,3 & \pm & 0,4 & 34,8 \\
n-Butanol & 37,1 & \pm & 1,9 & 0,5 & \pm & 0,0 & 1,7 \\
Acético & 632,8 & \pm & 13,2 & 10,5 & \pm & 0,2 & 35,8 \\
Porpiônico & 55,5 & \pm & 3,7 & 0,7 & \pm & 0,1 & 2,5 \\
Isobutírico & 231,5 & \pm & 35,2 & 2,6 & \pm & 0,4 & 8,9 \\
Butírico & 241,1 & \pm & 20,1 & 2,7 & \pm & 0,2 & 9,3 \\
Isovalérico & 8,8 & \pm & 0,4 & 0,1 & \pm & 0,0 & 0,3 \\
Valérico & 73,8 & \pm & 3,6 & 0,7 & \pm & 0,0 & 2,5 \\
Capróico & 126,7 & \pm & 5,5 & 1,2 & \pm & 0,1 & 4,2 \\
\hline
\end{tabular}


O monitoramento da série de sólidos é mostrado na Tabela 5.74, cujos valores apresentam um baixo teor de SSV no efluente e afluente, indicando a boa capacidade do reator em reter biomassa, mesmo no começo da operação.

Tabela 5.74 - Série de sólidos afluente e efluente (AnSBBR com agitação mecânica e lactose - Condição 5)

\begin{tabular}{lcccc}
\hline & $\begin{array}{c}\text { ST } \\
\left(\mathrm{mg} . L^{-1}\right)\end{array}$ & $\begin{array}{c}\text { SVT } \\
\left(\mathrm{mg} . L^{-1}\right)\end{array}$ & $\begin{array}{c}\text { SST } \\
\left(\mathrm{mg} . L^{-1}\right)\end{array}$ & $\begin{array}{c}\text { SSV } \\
\left(\mathrm{mg} . \mathrm{L}^{-1}\right)\end{array}$ \\
\hline Afluente & $3158 \pm 219$ & $2699 \pm 177$ & $36 \pm 10$ & $22 \pm 14$ \\
Efluente & $1592 \pm 95$ & $1191 \pm 41$ & $61 \pm 27$ & $54 \pm 27$ \\
\hline
\end{tabular}

*Número de amostras consideradas $=5$.

A produção do biogás por ciclo, em aspecto quantitativo, pode ser observada na Figura 5-306. A produção média foi de 1002 mL (CNTP). A Figura 5-307 apresenta o monitoramento das concentrações dos componentes do biogás no final do ciclo, enquanto que a Figura 5-308 apresenta a distribuição destes mesmos componentes. Os valores médios de concentração de $\mathrm{H}_{2}, \mathrm{CH}_{4}$ e $\mathrm{CO}_{2}$ foram 5,6, 0,0 e 12,1 mmol.L ${ }^{-1}$, respectivamente. Além disso, a distribuição percentual média de $\mathrm{H}_{2}$ foi de $30,8 \%$, a de $\mathrm{CH}_{4}$ foi de $0,0 \%$ e a de $\mathrm{CO}_{2}$ foi de $69,2 \%$.

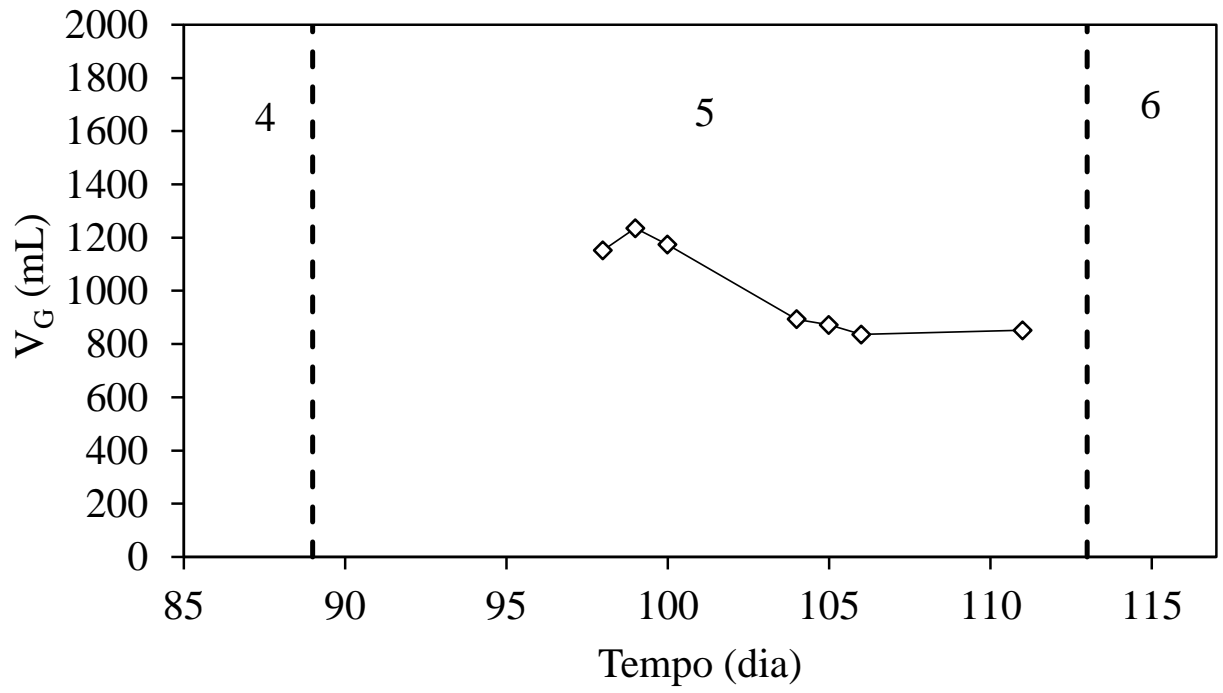

Figura 5-306 - Volume de biogás produzido por ciclo (AnSBBR com agitação mecânica e lactose - Condição 5). 


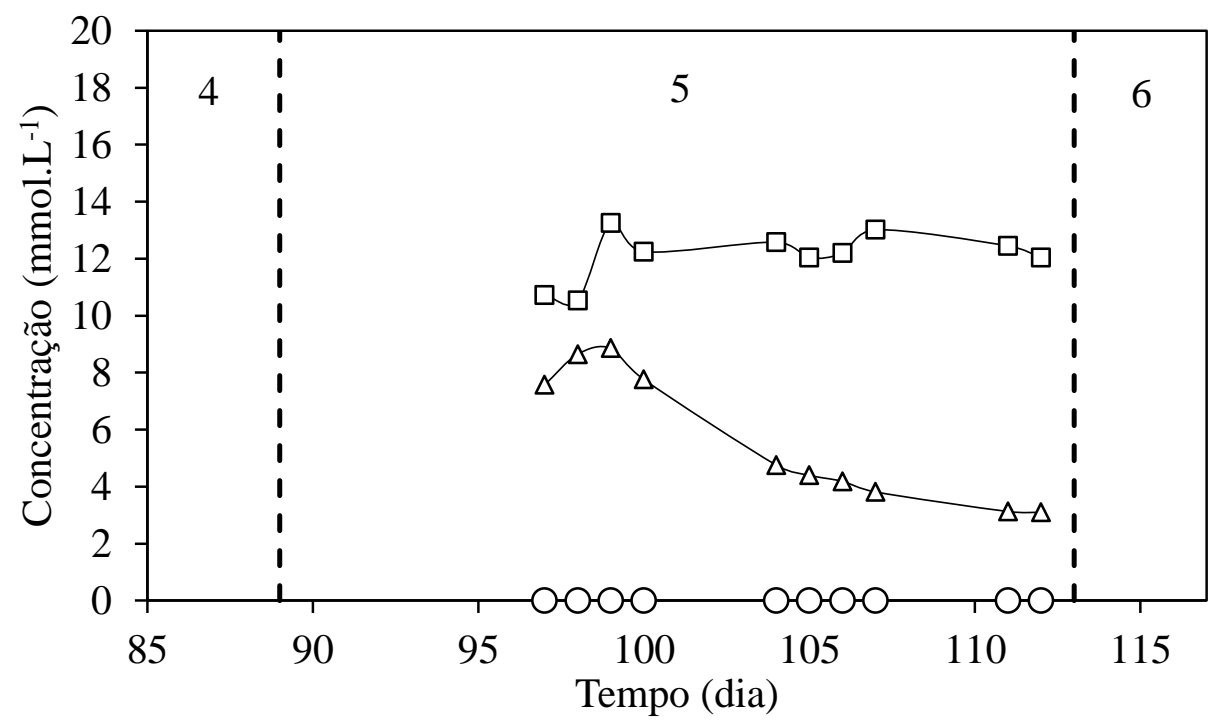

Figura 5-307 - Concentrações dos componentes do biogás no final do ciclo: $\square-\mathrm{CO}_{2} ; \Delta$ - $\mathrm{H}_{2} ; \circ-\mathrm{CH}_{4}$ (AnSBBR com agitação mecânica e lactose - Condição 5).

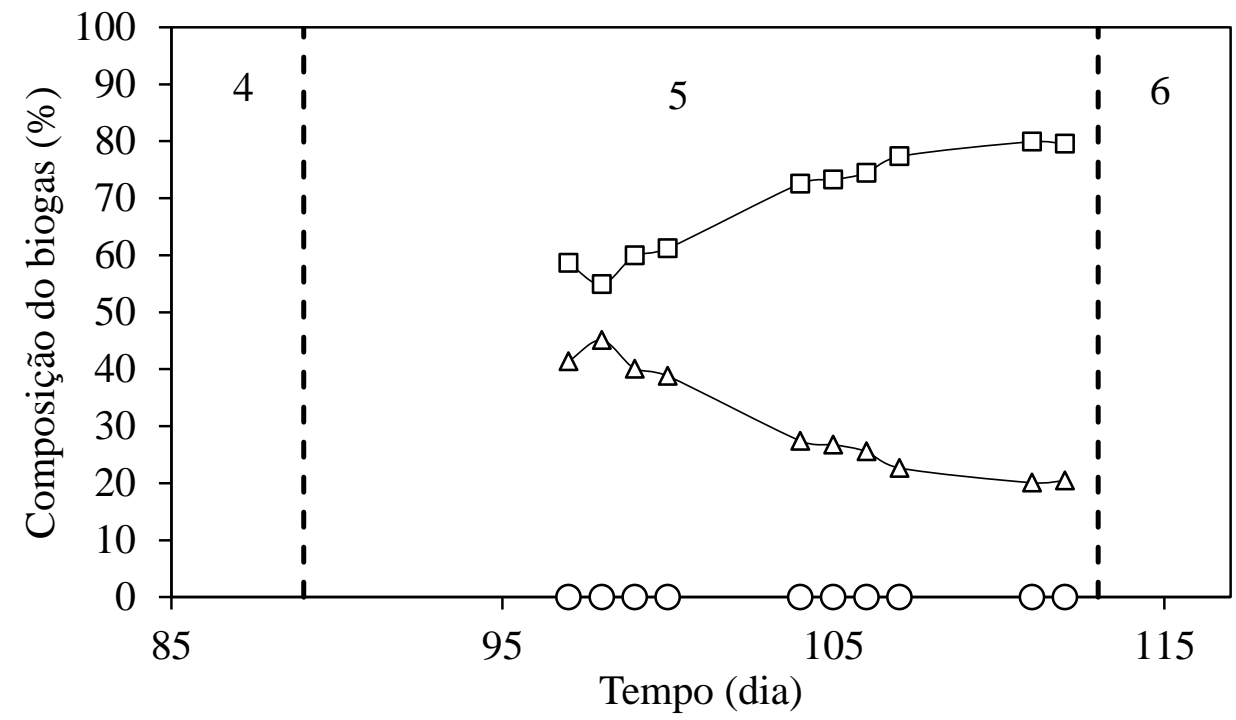

Figura 5-308 - Distribuições dos componentes do biogás no final do ciclo: $\square-\mathrm{CO}_{2} ; \Delta-$ $\mathrm{H}_{2} ;$ ○ $-\mathrm{CH}_{4}$ (AnSBBR com agitação mecânica e lactose - Condição 5).

No final da operação foi realizado o perfil temporal, com o intuito de entender melhor como os parâmetros indicativos de eficiência do sistema se comportavam durante um ciclo completo. A Figura 5-309 apresenta a evolução da concentração de carboidrato ao longo do ciclo e a eficiência de remoção do mesmo. Ao inicio do ciclo 
(tempo zero) o volume afluente é diluído no volume residual resultando em uma concentração em sacarose da ordem de $1200 \mathrm{mg} \cdot \mathrm{L}^{-1}$. A conversão de carboidrato se faz de maneira progressiva ao longo do ciclo, atingindo valores na ordem de $99 \%$ no final do mesmo, com um residual aproximado de $15 \mathrm{mg} . \mathrm{L}^{-1}$.

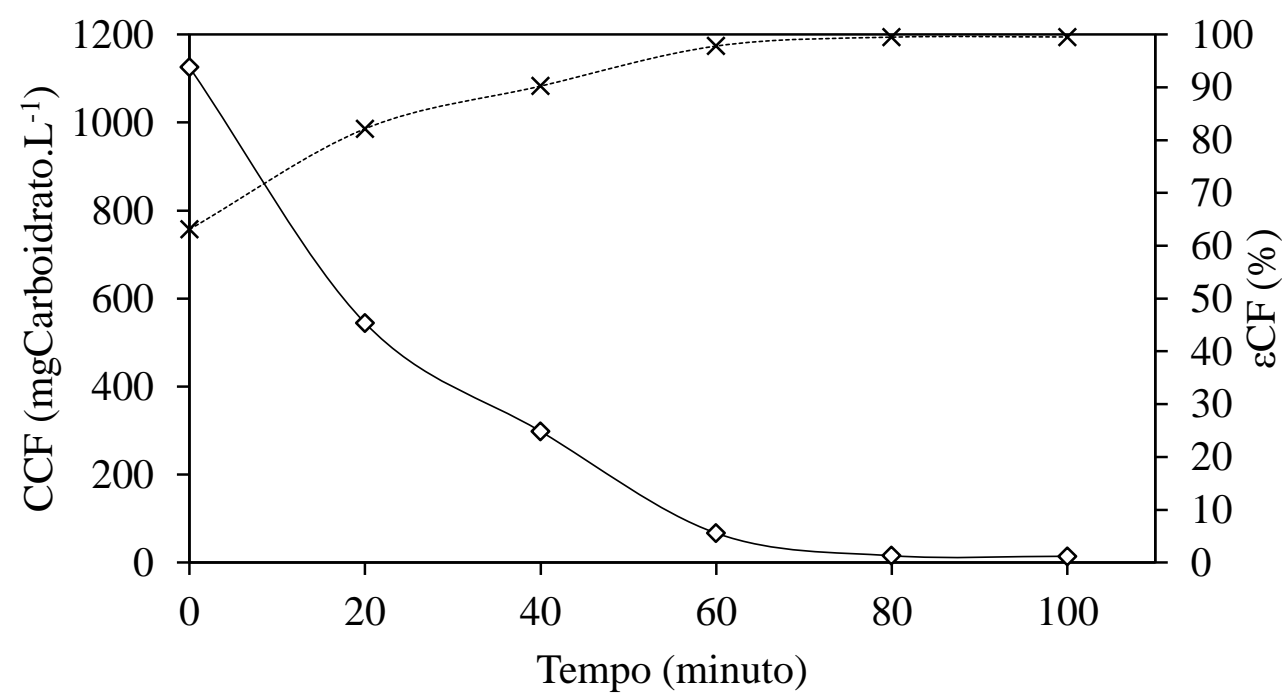

Figura 5-309 - Concentração e eficiência de degradação de carboidrato: $\diamond$ - perfil e * eficiência (AnSBBR com agitação mecânica e lactose - Condição 5).

A Figura 5-310 apresenta a evolução da concentração de matéria orgânica ao longo do ciclo. Observa-se uma baixa remoção da DQO, levando a uma alta concentração da mesma no volume residual. Assim, no inicio do ciclo, a diluição do volume carregado pelo volume residual é realizada em proporção bem menor do que no caso dos carboidratos totais, tendo em vista que as concentrações afluente e residual são muito próximas. No inicio do ciclo, a concentração é da ordem de $3200 \mathrm{mg} . \mathrm{L}^{-1}$ atingindo valores próximos a $3000 \mathrm{mg} . \mathrm{L}^{-1}$ no último ponto do ciclo. 


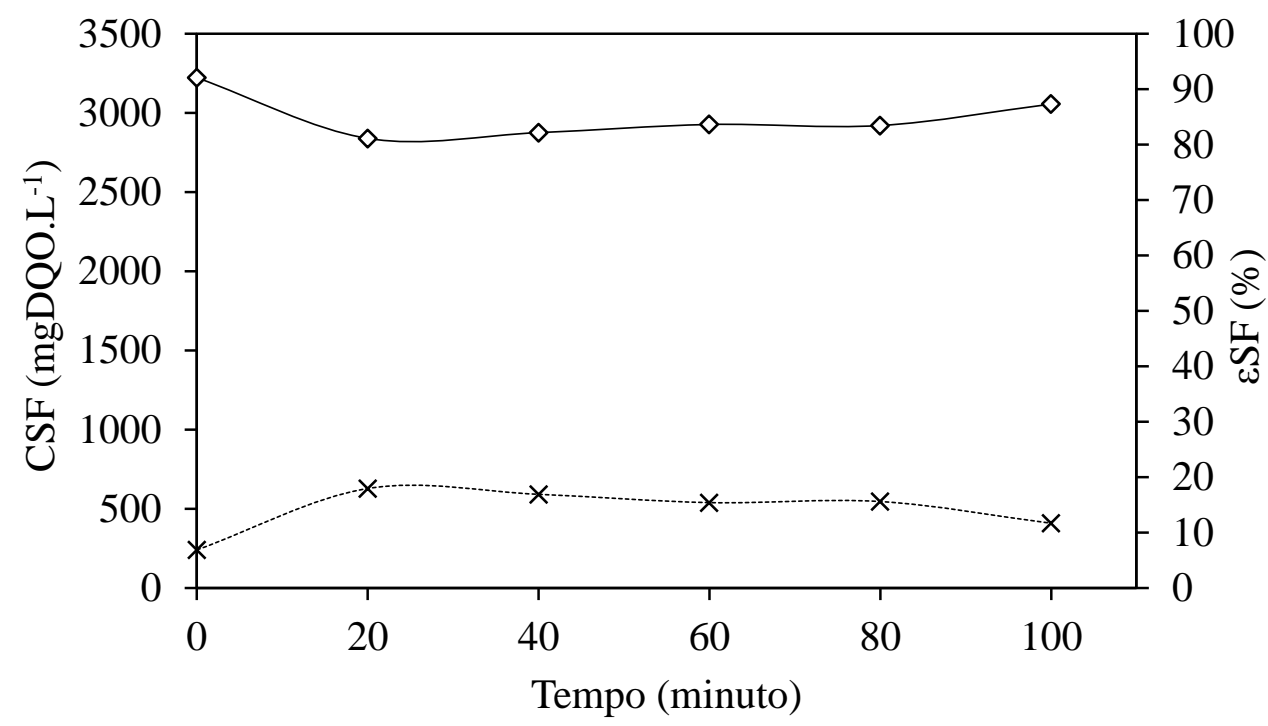

Figura 5-310 - Concentração e eficiência de degradação de matéria orgânica: $\diamond$ - perfil e * eficiência (AnSBBR com agitação mecânica e lactose - Condição 5).

O acúmulo de ácidos voláteis totais por titulação ao longo do ciclo pode ser observado na Figura 5-311. A concentração destes aumenta claramente durante a fase de reação para atingir um máximo no final do ciclo na ordem de 850 mgHAc. $\mathrm{L}^{-1}$.

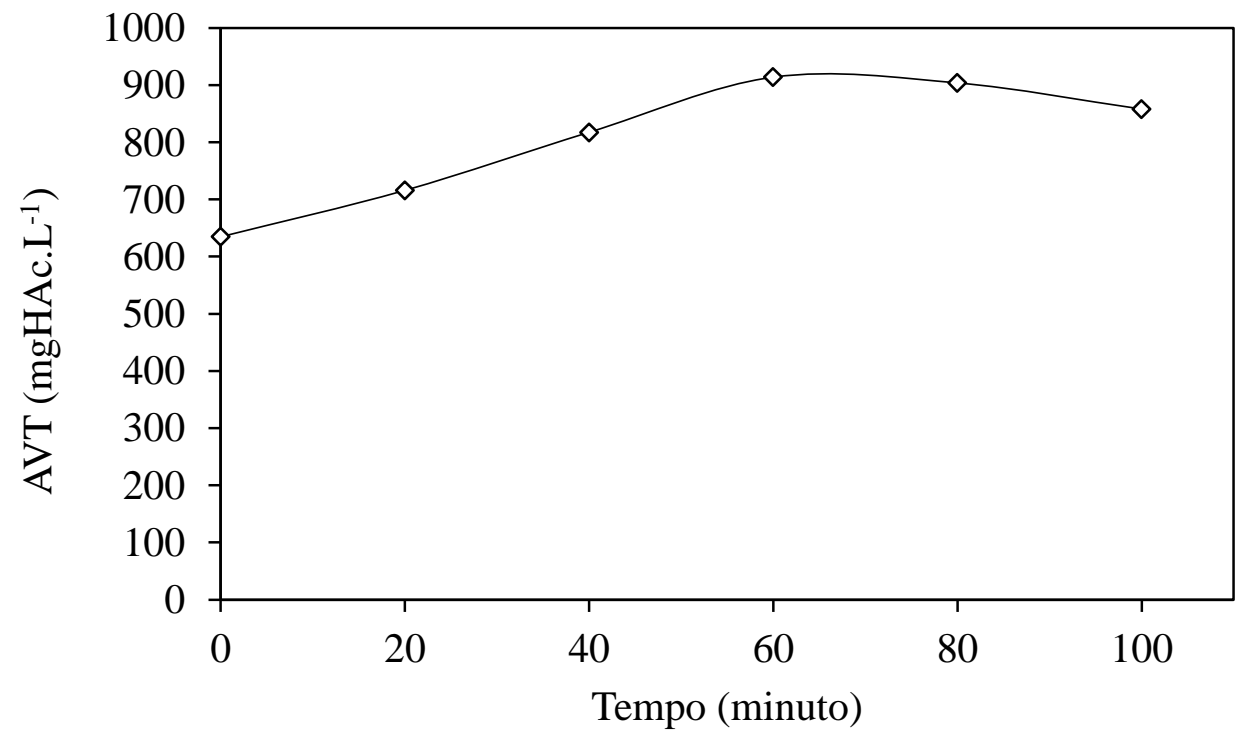

Figura 5-311 - Ácidos voláteis totais $(\diamond)$ do perfil (AnSBBR com agitação mecânica e lactose - Condição 5). 
Os resultados dos compostos intermediários por cromatografia gasosa são apresentados na Figura 5-312. Estes permaneceram praticamente estáveis durante todo o perfil. O etanol foi o intermediário que apresentou o maior aumento, indo de 292,8 mg. $\mathrm{L}^{-1}$ no início do ciclo até $488,9 \mathrm{mg} . \mathrm{L}^{-1}$ no final do ciclo. O ácido acético apresentou uma pequena instabilidade de produção à partir minuto 40 do ciclo.

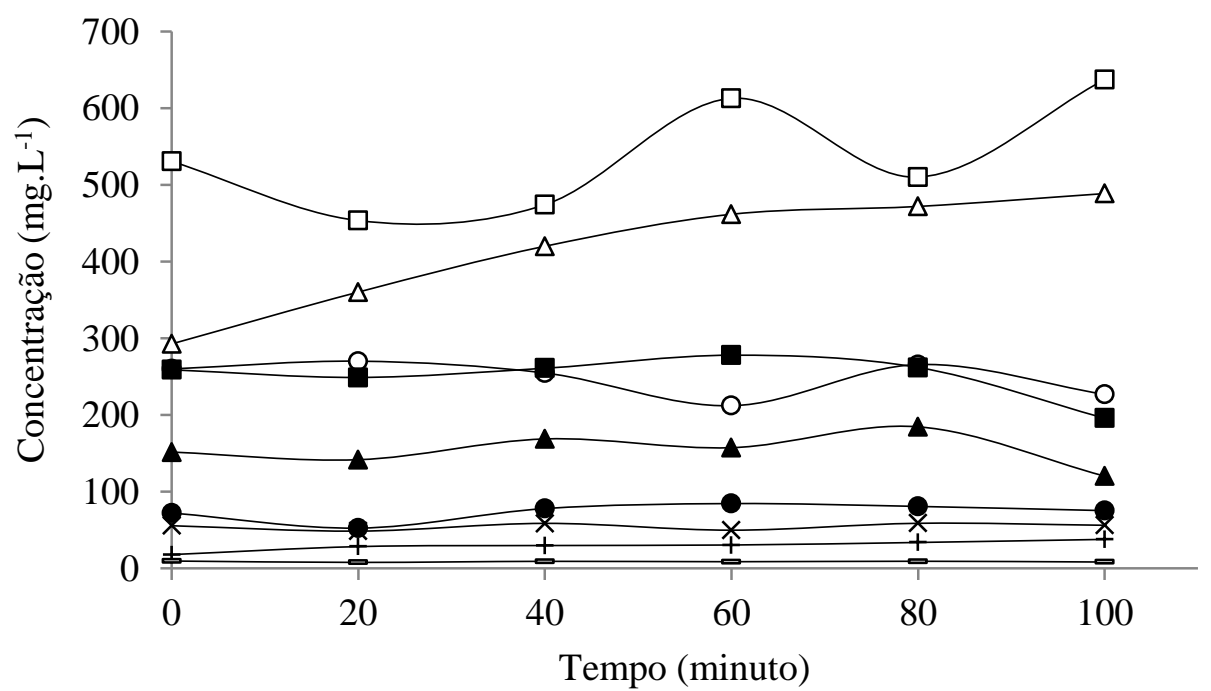

Figura 5-312 - Concentração dos compostos intermediários ao longo do ciclo: $\square$ - ácido acético; $\Delta$ - etanol; ○ - ácido butírico; $\mathbf{\square}$-ácido isobutírico; $\boldsymbol{\Delta}$ - ácido capróico; • ácido valérico; - -ácido propiônico; +butanol; - ácido isovalérico (AnSBBR com agitação mecânica e lactose - Condição 5).

$\mathrm{O}$ pH diminuiu instantaneamente em relação ao afluente devido à diluição do mesmo com o volume residual no inicio do ciclo (alimentação do reator em 10 minutos) e permaneceu estável ao longo da operação com uma ligeira queda nos primeiros pontos do perfil, conforme a Figura 5-313. Esta estabilidade do $\mathrm{pH}$ era esperada pois, como pode ser visto na Figura 5-314, o meio de alimentação possuía alcalinidade suficiente para tamponar o sistema que foi consumida durante o ciclo. 


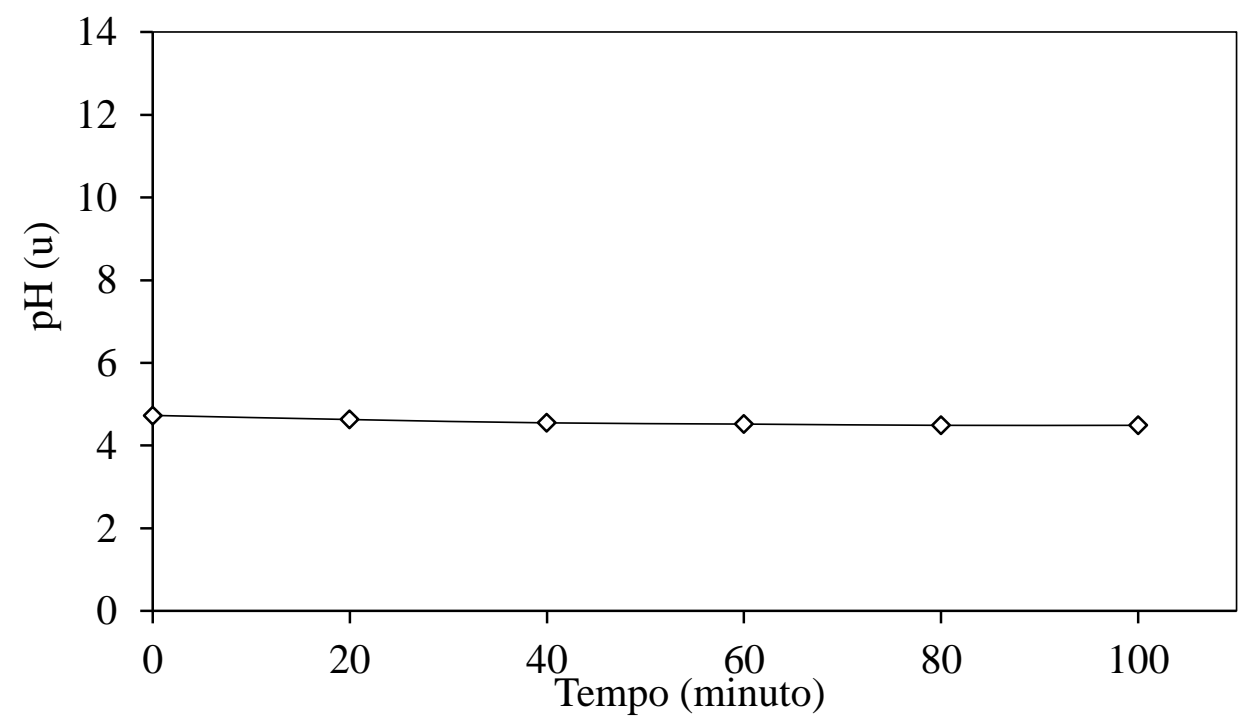

Figura 5-313 - Valores de pH $(\diamond)$ do perfil (AnSBBR com agitação mecânica e lactose Condição 5).

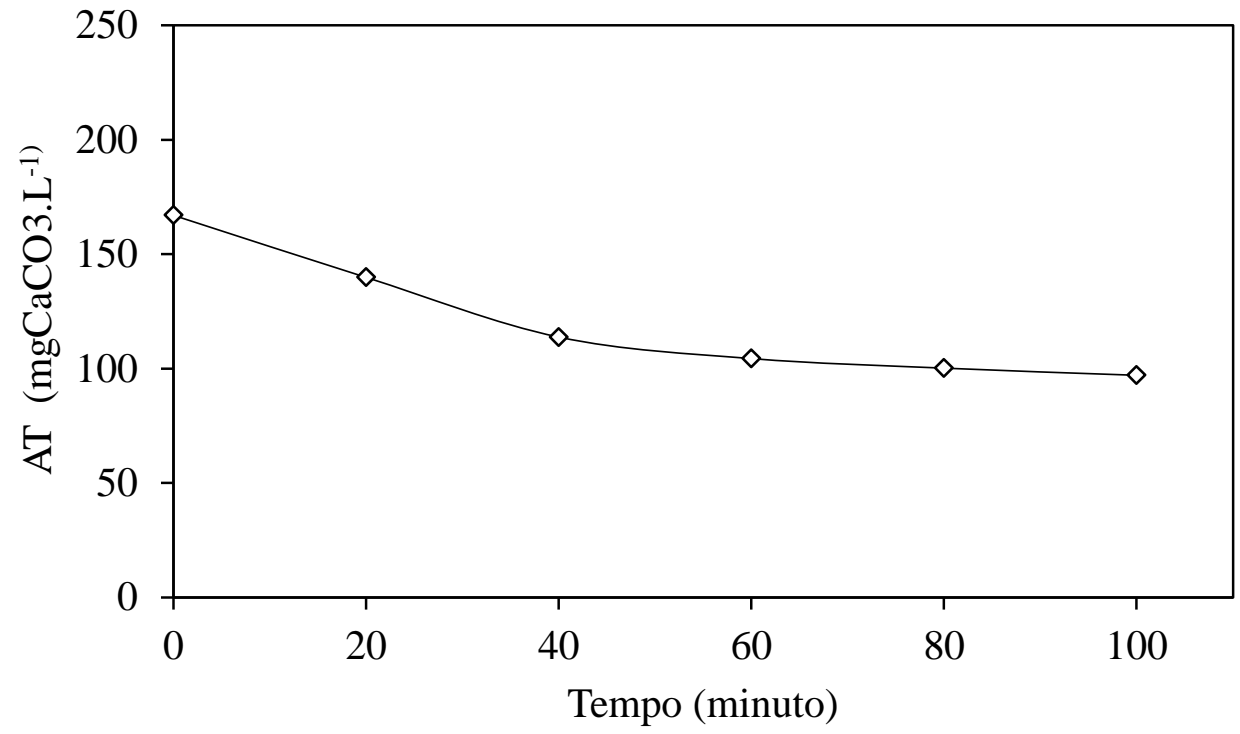

Figura 5-314 - Alcalinidade total $(\diamond)$ do perfil (AnSBBR com agitação mecânica e lactose - Condição 5).

A produção volumétrica média acumulada do biogás, realizada com os valores dos perfis quantitativos mais consistentes obtidos durante a operação, juntamente com os desvios padrões encontram-se na Figura 5-315. Toda produção ocorre na primeira hora do ciclo. A Tabela 5.75 resume os valores médios da produção, fração molar e os volumes individuais da mistura do biogás. A Figura 5-316 apresenta os volumes 
acumulados médios dos perfis de $\mathrm{H}_{2}, \mathrm{CO}_{2}$ e $\mathrm{CH}_{4}$ produzidos durante o ciclo. Apenas $\mathrm{H}_{2}$ e $\mathrm{CO}_{2}$ foram produzidos, sem a presença de $\mathrm{CH}_{4}$.

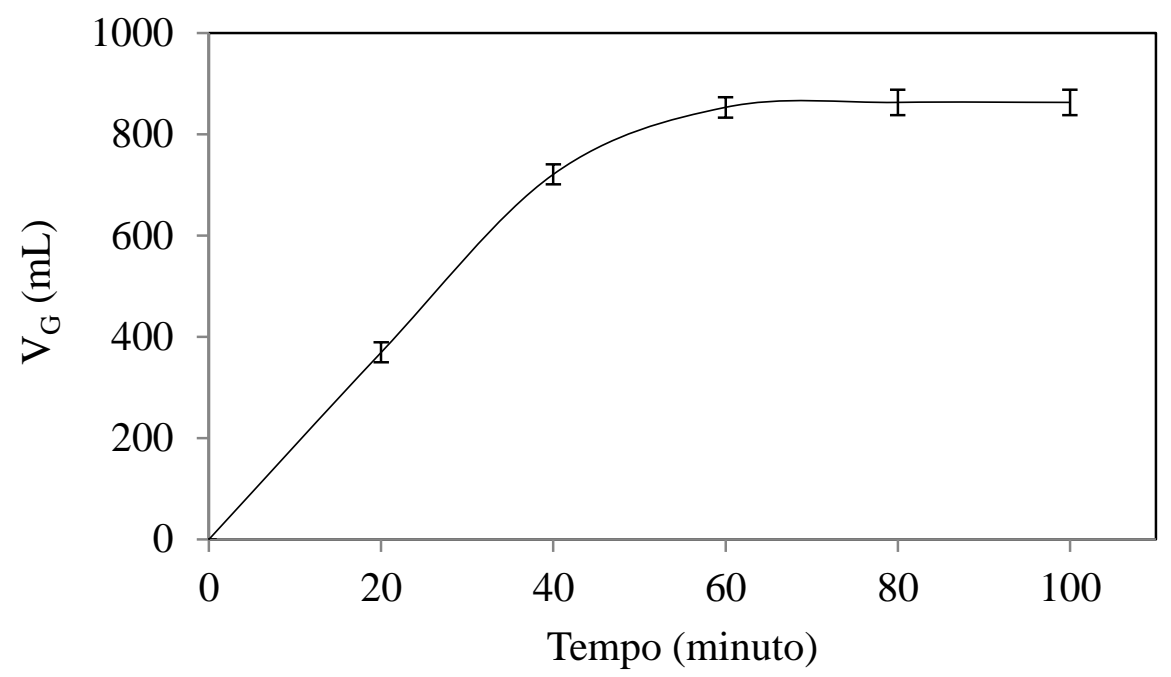

Figura 5-315 - Produção volumétrica média acumulada do biogás durante o ciclo (AnSBBR com agitação mecânica e lactose - Condição 5).

Tabela 5.75 - Valores médios da produção, fração molar e os volumes individuais da mistura do biogás (AnSBBR com agitação mecânica e lactose - Condição 5).

\begin{tabular}{ccccccccccc}
\hline $\begin{array}{c}\text { Tempo } \\
(\mathrm{min})\end{array}$ & \multirow{2}{*}{$\mathrm{V}_{\mathrm{G}}$} & \multicolumn{3}{c}{$\mathrm{C}_{\mathrm{G}}\left(\mathrm{mmol} \cdot \mathrm{L}^{-1}\right)$} & \multicolumn{3}{c}{ Fração Molar $(\%)$} & \multicolumn{3}{c}{ Volume (mL - CNTP) } \\
& & $\mathrm{H}_{2}$ & $\mathrm{CO}_{2}$ & $\mathrm{CH}_{4}$ & $\mathrm{H}_{2}$ & $\mathrm{CO}_{2}$ & $\mathrm{CH}_{4}$ & $\mathrm{H}_{2}$ & $\mathrm{CO}_{2}$ & $\mathrm{CH}_{4}$ \\
\hline 0 & 0,0 & 0,0 & 0,0 & 0,0 & 0,0 & 0,0 & 0,0 & 0,0 & 0,0 & 0,0 \\
20 & 369,2 & 1,4 & 5,0 & 0,0 & 21,5 & 78,5 & 0,0 & 79,5 & 289,8 & 0,0 \\
40 & 721,0 & 1,9 & 8,1 & 0,0 & 19,0 & 81,0 & 0,0 & 146,3 & 574,7 & 0,0 \\
60 & 853,3 & 2,5 & 10,5 & 0,0 & 19,1 & 80,9 & 0,0 & 171,6 & 681,8 & 0,0 \\
80 & 863,1 & 2,9 & 11,8 & 0,0 & 19,5 & 80,5 & 0,0 & 173,5 & 689,6 & 0,0 \\
100 & 863,1 & 3,1 & 12,0 & 0,0 & 20,5 & 79,5 & 0,0 & 173,5 & 689,6 & 0,0 \\
\hline
\end{tabular}




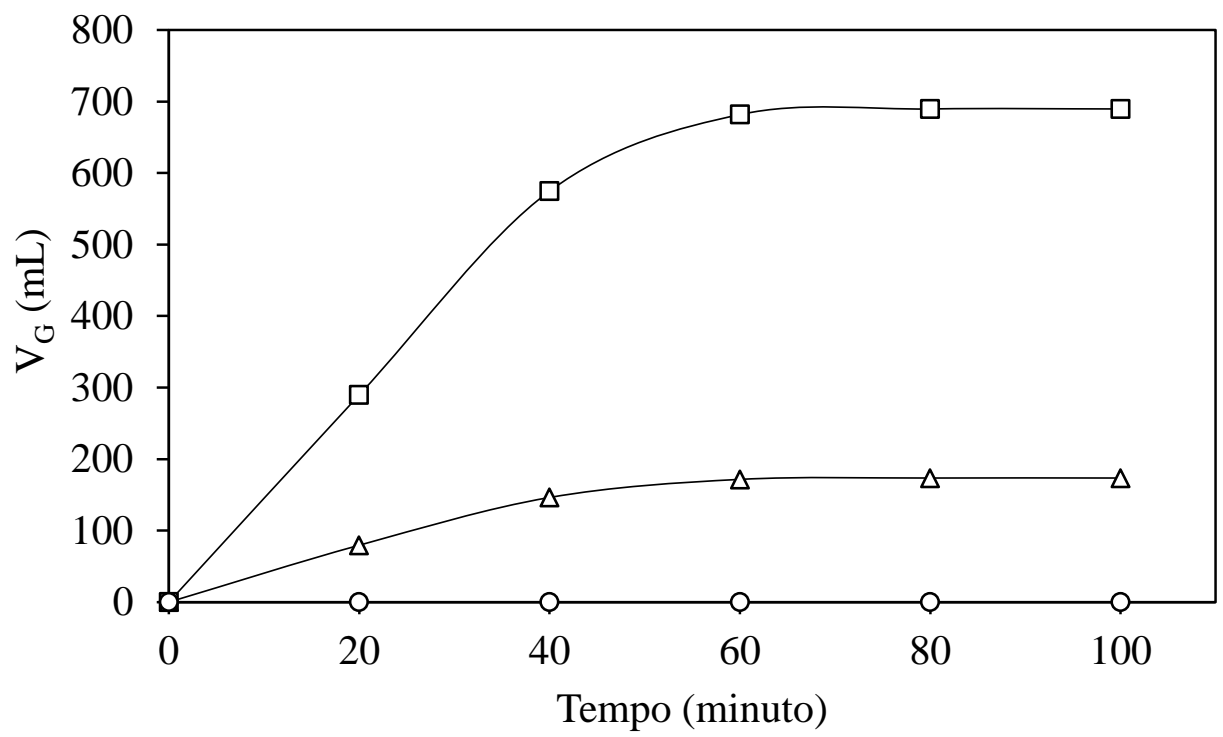

Figura 5-316 - Volumes acumulados médios produzidos ao longo do ciclo: $\square-\mathrm{CO}_{2} ; \Delta$ $\mathrm{H}_{2} ;$ ○ $-\mathrm{CH}_{4}$ (AnSBBR com agitação mecânica e lactose - Condição 5). 
5.3.6. Condição $6\left(D Q O=5400 \mathrm{mg}^{-L^{-1}}\right.$ e $t_{C}=2$ horas $)$

A condição experimental 6 apresentou uma COAV nominal de 27,8 kgDQO.m ${ }^{3} \cdot \mathrm{d}^{-1}$ e duração do ciclo de 2 horas, indo do dia 113 ao dia 134 (22 dias de operação). A Tabela 5.76 apresenta os valores médios dos parâmetros monitorados. 
Tabela 5.76 - Valores médios dos parâmetros monitorados na condição experimental 6 (Lactose - $5400 \mathrm{mgDQO} . \mathrm{L}^{-1}-\mathrm{t}_{\mathrm{C}} 2 \mathrm{~h}$ ).

\begin{tabular}{|c|c|c|c|c|c|c|c|c|c|c|c|c|}
\hline \multicolumn{2}{|r|}{ Parâmetro } & \multicolumn{5}{|c|}{ Afluente } & \multicolumn{6}{|c|}{ Efluente } \\
\hline $\mathrm{C}_{\mathrm{ST}}$ & $\left(\mathrm{mgDQO} \cdot \mathrm{L}^{-1}\right)$ & 5206 & \pm & 275 & ()$^{9}$ & ) & 4389 & \pm & 276 & ( & 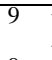 & ) \\
\hline $\mathrm{C}_{\mathrm{SF}}$ & $\left(\mathrm{mgDQO} \cdot \mathrm{L}^{-1}\right)$ & - & \pm & - & ()$^{3}$ & ) & 4289 & \pm & 224 & ( & 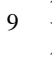 & ) \\
\hline$\varepsilon_{\mathrm{ST}}$ & $(\%)$ & - & & - & & & 16 & \pm & 5 & ( & 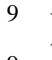 & ) \\
\hline$\varepsilon_{\mathrm{SF}}$ & $(\%)$ & - & & - & & & 18 & \pm & 4 & ( & 9 & ) \\
\hline $\mathrm{C}_{\mathrm{CT}}$ & (mgCarboidrato. $\mathrm{L}^{-1}$ ) & 4859 & \pm & 483 & $\left({ }^{9}\right.$ & ) & 547 & \pm & 401 & ( & 9 & ) \\
\hline $\mathrm{C}_{\mathrm{CF}}$ & (mgCarboidrato. $\mathrm{L}^{-1}$ ) & - & \pm & - & & & 181 & \pm & 345 & ( & 9 & ) \\
\hline$\varepsilon_{\mathrm{CT}}$ & $(\%)$ & - & & - & & & 89 & \pm & 8 & ( & 9 & ) \\
\hline$\varepsilon_{\mathrm{CF}}$ & $(\%)$ & - & & - & & & 96 & \pm & 7 & ( & 9 & ) \\
\hline $\mathrm{pH}$ & (u) & 7,82 & \pm & 0,13 & $(9$ & ) & 4,09 & \pm & 0,14 & ( & 9 & ) \\
\hline AVT & $\left(\mathrm{mgHAc} . \mathrm{L}^{-1}\right)$ & 29 & \pm & 9 & $(9$ & ) & 1293 & \pm & 230 & ( & 9 & ) \\
\hline AT & $\left(\mathrm{mgCaCO}_{3} \cdot \mathrm{L}^{-1}\right)$ & 361 & \pm & 29 & $(9$ & ) & 8 & \pm & 23 & ( & 9 & ) \\
\hline $\mathrm{AP}$ & $\left(\mathrm{mgCaCO}_{3} \cdot \mathrm{L}^{-1}\right)$ & 263 & \pm & 25 & $(9$ & ) & 0 & \pm & 0 & ( & 9 & ) \\
\hline $\mathrm{AI}$ & $\left(\mathrm{mgCaCO}_{3} \cdot \mathrm{L}^{-1}\right)$ & 99 & \pm & 26 & $(9$ & ) & 8 & \pm & 23 & ( & 9 & ) \\
\hline $\mathrm{AB}$ & $\left(\mathrm{mgCaCO}_{3} \cdot \mathrm{L}^{-1}\right)$ & 341 & \pm & 29 & $(9$ & ) & 0 & \pm & 0 & ( & 9 & ) \\
\hline ST & $\left(\mathrm{mg} . \mathrm{L}^{-1}\right)$ & 4169 & \pm & 380 & $\left({ }^{4}\right.$ & ) & 2366 & \pm & 64 & ( & 4 & ) \\
\hline STV & $\left(\mathrm{mg} \cdot \mathrm{L}^{-1}\right)$ & 3629 & \pm & 300 & $\left({ }^{4}\right.$ & ) & 1879 & \pm & 126 & ( & 4 & ) \\
\hline SST & $\left(\mathrm{mg} \cdot \mathrm{L}^{-1}\right)$ & 18 & \pm & 11 & $\left({ }^{4}\right.$ & ) & 76 & \pm & 13 & ( & 4 & ) \\
\hline SSV & $\left(\mathrm{mg} \cdot \mathrm{L}^{-1}\right)$ & 9 & \pm & 9 & $\left(\begin{array}{c}4 \\
-1\end{array}\right.$ & ) & 73 & \pm & 20 & ( & 4 & ) \\
\hline $\mathrm{M}_{\mathrm{STV}}$ & $(\mathrm{g})$ & - & & - & & & 16,6 & & - & & & \\
\hline $\mathrm{C}_{\mathrm{X}}$ & $\left(\right.$ g. $\left.\mathrm{L}^{-1}\right)$ & - & & - & & & 4,8 & & - & & & \\
\hline $\mathrm{C}_{\mathrm{X}}^{\prime}$ & (g.gsuporte ${ }^{-1}$ ) & - & & - & & & 0,017 & & - & & & \\
\hline $\mathrm{V}_{\mathrm{G}}$ & (mL-CNTP) & - & & - & & & 1422 & \pm & 50 & ( & 3 & ) \\
\hline $\mathrm{V}_{\mathrm{H} 2}$ & (mL-CNTP) & - & & - & & & 410 & \pm & - & ( & 1 & ) \\
\hline $\mathrm{COAV}_{\mathrm{STA}}$ & $\left(\operatorname{kgDQO} \cdot \mathrm{m}^{-3} \cdot \mathrm{d}^{-1}\right)$ & 26,8 & & - & & & - & & - & & & \\
\hline $\mathrm{CORV}_{\mathrm{SFE}}$ & $\left(\operatorname{kgDQO} \cdot \mathrm{m}^{-3} \cdot \mathrm{d}^{-1}\right)$ & - & & - & & & 4,7 & & - & & & \\
\hline $\mathrm{COAV}_{\mathrm{CTA}}$ & $\left(\right.$ kgCarboidrato. $\left.\mathrm{m}^{-3} \cdot \mathrm{d}^{-1}\right)$ & 25,0 & & - & & & - & & - & & & \\
\hline $\mathrm{CORV}_{\mathrm{CFE}}$ & $\left(\right.$ kgCarboidrato. $\left.\mathrm{m}^{-3} \cdot \mathrm{d}^{-1}\right)$ & - & & - & & & 24,1 & & - & & & \\
\hline $\mathrm{COAE}_{\mathrm{STA}}$ & $\left(\mathrm{kgDQO} \cdot \mathrm{kgSTV}^{-1} \cdot \mathrm{d}^{-1}\right)$ & 5,64 & & - & & & - & & - & & & \\
\hline $\mathrm{CORE}_{\mathrm{SFE}}$ & $\left(\operatorname{kgDQO} \cdot \mathrm{kgSTV}^{-1} \cdot \mathrm{d}^{-1}\right)$ & - & & - & & & 1,0 & & - & & & \\
\hline $\mathrm{COAE}_{\mathrm{CTA}}$ & (kgCarboidrato.kgSTV $\left.{ }^{-1} \cdot \mathrm{d}^{-1}\right)$ & 5,26 & & - & & & - & & - & & & \\
\hline $\mathrm{CORE}_{\mathrm{CFE}}$ & $\left(\mathrm{kgCarboidrato} \mathrm{kgSTV}^{-1} \cdot \mathrm{d}^{-1}\right)$ & - & & - & & & 5,1 & & - & & & \\
\hline $\mathrm{RMCR}_{\mathrm{C}, \mathrm{n}}$ & $\left(\mathrm{molH}_{2 .}\right.$ molCarboidrato $\left.{ }^{-1}\right)$ & - & & - & & & 0,97 & & - & & & \\
\hline $\mathrm{n}_{\mathrm{H} 2}$ & $\left(\mathrm{molH}_{2} \cdot \mathrm{d}^{-1}\right)$ & - & & - & & & 0,220 & & - & & & \\
\hline PrM & $\left(\mathrm{molH}_{2} \cdot \mathrm{m}^{-3} \cdot \mathrm{d}^{-1}\right)$ & - & & - & & & 63,2 & & - & & & \\
\hline PrME & $\left(\mathrm{molH}_{2} \cdot \mathrm{kgSVT}^{-1} \cdot \mathrm{d}^{-1}\right)$ & - & & - & & & 13,2 & & - & & & \\
\hline $\mathrm{RMCA}_{\mathrm{S}, \mathrm{m}}$ & $\left(\mathrm{molH}_{2} \cdot \mathrm{kgDQO}^{-1} \cdot \mathrm{d}^{-1}\right)$ & 2,3 & & - & & & - & & - & & & \\
\hline $\mathrm{RMCA}_{\mathrm{C}, \mathrm{m}}$ & $\left(\mathrm{molH}_{2} \cdot \mathrm{kg}^{-1} \cdot \mathrm{d}^{-1}\right)$ & 2,5 & & - & & & - & & - & & & \\
\hline $\mathrm{RMCR}_{\mathrm{S}, \mathrm{m}}$ & $\left(\mathrm{molH}_{2} \cdot \mathrm{kgDQO}^{-1} \cdot \mathrm{d}^{-1}\right)$ & - & & - & & & 13,3 & & - & & & \\
\hline $\mathrm{RMCR}_{\mathrm{C}, \mathrm{m}}$ & $\left(\mathrm{molH}_{2} \cdot \mathrm{kg}^{-1} \cdot \mathrm{d}^{-1}\right)$ & - & & - & & & 2,6 & & - & & & \\
\hline $\mathrm{V}_{\mathrm{R}}$ & $(\mathrm{mL})$ & 1980 & & & & & - & & - & & & \\
\hline $\mathrm{V}_{\mathrm{A}}$ & $(\mathrm{mL})$ & 1493,33 & \pm & 17,32 & & ) & & & & & & \\
\hline
\end{tabular}

(*) Entre parêntese o número de amostras considerado no cálculo da média 
A Figura 5-317 apresenta os valores da concentração afluente (não filtrada) e efluente (não filtrada e filtrada) de matéria orgânica (DQO) no sistema, enquanto que a Figura 5-318 apresenta a eficiência de remoção do mesmo parâmetro durante o monitoramento diário. Esta eficiência atingiu, em média, 18\% para as amostras filtradas e $16 \%$ para amostras não filtradas. A média de concentração afluente não filtrada do substrato foi de $5206 \mathrm{mgDQO} . \mathrm{L}^{-1}$ e de $4389 \mathrm{mgDQO} . \mathrm{L}^{-1}$ e $4289 \mathrm{mgDQO} . \mathrm{L}^{-1}$ para amostras de efluente não filtrado e filtrado, respectivamente.

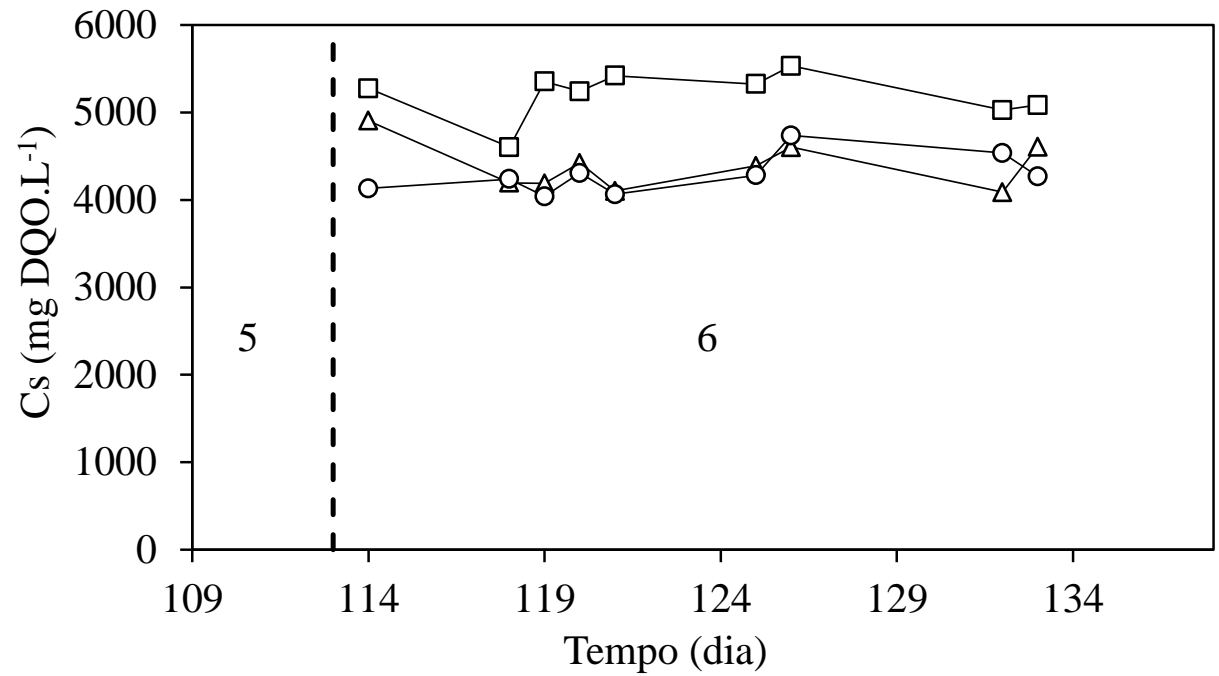

Figura 5-317 - Concentração de matéria orgânica (DQO): $\square$ - afluente não filtrada; $\Delta$ efluente não filtrada; 0 - efluente filtrada (AnSBBR com agitação mecânica e lactose Condição 6). 


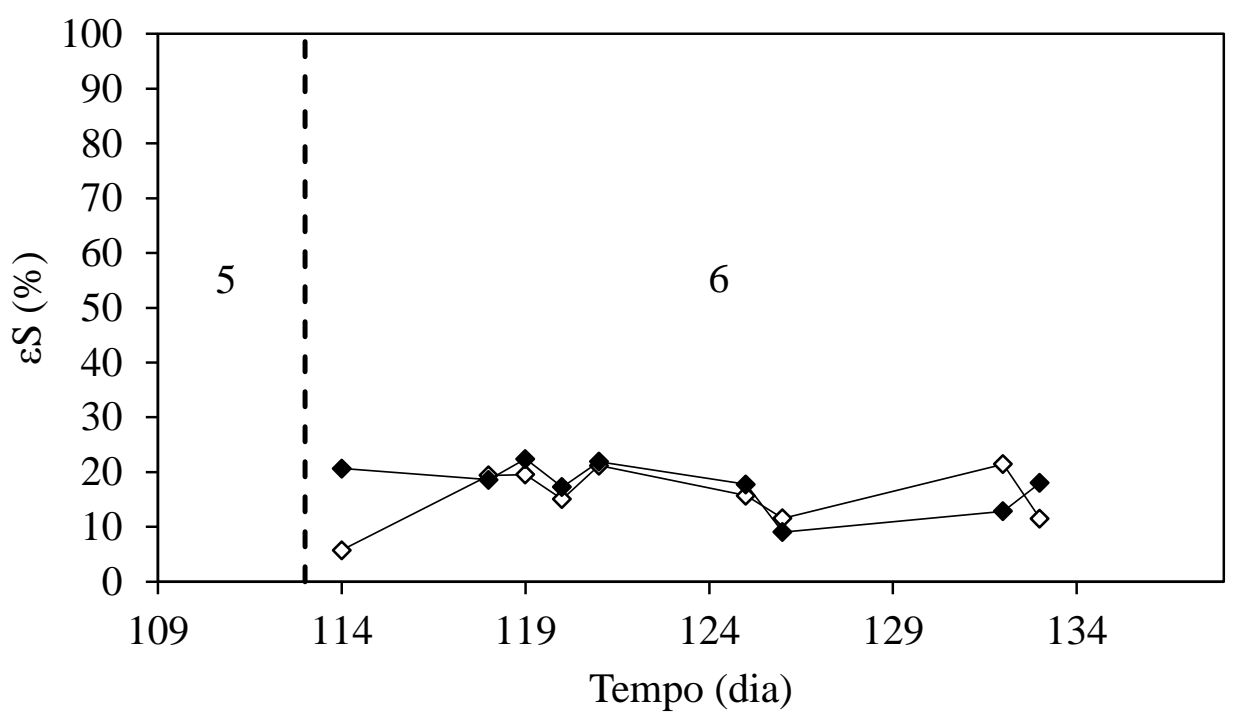

Figura 5-318 - Eficiência de remoção de matéria orgânica (DQO): $\diamond$ - não filtrada; filtrada (AnSBBR com agitação mecânica e lactose - Condição 6).

A Figura 5-319 apresenta os valores da concentração de carboidratos afluente e efluente (para amostras filtradas e não filtradas), enquanto a Figura 5-320 mostra a eficiência de remoção do mesmo parâmetro (não filtrada e filtrada) durante o monitoramento diário. A média da concentração afluente foi de 4859 mgCarboidrato.: ${ }^{-}$ ${ }^{1}$, enquanto que a concentração residual não filtrada foi de $547 \mathrm{mgCarboidrato.} \mathrm{L}^{-1}$ e 181 mgCarboidrato. $\mathrm{L}^{-1}$ para a concentração residual filtrada. A eficiência de remoção de sacarose foi, em média, de $96 \%$ e $89 \%$ para as amostras filtradas e não filtradas, respectivamente. 


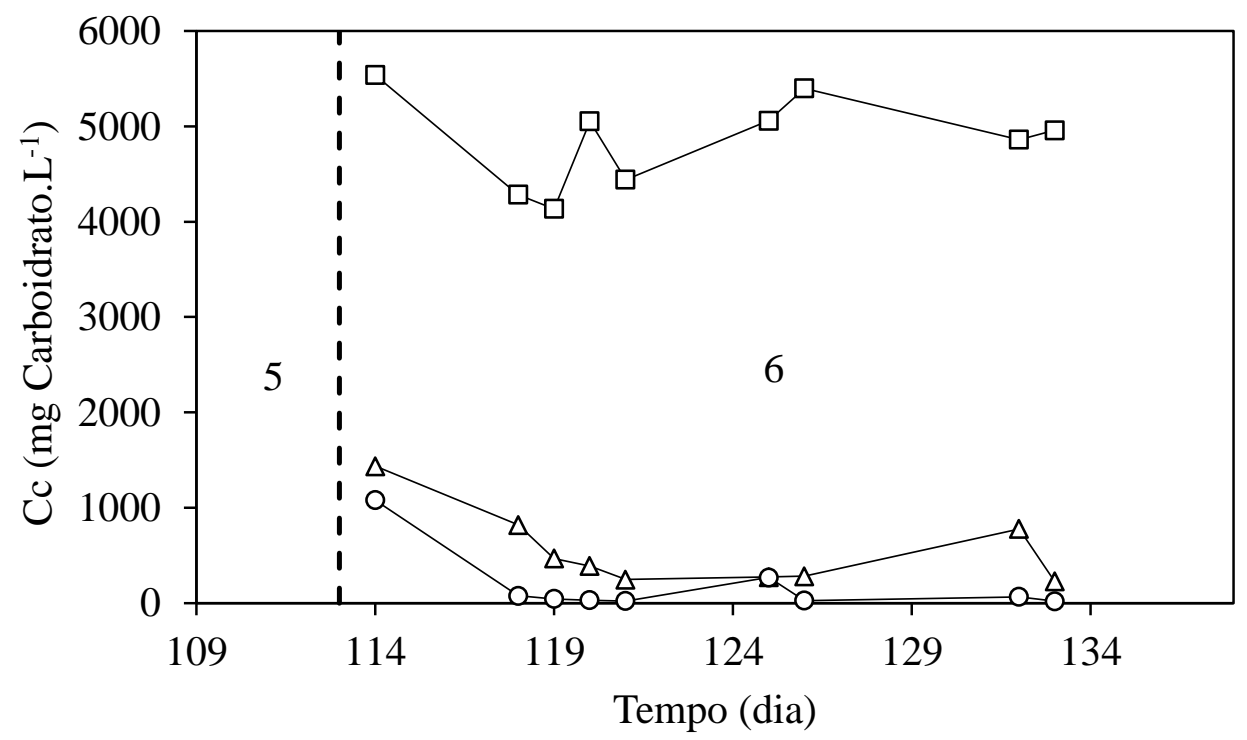

Figura 5-319 - Concentração de carboidrato: $\square$ - afluente não filtrada; $\Delta$ - efluente não filtrada; O - efluente filtrada (AnSBBR com agitação mecânica e lactose - Condição 6).

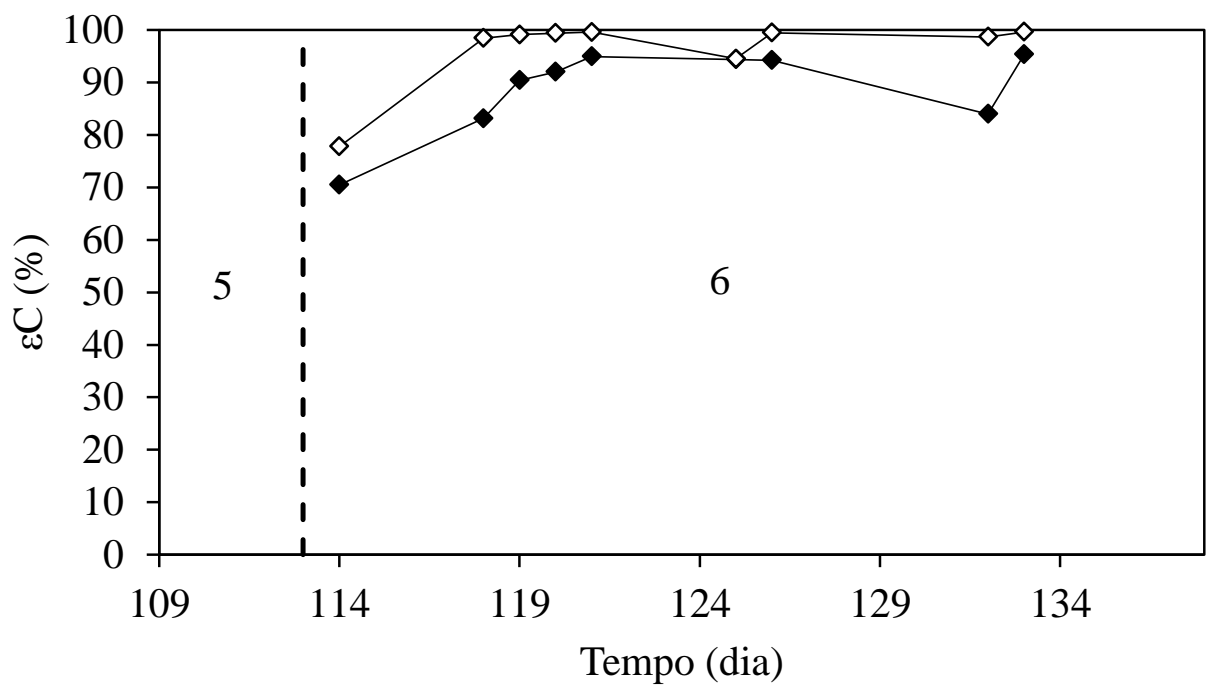

Figura 5-320 - Eficiência de remoção de carboidrato: $\diamond$ - não filtrada; $\bullet$ - filtrada (AnSBBR com agitação mecânica e lactose - Condição 6).

As Figura 5-321, Figura 5-322 e Figura 5-323 apresentam os valores, tanto para o afluente quanto para o efluente, do $\mathrm{pH}$, da alcalinidade total e dos ácidos voláteis totais por titulação, respectivamente. A média dos valores de $\mathrm{pH}$ afluente durante a Condição 1 foi de 7,82 e de pH efluente foi de 4,09. A média da alcalinidade total foi de 361 e $7 \mathrm{mgCaCO}_{3} \cdot \mathrm{L}^{-1}$ para o afluente e efluente, respectivamente. O valor médio da 
concentração de ácidos voláteis totais afluente foi de $29 \mathrm{mgHAc} . \mathrm{L}^{-1}$ e efluente de 1293 $\operatorname{mgHAc} . \mathrm{L}^{-1}$.

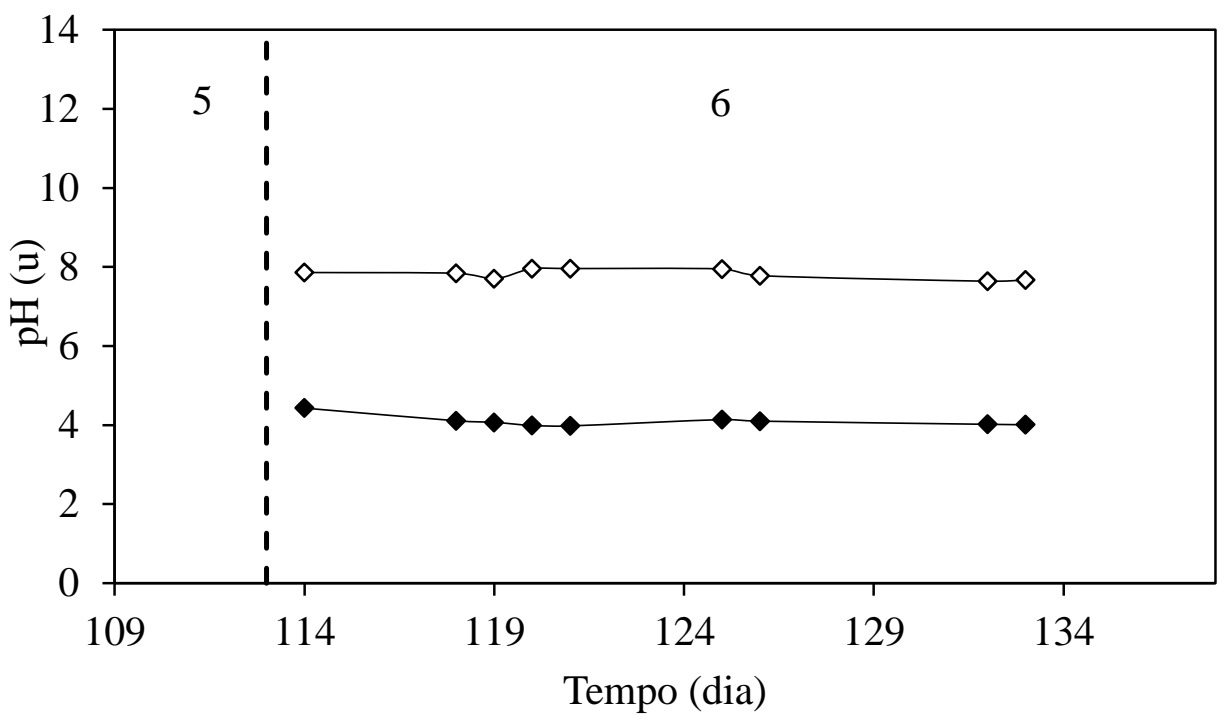

Figura 5-321 - Valores de pH: $\diamond$-afluente; - efluente (AnSBBR com agitação mecânica e lactose - Condição 6).

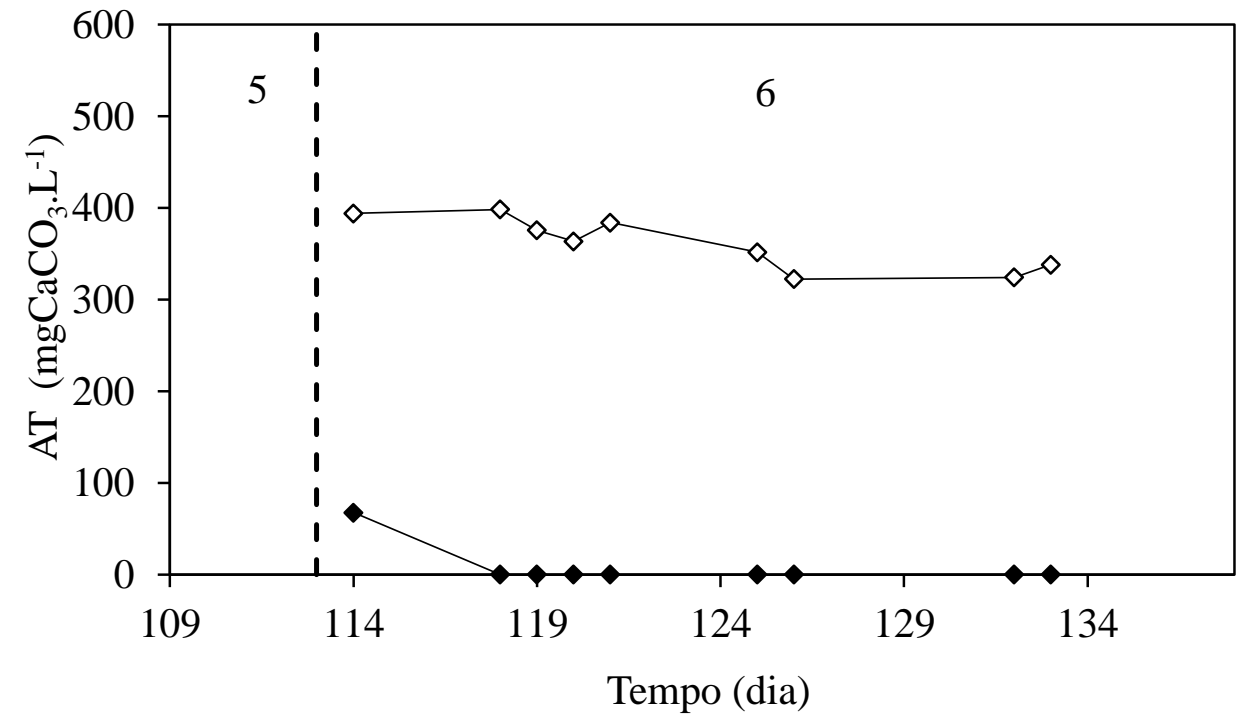

Figura 5-322 - Alcalinidade total: $\diamond$-afluente; - efluente (AnSBBR com agitação mecânica e lactose - Condição 6). 


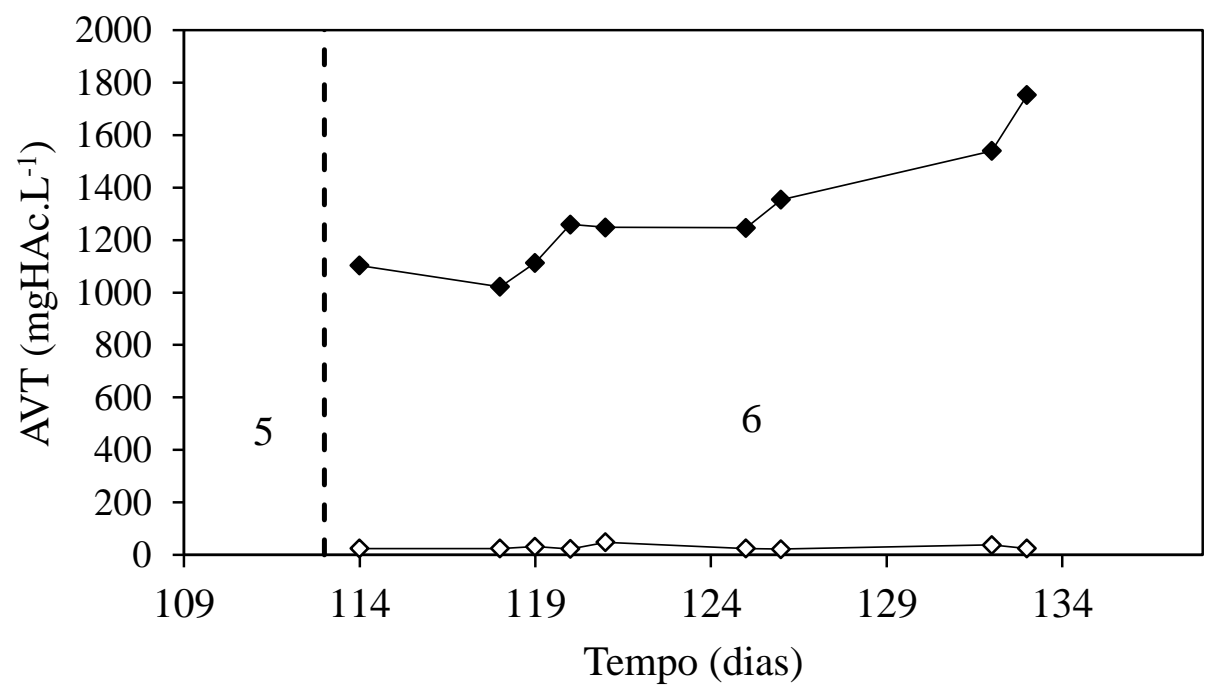

Figura 5-323 - Ácidos voláteis totais: $\diamond$-afluente; - efluente (AnSBBR com agitação mecânica e lactose - Condição 6).

A Figura 5-324 apresenta o monitoramento dos compostos intermediários contidos no efluente do sistema, enquanto que a Tabela 5.77 apresenta os valores da concentração média destes produtos. As amostras para análise destes compostos foram coletadas no dia do perfil temporal da condição (no descarte antes do ciclo do perfil, no ultimo ponto do perfil e no descarte após o ciclo do eprfil). O método cromatográfico aplicado não detectou a presença de acetona e metanol. Dentre os ácidos voláteis, o ácido acético predominou seguido pelo ácido propiônico representando respectivamente $50,8 \%$ e 10,8\% dos compostos intermediários. Entre os solventes o maior destaque foi o etanol representando $30,1 \%$ dos compostos. 


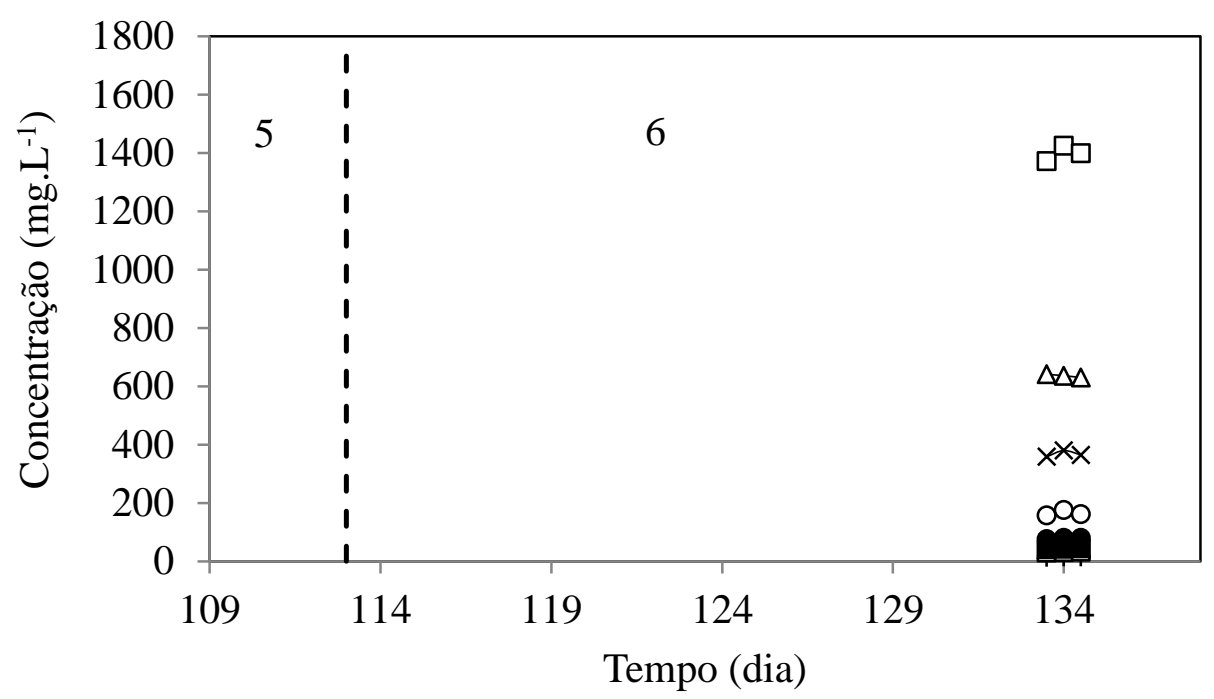

Figura 5-324 - Concentração dos compostos intermediários: $\square$ - ácido acético; $\Delta$ etanol; ○-ácido butírico; - ácido isobutírico; $\boldsymbol{\Delta}$ - ácido capróico; $\bullet$ - ácido valérico; * ácido propiônico; +butanol; - ácido isovalérico (AnSBBR com agitação mecânica e lactose - Condição 6).

Tabela 5.77 - Concentração e distribuição dos compostos intermediários (AnSBBR com agitação mecânica e lactose - Condição 6).

\begin{tabular}{cccccccc}
\hline $\begin{array}{c}\text { Produtos } \\
\text { intermediários }\end{array}$ & \multicolumn{5}{c}{ Concentrações médias } & \multicolumn{3}{c}{$\begin{array}{c}\text { Distribuição } \\
\left(\mathrm{mg} . \mathrm{L}^{-1}\right)\end{array}$} & \multicolumn{3}{c}{$\left(\mathrm{mmol. \textrm {L } ^ { - 1 } )}\right.$} & $(\%)$ \\
\hline Acetona & 0,0 & \pm & 0,0 & 0,0 & \pm & 0,0 & 0,0 \\
Metanol & 0,0 & \pm & 0,0 & 0,0 & \pm & 0,0 & 0,0 \\
Etanol & 635,8 & \pm & 5,5 & 13,8 & \pm & 0,1 & 30,1 \\
n-Butanol & 12,4 & \pm & 0,4 & 0,2 & \pm & 0,0 & 0,4 \\
Acético & 1398,3 & \pm & 26,1 & 23,3 & \pm & 0,4 & 50,8 \\
Porpiônico & 367,3 & \pm & 11,1 & 5,0 & \pm & 0,1 & 10,8 \\
Isobutírico & 40,5 & \pm & 1,7 & 0,5 & \pm & 0,0 & 1,0 \\
Butírico & 165,3 & \pm & 9,6 & 1,9 & \pm & 0,1 & 4,1 \\
Isovalérico & 7,3 & \pm & 1,4 & 0,1 & \pm & 0,0 & 0,2 \\
Valérico & 78,8 & \pm & 2,5 & 0,8 & \pm & 0,0 & 1,7 \\
Capróico & 49,0 & \pm & 3,6 & 0,5 & \pm & 0,0 & 1,0 \\
\hline
\end{tabular}

O monitoramento da série de sólidos é mostrado na Tabela 5.78, cujos valores apresentam um baixo teor de SSV no efluente e afluente, indicando mais uma vez a boa capacidade do reator em reter biomassa. 
Tabela 5.78 - Série de sólidos afluente e efluente (AnSBBR com agitação mecânica e lactose - Condição 6).

\begin{tabular}{lcccc}
\hline & $\begin{array}{c}\text { ST } \\
\left(\mathrm{mg} . \mathrm{L}^{-1}\right)\end{array}$ & $\begin{array}{c}\text { SVT } \\
\left(\mathrm{mg} . \mathrm{L}^{-1}\right)\end{array}$ & $\begin{array}{c}\text { SST } \\
\left(\mathrm{mg} . \mathrm{L}^{-1}\right)\end{array}$ & $\begin{array}{c}\text { SSV } \\
\left(\mathrm{mg} . \mathrm{L}^{-1}\right)\end{array}$ \\
\hline Afluente & $4169 \pm 380$ & $3629 \pm 300$ & $18 \pm 11$ & $9 \pm 9$ \\
Efluente & $2366 \pm 64$ & $1880 \pm 126$ & $76 \pm 13$ & $73 \pm 20$ \\
\hline
\end{tabular}

*Número de amostras consideradas $=4$.

A produção do biogás por ciclo, em aspecto quantitativo, pode ser observada na Figura 5-325. A produção média foi de $1535 \mathrm{~mL}$ (CNTP). A Figura 5-326 apresenta o monitoramento das concentrações dos componentes do biogás no final do ciclo, enquanto que a Figura 5-327 apresenta a distribuição destes mesmos componentes. Os valores médios de concentração de $\mathrm{H}_{2}, \mathrm{CH}_{4}$ e $\mathrm{CO}_{2}$ foram 7,9, 0,0 e 14,7 mmol.L ${ }^{-1}$, respectivamente. Além disso, a distribuição percentual média de $\mathrm{H}_{2}$ foi de $34,9 \%$, a de $\mathrm{CH}_{4}$ foi de $0,0 \%$ e a de $\mathrm{CO}_{2}$ foi de $65,1 \%$.

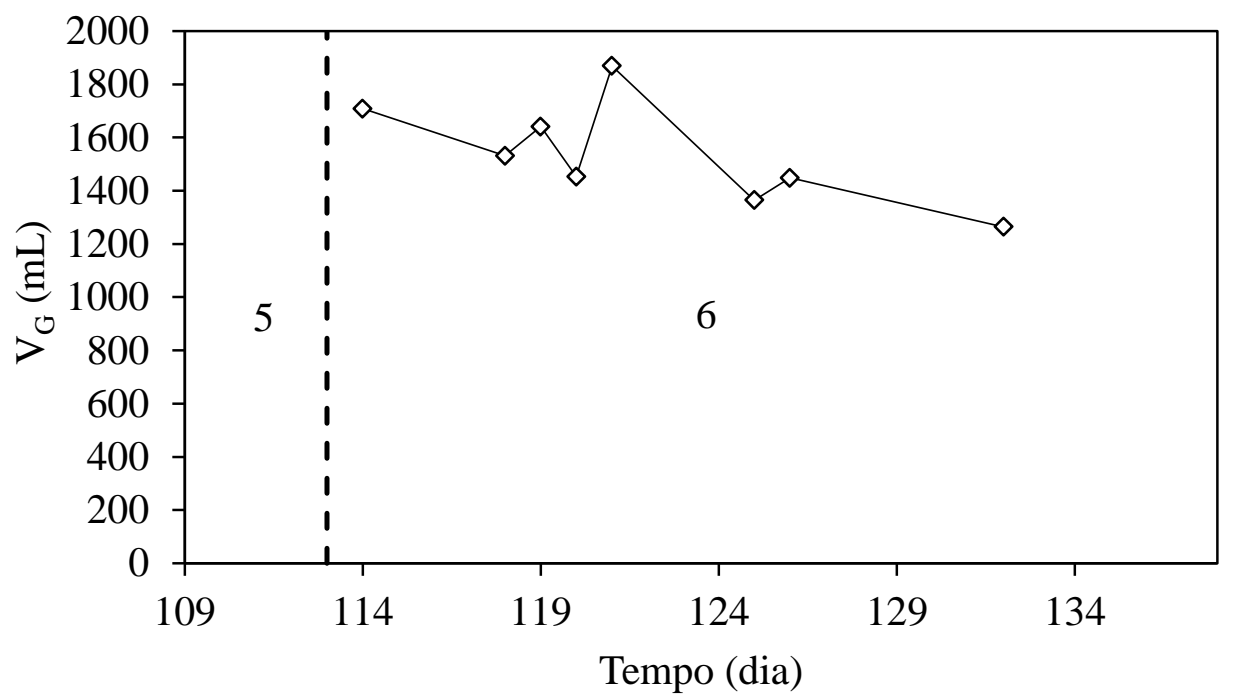

Figura 5-325 - Volume de biogás produzido por ciclo (AnSBBR com agitação mecânica e lactose - Condição 6). 


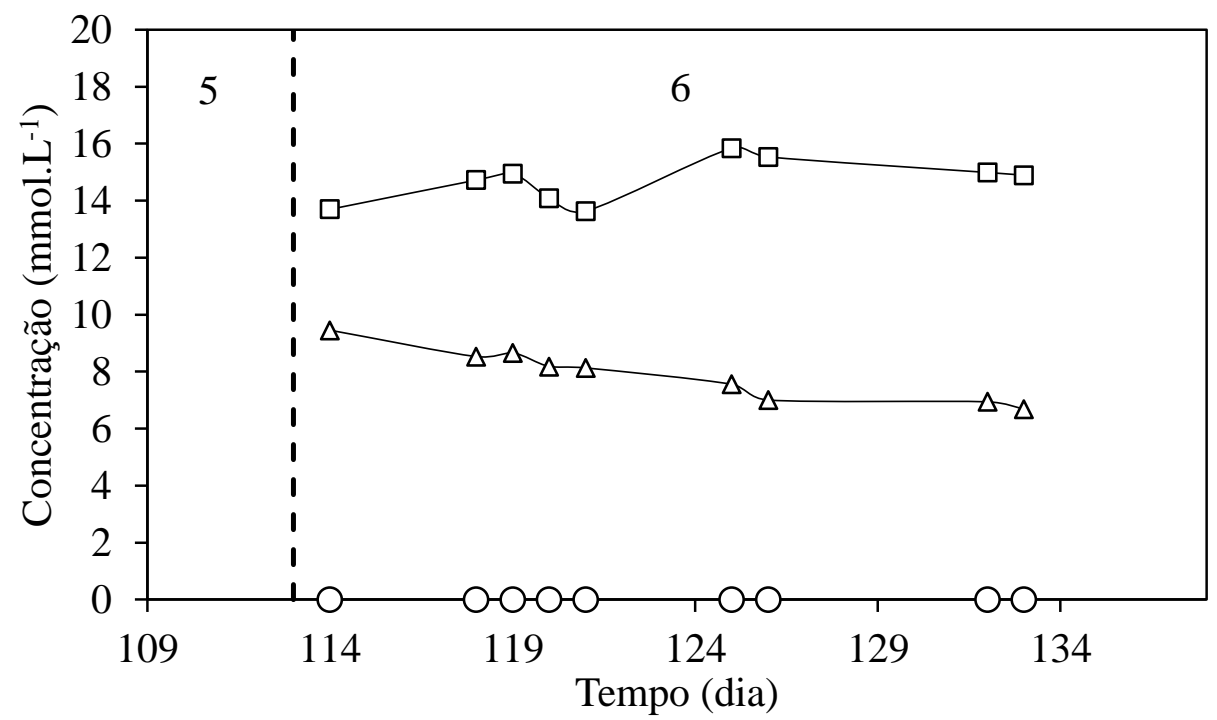

Figura 5-326 - Concentrações dos componentes do biogás no final do ciclo: $\square-\mathrm{CO}_{2} ; \Delta$ - $\mathrm{H}_{2} ;$ ○ - $\mathrm{CH}_{4}$ (AnSBBR com agitação mecânica e lactose - Condição 6).

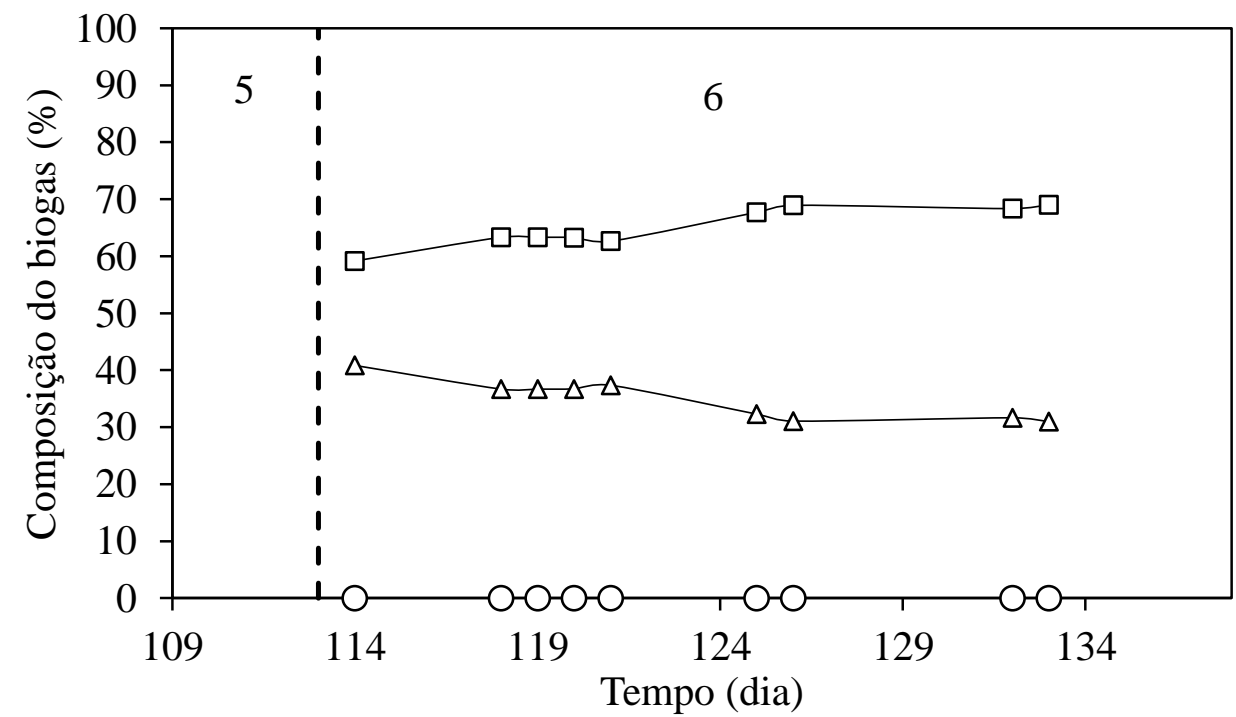

Figura 5-327 - Distribuições dos componentes do biogás no final do ciclo: $\square-\mathrm{CO}_{2} ; \Delta$ $\mathrm{H}_{2} ;$ ○ - $\mathrm{CH}_{4}$ (AnSBBR com agitação mecânica e lactose - Condição 6).

No final da operação foi realizado o perfil temporal, com o intuito de entender melhor como os parâmetros indicativos de eficiência do sistema se comportavam durante um ciclo completo. A Figura 5-328 apresenta a evolução da concentração de carboidrato ao longo do ciclo e a eficiência de remoção do mesmo. Ao inicio do ciclo (tempo zero) o volume afluente foi diluído no volume residual resultando em uma 
concentração de sacarose da ordem de $2000 \mathrm{mg} \cdot \mathrm{L}^{-1}$. A conversão de carboidrato se faz de maneira progressiva ao longo do ciclo, atingindo valores na ordem de $96 \%$ no final do mesmo, com um residual aproximado de $190 \mathrm{mg} \cdot \mathrm{L}^{-1}$.

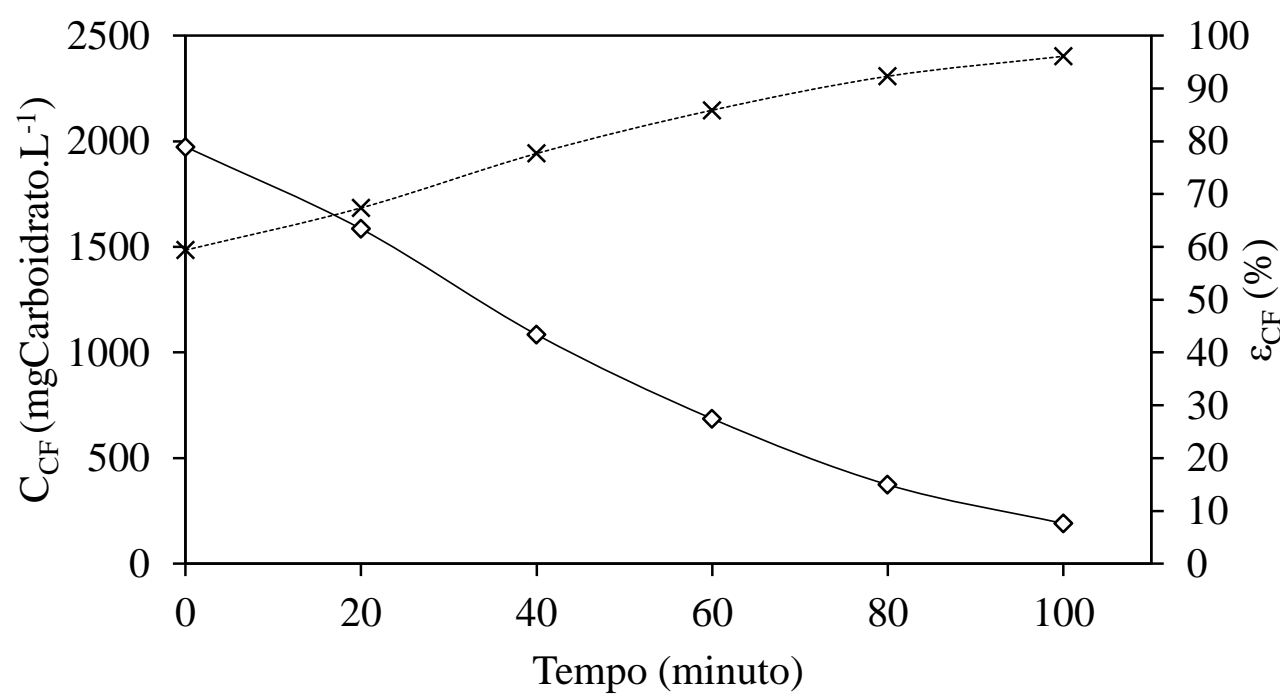

Figura 5-328 - Concentração e eficiência de degradação de carboidrato: $\diamond$ - perfil e * eficiência (AnSBBR com agitação mecânica e lactose - Condição 6).

A Figura 5-329 apresenta a evolução da concentração de matéria orgânica ao longo do ciclo. Observa-se uma baixa remoção da DQO, levando a uma alta concentração da mesma no volume residual. Assim, no inicio do ciclo, a diluição do volume carregado pelo volume residual é realizada mais uma vez em proporção bem menor do que no caso dos carboidratos totais, tendo em vista que as concentrações afluente e residual são muito próximas. No inicio do ciclo, a concentração é da ordem de $4700 \mathrm{mg} . \mathrm{L}^{-1}$ atingindo valores próximos a $4600 \mathrm{mg} . \mathrm{L}^{-1}$ no último ponto do ciclo. 


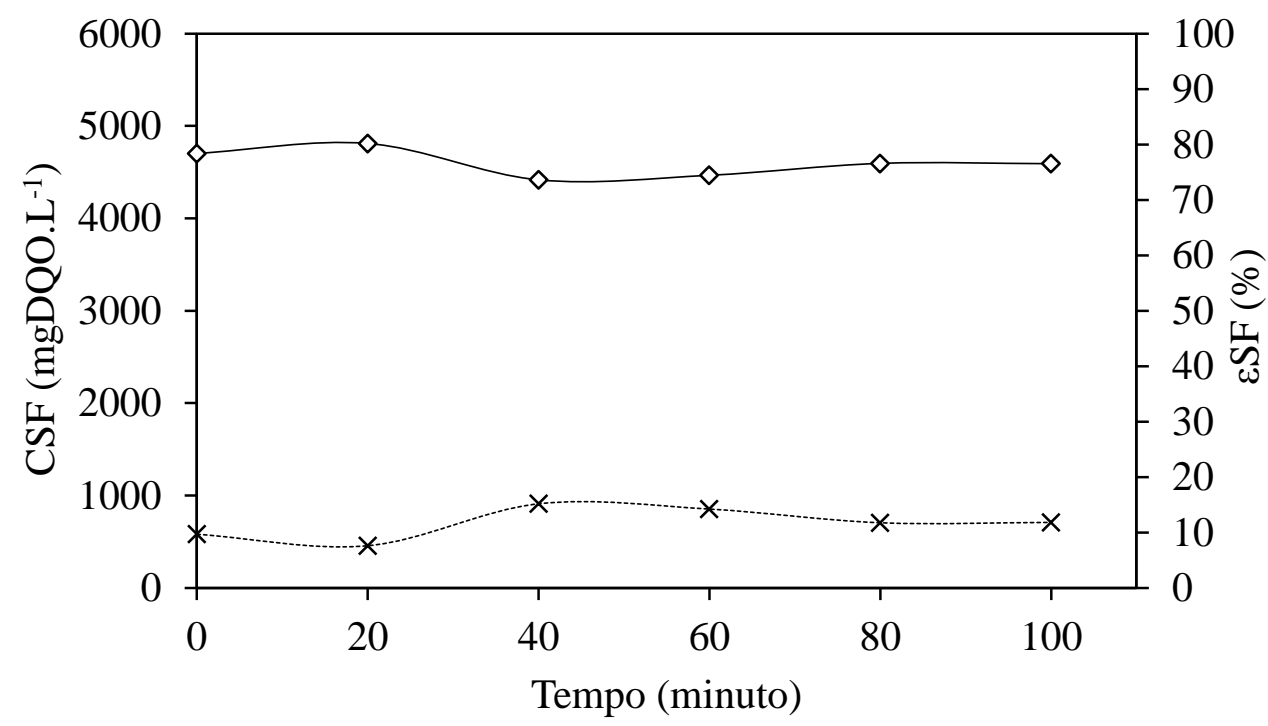

Figura 5-329 - Concentração e eficiência de degradação de matéria orgânica: $\diamond$ - perfil e * eficiência (AnSBBR com agitação mecânica e lactose - Condição 6).

O acúmulo de ácidos voláteis totais por titulação ao longo do ciclo pode ser observado na Figura 5-330. A concentração destes aumenta claramente durante a fase de reação para atingir um máximo no final do ciclo na ordem de $1500 \mathrm{mgHAc} . \mathrm{L}^{-1}$.

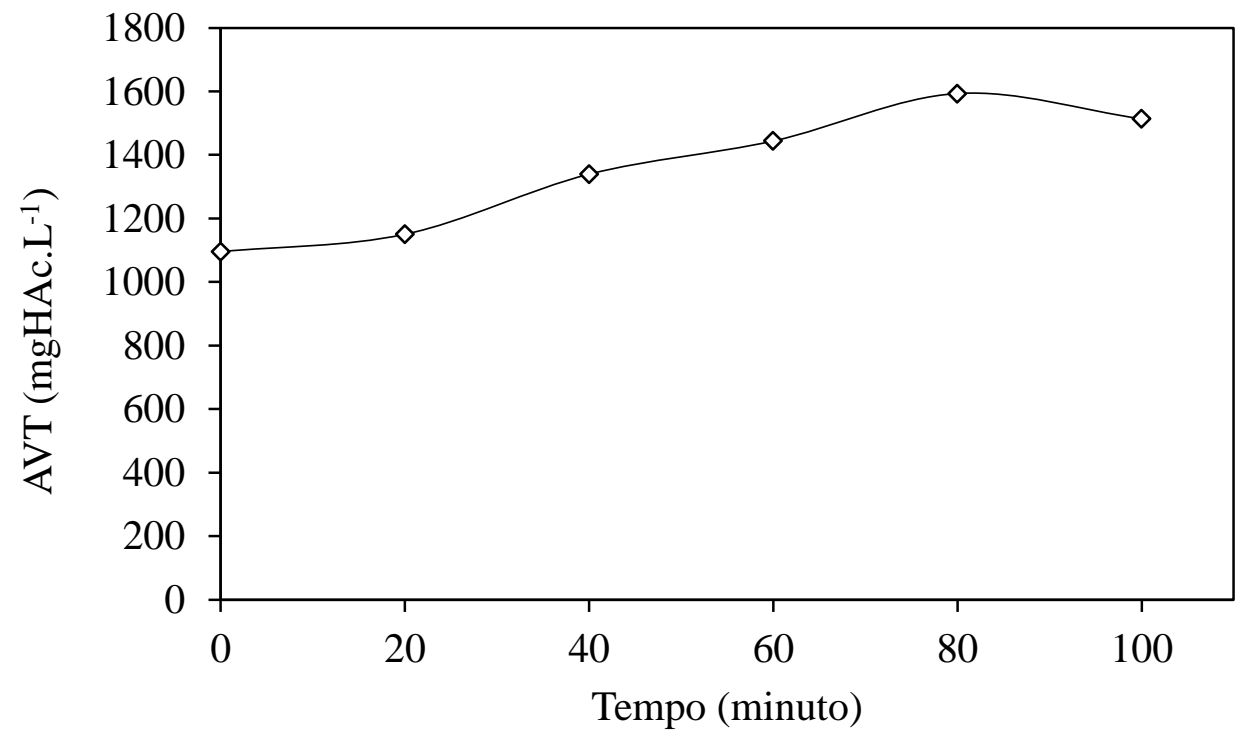

Figura 5-330 - Ácidos voláteis totais $(\diamond)$ do perfil (AnSBBR com agitação mecânica e lactose - Condição 6). 
Os resultados dos compostos intermediários por cromatografia gasosa são apresentados na Figura 5-331. Estes permaneceram estáveis durante todo o perfil, com uma ressalva para o ácido acético, que apresentou um aumento significativo e gradual em suas concentrações durante o ciclo, indo de 537,1 mg.L ${ }^{-1}$ no início do ciclo até 1424,2 mg. $\mathrm{L}^{-1}$ no final do ciclo.

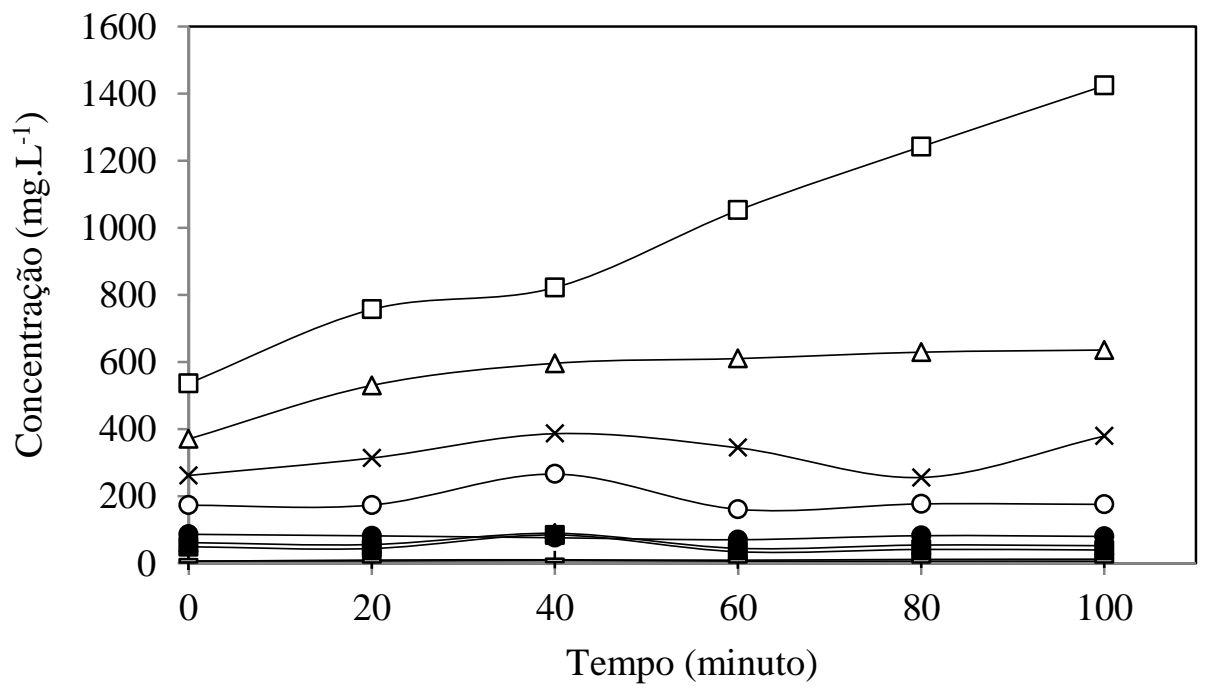

Figura 5-331 - Concentração dos compostos intermediários ao longo do ciclo: $\square$ - ácido acético; $\Delta$ - etanol; ○ - ácido butírico; $\mathbf{\square}$-ácido isobutírico; $\boldsymbol{\Delta}$ - ácido capróico; • ácido valérico; - -ácido propiônico; +butanol; - ácido isovalérico (AnSBBR com agitação mecânica e lactose - Condição 6).

$\mathrm{O}$ pH diminuiu instantaneamente em relação ao afluente devido à diluição do mesmo com o volume residual no inicio do ciclo (alimentação do reator em 10 minutos) e permaneceu estável ao longo da operação, conforme a Figura 5-332. Esta estabilidade do $\mathrm{pH}$ foi mantida mesmo com a alcalinidade do sistema sendo completamente consumida já na diluição do afluente no meio residual dentro do reator, como pode ser visto na Figura 5-333. 


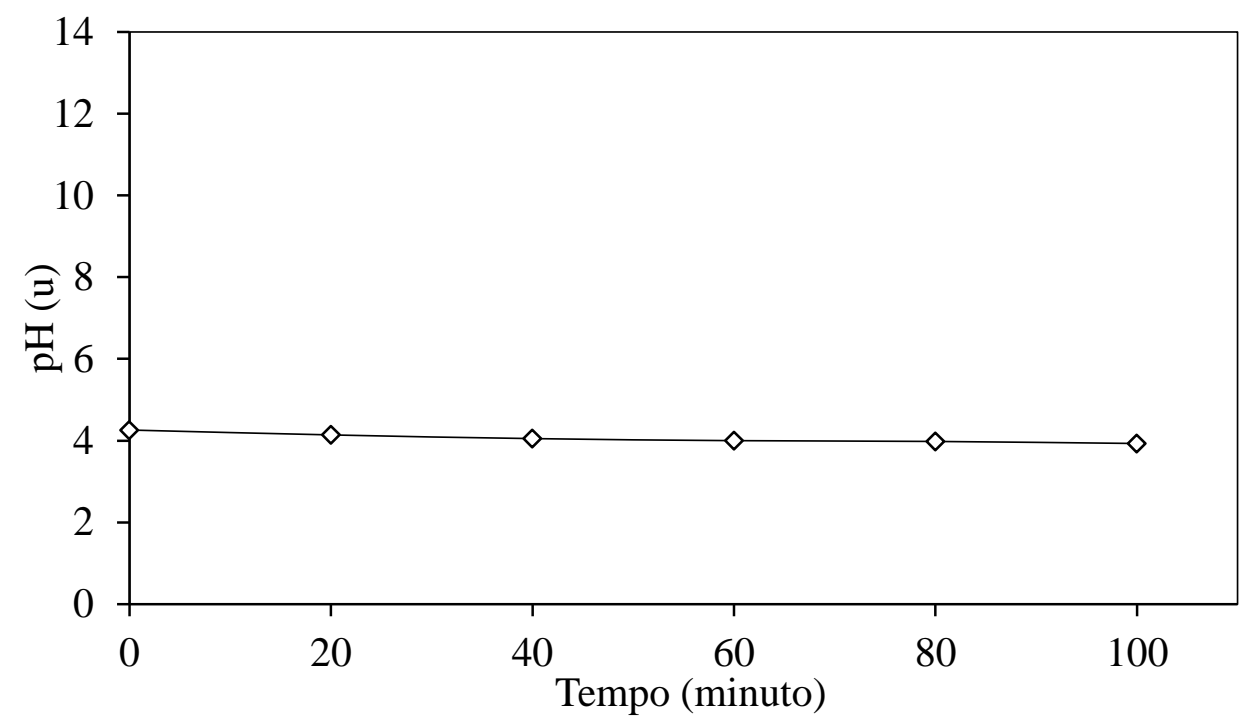

Figura 5-332 - Valores de pH $(\diamond)$ do perfil (AnSBBR com agitação mecânica e lactose Condição 6).

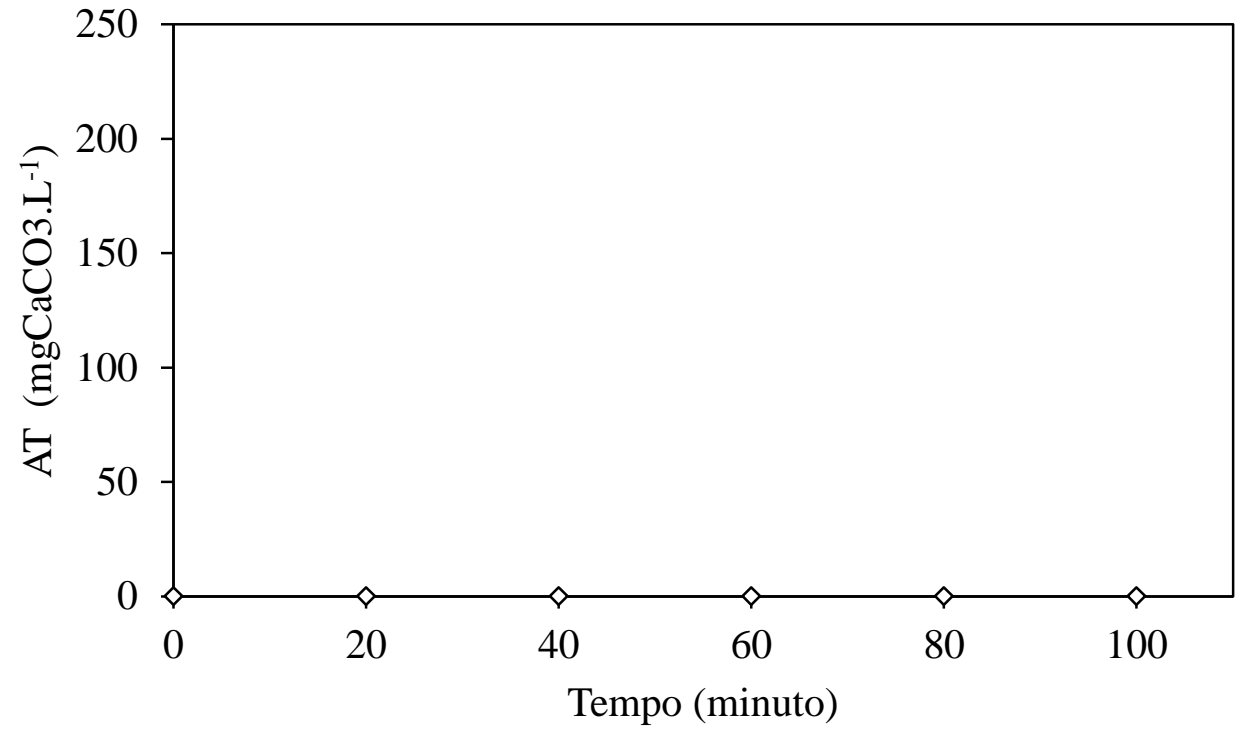

Figura 5-333 - Alcalinidade total $(\diamond)$ do perfil (AnSBBR com agitação mecânica e lactose - Condição 6).

A produção volumétrica média acumulada do biogás, realizada com os valores dos perfis quantitativos mais consistentes obtidos durante a operação, juntamente com os desvios padrões encontram-se na Figura 5-334. A produção foi crescente durante todo ciclo. A Tabela 5.79 resume os valores médios da produção, fração molar e os volumes individuais da mistura do biogás. A Figura 5-335 apresenta os volumes 
acumulados médios dos perfis de $\mathrm{H}_{2}, \mathrm{CO}_{2}$ e $\mathrm{CH}_{4}$ produzidos durante o ciclo. Novamente apenas hidrogênio e gás carbônico foram produzidos, sem a presença de metano.

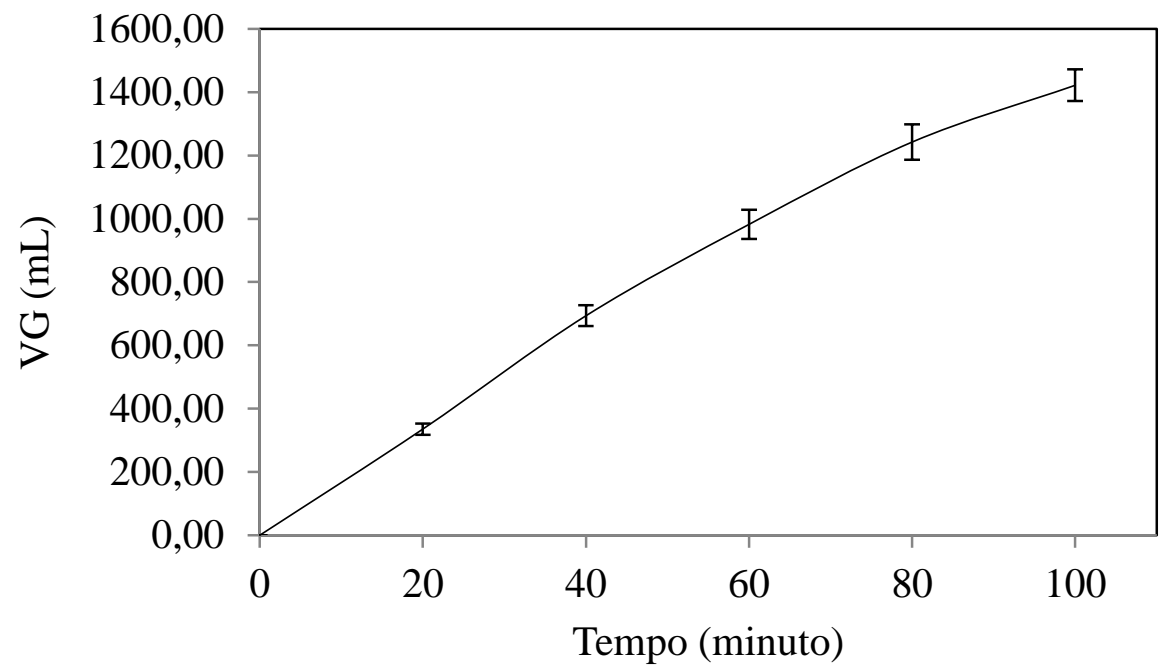

Figura 5-334 - Produção volumétrica média acumulada do biogás durante o ciclo (AnSBBR com agitação mecânica e lactose - Condição 6).

Tabela 5.79 - Valores médios da produção, fração molar e os volumes individuais da mistura do biogás (AnSBBR com agitação mecânica e lactose - Condição 6).

\begin{tabular}{ccccccccccc}
\hline $\begin{array}{c}\text { Tempo } \\
(\mathrm{h})\end{array}$ & $\begin{array}{c}\mathrm{V}_{\mathrm{G}} \\
(\mathrm{mL}-\mathrm{CNTP})\end{array}$ & \multicolumn{3}{c}{$\mathrm{C}_{\mathrm{G}}\left(\mathrm{mmol} \cdot \mathrm{L}^{-1}\right)$} & \multicolumn{3}{c}{ Fração Molar (\%) } & \multicolumn{3}{c}{ Volume $(\mathrm{mL}-\mathrm{CNTP})$} \\
& & $\mathrm{H}_{2}$ & $\mathrm{CO}_{2}$ & $\mathrm{CH}_{4}$ & $\mathrm{H}_{2}$ & $\mathrm{CO}_{2}$ & $\mathrm{CH}_{4}$ & $\mathrm{H}_{2}$ & $\mathrm{CO}_{2}$ & $\mathrm{CH}_{4}$ \\
\hline 0,0 & 0,0 & 0,0 & 0,0 & 0,0 & 0,0 & 0,0 & 0,0 & 0,0 & 0,0 & 0,0 \\
0,5 & 335,5 & 2,2 & 5,7 & 0,0 & 27,8 & 72,2 & 0,0 & 93,1 & 242,4 & 0,0 \\
1,0 & 693,6 & 3,5 & 9,0 & 0,0 & 28,1 & 71,9 & 0,0 & 193,7 & 499,8 & 0,0 \\
1,5 & 982,3 & 4,3 & 10,9 & 0,0 & 28,5 & 71,5 & 0,0 & 275,9 & 706,4 & 0,0 \\
2,0 & 1242,4 & 5,8 & 13,4 & 0,0 & 30,4 & 69,6 & 0,0 & 354,9 & 887,5 & 0,0 \\
2,5 & 1421,9 & 6,7 & 14,9 & 0,0 & 31,0 & 69,0 & 0,0 & 410,5 & 1011,4 & 0,0 \\
3,0 & 0,0 & 0,0 & 0,0 & 0,0 & 0,0 & 0,0 & 0,0 & 0,0 & 0,0 & 0,0 \\
3,7 & 335,5 & 2,2 & 5,7 & 0,0 & 27,8 & 72,2 & 0,0 & 93,1 & 242,4 & 0,0 \\
\hline
\end{tabular}




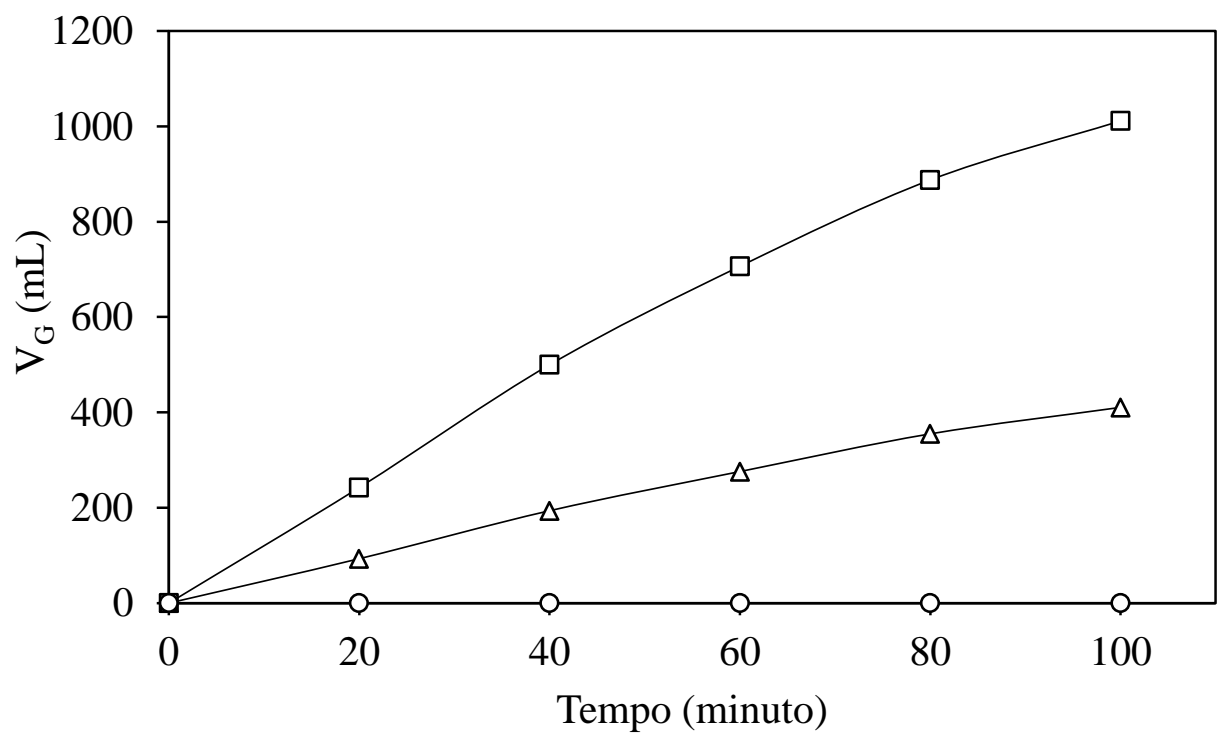

Figura 5-335 - Volumes acumulados médios produzidos ao longo do ciclo: $\square-\mathrm{CO}_{2} ; \Delta$ $\mathrm{H}_{2} ;$ ○ - $\mathrm{CH}_{4}$ (AnSBBR com agitação mecânica e lactose - Condição 6). 


\subsection{Análise comparativa das condições estudadas}

Nesta parte encontra-se o estudo comparativo entre todas as condições estudadas para o AnSBBR com recirculação da fase líquida (principal objetivo do trabalho) e para o AnSBBR com agitação mecânica (estudo complementar com a lactose, principal componente do soro de leite, buscando uma melhor compreensão da aplicação do referido carboidrato para produção de biohidrogênio).

\subsubsection{AnSBBR com recirculação da fase líquida - Primeira etapa (atingindo a estabilidade do processo).}

A operação do AnSBBR com recirculação da fase líquida e utilizando o soro de leite como substrato passou, desde o seu início, por problemas em produzir hidrogênio. Por esta razão o planejamento inicial que tinha como objetivo estudar a influência da carga orgânica aplicada mudando o tempo de ciclo e a concentração afluente teve que ser mudado, buscando uma produção estável de hidrogênio. Desta forma, foram oito condições que buscaram, através de diversas estratégias operacionais, eliminar a produção crescente de metano e a interrupção frequente da produção de hidrogênio. Apenas na última condição estudada foi possível atingir uma produção estável de hidrogênio, mesmo sem eliminar por completo a presença do metano, que ainda se mostrou presente, porém em baixas proporções, utilizando todos os conhecimentos obtidos com a execução das condições anteriores. No intuito de descrever de forma clara e sintética o que se passou nos 332 dias de operação nesta primeira fase de experimentos, neste item será realizada uma discussão global dos principais parâmetros 
analisados anteriormente. Um fluxograma com as condições estudadas pode ser observado na Figura 5-336. 


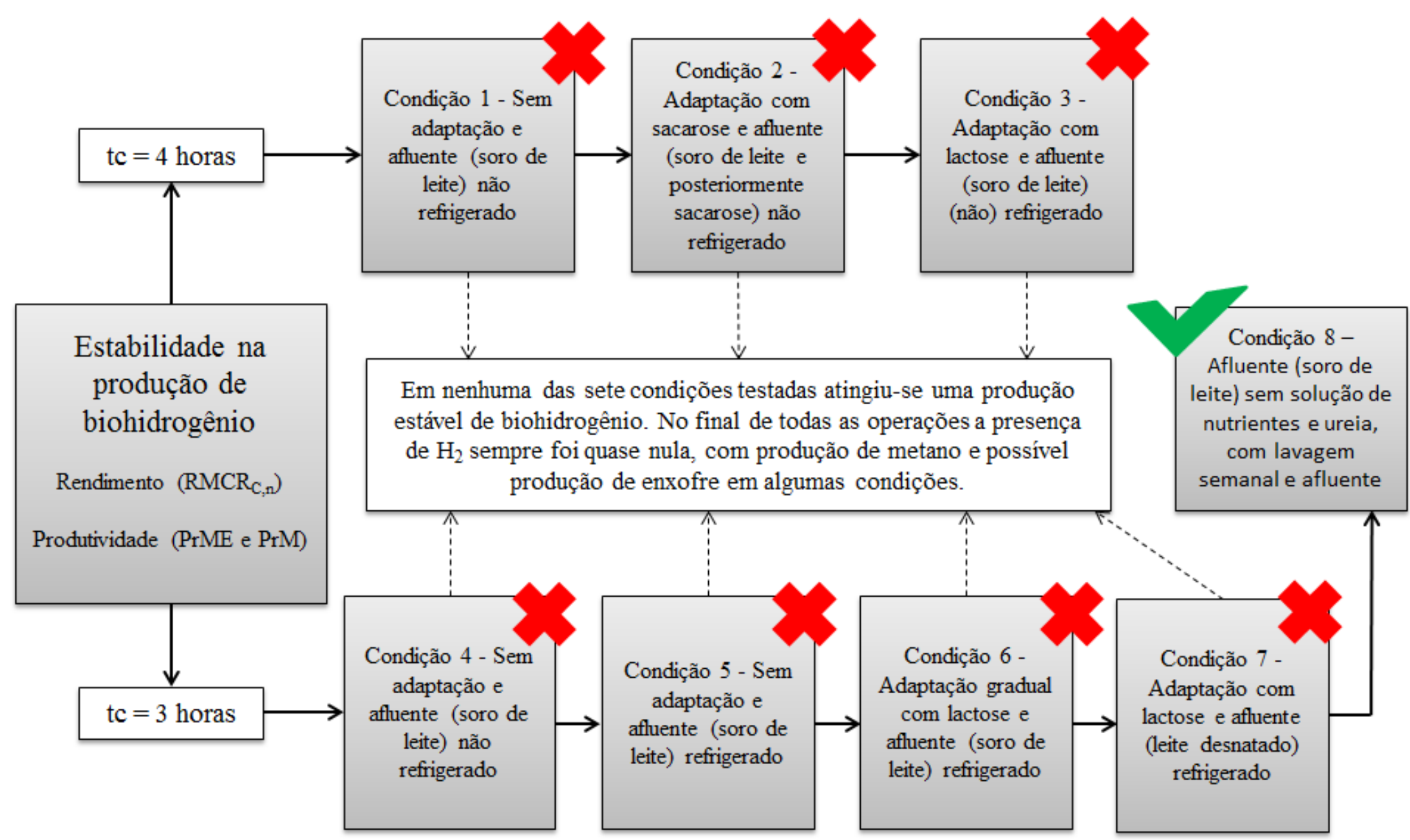

Figura 5-336 - Fluxograma das condições operadas na primeira fase do presente trabalho (AnSBBR com recirculação da fase líquida e soro de leite). 
A Figura 5-337 apresenta as concentrações de matéria orgânica na forma de DQO utilizadas enquanto que Figura 5-338 mostra a eficiência de remoção, podendo-se observar que esta eficiência sofreu variações relevantes, ocasionado provavelmente pela mudança da COAV e da produção de metano nas condições operadas com soro de leite. A remoção de matéria orgânica na forma de DQO é um importante indicador do processo de produção de hidrogênio. Em reatores acidogênicos as remoções são baixas pois o carboidrato é transformado em hidrogênio e nos produtos intermediários. Caso exista a metanogenese, estes produtos intermediários serão consumidos e serão observadas altas eficiências de remoção de matéria orgânica na forma de DQO. 


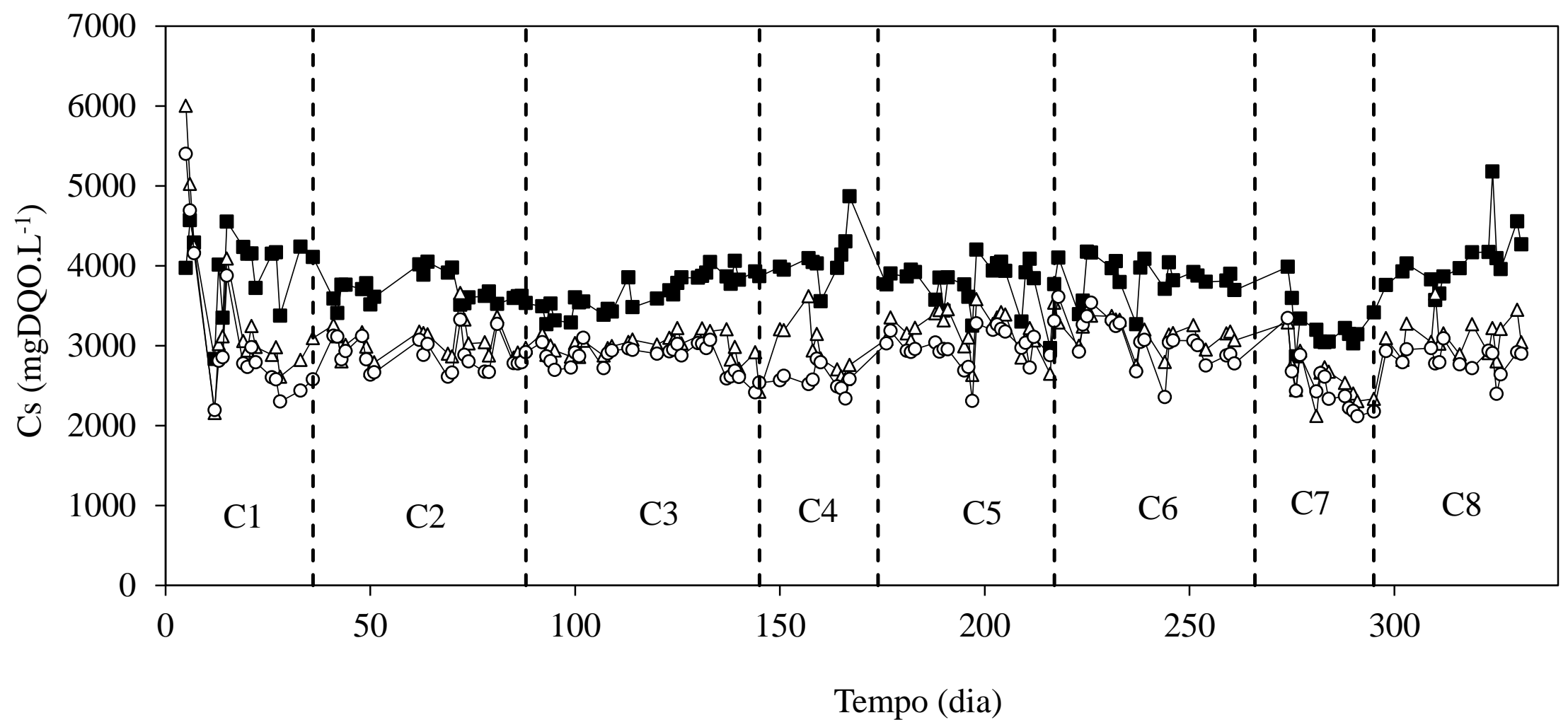

Figura 5-337 - Concentração de matéria orgânica (DQO): $\square$ - afluente não filtrada; $\Delta$ - efluente não filtrada; $~-$ efluente filtrada (Soro de leite: $\mathrm{C} 1=$ Sem adaptação e afluente não refrigerado - $4250 \mathrm{mgDQO} \cdot \mathrm{L}^{-1}-\mathrm{t}_{\mathrm{C}} 4 \mathrm{~h} ; \mathrm{C} 2=$ Adaptação com sacarose e afluente não refrigerado - 4250 mgDQO. $L^{-1}-t_{C} 4 h ; C 3=$ Adaptação com lactose e afluente (não) refrigerado - $4250 \mathrm{mgDQO} . \mathrm{L}^{-1}-\mathrm{t}_{\mathrm{C}} 4 \mathrm{~h}$; $\mathrm{C} 4$ = Sem adaptação e afluente não refrigerado - $4250 \mathrm{mgDQO} . \mathrm{L}^{-1}-\mathrm{t}_{\mathrm{C}} 3 \mathrm{~h} ; \mathrm{C} 5=\mathrm{Sem}$ adaptação e afluente refrigerado - $4250 \mathrm{mgDQO} \cdot \mathrm{L}^{-1}-\mathrm{t}_{\mathrm{C}} 3 \mathrm{~h}$; C6 = Adaptação com lactose e afluente refrigerado - $4250 \mathrm{mgDQO} . \mathrm{L}^{-1}-\mathrm{t}_{\mathrm{C}} 3 \mathrm{~h} ; \mathrm{C} 7$ = Adaptação com lactose, alimentação com leite desnatado e afluente refrigerado - 4250 mgDQO. $L^{-1}-t_{C} 3 h ; C 8=$ Afluente (soro de leite) sem solução de nutrientes e ureia, com lavagem semanal e afluente -4250 mgDQO.L $L^{-1}-t_{C} 3 h$ ). 


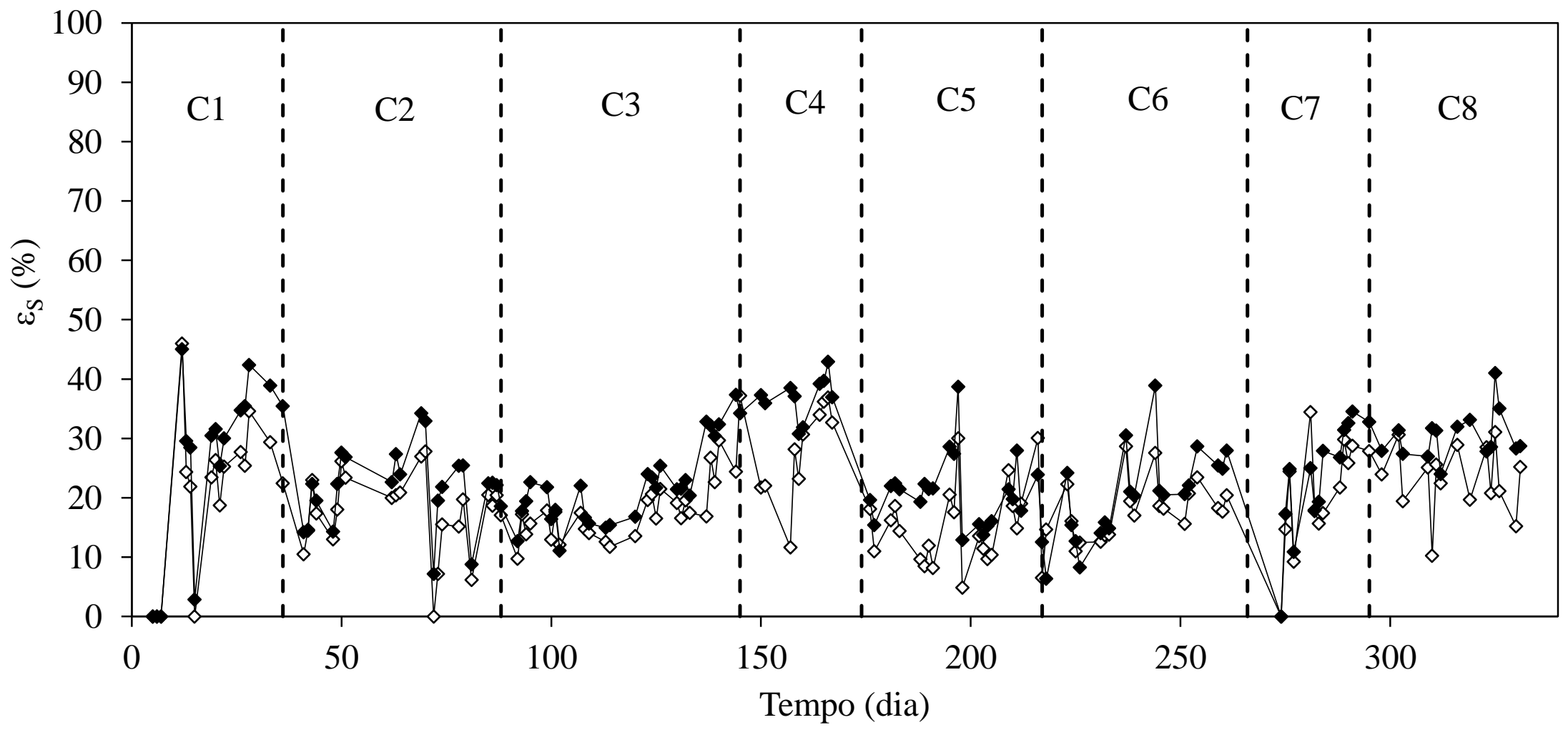

Figura 5-338 - Eficiência de remoção de matéria orgânica (DQO): $\diamond$ - não filtrada; - filtrada (Soro de leite: C1 = Sem adaptação e afluente não refrigerado - $4250 \mathrm{mgDQO} . \mathrm{L}^{-1}-\mathrm{t}_{\mathrm{C}} 4 \mathrm{~h} ; \mathrm{C} 2=$ Adaptação com sacarose e afluente não refrigerado - $4250 \mathrm{mgDQO} . \mathrm{L}^{-1}-\mathrm{t}_{\mathrm{C}} 4 \mathrm{~h} ; \mathrm{C} 3=\mathrm{Adaptação} \mathrm{com}$ lactose e afluente (não) refrigerado - $4250 \mathrm{mgDQO} . \mathrm{L}^{-1}-\mathrm{t}_{\mathrm{C}} 4 \mathrm{~h} ; \mathrm{C} 4=\mathrm{Sem}$ adaptação e afluente não refrigerado $-4250 \mathrm{mgDQO} . \mathrm{L}^{-1}-\mathrm{t}_{\mathrm{C}} 3 \mathrm{~h} ; \mathrm{C} 5=$ Sem adaptação e afluente refrigerado - $4250 \mathrm{mgDQO} . \mathrm{L}^{-1}-\mathrm{t}_{\mathrm{C}} 3 \mathrm{~h} ; \mathrm{C} 6=$ Adaptação com lactose e afluente refrigerado $-4250 \mathrm{mgDQO} . \mathrm{L}^{-1}-\mathrm{t}_{\mathrm{C}} 3 \mathrm{~h}$; C7 = Adaptação com lactose, alimentação com leite desnatado e afluente refrigerado - $4250 \mathrm{mgDQO} . \mathrm{L}^{-1}$ - $\mathrm{t}_{\mathrm{C}} 3 \mathrm{~h}$; C8 = Afluente (soro de leite) sem solução de nutrientes e ureia, com lavagem semanal e afluente - $4250 \mathrm{mgDQO} . \mathrm{L}^{-1}-\mathrm{t}_{\mathrm{C}} 3 \mathrm{~h}$ ). 
A Figura 5-339 exibe o comportamento da concentração de carboidratos afluente e efluente em todas as condições, podendo-se observar que praticamente toda a sacarose introduzida no reator foi consumida em todas as condições (com ou sem produção de metano e baixa ou alta produção de $\mathrm{H}_{2}$ ), dando origem aos ácidos e álcoois intermediários resultantes da acidogênese do processo. A Figura 5-340 exibe a eficiência de conversão de carboidratos, sempre com valores elevados e se apresentando estável. Os trechos com baixa remoção foram ocasionados por alguns fatores pontuais explicados nos itens anteriores, como mudança de substrato na alimentação e lavagem do material suporte, o que levava a uma nova adaptação da biomassa ao sistema. 


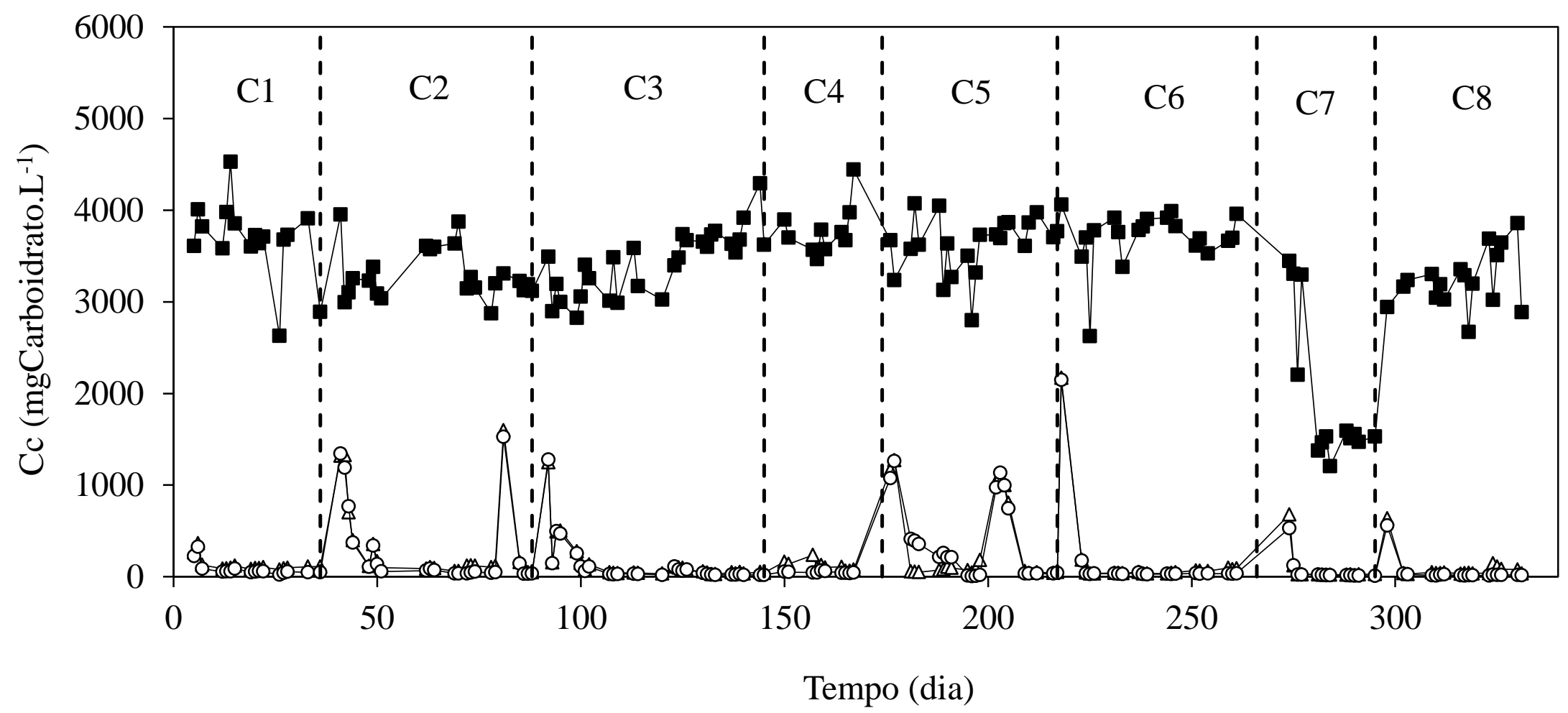

Figura 5-339 - Concentração de carboidrato: $\square$ - afluente não filtrada; $\Delta$ - efluente não filtrada; $\circ$ - efluente filtrada (Soro de leite: C1 = Sem adaptação e afluente não refrigerado - $4250 \mathrm{mgDQO} . \mathrm{L}^{-1}-\mathrm{t}_{\mathrm{C}} 4 \mathrm{~h} ; \mathrm{C} 2=$ Adaptação com sacarose e afluente não refrigerado - $4250 \mathrm{mgDQO} . \mathrm{L}^{-1}-\mathrm{t}_{\mathrm{C}}$ 4h; C3 = Adaptação com lactose e afluente (não) refrigerado - $4250 \mathrm{mgDQO} . \mathrm{L}^{-1}-\mathrm{t}_{\mathrm{C}} 4 \mathrm{~h} ; \mathrm{C} 4=$ Sem adaptação e afluente não refrigerado - 4250 mgDQO. $L^{-1}-t_{C} 3 h ; C 5=$ Sem adaptação e afluente refrigerado - $4250 \mathrm{mgDQO} . \mathrm{L}^{-1}-\mathrm{t}_{\mathrm{C}} 3 \mathrm{~h} ; \mathrm{C} 6=$ Adaptação com lactose e afluente refrigerado $4250 \mathrm{mgDQO} . \mathrm{L}^{-1}-\mathrm{t}_{\mathrm{C}} 3 \mathrm{~h} ; \mathrm{C} 7=$ Adaptação com lactose, alimentação com leite desnatado e afluente refrigerado $-4250 \mathrm{mgDQO} . \mathrm{L}^{-1}-\mathrm{t}_{\mathrm{C}} 3 \mathrm{~h} ; \mathrm{C} 8=$ Afluente (soro de leite) sem solução de nutrientes e ureia, com lavagem semanal e afluente $-4250 \mathrm{mgDQO} . \mathrm{L}^{-1}-\mathrm{t}_{\mathrm{C}} 3 \mathrm{~h}$ ). 


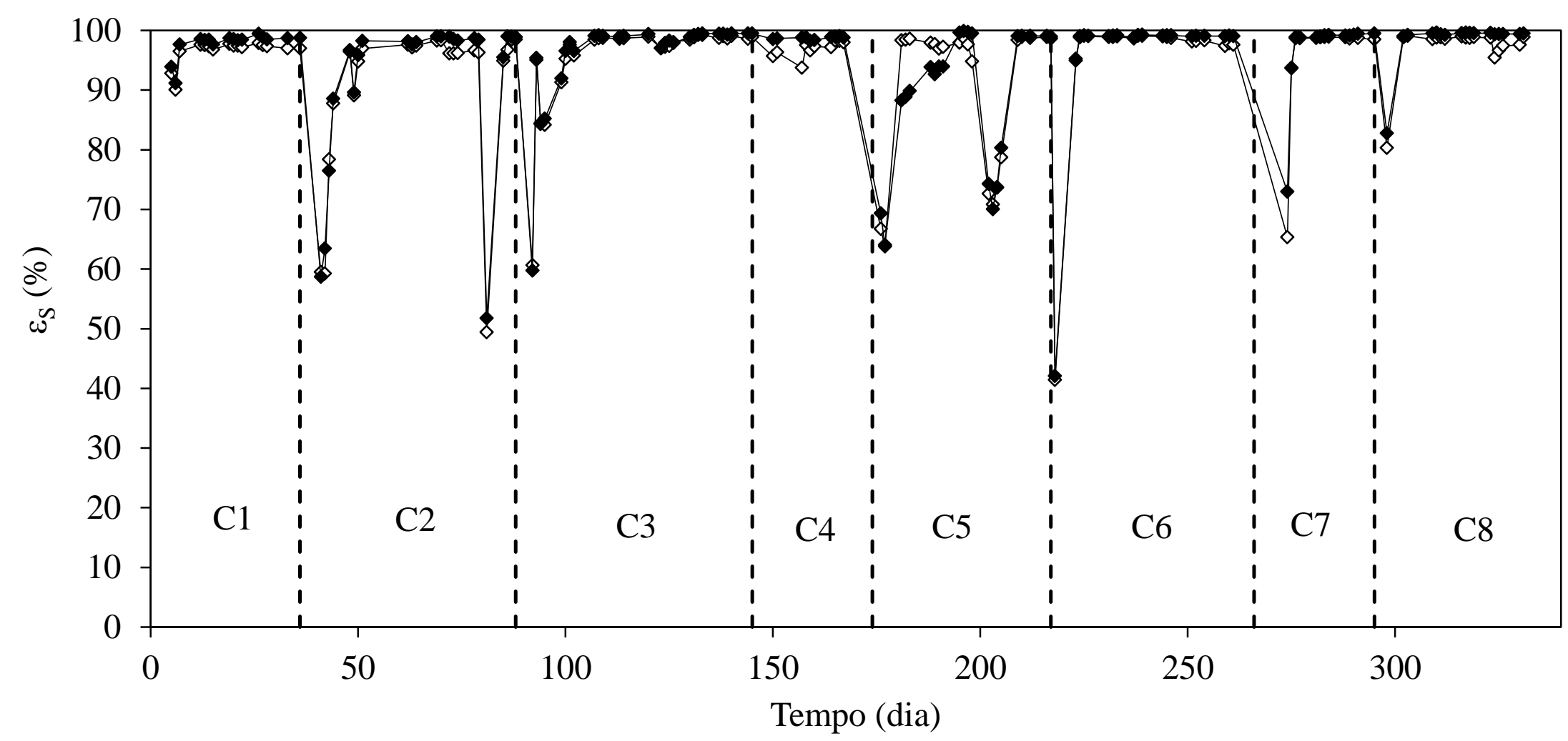

Figura 5-340 - Eficiência de remoção de carboidrato: $\diamond$ - não filtrada; - filtrada (Soro de leite: C1 = Sem adaptação e afluente não refrigerado $4250 \mathrm{mgDQO} . \mathrm{L}^{-1}-\mathrm{t}_{\mathrm{C}} 4 \mathrm{~h} ; \mathrm{C} 2=$ Adaptação com sacarose e afluente não refrigerado - $4250 \mathrm{mgDQO} . \mathrm{L}^{-1}-\mathrm{t}_{\mathrm{C}} 4 \mathrm{~h}$; $\mathrm{C} 3=$ Adaptação com lactose e afluente (não) refrigerado - $4250 \mathrm{mgDQO} . \mathrm{L}^{-1}-\mathrm{t}_{\mathrm{C}} 4 \mathrm{~h} ; \mathrm{C} 4=$ Sem adaptação e afluente não refrigerado $-4250 \mathrm{mgDQO} \cdot \mathrm{L}^{-1}-\mathrm{t}_{\mathrm{C}} 3 \mathrm{~h} ; \mathrm{C} 5=\mathrm{Sem}$ adaptação e afluente refrigerado - $4250 \mathrm{mgDQO} . \mathrm{L}^{-1}-\mathrm{t}_{\mathrm{C}} 3 \mathrm{~h} ; \mathrm{C} 6=$ Adaptação com lactose e afluente refrigerado $-4250 \mathrm{mgDQO} \cdot \mathrm{L}^{-1}-\mathrm{t}_{\mathrm{C}} 3 \mathrm{~h} ; \mathrm{C} 7=$ Adaptação com lactose, alimentação com leite desnatado e afluente refrigerado - $4250 \mathrm{mgDQO} . \mathrm{L}^{-1}-\mathrm{t}_{\mathrm{C}} 3 \mathrm{~h}$; $\mathrm{C} 8=\mathrm{Afluente}$ (soro de leite) sem solução de nutrientes e ureia, com lavagem semanal e afluente - $4250 \mathrm{mgDQO} . \mathrm{L}^{-1}-\mathrm{t}_{\mathrm{C}} 3 \mathrm{~h}$ ). 
A Figura 5-341 mostra a distribuição dos valores de $\mathrm{pH}$ afluente e efluente e a Figura 5-342 apresenta os ácidos voláteis totais, ambas em todas as condições. As quedas do $\mathrm{pH}$, tanto afluente quanto efluente (como explicadas nos itens anteriores), foram provocadas propositadamente, na tentativa de controle com ácido clorídrico. Os ácidos voláteis totais apresentaram valores estáveis, sofrendo alterações de valores ocasionadas pela mudança de substrato e das concentrações de matéria orgânica na alimentação, o que era esperado. 


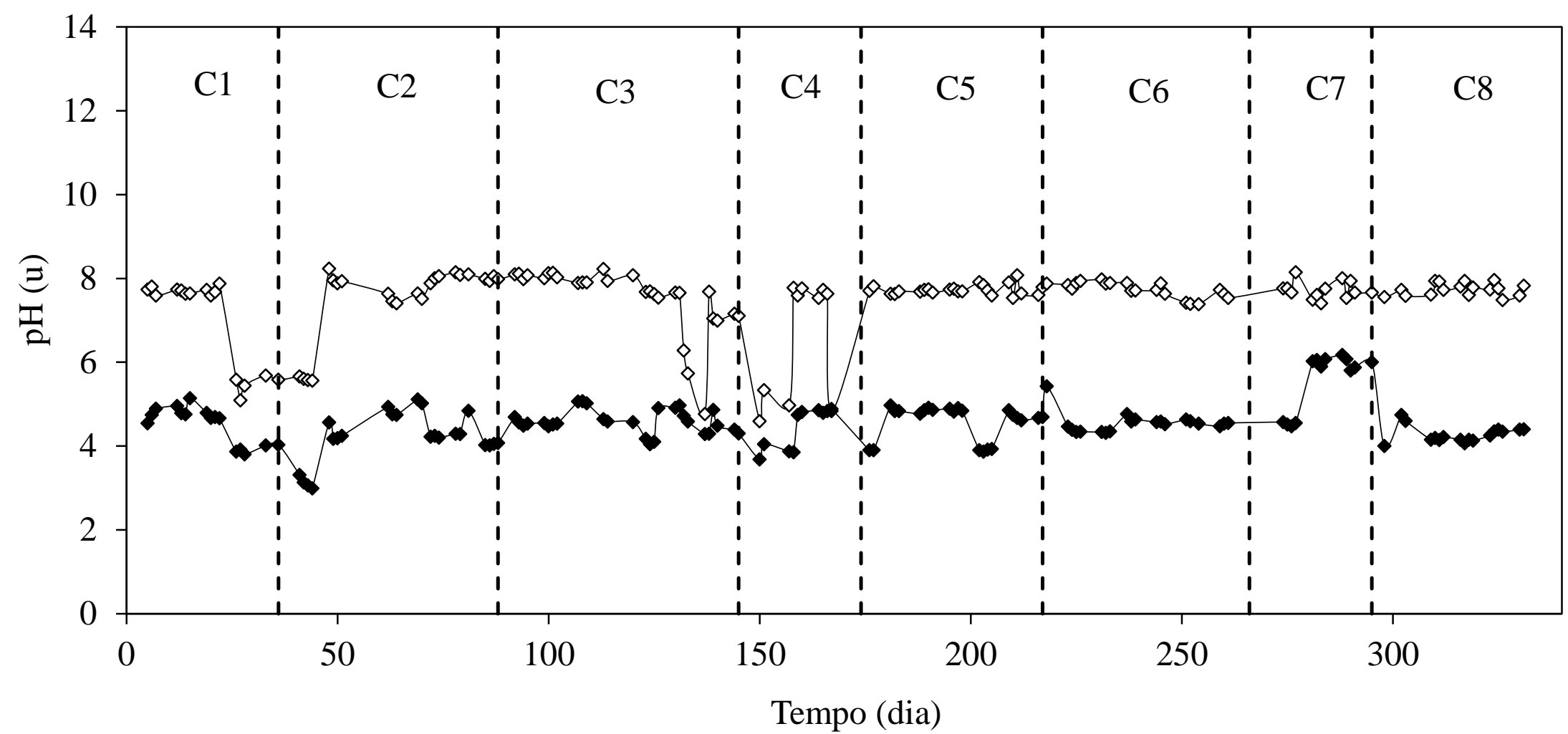

Figura 5-341 - Valores de pH: $\diamond$-afluente; - efluente (Soro de leite: $\mathrm{C} 1=$ Sem adaptação e afluente não refrigerado - $4250 \mathrm{mgDQO} . \mathrm{L}^{-1}$ - $\mathrm{t}_{\mathrm{C}} 4 \mathrm{~h}$; $\mathrm{C} 2$ = Adaptação com sacarose e afluente não refrigerado - $4250 \mathrm{mgDQO} . \mathrm{L}^{-1}-\mathrm{t}_{\mathrm{C}} 4 \mathrm{~h}$; $\mathrm{C} 3=$ Adaptação com lactose e afluente (não) refrigerado $4250 \mathrm{mgDQO} . \mathrm{L}^{-1}-\mathrm{t}_{\mathrm{C}} 4 \mathrm{~h} ; \mathrm{C} 4=$ Sem adaptação e afluente não refrigerado - $4250 \mathrm{mgDQO} . \mathrm{L}^{-1}-\mathrm{t}_{\mathrm{C}} 3 \mathrm{~h}$; C5 = Sem adaptação e afluente refrigerado $4250 \mathrm{mgDQO} . \mathrm{L}^{-1}-\mathrm{t}_{\mathrm{C}} 3 \mathrm{~h} ; \mathrm{C} 6=$ Adaptação com lactose e afluente refrigerado - $4250 \mathrm{mgDQO} . \mathrm{L}^{-1}-\mathrm{t}_{\mathrm{C}} 3 \mathrm{~h}$; $\mathrm{C} 7=$ Adaptação com lactose, alimentação com leite desnatado e afluente refrigerado - $4250 \mathrm{mgDQO} \cdot \mathrm{L}^{-1}-\mathrm{t}_{\mathrm{C}} 3 \mathrm{~h} ; \mathrm{C} 8=$ Afluente (soro de leite) sem solução de nutrientes e ureia, com lavagem semanal e afluente - $\left.4250 \mathrm{mgDQO} . \mathrm{L}^{-1}-\mathrm{t}_{\mathrm{C}} 3 \mathrm{~h}\right)$. 


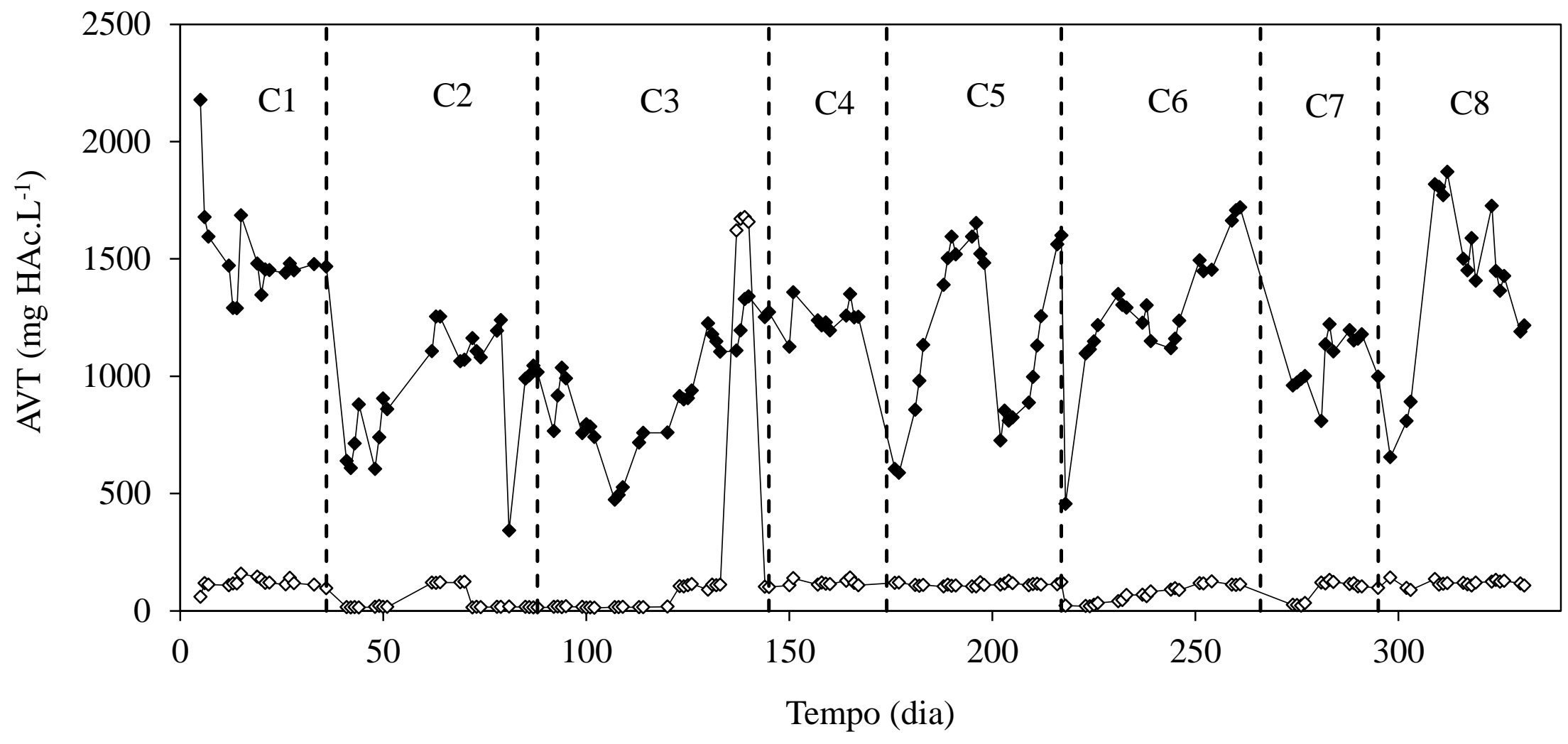

Figura 5-342 - Ácidos voláteis totais: $\diamond$-afluente; - efluente (Soro de leite: C1 = Sem adaptação e afluente não refrigerado - 4250 mgDQO.L ${ }^{-1}$ - $\mathrm{t}_{\mathrm{C}} 4 \mathrm{~h} ; \mathrm{C} 2=$ Adaptação com sacarose e afluente não refrigerado - $4250 \mathrm{mgDQO} \cdot \mathrm{L}^{-1}-\mathrm{t}_{\mathrm{C}} 4 \mathrm{~h} ; \mathrm{C} 3$ = Adaptação com lactose e afluente (não) refrigerado - $4250 \mathrm{mgDQO} . \mathrm{L}^{-1}-\mathrm{t}_{\mathrm{C}} 4 \mathrm{~h} ; \mathrm{C} 4=\mathrm{Sem}$ adaptação e afluente não refrigerado - $4250 \mathrm{mgDQO} \cdot \mathrm{L}^{-1}$ - $\mathrm{t}_{\mathrm{C}} 3 \mathrm{~h} ; \mathrm{C} 5=\mathrm{Sem}$ adaptação e afluente refrigerado - $4250 \mathrm{mgDQO} . \mathrm{L}^{-1}-\mathrm{t}_{\mathrm{C}} 3 \mathrm{~h} ; \mathrm{C} 6=$ Adaptação com lactose e afluente refrigerado $-4250 \mathrm{mgDQO} . \mathrm{L}^{-1}-\mathrm{t}_{\mathrm{C}} 3 \mathrm{~h} ; \mathrm{C} 7=\mathrm{Adaptação} \mathrm{com}$

lactose, alimentação com leite desnatado e afluente refrigerado - $4250 \mathrm{mgDQO} . \mathrm{L}^{-1}-\mathrm{t}_{\mathrm{C}} 3 \mathrm{~h}$; $\mathrm{C} 8=$ Afluente (soro de leite) sem solução de nutrientes e ureia, com lavagem semanal e afluente $-4250 \mathrm{mgDQO} . \mathrm{L}^{-1}-\mathrm{t}_{\mathrm{C}} 3 \mathrm{~h}$ ) 
A Figura 5-343 apresenta as concentrações de produtos intermediários em todas as condições nas quais as análises cromatográficas destes foram realizadas. Os metabólitos com maior destaque foram o ácido acético, o ácido butírico e o etanol. Nas condições alimentadas com soro de leite (sem produção de $\mathrm{H}_{2}$ ) o ácido acético apresentou as maiores concentrações, seguido pelo ácido butírico, com o etanol trazendo uma produção extremamente baixa. A operação com sacarose (onde ocorreu produção de $\mathrm{H}_{2}$ sem produção de $\mathrm{CH}_{4}$ ) mostrou uma distribuição diferente dos metabólitos, com uma queda do ácido butírico e um aumento acentuado do etanol, porém o ácido acético continuou com as maiores concentrações. Por último, a operação com lactose (com produção de $\mathrm{H}_{2}$ menor do que a condição alimentada com sacarose e também sem produção de $\mathrm{CH}_{4}$ ) apresentou um comportamento de distribuição similar à operação com sacarose, porém com as concentrações de ácido acético próximas às concentrações de etanol. Não foram realizadas medidas das concentrações dos metabólitos para a operação com leite desnatado longa vida. É possível notar, com essa mudança na produção dos metabólitos, que provavelmente a produção de hidrogênio no AnSBBR com recirculação é realizada por rotas metabólicas que produzem etanol concomitantemente à produção de acido acético. Estas rotas existem e já foram descritas em literatura (rota aceto-alcoólica sugerida por Zhu et al., 2009). 


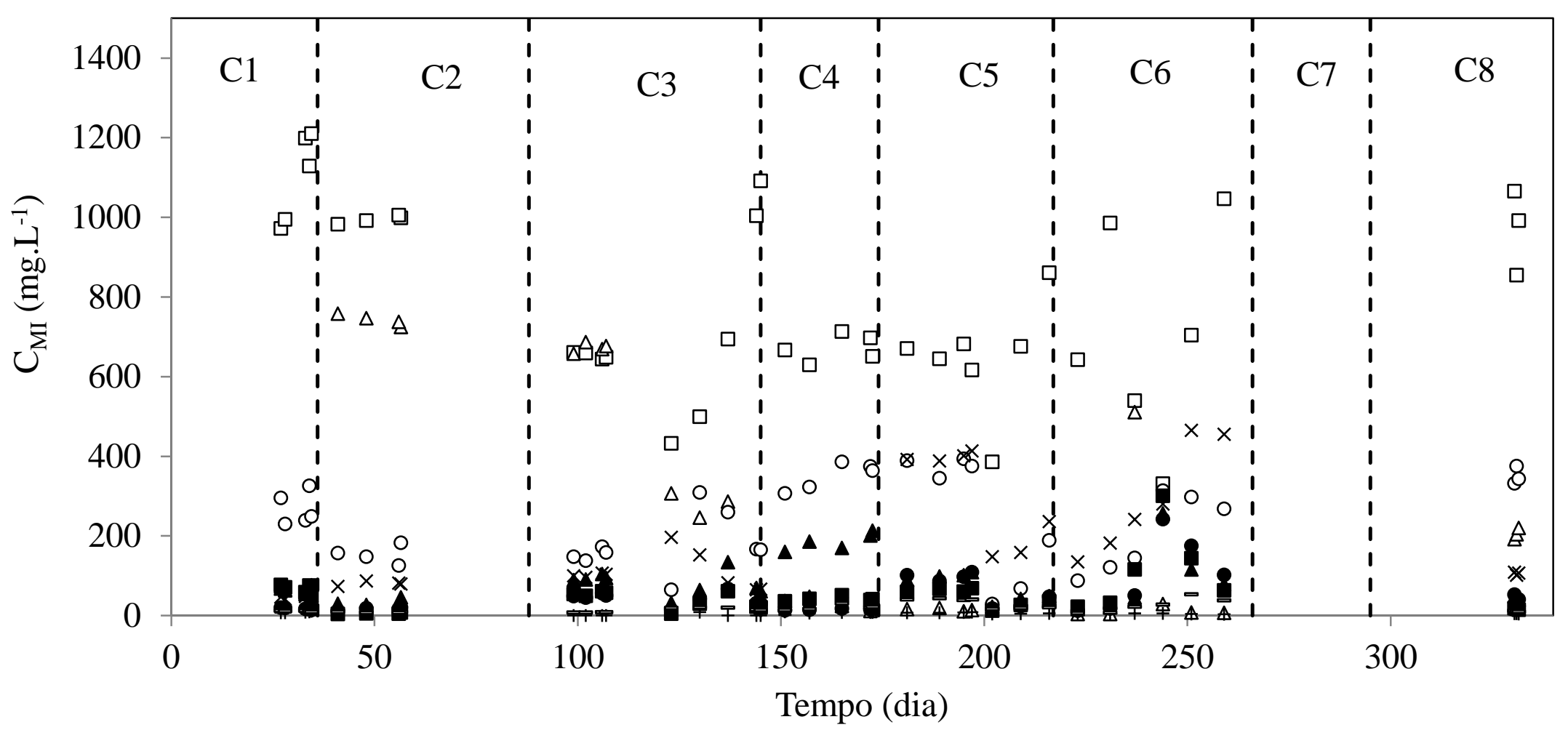

Figura 5-343 - Concentração dos compostos intermediários durante o monitoramento: $\square$ - ácido acético; $\Delta$ - etanol; o - ácido butírico; $\square$ - ácido isobutírico; $\boldsymbol{\Lambda}$ - ácido capróico; $\bullet$ - ácido valérico; - - ácido propiônico; +butanol; — ácido isovalérico (Soro de leite: C1 = Sem adaptação e afluente não refrigerado - $4250 \mathrm{mgDQO} . \mathrm{L}^{-1}-\mathrm{t}_{\mathrm{C}} 4 \mathrm{~h} ; \mathrm{C} 2=$ Adaptação com sacarose e afluente não refrigerado $-4250 \mathrm{mgDQO} . \mathrm{L}^{-1}-\mathrm{t}_{\mathrm{C}} 4 \mathrm{~h} ; \mathrm{C} 3=$ Adaptação com lactose e afluente (não) refrigerado - $4250 \mathrm{mgDQO} . \mathrm{L}^{-1}-\mathrm{t}_{\mathrm{C}} 4 \mathrm{~h}$; $\mathrm{C} 4=\mathrm{Sem}$ adaptação e afluente não refrigerado - $4250 \mathrm{mgDQO} . \mathrm{L}$

${ }^{1}-t_{C} 3 h ; C 5=$ Sem adaptação e afluente refrigerado - $4250 \mathrm{mgDQO} \cdot \mathrm{L}^{-1}-\mathrm{t}_{\mathrm{C}} 3 \mathrm{~h} ; \mathrm{C} 6=$ Adaptação com lactose e afluente refrigerado - 4250 mgDQO. $\mathrm{L}^{-1}-\mathrm{t}_{\mathrm{C}} 3 \mathrm{~h} ; \mathrm{C} 7$ = Adaptação com lactose, alimentação com leite desnatado e afluente refrigerado $-4250 \mathrm{mgDQO} \cdot \mathrm{L}^{-1}-\mathrm{t}_{\mathrm{C}} 3 \mathrm{~h} ; \mathrm{C} 8=$ Afluente (soro de leite) sem solução de nutrientes e ureia, com lavagem semanal e afluente $-4250 \mathrm{mgDQO} . \mathrm{L}^{-1}-\mathrm{t}_{\mathrm{C}} 3 \mathrm{~h}$ ). 
A produção quantitativa do biogás por ciclo é mostrada na Figura 5-344. A Figura 5-345 apresenta o monitoramento das concentrações dos componentes do biogás no final do ciclo e a Figura 5-346 apresenta a distribuição destes componentes. 


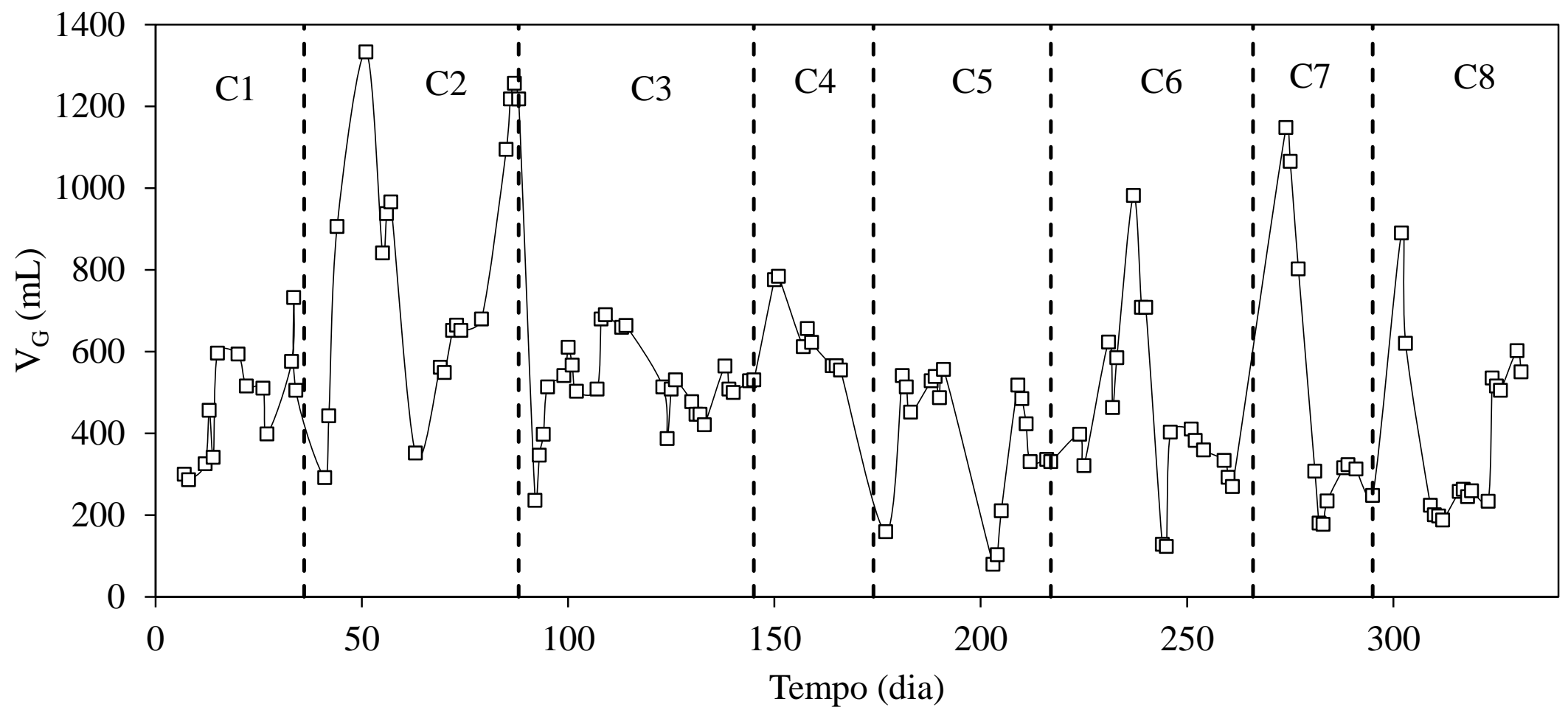

Figura 5-344 - Volume de biogás produzido por ciclo (Soro de leite: $\mathrm{C} 1=$ Sem adaptação e afluente não refrigerado $-4250 \mathrm{mgDQO} . \mathrm{L}^{-1}-\mathrm{t}_{\mathrm{C}} 4 \mathrm{~h}$; $\mathrm{C} 2$ = Adaptação com sacarose e afluente não refrigerado - $4250 \mathrm{mgDQO} \cdot \mathrm{L}^{-1}-\mathrm{t}_{\mathrm{C}} 4 \mathrm{~h} ; \mathrm{C} 3=$ Adaptação com lactose e afluente (não) refrigerado $4250 \mathrm{mgDQO} . \mathrm{L}^{-1}-\mathrm{t}_{\mathrm{C}} 4 \mathrm{~h} ; \mathrm{C} 4=$ Sem adaptação e afluente não refrigerado - $4250 \mathrm{mgDQO} . \mathrm{L}^{-1}-\mathrm{t}_{\mathrm{C}} 3 \mathrm{~h}$; $\mathrm{C} 5$ = Sem adaptação e afluente refrigerado -

$4250 \mathrm{mgDQO} . \mathrm{L}^{-1}-\mathrm{t}_{\mathrm{C}} 3 \mathrm{~h} ; \mathrm{C} 6=$ Adaptação com lactose e afluente refrigerado - $4250 \mathrm{mgDQO} . \mathrm{L}^{-1}-\mathrm{t}_{\mathrm{C}} 3 \mathrm{~h} ; \mathrm{C} 7=$ Adaptação com lactose,

alimentação com leite desnatado e afluente refrigerado - $4250 \mathrm{mgDQO} \cdot \mathrm{L}^{-1}-\mathrm{t}_{\mathrm{C}} 3 \mathrm{~h} ; \mathrm{C} 8=$ Afluente (soro de leite) sem solução de nutrientes e ureia, com lavagem semanal e afluente - $\left.4250 \mathrm{mgDQO} . \mathrm{L}^{-1}-\mathrm{t}_{\mathrm{C}} 3 \mathrm{~h}\right)$. 


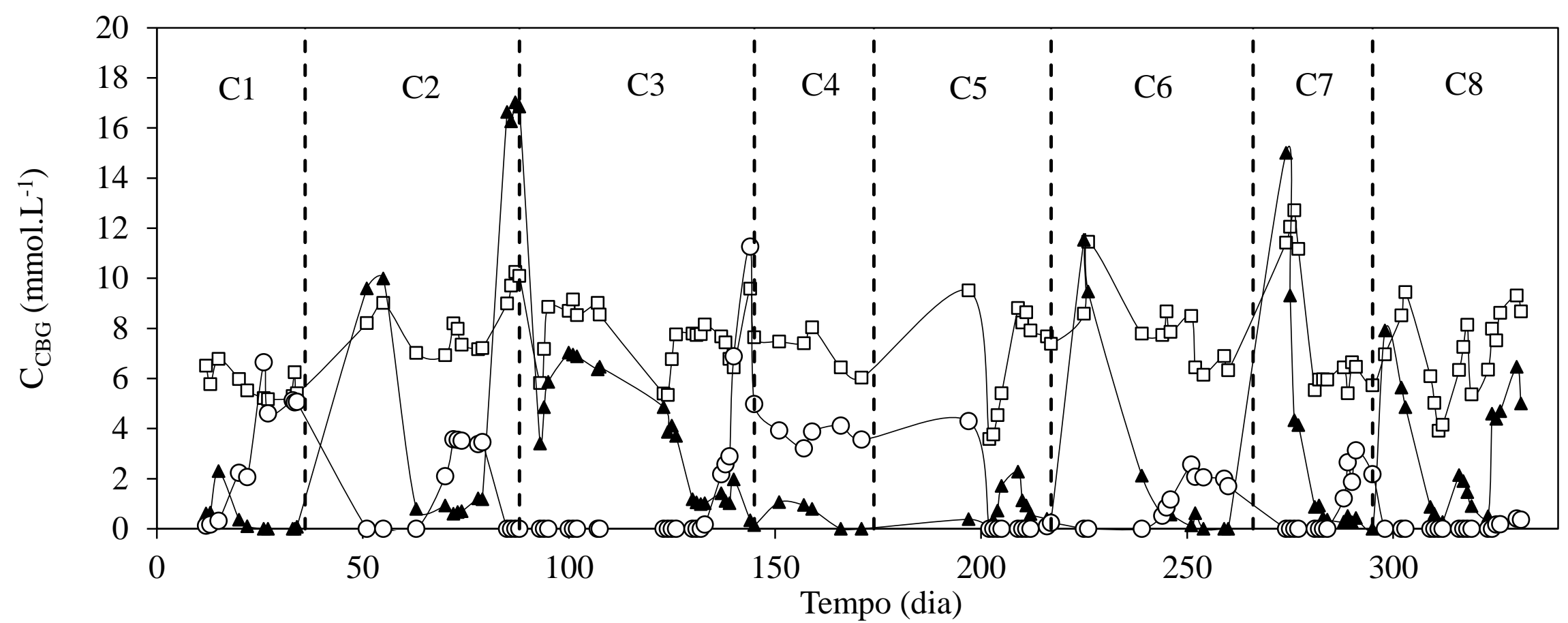

Figura 5-345 - Concentrações dos componentes do biogás no final do ciclo: $\square-\mathrm{CO}_{2} ; \Delta-\mathrm{H}_{2} ; \circ-\mathrm{CH}_{4}$ (Soro de leite: $\mathrm{C} 1=\mathrm{Sem}$ adaptação e afluente não refrigerado - $4250 \mathrm{mgDQO} . \mathrm{L}^{-1}-\mathrm{t}_{\mathrm{C}} 4 \mathrm{~h} ; \mathrm{C} 2=$ Adaptação com sacarose e afluente não refrigerado $-4250 \mathrm{mgDQO} \cdot \mathrm{L}^{-1}-\mathrm{t}_{\mathrm{C}} 4 \mathrm{~h} ; \mathrm{C} 3=$ Adaptação com lactose e afluente (não) refrigerado - $4250 \mathrm{mgDQO} . \mathrm{L}^{-1}-\mathrm{t}_{\mathrm{C}} 4 \mathrm{~h}$; $\mathrm{C} 4=$ Sem adaptação e afluente não refrigerado - $4250 \mathrm{mgDQO} . \mathrm{L}$

${ }^{1}-\mathrm{t}_{\mathrm{C}} 3 \mathrm{~h} ; \mathrm{C} 5=$ Sem adaptação e afluente refrigerado - $4250 \mathrm{mgDQO} . \mathrm{L}^{-1}-\mathrm{t}_{\mathrm{C}} 3 \mathrm{~h}$; C6 = Adaptação com lactose e afluente refrigerado - 4250

mgDQO. $\mathrm{L}^{-1}-\mathrm{t}_{\mathrm{C}} 3 \mathrm{~h} ; \mathrm{C7}=$ Adaptação com lactose, alimentação com leite desnatado e afluente refrigerado $-4250 \mathrm{mgDQO} \cdot \mathrm{L}^{-1}-\mathrm{t}_{\mathrm{C}} 3 \mathrm{~h} ; \mathrm{C} 8=$ Afluente (soro de leite) sem solução de nutrientes e ureia, com lavagem semanal e afluente $-4250 \mathrm{mgDQO} \cdot \mathrm{L}^{-1}-\mathrm{t}_{\mathrm{C}} 3 \mathrm{~h}$ ) 


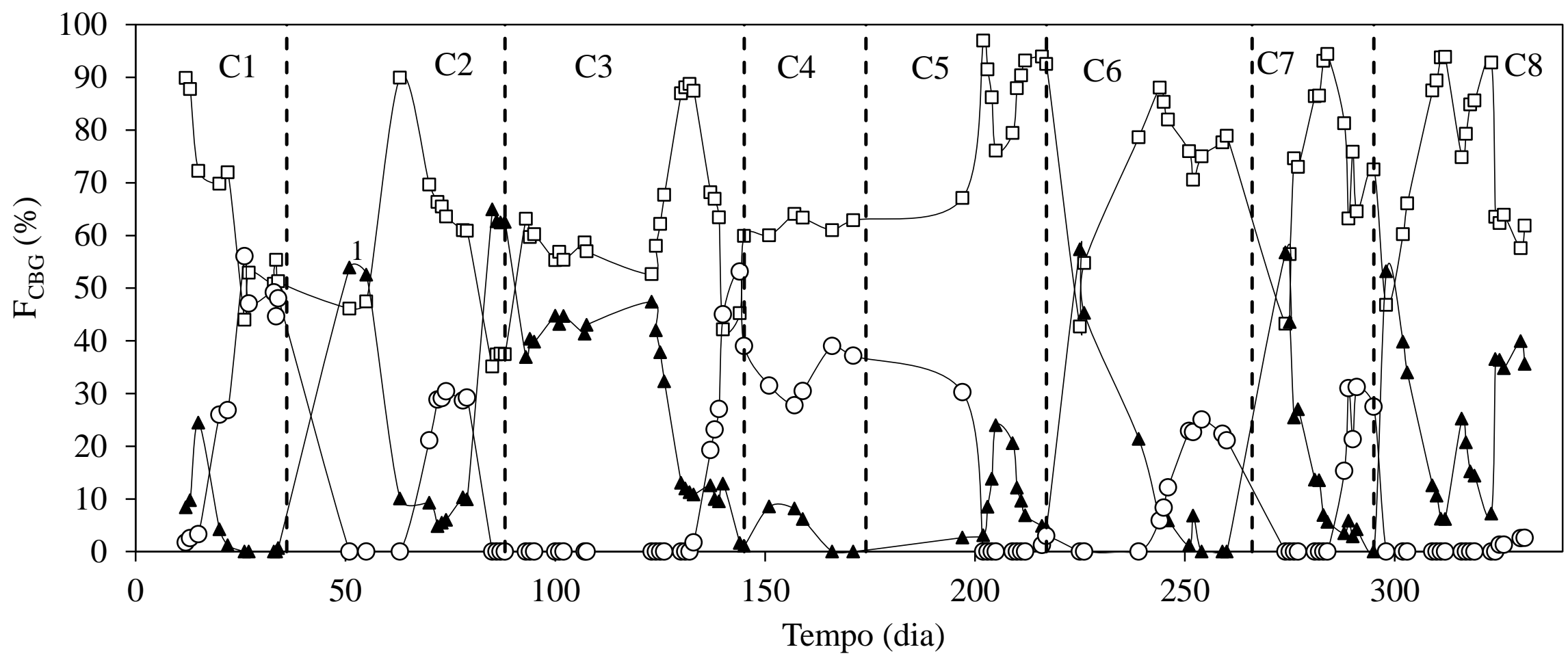

Figura 5-346 - Distribuições dos componentes do biogás no final do ciclo: $\square-\mathrm{CO}_{2} ; \Delta-\mathrm{H}_{2} ; \circ-\mathrm{CH}_{4}$ (Soro de leite: $\mathrm{C} 1=\mathrm{Sem}$ adaptação e afluente não refrigerado - $4250 \mathrm{mgDQO} . \mathrm{L}^{-1}-\mathrm{t}_{\mathrm{C}} 4 \mathrm{~h} ; \mathrm{C} 2=$ Adaptação com sacarose e afluente não refrigerado $-4250 \mathrm{mgDQO} . \mathrm{L}^{-1}-\mathrm{t}_{\mathrm{C}} 4 \mathrm{~h} ; \mathrm{C} 3=$ Adaptação com lactose e afluente (não) refrigerado - $4250 \mathrm{mgDQO} . \mathrm{L}^{-1}-\mathrm{t}_{\mathrm{C}} 4 \mathrm{~h}$; $\mathrm{C} 4=$ Sem adaptação e afluente não refrigerado - $4250 \mathrm{mgDQO} . \mathrm{L}^{-}$

${ }^{1}-\mathrm{t}_{\mathrm{C}} 3 \mathrm{~h} ; \mathrm{C} 5=$ Sem adaptação e afluente refrigerado - $4250 \mathrm{mgDQO} \cdot \mathrm{L}^{-1}-\mathrm{t}_{\mathrm{C}} 3 \mathrm{~h}$; C6 = Adaptação com lactose e afluente refrigerado - 4250 $\operatorname{mgDQO} . \mathrm{L}^{-1}-\mathrm{t}_{\mathrm{C}} 3 \mathrm{~h} ; \mathrm{C} 7$ = Adaptação com lactose, alimentação com leite desnatado e afluente refrigerado $-4250 \mathrm{mgDQO} \cdot \mathrm{L}^{-1}-\mathrm{t}_{\mathrm{C}} 3 \mathrm{~h} ; \mathrm{C} 8=$ Afluente (soro de leite) sem solução de nutrientes e ureia, com lavagem semanal e afluente $-4250 \mathrm{mgDQO} . \mathrm{L}^{-1}-\mathrm{t}_{\mathrm{C}} 3 \mathrm{~h}$ ). 
A operação com soro de leite apresentou problema com a produção de hidrogênio desde o início. As Condições 1 e 4, realizadas nas condições inicialmente planejadas não apresentaram sucesso na produção de hidrogênio. Em ambas as condições, a adição de ácido clorídrico buscando atingir um $\mathrm{pH}$ teoricamente desfavorável ao desenvolvimento de arqueias metanogênicas não surtiu efeito e ocorreu produção de metano. Presença de metano mesmo em $\mathrm{pH}$ abaixo de 5,0 já foi relatado em outros trabalhos que usaram soro de leite em reatores acidogênicos (Castelló, 2009; Carrilo-Reyes, 2012).

As operações de aclimatação da biomassa com carboidratos puros (sacarose e lactose) também não surtiram efeito, mesmo estas operações de aclimatação apresentando boa produção de hidrogênio, sem produção conjunta de metano. A adaptação gradual da Condição 6 também não surgiu efeitos positivos na produção de hidrogênio.

$\mathrm{O}$ armazenamento do meio de alimentação em geladeira a $4^{\circ} \mathrm{C}$ foi o primeiro passo positivo para a estabilidade de produção de hidrogênio. Isto porque provavelmente o soro de leite, devido à sua alta degradabilidade, já estava sendo consumido dentro do frasco de armazenamento do afluente, fazendo com que o AnSBBR com recirculação fosse alimentado com quantidades significativas de ácidos voláteis de modo a estimular a atividade metanogênica de um processo combinado acidogênico-metanogênico. A Tabela 5.80 apresenta os resultados de algumas análises realizadas com o "meio não refrigerado" (meio preparado no dia anterior antes de ser substituído por um meio novo), mostrando que o meio de alimentação estava sendo degradado já no frasco de armazenamento do afluente. A Tabela 5.81 apresenta algumas análises realizadas com o "meio refrigerado", mostrando que as características deste 
eram mantidas mesmo no dia seguinte, sem ocorrer nenhuma degradação de substrato ou aumento na produção de ácidos voláteis totais.

Tabela 5.80 - Análises realizadas com o meio de alimentação sem refrigeração

\begin{tabular}{|c|c|c|c|c|c|c|c|c|}
\hline \multirow[t]{2}{*}{ Tempo } & \multirow[t]{2}{*}{ Temperatura } & \multirow{3}{*}{$\begin{array}{l}\text { Concentração no } \\
\text { preparo do meio } \\
\left(\text { mgCarboidrato. } \mathrm{L}^{-1}\right)\end{array}$} & \multirow{3}{*}{$\begin{array}{l}\text { Concentração } \\
\text { após } 24 \mathrm{~h} \\
\left(\mathrm{mgCarboidrato.} \mathrm{L}^{-1}\right)\end{array}$} & \multirow{3}{*}{$\begin{array}{c}\text { Degradação } \\
(\%)\end{array}$} & \multicolumn{2}{|c|}{$\begin{array}{c}\text { Valores no } \\
\text { preparo do meio }\end{array}$} & \multicolumn{2}{|c|}{$\begin{array}{l}\text { Valores após } \\
24 \mathrm{~h}\end{array}$} \\
\hline & & & & & $\mathrm{pH}$ & AVT & $\mathrm{pH}$ & AVT \\
\hline (d) & $\left({ }^{\circ} \mathrm{C}\right)$ & & & & (u) & $\left(\mathrm{mgHAc} . \mathrm{L}^{-1}\right)$ & (u) & $\left(\mathrm{mgHAc} . \mathrm{L}^{-1}\right)$ \\
\hline 8 & 35 & 3822 & 680 & 82 & 7,59 & 112 & 4,11 & 823 \\
\hline 28 & 29 & 3679 & 2937 & 20 & 5,09 & 139 & 4,05 & 379 \\
\hline 32 & 26 & 3795 & 1996 & 47 & 5,44 & 118 & 4,05 & 361 \\
\hline 33 & 29 & 3795 & 2098 & 45 & 5,68 & 111 & 4,05 & 198 \\
\hline
\end{tabular}

Tabela 5.81 - Análises realizadas com o meio de alimentação com refrigeração

\begin{tabular}{|c|c|c|c|c|c|c|c|c|}
\hline \multirow{2}{*}{\multicolumn{2}{|c|}{ Tempo Temperatura }} & \multirow{3}{*}{$\begin{array}{l}\text { Concentração no } \\
\text { preparo do meio } \\
\left(\mathrm{mgCarboidrato.} \mathrm{L}^{-1}\right)\end{array}$} & \multirow{3}{*}{$\begin{array}{l}\text { Concentração } \\
\text { após } 24 \mathrm{~h} \\
(\text { mgCarboidrato..-1) }\end{array}$} & \multirow{3}{*}{$\begin{array}{c}\text { Degradação } \\
(\%)\end{array}$} & \multicolumn{2}{|c|}{$\begin{array}{c}\text { Valores no } \\
\text { preparo do meio }\end{array}$} & \multicolumn{2}{|c|}{ Valores após $24 \mathrm{~h}$} \\
\hline & & & & & $\mathrm{pH}$ & AVT & $\mathrm{pH}$ & AVT \\
\hline (d) & $\left({ }^{\circ} \mathrm{C}\right)$ & & & & (u) & $\left(\right.$ mgHAc. $\left.\mathrm{L}^{-1}\right)$ & (u) & $\left(\mathrm{mgHAc} . \mathrm{L}^{-1}\right)$ \\
\hline 125 & 4 & 3482 & 3439 & 1,2 & 7,69 & 103 & 7,92 & 108 \\
\hline 126 & 4 & 3736 & 3696 & 1,1 & 7,62 & 109 & 7,73 & 110 \\
\hline 129 & 4 & 3673 & 3521 & 4,1 & 7,54 & 114 & 7,94 & 116 \\
\hline 133 & 4 & 3732 & 3647 & 2,3 & 6,28 & 109 & 6,28 & 110 \\
\hline 139 & 4 & 3538 & 3445 & 2,6 & 7,68 & 111 & 7,91 & 117 \\
\hline
\end{tabular}

A refrigeração, por outro lado, gerou um resultado negativo: indícios de produção de $\mathrm{H}_{2} \mathrm{~S}$ (odor característico e formação de substância branca recobrindo o exterior das mangueiras de alimentação, como pode ser observado na Figura 5-347), provavelmente produzidas pela ação de bactérias redutoras de sulfato (BRS), apesar de análises específicas para detecção deste composto não terem sido realizadas. Isto explicaria a queda na produção de hidrogênio sem concomitante aumento do metano. 


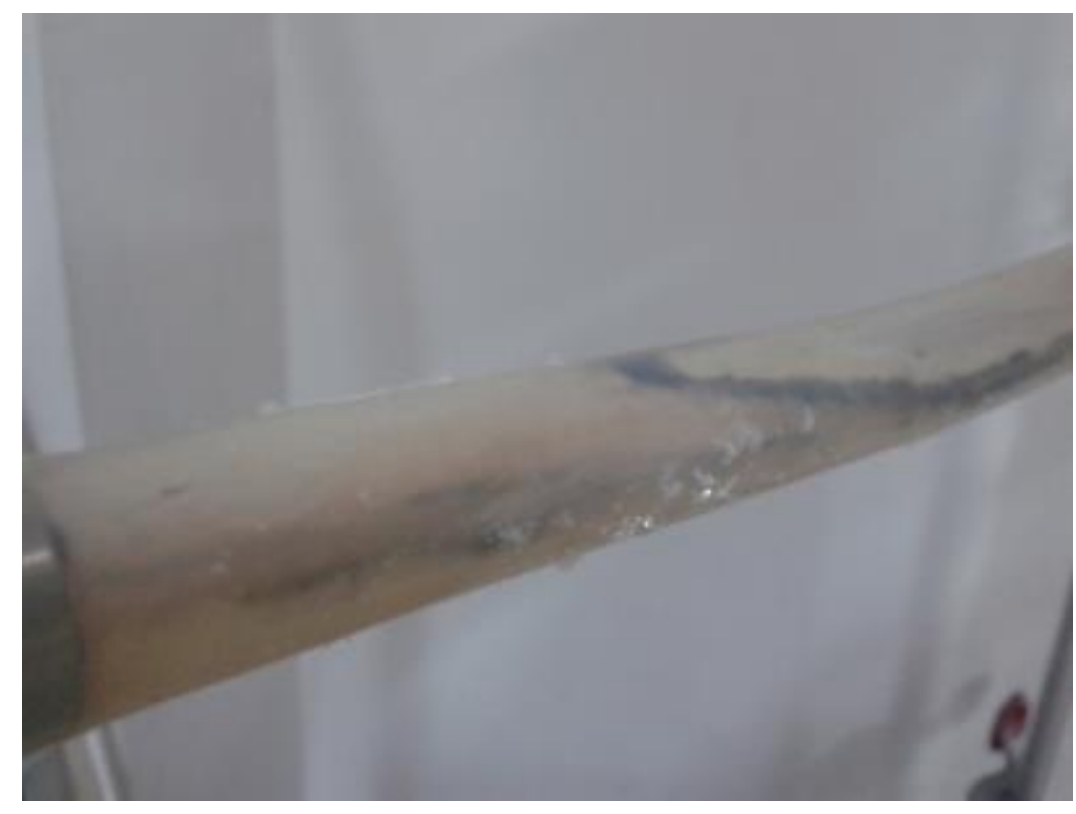

Figura 5-347 - Indícios de produção de $\mathrm{H}_{2} \mathrm{~S}$ nas mangueiras de recirculação.

A Condição 7 foi operada com leite desnatado longa vida com o intuito de verificar se o problema na produção de hidrogênio com o soro de leite como substrato estava relacionado com alguma possível contaminação deste. Esta hipótese seria confirmada caso uma produção de hidrogênio estável fosse atingida, tendo em vista que o leite longa vida é esterilizado. A operação com leite desnatado longa vida, porém, atingiu valores de concentração de hidrogênio iguais a zero no final da operação, dando indícios que a instabilidade na produção de hidrogênio com o soro de leite não foi ocasionada por alguma contaminação. Nesta condição também foram presenciados indícios de produção de $\mathrm{H}_{2} \mathrm{~S}$ (odor característico e formação de substância branca recobrindo o exterior das mangueiras de alimentação) por possível ação de bactérias redutoras de sulfato $(\mathrm{BRS})$.

Tendo em vista os indícios de produção de $\mathrm{H}_{2} \mathrm{~S}$, optou-se na Condição 8 em alimentar o reator apenas com soro de leite e bicarbonato de sódio, retirando-se a ureia e a suplmentação de nutrientes. Esta solução de nutrientes, adaptado de Del Nery (1987) continha uma quantidade aproximada de $13 \mathrm{mgSO}_{4} / \mathrm{L}$ no meio de alimentação (provenientes do sulfato de níquel e do sulfato ferroso), quantidade que pode ser 
considerada alta para um nutriente que é requisitado em pequenas quantidades para o crescimento celular. Além disso, lavagens do material suporte foram realizadas buscando um maior controle da biomassa dentro do reator.

A nova estratégia de operação surtiu efeito, eliminando os indícios de ação de bactérias redutoras de sulfato (BRS), que provavelmente estavam consumindo o hidrogênio na presença do sulfato em excesso de acordo com a reação:

$$
\mathrm{SO}_{4}^{2-}+4 \mathrm{H}_{2} \rightarrow \mathrm{H}_{2} \mathrm{~S}+2 \mathrm{H}_{2} \mathrm{O}+2 \mathrm{OH}^{-}(\Delta \mathrm{G}=-154 \mathrm{KJ}) .
$$

A produção de hidrogênio, porém, começou a apresentar uma queda juntamente com a produção do biogás, sem apresentar sinais de produção de $\mathrm{H}_{2} \mathrm{~S}$ ou de $\mathrm{CH}_{4}$. Assim optou-se por realizar lavagens do material suporte rotineiramente. Estas lavagens surtiram efeito no crescimento celular dentro do reator, removendo cada vez menos quantidades de biomassa (medida pela massa de SVT) e controlando as concentrações de $\mathrm{C}_{\mathrm{x}}$ e de $\mathrm{C}_{\mathrm{x}}$ ' (indicadores da quantidade de biomassa por volume de meio reacional e por massa de material suporte, respectivamente) em valores baixos.

A retirada da solução de nutrientes e da ureia do meio de alimentação em conjunto com a refrigeração deste e com a lavagem periódica do material suporte deram condições operacionais para atingir uma estabilidade na produção de hidrogênio, como pode ser observado entre os dias 324 e 331 nas Figura 5-345 e Figura 5-346.

A Tabela 5.82 apresenta os resultados dos indicadores de produção de biohidrogênio obtidos nas condições onde ocorreu estabilidade do processo (Condição 2 - sacarose; Condição 3 - lactose; Condição 8 - soro de leite). A sacarose apresentou melhores valores dos indicadores de produção de biohidrogênio do que a lactose, o que ser justificado pela melhor degradabilidade, e o soro apresentou melhor produção de 
hidrogênio do que a lactose, fato este interessante por se tratar de um substrato complexo.

Tabela 5.82 - Indicadores de desempenho de produção de biohidrogênio nas condições com sacarose e lactose.

\begin{tabular}{|c|c|c|c|c|c|c|c|c|}
\hline Substrato & $\mathrm{RMCR}_{\mathrm{C}, \mathrm{n}}$ & $\mathrm{nH}_{2}$ & PrM & PrME & $\mathrm{RMCA}_{\mathrm{S}, \mathrm{m}}$ & $\mathrm{RMCA}_{\mathrm{C}, \mathrm{m}}$ & $\mathrm{RMCR}_{\mathrm{S}, \mathrm{m}}$ & $\mathrm{RMCR}_{\mathrm{C}, \mathrm{m}}$ \\
\hline Sacarose & 1,5 & 0,11 & 31,1 & - & 3,3 & 3,7 & 16,4 & 4,5 \\
\hline Lactose & 0,48 & 0,04 & 10,5 & 2,1 & 1,2 & 1,3 & 6,9 & 1,4 \\
\hline $\begin{array}{l}\text { Soro de } \\
\text { leite }\end{array}$ & 0,60 & 0,07 & 18,1 & 4,3 & 1,4 & 1,7 & 4,5 & 1,7 \\
\hline Metabólito & \multicolumn{5}{|c|}{ Rota metabólica } & \multicolumn{2}{|c|}{$\begin{array}{l}\mathrm{RMCR}_{\mathrm{C}, \mathrm{n}} \\
\text { teórico }\end{array}$} & $\begin{array}{c}\mathrm{RMCA}_{\mathrm{C}, \mathrm{m}} \\
\text { teórico }\end{array}$ \\
\hline Ác. Acético & \multicolumn{5}{|c|}{$\mathrm{C}_{12} \mathrm{H}_{22} \mathrm{O}_{11}+5 \mathrm{H}_{2} \mathrm{O} \rightarrow 4 \mathrm{CH}_{3} \mathrm{COOH}+4 \mathrm{CO}_{2}+8 \mathrm{H}_{2}$} & \multicolumn{2}{|c|}{8} & 23,4 \\
\hline Ác. Butírico & \multicolumn{5}{|c|}{$\mathrm{C}_{12} \mathrm{H}_{22} \mathrm{O}_{11}+2 \mathrm{H}_{2} \mathrm{O} \rightarrow 2 \mathrm{CH}_{3} \mathrm{CH}_{2} \mathrm{CH}_{2} \mathrm{COOH}+4 \mathrm{CO}_{2}+4 \mathrm{H}_{2}$} & \multicolumn{2}{|c|}{4} & 11,7 \\
\hline
\end{tabular}

Unidades: $\mathrm{RMCR}_{\mathrm{C}, \mathrm{n}}-\mathrm{molH}_{2}$. molCarboidrato ${ }^{-1}$

$\mathrm{nH}_{2}-\mathrm{molH}_{2} \cdot \mathrm{d}^{-1}$

PrM - $\mathrm{molH}_{2} \cdot \mathrm{m}^{-3} \cdot \mathrm{d}^{-1}$

$\mathrm{RMCA}_{\mathrm{s}, \mathrm{m}}-\mathrm{molH}_{2} \cdot \mathrm{kgDQO}^{-1}$

$\mathrm{RMCA}_{\mathrm{C}, \mathrm{m}}-\mathrm{molH}_{2} \cdot \mathrm{kgCarboidrato}^{-1}$

$\mathrm{RMCR}_{\mathrm{S}, \mathrm{m}}-\mathrm{molH}_{2} \cdot \mathrm{kgDQO}^{-1}$

$\mathrm{RMCR}_{\mathrm{C}, \mathrm{m}}-$ mol.kgCarboidrato ${ }^{-1}$ 


\subsubsection{AnSBBR com recirculação da fase líquida - Efeito de importantes} parâmetros operacionais (concentração afluente do substrato, tempo de enchimento e temperatura) na produção de biohidrogênio.

Após atingir a estabilidade na produção de hidrogênio utilizando as estratégias operacionais descritas anteriormente, o presente estudo prosseguiu analisando o efeito da concentração afluente, do tempo de enchimento e da temperatura na produção de biohidrogênio a partir do soro de leite. Em todas as condições estudadas nesta segunda etapa do projeto foi utilizado um tempo de ciclo de 3 horas. Esta segunda fase de experimentos durou 166 dias (incluindo a Condição 8, que também foi contabilizada na fase anterior).

O efeito da concentração afluente foi estudado a partir dos seguintes valores: $4250 \mathrm{mg} \cdot \mathrm{L}^{-1}$ (Condição 8 - C8), $6350 \mathrm{mg} \cdot \mathrm{L}^{-1}$ (Condição 9 - C9) e $5400 \mathrm{mg} \cdot \mathrm{L}^{-1}$ (Condição 10 - C10). Com a melhor condição obtida nesta primeira etapa (C10 - 5400 mg. $\mathrm{L}^{-1}$ ) estudou-se o efeito do tipo de alimentação (Condição 11 - C11) utilizando as mesmas condições experimentais da C10 mudando apenas o tempo de enchimento do reator (ao invés de alimentar o reator em 10 minutos, encheu-se o reator em 50\% do tempo de ciclo, ou seja, em 1 hora e 30 minutos). Por último avaliou-se o efeito da temperatura, utilizando os resultados da C10 (que foi operada em uma temperatura de $30^{\circ} \mathrm{C}$ ) e repetindo as mesmas condições experimentais desta, mudando apenas a temperatura para $45^{\circ} \mathrm{C}$ (Condição 12 - C12) e para $15^{\circ} \mathrm{C}$ (Condição 13 - C13).

A Figura 5-348 apresenta as concentrações de matéria orgânica na forma de DQO utilizadas enquanto que a Figura 5-349 mostra a eficiência de remoção É possível 
observar que esta eficiência manteve-se baixa, com valores médios próximos a 20\%, o que é esperado em um processo acidogênico. 


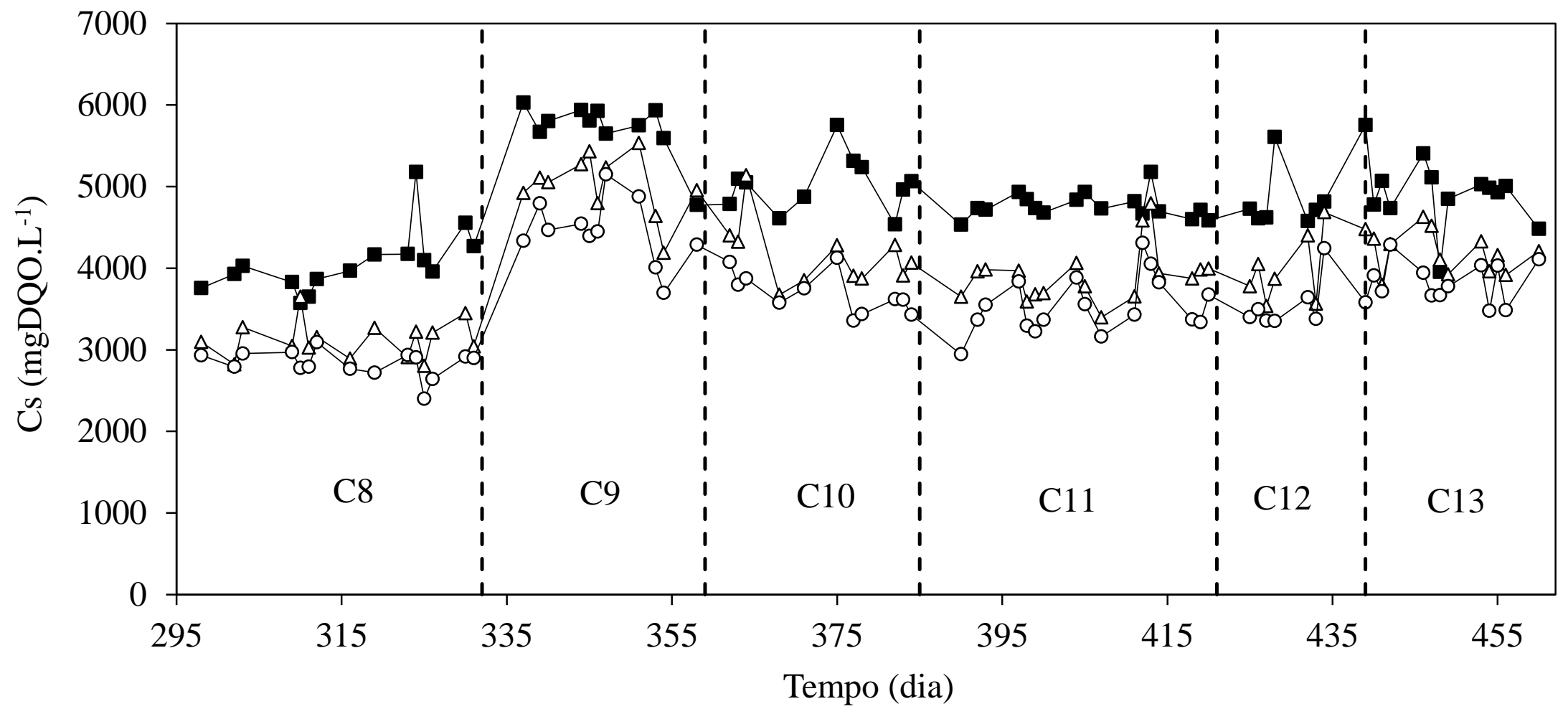

Figura 5-348 - Concentração de matéria orgânica (DQO): $\square$ - afluente não filtrada; $\Delta$ - efluente não filtrada; $\bigcirc$ - efluente filtrada (Soro de leite: $\mathrm{C} 8=\mathrm{t}_{\mathrm{C}}=3$ horas, $\mathrm{C}_{\mathrm{ST}}=4250 \mathrm{mgDQO} \cdot \mathrm{L}^{-1}-30^{\circ} \mathrm{C} ; \mathrm{C} 9=\mathrm{t}_{\mathrm{C}}=3$ horas, $\mathrm{C}_{\mathrm{ST}}=6350 \mathrm{mgDQO} . \mathrm{L}^{-1}-30^{\circ} \mathrm{C} ; \mathrm{C} 10=\mathrm{t}_{\mathrm{C}}=3$ horas, $\mathrm{C}_{\mathrm{ST}}=5500$ $\operatorname{mgDQO} . \mathrm{L}^{-1}-30^{\circ} \mathrm{C} ; \mathrm{C} 11=\mathrm{t}_{\mathrm{C}}=3$ horas, $\mathrm{C}_{\mathrm{ST}}=5500 \mathrm{mgDQO} \cdot \mathrm{L}^{-1}-30^{\circ} \mathrm{C}-$ Batelada alimentada $\left(\mathrm{t}_{\mathrm{A}}=0,5 . \mathrm{t}_{\mathrm{C}}=1,5\right.$ horas $) ; \mathrm{C} 12=\mathrm{t}_{\mathrm{C}}=3$ horas, $\mathrm{C}_{\mathrm{ST}}$ $=5500 \mathrm{mgDQO} \cdot \mathrm{L}^{-1}-45^{\circ} \mathrm{C} ; \mathrm{C} 13=\mathrm{t}_{\mathrm{C}}=3$ horas, $\left.\mathrm{C}_{\mathrm{ST}}=5500 \mathrm{mgDQO} \cdot \mathrm{L}^{-1}-15^{\circ} \mathrm{C}\right)$. 


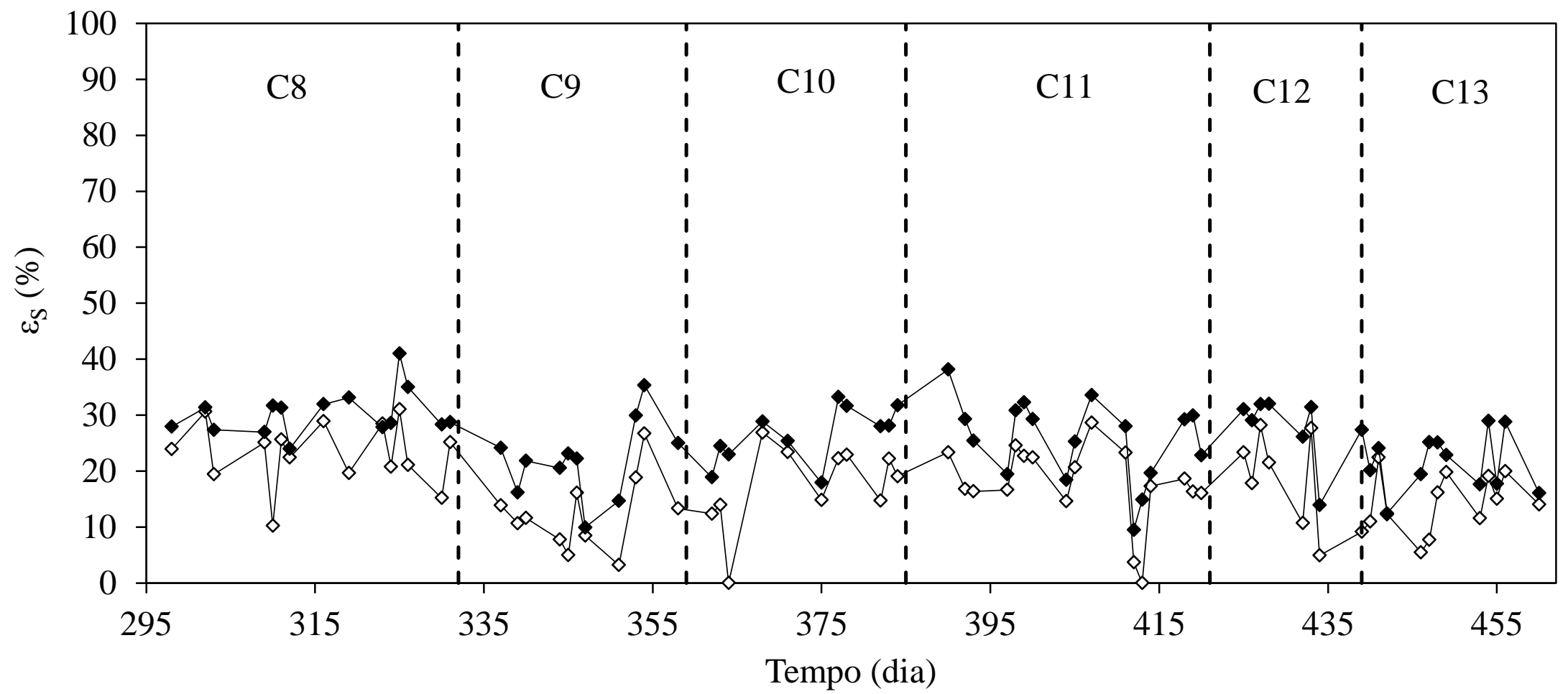

Figura 5-349 - Eficiência de remoção de matéria orgânica (DQO): $\diamond$ - não filtrada; - filtrada (Soro de leite: $\mathrm{C} 8=\mathrm{t}_{\mathrm{C}}=3$ horas, $\mathrm{C}_{\mathrm{ST}}=4250$ $\operatorname{mgDQO} . \mathrm{L}^{-1}-30^{\circ} \mathrm{C} ; \mathrm{C} 9=\mathrm{t}_{\mathrm{C}}=3$ horas, $\mathrm{C}_{\mathrm{ST}}=6350 \mathrm{mgDQO} . \mathrm{L}^{-1}-30^{\circ} \mathrm{C} ; \mathrm{C} 10=\mathrm{t}_{\mathrm{C}}=3$ horas, $\mathrm{C}_{\mathrm{ST}}=5500 \mathrm{mgDQO} . \mathrm{L}^{-1}-30^{\circ} \mathrm{C} ; \mathrm{C}_{11}=\mathrm{t}_{\mathrm{C}}=3$ horas, $\mathrm{C}_{\mathrm{ST}}=5500 \mathrm{mgDQO} \cdot \mathrm{L}^{-1}-30^{\circ} \mathrm{C}-$ Batelada alimentada $\left(\mathrm{t}_{\mathrm{A}}=0,5 \cdot \mathrm{t}_{\mathrm{C}}=1,5\right.$ horas $) ; \mathrm{C} 12=\mathrm{t}_{\mathrm{C}}=3$ horas, $\mathrm{C}_{\mathrm{ST}}=5500 \mathrm{mgDQO}^{\circ} \mathrm{L}^{-1}-45^{\circ} \mathrm{C} ; \mathrm{C} 13=\mathrm{t}_{\mathrm{C}}=3$ horas, $\left.\mathrm{C}_{\mathrm{ST}}=5500 \mathrm{mgDQO} \cdot \mathrm{L}^{-1}-15^{\circ} \mathrm{C}\right)$. 
A Figura 5-350 apresenta o comportamento da concentração de carboidratos afluente e efluente nas condições C8, C9, C10, C11, C12 e C13. É possível observar que praticamente toda a lactose introduzida no reator foi consumida em todas as condições. A Figura 5-351 exibe a eficiência de conversão de carboidratos, sempre com valores elevados e se apresentando estável. Os trechos com baixa remoção foram ocasionados, mais uma vez, por alguns fatores pontuais, como mudança de condição. A queda brusca na C11 foi ocasionada por uma recuperação do sistema durante a operação em batelada alimentada. Mesmo a C12 que no final parou de produzir hidrogênio e passou a produzir metano apresentou uma excelente remoção de carboidratos. Por último, a C13 operada com a menor temperatura apresentou uma remoção de carboidratos com menor velocidade, levando mais tempo do que as demais condições para ultrapassar o valor de remoção de $90 \%$ e permanecendo na estabilidade (ao contrário das outras condições que atingiram $99 \%$ de remoção de carboidratos na estabilidade). 


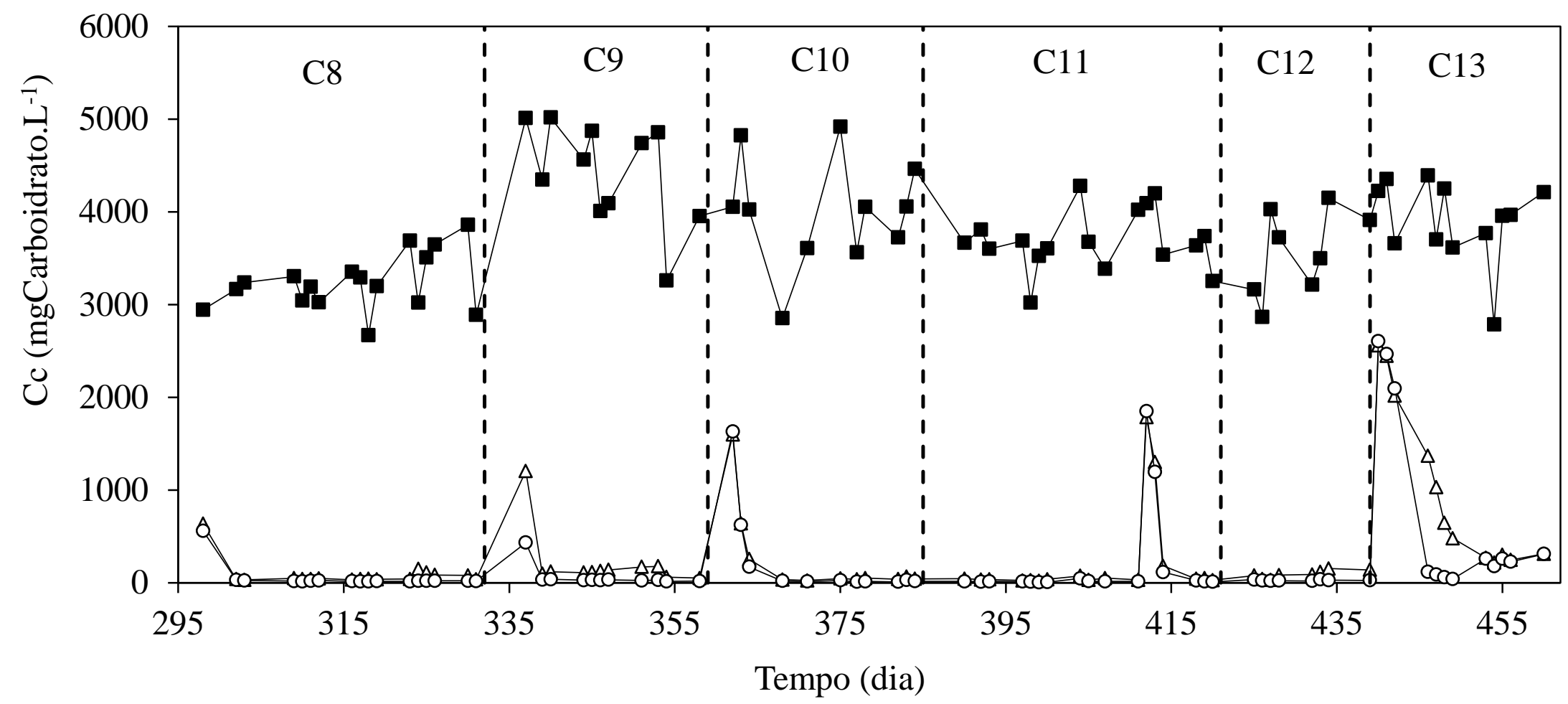

Figura 5-350 - Concentração de carboidrato: $\square-$ afluente não filtrada; $\Delta$ - efluente não filtrada; $\circ-$ efluente filtrada (Soro de leite: $\mathrm{C} 8=\mathrm{t}_{\mathrm{C}}=3$ horas, $\mathrm{C}_{\mathrm{ST}}=4250 \mathrm{mgDQO} . \mathrm{L}^{-1}-30^{\circ} \mathrm{C} ; \mathrm{C} 9=\mathrm{t}_{\mathrm{C}}=3$ horas, $\mathrm{C}_{\mathrm{ST}}=6350 \mathrm{mgDQO} . \mathrm{L}^{-1}-30^{\circ} \mathrm{C} ; \mathrm{C} 10=\mathrm{t}_{\mathrm{C}}=3$ horas, $\mathrm{C}_{\mathrm{ST}}=5500 \mathrm{mgDQO} . \mathrm{L}^{-1}-30^{\circ} \mathrm{C}$; $\mathrm{C} 11=\mathrm{t}_{\mathrm{C}}=3$ horas, $\mathrm{C}_{\mathrm{ST}}=5500 \mathrm{mgDQO} \cdot \mathrm{L}^{-1}-30^{\circ} \mathrm{C}-$ Batelada alimentada $\left(\mathrm{t}_{\mathrm{A}}=0,5 . \mathrm{t}_{\mathrm{C}}=1,5\right.$ horas $) ; \mathrm{C} 12=\mathrm{t}_{\mathrm{C}}=3$ horas, $\mathrm{C}_{\mathrm{ST}}=5500 \mathrm{mgDQO} \cdot \mathrm{L}^{-1}-$ $45^{\circ} \mathrm{C} ; \mathrm{C} 13=\mathrm{t}_{\mathrm{C}}=3$ horas, $\left.\mathrm{C}_{\mathrm{ST}}=5500 \mathrm{mgDQO} \cdot \mathrm{L}^{-1}-15^{\circ} \mathrm{C}\right)$. 


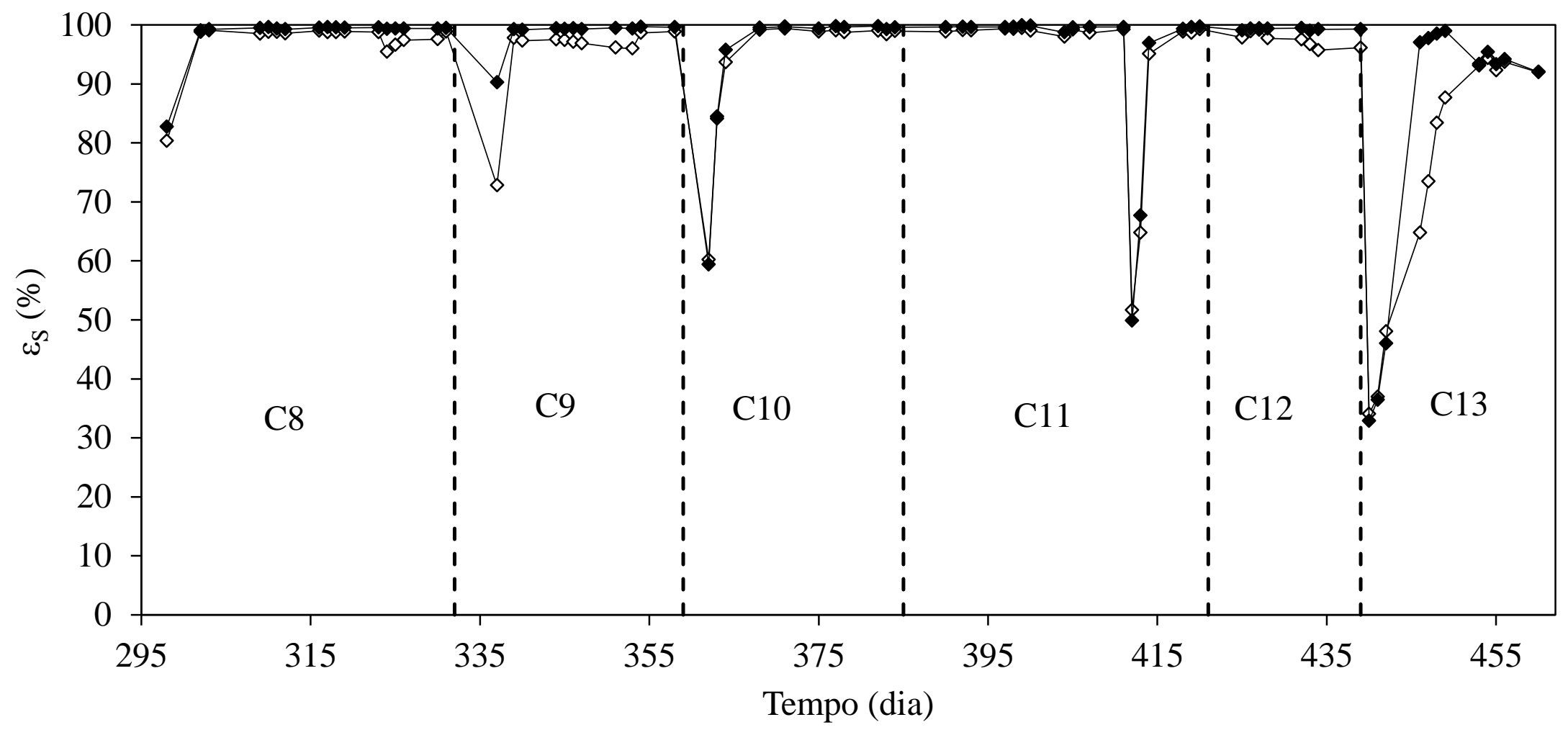

Figura 5-351 - Eficiência de remoção de carboidrato: $\diamond$ - não filtrada; - filtrada (Soro de leite: $\mathrm{C} 8=\mathrm{t}_{\mathrm{C}}=3$ horas, $\mathrm{C}_{\mathrm{ST}}=4250 \mathrm{mgDQO} . \mathrm{L}^{-1}-$ $30^{\circ} \mathrm{C} ; \mathrm{C} 9=\mathrm{t}_{\mathrm{C}}=3$ horas, $\mathrm{C}_{\mathrm{ST}}=6350 \mathrm{mgDQO} . \mathrm{L}^{-1}-30^{\circ} \mathrm{C} ; \mathrm{C} 10=\mathrm{t}_{\mathrm{C}}=3$ horas, $\mathrm{C}_{\mathrm{ST}}=5500 \mathrm{mgDQO} . \mathrm{L}^{-1}-30^{\circ} \mathrm{C} ; \mathrm{C} 11=\mathrm{t}_{\mathrm{C}}=3 \mathrm{horas}, \mathrm{C}_{\mathrm{ST}}=5500$ $\operatorname{mgDQO} . \mathrm{L}^{-1}-30^{\circ} \mathrm{C}-$ Batelada alimentada $\left(\mathrm{t}_{\mathrm{A}}=0,5 . \mathrm{t}_{\mathrm{C}}=1,5\right.$ horas $) ; \mathrm{C} 12=\mathrm{t}_{\mathrm{C}}=3$ horas, $\mathrm{C}_{\mathrm{ST}}=5500 \operatorname{mgDQO} \cdot \mathrm{L}^{-1}-45^{\circ} \mathrm{C} ; \mathrm{C} 13=\mathrm{t}_{\mathrm{C}}=3$ horas $\mathrm{C}_{\mathrm{ST}}$ $=5500 \mathrm{mgDQO} \cdot \mathrm{L}^{-1}-15^{\circ} \mathrm{C}$ ). 
A Figura 5-352 mostra a distribuição dos valores de $\mathrm{pH}$ afluente e efluente e a Figura 5-353 apresenta os ácidos voláteis totais, para as condições C8 a C13. Os ácidos voláteis totais apresentaram valores estáveis, sofrendo alterações de valores ocasionadas pela mudança das concentrações de matéria orgânica na alimentação e pela lavagem do material suporte, o que era esperado. 


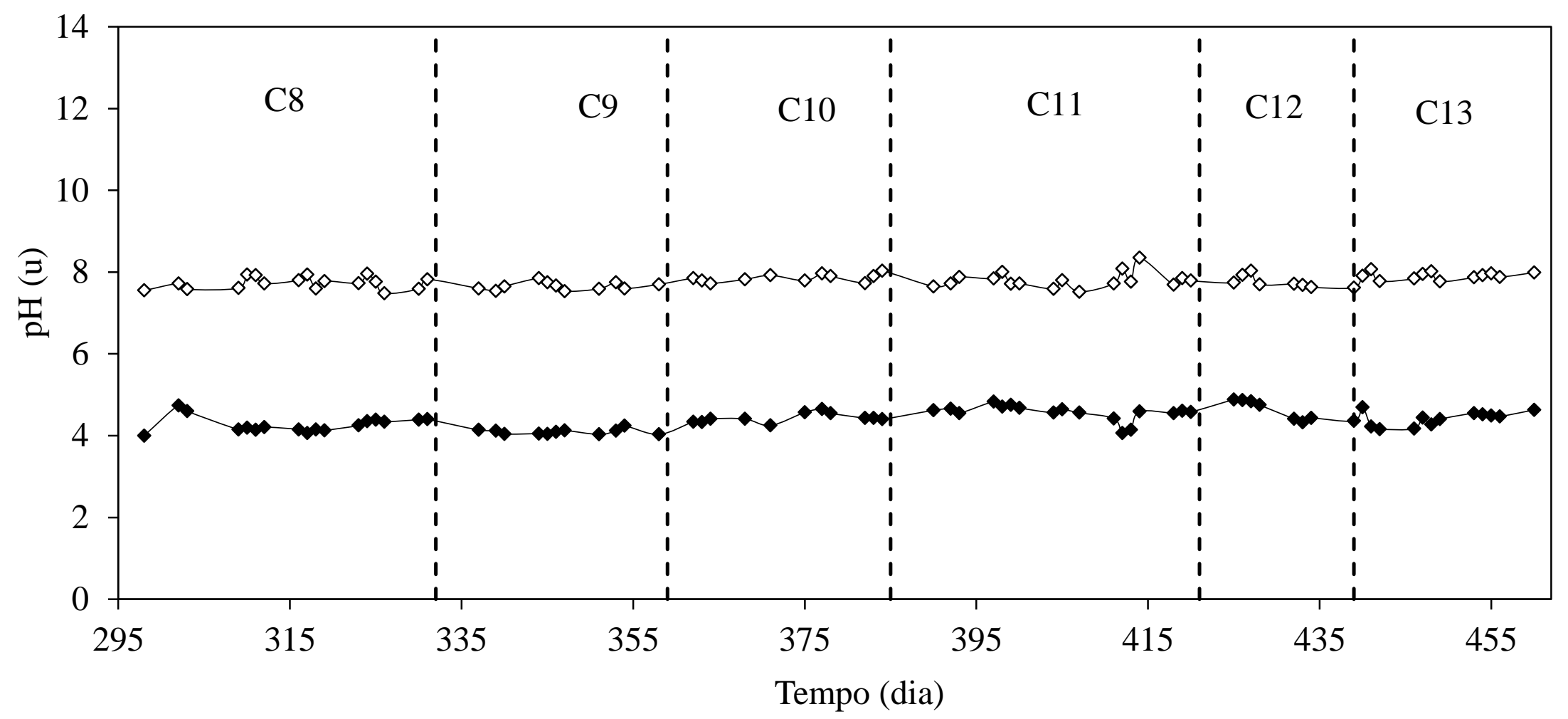

Figura 5-352 - Valores de $\mathrm{pH}: \diamond$-afluente; - efluente (Soro de leite: $\mathrm{C} 8=\mathrm{t}_{\mathrm{C}}=3$ horas, $\mathrm{C}_{\mathrm{ST}}=4250 \mathrm{mgDQO} \cdot \mathrm{L}^{-1}-30^{\circ} \mathrm{C}$; $\mathrm{C} 9=\mathrm{t}_{\mathrm{C}}=3$ horas, $\mathrm{C}_{\mathrm{ST}}$ $=6350 \mathrm{mgDQO} . \mathrm{L}^{-1}-30^{\circ} \mathrm{C} ; \mathrm{C} 10=\mathrm{t}_{\mathrm{C}}=3$ horas, $\mathrm{C}_{\mathrm{ST}}=5500 \mathrm{mgDQO} \cdot \mathrm{L}^{-1}-30^{\circ} \mathrm{C} ; \mathrm{C} 11=\mathrm{t}_{\mathrm{C}}=3$ horas, $\mathrm{C}_{\mathrm{ST}}=5500 \mathrm{mgDQO} \cdot \mathrm{L}^{-1}-30^{\circ} \mathrm{C}-\mathrm{Batelada}$ alimentada $\left(\mathrm{t}_{\mathrm{A}}=0,5 . \mathrm{t}_{\mathrm{C}}=1,5\right.$ horas $) ; \mathrm{C} 12=\mathrm{t}_{\mathrm{C}}=3$ horas, $\mathrm{C}_{\mathrm{ST}}=5500 \mathrm{mgDQO} \cdot \mathrm{L}^{-1}-45^{\circ} \mathrm{C} ; \mathrm{C} 13=\mathrm{t}_{\mathrm{C}}=3$ horas, $\left.\mathrm{C}_{\mathrm{ST}}=5500 \mathrm{mgDQO} \cdot \mathrm{L}^{-1}-15^{\circ} \mathrm{C}\right)$. 


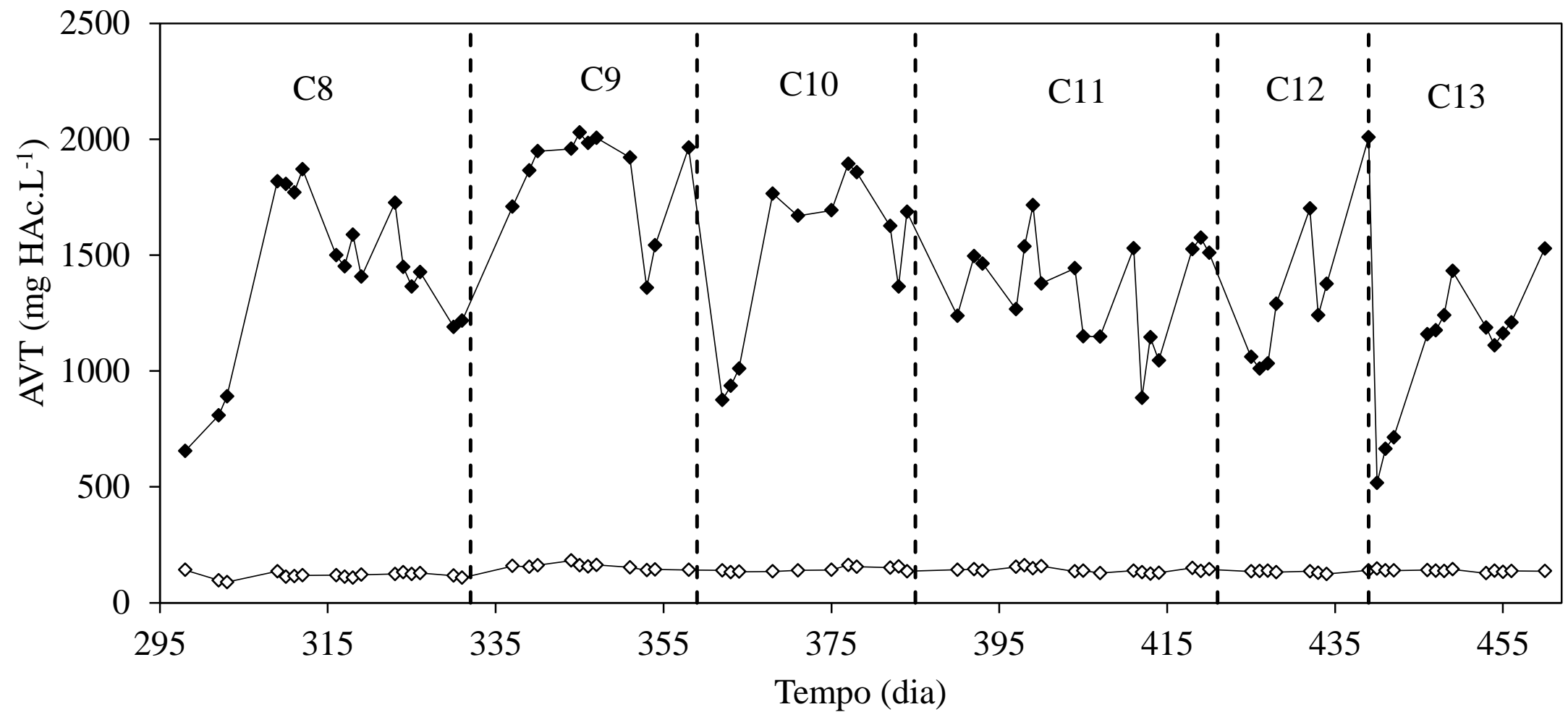

Figura 5-353 - Valores de $\mathrm{pH}: \diamond$-afluente; - efluente (Soro de leite: $\mathrm{C} 8=\mathrm{t}_{\mathrm{C}}=3$ horas, $\mathrm{C}_{\mathrm{ST}}=4250 \mathrm{mgDQO} \cdot \mathrm{L}^{-1}-30^{\circ} \mathrm{C}$; $\mathrm{C} 9=\mathrm{t}_{\mathrm{C}}=3$ horas, $\mathrm{C}_{\mathrm{ST}}$ $=6350 \mathrm{mgDQO} \cdot \mathrm{L}^{-1}-30^{\circ} \mathrm{C} ; \mathrm{C} 10=\mathrm{t}_{\mathrm{C}}=3$ horas, $\mathrm{C}_{\mathrm{ST}}=5500 \mathrm{mgDQO} \cdot \mathrm{L}^{-1}-30^{\circ} \mathrm{C} ; \mathrm{C} 11=\mathrm{t}_{\mathrm{C}}=3$ horas, $\mathrm{C}_{\mathrm{ST}}=5500 \mathrm{mgDQO} \cdot \mathrm{L}^{-1}-30^{\circ} \mathrm{C}-\mathrm{Batelada}$ alimentada $\left(\mathrm{t}_{\mathrm{A}}=0,5 . \mathrm{t}_{\mathrm{C}}=1,5\right.$ horas $) ; \mathrm{C} 12=\mathrm{t}_{\mathrm{C}}=3$ horas, $\mathrm{C}_{\mathrm{ST}}=5500 \mathrm{mgDQO} \cdot \mathrm{L}^{-1}-45^{\circ} \mathrm{C} ; \mathrm{C} 13=\mathrm{t}_{\mathrm{C}}=3$ horas, $\left.\mathrm{C}_{\mathrm{ST}}=5500 \mathrm{mgDQO} \cdot \mathrm{L}^{-1}-15^{\circ} \mathrm{C}\right)$. 
A Figura 5-354 apresenta as concentrações de produtos intermediários em todas as condições nas quais as. Os metabólitos com maior destaque foram o ácido acético, o ácido butírico e o etanol. Para a C12 não foram realizados monitoramentos dos produtos intermediários, tendo em vista que nesta condição não houve produção de hidrogênio no final do ciclo. 


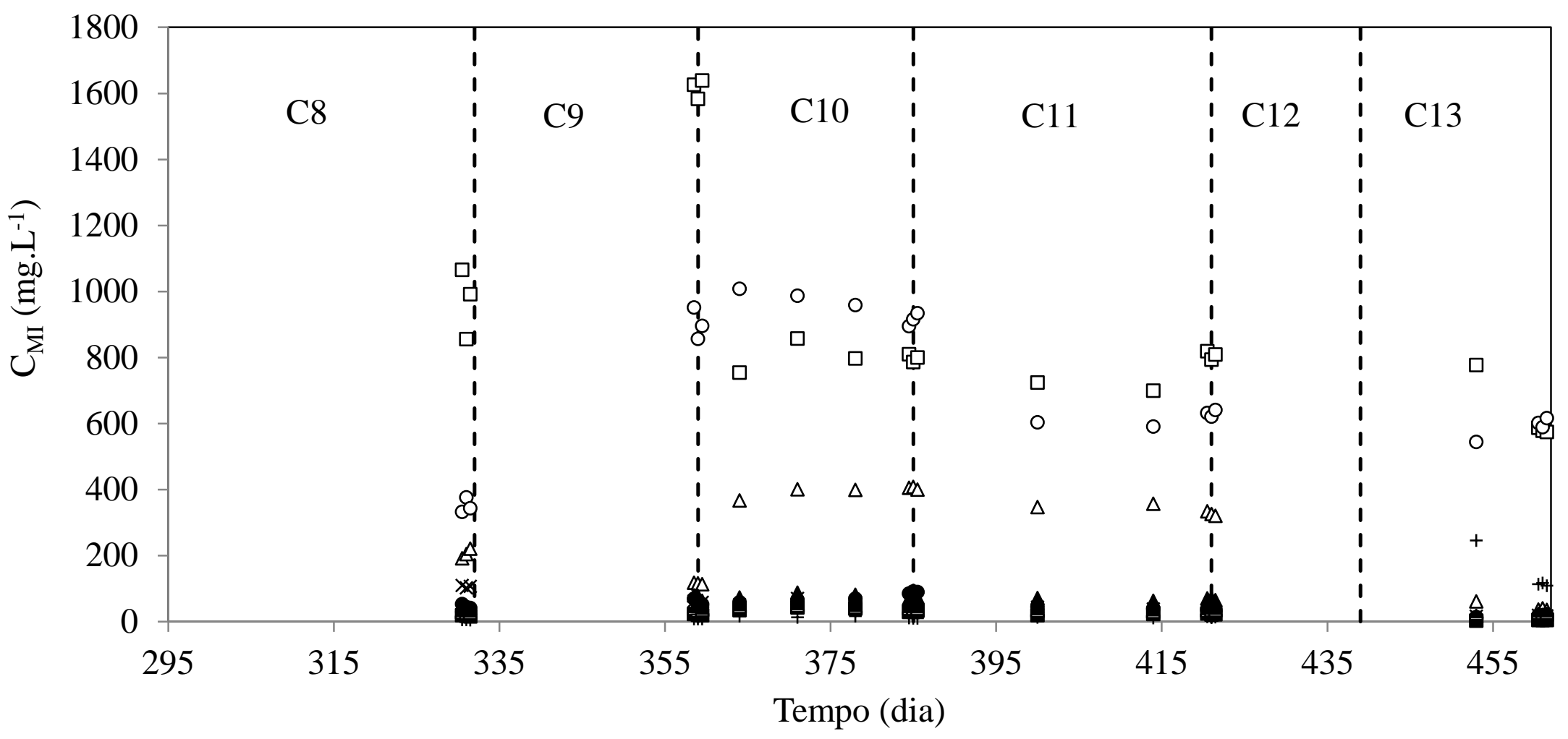

Figura 5-354 - Concentração dos compostos intermediários durante o monitoramento: $\square$ - ácido acético; $\Delta$ - etanol; 0 - ácido butírico; $\mathbf{-}$ - ácido isobutírico; $\boldsymbol{\Delta}$ - ácido capróico; $\bullet$ - ácido valérico; - $\mathrm{x}$ - ácido propiônico; -|-butanol; - ácido isovalérico (Soro de leite: $\mathrm{C} 8=\mathrm{t}_{\mathrm{C}}=3 \mathrm{horas}, \mathrm{C}_{\mathrm{ST}}=$ $4250 \mathrm{mgDQO} . \mathrm{L}^{-1}-30^{\circ} \mathrm{C} ; \mathrm{C} 9=\mathrm{t}_{\mathrm{C}}=3$ horas, $\mathrm{C}_{\mathrm{ST}}=6350 \mathrm{mgDQO} . \mathrm{L}^{-1}-30^{\circ} \mathrm{C} ; \mathrm{C} 10=\mathrm{t}_{\mathrm{C}}=3$ horas, $\mathrm{C}_{\mathrm{ST}}=5500 \mathrm{mgDQO} . \mathrm{L}^{-1}-30^{\circ} \mathrm{C} ; \mathrm{C} 11=\mathrm{t}_{\mathrm{C}}=3$ horas, $\mathrm{C}_{\mathrm{ST}}=5500 \mathrm{mgDQO} . \mathrm{L}^{-1}-30^{\circ} \mathrm{C}-$ Batelada alimentada $\left(\mathrm{t}_{\mathrm{A}}=0,5 . \mathrm{t}_{\mathrm{C}}=1,5\right.$ horas $) ; \mathrm{C} 12=\mathrm{t}_{\mathrm{C}}=3$ horas, $\mathrm{C}_{\mathrm{ST}}=5500 \mathrm{mgDQO} \cdot \mathrm{L}^{-1}-45^{\circ} \mathrm{C} ; \mathrm{C} 13=$ $\mathrm{t}_{\mathrm{C}}=3$ horas, $\mathrm{C}_{\mathrm{ST}}=5500 \mathrm{mgDQO} \cdot \mathrm{L}^{-1}-15^{\circ} \mathrm{C}$ ). 
A Figura 5-355 apresenta a vazão volumétrica do biogás e as vazões molares de cada componente deste biogás. Em todas as condições a estabilidade na produção de hidrogênio foi atingida no final da operação, exceto na condição C12. 


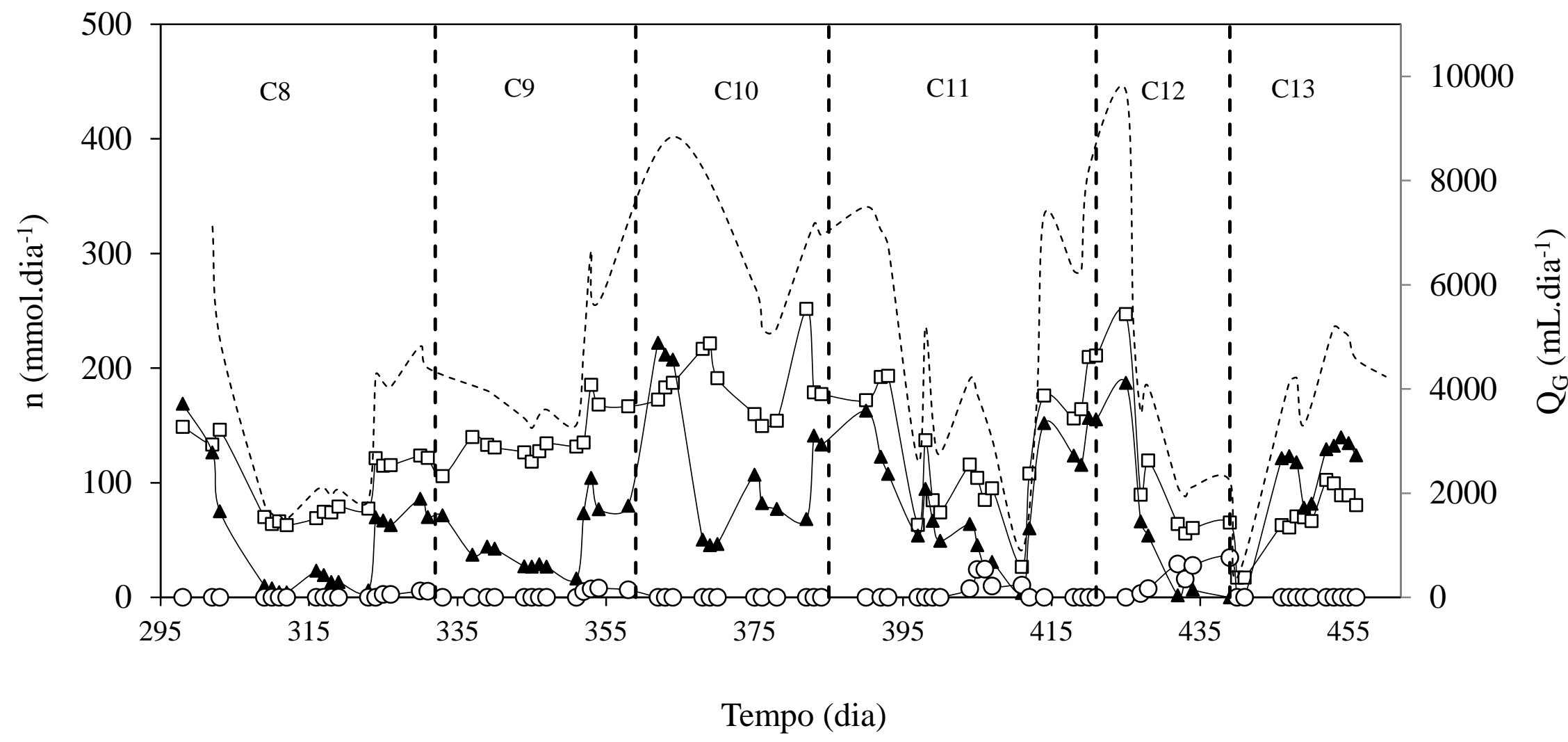

Figura 5-355 - Vazão molar de cada componente do biogás $\left(\square-\mathrm{CO}_{2} ; \boldsymbol{\Delta}-\mathrm{H}_{2} ; \circ-\mathrm{CH}_{4}\right)$ e vazão volumétrica do biogás (- -) (Soro de leite: $\mathrm{C} 8=$ $\mathrm{t}_{\mathrm{C}}=3$ horas, $\mathrm{C}_{\mathrm{ST}}=4250 \mathrm{mgDQO} . \mathrm{L}^{-1}-30^{\circ} \mathrm{C} ; \mathrm{C} 9=\mathrm{t}_{\mathrm{C}}=3$ horas, $\mathrm{C}_{\mathrm{ST}}=6350 \mathrm{mgDQO} . \mathrm{L}^{-1}-30^{\circ} \mathrm{C} ; \mathrm{C} 10=\mathrm{t}_{\mathrm{C}}=3$ horas, $\mathrm{C}_{\mathrm{ST}}=5500 \mathrm{mgDQO} . \mathrm{L}^{-1}-$ $30^{\circ} \mathrm{C} ; \mathrm{C} 11=\mathrm{t}_{\mathrm{C}}=3$ horas, $\mathrm{C}_{\mathrm{ST}}=5500 \mathrm{mgDQO} . \mathrm{L}^{-1}-30^{\circ} \mathrm{C}-$ Batelada alimentada $\left(\mathrm{t}_{\mathrm{A}}=0,5 . \mathrm{t}_{\mathrm{C}}=1,5\right.$ horas $) ; \mathrm{C} 12=\mathrm{t}_{\mathrm{C}}=3$ horas, $\mathrm{C}_{\mathrm{ST}}=5500$ $\operatorname{mgDQO} . \mathrm{L}^{-1}-45^{\circ} \mathrm{C} ; \mathrm{C} 13=\mathrm{t}_{\mathrm{C}}=3$ horas, $\left.\mathrm{C}_{\mathrm{ST}}=5500 \mathrm{mgDQO} \cdot \mathrm{L}^{-1}-15^{\circ} \mathrm{C}\right)$. 
O efeito da concentração afluente foi analisado comparando-se as condições C8 (4250 mg.L $\left.{ }^{-1}\right)$, C9 (6350 mg.L $\left.\mathrm{L}^{-1}\right)$ e C10 (5400 mg.L $\left.\mathrm{L}^{-1}\right)$. Os valores reais médios afluente aplicados ao sistema foram $4067 \mathrm{mg} . \mathrm{L}^{-1}\left(\mathrm{COAV}_{\mathrm{STA}}\right.$ de $\left.13,9 \mathrm{~g} \cdot \mathrm{L}^{-1} \cdot \mathrm{d}^{-1}\right), 5716 \mathrm{mg} . \mathrm{L}^{-1}$ $\left(\mathrm{COAV}_{\mathrm{STA}}\right.$ de 19,6 g.L $\left.\mathrm{L}^{-1} \cdot \mathrm{d}^{-1}\right)$ e $5025 \mathrm{mg} . \mathrm{L}^{-1}\left(\mathrm{COAV}_{\mathrm{STA}}\right.$ de $\left.17,2 \mathrm{~g} . \mathrm{L}^{-1} \cdot \mathrm{d}^{-1}\right)$ para as condições C8, C9 e C10, respectivamente.

A remoção de matéria orgânica na forma de DQO atingiu valores médios entre $20 \%$ e 30\% para C8, C9 e C10, o que já era esperado (Figura 5-349). As três condições analisadas também apresentaram um comportamento extremamente similar com relação à remoção de carboidratos, com todas atingindo $99 \%$ de degradação da lactose na estabilidade (Figura 5-351).

A Tabela 5.83 apresenta os resultados dos indicadores de produção de hidrogênio, bem como as concentrações afluentes $\mathrm{COAV}_{\mathrm{SAT}}$ teóricas e reais e a quantidade de biomassa dentro do reator na forma de $\mathrm{M}_{\mathrm{SVT}}$, com todos estes valores relacionados à análise da concentração afluente. É importante ressaltar que os valores utilizados para a comparação são médias obtidas na estabilidade do processo. É possível observar que para todos os indicadores de produção de hidrogênio (tanto os parâmetros intensivos - que estão relacionados com alguma variável que caracterize o "tamanho/capacidade" do sistema - quanto os extensivos) houve um ponto ótimo na C10, onde ocorreu o melhor aproveitamento da biotransformação do substrato consumido para a produção de biogás.

Tendo em vista que as remoções de matéria orgânica na forma de carboidrato foram similares (altas, em torno de 99\%) nas três condições comparadas, não era esperado um ponto de ótimo na concentração intermediária e sim uma crescente produção com o aumento da concentração (principalmente para parâmetros extensivos como a produção molar diária). Porém o aumento da concentração de alimentação pode 
acarretar alguns problemas para a produção de hidrogênio, já que nos processos fermentativos o substrato é utilizado como fonte de energia e convertido em hidrogênio, ácidos orgânicos e álcoois (a depender da rota metabólica utilizada pelos microrganismos envolvidos) e a energia livre de Gibbs dessas reações fermentativas são todas positivas, indicando que não são reações espontâneas. Assim, o acúmulo dessas substâncias pode ocasionar a inibição do processo (Kargi e Pamukoglu, 2009; Sreethawong et al., 2010). Entre estes produtos intermediários citados, uma atenção especial pode ser dada à pressão parcial de $\mathrm{H}_{2}$, que pode atingir altos valores ocasionados pela rápida formação do gás em questão em altas concentrações, principalmente em reatores biológicos que apresentam, na prática, limitações hidrodinâmicas e de transferência de massa entre a fase líquida e gasosa, retendo maiores quantidades do biogás produzido no meio líquido (Lima e Zaiat, 2012).

Pode-se somar a isso um provável nível elevado de homoacetogênese na condição C9 (maior concentração afluente) em relação às outras condições. Uma análise dos metabólitos produzidos (Figura 5-354) para as condições C8, C9, C10 mostra que prevaleceu a produção de ácido acético, ácido butírico e de etanol. Nas duas primeiras condições o ácido acético prevaleceu, atingindo os maiores valores em C9. Na C10, porém, o metabólito produzido em maiores quantidades foi o ácido butírico, além de apresentar a maior concentração de etanol entre as três condições analisadas. Apesar de tanto o ácido acético quanto o ácido butírico serem indicadores de produção de hidrogênio (Levin et al., 2004), a produção do primeiro está relacionada com a homoacetogênese que consume o hidrogênio produzido aumentando as concentrações deste metabólito (Luo et al., 2011). De fato, a C9 foi a que apresentou a pior produção de hidrogênio entre as três condições comparadas, o que pode estar relacionado com 
esta homoacetogênese. Além disso, é importante destacar que a C10 foi a única que não apresentou metano na composição final do biogás.

Tabela 5.83 - Concentração e $\mathrm{COAV}_{\mathrm{SAT}}$ teóricas e reais, indicadores de produção de hidrogênio e quantidade de biomassa dentro do reator - influencia da concentração afluente.

\begin{tabular}{|c|c|c|c|c|}
\hline Indicador & Unidades & $\mathrm{C} 8$ & C9 & $\mathrm{C} 10$ \\
\hline $\begin{array}{c}\text { Concentração afluente } \\
\text { teórica }\end{array}$ & mgDQO.L $L^{-1}$ & 4250 & 6350 & 5400 \\
\hline $\begin{array}{c}\text { Concentração afluente } \\
\text { real }\end{array}$ & mgDQO.L ${ }^{-1}$ & 4067 & 5716 & 5025 \\
\hline $\mathrm{COAV}_{\mathrm{STA}}$ teórica & gDQO.L $L^{-1} \cdot d^{-1}$ & 14,6 & 21,8 & 18,5 \\
\hline $\mathrm{COAV}_{\mathrm{STA}}$ real & gDQO.L ${ }^{-1} \cdot d^{-1}$ & 13,9 & 19,6 & 17,2 \\
\hline $\mathrm{RMCR}_{\mathrm{C}, \mathrm{n}}$ & $\left(\mathrm{molH}_{2} \cdot \mathrm{mol}^{-1}\right.$ lactose $)$ & 0,60 & 0,37 & 0,80 \\
\hline $\mathrm{n}_{\mathrm{H} 2}$ & $\left(\mathrm{molH}_{2} \cdot \mathrm{d}^{-1}\right)$ & 0,07 & 0,06 & 0,11 \\
\hline PrM & $\left(\mathrm{molH}_{2} \cdot \mathrm{m}^{-3} \cdot \mathrm{d}^{-1}\right)$ & 18,1 & 15,9 & 29,3 \\
\hline PrME & $\left(\mathrm{molH}_{2} \cdot \mathrm{kg}^{-1} \mathrm{SVT} . \mathrm{d}^{-1}\right)$ & 4,32 & 1,68 & 6,25 \\
\hline $\mathrm{RMCA}_{\mathrm{S}, \mathrm{m}}$ & $\left(\mathrm{molH}_{2} \cdot \mathrm{kg}^{-1} \mathrm{DQO}\right)$ & 1,37 & 0,83 & 1,84 \\
\hline $\mathrm{RMCA}_{\mathrm{C}, \mathrm{m}}$ & $\left(\mathrm{molH}_{2} \cdot \mathrm{kg}^{-1}\right.$ lactose $)$ & 1,72 & 1,07 & 2,30 \\
\hline $\mathrm{RMCR}_{\mathrm{S}, \mathrm{m}}$ & $\left(\mathrm{molH}_{2} \cdot \mathrm{kg}^{-1} \mathrm{DQO}\right)$ & 4,50 & 3,76 & 6,95 \\
\hline $\mathrm{RMCR}_{\mathrm{C}, \mathrm{m}}$ & $\left(\mathrm{molH}_{2} \cdot \mathrm{kg}^{-1}\right.$ lactose $)$ & 1,73 & 1,07 & 2,31 \\
\hline VHPR & $\left(\mathrm{LH}_{2} \cdot \mathrm{L}^{-1} \cdot \mathrm{d}^{-1}\right)$ & 0,41 & 0,36 & 0,66 \\
\hline Msvt & (g) & 15,5 & 33,9 & 17,8 \\
\hline $\mathrm{X}_{\mathrm{H} 2}$ & $(\%)$ & $35,6 \%$ & $31,6 \%$ & $44,0 \%$ \\
\hline $\mathrm{X}_{\mathrm{CH} 4}$ & $(\%)$ & $2,6 \%$ & $2,5 \%$ & $0,0 \%$ \\
\hline $\mathrm{X}_{\mathrm{CO} 2}$ & $(\%)$ & $61,8 \%$ & $65,9 \%$ & $56,0 \%$ \\
\hline
\end{tabular}


As lavagens do material suporte continuaram sendo realizadas nas Condições C9 e C10, surtindo o mesmo efeito observado na C8 no crescimento celular dentro do reator, removendo cada vez menor quantidade de biomassa (medida pela massa de SVT) e controlando as concentrações de $\mathrm{C}_{\mathrm{x}}$ e de $\mathrm{C}_{\mathrm{x}}$ ' (indicadores da quantidade de biomassa por volume de meio reacional e por massa de material suporte, respectivamente) em valores baixos.

Após a análise da concentração afluente mais propícia para produção de biohidrogênio, foi realizada um estudo da influência do tempo de enchimento no AnSBBR alimentado com soro de leite para obtenção de $\mathrm{H}_{2}$. A condição $\mathrm{C} 10$ (concentração afluente na forma de DQO de $5400 \mathrm{mg} . \mathrm{L}^{-1}$ ) foi repetida alterando-se apenas o tempo de enchimento do reator (ao invés de alimentar o reator em 10 minutos como foi feito na $\mathrm{C} 10$, encheu-se o reator em 50\% do tempo de ciclo, ou seja, em 1 hora e 30 minutos).

A remoção de matéria orgânica na forma de DQO mais uma vez atingiu valores médios entre $20 \%$ e $30 \%$ para C11 (Figura 5-349). Ambas as condições (C10 e C11) apresentaram um comportamento extremamente similar com relação à remoção de carboidratos, novamente atingindo $99 \%$ de degradação da lactose na estabilidade (Figura 5-351). A queda acentuada na condição C11 foi ocasionada por um problema pontual de operação, havendo uma rápida recuperação.

Analisando os metabólitos produzidos (Figura 5-354) para as condições C10 e C11 é possível observar que ambas as condições apresentaram produções muito similares de ácido acético e etanol (ordem de grandeza de $800 \mathrm{mg} . \mathrm{L}^{-1}$ e $350 \mathrm{mg} . \mathrm{L}^{-1}$, respectivamente). A principal diferença ocorreu para a produção do ácido butírico, para a qual C10 apresentou concentrações 50\% maiores do que C11. É importante ressaltar 
que para $\mathrm{C} 10$ o metabólito produzido em maior quantidade foi o ácido butírico, enquanto que para C11 foi o ácido acético.

A Tabela 5.84 apresenta os resultados dos indicadores de produção de hidrogênio, bem como as concentrações afluentes $\mathrm{COAV}_{\mathrm{SAT}}$ teóricas e reais e a quantidade de biomassa dentro do reator na forma de $\mathrm{M}_{\mathrm{SVT}}$ para o estudo da influência do tempo de alimentação na produção de $\mathrm{H}_{2}$. Novamente ressalta-se que os valores utilizados para a comparação são médias obtidas na estabilidade do processo.

Era esperado que a batelada alimentada apresentasse os melhores resultados de produção de $\mathrm{H}_{2}$ tanto para os parâmetros intensivos quanto para os extensivos, como foi observado por Inoue et al. (2014). Isto porque ocorreria uma influencia direta na relação $\mathrm{F} / \mathrm{M}$, com um fornecimento gradual de substrato e uma disponibilização mais lenta deste aos microrganismos, melhorando assim a assimilação e o rendimento pelas rotas metabólicas produtoras de hidrogênio. Porém os resultados obtidos foram bastante similares, não permitindo concluir qual tipo de alimentação foi melhor para a produção de biohidrogênio em um AnSBBR com recirculação da fase liquida alimentado com soro de leite. O único indicador que apresentou uma maior discrepância foi a PrME (mol.kg ${ }^{-1}$ SVT.d ${ }^{-1}$ ), devido ao maior crescimento da biomassa no interior do reator $(17,8$ e 35,7 g de SVT em C10 e C11, respectivamente). O fato da forma de alimentação não ter surtido um efeito perceptível no processo pode estar relacionado com o tipo de substrato utilizado. Enquanto que Inoue (2013) utilizou sacarose, um substrato de fácil degradação e assimilação, o presente trabalho utilizou soro de leite, substrato complexo que provavelmente é lentamente degradado e assimilado mesmo quando disponibilizado em menor tempo de enchimento.

Não ocorreu a presença de metano em nenhuma das condições. As lavagens do material suporte na Condição C11 continuaram sendo realizadas, surtindo o mesmo 
efeito benéfico observado nas condições anteriores com relação ao crescimento celular dentro do reator.

Tabela 5.84 - Concentração e $\operatorname{COAV}_{\mathrm{SAT}}$ teóricas e reais, indicadores de produção de hidrogênio e quantidade de biomassa dentro do reator - influencia do tempo de enchimento.

\begin{tabular}{|c|c|c|c|}
\hline Indicador & Unidades & $\mathrm{C} 10$ & $\mathrm{C} 11$ \\
\hline $\begin{array}{c}\text { Concentração afluente } \\
\text { teórica }\end{array}$ & mgDQO.L $\mathrm{L}^{-1}$ & 5400 & 5400 \\
\hline $\begin{array}{c}\text { Concentração afluente } \\
\text { real }\end{array}$ & mgDQO.L $L^{-1}$ & 5025 & 4761 \\
\hline $\mathrm{COAV}_{\mathrm{STA}}$ teórica & gDQO.L $\mathrm{L}^{-1} \cdot \mathrm{d}^{-1}$ & 18,5 & 18,5 \\
\hline $\mathrm{COAV}_{\mathrm{STA}}$ real & gDQO.L $L^{-1} \cdot d^{-1}$ & 17,2 & 16,3 \\
\hline $\mathrm{RMCR}_{\mathrm{C}, \mathrm{n}}$ & $\left(\mathrm{molH}_{2} \cdot \mathrm{mol}^{-1}\right.$ lactose $)$ & 0,80 & 0,86 \\
\hline $\mathrm{n}_{\mathrm{H} 2}$ & $\left(\mathrm{molH}_{2} \cdot \mathrm{d}^{-1}\right)$ & 0,11 & 0,11 \\
\hline $\operatorname{PrM}$ & $\left(\mathrm{molH}_{2} \cdot \mathrm{m}^{-3} \cdot \mathrm{d}^{-1}\right)$ & 29,3 & 32,9 \\
\hline PrME & $\left(\mathrm{molH}_{2} \cdot \mathrm{kg}^{-1} \mathrm{SVT} \cdot \mathrm{d}^{-1}\right)$ & 6,25 & 3,07 \\
\hline $\mathrm{RMCA}_{\mathrm{S}, \mathrm{m}}$ & $\left(\mathrm{molH}_{2} \cdot \mathrm{kg}^{-1} \mathrm{DQO}\right)$ & 1,84 & 1,92 \\
\hline $\mathrm{RMCA}_{\mathrm{C}, \mathrm{m}}$ & $\left(\mathrm{molH}_{2} \cdot \mathrm{kg}^{-1}\right.$ lactose $)$ & 2,30 & 2,48 \\
\hline $\mathrm{RMCR}_{\mathrm{S}, \mathrm{m}}$ & $\left(\mathrm{molH}_{2} \cdot \mathrm{kg}^{-1} \mathrm{DQO}\right)$ & 6,95 & 7,50 \\
\hline $\mathrm{RMCR}_{\mathrm{C}, \mathrm{m}}$ & $\left(\mathrm{molH}_{2} \cdot \mathrm{kg}^{-1}\right.$ lactose $)$ & 2,31 & 2,49 \\
\hline VHPR & $\left(\mathrm{LH}_{2} \cdot \mathrm{L}^{-1} \cdot \mathrm{d}^{-1}\right)$ & 0,66 & 0,74 \\
\hline Msvt & (g) & 17,8 & 35,7 \\
\hline $\mathrm{X}_{\mathrm{H} 2}$ & $(\%)$ & $44,0 \%$ & $42,4 \%$ \\
\hline $\mathrm{X}_{\mathrm{CH} 4}$ & $(\%)$ & $0,0 \%$ & $0,0 \%$ \\
\hline $\mathrm{X}_{\mathrm{CO} 2}$ & $(\%)$ & $56,0 \%$ & $57,6 \%$ \\
\hline
\end{tabular}


O último estudo realizado foi relacionado a influência da temperatura no processo de produção de biohidrogênio em um AnSBBR com recirculação alimentado com soro de leite. Novamente as condições experimentais de C10 (concentração afluente na forma de DQO de $5400 \mathrm{mg} . \mathrm{L}^{-1}$ ) foram repetidas alterando-se apenas a temperatura de operação do reator (ao invés de $30^{\circ} \mathrm{C}$ como foi utilizado em $\mathrm{C} 10$, o reator foi operado a uma temperatura de $45^{\circ} \mathrm{C}$ e $15^{\circ} \mathrm{C}$ em $\mathrm{C} 12$ e $\mathrm{C} 13$, respectivamente).

Novamente a remoção de matéria orgânica na forma de DQO atingiu valores médios entre $20 \%$ e $30 \%$ para as três condições estudadas, inclusive para C12 que no final da operação apresentou apenas metano e dióxido de carbono na composição do biogás produzido (Figura 5-349). Com relação à remoção de carboidratos, C12, assim como C10, atingiu 99\% de degradação da lactose na estabilidade, enquanto que C13 não ultrapassou o valor médio de remoção de 94\% na estabilidade (Figura 5-351).

Analisando os metabólitos produzidos (Figura 5-354) para as condições C10 e C13 é possível observar que a primeira apresentou maiores quantidades dos principais metabólitos (ácido acético, ácido butírico e etanol). Porém é importante notar que a condição C13 produziu apenas, praticamente, ácido acético e ácido butírico, metabólitos que estão ligados diretamente à produção de hidrogênio. Estes produtos intermediários não foram monitorados para a C12 tendo em vista que no final de operação não ocorreu produção de hidrogênio.

A Tabela 5.85 apresenta os resultados dos indicadores de produção de hidrogênio, bem como as concentrações afluentes $\mathrm{COAV}_{\mathrm{SAT}}$ teóricas e reais e a quantidade de biomassa dentro do reator na forma de $\mathrm{M}_{\mathrm{SVT}}$ para o estudo da temperatura na produção de $\mathrm{H}_{2}$. Mais uma vez destaca-se que os valores utilizados para a comparação são médias obtidas na estabilidade do processo. 
Tabela 5.85 - Concentração e $\mathrm{COAV}_{\mathrm{SAT}}$ teóricas e reais, indicadores de produção de hidrogênio e quantidade de biomassa dentro do reator - influência da temperatura.

\begin{tabular}{|c|c|c|c|c|}
\hline Indicador & Unidades & $\mathrm{C} 10$ & $\mathrm{C} 12$ & C13 \\
\hline $\begin{array}{c}\text { Concentração afluente } \\
\text { teórica }\end{array}$ & $\operatorname{mgDQO} . \mathrm{L}^{-1}$ & 5400 & 5400 & 5400 \\
\hline $\begin{array}{c}\text { Concentração afluente } \\
\text { real }\end{array}$ & $\operatorname{mgDQO} . \mathrm{L}^{-1}$ & 5025 & 4928 & 4896 \\
\hline $\mathrm{COAV}_{\mathrm{STA}}$ teórica & gDQO.L. ${ }^{-1} \cdot d^{-1}$ & 18,5 & 18,5 & 18,5 \\
\hline $\mathrm{COAV}_{\mathrm{STA}}$ real & gDQO.L $L^{-1} \cdot d^{-1}$ & 17,2 & 16,9 & 16,8 \\
\hline $\mathrm{RMCR}_{\mathrm{C}, \mathrm{n}}$ & $\left(\mathrm{molH}_{2} \cdot \mathrm{mol}^{-1}\right.$ lactose $)$ & 0,80 & 0,00 & 1,12 \\
\hline $\mathrm{n}_{\mathrm{H} 2}$ & $\left(\mathrm{molH}_{2} \cdot \mathrm{d}^{-1}\right)$ & 0,11 & 0,00 & 0,14 \\
\hline PrM & $\left(\mathrm{molH}_{2} \cdot \mathrm{m}^{-3} \cdot \mathrm{d}^{-1}\right)$ & 29,3 & 0,0 & 48,4 \\
\hline PrME & $\left(\mathrm{molH}_{2} \cdot \mathrm{kg}^{-1} \mathrm{SVT} . \mathrm{d}^{-1}\right)$ & 6,25 & 0,00 & 2,49 \\
\hline $\mathrm{RMCA}_{\mathrm{S}, \mathrm{m}}$ & $\left(\mathrm{molH}_{2} \cdot \mathrm{kg}^{-1} \mathrm{DQO}\right)$ & 1,84 & 0,00 & 2,41 \\
\hline $\mathrm{RMCA}_{\mathrm{C}, \mathrm{m}}$ & $\left(\mathrm{molH}_{2} \cdot \mathrm{kg}^{-1}\right.$ lactose $)$ & 2,30 & 0,00 & 3,04 \\
\hline $\mathrm{RMCR}_{\mathrm{S}, \mathrm{m}}$ & $\left(\mathrm{molH}_{2} \cdot \mathrm{kg}^{-1} \mathrm{DQO}\right)$ & 6,95 & 0,00 & 10,92 \\
\hline $\mathrm{RMCR}_{\mathrm{C}, \mathrm{m}}$ & $\left(\mathrm{molH}_{2} \cdot \mathrm{kg}^{-1}\right.$ lactose $)$ & 2,31 & 0,00 & 3,24 \\
\hline VHPR & $\left(\mathrm{LH}_{2} \cdot \mathrm{L}^{-1} \cdot \mathrm{d}^{-1}\right)$ & 0,66 & 0,00 & 1,08 \\
\hline Msvt & (g) & 17,8 & - & 56,7 \\
\hline $\mathrm{X}_{\mathrm{H} 2}$ & $(\%)$ & $44,0 \%$ & $0,0 \%$ & $61,5 \%$ \\
\hline $\mathrm{X}_{\mathrm{CH} 4}$ & $(\%)$ & $0,0 \%$ & $34,7 \%$ & $0,0 \%$ \\
\hline $\mathrm{X}_{\mathrm{CO} 2}$ & $(\%)$ & $56,0 \%$ & $65,3 \%$ & $38,5 \%$ \\
\hline
\end{tabular}

Existe bastante discordância com relação a uma temperatura ideal ou mesmo uma faixa de temperatura ideal para produção biológica de hidrogênio. Temperaturas altas proporcionam uma melhor transferência do gás do líquido reacional para a fase 
gasosa. Existe uma temperatura ótima até a qual ocorre uma melhora nas velocidades de degradação de substrato (e consequentemente na produção de hidrogênio). Porém pode ocorrer, após esta temperatura ótima, uma desnaturação das enzimas ligadas ao processo de produção de $\mathrm{H}_{2}$. Relacionado a este ótimo, o estudo de Wang e Wan (2008) foi realizado em frascos de vidro em batelada única, na faixa de 20 a $55^{\circ} \mathrm{C}$ de temperatura com esgoto sintético a base de glicose como afluente. Este estudo mostrou que o aumento de temperatura exerceu influência sobre a degradação do substrato e sobre a produtividade de hidrogênio, sendo que ambas aumentaram em 20 vezes a $40^{\circ} \mathrm{C}$, porém a partir deste ponto diminuíram consideravelmente. Lee et al. (2006) investigaram os efeitos da temperatura na produção de hidrogênio utilizando sacarose como substrato e concluíram que, em geral, a velocidade de produção de hidrogênio e o rendimento de produção de hidrogênio tenderam a aumentar com o aumento da temperatura de $30^{\circ} \mathrm{C}$ para $40^{\circ} \mathrm{C}$, enquanto que tenderam a diminuir com um posterior aumento da temperatura de $40^{\circ} \mathrm{C}$ para $45^{\circ} \mathrm{C}$. A temperatura ótima reportada por Valdez-Vazquez et al. (2005), por outro lado, foi de $55^{\circ} \mathrm{C}$. Gavala et al. (2006) estudaram dois reatores contínuo de mistura completa, um a $35^{\circ} \mathrm{C}$ e outro a $55^{\circ} \mathrm{C}$, e observaram que o rendimento da produção de hidrogênio e a produção volumétrica de hidrogênio especifica foram maiores em condições termofílicas do que em condições mesofílicas. As prováveis razões diferirem tanto pode estar relacionadas às diferenças entre o tipo de substrato utilizado, concentrações aplicadas, configurações de reator usadas, faixas de temperatura estudadas e tipos de inóculos envolvidos.

Apesar de, teoricamente, ser esperado que a produção de $\mathrm{H}_{2}$ aumente com o aumento da temperatura até um ponto ótimo, com uma queda subsequente, durante o presente estudo a melhor produção de hidrogênio (para todos os indicadores de produção deste componente do biogás) foi alcançada com a menor temperatura testada 
$\left(\mathrm{C} 13-15^{\circ} \mathrm{C}\right)$. Uma possível explicação para isto pode estar no fato de que a temperatura baixa inibiria a ação dos microorganismos competidores como os metanogênicos e os homoacetogênicos. Os microrganismos acidogênicos por possuírem uma velocidade de crescimento maior teriam a vantagem de se desenvolver com uma menor competição, mesmo em uma condição desfavorável. Vale destacar que apenas a condição C12 apresentou metano na composição do biogás produzido.

A lavagem do material suporte não precisou ser realizada na condição C13. A baixa temperatura acabou sendo um "controlador natural" do rápido crescimento característico das bactérias produtoras de hidrogênio. Provavelmente por este motivo C13 apresentou uma maior quantidade de biomassa dentro do reator (na forma de $\mathrm{M}_{\mathrm{SVT}}$ ) em comparação à C10. Esta quantificação da biomassa no interior do AnSBBR não foi realizada para C12 tendo em vista que no final de operação não ocorreu produção de hidrogênio.

Vale ressaltar que não existem trabalhos estudando temperaturas baixas utilizando soro de leite como substrato. Tais temperaturas, por outro lado, teriam algumas vantagens tecnológicas como operação em países frios que possuem uma indústria de laticínios bem desenvolvida e a vantagem de o soro de leite, devido à sua alta biodegradabilidade, precisar ser armazenado a baixas temperaturas.

Uma comparação importante que pode ser realizada está relacionada com as diferentes configurações de reatores (Tabela 5.86). Os valores de VHPR e de $\mathrm{RMCR}_{\mathrm{C}, \mathrm{n}}$ apresentados para os trabalhos referem-se ao final de operação da melhor etapa de cada estudo e não aos pontos de máximo obtidos. Não existem outros trabalhos na literatura específica utilizando um AnSBBR alimentado com soro de leite. Além disso, a configuração usada no presente trabalho apresentou excelentes resultados, para a sua melhor condição de operação, comparado com configurações tradicionais como o 
UASBr ou o CSTR. Outro ponto importante que deve ser destacado é a estabilidade atingida pelo AnSBBR, enquanto que grande parte das outras configurações apresentou uma alta instabilidade, com picos e quedas acentuados. Por último, a maior parte dos reatores utilizados nos demais trabalhos apresentou uma produção de metano concomitante à produção de hidrogênio, enquanto o presente trabalho apresentou apenas $\mathrm{H}_{2}$ e $\mathrm{CO}_{2}$ na composição do seu biogás.

Tabela 5.86 - Comparação entre diferentes configurações de reatores utilizando soro de leite como substrato.

\begin{tabular}{|c|c|c|c|c|c|c|c|c|}
\hline $\begin{array}{c}\text { Configuração } \\
\text { do reator }\end{array}$ & $\begin{array}{l}\mathrm{TDH} \\
\text { (h) }\end{array}$ & $\begin{array}{c}\text { Temperatura } \\
\left({ }^{\circ} \mathrm{C}\right)\end{array}$ & $\begin{array}{l}\text { Volume útil } \\
\text { (L) }\end{array}$ & $\begin{array}{c}\operatorname{AVOL}_{\mathrm{CT}} \\
\left(\mathrm{gCOD} \cdot \mathrm{L}^{-1} \cdot \mathrm{d}^{-1}\right)\end{array}$ & $\begin{array}{c}\text { VHPR } \\
\left(\mathrm{mLH}_{2} \cdot \mathrm{L}^{-1} \cdot \mathrm{d}^{-1}\right)\end{array}$ & $\begin{array}{c}\mathrm{RMCR}_{\mathrm{C}, \mathrm{n}} \\
\left(\mathrm{mol} \mathrm{H}_{2} \cdot \mathrm{mol}^{-1}\right. \\
\text { lactose })\end{array}$ & $\begin{array}{c}\text { Presença } \\
\text { de } \\
\text { metano }\end{array}$ & Referência \\
\hline UASBr & 6 & Ambiente & 1,3 & 20 & 360 & $0,34^{\mathrm{b}}$ & Sim & $\begin{array}{c}\text { (Carrillo- } \\
\text { Reyes et } \\
\text { al., 2012) }\end{array}$ \\
\hline CSTR & 24 & $55 \pm 1$ & 2,0 & 10 & 800 & $1,52^{\mathrm{b}}$ & Sim & $\begin{array}{l}\text { (Azbar et } \\
\text { al., 2009) }\end{array}$ \\
\hline CSTR & 24 & $35 \pm 1$ & 1,5 & 10 & 350 & $0,68^{\mathrm{b}}$ & Sim & $\begin{array}{l}\text { (Yang et } \\
\text { al., 2007) }\end{array}$ \\
\hline UASBr & 12 & $30 \pm 1$ & 4,6 & 20 & 122 & $0,12^{b}$ & Sim & $\begin{array}{l}\text { (Castelló } \\
\text { et al., } \\
\text { 2009) }\end{array}$ \\
\hline $\begin{array}{c}\text { Reator } \\
\text { anaeróbico } \\
\text { de leito fixo } \\
\text { e fluxo } \\
\text { ascendente }\end{array}$ & 24 & $30 \pm 1$ & 2,5 & 37 & 1000 & 1,10 & Não & $\begin{array}{l}\text { (Perna et } \\
\text { al., 2013) }\end{array}$ \\
\hline $\begin{array}{c}\text { Reator } \\
\text { anaeróbico } \\
\text { de leito } \\
\text { fluidizado }\end{array}$ & 6 & $30 \pm 1$ & 0,77 & 20 & 2880 & 1,27 & Não & $\begin{array}{c}(\text { Rosa } e t \\
\text { al., 2014) }\end{array}$ \\
\hline $\begin{array}{l}\text { Reator } \\
\text { tubular de } \\
\text { leito fixo }\end{array}$ & 48 & $35 \pm 1$ & 4,0 & 12,5 & $312,5^{b}$ & 0,50 & Não & $\begin{array}{l}\text { (Fernández } \\
\text { et al., } \\
\text { 2014) }\end{array}$ \\
\hline $\begin{array}{c}\text { AnSBBR } \\
\text { com } \\
\text { recirculação } \\
\text { da fase } \\
\text { líquida }\end{array}$ & $7^{\mathrm{a}}$ & $15 \pm 1$ & 3,5 & 14.6 & 1080 & 1,12 & Não & $\begin{array}{l}\text { Presente } \\
\text { trabalho }\end{array}$ \\
\hline
\end{tabular}


5.4.3. AnSBBR com agitação mecânica e lactose como substrato

A operação do AnSBBR com agitação mecânica deu-se durante 184 dias. A produção de biogás apresentou um comportamento estável durante todas as condições experimentais, como pode ser observado na Figura 5-356. 


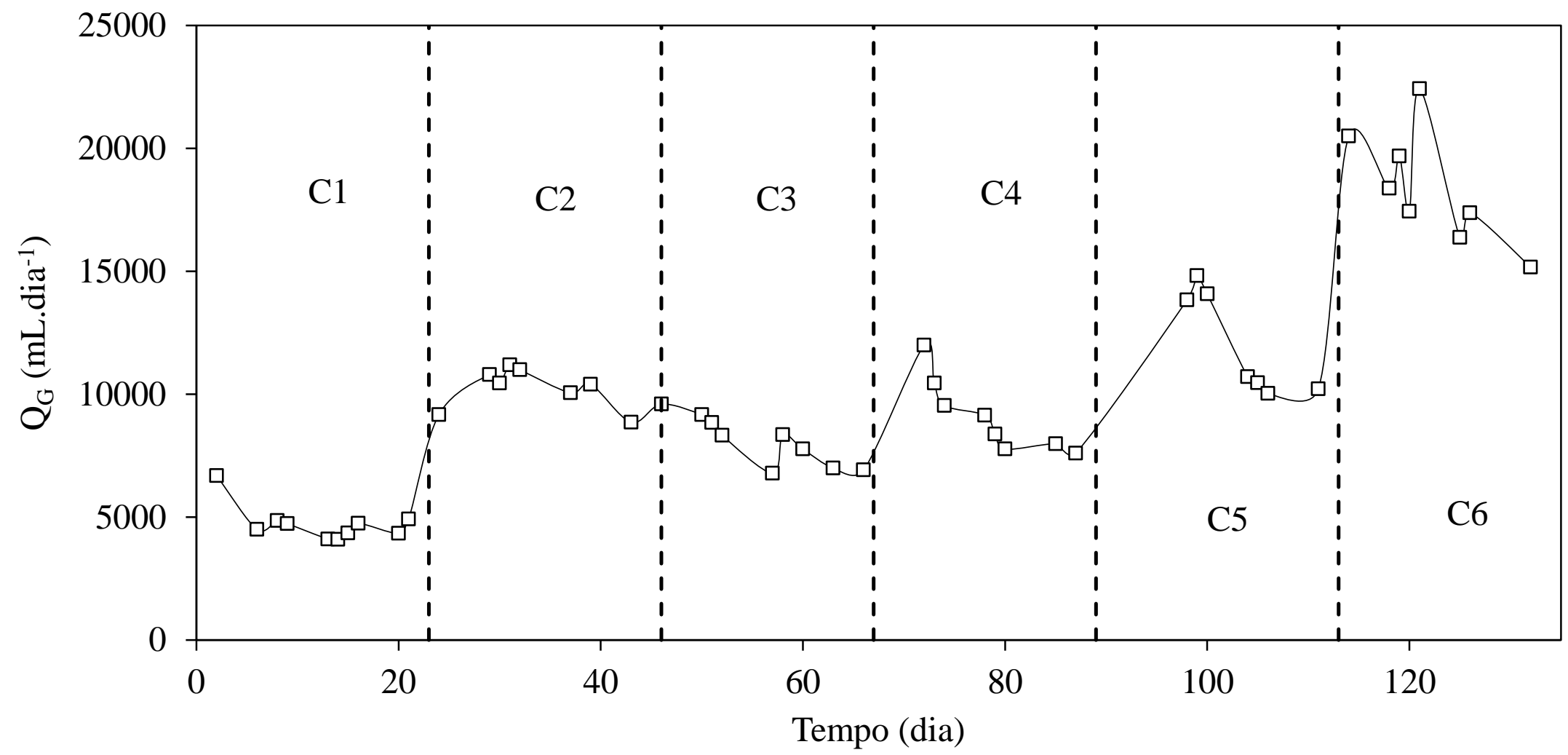

Figura 5-356 - Volume de biogás produzido por dia (Lactose: $\mathrm{C} 1=\mathrm{DQO}=3600 \mathrm{mg} \cdot \mathrm{L}^{-1} \mathrm{e} \mathrm{t}_{\mathrm{C}}=4$ horas; $\mathrm{C} 2=\mathrm{DQO}=5400 \mathrm{mg} \cdot \mathrm{L}^{-1} \mathrm{e} \mathrm{t}_{\mathrm{C}}=4$ horas; $\mathrm{C} 3=\mathrm{DQO}=3600 \mathrm{mg} \cdot \mathrm{L}^{-1}$ e $\mathrm{t}_{\mathrm{C}}=3$ horas $\mathrm{C} 4=\mathrm{DQO}=5400 \mathrm{mg} \cdot \mathrm{L}^{-1} \mathrm{e} \mathrm{t}_{\mathrm{C}}=3$ horas $; \mathrm{C} 5=\mathrm{DQO}=3600 \mathrm{mg} \cdot \mathrm{L}^{-1}$ e $\mathrm{t}_{\mathrm{C}}=2 \mathrm{horas} ; \mathrm{C} 6=\mathrm{DQO}=5400$ $\mathrm{mg} \cdot \mathrm{L}^{-1}$ e $\mathrm{t}_{\mathrm{C}}=2$ horas). 
As Figura 5-357 e Figura 5-358 apresentam a composição e a distribuição do biogás em todas as condições, respectivamente, enquanto que a Tabela 5.87 apresenta a distribuição dos componentes do biogás em cada condição, obtidos através dos perfis ao longo do ciclo. 


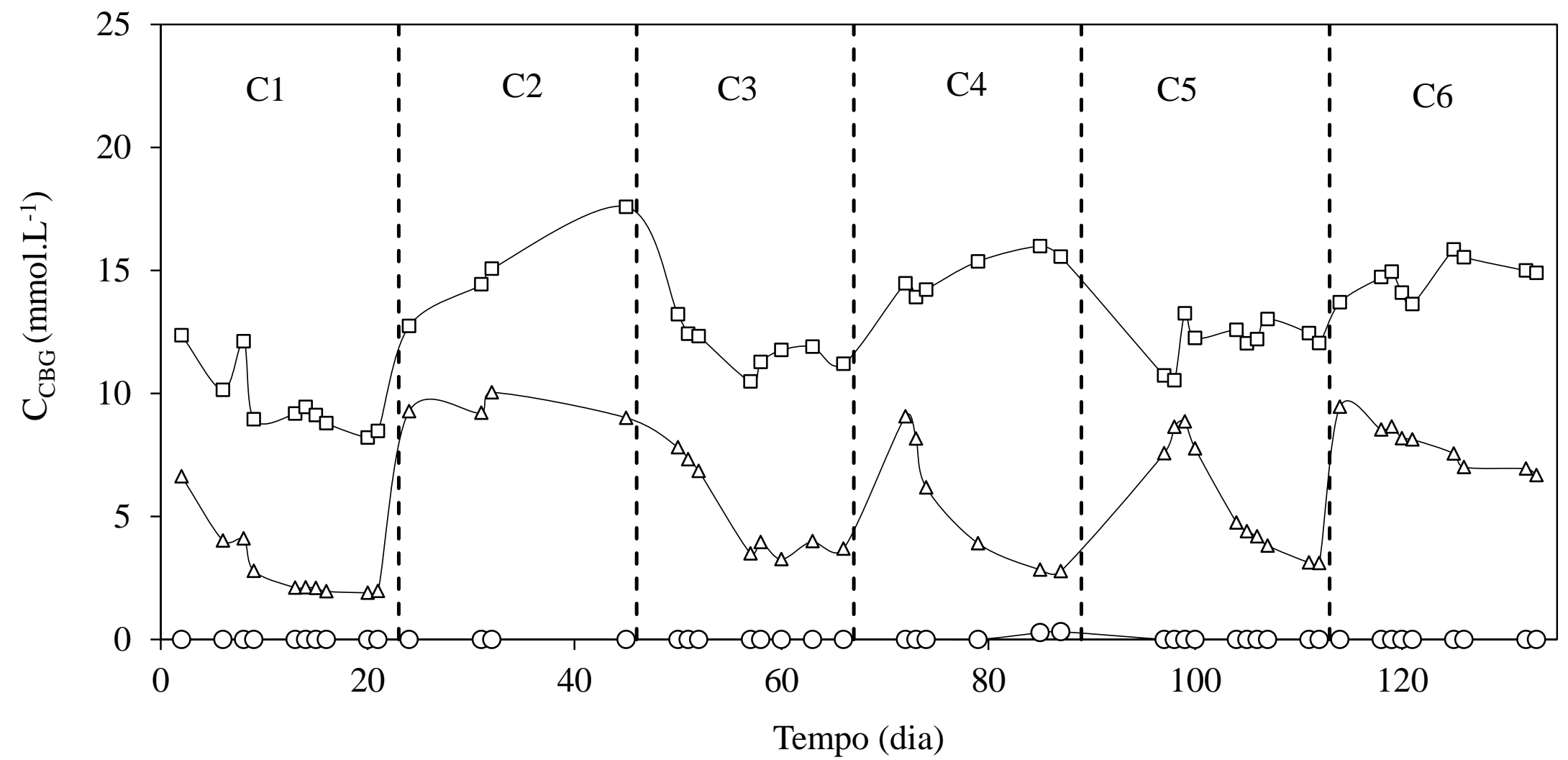

Figura 5-357 - Concentrações dos componentes do biogás em todas as condições: $\square-\mathrm{CO}_{2} ; \Delta-\mathrm{H}_{2} ; \circ-\mathrm{CH}_{4}\left(\mathrm{Lactose}: \mathrm{C} 1=\mathrm{DQO}=3600 \mathrm{mg} . \mathrm{L}^{-1}\right.$ e $\mathrm{t}_{\mathrm{C}}=4$ horas; $\mathrm{C} 2=\mathrm{DQO}=5400 \mathrm{mg} . \mathrm{L}^{-1} \mathrm{e} \mathrm{t} \mathrm{t}_{\mathrm{C}}=4$ horas; $\mathrm{C} 3=\mathrm{DQO}=3600 \mathrm{mg} . \mathrm{L}^{-1}$ e $\mathrm{t}_{\mathrm{C}}=3$ horas; $\mathrm{C} 4=\mathrm{DQO}=5400 \mathrm{mg} . \mathrm{L}^{-1} \mathrm{e} \mathrm{t} \mathrm{t}_{\mathrm{C}}=3$ horas; $\mathrm{C} 5=$ $\mathrm{DQO}=3600 \mathrm{mg} \cdot \mathrm{L}^{-1} \mathrm{e} \mathrm{t}_{\mathrm{C}}=2$ horas; $\mathrm{C} 6=\mathrm{DQO}=5400 \mathrm{mg} \cdot \mathrm{L}^{-1}$ e $\mathrm{t}_{\mathrm{C}}=2$ horas). 


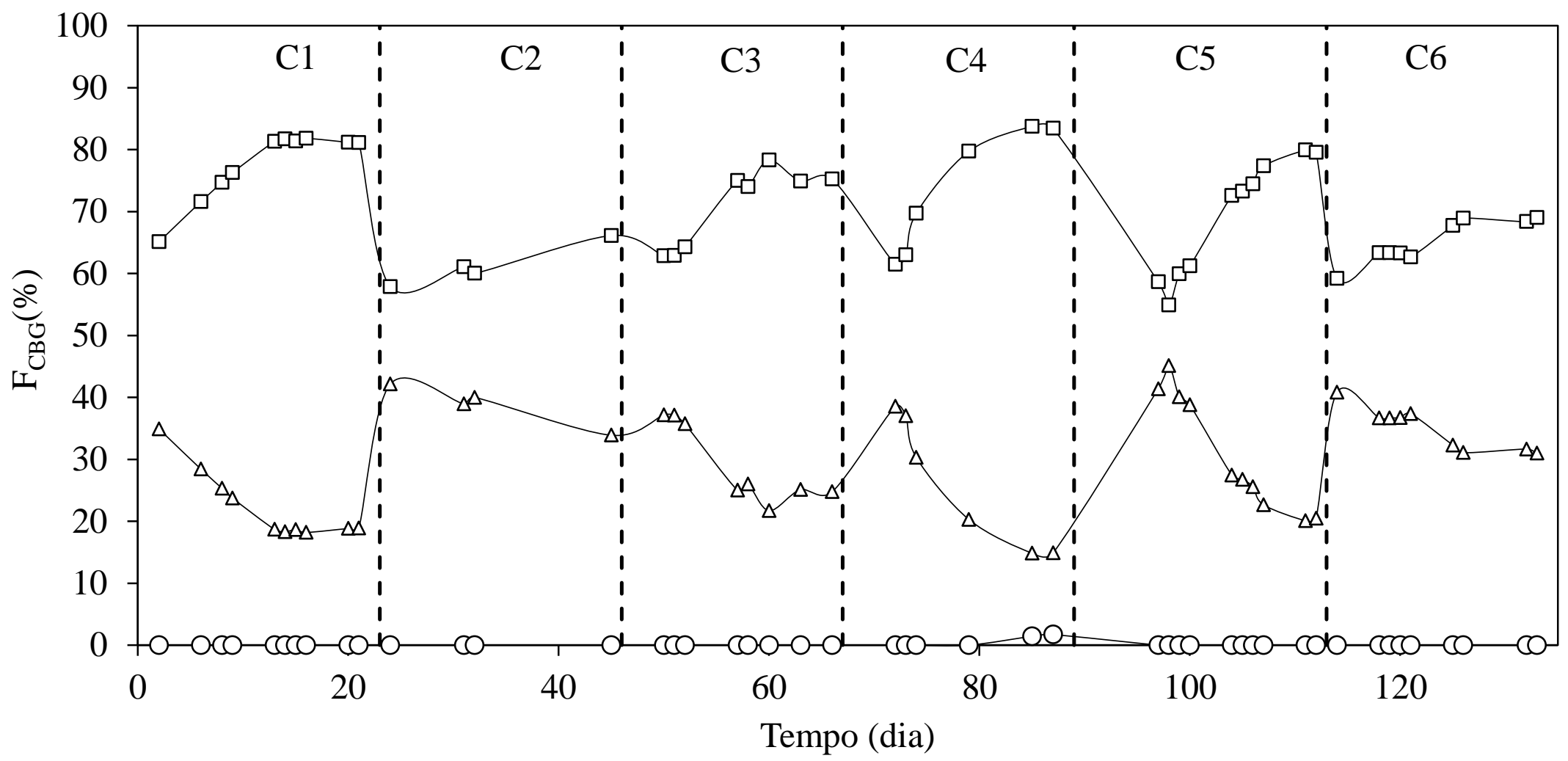

Figura 5-358 - Distribuições dos componentes do biogás em todas as condições: $\square-\mathrm{CO}_{2} ; \Delta-\mathrm{H}_{2} ; \circ-\mathrm{CH}_{4}\left(\mathrm{Lactose}: \mathrm{C} 1=\mathrm{DQO}=3600 \mathrm{mg} . \mathrm{L}^{-1} \mathrm{e}\right.$ $\mathrm{t}_{\mathrm{C}}=4$ horas; $\mathrm{C} 2=\mathrm{DQO}=5400 \mathrm{mg} \cdot \mathrm{L}^{-1}$ e $\mathrm{t}_{\mathrm{C}}=4$ horas $; \mathrm{C} 3=\mathrm{DQO}=3600 \mathrm{mg} \cdot \mathrm{L}^{-1}$ e $\mathrm{t}_{\mathrm{C}}=3$ horas; $\mathrm{C} 4=\mathrm{DQO}=5400 \mathrm{mg} \cdot \mathrm{L}^{-1}$ e $\mathrm{t}_{\mathrm{C}}=3$ horas; $\mathrm{C} 5=$ $\mathrm{DQO}=3600 \mathrm{mg} \cdot \mathrm{L}^{-1} \mathrm{e} \mathrm{t}_{\mathrm{C}}=2$ horas; $\mathrm{C} 6=\mathrm{DQO}=5400 \mathrm{mg} \cdot \mathrm{L}^{-1} \mathrm{e} \mathrm{t}_{\mathrm{C}}=2$ horas $)$. 
Tabela 5.87 - Distribuição dos componentes do biogás em todas as condições (Lactose: $\mathrm{C} 1=\mathrm{DQO}=3600 \mathrm{mg} \cdot \mathrm{L}^{-1}$ e $\mathrm{t}_{\mathrm{C}}=4$ horas; $\mathrm{C} 2=\mathrm{DQO}=5400 \mathrm{mg} \cdot \mathrm{L}^{-1}$ e $\mathrm{t}_{\mathrm{C}}=4$ horas; $\mathrm{C} 3=$ $\mathrm{DQO}=3600 \mathrm{mg} \cdot \mathrm{L}^{-1} \mathrm{e}_{\mathrm{C}}=3$ horas; $\mathrm{C} 4=\mathrm{DQO}=5400 \mathrm{mg} \cdot \mathrm{L}^{-1} \mathrm{e} \mathrm{t}_{\mathrm{C}}=3$ horas $; \mathrm{C} 5=\mathrm{DQO}$ $=3600 \mathrm{mg} \cdot \mathrm{L}^{-1}$ e $\mathrm{t}_{\mathrm{C}}=2$ horas; $\mathrm{C} 6=\mathrm{DQO}=5400 \mathrm{mg} \cdot \mathrm{L}^{-1}$ e $\mathrm{t}_{\mathrm{C}}=2$ horas $)$.

\begin{tabular}{ccccccc}
\hline $\begin{array}{c}\text { Proporção } \\
(\%)\end{array}$ & 1 & 2 & 3 & 4 & 5 & 6 \\
\hline $\mathrm{H}_{2}$ & 18,9 & 45,8 & 25,1 & 15,0 & 20,5 & 31,0 \\
$\mathrm{CO}_{2}$ & 81,1 & 54,2 & 74,9 & 83,5 & 79,5 & 69,0 \\
$\mathrm{CH}_{4}$ & 0,0 & 0,0 & 0,0 & 1,5 & 0,0 & 0,0 \\
\hline
\end{tabular}

A estabilidade obtida no processo de produção de $\mathrm{H}_{2}$ é uma característica importante nos reatores acidogênicos. Existem diversos relatos de instabilidade de produção do biogás durante a fase estacionária. Reatores de leito fixo tratando água residuária sintética a base de sacarose (Rojas, 2010; Fontes Lima, 2012; Penteado, 2012), nos quais a produção do biogás $\left(\mathrm{H}_{2}\right.$ e $\left.\mathrm{CO}_{2}\right)$ não pode ser estabilizada embora houvesse estabilidade no consumo de sacarose, $\mathrm{pH}$ e concentração dos compostos intermediários do metabolismo, sendo a causa atribuída ao crescimento de organismos homoacetogênicos, capazes de utilizar a rota Wood-Ljungdahl. Estes organismos podem crescer heterotroficamente em açúcares (hexoses e pentoses) ou autotroficamente (rota Wood-Ljungdahl) em gases $\left(\mathrm{CO}\right.$ ou $\left.\mathrm{CO}_{2}+\mathrm{H}_{2}\right)$

O AnSBBR parece não sofrer com problemas de estabilidade, como os descritos anteriormente, tendo em vista que não apresentaram indícios de redução de biogás durante as condições experimentais impostas durante o estudo, sendo essa estabilidade também alcançada pelos trabalhos de Santos (2012), El Manssouri (2012) e Inoue (2013) que utilizaram sistemas similares, porém alimentados com efluente sintético à base de sacarose.

O metano foi encontrado em baixas concentrações apenas no final da condição 4, sendo que El Manssouri (2012) e Inoue (2013) também obtiveram metano em reduzidas concentrações, ou seja, não conseguiram eliminar totalmente da 
metanogênese do processo sem haver comprometimento da estabilidade do processo, entretanto, tal característica pode ter influenciado, mesmo que em pequena proporção, no rendimento do hidrogênio produzido.

Com relação à remoção de matéria orgânica na forma de DQO (amostras filtradas), o reator apresentou baixa eficiência média em todas as condições: 17\%, 15\%, $14 \%, 17 \%, 19 \%$ e $18 \%$ para as condições $1,2,3,4,5$ e 6 , respectivamente, como é possível observar na Figura 5-359, não sendo possível se observar uma tendência de relação entre a eficiência de remoção de DQO e os parâmetros concentração afluente, tempo de ciclo e carga orgânica volumétrica aplicada. 


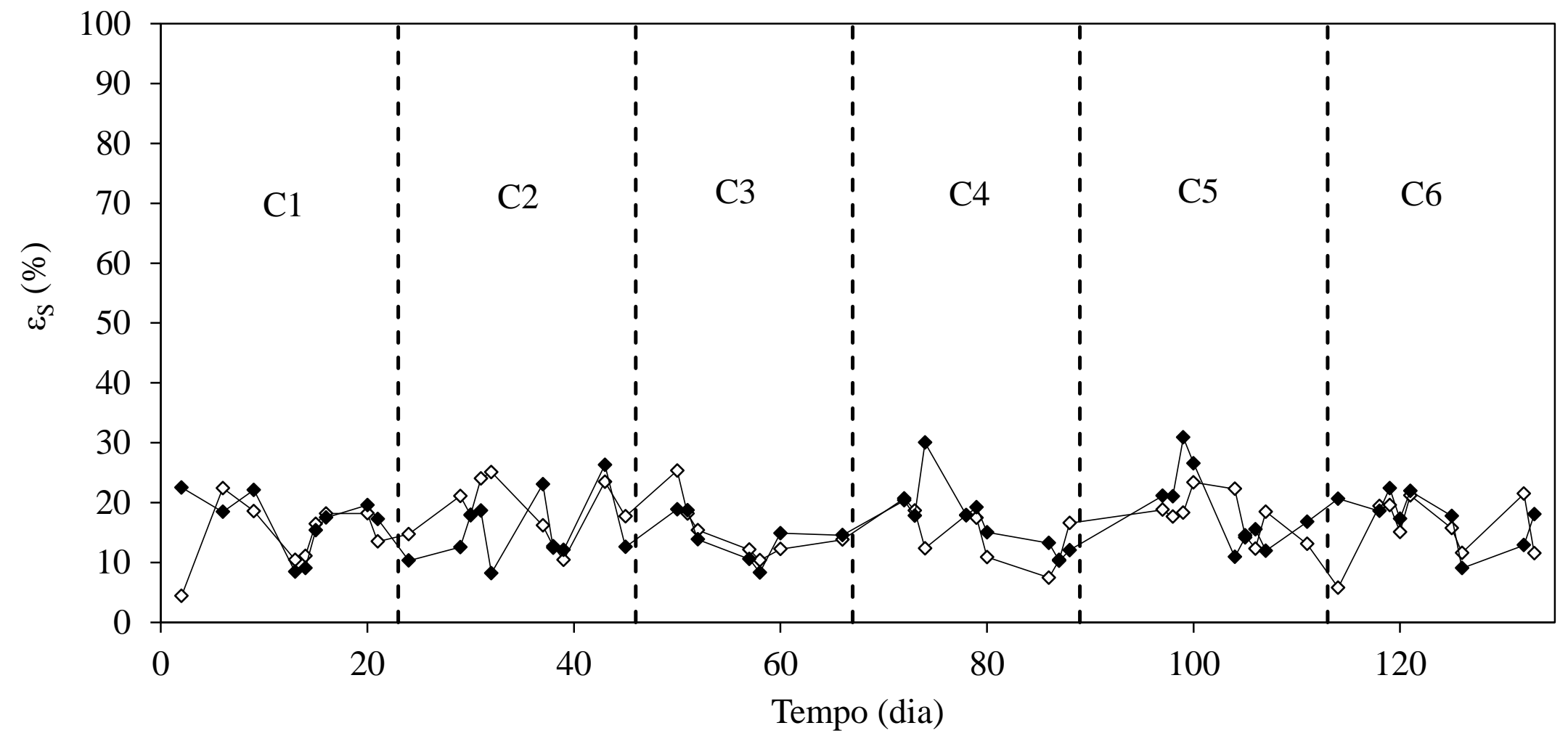

Figura 5-359 - Eficiência de remoção de matéria orgânica (DQO): $\diamond$ - não filtrada; $\bullet$ - filtrada em todas as condições (Lactose: C1 = DQO = $3600 \mathrm{mg} \cdot \mathrm{L}^{-1} \mathrm{e} \mathrm{t}_{\mathrm{C}}=4$ horas; $\mathrm{C} 2=\mathrm{DQO}=5400 \mathrm{mg} \cdot \mathrm{L}^{-1} \mathrm{e} \mathrm{t}_{\mathrm{C}}=4$ horas; $\mathrm{C} 3=\mathrm{DQO}=3600 \mathrm{mg} \cdot \mathrm{L}^{-1} \mathrm{e} \mathrm{t}_{\mathrm{C}}=3$ horas $; \mathrm{C} 4=\mathrm{DQO}=5400 \mathrm{mg} \cdot \mathrm{L}^{-1} \mathrm{e} \mathrm{t} \mathrm{t}_{\mathrm{C}}=3$ horas; $\mathrm{C} 5=\mathrm{DQO}=3600 \mathrm{mg} . \mathrm{L}^{-1} \mathrm{e} \mathrm{t}_{\mathrm{C}}=2$ horas; $\mathrm{C} 6=\mathrm{DQO}=5400 \mathrm{mg} . \mathrm{L}^{-1}$ e $\mathrm{t}_{\mathrm{C}}=2$ horas). 
A remoção média de matéria orgânica na forma de lactose (carboidratos amostras filtradas) mostrada na Figura 5-360 indica que o reator apresentou elevado desempenho em todas as condições operadas: $98 \%, 94 \%, 99 \%, 98 \%, 99 \%$ e $96 \%$ para as condições $1,2,3,4,5$ e 6 , respectivamente, sendo os valores médios para as amostras filtradas e não-filtradas bastante similares.

$\mathrm{O}$ aumento da $\mathrm{COAV}_{\mathrm{S}}$ não apresentou um padrão de aumento ou diminuição da eficiência de remoção de carboidrato. Vale destacar que diferente do que aconteceu nos trabalhos de Santos (2012), El Manssouri (2012) e Inoue (2013), o ciclo de $2 \mathrm{~h}$ foi suficiente para que o substrato fosse consumido da mesma maneira que nas demais condições. Em relação à influência do tempo de ciclo, a diminuição de $4 \mathrm{~h}$ para $3 \mathrm{~h}$ e depois para $2 \mathrm{~h}$ melhorou ligeiramente o desempenho para a concentração de 3600 mgDQO. $L^{-1}$ (condições 1, 3 e 5 que apresentaram 98\%, 99\% e 99\%), porém não apresentou uma tendência definida para a concentração de $5400 \mathrm{mgDQO} \cdot \mathrm{L}^{-1}$ (condições 2, 4 e 6 que apresentaram 94\%, 98\% e 96\%).

De modo análogo, quanto à influência da concentração afluente, todos os tempos de ciclo apresentaram uma redução no desempenho (as condições 1 e 2 com tempo de ciclo de 4 h apresentaram uma remoção de $98 \%$ e $94 \%$, respectivamente; as condições 3 e 4 com tempo de ciclo de 3h apresentaram uma remoção de 99\% e 98\%, respectivamente; por último, as condições 5 e 6 com tempo de ciclo de $2 \mathrm{~h}$ apresentaram remoção de $99 \%$ e $96 \%$, respectivamente. As condições 4 (5400 mgDQO.L ${ }^{-1}$ e 3 h) e 5 (3600 mgDQO.L $\mathrm{L}^{-1}$ e 2h) com mesma $\mathrm{COAV}_{\mathrm{S}}$ apresentaram pequena variação na remoção de sacarose de $98 \%$ e $99 \%$, respectivamente, ratificando a proximidade que existe quando diferentes concentrações afluente e tempos de ciclo definem a mesma $\mathrm{COAV}_{\mathrm{S}}$ 


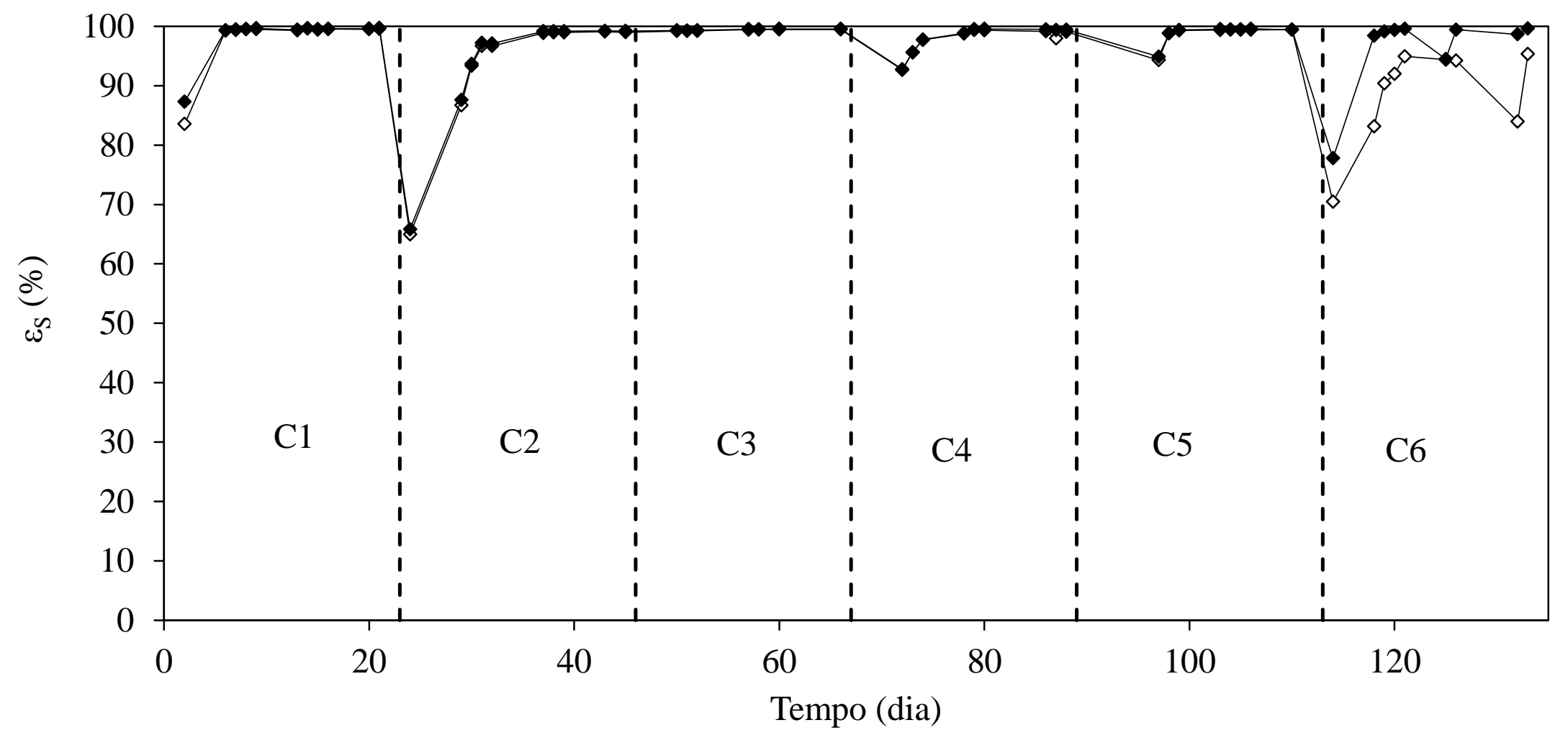

Figura 5-360 - Eficiência de remoção de carboidrato: $\diamond$ - não filtrada; - filtrada em todas as condições (Lactose: $\mathrm{C} 1=\mathrm{DQO}=3600 \mathrm{mg}$. $\mathrm{L}^{-1}$ e $\mathrm{t}_{\mathrm{C}}$ $=4$ horas; $\mathrm{C} 2=\mathrm{DQO}=5400 \mathrm{mg} . \mathrm{L}^{-1} \mathrm{e} \mathrm{t}_{\mathrm{C}}=4$ horas; $\mathrm{C} 3=\mathrm{DQO}=3600 \mathrm{mg} . \mathrm{L}^{-1} \mathrm{e} \mathrm{t}_{\mathrm{C}}=3$ horas; $\mathrm{C} 4=\mathrm{DQO}=5400 \mathrm{mg} . \mathrm{L}^{-1} \mathrm{e} \mathrm{t}_{\mathrm{C}}=3$ horas; $\mathrm{C} 5=$ $\mathrm{DQO}=3600 \mathrm{mg} \cdot \mathrm{L}^{-1} \mathrm{e} \mathrm{t}_{\mathrm{C}}=2$ horas; $\mathrm{C} 6=\mathrm{DQO}=5400 \mathrm{mg} \cdot \mathrm{L}^{-1} \mathrm{e} \mathrm{t}_{\mathrm{C}}=2$ horas$)$. 
A Tabela 5.88 apresenta os rendimentos obtidos em todas as condições experimentais, sendo tais valores obtidos das médias de DQO e lactose (carboidratos) aplicados ao reator com os valores de hidrogênio produzidos durante os perfis de biogás. Os dados foram disponibilizados de diferentes maneiras a fim de facilitar futuras comparações do desempenho do presente trabalho com dados obtidos em literatura. Rendimentos calculados em função da massa (em molH $2 \cdot \mathrm{kgSAC}^{-1} \mathrm{ou}^{\mathrm{molH}} 2 \cdot \mathrm{kgDQO}^{-1}$ ) são frequentemente utilizados, pois oferecem maior praticidade na aplicação de um processo produtivo. Porém, na produção de biohidrogênio o rendimento depende da quantidade de carboidrato consumido e das vias metabólicas adotadas pelos microrganismos na conversão desse substrato, sendo que diferentes vias metabólicas possuem diferentes relações estequiométricas entre hidrogênio produzido e substrato consumido, dessa maneira optou-se pela análise do $\mathrm{RMCR}_{\mathrm{C}, \mathrm{n}}\left(\mathrm{em} \mathrm{molH}_{2} \cdot \mathrm{molSAC}^{-1}\right)$ na análise dos dados obtidos pelo presente trabalho.

Tabela 5.88 - Rendimentos na produção de biohidrogênio em todas as condições experimentais (Lactose: $\mathrm{C} 1=\mathrm{DQO}=3600 \mathrm{mg} \cdot \mathrm{L}^{-1}$ e $\mathrm{t}_{\mathrm{C}}=4$ horas; $\mathrm{C} 2=\mathrm{DQO}=5400$ $\mathrm{mg} . \mathrm{L}^{-1}$ e $\mathrm{t}_{\mathrm{C}}=4$ horas; $\mathrm{C} 3=\mathrm{DQO}=3600 \mathrm{mg} . \mathrm{L}^{-1}$ e $\mathrm{t}_{\mathrm{C}}=3$ horas; $\mathrm{C} 4=\mathrm{DQO}=5400$ $\mathrm{mg} . \mathrm{L}^{-1}$ e $\mathrm{t}_{\mathrm{C}}=3$ horas; $\mathrm{C} 5=\mathrm{DQO}=3600 \mathrm{mg} . \mathrm{L}^{-1}$ e $\mathrm{t}_{\mathrm{C}}=2$ horas; $\mathrm{C} 6=\mathrm{DQO}=5400$ mg. $\mathrm{L}^{-1} \mathrm{e} \mathrm{t}_{\mathrm{C}}=2$ horas).

\begin{tabular}{lccccccc}
\hline \multirow{2}{*}{ Indicador } & Unidade & \multicolumn{7}{c}{ Condição } \\
& & 1 & 2 & 3 & 4 & 5 & 6 \\
\hline $\mathrm{RMCA}_{\mathrm{S}, \mathrm{m}}$ & $\left(\mathrm{molH}_{2} \cdot \mathrm{kgDQO}^{-1}\right)$ & 1,31 & 4,26 & 1,54 & 0,90 & 1,49 & 2,34 \\
$\mathrm{RMCR}_{\mathrm{S}, \mathrm{m}}$ & $\left(\mathrm{molH}_{2} \cdot \mathrm{kgDQO}^{-1}\right)$ & 6,32 & 27,65 & 10,84 & 5,19 & 7,95 & 13,31 \\
$\mathrm{RMCA}_{\mathrm{C}, \mathrm{m}}\left(\mathrm{molH}_{2} \cdot \mathrm{kgCarboidrato}^{-1}\right)$ & 1,42 & 4,51 & 1,67 & 0,95 & 1,69 & 2,51 \\
$\mathrm{RMCR}_{\mathrm{C}, \mathrm{m}}\left(\mathrm{molH}_{2} \cdot \mathrm{kgCarboidrato}^{-1}\right)$ & 1,44 & 4,81 & 1,68 & 0,97 & 1,71 & 2,61 \\
$\mathrm{RMCR}_{\mathrm{C}, \mathrm{n}}\left(\mathrm{molH}_{2} \cdot \mathrm{molCarboidrato}^{-1}\right)$ & 0,50 & 1,65 & 0,57 & 0,33 & 0,59 & 0,97
\end{tabular}

A diminuição do $t_{C}(4 h, 3 h$ e $2 h$ - Condições 1/3/5 e 2/4/6) apresentou tendência clara sobre o $\mathrm{RMCR}_{\mathrm{C}, \mathrm{n}}$ apenas para as condições com menor concentração afluente 
(Condições 1/3/5), com melhoria dos resultados obtidos. A literatura sugere que tempos de ciclos (em reatores em bateladas sequencias) ou tempos de detenção hidráulica (em reatores contínuos) menores devem ser utilizados visando lavar as arquéias metanogênicas dos reatores, que seria um dos motivos da diminuição dos rendimentos na produção de hidrogênio. Realmente observa-se que a condição 4 foi a única condição que apresentou produção de metano. Muito provavelmente por este fato a mesma tendência apresentada nas menores concentrações afluentes (melhores valores de produção de hidrogênio com a diminuição do tempo de ciclo) não foi atingida nas operações com maior concentração (Condições 2/4/6 que apresentaram valores de $\mathrm{RMCR}_{\mathrm{C}, \mathrm{n}}$ de $1,65,0,33$ e $0,97 \mathrm{molH}_{2} \cdot$ molCarboidrato $^{-1}$, respectivamente).

Analisando-se a influência da concentração afluente para valores iguais de tempos de ciclo (Condições 1/2, 3/4 e 5/6), tem-se que o aumento da concentração afluente elevou o $\mathrm{RMCR}_{\mathrm{C}, \mathrm{n}}$ em todas as faixas de tempo de ciclo (no $\mathrm{t}_{\mathrm{C}}=4 \mathrm{~h}$ de 0,50 para $1.65 \mathrm{e} \mathrm{em} \mathrm{t}_{\mathrm{C}}=2 \mathrm{~h}$ de 0,59 para $0,97 \mathrm{molH}_{2} \cdot \mathrm{molCarboidrato}^{-1}$ ), exceto para o tempo de ciclo de 3 h que na Condição 4 ocorreu produção de metano (o RMCR Ç, $_{\text {caiu de }}$ 0,57 para $0,33 \mathrm{molH}_{2} \cdot \mathrm{molCarboidrato}^{-1}$ ). Este efeito da concentração foi apresentado também por Inoue (2013) em seu estudo. Por outro lado, El Manssouri (2012) não encontrou o mesmo padrão de comportamento. Uma comparação da influência dos parâmetros intrínsecos a $\mathrm{COAV}_{\mathrm{S}}$ através das Condições 4 (concentração de $5400 \mathrm{mgDQO}^{-1} \mathrm{e} \mathrm{t}_{\mathrm{C}}$ de $3 \mathrm{~h}$ ) e 5 (concentração de $3600 \mathrm{mgDQO} . \mathrm{L}^{-1}$ e $\mathrm{t}_{\mathrm{C}}$ de $2 \mathrm{~h}$ ), em que ambos possuem mesma $\mathrm{COAV}_{\mathrm{S}}$ não pôde ser verificada, tendo em vista os problemas com produção de metano apresentado na condição 4 que provavelmente diminuiram os rendimentos de produção de $\mathrm{H}_{2}$.

Por último, é interessante destacar que o melhor $\mathrm{RMCR}_{\mathrm{C}, \mathrm{n}}$ obtido na operação com lactose $\left(1,65 \mathrm{molH}_{2} \cdot\right.$ molCarboidrato $^{-1}$ na Condição 2$)$ foi superior aos obtidos nos 
trabalhos de El Manssouri (2012) e Inoue (2013) utilizando sacarose (1,48 $\mathrm{molH}_{2} \cdot \mathrm{molCarboidrato}^{-1} 1,04 \mathrm{molH}_{2} \cdot \mathrm{molCarboidrato}^{-1}$, respectivamente), mesmo com a degradabilidade da lactose sendo menor do que a da sacarose.

A Tabela 5.89 apresenta os valores de produtividade molar volumétrica (PrM) e produtividade molar específica (PrME) em todas as condições experimentais, pela qual observa-se que o aumento da $\mathrm{COAV}_{\mathrm{S}}$ não resultou em uma tendência de aumento ou diminuição nem da PrM, ou seja, em função do volume do reator, nem da PrME, ou seja, em função da biomassa contida no reator. A desmontagem do reator ao término de cada condição experimental para a medida da biomassa $\left(\mathrm{M}_{\mathrm{SVT}}\right)$, a qual promoveu a lavagem de parte desta, principalmente na etapa de remontagem do sistema para a nova condição, minimizou o acúmulo excessivo de sólidos que parece prejudicar o desempenho do sistema.

Tabela 5.89 - Produtividades em todas as condições experimentais (Lactose: $\mathrm{C} 1=\mathrm{DQO}$ $=3600 \mathrm{mg} \cdot \mathrm{L}^{-1}$ e $\mathrm{t}_{\mathrm{C}}=4$ horas; $\mathrm{C} 2=\mathrm{DQO}=5400 \mathrm{mg} \cdot \mathrm{L}^{-1} \mathrm{e}_{\mathrm{C}}=4$ horas; $\mathrm{C} 3=\mathrm{DQO}=$ $3600 \mathrm{mg} \cdot \mathrm{L}^{-1} \mathrm{e} \mathrm{t}_{\mathrm{C}}=3$ horas; $\mathrm{C} 4=\mathrm{DQO}=5400 \mathrm{mg} \cdot \mathrm{L}^{-1}$ e $\mathrm{t}_{\mathrm{C}}=3$ horas; $\mathrm{C} 5=\mathrm{DQO}=3600$

\begin{tabular}{|c|c|c|c|c|c|c|c|}
\hline \multirow{2}{*}{ Indicador } & \multirow{2}{*}{ Unidade } & \multicolumn{6}{|c|}{ Condição } \\
\hline & & 1 & 2 & 3 & 4 & 5 & 6 \\
\hline PrM & $\left(\mathrm{molH}_{2} \cdot \mathrm{m}^{-3} \cdot \mathrm{d}^{-1}\right)$ & 10,2 & 50,3 & 15,7 & 14,9 & 26,5 & 63,2 \\
\hline PrME & $\left(\mathrm{molH}_{2} \cdot \mathrm{kgSVT}^{-1} \cdot \mathrm{d}^{-1}\right)$ & 2,2 & 15,8 & 3,5 & 2,9 & 5,4 & 13,2 \\
\hline
\end{tabular}

Analisando-se a influência do tempo do ciclo na PrM para a mesma concentração afluente (Condições 1/3/5 e 2/4/6), houve um aumento de 10,3 para 26,5 (160\%) nas Condições 1/3/5 e de 50,3 para 63,2 molH $2 \cdot \mathrm{m}^{-3} \cdot \mathrm{d}^{-1}$ (25\%) nas Condições 2/4/6, com queda na Condição 4, única condição que apresentou produção de metano. Com relação à influência da concentração afluente para o mesmo tempo de ciclo, houve um aumento de 10,2 para 50,3 (395\%) nas Condições 1/2, de 26,5 para 63,2 (138\%) nas 
Condições $5 / 6$ e uma queda de 15,7 para $14,9 \mathrm{molH}_{2} \cdot \mathrm{m}^{-3} \cdot \mathrm{d}^{-1}(5 \%)$ nas Cndições $3 / 4$ (onde ocorreu produção de metano). A comparação das Condições 4 (5400 mgDQO.L ${ }^{-1}$ e 3h) e 5 (3600 mgDQO. $\mathrm{L}^{-1}$ e $\left.2 \mathrm{~h}\right)$ que possuem a mesma $\mathrm{COAV}_{\mathrm{S}}$, resultaram em PrM de 14,9 e $26,5 \mathrm{molH}_{2} \cdot \mathrm{m}^{-3} \cdot \mathrm{d}^{-1}$, porém deve-se levar im consideração nesta comparação que uma delas apresentou produção de metano.

A diminuição do $t_{C}(4 h, 3 h$ e $2 h$ - Condições 1/3/5 e 2/4/6) elevou a PrME para a faixa de concentração de $3600 \mathrm{mgDQO} \cdot \mathrm{L}^{-1}$ (Condições 1/3/5) com valores de 2,2, 3,5 e $5,4 \mathrm{molH}_{2} \cdot \mathrm{gSVT}^{-1} \cdot \mathrm{d}^{-1}$, porém não teve o mesmo efeito para a faixa de concentração de 5400 mgDQO.L ${ }^{-1}$ (Condições 2/4/6), diminuindo da Condição 2 para 4 e aumentando da 4 para a 6, com valores de 15,8, 2,9 e 13,2 molH $_{2} \cdot \mathrm{gSVT}^{-1} \cdot \mathrm{d}^{-1}$ (a Condição 4 apresentou produção de metano). Ao contrário do que aconteceu para a PrM, a Condição 2 apresentou valores de PrME maiores do que a Condição 6 devido aos menores valores de $\mathrm{M}_{\mathrm{SvT}}$ como pode ser observado na Tabela 5.90. O aumento da concentração afluente surtiu na PrME o mesmo padrão de comportamento da PrM, assim como aconteceu na comparação das Condições 4 (concentração de 5400 mgDQO.L $\mathrm{L}^{-1}$ e $\mathrm{t}_{\mathrm{C}}$ de $3 \mathrm{~h}$ ) e 5 (concentração de $3600 \mathrm{mgDQO} \cdot \mathrm{L}^{-1}$ e $\mathrm{t}_{\mathrm{C}}$ de $2 \mathrm{~h}$ ) com mesma $\mathrm{COAV}_{\mathrm{S}}$

Tabela 5.90 - Quantidade de biomassa no interior do reator $\left(\mathrm{M}_{\mathrm{SVT}}\right)($ Lactose: $\mathrm{C} 1=\mathrm{DQO}$ $=3600 \mathrm{mg} \cdot \mathrm{L}^{-1}$ e $\mathrm{t}_{\mathrm{C}}=4$ horas $; \mathrm{C} 2=\mathrm{DQO}=5400 \mathrm{mg} \cdot \mathrm{L}^{-1} \mathrm{e} \mathrm{t}_{\mathrm{C}}=4$ horas; $\mathrm{C} 3=\mathrm{DQO}=$ $3600 \mathrm{mg} . \mathrm{L}^{-1}$ e $\mathrm{t}_{\mathrm{C}}=3$ horas; $\mathrm{C} 4=\mathrm{DQO}=5400 \mathrm{mg} \cdot \mathrm{L}^{-1} \mathrm{e} \mathrm{t}_{\mathrm{C}}=3$ horas; $\mathrm{C} 5=\mathrm{DQO}=3600$ $\mathrm{mg} . \mathrm{L}^{-1}$ e $\mathrm{t}_{\mathrm{C}}=2$ horas; $\mathrm{C} 6=\mathrm{DQO}=5400 \mathrm{mg} . \mathrm{L}^{-1}$ e $\mathrm{t}_{\mathrm{C}}=2$ horas)

\begin{tabular}{cccccccc}
\hline \multirow{2}{*}{ Parâmetro } & Unidade & \multicolumn{7}{c}{ Condição } \\
& & 1 & 2 & 3 & 4 & 5 & 6 \\
\hline $\mathrm{M}_{\mathrm{SVT}}$ & $(\mathrm{g})$ & 17,9 & 11,7 & 17,6 & 19,3 & 17,4 & 16,6 \\
\hline
\end{tabular}

A Figura 5-361 apresenta as concentrações dos compostos intermediários em todas as condições, podendo-se observar que houve o predomínio da via do ácido 
acético seguido pelo etanol, ácidos butírico e propiônico em todas as condições experimentais estudadas, mesmo na condição 4 que apresentou metano na composição do biogás produzido. 


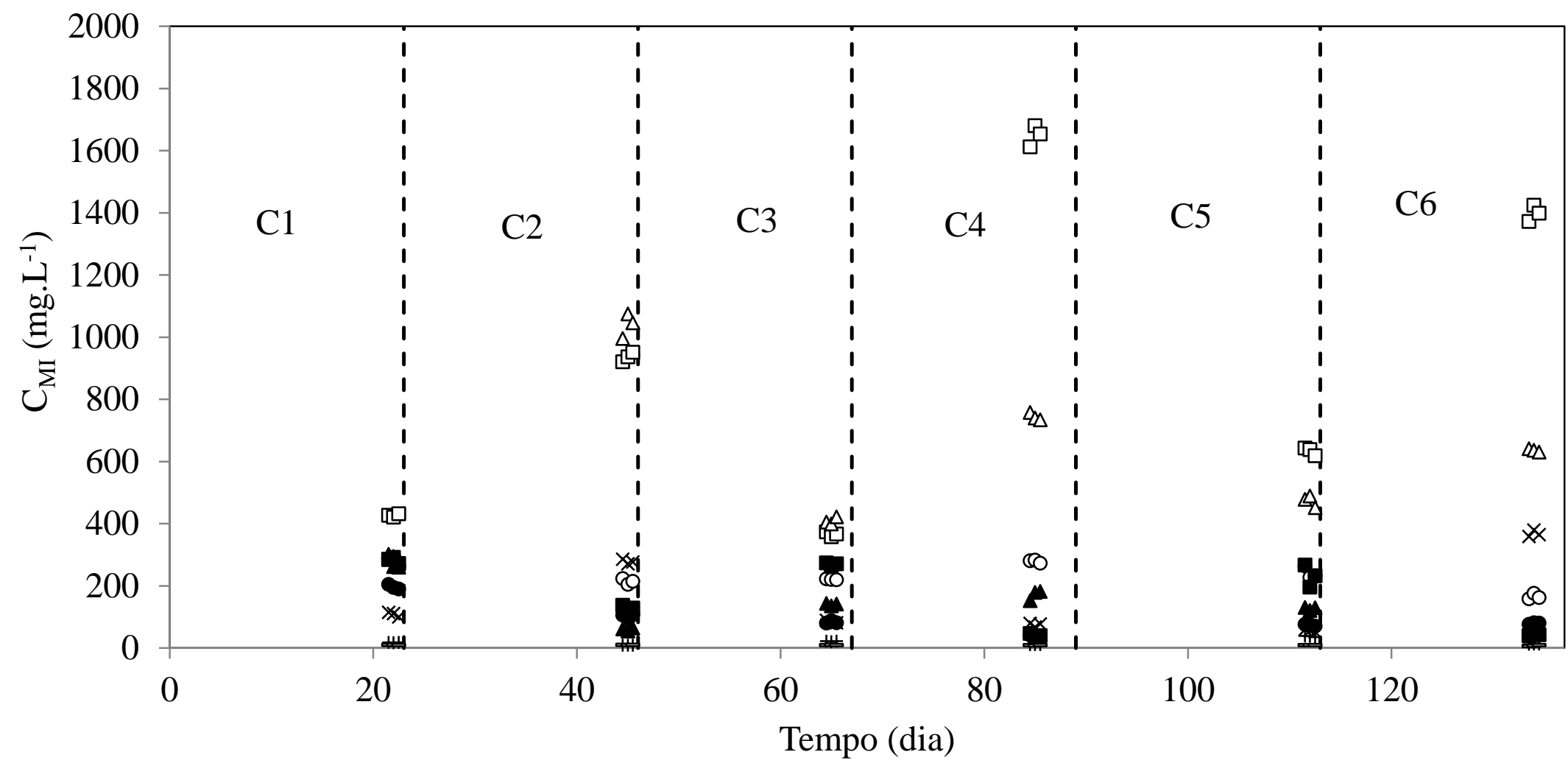

Figura 5-361 - Concentração dos compostos intermediários: $\square$ - ácido acético; $\Delta$ - etanol; ○ - ácido butírico; $\square$ - ácido isobutírico; $\boldsymbol{\Delta}$ - ácido capróico; • - ácido valérico; * ácido propiônico; +butanol; — ácido isovalérico em todas as condições (Lactose: $\mathrm{C} 1=\mathrm{DQO}=3600 \mathrm{mg} . \mathrm{L}^{-1}$ e t $\mathrm{t}_{\mathrm{C}}$ $=4$ horas $; \mathrm{C} 2=\mathrm{DQO}=5400 \mathrm{mg} \cdot \mathrm{L}^{-1}$ e $\mathrm{t}_{\mathrm{C}}=4$ horas $; \mathrm{C} 3=\mathrm{DQO}=3600 \mathrm{mg} \cdot \mathrm{L}^{-1}$ e $\mathrm{t}_{\mathrm{C}}=3$ horas $; \mathrm{C} 4=\mathrm{DQO}=5400 \mathrm{mg} \cdot \mathrm{L}^{-1} \mathrm{e} \mathrm{t}_{\mathrm{C}}=3$ horas; $\mathrm{C} 5=$ $\mathrm{DQO}=3600 \mathrm{mg} \cdot \mathrm{L}^{-1}$ e $\mathrm{t}_{\mathrm{C}}=2$ horas; $\mathrm{C} 6=\mathrm{DQO}=5400 \mathrm{mg} . \mathrm{L}^{-1} \mathrm{e}_{\mathrm{C}}=2$ horas ). 


\subsection{Caracterização filogenética do consórcio microbiano do AnSBBR operado a $15{ }^{\circ} \mathrm{C}(\mathbf{C 1 3})$}

A condição operacional C13 foi a que apresentou melhores resultados de produção de hidrogênio dentre todas as condições operacionais estudadas operadas com soro de leite (C1 a C13). Por esse motivo, uma amostra de biomassa do AnSBBR foi coletada visando a caracterização filogenética do consórcio microbiano. Foram analisadas as sequências de 80 clones, as quais foram agrupadas em 6 Unidades Taxonômicas Operacionais (UTO) (95\% de similaridade). Os microrganismos presentes no reator na condição C13 foram classificados como pertencentes ao Filo Firmicutes, dividindo-se entre as classes Bacilli e Clostridia e, em menor quantidade, classificados junto ao Filo Proteobacteria (Acetobacteraceae, 11,25\% dos clones). Dentro do Filo Firmicutes, 27,5 \% do total dos clones foram classificados como pertencentes à Família Lactobacillaceae e 61,25\% como Clostridiaceae (Figura 5-362 e Tabela 5.91).

A maioria dos clones analisados $(61,25 \%)$ foi semelhante à Clostridium, que é um microrganismo que tem sido relatado em diversos estudos que realizaram a caracterização filogenética de consórcios microbianos presentes em reatores aplicados à produção de hidrogênio.

Oh et al. (2004) utilizaram um reator anaeróbio de membrana (alimentado com glicose em pH 5,5) visando a produção de hidrogênio e encontraram bactérias filogeneticamente relacionadas com membros das Famílias Clostridiaceae e Flexibacteraceae, incluindo as espécies Clostridium acidisoli e Linmingia china. Iyer et al. (2004) avaliaram a influência de parâmetros operacionais (TDH e temperatura) na produção de $\mathrm{H}_{2}$ e na composição da comunidade microbiana presente em reator CSTR 
alimentado com glicose em $\mathrm{pH}$ 5,5. Maior diversidade microbiana foi encontrada para TDH de 30 horas (Bacillaceae, Clostridiaceae e Enterobacteriaceae) enquanto que em TDH de 10 horas somente representantes da Família Clostridiaceae foram encontrados. O aumento de temperatura de 30 para $37{ }^{\circ} \mathrm{C}$ causou notável alteração da população Clostridium acidisoli para populações de Clostridium acetobutylicum (Iyer et al., 2004). Microrganismos com elevada similaridade com Clostridium acidisoli também foram encontrados em reator CSTR aplicado a produção de hidrogênio e alimentado com melaço em pH 4-4,5 (Ren et al., 2007). Assim, sugere-se que independente do tipo de reator utilizado, as condições de cultivos, tais como disponibilidade de carboidrato, temperatura mesófila e condições anaeróbias parecem favorecer o crescimento e seleção de espécies de Clostridium.

As sequências representativas das OTUs 1 e 2 apresentaram elevada similaridade (> 98,8\%) com Clostridium acidisoli (AJ237756) (Tabela 5.91), cuja sequência foi depositada no banco de dados por Kuhner et al. (2000), que isolou duas cepas acidófilas de Clostridium (Clostridium akagii $\mathrm{CK}^{\mathrm{T}} 8^{\mathrm{T}}$ e Clostridium acidisoli $\mathrm{CK} 74^{\mathrm{T}}$ ). Entre as cepas, Clostridium acidisoli $\mathrm{CK} 74^{\mathrm{T}}$, foi capaz de crescer em faixa de pH variando entre 3,6-6,9, sem distinção entre o valor ótimo para a faixa $\mathrm{pH}$ estudada. Foi observado crescimento em faixa de temperatura variando entre 5 a $37^{\circ} \mathrm{C}$, sendo que o valor ótimo estava na faixa de $25-30^{\circ} \mathrm{C}$. A cepa $\mathrm{CK} 74^{\mathrm{T}}$ possui morfologia de bacilos gram-positivos móveis e formadores de endósporos, que é capaz de crescer em variedade de substratos: glicose, celobiose, xilose, arabonose, maltose, manose, lactose, sacarose e glicerol, entre outros. A fermentação da glicose gera como substratos $\mathrm{H}_{2}$, $\mathrm{CO}_{2}$, acetato, butirato, lactato e, em algumas condições também formiato. Acredita-se que o hidrogênio produzido na condição C13 deve-se majoritariamente ao metabolismo de microrganismos semelhantes à Clostridium acidisoli porque ele possui capacidade de 
crescer em ampla faixa de temperatura, principalmente em temperaturas reduzidas $\left(5{ }^{\circ} \mathrm{C}\right)$, de consumir açúcares e produzir $\mathrm{H}_{2}$.

As sequências representativas da OTUs 5 e 6 também relacionaram-se com elevada similaridade com microrganismos da Família Clostridiaceae. A UTO_5 apresentou elevada similaridade (>99,3\%) com bactéria não cultivada (JF281140), cuja sequência foi depositada no banco de dados por Castelló et al. (2011), que avaliaram a produção de hidrogênio em reator UASB alimentado como soro de leite a $30^{\circ} \mathrm{C}$. Para os referidos autores, apesar de terem sido encontrados no reator microrganismos filogeneticamente similares àqueles produtores de hidrogênio, tais como Clostridium, Ruminococcus e Enterobacter, também foram identificados microrganismos não produtores do referido gás (Lactobacillus, Dialister e Prevotella).

A sequência contida na OTU_6 foi similar a Clostridium sp. não cultivado (AY029593), cuja sequência foi depositada por Fang et al. (2002). Os autores fizeram a caracterização de grânulo produtor de hidrogênio proveniente de um fermentador (3L) alimentado com água residuária sintética a base de sacarose, mantido em $\mathrm{pH}$ 5,5 e $26{ }^{\circ} \mathrm{C}$.

Além de Clostridium, clones filogeneticamente semelhantes com a Família Lactobacilaceae, especificamente Lactobacillus rhamnosus (100 \% similaridade) (UTO_3, 27,7 \%) foram observados em menor porcentagem no reator.

O gênero Lactobacillus é o maior e mais diverso grupo de bactérias láticas agrupadas dentro do Filo Firmicutes. Os microrganismos deste gênero possuem morfologia de bacilos gram-positivos não formadores de endósporos, que, normalmente, não exibem motilidade e, ocasionalmente, são capazes de reduzir nitrato. De acordo com os produtos da fermentação da glicose, as bactérias láticas podem ser divididas em heteroláticas, que produzem ácido lático conjuntamente com $\mathrm{CO}_{2}$, etanol e 
ácido acético em quantidades equimolares; e as bactérias homoláticas, que produzem principalmente ácido lático (Zhang e Cai, 2014).

Segundo Mariakakis et al. (2012) diversos trabalham relatam a co-existência de microrganismos produtores de hidrogênio com outros grupos microbianos que competem com os primeiro pelo substrato: os homoacetogênicos produtores de ácido acético, as bactérias produtoras de ácido propiônico, as bactérias redutoras de sulfato e, principalmente, as bactérias produtoras de ácido lático. A presença de bactérias láticas em reatores aplicados à produção de hidrogênio foi discutida detalhadamente por Sikora et al. (2013). Na maior parte dos relatos, a presença destes microorganismos teve influência negativa na produção de hidrogênio. Segundo os autores o efeito negativo da presença de bactérias láticas pode ser justificado (1) pela competição por substrato entre microrganismos produtores de $\mathrm{H}_{2}$ e as bactérias láticas ou (2) pela excreção de bacteriocinas pelas bactérias láticas, que inibem o crescimento de outros microrganismos, por exemplo, Clostridium. Segundo os autores, em reatores operados por longos períodos, ocorre a predominância de bactérias láticas em relação às produtoras de hidrogênio e, concomitante com a alteração da dinâmica microbiana ocorre também o aumento da produção de ácido lático ou etanol. Na maioria dos estudos, a presença de bactérias láticas justifica um reduzido rendimento de produção de $\mathrm{H}_{2}$ (Castelló et al., 2011; Fernández et al., 2014), com exceção de um único estudo que reportou a capacidade de bactérias láticas em produzir hidrogênio a partir da fermentação da lactose (Yang et al., 2007).

A importância desses microrganismos reside principalmente na propriedade antimicrobiana que as bactérias láticas exibem e que as permite estender a vida útil de muitos alimentos. A inibição da deterioração de alimentos pode ser atribuída à produção de compostos anti-microbianos, os quais incluem ácidos orgânicos, peróxido de 
hidrogênio, antibióticos e bacteriocinas (Atrih et al., 1993). Muitas espécies de Lactobacillus utilizadas na fabricação de produtos lácteos inibem o crescimento de outras bactérias, incluindo patógenos intestinais, por meio da produção de bacteriocinas, que são polipeptídeos com atividade bactericida ou bacteriostática contra determinado grupo bacteriano. As bacteriocinas produzidas pelas bactérias láticas exibem amplo espectro inibitório, sendo potenciais preservativos de alimentos (Sarika et al., 2010).

O aumento da resistência aos antibióticos causada pelo uso excessivo destas drogas tem estimulado estudos acerca da produção de bacteriocinas por bactérias láticas. Lactobacillus rhamnosus já foi isolado de diversos habitats, incluindo leite e seus derivados, esgoto, carne, e podem ser facilmente obtidos visando a produção de bacteriocinas (Sarika et al., 2010). Devido ao interesse em utilizar bactérias láticas como probióticos, Sarika et al. (2010) estudaram diferentes condições de cultivo (temperatura, pH, período de incubação e concentração de substrato) para otimizar a produção de bacteriocinas por L. rhamnosus GP1. Segundo os autores, a bacteriocina produzida apresentou amplo espectro de atividade sendo efetiva na inibição do crescimento de microrganismos como, por exemplo, Bacillus brevis, B. pumilus, B. subtilis, Escherichia coli, Pseudomonas aeruginosa, Staphylococcus aureus. A atividade máxima da bacteriocina foi observada em meio de cultivo MRS incubado a $30^{\circ} \mathrm{C}(1200 \mathrm{AU} / \mathrm{mL})$ em comparação com outras temperaturas estudadas $(20,25,35 \mathrm{e}$ $\left.40^{\circ} \mathrm{C}\right)$.

Com base nos resultados reportados por Sarika et al. (2010) sugere-se que, no presente estudo, a redução da temperatura de incubação de $30^{\circ} \mathrm{C}(\mathrm{C} 10)$ para $15^{\circ} \mathrm{C}(\mathrm{C} 13)$ inibiu o crescimento e a produção de bacteriocinas por microrganismos do gênero Lactobacillus e, permitiu o estabelecimento de um consórcio microbiano composto majoritariamente por Clostridium. Possivelmente, a predominância de populações de 
Clostridium em detrimento de populações de Lactobacillus justifique o melhor de desempenho do reator AnSBBR mantido a $15^{\circ} \mathrm{C}$.

Em menor porcentagem foram encontrados clones com sequências semelhantes a Acetobacter indonesiensis (UTO_4, 100\% similaridade). Microrganismos do gênero Acetobacter são reconhecidos como grupo de bactérias capazes de oxidar etanol a ácido acético produzindo significativa quantidade do referido ácido (Asai e Shoda, 1958). Acetobacter indonesiensis foi descrita como espécie com morfologia de bacilos gramnegativos, que produzem ácido acético a partir de etanol, oxidam acetato e lactato a dióxido de carbono e água, e também produzem ácido a partir da glicose (Lisdiyanti et al., 2000). Sugere-se que tais microrganismos foram responsáveis pelo consumo de etanol e produção de ácido acético no reator mantido a $15^{\circ} \mathrm{C}$. Por isso, a quantidade deste ácido na condição C13 foi superior aos outros metabólitos gerados (ácido acético, 50,4\%; butírico, $32,1 \%$; etanol, $4,4 \%)$. Já na condição $\mathrm{C} 10\left(30^{\circ} \mathrm{C}\right)$ a produção de ácido acético $(37,2 \%)$, ácido butírico $(30 \%)$ e etanol (24\%) ocorreram em porcentagens semelhantes.

Ainda com relação à produção de ácido acético, não é possível relacionar sempre a elevada produção deste ácido com altos rendimentos de produção de hidrogênio, pois se sabe que há microrganismos que produzem o referido ácido a partir de etanol (Acetobacter) ou a partir de $\mathrm{H}_{2}$ e $\mathrm{CO}_{2}$ como na homoacetogênese (Clostridium carboxidivorans) (Saady, 2013).

Diversos estudos reportam a ocorrência de Clostridium em biorreatores produtores de hidrogênio. Sabe-se que tais microrganismos são produtores do referido gás e, por isso, diversas vezes são aplicados pré-tratamentos (térmico, ácido, básico) a diferentes fontes de inóculo visando a seleção de microrganismos formadores de endósporos, entre eles Clostridium. O tratamento do inóculo é eficaz e por isso tão 
amplamente utilizado. Todavia, ressalta-se que, para reatores contínuos, esse tratamento inicial parece não ser eficaz porque ao longo do período operacional microrganismos externos, por exemplo, aqueles provenientes da água residuária, colonizam o reator e prejudicam o processo, assim como citado por Castelló et al. (2011) sobre a ocorrência de microrganismos não produtores de $\mathrm{H}_{2}$. Com base nos resultados desse estudo, destaca-se que parâmetros operacionais, tais como a temperatura, podem ser ferramentas eficazes na seleção de microrganismos específicos dentro dos biorreatores. No caso do presente estudo, acredita-se que a temperatura permitiu a sobreposição de populações de Clostridium em detrimento de Lactobacillus e, com isso o melhor desempenho do AnSBBR mantido a $15^{\circ} \mathrm{C}$. 


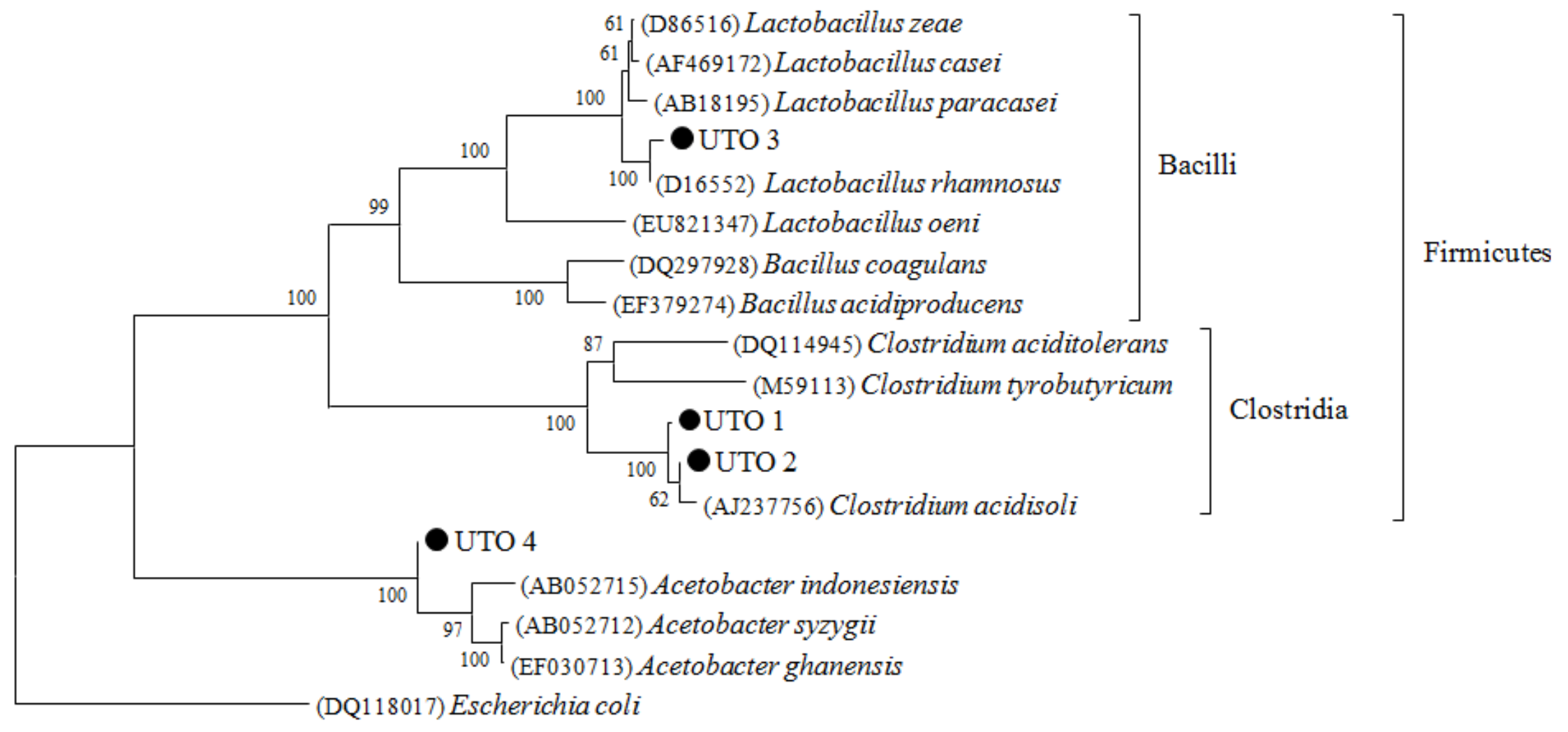

Figura 5-362 - Árvore filogenética construída a partir de distâncias evolutivas inferidas usando o método Neighbor-Joining (Saitou e Nei, 1987). A porcentagem de réplicas da árvore está apresentada próximo aos ramos e foi calculada com base em teste de bootstrap com 1000 réplicas (Felsenstein, 1985). As distâncias evolutivas foram calculadas usando o método de Jukes e Cantor (1969). A análise foi realizada com 18 sequências de nucleotídeos. 
Tabela 5.91 - Caracterização filogenética do consórcio microbiano proveniente do reator operado a $15^{\circ} \mathrm{C}$ alimentado como soro de leite.

\begin{tabular}{|c|c|c|c|c|c|c|c|c|}
\hline \multirow[b]{2}{*}{ UTO } & \multirow[b]{2}{*}{ Classificação } & \multirow{2}{*}{$\begin{array}{l}\text { Número } \\
\text { de } \\
\text { clones }\end{array}$} & \multicolumn{3}{|c|}{ Afiliação filogenética } & \multirow{2}{*}{$\begin{array}{l}\text { Produtos da } \\
\text { fermentação* }\end{array}$} & \multirow{2}{*}{$\begin{array}{c}\text { Produtor } \\
\text { de } \mathrm{H}_{2} *\end{array}$} & \multirow[b]{2}{*}{ Referências } \\
\hline & & & Espécie do Genbank & $\begin{array}{l}\text { Número de } \\
\text { acesso }\end{array}$ & $\begin{array}{c}\text { Similaridade } \\
(\%)\end{array}$ & & & \\
\hline UTO_1 & \multirow{2}{*}{ Clostridiaceae } & 21 & \multirow{2}{*}{ Clostridium acidisoli } & \multirow{2}{*}{ AJ237756 } & 98,8 & Acético, butírico, & \multirow{2}{*}{+} & Kuhner et \\
\hline UTO_2 & & 26 & & & 99,5 & lático e fórmico & & al. (2000) \\
\hline UTO_3 & Lactobacillaceae & 22 & Lactobacillus rhamnosus & D16552 & 100 & & - & $\begin{array}{l}\text { Collins et } \\
\text { al. (1991) }\end{array}$ \\
\hline UTO_4 & Acetobacteraceae & 9 & Acetobacter indonesiensis & AB052715 & 100 & & - & $\begin{array}{c}\text { Lisdiyanti } \\
\text { et al. } \\
(2001)\end{array}$ \\
\hline UTO_5 & Clostridiaceae & 1 & bactéria não cultivada & JF281140 & 99,3 & & + & $\begin{array}{l}\text { Castelló et } \\
\text { al. (2011) }\end{array}$ \\
\hline UTO_6 & Clostridiaceae & 1 & Clostridium sp. não cultivado & AY029593 & 97,2 & & + & $\begin{array}{l}\text { Fang et al. } \\
\text { (2002) }\end{array}$ \\
\hline
\end{tabular}

produtos da fermentação e produção de hidrogênio para membros do gênero/espécies de acordo com Kuhner et al. (2000), Collins et al. (1991), Lisdiyanti et al. (2001) 


\section{CONCLUSÕES}

Para o AnSBBR com recirculação da fase líquida:

- o uso do soro de leite apresentou problemas na produção de hidrogênio. Algumas alternativas, como adaptação da biomassa com substratos puros de degradação mais fácil, controle do $\mathrm{pH}$ em valores muito baixos e diferentes formas de inoculação foram testadas, entretanto, sem obtenção de sucesso.

- A refrigeração do meio de alimentação a $4{ }^{\circ} \mathrm{C}$ resolveu o problema de degradação do substrato no frasco de armazenamento do afluente, impedindo que o AnSBBR fosse alimentado com quantidades significativas de ácidos voláteis minimizando a atividade metanogênica de um processo combinado acidogênico-metanogênico. Esta refrigeração, por outro lado, gerou indícios de produção de $\mathrm{H}_{2} \mathrm{~S}$ (odor característico e formação de substância branca recobrindo o exterior das mangueiras de alimentação) por possível ação de bactérias redutoras de sulfato (BRS), apesar de análises específicas para detecção deste composto não terem sido realizadas. Desta forma, o afluente foi preparado apenas com soro de leite e bicarbonato de sódio, retirando-se a ureia e a complementação de nutrientes, evitando assim uma oferta de sulfato no meio de alimentação. Esta estratégia, juntamente com a lavagem periódica do material suporte deram condições operacionais para atingir uma estabilidade na produção de hidrogênio, mesmo com uma presença muito pequena de metano. 
- Comparando-se as três condições onde ocorreu estabilidade do processo (Condição 2 - sacarose; Condição 3 - lactose; Condição 8 - soro de leite) observou-se que sacarose apresentou melhores valores dos indicadores de produção de biohidrogênio do que a lactose, fato justificado pela diferença de degradabilidade, e o soro apresentou melhor produção de hidrogênio do que a lactose, mostrando a potencialidade de utilização desta água residuária em processos em escala plena.

- A concentração afluente afetou o processo, apresentando um ponto ótimo para a concentração de $5400 \mathrm{mgDQO} . \mathrm{L}^{-1}$, atingindo valores de 0,80 $\mathrm{molH}_{2} \cdot \mathrm{mol}^{-1}$ lactose e de $660 \mathrm{mLH}_{2} \cdot \mathrm{L}^{-1} \cdot \mathrm{d}^{-1}$ para o $\mathrm{RMCR}_{\mathrm{C}, \mathrm{n}}$ e para o VHPR, respectivamente.

- O tempo de enchimento não teve uma influência significativa no processo apresentando resultados similares para ambas as condições analisadas.

- A temperatura teve uma forte influência no processo, com a temperatura mais baixa $\left(15^{\circ} \mathrm{C}\right)$ apresentando os melhores resultados $(1,12$ $\mathrm{molH}_{2} \cdot$ mollactose $^{-1}$ e de $1080 \mathrm{mLH}_{2} \cdot \mathrm{L}^{-1} \cdot \mathrm{d}^{-1}$ para o $\mathrm{RMCR}_{\mathrm{C}, \mathrm{n}}$ e para o VHPR, respectivamente) e a temperatura mais alta $\left(45^{\circ} \mathrm{C}\right)$ apresentando efeitos negativos para o processo, com a produção de hidrogênio sendo anulada no final da operação, restando apenas metano e dióxido de carbono na composição do biogás produzido.

- Os resultados obtidos são importantes pois não existem trabalhos estudando temperaturas baixas utilizando soro de leite como substrato.

- Temperaturas baixas teriam algumas vantagens tecnológicas como operação em países frios que possuem uma indústria de laticínios bem 
desenvolvida e a vantagem de o soro de leite, devido à sua alta degradabilidade, precisar ser armazenado a baixas temperaturas.

- O AnSBBR se mostrou uma excelente opção de configuração de reator para produção de biohidrogênio à partir de soro de leite. Os melhores valores de VHPR e de $\mathrm{RMCR}_{\mathrm{C}, \mathrm{n}}$ obtidos com a presente configuração (durante a Condição 13) foram superiores aos obtidos em outros trabalhos utilizando configurações tradicionais como o UASBr e o CSTR.

- $\mathrm{O}$ AnSBBR apresentou apenas $\mathrm{H}_{2}$ e $\mathrm{CO}_{2}$ na composição do seu biogás e obteve grande estabilidade na produção de hidrogênio durante sua fase estacionária, enquanto que grande parte das outras configurações apresentou uma alta instabilidade, com picos e quedas acentuados.

- A maioria dos clones analisados foi semelhante à Clostridium, que é um microrganismo que tem sido relatado em diversos estudos que realizaram a caracterização filogenética de consórcios microbianos presentes em reatores aplicados à produção de hidrogênio.

- Além de Clostridium, clones filogeneticamente semelhantes com a Família Lactobacilaceae, especificamente Lactobacillus rhamnosus foram observados em menor porcentagem no reator.

- Também foram encontrados em menor porcentagem clones com sequências semelhantes a Acetobacter indonesiensis.

Para o estudo complementar com o AnSBBR com agitação mecânica alimentado com lactose: 
- O sistema obteve baixo desempenho na remoção de matéria orgânica na forma de DQO, com remoções médias sempre abaixo de $20 \%$ durante toda a fase experimental.

- O reator apresentou ótimo desempenho no consumo de carboidratos (lactose), com valores médios sempre acima de $90 \%$.

- Foi obtida uma produção estável de biohidrogênio com mínima formação de metano em uma das condições analisadas, fato importante tendo em vista que esta estabilidade não conseguiu ser obtida em outras configurações de reatores relatadas na literatura.

- A diminuição do $\mathrm{t}_{\mathrm{C}}(4 \mathrm{~h} / 3 \mathrm{~h} / 2 \mathrm{~h}$ - mesma concentração afluente) apresentou tendência positiva sobre o $\mathrm{RMCR}_{\mathrm{C}, \mathrm{n}}$ e $\mathrm{o}$ aumento da concentração afluente (3600 mgDQO.L $\mathrm{L}^{-1} / 5400 \mathrm{mgDQO} . \mathrm{L}^{-1}$ - mesmo tempo de ciclo) elevou o $\mathrm{RMCR}_{\mathrm{C}, \mathrm{n}}$ em todas as faixas de tempo.

- A análise dos metabólitos intermediários indicou que houve o predomínio da via do ácido acético seguido pelo etanol, ácidos butírico e propiônico em todas as condições experimentais estudadas.

- $\mathrm{O}$ melhor $\mathrm{RMCR}_{\mathrm{C}, \mathrm{n}}$ obtido na operação com lactose $(1,65$ molH $_{2}$.molCarboidrato ${ }^{-1}$ na Condição 2) foi superior aos obtidos nos trabalhos de El Manssouri (2012) e Inoue (2013) utilizando sacarose $\left(1,04 \mathrm{molH}_{2} \cdot \mathrm{molCarboidrato}^{-1} \quad 1,48 \quad \mathrm{molH}_{2} \cdot \mathrm{molCarboidrato}^{-1}\right.$, respectivamente), destacando que a degradabilidade da lactose é menor do que a da sacarose. 


\section{REFERÊNCIAS BIBLIOGRÁFICAS}

ALBANEZ, R.; CANTO, C. S. A.; RATUSZNEI, S. M.; RODRIGUES, J. A. D.; ZAIAT, M.; FORESTI, E. Feasibility of a sequencing reactor operated in batch and fed-batch mode applied to nitrification and denitrification processes. Revista de Química Teórica y Aplicada - Afinidad, v. 66, p. 44-55, 2009.

ALZATE-GAVIRIA, L. M.; SEBASTIAN, P. J.; PEREZ-HERNANDEZ, A.; EAPEN, D. Comparison of two anaerobic systems for hydrogen production from the organic fraction of municipal solid waste and synthetic wastewater. International Journal of Hydrogen Energy, v. 32, p. 3141-3146, 2007.

AMORIM, E. L. C.; BARROS, A. R.; DAMIANOVIC, M. H. R. Z.; SILVA, E. L. Anaerobic fluidized bed reactor with expanded clay as support for hydrogen production thorough dark fermentation of glucose. International Journal of Hydrogen Energy, v. 34, p. 783-790, 2009.

ANGENENT, L. T.; SUNG, S.; RASKIN, L. Methanogenic population dynamics during startup of a full-scale anaerobic sequencing batch reactor treating swine waste. Water Research, v. 36, p. 4648-4654, 2002.

ARGUN, H.; KARGI, F.; KAPDAN, I.; OZTEKIN, R. Biohydrogen production by dark fermentation of wheat powder solution: Effects of $\mathrm{C} / \mathrm{N}$ and $\mathrm{C} / \mathrm{P}$ ratio hydrogen yield and formation rate. International Journal of Hydrogen Energy, v. 33, p. 1813-1819, 2008.

AROOJ, M.; HAN, S.; KIM, S.; KIM, D.; SHIN, H. Effect of HRT on ASBR converting starch into biological hydrogen. International Journal of Hydrogen Energy, v. 33, n. 22, p. 6509-6514, 2008. 
ASAI, T.; SHODA, K. The taxonomy of Acetobacter and allied oxidative bacteria. Journal of Genetic and Applied Microbiology, v. 4, p. 289-311, 1958.

ATRIH, A.; REKHIF, N.; MILLIERE, J.B.; LEFEBVRE, G. Detection and characterization of a bacteriocin produced by Lactobacillus plantarum C19. Canadian Journal of Microbiology, v.39, p. 1173-1179, 1993.

BADIEI, M.; JAHIM, J. M.; ANUAR, N.; SHEIKH ABDULLAH, S. R. Effect of hydraulic retention time on biohydrogen production from palm oil mill effluent in anaerobic sequencing batch reactor. International Journal of Hydrogen Energy, v. 36, n. 10, p. 5912-5919, 2011.

BAGLEY, D. M. E; BRODKORB, T. S. Modeling microbial kinetics in an anaerobic sequencing batch reactor - model development and experimental validation. Water Environmental Research, v. 71, p. 1320-1332, 1999.

BARROS, A. R.; AMORIM, E. L. C.; REIS, C. M.; SHIDA, G. M.; SILVA, E. L. Biohydrogen production in anaerobic fluidized bed reactors: effect of support material and hydraulic retention time. International Journal of Hydrogen Energy, v. 35, p. 3379-3388, 2010.

BENEMANN, R. The technology of biohydrogen. Em: Zaborsky et al., editor. Biohydrogen. New York: Plenum Press, p. 19-30, 1998.

BERGAMO, C. M.; MONACO, R.; RATUSZNEI, S. M.; RODRIGUES, J. A. D.; ZAIAT, M.; FORESTI, E. Effects of temperature at different organic loading levels on the performance of a fluidized-bed anaerobic sequencing batch bioreactor. Chemical Engineering and Processing, v. 48, p. 789-796, 2009. 
BEZERRA, R. A.; RODRIGUES, J. A. D.; RATUSZNEI, S. M.; ZAIAT, M.; FORESTI, E. Effects of feed time, organic loading and shock loads in the anaerobic whey treatment by an AnSBBR with circulation. Applied Biochemistry and Biotechnology, v. 157, p. 140-158, 2009.

BORGES, A. C.; SIMAN, R. R.; RODRIGUES, J. A. D.; RATUSZNEI, S. M.; ZAIAT, M.; FORESTI, E.; BORZANI, W. Stirred anaerobic sequencing batch reactor containing immobilized biomass: a behavior study when submitted to different fill times. Water Science and Technology, v. 49, p. 311-318, 2004.

BOXMA, B.; DE GRAAF, R. M.; VAN DER STAAY, G. W. M.; VAN ALEN, T. A.; RICARD, G.; GABALDON, T.; VAN HOEK, A. H. A. M.; MOON-VAN DER STAAY, S. Y.; KOOPMAN, W. J. H.; VAN HELLEMOND, J. J.; TIELENS, A. G. M.; FRIEDRICH, T.; VEENHUIS, M.; HUYNEN, M. A.; HACKSTEIN, J. H. P. An anaerobic mitochondrion that produces hydrogen. Nature, v. 434, p. 74-79, 2005.

BRITO, A. G.; RODRIGUES, A. C.; MELO, F. L. Feasibility of a pulsed sequencing batch reactor with an anaerobic aggregated biomass for the treatment of low strength wastewaters. Water Science and Technology, v. 35, p. 193-198, 1997.

BUITRÓN, G.; CARVAJAL, C. Biohydrogen production from Tequila vinasses in an anaerobic sequencing batch reactor: Effect of initial substrate concentration, temperature and hydraulic retention time. Bioresource technology, v. 101, p. 9071-9077, 2010.

CALLI, B.; YUKSELEN, M. A. Anaerobic treatment by a hybrid reactor. Environmental Engineering Science. v. 19, p. 143-150, 2004. 
CAMARGO, E. F. M.; RATUSZNEI, S. M.; RODRIGUES, J. A. D.; ZAIAT, M.; BORZANI, W. Treatment of low-strength wastewater using immobilized biomass in a sequencing batch external loop reactor: influence of the medium superficial velocity on the stability and performance. Brazilian Journal of Chemical Engineering, v. 19, p. 267-275, 2002.

CARRILlO-REYES, J.; CELIS, L. B.; ALATRISTE-MONDRAGÓN，F.; RAZOFLORES, E. Different start-up strategies to enhance biohydrogen production from cheese whey in UASB reactor. International Journal of Hydrogen Energy, v. 37, p. 5591-5601, 2012.

CARVALHINHA, P. P.; FlÔRES, A.; RATUSZNEI, S. M.; RODRIGUES, J. A. D.; ZAIAT, M.; FORESTI, E. AnSBBR applied to the treatment of metalworking fluid wastewater: effect of organic and shock load. Applied Biochemistry and Biotechnology, v. 162, 1708-1724, 2010.

CASTELlÓ, E.; GARCIA y SANTOS, C.; IGLESIAS, T.; PAOLINO, G.; WENZEL, J.; BORZACCONI, L.; ETCHEBEHERE, C. Feasibility of biohydrogen production from cheese whey using a UASB reactor: Links between microbial community and reactor performance. International Journal of Hydrogen Energy, v. 34, p. 5674-5682, 2009.

CASTELLÓ, E.; PERNA, V.; WENZEL, J.; BORZACCONI, L.; ETCHEBEHERE, C. Microbial community composition and reactor performance during hydrogen productionin a UASB reactor fed with raw cheese whey inoculated with compost. Water Science and Technology, v. 64, p. 2265-73, 2011.

CHANG, F. Y.; LIN, C. Y. Biohydrogen production using an up-flow anaerobic sludge blanket reactor. International Journal of Hydrogen Energy, v. 29, p. 33-39, 2004. 
CHANG, J. S.; LEE, K. S.; LIN, P. J. Biohydrogen production with fixed-bed bioreactor, International Journal of Hydrogen Energy, v. 27, p. 1167-1174, 2002.

CHEBEL, F. X.; RATUSZNEI, S. M.; RODRIGUES, J. A. D.; ZAIAT, M.; FORESTI, E. Analysis of performance of an anaerobic sequential batch reactor submitted to increasing organic load with different influent concentrations and cycle lengths. Applied Biochemistry and Biotechnology, v. 133, p. 171-187, 2006.

CHEN, C. C.; CHEN, H. P.; WU, J. H.; LIN, C. Y. Fermentative hydrogen production at high sulfate concentration. International Journal of Hydrogen Energy, v. 33, p. $1573-1578,2008$.

CHEN, W.; SUNG, S.; CHEN, S. Biological hydrogen production in an anaerobic sequencing batch reactor: $\mathrm{pH}$ and cyclic duration effects. International Journal of Hydrogen Energy, v. 34, p. 227-234, 2009.

CHEONG, D. Y.; HANSEN, C. L. Effect of feeding strategy on the stability of anaerobic sequencing batch reactor responses to organic loading conditions. Bioresource Technology, v. 99, p. 5058-5068, 2008.

CHEONG, D.-YEOL; HANSEN, C. L.; STEVENS, D. K. Production of Bio-Hydrogen by Mesophilic Anaerobic Fermentation in an Acid-Phase Sequencing Batch Reactor. Biotechnology, v. 96, p. 421-432, 2007.

COLlinS, M. D.; RODRIGUES, U.; ASH, C.; AGUIRRE, M.; FARROW, J. A. E.; MARTINEZ-MURCIA, A.; PHILLIPS, B. A.; WILliAMS, A. M.; WALLBANKS, S. Phylogenetic analysis of the genus Lactobacillus and related lactic acid bacteria as determined by RT sequencing of $16 \mathrm{~S}$ rRNA. FEMS Microbiology. Lett, v. 77, p. 5-12, 1991. 
DAGUE, R. R.; HABBEN, C. E.; PIDAPARTI, S. R. Initial studies on the anaerobic sequencing batch reactor. Water Science and Technology, v. 26, p. 2429-2432, 1992.

DAMASCENO, L. H .S.; RODRIGUES, J. A. D.; RATUSZNEI, S. M.; ZAIAT, M.; FORESTI, E. Effect of mixing mode on the behavior of an ASBBR with immobilized biomass in the treatment of cheese whey. Brazilian Journal of Chemical Engineering, v. 25, p. 291-298, 2008.

DAMASCENO, L. H. S.; RODRIGUES, J. A. D.; RATUSZNEI, S. M.; ZAIAT, M.; FORESTI, E. Effects of feeding time and organic loading in an anaerobic sequencing batch biofilm reactor (ASBBR) treating diluted whey. Journal of Environmental Management, v. 85, p. 927-935, 2007.

DAS, D. Advances in biohydrogen production processes: An approach towards commercialization. International Journal of Hydrogen Energy, v. 34, p. 73497357, 2009.

DAS, D.; VEZIROGLU, T. N. Hydrogen production by biological processes: a survey of literature. International Journal of Hydrogen Energy, v. 26, p. 13-28, 2001.

DE WIT, J. N. Lecturer's Handbook on Whey and Whey Products. European Whey Products Association, Brussels: Belgium, 2001.

DEL NERY, V. Utilização de lodo anaeróbio imobilizado em gel no estudo de partida de reatores de fluxo ascendente com manta de lodo. Dissertação (mestrado), Escola de Engenharia de São Carlos, USP, 1987.

DOMINGUES, L.; LIMA, N.; TEIXEIRA, J. A. Novas Metodologias para a Fermentação Alcoólica do Soro de Queijo. Em: Atas da 6ª Conferência Nacional sobre a Qualidade do Ambiente. Universidade Nova de Lisboa, Lisboa, Portugal, v. 3, p. 271-280, 1999. 
DUBOIS, S. M.; GILlES, K. A.; HAMILTON, J. L.; REBERS, P. A.; SMITH, F. Colorimetric Methods for determination of sugar and related substance. Analytical Chemistry, v. 228, p. 13-21, 1956.

ERGÜDER, T. H.; TEZEL, U.; GÜVEN, E.; DEMIRER, G. N. Anaerobic biotransformation and methane generation potential of cheese whey in batch and UASB reactors. Waste Management, v. 21, p. 643-650, 2001.

FANG, H. H. P.; LIU, H.; ZHANG, T. Characterization of a hydrogen-producing granular sludge. Biotechnology Bioengineering, v. 78, p. 44-52, 2002.

FELSENSTEIN, J. Confidence limits on phylogenies: An approach using the bootstrap. Evolution, v. 39, p. 783-791, 1985.

FERCHICHI, M.; CRABBE, E.; GIL, G.-H.; HINTZ, W.; ALMADIDY, A. Influence of initial $\mathrm{pH}$ on hydrogen production from cheese whey. Journal of Biotechnology, v. 120, p. 402-409, 2005.

FERNANDES, B. S.; PEIXOTO, G.; ALBRECHT, F. R.; SAAVEDRA, N. K.; ZAIAT, M. Potential to produce biohydrogen from various wastewaters. Energy Sustainable Development, v. 14, p. 143-148, 2010.

FERNANDES, L.; KENNEDY, K. J.; NING, Z. Dynamic modeling of substrate degradation in sequencing batch anaerobic reactors (SBAR). Water Research, v. 27, p. 1619-1628, 1993.

FERNÁNDEZ, C.; CARRACEDO, B.; MARTÍNEZ, E. J.; GÓMEZ, X.; MORÁN, A. Application of a packed bed reactor for the production of hydrogen from cheese whey permeate: Effect of organic loading rate. Journal of Environmental Science and Health, Part A: Toxic/Hazardous Substances and Environmental Engineering, p. 49, v. 210-217, 2014. 
FONTES LIMA, D. M.; ZAIAT, M. The influence of the degree of back-mixing on hydrogen production in an anaerobic fixed-bed reactor. International Journal of Hydrogen Energy, v. 37, p. 9630-9635, 2012.

FRIEDL, G. F.; MOCKAITIS, G.; RODRIGUES, J. A. D.; RATUSZNEI, S. M.; ZAIAT, M.; FORESTI, E. AnSBBR applied to organic matter and sulfate removal: interaction effect between feed strategy and COD/sulfate ratio. Applied Biochemistry and Biotechnology, v. 159, p. 95-109, 2009.

GHALY, A. E.; KAMAL, M.A. Submerged yeast fermentation of acid cheese whey for protein production and pollution potential reduction. Water Research, v. 38, p. 631-644, 2004.

GHALY, A. E.; RAMKUMAR, D. R.; SADAKA, S. S.; ROCHON, J. D. Effect of reseeding and $\mathrm{pH}$ control on the performance of a two stage mesophilic anaerobic digester operating on acid cheese whey. Canadian Agricultural Engineering Journal, v. 42, p. 173-183, 2000.

GUWY, R. A. J.; HAWKES, F. R.; HAWAKES, D. L.; ROZZI, A. G. Hydrogen production in a high rate fluidized bed anaerobic digester. Water Research, v. 31, p. 1291-1298, 1997.

HAWKES, F. R.; DINSDALE, R.; HAWKES D. L.; HUSSY I. Sustainable fermentative hydrogen production: Challenges for process optimization. International Journal of Hydrogen Energy, v. 27, p. 1339-1347, 2002.

HUANG, G. H.; HSU, S. F.; LIANG, T. M.; HUANG, Y. H. Study on hydrogen production with hysteresis in UASB. Chemosphere, v. 54, p. 815-821, 2004.

HUNG, C. H.; CHANG, Y. T.; CHANG, Y. J. Roles of microorganisms other than Clostridium and Enterobacter in anaerobic fermentative biohydrogen production systems - A review. Bioresource Technology, v. 102, p. 8437-8444, 2011. 
INOUE, R. K.; FONTES LIMA, D. M. F.; RODRIGUES, J. A. D.; RATUSZNEI, S. M.; ZAIAT, M. Effect of organic loading rate and fill time on the biohydrogen production in a mechanically stirred AnSBBR treating synthetic sucrose based wastewater. Applied Biochemistry and Biotechnology, v. 174, p. 2326-2349, 2014.

ITO, T.; NAKASHIMADA, Y.; SENBA, K.; MATSUI, T.; NISHIO, N. Hydrogen and ethanol production from glycerol containing wastes discharges after biodiesel manufacturing process. Journal of Bioscience and Bioengineering, v. 100, p. 260-265, 2005.

IYER, P.; BRUNS, M.A.; ZHANG, H.; VAN GINKEL, S.; LOGAN, B.E. H $2^{-}$ Producing bacterial communities from a heat-treated soil inoculum. Applied Microbiology and Biotechnology, v. 66, p. 166-173, 2004s.

JEONG, T.; CHA, G.; YOO, I.; KIM, D. Hydrogen production from waste activated sludge by using separation membrane acid fermentation reactor and photosynthetic reactor. International Journal of Hydrogen Energy, v. 32, p. 525530, 2007.

JUKES, T. H.; CANTOR, C. R. Evolution of protein molecules. In Munro HN, editor, Mammalian Protein Metabolism, Academic Press, New York, p. 21-132, 1969

KARGI, F.; OZMIHCI, S. Utilization of cheese whey powder (CWP) for ethanol fermentations: effects of operating parameters. Enzyme Microbiology and Technology, v. 38, p. 711-718, 2006.

KHANAL, S.; CHEN, W.; SUNG, S. Biological hydrogen production: effects of pH and intermediate products. International Journal of Hydrogen Energy, v. 29, p. 1123-1131, 2003. 
KRUPP, M.; WIDMANN, R. Biohydrogen production by dark fermentation: Experiences of continuous operation in large lab scale. International Journal of Hydrogen Energy, v. 34, p. 4509-4516, 2009.

KUHNER, C. H.; MATTHIES, C.; ACKER, G.; SCHMITTROTH, M.; GÖBNER, A. S.; DRAKE, H. L. Clostridium akagii sp. nov. and Clostridium acidisoli sp. nov.: acid-tolerant, N2-fixing clostridia isolated from acidic forest soil and litter. International Journal of Systematic and Evolutionary Microbiology, v. 50, p. 873-881, 2000.

LAY, J. J. Biohydrogen generation by mesophilic anaerobic fermentation of microcrystalline cellulose. Biotechnology Bioengineering, v. 74, p. 280-287, 2001.

LAY, J. J.; LEE, Y. J.; NOIKE, T. Feasibility of biological hydrogen production from organic fraction of municipal solid waste. Water Research, v. 33, p. 2579-2586, 1999.

LEE, K. S.; LO, Y. S.; LO, Y. C.; LIN, P. J.; CHANG, J. S. H2 production with anaerobic sludge using activated-carbon supported packed-bed bioreactor. Biotechnology. Letter, v. 25, p. 133-138, 2003.

LEITE, J. A. C.; FERNANDES, B. S.; POZZI, E.; BARBOZA, M.; ZAIAT, M. Application of an anaerobic packed-bed bioreactor for the production of hydrogen and organic acids. International Journal of Hydrogen Energy, v. 33, p. $579-586,2008$

LETTINGA, G.; REBAC, S.; ZEEMAN, G. Challenge of psychrophilic anaerobic wastewater treatment. Trends in Biotechnology, v. 19, p. 363-370, 2001. 
LI, J.; LI, B.; ZHU, G.; REN, N.; BO, L.; HE, J. Hydrogen production from diluted molasses by anaerobic hydrogen producing bacteria in an anaerobic baffled reactor (ABR). International Journal of Hydrogen Energy, v. 32, p. 3274-3283, 2007.

LIN, C. Y.; CHANG, R. C. Fermentative hydrogen production at ambient temperature. International Journal of Hydrogen Energy, v. 29, p. 715-720, 2004.

LIN, C. Y.; LAY, C. H. A nutrient formulation for fermentative hydrogen production using anaerobic sewage sludge microflora. International Journal of Hydrogen Energy, v. 30, p. 285-292, 2005.

LIN, C.; LAY, C. Carbon/nitrogen ratio effect on fermentative hydrogen production by mixed microflora. International Journal of Hydrogen Energy, v. 29, p. 41-45, $2004 a$

LIN, C.; LAY, C. Effects of carbonate and phosphate concentrations on hydrogen production using anaerobic sewage sludge microflora. International Journal of Hydrogen Energy, v. 29, p. 275-281, 2004b.

LISDIYANTI, P.; KAWASAKI, H.; SEKI, T.; YAMADA, Y.; UCHIMURA, T.; KOMAGATA, K. Identification of Acetobacter strains isolated from Indonesian sources, and proposals of Acetobacter syzygii sp. nov., Acetobacter cibinongensis sp. nov., and Acetobacter orientalis sp. nov.. Journal of Genetic and Applied Microbiology, v. 47, p. 119-131, 2001.

LIU, H.; FANG, H. H. P. Hydrogen production from wastewater by acidogenic granular sludge. Water Science and Technology; v. 47, p. 153-158, 2002. 
MAINTINGUER, S. I.; FERNANDES, B. S.; DUARTE, I. C. S.; SAAVEDRA, N. K.; ADORNO, M. A. T.; VARESCHE, M. B. A. Fermentative hydrogen production by microbial consortium. International Journal of Hydrogen Energy, n. 33, p. 4309-4317, 2008.

MAINTINGUER, S. I. Obtenção e caracterização filogenérica de consórcio bacteriano utilizado em reator anaeróbio em batelada aplicado à produção de hidrogênio. São Carlos. 167 p. Tese (doutorado) - Escola de Engenharia de São Carlos, USP, 2009.

MANSSOURI, M.; RODRIGUES, J. A. D.; RATUSZNEI, S.; ZAIAT, M. Effects of organic loading, influent concentration and feed time on biohydrogen production in a mechanically stirred AnSBBR treating sucrose based wastewater. Applied Biochemistry and Biotechnology, v. 171, p. 1832-1854, 2013.

MARIAKAKIS, I.; MEYER, C.; STEINMETZ, H. Fermentative hydrogen production by molasses; effect of hydraulic retention time, organic loading rate and microbial dynamics, hydrogen energy - challenges and perspectives, Prof. Dragica Minic (Ed.), ISBN: 978-953-51-0812-2, InTech, DOI: 10.5772/47750. Available from: http://www.intechopen.com/books/hydrogen-energy-challenges-andperspectives/fermentative-hydrogen-production-by-molasses-effect-of-hydraulicretention-time-organic-loading-rate, 2012. 
MATHEWS, J.; WANG, G. Y. Metabolic pathway engineering for enhanced biohydrogen production. International Journal of Hydrogen Energy, v. 34, p. 7404-7416, 2009.

MICHELAN, R.; ZIMMER, T. R.; RODRIGUES, J. A. D.; RATUSZNEI, S. M.; MORAES, D.; ZAIAT, M.; FORESTI E. Effect of impeller type and mechanical agitation on the mass transfer and power consumption aspects of ASBR operation treating synthetic wastewater. Journal of Environmental Management, v. 90 , p. $1357-1364,2009$.

MOHAN, S. V.; BABU, V. L.; SARMA, P. N. Effect of various pretreatment methods on anaerobic mixed microflora to enhance biohydrogen production utilizing dairy wastewater as substrate. Bioresource Technology, v. 99, p. 59-67, 2008.

MOHANAKRISHNA, G.; VENKATA SUBHASH, G.; VENKATA MOHAN, S. Adaptation of biohydrogen producing reactor to higher substrate load: Redox controlled process integration strategy to overcome limitations. International Journal of Hydrogen Energy, v. 36, n. 15, p. 8943-8952, 2011.

MU, Y.; YU, H. Q.; WANG, G. A kinetic approach to anaerobic hydrogen-producing process. Water Research, v. 41, p. 1152-1160, 2007.

NG, W. J. A sequencing batch anaerobic reactor for treating piggery wastewater. Biological Wastes, v. 28, p. 39-51, 1989.

NISHIO, N.; NAKASHIMADA, Y. Recent development of digestion process for energy recovery from wastes. Journal of Bioscience and Bioengineering, v. 103, p. $105-112,2007$. 
NOVAES, L. F.; BORGES, L. O.; RODRIGUES, J. A. D.; RATUSZNEI, S. M.; ZAIAT, M.; FORESTI, E. Effect of fill time on the performance of pilot-scale ASBR and AnSBBR applied to sanitary wastewater treatment. Applied Biochemistry and Biotechnology, v. 162, p. 885-899, 2010.

OH, S.E.; IYER, P.; BRUNS, MA.; LOGAN, B.E. Biological hydrogen production using a membrane bioreactor. Biotechnology and Bioengineering, v. 87, p. 119$127,2004$.

OLIVEIRA, D. S.; PRINHOLATO, A. C.; RATUSZNEI, S. M.; RODRIGUES, J. A. D.; ZAIAT, M.; FORESTI, E. AnSBBR applied to the treatment of wastewater from a personal care industry: effect of organic load and fill time. Journal of Environmental Management, v. 90, p. 3070-3081, 2009.

OLIVEIRA, R. P.; GHILARDI, J. A.; RATUSZNEI, S. M.; RODRIGUES, J. A. D.; ZAIAT, M.; FORESTI, E. Anaerobic sequencing batch biofilm reactor applied to automobile industry wastewater treatment: volumetric loading rate and feed strategy effects. Chemical Engineering and Processing, v. 47, p. 1380-1389, 2008.

ORRA, A. A.; RATUSZNEI, S. M.; RODRIGUES, J. A. D.; FORESTI, E.; ZAIAT, M. Effects of feeding strategies on the performance of an anaerobic discontinuous reactor containing immobilized biomass with circulation system for liquid-phase mixing. Water Science and Technology, v. 49, p. 303-310, 2004.

O-THONG, S.; PRASERTSAN, P.; INTRASUNGKHA, N.; DHAMWICHUKORN, S.; BIRKELAND, N. Optimization of simultaneous thermophilic fermentative hydrogen production and COD reduction from palm oil mil effluent by Thermoanaerobaterium-rich sludge. International Journal of Hydrogen Energy, v. 33, p. 1221-1231, 2008. 
OZTEKIN, R.; KAPDAN, I.; KARGUI, F.; ARGUN, H. Optimization of media composition for hydrogen gas production from hydrolyzed wheat starch by dark fermentation. International Journal of Hydrogen Energy, v. 33, p. 4083-4090, 2008.

PEIXOTO, G.; SAAVEDRA, N. K.; VARESCHE, M. B. A.; ZAIAT, M. Hydrogen production from soft-drink wastewater in an upflow anaerobic packed-bed reactor. International Journal of Hydrogen Energy, v.36, p. 8953-8966, 2011.

PENTEADO, E. D.; LAZARO, C. Z.; SAKAMOTO, I. K; ZAIAT, M. Influence of seed sludge and pretreatment method on hydrogen production in packed-bed anaerobic reactors. International Journal of Hydrogen Energy, v. 38, p. 61376145, 2013.

RAJESHWARI, K. V.; BALAKRISHNAN, M.; KANSAL, A.; LATA, K.; KISHORE, V. V. N. State of- the-art of anaerobic digestion technology for industrial wastewater treatment. Renewable Sustainable Energy, v. 4, p. 135-156, 2000.

RATUSZNEI, S.; RODRIGUES, J. A. D.; CAMARGO, E. F. M. DE; ZAIAT, M.; BORZANI, W. Feasibility of a stirred anaerobic sequencing batch reactor containing immobilized biomass for wastewater treatment. Bioresource Technology, v. 75, n. 2, p. 127-132, 2000.

REIS, C. M.; SILVA, E. L. Effect of upflow velocity and hydraulic retention time in anaerobic fluidized-bed reactors used for hydrogen production. Chemical Engineering Journal, v. 172, p. 28-36, 2011.

REITH, J. H.; WIJFFELS, R. H.; BARTEN, H. Introduction: the perspectives of biological methane and hydrogen production, in Bio-methane and Bio-hydrogen. Dutch Biological Hydrogen Foundation Publisher, Hagen, p. 9-13, 2003. 
REN, N.; XING, D.; RITTMAN, B.; ZHAO, L.; XIE, T.; ZHAO, X. Microbial community structure of ethanol type fermentation in bio-hydrogen production. Environmental Microbiology, v. 9, n. 5, p. 1112-1125, 2007.

ROCHA, J. S.; BARBOSA, M. J.; WIJFFELS, R. H. Hydrogen production by photosynthetic bacteria: culture media, yields and efficiencies. Em: J. Miyake et al., editor. Biohydrogen II - An approach to environmentally acceptable technology. London, UK: Pergamon Press; 2001.

RODRIGUES, J. A. D.; PINTO, A. G.; RATUSZNEI, S. M.; ZAIAT, M.; GEDRAITE, R. Enhancement of the performance of an anaerobic sequencing batch reactor treating low strength wastewater through implementation of a variable stirring rate program. Brazilian Journal of Chemical Engineering, v. 21, p. 423-434, 2004.

RODRIGUES, J. A. D.; RATUSZNEI, S. M.; CAMARGO, E. F. M.; ZAIAT, M. Influence of agitation rate on the performance of an anaerobic sequencing batch reactor containing granulated biomass treating low-strength wastewater. Advances in Environmental Research, vol. 7, p. 405-410, 2003.

ROJAS, M. P. A. Influência da relação $\mathrm{C} / \mathrm{N}$ na produção de hidrogênio em reator anaeróbio de leito fixo. Dissertação (mestrado) - Escola de Engenharia de São Carlos, USP, 2010.

SAADY, N. M. C. Review homoacetogenesis during hydrogen production by mixed cultures dark fermentation: unresolved challenge. International Journal of Hydrogen Energy, v. 38, p. 13172-13191, 2013.

SABOURIN-PROVOST, G.; HALLENBECK, P.C. High yield conversion of a crude glycerol fraction from biodiesel production to hydrogen by photofermentation. Bioresource Technology, v. 100, p. 3513-3517, 2009. 
SANTOS, D. A.; RODRIGUES, J. A. D.; RATUSZNEI, S.; ZAIAT, M. AnSBBR with circulation applied to biohydrogen production treating sucrose based wastewater: effects of organic loading, influent concentration and cycle length. Brazilian Journal of Chemical Engineering, v. 31, 659-674, 2014.

SAITOU, N.; NEI, M. The neighbor-joining method: A new method for reconstructing phylogenetic trees. Molecular Biology and Evolution, v. 4, p. 406-425, 1987.

SARIKA, A.K.; LIPTON, A.P.; AISHWARYA, M.S. Bacteriocin Production by a new isolate of lactobacillus rhamnosus GP1 under different culture conditions. Advance Journal of Food Science and Technology, v. 2, p. 291-297, 2010.

SHIN, J. H.; YOON, J. H.; AHN, E. K.; KIM, M. S.; SIM, S. J.; PARK, T. H. Fermentative hydrogen production by the newly isolated Enterobacter asburiae SNU-1. International Journal of Hydrogen Energy, v. 32, p. 192-199, 2007

SHIZAS, I.; BAGLEY, D. M. Improving anaerobic sequencing batch reactor performance by modifying operational parameters. Water Research, v. 36, p. 363-367, 2002.

SIKORA, A.; BŁASZCZYK, M.; JURKOWSKI, M.; ZIELENKIEWICZ, U. Lactic Acid Bacteria in Hydrogen-Producing Consortia: On Purpose or by Coincidence?, Lactic Acid Bacteria - R \& D for Food, Health and Livestock Purposes, Dr. J. Marcelino Kongo (Ed.), ISBN: 978-953-51-0955-6, InTech, DOI: $\quad 10.5772 / 50364, \quad 2013 . \quad$ Available from: http://www.intechopen.com/books/lactic-acid-bacteria-r-d-for-food-health-andlivestock-purposes/lactic-acid-bacteria-in-hydrogen-producing-consortia-onpurpose-or-by-coincidence- 
SIRIWONGRUNGSON, V.; ZENG, R. J.; ANGELIDAKI, I. Homoacetogenesis as the alternative pathway for $\mathrm{H} 2$ sink during thermophilic anaerobic degradation of butyrate under suppressed methanogenesis. Water Research, v. 41, p. 42044210, 2007.

SPEECE, R. E. Anaerobic biotechnology for industrial wastewaters. Editora J. M. Speece, 1996.

SREETHAWONG, T.; NIYAMAPA, T.; NERAMITSUK, H. Hydrogen production from glucose-containing wastewater using an anaerobic sequencing batch reactor: Effects of COD loading rate, nitrogen content, and organic acid composition. Chemical Engineering Journal, v. 160, n. 1, p. 322-332, 2010.

TAMURA, K.; STECHER, G.; PETERSON, D.; FILIPSKI, A.; KUMAR, S. MEGA6: Molecular Evolutionary Genetics Analysis version 6.0. Molecular Biology and Evolution, v. 30, p. 2725-2729, 2013.

TANISHO, S. A scheme for developing the yield of hydrogen by fermentation. 2001

TANISHO S. B. V.; SUZUKI, Y.; WAKAO, N. Fermentative hydrogen evolution by Enterobacter aerogenes strain E.82005. International Journal of Hydrogen Energy, v. 20, p. 541-545, 1987.

TEJAYADI, S.; CHERYAN, M. Lactic acid from cheese whey permeate: Productivity and economics of a continuous membrane bioreactor. Applied Microbiology and. Biotechnology, v. 43, p. 242-248, 1995.

TURCOT, J.; BISAILLON, A.; HALLENBECK, P. Hydrogen production by continuous cultures of Escherichia coli under different nutrient regimes. International Journal of Hydrogen Energy, v. 33, p. 1465-1470, 2008. 
VALDEZ-VAZQUEZ，I.; RIOS-LEAL E.; ESPARZA-GARCIA F.; CECCHI F.; POGGI-VARALDO H. M. Semi-continuous solid substrate anaerobic reactors for $\mathrm{H}_{2}$ production from organic waste: mesophilic versus thermophilic regime. International Journal of Hydrogen Energy, v. 30, p. 1383-1391, 2005.

VENKATA MOHAN, S.; LALIT BABU, V.; SARMA, P. Anaerobic biohydrogen production from dairy wastewater treatment in sequencing batch reactor (AnSBR): Effect of organic loading rate. Enzyme and Microbial Technology, v. 41, n. 4, p. 506-515, 2007.

VEZIROGLU, T. N.; SAHIN, S. $21^{\text {st }}$ Century's energy: Hydrogen energy system. Energy Conversion and Management, v. 49, p. 1820-1831, 2008.

VEZIROGLU, T.N.; BARBIR, F. Hydrogen: The wonder fuel. International Journal of Hydrogen Energy, v. 17, p. 391-404, 1992.

VIJAYA BHASKAR, Y.; VENKATA MOHAN, S.; SARMA, P. N. Effect of substrate loading rate of chemical wastewater on fermentative biohydrogen production in biofilm configured sequencing batch reactor. Bioresource technology, v. 99, p. 6941-6948, 2008.

WANG, J. L.; WAN, W. Factors influencing fermentative hydrogen production: A review. International Journal of Hydrogen Energy, v. 34, p. 799-811, 2009.

WU, S. Y.; LIN, C. N.; CHANG, J. S.; LEE, K. S.; LIN, P. J. Hydrogen production with immobilized sewage sludge in three-phase fluidized-bed bioreactor, Biotechnology Progress, v. 19, p. 828-832, 2003.

WU, S. Y.; LIN, C. N.; CHANG, J. S.; LEE, K. S.; LIN, P. J. Microbial hydrogen production with immobilized sewage sludge, Biotechnology Progress, v. 18, p. 921- 926, 2002. 
WU, X.; YAO, W.; ZHU, J. Effect of $\mathrm{pH}$ on continuous biohydrogen production from liquid swine manure with glucose supplement using an anaerobic sequencing batch reactor. International Journal of Hydrogen Energy, v. 35, p. 6592-6599, 2010.

YANG, P.; ZHANG, R; McGARVEY, J. A.; BENEMANN J. R.. Biohydrogen production from cheese processing wastewater by anaerobic fermentation using mixed microbial communities. International Journal of Hydrogen Energy, v. 32, p. 4761-4771, 2007.

ZAIAT, M.; RODRIGUES, J. A. D.; RATUSZNEI, S. M.; CAMARGO, E. F. M.; BORZANI, W. Anaerobic sequencing batch reactors for wastewater treatment: a developing technology. Applied Microbiology and Biotechnology, v. 55, p. 29$35,2001$.

ZHANG, H.; CAI, Y. Lactic Acid Bacteria: Fundamentals and Practice. DOI: 10.1007/978-94-017-8841-0_1, Dordrecht: Springer Netherlands, 2014.

ZHANG, Y.; SHEN, J. Effect of temperature and iron concentration on the growth and hydrogen production of mixed bacteria. International Journal of Hydrogen Energy, v. 31, p. 441-446, 2005.

ZHU, H.; PARKER, W.; BASNAR, R,; PRORACKI, P.; FALLETA, P.; BÉLAND, M.; SETO, P. Buffer requirements for enhanced hydrogen production in acidogenic digestion of food wastes, Bioresource Technology, v. 100, p. 5097-5102, 2009.

ZIMMER, T. R.; MICHELAN, R.; CANTO, C. S. A.; RODRIGUES, J. A. D.; RATUSZNEI, S. M. Feed strategy study of a mechanically stirred anaerobic sequencing batch reactor equipped with a draft tube applied to whey treatment. Brazilian Journal of Food Technology, v. 11, p. 288-298, 2008. 